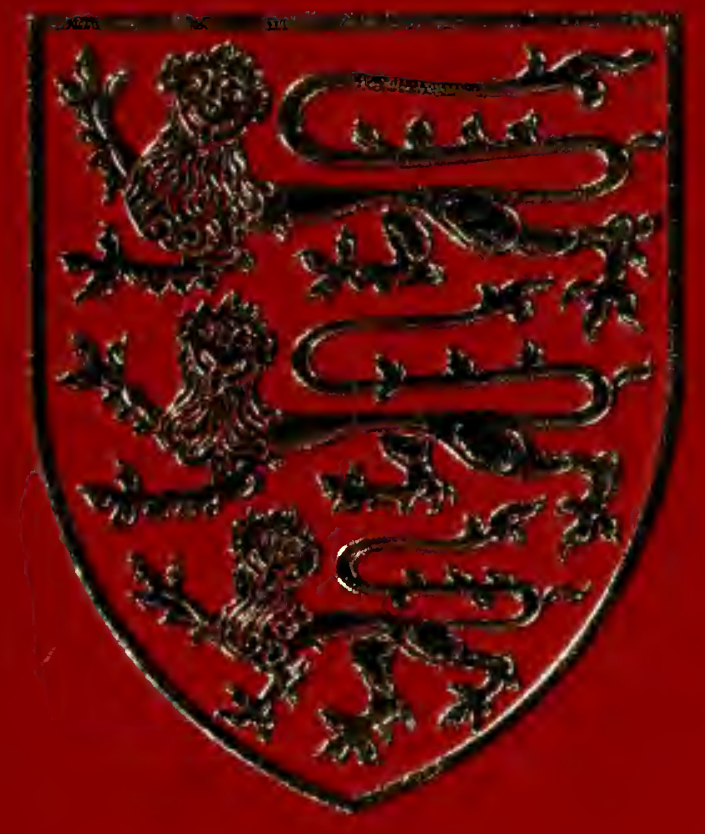


LIBRARY

UNIVERSIT OF

CALIFORNLA
SAN OIEGO 


$$
\begin{array}{r}
I f 5 \\
\because 6 \\
\because 6 \\
\therefore
\end{array}
$$



The Victoria Whistore of the

Countíes of Englano

EDITED BY WILLIAM PAGE, F.S.A.

\section{A HISTORY OF \\ D O R S E T \\ VOLUME II}





\section{THE}

\section{VICTORIA HISTORY}

OF THE COUNTIES

OF ENGLAND

D O R S E T

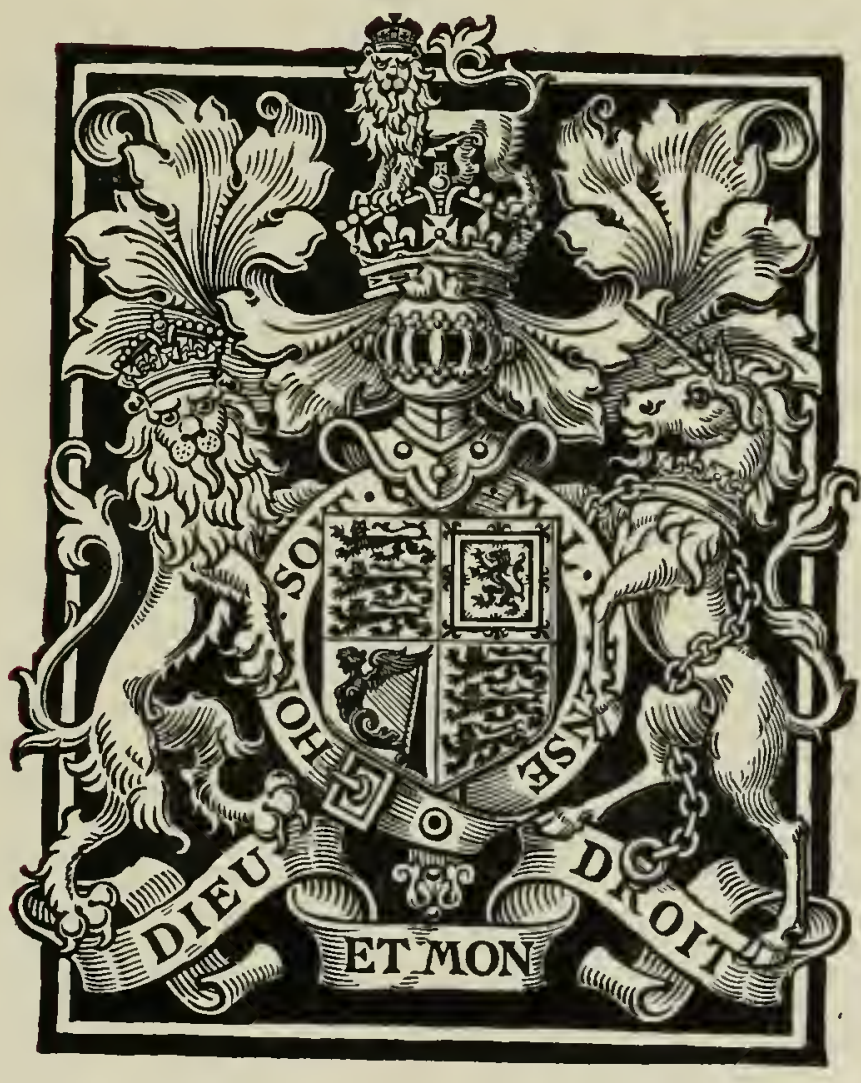

LONDON

ARCHIBALD CONSTABLE

AND COMPANY LIMITED 
This History is issued to Subscribers only By Archibald Constable \& Company Limited and printed by Eyre \& Spottisicoode H.M. Printers of London 


$$
\begin{gathered}
\text { INSCRIBED } \\
\text { TO THE MEMORY OF } \\
\text { HER LATE MAJESTY } \\
\text { QUEEN VICTORIA } \\
\text { WHO GRACIOUSLY GA VE } \\
\text { THE TITLE TO AND } \\
\text { ACCEPTED THE } \\
\text { DEDICATION OF } \\
\text { THIS HISTORY }
\end{gathered}
$$






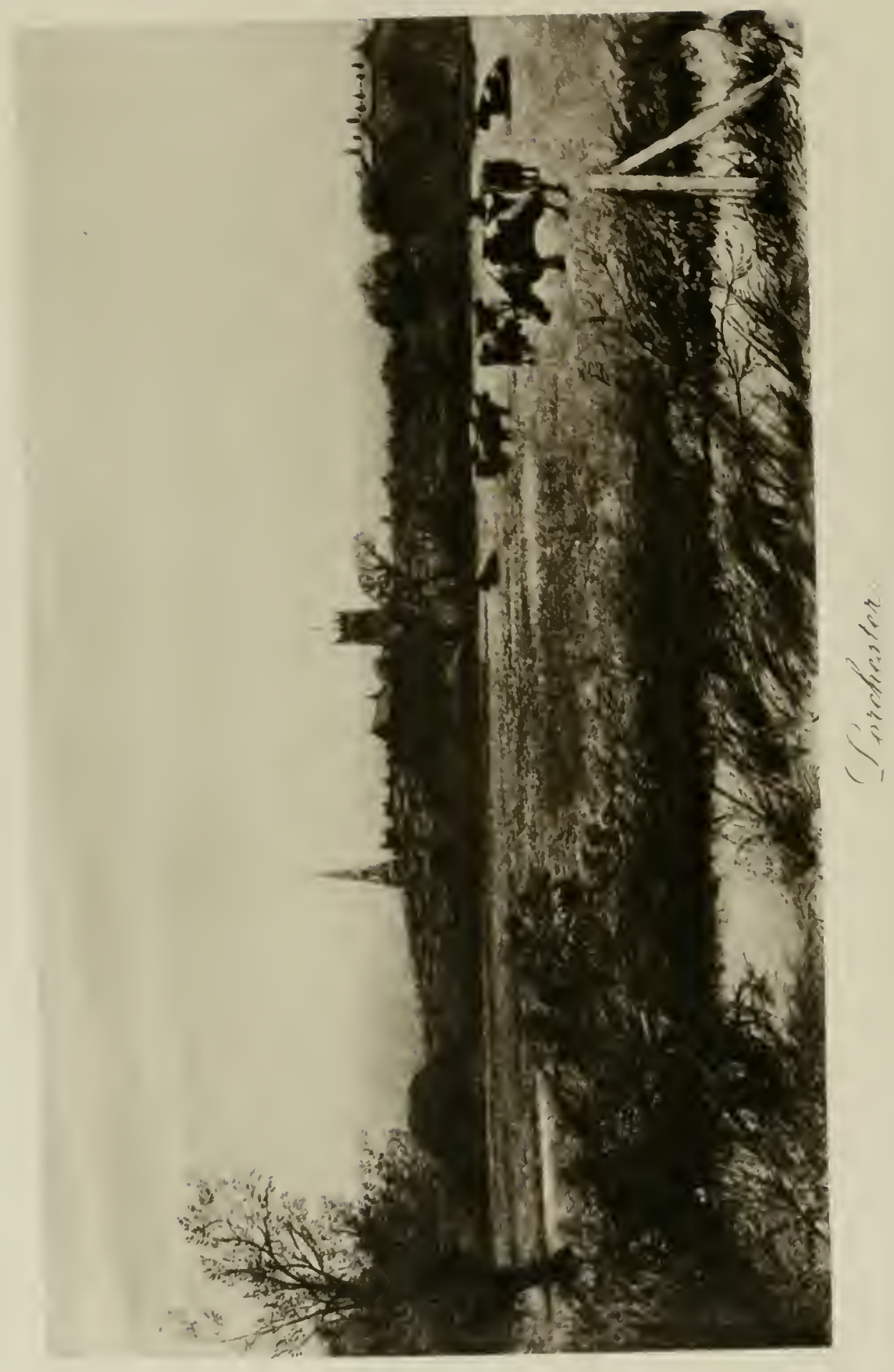




\section{THE}

VICTORIA HISTORY

OF THE COUNTY OF

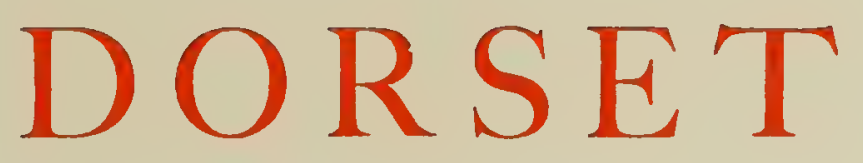

EDITED BY

WILLIAM PAGE, F.S.A.

VOLUME TWO

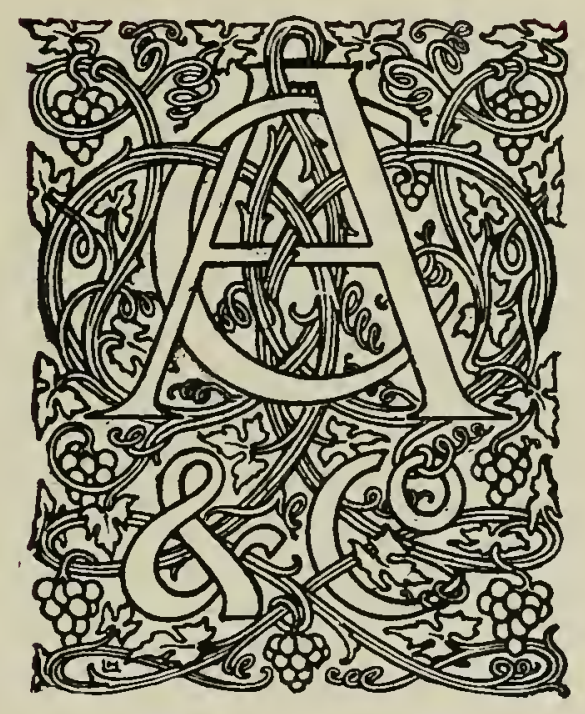

LONDON

ARCHIBALD CONSTABLE

AND COMPANY LIMITED

I 908 



\section{CONTENTS OF VOLUME TWO}

\section{Dedication}

\section{Contents}

List of Illustrations and Maps

Editorial Note

Ecclesiastical History

Religious Houses :-

Introduction

Abbey of Abbotsbury

Abbey of Cerne

Abbey of Milton

Abbey of Sherborne.

Priory of Cranborne .

Priory of Horton

Abbey of Shaftesbury

Priory of Holne or East Holme .

Abbey of Bindon

Abbey of Tarrant Kaines

Preceptory of Friar Mayne

Dominican Friars of Gillinghan .

Dominican Friars of Melcombe Regis .

By A. G. LitTle, M.A

By Miss Mi M. C. Calthrop.

Franciscan Friars of Dorchester

Carmelite Friars of Bridport

Carmelite Friars of Lyme

Austin Friars of Sherborne

'Priory' Hermitage' of Blackmour

Wilcheswood

Hospital of St. Mary Magdalen, Allington

Hospital of Long Blandford

Hospital of St. Mary and the Holy Spirit, Lyme

Hospital of St. John the Baptist, Bridport

Hospital of St. John the Baptist, Dorchester.

Hospital or Lazar-House, Dorchester .

Hospital of St. John the Baptist, Shaftesbury.

Hospital of St. John the Baptist and St. John the Evangelist, Sherborne .

Hospital of St. Thomas, Sherborne

Hospital of St Leonard, Tarrant Rushton

",
",
",
",
,
",
"
,

Hospital of St. Margaret and St. Anthony, Wimborne . . .

Hospital of Wareham

Wimborne Minster .

Priory of Frampton . 


\section{CON'TENTS OF VOLUME TWO}

Religious Houses (continued) -

Priory of Loders

Priory of Povington

Priory of Spettisbury

Priory of Wareham

Political History

Maritime History

Social and Economic History

Table of Population, I S01-1901 Agriculture

Forestry .

Sport, Ancient and Modern

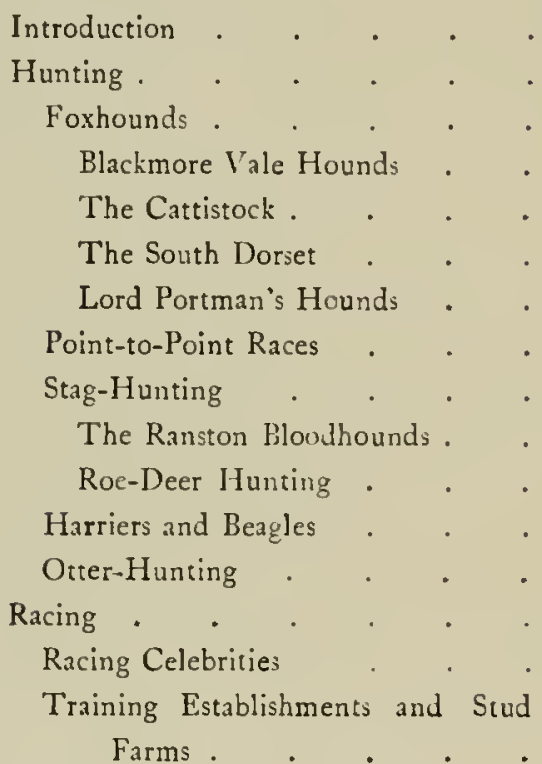

Polo

Shooting .

Falconry .

Angling .

Golf

Industries :-

Introduction

Quarrying

The Hemp Industry.

Fisheries .

Cloth

Silk

Pottery and Tiles

Erewing .

Cider
By Miss M. M. C. Calthrop . . . . 116

118

119

121

By Mrs. Eoward Fripp, Oxford Honouts School of Modern History . . . . . 123

By M. Oppenhem . . . . . . 175

By Miss Madfleine C. Fripp and Miss Phyllis IV RaGGE, Oxford Honours School of Modern History . . . . . . 229

By" George S. Minchin . . . . . 264

By A. J. Buckie . . . . . . 275

By the Rev. J. C. Cox, LL.D., F.S.A. • 287

Edited by the Rer. E. E. Doruing, M.A.

By the Rev. Pierce A. Butler ('Purbeck Pilgrim') 299

300

300

304

308

310

312

313

313

313

314

315

315

316

317

317

313

318

By Capt. Eustace Rsuclyff;, J.l?. . . . 319

By the Rev. Pifrce A. Butler ('Purbeck Pilgrim') 320

By the Rev. E. E. Dorling, M.A. . . . 322

By Miss M. M. CRick, B.A. (Dublin), Oxford Honours School of Modern History . . 325

By C. H. Vellacott, B.A. • . . . 331

By Miss M. M. CRICK, B.A. (Dublin), Oxford Honours School of Modern History . . $34+$

" " " " , 353

, " , , , $\quad 360$

" " $\quad$ " , , $\quad 362$

, n $\quad$, , $\quad, \quad 363$

By Miss M. M. С. Сıск, B.A (Dublin), Oxford Honours Schoul of Modern History, and C. $\mathrm{H}$. VELLACOTT, B.A. 


\section{LIST OF ILLUSTRATIONS AND MAPS}

PAGE

Dorchester. By William Hyde . . . . . . . . . . Frontispiece

Ecclesiastical Map of Dorset . . . . . . . . . . facing 45

Dorset Monastic Ssals :-

Plate I . . . . . . . . . . full-page plate facing 62

Plate II . . . . . . . . . . . . . $\quad$. $\quad$. 102

Map of Dorset shewing excess of Hamlets over Villages . . . . . . facing I 26

Plan of Portland Harbour shewing New Breakwater . . . . full-page plate facing 226 



\section{EDITORIAL NOTE}

THE Editor wishes to express his acknowledgements to Mr. J. Merrick Head and Sir J. Charles Robinson, C.B., F.S.A., for notes and assistance on the section on Mining in the article on the Industries of the county, and to the Hon. Thomas A. Brassey for an illustration to the article on Maritime History. 

A HISTORY OF

D O R S E T 



\section{ECCLESIASTICAL HISTORY}

AVE for the discovery of that early Christian emblem, the chirho, in a Roman pavement excavated at Frampton ${ }^{1}$ there is no evidence to connect Dorset with the early Roman-British church, or any proof that Christianity existed here before the later Roman mission." Nor can the ecclesiastical history of this county be said to commence in the seventh century with the conversion of the West Saxons at the preaching of Birinus their apostle and first bishop, who, on his landing in 635 , found the inhabitants of the district 'most pagan' (pagannissimos) according to Bede. ${ }^{3}$ Dorset, it should be remembered, formed no integral part of the West Saxon kingdom in which it afterwards became absorbed and no mention of it occurs under the earlier Wessex bishops whose seat was established at Dorchester (Oxford). While discarding an ancient record which names Cenwalch of Wessex, who died in 672, as one of the 'kings, founders of the church of Sherborne," an early foundation at Wareham may indicate previous fugitive attempts to draw Dorset in to the channel of church organization in Wessex as it then existed by establishing a mission centre to its south-east, but it was not until the military subjugation of the county had been completed that it was swept into the main stream of national ecclesiastical life by the establishment of a bishop-stool at Sherborne in 705 on the death of Bishop Haeddi and the division of the West Saxon diocese. ${ }^{5}$

What the precise limits of the new see were is not easy exactly to define. The two sees formed out of the old Wessex diocese are described roughly as 'east and west of Selwood,' the large forest of that name which stretched between them constituting a convenient border line. The AngloSaxon Cbronicle, recording the death of Bishop Aldhelm in 709, says, "this year died bishop Aldhelm : he was bishop of the west of Selwood.' ${ }^{6}$ Henry of Huntingdon again states: "Ine in the twentieth year of his reign divided the bishopric of Wessex which used to be one into two sees : that portion east of the woods Daniel held, that which was west of the woods was held by Aldhelm.'7 According to William of Malmesbury the see 'west of Selwood,' the bishop-stool of which was fixed at Sherborne, included the counties

'Arch. Fourm. xxviii (1872), $217-21$.

${ }^{2}$ Mr. Moule, in his description of Old Dorset (pp. 50-51), comments on the absence of reference to this county in the Monumenta Historica Britannica, which focusses all classic authorities of the period. In reference to the ancient British church in Wessex, the fact that St. Chad, afterwards bishop of Lichfield, was consecrated to the see of York by Wine, bishop of Wessex, assisted by two British bishops, seems to show that in that district the bishops who owed their ordination directly to Rome after the Roman Kentish mission were in communion with those of the earlier British school. Dioc. Hist. of Salisbury (S.P.C.K.), p. 28.

${ }^{3}$ Eccl. Hist. lib. iii, cap. vii. ${ }^{1}$ Cott. MS. Faust. A. ii, fol. 23.

${ }^{5} \mathrm{Wm}$. of Malmesbury, Gesta Pontif. (Rolls Ser.), 375. The division of the Wcssex dioceses into two sces, one established at Sherborne and the other at Winchester, is usually attributed to King Ine, but has also been ascribed to synodal authority. Wharton, Anglia Sacra, ii, 20.

${ }^{6}$ Anglo-Sax. Chron. (Rolls Ser.), 38.

${ }^{7}$ Hist. Angl. (Rolls Ser.), i, 110. 


\section{A HISTORY OF DORSET}

of Wilts., Dorset, Berks., Somerset, Devon, and Cornwall ; ${ }^{8}$ and we may perhaps conclude that the new diocese consisted at least of the whole of Dorset and Somerset, with a large part of Wiltshire, and probably included Devon and Cornwall.

If there had been delay and difficulty in bringing this county into line with the rest of Wessex, Dorset certainly sprang, ecclesiastically as well as politically, into the front rank from the date of the constitution of the see. The saintly Aldhelm, kinsman and partner of King Ine in all schemes for the welfare and advancement of the kingdom, was elected and by Archbishop Berchtwald consecrated first bishop of Sherborne in $705 .^{\circ}$ As regards his previous connexion with this county, William of Malmesbury recounts how, prior to his departure for Rome to obtain from the pope various privileges for the monasteries he had established, Aldhelm visited his Dorset estate near Wareham and Corfe Castle and built a church two miles from the sea, 'wherein he commended to God his going and returning.' According to the chronicler the church was still standing in his day-about the beginning of the twelfth century-and was regarded by the inhabitants of the country with singular veneration on account of the signs and miracles which had taken place there. The shepherds of the district, it was said, when storms broke over them, would fly for shelter within its walls, where no rain ever fell though the roof had fallen and all attempts to cover it had failed. ${ }^{10}$ During the four short years of his rule the bishop worthily initiated the work of the church in Dorset. At Sherborne he built, or at least commenced, his minster or cathedral church, ${ }^{11}$ to which was attached a house of secular canons, the 'familia,' or household, at that time always forming part of a bishop's seat. Another important religious foundation, dating not later than the formation of the episcopal see, was the house of religious virgins built by St. Cuthburga, sister of King Ine, at Wimborne, and specially referred to by Aldhelm in a letter, dated 705 , giving liberty of election to the monasteries under his charge, as 'the monastery by the river which is called Wimburnia presided over by the abbess Cuthburga.' 12 During the eighth century the fame of the nuns here and the report of the training and discipline of the abbess-founder and her successors spread even to the Continent, and St. Boniface, the apostle of the Germans, sent over to make request that the sisters Lioba and Agatha might be allowed to proceed abroad to take charge of the monastery he had founded at Biscoffsheim in order that the same rule and discipline might be planted there. ${ }^{13}$

To enumerate briefly the succession of bishops of Sherborne in the eighth and ninth centuries: Aldhelm, on his death in 709, was followed by Forthere, ${ }^{14}$ who in 737 is said to have accompanied Queen Frythogith to Rome ${ }^{15}$ and was succeeded by Herewald, consecrated by Archbishop Nothelm in $736,,^{16}$ in whose time was held the council of Clovesho (747), at which

${ }^{5}$ Gesta Pontif. (Rolls Ser.), 175.

${ }^{9}$ Flor. Worc. Cbron. (Engl. Hist. Soc.), i, 46 ; Wm. of Malmesbury, Gesta Pontif. (Rolls Ser.), 376.

${ }^{10}$ Ibid. $363-4$. "Ibid. 378 .

12 Birch, Cart. Sax. i, 168.

${ }^{13}$ Cressy, Church Hist. of Brit. lib. xxi, cap. xviii.

${ }^{14}$ Flor. Worc. Chron. $\left(\mathrm{En}_{5} 1\right.$. Hist. Soc.), i. 47 ; Bede, Eccl. Hist. lib. v, cap. xviii.

15 Anglo-Sax. Chron. (Rolls Ser.), 40.

${ }^{16}$ Sim. of Durham (Twysden), 100. Herewald appears to have acted as suffragan to Forthere before the death of the latter, for in a charter dated $734-7$, they both appear as bishop of the church of Sherborne; Kemble, Codex Dipl. i, 82. 


\section{ECCLESIASTICAL HISTORY}

he assisted. ${ }^{17}$ Æthelmod, 766-78; Denefrith, consecrated by Archbishop Ethelheard in $793 ;{ }^{18}$ Wigberht or Wibert, who went with Archbishop Wulfred to Rome in 8 I $2 .{ }^{19}$ Ealhstan, a valiant soldier no less than bishop, and esteemed for his military prowess, took an important part in the conflicts of his time, and not only assisted King Egbert in the subjugation of the kingdoms of Kent and Essex, but afforded him and his successor material help as well as active encouragement in their struggle against the Danes. ${ }^{20}$ William of Malmesbury, who described the bishop as of singular power in secular matters and pre-eminent in counsel, but resented his action in having appropriated the abbey of Malmesbury to the episcopal see, declared that avarice, spite of his liberality in the national cause, was the besetting sin of Ealhstan, adding, however, that he left his church well endowed. ${ }^{21}$ According to the Anglo-Saxon Cbronicle, Ealhstan died in 867, after he had held the bishopric of Sherborne 'fifty winters,' and ' his body lies there in the town.' ${ }^{22}$ Bishop Heahmund, who subscribed $868-70$, again recalls the fierce conflict going on with the Danes, for he, ' with many good men,' was slain in battle at Merton in $87 \mathrm{I}$; ${ }^{23}$ his successor, Ethelheah, subscribed $87 \mathrm{I}-8$; Wulfsige, Elfsige, or Alfsius, $883 .{ }^{24}$ Asser, chiefly remembered as the friend and biographer of King Alfred, signed acts in 900 and 904 . He was in all probability made bishop of the western portion of the diocese, which at that time reached to Land's End, in the lifetime of his predecessor and succeeded to the whole on the death of Wulfsige; this, at any rate, offers a solution of the fact that Asser is described by Alfred as 'my bishop' at a date previous to 890 , while Asser himself states that the king bestowed on him the charge of Exeter with the whole diocese that pertained to it in Saxony (Wessex) and Cornwall, ${ }^{25}$ and disposes of the confusion resulting from the two bishops appearing as contemporary occupants of the same see..$^{26}$

The beginning of the tenth century brings us to what has been described as 'the great ecclesiastical event of the reign of Edward the Elder,' ${ }^{27}$ the second division of the West Saxon see, with the account of the consecration of the seven bishops at Canterbury. 'In the year 904 of our Lord's nativity,' writes William of Malmesbury-

Pope Formosus sent letters into England by which he pronounced excommunication and malediction on king Edward and all his subjects, instead of the benediction which had been sent by Pope Gregory from the seat of St. Peter to the English people, because for 7 whole years the whole district of the West Saxons had been destitute of bishops. On hearing this king Edward assembled a council of the senators of the English people, over which Plegmund, archbishop of Canterbury, presided interpreting carefully the words of the apostolic message. Then the king and bishops chose a salutary council for themselves and their people and, according to the word of our Lord 'the harvest truly is plenteous but the

17 Wilkins, Concil. i, 94. $\quad 15$ Wharton, Anglia Sacra, i, 79.

${ }^{19}$ Flor. of Worc. Chron. (Engl. Hist. Soc.), i, 64 .

${ }^{20}$ Gesta Regum Angl. (Rolls Ser.), i, jog. King Ethelwulf is said to have had two excellent bishops: St. Swithun of Winchester, who directed the king in celestial matters; and Ealhstan of Sherborne, who advised him in earthly affairs.

"Gesta Pontif. (Rolls Ser.), 175-6. "Op. cit. 53.

${ }^{23}$ Ibid. 62. The following year King Ethelred, who received mortal injuries in the same battle, died and was buried at Wimborne (ibid.), his predecessors, Ethelbald and Ethelbert, having received burial at Sherborne ; ibid. $5^{8-9}$.

${ }^{24}$ Wm. of Malmesbury, Gesta Pontif. (Rolls Ser.), $177 . \quad 25$ Petrie, Monumenta Hist. Brit. 4, 9.

${ }^{96}$ Lingard, Anglo-Saxon Church, ii, 433 ; W. H. Jones, Early Annals of the Episcopate in Wilts and Dorset, 20-1.

"Stubbs, William of Malmesbury, Gesta Regum (Rolls Ser.), Introd. ii, p. liv. 


\section{A HISTORY OF DORSET}

labourers are few, they elected and constituted a bishop to every province of the West Saxons and divided the district which formerly had two bishoprics into five. The council being dismissed, the archbishop went to Rome with many presents and conciliating the Pope with great humility recited the king's ordinance which gave the pontiff great pleasure. And returning home, in one day he consecrated in the city of Canterbury 7 bishops to 7 churches, namely, Frithstan to Winchester, Ethelstan to Ramsbury, Waerstan to Sherborne, Athelm to Wells, Eadulf to Crediton, also to other provinces he constituted 2 bishops, Beornege to the South Saxons (Selsey) and to the Mercians Ceolwulf whose see was at Dorchester. ${ }^{28}$

On critical examination many of the details in the above account are shown to be inaccurate..$^{29} \quad$ The story of the negotiations of Edward the Elder with Pope Formosus falls to the ground as his pontificate ended four years before the king's reign began, while the immediate successor of Asser, whose death is recorded in the Anglo-Saxon Chronicle under the year $910,^{30}$ was not Waerstan but Ethelweard, who as bishop of Sherborne attested a charter of King Edward in 909. ${ }^{31}$ As to the tradition, dating from the eleventh century, of the consecration of seven bishops at Canterbury in one day, the story is said by its most eminent critic to contain 'no special improbability although it would be unwise to risk a positive identification of the persons consecrated.' ${ }^{32}$ The points to be retained are that the visit of Archbishop Plegmund to Rome in $908^{33}$ was followed by the division of the diocese of Winchester into two bishoprics, ${ }^{34}$ one remaining at Winchester as before, the other fixed at Ramsbury, and comprising the two counties of Wiltshire and Berkshire or such portion of them as belonged to the territory of the West Saxons; and that subsequently the diocese of Sherborne, as it existed prior to 909, was divided into three bishoprics: Sherborne for the county of Dorset, Wells for Somerset, and Crediton for Devonshire. ${ }^{35}$

To return to the succession of bishops of Sherborne after the division of the diocese: Waerstan, one of the seven prelates consecrated in one day by Archbishop Plegmund, was killed, according to William of Malmesbury, in 937 , on the eve of the battle of Brunanburh ; ${ }^{36}$ his signature is not found attached to any genuine charter. An interpolation of Florence of Worcester states that 'on the death of Waerstan, Æthelbald succeeded,' ${ }^{37}$ and his name follows in the list of bishops given by William of Malmesbury; Sighelm, or Sigelm, subscribed $925-93^{2} ;{ }^{38}$ Alfred, $933^{-943^{39}}$; Wulfsige, said to have been abbot of Westminster, ${ }^{40}$ signed 943, as Atlsius Dorsetensium Episcopus his death is recorded in the year $95^{8} ;{ }^{41}$ his successor Ælfwold, designated in the same manner, ${ }^{42}$ died in 978 and was buried at Sherborne ; ${ }^{43}$ Æthelsige, 979-99I, was present at the consecration of Winchester Cathedral in 98 I ; Wulfsige,

${ }^{89}$ Gesta Regum (Rolls Ser.), i, 140-1.

${ }^{23}$ W. H. Jones, Early Annals of the Episcopate in Wilts and Dorset, 22-3.

${ }^{30}$ Op. cit. 77 .

${ }^{31}$ Kemble, Codex Dipl. v, 1093. According to one account of William of Malmesbury the alms sent by King Alfred to St. Thomas of India and Christians beyond sea were conveyed by Sighelm, bishop of Sherborne, whom elsewhere he makes successor to Asser [Gesta Regum (Rolls Ser.), i, 130; Gesta Pontif. (Rolls Ser.), 177]. But a bishop of the name of Sighelm does not occur until three successors of Asser had passed away, and it is hardly probable that the two should be identical.

's2 Stubbs, Reg. Sacrum Anglic. $23 . \quad{ }^{33}$ Petrie, Monumento Hist. Brit. 519.

31 Wm. of Malmesbury, Gesta Pontif. (Rolls Ser.), 20 ; W. H. Jones, op. cit. $24-5$.

${ }^{35} \mathrm{Wm}$. of Malmesbury, Gesta Pontif. (Rolls Ser.), 178.

${ }^{36}$ Ibid. $\quad{ }^{37}$ Chron. (Engl. Hist. Soc.) i, 128, note 1 ; 133, note 2.

${ }^{35}$ Stubbs. Reg. Sacrum Anglic. 25. ${ }^{39}$ Ibid. p. 26.

$10 \mathrm{Wm}$. of Malmesbury, Gesta Pontif. (Rolls Ser.), 178.

"Flor. Worc. Chron. (Engl. Hist. Soc.), 137.

${ }^{43}$ Angl.-Sax. Chron. (Rolls Ser.), 178.

4 Ibid. i, 146.

"Arch. Fourn. (Winchester), 15. 


\section{ECCLESIASTICAL HISTORY}

Wulfsin or Wulfsy, 992-1001, was responsible for the reorganization of Sherborne, monks being substituted for the secular canons who had occupied the house since its foundation in $705 ;^{46}$ Æthelric, I OO I; ${ }^{46}$ Æthelsige or Æthelsie, ${ }^{47}$ IOI2-I4; Brihtwy or Brihtwin, included in the list of bishops given by William of Malmesbury and Florence of Worcester, but whose name does not appear in any charters of that period; ÆIfmaer, IOI7, whose succession is recorded under the year 1022 in the Decem Scriptores ${ }^{43}$; Brihtwy, 1023 , subscribed in 1044 as bishop of Sherborne to a charter of Edward the Confessor ; ${ }^{49}$ Elfwold, I 045 , to whom the Confessor addressed a charter testifying a grant to Orc or Orcus his minister, the founder of Abbotsbury, of the shore of all his lands. ${ }^{50}$ In 1058 by the appointment of Herman 'the king's priest,' who already held the bishopric of Ramsbury, the two sees of Sherborne and Ramsbury which had been separated on the division of the diocese in 909, became again united under one bishop holding jurisdiction over the counties of Berkshire, Wiltshire and Dorset. ${ }^{51}$ The bishop's stool remained at Sherborne till the year 1075, when, by decree of the council of London ordering the removal of sees from small towns and villages to more populous centres, it was transferred to the city of Old Sarum, ${ }^{62}$ and the head of the diocese, which had hitherto pertained to Dorset, passed finally away from the county.

Glancing back over the three and a half centuries that elapsed between the foundation of the see at Sherborne and its transference to Old Sarum, the characteristic feature of this period as regards this county will be found in the rise and growth of those religious houses on whose pivot the whole ecclesiastical structure seemed to turn. To it belonged those great Benedictine houses that were at once the glory and the distinctive feature of Dorset. Sherborne, coeval with the bishopric itself; Shaftesbury, linked in memory with the greatest of Saxon kings, the long line of whose abbesses commences in Alfred's daughter ; ${ }^{53}$ Milton, built by King Æthelstan about the year 953 to commemorate for the soul of the young Prince Edwin, or, as some monkish chroniclers insist, to expiate the crime of a brother's murder ${ }^{54}$ Cerne and Abbotsbury, whose traditionary history goes back to the very dawn of Christianity in this island, and the early mission of St. Augustine ${ }^{65}$; the later dependent cells of Cranborne and Horton, which before the Conquest enjoyed the status of abbeys. The action of the claimant Ethelwold in seizing Wimborne on the accession of his cousin Edward the Elder to the throne in 9or, and the declaration that here 'he would either live or lie,' ${ }^{56}$ illustrates the early importance that the town and church enjoyed as thê residence and sepulchre of Wessex kings. Few counties of the size of Dorset can show such a list of wealthy and influential houses as are to be found here at the time of the Domesday Survey.

${ }^{45}$ Leland, Collect. iii, 150 ; Itin. ii, $5 \mathbf{1 - 2 .}$

${ }^{46}$ Kemble, Codex Dipl. iii, 708.

"Ibid. vi, 1302.

${ }^{48}$ W. Thorne, De rebus Abbat. Cant. (Twysden), $178 z$.

${ }^{49}$ Codex Dipl. iv, 771, 774-5. His death is recorded in the Anglo-Sax. Chron. (Rolls Ser. 134) under the year 1043 .

${ }^{50}$ Codex Dipl. iv, 87 1.

${ }^{31}$ Wm. of Malmesbury, Gesta Pontif. (Rolls Ser.), 183.

${ }^{33}$ See Alfred's Charter of endowment, Birch, Cart. Sax. ii, 148.

${ }^{34}$ Dugdale, Mon. ii, 348, Chart. under Milton, No. iii.

${ }^{55}$ Coker, Particular Surs. of Dorset, 30, 66.

${ }^{53}$ Ibid. 66-8.

${ }^{56}$ Angl.-Sax. Chron. (Rolls Ser.), 75. 


\section{A HISTORY OF DORSET}

These early foundations, as in other parts of the country, appear in the first instance to have been occupied by secular canons, or monks following no established rule. Following the monastic reforms of Edgar and Archbishop Dunstan we find in 904 the seculars at Milton replaced by monks under the rule of Abbot Cyneward. ${ }^{67}$ In 987 Ælfric, the author of the famous Homilies, was appointed first abbot of Cerne, the inmates of which were ordered to follow the Benedictine rule..$^{63}$ Bishop Wulfsige, or Wulfsy, in 998 , as we have seen, substituted monks for the secular canons who had previously formed the community attached to the cathedral church of the diocese at Sherborne. ${ }^{59}$ The society of secular canons, established at Abbotsbury about 1026 by Orc or Orcus, steward of the household to King Cnut, was afterwards changed into a house of Benedictine monks by the founder, or by his widow after his death. ${ }^{60}$ On the other hand, Wimborne, originally 'a house of Holy Virgins,' was, on its restoration, converted into a house of secular canons, and continued as a royal free chapel under the government of a dean down to the Reformation. ${ }^{61}$

As regards the state of the church during the long and protracted struggle against the Danes, little can be positively ascertained save as it affected materially the religious foundations of the county. Wareham, one of the oldest monasteries in Dorset, is said to have been destroyed in an assault on the town in $876 . .^{62}$ Horton, again, is supposed to have shared the fate of Tavistock, which was destroyed in the raid of $997-8 .{ }^{63}$ A blank succeeds in the history of Wimborne after the reign of Edward the Elder, and the next mention of it records its restoration by Edward the Confessor. ${ }^{64}$ Cnut, we are told, raided the counties of Dorset, Somerset and Wiltshire in $1015,{ }^{65}$ and plundered the monastery of Cerne of which he afterwards became a benefactor. ${ }^{66}$ Ethelred 'the Unrede' in the midst of the troubles and turmoils of his reign granted by charter, dated IOOI, to the nuns of Shaftesbury the vill and monastery of Bradford (Wiltshire) that they might there retire as to a place which offered greater security against the attacks of the enemy. ${ }^{67}$ It would be impossible to leave the tenth century, with its disconnected record of destruction and reconstruction, without referring to the events of 978-80, which took place within the borders of Dorset and played so important a part in determining the future greatness of the abbey of Shaftesbury : the cruel murder of the young King Edward, if not by the actual hand, at least with the connivance of his stepmother Æthelthryth or Elfrida, the daughter of Ordgar, earl of Devon, the founder of Horton; and the solemn translation of his body by Dunstan and the alderman Alfhere from Wareham to the conventual church of the nunnery which, originally dedicated to the honour of the Blessed Virgin, soon after appears under the popular designation of St. Edward's. ${ }^{68}$

${ }^{37}$ Leland, Collect. ii, 186 ; iii, $72 . \quad{ }^{39}$ Cart. Antiq. D. 16.

${ }^{99}$ Leland, Itin. ii, 5 I-2.

${ }^{60}$ Tanner, Notitic (ed. 1 744), 105 ; Coker, Particular Surv. of Dorset, 30.

${ }^{61}$ Leland, Collect. i, 82 ; l tin. iii, $72 . \quad{ }^{62}$ Cressy, Church Hist. of Brit. lib. xxviii, cap. ix.

${ }^{63}$ Matt. of Westminster, Flores Hist. (Rolls Ser.), i, 324 .

${ }^{64} \mathrm{OI}$ 'King Edward,' supposed to be the Confessor ; Leland, Collect. i, 82 ; Itin. iii, 72.

${ }^{65}$ Angl.-Sax. Chron. (Rolls Ser.), $121 .{ }^{66}$ Leland, Collect. i, 66 ; iii, $67 .{ }^{67}$ Harl. MS. 61, fol. I.

${ }^{68}$ Angl.-Sax. Chron. (Rolls Ser.), i, 234 ; Wm. of Malmesbury, Gesta Reg. (Rolls Ser.), i, 258 ; Gesta pontif. (Rolls Ser.), 202-3. The relics of the murdered king, who as early as the year 1001 was referred to as 'the Blessed Martyr' (Harl. MS. 61, fol. 1), and whose festival was afterwards kept four times in the year, early attracted crowds of worshippers to his shrine. 


\section{ECCLESIASTICAL HISTORY}

The Domesday Survey of 1086 not only serves to show the ecclesiastical configuration of the county in the eleventh century, but confirms the impression of the wealth and importance already attained by the Church and the monasteries at that time. It has been pointed out that the great and dominant feature in the disposition of Dorset lands as there recorded is that more than a third of the whole county was in ecclesiastical hands at the time the Survey was taken, and that the patrimony of the church was greater than that of all the barons and greater feudatories combined. ${ }^{69}$ Among the seventy-six tenants including the thegns, holding in chief of the king, are entered the names of five bishops, eleven abbots, four abbesses, the community of Sherborne, the chapter of Coutances, and four Saxon priests, whose lands are designated under the title terra elemosinariorum Regis; the abbot of Marmontier, a subfeudatory, is entered under the holding of the earl of Mortain. As regards the estates of the various ecclesiastics, the bishop of Salisbury, besides the nine manors assigned to the use of the monks of Sherborne, ${ }^{70}$ held by right of the bishopric, the manors of Charminster, Alton Pancras, Up Cerne, Yetminster, Beaminster, Netherbury, Chardstock, a carucate of land at Lyme, half an acre at Bridport, two houses in Wareham, one in Dorchester, and other lands obtained in exchange. ${ }^{71}$ Odo, bishop of Bayeux, half-brother of the Conqueror, had as his sole Dorset estate the manor of Rampisham ; ${ }^{72}$ Geoffrey, bishop of Coutances, who for his services at the time of the Conquest had been granted large tracts of land in different counties, held the manor of Winterborne Houghton;' ${ }^{73}$ the bishop of Lisieux, Gilbert Maminot, had the manors of Tarrant Keynston and Coombe Keynes, with a hide of land in Tarrant Preston $;^{7 *}$ the small estate of Maurice, bishop of London, consisted of half a hide of land in Odeham. ${ }^{75}$ The eleven abbots holding in chief include the superiors of Cranborne, Cerne, Milton, Abbotsbury, and Horton, all belonging to this county ; the superiors of Glastonbury, Winchester, Athelney, and Tavistock outside its borders; and the Norman abbots of St. Stephen, Caen, and St. Wandragesil or Fontanel. The four abbesses were the superiors of Shaftesbury (Dorset), Wilton (Wiltshire), Holy Trinity Caen, and St. Mary of Montevillers. The holding of the Dorset religious houses was briefly as follows:-Cranborne held 2 carucates of land in Gillingham, the manors of Boveridge and Up Wimborne, Lestesford, half a hide in Langford, and the manor of Tarrant Monkton ; under the holding of the widow of Ralph Fitz Grip, the Norman sheriff, it is recorded that Hugh gave to the church of St. Mary of Cranborne half a hide of land in Orchard, 'and it is worth 20s.' ; ${ }^{76}$ Cerne held manors or estates at Cerne, Little Puddle, Radipole, Bloxworth, Affpuddle, Poxwell, East Woodsford, Heffleton, 'Vergroh,' Little

${ }^{69}$ R. D. Eyton, Key to Domesday Surv. of Dorset, 156 . Thus, supposing the whole territory of Dorset to be divided into 265 parts, the king held nearly $36 \frac{1}{2}$ such parts, the bishop of Salisbury followed with nearly 26 , the abbess of Shaftesbury had more than 161 , the abbots of Cerne and Milton more than 12 each, the abbot of Abbotsbury more than $7 \frac{1}{2}$; ibid.

${ }^{70}$ These included the manors of Sherborne, Oborne, Thornford, Bradford, Over and Nether Compton, Stalbridge, Weston, Corscombe, and Stoke Abbott.

"Dom. Bk. (Rec. Com.), i, 75-7. From the enumeration of estates in the foundation charter of the cathedral by Bishop Osmond in Iog 1 it is evident that many of the old endowments of the bishopric of Salisbury had passed over into the possession of the church of Sarum ; Reg. of St. Osmund (Rolls Ser.), i, 198.

${ }^{73}$ Dom. Bk. (Rec. Com.), i, 77 . ${ }^{73}$ Ibid. "Ibid. 776 .

${ }^{75}$ Ibid. In the parish of Wimborne which it is conjectured he held in virtue of the deanery; R. D. Eyton, op. cit. I I 3 , note 3 .

${ }^{76}$ Dom. Bk. (Rec. Com.), i, 8 . 


\section{A HISTORY OF DORSET}

Bredy, Winterborne Abbas, Long Bredy, Nettlecombe, Milton, Kimmeridge, Rentscombe, and Symondsbury ; ${ }^{77}$ Milton at Sydling, Milton, Compton Abbas, Cattistock, Puddle, Clyffe, Osmington, Whitcombe, Lyscombe, Woolland, Winterborne Hillfield, Ower, Stockland, Piddletrenthide, and Cerne ; Abbotsbury, the manors of Abbotsbury, Tolpuddle, Hilton, Portisham, 5 virgates of land at Shilvinghampton, $2 \frac{1}{2}$ hides at Wootton Abbas, half a hide in Bourton, and the manor of Stoke Atrum. To the abbey of Horton, besides estates in Devonshire, belonged the manor of Horton, the two best hides of which had been retained by the king in his forest of Wimborne, the little church (ecclesiola) in Wimborne, with the site of two houses, a church in Wareham with five houses paying a rent of $65 \mathrm{~d}$., and a house in Dorchester. ${ }^{78}$ The abbess of Shaftesbury, the largest monastic landowner in the county, besides extensive estates outside Dorset, held here the manors of Handley, Hinton St. Mary, Stour, Fontmell, Compton Abbas, Melbury, Iwerne Minster, Tarrant Hinton, Fifehead, Stoke, and Cheselbourne, with a hide of land at Farnham. ${ }^{79}$ The chapter of Coutances in Normandy held the manor of Winterborne Stickland, which they retained in their possession down to the fourteenth century.

As the object of the Survey was purely fiscal and it did not include within its scope the return of parish churches no clue is afforded as to the number of churches then in existence; even in those instances where a reference to a church occurs, it is almost invariably in connexion with the endowment or lands belonging to it. The names of those actually given are as follows:- the four churches belonging to the Norman abbey of St. Wandragesil, viz. Burton Bradstock, Bridport, Whitchurch Canonicorum and St. Mary Wareham ; ${ }^{80}$ the six entered under the heading terra elemosinariorum Regis: Holy Trinity Dorchester, Bere Regis, Winfrith Newburgh, Puddletown, East Chaldown, and Fleet. ${ }^{81}$ Under the estates of the abbey of Shaftesbury it is recorded that the king gave to the abbess the advowson of the church of Gillingham in exchange for one of the 16 hides of the manor of Kingston, on which he built the castle of Wareham or Corfe. ${ }^{82}$ Besides the brief reference to the collegiate church of Wimborne Minster ${ }^{83}$ the little church (ecclesiola) belonging to the abbey of Horton in Wimborne ${ }^{84}$ must not be forgotten, which, with the church in Wareham, ${ }^{55}$ completes the list.

i7 Dom. Bk. (Rec. Com.), 776,78 .

is As regards superiors outside this county holding land in Dorset, the abbot of Glastonbury held then, and in the time of Edward the Confessor, the manors of Sturminster Newton, Okeford Fitzpaine, Buckland Newton, East Woodyates, Pentridge, and three hides of land in Lyme Regis (ibid. $77 b$ ); the abbot of St. Peter, Winchester, had only the manor of Piddletrenthide (ibid.); the abbot of Athelney (Somerset) the manor of Caundle Purse (ibid. $78 b$ ), still in the possession of the abbey when the Taxatio of Pope Nicholas was taken (Pope Nich. Tax. (Rec. Com.), 185); the abbot of Tavistock the manors of Askerswell and Poorton (ibid.); the Norman abbey of St. Stephen of Caen held the manors of Frampton and Bincombe (ibid.) : and the abbey of St. Wandragesil the churches of Burton Bradstock, Bridport, and Whitchurch Canonicorum, with four hides of land appurtenant thereto, the church of St. Mary, Wareham, with one hide of land (ibid).

${ }^{79}$ Ibid 78 . The abbess of Wilton had the manor of Didlington and $3 \frac{1}{2}$ hides of land in the parish of Wimborne St. Giles (ibid. 79); the abbess of Holy Trinity, Caen, the manor of Tarrant Launceston (ibid.); the abbess of St. Mary of Montevillers the manor of Friar Waddon (ibid.).

${ }^{80} 1$ bid. 786 . $\quad{ }^{81}$ Ibid. $79 . \quad$ Ibid. $7 \$ 6 . \quad{ }^{83}$ Ibid. $75 . \quad$ Ibid. $78 b$.

ss Said to be that of St. Martin; R. D. Eyton, op. cit. 44. Various references to priests imply at least the existence of churches elsewhere ; thus under the survey of the manor of Hinton, which had devolved to the crown through the death of Hugh Fitz Grif, tesides a mention of two priests who had parcels of land in the time of Edward the Confessor, there is incidentally a reference to the priest of the manor, who was probably. the incumbent of Hinton (ibid. 75); while the further entry 'of this land' (the fourteen hides and one virgate 


\section{ECCLESIASTICAL HISTORY}

The addition of Norman and foreign superiors to those monastic bodies already holding property in Dorset marks the great dynastic and political change that had recently taken place, but so far as the older houses are concerned the Survey shows that it had had, with some exceptions ${ }^{86}$ comparatively little effect in the loss or depreciation of their lands; while in the case of Shaftesbury these had greatly risen in value. If the monks of Abbotsbury had reason to complain of the losses they had suffered under Hugh Fitz Grip, late Norman sheriff, and his widow, ${ }^{87}$ and the community at Sherborne reported that William, son of the Conqueror, had seized three virgates of land in their manor of Stalbridge "without the consent of the bishop and the monks,' ${ }^{88}$ the abbess and nuns of Shaftesbury had not forgotten their injuries at the hands of Earl Harold, while they placed on record that the Conqueror had, at least, restored to them the manor of Stour of which they had been deprived by the late earl though he still retained that of Melcombe. ${ }^{89}$

But if the Conquest brought little territorial change to the monastic establishments of the county, the eleventh century witnessed various other changes that had a distinct bearing on the social and ecclesiastical position of Dorset..$^{90}$ An administrative scheme, rendered necessary by the Conqueror's action in separating the secular from the ecclesiastical courts of justice, was the division of the diocese into districts and the appointment of an official hitherto known as the bishop's 'eye,' his deputy or archdeacon, who now became a territorial officer with definite functions, holding courts and presiding over a district for which he was personally responsible to the bishop. The first mention of this newly constituted officer occurs in a copy of that original Institutio Osmundi, contemporary with the foundation charter of the cathedral of Salisbury in rogr, which, in elaborating and explaining the rights and duties of the cathedral dignitaries, orders that the attention of the archdeacon should be specially directed to the "care of parishes and the cure of souls.' ${ }^{21}$ The "Consuetudinary' of the bishop states that in the church of Sarum are four archdeacons, one for Dorset, one for Berkshire, and two for Wiltshire. ${ }^{92}$ To the archdeaconry of Dorset, sometimes called the first (primus) archdeaconry, ${ }^{93}$ was annexed the rectory of Gussage Regis, the valuation of which was assessed in the Taxatio of 1291 at $f_{0} 736 s .8 d^{94}$ The Register of

of Hinton) 'holds another priest living in Tarrant one hide and a third part of a hide,' probably constitutes a reference to the incumbent of a church at Tarrant. A resident priest is mentioned under the manor of Roger de Belmont in Church Knowle (ibid. 80a), and another priest is recorded in the manor of Long Blandford or Langton held by Edwin Venator (ibid. $8+6$ ).

${ }_{66}$ 'The exceptions are notoriously house property in the boroughs. In Shaftesbury, for example, of the 153 houses belonging to the abbess in the time of Edward the Confessor, I I were left at the date the Survey was taken; 42 had been altogether destroyed (ibid. 75 ). In Wareham of 45 houscs standing in the demesne of the abbey of St. Wandragesil 17 were laid waste. The estates of the abbot of Glastonbury are another exception, but the lands of the abbey had recently been in the custody of the crown following the wasteful management of Abbot Thurston. R. W. Eyton, op. cit. 21.

${ }_{97}^{87} \mathrm{Dm} . B k$. (Rec. Com.), i, 78.

90 The transfer of the bishop's seat from Sherborne to O'd Sarum and the removal of the capital from Winchester to London naturally moved this county further away from the centre of activity and tended to place it outside the circle of influence it had once accupied. As regards this diminution of importance it has elsewhere been pointed out (H. J. Moule, Old Drrset, 5I), that in the following centurics the position of Dorset, as compared with the advance of other counties, would more fitly be described as stationary.

$\begin{array}{ll}{ }_{91} \text { Reg. of St. Osmund (Rolls Ser.), i, } 214 . & { }^{92} \text { Ibid. i, 3. } \\ { }_{93} \text { Valor Eccl. (Rec. Com.), ii, 72. } & { }^{91} \text { Pope Nich. Tax. (Rec. Com.), i } 82 b .\end{array}$ 


\section{A HISTORY OF DORSET}

Bishop Osmund records the names of two of the earliest archdeacons of the county, Adam, about the year 1097, and John, about I I 20.95 Adelelm, archdeacon of Dorset, occurs in a charter of Bishop Roger of Salisbury, I $30-35{ }^{96}$ and William witnessed a deed of Bishop Hubert about I 190.97 Later on, in the thirteenth and fourteenth centuries, when the abuse of papal provision was at its height we find the archdeaconry constantly held in succession by Roman cardinals and ecclesiastics.

In passing we may note that the strong wave of monastic feeling and sympathy which swept over the country in the twelfth century left its trace in Dorset in the number of foreign cells and dependent priories which then sprang into existence. The two centuries that elapsed between the Survey of 1086 and the Taxatio of I29 I witnessed the introduction of an alien community at Loders belonging to the abbey of St. Mary of Montebourg; the grant of Povington to the abbey of Bec, Spettisbury and Stour Provost to the abbeys of St. Peter and St. Leger of Préaux, and of Winterborne Monkton to the Cluniac priory of Wast or de Vasto; the Norman abbeys of Tiron and Lyre were also among the ecclesiastical landowners of the county. As regards the older and pre-Conquest foundations, many of the changes brought about in the earlier part of the century were doubtless necessary modifications and adjustments in face of altered circumstances. $^{98}$

For information as to the spread of parish churches and the systematic organization and adjustment of parochial endowments in Dorset in the twelfth and thirteenth centuries one turns again to the Register of St. Osmund, as well as to the collection of deeds and charters relating to the cathedral of Salisbury with their many references to this county, as the most available source. ${ }^{99}$ The foundation charter of Salisbury in 109 I enumerates, among the endowments of the cathedral, the churches of Sherborne, Bere Regis, and St. George of Dorchester, the last generally identified with the church of Fordington which, united with the manor of Writhlington in Somerset, made up a prebend in Sarum. ${ }^{100}$ The parish churches of Yetminster, Alton Pancras, Charminster, Beaminster, and Netherbury, the manors of which were also included among the possessions of the cathedral in $109 \mathrm{I},{ }^{101}$ are afterwards found among the peculiars of the dean and chapter of Salisbury. ${ }^{102}$ The Norman abbot of St. Wandragesil or Fontanel in 1200 released to the chapter the church of Whitchurch Canonicorum, ${ }^{103}$ already in his hands at

9s Jones, Fasti Eccl. Sarisb. 1 37. Le Neve quoting from the same register gives Adam as the first archdeacon of Dorset ; Fasti Eccl. Angl. ii, 637.

${ }_{96}$ Reg. of St. Osmund (Rolls Ser.), i, 349 .

97 Ibid. 241 .

9) Thus Bishop Roger of Salisbury endeavouring to restore the loss of status consequent on the remoral of the see constituted Sherborne into an abbey and annexed to it as a dependent cell the former abbey of Horton, now evidently in a state of decay. The bishop's action in appropriating Abbotsbury to the episcopal see 'as far as he could' does not on the other hand appear to have had a lasting effect [William of Malmesbury, Hist. Novello (Rolls Ser.), ii, 559]. Another modification took place in 1122 when the former abbey of Cranhorne was reduced to a priory and made subordinate to Tewkesbury, of which formerly it had been the head house.

${ }_{99}$ The general scheme of organizing and adjusting the estates of the cathedral church at this period had the effect of adding many more churches to those already held by the cathedral chapter in Dorset.

${ }_{100}$ Reg. of St. Osmund (Rolls Ser.), i, 195.

${ }^{101}$ Ibid.

${ }^{\circ}$ Valor Eccl. (Rec. Com.), i, App. p. 458.

${ }^{03}$ Of the four churches belonging to this Norman abbey in the Domesday Survey two were granted, Whitchurch Canonicorum, and Burton Bradstock by charter of the Conqueror to the abbej" "for the sake of Guntard my chaplain,' monk of the monastery' ; Reg. of St. Osmund (Rolls Ser.), i, 231. 


\section{ECCLESIASTICAL HISTORY}

the time of Domesday, and was granted the prebend of Upavon in the cathedral which entitled him to a stall in the choir and a voice in the cathedral chapter. ${ }^{104}$ The abbot of St. Mary Montebourg, who had a cell at Loders, likewise conveyed to the chapter about the year I 2 I 3 his churches of Powerstock and Fleet, ${ }^{105}$ and in return was allowed to retain the church of Loders and the chapel of Radipole as a prebend in Salisbury. ${ }^{108}$ The church of Sherborne appears from the foundation of the cathedral to have constituted a prebend in Salisbury, held by the abbot in virtue of his office. ${ }^{107}$ A dispute arising early in the thirteenth century respecting the claim of the dean of Salisbury to the church of Frome Whitfield, as attached to his prebend of Charminster, was peaceably settled by an agreement whereby the church itself was annexed to the prebend, but the patronage vested in William de Whitfield, Matilda his wife, and their heirs who, on a vacancy, should present a candidate for institution to the dean and his successors. ${ }^{108}$ By an arrangement in 1225 certain pensions out of the churches of Tarrant Keynston, Combe, Somerford, and Lulworth were reserved to the priory of Merton, the church of Tarrant Keynston at the special request of the prior and canons being assigned to the perpetual use of the nuns of Tarrant, who in return for this grant were charged to offer special prayers every Sunday for the brethren of Merton as for their benefactors. ${ }^{109}$ In 1224 the church of Bishop's Caundle was made over to the ordinary by the prior and canons of Breamore. ${ }^{110}$ The churches of Stourpaine and Burstock were placed by the prior and convent of Christchurch (Twyneham) in I 244 at the disposition of the bishop who the following year ordained that the church of Fleet, previously resigned by the abbot of St. Mary Montebourg, should be appropriated to the convent of Christchurch, the church of Stourpaine to the chapter of Salisbury, while the church of Burstock was assigned to the maintenance of the bridge at Salisbury, all three churches being made exempt from the jurisdiction of the ordinary and the archdeacon, the bishop in his deed stipulating that they should be 'honestly' and fitly served and the cure of souls in no way neglected. ${ }^{111}$

With reference to the question of parochial endowments, instances are not wanting to illustrate the liberty of large landowners to bestow tithes of their lands at will on one place or another. A deed of Ralph de St. Leger about the year I2I7 recites that he has granted to Roger, chaplain of Petersham, within the parish of Wimborne, his oratory or free chapel of Todber, together with all tithes of his demesne \&c., as an endowment. ${ }^{112}$ Sir Bartholomew de Turbervill, by deed in 1242 , attached all tithes of his demesne at Winterborne Turberville, which he declared had been always bestowed by his ancestors and himself on whomsoever they desired, to the prebend of Charminster and Bere Regis, in consideration of which grant he obtained a licence for a private chantry or chapel for the use of himself, his household

${ }^{104}$ Reg. of St. Osmund (Rolls Ser.), i, $7 \mathbf{1}$.

105 Ibid. i, 225.

${ }^{106}$ Ibid. $\mathrm{i}, 226$. The abbot of Bec, to whose abbey belonged a small cell at Povington reckoned as parcel of the priory of Ogbourne (Wilts.), held the prebend of Ogbourne constituted in the cathedral by Bishop le Poor in 1208 ; ibid. i, 189.

107 Ibid. 249.

109 Ibid. 255 .

${ }^{109}$ Ibid. ii, 26.

${ }^{110}$ Sarum Chart. and Doc. (Rolls Ser.), 163-6.

11 The canons of Christchurch were ordered to pay the sum of a mark yearly to the archdeacon of Dorset by way of compensation for the loss of jurisdiction involving dues; ibid. $291-3$.

${ }^{112}$ Ibid. 81. 


\section{A HISTORY OF DORSET}

and guests, and his heirs, to be served by a perpetual chaplain. ${ }^{113}$ Perhaps the most interesting case of voluntary endowment was the one confirmed by Bishop Richard le Poor in 1218 , wherein seven parishioners of Mosterton bestowed various gifts of land for the establishment and maintenance of a chaplain who, with the consent of the rector of South Perrott, should make personal residence and serve a chapel there. ${ }^{114}$ With the growth of parish churches there were springing up through the thirteenth century these dependent chapels whose claims impinging on parochial rights required constant readjustment, and were the cause of so many of the ecclesiastical disputes in the succeeding century. ${ }^{115}$

During this period of parochial organization which marks the thirteenth century, the ordination of vicarages was not neglected. The practice which came into vogue after the Conquest of granting the presentation of churches and alienating the tithes to cathedral and monastic bodies had as a consequence lowered incumbents from the position of rectors, which they enjoyed in primitive times, to that of curates forced to content themselves with whatever remuneration they might be allowed. Various attempts were made to counteract this evil, which in addition left the spiritual needs of the parishioners at the mercy of rectors with whom their importance was not always paramount. In I 200 the council of Westminster directed that every vicar should be instituted by the bishop to whom he should be responsible for the discharge of his duties, and that he should be provided with a sufficient competence from the issues of the church. ${ }^{116}$ The vicar's income in addition to a competent manse was usually reckoned at about a third of the total profits. The rector took the great tithe, viz., of corn, and the incidental charges such as synodals, and the archdeacon's fees were usually arranged between the rector and the vicar in proportion to their respective portions. An early instance of care in defining precisely the portion that should be assigned to the vicar occurs in a deed appropriating to the abbey of Sherborne the churches of Stalbridge and Stoke Abbott in I I9I. The vicar of Stalbridge, according to this ordination, was to have all that estate (tenementum) which Sewale had of the estate of the said church and all things pertaining to the church save the free land and those tithes, viz., of sheaves as well as small tithes, which should be assigned to the use of the sacrist of Sherborne; in addition he should have free pasture and a horse and four beasts in the pasture of the abbot's demesne and should sustain all episcopal dues. The vicar of Stoke Abbott should have all things pertaining to the church which Gerrud used to have and should sustain all episcopal dues likewise; the remainder of the issues were to be assigned to the clothing of the monks of Sherborne. ${ }^{117}$ The dean and cathedral chapter confirmed the ordination of the vicarage of Fordington made by Lawrence of Saint

${ }^{113}$ Sarum Chart. and Doc. (Rolls Ser.), 278-80.

114 Ibid. $82-3$.

115 In some instances these chapels became further endowed and were eventually erected into parish churches, but after the Black Death they frequently became too impoverished to support a chaplain, and sank into disuse.

${ }^{116}$ The council of Oxford laid down the principle of providing a sufficient income, irrespective of the actual value of a benefice, by decreeing that the vicar's stipend should not amount to less than 5 marks, except in Wales. Wilkins, Concilia, i, 587 .

117 Sarum Chart. and Doc. (Rolls Ser.), 49. In I 238 the abbot and convent of Sherborne resigned to Bishop Robert Bingham of Salisbury and the chapter the appropriation of these two churches of Stalbridge and Stoke Abbott, reserving to themselves the advowson and certain issues; ibid. $2+8-9$. 


\section{ECCLESIASTICAL HISTORY}

Nicholas, canon of Salisbury, in 1222, wherein was assigned to Robert de Dorchester, chaplain, perpetual vicar, all obventions of the altar and cemetery of the church, all small tithes, and the sum of $24 s$. I $d$. to be annually paid by the tenants of the said church; to the canon and to his successors were assigned all sheaves of whatever kind of grain and wherever sown. The vicar was bound to serve the church personally and at his own expense, and to bear all charges incumbent on the vicarage. ${ }^{118}$ The endowment of the vicarage of Alton Pancras was fixed in $1227,{ }^{119}$ the ordination of the vicarage of Whitchurch, the church of which was appropriated to the chapters of Salisbury and Wells, in I 240 ; the vicar of the latter was charged to find a chaplain and clerk to serve the dependent chapels of Stanton and Chideock and another chaplain and clerk for the chapel of Marshwood, and the ordination included the appointment of a chaplain to celebrate daily in the church for the benefactors and faithful departed of both cathedral chapters, and the assignment of a certain portion of tithes for his maintenance. ${ }^{120}$ The chapter of Salisbury in 1242 confirmed the endowment of the vicarage of Bere Regis by Robert de Lexinton, canon of Salisbury, who by deed notified that he had granted to John de Dorchester, chaplain, the whole altarage of the church of Bere Regis and the chapel of Winterborne Regis with tithes of wool and lambs, and all small tithes and oblations, together with a messuage and two acres of land in the town of Bere Regis, which William the vicar had held in the name of a perpetual vicarage, reserving to himself and his successors all tithes of corn, hay and mills, with all the oblations of 'Windebyre' on the feast of the Nativity of the B.V.M. and the sum of 6 marks to be annually received in equal portions at the four terms. ${ }^{121}$ In 1255 the vicarage of the church of Powerstock with the ordination of its endowment was granted by the cathedral of Salisbury to Roger de Mere, chaplain, who as vicar was charged with all expenses incumbent on the dean and chapter for the said church and its chapels in keeping the roof of the chancel in repair, and in providing books, vestments, and other necessaries for divine service, as well as with the annual payment of a mark to the abbot and convent of Cerne for the chapel of Milton in virtue of a former composition between the abbey and the chapter of Salisbury. ${ }^{122}$ It will be noted that as a rule these early examples of ordination of vicarages relate to churches in the possession of the cathedral church of the diocese, but they may be accepted as fairly typical of the work then going forward in regulating and systematizing parochial endowments generally.

The work of two centuries seems fitly crowned by that compilation of church property known as the taxation of Pope Nicholas IV which marks the close of the thirteenth century, and from it may be gathered a fairly comprehensive picture of the ecclesiastical organization of the county as it was then complete. Within the archdeaconry of Dorset, divided into the five deaneries of Shaftesbury, Pimperne, Whitchurch, Dorchester, and Bridport, ${ }^{123}$ are recorded the names of 17 I churches exclusive

${ }^{118}$ Reg. of St. Osmund (Rolls Ser.), i, 322.

120 Sarum Chart. and Doc. (Rolls Ser.), 261-6.

121 Ibid. 277.

${ }_{123}$ Though rural deans are frequently mentioned in the ecclesiastical councils of the twelfth century (Wilkins, Concil. i, 388, 502, 505), the date when the territorial limits of the deaneries were fixed is uncertain. 


\section{A HISTORY OF DORSET}

of Wimborne Minster, which constituted a deanery in itself. ${ }^{124}$ The value of the spiritual property of the church in Dorset was assessed at $f_{0} \mathrm{r}, 4 \mathrm{I} 8 \mathrm{I} 6 s .5^{d}$., ${ }^{125}$ the temporalities were valued at $f_{0} \mathrm{I}, 929$ os. $8 \frac{1}{4} d .^{126}$ None of the benefices were of any great value, only nine amounted to $f_{0} 20$ or more, thirty-seven were under $£_{5} 5$ a year with one not reckoned at all; among the prebends Sherborne was assessed at $f_{0} 40 .{ }^{127}$ Twelve other vicarages are recorded in addition to those vicarages established in connexion with these churches prebendal to Salisbury: Sturminster Newton in the deanery of Shaftesbury, the church of which was appropriated to the abbey of Glastonbury; Blandford Forum appropriated to the priory of Christchurch, Cranborne to Tewkesbury, Horton to Sherborne in the deanery of Pimperne; Canford appropriated to the priory of Bradenstoke, Sturminster Marshall to the hospital of St. Giles of Pont Adomar, Puddletown to the priory of Christchurch, Dewlish belonging to Tewkesbury and the vicarage of Buckland, all in the Whitchurch deanery ; in the deanery of Dorchester there was the vicarage of Coombe Keynes; and the vicarages of Portisham and Abbotsbury, the churches of which belonged to the abbey of Abbotsbury, in the Bridport deanery. Of the twelve, Sturminster Marshall, valued at $\oint_{0} 20$, was the richest, Sturminster Newton came next valued at $f_{0} 10$, Canford was assessed at $f_{0} 6 \mathrm{I}_{3} 3^{s} 4 d$., Horton, Puddletown and Dewlish were worth $\oint_{0} 5$ a year, Cranborne and. Buckland, the poorest, $£_{0} 46 \mathrm{~s} .8 \mathrm{~d}$. As regards chapels, at that period to be found annexed to nearly all large churches, ${ }^{128}$ the following are amongst those entered by name: Hinton St. Mary, in the parish of Iwerne Minster, and Wimborne St. Giles, now parochial churches; Charlton Marshall annexed to the rectory of Spettisbury ; Studland now a rectory and parish church; Broadway now a rectory annexed to Bincombe; St. Aldhelm's chapel, Burton Bradstock, and Little Bredy now erected into parish churches.

The blight even at that time affecting the spiritual side of monasticism, and the practical restraint placed on religious endowments on a large scale by the statute of Mortmain, are the causes no doubt that contributed to the particular form adopted by the pious donor of the thirteenth century for the expression of his devotional feelings. Instead of erecting fresh monasteries he endowed chapels attached to existing churches with priests to sing masses for his soul, the souls of his family and all the faithful departed. As the practice of endowing such memorial chapels or chantries spread the ranks of the beneficed clergy, in addition to the parochial chaplains, became further reinforced by the chantry priests to be found in all churches of any size officiating side by side with the parish priests. The conventual churches of the monasteries generally, and in Dorset of the Benedictine houses in particular, lent themselves readily to this development, and the popular nature of it as a means of religious expression is evidenced by its growth during the centuries that preceded and led up to its abolition. The trend of religious feeling may be clearly traced from the foundation of the earlier chantries, ordained simply for the performance

124 Under the deanery of Shaftesbury 32 churches are recorded, 3 I under Pimperne, 38 under Whitchurch, 4 I under Dorchester, 29 under Bridport; Pope Nich. Tax. (Rec. Com.), 177-80.

125 Ibid. 180.

${ }^{198}$ Gillingham with its numerous chapels is a striking example. 


\section{ECCLESIASTICAL HISTORY}

of prayers and masses for the benefit of the donor and his family, and friends, combined in most instances with almsgiving, and the establishment of such a chantry as that founded by the countess of Richmond and Derby in Wimborne Minster, in the early sixteenth century, when education was beginning to be part of the popular religious creed, to which was appointed a priest 'ther to kepe continuall residence and teche frely gramer to all them that will come thereunto.' Of the number of these memorial chapels the return furnished by the commissioners of Henry VIII and Edward VI in the sixteenth century furnishes but a slight idea. Most of those connected with the monasteries appear to have vanished at the Dissolution, of the ten or a dozen founded in Shaftesbury Abbey, for instance, only three are given in the return; and it is equally certain that many had ceased previously, owing to the difficulty in maintaining them during the financial difficulties of the fourteenth and fifteenth centuries.

In spite of the advance in ecclesiastical organization the episcopal registers, the series of which commence on the eve of the twelfth century, show a considerable amount of neglect and irregularity then prevalent in the diocese: churches so defective that Bishop Simon of Ghent in a letter addressed to all his archdeacons in October, I 299, after a recent visitation, remarks a year's income would hardly suffice to cover the cost of their repair; want of books, ornaments, and other necessaries for the celebration of divine service; absentee rectors and vicars, incumbents who had neglected to take higher orders, benefices held in plurality and in the possession of those who could show no title. ${ }^{129}$ Measures were in the first instance taken with regard to those fabrics that had not yet been dedicated, and in 1298 , soon after his promotion to the see, Bishop Simon wrote to the locum tenens of the dean of Salisbury calling his attention to this matter, citing in particular the church of Lyme Regis, and desiring that all the prebendal churches should be consecrated without delay. ${ }^{130}$ A further examination brought the extensive nature of this neglect into such prominence that the bishop in April, I 302, wrote to the archdeacon of Dorset, ordering him to institute a special inquiry into the circumstances of those churches still unconsecrated, of which he had heard an inordinate number (effrenatam multitudinem) still remained in the archdeaconry, and to warn all rectors and vicars; ${ }^{131}$ this order was followed by a commission to the archdeacon's official directing him or the dean of Shaftesbury to summon the rectors of the following churches to provide everything necessary for the consecration of the edifices at the dates fixed in the inclosed schedule: Stour Provost on the Friday after the Feast of St. James the Apostle, Manston the Sunday following, Iwerne Courtney, Okeford, Stoke Wake, Bishop's Caundle, and Pulham on the days immediately succeeding as should be most convenient. ${ }^{132}$ The

${ }^{129}$ Sarum Epis. Reg. Simon of Ghent, fol. 23. In regard to the care of churchyards and cemeteries, regulations for which were passed in the thirteenth century, the bishop in 1311 wrote to the dean of Shaftesbury denouncing the rough games and sports that were allowed in the inclosure (atrium) round the conventual church of Shaftesbury, and the pasturing of animals turned in to graze "where the bodies of the faithful rest,' desiring that such practices should be put a stop to, and all neighbouring rectors and vicars warned to proclaim their abolition; ibid. fol. 134.

${ }_{130}$ Jbid. fol. $5 d$.

${ }^{131}$ Ibid. fol. 22. This refers, probably in every case, to re-consecration necessitated by structural alterations, and does not imply that the churches had not been duly dedicated at the time of their erection.

${ }^{132} 1$ bid. 


\section{A HISTORY. OF DORSET}

early part of the fourteenth century was probably marked by much activity in the building, or more probably the rebuilding on a larger scale, of churches in this county; of the fifty-three dedicated by Robert Petyt, bishop of Enaghdun, ${ }^{133}$ in 1326 , by authority of the diocesan, by far the greater number were in Dorset. ${ }^{134}$

As regards non-residence, the practice so frequently noted of granting licences to incumbents to absent themselves for purposes of study did much to nullify the earnest efforts of Simon of Ghent and his successors to enforce personal residence on the clergy $;^{135}$ nevertheless, it must be remembered that the carelessness of patrons as to the age and qualifications of the candidates they presented for institution rendered such a measure the best guarantee for the spiritual welfare of parishioners that the ordinary could perhaps at that time enforce. ${ }^{136}$ Another element of disorder was to be found in the increasing demands of Rome and the abuse then generally rampant of papal provision. That the bishops were keenly alive to these contributive causes is evident from various records in their registers. After a meeting of the chapter at Salisbury, i 8 March, I326, at which the bishop, dean, and others were present, a letter was addressed to Pope John XXII by Bishop Mortival, in which he stated that though there were in the church of Salisbury forty-one prebends, four dignities, four archdeaconries, and the sub-deanery to which he had the original right of collation, there were, nevertheless, at that time a dean, an archdeacon, and six prebendaries who had been appointed by the late pope, while the precentor, treasurer, one archdeacon, and seventeen prebendaries held their offices by provision of the present pope; that hardly more than three out of that whole number ever resided in Salisbury, and finally that there were no less than eight who were waiting for vacancies, having been appointed as canons with the right

${ }^{133}$ Both Simon of Ghent and Roger de Mortival made use of suffragans to assist them in their diocesan duties, especially in such offices as the dedication of churches and altars, the reconciliation of churches, \&c., which required the personal services of a bishop. The institutions of Bishop Simon in particular witness the bishop's readiness to grant a coadjutor to the parochial clergy in the case of sickness and disablement.

${ }^{134}$ The list includes the following: Wimborne St. Giles, Horton, Edmondsham, Winterborne Vyshath, Winterborne Tomson, Cheselbourne, Turners Puddle, Milborne, Ringstead, Poxwell, Winterborne Abbas, Winterborne Steepleton, Little Bredy, Tyneham, Chaldon Boy's, Ham-by-Sturminster, Fifehead, Stafford, Bincombe, Stour Provost, All Saints Dorchester, Frome Whitfield, St. John Shaftesbury, Moreton, Povington, Minterne, Up Cerne, Batcombe, Yetminster, Ryme Intrinseca. Evershot, Stockwood, Pulham, Bishop's Caundle, Caundle Haddon, Fifehead, 'Tarrant-Abbates, Stower Wake, Stower IWeston,' Gillingham, Caundle Purse, and Rampisham [Ibid. Mortival, ii, fol. 185]. One of the first acts of Bishop Mortival on his promotion to Salisbury in 1315 was to issue a commission for the dedication of altars [Ibid. fol. 1]. In I 317 he granted letters of indulgence for the altar in the conventual church of Shaftesbury, rebuilt and dedicated in honour of St. Mary and St. Edward, king and martyr. [Ibid].

${ }^{135}$ Bishop Simon in $\mathbf{I} 30 \mathrm{r}$ addressed a letter to his archdeacons bidding them summon all absent rectors and vicars to make personal residence, understanding that many were at that time absent without licence [Ibid. fol. 17]. His successor, Mortival, wrote in December, I319, to the archdeacon of Dorset denouncing all such incumbents as let their churches to farm, and did not make personal residence, desiring that their names should be sent in to him by a fixed date [1bid. Mortival, lib. ii, fol. 95d]. Bishop Wyville, in March, $13+3$, forwarded to the archdeacon a schedule with list of offenders who were to be summoned to appear before the bishop or his commissary in the prebendal church of Chardstock the next law day after the Feast of St. Edward, king and martyr, a strict inquiry was to be made into the issues of their churches which were to be sequestered, care being taken that the services of the church should not be neglected [Ibid. Wyville, lib. i]. After the losses and disorder occasioned by the Black Death the abuse of non-residence increased rather than diminished.

${ }^{136}$ Licence to let his church to farm for the purpose of study being only in acolyte's orders was granted to the rector of 'Bentfeld' in 1316 ; ibid. Mortival, ii, fol. 31 d. 


\section{ECCLESIASTICAL HISTORY}

of succeeding to prebends as they became void. ${ }^{137}$ For instances of this particular abuse in Dorset we need go no further than the archdeaconry. The papal registers record a faculty granted by Alexander IV in 1258 to the bishop of Salisbury to give the archdeaconry of Dorset, held by Martin Jordan, vice-chancellor of the Roman Church and notary apostolic, to Simon de Bridport, canon of Salisbury, or any other person by the consent of the said Jordan so soon as he shall have obtained a prebend of Salisbury to the value of 150 marks. ${ }^{139}$ Six years later this same Jordan, cardinal of Sts. Cosmos and Damian, and archdeacon of Dorset, received from Pope Urban IV a grant of one of the 'fattest' prebends of Salisbury 'if one is vacant, and if not the reservation of one.' ${ }^{\prime 39}$ In I 300 the then archdeacon, Henry de Bluntesdon, received at the king's request a dispensation to retain the archdeaconry of Dorset, to which was annexed the church of Gussage All Saints, with the churches of Grittleton, Wootton Bassett, Hannington, Runwell, and Middleton in the dioceses of Salisbury, London, and York, which he had obtained without licence since the council of Lyons, together with canonries and prebends of Salisbury, Wells, Chichester, and St. Paul's London. ${ }^{1 * 0}$ Bertrand d'Eux, cardinal of St. Mark's, obtained in I 347 an indult to visit his archdeaconry of 'Dorchester' (Dorset) by deputy for five years, and to receive procuration not exceeding 30 silver tournois a day. ${ }^{141}$ The intrusion of these Roman ecclesiastics into English benefices was anything but welcome, ${ }^{162}$ and a brawl arose towards the close of the same year on the occasion of the appointment of another cardinal to the treasurership of the cathedral; Thomas Hotoft, with other citizens of Salisbury and armed accomplices, upholding the claim of the then holder of the prebend, John de Breydon, attacked the sub-executor and proctor of the cardinal, saying they should lose their heads, and according to the report would have actually killed them had they not been restrained by one of the canons and one of the vicars. ${ }^{14}$ In 1373 Robert of Geneva, cardinal of the Twelve Apostles, bishop of Tironane, and afterwards anti-Pope Clement VII, received as sub-dean of York and archdeacon of Dorset an indult to visit his archdeaconry by deputy for five years. ${ }^{145}$ The office was held by the cardinal of Naples about the year I 379, the king in June of the following year granting a licence for any of the king's lieges to become the proctors of the cardinal of Naples and receive the profits of his archdeaconry of 'Dorchester,' the treasurership of Salisbury Cathedral, and prebend of Erpingham in Lincoln. ${ }^{155}$ In I 410 John Mackworth, then in possession of the Dorset archdeaconry, obtained a dispensation to hold that office with the archdeaconry of Norfolk, in respect of which he was already litigating in the apostolic palace, 'if he should win it.' ${ }^{1+6}$ The claims of the apostolic see,

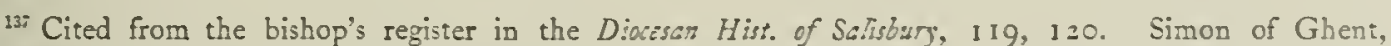
Mortival's predecessor, at first refused to admit Rermund, a Roman cardinal to the office of the dean, to which he had been provided, on the ground that election to the same belonged to the chapter, and issued monitions to various of the cathedral dignitaries to make residence; itid. $11 \%$.
${ }_{13}$ Cal. Pop. Letters, i, $j ; 6-i$.
14) Ibid. i, 5 SS.
1s9 Ibid. i, $4 \mathrm{I}$ I.
${ }^{141}$ Ibid. iii, 255.

${ }_{14}$ An entry in the fatent rolls of $13+7$ (21 Edw. III, Ft. 1, m. 35) records that letters of frotection were obtained from the king for Master Robert de Redrnges, froctor of Berisand, cardinal of the holy Roman Church and archdeacon of Dorset, an alien, and for his fellows.

${ }_{143}$ Cal. Pap. Letits, iii, 255 . ${ }_{14}$ Ibid. ir, ISS. Pat. 3 Ric. II, pt. 3 , m. 4.

${ }_{145}$ Cal. Pap. Lexirs, ri, 211 . Mackworth afterwards became dean of Lincoln, where he froved a veritable frebrand, and inrolred his chafter in almost endless dissension. See V.C.H. Lircs. ii, $\$$ j-6. 


\section{A HISTORY OF DORSET}

which included a right to the reservation of benefices rendered vacant by the death of holders at the Roman Court, frequently led to conflicting appointments and protracted disputes. Thus in 1397 on the death of Adam, cardinal priest of St. Cecilia's, who held the archdeaconry of Dorset by grant of the papal court, the appointment was claimed by two candidates, Nicholas Bubwith provided by the pope, Michael Cergeaux nominated by letters patent of Richard II. ${ }^{147}$ The latter prevailed, but two years later Bubwith again put forward his claim to the archdeaconry, void by the death of Cergeaux or Sergeaux, 'pretended' archdeacon, and was again opposed, this time by Henry Chicheley, who claimed to have obtained the appointment by authority of the ordinary. ${ }^{143}$ A dispute ensued, and the case being referred for trial to John, bishop of Lübeck and papal chaplain and auditor, it was decided on a report that the late Michael had only held the archdeaconry by despoiling Adam, cardinal priest of St. Cecilia's, that neither litigants had any claim. The pope commissioned the judge if he found this to be the case to collate and assign the dignity to Henry Chicheley; he, however, adjudged it to Bubwith; Chicheley appealed without success, but on the strength of his former collation continued to intrude himself still in the archdeaconry, and the pope having imposed perpetual silence on Nicholas extinguished the suit. ${ }^{149}$ In I 403 Nicholas Bubwith was collated to the archdeaconry of Dorset in the place of Henry Chicheley, who had been appointed to the archdeaconry of Sarum the previous year, ${ }^{150}$ and finally became archbishop of Canterbury in I 408. Nicholas Bubwith was in 1406 elected to the see of London by the chapter of St. Paul's in ignorance of the fact that the pope had already made reservation of it for him. ${ }^{151}$ The papal registers throughout this period afford ample evidence of the extent to which papal provision was carried in this county as elsewhere. The prebends in the conventual church of Shaftesbury continually fell a prey to Roman usurpation, and Fuller instances the archdeaconry of Dorset as a flagrant instance of what, in a characteristic passage, he designates 'the greatest grievance of the land, namely, foreigners holding ecclesiastical benefices.' 152 As for the kindred evil, the holding of benefices in plurality, the royal college and chapel of Wimborne Minster in this county again affords a

${ }_{17}$ Cal. Pap. Letters, v, 82 ; Pat. 20 Ric. II, pt. 1, m. 8. Both were largely beneficed, Bubwith held canonries in Beverley, Lichfield, Ripon, and York, and the rectories of Brington and Naseby in the Lincoln diocese; Cergeaux besides holding the rectory of Harrow was canon of Chichester, Exeter, Howden, Lichfield, and Wells.

${ }^{143}$ Besides the two there appears to have been a third claimant, Walter Medeford, nominated by patent letters of Richard II, 20 Aug. 1397 ; Pat. 2 I Ric. II, pt. I, m. 21.

${ }^{149}$ Cal. Pap. Letiers, v, 206.

${ }^{151}$ Cal. Pap. Letters, vi, 82.

iso Le Nere, Fasti Eccl. Angl. ii, 539.

${ }^{139}$ For at this time [says Fuller], the church of England might say with Israel 'Our inheritance is turned to strangers, our houses to aliens.' Many Italians who knew no more English than the difference between a teston and a shilling, a golden noble and an angel in receiving their rents, had the fattest livings in England by the pope collated upon them. Yea, many great cardinals resident at Rome (those hinges of the church must be greased with English revenues) were possessed of the best prebends and parsonages in the land whence many mischiefs did ensue. First they never preached in their parishes : of such shepherds it could not properly be said that he leaseth the sheep and fecth, who (though taking the title of shepherd upon them) never saw their flock nor set foot on English ground. Secondly, no hospitality was kept for relief of the poor; except they could fill their bellies upon the hard names of their pastors which they could not pronounce.

Yea, the Italians generally farmed out their places to proctors, their own countrymen, who instead of filling the bellies grinded the faces of poor feople; so that what betwixt the Italian hospitality which none could ever see and the Latin service which none could understand the poor English were ill-fed and worse taught. Church Hist. ii, 350-2. 


\section{ECCLESIASTICAL HISTORY}

striking instance. Presentation to the deanery was in the hands of the crown, and as a court appointment was always held by men holding other offices and frequently pursuing secular avocations. ${ }^{163}$

Of the new religious orders in the thirteenth century, to whose example so many bishops turned as a means of rousing the parochial clergy to a more lively sense of their responsibilities, little is heard till the following century. The Franciscans had a house at Dorchester founded according to Tanner by the ancestors of Sir John Chideock, but no reference to it occurs earlier than the reign of Edward II. ${ }^{154}$ Entries in the episcopal registers of Ghent and Mortival show that the friars were already making their presence felt throughout the diocese, ${ }^{255}$ but their most effectual work in this county was due to the Dominicans, whose establishment at Melcombe Regis deserves special attention. The twin boroughs of Weymouth and Melcombe, composing the modern town of Weymouth, were at that time served respectively by the mother churches of Wyke Regis and Radipole in the parishes of which each lay. The register of Bishop Simon of Ghent records various unsuccessful attempts on the part of certain parishioners of Melcombe to obtain parochial rights for a chapel, to the detriment, it was complained, of the mother church of Radipole, ${ }^{166}$ and Bishop Mortival in $\mathrm{I} 32 \mathrm{I}$, granting an indulgence of thirty days for the parishioners of Wyke who should attend their parish church on Sundays and feast days, mentions a complaint that certain of the inhabitants were in the habit of attending a chapel at Weymouth ${ }^{257}$ to the obvious injury of the said parish church.

As time went on, and the importance of those two outlying districts increased there seems to have been-particularly on the part of the Melcombe parishioners-a constant struggle to obtain a right to a place of worship of their own, which was as often defeated by the authorities. The Dominicans in the meantime settled at Melcombe and a return made on 18 November, I 425, by John Morton, commissary and sequestrator-general to the bishop, respecting the erection of an altar at Melcombe Regis in a place 'profane and inhonest' without the consent or authority of the ordinary, stated that the said altar had been erected for the celebration of mass by Edward Poliny and John Lok of the order of friars preachers, and that many of the inhabitants of Weymouth had assisted in its erection. For some reason not stated the friars thought fit to disregard the bishop's citation to appear before him or his commissary on the 2 Ist of that month to explain their action, and

153 Thus Martin de Patishull, appointed to the deanery in 1223 , besides holding various ecclesiastical appointments, was a justice of the King's Bench, a justice itinerant and constantly employed as a judge. His successor, Randolf Brito, was in the year of his presentation to Wimborne appointed constable of Colchester Castle and warden of the ports of Essex (Pat. I 3 Hen. III, m. 9). The deanery of Wimborne is not even mentioned in the list given by Matthew Paris (Cbron. Maj.) of the many offices held by John Mansel appointed in 1247. In the case of John de Kirkeby, who had recommended himself to the court by his successful methods of collecting subsidies and taxes, Archbishop Peckham annulled his election to Rochester in 1285 on the ground of his notorious pluralism; Reg. Epist. Peckham (Rolls Ser.), ii, 575. He appears to have held the deanery from 1265 , while only in deacon's orders, being ordained priest the day before his consecration to Ely in 1286 [ibid. iii, App. 2, p. IO4I]. Down to the suppression of the college under Edward VI 'the little deanery' was frequently one of the main links connecting this county with current political events and personages outside its borders.

154 Tanner, Notitia, Dorset, $\mathbf{x}$.

${ }^{155}$ The bishop in a letter to the archdeacon of Dorset in 1319 directed the names of all friars of the Franciscan and Dominican orders and of the order of the hermits of St. Augustine to be submitted to him before being licensed to hear confessions, and to absolve. Sarum Epis. Reg. Mortival, ii, fol. 94.

${ }^{156}$ Ibld. Simon of Ghent, fol. 7 d. 35 d. 37 .

157 Ibid. Mortival, ii, fol. 125. 


\section{A HISTORY OF DORSET}

among the last entries of Bishop Chandler, who died the following July, was a notification dated 7 May, I 426, wherein he interdicted Edward Poliny, John Lok, and John Lowyer, of the order of mendicants of St. Dominic, for their contumacy in disobeying his citation, and denounced their conduct in putting up an altar within the limits of the parish church of Radipole, extorting the oblations and devotions of the faithful in Christ flocking to them whom they had callously seduced. It was forbidden either to celebrate or to hear celebration in the place, and all those who had assisted, contrary to the bishop's admonition, were ordered to appear before him to give account of their conduct. ${ }^{158}$ The matter did not end here, for John Roger and Hugh Deveril, knt., and others came forward and stated that 'there was no place dedicated to God in the vill of Melcombe Regis,' that the parish church, distant by a mile and a half away, was not easy of access to the inhabitants of the town, their families, guests, and the merchants who visited the town by land and sea, so that the said inhabitants were notoriously rude and unlearned (valde rudes sint et indocti), that moved by the spirit of piety, and pitying the desolation of the vill they had begun a house for the perpetual habitation of the friars preachers, who bad for no small time given themselves to the service of God and the salvation of men in the place where they laboured. The petitioners further begged the bishop's consideration of the following articles: (I) of the intention of the builders in beginning the work, (2) the fitness of the place to be dedicated as a church, (3) its endowment, (4) the apostolic and regal licence obtained for commencing the foundation, (5) the question whether the house of the friars' preachers could be dedicated without diminution of the episcopal jurisdiction and saving the rights of the parish church. ${ }^{159}$ The registers record no definite reply to this petition, but among the orders celebrated during the rule of Neville are entries stating that Richard, bishop of 'Caten,' held ordinations for the diocesan in the church of the Dominican friars of Melcombe on 22 May, Vigil of Holy Trinity, I 434, and on 25 May, I $437^{160}$

That terrible landmark of the fourteenth century, the visitation of the plague known as the Black Death, acquires a special interest in this county, inasmuch as nearly all contemporary writers are agreed that Dorset was the first district to be attacked, and Melcombe Regis is usually supposed to be the place where the disease first showed itself. 'In the year of Our Lord, I 348 , about the feast of the translation of St. Thomas (7 July), says the author of the Eulogium Historiarum, 'the cruel pestilence, terrible to all future ages, from parts over the sea came to the south coast of England to a port which is called Melcombe in Dorset, and sweeping over the southern districts destroyed innumerable people in Dorset, Devon, and Somerset.' ${ }^{61}$ Judging from the institutions of that time the epidemic did not fully manifest itself till the year had somewhat advanced, when it fell with fatal effect on the county, its ravages being especially marked on the coast where it first showed itself, and in the low-lying districts. One of the earliest victims

15. Sarum Epis. Reg. Chandler, fol. 54, 55. $\quad{ }^{159}$ Ibid. Neville, fol. 34. $\quad{ }^{160}$ Ibid. Orders celebrated.

161 Op. cit. (Rolls Ser.), iii, 213 . The graphic account of Henry Knighton, canon of Leicester, says that at that time a lamentable pest penetrated into those parts nearest the sea by Southampton, and coming to Bristol there died of it as it were all the healthy folk of the town, taken away by sudden death, for few people kept their beds more than two or three days, and some only half a day, before death came to them at the setting of the sun, Leic. Chron. (Rolls Ser.), 61 . 


\section{ECCLESIASTICAL HISTORY}

was the superior of the alien priory of Wareham to whom the king appointed a successor on 4 November, ${ }^{162}$ and by the 18 th the churches of Bridport, Tyneham in Purbeck, Lulworth, and Cerne were all vacant by death of their incumbents. ${ }^{163} \mathrm{~A}$ table of the institutions for Dorset during this period shows that the mortality, beginning in October, was highest during the months of November, December, January, and February. ${ }^{164}$ From 8 October, I 348 , to January, I 349 , the crown, it is said, presented to no less than thirty livings in the diocese of Salisbury, the greater number of which belonged to this county. ${ }^{165}$ In all probability, the regulars suffered no less than the secular clergy, though it is impossible to calculate in the same manner the number swept away. Following the prior of Wareham, the abbot of Abbotsbury was dead before 3 December for on that date the presentation to the vicarage, vacant also by death of the vicar, was in the king's hands by reason of the voidance of the abbey. ${ }^{168}$ The warden of the hospital of St. John, Shaftesbury, fell a victim about the same time; ${ }^{167}$ on 7 February, I 349, John Firth received confirmation of his appointment as abbot of Sherborne. ${ }^{168}$ The second visitation of the plague in ${ }_{13} 6 \mathrm{I}$ was hardly less severe, the list of institutions for the last six months of that year being especially heavy. ${ }^{169}$

The effect of these terrible scourges, accompanied by mortality among the cattle and followed by a scarcity of labour owing to the number of agricultural labourers who died, pressed very heavily on all landowning classes, and especially on the monks, whose difficulties, in the case of those living near the sea, and whose lands adjoined the coast, were much increased by a position which exposed them to inroads from sea marauders and foreign invaders, while their stores were eaten up by defenders sent to repel invasion. ${ }^{170}$ The temporal decline of the monasteries, dating from the great pestilence, reached a climax towards the close of the century, when they sank to a spiritual level from which in a measure they appear to have been rescued before their final disappearance. As regards the local clergy the effect of the loss in their ranks was to accentuate many existing abuses; in the scarcity of priests to fill the places of those swept away scruples as to fitness and capacity had perforce to go by the board. ${ }^{171}$ Licences to study increased in the absence

${ }^{163}$ Orig. R. 22 Edw. III, m. 4 .

${ }^{163}$ Sarum Epis. Reg. Wyville, ii, fol. 90-1 9 I.

${ }^{164}$ Dr. Gasquet, from whom these figures are taken, estimates the number of institutions as follows :Oct. 5, Nov. I 5, Dec. I7, Jan. I6, Feb. I4, Mar. 10, Apr. 4 (The Great Pestilcnce, 79). He reckons the whole number of collations by the bishop in the diocese consisting of the three counties of Dorset, Wilts. and Berks. for the year beginning 25 Mar. 1348 , and ending 25 Mar. 1349 , at no less than 202 , and at 243 for a like period the succeeding year. Ibid. 162. In Dorset it is reckoned that about half the number of benefices became vacant during the whole course of the visitation.

${ }^{163}$ Ibid. 78. Among other collations the patent rolls record the presentation to Blandford (Pat. 22 Edw. III, pt. 3, m. 23), and to Spettisbury on 7 and 10 Dec. 1348 , and on 4 Jan. I 349 (Ibid. m. I I, I6, I 7 ).

166 Sarum Epis. Reg. Wyville, ii, Inst. fol. 192.

167 Ibid. fol. I 93.

169 Ibid. fol. 199.

169 The cause of vacancy is not always stated in the institutions of 1361 , and as exchanges were at that time becoming very general it prevents such an accurate return being given of the number of deaths in that year.

${ }^{170}$ In I 397 Pope Urban VI ordered the church of Tolpuddle to be appropriated to the abbey of Abbotsbury on this account. Cal. Pap. Letters, v, 77.

${ }^{17 t}$ So great, [says Knighton] was the scarcity of priests that many churches were desolate, being without divine offices. Hardly could a chaplain be got under $f_{1} 10$ or 10 marks to minister in any church, and where before a chaplain could be had for 4 or 5 marks, or 2 marks with board, so numerous were priests before the pestilence, now scarce any would accept a vicarage of $£ 20$ or 20 marks. But in a short time there came crowding into orders a multitude of those whose wives had died in the plague, of whom many were illiterate, only able to read after a fashion, and not able to understand what they read. Leic. Chron. (Rolls Ser.), 63. 


\section{A HISTORY OF DORSET}

of a sufficiency of candidates who had attained the requisite orders. Bishop Wyville in a letter to the archdeacon in I 366 refers to a report of the number of absent rectors and vicars in the diocese and particularly in Dorset who let their churches to laymen, religious men ${ }^{172}$ being specially mentioned in this connexion. ${ }^{178}$ Erghum, six years later, noting the neglect of divine service and hospitality and the danger to the souls of parishioners resulting from the practice of absentee incumbents making over their churches to laymen and unfit persons, desired to be certified as to their number in the archdeaconry, the period of absence and the names of those to whom benefices had been let. ${ }^{174}$ Waltham, early in his episcopate, issued an order to his vicar-general in spirituals to enforce residence on the clergy, and punish those who did not comply. ${ }^{175}$ The deaneries of Shaftesbury and Pimperne were visited by the bishop in I 393-4, the chief offences recorded in the list of presentments for the Shaftesbury deanery, visited in the church of Holy Trinity, Shaftesbury, appear to have consisted of moral lapses and the detention of tithes. ${ }^{176}$ Many rural districts never fully recovered from the effect of the pestilence. There was a general fall in parochial endowments, and from the registers rve learn of a number of churches, or moieties of churches, united on account of the insufficiency of the stipend to support an incumbent. ${ }^{177}$ At the same time we find the bishops striving to restrain the 'insatiable rapacity' of the clergy much in the same way as Parliament was endeavouring to put down the demands of the labourers. ${ }^{178}$ Bishop Hallam in a monition (undated) addressed to his sons in general respecting a report of John Rygges, rector of Holy Trinity, Dorchester, that the church of St. Peter in the same town remains unserved denounces the refusal of any chaplain to accept a cure for a competent wage. ${ }^{179}$ Hallam's register contains frequent entries of licences for private oratories, and confronted by the difficulty of obtaining a sufficient supply of well-educated men to meet the growing demand it is evident that the bishops of that period turned for assistance to the use of licensed preachers. ${ }^{180}$

179 i.e. men of the religious orders.

1 is Ibid. Erghum, ii, fol. 8.

175 Ibid. Waltham, fol. I 5 .

${ }^{173}$ Sarum Epis. Reg. Wyville, ii, fol. 225.

177 These include the union of All Saints and St. James, Shaftesbury, in 1424 , the church of All Saints being very much reduced (ibid. Chandler, fol. $4 \mathrm{I}$ d.); the two moieties of Child Okeford on account of poverty (ibid. Neville, ii, fol. 2 d.); the church of Winterborne. Clenston to Winterborne Nicholas in 1436 , the issues being insufficient to maintain two priests (ibid. ii, fol. 42 d.); the rectory of Chaldon Boys to Chaldon Herring in 1446, the issues of Chaldon Boys being insufficient to sustain a rector and the church consequently remaining vacant (ibid. Ayscough, fol. 57); the union of the vicarage of Spettisbury to the

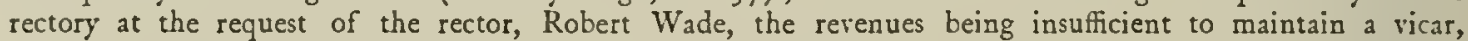
Oct. 1439 (ibid. fol. 69 d.); the church of Puncknowle to that of Bexington in 1431 (ibid. Beauchamp, ii, fol. I I). The chaplain of the chantry in the church of Whitchurch was in 1454 licensed to accept a cure on account of the decay in the issues of the chantry (ibid. fol. 43) the churches of Ringstead and Osmington were united in 1488 (ibid. Langton, fol. 29 d.); the church of Wraxall was on account of its poverty united to the church of Chilfrome in 1503 (ibid. Blyth, fol. I1); the churches of Durweston and Knighton were by the request of the patron, Robert de Fitzhaye, united in 1381 (ibid. Erghum, fol. 44 d.).

${ }_{135}$ IVilkins, Concil. iii, $30,50,135$.

${ }^{179}$ Sarum Epis. Reg. Hallam, fol. ;2. The clergy were denounced by the people for their supposed greed and rapacity, but it should be remembered that they shared the general agricultural distress, and were ground down by the increasing demands of the papal curia and the abuse of papal provision and reservation.

${ }^{160}$ In 1409 , John Possell, prepositus of Oriel College, Oxford, Richard Stabull, vicar of St. Peter in the East, Oxford, John Luke, bachelor of thcology, were licensed to preach throughout the city and diocese of Salisbury ; the following year the bishop granted a similar licence to Walter Bexhampton of Bridport, chaplain; Ibid. pt. ii (Inst.), fol. $4,5,46$. 


\section{ECCLESIASTICAL HISTORY}

The general distress and discontent of the period did much to foster that form of religious activity which marks the later fourteenth and earlier fifteenth centuries. But with signs of a loosened hold on the part of the Church on other rural districts, so far as this county is concerned there is little evidence of any active sympathy with the movement identified with the name of John Wycliff. Prevalent as was Lollardy in other parts of the diocese, at Devizes, Reading, and along the valley of the Thames, it never seems to have taken strong hold of Dorset, and the instances recorded are very few and unimportant. The first that occurs is that of William Ramsbury, whose trial in June, I 389 , was presided over by Robert Regenhill, archdeacon of Dorset ; having been found guilty of heretical views and opinions respecting the sacraments, and confessed that he had openly affirmed and published the same in different parts of the diocese, Blandford, Sturminster, \&c., as well as in secret, he was condemned to make public recantation of his errors in the cathedral of Salisbury. ${ }^{181}$ The fifteenth and early sixteenth centuries, so prolific elsewhere in religious persecution, only produce two further examples in Dorset. On 6 May, I 4 I 4, the official of the dean of Salisbury certified the bishop that in obedience to his commission he had cited Thomas Turle, vicar of the prebendal church of Bere, to appear before the bishop on the IIth inst., in the church of Potterne, to answer the charge of holding heretical opinions requiring correction. ${ }^{182}$ The register of Bishop Blyth in 1516 , amidst various trials for heretical opinion in Wiltshire and Berkshire, records the abjuration of one Michael Gamare, of the parish of Wimborne St. Giles who, 'being easely and lightly suspecte of heresye to you myne ordinarye by the depositions and sayings of certayn witnesses deposying agenst me,' first that he had said

\footnotetext{
it is a lewde thyng and a madde condition or use occupyed in this contree or paryshe that women will come and sette their candles afore a tree, the image of Saynt Gylys, and that it were as good and as myche remedy . . . and they myght as well sette their candles in their pewys setys or upon a chymney and as grete devocion the oon as the other . . . for the very saynte is in hevyn or where it pleasith God and the image of Saynt Gylys is but a stocke or a stone and if the saide image fell doune it wold breke their hedes
}

confessed the above saying to be 'blassemose sclanderose and heresie and he does forsake and abjure ye same.' ${ }^{183}$

The suppression of alien houses in England by decree of the Parliament of Leicester in 1414 brings again to our notice those alien dependencies whose erection here was the feature of the monastic revival in the twelfth century. Their career and the presence of foreign beneficed clergy in Dorset deserves a passing notice. With the loss of Normandy in the succeeding century the prospects of these foreign settlements darkened considerably, and John's action in seizing their possessions among the estates of Norman landowners in England in retaliation for his loss of the duchy ${ }^{184}$ was but an earnest of their fate during the greater part of the remainder of their existence. In truth the position of these alien communities was but a thankless one; placed on the basis of the native clergy and expected to contribute towards royal subsidies and national expenses in times of peace ${ }^{185}$ in war time they were

\footnotetext{
${ }^{181}$ Sarum Epis. Reg. Waltham, ii, fol. 31.

${ }^{183}$ Ibid. Blyth, fol. I $5^{8 .}$

${ }^{185}$ Close 3 Edw. II, m. 5 d. ced. ; 5 Edw. III, pt. I, m. 6 d.

${ }^{169}$ Ibid. Hallam, ii, fol. 16.

${ }^{184}$ Rot. Norman. (ed. Hardy), i, $122-4$.
} 


\section{A HISTORY OF DORSET}

regarded as adherents of the enemy, their goods taken into custody and heavily taxed; they escaped none of the burdens and enjoyed none of the immunities. From the commencement of the Hundred Years' War these foreign cells were, with brief intervals, seized into the hands of the king, who appointed custodians to farm their revenues. It was to the advantage of the head house abroad to get rid of their English dependencies, on as advantageous terms as possible but in any case to rid themselves of what involved merely responsibility, and the chapter of Coutances were fortunate in obtaining a purchaser for their manor of Winterborne Stickland in the earlier part of the French wars. ${ }^{186}$ After a continued course of farming the spiritual duties that attached to these dependent cells became almost lost sight of; at the close of the war the general verdict pronounced that charity and almsgiving had been withdrawn and divine service ceased in the case of the greater number of them, and it cannot be said that the country generally seems to have suffered much spiritual loss by their suppression. In Dorset their number and proximity to the coast, bringing them within easy reach of communication with the enemy, rendered their presence a very lively source of suspicion. The fear of invasion which marked the close of the reign of Edward II is reflected in the register of Bishop Mortival, which at that time teems with entries dealing with precautions for preventing any possible collusion between the foreigners domiciled in the country and the threatening force of invasion. ${ }^{187}$ The return furnished by the bishop of those foreign beneficiaries who were ordered to appear before the council at Westminster and to give security for their good behaviour includes the names of Richard Gouch, rector of Toller Porcorum, Simon Avenel, rector of Winterbourne Stickland, Ralph Moreb, rector of Spettisbury and canon of Salisbury. ${ }^{188}$ In obedience to an order for the removal of certain religious men from their houses near the sea to others further inland, the bishop certified that he had transferred William Pyequier of Frampton and Ralph Pothyn of Loders to the abbey of Sherborne. ${ }^{189}$ The final seizure of the cells and granges of alien houses in Dorset greatly enriched the English foundations to which they were granted as their leases fell in. Thus on its reversion to the crown in I 437 Henry VI bestowed the priory of Frampton in free alms on the dean and canons of St. Stephen of Westminster. ${ }^{190}$ The cell of Loders was made over by Henry $\mathrm{V}$ to the nunnery of Syon (Middlesex) which he had founded, the grant being afterwards confirmed by Henry VI. ${ }^{191}$ Muckleford, as parcel of the alien priory of Andwell (Hants), passed over to Winchester college, ${ }^{1 ! 2}$ Povington to Eton college, ${ }^{193}$ Spettisbury became the property of the Carthusian priory of Witham (Somerset), ${ }^{194}$ Stour Provost, bestowed in the first instance by Henry VI on Eton College, was transferred by Edward IV to the provost and scholars of King's College, Cambridge. ${ }^{195}$ The prior of Wast or de Vasto succeeded in the reign of Edward II in letting his estate at Winterborne Monkton and Bockhampton, and from that time the property remained in the hands of English tenants. ${ }^{196}$ Wareham was granted by Richard II

${ }^{156}$ Pat. 10 Edw. III, pt. 2, m. 8.
${ }^{189}$ Ibid. fol. 240a.
${ }_{190}$ Pat. 6 Hen. VI, pt. I, m. 14.
${ }^{192}$ A. F. Leach, Hist. of Winchester College, x, 144.
${ }^{194}$ Pat. 7 Hen. VI, pt. 1, m. I 3.
${ }^{106}$ Hutchins, Hist. of Dorset, ii, 321 .

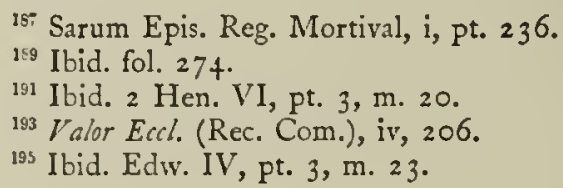

iss Ibid. Edw. IV, pt. 3, m. 23. 


\section{ECCLESIASTICAL HISTORY}

in May, I 399, together with the priories of Hinckley (Leicestershire) and Carisbrooke (Isle of Wight) and all other possessions of the Norman abbey of Lyre in England to the prior and convent of Mountgrace of the Carthusian order. ${ }^{197}$ Though these dependencies of foreign houses are often alluded to as 'reputed' priories, only four of them can be proved to have maintained a religious community.

It is difficult to summarize the religious position of the fifteenth century as it advanced, or rather it requires a summary from more than one point of view. With an inevitable amount of dissatisfaction, and, on the part of the faithful, of discontent with the secular aims that animated most of the bishops and the higher ranks of the clergy, we have still to consider the evidence of the reality and movement of church life and the progress of religious aspiration. The chantries founded at that time and up to the Reformation are perhaps most significant of this advance, for, while the devout remained faithful to the form chosen by an earlier generation for the expression of their religious feelings, the introduction of other objects in their ordination testifies to the spread and growth of the ideal of education and enlightenment as a means to the amelioration of society. Again, indulgences are more frequently granted for purely secular objects. The register of Bishop Ayscough, 1439-50, records an indulgence for those assisting the building of a new haven at Bridport for the safety of merchants and mariners, to further the construction of which all the ecclesiastical authorities of the town banded themselves into a common association. ${ }^{198}$ Neither was diocesan visitation neglected. In January, $\mathrm{I}_{503}$, in the midst of a visitation of the diocese by the bishop's vicar-general in spirituals, Bishop Audley wrote to the deans of Bridport and Shaftesbury respecting the excessive number of those begging alms and attempting to deceive the people by selling indulgences, denouncing all such traffic, forbidding the vendors to be allowed to preach in any of the churches of the above deaneries, and ordering the clergy to be warned against them ; this prohibition was not to apply to the nuncios of the order of St. John of Jerusalem in England. ${ }^{199}$

The religious houses of Dorset appear to have reached their lowest level in the fourteenth century when their condition frequently called for intervention on the part of the king and ordinary and the appointment of custodians. Their poverty, the natural result of the economic pressure of that time, was in many cases greatly enhanced by the bad and inefficient rule of superiors, the effects of which lasted much longer than the actual period over which it extended. The troubles, for instance, of the Cistercian abbey of Bindon, whose history throughout the fourteenth century is one sordid record of debt, disorder, and dissension calculated to lower the tone of any community, came to a climax under the rule of John de Monte Acuto; and his deposition in I 33 I by order of the chapter-general of Citeaux ${ }^{200}$ by no means put an end to the embarrassments his government had done so much to foster. The difficulties again of the abbey of Shaftesbury, the extent of whose property gave rise to the proverb 'if the abbot of Glastonbury could marry the abbess of Shaftesbury their heir would hold more land than the king of England,' ${ }^{201}$ were mainly

${ }_{197}$ Pat. 22 Ric. II, pt. 3, m. IO-I 1.

${ }^{199}$ Ibid. Audley, fol. 114.

${ }^{201}$ Fuller, Church Hist. iii, 332.
${ }^{198}$ Sarum Epis. Reg. Ayscough, fol. 71.

${ }^{200}$ Close, 6 Edw. III, m. $3 d$. 


\section{A HISTORY OF DORSET}

caused by the unwieldiness of a community whose numbers taxed even its resources, and demanded powers of organization and government not always at command.

The absence of visitation reports in the century preceding the Dissolution makes one hesitate to pronounce with any certainty as to the condition of the monasteries in the latter part of their career, but, in spite of the fact that the number of their inmates had undoubtedly fallen, signs are not wanting of renewed vitality and a restoration of discipline and order. The chantries that continued to be founded in their conventual churches testify to the hold they still maintained on the affections of many. As the social and religious ideals of a succeeding age slowly emerged we find schools established in connexion with them, whose value even those engineering the changes of the sixteenth century were forced to recognize. ${ }^{202}$ The Valor Ecclesiasticus with its record of organized almsgiving and round of fixed anniversaries exhibits the monks still faithful to the memory and charitable bequests of their founders and benefactors.

It is interesting to note the shadow of coming events in the appointment of superiors on the eve of the Dissolution. Many appear to have been expressly chosen with a view to their compliance with court schemes, and all were carefully imbued with the idea that liberal treatment would attend due submission. The example of Bindon, the only house in Dorset coming under the earlier Act for the suppression of monasteries under the yearly value of $f_{0} 200,{ }^{203}$ doubtless encouraged a delusion that certain houses might be spared for a consideration. Sir Thomas Arundel wrote to Cromwell on 18 December, 1538 that in spite of representations the abbess of Shaftesbury refused to follow the 'moo' (majority) and yield her abbey, and that she and the abbot of Cerne were prepared to offer 'His Majesty' 500 marks and 'your lordship' £ioo to obtain the continuation of their houses. ${ }^{204}$ It was useless, the stroke that in less than a month should deprive Dorset of her sole remaining links with an historic past, the outward and visible signs of ancient glory departed, fell the March following (1539); Milton, which surrendered on the I I th of that month, was followed by Abbotsbury on the 12th, Tarrant Kaines on the $13^{\text {th }}$, Bindon on the I $4^{\text {th }}$, Sherborne with its dependent cell, the priory of Horton, on the i 8 th, Holme, a dependent cell of Montacute (Somerset), on the 2oth, Shaftesbury, greatest and last of all, ${ }^{205}$ fell on the 23 rd.

The heavy hand of Henry VIII did not stop with the monasteries, and to his successor he bequeathed measures for the suppression of colleges, chantries, gilds, and hospitals which were carried out by Acts I and 2 Edward VI. The commissioners appointed to report on the 'lands, tenements, jewels, plate, goods and stocke' belonging to the colleges \&c. in this county estimated their value at $f_{0} 63 \mathrm{I}$ os. I d., with a deduction in 'rents resolute' of

20: Besides the well-known school at Sherborne and the free school established in connexion with the chantry of the countess of Richmond and Derby in Wimborne Minster, there was a free school founded by William de Middleton, abbot of Milton, which was described as "of good regard and in former times much frequented.' Hutchins, Hist. of Dorset, iv, 396.

${ }^{903}$ Bindon, on the payment of 6300 to the king, was restored by royal letters patent 29 Sept. 1538 , only to fall a few months later with the larger houscs. L. and P. Hen. VIII, xiii (2), I77; xiv (I), 506.

204 Ibid. xiii (2), 1090.

"3) The last with the exception of Cranborne which was surrendered with the abbey of Tewkesbury, j I Jan. I 5 fo. Ibid. $x v,+9$. 


\section{ECCLESIASTICAL HISTORY}

6948 s. $2 d^{200} \quad$ Besides a number of small endowments for the maintenance of lamps, obits, and various services, the foundations surveyed in both certificates relating to Dorset comprise some 25 or 26 chantries, I4 free chapels, 4 gilds or fraternities, ${ }^{207}$ and 9 hospitals. ${ }^{208}$ In many cases reference to the benefits rendered by these foundations gives some idea of what the county was to be deprived on the plea of abolishing the superstitions with which they had unfortunately become associated; the worst to be gathered from the returns is that in a few cases funds had been diverted from the objects originally intended, while on the other hand frequent entries testify to the good work done in connexion with many of the chantries and of the loss occasioned by their destruction. Thus, under the chantry in Netherbury church, the certificate notes a grammar school kept by Martyn Smyth, priest, who received for his stipend $£_{5} 6 \mathrm{~s} .8 d^{209}$ Under Wareham the sum of $f_{.} 8$ constituting the endowment of a free school founded by Sir John Loders, priest, and others in the parish of Milton Tregonwell, was yearly paid to the 'scolemaster for his stipend. ${ }^{210}$ A memorandum states that the free chapel of West Hemsworth was ordained for a schoolmaster to be maintained in Long Blandford. ${ }^{211}$ As regards the hospitals the endowment of that of Allington near Bridport served only to maintain a chaplain, the 'power men' living by alms of the town, ${ }^{212}$ and in the same way the income of St. John Baptist of Bridport, amounting to $\oint_{0} 68 s .9 \frac{1}{2} d$. clear, was assigned to the priest serving it. ${ }^{213}$ The inmates, five poor men, of the hospital of St. John Baptist of Shaftesbury, had to rely for their maintenance on the charity of the inhabitants of the town, the whole of the revenues, consisting of $73^{s}$. $6 d$. yearly, being handed over to the chaplain..$^{214}$

The district on which the confiscation of these endowments fell most heavily was Wimborne; there are several indications of the important part played by the college in the social and ecclesiastical life of the neighbourhood now deprived of the services of four priests and four clerks which the dean and prebendaries were bound to provide to serve the four chapels round: St. Peter's in the town, St. Catherine's of Leigh, St. James at Holt, and St. Stephen's at Kingston. 'Memd.' runs the report of the commissioners

to have 4 priests to serve the cure in the parish of Wimborne because there be 3 chapels wherein there is devyne service which said chapels be distant from the church of Wimborne 3 miles and are for the ease of the people. ${ }^{215}$

There was also the 'schole masters chauntry' of Margaret, countess of Richmond and Derby, in the collegiate church. ${ }^{216}$

${ }^{206}$ Coll and Chant. Cert. xiv, Nos. $1-35$.

${ }^{307}$ The gilds are that of Corpus Christi in Wareham, the fraternity of Our Lady in St. Peter's church, Dorchester, that of St. George in Poole, and St. George in Weymouth.

${ }^{309}$ These were at Allington, Bridport, Dorchester, Shaftesbury, Sherborne, Wimborne, and Wareham.

${ }^{209}$ Ibid. No. 59.

"11 Ibid. No. 115. ${ }^{210}$ Ibid. No. 8 I.

${ }^{213}$ Ibid. No. 62.

${ }^{213}$ Ibid. No. 6r.

${ }^{214}$ Ibid. No. 100 . In the case of Wimborne the alms of the town supplemented the scanty endowment of the hospital which produced only a yearly income of $29 \mathrm{~s} .8 d$., and the rcturn states that the eight poor men 'not only live by the profits of the said house but by the devotion of the people of Wimborne' (ibid. No. 112). The hospital of Sherborne, the last religious house to be erected in Dorset, had by far the richest endowment, out of a clear income of 6315 s. the chaplain received halfycarly f 10 6s. $8 d$., the remainder being assigned to the finding of eleven poor and impotent men and four poor women (ibid. No. 91).

215 Ibid. No. 110.

${ }^{316}$ Ibid. No. 106. 


\section{A HISTORY OF DORSET}

In addition to the suppression of colleges and chantries, which in effect deprived the parochial clergy of the services of a body of assistant chaplains whose services had cost them nothing, the reign of Edward VI was responsible for further changes in the removal of pictures and images from parish churches, the taking down of roods, ${ }^{217}$ the setting up of tables in the place of altars, the whitewashing of the walls of the edifice, the confiscation of vestments and parish plate. That section of the return of the commissioners appointed to take possession of all superfluous church plate for the king's use which relates to chalices has been already dealt with for the county of Dorset. ${ }^{218}$ Of the 265 entries therein contained, 254 relate to parish churches, and eleven to attached chapels. Six of these parishes only had three chalices: Long and Little Bredy, Corscombe, Cranborne, Marnhull, Bradford Abbas and Sturminster Newton; the number having two in use was thirty-five, 204 had one. Eight parishes were entered under 'defaults,' seven of which had sold or otherwise disposed of a chalice, and there was one instance of a chalice being stolen. ${ }^{219}$ As the plague was raging in the county during the proceedings of the commissioners no return was made for Canford, Wimborne Minster and Poole, and an entry explaining this absence states 'ther be no inventories taken by reason of the plague and they have lost ther olde enventories as they have sent us word wher uppon ther ys no newe taken.' According to an earlier inventory specially taken in I 545 Poole made a return of seven chalices; in a second return of the commissioners of Edward VI in I 553 it is stated that there were reserved for the use of the church of Poole one chalice weighing $\mathrm{I} 2 \mathrm{oz}$. and two bells in the town estimated at $6 \mathrm{cwt}$.; the remaining six bells had been sold 'for the makyng of bulworks and dyches for the defence of the saide towne by direction of My Lord's Grace (the Protector Somerset) at his being in Poole.' ${ }^{220}$ Another return of the church goods of Poole in I 559 before the commissioners of Queen Elizabeth reported 'our images be all defaced and brente.' As for the chalices no parish was allowed to retain more than one, and the one left for future parish use was almost invariably the worst or the least. ${ }^{2.1}$

Under Mary there was an attempt to restore the confiscated church goods and in the absence of any settlement with regard to the transactions of Edward VI's commissioners the government issued an order to compel them to render an exact account of their proceedings. Accordingly Sir Giles Strangways ${ }^{222}$ set off for London, the plate and money being sent after him. The plate was delivered at the Tower, and $f_{0} 75$ paid in as part payment of

${ }^{217}$ An entry of a payment of 25 . for 'takyne downe ye rode' occurs under the year 1547 in the churchwardens' accounts of IVimborne Minster.

${ }_{218}$ By Mr. Nightingale in his book, Church Plate of Dorset, from which the following figures are taken.

${ }^{919}$ Mr. Nightingale quotes the following as typical of the church possessions of a Dorset village (it relates to Woolland) in I552 : 'Fyrst, j chalis sylver parcell gylt ; j pyx sylver, j whyte cope of sylke; j whyt rest't" of dornix, $\mathrm{j}$ redd rest ${ }^{\mathrm{mt}}$ of dornix, ij table clothes, iij candlesticks of bras, $\mathrm{j}$ holy water pot bras, $\mathrm{j}$ lyche bell, ii cruets of leade, $j$ surplis, ij crosses of tyn, $j$ saucer of bras, $j$ chasuble of grene, $j$ vest ${ }^{\text {tht }}$ of black velvet. To the use of the Churche.-Appoynted by the said commissioners $j$ chalis, $j$ white cope of sylk $w^{\text {th }}$ all the table clothes and surplices. The residue of all the possessions commytted to the custody of these men whose names be underwrytten, Sir John Whyt, curate, John Hayson, senr., John Hayson, junr., John Carter, Thomas Baker, clias Galpyn. Ibid. Pref. 7 .

290 Ibid. 126.

${ }^{221}$ Mr. Nightingale estimates the number of mediaeval church plate in use before the Reformation and now remaining in Dorset at only three.

${ }^{222}$ The Commissioners appointed in Dorset were Sir Giles Strangways, Sir John Horsey, Sir George de la Ly'nde, and Thomas Trenchard. Later on we find them constantly employed as justices of the peace in trying recusants. 


\section{ECCLESIASTICAL HISTORY}

$f_{1} 3^{2} 5^{s}$. 5 d. for which the ornaments and other church goods in Dorset had been sold, the remaining sum being retained for the expense of conveying the money and plate to London. ${ }^{223}$

Another very material change brought about in the reign of Henry VIII was the removal of this county out of the see of Salisbury and its transference to the new diocese of Bristol, erected by letters patent of 4 June, $1542,{ }^{224}$ under which it remained until the year 1836 , when by an order in council the archdeaconry of Dorset was again united to the Salisbury diocese. During the whole period of its existence under Bristol, however, those churches and prebends belonging to the chapter of Salisbury continued to remain under the peculiar jurisdiction of the dean by whom they were visited, and the records of whose visitations are preserved among the archives of the cathedral. ${ }^{225}$ The injunctions circulated by Bishop Shaxton throughout his diocese in $153^{8}$ give some idea of the parochial ministrations of the clergy on the eve of impending change. They begin with provisions as to non-residents and their curates, directing that no French or Irish priest that could not perfectly speak the English tongue should be allowed to serve as curate. The clergy were charged at high mass to read the Gospel and Epistle in English, and to set out the Royal Supremacy with the usurpations of the bishop of Rome, they were also bidden to preach purely, sincerely and according to the true scriptures of God, and regulations were laid down for the frequent use of sermons in proportion to the value of their livings; as a general rule four sermons were to be preached every year, one in each quarter. No friar was to be permitted to perform any service in the church. The clergy were also required to read a chapter of the New Testament every day, and every person having a cure of souls should be able to repeat without book the gospels of St. Matthew and St. John, and the epistles to the Romans, Galatians, and Corinthians, with the Acts of the Apostles and the canonical epistles. ${ }^{226}$

Probably the first effect of the transference to another see in the midst of other changes was to paralyse church effort and organization for a time ; we find that the services of the chapels attached to Wimborne Minster were not restored till the reign of Elizabeth, and as late as 1577 Sir John Horsey and George Trenchard explained to the Council the difficulty of obtaining information respecting recusants in Dorset, 'as it was uncertain in whose diocese the shire was.' ${ }^{227}$ It is also unfortunate that we have no means of ascertaining definitely how far the personnel of the Dorset clergy was affected by the measures introduced on the accession of Mary in 1 553: ${ }^{228}$ the queen's great Statute of Repeals abolishing the Edwardian Act of I 549, and the 'Injunctions' for the removal of all priests who had availed themselves of the permission to marry granted in the last reign. ${ }^{229}$ Nor when the death of Mary and the accession of Elizabeth set the pendulum of religious opinion swinging in another direction can we find any evidence of the number of clergy deprived for refusing to subscribe to the queen's

${ }^{223}$ Nightingale, Church Plate of Dorset, Pref. p. 8.

${ }_{295}$ Liber Visitotionum Decani.

${ }_{222}$ Burnet, Hist. of the Reformation, iii, $245 . \quad{ }_{227}^{227}$ Cal. S.P. Dom. 1547-80, p. 56 I.

${ }^{229}$ Owing to the destruction of the records at Bristol in the fire of 1831 . W. H. Frere, The Marian Reaction, 32.

${ }_{229}$ It was, however, provided that such priests as consented to put away their wives should, after due penance, be re-admitted to officiate 'so it be not in the same place.' Ibid. 61 . 


\section{A HISTORY OF DORSET}

supremacy, and the Act for the Uniformity of Common Prayer and Administration of the Sacraments which formed the basis of the Elizabethan church settlement. ${ }^{230}$

As regards the state of feeling in the county generally there is no sign that the violent changes brought about by Henry VIII and Edward VI met with the strong disapproval they evoked in Lincolnshire and the north. ${ }^{231}$ At Poole especially, which afterwards distinguished itself as one of the strongholds of Puritan feeling and the Parliamentary party, the accession of Mary was attended by religious feuds between the favourers of the new religion and the adherents of the old faith which were largely fomented by the influence of Thomas Hancock, nominated to the living of Poole in 1546 , through whose preaching the inhabitants of the town became strong partisans of the new party in the Church, and were said to be 'the first that in that parte of England were called Protestantes.' ${ }^{232}$

But in spite of strong Protestant sympathy, specially marked in the towns of Poole and Dorchester, there are tokens of deep though latent and suppressed affection for the old religion, especially on the part of certain families whose loyalty survived all the changes of the sixteenth century and later persecutions. Tacit sympathy with recusancy is exhibited as late as 1591 , when an order was sent to Thomas Husseye and Robert Kennele, esqs., to make inquiry into a report that at the last quarter sessions when the Grand Jury were charged to present recusants and such as refused to come to church secret warning and intelligence was given them not to do this, "according to the revelation of Mr. Coker of Ashe, and Mr. Seymor of Hanford.' ${ }^{2 s s}$ The prevalence of recusancy among the feminine half of the community provoked a query the following year (I 592) as to whether the recusant wives of conforming husbands might be committed to prison and whether their husbands should be 'punishable by any pecuniary paine for that offence of their wives;' the commissioners for the apprehension of recusants in Dorset being directed by the council to forbear committing these ladies ' until Her Majestie has taken the opinion of judges.' 234

At the beginning of Elizabeth's reign, save for the clergy, the Act of Uniformity does not appear to have been rigidly enforced, but the promulgation of the bull of Pope Pius $V$ in I 570 absolving her subjects from their allegiance materially altered conditions and placed Catholic Nonconformity in the light of a dangerous element in the state. In Dorset with the uncertainty ' in whose diocese the shire was,' no convictions were pressed till the year I 582, when an order was sent to Sir John Horsey, knt., and George Trenchard, esq., 'to apprehend and send up one Slade a verie dangerous Papist lurking within the countie of Dorset, and all such superstitious ornaments and tromperie as they can by diligent search find out,' with directions to make search and apprehend from time to time 'anie Jesuit and seminarie priest.' ${ }^{235}$ The examination of John Meere of Dorset, student

${ }^{230}$ Gee, The Elizabethan Clergy, 31 .

${ }^{231}$ It was the fear of being put again under the domination of Rome that was productive of disturbance in 1554 , and in 1557 the authorities were ordered to be fully prepared in the event of a rising. Acts of P.C. (New Ser.), I 556-8, p. 87 .

${ }^{873}$ Hutchins, Hist. of Dorset, $\mathrm{i}, 52$, gives an account of the feuds there.

${ }^{233}$ Acts of P.C. (New Ser.), $1590-1$, p. $358 . \quad{ }^{234}$ Ibid. 1592 , p. 182.

${ }^{233}$ Ibid. 1582 , p. 446 . The Recusancy Roll 37 Eliz. (1 594-5) records that John Slade, late of Manston, gent, was fined $\mathcal{L}_{100}$ for non-attendance at church five months. L.T.R. (Pipe Off. Ser.). 


\section{ECCLESIASTICAL HISTORY}

in the Temple and prisoner in the Fleet, is recorded 23 June, $1585 .{ }^{996}$ In February, 1 586, letters were forwarded to special commissioners in various counties, including Dorset, to enforce a regular assessment of fines for recusancy. ${ }^{237}$ In December, I 591, a commission of inquiry was issued for Jesuits and seminary priests in Dorset, and the following year it was renewed for the purpose of adding to the commission. ${ }^{238}$ In spite of the increasing severity of the penalties inflicted on recusants, it seems evident that their numbers were largely increasing. The first Recusancy roll under Elizabeth, I $59 \mathrm{I}-2$, gives eighty-six names, and indicates pretty clearly the chief centres of Catholic sentiment: Hampreston, the neighbourhood of Wimborne, Corfe, Canford, Swanage, and above all Chideock where the forfeitures of Charles Sturton of Chideock, gent., Dorothea Arundel, Cecilia Arundel, Gertrude Arundel, Elizabeth Chernock, and John Chernock are followed by those of twenty-five retainers, members of the household and tenants. ${ }^{239}$ A list on I October, I 598 , of certain recusants fined $f_{0}$ I 5 each towards the Irish Light Horse gives the names of Lady Sturton, Charles Sturton, esq., Mr. Martin of Athelhampton, Henry Cary of Hamworthy, and Mr. Slade of Mawston (Manston), gent. ${ }^{240}$ The names of most frequent, and in some cases continual, recurrence in the recusancy rolls of the whole of Elizabeth and early part of James I are those of William Gerard of Clerkenwell, who forfeited two parts of the manor of Broadway, William Morecock of Nether Kincombe, Gregory Durdo of Iwerne Minster, Henry Yunge of Wimborne, Henry Cary of Hamworthy, the Stourtons, the Arundels, the Wells, the Lockyers, the Loapes or Loopes of Hampreston, the Martins of Athelhampton, the Goulds of Cranborne and Edmondsham. ${ }^{241}$ The State Papers of James I, under date of 23 December, 1607, record the grant to Lawrence Marbury of the benefit of the recusancy of Elizabeth Wells of Dorset, ${ }^{2.22}$ on 10 January, I608, the grant of the benefit of the recusancy of Mary Gerard, widow ; ${ }^{243}$ on $20 \mathrm{July}, \mathrm{I} 609$, came an order to inquire into the goods of Anne Turberville of Dorset the benefit of whose recusancy was granted to Sir John Cowper. ${ }^{244}$

The chief source of anxiety to the authorities was the position that Catholicism was able to take up in Dorset owing to the support it continued to receive from some of the oldest and most influential families in the county. The chief centre of Catholic leaning in the sixteenth century was at Chideock, the residence of the Arundel family, ${ }^{245}$ who like the Webbs of Canford, and the Welds of Lulworth, remained faithful to the Royalist cause during the later rebellion. ${ }^{246}$ Most of the Popish priests executed during that

${ }^{236}$ Cal. S.P. Dom. $1581-90$, p. 247. ${ }^{237}$ Acts of P.C. (New Ser.), 1586-7, pp. 15, 16.

${ }^{238}$ Cal. S.P. Dom. $1591-t$, pp. $137,212$.

${ }_{279}$ Recus. R. 34 Eliz. Exch. L.T.R. (Pipe Off. Ser.). In 1586 a note of the names of the wives and widows 'who are most obstinate recusants in the county of Bedford' records the name of Elizabeth Charnock, daughter of Sir John Arundel and wife of John Charnock. Cal. S.P. Dom. 1581-90, p. 376.

${ }_{240}$ Acts of P.C. (New Ser.), $1598-9$, p. 203.

${ }^{242}$ Cal. S.P. Dom. $1603-10$, p. 395. ${ }_{2+1}$ Recus. R. Exch. L.T.R. (Pipe Off. Ser), 1-14. 243 Ibid. ${ }^{244}$ Ibid. 530.

${ }^{245}$ Chideock came into the hands of the Arundel family in the reign of Henry VII by the marriage of Katherine Chideock, youngest daughter of Sir John Chideock and last of the family, to Sir John Arundel, of Lanherne (Foley, Rec. of Engl. Province of S.J. Jiii, 426).

${ }^{246}$ Chideock Castle fell alternately into the hands of the Royalist and Parliamentary party during the Civil War. According to Hutchins (Hist. of Dorset, ii, 259) it was at last taken in $16+5$ by the Parliamentary forces quartered at Lyme, and in the same year thirteen owners of small tenements, whereof seven were recusants, had their ertates sequestered, doubtless as a punishment for their loyal defence of the house. 


\section{A HISTORY OF DORSET}

period are said to have officiated as chaplains at Chideock.Castle, ${ }^{247}$ and a sketch of the fortunes of this family under Elizabeth gives probably the best picture of the trials and risks of a Catholic household at that time. In $158 \mathrm{I}$ Sir John Arundel was summoned to London and for a time committed to close custody by the queen; following her husband's arrest Lady Arundel, daughter of Edward earl of Derby and relict of Charles, Lord Stourton, also suffered a term of imprisonment. On 9 April, 1584 , she was examined as to her speeches against the present government, reception of Jesuits and seminary priests, hearing mass and receiving letters from Charles Paget, \&cc. ${ }^{248}$ On 9 June she begged Walsingham to use his interest with the queen to procure her release, protesting that ' her own heart could not accuse her of any undutiful thought towards Her Majesty ' ${ }^{249}$ fortunately the lady's plea received favourable consideration, and she was soon after released. ${ }^{\text {so }}$ On the death of Sir John at Isleworth his widow returned to Chideock where she took up her residence and, save for the fines imposed on the household for recusancy, appears for a short time to have been left in peace. But the castle remained a centre of Catholic influence in Dorset, and the resort of seminarists, among whom was Father Cornelius, a native of Cornwall, who having been educated by Sir John Arundel at Oxford and the English college at Rheims, returned later to England in the capacity of chaplain to his patron and by him was recommended to the care of his wife on his deathbed. The priest was a marked man to the government who only required opportunity to lay hands on him. It came in the usual fashion by treachery ; a member of the household, William Holmes, enraged at some reproof for his conduct went to the high sheriff, Sir George Morton, with information whereby a plan was concerted for the apprehension of the priest. For this purpose Easter Sunday, 3 I March, I 594, was chosen, when there was every prospect of a mass being celebrated, and for five miles watch and ward was set round the castle. The trap failed owing to the precautions taken, but a second attempt a fortnight later resulted in success, and after a prolonged search Father Cornelius was dragged from his hiding place in one of the priest's holes. ${ }^{251}$ On 2 I April the prisoner was examined before the justices, Sir George Trenchard, Sir Ralph Horsey, and John Williams, and the evidence taken of the informer, William Holmes, who testified to the presence of Catholic priests attached to the household of the late Sir John Arundel during the period he had been in his service; that the said Cornelius dwelt with Sir John and his widow for a year; that another priest, John Sherwood, now deceased,

${ }^{247}$ One of these, Thomas Pilchard, was executed at Dorchester on 21 March, I 587, with ail the barbarous rites that attended such executions; another Catholic recusant, a Mr. Jessop, dying soon after in Dorchester gaol, was by his own desire buried next to Mr. Pilchard. (Foley, op. cit. iii, 428-9.) Other names given are Cornelius 1594 , Green 1642 . Arthur Browne, another seminary priest, purchased his life at the price of recantation (Oliver, Hist. of Catholic Religion in Comw. and Dors. etc. 1857 , pp. 35-9). John Mundyn, priest at Mapperton, was executed at Tyburn I2 Feb. 1589 (Ibid. 39).

${ }_{215}$ Cal. S.P. Dom. $158 \mathrm{I}-90$, p. $171 . \quad 249$ Ibid. $180 . \quad 250$ Ibid. $201-260$.

251 The account of this famous seminary priest (Foley, Rec. of the Engl. Province of S.F. iii, 435,474) is largely based on the Acts of Father Cornclius written by Miss Dorothy Arundel, the daughter of Sir John, who after the priest's execution went abroad and entered the convent of the English Benedictine nuns at Brussels, where she was professed 1600 and died in 1613 . She gives a graphic account of Cornelius' apprehension and preliminary examination before the justices. On being summoned together with the rest of the household and questioned as to her share in harbouring and concealing a public traitor and enemy to Her Majesty the Queen, this spirited lady broke out ' $I$ gather together traitors and enemies of the Queen, $I$ sustain them, $I$ conceal them ! If you would have men of that kind I know them not. I well know that I know none such.' Ibid. iii, 455 . 


\section{ECCLESIASTICAL HISTORY}

' dwelled likewise with the said Sir John Arundel and his lady for the space of viii years and upwards before his death, and others'; that after Sir John removed his house from Clerkenwell to Moushill, where he lived for about three years, the said Cornelius and Sherwood continued with him; after that the knight removed to Isleworth where he remained for about six or seven weeks and then died, and there he was visited by another priest whose name was William Patinson. The witness further deposed that Cornelius and Sherwood did daily say mass at Clerkenwell and Moushill and at Isleworth, but that he was not admitted to hear mass until he came to Isleworth where he heard the three priests say several masses; he was also present at many masses said by the three priests at Chideock, whither his lady had removed since the death of Sir John, and for a time was appointed to wait on them in their chamber. On the departure of William Patinson to London, where he was soon after executed, ${ }^{252}$ his place was taken by another priest, John Currie, who remained until after the death of Sherwood twelve months since, the latter, as the witness understood, being buried in the chapel of Chideock House, and on Currie's departure to London at Michaelmas, he was succeeded by Green, alias Lusty Green, who remained in company with Cornelius until Easter day last ; at which time, about one o'clock in the morning before day, having said mass and received intelligence of an intended search they each went their ways, Green going to Cornwall, but Cornelius having his mother in Chideock House returned there the next day and remained till he was apprehended. The informer gave the names of the household who daily attended mass; ${ }^{253}$ the boys and hinds in the house were not admitted, nor had he, the witness, been admitted since a year last Michaelmas, and he stated that Cary and Patrick, now prisoners in Dorchester gaol, had been in attendance upon the said priests in their chamber both before and after his discharge from that duty. The priest, John Cornelius, alias Moone late of Bodmin, Cornwall, on interrogation, stated that he was forty years of age, had been ordained priest in the seminary at Rome thirteen or fourteen years since, had returned to England eleven years ago, and had since continued travelling to and fro 'to do good and to instruct in the Romish religion according to his function;' he refused to say where he had lodged for fear of bringing others into danger. ${ }^{25 t}$ That Chideock was regarded as a hot-bed of Catholicism is evident from the letter addressed by the justices of the peace who conducted this examination to Lord Keeper Pickering and Lord Buckhurst, together with their report, Io June, I 594. Referring to the priest Cornelius they say

his repair with that of others not yet taken to the lady's house has nursed up many ill imps and given comfort to not a few ill subjects, whereby we are daily encumbered and the country is drawn back from the faith. In regard thereof we desire that the said lady may

${ }^{252}$ He was hanged at Tyburn 22 Jan. 1592.

${ }^{253}$ The Lord Stourton; Mr. Charles Stourton; Mr. John Easton and Margaret his wife ; Mrs. Dorothy Arundel; Mrs. Gertrude Arundel ; Mr. Thomas Bosgrave, Thomas Stone, committed to gaol ; Henry Barbye, John Cooke ; Jeffrey Cardew; - Holcombe ; Ann Tremayne ; Margaret Tremayne ; Jane Tremayne; Dorothy Prideaux ; Jane Woodcocks ; Julyan Morgan, widow ; Christian Storche; Mother Mawde, mother to Cornelius; Faith Victor, attendant upon her ; Eliz. Diggenson, an old woman.

${ }^{254}$ Cal. S.P. Dom. 1591-4, pp. 488-9. The prisoner, after confinement for a fortnight at the house of the justice Trenchard, was ordered by the Council to be removed to London unless he could be persuaded to. renounce his religion. Hespent two months in the Marshalsea and was then transferred to Dorchester, where having been put upon trial he was convicted of the crime of high treason and rebellion against the queen and. executed 4 July, 1594, together with three companions from Chideock, Mr. Bosgrave, and the men-servants. John Cary and Patrick. Foley, op. cit. iii, $465-72$. 


\section{A HISTORY OF DORSET}

be removed to some other house and friends or placed with the sheriff of the county for the time being, for that if she should continue in the place where she is now resident we doubt would breed further mischief. For under cover of great hospitality and her bounty to the poor many are drawn to her faction and repair thither as to their only supporter. ${ }^{255}$

Subsequently the lady was imprisoned together with nearly all her household and heavily fined. ${ }^{256}$

During the seventeenth century, Catholic sentiment was kept alive in Dorset by the Webbs at Canford, and the Welds who came into possession of Lulworth Castle in I64I. Their sons swelled the ranks of the seminary priests, their daughters joined those communities established abroad for English nuns on their dispersal in whose establishment and maintenance they were largely instrumental.57 Together with the owners of Chideock they remained faithful to the Royalist cause on the outbreak of civil war. Sir John Webb was ordered to be arrested by the Parliamentarians in $164 \mathrm{I}$, but managed to escape, and rendered such services to Charles $I$, that in reward of them he was created a baronet. ${ }^{258}$ Later on, about the time of Oates' plot, suspicion fell upon Mr. Humphrey Weld, and in I679, by the advice of the Lords' Committee for investigating matters relating to the late 'horrid conspiracy,' he was deprived of the governorship of Portland Castle and his commission of the peace, the Privy Council directing that the castle of Lulworth, his dwelling in Portland Castle and 'Weld House,' London, should be searched for arms. ${ }^{259}$ Since that time the Catholic owners of Lulworth have been visited by various sovereigns and members of the royal family, including George III and George IV when prince of Wales; ${ }^{260}$ The first Roman Catholic church erected in England since the Reformation was built here in I 794 by express permission of George III. ${ }^{261}$

As regards the state generally of church activity in the archdeaconry during the earlier half of the seventeenth century, we may note that an Act was passed at the beginning of the reign of James $I$, for the transference of the rectory from Radipole to Melcombe, and the erection of a new parish church at the latter place, which was consecrated in 1606 by Dr. Zouch, suffragan to the bishop of Bristol. ${ }^{282}$ Reports of the primary visitations carried out every three years by the dean of Salisbury in the prebends of the cathedral give a few entries of interest. A note in the year 1628 states that after the visitation of Sherborne, I 4 July, it was ordained

upon entreaty of the minister and parishioners of Sherborne that for the convenience of the minister in going to the pulpitt and the people in hearing that the pulpitt shall be removed unto the next pillar of the church westward on that side where now he standith and so to be made that the minister may goe out of his seate where he readith prayers into the pulpitt, and the seates in the gallery which are so arranged that the faces of the people turn from the minister are to be altered so that they may face the minister for the better hearing. ${ }^{203}$

${ }_{255}$ Cal. S.P. Dom. $1591-4$, p. 521.

${ }^{256}$ Foley, op. cit. iii, 472.

${ }^{257}$ Ibid. 540. A member of the Webb family, Agatha, was one of several ladies of birth and 'singular virtue,' who accompanied Mary Caryll, of a well-known Catholic family of West Grinstead, as assistant in the establishment of a Benedictine monastery at Dunkirk, in 1662.

${ }^{259}$ I bid. $540, n .9 ; \mathrm{v}, 812$

${ }^{259}$ Lds. Journ.

${ }^{260}$ The celebrated Mrs. Fitzherbert was by her first marriage a Mrs. Weld of Lulworth.

${ }^{261}$ It is said that George III gave permission for a mausolcum, which would include a church or chapel, but the idea of which was less calculated to upset lingering prejudice.

${ }_{263}$ Handbook for Church Congress at Weymouth, 1905 ; Rev. S. Lambert, Notes on Ch. of Wiymouth.

${ }^{263}$ Liber Visit. Deconi, 1628. 


\section{ECCLESIASTICAL HISTORY}

In 1635 occurs a name destined to be one of the greatest in the century succeeding : John Deane of Lyme Regis was presented ' for refusing to receive the communion of Mr. Westley. ${ }^{26 *}$ Elizabeth Bugler was in 1639 presented for breaking the sabbath,

when summoned the widow confessed that upon the Sunday before Whitsunday upon urgent occasion she did for some of her customers grind in her mill at Sherborne certayne gristes for which she is heartily sorry. ${ }^{265}$

For the most part presentments at this time were made for moral offences, drunkenness and violence in church, occasionally for non-attendance at church or communion; in 1635 , Marian Davies, wife of Jenkin Davies of Sherborne, 'for striking Ryw Palmers wife in ye church'; ${ }^{266}$ in ${ }^{6} 638$, Joanna Kelleway, 'for not receiving the Communion at Easter last' ${ }^{267}$; Thomas Thomas of Alton Pancras was presented 'in that he absented himself from his parish church at tyme of divine prayers and hath not received the Sacrament in all his life tyme he being of the age of 27 yeares'; this last acknowledged his fault, humbly submitted himself, and was ordered to frequent the church and receive the sacrament the next week. ${ }^{268}$

Meantime, in spite of the existence of hotbeds of Catholicism such as we have indicated, the tide of public opinion in this county flowed steadily in the direction of Puritanism. So strong was the hold it had already obtained here, that in 1634 Laud complained that there were Puritans in nearly every parish in Dorset. ${ }^{269}$ Bishop Skinner of Bristol in an address to the clergy at a visitation held by him at Dorchester, 18 September, I 637, proceeds, after emphasizing the importance of sound doctrine, to plead the value of ancient custom with regard to the practice of kneeling at prayers, the use of the cross in baptism, and the observance of set feasts and holidays. ${ }^{270}$ That the general desire of a reform in church matters was very strong is shown by the message presented by this county to Parliament by word of mouth of Lord Digby in the general petition of grievances in $1640 .^{271}$ The influence of John White, appointed to Holy Trinity in 1606 , probably had much to do with making Dorchester a stronghold of Puritan sentiment. ${ }^{272}$ The 'Patriarch of Dorchester,' as he was termed, was instrumental in organizing a scheme for sending out a colony chiefly composed of Dorset men to settle at New Dorchester, Mass. At the beginning of the Long Parliament he took the covenant, and succeeded in inducing many of his fellow-townsmen to do the same. ${ }^{273} \mathrm{He}$ and his friend William Benn, rector of All Saints', who

${ }^{264}$ Liber Visit. Decani, 1635. This would be Bartholomew Wesley, the great-grandfather of the revivalist of the eighteenth century.

$$
{ }^{265} \text { Ibid. } 1639 .
$$

267 Ibid. 1638.

${ }^{268}$ Ibid. I669. The Rev. C. H. Mayo has noted in Buckland Newton Parish Reg. how church discipline was still maintained in the later part of the seventeenth century. On $3 \mathrm{May}, 1674$, the register records that Mr. William Aarnold and Jone Lane were excommunicated in Buckland church; on the 16 th of the same month that Martha Lane, the reputed 'dafter' of Thomas Trew of Clinger, was baptized; a few days after, on 31 May, "Thomas 'Trew bore penance in Church' (p. 10). Mr. William Arnold was again excommunicated on 4 Oct. 1685.

${ }^{269}$ W. Densham and J. Ogle, Congregational Ch. in Dorset, Introd. p. vii.

${ }^{270}$ Speech of Dr. R. Skinner, Lord Bp. of Bristol, at the Visit. at Dorchester (published 1744).

${ }^{271}$ Shaw, Hist. of $C b$. of Engl. during the Civil War, i, 9-12.

${ }^{272}$ According to Fuller (Worthies, i, 340), his influence brought about great reforms in the condition of the town. Beginning as a moderate Puritan, his views were probably rendered more extreme by the persecution to which he was subjected. He was summoned before the Court of High Commission in 1625 , to answer respecting certain papers that had been found in his study, but was eventually discharged and his informant reproved for 'twattling.' Cal. S.P. Dom. $1635-6$, p. $513 ; 1638-9$, p. 217.

${ }^{273}$ Hutchins, Hist. of Dorset, ii, 375 . 


\section{A HISTORY OF DORSET}

seconded all his efforts to promote the Presbyterian cause in the town, were both among the triers deputed to examine the qualifications of candidates for the cure of souls under the Commonwealth, and two daughters of Mr. White married ministers who were among the ejected in this county at the Restoration: John Wesley and Benjamin Way.

The recent publication of the minute books of the Dorset Standing Committee, ${ }^{27 t}$ which came into operation shortly after the issue of the ordinance of I July, I 644, affords ample information as to the ecclesiastical working of the county during the Commonwealth. The ecclesiastical powers vested in the members of this committee enabled them to determine the delinquency, scandal, or malignancy of any incumbent, whether he had preached against the Parliament or joined the king's army, ${ }^{275}$ to enforce the use of the Directory, and to make appointment of other ministers to serve in the cures that had been sequestered, provided their names had been approved by those deputed to examine them. Besides these duties they are found ordering additions to small stipends, as in the case of the vicar of Abbotsbury, ${ }^{276}$ appointing lecturers, ${ }^{277}$ assigning stipends to schoolmasters, ${ }^{273}$ directing the payment of fifths to which the families of ejected ministers were entitled out of sequestered benefices; in many cases intruded ministers showed great reluctance to pay and the committee had to resort to threats in order to enforce payment. Among these was Bartholomew 'Westleye' of Charmouth, the great-grandfather of the revivalist, who in January, I 648, was ordered to pay the full fifths of the parsonage, or to show cause why he refused; the following February came the order, "whereas it is made known to us that Mr. Norrington who was outed from the church of Charmouth for scandal hath since obtained in the county of Wilts $f_{3} 30$ per annum for his livelybood, Mr. Westley is released from payment of fifths, as the whole profits of Charmouth only amount to about $\AA_{20}{ }^{2}{ }^{279}$ Among smaller matters of detail referred to the committee was the official custody of the church key, ${ }^{280}$ which at Stoke Abbott had been detained by the 'outed' incumbent. ${ }^{281}$ Out of the lands, tenements, \&c., belonging to any dean and chapter or impropriated personages within the county under sequestration, they advised the assignment of certain sums in augmentation of the living or the maintenance of a lecture in some fifty different parishes, the ministers or lecturers of which should first be approved by the committee before the extra payment should be made to them..$^{282}$ On 6 January, I646, Walter Fry and John Squibb, gent., were appointed to receive and distribute their payments out of the rents payable from the

274 Dorset Stand. Com. ed. by C. H. Mayo, 1902.

${ }^{375}$ On 22 Dec. $16+2$, it was moved in Parliament that in the case of those ministers who had left their charges and joined the king's forces the profits of their livings should be sequestered and their names presented to 'this House.' Lds. Journ. v, 516.

27 Ibid. 67.

${ }^{276}$ Min. Bks. of Dorset Stand. Com. 78 .

${ }^{278}$ At Beaminster and Dorchester. Ibid. 29,$8 ;$

${ }^{279}$ lbid. 49i, 500-1. Walker's account of the fate of this outed minister is that 'he left his wife and Five Children as poor as Misery could make them,' and that 'his widow was at length constrained to beg the charity of the Corporation for Ministers' Widows by whom she was relieved'; Sufferings of the Clergy, ii, 318. Other intruded ministers who appeared unwilling to pay were John Galping at Durweston, who was admonished in $16+7$ and again in 1648, "on the sad complaint of Mr. Richard Hooke, last incumbent of Durweston in this countie on the behalfe of himself his wife and children' (Min. Bks. 282, +32 ); James Rawson, of Haselbury Bryan (ibid. $3 \circ 4,438$ ); John Salway, of Whitchurch Canonicorum (ibid. 347,403 ), who, according to Walker (Sufferings of the Clergy, ii, 293), protested 'that hee will rather leave the place than paie any" fifths'; John Moulas, at Tarrant Gunville (Min. Bks. 374); William Hardy at Sturminster Marshall (ibid. 464, 538); Henry Lamb, at Burton Bradstock (ibid. 522 ).

250 Ibid. $152,176,341,540$.

251 Ibid. 101.

252 Ibid. 1 59-60. 


\section{ECCLESIASTICAL HISTORY}

revenues of the dean and chapter. ${ }^{283}$ The following benefices, or portions of benefices, were ordered to be united :-Knighton to Lillington, Beer Hackett to Yetminster, Stockwood to Melbury Bubb, Knowlton to Horton, Chilcombe to Askerswell, Wraxall to Rampisham, East Holme to East Stoke and the three Wareham churches; the inhabitants of the annexed churches were admonished to attend the other. Motcombe was ordered to be separated from Gillingham. ${ }^{28 t}$ On 25 December, 1646 , we read an order was issued for the rebuilding of the town of Beaminster after the fire, to be paid for out of the sequestered estate (amounting to $£_{2}, 000$ ) of Mr. George Penny of Toller, a recusant. ${ }^{285}$

As regards the actual number of sequestrations that took place during the Commonwealth and the new régime introduced by the Parliament, they cannot be much under seventy. From the minute books of the committee as many as fifty-nine have been extracted, the greater number of which, it has been noted, had already occurred when the minute books, commencing in August, I645, began. ${ }^{286}$ The names of six more sequestered clergy are also given from another source, ${ }^{287}$ and Walker's list, containing only seventeen names, includes three that are not given in either of the other two lists. ${ }^{288}$ In October, I646, William Gollop, rector of Stoke Abbott, was declared 'not only a delinquent and within the ordinance of sequestration, but allso a malignant and a scandalous minister and an enemy ag ${ }^{\mathrm{t}}$ the pliam.t. ${ }^{2}{ }^{289}$ Another entry states: 'the inhabitants of Wareham desire the removall of Thos. Whiteroe clerke who now doth officiate in that towne in respect of his insufficiency and scandalous lyfe. ${ }^{290}$ On 6 January, I 646-7, an unordained person, one Mr. Stapleton, who had been admitted to preach in the church of Radipole 'to the great disturbance and hazard of the garrison of Weymouth and Melcombe Regis,' was inhibited. ${ }^{291}$ The changes introduced by the committee did not, however, meet with universal approval in the county, and in sundry places parishioners refused to pay tithes to the newly-appointed ministers. At Charlton Marshall such a dispute arose between Mr. John Trottle and his flock that three members of the committee, Mr. Chettle, Mr. Elias Bond, and Mr. John Squibb, were desired to make inquiry into its cause. ${ }^{292}$ At Silton the dissatisfaction of the parishioners with the minister for whom they had petitioned became so great that the Committee 'finde the discontent between them to bee growne soe high as that we conceive the sayd Mr. Boles will not be able to doe any good in the way of his ministry in that place,' and he was forthwith discharged from officiating there. ${ }^{293}$ Among the archives of Weymouth and Melcombe Regis a minute book of the Corporation, I 644-9, during the period when the town was occupied by the Parliamentarians, records, Io A pril, I 646, that Robert Saunders, mariner, was heard to say 'that $\mathrm{Mr}$. Ince and $\mathrm{Mr}$. Way, the two ministers, were knaves both in their preaching, and that the said Mr. Way did preach plaine Popery; and that he would justifie to Mr. Ince his face, that he was a knave in his preaching, and that he would soundly heare of it, or used words to the like effect.' ${ }^{29 *}$ A later entry the same year, however, states that the said $\mathrm{Mr}$. Ince

\footnotetext{
${ }^{283}$ Min. Bks. of Dorset Stand. Com. $159-60$.

${ }^{283}$ Ibid. $139-140$.

${ }^{256}$ Ibid.Introd. pp. xxxvi-xxxviii

${ }^{288}$ Walker, Sufferings of the Clergy, ii, passim.

290 Ibit. 67.

293 Ibid. 234.

291 Ibid. 60, 61, 105, 1 1 2, 1 25, 1 38, 148, 206.

${ }^{291}$ Ibid. 130

${ }^{294}$ Hist. MSS. Com. Rep. v, App. pt. i, 587.

${ }^{287}$ Add. MS. 8845 .

${ }^{259}$ Minute Bks. 58, 59.

${ }^{292}$ Ibid. 333.
} 


\section{A HISTORY OF DORSET}

' having used his function of a minister in the town as a preacher to the garrison almost two yeares,' the mayor, aldermen, bailiffs, and burgesses were anxious to secure him as their pastor, ${ }^{295}$ and to this end sent a petition to Parliament 'to settle some mayntenance on the towne for a minister, nothing arising out of the towne (being very poore and populous) but what the people please voluntarily to contribute.' A promise of $\oint_{0}$ roo per annum 'to be settled upon this and Radipole which is but one pastorall charge,' was obtained, and the townsmen generally promised to make a contribution according to their abilities and to provide a house, but Mr. Ince in the meantime had been negotiating with the parishioners of Donhead in Wiltshire, and had promised himself as their minister. The 'souldiery and the townesmen' were very much troubled and discontented upon receiving this news, and efforts were made to induce $\mathrm{Mr}$. Ince to break his promise to the people of Donhead. The matter was referred at last to the House of Commons who again referred the case to certain members of the Assembly of Divines, but their decision is not given. ${ }^{296}$

The confidence of the Puritan party in the sincerity of the promises contained in the Declaration of Breda, 1660 , assuring 'liberty to tender consciences, and that no man shall be disquieted or called in question for differences of opinion in matters of religion which do not disturb the peace of the kingdom,' ${ }^{297}$ was speedily banished after the Restoration had become an accomplished fact. Of the 2,000 ministers-composing about a fifth of the entire number-who, in obedience to their consciences on the passing of the Act of Uniformity, laid down their offices ${ }^{298}$ some seventy or eighty belonged to this county. ${ }^{299}$ The very date fixed for the Act in 1662 to come into operation (24 August) seems to have been designed with the object of making its severity most keenly felt, for it was appointed for a time when a whole year's tithe was due but not yet paid. ${ }^{300}$ Many of the ministers thus forcibly retired from their cures continued to reside in the places where they had officiated until they were driven from their homes by the Five Mile Act, holding services where they could in private houses and meeting with much persecution. Of these, Calamy notes Thomas Rowe, ejected from Lytchett Matravers, 'twice imprisoned with some other ministers tho' not above a fortnight either time. On the Five Mile Act he removed to Little Canford near Wimborne and preached several times in his own house without any persecution or disturbance, the reason of which was supposed to be the great number of Papists in those parts who lived under the countenance of a considerable knight of that religion, for they who were disposed could not for shame disturb him and leave them unmolested.' ${ }^{301}$ Mr. John Weeks of Buckland Newton, for six months twice imprisoned for Nonconformity, during his confinement 'preached out of the prison windows to any that were disposed to hear him." ${ }^{02}$ ' Other ejected ministers were Mr. John Hardy of

295 This was in November, $16+6$; the previous year on II March the authorities of the town sent a petition to the Standing Committee stating that 'being deeply affected with the necessity of having an able godly preacher of the Word to be settled amongst them, and a sufficient mayntenance for such a minister, doe conceive itt their duty to present their petition to that end unto youre high Court of Parliament'; ibid.

${ }^{296}$ Ibid. $588-9$.

${ }^{298}$ Calamy, Nonconformist Memorial, vol. i, Pref. iii.

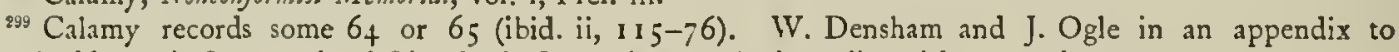
their valuable work Congregational Churches in Dorset $(407-15)$ give a list with some nine more.

${ }^{300}$ Ibid. Introd. $x$.

${ }^{301}$ Nonconformist Memorial, ii, 133.

${ }^{302}$ Continuation, $\mathrm{i},+15$. 


\section{ECCLESIASTICAL HISTORY}

Symondsbury, who preached in Westminster Abbey on the Day of Thanksgiving for the Restoration; ${ }^{303} \mathrm{Mr}$. Timothy Sacheverel of Tarrant Hinton, great-uncle to the famous Doctor Sacheverel of Queen Anne's time, who, with three other ministers, Mr. Ince, Mr. Hallet of Shaftesbury, and Mr. Bampfield, was arrested for preaching publicly, and indicted at the assizes 7 August, 1663 , for 'a riotous and unlawful assembly held at Shaftesbury 23 July ;' they were all found guilty and fined 40 marks each. ${ }^{305}$

But the most interesting of the sufferers of 'the fatal Bartholomew' 306 are the Wesleys, Bartholomew and John, great-grandfather and grandfather respectively of the eighteenth-century Reformer. The former, who had been ' intruded ' by Parliament in the place of Mr. Norrington, 'outed' minister at Charmouth, was in his turn ejected from his cure there. He continued to reside at Charmouth until driven away by the passing of the Five Mile Act, as his abode lay within two miles of the town. ${ }^{307}$ The final record of him states that 'he lived several years after he was silenced, but the death of his son made a very sensible alteration in the father, so that he declined apace and did not long survive him.' ${ }^{308}$ John Wesley, his son, sent in $165^{8}$ to preach at Winterborne Whitchurch on leaving Oxford, appears to have become early a marked man in the county. It was reported to the bishop of Bristol, Gilbert Ironside, when visiting the diocese on his appointment in $\mathrm{I} 66 \mathrm{I}$, that Mr. Wesley refused to read the Book of Common Prayer after the passing of the Act of Uniformity, and the bishop sent for him to question him as to his views and the legality of his orders. At the close of an interview, which in its real kindness and consideration on the part of the bishop is in marked contrast to the one held by his successor, James Butler, in 1739, with the great revivalist, ${ }^{309}$ Ironside, finding the preacher deaf to all arguments, dismissed him with the words 'I will not meddle with you, and will do you all the good I can.' ${ }^{310}$ But John Wesley was evidently a man to inspire animosity in those who differed from him and were not, like Bishop Ironside, able to appreciate the rigid honesty and sincerity of purpose that underlay his obstinacy. At the instigation, it is said, of some 'persons of Figure' in the neighbourhood, he was seized on the Lord's Day as he was coming out of church early in 1662 before the Act had come into effect, carried off to Blandford, and committed to prison. ${ }^{311} \mathrm{He}$ was afterwards released, but bound over to appear at the assizes, where he triumphantly asserted himself, and

${ }^{303}$ Continuation, 414 .

${ }^{305}$ Continuation, $\mathrm{i}, 449$.

${ }^{304}$ Nonconformist Memorial, ii, 157.

${ }^{306}$ The 24 Aug. was St. Bartholomew's Day, and the date fixed for the Act of Uniformity to take effect is often alluded to as 'the second Bartholomew.'

${ }^{307}$ Beal, Biog. Notices of the Wesley Family, 13. 'Forbidden by law,' says Calamy, 'the Nonconformists of the south-west of Dorset stole away to the solitudes of Pinney, and there in a dell between rocks like the Covenanters elsewhere they worshipped their God. 'The place has ever since been known as Whitechapel Rocks.' Continuation, i, 429 . ${ }^{308}$ Ibid.

sug The bishop of Bristol in his famous interview with John Wesley charged the Methodists with 'a horrid thing, a very horrid thing,' namely, with pretending to extraordinary revelations and gifts of the Holy Spirit and concluded by telling the reformer he had no business in the diocese, and advising him 'to go hence.' I'esley's Works, xiii, 470 .

${ }^{310}$ Calamy, Continuation, i, 439. Kennett in his account of the interview says "the bishop was more civil to him (Wesley) than he to the bishop.' A son of Ironside succeeded his father as rector of Long Bredy in Dorset; he is said to have been ejected from his benefice by the Long Parliament, and reduced to the utmost poverty ; Hutchins, Hist. of Dorset, ii, 149.

311 An entry in the Cal. S.P. Dom. (1660-1, p. 504), under date 5 Feb. 166r, records information laid against John Wesley, vicar of Winterborne Whitchurch, 'for diabolically railing in the pulpit against the late ting and his posterity, and praising Cromwell.' 


\section{A HISTORY OF DORSET}

though bound over to appear again 'came joyfully home,' and continued to preach every Lord's Day till i7 August, when he gave a final address to a 'weeping auditory' from Acts $\mathrm{xx}, 32$. On 26 October the place was declared vacant and an order given to sequestrate the profits, "but his people had given him what was his due.' Wesley then established himself with his family at Melcombe Regis, but the corporation made an order against his settlement there, imposing a fine of $f_{0} 20$ upon his landlady and $5^{s}$. per week upon him. These proceedings forced him out of the borough and he went to Bridgwater, Ilminster, and Taunton, where he met with great kindness from the three denominations of Dissenters, and was almost daily employed in preaching. At length a gentleman living at Preston, two or three miles from Melcombe, offered him the use of his house as a residence rent free. The offer was accepted; he removed thither, ${ }^{312}$ and his son Samuel, the father of the Revivalist, is said to have been born at Preston. But the Five Mile Act subsequently drove John Wesley from this refuge. After being concealed for some time he ventured to return again to his family, was seized, imprisoned, and finally died before his father. ${ }^{313}$ At Dorchester, always a lively centre of Puritan feeling, it was reported at the close of $\mathrm{I}_{6} 64$ that out of nine Nonconformist ministers four had been lately arrested on suspicion of being privy to the plot. ${ }^{314}$ Six ministers and seventy others were now in prison for Nonconformity, 'the town is most factious and has daily conventicles.' 315

The proclamation of an Indulgence for Nonconformists in I 672 was. quickly followed by applications for licences to hold Nonconformist services in the following places: Beaminster, Bettiscombe, Bothenwood, Bradford Abbas, Bridport, Broadwindsor, Cerne, Dorchester, East Morden, Fordington, Hawkchurch, Lyme, Marshwood, Milton Abbas, Morden, Motcombe, Over Compton, Quarleston Stickland, Stalbridge, Shaftesbury, Stour Provost, Tarrant Monkton, Thornhill, Wareham, Weymouth, Wimborne, Winterborne Kingston, Winterborne Zelstone, Wootton Fitzpaine ; ${ }^{316}$ and a 'thankful address' signed by thirty-eight dissenting ministers in Dorset was presented to the king thanking him for his clemency and promising continually to pray for 'Your Royal Person, familie, Councill and Government as Dutie obligeth us your loyal subjects and ministers of the Gospel.' ${ }^{\text {s17 }}$ In all the principal towns in this county Nonconformity can show an honourable succession of dissenting ministers, many dating from the ejection of St. Bartholomew's Day, 1662, and subsequent persecutions. ${ }^{318}$

Before quitting a period which closes with the passing of the Act of Toleration in $\mathrm{r} 689$, a word must be said of the Quakers, of whom a consider-

31s Calamy, Continuation, $\mathrm{i}, 448$. The borough records of Weymouth during $166 ;-6$ record a number of people of Melcombe Regis and the neighbourhood convicted of meeting to hold services other than those allowed in the liturgy of the Church of England. Most of these meetings appear to have been held in the house of Henry Saunders, mariner of Melcombe Regis and Dorothy his wife, the latter being convicted several times. For a first offence they were fined, on a second conviction committed to the town gaol 'for the space of 3 months and a day.' In all probability John Wesley was present at some of these meetings. Beal, Fathers of the V'esley Family, 96-8.

${ }^{313}$ Ibid. Biog. Notices of Wesley Family, 31.

31 In 1663 it was reported that a rising was daily expected in Somerset and Dorset; Cal. S.P. Dom. $1663-4$, p. 150 .

${ }_{313}$ Ibid. $1664-5$, p. 130.

s17 Ibid. 527 . The Indulgence was withdrawn the following year.

${ }^{318}$ Somerset and Dorset $N$. and $Q$. ; Nonconformist Succession in Dorset, vols. i, ii, passim. 


\section{ECCLESIASTICAL HISTORY}

able number were formerly to be found in Dorset. ${ }^{319}$ The sect of the Society of Friends, which sprang up towards the middle of the century and to whom the term Quaker was first applied in $1650,{ }^{320}$ appears to have suffered equally under the régime of the Parliament and the Acts passed on the Restoration. ${ }^{321}$ The tenets of their persuasion, their refusal to pay tithes or to be chargeable for the rates and assessments of churches whose worship they disapproved, exposed them to much contempt and dislike, while their objection to taking an oath in a court of justice or to remove their hats seems to have been universally misunderstood. In Dorset, between 1650 and 1660 , some fifty-six names are recorded of those committed to prison, and sixty-six from 1660 onwards; ${ }^{322}$ there is evidence of meeting houses at Bridport, Dorchester, Hawkchurch, Sherborne, Evershot, Corfe, South Perrott, Poole. At the beginning it must be admitted many convictions were due not only to adherence to the above unpopular views, but also to 'speaking to the people in the steeple-house,' or ' declaring truth,' \&c. Thus

on 16th of the 9th month (1656) Jasper Bett being at the steeple-house in Weymouth (Melcombe Regis) when the Priest had done asked him whetber be was a minister of Christ? The Priest answered $I \mathrm{am}$, and went away; but the People fell violently upon Jasper beating and abusing him sorely and then hailed him to prison where he lay several days. ${ }^{323}$

As persecutions became severer these officious testimonies to the 'truth' were dropped, offenders were 'set in the stockes,' ${ }^{32 t}$ several on their way to attend meetings were 'whipped and put outside the town under pretence that they were vagabonds.' " 225 In I 657 six were committed to gaol for ' uncourtly behaviour before the justices,' i.e. refusing to uncover. ${ }^{326}$ Quaker meetings were always subject to interruption, and those attending them to insult, even in the open street. ${ }^{327}$ An Act was passed in $166 \mathrm{I}$ with special reference to their refusal to take an oath, ${ }^{328}$ and the following year it is stated there were about 200 Quakers imprisoned in Dorset for wearing their hats in court, not swearing, and opening their shops on 29 May and 12 June, days appointed to be observed as a fast for fine weather. ${ }^{329}$

Non-juring at the close of the century seems to have confined itself mostly to the Roman Catholics, or ' popish recusants' as they were still called, ${ }^{330}$ who, after the 'Unnatural Rebellion' of I7 I 5, were obliged to register their names and estates. The return furnished of those 'Roman Catholic Nonjurors and others in Dorset, who refused to take the oaths to king George' gives fifty-

${ }^{319}$ In response to an inquiry in the Somerset and Dorset Notes and Queries as to Dorset Quaker burial grounds a list is there given (i, 153) showing their existence at Bridport, Cerne, Corfe, Dorchester, Hawkchurch, Lyme Regis, Marnhull, Poole, Ryme Intrinseca, Shaftesbury, Sherborne, and Weymouth.

320 The year succeeding the imprisonment of George Fox at Nottingham.

${ }^{321}$ Besse, Abstract of Sufferings of the Quakcrs, i, Introd. vi, vii, viii, ix.

${ }^{322}$ Ibid. $530-1 ; \mathrm{ii}, 463-4$.

${ }^{395}$ Ibid.

${ }_{927}$ Ibid. $80-81$.

${ }^{326}$ Ibid. 79 .

${ }^{328}$ Ibid. ii, Pref. pp. xi-xv.

${ }^{319}$ Cal. S.P. Dom. $1668-2$, p. 426. Persecutions did not cease till the passing of the Act of Toleration, 1689 , and members of this sect continued to be presented at the assizes at Dorchester for adherence to their opinions. 'A powerful factor,' says Besse, 'in granting warrants for distresses in $167+$ for holding meetings, amounting to 697 95. 10d. was Justice Culliford, who much transgressed the Bounds of his office in kicking Deborah Coleman an innocent woman on her Belly and other parts of her Body and striking her with his Dogwhip'; Collections of Sufferings of Quakers, i, 170.

${ }^{330}$ Oberton's list of clerical and lay non-jurors who refused to take the oath of allegiance to William and Mary in 1689 and again in 1701-2 and 1714, only gives the name of one clergyman in the Bristol diocese who can be claimed for Dorset: W. Flud, Fludd, or Flood, vicar of Halstock; The Nonjurors, 478. 


\section{A HISTORY OF DORSET}

eight names, of whom many, like the Arundels, Sir John Webb of Great Canford, and Humphrey Weld of Lulworth Castle, are already familiar. ${ }^{331}$

After the turmoil and struggles of the seventeenth, the eighteenth century with its moral and spiritual destitution, its ' colourless indifferentism,' comes as a period remarkable chiefly for its stagnation and lack of effort generally in the church. ${ }^{332}$ The abuses, pluralism, and non-residence, that marked the clergy in the mass, the poverty of the greater number of them, the great social difference that showed itself between their different ranks ${ }^{3 s 3}$ were probably as much present in Dorset, with its rural districts comprising many small and ill-paid benefices, as in other parts of the country. From the churchwardens' accounts of Ashmore, says the historian of the parish,

to some extent we can trace the degradation of the church. It was found at three vestry meetings held in succession in $180 \mathrm{I}-2$ that the roof of the church was dangerous to worshippers, the pulpit and altar rail rotten, that the gallery, the steps into it, and the seats both in gallery and body of the church were in need of repair. The Holy Communion, it appeared, was celebrated three times a year-Christmas, Easter and IVhitsunday-till I 79I, afterwards quarterly for a considerable number of years. ${ }^{334}$

As regards those flourishing Nonconformist communities that the previous century had done so much to establish and organize, though there may have been, as has been said, an awakening among them contemporaneous with Wesley's great work, ${ }^{335}$ it has also been shown what a disintegrating influence Arianism had especially in the west of England where it seized on the younger and more highly educated generation of ministers. ${ }^{386}$ "Nonconformity went into the controversy united and strong,' say the authors of the Story of Congregational. Churches m Dorset, 'having the adhesion of a large number of the most influential and even aristocratic families in the country. It came out of it disunited and impoverished.' 337 That Nonconformist succession in Dorset, to which allusion has been made, in many cases shows the manner in which congregations split up and seceded over this controversy.

As far as the work of John Wesley actually in Dorset is concerned the Fournal shows that, with the exception of Shaftesbury, he visited the county where his name was already so familiar but rarely. At Shaftesbury he stopped frequently on his way to and from the west. On the first of these occasions, recorded in the Fournal, 3 I July, $175^{\circ}$, he preached in the evening in a house accommodating from four to five hundred people, 'it was soon filled from end to end . . . none stirred, none spoke, none smiled, many were in tears and many others were filled with joy unspeakable.' ${ }^{3 s s}$ Returning from Cornwall IVesley called again at Shaftesbury, and the day after his

${ }^{331}$ Return transmitted to the Commissioners (printed 1745).

3) The bishopric of Bristol-the poorest in England - was throughout the century held in succession by men who obriously only accepted it as a stepping-stone to higher things. Thomas Gooch, $1737-8$, stayed so short a time 'as never to have visited his diocese.' Joseph Butler accepting the offer of the bishopric in 17,3 could not help remarking that it was 'not very suitable either to the condition of my fortune or the circumstances of my preferment, nor as I should have thought to the recommendation with which I was honoured,' referring to the queen's interest (Dict. Nat. Biog. viii, 69). Bishop Newton, 176 J-82, 'plaintively' enumerates the various preferments he was called on to resign on his promotion to Bristol, 'the prebend of Westminster, the precentorship of York, the lectureship of St. George's, Hanover Square, and the genteel office of the sub-almoner.'

ss3 Overton, Engl. Ch. in Eightienth Cent. 287.

${ }^{335}$ IV. Densham and J. Ogle, Congl. Clurckes in Dorset, Introd. xiv.

${ }^{336}$ Ibid. App. $+2+-6$.

${ }^{334}$ E. IV. Watson, Hist. of Parish of Ashmorc, 92. 


\section{ECCLESIASTICAL HISTORY}

arrival 'preached at noon in the most riotous part of the town where four ways met; but none made any noise or spoke one word while I called the wicked to forsake his way.' ${ }^{3 s 9}$ 'The civic authorities, however, took alarm, and 'after I was set down a constable came and said, "Sir, the mayor discharges you from preaching in the Borough any more," whereupon Wesley replied, "While King George gives me leave to preach I shall not ask leave of the mayor of Shaftesbury.' ${ }^{3 * 0}$ Wesley's impressions of the town underwent many changes in the years succeeding. In 1755, after preaching to 'sleepy' congregations at Reading, he reported ' a much more lively people at Shaftesbury,' ${ }^{441}$ but on the occasion of a visit, 28 September, I766, described the town as 'cold, uncomfortable Shaftesbury . . . spoke exceeding strong words.' ${ }^{342}$ The previous 29 August he had opened the new chapel here. ${ }^{343}$ In $177 \mathrm{I}$, stopping at Shaftesbury on his way to Portsmouth from Bristol, the Fournal records 'preached to a numerous congregation but wonderfully unconcerned. I scarce know a town in England where so much preaching has been to so little purpose.' ${ }^{444}$ The indifference and coldness of which Wesley complained at Shaftesbury may possibly be explained by a reference to another town not far removed : Frome, 'dry, barren, uncomfortable place.' ${ }^{3+5}$ 'In this town,' says Wesley, 'there be such a mixture of men of all opinions, Anabaptists, Quakers, Presbyterians, Arians, Antinomians, Moravians and what not. If any hold to the truth in the midst of all these surely the power must be of God. ${ }^{346}$ His last reference to Shaftesbury, however, is more encouraging, 'I preached,' says the Fournal, I 5 August, I 785 , ' at Shaftesbury at nine to such a congregation as $\mathrm{I}$ had not seen there before. I was glad to see among them the gentleman who thirty years ago sent his officer to discharge me from preaching in his borough.' ${ }^{347}$

The spiritual awakening in the Church, which towards the middle of the nineteenth century resulted from the Oxford Movement, dates in Dorset from the year 1836 , when by an order in council the whole county forming the archdeaconry was detached from the diocese of Bristol and became again united to that of Salisbury. In such dioceses as Salisbury under Bishops Denison, Hamilton and Moberly you trace, says the ecclesiastical historian of this period, the peculiar stamp of the Revival in what was done. ${ }^{348}$ The charge delivered in 1855 by Bishop Kerr Hamilton in which he outlines the changes initiated by his predecessor Bishop Denison, I $837-54$, gives some idea of the practical work accomplished in the parishes and in the diocese at large. ${ }^{349}$ Beginning with confirmation, the late bishop's first care, he says :

The old custom in this diocese before the present century was, I believe, to confirm only at the few places at which visitations were held. This number had been afterwards a little increased, but the year in which Bishop Denison began his ministry he formed, with the assistance of the archdeacons, a much enlarged scheme for holding 28 confirmations in Dorset and 29 in Wilts. At his last tour of confirmations this number was increased to 45 in Dorset and to 40 in Wilts, and he also arranged that there should be an annual confirmation in the chief towns of that part of the diocese where the general confirmation was not held. ${ }^{350}$

s39 Fourn. ii, $172 . \quad{ }^{340}$ Ibid. $\quad{ }^{941}$ Ibid. $305 . \quad{ }^{342}$ Ibid. iii, $351 . \quad{ }^{343}$ Ibid. 217

944 Ibid. $45 \mathrm{I}$. Another entry records that Wesley preached at Melcombe and Shaftesbury on is Sept.

1779. Ibid. iv, 169 .

315 Ibid. ii, 264 .

s48 Overton, The Anglicon Revival, 218.

${ }^{39}$ Charge to the Clergy of Diocese of Salisbury at his primary visitation.

stz Ibid. iv, 327 .

950 Ibid. 13. 


\section{A HISTORY OF DORSET}

Sixteen years ago (continues the bishop) out of the 556 churches and chapels in the diocese there were 2 sermons on Sunday in only 143 . There are now 2 sermons or lectures in 426 , that is to say 214 out of the 298 churches and chapels in Dorset. Of the 84 churches and chapels in Dorset where there are not 2 services and 2 sermons the account is as follows: in 16 parishes where there are 2 churches there is only 1 service and I sermon, in 33 parishes where there is one church there is one sermon, and in 24 only one service. In 35 parishes held in plurality there is but one sermon, and in 33 parishes similarly circumstanced one service. ${ }^{351}$

Bishop Kerr Hamilton, I $854-69$, threw himself strenuously into the work of church building and restoration. The number of churches consecrated during his episcopate amounted to 84 , of those restored, to $104 .{ }^{352}$ Under his successor Bishop Moberly, I $869-85$, the number of churches restored in the diocese reached a figure of $160 .{ }^{353}$ The nineteenth century was prolific in church building; to take the largest town in Dorset, Weymouth, no less than five churches have been built within the borough since its commencement: St. Mary's church, the foundation stone of which was laid in I 8 I 5 by command of Princess Charlotte of Wales; Holy Trinity, erected I 836 ; St. John's, I 854 ; Christchurch, built in 1874 as a chapel of ease to the parish of St. Mary; St. Paul's of Westham, formerly within the parish of Wyke Regis but formed in 1902 into an ecclesiastical parish under the name of St. Paul's Weymouth, was opened in 1896.55

In Dorset, as elsewhere, the duty that confronts the Church is not only to carry on the work and organization so well begun but to grapple with the difficulties presented by the different circumstances that have arisen since the earlier part of the last century. That this is well understood may be seen from the objects and purposes of the Queen Victoria Clergy Fund, to which the Salisbury Diocesan Board has been affiliated since its incorporation in 1897 , which aims at raising the value of poor benefices, with populations of not less than 150 , to an income of $f 200$ per annum, while a movement has been set on foot in the diocese for the union of small benefices and the re-arrangement of neighbouring parishes enabling them to be worked by one incumbent. ${ }^{355}$ In this manner it is hoped to meet the difficulties of the present agricultural decline, the diminishing number of candidates who offer themselves for ordination, and to ensure the fulfilment of the Apostolic injunction that they which 'preach the Gospel ' shall also 'live of the Gospel.'

${ }^{351}$ Charges to the Clergy of Diocese of Salisbury at his primary visitation, $1+, 15$. The bishop in 1842 in his charge spoke of an improvement in the observance of Ash Wednesday and Holy Thursday, "of late almost universally neglected; ' but by the returns made in 1854 Ash. Wednesday was still disregarded in 112 churches and chapels in Dorset, and in 133 the Feast of our Lord's Ascension was still not kept. Ibid. 15 . As regards the practice of morning and evening service daily, Bishop Hamilton, at least in later years, took occasion to uphold their being said in private if not in public according to the directions of the Prayer Book. H. P. Liddon, Walter Kerr Hamilton, Bp. of Salisbury: A Skctch, 57. In 1858 there were twenty-six churches in the whole diocese where daily services were held, in I86I there were thirty-nine.

${ }^{35 s}$ Ibid. App. 126.

${ }^{353}$ Though some smaller works may be included in this list. John Wordsworth, Bp. of Salisbury, Four addresses to clergy and churchaeardens of diocese of Salisbury at his primary zisitation.

${ }^{351}$ Handbook for Church Congress at Weymouth, 1905 ; Rev. S. Lambert, Notes on Ch. of Weymouth, 75-81.

${ }^{35 s}$ Report of the Board to the Diocesan Synod, Salisbury Diocesan Gazette, April, $1906,67$. 



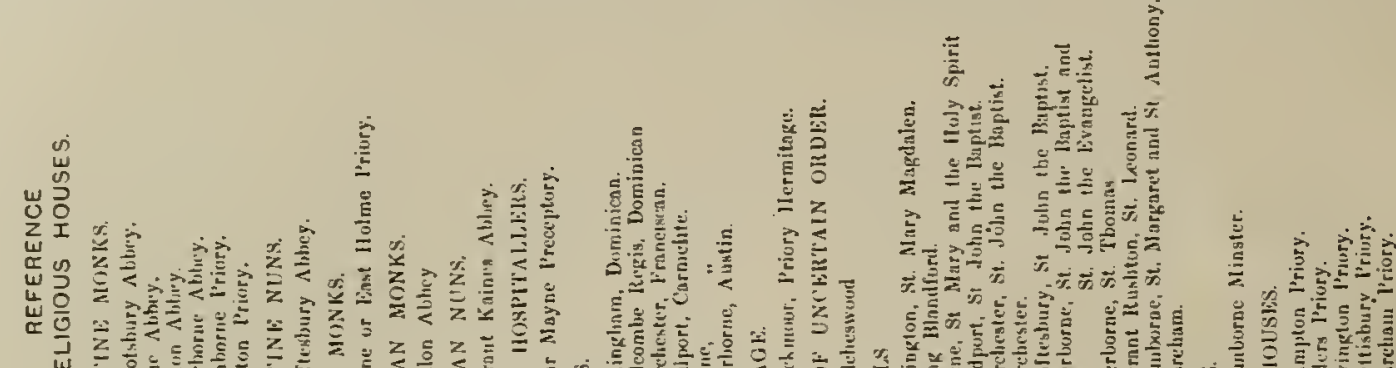

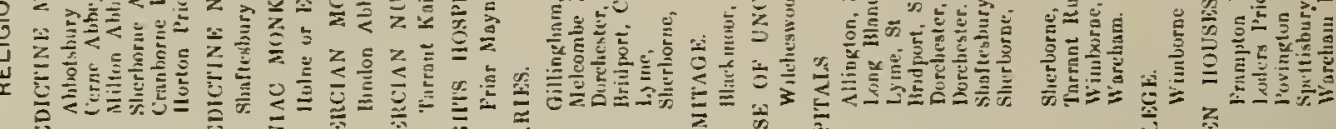

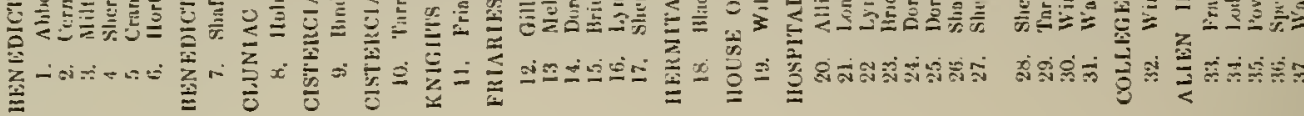

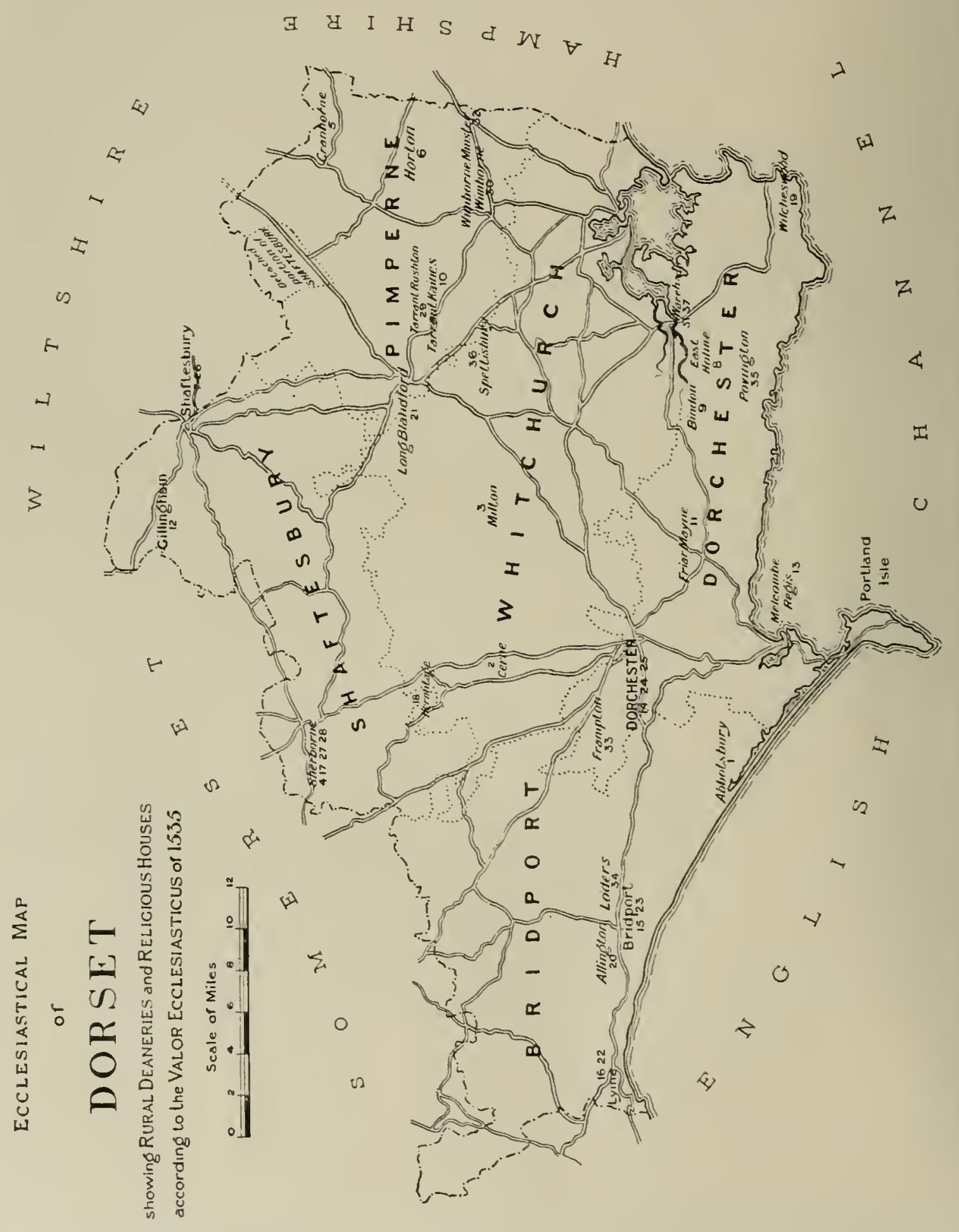




\section{ECCLESIASTICAL HISTORY}

\section{APPENDIX}

\section{ECCLESIASTICAL DIVISIONS OF THE COUNTY}

The conversion of Dorset, as has been already described, was finally accomplished by the establishment in 705 of a bishop-stool at Sherborne, the see of which, described roughly as lying 'west of Selwood,' was carved out of the old Wessex diocese on its partition at the death of Bishop Haeddi. For more than three centuries - and in spite of many fluctuations-the head of the diocese pertained to this county, but in 1075, following the decree of the Council of London which ordered the removal of sees generally to more populous centres, it was transferred to Old Sarum and subsequently to Salisbury to the diocese of which Dorset was attached down to the sixteenth century. In I 542 this county, then forming the archdeaconry of Dorset, was severed from Salisbury and annexed to the new see erected at Bristol under which it remained until the year 1836 , when by an order in council it was again united to the Salisbury diocese.

The thirteenth-century compilation of church property, known as the Taxation of Pope Nicholas IV, gives the five rural deaneries into which the archdeaconry of Dorset was then divided, namely, Shaftesbury, Pimperne, Whitchurch, Dorchester, and Bridport, and records the names of I 7 churches besides Wimborne Minster-a deanery in itself-and several dependent chapelries. The Survey of 1340 , recording the value of the ninth of corn, wool, and lambs which had been granted to Edward III, shows a marked increase in churches, which then numbered 218 . The Valor Ecclesiasticus, which Henry VIII ordered to be taken in 1535 , shows a further increase to 234 .

At the present time no addition has been made to the number of deaneries, but each deanery has been subdivided into two, three, or four portions.

The names of the different parishes under their several deaneries and portions are as follows :-

\section{DEANERY OF BRIDPORT}

Abbotsbury Portion: Abbotsbury, Long Bredy with Little Bredy, Cattistock, Chilfrome, Compton Abbas or West Compton, Langton Herring, Litton Cheney, Maiden Newton, Portisham, Puncknowle, Swyre, Winterborne Abbas with Winterborne Steepleton.

Bridport Portion: Allington, Askerswell, Bothenhampton, Bradpole with St. Andrew's Chapel, Bridport, Burton Bradstock with Shipton Gorge, Chilcombe, Loders, Powerstock with West Milton, North Poorton, Rampisham with Wraxall, Symondsbury with Eype and Broad Oak, Toller Porcorum, Walditch, Wytherstone.

Lyme Portion : Bettiscombe, Catherston Leweston, Chardstock St. Andrew, Chardstock All Saints, Chideock, Hawkchurch, Lyme Regis, Monkton Wyld, Pilsdon, Thorncombe, Wambrook, Whitchurch Canonicorum with Marshwood and Stanton St. Gabriel, Wootton Fitzpaine.

Beaminster Portion: Beaminster with Trinity Chapel, Broadwindsor with Blackdown and Drimpton and Burstock, Cheddington, East Chelborough or Lewcombe with West Chelborough, Corscombe, Halstock, Hooke, Mapperton, Melplash, Netherbury with Solway Ash, South Perrott with Mosterton, Stoke Abbott or Abbotstoke, Toller Whelme.

\section{DEANERY OF DORChESTER}

Dorchester Portion : Bradford Peverell, Broadmayne with West Knighton, Charminster with Stratton, Compton Valence, Dorchester St.-Peter, Dorchester Holy Trinity with Frome Whitfield, Dorchester All Saints, Fordington, West Fordington, Frampton, Frome Vauchurch, Moreton, Stafford, Toller Fratrum with Wynford Eagle, Whitcombe, Winterborne Monkton, Winterborne St. Martin, Winterborne Came, Woodsford.

IVeymouth Portion : Bincombe with Broadway, Buckland Ripers, West Chickerell, Fleet, Melcombe Regis with Christchurch and Radipole, Osmington, Owermoigne, Portland St. George with Southwell St. Andrew, Portland St. John, Portland St. Peter, Preston, Upway, Warmwell with Poxwell, Weymouth St. John, Weymouth Holy Trinity, Weymouth St. Paul, Wyke Regis. 


\section{A HISTORY OF DORSET}

Purbeck Portion: Branksea, Chaldon Herring, Church Knowle, Coombe Keynes, Corfe Castle, East Holme, Kimmeridge, Kingston, Langton Matravers, East Lulworth, IVest Lulworth, Steeple with the Grange Chapel and Tyneham, East Stoke, Studland, Swanage with Herston, Winfrith Newburgh with Burton, Worth Matravers, Wool.

\section{DeAnery of Pimperne}

Blandford Portion: Ashmore, Blandford Forum, Chettle, Farnham, Handley with Gussage St. Andrew, Langton Long Blandford, Pimperne, Shapwick, Steepleton Iwerne, Stourpaine, Tarrant Crawford, Tarrant Gunville, Tarrant Hinton, Tarrant Key'nston, Tarrant Monkton with Tarrant Launceston, Tarrant Rushton with Tarrant Rawston.

Wimborne Portion: Alderholt, Chalbury, Colehill, Cranborne with Boveridge, Long Crichel with Crichel Moor, Edmondsham, Gussage All Saints, Gussage St. Michael, Hampreston, Hinton Martell, Hinton Parva or Stanbridge, Holt, Horton with Woodlands, West Parley, Pentridge, Verwood with West Moors, Wimborne Minster, Wimborne St. John, Wimborne St. Giles, Witchampton.

\section{DEANERY OF SHAFTESBURY}

Shaftesbury Portion: Bourton, Buckhorn Weston, Fifehead Magdalen, Gillingham with East and West Stour and Milton, Kington Magna, Marnhull, Motcombe with Enmore Green, Shaftesbury St. James, Shaftesbury Holy Trinity with St. Peter, Shaftesbury St. Rumbold or Cann, Silton, Stour Provost with Todber.

Stalbridge Portion : Long Burton with Holnest, Bishop's Caundle, Caundle Marsh, Purse Caundle, Stourton Caundle, Folke, Haydon, Holwell, Lydlinch, Stalbridge, Stock Gaylard, North Wootton.

Sherborne Portion: Batcombe, Beer Hackett, Bradford Abbas with Clifton Maybank, Castleton, Over Compton with Nether Compton, Hermitage, Leigh, Lillington, Melbury Osmond and Stockwood with Melbury Sampford, Oborne, Ryme Intrinseca, Sherborne, Thornford, Yetminster with Chetnole.

Sturminster Newton Portion: Compton Abbas, Fontmell Magna with West Orchard, Hammoon, Hanford, Hinton St. Mary, Iwerne Minster, Iwerne Courtney with Farringdon, Manston, Melbury Abbas, Child Okeford, Okeford Fitzpaine, East Orchard with Margaret Marsh, Sturminster Newton, Sutton Valdron.

\section{DEANERY OF WHITCHURCH}

Bere Regis Portion: Affpuddle with Turners Puddle, Athelhampton with Burleston, Bere Regis with Winterborne Kingston, Cheselbourne, Milborne St. Andrew with Dewlish, Melcombe Bingham, Piddlehinton, Piddletrenthide, Puddletown, Stinsford, Tincleton, Tolpuddle.

Poole Portion: Almer, Arne, Bloxworth, Branksome All Saints, Branksome St. Clements, Canford Magna, Charborough, Corfe Mullen, Hamworthy, Heatherlands, Kinson with Talbot Village, Longfleet, Lytchett Matravers, Lytchett Minster, East Morden, Parkstone, Poole St. James, Poole St. Paul, Sturminster Marshall, Wareham, Winterborne Anderson, Winterborne Tomson, Winterborne Zelstone.

Cerne Portion: Alton Pancras, Buckland Newton with Plush, Cerne Abbas, Fifehead Neville, Frome St. Quintin with Melbury Bubb and Evershot, Godmanstone, Haselbury Bryan, Hillfield, Mappowder, Minterne Magna, Nether Cerne, Pulham, Sydling St. Nicholas, Up Cerne, Wootton Glanville.

Milton Portion: Blandford St. Mary, Bryanston with Durweston, Hilton, Ibberton with Belchalwell, Milton Abbas, Shillingstone, Spettisbury with Charlton Marshall, Stoke IVake, Turnworth, Winterborne Clenston, Winterborne Houghton, Winterborne Stickland, Winterborne Whitchurch, Woolland. 


\section{THE RELIGIOUS HOUSES OF DORSET}

\section{INTRODUCTION}

Dorset enjoyed a unique pre-eminence for the number and importance of its religious houses founded during the Saxon period. No fewer than nine monastic establishments are known to have existed in the county prior to the Norman Conquest; of these the great houses of Sherborne, Shaftesbury, Abbotsbury, Cerne, and Milton continued after that epoch to rank as Benedictine abbeys; the two abbeys of Cranborne and Horton survived as priories, dependent respectively upon the abbeys of Tewkesbury and Sherborne; the famous early nunnery of Wimborne was converted into a college of secular canons, while at Wareham, where an early house of nuns is said to have been destroyed by the Danes in 876 , a small priory sprang up as a cell to the Norman abbey of Lire.

The reformed Benedictines of the order of Cluny had a small priory at East Holme, and the Cistercians an abbey at Bindon, both founded before the end of the twelfth century. The Cistercians had also a house of nuns of much celebrity at Tarrant Kaines; and it is probable that the 'Camesterne,' where, according to the Mappa Mundi ${ }^{1}$ compiled at the close of the twelfth century, certain 'white nuns' were established, is a corruption of Kaines Tarrant.

It is remarkable that the canons of the Austin and Premonstratensian rules, so numerous elsewhere, had no foundations within this county, unless perhaps the obscure 'priory' or 'chantry' of Wilcheswood in Langton Wallis belonged to the canons regular. It seems, however, more probable that Wilcheswood should be considered as a small collegiate church, of which class the other example in Dorset was Wimborne Minster.

The Templars were unrepresented, but the Knights Hospitallers had a preceptory at Friar Mayne. The Dominican Friars are mentioned at Gillingham in 1267 ; their other settlement, at Melcombe Regis, was of far greater importance, and is remarkable as being the last house of the order established in England. The Franciscans settled at Dorchester, and the Carmelites had a short-lived settlement at Bridport. During the fourteenth century unsuccessful attempts appear to have been made to introduce Carmelites at Lyme, and Austin Friars at Sherborne. A remarkable 'priory

${ }^{1}$ Gervase of Cant. Op. Hist. (Rolls Ser.), ii, 422 . On the other hand, it has been suggested (Hutchins, Hist. of Dorset, ii, 289) that this was a settlement at Winterborne Came. Leland's statement that the nuns were Benedictines (Itin. viii (2),62) is presumably a slip, as the latter wore black. 


\section{A HISTORY OF DORSET}

hermitage' at Blackmoor, although stated to have been under the rule of St. Augustine, does not seem to have belonged to the Austin 'Friars Hermits,' nor yet to have become a house of Austin canons, as was sometimes the fate of such hermitages.

Some twelve hospitals are known to have existed in this county, but they were mostly small, and some were apparently unendowed lazar-houses.

A considerable amount of property was held in Dorset by alien houses, and in five or six cases the parent house established a cell or small priory upon its estates. These instances were at Frampton (the abbey of St. Stephen of Caen), Loders (St. Mary of Montebourg), Spettisbury (the abbey of Préaux), Wareham (the abbey of Lire), and possibly Povington (the abbey of Bec Hellouin). The latter is only called a priory in 1467 , more than fifty years after it had been separated from the Norman abbey, and it is probable that it was never more than a grange or estate managed by the abbey's chief English cell, the priory of Ogbourne. In the same way the lands given by Roger de Beaumont in Stour Provost to the nuns of St. Leger of Préaux, and those in the neighbourhood of Winterborne Wast bestowed upon the Cluniac priory 'de Vasto,' near Boulogne, were never the site of any cell and priory. At Muckleford, which estate was granted with the advowson of Bradford Peverell to the Norman abbey of Tiron, ${ }^{2}$ a cell was said to have been established, ${ }^{3}$ but it is clear that the estate was really under the control of the abbey's cell of Andwell in Hampshire." Similarly, the supposed cell of the Carthusian priory of Sheen at Shapwick ${ }^{5}$ was clearly no more than a grange.

\section{HOUSES OF BENEDICTINE MONKS}

\section{THE ABBEY OF ABBOTSBURY}

Coker states in his Survey of the Countie of Dorset, quoting the register of the monastery, unfortunately destroyed with the mansion-house of the Strangeways at Abbotsbury in the civil wars of Charles I, that here

was built in the verie infancie of Christianitie amongst the Britains a church to St. Peter by Bertufus an holie priest unto whom the same saint had often appeared and amongst other things gave him a charter written with his owne Hande,

professing therein ' to have consecrated the church himself and to have given it to Name Abodesbyry.' Afterwards

King Canute gave to Sir Ore his Houscarle this Abotsbury as alsoe Portsham and Helton; all which the said Ore and Dame Thole his wife having no issue gave unto the church of St. Peter at Abotsbury, longe before built but then decayed and forsaken by reason the Rovers from the sea often infested it. ${ }^{1}$

${ }^{2}$ Cal. Doc. France, 358.

${ }^{3}$ Hutchins, Hist. of Dorset, ii, 536.

- Arch. Fourn. ix, 250.

s Hutchins, Hist. of Dorset, iii, 166.

'Particular Surc'. of the Ccurtie of Dorset (1732), 30 .
In the above account we have the name of the founder of Abbotsbury as generally accepted: 'Sir Ore' or Orc, Orcus, Orcy or Urce, steward of the palace of King Canute and Tola or Thola his wife. The date of their foundation however varies with different historians. Reyner, in his history of the Benedictine order in England, gives the year 1026, ${ }^{2}$ Tanner states that about 1026 Orcus instituted a society of secular canons here which he or Tola his widow changed to a monastery of the Benedictine order in the reign of Edward the Confessor ${ }^{3}$ Again, according to Coker, the monastery was built by Orcus in 1044 and 'stored' with Benedictine monks from the abbey of Cerne. ${ }^{4}$ It would seem from the rules drawn up by Orcus for his gild or fraternity of St. Peter at Abbotsbury ${ }^{5}$ that a society existed here previously which was later converted into a monastic establishment.

- Apostolat. Benedict. Tract ii, sec. vi, m. 3.

${ }^{3}$ Notitio (ed.1744) Dorsct, 105. Orcus the steward of King Canute having expelled secular canons introduced monks. $\mathrm{He}$ was buried here with Thola his wife. Leland, Collect. iii, 254.

'Surv. of Dorset (1732), 30.

${ }^{5}$ Dugdale, Mon. (Charters under Abbotsbury, No. iii), iii, 35 . 


\section{RELIGIOUS HOUSES}

Canute by charter dated 1024 bestowed Portisham on his servant Orcus. ${ }^{6}$ Tola or Thola, the wife of Orcus, and a native of Rouen, Normandy, purchased Tolpuddle, and with her husband gave it to the monks together with Abbotsbury, Portisham, Hilton and 'Anstic." Edward the Confessor by one charter gave to Orcus, who was his housecarl as he had been Canute's, the shore in all his lands and all wrecks of the same, ${ }^{8}$ and by another charter notified Herman the bishop and Harold the earl that he had granted a licence to Tola the widow of Orcus to bequeath all her land and goods to the monastery of St. Peter of Abbotsbury, according to an agreement that on the death of husband and wife their possessions should pass to the house, of which the king now declared himself the guardian and protector. ${ }^{9}$ William the Conqueror testified by his charter to the same bishop and Hugh Fitz Grip, the Norman sheriff, that, for the love of God and the soul of his kinsman King Edward, he had granted to the abbot and brethren of Abbotsbury their land as frae and quit as it was held in the time of his predecessor together with the right of soc, sac, tol, team, infangnetheof and wreck of the sea, and he desired the abbey should lose nothing unjustly but should be honourably treated. ${ }^{10}$

In the Domesday Survey the abbey held the following manors: Abbotsbury, Tolpuddle, Hilton, Portisham, Shilvinghampton, Wootton Abbas, Bourton and Stoke Atram. The monks complained at the same time that a hide belonging to the manor of Abbotsbury, which had been assigned to their living in the time of Edward the Confessor, had been unjustly reft from them by the Norman sheriff Hugh Fitz Grip, and that his widow had taken six; in the same manner they had been deprived of a virgate of land in Portisham. "I In a letter to the king about his assessment in the year I 166 Abbot Geoffrey deposed that Roger the bishop when he had the custody of the abbey gave to Nicholas de Meriet 2 hides of land at Stoke Atram for the marriage of a niece, the deed being contrary to the wish of the convent. ${ }^{12}$

By an inquisition before the king's escheator John le Moyne, and Andrew Wake sheriff of Dorset, at Uggscombe, Wednesday before the Feast of St. Simon and St. Jude (28 Oct.), 1268, as to the rights and privileges of the abbey, it was declared that the abbot and his predecessors had all liberties and free customs with soc, sac, tol, team and infangnetheof within their lands in the hundred of Uggscombe but not in their

${ }^{6}$ Dugdale, Mon. (No. ii), iii, 55 .

${ }^{7}$ Ibid. (No. i), iii, 54. ${ }^{8}$ Ibid. (No. iv), iii, 36.

${ }^{9}$ Ibid. (No. v); Kemble, Codex Dipl. iv, 841 .

${ }^{10}$ By inspex. Chart. R. 8 Edw. II, No. 5.

$"$ Dom. Bk. (Rec. Com.), i, 78 .

${ }^{12}$ Red Bk. of the Exch. (Rolls Ser.), i, 2 I I. William of Malmesbury records (Gesta Regum [Rolls Ser.], ii, other lands at Hilton, Tolpuddle, 'Oth,' and Wootton Abbas 'which last is in the hundred of Whitchurch,' that they were free of the suit of that hundred by grant of Robert de Mandevile, formerly lord of the hundred, except that their villeins were bound to come thrice a year to la lagh-day to present the pleas of the crown without hindrance. The abbot and his predecessors were discharged from all military service to the king by the service of one knight ; ${ }^{13}$ wreck of the sea was said always to have belonged to them, and they had always enjoyed it. The jury further declared that the abbey had acquired grants of land in the following places: Granston, Wytherstone, 'Deneham,' 'Poeyeto,' Bexington, Shipton, Poorton, East and West Chaldon, Morebath, Wraxall, Winterborne Steepleton, Wareham, Upway, Broadway, Langton, Bridport, Dorchester, 'Brigge,' Preston in co. Somerset, and Hornington. ${ }^{14}$ Henry III by charter dated 15 November, 1269, inspected and confirmed the charters previously granted to the abbey by his predecessors the kings of England, William the Conqueror, Henry I, Stephen, and Henry II, with all privileges and gifts. ${ }^{15}$ The convent obtained from the king two years later a grant enabling them to hold a weekly market and yearly fair in their manor of Hilton. ${ }^{16}$ Edward I gave them leave to hold a market at Abbotsbury. ${ }^{17}$ Edward II in 1315 confirmed anew their right to wreck of the sea in connexion with a whale (crassus piscis) cast up on the coast. ${ }^{18}$ Edward III confirmed their right of free warren over their lands at Abbotsbury, Portisham, Granston, Wootton Abbas, Wytherstone, Hilton, Tolpuddle, Ramsbury (Dorset), and Holwell (Somerset. ${ }^{19}$ Edward IV in the first year of his reign, 1461, made a grant to the abbot and convent of St. Peter's, Abbotsbury, of the hundred of Uggscombe, with view of frankpledge and all issues pertaining thereto, rendering the true yearly value at the exchequer. ${ }^{20}$

According to the Taxatio of I29 I the spiritualities of the abbey amounted to $f_{13} 95.4 d$,

559) that Bishop Roger appropriated Abbotsbury to the bishopric so far as he was able.

13 The abbot was returned for the service of one knight's fee under Henry II (Red Bk. of the Exch. [Rolls Ser.], passim), Richard I, John, Henry III (Pat. I Hen. III, m. 8), and Edward I (Close, I6 Edw. I, m. 3).

${ }^{14}$ Chan. Inq. p.m. $53 \mathrm{Hen}$. III, No. 40.

${ }^{15}$ The original of this charter according to Hutchins, who cites it (Hist. of Dorset, ii, 733), was in the possession of the earl of Ilchester, 1867 .

${ }^{16}$ Chart. R. 56 Hen. III, m. 3.

${ }^{17}$ Ibid. 9 Ediv. I, No. 55.

${ }^{13}$ Chart. R. 8 Edw. III, No. 5 ; Pat. 8 Edw. II, pt. $2, \mathrm{~m} .6,19 d$. In 1388 the owner of a cargo complained that his merchandise had been seized by the abbot and others as though it had been wreck, although thirteen of the crew had escaped. Ibid. I 2 Ric. II, pt. I, m. I I d. ${ }^{19}$ Chart. R. Io Edw. III, No. 4 !. ${ }^{20}$ Pat. I Edw. IV, pt. 3, m. 19. 


\section{A HISTORY OF DORSET}

including $£_{12}$ from the church of Tolpuddle assigned to the pittance of the monks; their temporalities were valued at $6.8 \mathrm{I}$ Ios. $10 d$. in the deanery of Bridport including $\oint_{3} 3^{1} 7$ s. $2 d$. from Abbotsbury with 'Luk' and Langton, $£ 3$ Is. from the deanery of Dorchester, 6.3675 . 6\%. from the deanery of Whitchurch and $£_{1} 6$ s. $8 d$. from the deanery of Shaftesbury, the whole income of the convent being assessed at $f_{1} 3515$ s. $+d^{2.1}$

At the beginning of the thirteenth century, the abbey in common with other ecclesiastical appointments was kept vacant by John who, in the meantime, enjoyed the proceeds or bestowed them on his followers. We read that in April, 1212 , the king presented to the church of Hilton, the abbey being void and in his hands. ${ }^{22}$ The January following, the custody of the house was granted during pleasure to Roger de Preauton; it was not until I5 July, I213, that an order was directed to the prior and convent to send certain men out of their number whom they should choose to the king for an abbot to be appointed. ${ }^{23}$ A few days later the custodians of the abbeys of Abbotsbury, Milton and Sherborne were notified that the king had sent to them eighteen cart-horses and seven sick palfreys, and that all charges both for them and the men accompanying them should be accounted for at the exchequer. ${ }^{24}$

Abbotsbury escaped none of the burdens incidental to a religious house of any importance and under the royal patronage. In 1244 Henry Lombard was sent to the abbot and convent with a request that they would find him the necessaries of life in their house. ${ }^{25}$ Edward II in 1309 sent Norman Beaufiz to receive maintenance, and a robe or 20 . y'early. ${ }^{26}$ During the period of the Scotch wars the abbey received the usual requests for aid, and a little later for shelter for disabled warriors. ${ }^{27}$ William Spyney, crossbowman, was transferred here in January, $1317 ;^{28}$ William Deyvill was sent in August, 1331, to receive such maintenance as Norman Beaufiz, deceased, had had; ${ }^{29}$ and six years later a request was made that the abbot and convent would give maintenance to John de Sancto Albano. ${ }^{30}$ It is evident that demands of this kind were not welcomed by the different religious houses. On 20 April, I 339, the abbey of Abbotsbury was ordered to receive and provide maintenance for two hostages of the town of

\footnotetext{
"Pope Nich. Tax. (Rec. Com.), 183-5.

${ }^{2}$ Pat. 13 John, m. 3.

${ }^{23}$ Close, if John, m. 3 ; I 5 John, m. 7 .

" Ibid. m. 4 .

${ }_{25}$ Ibid. 22 Edw. I, m. II $\%$.

${ }^{9}$ Ibid. $2 \mathrm{Edw}$. II, m. $13 d$.

${ }^{27}$ Ibid. 3 Edw. II, m. 5 d.; $8 \mathrm{Edw}$. III, m. 5 d. ; Parl. U'rits (Rec. Com.), iii, div. ii, $4 \hat{3}$.

"Close, 10 Edw. II, m. 15 d.

${ }^{93}$ Ibid. 5 Edw. III, pt. 1, m. $6 d$.

${ }^{30}$ Ibid. 11 Edw. III, pt. 1, m. $27 d$.
}

Berwick-on-Tweed to be sent to them from the abbey of Glastonbury, ${ }^{31}$ and on 6 October of the same year they were ordered to transfer them to the abbey of Tavistock. ${ }^{32}$ The monks of Tavistock appear to have flatly declined to receive the hostages, ${ }^{33}$ who consequently remained at A bbotsbury. On 3 December orders were issued for their removal to the priory of Bruton; ${ }^{34}$ on 16 January next, 1340, to the abbey of St. Augustine, Bristol; ${ }^{35}$ on 15 February the abbot and convent of Chertsey were ordered to receive these unwelcome guests; ${ }^{36}$ the abbot and convent of Shrewsbury received a similar order the following day. ${ }^{37}$

Nor did this exhaust the calls made upon the house; the community who enjoyed the royal patronage were required on the creation of an abbot to grant a pension to a clerk of the king's appointment, and in December, 1321 , following the election of Peter de Sherborne, we read that the pension was claimed by John Bellymont, king's clerk; ${ }^{38}$ in $13^{2} 4$, on the election of William Fauconer, Peter de Mount Toure obtained letters entitling him to the same; ${ }^{39}$ and in 1344 , on the election of Walter de Saunford, the abbot was ordered to grant the customary pension to Jordan de Cantuaria. ${ }^{40}$ These various grants and liveries were still claimed in the succeeding century. Thomas Ryngwode in 1400 was sent to the convent to receive such sustenance as Thomas Stanes deceased, had had, 11 and a corrody in the monastery was granted in 1517 to Robert Penne, gentleman of the Chapel Royal vice Edward Jones deceased. ${ }^{42}$

The abbey was frequently chosen as a place of burial, and for the foundation of chantries. A licence was granted in 1323 to Robert le Bret for the alienation of certain lands in Holwell to the abbot and convent for the provision of a chaplain to celebrate daily in the abbey church for the soul of Richard le Bret, the father of the founder, for the souls of his ancestors, and all the faichful departed ; ${ }^{43}$ and in 1392 , on payment of $£ 20$ by the monks, Robert, vicar of Portisham, and others were licensed to alienate two messuages in Dorchester, \&ic., for the provision of a monk chaplain who should celebrate daily at the altar of St. Andrew in the abbey for the good estate of Elizabeth, late the wife of John Mau-

\footnotetext{
${ }^{31}$ Ibid. 13 Edw. III, pt. 1, m. 12.

3: Ibid. pt. 2, m. $9 d$.

${ }^{33}$ Ibid. pt. 3, m. $26 d$.

st Ibid. m. $16 \%$.

${ }^{35}$ Ibid. m. 9.

${ }^{36}$ Ibid. 14 Edw. III, pt. 1, m. 43.

s7 Ibid. 35 .

s. Ibid. $15 \mathrm{Edw}$ II, m. 21 d.

ss Ibid. $17 \mathrm{Edw}$. II, m. $19 d$.

to Ibid. $18 \mathrm{Edw}$. III, pt. 1, m. 29 d.

"Cal. of Pat. 1399-1 401, p. 359.

49 $L$. and P. Hen.VIII, $\mathrm{i}, 310 \mathrm{I}$.

${ }^{43}$ Pat. 16 Edw. II, pt. I, m. I.
} 


\section{RELIGIOUS HOUSES}

travers, knt., for her soul after death, and that of her husband, for the maintenance of their anniversary, and for certain other charges and works of piety. ${ }^{44}$ The Clopton chantry, founded by Sir Walter Clopton, was valued at the time of its suppression at $108 s .4 d .{ }^{45}$ The Strangeways chantry was founded in 1505 in the chapel of St. Mary within the abbey, the abbot by a tripartite deed between himself and the convent of the one part, William abbot of Milton of the other part, and Thomas Strangeways, executor of Alianor, late the wife of Thomas Strangeways, senior, of the third part, engaging in return for certain benefactions to provide a chaplain to celebrate daily for the good estate of Henry VII and Edmund, bishop of Salisbury, \&c., and for the souls of the said Alianor and Thomas Strangeways and their friends and ancestors. ${ }^{46}$ This does not exhaust the number of those who made considerable bequests to the community in order to receive the benefit of their prayers.

The poverty which befel Abbotsbury in the fourteenth century, though largely due to its situation-exposed on the one hand to the attack of invaders, and eaten up on the other by the forces sent to defend the coast-was at the same time greatly fostered by the bad government of one of the abbots, Walter de Stokes (1 $348-54) \cdot{ }^{47}$ The attention of the bishop was drawn to the house during his rule, and on 29 October, 1353, he wrote to the abbot and convent that since visiting their monastery 'for various causes' and being at considerable pains to reform what he had found amiss, it had come to his ears that against 'good obedience' the community had deliberately spurned his orders to the danger of souls and the scandal of the neighbourhood; he therefore summoned them to appear before him or his official in the chapter-house of their abbey on Monday, after the feast of St. Martin the Bishop (I I November) to answer for their conduct. ${ }^{48}$ A letter from Edward III to the bishop soon followed, stating that he had committed the custody of the goods of the house, which, owing to the defective rule of the abbot, were insufficient to maintain the

${ }^{4}$ Pat. 16 Ric. II, pt. 1, m. 79.

${ }^{45}$ Chant. Cert. 16 (Dorset), Nos. 45-64. Thomas Jenkyns is here given as the last incumbent.

${ }^{46}$ Dugdale, Mon. iii, 58, No. 12. A copy of this deed may be seen in Hutchins, Hist. of Dorset, ii, 720.

${ }^{47}$ He succeeded to Walter de Saunford, who proprobably fell a victim to the plague in 1348 . The episcopal registers record that in December of that year the abbot and vicar of Abbotsbury were both dead. Sarum Epis. Reg. Wyville, pt. 2, fol. I92.

${ }^{49}$ Ibid. pt. 1, fol. 167. In his inability to attend personally to the matter, the bishop wrote to two canons of Salisbury and commissioned them, with John de Wyley, rector of S., to correct the misdeeds of the brethren, and see his decrees carried out; ibid. fol. $166 d$. community or to meet its debts, to Robert de Faryngdon, prior, and Henry de Tolre, monk, Walter Waleys, clerk, Thomas Carey, and John de Mautravers. ${ }^{49}$ This arrangement was not destined to run as smoothly as might have been desired. Among the collection of Ancient Petitions is a letter addressed by the abbot, whose bad rule had caused him to be set aside, to the archbishop of York, in which, complaining bitterly of his treatment at the hands of the above custodians, he states that they had withdrawn from him all the privileges to which he was entitled-his accustomed chamber, competent board and clothing, the services of a squire, two chamberlains and two grooms to attend to his horses-so that, 'insufficiently clad' (indecenter vestitus) and with his shoes 'enormously in holes' (enormiter infractis) he had been compelled to proceed more than 18 miles on foot in order to execute his business. ${ }^{60}$ The prior and other custodians had also their tale of complaints. According to them, the abbot had declined to fall in with the arrangements made for the whole community to lodge in one convenient house until the debt on the abbey, amounting to $£, 534$, had been wiped off; he omitted to attend the offices, would not come to the refectory, required all his meals to be served at his own convenience in his own chamber, and was spending money in divers parts of the county, heaping up debts and obligations which the house was wholly unable to meet; at the same time the seal of the abbey had been stolen by his adherents, and affixed to various deeds and grants prejudicial to the monastery. ${ }^{61}$ These complaints were not groundless, as was found by an inquisition held on 25 March, 1354, to inquire as to the lands and rents illegally alienated; the jury reported that among various grants by the abbot before the custody had been taken out of his hands was one for a corrody and a robe for which he had received $f_{20}$; he was also said to keep hunting dogs, to have retained an excessive number of servants and retainers, and to be in the habit of giving unnecessary presents; the injury he had thus done to the house being estimated at $6_{8}^{8} 55$ I os. $8 d{ }^{62}$ Fortunately for the community the abbot's career was cut short by death the same year. The following year the church of Winterborne St. Martin was appropriated to the monastery ${ }^{63}$ in 1361 the church of Toller Porcorum was annexed on account of poverty, and the charges incurred by the reception of numerous guests. ${ }^{64}$ In I386 Pope Urban VI, in reply to a petition from the abbot and convent representing their house, which was situated on the coast, as

${ }^{49}$ Ibid.

${ }^{50}$ Anct. Petitions, 10470.

${ }^{31}$ Ibid. 1047 1-2-3-4.

${ }^{52}$ Ibid. 10475.

${ }^{53}$ Sarum Epis. Reg. Wyville, pt. 1, fol. 24 I.

5s Ibid. fol. 242. 


\section{A HISTORY OF DORSET}

frequently invaded by Spaniards, Normans, and Bretons, and eaten up by the defenders of the kingdom, so that unless help could be afforded it must be destroyed and divine services cease, requested the bishop of Salisbury to appropriate the church of Tolpuddle to the uses of the brethren. ${ }^{55}$ The convent in 1390 obtained from Boniface IX a grant appropriating anew the parish churches of Abbotsbury, Portisham, Winterborne St. Martin, Toller Porcorum, and Tolpuddle, 'of which the first two were of old and the next 3 over 40 years ago incorporated by authority of the ordinary, and the last 2 by papal authority.' Their revenues, after deducting vicars' portions, came to 400 marks, the revenues of the monastery being 500, and I 4 marks were to be assigned to each vicar. ${ }^{56}$

With the exception of the appointment of abbots, references to Abbotsbury in the fifteenth century are rare. ${ }^{57}$ We have the decrees published by Bishop Chandler after visiting the abbey in 1436 . The community were warned generally against making grants rashly, and greater formality in their drawing up was enjoined. The abbot was directed, 'as wine and women cause men to err,' not to buy more wine than was absolutely necessary for the use of the monastery; he was to be permitted to have sweet wine for his table and the entertainment of his guests ' in small and minute vessels' (vasis); the entrance of women was prohibited, the abbot, if convicted on the evidence of two witnesses, should be suspended for a month; the brethren were forbidden to resort to a certain chamber for the purpose of 'confabulation. ${ }^{3.9}$

The notorious Dr. Legh appears to have visited this house on the eve of the Dissolution, for in a letter headed 'Thos. Legh, visitor of Abbotsbury,' he appoints a certain Vincent to be prior in the house, and desires the inmates to be attentive and obedient to him. ${ }^{59}$ Thomas Bradford occurs, however, as prior in the surrender deed of the house.

In the Valor of 1535 the spiritualities of the abbey were returned at $£ .459$ s. $3 d$. from the churches of Tolpuddle, Portisham, Abbotsbury, Winterborne St. Martin, and Toller Porcorum ${ }^{60}$;

${ }^{35}$ Sarum Epis. Reg. Erghum, fol. 81,82. Richard II licensed the appropriation on account of expenses connected with the defence of the coast; Pat. 9 Ric. Il, pt. I, m. 19.

${ }^{50}$ Cal. Pap. Letters, iv, $3+2 ; \mathrm{v}, 77$.

37 With the exception also of bequests and references in wills.

${ }^{55}$ Sarum Epis. Reg. Chandler, fol. 67d. Unfortunately no report can be found of the visitations ordered in 1488 and 1503.

${ }_{59}$ Cott. MS. Cleop. iv, 57. The letter is inscribed on the back. 'To the abbot of Abbotsbury, or in his absence to Dom Vincent.'

${ }_{60}$ Valor Eccl. (Rec. Com.), i, 277-8. the temporalities were valued at $£ 3566$ s. $7 d$., ${ }^{61}$ making a total income of $£$ toI I 5 s. IOd. It would seem, from the list of anniversaries kept by the monks, that the community were faithtul in the observance of one of their main duties, the obligation to commemorate for the souls of their founders and benefactors. ${ }^{62}$

A curious document, cited by Hutchins in full, ${ }^{63}$ brings certain charges against the last abbot of Abbotsbury, Roger Roddon, elected in $1534 .^{6+}$ Headed ' of the monasterye of Abbotsburye and of the saide Abbate thereof, of the mysse-usynge of hymselfe,' it runs, 'whereas he doth breke the kyng's foundacons and the injuncyonsof the same,' and proceeds to denounce the superior for nonobservance of the conditions on which the monastery had received land from benefactors; for wasting and wrongfully selling woods; for making away with jewels and plate out of the treasury of the value of which no record has been kept ;

also that he hath an abhomynable rule wyth kepyng of wymen not: wyth $i$, ii or iii but wyth manie more ... and no relegon he kepyth nor bye day nether bye nyghte.

Unfortunately we have no information as to the veracity of the writer ${ }^{65}$ who signs himself 'Dan. Will. Grey, Muncke of Abbatsburie.' He is included in the list of those who received pensions on the surrender of the abbey, I2 March, I 539 ; the abbot wlio surrendered witl the prior and eight brethren receiving a pension of $\$ 80$; the prior, Thomas Bradford, 69 ; Thomas Tolpuddle, $£ 7$; six other brethren, among whose names are entered William Grey and John Vynsant, $\AA^{6}$ to $£ 5$ each; Thomas Holnest, $405 .{ }^{66}$

The site of the abbey was afterwards granted to Sir Giles Strangeway's, knt., by Henry VIII. ${ }^{6 i}$

61 Ibid. 228-30.

6: On 2 April, 22s. 4d. was distributed to the poor of Abbotsbury for the souls of Thomas Strangeways and Alianor or Eleanor his wife (ibid. 227) ; on 6 July. and 7 Sept. 2 Is. 4 d. for the souls of Henry Russell and Alice his wife (ibid. 223); 6 s. $8 d$. on the feast of the Eleven Thousand Virgins for the souls of Walter Clopton and Joan his wife (ibid. 229); on 16 June, 9s. 1 d. for the soul of John Mautravers; on 26 May, 75. 2d. for the soul of John Cary (ibid. 229-30) ; on I 2 March, 8s. 8d. for the soul of Robert Bylsay ; a pension in the abbey and certain doles were assigned in commemoration for the souls of 'Orke and Thole his wife,' the original founders.

${ }^{63}$ Ibid. Hutchins, Hist. of Dorset, ii, 720.

${ }^{6} L$. and P. Hen. VIII, vii, 1607 (21).

${ }^{65}$ In many cases of this kind close examination has tended to destroy much of the value of accusations levelled against superiors by discontented monks. See 'Religious Houses,' I.C.H. Worcs. ii, 135.

${ }_{66}^{6}$ L. and P. Hen. VIII, xiv (1), 506.

${ }^{67}$ Dugdale, $M \circ n$. iii, 60 . 


\section{RELIGIOUS HOUSES}

Abbots of Abbotsbury

William tempo Henry ii ${ }^{68}$

Geoffrey occurs about $1166^{69}$

Roger occurs $1201^{70}$

Hugh occurs $1204-5^{71}$

Hugh occurs $123^{72}$

Roger de Brideton elected $1246^{73}$

John de Hilton elected $1257^{74}$ died 1284

Philip de Sherborne elected $1284^{75}$ died 1296

William de Kingston elected $1297^{76}$ but his election quashed by the bishop

Benedict de Loders appointed $1297^{77}$ died I 320

Ralph de Sherborne elected $1320^{78}$ died 132 I

Peter de Sherborne elected 132 I $^{79}$ died 1324

William de Faukener or Fauconer elected I $324^{80}$ died 1343

Walter de Saunford or Samford elected $1343^{81}$ died I 348 probably of the plague

Walter de Stokes elected $1348^{82}$ died 1354

Henry 'Tolre elected $1354^{83}$

Henry de Thorpe died $1376^{84}$

William Cerne elected I $376^{85}$ died I 40 I

Robert Bylsay elected I $40 \mathbf{I}^{86}$ died 1426

Richard Percy elected $1426^{87}$ resigned 1442

Edward Watton elected $1442^{88}$ died 1452

William Wuller elected $1452^{89}$ died 1468

Hugh Dorchester elected $1468^{90}$ died 1496

John Abbotsbury elected $1496^{91}$

John Portesham elected $1505^{92}$

Roger Roddon elected I534 surrendered $1539^{93}$

${ }^{69}$ Geoffrey who succeeded him speaks of William, his predecessor, in a charter. Red Bk. of the Exch. (Rolls Ser.), i, 211 .

${ }^{69}$ Ibid.

${ }^{70}$ Pedes Fin. (Hunter), ii, 78-81.

${ }^{71}$ In a patent roll of Edward II, Hugh is given as abbot in the sixth year of King John. Pat. 8 Edw. II, pt. 2, m. $6 d$. The abbey was vacant in 1212 and 1213 . Ibid. 13 John, m. 3 ; 14 John, m. 3 .

${ }^{72}$ As witness to an agreement between the bishop of Salisbury and abbot of Sherborne. Reg. Rubrum, fol. 158.

is Ibid. 42 Hen. III, m. I.

${ }^{75}$ Ibid. 12 Edw. I, m. I I.

${ }^{76}$ Ibid. 25 Edw. I, m. 20.

${ } 7$ Close 25 Edw. I, m. 12.

${ }^{78}$ Pat. 13 Edw. II, m. 7 ; Sarum Epis. Reg. Simon of Ghent, pt. 2, fol. 182 .

${ }^{79}$ Pat. 14 Edw. II, pt. 2, m. 21.

${ }_{80}$ Ibid. 17 Edw. II, pt. I, m. 2.

${ }^{81}$ Ibid. 17 Edw. III, pt. 2, m. 6.

${ }^{82}$ Ibid. 22 Edw. III, pt. 3, m. 14.

${ }^{83}$ Ibid. $28 \mathrm{Edw}$. III, pt. 2, m. 13.

${ }^{84}$ Ibid. 50 Edw. III, pt. 2, m. 5 .

${ }^{85}$ Sarum Epis. Reg. Erghum, fol. 8.

${ }^{86}$ Pat. 3 Hen. IV, pt. I, m. 23.

${ }^{87}$ Ibid. 5 Hen. VI, pt. 1, m. 19.

${ }^{89}$ Sarum Epis. Reg. Aiscough, fol. 12.

${ }^{89}$ Ibid. Beauchamp. pt. 2, fol. 22.

9n Ibid. pt. 2 (Inst.), fol. I 16.

${ }^{91}$ Ibid. Blyth, fol. 91.

${ }^{98}$ Ibid. fol. $128 d$.

${ }_{93}$ L. and P. Hen. VIII, vii, 1607 (21); xiv, 506.
A round eleventh-century seal attached to the surrender deed of the abbey, the impression of which is fragmentary, represents one of the fronts of the abbey church with porch and side towers. At base is an arcade of round-headed arches. The legend is destroyed..$^{94}$

The seal of Abbot Walter [1353] represents in a quatrefoiled panel St. Catherine with a wheel, the abbot kneeling before her. ${ }^{95}$ The legend is very defective.

\section{THE ABBEY OF CERNE}

The Benedictine abbey of Cerne was, traditionally, founded by the first apostle of the English, St. Augustine, who, according to William of Malmesbury, having converted Kent to the faith of Christ proceeded to penetrate into the rest of the English provinces over which the rule of King Ethelbert extended, that is to say over the whole of England with the exception of Northumbria, and coming to these parts met with great rudeness from the inhabitants of the country who fastening derisively the tails of cows ${ }^{1}$ to the garments of the evangelist and his companions drove them away. Whereupon the holy man perceiving the change that should rapidly take place in the minds of the people and 'patiently and modestly rejoicing to bear reproach for the name of Christ' cried to his companions 'Cerno Deum qui et nobis retribuet gratiam et furentibus illis emendationem infundet animam' (I see God who shall give us grace and impart to these deluded people a clange of heart). The prophecy was not long of fulfilment, the people repenting of what they had done approached St. Augustine desiring to be reconciled, and he, attributing this change to God, gave to the place the name of Cernel, compounded from the Hebrew word $\mathrm{Hel}_{\mathrm{l}}$ or $\mathrm{El}$ God and the Latin Cerno. Soon after the inhabitants became converted to the new faith and water being required to baptize them a fountain sprang out of the ground at the word of Augustine.?

In succeeding times, continues the chronicler, Edwold, brother to Edmund, king of the East

${ }^{94}$ Deeds of Surrender, No. I.

${ }^{95}$ B.M. Seals, lxii, 22.

1 This is the translation of caudas rackarum given by Hutchins (Hist. of Dorset, iv, I 8), Fuller, who repeats the story, calls them fishes' tails, Church Hist. i, 166.

This obviously mythical account of the origin of Cerne by William of Malmesbury (Gesta Pontif. (Rolls Ser.), $184-5$ ) is subsequently repeated by Capgrave in his life of St. Augustine, by Reyner, and again by Camden. See Coker, Particular Survey of Dorset (1732) 65,66 . From the account given by the thirteenth-century chronicler, Walter of Coventry, it would seem that Helith was the name of the primitive deity of these parts whose worship was destroyed by St. Augustine. $O p$. (Rolls Ser.) i, 6o ; Leland, Collect. i, $285 ;$ ii, 252 . 


\section{A HISTORY OF DORSET}

Anglians, retiring from the world on the death of his brother at the hands of the Danes, lived the life of a hermit at St. Augustine's well 'called the silver well' at Cerne, where he $\operatorname{died}^{3}$ So great was the respect felt for his memory that in later times the abbey appears under his patronage as well as that of the Blessed Virgin and St. Peter. ${ }^{4}$ After his death Ailmer or Æthelmar, generally styled earl or duke of Cornwall, translated the relics of Edwold with the assistance of Dunstan to the old church of Cerne "where now the parish church is' and built or rebuilt the monastery which he dedicated to the honour of St. Peter. ${ }^{5}$ The foundation was begun in the reign of Edgar according to Leland and completed in the year 987 .

In his foundation charter of that year Ethelmar (or Ailmer) son of Ælward, nobleman of king Æthelred, notifies to Archbishop Dunstan and Bishop Elfheah of Winchester that he has given to God and the monks there the place which is called Cernel in honour of the Blessed Virgin, St. Peter and St. Benedict, for his dear master king Æthelred, for himself and the redemption of his ancestors; he has granted to them also 6 cassates of land in Minterne, ro manses at Winterborne, 6 at Bredy, I 2 in the further Bredy, 3 in Rentscombe; Leofric, clerk of Poxwell, has added to the donation the rill of Poxwell which was confirmed by grant of king Ethelred; 死lfrith a relative of Æthelmar at Bincombe has given 4 cassates of land at Affpuddle, Alfwold gave 5 manses at Bloxworth; after the death of his wife the founder further bestowed on the monastery tithes of his yearly rent in Cerne and Cheselbourne together with tithes of honey, cheese and fat hogs in his other lands and desired that the monks should observe the rule of St. Benedict and should choose whatever secular patron they pleased. ${ }^{6}$

Canute is said to have plundered this monastery when he wasted the town but afterwards he became a considerable benefactor to it. ${ }^{7}$ The abbey had added largely to its endowment at the time the Domesday Survey was taken; the church of St. Peter was then returned as holding land in the following places: Cerne, Little Puddle, Radipole, Bloxworth, Affpuddle, Poxwell, East IVoodsford, Heffleton, 'Vergroth,' Little Bredy, IVinterborne, Long Bredy, Nettlecombe, Milton, Kimmeridge, Rentscombe and Symonds-

${ }^{3}$ WVill. of Malmesbury, op. cit. ; Leland, Collect. iii, 67 .

'Rymer, Foedcra, xiv, 637.

${ }^{5}$ Leland, Collect. iii, 67. The founder's name appears under various forms, Leland calls him Ailmer, Egelward (ibid. i, 26), and Elward (i, 25 5). Previous to his foundation there is said to have been a small monastery here of three monks. Ibid. iii, 67 ; Tanner, Nositis, Dorset, viii.

${ }^{6}$ Cart. Antiq. W. 16.

'Leland, Collect. i, 66; iii, 67. Coker, Particular Surv. of Dorsct, 65 . bury ; ${ }^{s}$ the total, amounting to I I 3 hides and 3 virgates, was valued at $f_{0} 115$, leaving out Affpuddle, the assessment of which was omitted. The widow of Hugh Fitz Grip, the Norman sheriff, held, we are told, I carucate in Poxwell formerly belonging to the demesne of the monks.

In 1 I 56 the abbot of Cerne was returned as holding by the service of three knights. ${ }^{9}$ Robert the abbot in I I 66 notified the king the knights' fees of his church and the knights who held them. Amongst these may be noted Robert Russell who held a knight's fee, less one virgate, unjustly and against the will of the convent because neither his grandfather nor his father held it of the church nor should hold it. In the demesne of the church were three and a half knights' fees in the vill of Cerne with freehold tenure (cum tenura Francolensium). Each one of these ought to keep ward at the king's command at Corfe Castle one month in the year, or, if it should please the king to have them in the army, two knights should be found for his service in the absence of ward (interin dismissa wardia.) ${ }^{20}$ The abbot of Cerne as a knight of the shire was summoned to Parliament in 1315 and to attend the Great Council at IVestminster in $1324^{11}$

The income of the abbey in the Taxatio of I 29 I was assessed at $£_{1} 778$ s., including spiritualities amounting to $f_{1} 3 \mathrm{I}_{75}$. $4 d$. from the churches of Radipole, Poxwell, Hawkchurch, Symondsbury, Long Bredy with the chapel of Little Bredy, and Powerstock, ${ }^{12}$ and temporalities valued at $f_{1} 6_{4}$ os. $8 d$. within the deaneries of Bridport, Dorchester and IVhitchurch. ${ }^{13}$ The clear annual income of the monks in the Valor Ecclesiasticus of 1535 was declared at

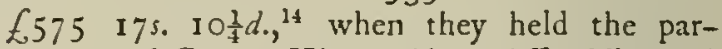
sonages of Cerne, Kimmeridge, Affpuddle, and Hermitage ${ }^{15}$ the manors of Cerne, Hawkchurch, Milton, Symondsbury, Maiden Newton, Mappercombe with Nettlecombe, Little Bredy, Long Bredy, Winterborne, Nether Cerne, Minterne, Middlemarsh, Bloxworth, Poxwell, Affpuddle, and Milborne St. Andrew, with parcels of land in various other manors and parishes. ${ }^{16}$

The history of the abbey is perhaps the least eventful of any of the Dorset houses with the exception of that of the sisters at Tarrant Kaines ;

${ }^{8}$ Dom. Bk. (Rec. Com.), 77 d. 78.

${ }^{9}$ Red Bk. of the Exch. (Rolls Ser.), i, 15.

${ }^{10}$ Ibid. i, 212.

$"$ Parl. Writs (Rec. Com.), ii, div. iii, 653 .

${ }^{13}$ Pope Nich. Tax. (Rec. Com.), 179, 180, 182.

is Ibid. Is 3, is 4 .

it Irolor Eccl. (Rec. Com.), i, 257.

15 Ibid. 253.

${ }^{16}$ lbid. 253-6. These manors are returned as being in the possession of the monks at the date the Volor was taken. The Monasticon (ii, 622) gives a list of lands and manors held by them at different times extracted from Hutchins' Hist. of Dorset. 


\section{RELIGIOUS HOUSES}

the period between the two great assessments of church property is almost entirely filled in with the record of fresh grants and privileges added to those the house already enjoyed, varied with the usual charges and demands made on houses of the royal patronage. Henry II by a charter undated granted to the monks wreck in all their lands by the sea, and rights of 'bellum' 'polam' and 'forum' (market) in the vill of Cerne, with all their liberties to their knights and free-tenants, and their services, doing service of two knights for scutage and of one knight on an expedition. ${ }^{17}$ John in 1213 ordered Hugh de Neville to grant the abbot seisin of his wood pertaining to the manor of Bloxworth of which he had previously been disseised by the king. ${ }^{18}$ Henry III, who was at the abbey II January $1223,{ }^{19}$ signified his assent on I 2 February, I 230 , to the election of Richard prior of Abbotsbury as abbot; the appointment of a superior being relegated to the election of the said prior, the sub-prior and sacrist or any two of them. ${ }^{20}$ An inquiry was instituted in 1275 in to the complaint of the abbot that whereas the charters of Henry II and Henry III, inspected and confirmed by the present king, entitled him to wreck of the sea on the coast of his lands in Brownsea and Rentscombe as enjoyed by his predecessors, two tuns of wine cast upon his lands had been seized by the constable of Corfe Castle and conveyed to the castle; ${ }^{21}$ as a result of the inquisition Edward I the following year confirmed the abbot's claim and ordered the constable to return the tuns in question or make due reparation.22 In October of the same year the convent received a grant of protection to last a year. ${ }^{23}$ Edward II in 1318 granted a licence for the monks to acquire lands and rents to the yearly value of $f_{1} \mathrm{O}$, in part satisfaction of which they obtained 5 messuages, 30 acres of land and a moiety of an acre of meadow in Cerne, and added to that another five messuages and land in Cerne and Middlemarsh and ten acres of land in Wootton by Bridport. ${ }^{24}$ In the sarne year they obtained a charter of free warren over their lands in Cerne, Minterne, Middlemarsh, Winterborne, Little Bredy, Poxwell, Bloxworth, Symondsbury, Wootton, Hawkchurch, Brownsea, Mappercombe, Nettlecombe, Milton, and Long Bredy \&c. ${ }^{25}$ From Edward III the brethren secured a licence enabling them to acquire further lands in Estyep by Symondsbury, Wootton and

${ }_{17}$ Harl. MS. 6748 , fol. 7.

${ }^{18}$ Close, 15 John, m. 9.

${ }^{19}$ Close, 7 Hen. III, m. 22.

${ }^{20}$ Close, 4 Hen. III, m. 15.

${ }^{21}$ Pat. 3 Edw. I, m. $24 d$.

${ }^{22}$ Close, 4 Edw. I, m. 3 ; 5 Edw. I, m. 7 .

${ }^{23}$ Pat. 4 Edw. I, m. 9.

${ }^{34}$ Pat. II Edw. II, pt. I, m. 6 ; pt. 2, m. 6.

${ }^{23}$ Chart. R. I I Edw. II, No. 34. A few years later a nother charter with right of free warren in their manor of Symondsbury was accorded. Ibid. 19 Edw. II, No. 13 .
Bloxworth. ${ }^{26}$ On the death of Abbot John de Hayle, who died at the close of 1382 after holding office for only six months, the king made over to the prior and convent the custody of the temporalities of the house, retaining only the knights' fees and advowsons, for the payment of $£_{20}$ at the exchequer for the first five weeks or part of the same, and afterwards at the rate of $f_{4}$ a week. ${ }^{27}$ Richard II on payment of a fine in 1392 gave a licence for the alienation in mortmain by William Batecombe and Edward Stykelane of one messuage, \&c., and 5s. rent in Frome St. Quintin and Milborne St. Andrew to the abbot and convent in aid of their maintenance and for the support of certain charges. ${ }^{23}$ Two years later by another licence Richard Chideock and Joan his wife were permitted to make over certain lands in Symondsbury, not held in chief, to the brethren to support the charges of the fabric of their church. ${ }^{29}$ The monks took the precaution of obtaining from Henry IV, Henry VI and Edward IV inspection and confirmation of the letters patent of Richard II confirming their previous charters. ${ }^{30}$ On 10 August, 147 1, Edward IV issued a general pardon to the abbot for all offences committed by him previous to 6 August and for all alienations and acquisitions of land made without the king's licence. ${ }^{31}$ Henry VIII in 1513 made over to the abbey the free chapel called 'le Hermytage' of Blackmoor, Dorset.

The charges on the abbey included the usual requests for aid in the Scotch war, ${ }^{33}$ and later on for loans in the war with France. ${ }^{34}$ In the general distribution of pensioners among the religious houses during the wars Hugh Cade was allotted to Cerne Abbey in $1315 ;{ }^{35}$ the following year John de Kent was sent to receive the allowance which John Hawayt had had. ${ }^{36}$ Peter Polter, or Pulter, was sent by Edward III to the abbey in 1338 in the place of Thomas de

${ }^{26}$ Pat. 4 Edw. III, pt. 1, m. 35 .

${ }^{27}$ Ibid. 6 Ric. II, pt. 2, m. 29. The grant was confirmed later by Henry IV. Ibid. 2 Hen. IV, pt. 3 , m. 32 .

${ }^{23}$ Ibid. 16 Ric. II, pt. 1, m. 26.

${ }^{29}$ Ibid. 18 Ric. II, pt. I, m. 3.

${ }^{30}$ Ibid. 2 Hen. IV, pt. 3, m. 32 ; 5 Hen. VI, pt. 2, m. 12, I 3, 21 ; Edw. IV, pt. 1, m. 7 .

s1 Ibid. I1 Edw. IV, pt. I, m. 12. His offence may have consisted in acquiring the temporalities of the house on his election by licence of the late king, Henry VI (Ibid. m. 6), but there is also a tradition which this pardon rather confirms that Margaret of Anjou was entertained at the abbey and held a council there before the battle of Tewkesbury. She certainly landed in this county. Hutchins, Hist. of Dorset, iv, 29.

${ }^{3} L$. and P. Hen. VIII, i, 3853 .

${ }^{33}$ Close, 3 Edw. II, m. 5 d, ced. ; 8 Edw. III, m. $5 d$.

${ }^{3}$ Pat. 2 Ric. II, pt. 2, m. 27-8.

${ }^{35}$ Close, 9 Edw. II, m. $27 \%$.

${ }^{s 0}$ Ibid. 1o Edw. II, m. 24. 


\section{A HISTORY OF DORSET}

la Garderobe, deceased, ${ }^{37}$ and in his turn was succeeded by John Serle in $13+7 . .^{38}$ In accordance with the usual custom in connexion with houses of the royal patronage the Close Rolls record the appointment of a clerk to receive a pension in 1312 on the election of a new abbot, ${ }^{39}$ and again in the year $1324 .{ }^{40}$ In the reign of Henry VIII William Bonde, yeoman of the guard, in $\mathrm{I} 337$ received a grant of a corrody in the monastery void by the death of Richard March. ${ }^{41}$ The contribution by the abbey to the grant raised by the spirituality in aid of the expenses incurred by Henry VIII ' in recovering the crown of France' is set down at $£ 200.42$

Many of the grants to the abbey were made with the object of founding chantries and establishing anniversaries for the benefit of the grantors. In I 335 William de Whitefield gave his manor of Milborne Michelstone to the abbot and convent for the provision of two chaplains to celebrate daily in the abbey church for his soul and the souls of his ancestors and heirs. ${ }^{43}$

Roger Manyngford and John his son in I 382 obtained from Richard II a licence permitting them to grant the convent the advowson of the church and, on the death of the chaplain, the reversion of the manor of Stoke by Bindon for daily celebration for the good estate of the said Roger while living, and for his soul after death, and the souls of his wives, children and ancestors, and for the performance of other works of charity. ${ }^{41}$ Edward IV in $1+82$ permitted the appropriation of a third part of the manor of Maiden Newton to the monastery for the sustenance of a chaplain to celebrate daily at the altar of St. John Baptist for the good estate of the king and Elizabeth his consort. ${ }^{45}$ Among the few references to this abbey in the episcopal registers may be found the record of the establishment of the Stafford chantry by an indenture dated Trinity Sunday, I 403, between the abbot and Humphrey Stafford, knt., whereby, in return for the grant of the manor of Milborne St. Andrew, the convent agreed to provide a chaplain to celebrate a daily mass to be called 'the Stafford masse' at the altar of Holy Cross in

${ }^{37}$ Close, 12 Edw. IH, pt. 1, m. $32 d$.

${ }^{3 s}$ Ibid. 21 Edw. III, pt. 1 , in. $23 d$.

${ }^{39}$ Ibid. $6 \mathrm{Edw} .11, \mathrm{~m} .26 \%$

10 Ibid. 17 Edw. II, m. $11 \%$

"L. and P. Hen. VIII, xii (2), 1008 (24). The Valor of 1535 estimates this corrody or pension in the gift of the crown 'in the name of the janitor or warden of the gate of the monastery' at $66 \mathrm{~s}$. $8 \%$. There was another corrody or pension also at the king's disposal valued at $66 \mathrm{~s} .8 \%$. Falor Eecl. (Rec. Com.), i, $2 ; 6$.

${ }^{42}$ L. and P. Hen. FIll, iii, $248_{3}$.

${ }^{13}$ Pat. 9 Edw. III, pt. 1, m. 10.

1 Pat. 5 Ric. II, pt. 2, m. 16.

${ }^{4}$ Ibid. 21 Edw. IV, pt. 1, m. 8. the nave of the church or of St. Michael near, ${ }^{46}$ for the good estate of the said Humphrey and Elizabeth his wife, and for their souls after death, together with the soul of the abbot, and of various other members of the Stafford family, who, it was stipulated, should be admitted as participants in all the spiritual benefits of the house, vigils, sacraments, almsgiving, and in the masses of the monks. An anniversary was to be fixed on which certain doles and distributions should be made, and a poor man or bedeman yearly appointed whose special duty it was to be present at the founders' mass, and to pray continually for their souls, in return for which he should receive the sum of $175.4 d$. yearly, and five yards of cloth for a gown. ${ }^{47}$ In the Valor of 1535 the charges on the monastery include the sum of $46 \mathrm{~s} .8 \mathrm{~d}$. in a yearly distribution to the poor on 14 December for the soul of Ailmer, 'sometime duke of Cornwall, founder of the monastery ;' $66 \mathrm{~s}$. $8 d$. assigned for the provision of food, clothing, beds and other necessaries in the abbey for two poor men for the soul of the said founder, and a weekly distribution of bread and ale to thirteen poor men 'called freers' at a yearly cost of EI I 5s. $4 d^{43}$ The total annual expenditure of the house under the head of almsgiving and in commemoration of the souls of founders and benefactors came to $£ 34$ 6s. $3_{\text {d. }}{ }^{49}$

Articles containing charges of a serious character were brought up on the eve of the dissolution against the last abbot, Thomas Corton, wherein he was denounced (I) for gross immorality, (2) for letting the church and abbey lands go to ruin, (3) for wasting the goods of the house on his mistresses and natural children, and bestowing gifts out of the conventual funds on the former on their marriage. ${ }^{53}$ William Christchurch, monk of the house, came forward also with complaints that the abbot did not maintain constituted obits and doles, and permitted some of his monks to be proprietors, that he allowed two of them 'who daily haunt queans' to celebrate mass without confession, to play at dice and cards all night and celebrate in the morn-

${ }^{16}$ Hutchins cites an MS. 'in the public library at Cambridge,' which gives the dedication of various altars in the abbey church. In 1311 an altar in the abbot's chapel was dedicated in honour of St. Stephen and St. Katharine by an Irish bishop of Annadown (Enachdunensis), who granted an indulgence of 20 days to those who should visit it. The same bishop dedicated the chapel of the infirmary in honour of the Virgin, St. Margaret, and St. Apollonia, and granted an indulgence of 30 days. In 1318 the bishop of Salisbury dedicated the high altar in honour of the Virgin and St. Peter with a similar grant of 40 day's" indulgence. Hist. of Dorset, iv, 20.

17 Sarum Epis. Reg. Campegio, fol. ult.

48 Valor Eccl. (Rec. Com.), i, 256.

4 Ibid. 257 .

${ }^{\text {so }} L$. and $P$. Hen. $V I I I$, viii, 148 . 


\section{RELIGIOUS HOUSES}

ing; women, it was alleged, were allowed freely into the abbey. In addition "Dan Will Christchurch' had his tale of personal injuries to recount; he had been imprisoned by the abbot for his illspeaking, dismissed from the monastery, and the prior of Monmouth had been given twenty nobles to receive him in his priory where he had been very ill-handled.5! It would be rash to accept these statements without more reliable evidence, but they were sufficient to draw down on the abbey the officials of the High Commissioner, and abbot and monks were forbidden to go outside the bounds of the monastery. Great inconvenience naturally resulted, and on 2 September, I 535, a letter was written to Cromwell requesting in the interests of the house that the abbot might have liberty to ride abroad to attend to the affairs of his monastery 'as you have allowed the abbot of Sherborne,' adding, 'the abbot sends you his fee of 5 marks sterling.' 52

The King's Commissioners were instructed to induce superiors to surrender their houses promptly and willingly in the hope of securing liberal treatment for themselves. In December, 1 538, Sir Thomas Arundel wrote to Cromwell that the abbot of Cerne, in spite of persuasion, was making efforts to obtain the continuance of his house, and with that object in view was prepared to offer 'His Majesty' 500 marks and 'your lordship' $\ell_{100.53}$ The doom of the house could not be averted, however, and on I 5 March following (1539) the abbot, with the prior and fifteen of his brethren surrendered the abbey to the king in the person of John Tregonwell, the commissioner, ${ }^{54}$ the abbot subsequently receiving a pension of $E_{0} 100$, the prior $E_{10}$, one brother $f_{0}$, another $\AA_{0} 7$, the sub-prior and nine of the inmates sums ranging from $£^{6} \quad 13^{s}$. $4 d$. to £5 6s. 8d, and three remaining brethren 40 s. each. 55

\section{Abbots of Cerne}

Elfric, appointed about 987 , on the refoundation of Cerne as a Benedictine monastery ${ }^{56}$

Alfric Puttoc, occurs $1023^{37}$

Withelmus, occurs $1085^{68}$

Haimo, deposed I 102 for simony ${ }^{59}$

"L. and P. Hen. VIII, viii, 148.

${ }^{52}$ Ibid. ix, $256 . \quad{ }^{53}$ Ibid. xiii (2), 1090.

${ }^{5}$ Among the fifteen two are entered as students. lbid. xiv (1), 523 .

is Ibid.

${ }^{56}$ This was the author of the Homilies, who began as a monk of Abingdon, was successively abbot of Cerne and St. Albans, and finally archbishop of Canterbury.

${ }^{57}$ Dugdale and Hutchins give this without reference.

${ }^{58}$ Hutchins cites this from the Annals of Lanercost, Hist. of Dorset, iv, 22.

${ }^{59}$ Walter of Coventry, OP. (Rolls Ser.), i, 121.
William, occurs 112 I 60

Bernard, became abbot of Burton in $1160^{61}$

Robert, occurs I $166^{62}$

Dionysius, occurs $1206,{ }^{63}$ resigned 1220

R., elected I $220^{64}$

William de Hungerford, elected $1232^{65}$

Richard de Suwell or Sawel, elected I $244,{ }^{66}$ died 1260

Philip, elected $1260^{67}$

Thomas de Ebblesbury, elected $1274^{68}$

Gilbert de Minterne, elected $1296,{ }^{69}$ died I3 2

Ralph de Cerne, elected I $12,{ }^{70}$ died I 324

Richard de Osmington, elected $1324^{71}$

Stephen Sherrard, elected $135^{72}$

Thomas Sewale, elected I $361,{ }^{73}$ died 1382

John de Hayle, elected $1382,{ }^{74}$ died in same year

Robert Symondsbury, elected $1382^{75}$

John Wede, elected I $411{ }^{76}$ died 1427

John Winterborne, elected $1427,{ }^{77}$ died 1436

John Godmanston, elected I 436,78 died I 45 I

William Cattistoke, elected $1451,{ }^{79}$ died I 454

John Helyer, elected $1454,{ }^{80}$ resigned I $45^{8}$

John Vanne, elected I $458,{ }^{81}$ died I 47 I

Roger Bemyster, elected I 47 1, ${ }^{82}$ died I 497

Thomas Sam, elected $1497,{ }^{83}$ died 1509

Robert Westbury, elected 1510,84 died I 524

Thomas Corton, elected $1524,{ }^{85}$ surrendered his abbey I 539

${ }^{60} \mathrm{He}$ was a witness to the foundation charter of Plympton Priory (Devon). Dugdale, Mon. vi, 2 I.

${ }^{61} \mathrm{He}$ is said to have then been a monk at Gloucester, and to have previously quitted Cerne on account of the great disorders of the house. Ann. Mon. (Rolls. Ser.), i, 187 .

${ }^{62}$ Red Bk. of the Exch. (Rolls Ser.), i, 2 I 2.

${ }^{63}$ Pat. 7 John, m. 5.

${ }^{64}$ Ibid. 4 Hen. III, m. 6.

${ }^{65}$ Ibid. 16 Hen. III, m. 7 .

${ }^{66}$ Ibid. 28 Hen. III, m. 7 .

${ }^{67}$ Ibid. 44 Hen. II, m. I.

68 Ibid. 3 Edw. I, m. 36.

${ }^{69}$ Ibid. 25 Edw. I, pt. 1, m. $15 d$.

${ }^{70}$ Ibid. 6 Edw. II, pt. 2, m. 8 ; Sarum Epis. Reg.

Simon of Ghent, pt. 2, fol. 121.

${ }^{11}$ Pat. 17 Edw. 11, pt. 2, m. 19.

72 Sarum Epis. Reg. Mortival, fol. 103 d; Pat. 30.

Edw. III, pt. 3 .

${ }^{73}$ Sarum Epis. Reg. Wyville, ii (Inst.), fol. 29 4.

${ }^{7}$ Pat. 6 Ric. II, pt. I, m. 35.

${ }^{75}$ Ibid. pt. 2, m. 22.

${ }^{76}$ Ibid. 12 Hen. IV, pt. I.

${ }^{77}$ Ibid. 5 Hen. VI, pt. 1, m. 16.

${ }^{8}$ Hutchins, Hist. of Dorset, iv, 23.

${ }^{80}$ Sarum Epis. Reg. Beauchamp, ii, fol. 23.

${ }^{81}$ Pat. 37 Hen. VI, pt. I, m. 12.

${ }^{63}$ Pat. 49 Hen. VI.

${ }^{33}$ Sarum Epis. Reg. Langton, fol. 99.

L. and P. Hen. VIII, i, 822 .

${ }^{85}$ Ibid. iv, 436 . 


\section{A HISTORY OF DORSET}

A thirteenth-century round seal with very fine but imperfect impression represents the west front of the church, with elaborate details of early English architecture. On the foliated crockets of the roof on the left side there is a small bird, on the right the corresponding bird has been broken off. In base under two roundheaded arches of masonry are two half-length figures of the founders, St. Augustine and Æthelmar, with their hands uplifted to support the church above them. On each side behind them a cinquefoil, that on the right broken away. The legend is wanting. ${ }^{86}$

An example of the above seal with very imperfect impression is to be found attached to the surrender deed of the abbey. ${ }^{87}$

The abbot's seal of the fifteenth century, pointed oval, with fine but imperfect impression, shows in three canopied niches full-length figures of the Virgin crowned, with the Child in her right hand, and a sceptre fleur-de-lis in her left hand, St. Catherine with crown, nimbus and wheel on the left, and St. Margaret with crown on the right standing on a dragon and piercing his head. In base under a round-headed arch the abbot, half-length, with mitre and staff, praying. On the masonry at the sides two shields of arms; on the left a lion rampant within a border bezanty; the right a cross engrailed hetween four lily-flowers slipped, Cerne Abbey. ${ }^{\circledR 8} \quad$ Legend defective :-

\section{SIGILL ... DE CERNE}

The signet of Abbot Roger Bemyster is attached to a deed dated 1475 , of which only an indistinct fragment remains representing a ram or goat with the legend [R]OGER[US]. ${ }^{89}$

\section{THE ABBEY OF MILTON}

The Benedictine abbey of Milton or Middleton was built in the year $933^{1}$ by King Ethelstan for the soul of his brother Edwirn, or, as some historians aver, to expiate the crime of a brother's murder, ${ }^{2}$ the king, in his foundation charter,

${ }^{66}$ B.M. Seals, lxii, 30.

${ }^{67}$ Deeds of Surrender, No. 52.

${ }^{85}$ B.M. Seals, lxii, 3 I. ${ }^{69} \mathrm{Harl}$. Chart. $4+$ B. 48.

1 Tanner, Notitia, Dorset, xviii. The tenth year of King Ethelstan is the date generally accepted, and it agrees with the date of the death of Prince Edwin. Angl.-Sax. Chron. (Rolls Ser.), 85; Sim. of Durham, Op. (Twysden), p. 154. Dugdale quotes an account of the foundation from a register of the abbey, no longer in existence, which states that the house was built in the tenth year of Xthelstan's reign, which began in 824 (Mon., Chart. of Milton, No. 3, vol. ii, 348). This is palpably a mistake, as is also the date given in the foundation charter. Birch, Cart. Sax., ii, $452-3$.

"According to the account given in the abovementioned register Æthelstan, upon false suggestions that Edwin was concerting a plot against him, caused testifying (without reference to the above incident) that for an endowment he had granted for the good of his soul, and the souls of his successors, the kings of England, to God, St. Mary, St. Sampson, and St. Branwalader the following lands: -26 hides at Milborne, 5 at Woolland, 3 at Fromemouthe, viz. : 2 in an island and one at Ore (Ower), 3 hides at Clyffe with a meadow, $3 \frac{1}{2}$ at Lyscombe, I at Burleston, I at Little Puddle, 5 at Cattistock, 6 at Compton Abbas, 2 at Whitcombe, 5 at Osmington, 6 at Holworth-in all 67 hides; a weir on the Avon at Twyneham (co. Hants), all the water within the shore at Weymouth and half the stream out to sea, I 2 acres of land for the support of the weir and the person in charge of it, and 3 thaynes in Sussex and a saltern by the weir, 30 hides of land at Sydling for the maintenance of the monks, 2 at Chelmington, 6 at Hillfield, and 10 at Ercecombe (Stockland). ${ }^{3}$ The king further bestowed rich gifts on the abbey wherein he buried the body of his mother, together with numerous relics procured from Rome and Brittany, including the arm and bones of St. Sampson, archbishop of Dol, and the arm of St. Branwalader the bishop. ${ }^{4}$ In the reform of monasticism under Edgar and Dunstan the secular priests here were replaced in 964 by monks under an abbot, Cyneward. 5

At the time of the Domesday Survey besides twelve acres of land in Hampshire, held of the abbey by the sheriff Edward, ${ }^{6}$ the church of Milton had manors or estates in the following places :-Sydling, Milton, Compton Abbas, Cattistock, Puddle, Clyffe, Osmington, Whitcombe, Lyscombe, Woolland, Winterborne, Hillfield - the rent of which was $£^{2}$ and a sextary of honey-'Ora' (Ower), Stockland-

the prince to put out to sea in an open boat with a single attendant. The prince in despair threw himself overboard and was drowned, his squire with great difficulty managed to swim to shore at Whitsand with his body. The king repenting of his deed is said to have confined himself seven years at the monastery of Landport (Somerset) as a penance, and to have founded the two abbeys of Michelney and Milton. Dugdale, Mon., Chart. of Milton, No. 2, ii, $34 \mathrm{~S}$; Will. of Malmes. Gesta Regum (Rolls Ser.), i, 156 ; Leland, Coll., ii, 252 ; iii, 71 ; Stowe MS., 1046 , fol. 24 .

${ }^{3}$ Birch, Cart. Sax., ii, 452-3. The version given by Kemble (Cod. Dipl., ii, 245) omits the grant of the 'water at Wermouth,' but it is included in what is called the Middle English version of the same charter $(v, 235)$, though left out in the confirniation charter of Henry I. Dugdale, Mon., Chart. of Milton, No. $7, \mathrm{ii}, 350$.

${ }^{4}$ Ibid. Chart. of Milton, No. 5, ii, 349 ; Will. of Malmes., Gesta Pontif. (Rolls Ser.), I $66,400-1$; Leland, Coll., jii, 71.

${ }^{3}$ Ibid. ii, 186 ; iii, 72. Angl-Sax. Chron. (Rol's Ser.), 94 .

${ }^{8}$ Dom. Bk. (Rec. Com.), i, $43 b$. 


\section{RELIGIOUS HOUSES}

which belonged to the demesne of the monks, and was assigned towards the expenses of their living and clothing - and Piddletrenthide. ${ }^{7}$ Henry I, reciting the charter of Æthelstan, king of England, the founder, confirmed to the abbey of Milton and the monks serving God there their possessions therein enumerated with all liberties, free customs and acquittances, the right of soc, sac, tol, team, and infangnetheof, waif, assize of bread and ale, gallows, pillory, and all other appurtenances. ${ }^{8}$ From Henry III the abbot and convent obtained a charter in 1252 for the right of free warren over all their demesne lands in Dorset, provided they should not be within the king's forest, with a licence to hold a weekly market at the monastery within the manor of Milton on Thursday, a yearly fair there on the vigil, feast, and morrow of the Assumption of the Blessed Virgin Mary, and a yearly fair in their manor of Stockland on the same three days. ${ }^{9}$ The Taxatio of I 291 gave the abbey spiritualities amounting to 69 I 8 s. $8 d$. from the churches of Sydling, Puddletown, Tolpuddle, Dewlish, Whitcombe, and Holworth, Stockland, Cattistock and Compton; ${ }^{10}$ and temporalities valued at $\oint_{12} 6$ 9s. ${ }^{11}$ in the deaneries of Bridport, Dorchester, and IVhitchurch, the total income from both sources being assessed at $f_{0} 3^{6} 7 \mathrm{~s} .8 \mathrm{~d}$.

The abbot was assessed for his holding at two knights' fees in the reign of Henry II ; ${ }^{12}$ in I $155^{-6}$ he paid 40s. scutage. ${ }^{13}$ He certified the king by charter in I 66 that originally the abbey owed no knights' fees either of the old or new feoffment, but that Roger, bishop of Salisbury, on the occasion when he took the abbey into custody on its voidance at the command of Henry I, enfeoffed one knight of a tenement, viz. 2 hides held by Robert de Monasteriis, and another knight of another tenement, viz. $2 \frac{1}{2}$ hides which William Fitz Walter held. Afterwards R., the predecessor of the present abbot, had returned these fees to their original state, and the knights constituted by the bishop had been made censuarii, and held thus in the time of the aforesaid R., as did their heirs at the present time: William de Monasteriis and William Brito. ${ }^{14}$ In the year 1184 Osbert de Dorchester and Robert de Godmanston rendered

${ }^{7}$ Dom. Bk. (Rec. Com.), i, 78 .

${ }^{8}$ Dugdale, Mon., Chart. of Milton, No. 7, ii, 350-1.

${ }_{9}^{9}$ Chart. R. 37 Hen. III, m. 16. Edward II, in his subsequent exemplification of the possessions and liberties of the monks previous to their disastrous fire of 1309 , declared that these markets and fairs were originally granted by their founder Æthelstan. Pat. 5 Edw. II, pt. 1, m. 17.

${ }^{10}$ Pope Nich. Tax. (Rec. Com.), 179.

"Ibid. 183-4.

${ }^{12}$ Red Bk. of the Exch. (Rolls Ser.), i, 15, 26, 33,54 .

I3 Ibid. ii, 678 .

14 Ibid. i, 211. an account to the Exchequer of the farm of the possessions of the abbey for half a year. ${ }^{15}$ An account for three terms was rendered in $1213,{ }^{16}$ and on July of that year John intimated to the custodians of the abbeys of Abbotsbury, Sherborne, and Milton that he was sending down a number of sick horses to be placed in their charge. ${ }^{17}$ Edward I, in the first year of his reign, granted to the prior and convent on payment of a fine of fifty marks the custody of their abbey, void by the death of Abbot William de Taunton. ${ }^{18}$ The convent, in common with other ecclesiastics, received in 1294 a grant of protection for a year in consideration of the money which they had contributed towards the royal subsidy. ${ }^{19}$

A great misfortune befell the community in 1309 ; on the night of 2 September the wooden belfry of their church was struck by lightning in the midst of a violent thunderstorm and gale; the building took fire, and in its destruction perished the bells, ornaments, and vestments of the monks, together with all their books, charters, and muniments. ${ }^{20}$ The bishop of Salisbury immediately granted an indulgence of forty days in aid of the restoration of the church; ${ }^{21}$ and with the object of replacing the title deeds which had been lost Edward II ordered a commission to inquire as to the lands and rents held by the abbot and convent previous to the destruction of their charters, ${ }^{22}$ by his own charter two years later reciting the return made by the inquisition and confirming to the brethren all gifts and privileges granted to the abbey by King Ethelstan, his predecessor, and all subsequent benefactors. ${ }^{23}$ The abbot and convent received a licence from the king in 1315 for the appropriation of the church of Sydling to their own uses, the issues being charged with a sum of 20 marks, to be paid yearly to the chapter of Salisbury towards the maintenance of the chantry and obit of Nicolas Longespée, sometime bishop of Salisbury, in the cathedral $;^{24}$ and in $133^{2}$ Edward III gave permission for the convent to appropriate the church of Stockland, 'said to be

${ }^{15}$ Madox, Hist. of the Exch. i, 310.

${ }^{16}$ Ibid. 312.

${ }^{17}$ Close, 15 John, m. 4 .

${ }^{18}$ Pat. I Edw. I, m. 17.

Ibid. 22 Ediv. I, m. 8.

Sarum Epis. Reg. Simon of Ghent, i, fol. 86 ; Trivett, Annals (Rolls Ser.), ii, 7 ; Walsingham [Hist. Angl. (Rolls Ser.), i, 126] erroneously dates this fire in 13 II.

${ }^{21}$ Sarum Epis. Reg. Simon of Ghent, i, fol. 86.

${ }^{22}$ Pat. 3 Edw. II, m. 32.

${ }^{23}$ Ibid. 5 Edw. II, pt. 1, m. 17. This confirmation was in 1393 inspected and confirmed again to the monks by Richard II. Ibid. 17 Ric. II, m. 27 .

${ }^{24}$ Ibid. 8 Edw. II, pt. I, m. 31 ; Sarum Epis. Reg. Mortival, ii, fol. 49 ; see Cal. Pap. Letters, iv, $207 \%$ 


\section{A HISTORY OF DORSET}

of their advowson.' ${ }^{25}$ In 1324 Robert de Farendon alienated to the community roos. rent from a messuage and land in Upper Sydling for the provision of a monk to celebrate daily in the chapel of St. Mary Milton for his soul and the souls of his ancestors; ${ }^{26}$ and in 1329 a further grant was made by Nicholas de WVeye and William de $\mathrm{W}_{y}$ decombe, chaplain, in aid of the maintenance of a monk who should celebrate daily in the abbey for their souls and those of their ancestors and successors. ${ }^{27}$ In 1336 the convent were permitted to purchase the manor with the advowson of the church of IVinterborne Stickland from the chapter of Coutances in Normandy ; at the same time it was ordained that Io marks should be paid annually out of the same, and other lands in Milton and Osmington, to the chapter of Salisbury for a chantry established in the cathedral for the kings of England and Simon of Ghent, late bishop; another 5 marks for a chantry in the church of Melcombe Regis for the soul of Edward III, and 5 marks for a chantry in the church of Milton for the good estate of the king, Queen Philippa his consort, and their children, and for their souls after deatl. ${ }^{28}$ A carucate of land in Bryanston was conveyed to the convent in $\mathrm{I} 344$ for the yearly observance, on 3 I January, of the anniversary of William de Stokes. ${ }^{29}$ In 1392 the brethren, on payment of a fine of roo marks, obtained from Richard II licence to acquire various parcels of land in Hunsworth, Langford, Milton, and Bedeshurst to be assigned towards the yearly maintenance of the anniversaries of Roger Manyngford ${ }^{30}$ and Margaret his wife, and other works of piety.

Henry IV, on 22 October, I 400 , inspected and confirmed an agreement made in 1386 between the abbot and convent and Nicholas Langford, whereby the former consented to receive the latter into their confraternity so that in life he should participate in all the spiritual benefits of the monastery and order, should receive a weekly corrody of bread and ale, a robe with fur every year, a 'good chamber' within the abbey with fuel and litter, stabling, and keep for his horse, and a yearly rent of 40 s., and after death that his name should be sent round with the names of other dead monks throughout England; in return for these benefits it was stipulated that he should assist the community in their business with his counsel. ${ }^{3 I}$

The abbey was spared none of the charges imposed on houses of any standing belonging to the

${ }^{25}$ Pat. 6 Edw. III, pt. I, m. 16.

${ }^{26}$ Ibid. $18 \mathrm{Edw}$. II, pt. 1, m. 28.

si Ibid. 2 Edw. III, pt. 2, m. 29.

"Ibid. Io Edw. III, pt. 2, m. 8 ; 15 Edw. III, pt. 3 , m. 6 ; 2 I Edw. III, pt. 3, m. 3 I.

${ }^{39}$ Ibid. I 8 Edw. III, pt. 2, m. 9 .

${ }^{30}$ Ibid. 16 Ric. II, pt. 1, m. 30.

${ }^{31}$ Ibid. 2 Hen. IV, pt. 1, m. 35.
Benedictine order and of the royal patronage. ${ }^{32}$ Pensioners were bestowed on the house with unfailing regularity by Edward II and Edward III, ${ }^{33}$ and on the appointment of a new abbot they did not fail to present a clerk for the pension due at the royal nomination. ${ }^{34}$ In 1332 the abbot was requested to contribute towards the subsidy raised on the occasion of the marriage of the king's sister; ${ }^{35}$ and two years later to give a tenth towards the expenses incurred by the Scotch war. ${ }^{36}$

The community, which is said to have originally numbered forty, ${ }^{37}$ was considerably reduced in numbers in the latter part of its existence, the change being attributed in the first place to the loss incurred by the fire of $1309 .{ }^{38}$ Other causes were not wanting, and the strain on the resources of the abbey became marked during the rule of Richard de Maury, $1331-52.39$ On 24 April, I344, the king ordered the chancellor of Salisbury, John de Tylvyngton, Thomas Cary, and John Maury to take the house, now in a state of great depression and indebtedness owing to dissensions between the abbot and convent, into their

s3 With the exception of the year following its loss by fire, when Milton was omitted from the list of abbots who were requested to aid the king with victuals for the Scotch war; Close, 3 Edw. II, m. 5 d.

${ }^{33}$ Close, 8 Edw. II, m. I I d.; I 2 Edw. II, m. I 9 d.; 6 Edw. III, m. $18 d . ; 7$ Edw. III, pt. 1, m. $3 d . ;$ 8 Edw. III, pt. I, m. I $d . ; 2$ I Edw. III, pt. I, m. $2 d$. ; $23 \mathrm{Edw}$. III, pt. 1, m. $12 d$.

s4 Ibid. 8 Edw. II, m. 20 d.; 26 Edw. III, m. $5 d$.

${ }^{35}$ Ibid. $6 \mathrm{Edw}$. III, m. $16 d$.

${ }^{36}$ Ibid. 8 Edw. III, m. 5 d.

${ }^{37}$ Hutchins (Hist. of Dorset, iv, 390) cites this from 'an anonymous author in the Cotton Library.'

33 'The excuse put forward by the community in 1320 for declining to receive a certain Robert Oysel, clerk, who desired to enter the monastery, was that their house was already burdened beyond its capacity to sustain its present number, and would not admit of another; Sarum Epis. Reg. Mortival, ii, fol. 99 .

${ }^{39}$ The abbot, who receired the benediction on his election in 1331 at the hands of Simon, archbishop of Canterbury, "in the exercise of his right of visitation in the diocese of Salisbury' (Pat. 5 Edw. III, pt. 2, m. 32), does not seem to have been acknowledged by his bishop till the year 1336 , when he was formally pardoned for his irregularity in seeking confirmation from the primate instead of from his ordinary (Sarum Epis. Reg. Wyville, fol. 30 d.). A commission of oger and terminer was issued in 1338 and 1340 to investigate complaints of trespass against the superior (Pat. 12 Edw. IlI, pt. 3, m. I6d.; 14 Edw. III, pt. $1, m .+1 d$ ), who in 1342 appears to have been imprisoned for trespass at Rockingham (Close, $16 \mathrm{Edw}$. III, pt. 1, m. 22). In 1348 he was charged with breaking the park of Alesia, countess of Lincoln, at Kingston Lacy (Pat. 22 Edw. III, pt. I, m. 43 d.). In I 35 ' 'Richard Maury, monk, formerly for more than eighteen years abbot of Milton, in which time the abbey acquired more than 60 marks annual rent,' 


\section{RELIGIOUS HOUSES}

custody, and after making a reasonable allowance to the inmates at the rate of 5 marks a year each, and defraying the expenses of its ministers, to apply the remainder of $i$ ts revenues towards relieving it of debt. ${ }^{40}$ The decrees forwarded by the bishop after a visitation in July of that year laid stress again on the discords in the abbey and the fact that the inmates were too many for its present financial condition." The abbot and convent were ordered to adhere rigidly to the scheme of retrenchment laid down by the bishop, though they were warned about the same time not to withdraw the chaplains serving various chantries, or to neglect the needs of the sick. The bishop also desired them to re-admit Brother Walter de Sherborne, who had left the abbey with the object of attaching himself to a severer rule, but after joining the Brothers Preachers for some time had apostatized to the world, and now, repenting of his excesses, with tears desired to return. ${ }^{42}$ The visitation report of 1378 , containing various suggestions for matters in need of correction, makes no special reference to poverty. The attention of the abbot-who was enjoined to bear himself modestly and benignantly towards his fellow monks-was directed towards the quality of the bread and ale served out to the household and to the condition of the drains, "which corrupt the air and are the cause of various infirmities.' The usual prohibition against the entrance of women was coupled with an injunction forbidding the admission of certain ladies mentioned by name within the precincts of the monastery. ${ }^{43}$

Save for the appointment of abbots references to Milton are rare in the century preceding the Dissolution. A report issued after a visitation in 1425 comments severely on various details of the management of the then abbot, Richard Cley; and he was ordered, under penalty of suspension from choir and deprivation for forty days of the pastoral staff, to appoint a receiver of moneys retained by him without rendering of any account, and to redeem the jewels and silver vessels which he had sold. ${ }^{4}$ In ${ }^{4} 43^{8}$ the number of the community seems to have fallen to fifteen if we may accept the count

obtained exemption from the jurisdiction of his superiors, by grant of Pope Clement VI, with indult to retain the goods which lawfully belonged to him and to convert them to his own use, and licence to choose one of the monks to say the canonical hours with him and serve him in other ways; Cal. Pap. Letters, iii, 432.

${ }^{10}$ Pat. 18 Edw. III, pt. I, m. 3 .

"1) The community consisted at this time, it is said, of twenty-one monks, the number being increased by the return of two absent brethren to twenty-three, as was notified to the bishop by letter shortly after his wisit.

"Sarum Epis. Reg. Wyville, fol. 1 30-1.

${ }^{43}$ Ibid. Erghum, fol. I 5.

4t Ibid. Chandler, fol. 51 . of those monks who assembled on 10 June of that year for the election of John Breweton or Bruton. ${ }^{45}$

The abbot and convent obtained from Henry VIII in 1512 a licence to hold the yearly fair in their manor of Stockland on the eve, day, and morrow of St. Barnabas, instead of St. Michael, as ${ }^{-}$was granted by Henry VI, ${ }^{46}$ on account of the injury to other fairs in the neighbourhood. ${ }^{47}$ Among the benefactions of Abbot William de Middleton, I $482-1523$, must be mentioned the erection of a free school within the town of Milton, for the maintenance of which the abbot, by deed dated ro February, 1521 , and sealed with the common seal of the abbey, made over the manor of Little Mayne, \&c., to Giles Strangeways, knt., Thomas Arundel, knt., and other trustees. ${ }^{48}$

The Valor of 1535 gives the abbey a clear income of $6_{6} 66535.3 \frac{1}{2} d$. from the parsonages of Milton, Stockland, Sydling, and Osmington, ${ }^{49}$ and the manors of Milton, Stockland, 'Huysshe,' Sydling, Compton Abbas, Holway, Cattistock, Hillfield, Knowle, Osmington, Whitcombe and Dorchester, Frome and Stafford, Burleston, Lyscombe, Winterborne Stickland, La Lee, and other lands. ${ }^{50}$ Among the annual charges was a sum of $f_{0} 5 \mathrm{r}$ I $6 s^{\text {., }}$, set down under the head of almsgiving, assigned towards the observance of the anniversaries of founders, including $\mathrm{King}$ Æ.thelstan."

The appointment of John Bradley, last abbot of Milton, as bishop suffragan of Shaftesbury, February, $1539,{ }^{62}$ preceded the suppression of the abbey by a few days only. The abbot, who surrendered the house with twelve of the monks on I I March, 1539, received a pension of fI33 6s. 8d., the prior $f_{1} 3$ 6s. 8d, the subprior $\ell^{8} 8$, and the ten remaining brethren $t^{6} \mathrm{I}^{5}$. $4 d$. each. ${ }^{53}$

45 Ibid. Beauchamp.

${ }^{46}$ Pat. 25 Hen. VI, pt. 2, m. 26.

${ }^{47} \mathrm{~L}$. and P. Hen. VIII, i, 3529.

${ }^{18}$ Hutchins, Hist. of Dorset, iv. 396 . The chantry commissioners of Edward VI found that the rent of the lands thus assigned amounted to $£ 8$ a year, which was paid yearly to the 'scolemaster' for his stipend; Chant. Cert. 16, No. 81. An inquisition in 1600 under Elizabeth reported the school 'to be of good regard and in former times much frequented'; Hutchins, op. cit.

43 Valor Eccl. (Rec. Com.), i, 248.

${ }^{50}$ Ibid. 249. The sum contributed by Milton towards the king's expenses for the recovery of the crown of France was $£ 100$, as against $£ 200$ by Cerne and $\ell_{0} 186 s .8 d$. by Abbotsbury; L. and P. Hen.VIII, iii, 2483 .

${ }^{31}$ Of this sum $£ 30$ represented the cost of providing the daily necessaries of thirteen poor men of the town of Milton nominated yearly by the convent ; Valor Eccl. (Rec. Com.), i, 151.

53 Pat. 30 Hen. VIII, pt. 2, m. 20.

${ }^{33} L$. and P. Hen. VIII, xiv (I), 500. 


\section{A HISTORY OF DORSET}

The king the following year granted the house and site of the abbey, with the church, belfry, bells, and churchyard, the advowson of the vicarage, manor, and rectory, to John Tregonwell, the commissioner deputed to receive the resignation of the community. ${ }^{\mathrm{st}}$

\section{Aвbots of Mrlton}

Cyneward, appointed 964 by King Edgar ${ }^{35}$

Egelric, deposed 1102 for simony ${ }^{66}$

R., occurs in reign of Henry $I^{\text {s7 }}$

A., occurs in reign of Henry $\mathrm{II}^{58}$

Eustace, elected I $198^{59}$

William de Stokes, elected $1222^{60}$

William de Taunton, elected $1256,{ }^{61}$ died 1273

Robert de Corfe, elected $1273^{62}$

Walter de Sideling, elected I $29 \mathrm{I}^{63}$ died I 3 I 4

Robert le Fauconer, elected $1314,{ }^{64}$ died 133 I

Richard de Mauro or Maury, elected 1331 , ${ }^{65}$ resigned 1352

Robert de Burbache, elected I $352,{ }^{66}$ died I 382

John Hentin, elected $1382,{ }^{67}$ died $13^{8} 3$

Walter Archer, elected $1383,{ }^{68}$ died 1417

Richard Cley, elected 1417 , ${ }^{69}$ resigned 1431

John Haselbere, elected $1+3^{1},{ }^{70}$ died $145^{8}$

John Breweton or Bruton, elected 1458 , , died 1482

William Middleton, elected $1482^{72}$

John Bradley, elected $1525,{ }^{73}$ surrendered 1539

The round, thirteenth-century seal of the abbey, ${ }^{74}$ the impression of which is very fine though the edge is imperfect, represents on the obverse side the abbey church with a centre and two towers, each having a tall spire and two side turrets. Under the central tower be-

${ }^{54} L$. and $P$. Hen. $Y I I I, \mathrm{xv}, 28 \mathrm{z}$ (g. 90).

ss Angl-Sax. Chron. (Rolls Ser.), ii, 94.

${ }^{56} \mathrm{Wm}$. of Malmesbury, Gesta Pontif. (Rolls Ser.), 119.

${ }^{57}$ Red Bk. of the Exch. (Rolls Ser.), i, 211.

${ }^{39}$ Ibid.

${ }^{60}$ Close, 7 Hen. III, m. 28.

cl Ann. Mon. (Rolls Ser.), ii, 96.

${ }^{62}$ Pat. I Edw. I, m. 17. He is probably identical with Walter de Corfe, to whom the temporalities of the abbey were restored 17 June in the same year; ibid. m. 15.

${ }^{63}$ Ibid. 19 Edw. I, m. 16.

${ }^{61}$ Ibid. 8 Edw. II, pt. 1, m. 9.

${ }^{65}$ Ibid. 5 Edw. III, pt. 1, m. 2, 32.

${ }_{66}^{6}$ Ibid. 26 Edw. III, pt. 3 .

67 Ibid. 6 Ric. II, pt. 1 , m. 16.

${ }^{63}$ Ibid. pt. 2, m. 23.

${ }^{69}$ Sarum Epis. Reg. Chandler, fol. I I.

${ }^{70}$ Ibid. Neville, fol. 11 .

${ }^{71}$ Ibid. Beauchamp, i, fol. 50.

"Pat. 2 I Edw. IV, pt. 1, m. 7.

${ }^{73}$ L. and P. Hin. VIll, iv (1), 1291-1+24; xiv (1), 500 .

B.M. Seals, $x \mathrm{xl}, 3$. neath a trefoiled arch the Virgin is seated, crowned, the Holy Child with nimbus on her left knee, in her right hand an orb. Under the arch of each of the side towers a mitred abbot or bishop, full-length. In the foreground an embattled wall. In the field over the roof two demi-angels issuing from the heavens, each swinging a censer, and on the left a cross. Legend :-

$$
\begin{aligned}
& + \text { SIGILL' }: \text { CONVEN . . A AN . . MID- } \\
& \text { ELTONENSIS : E . . L'IE }
\end{aligned}
$$

The reverse represents the abbey church from another point of view. Under two trefoiled arches in the centre, the Annunciation of the Virgin. In the triangular pediment above is a bust. Legend :-

[PCRTA : SA] LVTIS : AVE : $f$ : TE : PATET : E[XITVS: A : VE] [VENIT : AB : EVA :]VE : VE : Q́ : TOLLIS : AVE

A fine fragment of the same seal is found attached to a deed dated $1315,^{i 5}$ and to the surrender deed of the abbey in $15390^{76}$

\section{THE ABBEY OF SHERBORNE}

The foundation of the abbey of St. Mary is usually attributed to Bishop Aldhelm at or about the time of the establishment of the episcopal see at Sherborne in $705,{ }^{1}$ and though, according to an ancient record mentioning a grant to the house of 100 hides of land at 'Lanprobi' by Cenwalch, king of the IVest Saxons, who died in $672,{ }^{2}$ it might be said to claim even greater antiquity, this is the date popularly accepted.

Among the grants enumerated in a list of the names and benefactions of the ' $k$ ings, founders of the church of Sherborne, ${ }^{3}$ are lands, many of which figure later in the possessions of the monks on the reconstruction of the house originally built for secular canons, and must have formed its earlier endowment: 5 hides of land at Oborne the gift of King Edgar; 5 hides out of 36 at Bradford, 'Cerdel,' Halstock, and Yetminster, with Netherbury and 'Ethelaldingham' granted by King Æthelwulf (Athulfus); King Athertus gave the liberty of 140 hides, and in Up Cerne 12 hides, in Tavistock 8, in Stalbridge 20, in Compton 8; King Kenewulf gave 5 hides at Affpuddle and I hide in Lyme; King Cuthred 12 hides in 'Lydene,' 10 in Corscombe, 25 at 'Menedid'; King Kenewulf 6 hides in Chard-

75 Harl. Chart. 86 A. 43.

${ }^{76}$ Deeds of Surrender, No. 153.

$1 \mathrm{Wm}$. of Malmes. Gesta Pontif. (Rolls Ser.), 375-8. Leland states that it was founded by King Æthelred [c. 870], but probably confuses its foundation with its. reconstruction; Coll. i, 66 ; Tanner, Notitia, Dorset $\mathrm{xxy}$.

Cott. MS. Faust. A. ii, fol. 23 . ' Ibid. 

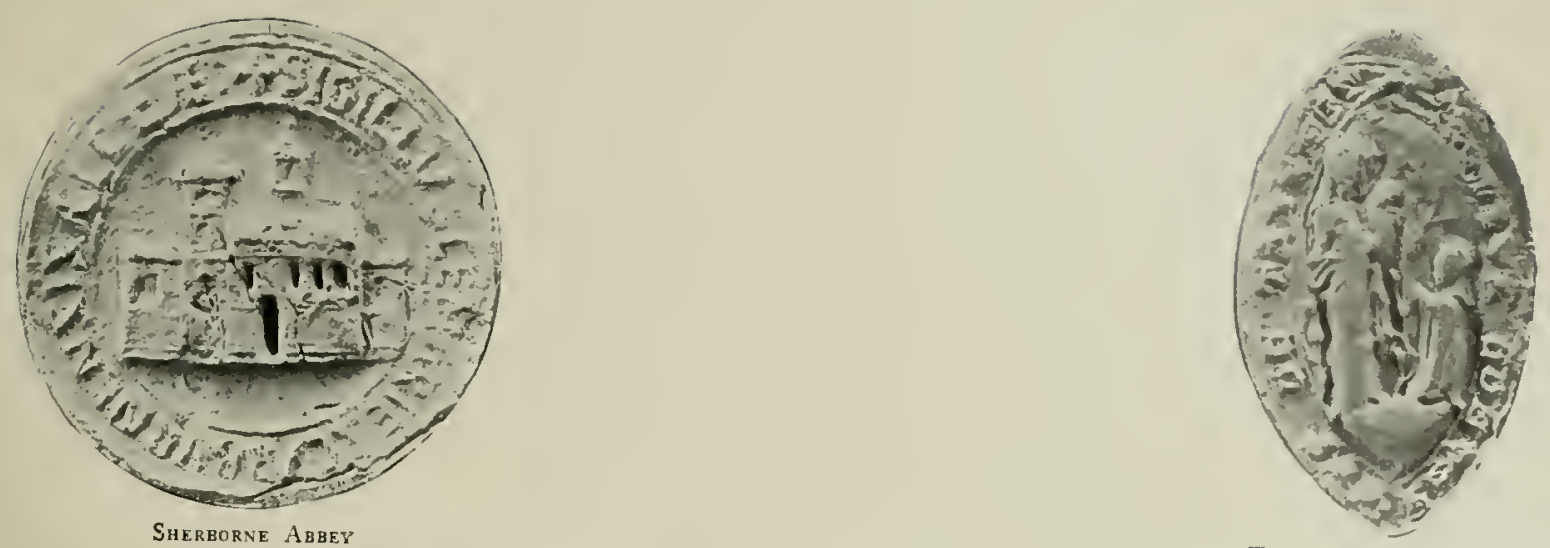

Tarrint Kalies ABeey
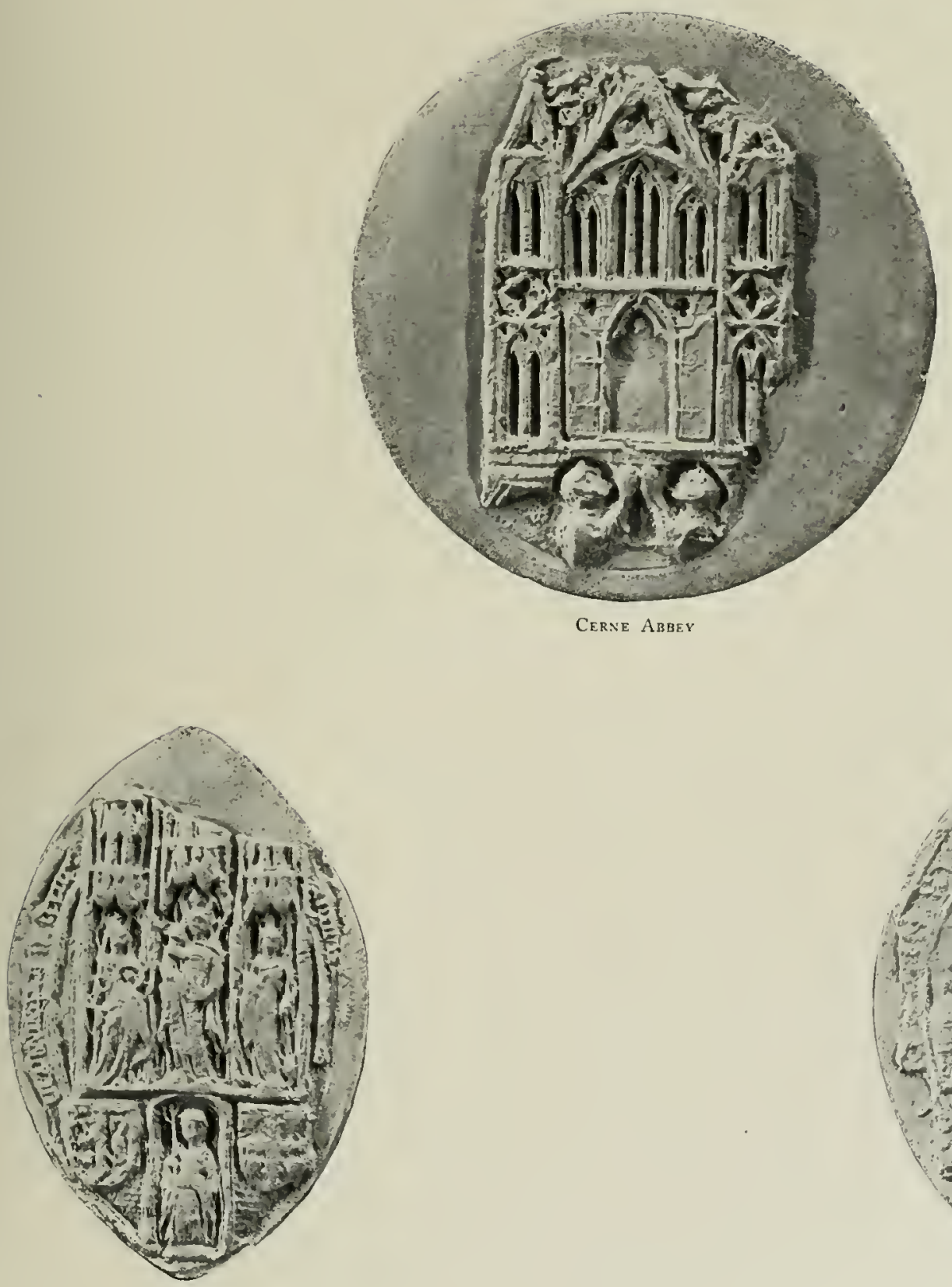

Abrot of Cerne (Fifteenth Century)

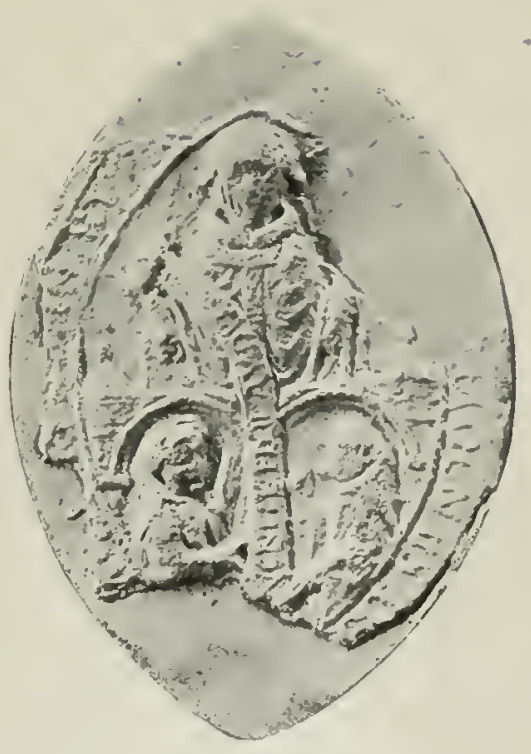

Clement, Abrot of Sherborie (I 63 ) 



\section{RELIGIOUS HOUSES}

stock, 8 in 'Toller Whelme, in 'Wegencesfunte' and Alton 30 hides, in 'Crutesdune' 36 hides and 'Wytecumbe' and 'Wluene'; King Offa Potterne with its appurtenances; King Egbert Io hides near Cerne, \&ic.; King Sigeberht 5 hides in 'Boselington' and 7 in East Cann; King Ine gave 7 hides near 'Predian' and in 'Conbusburie' 20 hides; King Geroncius gave 5 hides in 'Macnir by 'Thamar'; King Æthelred gave 'Atforde' and 'Clethangre,' and gave and restored Corscombe in oblatum, which Canute afterwards restored. ${ }^{4}$ It is recorded in addition to these grants ${ }^{5}$ that King Æthelstan by charter gave to the familia at Sherborne land at Bradford Abbas on condition that they should say psalms and masses for the redemption of his soul on the feast of All Saints, ${ }^{6}$ and at Weston with the stipulation that they should pray for his soul and the soul of Beorhtwulf the earl $;^{7}$ about the year 903 King Eadred granted to Bishop Wulfsige 8 carucates of land at Thornford, with the reversion of the estate on his death to the monastery. ${ }^{8}$

In the ninth century the abbey seems to have shared with Wimborne the honour of giving burial to the kings and bishops of Wessex. The Anglo-Saxon Chronicle states that King Æthelbald was buried here in 860 , and Ethelbert, who succeeded him, in $866 . .^{\circ}$ Leland, writing in the sixteenth century, says the two kings were buried ' $y n$ a place behinde the highe altare of S. Marie chirche, but ther now be no tumbes, nor no writing of them sene.' 10 In 867, after he had held the bishopric 'fifty winters,' died Bishop Ealhstan, 'of great power in worldly affairs and eminent in counsel,' who took a personal share in the wars of Egbert, and by his example and generosity inspired king and people to continue the struggle against the Danes; ${ }^{11}$ "his body lies in the town.' 12

${ }^{4}$ Cott. MS. Faust. A. ii, fol.23.

'The charters of the monks include one by Cenwalch of Wessex, 643-72, granting various privileges to the pontifical see at Sherborne and the community there; ir is witnessed, however by Laurentinus, archbishop of Canterbury, who died in 619 , and of more than doubrful authenticity; Birch, Cart. Sax. i, 46 .

Ibid. ii, 392.

' Ibid. ii, 394.

${ }^{8}$ Ibid. $\mathrm{iii}, 52$. Hutchins in addition cites (Hist. of Dorsct, iv, 228) two charters by King Erhelwulf, the first dated in 841 , reciting a grant in perpetual alms of 15 cassates of land in the place called 'Halganstoc' (Halstock) 'for the honour of God and love of St. Michael the archangel, whose church remains in the said little monastery, to Eadberth the dcacon for his faithful service there; the other recording the grant in 844 of 2 cassares of land in a place called 'Osanstoc' for the redemption of the soul of King Æthelwulf and the souls of his sons Æthelbald and Æthelbert.

${ }^{9}$ Angl.-Sax. Chron. (Rolls Ser.), i, I 29, 130.

${ }^{10}$ Itinerary, ii, 48.

$"$ Angl.-Sax. Chron. (Rolls Ser.), i, I 20-I.

${ }^{12}$ Ibid. i, 132.
The reconstruction of the house and the substitution of monks for the secular canons, who had occupied it for nearly two centuries, took place in the reign of Ethelred by the agency of Bishop Wulfsige, 992-I00I.13 The king's charter, dated 998 , recites that by the persuasion of Archbishop Elfric and the advice of his nobles he has licensed the bishop to ordain and institute a rule of monks in the monastery of Sherborne according to the constitution of St. Benedict, and enacts that none of the bishop's successors should in consequence usurp the temporal possessions of the monks, but as-shepherds, and not tyrants nor with wolfish rapacity, should govern according to pastoral authority and for the benefit of the community, while any question creating discord between the shepherd and the flock should be referred to the archbishop, who should advise the king as to any necessary amendments; and whereas it was not usual to constitute an abbot in the episcopal see, the bishop in virtue of his office should be abbot and father to the brethren, who should be obedient to him as sons and live as monks, in chastity, humility, and subjection. ${ }^{\mathrm{I}}$ The charter of Bishop Wulfsige declares that having expelled the clerks in pursuance of the king's order, he has ordained and constituted worthy (sapientes) monks in their place in the church of St. Mary of Sherborne, and restored to them the lands and possessions or those who from the beginning served in this holy place to the praise and glory of God, together with a carucate of land in the vill of Sherborne, the tithe of the bishopric and every tenth field in the whole of the said vill, and 24 cart-loads of wood yearly. ${ }^{15}$

On comparing the estates confirmed to the reconstituted house by King $Æ$ thelred, at the close of the tenth century, with the lands in the possession of the monks in the return of 1086 , it will be found that the monastery had passed through the social and political changes following the Norman Conquest without incurring any serious territorial loss or deprivation. ${ }^{16}$ The possessions enumerated in the confirmation charter of Athelred in 998 consist of a hundred fields in a place called Stockland in Sherborne itself, with the estate (praedium) of the monastery as Bishop Wulfsige had inclosed it with hedges and ditches ; 9 cassates of land in a place called 'Holancumb,' I 5 in Halstock, 7 in Thornford, ro in Bradford, 5 in Oborne, 8 in Weston, 20 in Stalbridge, Io in 'Wulfhcardingstoke,' 8 in Compton, 2 in 'Osanstoke,' and a manor near

${ }^{13}$ Leland, Coll. iii, 150.

${ }^{14}$ Ibid. Itin. ii, 5 1, 52 .

${ }^{15}$ Ibid.

${ }_{16}$ The omission of Halstock in the Domesday Survey is curious, as it was one of the earliest possessions of the house, and is entered in the bull of Pope Eugenius III in 1145 , and remained in the possession of the abbey down to the Reformation; Hutchins, Hist. of Dorset, iv, 403 . 


\section{A HISTORY OF DORSET}

the sea-coast called 'At Lyme.' ${ }^{27}$ 'The nine manors specifically assigned to the living of the monks, apart from the "land of the bishop of Salisbury,' in the Domesday Survey are returned as follows:- Sherborne with $9 \frac{1}{2}$ carucates of land valued at $f_{0} 6$ ros., Oborne with 5 hides, Thornford with 7 , Bradford with Io, Compton with 6 hides and 3 virgates, Stalbridge with 20 hides, Weston with 8, Corscombe with Io hides less I virgate, Stoke Abbas with Io hides; the value of the whole amounting to $f_{6}^{6} 3$ 10s. $^{18}$ It was reported that 3 virgates of land in the manor of Stalbridge, held by Manasses, had been taken from the church by W. the king's son, without the consent of the bishop or the monks.

The loss of influence and position that might have been expected to follow the removal in 1075 of the episcopal see from Sherborne to Old Sarum was in a great measure obviated by the readjustments initiated by Roger of Salisbury in the succeeding century. The bishop in I I 22, with the consent of Henry I, united the former abbey of Horton to Sherborne as a dependent cell, and raised the latter house, of which he as diocesan was titular head, to the dignity of an abbey, ${ }^{19}$ Thurstan being consecrated the same year its first abbot. ${ }^{20}$ Various other arrangements and agreements on the part of successive abbots and the bishop and chapter of Salisbury followed this change. Clement, then abbot, quitclaimed to Jocelin the bishop and the cathedral church of Salisbury, about the year I 160 , the castle of Sherborne, formerly built by the great Roger of Salisbury ; ${ }^{21}$ and the same bishop by his charter recited and confirmed the rights and privileges of the abbot as holder of a prebend in the cathedral, constituted by Bishop Osmund from the parish church of Sherborne and its tithes and chapels, which entitled the superior of the abbey to a stall in the cathedral choir and a place in the chapter, the grant expressly stipulating that on the decease of an abbot no portion of the profits of the prebend should fall to the communa because it was conferred on the monastery itself and not expressly on the abbot. ${ }^{22}$ The patent rolls record that on 22 July, 1386, the abbot and convent leased their house in the cathedral close in favour of John de Chilterne, canon of Salisbury..$^{23}$ In

${ }_{17}$ Leland, Itin. ii, 5 I, 52.

${ }^{18}$ Dom. Bk. (Rec. Com.), i, fol. 77.

${ }_{19}$ Ann. Mon. (Rolls Ser.), i, 10. William of Malmesbury, who mentions other changes, by mistake ascribes it to the fourth year of King Stephen, I1 39 ; Gesto Regum (Rolls Ser.), ii, 559 .

${ }^{20}$ Cott. MS. Faust. A. ii, fol. $25 \%$.

"Reg. St. Osmund. (Rolls Ser.), i, 235.

${ }^{2}$ Ibid. 250. The abbot is mentioned among those prebendaries present at the framing of the New Constitution (NorG Constitutio) in 1214 (ibid. 374). The prebend was assessed at 2.40 in the Taxasio of 1291 . Pope Nich. Tax. (Rec. Com.), I S2.

${ }^{23}$ Pat. 10 Rich. II, pt. 1, m. 3 j.
IIgI the monks made over the churches of Lyme and Halstock to the bishop and chapter to constitute a prebend in the cathedral church of Salisbury to the honour of God and the 'glorious virgin," ${ }^{24}$ and on the same date received a grant appropriating the church of Stalbridge and Stoke to the use of the abbey-saving a reasonable sustenance to be provided for the perpetual vicar ministering in the aforesaid churches-and a licence to receive 2 marks annually from the church of Corscombe when it should next become vacant. ${ }^{25}$ Though by no means inconsiderable, the rent-roll of the abbey of Sherborne was comparable at no time to that of Shaftesbury, and even at this early date 'the poverty and narrowness of means of the house of Sherborne' are alluded to in the bishop's grant. In 1238 a composition between the convent and the bishop of Salisbury released to the former all amercements of the assize of bread and ale in the hundred of Sherborne and Beaminster which had been claimed against them, in return for which they agreed to pay the bishop and his successors half a mark annually at Easter. ${ }^{26}$ The bishop claimed the right to instal all superiors on their appointment; and in or about the year I2 7 Philip, abbot of Sherborne, acknowledging that he had incurred the displeasure of the diocesan by entering on the abbacy without his authority, pledged himself that no abbot in future should be enthroned save by the bishop of Salisbury or by his special mandate. ${ }^{27}$ The cathedral chapter, too, had their prerogative, and in 1242 the prior and convent were required to certify that the rights of the church of Salisbury should not in furure suffer infringement because the abbot-elect, John de Hele, had recently received the benediction at Ramsbury on account of the ill health of the diocesan instead of in the cathedral. ${ }^{28}$

The bull of Pope Eugenius III in I 45 recites that at the request of the monks he has confirmed to the monastery of St. Mary of Sherborne, which he has taken under the protection of St. Peter, the following possessions :-The monastery itself with all its lands, rents, and liberties conferred by the kings of England and the bishops of Salisbury; the church of Stalbridge and of Horton with its chapels of Knowlton and 'Chesilberie'; the chapel of Oborne ; the church of St. Mary Magdalen by the castle with its two chapels and appurtenances; the church of St. Andrew in Sherborne; the churches of Bradford, Halstock, Corscombe, and Stoke with the chapel and all its appurtenances; the churches of Ly'me and Fleet (Dorset), Littleham and Carswell (Devon), and 'Cadweli' or Kidwelly in Caer-

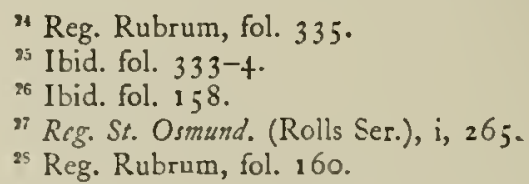

" Reg. Rubrum, fol. 335 .

26 Ibid. fol 158 .

2 Reg. St. Osmund. (Rolls Ser.), 1, 265. 


\section{RELIGIOUS HOUSES}

marthenshire, ${ }^{29}$ cell to Sherborne; the towns of Stalbridge, Weston, Oborne, Thornford, Bradford, Wyke, and 'Hloscum' with all their appurtenances; Compton with Over and Nether Compton, 'Propeschirche' and Stockland with woods, meadows and two mills; the street before the monastery in Sherborne, extending as far as the church of St. Andrew, with the mill by the monastery and the mill by St. Andrew's church; three taxable houses in Sherborne with other houses belonging to them, the taxable houses round the court (atrium) of the monastery with their orchards and appurtenances; all the taxable houses in the burgh of Wareham with the chapel of St. Andrew; the towns of Horton, Kington, Halstock, Coringdon, Corscombe, Stoke, Bromley, 'Laurechestoc,' Fleet, Beer, and Seaton with their salt-pits and other appurtenances; the fisheries of Fleet, Beer, and Seaton ; Littleham with its fisheries, meadows, woods, \&c. ; Carswel! and Bromley; various tithes with three cart-loads of hay yearly in Bere, and one cart-load from the demesne of the bishop; the sepulture of the place free for those who should desire to be buried there, except for such as should die excommunicated and saving the rights of the mother church. On the death of the abbot or any of his successors no one should be set over them except by the common consent of the brethren or the counsel of the wiser of them. ${ }^{30}$ The bull of Alexander III, with some additions, confirms to the abbey in 1163 the possessions enumerated in the bull of 1 1 45.31 The Taxatio of 129 I gives the abbot and convent pensions amounting to $£ 9$ i 2 s. $6 d$. from the churches of Stalbridge, Holy Trinity Wareham, and Corscombe in the diocese of Salisbury; ${ }^{32}$ their temporalities assessed at $£_{12} 6$ I 5s. $2 d$. included lands and rents valued at $£ 2345.8 d$. in the diocese of Exeter ${ }^{33} ; £ 5$ in the diocese of Bath and Wells ${ }^{34}$; and $£ 66$ 2s. 2d. in the deanery of Shaftesbury in the Salisbury diocese. ${ }^{35}$

The possessions of the abbey rendered it liable to various services and taxations, and the demands incidental more especially to houses of the Benedictine order and of the royal patronage. The abbot in 1156 and $1160-1$ acquitted himself to the king for the holding of two knights' fees. ${ }^{36}$ In 1 66 the fees of the house were certified by charter thus :- Richard Fitz Hildebrant holds of the abbey half a knight's fee, Thomas de Hasweria one fee, Jordan de Netherstock halí a fee,

23 Roger, bishop of Salisbury, gave a carucate of land at Kidwelly and 'the mountain called Salomon's'; the churches of Pennalt, Kidwelly, and Penbray were granted to the abbey by Richard Fitz William. Dugdale, Mon. i, 424.

${ }^{30}$ Leland, Itin. ii, 53, 54; Dugdale, Mon. i, 335. Chart. of Sherborne, No. v.

${ }^{31}$ Ibid. No. vi, i, 339.

"Pope Nich. Tax. (Rec. Com.), $178-9$.

${ }^{38}$ Ibid. 15 1. ${ }^{34}$ Ibid. $203 .{ }^{35}$ Ibid. $184-5$.

${ }^{36}$ Red Bk. of the Exch. (Rolls Ser.), i, J 5, 27.
Geoffrey de Stokes one-fifth of a fee, the above constituting fees of the old feoffment; of the new feoffment Simon de Clierd holds two parts of a fee, Walter Fitz Hugh one-fifth, Robert de Thorncombe cne-fifth. ${ }^{37}$ From that date the abbct appears to have rendered service for two knights' fees and a fifth part of a fee. ${ }^{38}$ In the course of the war with Scotland he was summoned by writ to send his service against the Scots, and in 1324 was requested to raise forces in defence of the duchy of Aquitaine ; ${ }^{39}$ his tenure entitled him to a seat in Parliament, ${ }^{40}$ and he received the usual notifications to attend. The convent on frequent occasions received requests or orders from Edward II and Edward III to supply maintenance in their abbey for boarders of the king's nomination, ${ }^{41}$ and in accordance with the usual custom, were expected to provide a pension for a clerk whenever a new abbot was appointed. ${ }^{42}$ An order was issued to the escheator in July, I310, respiting until Michaelmas a demand of a palfrey and a silver cup from the abbot of Sherborne by reason of the last voidance, the abbot protesting that lie was not chargeable, as his predecessors had been quit of this special payment 'from time out of mind.'43 On more than one occasion the monastery was used as a depository for taxes and subsidies co:lected in the county, a strong and suitable room being requisitioned within the abbey in 1334 for the reception of the moneys collected in Dorset for the tenths and fifteenths voted to the king for the expenses of the war, with free ingress and egress to be permitted to the collectors, who were bound to answer for the amount. ${ }^{45}$

The history of Sherborne, from the date of its elevation in the twelfth century to the dignity of an abbey down to the stirring incident which led to the destruction of the church by fire in the fifteenth century, is very uneventful, and consists chiefly of small disconnected incidents. Henry II, by one charter, confirmed a composition

37 Ibid. 213

38 Ibid. $34,64,80,101,125,166$; ii, 344.

${ }^{39}$ Parl. Writs (Rec. Com.), i, div. viii, $1427-8$.

40 Ibid.

"In 1309 William Beausamys was sent to the abbey to receive maintenance for himself, a horse and groom (Close, 2 Edw. II, m. 12). Hugh Cade was sent in 13 I 5 to receive such allowance as Richard le Potager had had (ibid. $8 \mathrm{Edw}$. II, m. I I d.). From the manner in which on the death of one boarder another was sent to take his place, it would seem that two was the number maintained at a time (ibid. Io Edw. II, m. 22 d. ; ibid. I I Edw. II, m. 9 d. ; 12 Edw. II, m. 30 ; 6 Edw. III, m. 2 d.). A complaint was lodged in 1335 that the abbey declined to provide full and proper maintenance, and contented itself with merely admitting the king's candidate. Pat. 9 Edw. III, pt. 2, m. 2 I $d$.

43 Close, 4 Edw. II, m. $18 d$.

43 Ibid. m. $26 . \quad$ "Ibid. 4 Edw. I, m. $3 \%$

${ }^{45}$ Parl. R. (Rec. Com.), ii, 451 . 


\section{A HISTORY OF DORSET}

between G., abbot of Sherborne, and Richard Fitz Hildebrand restoring to the abbey the towns of Bradford and Corscombe on the death of the said Richard, in accordance with a deed of Bishop Roger of Salisbury testifying that he had unjustly taken them away from the church to give to his brother Humphrey, and afterwards restored them; ${ }^{46}$ and by another charter, subsequently confirmed by Edward I, bestowed the church of Stalbridge on the office of the sacristan. ${ }^{47}$ The abbey was in the king's hand in the first year of Richard I, when Thomas de Husseburna rendered account of $f_{0} 1002 \mathrm{~s} .5 \mathrm{~d}$. for the fixed rent of the house; ${ }^{48}$ and again in 1213 , John, on I 5 July of that year, notifying the custodian of the monastery that he had given instructions for the prior and convent in the voidance of the abbey to choose and send him suitable candidates from whom an abbot could be selected, and desiring that their expenses should be provided. ${ }^{49}$ In the month preceding his death in 1216 John gave instructions for the abbey of Shaftesbury to be committed during voidance to the custody of the abbot of Sherborne. ${ }^{80}$ Henry III, on 7 January, 1223, issued an order for John, almoner of Sherborne, to be allowed twenty rafters in aid of the almonry in course of building, ${ }^{51}$ and by another grant in 1246 the monks were allowed two cart-loads of dead wood weekly from the forest of Pamber. ${ }^{52}$ Letters of protection were obtained in 1241 by Abbot Henry going beyond seas, until he should return from his pilgrimage, ${ }^{53}$ licence to elect being granted to the convent the following year on his resignation. ${ }^{5 *}$ Edward I, in 1290 , granted the abbot and convent licence to hold a market and fair at Stalbridge, and to have right of free warren in their demesne lands of WVeston, Oborne, Stalbridge, W yke, Bradford, Thornford, Corscombe, and 'Stawel,' in Dorset, and their lands in Devonshire. $^{55}$ Edward II granted permission in 1317 for the abbot and convent to acquire lands and rents to the yearly value of $£_{1} 0$, provided they should find a monk or chaplain to celebrate daily in the abbey for the soul of the late king, of Robert Fitz Payne, and all Christians ; ${ }^{56}$ in part satisfaction of this grant the convent obtained lands in Beer and Seaton (Devonshire). ${ }^{57}$ On payment of a fine of 50 marks, Richard II granted a

15 By inspeximus of Edward I. Chart. R. 2o Edw. I, No. 3

47 Ibid. ${ }^{49}$ Madox, Hist. of the Exch. i, 311.

${ }^{19}$ Close, 15 John, m. 7

${ }^{30}$ Ibid. $1 \mathrm{~S}$ John, m. 3 .

51 Ibid. 7 Hen. III, m. 22.

32 Pat. 30 Hen. III, m. 6.

${ }^{53}$ Ibid. 25 Hen. III, m. 8.

st Ibid. 26 Hen. III, pt. 2, m. 2.

${ }^{35}$ Chart. R. 18 Edw. 1, No.66. A grant was made to the bishop of Salisbury of a four day's' fair at Sherborne. Chart. R. $2+$ Hen. III, m. 2 .

${ }^{36}$ Pat. 11 Edw. II, pt. 1, m. 34.

${ }^{57}$ Ibid. 17 Edw. II, pt. 1, m. 6. licence in 1392 for the alienation of lands in Coringdon, and the reversion of lands and rent in Stoke Abbott to the abbey. ${ }^{58}$ The episcopal registers record an indulgence granted by Bishop Mitford in 1397 for a chantry founded at the altar of St. Nicholas within the conventual church. ${ }^{59}$ Various other indulgences were obtained by the community at the beginning of the thirteenth century, no doubt with the object of supplementing insufficient revenues with the alms of the faithful. Pope Boniface IX, in I for, granted an indulgence to those visiting the conventual church of Sherborne on the Annunciation, the Feast of St. Michael the Archangel, and the Sunday following the latter feast, from the first to the second vespers and giving alms, together with an indult to the abbot and eight priests chosen by him, secular or religious, to hear confessions and grant absolution. ${ }^{60}$ The abbot in 1412 received an indult to dispense four of his monks for promotion to holy orders. ${ }^{61}$ The following year the pope published an indulgence with relaxation of seven years and seven quarantines of enjoined penance, to penitents who, on the principal feasts of the year, and Ioo days to those who on other days, should visit and give alms for the conservation of the altar of Holy Trinity and All Saints, in the church of Sherborne. $^{62}$

The election of superiors and their benediction by the ordinary are recorded in the episcopal registers, but the official records of the bishops of Salisbury throw little light on the internal condition of the house, as they contain no visitation reports for Sherborne. IVe may perhaps infer from this omission that its management was on the whole satisfactory. Up to the incident of 1436 existence seems to have flowed on peacefully and harmoniously, with but few interruptions. A small break is reported among the last entries of Bishop Mortival's register in I 329 , in connexion with the election of John de Compton; the sacristan and a certain number of monks appealing to the apostolic see and the Court of Canterbury against his appointment on the ground that at the time of his election he had incurred sentence of excommunication for the violent laying of hands on a clerk. The official of the Court of Canterbury ordered the bishop to cite the said John to appear before the court in London, and to proceed no further till the case had been decided. ${ }^{63}$ Nothing further is recorded, and John de Compton remained in office till his death in 1342 . A dispute arose in 1331 between the convent and the rector of the church at Stalbridge of their advowson, respecting a yearly pension of 10 marks claimed by the monks which

${ }^{58}$ Ibid. 16 Ric. 11, pt. 1, m. 35.

${ }^{39}$ Sarum Epis. Reg. Mitford, fol. $121 d$.

${ }^{60}$ Cal. of Pap. Latsers, r, to6.

${ }^{61}$ Ibid. vi, 282 . "Ibid. ri, 378

${ }^{63}$ Sarum Epis. Reg. Mortival, ii, fol. $36+\%$. 


\section{RELIGIOUS HOUSES}

the rector had neglected to pay for two years. ${ }^{64}$ The parishioners of the church of Compton 'Hawy,' who had hitherto been obliged to carry their dead for burial at Sherborne, in 1437 obtained a bull from the pope conferring the right of sepulture on their church. ${ }^{65}$ It is probable that during the latter part of the abbey's existence, owing to financial strain, the community sank far below the original number of its inmates; the voting body of professed monks at the election of John Saunders in I 459 numbered only fifteen, ${ }^{86}$ and about that number assembled for the election of John Mere in $1504 .{ }^{67}$ At the Dissolution the surrender deed of the abbey was signed by fifteen brethren besides the abbot and prior, and including the priors of the subordinate cells of Horton (Dorset) and Kidwelly (Caermarthenshire). ${ }^{68}$

That oft-quoted incident, the destruction or partial destruction of the abbey by fire in a riot in 1436, was the sequel of a violent and bitter dispute between the monks and townsmen as to their respective rights within the minster or conventual church of Sherborne, the mother church of the district, a portion of which, at the extremity of the nave, served the inhabitants as their parish church. ${ }^{69}$ The register of Bishop Neville sets forth the dispute in full, reciting the appeal of the abbot and convent to the diocesan against the parishioners, who, to the detriment and injury of the monastery, had set up a new font in their parish church, and had caused the monks much annoyance by ringing the parish bells for mattins at unreasonable hours. The bishop visited Sherborne before taking steps, with the object of hearing both sides, and sitting in the hall of the abbot there appeared before him, I 2 November, I 436, John Bazet, John Kayleway, Richard Rochett, and John Sprotert on the part of and in the name of all the parishioners, who set before him their grievances, namely, that the monks had removed the font from its old position in the nave, and had narrowed the doorway in the intermediate wall between the parishioners' portion and the body of the church by which the baptismal processions were wont to pass, and they prayed him to restore the font to its original place and all things to their ancient use. The bishop having heard all that could be said on the part of either disputants announced his decision,

6s Sarum Epis. Reg. Wyville, i, fol. 178.

${ }^{65}$ Ibid. Neville, fol. $88 d$.

${ }^{66}$ Ibid. Beauchamp, i (2), fol. 53.

${ }^{67}$ Ibid. Audley, fol. 125.

${ }^{69} L$. and P. Hen. VIII, xiv (1), 336.

${ }^{69}$ Professor Willis in a paper on the minster or church of Sherborne says :- 'At the west end of the minster are fragments which clearly show that the nave was prolonged in the $14^{\text {th }}$ century by a building closely resembling a parish church with 3 aisles, the plan of which can be pretty accurately traced. This is known as the church or chapel of Alhalowes.' Arch. Journ. xxii, 180 . decreeing in the first instance on behalf of the religious men, that the new font, "which had been then newly and with daring rashness erected,' should be altogether destroyed, removed, and carried out of the church by those who had caused its erection, and that the bells of 'Alhalowes' should not be rung for mattins, except on the solemn feasts of All Saints, Christmas, Epiphany, and Easter, until after the striking of the sixth hour by the clock of the monastery and not before; on behalf of the inhabitants he ordered the font to be replaced in its old and accustomed place, and the door for the entrance of the procession of the parishioners to the font to be enlarged and arched so as to give more space and restored to its previous form, the manner and form of the procession round the font to be still retained, and a partition to be made in the nave between the section of the monks and that of the parishioners at the expense of the monastery, the font to be replaced and the door enlarged by Christmas Day following, and all things to be inviolably observed by both parties under pain of the greater excommunication. ${ }^{70}$ Practical and wise as the bishop's decision sounds, it failed at the moment to soothe the bitter feelings which had been roused during the controversy, and a riot ensued, which is described by Leland in his account of Sherborne-

The body of the abbay chirch dedicate to our Lady servid ontille a hundrith yeres syns for the chife paroche chirch of the town. This was the cause of the abolition of the paroche chirch there. The monkes and the townes men felle at variance by cause the townes men took privilege to use the sacrament of haptism in the chapelle of Alhalowes. Wherapon one Walter Gallor, a stoute bucher, dwelling yn Shirburn, defacid clene the font-stone and after the variance growing to a playne sedition and the townesmenne by the meanes of an erle of Huntendune, lying $y n$ those quarters and taking the townes-mennes part, and the bishop of Saresbyri the monkes part, a prest of Alhalowes shot a shaft with fier into the toppe of that part of St. Marys chirch that divided the Est part that the monkes usid, from that the townes-men usid; and this partition chauncing at that tyme to be thakkid yn the rofe was sette afire and consequently al the hole chirch, the lede, and belles meltid, was defacid. $^{71}$

The abbot at that time, William Bradford, 'persecuted' this injury, we are told, and the inhabitants of the town were forced to contribute to the 're-edifying' of their church. ${ }^{72}$

For the remainder of the fifteenth century the community were fully occupied in the task of restoration. Henry VI at their petition granted a licence for them to acquire more lands to the yearly value of $f_{1} \circ$ in aid of rebuilding. ${ }^{73}$ The east end of the church was rebuilt in the time of Abbot Bradford or of John Saunders his

\footnotetext{
${ }^{70}$ Sarum Epis. Reg. Neville, fol. $108 d$.

${ }^{71}$ Leland, Itim. ii, 48.

${ }^{73}$ Pat. 24 Hen. VI, pt. I, m. 6.
} 


\section{A HISTORY OF DORSET}

successor. ${ }^{74}$ Peter Rampisham, elected in 1475 built the west part ' not many yeres syns,' says Leland. ${ }^{75}$ From the time of the fire down to the Dissolution, when the abbey church was sold by Sir John Horsey to the parishioners, and the chapel was pulled down as being no longer required, Alhalowes' was legally and definitely assigned to the inhabitants of Sherborne as the parish church. ${ }^{78}$ The income of the abbey on the eve of the Reformation was declared by the Valor of 1535 at $£ 682$ I 4 s. $7 \frac{3}{4} d$. net. ${ }^{77}$ The churches in the possession of the monks included the parsonages of Bradford and Horton (Dorset), Carswell and Beer and Seaton (Devon) $;^{78}$ and among their temporalities were the manors of Stoke Abbott, Corscombe, Halstock, Bradford, Wyke, 'Stawell,' Thornford, Oborne, Weston, and Stalbridge (Dorset), Carswell, Littleham and Exmouth, Beer and Seaton (Devon) ${ }^{79} \quad$ The amount assigned for distribution in alms to the poor on the anniversary of founders, \&c., shows that the brethren did not neglect one of the main duties of a religious community. In Thornford, assigned to the office of the almoner, there was a yearly charge of $f^{6} 6$ s. as follows:- 4 s. in bread distributed annually to the poor of Sherborne on the day of St. Cadast (?) for the soul of John Send (Saunde or Saunders), sometime abbot ; 6s. $8 d$. in bread distributed on the feast of St. Benedict for the soul of Alfric Thornecomb; $£ .5$ in a daily distribution from the house of the almoner for the soul of the aforesaid Alfric ; 2s. in bread distributed on Palm Sunday for the soul of Richard Chynnock; I 3s. 4d. in bread, ale, fish, and money distributed to the poor on Maundy Thursday for the soul of the aforesaid founder. ${ }^{80}$ From the rectory of Corscombe 2s. $8 d$. was assigned in bread to the poor at Sherborne for the soul of Ralph Vatrell on the feast of St. Peter and St. Paul. ${ }^{81}$ From the manor of Stalbridge a distribution of 2s. $4 d$. was yearly made to the poor for the soul of the mother of William de la Wyll by the foundation of the said William. ${ }^{82}$ The sum of $£_{4}$ IIs. was laid out in a distribution of bread for the soul of Peter Rampisham, late abbot of Sherborne, and 6s. 8d. for the soul of Roger Gylden ; ${ }^{83}$ on the feast of St. Bartholomew bread

it 'All the est parte of St. Mary Chirch was reedified in abate Bradeford's tyme,' says Leland in one place, "saving a chapelle of Our Lady, an olde peace of work that the fier came not to by reason that it was of an older building' (Itin. ii, 48$)$. In another place he says, "Peter Ramsunne, next abbate save one to Bradaford, buildid al the west part of the chirch' (ibid. iii, 9o).

${ }^{73}$ According to Leland the same abbot "sette a chapelle caullid our lady of Bowe harde to the south side of the old Lady Chapplle' (ii, 49).

${ }^{76}$ From the parish register of Sherborne quoted by Dugdale, Mon. i, 335 .

Valor Ecel. (Rec. Com.), i, 285.

${ }^{78}$ Ibid. 281 . 79 Ibid. $282-4$.

${ }^{81}$ Ibid. $282 . \quad{ }^{83}$ Ibid. 286.

${ }^{60}$ Ibid. 2.

${ }^{83}$ Ibid. 284 . to the value of IOs. was annually distributed for the soul of Robert Ayam, knt., and alms were daily distributed at the door of the refectory, called ' le frayter,' for the soul of Philip, sometime abbot of Sherborne, viz. one loaf of monks' bread and a measure of ale, at a yearly charge of $\chi^{2} 5$ s. $9 d^{84}$ Among the charges on the abbey was the sum of $78 \mathrm{~s}$. for the exhibition of three scholars in the grammar school of Sherborne of the foundation of Alfric Thornecomb, ${ }^{83}$ and $£ 5$ for a corrody for a person to be nominated from time to time by the king, and at that time held by William Burn.

In the promotion of John Barnstable as abbot on the resignation of John Mere in $1535,{ }^{86}$ the policy of securing superiors unlikely to lend opposition to the new order of things is not far to seek. 'I thank you,' writes Sir John Horsey, to whom the dissolved abbey was afterwards granted, to Cromwell on 9 May from Sherborne, "for offering my friend Dan John Barnstable to be abbot of Shyrborne on the resignation of Dan John Mere late abbot,' "the monastery,' he adds, 'are well pleased with the appointment.' ${ }^{87}$ The new abbot, in a letter to the 'Visitor General of the monasteries' thanking him for his appointment, expresses his willingness to follow various directions as to the management of the house, ${ }^{88}$ his compliance receiving due reward in the measure of liberty allowed him. ${ }^{89}$ On the fall of the house 18 March, 1539 , the abbot, who had surrendered with sixteen of his brethren, received a pension of $£$ roo, the priors of Horton and Kidwelly $£ 8$ each, the subprior of Sherborne and another monk $£ 7$ each, seven of the brethren $£ 6$ i 3 s. $4 d$. each, and four monks $f^{6}$ each. $^{90}$ Henry VIII on 4 January, I 540, made over to Sir John Horsey the house and site of the late dissolved monastery together with certain of its possessions. ${ }^{91}$ Sir John, on 26 March following, sold to the parishioners of Sherborne, for the sum of 100 marks, the conventual church, which has from that time been the parish church of the town.

\section{AbBots of Sherborne ${ }^{92}$}

Thurstan, consecrated I I $22^{93}$

Peter, occurs about I $142^{94}$

84 Ibid. 285 .

as Ibid.

${ }^{8} L$. and $P$. Hen. VII, viii, 852. John Mere secured a pension of $£ 4^{\circ}$ on his resignation.

87 Ibid. 693 .

${ }^{89}$ Ibid. ix, 256.

${ }^{21}$ Ibid. $x v, 562$.

${ }^{83}$ Ibid. 852.

90 Ibid. xiv (1), 556

"Of the early superiors of Sherborne who presided in the capacity of pracpositus primus or decanus over the secular canons, and on their removal as priors over the monks substituted in their place, no record seems left prior to the erection of Sherborne into an abbey in the year 1122 , when Thurstan was consecrated abbot. Cott. MS. Faust. ii, fol. 25 d.

${ }_{93}^{9}$ Ibid. ${ }_{94}$ Hutchins, Hist. of Dorset, iv, 232. 


\section{RELIGIOUS HOUSES}

Clement, occurs about $1160^{95}$

Henry, occurs about I $65^{96}$

E., occurs in reign of Henry II ${ }^{97}$

G., occurs in reign of Henry II ${ }^{98}$

Philip, occurs about $1217^{99^{\circ}}$

William of 'Tewkesbury ${ }^{100}$

Henry, elected $1227,{ }^{101}$ resigned 1242

John de Hele, elected I $242^{102}$

Lawrence de Bradford, elected $1246^{103}$

John de Saunde, elected I261, died I $286^{104}$

Hugh de Staplebridge, elected $1286,{ }^{105}$ died I 310

John Thornford, elected $1310,{ }^{106}$ died I 3 r 6

Robert de Ramsbury, elected 1316, ${ }^{107}$ died I 329

John de Compton, elected $1329,{ }^{108}$ died 1342

John de Henton, elected $1342,{ }^{100}$ died 1348

John de Frith, elected 1348 :10

Edward Goude, elected 137 I $^{110 a}$ died $1385^{111}$

Robert Bruynyng, elected $1385,{ }^{122}$ died 1415

John Bruynyng, elected $1415,{ }^{113}$ died 1436

William Bradford, elected 1436, 114 died 1459

John Saunders, elected 1459 , ${ }^{115}$ died 1475

Peter Rampisham, elected $1475,^{116}$ died 1504

John Mere, elected 1 505, ${ }^{117}$ resigned 1535

John Barnstable, elected $1535,{ }^{118}$ surrendered the abbey i 8 March, $1539^{119}$

${ }_{95}$ When he quitclaimed to Bishop Jocelin of Salisbury and the cathedral church the castle of Sherborne (Reg. St. Osmund. [Rolls Ser.], i, 235). Willis gives the year 1163 ; Hist. of Mirred Abbeys, ii, 71 .

${ }^{96}$ About that date Jocelin, bishop of Salisbury, by charter to Henry the abbot and convent of Sherborne, recited the rights of the abbot as the holder of a prebend in the cathedral ; Reg. St. Osmund. (Rolls Ser.), i, 249.

${ }_{97}$ The abbots $E$. and $G$. occur in charters of Henry II, inspected and confirmed by Edward I ; Chart. R. 20 Edw. I, No. 3. ${ }^{98}$ Ibid.

${ }^{94}$ Reg. St. Osmund. (Rolls Ser.), i, 265.

${ }^{100}$ Hutchins, without a date (Hist. of Dorset, iv, 232) from the Kennett MS.

${ }^{101}$ Pat. 11 Hen. III, m. 15.

${ }^{103}$ Ibid. 26 Hen. III, pt. 2, m. 2.

${ }^{109}$ Ibid. 3 I Hen. III, m. 9.

${ }^{104}$ Ibid. 14 Edw. I, m. 17.

${ }^{105}$ Ibid. m. 12.

${ }^{106}$ Ibid. 3 Edw. II, m. 6 ; Sarum Epis. Reg. Simon of Ghent, ii, fol. 89 .

${ }^{107}$ Ibid. Mortival, i, fol. 182 ; Pat. 10 Edw. II, pt. I, m. 6 .

${ }_{108}$ Ibid. 3 Edw. III, pt. 2, m. 15.

${ }^{109}$ Ibid. $16 \mathrm{Edw}$. III, pt. 3, m. 6.

${ }_{110}$ Ibid. $22 \mathrm{Edw}$. III, pt. 3, m. 10; Sarum Epis. Reg. Wyville, ii, fol. 198.

${ }^{1103}$ Hutchins, op. cit. iv, 233.

${ }^{11}$ Pat. 9 Ric. II, pt. 1, m. 39.

112 Ibid. m. 40.

${ }^{113}$ Ibid. 2 Hen. V, pt. 3, m. 7 .

114 Ibid. 15 Hen. VI, m. 38 .

116 Sarum Epis. Reg. Beauchamp, i (2), fol. 53.

${ }^{116}$ Pat. 15 Edw. IV, pt. 3, m. 1.

117 Sarum Epis. Reg. Audley, fol. 125.

I1s L. and P. Hen. VIII, viii, 802 (27).

${ }^{139}$ Ibid. xiv (1), 556.
An eleventh-century seal of the munastery (round) gives a fine impression of the abbey church from the north with apse, towers, and porch ; the windows of the clearstory and towers and the door way are round-headed. ${ }^{120}$ Legend:-

\section{SIGILL $\vec{V}$ - SLE - MARIE - SLYRBVRNENSIS ALCL'E}

A broken example of the above seal is to be found attached to the surrender deed of the abbey in $1539 .{ }^{121}$

The pointed oval seal of Abbot Clement (circa I I60) represents St. Benedict, half-length, holding in his right hand a scroll inscribed: vERTITE FILII AVDITE ME. In bars under two round-headed arches are two half-length monks looking upward. ${ }^{122}$

The legend is defective owing to the edge of the seal being rubbed.

... EMENTIS DE ..... BVRN ...

The seal of Abbot Laurence de Bradford (1246-59), pointed oval, the impression very imperfect, gives the abbot standing on a carved corbel, in his right hand a pastoral staff, in his left a book. The background diapered lozengy with a reticular pattern and small annular depression in each space. On the left is a countersunk quatrefoil containing a monk's head, the subject on the right corresponding is broken away. ${ }^{123}$

A small pointed oval seal, with very fine impression but imperfect, represents on a church with pinnacled turrets at the sides the Virgin, half-length, holding the Child on the right arm. In base, under a trefoiled arch, is an abbot with pastoral staff, half-length, in prayer. ${ }^{124}$

The legend, which is defective, runs :-

$$
\text { .... CRA : DEI .... MEM ... }
$$

The signet of Abbot John de Flixton, attached to an indenture dated 1347 , small, oval, chipped at the top, represents in a finely-carved and pointed quatrefoil St. Margaret standing on a dragon and piercing its head with a long cross held in her right hand. ${ }^{225}$

The legend is partly defective :-

$$
\text { ... [v]Irgo } \cdot \text { vermem - pVo[c]Ando }
$$

The signet of Abbot John Frith attached to a deed dated $\mathrm{r} 37 \mathrm{I}$, red, represents in a finely-carved and pointed quatrefoil a dog sitting between two trees. ${ }^{126}$

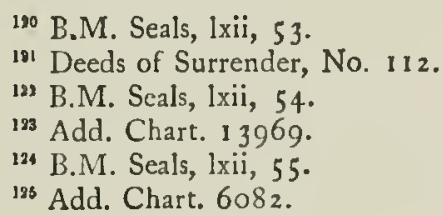

${ }^{126}$ Ibid. 6083. 


\section{A HISTORY OF DORSET}

The green pointed oval seal of William the prior, attached by a woven cord of red silk strands to a document dated $12+2,{ }^{127}$ represents the prior full length, holding in his right hand a pastoral staff, in his left hand a book. The legend runs :-

I SIGILIYM - WIL'I - PRIORIS : SIREBURNE

\section{THE PRIORY OF CRANBORNE}

The monastery of Cranborne is said to have been founded as an abbey for Benedictine monks about the year $980 .{ }^{1} \quad$ The chronicle of Tewkesbury describes its foundation and early connexion with the more widely-famous abbey in Gloucestershire in the following manner:

About the year 930, in the reign of King Athelstan, flourished a certain noble knight sprung of the illustrious stock of Edward the Elder and known by the name of Haylward Snew on account of his fairness. And being not unmindful of his end, he built for himself and $\cong l$ lgifu his wife in the day's of King Ethelred and St. Dunstan the archbishop a small monastery to the honour of God and Our Lord Jesus Christ, His Mother, and St. Bartholomew the Apostle, and endowed it with lands and possessions. And having assembled there brethren to serve under the obedience of an abbot according to the rule of St. Benedict, he made Tewkesbury, of which he was patron, wholly subject to it. These things were done about the year 980. And Haylward, having died and received burial in the church which he had built, was succeeded by Elfgar his son, the father of Brihtric, who according to the vow of his parents 'amplified' the church which they had begun."

\section{'Subsequently,' pursues the chronicle-}

William Duke of Normandy acquired England, bringing with him Robert Fitz-Hamon, lord of Astremarvilla in Normandy, and Matilda the wife of the Conqueror hated the said Brihtric Snew or Meaw because when sent abroad on an embassy for the affairs of the realm he refused her hand in marriage. She afterwards married William, and having sought opportunity stirred up the king's wrath against the Saxon nobleman so that he was seized by the king's order in the manor of Hanley (Worcestershire) and conveyed to Winchester, where he died and was buried leaving no heir. ${ }^{3}$

\section{${ }^{197}$ Add. Chart. 20372}

${ }^{1}$ Cott. MS. Cleop. C. iii, fol. 220. Dugdale mentions a tradition of a still earlier foundation, contained in an MIS, in the Ashmolean Museum, 'de abbatiis et abbatibus Norman. et eorum fundatoribus,' which states that a college of six monks was built here in meisory of the Britons who had here been slain. Mon. iv, 465 .

${ }^{2}$ Cott. MS. Clec?. C. iii, fol. 220 . Freeman dismisses this pedigree with the remark that as ' a piece of chronalogy it attributes a wonderfully long life to the persons concerned;' Norman Cong. iv, App. T. p. $76_{3}$.

${ }^{3}$ Cott. MIS. Cleop. C. iii, fol. 220. Freeman commenting on this 'legend,' which comes from the continuator of Wace and may be found in Chronigucs
His estates were granted to Queen Matilda and subsequently to Robert Fitz Hamon, who, in the year II02, "led by the Holy Spirit' and at the instigation of 'his good wife Sybil' and of Gerold, abbot of Cranborne, greatly enlarged the church of Tewkesbury and endowed it witl further possessions; and finding that the place enjoyed a more agreeable site and a more fertile soil he transferred the whole community from Cranborne thither, leaving only a prior and two monks that the memory of its founders might be held for ever in remembrance, and so, transforming the former abbey into a priory, he made it entirely subject to the abbey of Tewkesbury." The regulations for the newly-constituted abbey drawn up by Abbot Gerold in the year I105, when the transference to Tewkesbury seems to have been finally completed, assigned the manor of Tarrant (Monkton) towards the improvement of the monks' food, the churches 'which had belonged to Robert the chaplain' towards their clothing, and the manor of Chettle in Dorset for almsgiving."

Previous to this removal the Domesday Survey of I086, which separates the estates of Cranborne from those of Tewkesbury, states that the church of St. Mary here held 2 carucates of land in Gillingham valued at 6os. in Edward the Confessor's time, but then worth 20s., Boveridge and Up IVimborne, both of which had been and were then worth I Oos., Lestisford, half a bide in Langford in the parish of Frampton, and the manor of 'Tarrant Monkton, which had fallen in value from $£ 12$ to $\&_{10}{ }^{6}$ Under the holding of the widow of Hugh Fitz Grip it is recorded that Hugh gave the church of St. Mary, Cranborne, a hide of land in Orchard for the good of her soul, and ' it is worth 20 s." $^{\text {" A }}$ charter of Roger, bishop of Salisbury, confirmed to the abbey of Tewkesbury the gifts of Robert Fitz Hamon and his knights in the year I IOg, including the church of St. Mary of Cranborne with all its appurtenances, and certain churches which had belonged to R[obert] the chaplain, viz., Pentridge, Ashmore, and Frome, with other tithes. $^{8}$ The Taxatio of I29I gives the abbey spiritualities valued at $E_{1}$ I 12 s. from the churches of Belchalwell, Pentridge, and Langton Matravers $;{ }^{9}$ those of the priory of Cranborne, amounting to $£^{2}$ Is., consisted of a pension of 75 . from the church of Sturminster Newton, I 2s. from the church of Edmondsliam, 2s. from that of IVimborne Karentham, and $\mathscr{E}_{\mathrm{I}}$ from the vicarage of Anglo-Normondes (i, 73), says 'it has this much of corroboration from history that a portion of the lands of Brihtric did pass to Matilda'; Norman Conq.iv, 166.

- Cott. MS. Cleop. C. iii, fol. 220.

${ }^{3}$ Cott. MS. Cleop. A. vii, fol. $94 b$. The Annales of Winchester and Worcester are wrong in giving 1086 as the year in which the removal of Tewkes. bury took place. Ann. Mon. (Rolls Ser.), ii, 34 ; iv, 373.

Ibid. $S_{4}-{ }^{8} \mathrm{Cott}$

${ }^{9}$ Pope Nich. Tax. (Rec. Com.), 178b, 179. 


\section{RELIGIOUS HOUSES}

Dewlish. ${ }^{10}$ The temporalities were all entered under "Tewkesbury, and realized $£_{2} 5$ I2s. 6d."1

From the date of its subjection to Tewkesbury the history of the cell is all but entirely merged in that of the larger house, and save on one or two occasions, when the abbot is shown as keeping a watchful eye on his estate here lest any of his rights should be infringed by his powerful neighbour, the earl of Gloucester, ${ }^{12}$ references to $i t$ are brief and rare. We read that the body of Gilbert de Clare, earl of Gloucester, who died abroad in I230, was conveyed home for burial, and stopped at Cranborne on its way to Tewkesbury. ${ }^{13}$ The church was rebuilt in 1252 and dedicated to St. Mary and St. Bartholomew. ${ }^{14}$ Occasionally the prior acted as proxy or attorney for the abbot, as in 1314 when he was appointed to do suit and service to the abbot of Glastonbury for lands held in his manor of Damerham (Wiltshire). ${ }^{15}$ In the course of a diocesan visitation by the bishop in 1379 he was ordered to appear in the church of Sonning the second Thursday after the Feast of St. Barnabas, prepared to exhibit the title deeds of the abbot and convent of Tewkesbury for their possessions in the Salisbury diocese. ${ }^{16}$ Among the expenses charged on the priory in the Valor of 1535 is an entry of $7 \mathrm{~s}$. Iod. due to the bishop of Salisbury for the triennial visitation of the church of Cranborne. ${ }^{17}$ In the course of the Hundred Years' War the prior was required, together with the abbots of Sherborne, Cerne, Bindon, and Abbotsbury, \&c., to move nearer the sea-coast for the purpose of repelling invasion, under peril of being regarded as rebels and favourers of the enemy. ${ }^{18}$ Edward III in I $329^{\text {s out of affection }}$ for Peter de Broadway, prior of Cranborne,' granted a licence for the abbot and convent of Tewkesbury to acquire in mortmain lands not held in chief to the value of $£_{10}$; three years later the prior of the subject-cell was induced to surrender this grant and another was obtained more specifically in favour of the parent house. ${ }^{19}$

${ }^{10}$ Pope Nich. Tax. (Rec. Com.), 178, 1 786, 179.

"Ibid. fol. 183,18 f.

${ }^{12}$ Cott. MS. Cleop. A. vii, fol. 96-8; Ann. Mon. (Rolls Ser.), i, I $40,144$.

${ }^{13}$ Ibid. i, 76.

11 Ibid. i, 149, 150.

15 Hoare, Modern Wilts. Hund. of S. Damerham, 30.

${ }^{16}$ Sarum Epis. Reg. Erghum, fol. 29.

17 Valor Eccl. (Rec. Com.), ii, 485 . In 1433 a royal writ was issued desiring to be certified as to whether the prior and convent of Cranborne held and hold the parish church of Cranborne, what was the portion of the prior therein, and at what was it assessed in all clerical subsidies. The return stated that the church of Cranborne, with the chapel of Archnal, was appropriated to the prior and convent, and taxed at 25 marks, the vicar of Cranborne was taxed at $6 \frac{1}{2}$ marks. Sarum Epis. Reg. Chandler, fol. I I 4 .

${ }^{18}$ Rymer, Foed. (Rec. Com.), ii, (2), ro6z.

${ }^{19}$ Pat. 3 Edw. III, pt. I, m. 21; 6 Edw. III, p. 3, m. 4 .
According to the Valor of 1535 the gross income of the priory at that time amounted to $f .55$ 6s. I $d$.; the expenses to $f^{1} 7$ I6s. $8 d$., including $f_{1} 0$ paid to the vicar of Cranborne for his stipend 'according to the composition made by the ordinary,' and a yearly distribution of IOs. in bread to the poor, for the soul of the founder 'Ailward Mayewe'; Henry Bromall was then prior. ${ }^{20}$

At the Dissolution the cell shared the fate of the abbey, which was surrendered to the king's commissioners 3 I January, I 540. William Dydcotte, who in 1335 held the office of sacrist of Tewkesbury, received a pension of $f, I 0$ as the last prior of Cranborne. ${ }^{21}$

The manor of Cranborne Priory, pertaining to the late abbey of 'Tewkesbury and rated at f. I 4 I 3 s. $3 d$., was sold in the reign of Philip and Mary to Robert Freke at seventy-four years' purchase ; the manor, rectory, and advowson of the vicarage in the first year of Elizabeth were granted to Thomas Francis for life. Subsequently they were given by James I to Robert Cecil, earl of Salisbury, in the possession of whose family they still remain. ${ }^{22}$

\section{Priors of Cranborne}

Gerold, abbot of Cranborne, transferred the abbey to Tewkesbury I $102{ }^{23}$

Adam de Preston, died I $262^{24}$

Walter de Appleleigh, occurs $1314^{25}$

Peter de Broadway, occurs I 329 and $1332^{26}$

Henry Bromall, occurs $1535^{27}$

William Dydcotte, last prior $1540^{28}$

\section{THE PRIORY OF HORTON}

(Cell to the abbey of Sherborne)

The foundation of the Benedictine abbey, afterwards priory, of Horton is generally attributed to Ordgar or Orgar, earl of Devon, the founder of Tavistock, who flourished in the reign of King Edgar and died in the year 971.'

${ }^{20}$ Valor Eccl. (Rec. Com.), ii, 48 ;

"1 L. and P. Hen. VIII, xv, 49 .

${ }^{23}$ Hutchins, Hist. of Dorsct, iii, $382-3$.

${ }^{23}$ Ann. Mon. (Rolls Ser.), i, 44. ${ }^{24}$ Ibid. i, 169.

${ }^{25}$ Hoare, Modern IVilts. Hund. of S. Damerham, 30.

${ }_{25}$ Pat. $3 \mathrm{Edw}$. III, pt. 1, m. 21 ; $6 \mathrm{Edw}$. III, pt. 3, m. 4 .

27 Valor Eccl. (Rec. Com.), ii, 485 .

${ }^{29}$ L. and P. Hen. VIII, xv, 49.

${ }^{1}$ Hutchins gives the date of Horton as $96 \mathbf{1}$ (Hist. of Dorset, iii, 149), the same year in which Ordgar founded Tavistock accurding to Matthew of Westminster (Flores Hist. [Rolls Ser.], i, 508). Ordgar will always be remembered as the father of the notorious Queen Elfrida, who, after disposing of her first husband, became the wife of Edgar, and whom tradition has charged with the murder of her step-son Edward the Martyr. 


\section{A HISTORY OF DORSET}

The account, however, of IVilliam of Malmesbury, from which all subsequent accounts are drawn, ${ }^{2}$ seems rather to imply that the abbey was the work of Ordulph or Edulph, son of Ordgar, and should consequently be dated a little later; possibly the two accounts may be reconciled by supposing that it was begun by the elder man and carried on to completion by the younger in deference to his father's wishes. Horton, dedicated to St. Wolfrida, the mother of Edith abbess of IVilton, was situated, like Little Malvern and other foundations of that age, in the midst of forest $;^{3}$ centuries later Leland writes of the abbey as four miles distant from Wimborne 'much by woody ground.' 1

The earlier chronicler relates some of the stories that have been handed down anent the enormous strength and prowess of the younger founder, the giant Edulph," but adds "spite of this matchless physical strength death carried him off in the flower of his age, and he ordered that he should be buried at Horton.' Abbot Sihtric of Tavistock, however, foreseeing the advantage that would thence accrue to the smaller foundation, stepped in and 'by violence' caused the body to be transferred to his own church where Earl Ordgar already lay buried.

In all probability Horton shared the fate of Tavistock, which was destroyed in the Danish raid of $997 .^{6}$ To return to the account of William of Malmesbury, Abbot Sihtric added to his crime in robbing Horton of the body of Edulph by turning pirate in the reign of William the Conqueror, whereby he 'polluted religion' and 'defamed the church.'"

At the time of the Domesday Survey the abbey was in possession of the nuanor of Horton, which was taxed at 7 hides and valued at $£ 4$, 'the king holds two of the best hides in the forest of Wimborne., ${ }^{8}$ The church would go with the possession of the manor as was then the custom and the monks held at the same time a little church or chapel (ecclesiola) in Wimborne and land with two houses, the church of Holy Trinity, Wareham, and five houses paying a rent of $65 d^{2}$, and a house in Dorchester ${ }^{9}$ besides estates in Devonshire.

Among the changes in his diocese introduced by Roger, the great bishop of Salisbury and chancellor of Henry I, was the reduction of Horton from an abbey to a priory and its subsequent anuexation as a subordinate cell to Sherborne, which in the same manner was raised to the

'Will. of Malmes. Gesta Pontif. (Rolls Ser.), 202-3. 'Ibid. 'Itin. iii, 73 .

${ }^{5}$ Will. of Malmes. Gesta Pontif. (Rolls Ser.), 203.

${ }^{6}$ Matt. of Westm. Flores Hist. (Rolls Ser.), i, 524.

${ }^{7}$ Owing to a misreading of the text, the abbot in many accounts is charged with firing the church (inglamaris instead of injomavit).

${ }^{s}$ Dom. Bk. (Rec. Com.), i, 786.

Ibid. position of an abbey, the transference taking place in I 122 according to the Annals of Margam, ${ }^{\text {, }}$ in I 39 according to William of Malmesbury." By this change the lands and possessions of Horton passed over to Sherborne, as we may gather from a bull of Pope Eugenius III in I 45 and again of Pope Alexander III in I I63, confirming the possessions of Sherborne and enumerating among them the manor and church of Horton with the adjacent chapel of Knowlton, the chapel of Holy Trinity, Wareham, and the church of St. Mary Wimborne. ${ }^{12}$ The Taxatio of I 291 gives the prior of Horton temporalities at Horton valued at E. 17 s. $4 d .{ }^{13}$ the church of Horton belonging to Sherborne was valued at $\oint_{1} \mathrm{I}$, the endowment of the vicarage amounting to $£ .50^{14}$ In 1535 the rectory was not worth more than $f_{9} 5$ s. $4 d$., the vicar only receiving $175.4 d$. ; ${ }^{16}$ the gross value of the manor at that time was returned at 622 Ios. $6 d$., out of which $2 s$. was paid to the hundred court, and a fee of I6s. $8 d$. to Giles Strangweys, knt., steward of the manor. ${ }^{16}$

From the date of its annexation to Sherborne the priory sinks into that obscurity mostly attending the existence of small dependent cells from which it rarely emerges. ${ }^{17}$ In April 1286 we read that simple protection, until the Feast of St. Peter ad Vincula, was granted to Hugh prior of Horton, going beyond seas, and appointing John de Chegy and Henry son of William de Horton his attorneys during his absence. ${ }^{18}$ A commission was issued in February, I 348 , on the complaint of Alesia countess of Lincoln, that the abbots of Sherborne and Milton, John de Bradeford, prior of Horton, and others, had broken her park at Kingston Lacy, cut down her trees and hunted her deer. ${ }^{19}$ Again in 1401 dispensation was granted to John Cosyn, Benedictine prior of Horton, 'who is also a monk of Sherborne,' to hold another benefice, office, dignity',

${ }^{10}$ Ann. Mon. (Rolls Ser.), i, 10.

$"$ Cott. MS. Faust. A. ii. The account given by the chronicler in his Historia Nocella (Rolls Ser.), ii, 559, is that Roger of Salisbury first desiroyed Horton and then added it to Sherborne; he may be expressing the same thing in his other account of Horton which speaks of the abbey so being destroyed at the time in which he was writing the Gesta Pontif. (Rolls Ser. 202), meaning that the status of Horton as an abbey had been done away with and not that its existence had ceased.

12 Dugdale, Mors. under Sherborne, i, Nos. v, vi, $338-9$.

${ }^{13}$ Pope Nich. Tax. (Rec. Com.), 1846.

${ }^{14}$ Ibid. $174^{b}$.

15 Valor Eccl. (Rec. Com.), 1, 281.

${ }^{16}$ Ibid. 287.

17 Various references given by Tanner under this house belong to Monks Horton, a Cluniac foundation cell to Lewes with which the Dorset Horton is frequently confounded.

${ }^{15}$ Pat. ${ }_{4} 4$ Edw. I, m. 18, 19.

${ }^{19}$ Ibid. 22 Edw. III, pt. I, m. $43 d$. 


\section{RELIGIOUS HOUSES}

or priory of the same or another order and to resign it in exchange for another as often as he pleases. ${ }^{20}$

At the Dissolution the abbey of Sherborne was surrendered to the king on $18 \mathrm{March}$, 1339, the deed being signed among others 'per me John Hart,' ${ }^{21}$ the same John Hart or Herte alias Raynold, prior of Horton, receiving a pension of 68. ${ }^{.9}$ The manors, together with the site of the priory, the rectory and advowson of the vicarage, were granted in the first year of Edward VI to Edward duke of Somerset, and on his attainder to the earl of Pembroke. ${ }^{23}$

\section{PrIORS OF HoRTON ${ }^{24}$}

Hugh, occurs $1286^{23}$

John de Bradeford, occurs I $348^{26}$

John Cosyn, eccurs I $401{ }^{27}$

Henry Trew, occurs I 459-60 28

John Dorchester, occurs $1504{ }^{29}$

John Hart or Herte alias Raynold, occurs on its surrender, $1539^{30}$

\section{HOUSE OF BENEDICTINE NUNS}

\section{THE ABBEY OF SHAFTESBURY}

The Benedictine nunnery of Shaftesbury is generally, though not universally, ascribed to the foundation of Alfred the Great ${ }^{1}$ about the year 888 ; $^{2}$ the king, by his charter in honour of God the Blessed Virgin and all the saints, conferring on the nunnery, over which his daughter Elfgiva, Æthelgeofu or Algiva, presided as abbess, 100 hides of land as an endowment, consisting of 40 hides at Donhead St. Andrew, and Compton Bassett (Wiltshire), 20 hides at Handley and Gussage, 10 hides at Tarrant, 15 hides at Iwerne Minster and 15 at Fontmell. ${ }^{3}$

This nucleus was much increased by the grants of Alfred's successors ; from Ethelstan in 932 the nuns obtained $4 \frac{1}{2}$ carucates of land at Fontmell on condition that they should sing psalms for the redemption of his soul ${ }^{4}$ and by another charter in 935 land at Tarrant in Pimperne Hundred. 5 Edmund in 942 gave to the religious woman Wenflede the land of twenty manses at Cheselbourne; ${ }^{6}$ Eadred in 948 land in Purbeck

${ }^{20}$ Cal. Pap. Letters, v, 362.

${ }^{21}$ P.R.O. Deeds of Surrender, No. 40.

${ }^{23}$ L. and P. Hen. VIII, xiv (i), 556 .

${ }^{23}$ Hutchins, Hist. of Dorset, iii, 143

9t Very few of these can be recovered, the prior was 'dative and removeable' by the abbey, consequently his appointment is never recorded in the episcopal registers or in the patent rolls. Dugdale only gives the names of two.

${ }^{25}$ Pat. $14 \mathrm{Edw} . \mathrm{I}$, m. 18, 19.

${ }^{26}$ Ibid. 22 Edw. III, pt. 1, m. 43 d.

${ }^{27}$ Cal. Pap. Letters, v, 362 .

${ }^{98}$ Dugdale, Mon. ii, 511. "Ibid.

${ }^{30}$ P.R.O. Deeds of Surrender, No. $40 ; L$. and $P$. Hen. VIII, xiv (i), 556.

' Will. of Malmes. Gesta Regum (Rolls Ser.), i, I 3 I ; Matt. of Westm. Flores Hist. (Rolls Ser.), i, 468 ; Leland, Coll. i, 26; Leland, however, in another place (ibid. i, 67) speaks of $Æ$ thelbald, the son of Æthelwulf of Wessex, as the founder, and his brothers Æthelbert, Ethelred, and Alfred as co-founders. In various other passages the above authorities ascribe the foundation to St. Elgiva, wife of King Edmund, with her husband a great benefactor of the abbey (Will. of to the religious woman Elfthrith ; ${ }^{7}$ Edwy bestowed on the nunnery in 956 for the love of Christ the land of 80 manses at Donhead St. Andrew, Easton Bassett (Wiltshire), Compton Abbas, Handley and Iwerne Minster (Dorset). ${ }^{8}$ Edgar confirmed and renewed to the church and nuns of Shaftesbury in 966 ten cassates of land at Piddle formerly granted to then by his grandmother Wenfiede, the record of which through carelessness had been lost.? Ethelred 'the unrede" gave in 984 the land of twenty manses at Tisbury (Wiltshire), ${ }^{10}$ and by another charter in IOOI bestowed on the church of St. Edward the vill and monastery of Bradford (Wiltshire) to be subject to the nuns, that with the relics of the Blessed Martyr (King Edward) and other saints they might find there a refuge against the attacks of the Danes, the king stipulating that on the restoration of peace and tranquillity when the sisters returned to their ancient home they should leave behind at Bradford a sufficient community, according as the prior should think fit, for its monastic state to be maintained. "The chartulary of the monastery records that in IOI9 Canute, who died here in $1035,{ }^{12}$ made a grant of sixteen cassates of land

Malmes. Gesta Pontif. (Rolls Ser.), 186-7 ; Matt. of Westm. op. cit. i, 455; Leland, op. cit. ii, 252 '. It may be that the similarity in the name of the first abbess, Alfred's daughter, and that of the benefactress who followed her and was buried in the abbey, has led to this confusion as to the founder.

'Asser, De rebus gestis Elfredi (Camd. Soc.), 19 ; Sim. of Durham, Opera (Twysden), 150; Leland, Coll. iii, 7 I.

${ }^{3}$ Birch, Cart. Sax. ii, 148 . The date, however, $87 \mathrm{I}$, generally ascribed to this charter is some years previous to that usually given for the foundation of Shaftesbury.

'Ibid. ii, $3^{8} 3$; Harl. MS. 61, fo!. 11.

${ }^{5}$ lbid. fol. 15 ; Cart. Sax. ii, 414.

${ }^{6}$ Ibid. 509 ; Harl. MS. 61, fol. 7 .

${ }^{7}$ Ibid. fol. 4 .

${ }^{8}$ Ibid. fol. 20 d. ; Cart. Sax. iii, 158.

Ibid. iii, 449 ; Harl. MS. 61, fol. $13 d$.

${ }^{10}$ Ibid. fol. 2.

"Angl.-Sax. Chron. (Rolls Ser.), ii, 128. 


\section{A HISTORY OF DORSET}

at Cheselbourne to his servant Agemund with the object of their ultimate reversion to the church.13

During the first century of its existence the abbey appears under the dedication of the Blessed Virgin, but after the translation to Shaftesbury of the body of Edward the Martyr, murdered in $978,{ }^{14}$ it was called after him and became popularly known as St. Edward's ; the earlier dedication, however, was never formally dropped and the house frequently occurs, as in the Domesday Survey, under the dedication of both St. Mary and St. Edward.15

According to the Survey of 1086 the abbey at that time held the following lands: $15 \frac{1}{2}$ hides at Felpham in Sussex $;^{16} 5$ hides at Beechingstoke ; Io at Tisbury; 40 at Donhead ; 42 at Bradford ; 7 at Alvediston; 38 at Liddington ; and 20 at Downton (Domnitone) in the county of IVilts ; ${ }^{17} 5$ hides at Combe, and a rent of $50 d$. paid by six burgesses of Milborne in the county of Somerset ; ${ }^{18}$ in this county the possessions of the nuns were as follows: 20 hides at Handley; 8 at Hinton St. Mary ; I 7 at Stour ; I 5 at Fontmell; I 0 at Compton Abbas; 10 at Melbury; 18 at Iwerne Minster; 10 at Tarrant; 5 at Fifehead; IO at Kingston; I at Farnham ; 5 at Stoke; I I at Mapperton and Io at Cheselbourne. ${ }^{19}$ In the time of Edward the Confessor the abbess had 153 houses in the town of Shaftesbury, now owing to the destruction of forty-two she only had I I , she also held at the time the Survey was taken 15 I burgesses in the same town, twenty vacant houses and a garden. ${ }^{20}$ A great increase in the value of the manors had taken place since Edward the Confessor's time and Domesday records that IVilliam the Conqueror had given the church of Gillingham to the nuns in place of a hide of their manor of Kingston on which he had built his castle of Wareham, and had restored to them the manors of Cheselbourne and Stour, of which they had been robbed by Earl Harold, on the production of a writ by the late king ordering their restoration together with the manor of Melcombe, which the Conqueror still retained for himself. Puddle was another manor that had been seized by the late earl. ${ }^{21}$

The Norman and Plantagenet kings by their gifts and privileges added enormously to the power and wealth already enjoyed by this richly-

${ }^{13}$ Harl. MS. 61, fol. 8.

14 Angl.-Sax. Chron. (Rolls Ser.), 102 ; Leland, Coll. i, 219 ; ii, 252.

${ }^{13}$ The possessions of the abbey for instance in Sussex and Somerset are entered under 'Terra Sancti Edwardi,' in Wilts and Dorset under 'ecclesia S. Mariac Sceptesberiensis.'

${ }^{16}$ Dom. Bk. (Rec. Com.), i, 176 .

${ }^{17}$ Ibid. i, fol. 6-6.

18 Ibid. i, fol. 9 I.

Ibid.

19 Ibid. i, fol. 75 . ${ }^{21}$ Ibid. endowed house. ${ }^{22}$ William Rufus in rogo confirmed to the church of St. Mary and St. Edward and to Eulalia the abbess various grants by different persons, each grantor bestowing a daughter as a nun in the house as a condition of his gift. $^{23}$ Henry I confirmed the manor of Donhead to the nuns 'for their clothing' to be held quit of all geld and tax, pleas of the hundred, suits and quarrels save for murder and theft. ${ }^{24}$ Stephen by his charter confirmed the lands which Emma the abbess had proved to belong to the abbey in the presence of Henry I and his barons. ${ }^{25}$ Henry II took the community under his special protection and made them free of all toll and passage. ${ }^{26}$ Richard I in the first year of his reign granted to the abbey, and especially to the abbess Mary, the privilege of the hundred in their manor of Bradford. ${ }^{27}$ John count of Mortain gave the nuns, at the special request 'of my dearest friend the abbess Mary' of Shaftesbury, two loads of brushwood daily in his manor of Gillingham. ${ }^{23}$ The abbess received from Henry III a charter for wreck of the sea in her manor of Kingston, ${ }^{29}$ licence to hold a market and two fairs at Kintbury (Berkshire), ${ }^{30}$ and right of free warren over her lands at Barton, Cheselbourne, Almer and Caundle (Dorset), Donhead, Tisbury and Bradford (Wiltshire), and Felpham (Sussex). ${ }^{31}$ Edward I by letters patent in 1290 licensed the alienation to the abbey by Edward de Manneston of land and two messuages in Donhead and Tisbury, ${ }^{32}$ and on payment of a fine in 1304 allowed the nuns to acquire the manor of Stour by feoffment of Ralph IVake. ${ }^{33}$ By licence of Edward II in 1318 Stephen Pruet, parson of Compton Abbas, bestowed on the convent 20 s. yearly rent out of Donliead (IViltshire) for the provision of a light to burn through the night in the cloister of their abbey. ${ }^{34}$ Edward III in I 337 gave a licence for the sisters to acquire more land to the value of $f$ io yearly. ${ }^{35}$ The king in 1340 after an inquisition confirmed to them the right to have four horse-loads of brush-

"A summary of the charters contained in the register of Shaftesbury (Harl. MS. 61) is given by Dugdale, Mon. ii, 68.

${ }^{5}$ Harl. MS. 6r, fol. 23 . 2 Ibid. fol. 24.

"I Ibid.

${ }^{27}$ Ibid. fol. 26.

${ }^{26}$ Ibid. fol. 25 .

2' Ibid. fol. 27.

"Pat. 54 Hen. III, No. 50. Confirmed by Edward IV; ibid. 2I Edw. IV, pt. 1, m. II.

${ }^{30}$ Chart. R. 52 Hen. III, n. 12.

s1 Ibid. 22 Edw. I.

s3 Pat. 18 Edw. I, m. II.

${ }^{33}$ Ibid. 32 Edw. I, m. I6.

"I Ibid. 11 Edw. II, pt. 2, m. 32.

${ }^{3}$ Ibid. 11 Edw. III, pt. I, m. 32 . In part satisfaction of this grant they obtained in 1348 lands and messuages in Shaftesbury; Cann, Gussage St. Andrew and Minchington (Dorset), Ke'ston (Somerset), and Donhead St. Mary and St. Andrew (Wilts). Ibid. 22 Edw. IlI, pt. i, m. I 3 . 


\section{RELIGIOUS HOUSES}

wood daily except Sunday from the forest of Gillingham. ${ }^{36}$ Hugh le Despenser in 1343 bestowed a yearly rent of 10 marks from the manor of Broad Town (Wiltshire) for the lifetime of his sister Joan, a nun in the abbey, ${ }^{37}$ and the following year the community obtained in proprios usus the church of Felpham (Sussex) of their advowson. ${ }^{33}$ The abbess was allowed in 1368 to crenellate the abbey for the purpose of defence. ${ }^{39}$ At the beginning of the fifteenth century the convent obtained from Henry IV letters patent inspecting and confirming the charters granted to them by his predecessors, ${ }^{10}$ and in 1481 Edward IV inspected and confirmed by his letters patent a grant of Henry III for wreck of the sea in their manor of Kingston. ${ }^{41}$

That popular form of religious endowment, the foundation of chantries, was the object of many additional grants to the abbey in the fourteenth century. In 1326 , and again in the first year of Edward III, the community acquired two messuages in Shaftesbury in aid of the maintenance of a chaplain who should celebrate daily in the church of St. Mary and St. Edward for the souls of Edward I and all the faithful departed. ${ }^{42}$ In 1330 Walter Hervy obtained a licence for the alienation of a toft and 8 acres of land in Shaftesbury for the provision of a chaplain to officiate daily at the altar of St. Anne in the conventual church ; ${ }^{43}$ by another licence in 1334 three messuages, 26 acres of land, and 4 acres of meadow in the town were alienated for the maintenance of a chaplain to celebrate daily for the souls of Sibyl Cokyn, Thomas de Hacche, John Kokyn, and Agnes de Hacche, their ancestors and heirs, at the altar of St. Thomas the Apostle. ${ }^{44}$ Richard Poinz in 1340 made over a rent of 155 . for the provision of a chaplain who should celebrate daily in the church for his soul and the souls of his ancestors; ${ }^{45}$ and in 1342 a chantry was founded at the altar of St. Nicholas for the good estate of Thomas Platel of Shaftesbury and Alice his wife and for their souls after death, and the souls of their ancestors, heirs, and benefactors. ${ }^{46}$ The

${ }^{36}$ Pat. I 4 Edw. III, pt. 2, m. 6.

${ }^{37}$ Ibid. 17 Edw. III, pt. 2, m. 3.

${ }^{38}$ Ibid. I $8 \mathrm{Edw}$. III, pt. 2, m. I5.

${ }^{39}$ Ibid. 42 Edw. I, pt. I, m. 25. A complaint was made by the abbess and the king's tenants of Shaftesbury in $134^{1}$ that many evil-doers and breakers of the peace were going about armed, robbing and killing their servants, and that no remedy had been provided hitherto. Ibid. $15 \mathrm{Edw}$. III, pt. 2, m. 45 .

${ }^{40}$ Ibid. 2 Hen. IV, pt. 3, m. 20; 4 Hen. IV, pt. 2, m. 23.

41 Ibid. 2 I Edw. IV, pt. I, m. I1.

${ }^{42}$ Ibid. 19 Edw. II, pt. 2, m. 2 ; ibid. 1 Edw. III, pt. 2, m. 23 .

${ }^{43}$ Ibid. 4 Edw. III, pt. 1, m. 18.

"Ibid. 8 Edw. III, pt. 2, m. 21.

${ }^{4}$ Ibid. 14 Edw. III, pt. 3 , m. 20.

${ }^{46}$ Ibid. 16 Edw. III, pt. 2, m. 32 . priest serving the chantry at the altar of Holy Cross was in 1364 transferred by the bishop to the church of Holy Trinity within the churchyard of the monastery, and inducted therein as perpetual chaplain with a fit salary assigned. ${ }^{17}$ Various other chantries were established to commemorate the souls of certain of the abbesses. ${ }^{48}$ In the episcopal registers mention is made of the chantry of St. Edward within the abbey, ${ }^{49}$ and the chantry commissioners of Edward VI in the sixteenth century made a return of three chantries at Shaftesbury: St. Catherine's at the altar of St. Catherine, St. John Baptist, and the chantry of St. Anne de la Gore in the chapel of that name within the parish of St. James. ${ }^{50}$ The abbess and convent were granted in 1386 reversion of the manor of Brydesyerd for the support of a chaplain officiating in a place called 'le Belhous' in Shaftesbury and of the twelve poor inmates there. ${ }^{51}$ In the Valor of 1535 various sums were assigned by the community in support of these twelve poor men in the 'Maudelyn' or 'Belhous' of Shaftesbury, who in return for their maintenance were bound to pray for the founders of the monastery. ${ }^{52}$

'The endowment of the monastery was so considerable and the extent of its possessions so vast that in the Middle Ages there was a popular saying, 'If the abbot of Glastonbury could marry the abbess of Shaftesbury their heir would hold more land than the king of England,' ${ }^{53}$ In the reign of Henry II the holding of the abbess was assessed at the service of seven knights, ${ }^{54}$ three of whom appear to have represented her fees in Dorset and Somerset and four those in Wiltshire. ${ }^{55}$ In I 66 she certified the king by charter that the seven knights she was bound to find for his service were as follows: Earl Patrick one fee, Anselin Mauduit, Jordan de Necche, and Thurstan de Huseldure a fee each, Robert FitzPeter and Roger de Thoka held the fifth fee, and the sixth and seventh were held 'against the convent' by Roger de Newburgh, who in addition held Almer at a rent of $40 s$. and said that he ought to hold it for half a fee, which however the abbess declared William de Glastonia never did; twelve other tenants held various fractions of fees. ${ }^{56}$ Henry III by charter of

17 Sarum Epis. Reg. Wyville, fol. 315. See Pat. 41 Edw. III, pt. 1, n. I6.

${ }^{49}$ Dionysia le Blunde, Cecilia Fovent, Edith Bonham, and Margaret St. John. Hutchins, Hist. of Dorset, iii, 36 .

${ }^{49}$ According to an institution in Bishop Chandler's register (fol. 44) the chantry of Edward, King and Martyr, was founded at the altar of St. Nicholas.

${ }^{50}$ Chant. Cert. Dorset, 16, Nos. 17-19, 95-7.

${ }^{51}$ Pat. 9 Rich. II, pt. 2, m. 3 I.

52 Valor Eccl. (Rec. Com.), i, 280.

${ }^{53}$ Fuller, Church Hist. iii, 332.

${ }^{54}$ Red Bk. of the Exch. (Rolls Ser.), i, 27, 33, 43, 54,80 .

${ }_{65}$ Ibid. $64,65$. 


\section{A HISTORY OF DORSET}

4 May, 1233, released to the Abbess Amicia and her successors the demand made by the king and his ancestors of the service of three knights and the fourth part and sixth part of a fee in addition to the seven already enumerated, ordaining that in future the said abbess should be accountable only for the service of seven knights, which she admitted to be due. ${ }^{57}$ At the close of the thirteenth century the Taxatio assessed the temporalities of the abbey in the diocese of Salisbury at $£, 506145 .,{ }^{58}$ in the diocese of Chichester at $f_{.50}{ }^{59}$ and $£ 33$ in the diocese of Bath and Wells. ${ }^{60}$ The spiritualities of the convent, reckoned only at $£^{14}$, consisted of pensions from the churches of St. James, Shaftesbury, Tisbury, and Bradford. ${ }^{61}$ The power and influence in the district possessed by the abbess can have been only less than supreme; to her belonged a moiety of the manor of Shaftesburythe other half pertaining to the king ${ }^{62}$-and the custody of the vill for which she paid a fee farm of $f_{12.63}$ The patronage in her hands and those of the community was above that of any other religious house in the county; in addition to the presentation of all the churches in Shaftesbury, at that time numbering twelve with the abbey, and the advowson of the hospital of St. John super montem, she had within her gift the four prebends or portions for secular priests within the conventual church, viz., Iwerne Minster, Gillingham, Liddington, and Fontmell, the appointment of the various chaplains officiating at the different chantries, and the presentation to the office of deacon of the high altar within the church, collation to which fell to the crown in the vacancy of the abbey. ${ }^{61}$ In the return of church property of 1535 the receipts and disbursements are entered of an official appointed by the abbess and removable at her will, William Breton, clerk, who held the office of sacrist of the abbey and to whom was assigned certain rents for the maintenance and repair of the church, the provision of bread, wine, and other necessaries for the celebration of divine offices, and the payment of salaries and pensions for certain priests officiating in the church. ${ }^{65}$

On the eve of the Dissolution the net income of the abbey was assessed at $£ 1,329$ is. $3^{d}$. ; ${ }^{86}$ the spiritualities of the community included the parsonages of Bradford and Tisbury and tithes from Barton, ${ }^{67}$ their temporalities the manors

${ }^{57}$ Chart. R. 17 Hen. III, m. Io.

${ }^{59}$ Pope Nich. Tax. (Rec. Com.), I $83 . \quad{ }^{59}$ Ibid. I 39.

${ }^{60}$ Ibid. 203. ${ }^{61}$ Ibid. 178, 180-1.

${ }^{62}$ Hutchins, Hist. of Dorset, iii, $11-13$.

63 In 1391 Richard II made a life-grant to John Roos of this fee farm paid by the abbess for the town. Pat. 14 Rich. II, pt. 1, m. 30.

Ibid. 18 Rich. II, pt. I, m. 10.

${ }^{63} \mathrm{Yalor}$ Eccl. (Rec. Com.), i, 280.

${ }^{16}$ Ibid. ${ }_{67}$ Ibid. 276. of Barton, Downton, Fontmell, Tarrant, Liddington (Wiltshire), Hinton, Felpham (Sussex), Kingston, Donhead (Wiltshire), Stour, Tisbury (Wiltshire), Cheselbourne, Combe (Somerset), Caundle, 'Arne,' 'Kulmyngton,' Handley, Melbury, Sedgehill (Wiltshire), Berwick (Wiltshire), Almer, Iwerne Minster and Kelston (Somerset). ${ }^{68}$ But if the revenues of the abbey were enormous, ${ }^{69}$ the charges on the house were by no means trifling, and the management of so vast an estate and the direction of so large a community called for powers of government and organization which it is more than probable every abbess did not possess. Whether the difficulties that arose were due mainly to the too frequent absence of these qualities or sprang from other causes the fact remains that from the fourteenth century, and even earlier, onwards, the house with every outward sign and manifestation of wealth and influence was continuously crippled by insufficient means and its existence chequered by the constant recurrence of debt and insolvency. As regards the charges on the house, the abbess was summoned by writ to furnish soldiers for the field in proportion to the number of her fees ${ }^{70}$ the summons to Parliament, to which by tenure she was entitled, was omitted on the ground of her sex. The convent, in common with the majority of houses under the royal patronage, was called on to provide maintenance for boarders at the king's presentation, ${ }^{71}$ and was expected on the occasion of the new creation of an abbess to furnish a pension for a clerk at the royal appointment. ${ }^{72}$ In addition the king claimed a right to present a nun on the occasion of the voidance of the abbey, ${ }^{73}$ and the episcopal registers record that the bishop of Salisbury, on his promotion to the see, had the right of placing an inmate in the house and of appointing one of the nuns to act as her instructor. ${ }^{74}$ Henry $V$, in the first year of his reign, presented Iodonia Wodehill to the convent in accordance with his prerogative to nominate a nun to the abbey on his coronation. ${ }^{75}$ Henry VI, in 1480 , recalling this ancient privilege, presented

${ }^{68}$ Ibid. $276-9$.

${ }^{69}$ The contrast between the wealth of Shaftesbury and that of all the other houses in the county is perhaps most vividly brought home to us when we read the list of grants made by the spirituality in 1527 towards the king's expenses in the recovery of the crown of France; Shaftesbury, like Glastonbury, contributed $\oint_{1}, 000$, double the contribution of the chapter of Salisbury and ten times the amount paid by Sherborne. L. and P. Hen. VIII, iii, 2483.

${ }_{70}$ Parl. Writs (Rec. Com.), ii, div. 3,1424 .

${ }^{11}$ Close, 4 Edw. II, m. 25 d.; 18 Edw. II, m. 5 d; 13 Edw. III, pt. 3 , m. $16 d$.

"Ibid. I 9 Edw. III, pt. 3, m. $14 d$.

7 Ibid. pt. 2, m. 17.

7 Sarum Epis. Reg. Mitford, fol. 139; Neville, fol. 51 d.; Blyth, fol. 40 .

${ }^{75}$ Rymer, Foed. ix, 11. 


\section{RELIGIOUS HOUSES}

Joan Archcombe, 'of good life and honest conversation ;" in like manner, ${ }^{70}$ Richard III in his first year issued letters of recommendation for Elizabeth Bryther to be the king's 'mynchyne' at Shaftesbury. ${ }^{77}$

One of the causes contributing to the troubles of the monastery was the excessive number of its inmates. The pope, whose attention in 1217 was directed to the abbey by an appeal made to him in connexion with a disputed election, ${ }^{78}$ in 12 I 8 forbad the community to admit nuns beyond the number of a hundred, on the ground that they were unable to support more or to give alms to the poor. ${ }^{79}$ Evidently the decree was not observed, for in 1322 the bishop of Salisbury, after a recent visitation of the house, wrote to the abbess and convent pointing out that they had neglected the order of the Holy Father, that the inmates of the house were far too many for its goods to support, and forbidding them to admit more until the state of the abbey had been relieved. ${ }^{80}$ Four years later, in response to a petition from the abbess asking him to fix a statutory number, the bishop issued an order stating that the house was capable of maintaining 120 nuns and no more, and until the community had been reduced to that number the abbess and convent should not receive any more inmates. ${ }^{81}$ It is evident that this number became considerably reduced a century later. The voting body at the election of Edith Bonham in I44 I consisted of forty-one professed sisters and fourteen awaiting profession (tacite professae) ${ }^{82}$ the total number at the election of Margaret St. John in 1460 was fifty-one; ${ }^{83}$ at the election of Margaret Twyneo in 1496 twenty-five professed sisters and eleven not yet professed are mentioned; ${ }^{84}$ at the election of Elizabeth Shelford, I 504, twenty-eight professed and twenty-two tacitly professed voted. ${ }^{83}$ The surrender deed of the abbey on its dissolution gives the names of fiftyfive sisters besides the abbess and prioress. ${ }^{80}$

The usual expedients were adopted in order to relieve the financial difficulties of the abbey. The sisters, after a petition setting forth the charges

${ }^{36}$ Rymer, Foed. x, 438.

${ }^{77}$ Harl. MS. 433, fol. $22 d$.

${ }^{8}$ Three judges were appointed by the pope to examine the case of A., nun of St. Edward's, who, as she declared, having been elected abbess was forced by her electors to renounce the right of her election. The case having been tried, however, the pope, on the petition of J., abbess of Shaftesbury, ordered the bishop of Salisbury, the prior of Amesbury, and the chancellor of Salisbury to impose silence on the said A., sacristan of the place, whose claim was found to be void. Cal. Pap. Letters, i, 49, 61.

${ }^{79}$ Ibid. $5 \mathrm{I}$.

Sarum Epis. Reg. Mortival, fol. 140.

${ }^{81}$ Ibid. pt. 2, fol. 23 I. ${ }_{82}$ Ibid. Aiscough, fol. ro.

${ }^{83}$ Ibid. Beauchamp, i, fol. 34.

${ }^{84}$ Ibid. Blyth, fol. 95.

se L. and P. Hen. VIII, xiv (1), 586 . incumbent on them for the maintenance of the statutory number of 120 nuns and the exercise of hospitality, as well as the losses they had incurred through the inundation of their lands, obtained a bull from the pope in 1343 apprcpriating to their use the church of Bradford of their advowson. ${ }^{87}$ Edward III in 1365 , by a charter reciting the reduction of the house by tempestuous winds, pestilences, and other adversities, so that its means barely sufficed to support the community or to meet the charges incumbent on them, granted to the prioress and nuns the custody of the temporalities of the abbey on the occasion of its next voidance by the death of Abbess Joan Formage. ${ }^{88}$ In 1380 the sisters were allowed, in consideration of the damage to their lands by encroachments of the sea and losses of sheep and cattle, to appropriate to themselves the church of Tisbury, the advowson of which already belonged to them. ${ }^{89}$ About the same time Bishop Erghum made an ordination assigning a weekly allowance of $2 d$. to each nun from the issues of the house with the object of reducing as far as possible the expenditure ot the community. ${ }^{30}$ The convent in 1382 petitioned Richard II that, whereas they could not hold out another year against their indebtedness unless some remedy were provided, the king would on all future occasions of a voidance in the abbey allow the community to retain the temporalities in their own hands (saving to the king knights' fees and advowsons), rendering an account of the same to the Exchequer for a year or any part of a year. ${ }^{91}$ Bishop Aiscough in the fifteenth century sanctioned the appropriation of the church of Gillingham to the abbey, which, through pestilence, failure of crops, want of labourers ' and their excessive demands,' was said to be much reduced. ${ }^{92}$

To focuss the various references to Shaftesbury in the episcopal registers so as to gain some idea of the state of the monastery, apart from its financial condition and worldly standing, is a task of extreme difficulty. Incidents that illustrate the inevitable defects and shortcomings of a house are calculated to mislead in many instances, and doubly so if accepted as representing the normal state of affairs in connexion with a community of the size and importance

${ }^{37}$ Cal. Pap. Letters, iii, 137 . This grant was confirmed by the bishop, and received the royal sanction; Sarum Epis. Reg. Wyville, i, fol. 132 d.; Pat. 23 Edw. III, pt. 1, m. 17 .

${ }^{8}$ Harl. MS. 6i, fol. 1 6 . A grant of the custody during voidance was first obtained by the nuns from Edward $I$ in 1285 , on payment of a fine of 6100 (Close, 13 Edw. I, m. 3; 14 Edw. I, m. 8). It became the usual custom, but a confirmation of the grant was generally obtained on every separate occasion.

${ }^{89}$ Pat. 3 Ric. II, pt. 3, m. 14 ; Sarum Epis. Reg.

Erghum, fol. 41.

${ }^{91}$ Parl. R. (Rec. Com.), iii, ז 29.

${ }^{22}$ Sarum Epis. Reg. Aiscough, fol. 60. 


\section{A HISTORY OF DORSET}

of the abbey of St. Edward.93 The house was visited from time to time by the bishop of Salisbury or his commissary; he received the profession of canonical obedience from the abbess, and bestowed the benediction on her election. The episcopal registers record the appointment by him of confessors to the abbey and the reception of the profession of the nuns. An order was sent in 1298 to Robert, rector of the church of Donington, desiring him to enforce suitable penance to the abbess and nuns of Shaftesbury, who, 'for their offences against God and by the creation of scandal,' had incurred sentence of excommunication. ${ }^{94}$ A copy of the edict of Pope Boniface for the stricter inclosure of nuns was forwarded to the sisters at the beginning of the fourteenth century by Simon of Ghent, who announced that by the 'new constitution' he was bound to visit yearly the nuns subject to his authority. ${ }^{95}$ The abbess, after a visitation in 1309, was strictly admonished not to allow the sisters to go out into the town of Shaftesbury save under special conditions, "lest scandal enter in and not without negligence on your part.' 96 Further, one of the nuns, Christina Baryl, was ordered to be confined within the cloister of the monastery until notice had been sent by the bishop. ${ }^{97}$ The archdeacon of Dorset and William of Braybrook, canon of Salisbury, were ordered in 1 316 to adjudicate in a dispute which had arisen in the monastery between the abbess and certain of the nuns. ${ }^{98}$ Joan Formage, who was elected abbess in 1362 , received a dispensation from the bishop in I 368 to leave the abbey for a year and reside in her manors for the sake of air and recreation..$^{99}$ On her death in August, 1394, the bishop ordered the abbey to be sequestrated, and annulled a will by which she had alienated the goods of the house in bequests to friends, declaring such a disposition to be injurious to the community and contrary to the usage of religious women. ${ }^{100}$ A good deal of disturbance and a species of interregnum ensued before the appointment of a successor, in spite of the consideration of Richard II, who granted a licence to elect inmediately on the voidance of the abbey, ${ }^{101}$ and, 'in pity for the poverty of the house,'

${ }_{93}$ The register of Mifford contains a letter from the pope to the bishop desiring him to restore Alice Wilton, nun of Shaftesbury, to the position in the abbey which she had forfeited by the most grievous lapse of which a religious could be convicted, the sin of incontinence. The bishop, in accordance with the order, reinstated the nun, who had proved her penitence for the offence, and declared her eligible for all offices in the monastery save that of abbess; Sarum Epis. Reg. Mitford, fol. 122.

"Ibid. Simon of Ghent, i, fol. $5 d$.

${ }_{95}$ Ibid. fol. $33 . \quad{ }_{96}$ Ibid. fol. 127.

${ }^{97}$ Ibid. ${ }^{98}$ Ibid. Mortival, ii, fol. $47 \mathrm{~d}$.

${ }^{99}$ Ibid. Wrville, ii, fol. 230.

100 Ibid. Waltham, fol. 24 .

${ }^{101}$ Pat. I 8 Ric. II, pt. 1 , m. $t o$. directed the bishop to signify the royal assent without delay to the choice of the communityr. ${ }^{102}$ In November of the same year Richard Pittes, canon of Salisbury, John Gowayn, and Thomas Bonham were appointed to examine and take charge of the abbey, to inform themselves as to its condition, the withdrawal and waste of its goods, as well as to make allowances for the maintenance of the nuns and their household, holding the remainder of the revenues in charge until further orders. According to the letters patent of this commission the king had been forced to abrogate the grant made by himself and his predecessors to the prioress and convent of the temporalities of the abbey during voidance, as by fraudulent means an election had been obtained of an unfit person, who, with the object of securing confirmation of her appointment, had repaired with an excessive number of men to places remote, to the waste and destruction of the possessions of the community. ${ }^{103}$ Richard II, after an interval of more than six months had elapsed since the death of abbess Joan Formage, wrote to the bishop, April, I 395, desiring him to provide a fit person to the abbey, which by this time had lapsed to his collation. ${ }^{104}$ The choice fell on Egelina de Counteville; the pope, at the king's special request, confirmed her election as abbess, 'although Lucy Fitzherberde has the greater number of votes,' 105 and so the matter ended. Bishop Hallam in 1410 , on a report that the nuns were given to frequenting places outside the monastery, addressed a letter of admonition to the abbess and convent, bidding them consider the punishment that overtook Dinah the daughter of Jacob for yielding to the desire to go abroad. ${ }^{106}$ In the same year the bishop issued an indulgence for those who should visit the monastery on the principal feasts of St. Edward, King and Martyr, from the time of the first to the second vespers. ${ }^{107}$ In 1412 letters of indulgence were published for those visiting the shrine of St. Edward on the feast of his translation, 20 June. ${ }^{108}$ There are no visitation reports of Shaftesbury during the fifteenth century, and few references during the remainder of its existence save those recording the election of superiors and the admission of the profession of nuns. ${ }^{109}$

The last abbess of Shaftesbury, Elizabeth Zouche, hoped doubtless by a conciliatory attitude to secure from the court party some measure of consideration for her house. Sir Thomas

$$
\begin{aligned}
& { }^{102} \text { Ibid. In. } 5 \text {. } \\
& { }^{100} \text { Ibid. I } 8 \text { Ric. II, pt. 2, m. I5. } \\
& { }^{105} \text { Cal. of Pap. Letters, iv, } 524 \text {. Lucy Fitzherberde } \\
& \text { was probably the "unfit person' elected on the first } \\
& \text { occasion. }{ }^{106} \text { Sarum Epis. Reg. Hallam, fol. } 29 . \\
& { }^{107} \text { Ibid. } \\
& { }^{109} \text { In } 1442 \text { the profession was received by the }
\end{aligned}
$$
bishop of fifteen of the nuns, and in 1453 of fourteen ; ibid. Aiscough, fol. 97 ; Beauchamp, i (2), fol. 150. 


\section{RELIGIOUS HOUSES}

Arundel, in a letter to the "visitor-general of monasteries,' in 1536 , states that by the advice of the writer the abbess and convent have given him (Cromwell) the next presentation to the parsonage of Tarrant, for which he had expressed a desire, adding, 'my lady is right glad to do you pleasure.' 120 'The transfer to Shaftesbury in the same year of the prioress and nuns of the small Benedictine priory of Cannington (Somerset), dissolved by the earlier Act of suppression, ${ }^{111}$ may have encouraged the poor lady to continue her efforts, and nerved her to bold out longer than was the general disposition in this county. At any rate, Sir Thomas Arundel, writing again to Cromwell in December, $153^{8}$, informs him that, contrary to advice, the abbess of Shaftesbury refuses to follow the 'moo' (majority), and resign, and offers the king 500 marks and Cromwell $£$ I 00 for her house to be allowed to stand.12 The offer was fruitless; the fate of Shaftesbury was sealed, though the house, owing perhaps to the abbess's spirited endeavour, was the last to fall in this county. With the surrender of Elizabeth Zouche and her fifty-six nuns on 2 March, I 539, ${ }^{113}$ ends the long line of abbesses headed in the ninth century by Alfred's daughter.

\section{ABBESSES OF SHAFTESBURY}

Elfgiva or Ethelgeofu or Algiva, first abbess about $888^{114}$

Elfthrith, occurs $94^{215}$

Herleva, occurs $966,,^{116}$ died $982^{117}$

Alfrida, occurs IOOI or $1009^{118}$

Leueua, occurs temp. Edward the Confessor ${ }^{119}$

Eulalia, appointed $1077^{120}$

Eustachia 121

Cecilia, appointed I $\mathrm{O} 7^{122}$

limma, occurs temp. Henry $\mathrm{I}^{123}$

Mary, occurs I I $89^{124}$

J., elected I 2 I $6^{125}$

Amicia Russell, elected $1223^{126}$

${ }^{110}$ L. and P. Hen. VIII, xi, 1340.

111 Ibid. 1450.

${ }^{113}$ Ibid. xiv (1), 586. To Elizabeth Zouche was assigned on her surrender a pension of $\mathcal{L}^{1} 33$ 6s. $8 d$.; the prioress received a pension of $\mathscr{£} 20$, the subprioress $\mathcal{L}_{7}$, and the remainder of the sisters yearly sums ranging from $f 613$ s. $4 d$. to 56 s. $8 d$.; ibid.

1i. Will. of Malmes. Gesta Regum (Rolls Ser.), i, $13 \mathrm{I}$; Flor. Wigorn. Chron. (Engl. Hist. Soc), i, Io4.

115 She is mentioned in a charter of King Ædred,

Harl. MS. 6I, fol. 4 .

${ }^{116}$ Gale, Rerum Angl. Script. i, 45.

117 Angl.Sax. Chron. (Rolls Ser.), i, 103.

${ }^{118}$ Hutchins, Hist. of Dorset, iii, 27.

113 Dugdale (Mon. ii, 473), from Exon. Domesday.

${ }_{120}$ Ann. Mon. (Rolls Ser.), ii, 30.

121 Dugdale, Mon. ii, 473 .

${ }^{122}$ The third daughter of Robert Fitz Hamon, who e'evated Tewkesbury to the dignity of an abbey. Ibid. ii, 473 .

$1: 4$ Ibid. fol. 26. ${ }^{123}$ Harl. MS. 61, fol. 23.

${ }^{126}$ Ibid. 7 Hen. III, m. 3.
Agnes Lungespee, elected $1243^{127}$ Agnes de Ferrers, elected $1247^{128}$

Juliana de Bauceyn, died I $279^{129}$

Laurentia de Muscegros, elected $1279,{ }^{130}$ died 1290

Joan de Bridport, elected $1290,{ }^{131}$ died 129 I

Mabel Gifford, elected I 29 I ${ }^{132}$

Alice de Lavyngton, elected I $302,{ }^{133}$ died I 3 I 5

Margaret Aucher, elected $1315,^{134}$ died 1329

Dionisia le Blunde, elected I $329,{ }^{135}$ died I 345

Joan Duket, elected I $345,{ }^{130}$ died I 350

Margaret de Leukenore, elected $1350^{137}$

Joan Formage, elected 1362, ${ }^{138}$ died 1394

Egelina de Counteville, appointed $1395^{139}$

Cecilia Fovent, occurs I 398, ${ }^{140}$ died 1423

Margaret Stourton, elected $1423,{ }^{161}$ died I 44 I

Edith Bonham, elected I 441, ${ }^{142}$ died I 460

Margaret St. John, elected $1460^{143}$

Alice Gibbes, died I $496^{144}$

Margaret 'Twyneo, elected I 496, ${ }^{145}$ died 1505

Elizabeth Shelford, elected $1505,{ }^{145}$ died 1528

Elizabeth Zouche or Zuche, elected I 529 , surrendered her abbey, $1539^{147}$

The round thirteenth-century seal attached to the surrender deed of the abbey gives on the obverse an elaborate design of the church. In the doorway St. Edward, King and Martyr, fulllength, with the name s' EDw-ARDvs upon the string-courses at the sides. ${ }^{148}$ Legend :-

SA[LUE :] STELLA : MARIS : TU : NOBIS :

AVX [ILIARIS :] [GEMMA :] PVELLARIS : REGIA : DONA : PARIS

The reverse shows within a carved quatrefoil the Coronation of the Virgin. Overhead the Dove; at the sides two candlesticks, crescents, and other emblems. In base, under a trefoiled arch, an abbess, half-length, holding a pastoral staff, is in prayer. ${ }^{149}$ Legend :-

采 SIGILL' : sĈE : MARIE : ET : sc̄ı : EDWARDI : [RE]GIS : ET : MARTIRIS : SCHEF[TONIE]

${ }^{127}$ Ibid. 27 Hen. III, m. 2.

${ }^{128}$ Ibid. 3 I Hen. III, m. 8.

199 Ibid. 7 Edw. I, m. 21.

${ }^{130}$ Ibid. m. 16.

${ }^{131}$ Ibid. 18 Edw. I, m. 34

${ }^{132}$ Ibid. 19 Edw. I, m. 3.

${ }^{133}$ Sarum Epis. Reg. Simon of Ghent.

134 Pat. 9 Edw. 1I, pt. 1, m. 14.

${ }^{135}$ Ibid. 3 Edw. III, pt. I, M. I 3.

${ }^{136}$ Ibid. $19 \mathrm{Edw}$. III, pt. 2, m. 13.

${ }^{137}$ Ibid. 24 Edw. 1II, pt. 2, m. 21.

${ }^{138}$ Hutchins, Hist. of Dorset, iii, 27.

${ }_{139}$ Pat. 18 Ric. II, pt. I, m. 10.

${ }^{140}$ Sarum Epis. Reg. Mitford, fol. 105.

141 Pat. 2 Hen. VI, pt. 1, m. 22.

112 Sarum Epis. Reg. Aiscough, fol. 10.

${ }^{143}$ Ibid. Beauchamp, i, fol. 37.

${ }^{14}$ Ibid. Blyth, fol. 95.

14i Ibid. Audley, fol. I $26 d$.

${ }^{14}$ L. and P. Hen. Fll1, iv, 5290 ; xiv (1), 586.

148 Deeds of Surrender, No. 211. See also B.M. Seals, lxii, 49 . 


\section{A HISTORY OF DORSET}

\section{HOUSE OF CLUNIAC MONKS}

\section{THE PRIORY OF HOLNE OR EAST HOLME}

The priory of Holme, or Holne as it was anciently called, a cell of the Cluniac priory of Montacute in Somerset, was founded towards the middle of the twelfth century ${ }^{\mathbf{I}}$ by Robert de Lincoln, the son of Alured de Lincoln. The founder, in his charter for the endowment of the new establishment, recites that ' moved by divine instinct to build a house of religion in honour of God' he has given to God and the church of St. Peter of Montacute and the monks serving God there his land which is called Holne, ${ }^{2}$ in perpetual alms for the maintenance of thirteen monks, the gift being made with the concurrence of Bcuza his wife and Alured his son, by the counsel and consent of the bishop of Salisbury, in the presence of the prior and monks of Montacute, and of Gilbert the monk, 'to whom I afterwards personally gave the place,' for the souls of King Henry, of the donor's father and mother, of himself, his wife, and children, relations, and friends. The original endowment also consisted of three virgates of land at Weston Worth (IV rda) in Purbeck, a tithe of the bread, meat, and fish provided for the use of his household (de dispensa dontus mee) and that of his heirs, a salt-pan of the salt works adjacent to his manor of Langton, with tithes of his demesne at Okeford Fitzpaine, at Winterborne Whitchurch, Langton near Abbotsbury, and Corton in Portisham, besides tithes of the demesne at Cheselbourne and Watercombe, the gift of Bardolph 'my knight.' 3 Alured, the founder's son, added to the gifts of his father and confirmed all former grants, stating that they were bestowed in free

'It cannot be later than the twelfth year of Henry II, as in that year Alured, the son of the founder, was in possession of the paternal estate.

'In a charter of Henry I, the king testifies to Roger bishop of Salisbury and Warin the sheriff that he has granted a licence to Alured de Lincoln to hold the land of Holme, which he has obtained by purchase of 'Grimaldus medicus' in fee. See early account of Holme Priory by Thomas Bond (Hutchins, Hist. of Dorset, i) inserted between pp. $552-3$. This Alured has sometimes been identified with the Alured de Lincoln who held estates in Lincolnshire at the time of the Domesday Survey, and in all probability they came of the same family. The Dorset branch is subsequently found in possession of nearly the whole estate held in this county at the time of the Survey by the widow of Hugh Fitz Grip (Dom. Bk. [Rec. Com.], $\mathrm{i},{ }^{3} 3^{b}$ ), which they probably obtained by marriage; Hutchins, Hist. of Dorset, i, 552-3.

Ibid. alms, quit of all suit and service save of celebrating divine offices for the soul of the founder, of his ancestors and successors, and of all the faithful departed. ${ }^{4}$

An inquisition, held in June, $128 \mathrm{I}$, as to the lands and tenements of the prior of Montacute in the isle of Purbeck reported that these were extended to the value of $f_{1} 166 s .2 d$, and included, besides the advowson of the church of Holme, valued at 60s., a garden and curtilage with 34 acres of arable land, 40 acres of meadow, a turbary, fish-pond, fixed rents (reddit' assis') of the villeins, their works, pleas, perquisites, fines of land and heriots within the manor of Holme. ${ }^{5}$ The Taxatio of I 29 I gives the priory an income only of $£ .5$ I os. $8 d$., the spiritualities, amounting to $f_{0}{ }^{2}{ }^{1} 3$ s. $8 d$., derived from pensions from the following churches:- Puddletown, ${ }^{6}$ Warmwell, ${ }^{7}$ Corton, Langton Herring, and Powerstock; ${ }^{8}$ the temporalities were valued at $£_{2}$ I 75 ., of which $\ell^{2}$ is. $8 d$. came from Weston Worth in Purbeck. ${ }^{9}$

As a cell subordinate to an alien house, Holme was constantly in the hands of the crown during the Hundred Years' War. On 8 October, $13^{2} 4$, the farm of the lands of the prior of Montacute in Holme and Plush was committed by Edward II to Walter Beril and Roger de Blokkesworthe until the superior had found sufficient security to satisfy the king, after which they were ordered to amove their hand. ${ }^{10}$ Edward III, shortly after his accession, made a general restoration to the abbot of Cluny of all his lands and possessions in England, "but they were subsequently re-seized, and in 1337 the prior of Holme was ordered to pay a fine of six marks and 40 . for the custody of his priory. ${ }^{12}$ In 1339

- The charter of the founder and his son are given by Thomas Bond in his early account of the priory. Ibid. $i, 552-3$. Among other grants, Alured, son of the founder, conferred on the monks land at Plush, with the right of pasturing ten oxen, one heifer, and 250 sheep there with the cattle of the abbot of Glastonbury.

'Inq. p.m. 6 Edw. I, No. 47.

'Pope Nich. Tax. (Rec. Com.), 179.

'Ibid. 1796. The charter of Alured, the founder's son, records the grant of the church of Warmwell to the monks by 'Gunfridus my man.'

Ibid. 180,1826 .

- Ib:d. 1836 .

${ }^{10}$ Mins. Acts. bdle. 1125 , No. 7 .

"Rymer, Focdera, iv, 246-7.

${ }^{18}$ Close, if Edw. III, pt. 2, m. 36. The prior, in 1332 , was requisitioned for a contribution towards the expenses incurred by the king for the marriage of his sister ; ibid. 6 Edw. III, m. $16 \%$ 


\section{RELIGIOUS HOUSES}

Edward III granted to William de Montacute, earl of Salisbury and his heirs the advowson of the priory of Montacute, with the custody whenever it should be seized into the king's hand by reason of the war with France, and at the earl's petition the following year he added on similar terms the advowson and custody of Carswell, Holme, St. Carric, and Malpas, cells pertaining to the said priory 'from the time of which memory does not exist.' ${ }^{13}$ One of the earliest acts of Henry IV on his accession was to restore, among others, the alien priory of Montacute with its subject cells, remitting the farm lately paid to the king and his heirs or, by virtue of a former grant, to the earl of Salisbury and his heirs, and reserving only the payment of the ancient 'apport,' paid in time of peace to the head house. The prior in 1407 , by the payment of a sum of 300 marks, obtained a charter of denization for his house, which made the priory, with all its possessions, advowsons, \&c., indigenous of England, and provided that its superior should be elected by the convent without collation or institution of the abbot of Cluny. ${ }^{14}$ Holme continued up to the Dissolution as a dependent cell with a prior 'dative and removable' by the head house. ${ }^{15}$

Though ordained by the founder for the maintenance of thirteen monks, there appears from early times to have been a considerable decline from the original design. The inquisition held in $128 \mathbf{1}$ declared that the prior of Montacute held the church and manor of Holme subject to the charge of finding four monks to sing for the soul of Alured de Lincoln, his progenitors and successors. ${ }^{16}$ Two years previous to that the priors of Mont Didier in France and Lenton in England, appointed by the abbot of Cluny, in 1279, to visit English houses of the order, found here two monks and a prior, ${ }^{17}$ while a fifteenth-century description, probably drawn up from visitation reports of 1298,1390 , and I 405, stated that the community consisted of a prior and two monks. ${ }^{18}$ Leland, in the sixteenth century, said that the four cells belonging to Montacute had only two monks each. ${ }^{19}$

${ }^{13}$ Pat. 14 Edw. III, pt. 1, m. 7. Notwithstanding this grant the prior of Holme was summoned before the council at Westminster with other aliens to answer for his charge in 1341 and 1347 . (Close, 15 Edw. III, pt. 3, m. 6; 21 Edw. III, pt. 1, m. 6 d.) On the conclusion of a peace in 1361 Edward III restored their possessions to Montacute and nine other alien priories. Rymer, Foedera, vi, 3 I I.

14 See inspeximus charters of Henry IV to the priory of Montacute. Pat. I2 Hen. IV, m. 37.

is Valor Eccl. (Rec. Com.), i, 196.

${ }^{16}$ Inq. p.m. 9 Edw. I, No. 47.

${ }^{17}$ Duckett, Chart. and Rec. of Cluny, ii, 136.

18 Ibid. 213.

13 Collect. i, 81.
With regard to the internal condition and management of the house, the visitors appointed in 1279 reported that the inmates lived well and commendably according to the rule, fulfilling their religious duties as far as the exigencies of the place permitted and the limited number of the community. ${ }^{20}$ The prior, who had been in office for three years, had taken over the house burdened with a debt of twenty marks, which he had managed to pay off, and it was now free of debt. ${ }^{21}$ The buildings and church were in good repair, and there was a sufficient store to last till the following harvest. The Cluniac order being exempt from episcopal jurisdiction and visitation by the ordinary the Salisbury registers throw no light on the history of the house, but various references are made to it in other records. In January, I 33 I, a commission of oyer and terminer was issued on the complaint of the abbot of Bindon against John de Montacute, sometime abbot of Bindon, who, both before and after his deposition, proved such a source of trouble to his house; in his quarrel with his own community he seems to have enlisted the active support of the then prior of Holme, Walter de Welham, at all events the two, with others, were accused of breaking into the abbey by night, driving away cattle, and carrying off books, vessels, and ornaments of the church, together with the conventual seal, which they further proceeded to append to various documents to the prejudice of the community. ${ }^{22}$ In 1348 a certain Ralph de Midelneye was charged with having acquired from the same prior, Walter de Welham, then deceased, certain premises in Winterborne Wast, Bockhampton, and Swanage, and having entered on the same without obtaining a licence of the king. ${ }^{23}$ Edward III, in 1344 , directed the mayor and bailiffs of Dover to permit Gerard de Noiale, prior of Holme, to cross the Channel in order to visit the Roman court 'for the correction of his soul.'24

The Valor of I 535 states that John Wales was then prior of this cell, valued at EI6 95. $4 d .{ }^{25}$ and on the surrender of Montacute Priory, 20 March, 1539, the same John was appointed to serve the cure of Holme with a stipend of $£ 8$; in the event of his being ' $\mathrm{im}$ potente and lame' and past work he should receive a pension of $£ .5135 .4 d^{26}{ }^{26}$ The house and site of the dissolved cell were granted by Henry VIII to Richard Hamper for a term of

\footnotetext{
${ }^{20}$ Duckett, Ghart. and Rec. of Cluny, ii, 136.

${ }^{21}$ Ibid.

${ }^{22}$ Pat. 4 Edw. III, pt. 2, m. 7 d. ; see below, Bindon, 1.. 84 .

${ }^{23}$ Pat. 22 Edw. III, pt. 2, m. 40 d.

"Close, $18 \mathrm{Edw}$. III, pt. 1, m. I 3 \%.

${ }^{35}$ Valor Eccl. (Rec. Com.), i, 196.

${ }^{26} L$. and P. Hen. VIII, xiv (1), 575.
} 


\section{A HISTORY OF DORSET}

twenty-one years; Edward VI, in the first year of his reign, bestowed the reversion of the property on the duke of Somerset and his heirs. By the attainder of the duke the estate reverted again to the crown, by whom it was granted to John Hannam of Wimborne Minster, in whose family it remained till the reign of Villiam and Mary, when it came into the Bond family. ${ }^{27}$

\section{PrIORS OF Holme ${ }^{23}$}

Hada, occurs $1217-18^{29}$

Geoffrey, occurs $1262^{30}$

Walter de Welham, occurs $1330^{31}$

Gerard de Noiale, occurs $1344^{32}$

William Pope, occurs I $444^{33}$

John Wales, or Wallis, occurs 1535 and $1539^{34}$

\section{HOUSE OF CISTERCIAN MONKS}

\section{THE ABBEY OF BINDON ${ }^{1}$}

A Cistercian abbey was built here in $1172^{2}$ by Roger de Newburgh and Maud his wife, who transferred to Great Bindon the earlier monastery which IVilliam de Glastonia and Maud his wife had begun to build at a spot now identified with Little Bindon. King John, by his charter, confirmed to the monks the site of the abbey, 2 acres of land the gift of IVilliam de Glastonia, 2 virgates in Lulworth, the manor of 'Borton,' the land of Nottington, the land of Wood Street with the meadows adjoining, and half a hide of land with pasture for 300 sheep in the manor of Chaldon (Herring) the gift of Thomas Harang. ${ }^{3}$ The founder himself bestowed on the abbey his manor of Woolaston (Northants) with all its appurtenances, to be held by the monks in free alms quit of all secular suits and exaction. ${ }^{4}$

A charter of Henry III, dated 4 April, 1234 , confirmed to the church of St. Mary of Bindon and the monks serving God there the site of their abbey, the gift of Roger de Newburgh and Maud his wife, together with the place in which the first monastery had been commenced, the gift of William de Glastonia, the manor of Bexington, given by Maud de Arundel by leave of King Henry, ${ }^{6}$ the land of Nottington and Luca, purchased by Gilbert de Percy from the monks of Ford and bestowed on Bindon, the land of Hethfelton according to the agreement between the monks and Simon de Eneford, the land of IVood Street which the abbey and convent held of IVilliam de

${ }^{37}$ Hutchins, Hist. of Dorsct, i, 552.

${ }^{8}$ Hutchins, in his account of the priory, gives the names of three; Hist. of Dorst, i, 553 .

${ }^{3} \mathrm{Hada}$, prior of Holme, is mentioned in a fine respecting the church of Warmwell, 2 Henry III. Ibid. $i,+34$, note.

${ }_{s 0}$ Duckett, Chart. and Rec. of Chrny, ii, 123.

${ }^{31}$ Pat. 22 Edw. III, pt. 2 , m. 40.

${ }^{33}$ Close, 18 Edw. III, pt. 1, m. 13.

${ }^{33}$ Hutchins, Hist. of Dorset, $i, 553$

34 Valor Eccl. (Rec. Com.), i, 196; L. and P. Her. VIII, xiv (8), 575 .

'A ground plan of the abbey, which was visited by the British Archaeological Association, 26 August, is 7 , , may be seen in their fourn. xxviii, 392 .

'Cott. MS. 'Chron. S. Werburgae Cest.' Faust. B. viii, 4 ; Hutchins, Dorset, i, 349 .
Wodestert as his charter testifies, and half a hide of land with pasturage for 300 sheep as confirmed by the charter of Thomas Harang. ${ }^{7}$ By another charter in June of the same year, the king further confirmed to the abbey the rood of Stotwode, part of Hamsted wood with common pasture, the whole land of Pulham, 150 acres of waste, the mill of Lulworth with the land pertaining to it and the moltura of the men of Lulworth given by Robert de Newburgh, with certain houses in Dorchester and all the arable land which the monks held under the walls of Dorchester, the gift of William Lock of Dorchester. $^{8}$

A charter of Edward II inspecting all previous grants confirmed to the abbot and convent lands and rents in Lulworth, Bexington, Nottington, Hethfelton, Chaldon, Winfrith Newburgh, mills at Fordington, Cranborne, and outside Dorchester, the churches of Chaldon Herring and Fossil, and the right to hold a market and fair at Wool, with the right of free warren in all their demesne lands at Stockford, Wood Street, Wool, Bovington, Lulworth, Bindon, and Hethfelton. ${ }^{9}$

In the Taxatio of 129 I the spiritualities of the abbey are not given; the temporalities amount to EIO7 6s., of which gr $^{4}$ s. was reckoned from possessions in the deanery of Dorchester, ${ }^{10}$ f 12 2s. from the manor of Bexington in the Bridport deanery," and $£ 4$ from Pulham and IVinterborne Monkton in the deanery of Whitchurch. $^{13}$

${ }^{3}$ Harl. MIS. 6748, fol. 7.

4 Ibid.

${ }^{5}$ Bindon, like all Cistercian houses, was dedicated to the honour of the B. V. Mary. Dugdale cites a charter of the reign of Henry III wherein it is styled St. Salvator of Bindon, Mon. v, 556 .

' Coker, citing 'an olde manuscript,' states 'that Maud,' countess of Sarum, afterwards the wife of William de Newburgh, "was so great a benefactour to this abbie that she was reckoned a foundress.' Partic. Surv. of Dorset, 76 ; Leland, Coll. i, 82 .

${ }^{7}$ By inspex. of Edward I. Chart. R. 9 Edw. I, No. 9o, m. 13 ; see Cart. Antiq. Q. 18.

${ }^{8}$ Chart. R. 9 Edw. I, m. 13 .

${ }^{9}$ Ibid. 6 Edw. II, Nos. $12-15$.

${ }^{10}$ Pope Nich. Tax. (Rec. Com.), I 836,184 .

"Ibid. 183 .

12 Ibid. 184. 


\section{RELIGIOUS HOUSES}

The house from the outset received much attention and kindness from the Plantagenets. The abbot occurs frequently in the records of John's reign, and from various entries in the Liberate and Misae Rolls appears to have been employed by the king in affairs of a confidential

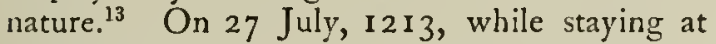
the abbey, John issued letters allowing the inonks thirty cart-loads of lead for the purpose of roofing their monastery, together with fifty oak logs. ${ }^{14}$ During the year 1215 the king's treasure was dispersed about in the custody of various monasteries, preference apparently being shown for those of the Cistercians and Premonstratensians; an order issued on 24 June of that year directed that it should be delivered up to the king, and an entry under date of 3 July in the patent rolls records that on the feast of St. Peter and St. Paul (29 June) John, while at Marlborough, received at the hands of Robert the precentor a staff (baculum) set with nineteen sapphires, and another set with ten, which had been deposited in Bindon Abbey. ${ }^{15}$

Henry III also showed favour to the community, to whom, in 1229 and 1247 , he granted letters of protection. ${ }^{16}$ In 1235 they received by gift of the king an order allowing them fifty oak logs to rebuild their churcl.$^{17}$ In 1272 Henry de Newburgh, who at that time held the advowson, granted the monks leave to elect whom they would to be their patron, and in view of past favours it is not surprising that the choice of the brethren fell on the king and Qucen Eleanor. Henry and his consort accepted their election, the former, by his charter, signifying that he had taken the abbey, of which he and his heirs were now the patrons, into his protection and defence. ${ }^{18}$ Early in the reign of Edward I Queen Eleanor granted to the church of St. Mary of Bindon and the monks serving God there, for the soul of her late husband and his ancestors, 'our' children, ancestors and successors, all lands and tenements in Wool which she held by gift of Thomas de Wool, son and heir of William de Wool, to be held by them in free alıns. ${ }^{19}$

The abbot and monks bore their share in all charges and contributions incidental to the tenure of ecclesiastical landowners. In May, 1278 , they contributed to the 'courtesy' of f 1,000 raised for the king by the whole order

${ }^{13}$ Rot. de Liberate (Rec. Com.), $128,144,146$.

"Close, 15 John, m. 7, 8.

${ }_{15}$ Pat. 17 John, m. 21.

${ }^{16}$ Pat. 13 Hen. III, m. 3 ; 31 Hen. III, m. 6.

${ }^{17}$ Close, 19 Hen. III, m. 12

${ }^{18}$ By inspex. Pat. 7 Edw. I, pt. 1, m. 1.

${ }_{19}$ Pat. 4 Edw. I, m. 32 ; Edward I in 1275 granted letters of simple protection to the abbot to Iast two ycars (ibid. 3 Edw. I, m. 32) ; and a few years later confirmed his mother's gift of Wool to the abbey (ibid. $9 \mathrm{Edw} . \mathrm{I}, \mathrm{m}, \mathrm{I} 3)$. in England, ${ }^{20}$ and in 1294 the abbot received protection for a year in favour of his person and goods in consideration of the fact that with the rest of 'exempt' abbots he had granted a moiety of his benefices and goods towards the Holy Land. ${ }^{21}$ In the reign of Edward II the house was twice called on to assist in the Scotch war. ${ }^{22}$ In December, 1309 , John Dassh was sent in place of William Brid to lodge in the abbey and receive the necessaries of life, ${ }^{23}$ and in May, 1335 , in the midst of financial and other embarrassments, the community was requested by the king to allow Hugh Prest such maintenance in their house as their earlier boarder William Brid had had. ${ }^{24}$ In return for these accommodations the abbot received frequent grants of protection and was permitted freely to visit the parent house at Cîteaux and to attend the general chapter of his order. ${ }^{25}$

It is to be regretted that however favourable the circumstances of the house under the earlier Plantagenets, frequent references to the community in the fourteenth century range themselves for the most part under the head of debt and disorder, internal dissension among themselves, and open strife with their neighbours, making up a sufficiently sordid story. The first mention of financial insecurity occurs in the year 1275, when Edward I appointed Henry de Monte Forte custodian during pleasure of the abbey, which had fallen into debt. ${ }^{26}$ Passing over a small incident in 1283 of a common enough nature in those days, ${ }^{27}$ the first breach with the neighbourhood occurred in J296, when a charge was brought against the abbot of causing the death of brother Nicholas de Wyther of

${ }^{20}$ Ibid. 4 Edw. I, m. 88. The Cistercians by special privilege were exempt from the payment of all such tithe and subsidy and at one time were inclined to uphold their right to refuse any contribution; gradually, however, they found it politic to yield so far as to give 'by courtesy' what they declined to pay as an obligation. ${ }^{21}$ Pat. 22 Edw. I, m. 8 .

${ }^{22}$ Close, 3 Edw. II, m. 5, ced.; Parl. Writs (Rec. Com.), ii, div. 3 , p. 542

${ }^{23}$ Close, 3 Edw. II, m. 15 d.

${ }^{8}$ Ibid. 9 Edw. III, m. 27 d. Ten years later, in April, I 345 , the monks were ordered to send a strong horse to Chancery for carrying the Chancery rolls. Ibid. 19 Edw. III, pt. I, m. I 6.

${ }^{25}$ On $27 \mathrm{July}, 1278$, the abbot going beyond seas had letters of protection till All Saints (I'at. $6 \mathrm{Edw}$. I, m. 8). In 1286 and 1290 he obtained letters of protection to attend the general chapter of his order (ibid. It Edw. I, m. 8 ; $18 \mathrm{Edw} . \mathrm{I}, \mathrm{m} .29$ ), and in January, 1333 , he nominated attorney's to act during his absence at the general chapter. (Ibid. 7 Edw. III, pt. I, m. 2I).

${ }^{26}$ Pat. 3 Edw. I, m. 32. The house may for the time have recovered itself, for it seems to have met all the various charges of the reign of Edward II.

${ }^{27}$ A commission was appointed to inquire touching those persons who had depastured the corn of the abbot and convent at Lulworth (ibid. $11 \mathrm{Edw}$. I, m. I 2 d.) 


\section{A HISTORY OF DORSET}

Bexington, sometime monk of Bindon, and brother Maurice, also sometime monk of this place by relatives of the deceased. A commission of oyer and terminer was issued in February and again in July, 1296, but the matter proceeding too slowly for their taste the plaintiffs appear to lave taken the law into their own hands, with the result that another commission was appointed the following March to investigate the complaint of the abbot against a number of persons who had come to the abbey and imprisoned him and carried away his goods. ${ }^{23}$ What the upshot was we do not know ; the abbot in the same month received a grant of protection from the king and the matter dropped. ${ }^{29}$ Ill-feeling, however, seems to have remained in the district, and a complaint by the abbot in I3I 5 of trespass and assault on the part of IVilliam de Whitefield, knt., and others provoked from the accused knight and his adherents a counter-charge that the abbot and monks had trespassed in his meadow and assaulted his men, both sides at the same time claiming to be under the royal protection. ${ }^{30}$

The troubles of the community came to a climax in the early part of the reign of Edward III, and the causes mainly contributing to the state of affairs then disclosed are clearly expressed in the king's letter of 21 May, I329, appointing the abbot of Beaulieu, Hugh de Courtenay and Hugh Poynitz custodians of the king's abbey of Bindon, lately taken into custody in consequence of the grievous dissension which had arisen on the question of the removal of the abbot, resulting in the carrying away of the goods of the house by a large mob of people, the withdrawal of many of the monks, and the cessation of divine offices and alms founded there by the king's ancestors. ${ }^{31}$ The custodians appointed were empowered to collect the revenues, recover the goods carried away, and after reserving a reasonable sum to its maintenance, to apply the residue to the discharge of its debts and the best interests of the house. ${ }^{32}$ On 28 July of the same year John Mautravers the younger and William de Whitefield, knt., were appointed to the custody of the abbey, 'now grievously burdened with debt for want of good rule; ${ }^{33}$ in December the following year, 1330 , the custody was transferred to Hugh de Courtenay, both the elder and the younger, and the abbot of Ford. ${ }^{34}$ The exact date of the deposition of Abbot John de Monte Acuto, who appears to have so grievously abused his trust, cannot be found, but as his successor, according to the episcopal registers, was

"9 Pat. 24 Edw. I, m. I2, 17d. ; 25 Edw. I, pt. I, m. $17 d$.

29 Ibid. 25 Edw. I, pt. 1, m. 13.

${ }^{30}$ Ibid. $8 \mathrm{Edw}$. III, pt. 1, m. $4 d$.; 9 Edw. II, pt. 1, m. 29 d.

${ }^{31}$ Ibid. 3 Edw. III, pt. 1, m. 18.

${ }^{33}$ Ibid. 3 Edw. III, pt 1, m. 18. blessed by the bishop in September, $1332^{35}$ a species of interregnum may have ensued between the early part of 1331 and that date; for in January of the former year the king ordered a commission of inquiry into the complaint of the abbot that brother Jolnn de Monte Acuto, 'bearing himself as a monk of the house,' with a number of adherents had invaded the abbey, driven away cattle and sheep to the value of $f .700$, carried away books, chalices, and other ornaments of the church as well as charters, deeds, and muniments, and breaking open a chest had carried away the seal of the abbey with which divers bonds had been sealed, \&cc., to the prejudice of the house. ${ }^{36}$ In March William de Warenna and John Fraunceys were ordered to arrest John de Monte Acuto, an apostate monk fugitive from the Cistercian abbey of Bindon, and on 29 April the chief culprit together with another apostate monk, John de Wille, was arrested while wandering about the country, sometimes in secular and sometimes in regular habit to the contempt of his profession, and ordered to be taken back to the abbey. ${ }^{37}$ Unfortunately, John seems to have obtained a certain following in the neighbourhood and even among the inmates of the house, and a letter, amongst various communications addressed about this time to the king by the brethren, ${ }^{38}$ petitions that whereas Brother John de Montagu by favour and power had been made abbot of Bindon, and for the destruction he had wrought had afterwards beetr deposed by the abbot of Ford, 'son visitour,' and 'for his great sins' had been placed by the chapter-general under perpetual ward, but by favour of his keepers had escaped, the king will order the abbots of Beaulieu and L . . . to take him into safe custody that he may not again escape, and that scandal may not thence arise to the order through his being at large. ${ }^{39}$

${ }^{35}$ Sarum Epis. Reg. Wyville, ii (Inst.), fol. 17. It may be that a temporary appointment was made, for in October, 1331, a commission was appointed on complaint by William, abbot of Bindon, that IVilliam de Stoke and others had assaulted and imprisoned him at Great Crawford (Pat. 5 Edw. III, pt. 2, m. 15 d.).

${ }^{36}$ Pat. + Edw. III, pt. 2, m. 7 d.; 5 Edw. III, pt. 1, m. $32 d$.

${ }^{37}$ Ibid. 5 Edw. III, pt. 1, m. 2 I, 9 d.

${ }^{38}$ Unfortunately these letters, which with the official records give a very vivid picture of the state of the monastery, are all undated. They abound in complaints of the insolvent condition of the house, of the misdeeds "dun mauveis abbe, frere John de Montague, qui a grand droit fust oste e depose' (Anct. Pet. I $19+3)$ and of entreaties to Edward III to come to the relief of his almoners the monks, "qui sont en dispersion' (Anct. Pet. 1829-3I).

s9 Anct. Pet. 1830 . The patent rolls record that the late abbot having made good his escape, certain men were appointed on 1 August of that year (133I) to retake him and conduct him back to the abbey to be chastised according to the rule of his order. Pat. 5 Edw. III, pt. 2, m. $26 d$. 


\section{RELIGIOUS HOUSES}

The connexion of Bindon with the abbey of Ford was at this pass most unfavourable for the restoration of peace, and in November, 1332, Edward III wrote to the abbot of Citteaux reciting the injuries that had been inflicted on the monastery of Bindon 'by the indiscreet government and detestable presumption' of the late abbot who, although he had been removed and brother Roger substituted in his place, yet found adherents in the neighbourhood and even among the monks, and was a source of constant annoyance and loss, so that the dispersal of the monks was feared unless a remedy could be provided, and requesting that John and his accomplices, "who go armed to the scandal of the order,' should be removed to places far distant to do perpetual penance and stay there until the state of the house could be reformed, and that as the abbot of Ford, "to whom the house of Bindon is subject by affiliation,' encouraged John in his wrong-doing the abbot-general would reserve the visitation of the house to himself and commit it to some discreet abbot in whom he had full confidence. ${ }^{40}$

The following January, 1333, Roger, the newly appointed abbot, with the intention of attending the general chapter of his order, nominated his attorney in England for a year, ${ }^{11}$ and on 3 February the abbot of Beaulieu and Roger de Guldene were appointed to the custody of the house, 'burdened with debt by neglect and bad rule of abbots.' ${ }^{2}$ A commission of oyer and terminer was issued on I May of that year touching the trespasses of William le Rede of Wool and others in imprisoning Roger the abbot of Bindon and nine of his monks while the abbey was under the king's protection and in the custody of those appointed by him. ${ }^{13}$

The sordid story continues to run on with its tale of debt, which the appointment of custodians failed to relieve, ${ }^{44}$ and of ill-feeling that refused to be placated. ${ }^{4}$ On I1 April, 1348, the mayor of Dover was directed to allow the abbot of Bindon to cross to the Roman court, whither he was bound in the interests of his abbey, ${ }^{46}$ and in

10 Close, 6 Edw. III, m. $3 d$.

${ }^{41}$ Pat. 7 Edw. III, pt. 1, m. 29.

42 Ibid. m. 21. The abbot and convent in that year made a lease of the manor of Crich. Ibid. 7 Edw. III, pt. 2, m. $10 . \quad{ }^{13}$ Ibid. pt. 1, m. 7 d.

" The Close Rolls of 1 334, 1 335, 1338, 1339, $1344,1347,1348$, and 1352 enroll acknowledgements of debt, loans, \&c., on the part of the abbot. On the reappointment of custodians in 1334 and 1335 the patent rolls reiterate that owing to its condition the works of piety with which the house was charged could not be maintained, and the monks were likely to be dispersed unless a remedy could be found. Pat. 8 Edw. III, pt. 2, m. 20 ; 9 Edw. III, pt. 1, m. 34 . ${ }^{45}$ A complaint of trespass was again lodged by the abbot in I335. Ibid. $8 \mathrm{Edw}$. III, pt. 2, m. 6 . ; 9 Edw. III, pt. I, m. 25 d.

${ }^{46}$ Close, 22 Edw. III, pt. I, m. $30 d$. the same year protection was granted to the abbey with the appointment of $\mathrm{Hugh}$ de Courtenay, earl of Devon, and Hugh his son as custodians; we may note that at this time the reason hitherto alleged for its poverty-stricken condition-the bad rule of abbots-had given place to another- ' the frequent visits of the king's enemies coming upon us unawares.' ${ }^{17}$ Richard II on 8 July, 1392, on payment of a fine licensed John Dygon and Gilbert Martyn to alienate ten messuages, with lands and rents in East Burton, to the abbot and convent in aid of their maintenance. ${ }^{43}$ The only entries in the course of the fourteenth century that do not relate to the material condition of the abbey occur in 1317 , when the abbot and convent obtained leave to acquire lands and rents to the yearly value of $\oint_{1} 0$ for the provision of a chaplain to celebrate daily in the abbey for the soul of Edward I and of all good Christians, and for the good estate of the king and of Roger Damory; ${ }^{49}$ and again in 1325, when Thomas Crubbe of Dorchester was licensed to alienate two messuages and Ios. rent in Dorchester in augmentation of the maintenance of a chaplain to celebrate daily in the abbey for the soul of the said Thomas, his ancestors, and all the faithful departed..$^{50}$

The history of the abbey during the fifteenth century is practically a blank, and, as a house of the Cistercian order and 'exempt,' there are no references to Bindon in the episcopal registers which throw light on its later condition. ${ }^{51}$ Henry IV, in the first year of his reign, made over to his servant, John Crosby, the $f_{2} 20$ which the convent had paid yearly to the late earl of Salisbury from the issues of the manor of Lulworth, ${ }^{52}$ and in 1401 he made a life-grant to the abbot of a butt of wine yearly from the port of Melcombe. ${ }^{53}$ In $1485 \mathrm{John}$, then abbot of Bindon, was licensed to accept an ecclesiastical benefice with or without cure. ${ }^{54}$

There are various references to Bindon in the reign of Henry VIII. In 1512 a grant of a corrody in the monastery was made in survivorship to William Wycombe on its surrender by Robert Thorney. ${ }^{55}$ In 1522 the abbot contributed $£^{66}$ I $3^{\text {s. }} 4 d$. towards the grant by the spirituality for the expenses of the king in recovering the crown of France. ${ }^{56}$ He was summoned to convocation in $1529 .{ }^{57}$ On the abbey

${ }^{47}$ Pat. 22 Edw. III, pt. I, m. 9.

18 Ibid. 16 Ric. II, pt. 1, m. 19.

9 Ibid. I I Edw. II, pt. 1, m. I9.

${ }^{50}$ Ibid. $18 \mathrm{Edw}$. II, pt. 2, m. 29.

s1 In the middle of the fifteenth century the poor religious of the monastery of Bindon were declared 'exempt' by ancient custom from the payment of tithe. Sarum Epis. Reg. Beauchamp, fol. I $87 d$.

${ }^{52}$ Pat. I Hen. IV, pt. 5, m. 9.

${ }^{53}$ Ibid. 3 Hen. IV, pt. I, m. 23.

st Sarum Epis. Reg. Langton, fol. 23 d.

${ }^{35} L$. and P. Hen. VIII, i, 3567 .

${ }^{56}$ Ibid. iii, 2483 . $\quad{ }_{37}$ Ibid. iv, 6047. 


\section{A HISTORY OF DORSET}

becoming void in 1534 the duke of Richmond wrote to Cromwell requesting him to grant the monks liberty to elect their own abbot, 'as the convent intends to take care of my deer' in certain lands adjoining the monastery. ${ }^{58}$ In January the following year, the abbot of Ford, by virtue of the royal commission, was authorized to visit the Cistercian houses of Bindon and Tarrant, ${ }^{59}$ but no report has been found as to his 'findings.'

The Valor of I 535 gave the abbey spiritualities amounting to $\ell_{1} 34$ s. $6 \mathrm{~d}$. from the parsonage of Chaldon, and tithes in Winfrith Newburgh, Burngate, and West Chaldon, ${ }^{60}$ and temporalities from the manors of Bindon, Wool, East Burton, Pulham, Chaldon Herring, and South Fossil, West Lulworth, and other lands. ${ }^{61}$ Among the expenses was the sum of $3^{s} .4 d$. annually distributed to the poor in Chaldon, and $13^{s} .4 d$. annually distributed at Abbotsbury for the soul of the founders, 'Roger' Newburgh and Matilda his wife. The abbey, with a clear annual income of $f_{0} 147$ 7s. $9 \frac{3}{4} d .{ }^{62}$ came under the earlier Act for the suppression of all houses under the yearly value of $f_{0} 200{ }^{63}$ There is no evidence of a genuine desire on the part of Henry VIII to save the house, but on the payment of $£ 300^{64}$ the king, by letters patent dated 6 November, I536, restored it and constituted the former abbot head; the respite was of a very temporary nature, for the house fell with the larger monasteries in 1539 and was suppressed on 14 March of that year. ${ }^{65}$ The abbot, John Norman, who signed the surrender deed with the prior and six brethren, received a pension of 650 ; the prior, who had a yearly corrody in the monastery of $E_{10}$, received $E_{0}^{8}$; Stephen Farsey was appointed to the living of Bindon, worth f6 I $3^{s} .4 d$. without tithes and oblations, 'if he be impotent then to have I06s. $4 d$.; ' the subprior had $f_{0}$; and of the four remaining, one had $f_{5}$, another $f_{4}$, and two received $f_{2}$ each. ${ }^{6}$

\section{ABbots of Bindon}

John, resigned I 91, in which year he became abbot of Ford ${ }^{67}$

Henry ${ }^{68}$

Ralph, occurs $1227^{60}$

John, occurs $1232^{70}$

William $^{71}$

${ }^{53}$ L. and P. Her. VIII, vii, 821 . ${ }^{53}$ Ibid. viii, 74 .

${ }^{60}$ Valor Eccl. (Rec. Com.), i, $239 .{ }^{61}$ Ibid. 240-1.

${ }^{62}$ Ibid. ${ }^{63} L$. and P. Hen. VIII, x, 1238.

'Ibid. xiii (2), 457, 1 (3).

${ }^{65}$ Ibid. xiv (1), 509 .

${ }^{66}$ Ibid.

${ }^{67}$ Ann. Mon. (Rolls Ser.), i, 2 I.

${ }^{6 s}$ Given by Hutchins without reference, Hist. of Dors. iii, 355 .

${ }^{69}$ Ibid. from Fin. Conc. Dors. I I Hen. III, No. 30.

${ }^{70}$ Pat. $16 \mathrm{Hen}$. III, m. $8 d$.

"Cited by Hutchins from a charter undated. Custum. Glaston. 84.
Robert, occurs 1243 and $1252^{72}$

Reginald, occurs $1275^{73}$

William, occurs $1290^{74}$

Walter, elected $1309^{75}$

Richard, occurs $1316^{76}$

John de Monte Acuto, deposed 1331-2 by order of the chapter-general of Cîteaux ${ }^{77}$

William, occurs I $33^{2}{ }^{78}$

Roger Harnhull, appointed $1332^{\text {i9 }}$

William de Comenore, elected $133^{80}$

Philip, occurs I $350^{81}$

William Chetus or Cletus, elected $1361^{83}$

William Fordington, occurs $1400^{83}$

Robert Lulworth, occurs $1433^{81}$

John Smith, occurs $1444^{85}$

William Comere, occurs $1446^{86}$

Robert, occurs I $45^{8}$ and $1464^{87}$

Thomas, occurs $1467^{88}$

John, occurs 1485 and $1495^{83}$

John Bryan, occurs $1499^{90}$

John Waleys, occurs I $523^{91}$

Thomas, occurs $1529^{92}$

John Norman, elected I534, surrendered finally I $539^{83}$

A fourteenth-century pointed oval seal with a very imperfect impression and the legend entirely defaced represents two crowned saints in a canopied niche. There is an obliterated shield of arms on each side. In base under a pointed arch an abbot is lifting up his hands in adoration. ${ }^{94}$ A much mutilated example of this seal is attached to the surrender deed of the abbey. ${ }^{95}$

${ }^{72}$ Hutchins, Hist of Dors. iii, $355 . \quad{ }^{73} \mathrm{Ibid}$.

${ }^{3}$ Pat. 18 Edw. I, m. 29. He may probably be identical with William de Huleburn, who occurs 1296. Ibid. 24 Edw. I, m. 17 d.

${ }_{75} \mathrm{He}$ made his profession and was blest by the bishop 5 Ides May of that year. Sarum Epis. Reg. Simon of Ghent, ii, fol. $79 d$.

${ }^{76}$ He was summoned to convocation in that year. Ibid. Mortival, ii, fol. $3 \mathrm{I}$.

7 Close, 6 Edw. III, m. $3 d$.

${ }_{73}$ Pat. 5 Edw. III, pt. 2, m. 15. This was probably mcrely a temporary appointment.

${ }^{79}$ Sarum Epis. Reg. Wyville, ii (Inst.), fol. 17.

${ }^{60}$ Ibid. fol. $57 \mathrm{~d}$.

${ }^{81}$ Cal. Pap. Letters, iii, 204.

63 Sarum Epis. Reg. Wy'ville, ii (Inst.), fol. 286 \%.

${ }^{83}$ Hutchins, op. cit. $\quad$ Ibid.

${ }^{65}$ Sarum Epis. Reg. Aiscough.

${ }^{66}$ Ibid. ${ }_{87}^{87}$ Hutchins, op. cit.

${ }^{89}$ Sarum Epis. Reg. Beauchamp, ii, fol. 104.

${ }^{63}$ Ibid. Langton, fol. 230 ; Blyth, fol. $47 d$.

${ }^{90}$ According to Hutchins (op. cit.) in that ycar John Bryan was made rector of Chaldon Herring by apostolic dispensation.

${ }^{91}$ Hutchins, op. cit.

${ }^{92}$ L. and P. Her. VIII, iv, 6047 .

${ }^{33}$ Cf. L. and P. Hen. VIII, vii, $82 \mathrm{I}$; Valor Eccl. (Rec. Com.), i, 421 ; L. and P. Hen. VIII, xiv (1), 519.

${ }_{34}$ B.M. Seals, 1xii, 24.

${ }^{95}$ Deeds of Surrender, No. 21. 


\section{RELIGIOUS HOUSES}

\section{HOUSE OF CISTERCIAN NUNS}

\section{THE ABBEY OF TARRANT KAINES ${ }^{1}$}

The Cistercian nunnery of Tarrant Kaines, commonly said to be of the foundation of Richard le Poor of Salisbury, owed its early origin to the "ancient and renowned familie of Keines,' a member of which-Ralph de Kahaynes-according to Coker, 'in Richard the first's time built neare his mansion house a little monasterie for nunnes which his son William de Kahaynes much encreased.'

Accepting the tradition which identifies these nuns with the sisters to whom was addressed that famous treatise, the 'Ancren Riwle,' that modern authority has attributed to Bishop Poor, ${ }^{3}$ and assuming that the 'Riwle' was written about the commencement of the thirteenth century, we find that the community at that time consisted of three ladies with their domestic servants, and that they are described as being 'for your goodness and nobleness of mind beloved of many, sisters of one father and of one mother, having in the bloom of your youth forsaken all the pleasures of the world and become anchoresses.' ${ }^{4}$ It also appears that the sisters, though they had renounced the world to apply themselves to pious exercises and devout meditations, had not as yet joined any existing order, for the bishop advises them 'if any ignorant person ask you of what order you are, say that you are of the order of St. James,' which indeed had no existence in actual fact, but whose rule (Epist. i, 27), and especially the latter part of it, 'to keep unspotted from the world,' was specially to be observed by them. It was probably by the counsel and consent of their benefactor that the community finally adopted the Cistercian rule, and it may account for the tradition soon after prevailing that the bishop was their actual founder. The step must have been taken before his translation to Durham in 1228 , for the profession of Clarice, abbess of Tarrant Kaines, to Bishop Richard le Poor as ordinary can still be seen at Salisbury. ${ }^{5}$

${ }^{1}$ In the modern parish of Tarrant Crawford.

${ }^{2}$ Particular Sury. of Dorset (1732), 106. As Ralph de Kahaignes is returned in the Great Roll of the Pipe of 1167-8 for the knights' fees at which he was assessed in the county, and William de Chahaygnes in the Roll of 1186-7, it seems more than probable that this 'little monasterie' was founded during the reign of Henry II. Red Bk. of the Exch. (Rolls Ser.), i, 44-64.

${ }^{3}$ The 'Ancren Riwle' (The King's Classics), I 905. Preface. Ibid. p. 145 .

${ }^{5}$ Among a number of 'professions' kept in the muniment room of the cathedral. The nuns are described as belonging to that order in a royal mandate
The earliest of a series of charters granted to the abbess and convent during the reign of Henry III is dated 24 July, 1235 , and confirms to God, the church of All Saints, and the nuns serving God there all previous gifts, including those of the original founder and his son. Of the gift of Ralph de Kahaynes: the church of All Saints, the manse before the church and the croft near it, the mill before the manse, all the downs called 'Thorendon,' 'Holdeley,' and

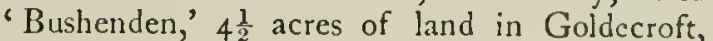
the land called Medgare, and 2 acres of meadow at the hedge of Crawford, 2 acres of wood at Fordham Serlon, ${ }^{6} 2$ acres of wood in Chetred, and pasture for a plough-team of oxen with the oxen of the grantor, a virgate of land in Spettisbury. William de Kahaynes added to his father's benefactions a tithe of all the bread made in his household wherever he should be in any part of his demesne 'saving the bread of Renges,' a tithe of all salt meat whether of pigs, sheep, or cows killed in his household each year, one barrel of his prime and good ale for Christmas with another barrel of second ale, or malt to make as much, yearly ; the prior and convent of Christchurch, Twyneham, among other gifts gave two mills in Tarrant and pasturage for sheep and cattle, \&c. ; the manor of Woodyates was the gift of William de Woodyates; Richard, bishop of Durham, bestowed all the right which John de Reygate gave to him in the third part of a hide and in a messuage and garden in Pimperne.

Bishop Poor's interest in the house he had practically re-founded did not diminish on his translation to Durham; he made over to the sisters the custody of the manor of Tarrant Kaines granted to him by Henry III during the minority of William, son and heir of William de Kahaynes, the king sanctioning the transfer on 7 February, 1237, and at the same time granting letters of protection to the abbess of the 'Blessed place upon the Tarrant." ${ }^{8}$ Two months later the bishop turned his steps homeward to die in his native place. ${ }^{9}$

of 1233 prohibiting the exaction of any subsidy from the Cistercians. Close, 17 Hen. III, m. $13 d$.

The church appears originally under the dedication of All Saints, but as all abbcy churches of the Cistercian order were ipso facto dedicated in honour of the Blessed Virgin the church of Tarrant Crawford subsequently appears under the double dedication of St. Mary and All Saints (See Tanner, Notitia, Dorset, xxviii), though it is also given as the church of St. Mary only. Valor Eccl. (Rec. Com.), i, 265.

'Chart. R. Ig Hen. III, m. 4 .

${ }^{8}$ Pat. 2 I Hen. III, m. 10.

9 Tarrant is generally assumed to be lis birthplace. Lcland, Itin. iii, 62. 


\section{A HISTORY OF DORSET}

Matthew Paris describes the scene at Tarrant on I 3 April, 1237, when, surrounded by the household, at the hour of compline, devoutly following the prayers, Richard le Poor at the words, 'I will lay me down in peace and sleep' passed peacefully away. ${ }^{10}$ Before his death he had sought to secure the welfare of this loved community by placing the house under the patronage of Queen Eleanor, wife of Henry III, who is afterwards occasionally termed the founder, the house becoming popularly known as Bencdictus Locus Regine super Tarant. In October following the death of their benefactor Henry III confirmed to the sisters the grants set out in his previous charter of 1235 with fresh additions, including the gift by William de la Prentice of all his right in the hermitage of Mannington, at the same time notifying that he had taken under his protection the abbey of Tarrant 'which Richard, sometime bishop of Durham, founded.' In 1265 the king bestowed on the abbess and convent-styled 'of the Cistercian order'-for the good of his soul and the soul of Eleanor, queen of England, 'our consort,' his manor of Hurstbourne Tarrant in Hants for the service of halt a knight's fee."

The year following the bishop's death the abbey was called on to give burial to a sister of Henry III, Joan the wife of Alexander II of Scotland, who fell ill while on a viste south to her brother, and dying 4 March, 1238, bequeathed her body to the nuns for burial; ${ }^{12}$ the king in the same month testified that he was bound to assign to the abbess and convent, within fifteen days of Easter next, land to the value of $£ 20$ a year according to a bequest made to them by his sister Joan, sometime queen of Scotland. ${ }^{13}$ A few years later, in 1246, a grant was made to the Abbess Maud that the sheriff of Dorset should henceforth be charged with the provision of two wax lights to burn day and night in the abbey, one before the host and the other before the place where the body of the late queen lay buried. ${ }^{14}$

It would be impossible to enumerate all the gifts made to this favoured house in the course of the thirteenth century. A charter dated 2 I April, 1242 , sets out at considerable length all previous grants, many of which had been included in the charters of 1235 and 1237 already

${ }^{10}$ Matt. Paris, Chrom. Maj. (Rolls Ser.), iii, 479.

"Rot. Fin. 50 Hen. III, m. 8.

${ }^{13}$ Matt. Paris, Chron. Maj. (Rolls Ser.), iii, 479. The sheriff of the county lodged an account in the Exchequer for roos. which at the king's command he had paid for having an effigy of a quecn carred in marble stone, for the carriage of the same to the abbey of Tarrant and there placing it over the tomb of the queen of Scotland.

${ }^{13}$ Pat. 22 Hen. III, m. 8.

"Ibid. 30 Hen. III, m. 3 . mentioned. ${ }^{15}$ On 5 December, I 252, Henry III granted to the nuns for the soul of his sister Joan that they and their men should be quit of suits of the county and hundred court and of sheriff's tourn, that they might claim the amercements of their men before the king's justices whether in eyre or on the bench; the right of free election 'as fully as obtains in the Cistercian order,' and the right of free warren in all their demesne lands in Dorset, Wilts., and Sussex, provided they should not be within the king's forest. ${ }^{18}$ Edward I exhibited the same regard shown by his father, and at the instance of his wife, Eleanor of Castille, restored to the nuns the wood of Beer which John de Bohun had formerly bestowed on them without licence of the king, with the result that it had escheated to the crown. ${ }^{17}$ The manor of Binderton, the gift of Bernard de Sauve, was included in a charter of confirmation granted in the eighth year of the king. ${ }^{18}$

According to the Taxatio of I29 I the yearly income of the convent came to $£$ I 26 I 6s. $4 \frac{1}{2} d$., including spiritualities from the churches of Tarrant Kaines, Little Crawford, and Woodyates amounting to $£_{12} 2$ s. $8 d^{19}$ Their temporalities were assessed at $\oint_{1} 3$ in the deanery of Dorchester, $£ 33$ IOs. $8 \frac{1}{2} d$. in the deanery of Whitchurch, $f_{1} 9$ 9s. $7 d$. in the deanery of Pimperne, $£_{22}$ I6s. $5 d$. in the manor of Hanford within the Shaftesbury deanery. ${ }^{20}$ The total value of their possessions within this county came to $f_{1}$ OI 3 3. $4 \frac{1}{2} d$., and they had $\ell_{1} 5$ from the manor of Binderton in the diocese of Chichester, ${ }^{11}$ and $\ell_{10} 3^{\text {s. from the manor }}$ of Hurstbourne Tarrant in the Winchester diocese. $^{22}$ In spite of the respectable rent-roll represented by these figures we read that in 1292 the abbess obtained leave from the king to sell forty oaks from her manor of

${ }^{15}$ Chart. R. 26 Hen. III, m. 3. Among other gifts the charter includes the church of St. Nicholas of Woodyates with a virgate of land, the gift of the prior and canons of Breamore (Hants), the manor, adrowson of the church, and mill of Hanford given by John de Mares and Agatha his wife, which the king had confirmed, quit of all suit and forcign service, 26 February, 1240 (ibid. 24 Hen. III, m. 3 ), with licence to hold a weekly market on Tucsday, and a yearly fair on the vigil, feast, and morrow of St. James (ibid. $25 \mathrm{Hen}$. III, m. 3).

${ }^{16}$ Chart. R. 37 Hen. III, m. 18. On 1 July, 1245 , a royal licence was granted for the abbess to hold free of service and in frankalmoign all the land in Gussage All Saints, which by a former grant the king had permitted Imbert Pugnes to give to them for the same service for which he had held it. Ibid.

29 Hen. III, m. 3.

${ }^{17}$ Close, 4 Edw. I, m. 10.

${ }^{18}$ Chart. 8 Edw. I, No. 35.

${ }^{19}$ Pope Nich. Tax. (Rec. Com.), 178.

${ }^{20}$ Ibid. $184 b, 185$.

${ }^{21}$ Ibid. 1386 .

${ }^{22}$ Ibid. $213^{b}$. 


\section{RELIGIOUS HOUSES}

Hurstbourne to whomsoever she would in order to pay her debts. ${ }^{23}$

Save for the record of their temporal possessions the community rarely emerge from the obscurity that veils their history. It is evident that the name by which they continued to be known, 'the poor nuns of Tarrant,' 24 was something of a misnomer if it should be read to imply absolute poverty. The time had long gone by since the days when the sisters were warned by the bishop to avoid the holding of personal property: 'Ye shall not possess any beast, my dear sisters, except only a cat,' or, when seeking their pittance in the hall of their early founder, were bidden 'be glad in your heart if ye suffer insolence from Slurry the cook's boy who washeth dishes in the kitchen.' ${ }^{25}$ As belonging to the Cistercian order the house was technically 'exempt,' and beyond forwarding a copy of the Constitutions of Pope Boniface for enforcing the stricter inclosure of nuns in 1301 the bishop, so far as we can gather from the registers, made no attempt to impose his authority therein. ${ }^{26}$ At all events history does not deprive us of the hope that these ladies remained true to the ideal of the Christian life pointed out to them by their early friend.

In the fourteenth century certain chantries were founded in the conventual church that prayers might continually be offered for the souls of royal and distinguished benefactors. In I 347 in consideration of the sum of $465.8 \mathrm{~d}$., Thomas Baret obtained a licence to bestow certain messuages and lands in Charlton and Little Crawford tor the provision of a chaplain to celebrate every Monday in the abbey church at the altar of St. Mary for the good estate of the king, for his soul when dead, the souls of his progenitors, the grantor and his heirs. ${ }^{27}$ Thirty years later, by an indenture dated 'Nuns Tarent, Saturday, St. Mark,' the nuns granted to 'Sir' Thomas Gilden, chaplain, a weekly corrody for life from their abbey, with a chamber in the houses lately built by Thomas Baret to be kept in repair by the abbess, and assigned to him the office of chaplain of the parish church of All Saints, Little Crawford, 'otherwise called St. Margaret's Chapel,' in return

\section{${ }^{23}$ Close, 20 Edw. I, m. 9.}

34 The name by which the sisters are designated in the reigns of Henry III and Henry IV, and later still when they were deciared to be 'exempt' by ancient custom from the payment of tax and subsidy. Close, 17 Hen. III, m. I3 d.; Pat. 1 Hen. IV, pt. 2, m. 17, 28 ; Sarum Epis. Reg. Beauchamp, fol. $187 \mathrm{~d}$.

'The 'Ancren Riwle' (the King's Classics), 316 , 287 .

${ }_{96}$ Sarum Epis. Reg. Simon of Ghent, fol. 73. The abbess, in common with Bindon and the heads generally of Cistercian houses, was blessed by the bishop, to whom she made profession on her election.

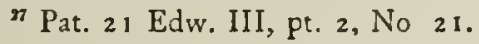

for $\oint_{2} 20$ paid by him to the abbess and for other benefits. $^{93}$ In 1383 Sir Robert Rous, whom Leland mentions as a great benefactor of the sisters, ${ }^{29}$ desired by his will to be buried in the abbey, 'the place of St. Richard the Bishop;' among other legacies bequeathing to every nun at Tarrant $40 d$., to every sister 25 ., and an annual rent of 8 marks for the provision of four priests to celebrate at the altar 'near the body of St. Richard in St. Michael's church in Tarrant Kaines,' and two priests in the church of St. Mary at Tarrant Crawford; to the abbess he left a pair of gold beads with other plate engraved with his own and his wife's arms. ${ }^{30}$ On 23 February, I 389 , a licence was granted for the alienation of the manor of Tarrant Keynston by Robert, bishop of London, Walter Clopton, William Gascoigne, and John, parson of Keynston, to the abbess and convent for the ordination of a chantry of two chaplains in the abbey to celebrate daily for the souls of Robert Rous, knt., Joan his wife, his parents and friends, and to perpetuate various acts of piety for the benefit of their souls and the souls of the father and mother of Joan, according to the ordinance of the bishop. ${ }^{31}$

The fifteenth century is almost bare of records relating to this house. Henry IV on 3 March, I 403, inspected and confirmed letters patent of Richard II in I394, confirming the charter of Henry III for the right of free warren within all the demesne lands of the abbey. ${ }^{32}$ The grant may have been specially made in consequence of a complaint lodged by the Abbess Joan in May, I 402, that Robert Turbulville, 'chevalier,' and others had transgressed her right of free warren at Beer, hunted and fished her preserves, felled her trees, and assaulted her servants. ${ }^{33}$ The episcopal registers record that a dispensation was granted to the abbess on 9 September, I 406, allowing her to have divine service celebrated for

${ }^{29}$ The corrody was to consist of a weekly allowance of bread and ale, with a daily pittance of fish or flesh 'such as each nun received,' a cart-load of wood and a cart-load of litter yearly at Michaelmas. Pat. 5 Ric. II, pt. I, m. 3I. By inspeximus.

${ }^{29}$ Leland, Itin. iii, 62 .

${ }^{30}$ The terms of the will, if correctly reported by Hutchins (Hist. of Dorset, iii, 122), are somewhat perplexing, as the bishop of Durham, Richard Poor, was buried in the church of Tarrant Crawford or Little Crawford, and not in the church of Tarrant Kaines. The two churches are described as 'not 4 furlongs apart,' and were united in the seventeenth century. Ibid. iii, 122 . See a paper of the Rev. E. Highton, Last Resting Place of a Scottish Queen and a great English Bishop.

${ }^{11}$ Pat. 12 Ric. II, pt. 2, m. 20 . This foundation is not entered in the list of chantries suppressed by the Acts of Henry VIII and Edward VI.

2 Ibid. 4 Hen. IV, pt. 2, m. 37.

${ }^{33}$ A commission was appointed to investigate the case. lbid. 3 Hen. IV, pt. 2 , m. 17 d.; 5 Hen. IV,

pt. 1, m. $12 d$.; pt. 2, m. $29 d$. 


\section{A HISTORY OF DORSET}

herself and her household wherever she might be $w$ thin the city and diocese of Salisbury. ${ }^{34}$

'Terenta of the Nuns' was included among religious houses of the Cistercian order to be visited by the abbot of Ford in virtue of the royal commission, January, $1535,{ }^{35}$ but no report is recorded of its condition.

The Valor of the same year gives the abbey a clear annual income of $\{21475.9 d$., the abbess claiming to be discharged of a yearly allowance of $£_{3} 3$ for an annual distribution of bread to the poor on Maundy Thursday in commemoration of "Eleanor, sometime queen of England, the foundress.' ${ }^{36}$ The convent held the parsonages of Little Crawford, Woodyates, and Hanford, with a portion out of the church of Tarrant Keynston. The abbey was at that time void, conge d'dire on the death of Edith, last abbess, being granted in August of the same year. ${ }^{3}$ The names of the principal officers are given as follows : - Margaret Ly'nde, prioress; Anna Cheverell, sub-prioress; Joan More, cellarer; Alicia Hart, sacrist. ${ }^{39}$

Margaret Russell, who succeeded, held office till I 3 March, I 539, when with the sub-prioress and eighteen of her nuns she surrendered the abbey into the hands of the royal commissioner, John Smyth. A pension of $f_{4} 0$ was assigned to the abbess, to the prioress 66 i $3^{s .} 4 d$., to the subprioress IOOs., and to the seventeen remaining sisters sums ranging from $\mathrm{f}_{4}$ to $66 \mathrm{~s}$. $\mathrm{Sd}$. each. ${ }^{40}$
William Joliffe, chaplain, Iater received a pension of 53 s. $4 d^{41}$

After the Dissolution the abbey, with the manor of Preston or Tarrant Crawford, was granted in reversion to Sir Thomas Wyatt; ${ }^{42}$ a few years later it came into the hands of Richard Savage and IV. Strangways. ${ }^{43}$

\section{Abbesses of Tarrant Kalnes}

Claricia, elected about $1228^{44}$

Emelina ${ }^{45}$

Maud, occurs $1240^{46}$

Isolda, occurs $12 \mathrm{So}^{47}$

Elena, elected 129843

Anne, occurs 135199

Clemence de Cernyngton, occurs $1377^{\text {s0 }}$

Joan, occurs $1402^{51}$

Avice, occurs $\mathrm{I}_{4} \mathrm{4}^{52}$

Edith Coker, died in $1535^{53}$

Margaret Russell, elected $1535,{ }^{64}$ surrendered March, $1539^{\text {ss }}$

The thirteenth-century pointed oval seal attached to the surrender deed of the abbey represents on a corbel the Virgin with crown, standing, the Holy Child on the left arm. Before her the abbess kneeling holds up a flowering branch. In the field two trees. ${ }^{56}$

The legend runs :-

A sigillvm . conventvs . De . TARent

\section{HOUSES OF KNIGHTS HOSPITALLERS}

\section{THE PRECEPTORY OF FRIAR MAYNE}

It cannot exactly be stated when the preceptory of Friar Mayne was erected, though there is ample evidence that the Kuights Hospitallers possessed property here and at IVest Knighton early in the reign of Edward I. ${ }^{1}$ Thus it is reported among the inquisitions returned 3 Edward I that Thomas del Boy's gave to the hospital of St. John of

"Sarum Epis. Reg. Mitford, fol. I1 5 d.

${ }^{35}$ L. and P. Hen. VIII, viii, 74 .

${ }^{36}$ Valor Eccl. (Rec. Com.), i, 26;-7. $\$$ Ii Ibid.

${ }^{35} L$. and P. Hen. VIII, ix, 236 .

3) Valor Eccl. (Rec. Com.), i, 267.

${ }^{10} L$. and $P$. Hen. VIII, xiv (1), 515 .

$"$ Add. MS. 19047, fol. 6.

"Dugdale, Mon. v, 628 .

"T Tanner, Notisic, Dorset, No. xxviii.

"Her profession to Richard le Poor, bishop of Salisbury, cannot be later, as in that year he was translated to Durham.

${ }^{43}$ Her profession on election, undated, can be seen in the muniment room at the cathedral at Salisbury.

${ }^{46}$ Chart. R. 24 Hen. III, m. 3.

"7utchins, Hist. of Dorset, iii, 121.

"In that year she did homage to the bishop on her election; Sarum Epis. Reg. Simon of Ghent, i, fol. 33.
Jerusalem land in Kyngeston or Knighton which used to do suit and service at the hundred court, and that this service valued at 25 . had been withdrawn by the prior and brethren. ${ }^{2}$ In 1290 the prior of the order obtained from Edward I a charter of free warren in all the demesne lands of his manor of Mayne, ${ }^{3}$ and in the Taxatio of

9 Cat. of Pap. Letters, iii, 407.

${ }^{50}$ Pat. 5 Ric. II, pt. I, m. 3 I.

${ }^{31}$ Ibid. 3 Hen. IV, pt. 2, m. $17 d$.

52 Ibid. 5 Hen. IV, pt. 2, m. $29 d$.

${ }^{53}$ L. and P. Hen. ITIL, ix, 236.

${ }^{54}$ Both Dugdale and Tanner make the mistake of giving Margaret Lynde, who was frioress when the Valor of 1535 was taken, as abbess; Dugdale, Mon. v, $6_{20}$; Hutchins, Hist. of Dorset, iii, 121 .

${ }^{33} L$. and P. Hen. VIII, xiv (1), 5 15. This list, with the addition of fresh names and some corrections of date, closely follows that of Hutchins, Hist. of Dorset, iii, 121.

${ }^{36}$ Deeds of Surrender, No. 233.

1 According to Hutchins (Hist. of Dorset, ii, 498) Knighton took its name from the Knights Templars or Hospitallers here (Knightoun); Friar Mayne, now a hamlet in West Knighton parish, was formerly a manor adjoining.

${ }^{3}$ Hurs. R. (Rec. Com.), i, Ioo.

${ }^{3}$ Chart. R. 18 Edw. I, No. 8 ro. 


\section{RELIGIOUS HOUSES}

I 29 I he is said to have had a portion out of the church of Knighton."

The preceptory was founded some time between then and the year 1338, when full particulars of the bailiwick of Mayne are given in the return made of the possessions of the Hospitallers of England to the Grand Master of the Order by Philip de Thame, provincial prior of England. The 'bajulia de Maine' with its members Knighton and Waye was valued at 144 marks, 2s. $10 d . ;{ }^{5}$ the outgoings amounted to 63 marks 5 s. 4 d., and included ordinary expenses of the household with the exercise of hospitality, a duty much enjoined on all members of the order- $f^{8}$ I $_{4}$ s.; a life-corrody to Sir Robert de Norfolk at the table of the brethren, a robe and his necessaries, 27s.; the kitchen, $£ 7$ I 6s.; the brewing of the beer, $£ 5$ I $45.2 d$.; robes, mantles, and other necessaries for the preceptor and his brother knight, 69 s. $4 d$.; for the squire and others of the household, 50s. ; the chaplain's stipend for celebrating in the chapel was 20 s.; the cost of entertaining the prior for three days on his annual visit came to 6os. An annual pension of $\ell_{2} 6$ s. $8 d$. was paid to the vicar of Stinsford, ${ }^{6}$ and small payments of $6 s$, and 75 . to the rector of Warmwell and the prior of Holme respectively. The household consisted at that time of the preceptor, brother John Larcher, junior ; Richard Bernard, his brother knight ; and Sir Robert de Norfolk, the corrody-man or boarder ' in the place of a knight,' besides squire and servants." "The balance to be paid into the treasury after all expenses had been met amounted to 79 marks IOs. Iod. The house was not reported in a very good state, for the court at Mayne was 'badly built,' the house in ruins: 'burnt by misfortune,' so that the whole return of the bailiwick for one year would hardly suffice to repair the buildings, and owing to these un-

"Pope Nich. Tax. (Rec. Com.), 179. The first presentation to the rectory of West Knighton was made in 1304 (Hutchins, Hist. of Dorset, ii, 504). Stinsford church is not mentioned in the Taxation of 1291 , but is given as appropriated to the preceptory and worth 18 marks in the return made by the provincial prior of England in 1338 (Larking, Krights Hospitallers in England [Camd. Soc.], it) ; the first presentation to the vicarage is recorded in 1319 (Hutchins, Hist. of Dorset, ii, 569).

${ }^{3}$ At Mayne besides dovecot and water-mill there were $34^{\circ}$ acres of land, $15 \frac{1}{2}$ acres of meadow and pasture for 12 oxen, 12 cows, and 500 sheep; at Knighton, a messuage and garden, 68 acres of land, $1 \frac{1}{2}$ acres of meadow, and pasture for 6 oxen, 8 cows, and 100 sheep; at Waye a messuage with garden, Io acres of meadow, 160 acres of land, and pasture for 6 oxen, 8 cows, and 100 sheep; Larking, Krights Hospitallers in England (Camd. Soc.), I0-I I.

${ }^{6}$ This payment was made up to 1535 , and is given in the Valor Eccl. of that year; op. cit. (Rec. Com.), i, 262 .

${ }^{7}$ Larking, Knights Hospitallers in England (Camd. Soc.), $10-11$. fortunate circumstances that voluntary contribution to their funds by the neighbourhood, on which every preceptory relied for a large fraction of its income, could hardly be expected to reach the average of 36 marks. ${ }^{8}$

The establishment at Mayne previous to the Dissolution seems to have become incorporated with or united to the larger and more flourishing preceptory of Baddesley or Godsfield in Hampshire. In I 523 brother William Weston paid $63^{8}$ i $7^{s}$. $\mathbf{I} d$. for the commandery of Baddesley and Mayne into the treasury or capital fund of the order for the year ending at the feast of St. John the Baptist, ${ }^{9}$ and in I 533 the prior and hospital of St. John of Jerusalem, by an indenture dated 27 June, leased to John Gerard of Tincleton the capital messuage or mansion of their manor of Friar Mayne with the tithes of the chapel and a warren of coneys in Lewell or East Stafford for a term of twenty-one years. ${ }^{10}$ The preceptory, therefore, in all but the name, seems to have sunk to the position of a ' camera' or cstate maintaining no community and farmed out for the benefit of the society.

In the Valor of I 535 all receipts and payments, with the exception of the rectory of West Knighton, are made out jointly in the name of the commandery or preceptory of Baddesley or Mayne; the receipts were 20s. $8 d$. from the aforesaid rectory, ${ }^{21} 4 d$. out of the rectory of Langton Matravers and Worth, ${ }^{12}$ and 5 s. in tithes out of West Chaldon; ${ }^{13}$ the vicar of Stinsford received a stipend of $f_{2} 6$ s. $8 d$. as in the return of 1338.14

At the Dissolution the property of the Knights Hospitallers was by Act of Parliament vested in the crown, and the manor and premises here in reversion of the afore-mentioned lease were granted by Edward VI to William Dennys for twenty-one years. ${ }^{15}$ On the re-establishment of the order under Philip and Mary they were restored in $155^{8}$ to Thomas Tresham, Grand Preceptor of St. John of Jerusalem, ${ }^{16}$ but the advent

${ }^{8}$ Ibid.

9 Hutchins, quoting from the records of the Knights Hospitallers at Malta, says that in 1531 Roger Boydell, preceptor of Baddesley and Mayne, paid by the hand of Francis Balyard $\complement_{44} 123.1 d$. into the treasury and the same in 1532 . In 1533-4 Thomas Dingley paid $\int_{0} 44$ 12s. Id. for Baddesley and Mayne for half a year, and he owed the same sum for 1535 . Hist. of Dorset, ii, 501.

"Valor Eccl. (Rec. Com.), i, $244 . \quad{ }^{13}$ Ibid.

13 Ibid. 239. ${ }^{14}$ Ibid. $262 .{ }^{15}$ Pat. 5 Edw. VI.

${ }^{16}$ Pat. 4 \& 5 Phil. and Mary, pt. 14. This restoration comprised not only the manor of Friar Mayne and Westbroke with messuages and lands in Westbroke, East Stafford, Warmwell, West Waddon, and Dorchester and a pension of 20 s. $8 d$. from West Knighton rectory, all belonging to the preceptory of Friar Mayne, but certain other lands and rents in the county belonging to the preceptory of Temple Combe in Somerset included in the same patent of reedification. 


\section{A HISTORY OF DORSET}

to the throne of Elizabeth brought about the destruction of the order anew, and the queen in April, 1564 , in consideration of the sum of f. I, I 89 I $9 s .7 d$. re-granted the manor in reversion of the former lease of Edward VI to IVilliam Pole of Shute and Edward Downing and their heirs. ${ }^{17}$ In addition to the preceptory of Mayne with its members West Knighton and Waye, the order possessed a smaller estate re- turned in $133^{8}$ as the 'camera' of Chilcombe, which comprised the manors of Chilcombe and Toller Fratrum with the rectory of the latter; it was valued at $\ell_{0} 4$ 5s. $4 d$., paid 30 marks into the treasury at Clerkenwell, and was farmed out to Ivo de Chilcombe. ${ }^{18}$ The Hospitallers also held lands in Hammoon, Watercombe, Marnhull, Wareham, Upway, Charlton Marshall, Turnworth, and Shroton. ${ }^{10}$

\section{FRIARIES}

\section{THE DOMINICAN FRIARS OF GILLINGHAM}

On $\&$ December, 1267 , Henry III granted twelve oaks in Gillingham Forest to the Friars Preachers to repair the fabric of their church at Gillingham. ${ }^{I}$ This was probably a chapel connected with the royal palace. ${ }^{2}$ No other reference to the house has yet been found.

\section{I3. 'THE DOMINICAN FRIARS OF MELCOMBE REGIS ${ }^{3}$}

The friary at Melcombe Regis was the last Dominican house established in England. It was founded by Hugh Deverell, knt., and John Rogers, chief of the house of Rogers of Bryanston in Dorset." In furtherance of their purpose the provincial of England, supported by the mastergeneral of the order, applied to the Holy See in I 418 for powers to make the foundation; and on I 7 August Martin $\mathrm{V}$ gave the necessary leave for erecting a convent here, with church, belfry, churchyard and cloister, and all things necessary for a religious house, even without the consent of the ordinary of the diocese, provided there was no other house of Mendicants within the distance of I 50 cannae (about 280 yards) and saving the rights of the parochial churches. ${ }^{5}$ Deverell and Rogers then gave two messuages, two tofts and four curtilages, containing altogether $270 \mathrm{ft}$. in length and $160 \mathrm{ft}$. in breadth, held of the crown in free burgage at a rent of $2 s$. $1 \frac{1}{2} d$. a year and estimated at the annual value of $6 s .8 d$. This site wasconveyed to Edward Polyng, who was appointed the first prior "both by the superiors of the Order and by the aforesaid Hugh and John, ${ }^{16}$ and with

17 Tanner, Notitic, Dorset, xvi.

"Larking, The Knights Hospitallers in England (Camd. Soc.), 105-6.

${ }^{19}$ Hutchins, Hiss. of Dorset, i1, 502.

${ }^{1}$ Close, 52 Hen. III, m. 12.

${ }^{2} \mathrm{Cf}$, the houses of Friars Preachers and Minors at Clarendon; Liberate R. 34 Hen. III, m. 5 ; 54 Hen. III, m. 2.

${ }^{3}$ Rev. C. F. R. Palmer, "The Friar-Preachers of Melcombe Regis,' in The Religuary, xxi, 72-6.

'Cf. Leland, ltin. (ed. I745), iii, 65.

${ }^{3}$ Relig. xxi, from Bull. Ord. Praed.

${ }^{6}$ Pat. 8 Her. VI, pt. 3 , m. 4. him were associated friars John Lok and John Lowen to carry on the new foundation. They immediately established a chapel and set up an altar in one of the houses and began their spiritual ministrations among the people. John Chandler, bishop of Sarum, opposed the new foundation, and in 1426 shortly before his death declared the friars contumacious and forbade their proceedings. ${ }^{7}$ Deverell and Rogers, however, secured the royal licence for the foundation 16 February $1430-1{ }^{8}$ and addressed a petition to the bishop, Robert Neville. ${ }^{9}$ In this they stated that they had begun the house moved by the desolation of the town ; that there was no place dedicated to God in Melcombe; that the parochial church of Radipole was a long mile and a half away and was inconvenient for the burgesses; that the inhabitants were rude, illiterate, and situated in angulo terrae: that the vill lay open to enemies, whereby the king's rent was not paid and the customs were diminished. An arrangement was soon made with the bishop and the prohibition removed.

The friars did not confine their attention to the spritual welfare of the inhabitants, but contributed to the defence of the town and increase of the port by building a jetty against the ebb and flow of the tide. After they had begun this work, they determined to add a tower as a fortification for the town, port, and their own house. They therefore applied to the crown for help, and on 17 February, I 445-6, received from the king and council a grant of land, $1,000 \mathrm{ft}$. long and $600 \mathrm{ft}$. broad by the sea for the site of the tower in free alms without any rent, and also a sum of $f_{1}$ IO a year for twelve years out of the customs and subsidies of the port of Poole towards the expenses of making the jetty. ${ }^{30}$ In the Act of Resunption passed in 1450 this grant was specially exempted in consideration of the great charge and costs that they have had and yet must have in making and repairing of a jetty in defence of the said town of Melcombe against the flowing of the sea. ${ }^{11}$

'Sarum Epis. Reg. Chandler inter acta, fol. 54; Hutchins, Hist. of Dorset (ed. 3), ii, 454.

${ }^{8}$ Pat. 8 Hen. VI, pt. 3, m. 4.

- Sarum Epis. Reg. Neville, inter acta, fol. 34; Hutchins, loc. cit.

${ }^{10}$ Pat. 24 Hen. VI, pt. 2, m. 24.

"Parl. R. v, 187 . 


\section{RELIGIOUS HOUSES}

Friar Simon Ball or Bell, sometime prior of this house, was collated to the rectory of Radipole, 18 December, I 533. ${ }^{12}$ Owen Watson, rector of Portland, who died in 1533, willed his body to be buried at the Friars Preachers here where he had built a tomb for himself. ${ }^{33}$

Shortly before the Dissolution some new altars were erected and new stalls placed in the choir and new seats in the church, as appears from the inventory of the 'stuff' taken at the end of September $153^{8}$, when the bishop of Dover as visitor took the priory into the king's hands. ${ }^{14}$ Among the belongings of the house may be noticed in the choir a fair table of alabaster, 'a fair table follt of beyond sea work,' a frame of iron hanging for tapers, and new stalls: in the church, new altars, seven images, six marble stones, new ceiled seats at the Jesus altar, new seats in the body of the church, and a little bell in the steeple. The contents of the parlour, buttery, and vestry were few and poor: in the chambers were four old bedsteads, one feather bed and one flock bed : the kitchen also was scantily furnished, though everything seems to be included in the inventory down to a broken saucer. The visitor, however, paid his expenses and discharged the debts owing by the house, which amounted only to 20 s. He carried away a chalice weighing I I $\frac{1}{2} \mathrm{oz}$. and left the house in charge of John Clerke, controller of the customs. ${ }^{15}$ There was no lead except a few gutters, ${ }^{16}$ and the timber was hardly sufficient to keep the fences in repair. ${ }^{17}$

The Black Friars was let in 1541 to Sir John Rogers, knt., grandson of the founder, for twenty-one years at a rent of I 3 s. $4 d$. a year. ${ }^{18}$ Sir John purchased the whole with other

${ }^{12}$ Ellis, Hist. and Antig. of Weymouth, 261 ; Hist. MSS. Com. Rep. v, $58 \mathrm{I}$.

${ }^{13}$ Hutchins, Hist. of Dorset, ii, 454.

${ }^{16} L$. and $P$. Hen. VIII, xiii (2), 1214 .

15 Ibid. Ellis in his History and Antiquities of Weymouth (1829) has preserved an inventory of jewels and plate of this house which probably dates from the Dissolution; the articles mentioned are a short pair of beads of gold coral with eighteen stones of silver and a ring of silver and a Saint Dominic's shell ; sixteen rings of gold, and a 'gymmere' (a ring with two rounds of pearls) of stones and a buckle of gold; an Agnus Dei of silver; a circlet of silver ; a cross of silver ; a box with two silver beads; a paten of silver; a chalice of silver; a Holy Rood; a piscina; a pair of beads of gilt with stones of silver; a pyx; an ampul, etc. He also mentions a tradition that the prior had a wonder-working chair, the gift of a cardinal and engraved with a cardinal's hat and 'certain arms,' which at the Dissolution was 'converted into the municipal office of holding the persons of the borough representatives.' Ellis had, however, found no trace of it. The tradition (mentioned by Hutchins) that there was a nunnery adjoining the priory is without foundation.

${ }^{16}$ L. and P. Hen. VIII, xiii (2), 489 .

${ }^{17}$ Partic. for Gts. (P.R.O.), file 944.

19 lbid.; L. and P. Hen. VIII, xvii, 703 . monastic lands in 1543 , holding the friary at a rent of $16 d$. from the crown. ${ }^{19}$

The friary was situated in the east part of the town, in Maiden Street, near the sea. ${ }^{20}$ Leland called it a 'fair house.' 21 The patron saint of the church was, according to Speed, St. Dominic; according to Willis, St. Winifred. The cemetery appears to have been on the north side, where many skulls and bones were dug up in 1682. The priory was in a ruinous condition in 1650 , but some old buildings still remained in 1803 , including the church, which had been converted into a malt-house. In 186 I the whole of the buildings were pulled down and the ground cut up into building plots. ${ }^{22}$

\section{THE FRANCISCAN FRIARS OF DORCHESTER}

The Franciscan friary, or the priory, as it is generally called, stood on the north side of the town, on the banks of the river, a little east of the castle. ${ }^{23}$

The date and circumstances of its foundation are unknown. It was already in existence in 1267 , as in that year the friars were presented for encroaching upon the road by erecting a wall; ${ }^{24}$ that the encroachment was of recent date is shown by the entry in the same year of the death of a workmen who fell off the wall while building it. ${ }^{25}$ It is said by Speed to have been built by the ancestors of Sir John Chideock. ${ }^{26}$ Richard III claimed it as a royal foundation, ${ }^{27}$ probably with justice. At the time of the Dissolution there was still a room in the friary known as 'the king's chamber.' ${ }^{28}$ The house was already a large one containing thirty-two friars in May 1296, when Edward I gave them 32s. for three days' food through Friar Nicholas of Exeter. ${ }^{29}$ In a deed

19 L. and P. Hen. VIII, xviii (2), 241 (31); xix (1), 278 (40); Pat. 35 Hen. VIII, pt. 1, m. 34 ; and pt. $14, \mathrm{~m}$. 11 .

${ }^{20}$ Hutchins, Hist. of Dorset, ii, 454.

"Leland, Itin. iii, 65.

23 Hutchins, $H$ ist. of Dorset, ii, 455 .

${ }^{23}$ I bid. (ed. 3), ii, 364.

2 Assize R. 202. ${ }^{25}$ Ibid.

${ }^{26}$ Speed, Hist. 1055. Dugdale and others say it was built 'out of the ruins of the Castle.' The tradition that some monuments in St. Peter's church were monuments of the Chideocks and were removed from the Grey Friars church lacks confirmation: Hutchins, Hist. of Dorset, ii, 381 . For pedigree of the Chideock family, see ibid. 257. In the Year Book of $136+$ there is a reference to a 'college de $8 x x$ soers in le Precheurs de Dorcet': this is probably a mistake for Dartford: Les Reports des Cases on Ley (1679), Mich. 36 Edw. 111, 28.

${ }^{27} \mathrm{Harl}$. MS. 433 , fol. I 31.

${ }^{88} \mathrm{~L}$. and $P$. HEn. VIII, xiii (2), 474 (2).

${ }^{22}$ B.M. Add. MS. 7965 , fol. 7 . 


\section{A HISTORY OF DORSET}

dated I 3 IO a burgage held by the abbey of Milton is described as lying near the Friars Minors, ${ }^{30}$ and in the same year the house received legacies from Thomas Button, bishop of Exeter, ${ }^{31}$ and from Robert Bingham of Dorchester. ${ }^{39}$

Friars of this house received licence to preach and hear confessions, 2s Friar John of Grymston in $133^{8.3}$ About the time of the Peasant Revolt the head of the house was ordered by the king to correct Friar John Grey for having excited the cottagers and tenants of the abbot of Milton against their lord. ${ }^{34}$

Alexander Riston, rector of the church of Sarum, left these friars two quarters of corn and one of barley, c. 1 $393:{ }^{35}$ and Robert Grenelefe alias Baker of Dorchester left them his 'best bason with ewer and best brass pot' in 1420.6 They also had bequests from Elizabeth de Burgh, Lady Clare (1 355), ${ }^{37}$ Sir Robert Rous, knt. ( $\left.{ }^{8}{ }_{3}\right),{ }^{33}$ John de Waltham, bishop of Salisbury (1395), ${ }^{39}$ John Seward (1400), ${ }^{10}$ Sir William Boneville, knt. (1 407), ${ }^{4 J}$ William Ekerdon, canon of Exeter (1413), John Pury of Dorchester $(1436),{ }^{43}$ William Wenard of Devonshire (1441), 14 John Martyn of Dorchester (1 450), ${ }^{45}$ Thomas Strangways (I 5 I 4 ). ${ }^{46}$

Richard III in 1483 granted to the warden and brethren of this house full power to have the rule and governance of the hospital of St. John the Baptist in Dorchester, lately occupied by Sir Richard Hill, priest, and now in the king's hands, and to minister divine service there and receive the rents to their use, ${ }^{47}$ This hospital had been endowed with Ioos. of rent by William Mareschal of Dorchester in $1324{ }^{48}$ and in the time of Henry VIII the master of the chapel of St. John held nine burgages or tenements in the parish of St. Peter, thirteen in the parisl of All Saints, and two in that of Holy Trinity. ${ }^{49}$ The hospital had already been

${ }^{30}$ Hutchins, Hist. of Dorset, ii, 364 .

${ }^{31}$ Account of the Exicutors of . . Thomas bishop of Exeter (Camd. Soc.), 42.

${ }^{32}$ Hutchins, Hist. of Dorset, ii, 364 .

${ }^{33}$ Reg. Rad. de Salopia (Somers. Rec. Soc. ix), 322.

${ }^{34}$ Camb. Univ. Lib. MS. Dd. iii, 53 , fol. 97.

${ }^{35}$ P.C.C. Rous, fol. $66 b$.

${ }^{36}$ Hutchins, Hist. of Dorset, ii, 387 .

${ }^{37}$ Nicholas, Royal and Noble W'ills, 33-4.

${ }^{39}$ P.C.C. Rous, fol. 1 ; Coll. Top. et Geneal. iii, 100.

${ }^{39}$ P.C.C. Rous, fol. 32.

${ }^{10}$ Cant. Archiepis. Reg. Arundel i, fol. I93a; cf. Hutchins, Hist. of Dorset, ii, 389-9o.

"Excter Epis. Reg. Stafford, 391.

12 Ibid. 402

${ }^{33}$ Hutchins, Hist of Dorset, ii, 364,388 .

"P.C.C. Rous, fol. 105.

is Hutchins, Hist. of Dorset, ii, 364,388 .

${ }^{16}$ P.C.C. Fetiplace, qu. I 3 .

"Harl. MS. 433 , fol. $13 \mathrm{~J}$.

4 Pat. 17 Edw. II, pt. 2, m. 28.

'Hutchins, Hist. of Dorset, ii, 408-9. conferred on Eton College by Henry VI and it is doubtful whether the grant of it to the Grey Friars took effect. ${ }^{50}$ The friars, however, at the time of the Dissolution held three tenements in the parish of All Saints and four in the parish of Holy Trinity. ${ }^{51}$ In March 1483-4 the king further ordered the receivers and tenants of the manors of Litcle Crichel, Chideock, and Caundle Haddon to pay in all 80 s. a year to this friary. ${ }^{52}$

An important addition was made to the possessions of the convent in 1485 , when Sir John Byconil, knt., built and gave them some mills on the water that ran by the friary. The friars in return recognized him as chief founder of the house, conferred on him special spritual benefits and engaged to celebrate his decease on the day after the feast of St. Francis. The mills were given on the following conditions : (1) that 40 s. of the profits of the mills should be set aside each year for repairs; (2) that the friars should take it in turn week by week to pray for the donor and each should at the end of his week receive $6 d$.; the cursors or lecturers 'being diligently employed about their scholars' were excused this service and entitled to receive the alms, provided that they substituted another to perform the office; (3) each friar praying at the obsequies of Sir John should receive an alms; (4) the remainder of the revenues derived from the mills was to be employed

in bringing of boys into the Order and their education in good manners and learning and in making good the books in the choir and in no other way : and the brethren so brought in and educated to the perpetual memory of the said John were to be called Byconil's Friars and none of them to be called by their surnames.

If these conditions were not fulfilled, the profits of the mills were to be divided equally between the Franciscan houses of Bristol, Bridgwater, and Exeter. The agreement was confirmed by William Goddard, D.D., provincial minister, and John Whitefield, custodian of Bristol, and the seals of the provincial minister, the custodian, and the convent were affixed to the deed. ${ }^{53}$

It is noteworthy that Sir John Byconil made no bequest to any houses of friars in his will in I 500. ${ }^{54}$ His widow Elizabeth left 20s. to the friars of Dorchester in $1504 .^{55}$ In 1510 John Coker, esq., having given the friars a barn and a garden annexed, on the south side of the cenetery, was admitted with his family and

${ }^{50}$ On this hospital see Dugdale, Mon. vi, 759.

sl Ibid.

${ }^{52}$ Harl. MS. 433 , fol. $164 b$.

${ }^{33}$ Fr. a. S. Clara (Chr. Davenport), Hist. Minor Frotrum Minorum Pros. Angliae, 37-8; Collecsanca Ang.o-Minoritica, i, 208 ; Dugdale, Mon. vi ; Hutchins, Hist. of Dorset, ii, 364 .

${ }^{34}$ P.C.C. Blamyr, 5

ss Ibid. Holgrave, 15. 


\section{RELIGIOUS HOUSES}

successors to the privileges of confraternity by Richard Draper, D.D., custodian of the custody of Bristol and warden of the convent of Dorchester. ${ }^{86}$

Sir Roger of Newborough, knt., and William who was abbot of Milton $1481-$ I 525 granted to these friars an annual alms of 43 s. $4 d$. from lands in Upper Stirthill. ${ }^{37}$

The bishop of Dover visited the house in September, 1538, and had some difficulty in obtaining the surrender; ${ }^{58}$ he notes that the warden, Dr. Germen, ${ }^{89}$ had been there many years and was in high favour, so that he (the writer) had much trouble to come to a knowledge of the state of the house. Finding that the mill, which was worth $f$ io a year, had been recently let to Lord Stourton for $£ 4$, the visitor seized it into the king's hands and retained the miller to the king's use. The deed of surrender was signed on 30 September, I 538, by Dr. William Germen, Edmund Dorcet, Thomas Clas, John Tregynzyon, John Clement, John Laurens, Stephen Popynjay, and Thomas Wyre. ${ }^{60}$ The 'stuff' was delivered to the bailiffs of the town on behalf of the king: it included a table at the high altar of imagery after the old fashion, a small pair of organs, fair stalls well canopied, and divers tombs in the choir, four tables and three great images of alabaster, a new tabernacle for the image of St. Francis, divers images stolen (?), and divers tombs in the church; three bells of different sizes in the steeple. In the vestry six suits with other vestments, some of them with blue velvet embroidered. In the chambers a feather bed without a bolster, blankets, quilt and sheets; two old carpets, 'one of them in the king's chamber,' besides furniture in the hall, frater, buttery, kitclien and brew-house. Further, to redeem plate in pledge for $£ 3$ and to pay certain wages and the visitor's charges the following articles were sold : an iron grate about a tomb in the church (40s.), a white vestment with deacon and subdeacon (4Os.), two feather beds and a covering ( 1 Os.), ' an old cope durneks,' a pillow and old iron with a holy water stoup (75. 8d.). The visitor also sold a press standing in the vestry for 13s. $4 d$. The plate weighed $126 \frac{1}{2}$ oz. There were also various deeds and 'two horses belonging to the mill.' ${ }^{61}$ Part of the steeple and three panes of the cloister were covered with lead. ${ }^{62}$

William, Lord Stourton, sought to secure a grant of the Grey Friars, ${ }^{63}$ but the house and grounds were in 1539 leased and in 1543 sold

\footnotetext{
${ }^{56}$ Hutchins, Hist. of Dorset, ii, 365 .

57 Valor Eccl. (Rec. Com.), i, 251.

${ }^{58}$ L. and P. Hen. VIII, xiii (2), 482 .

${ }^{59}$ Cf. Little, Grey Friars in Oxf. (Oxf. Hist. Soc.),

${ }_{60} L$. and P. Hen. VIII, xiii (2), 474.

61 Ibid.

6? Treas. Receipts (P.R.O.), A. $\frac{3}{11}$, fol. 4 .

${ }^{63} L$. and P. Hen. VIII, xiii (z), $4^{82}$.
} 275 . to Edmund Peckham, cofferer to the king's household. ${ }^{64}$ The property, consisting of the house and site, with water-mill and 6 acres of ground, was valued at $£ 4$ a year, less 8 s. for the tenth, and the price paid was $£ 72 .^{65}$ Peckham had at the time of the Dissolution bought the elms growing on the property for $£ 8{ }^{66}$ He sold the estate to Thomas Wriothesley, earl of Southampton, and Paul Dorrel, esq., in 1547, and it subsequently passed to Sir Francis Ashley, knt., whose heiress brought it to Denzil, Lord Holles. ${ }^{67}$

\section{WARDENS}

John Colsweyn, $1327^{68}$
John Loss, I $485^{69}$
Richard Draper, I 510
William Germen, I $53^{8}$

\section{THE CARMELITE FRIARS OF BRIDPORT}

In a letter of which the superscription is lost the writer, who represents himself as the special protector of the Carmelite order, requests his correspondent 'to permit the friars to perform divine offices without molestation or difficulty in the oratory which they have built at Bridport. The letter was probably written by Cardinal Ottobon, papal legate in England 1265 to 1268 , to Walter de la Wyle, bishop of Salisbury. ${ }^{70}$ In 1269 the Carmelites of Bridport received a legacy of 2s. from Christina de Strikelane, widow, of Bridport. ${ }^{71}$

The house had only a brief existence. In 1 365 Sir John Chideock, knt., applied for licence to confer on the provincial prior and Carmelite Friars of England 3 acres of land in Bridport for the establishment of a friary, together with a mill the profits of which would supply them with bread, wine, wax, and other things necessary for celebrating masses. An inquiry being held, the jurors declared that the grant would be injurious to the patron and rector of the church of Bridport, and the licence was not given. ${ }^{72}$ It would appear from this that the

64 Ibid. xv, 555 (Aug. Off. Bk. 211 , fol. 24); xviii (1), 98 I (1 08).

${ }^{65}$ Partic. for Grants, file 852, m. 2, 6 ; Hutchins, Hist. of Dorset, ii, 366.

66 Partic. for Grants, ibid. m. 3.

67 On the history of the site see Hutchins, Hist. of Dorset, ii, $36_{5}-6$.

${ }^{68}$ Sarum Epis. Reg. Mortival, ii, 187 ; Hutchins, Hist. of Dorset, ii, 365 .

${ }^{69}$ Franc. a. S. Clara (Chr. Davenport), Hist. Min. Frat. Minorum Prov. Angl. 37-8.

${ }^{70}$ Bodl. MS. Laud. Misc. 645 , fol. I 35 ; other letters in the collection appear to have been written by a papal legate about this time.

${ }_{11}$ Hutchins, Hist. of Dorset (ed. 3), ii, 19.

${ }^{72}$ Inq. a.q.d. file 355 , No. 13. The writ says roa., the return $3 a$. 


\section{A HISTORY OF DORSET}

original settlement had either ceased to exist or that the friars were for some reason compelled to vacate their premises. No further attempt to re-establish the Carmelites in Bridport appears to have been made.

\section{I6. THE CARMELITE FRIARS OF LYME}

In November, 1325 , a jury of inquest declared that it would not be to the king's prejudice if he licensed William Darre, chaplain, to grant a 'nessuage and 8 acres of land in Lyme to the Carmelite Friars. The land paid 155. I0 $\frac{3}{4} d$. towards the firm of the town and was worth 2 s. a year besides. ${ }^{73}$

The house does not seem to have been founded. ${ }^{76}$

\section{THE AUSTIN FRIARS OF SHER- BORNE}

In 1343 Robert of Bradford had licence to grant to the provincial prior and Austin Friars in England a messuage and 8 acres of land in Sherborne to build thereon an oratory and houses for friars of their order. ${ }^{75}$ The house does not seem to have been founded.

\section{HERMITAGE}

\section{THE 'PRIORY HERMITAGE' OF BLACKMOOR ${ }^{1}$}

Obscure though the early history of this house is it may reasonably be assumed that, originally a hermit settlement in the heart of the forest of Blackmoor, it attracted to itself so large a company of the faithful that a community was formed, a rule adopted-apparently similar to that of the friars hermits of St. Augustine, though the hermitage seems clearly never to have been affiliated to that order-and the brethren placing themselves under the protection of the lords of the forest, the earls of Cornwall, who had permitted if not built the earlier foundation, acquired the site of their dwelling and such property from time to time as the generosity of their patrons added to them. The precise date of these events cannot be given, though they probably took place in the reign of Henry III. Edmund, earl of Cornwall, died in I 300 seised of the hermitage in Blackmoor, ${ }^{2}$ and in 1314 Edward II granted a licence to the brethren to retain without let or hindrance of any justice or forest officer the land which they had acquired within the forest without licence from his predecessors, comprising the site of their hermitage,

${ }^{73}$ Inq. a q.d. file $18_{3}$, No. 4 .

"William of Worcester (Itin. 372), speaking of Thomas Beaufort, duke of Exetcr, says : 'Item habuit iii vel iiii infantes et obierunt apud Lyme inter fratres.' (?)

${ }^{75}$ Inq. a.q.d. file 265 , No. 12 ; Pat. 17 Edw. III, pt. 1, m. 17 .

1 This house has not been fully or correctly treated by previous compilers. Tanner, in the earlier Notitio (1744), mistaking it for an Austin priory of the samc name in Essex, states that it was dedicated to St. Lawrence and attributes to it various references relating to the Essex house. The matter is not cleared up in the later Notitia, and the edition of the third and corrected edition of Hutchins, while giving much fresh information, repeats some of the old errors. Hist. of Dorset, iv, 467 . consisting of 10 acres of land the gift of Ralph, earl of Cornwall, 7 acres acquired from Richard, earl of Cornwall, who died in 1272 , and 7 acres bestowed by Edmund, the late earl, ${ }^{3}$ which they had inclosed according to the assize of the forest so that the deer could enter and leave. The following year the prior and hermits were allowed 8 acres of land out of the waste of the forest in a place called 'Rocumbe,' with liberty to inclose the same with a little dyke and low hedge and bring it into cultivation, ${ }^{4}$ and in I 325 Ingelram Berenger, who had been appointed steward of the forest, ${ }^{5}$ made over to them Ioo acres of land in 'Rocumbe,' held in clief for the service of rendering $32 \mathrm{~s}$. $4 \%$. at the Exchequer, on condition that they should find a chaplain to celebrate daily in the church of the hermitage for the souls of the said Ingelram and the faithful departed and for the maintenance of ten mendicants to be refreshed once a day in the hermitage. ${ }^{6}$ The last charge seems to have dropped speedily out of practice and even memory, for the return made to the writ of Edward III, dated November, 1338, requiring to be certified whether it would be to the injury of the king or any other for the prior and chaplains of the hermitage of Blackmoor Regis, Dorset, to retain It messuages, IOO acres of land, $2 \frac{1}{2}$ acres of meadow with a rent of 67 s. 4 d. and of a pound of cummin in Knighton, Fossil, Winfrith, and Baltington, which they had acquired in fee from the late Ingelram Berenger since the publication of the Statute of Mortmain without licence of the late king,

\footnotetext{
'Inq. p.m. 28 Edw. I, No. 44. Unfortunately the section giving the return relating to the hermitage within Blackmoor forest, parcel of the duchy of Cornwall, is reported as 'missing' at the P.R.O.

${ }^{3}$ Pat. 7 Edw. II, pt. 2, In. 15; see Dugdale, Baron. of Engl. i, 761 .

- Pat. 9 Edw. II, pt. 1, m. 28.

Ibid. 18 Edw. II, pt. 1, m. 25.

- Ibid. 19 Edw. II, pt. I, m. 13 .
} 


\section{RELIGIOUS HOUSES}

stated that the grant had been made on condition that the brethren should pay the said Ingelram the true yearly value of the same during his life and after his death should provide a chaplain to celebrate daily for the souls of the kings of England, of Ingelram and the faithful departed, ${ }^{7}$ without mention of the daily provision for mendicants ; possibly it may have ceased owing to the financial condition of the house, for the grant of the following February, enabling them to retain the land and premises, records that it was made by fine of roos. because of the poverty of the said chaplains. ${ }^{8}$

A few particulars as to this forest house may be gleaned from the episiopal registers. They record that the house belonged to the order of St. Augustine and that the prior and brethren were presented to the ordinary for examination and approval before admission, as in the case of John de Ramesham, 28 October, 1327 ; $^{\circ}$ William de Bradewas, who was presented to the custodian of the spiritualities of the bishopric, Robert de Worth, ${ }^{10}$ in the vacancy of the see, 8 May, I330; another instance is recorded 2 October, $1387 .{ }^{11}$ On the resignation of John de Ramesham the house presented John de Wyke to the bishop, who on account of the poverty of the brethren proceeded to admit him in a summary manner, 9 July, $1340 .{ }^{12}$ In I 389 , all the inmates being dead, the bishop bestowed the house in commendam on Thomas Wilton 25 August. $^{\mathbf{1 3}}$ An inquisition being held as to its state in 1424 it was found that the house was of royal foundation and that the king held the custody of it when vacant, that the brethren elected a prior subject to the royal assent, and that the house was not taxed at Io marks per annum.

After this date the style of the house alters and it becomes known as the free chapel of St. Mary, 'called the Hermitage,' and as such was placed by Edward IV in 1469 in the custody of William Brown, clerk, who already held the mastership of the hospital of St. John the Baptist, Dorchester, with a grant for life of the yearly pension or annuity of $525.2 d$. with which the chapel was charged to the king, of which $38 s$. rod. was payable to the Exchequer and 13s. $4 d$. to the bailiff of the king's manor of Fordington for the use of the duke of Cornwall, on condition that he should maintain the old service and pray for the good estate of the king

\footnotetext{
${ }^{7}$ Inq. p.m. 2 Edw. III (2nd nos.), No. 147.

${ }^{8}$ Pat. 3 Edw. III, pt. I, m. 35.

${ }^{9}$ Sarum Epis. Reg. Mortival, fol. 164.

${ }^{10}$ Ibid. Wyville, fol. 3.

"Ibid. Erghum, foI. 84 .

${ }^{12}$ Ibid. Wyville.

13 Ibid. Waltham.
}

and his consort and for their souls after death. ${ }^{14}$ Henry VI the following year, I 7 December, 1470 , ratified the estate of William Brown as master of the hospital of St. John the Baptist, Dorchester, and as master of the house or chapel called 'le priory hermitage' by Dorchester. ${ }^{15}$ On the death or cession of William in I473 Edward IV made a grant of the custody of the 'chapel' to Robert Bothe, doctor of law, ${ }^{16}$ the deed being annulled four years later, November, 1477, in favour of Master Robert Myddelham, bachelor of theology. ${ }^{17} \mathrm{He}$ was succeeded by Richard Hill, dean of the king's chapel, appointed by Henry VII in the first year of his reign, ${ }^{18}$ who was again followed by John Cole, appointed by Henry VIII in $1511 .{ }^{19}$ Two years later, on the surrender of the patent by which it had been bestowed on John Cole, ${ }^{20}$ the king granted the free chapel called 'le Hermytage' in Blackmoor to the abbot and convent of Cerne.

No reference is made to this house in the chantry certificates of Henry VIII and Edward VI.

\section{Priors or Masters of Blackmoor}

William, occurs $1327^{21}$

John de Ramesham, resigned $13+0^{22}$

John de Wyke, presented $1340^{23}$

Richard Andrew, presented $1349^{24}$

Thomas Marshall ${ }^{25}$

Thomas Wilton, appointed $1389^{28}$

John Baret, appointed $1424^{27}$

William Brown, appointed $1469^{28}$

Robert Bothe, appointed $1473^{29}$

Robert Myddelham, appointed $1477^{30}$

Richard Hill, appointed $1485^{-6}{ }^{31}$

John Cole, appointed 1511 , surrendered $15^{1} 3$ on the annexation of 'le Hermytage' to the abbey of Cerne ${ }^{32}$

14 Pat. 9 Edw. IV, pt. 2, m. 22.

15 Ibid. 49 Hen. VI, m. 12.

16 Ibid. 13 Edw. IV, pt. 1, m. 3 .

${ }^{17}$ Ibid. $17 \mathrm{Edw}$. IV, pt. 2, m. 23.

${ }^{18}$ Hutchins, Hist. of Dorset, iv, 467 .

${ }^{19}$ Pat. 3 Hen. VIII, pt. 1, m. $3 d$.

${ }^{2}$ L. and P. Hen. Vlll, i, 3853 .

11 Sarum Epis. Reg. Mortival, fol. 164.

${ }^{23}$ Ibid. Wyville.

${ }^{23}$ Ibid. ${ }^{24}$ Ibid.

${ }^{2.5}$ Hutchins, Hist. of Dorset, iv, 467 .

"2 Sarum Epis. Reg. Waltham.

${ }^{27}$ Hutchins, Hist. of Dorset, iv, 467 .

${ }^{28}$ Pat. 9 Edw. IV, pt. 2, m. 22.

${ }^{29}$ Ibid. 13 Edw. IV, pt. 1, m. 3 .

${ }^{30}$ Ibid. $17 \mathrm{Edw}$. IV, pt. 2, m. 23.

s1 Hutchins, Hist. of Dorset, iv, 467 .

${ }^{32}$ Pat. 3 Hen. VIII, pt. $1, \mathrm{~m} .3 d$. $L$. and $P$. Hen. VIII, i, 3853 . 


\section{A HISTORY OF DORSET}

\section{HOUSE OF UNCERTAIN ORDER}

\section{WILCHESWOOD 1}

The history of this priory, chantry, or free chapel is very obscure, and can only be partially reconstructed with the help of certain documents which came into the possession of the Coker family on the Dissolution. ${ }^{2}$ Coker, in his Survey of Dorset (1 732), states that this house,'dedicated to St. Leonard, was founded by Roger le Walleys, lord of the manor of Langton Wallis and grandson of Ingelram le Walleys, in the fortyseventh year of Edward III (1373); ${ }^{3}$ but it was certainly founded many years earlier, probably in the first part of the century. According to a charter, undated, Alice, once the wife of William de Ponsont and widow of Ingelram le IValleys, gave a tenement in the manor of Mappowder for the maintenance of IVilliam Bonet, chaplain, to celebrate an obit for the souls of the said William and their ancestors at Wilcheswood for life, with a proviso that in the event of the transference of the prior and brethren of the house the chaplain should receive satisfaction out of the revenues. ${ }^{4}$ By another deed, also undated, IVilliam de Watercumb, chaplain, warden of the house of St. Leonard at Wilcheswood and the brethren there leased to William Aignel and his wife of Stour Provost a certain tenement with houses, lands, \&ic., for the term of their lives for the sum of 8 marks sterling in hand. ${ }^{5}$

Roger le WValleys, Wallis, or Walsh, whom Coker erroneously gives as the founder, appears to have added rather to the endowment of the house; in 1373 he presented Henry Attechapelle, chaplain, to the chantry, that he might find maintenance for himself and two fellows (socii) in the chapel of Wilcheswood and St. George of Langton (Matravers), serving God and St. Leonard there, with the grant for life of I caru- cate of land in Mappowder, and charged only with the provision of a lamp to burn during mass in the chapel of Langton. ${ }^{6}$

The advowson of the priory appears always to have accompanied the manor, and by a fine levied in 1398 between John Fauntleroy and Joanna his wife, granddaughter of Roger le Walleys, and John Foliol, the second husband of Margaret, daughter of the same, the manor of Langton IVallis, \& c. with the 'chantry' of Wilcheswood was granted to John Foliol for his life with remainder to William Foliol his son and Joanna his wife and the heirs of Joanna. ${ }^{7}$ In the third year of Henry $V$ William Talbot, clerk, warden of the chantry of IVilcheswood, delivered over to IVillian Foliol the muniments of the chantry, consisting of nineteen charters and indentures sealed, and one indenture unsealed, two papal bulls, four royal letters patent, and a copy of the presentation of Henry Attechapelle by Roger le Walleys. ${ }^{8}$

The lands of the priory in the reign of Henry VIII consisted of a carucate of land in Mappowder valued at 6s., lands in Knowlton, parcel of the manor of IVoodlands, with other lands and a mill estimated at $f_{6} 6 \mathrm{I} 6 \mathrm{~s} .4 d . ;^{9}$ after the Dissolution these came into the hands of the Coker family.

\section{Chaplains or Wardens}

Adam de Watercumb, occurs in a deed without date 10

Ralph de Sayr, occurs in a deed of $1316-17^{11}$

Henry Attechapelle, presented $1373^{12}$

William Talbot, occurs 1413 and $1417^{13}$

Richard Petworth, presented $1417^{14}$

Hugh Filiol, occurs 1506-7, and in the reign of Henry VIII ${ }^{16}$

\section{HOSPITALS}

\section{THE HOSPITAL OF ST. MARY MAGDALEN, ALLINGTON}

At Allington, ${ }^{1}$ anciently a village not far distant from Bridport and now forming part of the borough, was a lazar house or hospital for lepers dedicated to the honour of St. Mary Magdalen.

\footnotetext{
1 At the time of the Domesday Surver, Wilceswode, as it is termed, formed part of the holding of the widow of Hugh Fitz Grip; Dom. Bk. (Rec. Com.), i, 84 .

"Hutchins, Hist. of Dorset, i, $6+1$; iii, 729 , note $b$.

${ }^{3}$ Hutchins, op. cit. i, 48 . 'Ibid. i, 641 .

${ }^{5}$ Ibid. iii, 729 . ${ }^{6}$ Ibid. i, 641 .

Ibid. 637 Ibid. 641 .

Ibid. and iii, 729 .
}

Various accounts are given of its foundation. Coker, in his Survey of Dorset, attributes it to the family of the Chideocks. ${ }^{2}$ Hutchins, reciting an instrument contained in the corporation archives of Bridport, states that it was 'founded, or rather better endowed,' by John Holtby;, canon of Salisbury and custos of the house de

${ }^{10}$ Hutchins, Hist. of Dorset, $\mathrm{i}, 6+1$.

"Ibid. iii, 729. $\quad{ }^{18}$ Ibid. i, 64 I.

${ }^{13}$ Ibid. iii, $729 ;$ i, 641 .

"Ibid.

${ }^{1}$ In Domesday Book the village occurs as Adelingtone (Rec. Com. i, 8ob). Later it is given also as Athelington or Allington.

2 Op. cit. (ed. 1732), 24. 


\section{RELIGIOUS HOUSES}

valle scholarium or Vaux College, in the latter part of the reign of Henry $\mathrm{VI} .^{3}$

Other records show us, however, that the house had at that time been in existence for considerably over two hundred years, and may claim to be one of the earliest foundations of its kind within the county. In I 232 Henry III granted letters of protection without limit to the lepers of St. Mary Magdalen of Bridport, ${ }^{4}$ as from its proximity to the town it was indifferently termed, and by her will dated St. Gregory's Day, I268, Christine de Stikelane left among other bequests to the religious establishments of the town and neighbourhood 'vid. to the Magdalene house of Adlington.' 5 The hospital appears to owe its original endowment-if not foundation-to the de Lega or de Legh family, for by a document, previous to the year 1265 , and still preserved at Bridport, William de Legh the son of Philip de Legh ${ }^{6}$ granted to the house of St. Mary Magdalen of Allington called 'The Hospital of the Lepers of Mary Magdalen of Bridport' for the good of his soul and for the soul of his wife. Dame Nicola de Legh 50 acres of arable land in 'Alingtone' with pasture for one steer, six oxen, three cows, and fifty sheep, a sufficiency of marl for marling their lands, of turf to be taken from his moor, and liberty to be 'sterefry' and toll-free in his mill. In return for these benefactions two chaplains at least should be appointed by the house 'of laudable life and honest conversation, one of whom should say a mass of the Blessed Virgin Mary with a special collect for his soul and for the souls of Dame Nicola his wife, Geoffrey de Auk' and Isota his wife, Master John de Bridport, physician, and Robert the serjeant of 'Alingtone'; the other chaplain, on days not feast days, should pray in his first prayer especially for the souls of the same. ${ }^{7}$

Further, a covenant dated at Leghe, I 265 , between William de Legh, knight and lord of Allington, and William de Stikelane and Hugh Rodhum, provosts of Bridport, and other good and lawful men, sets forth that whereas the said William had given to the said provosts \&c. full power to administer his grant of lands to the two chaplains, brethren, and lepers of St. Mary Magdalen of 'Alingtone' aforesaid, they were empowered to compel the said chaplains, brethren, and lepers to observe the terms of the grant, and directed to hold an inquisition yearly at Easter

${ }^{3}$ Hutchins, Hist. of Dorset, ii, 206.

- Pat. 6 Hen. III, m. 3.

B From the corporation archives quoted by Hutchins under 'Bridport,' ii, 19, note $a$.

${ }^{6}$ In the reign of King John, 1206, Richard Wallensis quitclaimed to Philip de Lega and Clarice his mother all his rights in half a knight's fee in Allington; Hunter, Pedes Fin. ii, 95.

${ }^{7}$ Rec. of Corp. of Bridport (Hist. MSS. Com.), Rep. vi, App. 486. and Michaelmas to ascertain whether the chaplains were living honestly, and whether the brethren and lepers were treated in a due and humane manner, together with other conditions of the grant. ${ }^{8}$

The later grant of John Holtby in 3 I Henry VI aforementioned was of the nature of a re-foundation, the terms of which were carefully planned with a view to safeguard the interests of the parochial chapel of St. Swithun, within whose limits the hospital lay, and to prevent the possibility of any dispute between the two. Drawn up with the consent of the dean and chapter of Salisbury, here given as patrons of the house, it gave permission to the brethren and sisters of the hospital to have two chaplains to celebrate daily in their chapel, 'saving the rights of the chapel of St. Swithun.' They might receive all obventions and oblations of the said chapel, but none from the parishioners of Adelington or Allington. Certain tithes were assigned or rather confirmed to them from their first foundation and their present benefactor quitclaimed to them I mark of silver which they were accustomed to pay annually to the chapel of St. Swithun for their 'chantry.' The brethren and sisters were expected to provide for the chaplains. ${ }^{9}$

As time went on and Allington became practically merged into Bridport, we find the hospital more usually entered under the name of the latter; in the confusion thence arising, many writers have supposed that there were two religious foundations at Bridport, both of which, according to the early edition of Hutchins and Tanner, were dedicated to the honour of St. John the Baptist, while the explanation offered by the editors of the late and amended edition of Hutchins hardly accounts for the fact of two entries appearing under Bridport in the Valor Ecclesiasticus of 1535 , one of which we can now see belongs to Allington. ${ }^{10}$ All the ecclesiastical authorities of the town in 1444 joined together in aid of the work of repairing the haven, promising for themselves and their successors that all benefactors of the port should be remembered in the prayers and masses they were bound to offer daily for their founders; the list of clerical persons thus associated includes the names of John Hasard, chaplain of the 'chantry' of the Blessed Mary Magdalen, and John Brode, chaplain and stipendiary there."

${ }^{8}$ Ibid. $485-6$.

${ }^{9}$ Hutchins, Hist. of Dorset, ii, 206.

10 They hazard the conjecture that these two houses were one and the same without accounting for the fact of the separate entries. Leland's description by its ambiguity has furthered the error. Proceeding from Chideock to Bridport he says 'there was in sight or ever I came over the river into Bridport a lazar house and not far off a chapel of St. Magdalen in the which is a chantry founded. And over the bridge a little by west in the town is a chapel of St. John'; Leland, Itin. iii, 6 I.
Ibid. ii, 16. 


\section{A HISTORY OF DORSET}

The Valor of 1535, which gives the hospital as the priory of Blessed Mary Magdalen of Bridport, states that it was worth $f_{0} 6$, and that Henry Danyell was prior there ${ }^{13}$; by the chantry commissioners it was valued at $£^{6} 8$ s. $4 d$., and again at $£ 78 \mathrm{~s} .4 d$., and they reported that it had among its possessions 'one chalice of $6 \mathrm{oz}$.' two pairs of old vestments, two candlesticks worth $8 d$, and two bells worth $20 s_{0}$; the house was certified

to be ordeyned for the relief of lefers and lazar men and to one priest to say mass before them, the profits thereof the priest hath for his stipend, the poor men live by alms of the town. ${ }^{13}$

The last incumbent, Robert Blakewell, received a pension of $£^{6 .{ }^{14}}$ In the third year of his reign Edward VI granted the hospital and lands belonging to it to Sir Michael Stanhope and John Bellow, and in the same year they came into the possession of Giles Kelway. ${ }^{15}$ Unter the name of the Magdalen Charity the hospital still exists as an almshouse for eight poor women.

\section{Masters}

John Brode, occurs $1444^{16}$

Henry Danyell, occurs $1535^{17}$

Robert Blakewell, last incumbent ${ }^{28}$

\section{HOSPITAL OF LONG BLAND- FORD}

Hutchins states that there was here a hospital for lepers, mentioned in an old deed of the date of $10 \mathrm{Edward}$ I. ${ }^{19}$ Nothing further is known of its existence, but local tradition preserves its memory in a farmhouse w thin the parish of Langton or Langton Long Blandford, known as St. Leonard's Farm.

\section{HOSPITAL OF ST. MARY AND THE HOLY SPIRIT, LYME}

Beyond one reference we know nothing of a hospital for lepers founded here. In 1336 Bishop Robert Wyville of Salisbury granted an indulgence for the repair of the fabric and belltower. ${ }^{20}$

${ }^{13}$ Valor Eccl. (Rec. Com.), i, 232.

${ }^{13}$ Chant. Cert. 16, Nos. 5t, 62.

14 Pensions to Religious in Dorset, Add. MS. 19047, fol. $8 d$.

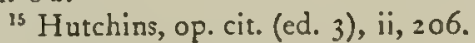

16 Ibid. 16.

17 Valor Eccl. (Rec. Com.), i, 232.

19 Add. MSS. 19047 , fol. $8 d$.

${ }^{19}$ Hist. of Dorset, i, 98.

${ }^{20}$ Sarum Epis. Reg. Wyrille, i, fol. 40 d. Hutchins, Tanner, and Dugdale state that this hospital is valued in the chantry certificate of Edward Vl at 38s. 11 , , but furcher evidence is wanting to establish identity

\section{HOSPITAL OF ST. JOHN THE BAPTIST, BRIDPORT}

Though the date of its foundation caunot be exactly stated it is evident, from its mention in various deeds of the time of Henry III belonging to the corporation of Bridport, that the hospital here, like that of Aliington, was already in existence in the earlier half of the thirteenth century. ${ }^{21}$ Among these documents is a charter, dated 1240 , which recites that Helias de IVroccheshel, for the good of his soul and those of his ancestors and successors, has granted and confirmed to the house of the Blessed John the Baptist in Bridport within the east bridge, and to the brethren and sisters serving God there, leave to graze ten oxen, four yearling cows, one hog, one steer, and fifty sheep in the whole of his pasture land at IValditch, except in his meadows in fence-time (in tcmpore defencionis), as well as sufficient fencing from his wood to inclose their land in IValditch. ${ }^{22}$ Another deed sets forth an agreement, made on Christmas Day, 1271, whereby John, son of IVilliam Telle of Bridport, leased to Sir William, prior of the hospital of St. John, a certain croft situated between the land of St. John and the way leading to the mill of Richard Killing, together with a house, curtilage, and croft bounded by the curtilage which lately belonged to Osbert Baldwyn. ${ }^{23}$ The benefactors of the hospital were numerous, and included Mabel, the daughter of Edward Hux, who, in her widowhood, gave to God and the brethren and sisters serving God in the hospital of St. John, Bridport, $1 \frac{1}{2}$ acres of land in Portmannefeld for the soul of Richard her late husband; ${ }^{24}$ Richard Hux, who, by charter undated but belonging to the time of Edward I, engaged himself to pay $12 d$. yearly to Roger de Rydeclive, warden of the hospital and his successors, from his tenement in the South Street of Bridport ; ${ }^{25}$ Christine de Stikelane, who, by her will, dated in 1268 , left various small sums to the religious foundations of her town, bequeathed ' $x$ iid. to the "church" of the Blessed John." ${ }^{26}$

Little is recorded of this hospital beyond what is contained in these and similar charters. It appears to have been in the patronage of the bailiffs and commonalty of Bridport, who, by an indenture dated on Sunday after the Feast of

between this hospital for lepers and the service of the Blessed Mary, for which the sum of 38 s. $11 d$. was applied towards the finding of ' a clerke and children,' the only entry under Lyme Regis in the said chantry certificate. Chant. Cert. 16, No. 71.

"Rec. of Corp. of Bridport (Hist. MSS. Com.), Rep. vi, App. 475-99. $\quad{ }^{23}$ Ibid. 48 z.

${ }^{23}$ Given by Hutchins from the same source, Hist. of Dorset, ii, 19.

${ }^{24}$ Hist. MSS. Com. Rep. vi, ApP. 479.

${ }^{25}$ Ibid. $4^{8}+6$.

${ }^{26}$ Hutchins, Hist. of Dorset, ii, 19, note $a$. 


\section{RELIGIOUS HOUSES}

St. Peter and St. Paul (29 June), I 357, granted the custody of the hospital, together with the administration of its goods, to John de Shapwick, chaplain, on the understanding that he by himself or a fit chaplain should celebrate daily in the chapel. ${ }^{27}$ A document still exists among the town archives entitled-

Implements of the priory of St. John the Baptist delivered to Sir John Syltere by Richard Burgh and John Cryps, Bailiffs of Bridport, received from Hugh Prior, late prior there, the 9th October in the 32 nd year of King Henry VI,

the possessions and furniture of the inmates are set out under the following headings:-In the Chapel, In the Hall, In the Pantry, In the Kitchen, In the Chamber. ${ }^{28}$ In the deed of I 444, to which all the ecclesiastical authorities of the town set their hands pledging themselves to assist in the pious work of repairing the haven, the master or warden here, John Shipper, is styled 'prior of St. John.' ${ }^{29}$

The clear income of the house, according to the Valor of $1535,^{30}$ was estimated at $£ 86$ s. I $d$., the name of the then prior being Robert Chard. The chantry commissioners in the reign of Edward VI stated that it was worth $f^{6}$ I 5 s. $8 d$, out of which $16 s$. should be deducted in rents resolute; ${ }^{31}$ the incumbent, William Chard, received the whole profits for his own use ; ${ }^{32}$ there was found there 'one chalice and one gold ringe of I 2 oz.,' two 'lytle' bells worth 20s., and 'certain ornaments' worth $20 d^{33}$ The last warden, William Shard or Chard, who may be the same as the Robert Chard of 1535 , received a pension of $f_{0} 5^{3 .}$

\section{Wardens or Priors of Bridport Hospital}

William, occurs $127 \mathrm{I}^{35}$

Roger de Rydeclive, occurs temp. Edward I ${ }^{36}$

${ }^{37}$ Hutchins, Hist. of Dorset, ii, 21.

${ }^{23}$ Hist. MSS. Com. Rep. vi, App. 493.

${ }^{29}$ Hutchins, Hist. of Dorset, ii, $\mathrm{i} 6$.

${ }^{30}$ Hutchins, in the earlier edition of the Hist. of Dorset, and Tanner after him, has fallen into the mistake of supposing that there were two foundations at Bridport both dedicated to St. John the Baptist, and the error is not entirely explained away by the editors of the last edition of Hutchins; they give it as their opinion that there was only one foundation, 'the chapel of St. John over the bridge a little by west in the town, described by Leland in his Itinerary (iii, 61), and fail to see that onc of the foundations valued in 1535 under Bridport belongs to the hospital of Allington; Valor Eccl. (Rec. Com.), i, $232-4$.

${ }^{31}$ Chant. Cert. Dorset, 16, No. 49.

${ }^{33}$ These, in a further section of the roll, were reduced to 6.68 s. $9 \frac{1}{2} d$. Ibid. No. $61 . \quad{ }^{33}$ Ibid. No. 49.

${ }_{34}$ B. Willis, Hist. of Mitred Abbcys, ii, 72 .

${ }^{35}$ Hutchins, Hist of Dorset, ii, 19.

${ }^{36}$ In a charter of Richard Hux; Hist. MSS. Com. Rep. vi, App. $4^{8} 4$ a.
William Worgan, occurs temp. Edward I ${ }^{37}$

Richard Castelayn, occurs $1295-6$ and $1316-17^{38}$

John de Shapwick, appointed 1357 , $^{39}$ resigned before $I_{4} I^{40}$

John Shipper, occurs $1444^{41}$

Hugh Prior, occurs in 1453 as 'late' prior ${ }^{42}$

Robert Chard, occurs $1535^{43}$

William Shard or Chard, last incumbent ${ }^{44}$

\section{HOSPITAL OF ST. JOHN THE BAPTIST, DORCHESTER}

The hospital here, commonly called 'St. John's House,' was under the royal patronage, and presumably of royal foundation, but we hear nothing of it until the year 1324 , when William Marshall of Dorchester obtained a licence from Edward II to endow a chaplain who should celebrate daily in the chapel of the hospital of St. John, Dorchester, for the soul of the said William, for the souls of his ancestors and successors and all the faithful departed. ss $^{\text {T }}$ The date, therefore, when the hospital was built cannot be definitely stated.

The wardenship, like that of many other royal free chapels and hospitals within the gift of the crown, was frequently held with other offices. In June, I 334, Edward III presented his clerk, Martin de Ixnyngge, to the custedy of the king's hospital of Dorchester for life, directing the brethren and sisters of the house to be 'intendant' to their new head, ${ }^{46}$ who, in the previous February, had been appointed master of the hospital of Maidstone, Kent. ${ }^{47}$ In 1451 William

${ }^{37}$ William Worgan occurs as 'prior' of the hospital in another charter by the same Richard Hux, conceding certain lands to the brethren and sisters of the hospital of St. John the Baptist ; ibid.

${ }^{38} \mathrm{He}$ occurs as master in a further charter of Richard Hux, dated 24 Edw. I, and is given as 'keeper of the gate of the hospital of St. John of Bridport' in a grant of Stephen Crul of Walditch, dated ro Edw. II. From the archives of Bridport; Hutchins, Hist. of Dorset, ii, 20.

${ }^{39}$ Ibid. 21.

"In that year an inquiry was instituted into the consanguinity of John Shapwick, late prior of the hospital of St. John of Bridport; Madox, Formulare Angl. 15.

41 Hutchins, Hist. of Dorset, ii, 16.

${ }^{4} \mathrm{He}$ is called late prior of the hospital in the inventory of goods of 9 O.t. 1453 ; Hist. MSS. Com. Rcp. vi, App. 493 .

${ }^{43}$ Valor Ecel. (Rec. Com.), i, 234.

11 Chant. Cert. 16, No. 61; B. Willis, Hist. of Mitred Abbcys, ii, 72.

${ }^{4}$ Pat. 17 Edw. II, pt. 2, m. 28.

${ }^{46}$ Ibid. 8 Edw. III, pt. 1, m. 14

17 Ibid. m. 4 I ; see Newcourt, Eccl. Repert. (i, 748), for a list of the preferments at different times of this clerk. 


\section{A HISTORY OF DORSET}

Man, vicar of Sturminster Marshall, was warden of this hospital. ${ }^{43}$

As far as its internal management is concerned a royal writ was issued, 18 November, I 359, directing the escheator of the county to make inquiry into the truth of the report that certain lands and rents pertaining to the hospital of St. John of Dorchester 'of our patronage' had been granted away by former custodians to the great waste and destruction of the house, so that various services and almsgiving, established for the souls of the king's progenitors, had ceased and been withdrawn; a jury should be empanelled to ascertain what lands and rents formerly belonged to the house, what had been alienated away, and by whom it had been done. ${ }^{49}$ The return, made the following month, stated that the hospital formerly possessed seventeen messuages in the town of Dorchester which produced a yearly rent of $£ 76 s$. 4 d., a water-mill, 96 acres of arable land, and 7 acres of meadow in Fordington, two cottages, 5 acres of land and meadow in Puddletown with appurtenances, and that Richard Creyk, late master, eight years ago alienated one messuage to Richard Tannere, chaplain, for the annual rent of 17 s. for the term of his life. Since that time the present warden, Simon de Brantingham, had made further alienations, and had not only conveyed away land but carried off the goods and chattels of the house, including linen (naperia) and bedding. ${ }^{50}$ In the course of these proceedings the said Simon seems to have been either deposed or suspended, for the following year the patent rolls, under date of 6 July, I 360 , record that Edward III granted to his beloved clerk, Thomas de Brantingham, the life custody of the hospital of St. John Baptist, Dorchester, vacant and in his gift. ${ }^{\circ 1}$

In March, I 45 I, Henry VI made a grant of the hospital (vulgarly called 'Sayntjohneshous') with all its emoluments to the provost and college of Eton, his deed reciting that whereas the custody was then in the hands of IVilliam Man, vicar of Sturminster Marshall, the present grant should not hold good until by the death or cession of the said incumbent the hospital should next come into the king's hands. ${ }^{52}$ Whether this grant ever took effect it is difficult to say, for though it was confirmed by Edward IV in $1467,{ }^{63}$ and again in $1473,3^{64}$ the crown continued to appoint as the cus-

19 Pat. 29 Hen. VI, pt. I, m. 8.

49 Inq. p.m. 33 Edw. III ( 2 nd Nos.), 88.

${ }^{50}$ Ibid.

${ }^{51}$ Pat. 34 Edw. IlI, pt. 2, m. 23. This may be an error of the scribe and refer to Simon, or it may be mere coincidence for two wardens to have the same name.

${ }^{33}$ Ibid. 29 Hen. VI, pt. I, m. 8.

${ }^{33}$ Ibid. 7 Edw. IV, pt. 3, m. 13.

${ }^{54}$ Ibid. $13 \mathrm{Edw} . \mathrm{IV}$, pt. 1, m. 10. tody fell vacant, ${ }^{65}$ and in the first year of his reign Richard III bestowed the hospital, "lately occupied by a priest and of our disposal,' on the Friars Minor of Dorchester. ${ }^{66}$ The Act of Resumption passed on the accession of Henry VII ordained that it should not be prejudicial ' to any graunte or letters patents made by King Edward IV, late king of England, to Maister Richard Hill, now dean of the king's chapell, of and for the free chapell of Seynt John's in Dorchester.' ${ }^{37}$

The Valor of 1535 gives this house a clear income of $£ 34^{s}$. Antony Weldon was then 'rector' or incumbent. ${ }^{58}$ By the Chantry Commissioners it was valued at $£ 9 \mathbf{r}^{5}$. $2 d$., out of which $42 s$. $8 d$. was deducted in 'rents resolute,' leaving a balance of $f 7$ ros. $6 d .^{59}$ The whole amount was received by the last incumbent, Edward Weldon, 'towards his exhibition at the University of Oxford by virtue of king's letters patent dated 4 August 32 Henry VIII' (I 540). ${ }^{60}$ On the confiscation of colleges and chantries he was assigned a pension of $£^{6.61}$

\section{IVARdens of Dorchester Hospital ${ }^{63}$}

\section{Martin de Ixnyngge, appointed $1334^{63}$}

Robert Creyk, appointed I 35 I $^{64}$

Simon de Brantingham, appointed $1354^{65}$

Thomas de Brantingham, appointed $1360^{66}$

Roger de Stoke, appointed $1370^{67}$

Thomas de Brounflet, appointed $1376^{68}$

${ }^{55}$ Edward IV in the first year of his reign, 21 Feb. 1462 , appointed William Brown to the custody (ibid. I Edw. IV, pt. 5, m. 18). Henry VI on his brief return to power in 1470 , without reference to his former grant, ratified the estate of the said IVilliam as master or warden of St. John Baptist, Dorchester, as well as master of the house or chapel called ' le priory hermitage' by Dorchester (ibid. $49 \mathrm{Hen}$. VI, m. I2). Edward IV, after granting the reversion of the house, when it should next come into the king's hand, in frankalmoign to William Westbury, the provost and college of Eton, March, 1473, in Norember of the same year committed the custody to Master Oliver Kyng, one of the clerks of the Signet (ibid. I 3 Edw. IV, pt. 1, m. 10 and 2), the letters patent for the last being exchanged in November, 1477 , in favour of Richard Hill (ibid. 17 Edw. IV, pt. 2, m. 29).

${ }^{56} \mathrm{Harl}$. MS. 433, 1603 , fol. I31.

${ }^{57}$ Parl. R. (Rec. Com.), vi, 367.

ss Valor Eecl. (Rec. Com.), i, 243 .

${ }^{59}$ Chant. Cert. 16, No. 2.

6 Ibid. 1484 . The clear income was estimated again at 6715 s. 5 d.; ibid.

${ }^{61} \mathrm{~B}$. Willis, Hist. of Mirred Abbcys, ii, 72.

6s The following list of wardens is taken, with some additional names and corrections, from that supplied by Hutchins from B. Willis, Hist. of Dorset, ii, 416 .

${ }_{63}$ Pat. 8 Edw. III, pt. 1, m. 14.
6 Hutchins, Hist. of Dorset, ii, 416.

${ }_{66}^{6}$ Pat. 34 Edw. III, pt. 2, m. 23.

67 Hutchins, Hist. of Dorset, ii, 416.

es Pat. 50 Edw. III, pt. 2, m. 5 .

${ }^{65}$ Ibid. 


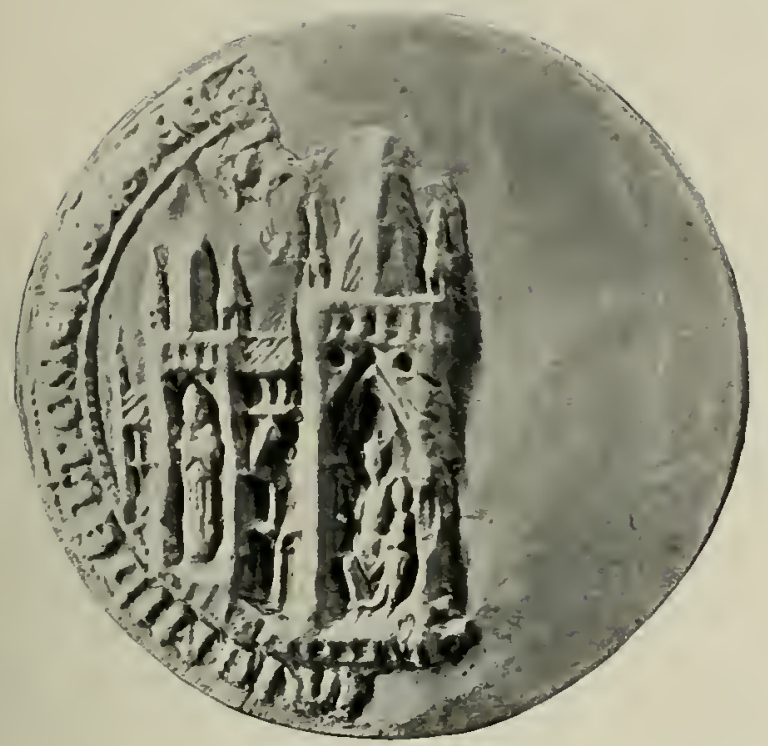

Mitton Ageey (Obverse)

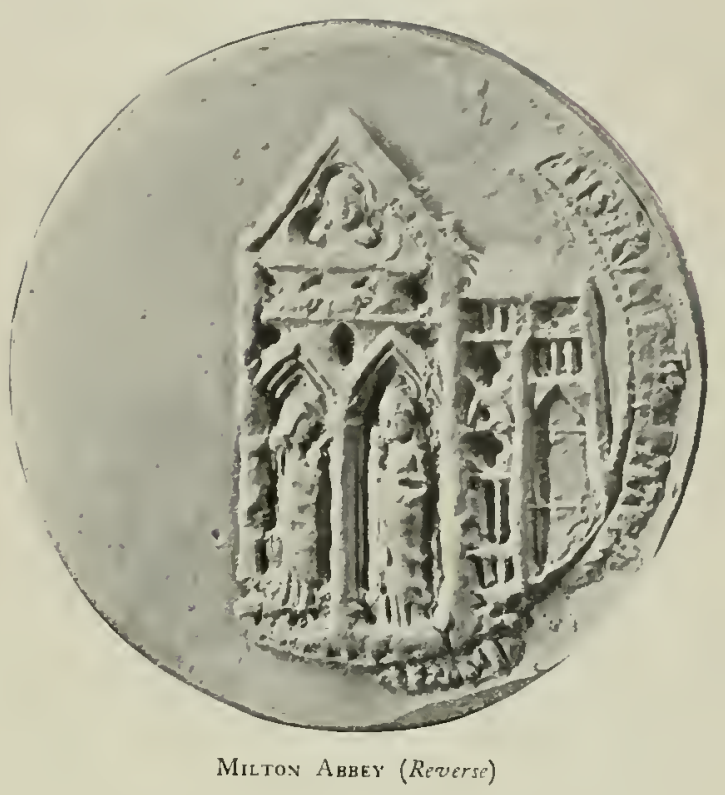

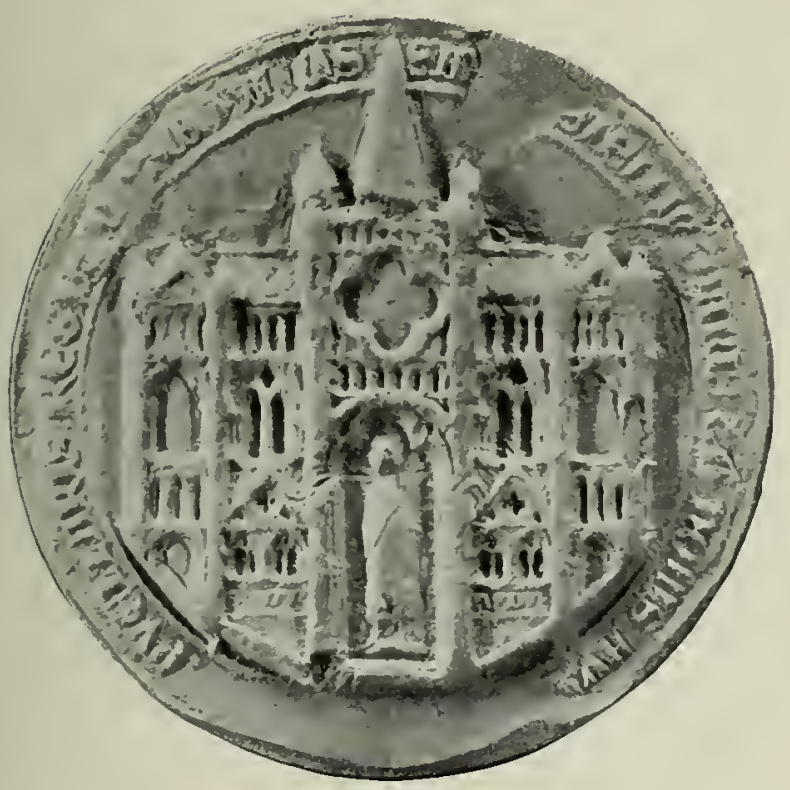

Shaftesbury Abbey (Obvirse)

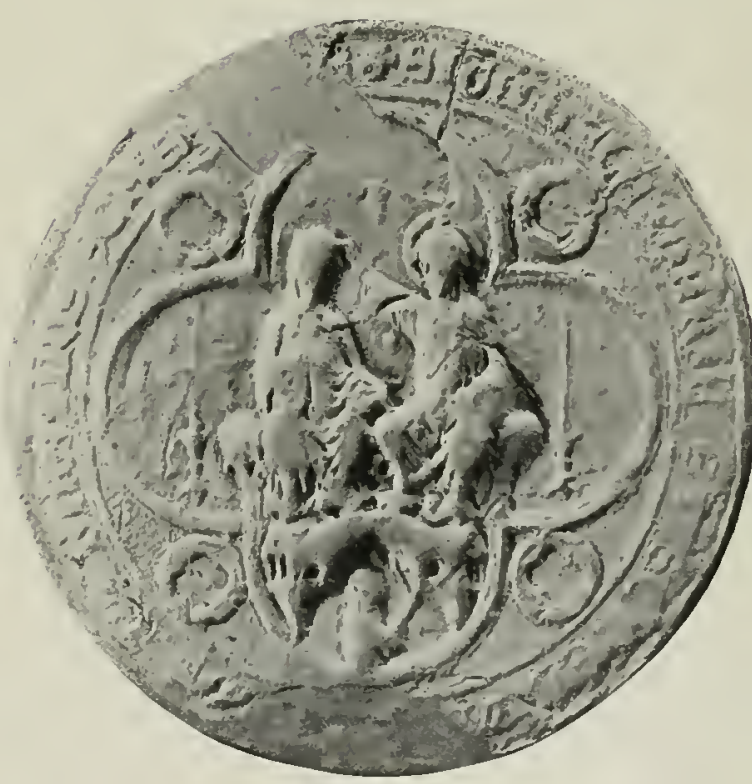

Shaftesbury Abeey (Reverse) 



\section{RELIGIOUS HOUSES}

Henry Harburgh, $1399^{69}$

William Man, occurs $145^{70}$

William Brown, appointed $1462,{ }^{71}$ occurs $1470^{72}$

Oliver Kyng, appointed $1473^{73}$

Richard Hill, appointed $1477,{ }^{74}$ resigned before $1485^{75}$

Thomas Otteley, $1485^{76}$

John Burton, 1 495, ${ }^{77}$ died 1499

John Argentine, I $499^{78}$

Antony Weldon, occurs $1535^{79}$

Edward Weldon, last incumbent ${ }^{80}$

\section{HOSPITAL OR LAZAR-HOUSE, DORCHESTER}

There appears to have been a hospital built here for the relief of lepers, but no particulars have yet been recovered as to the date when it was founded or the name of the founder. The chantry certificate of Edward VI states that the hospital or 'house of leprosy' at Dorchester had no lands, but consisted of ten poor men who received an annual rent of 40 s. for their gowns 'by the hands of Mr. Williams, Esquire.' ${ }^{81}$

\section{HOSPITAL OF ST. JOHN THE BAPTIST, SHAFTESBURY ${ }^{82}$}

When and by whom this hospital was founded history does not say. The earliest notice of it occurs 5 January, 1223 , when the king issued an order to John Lancelive, bailiff of Brian de Insula of the forest of Dorset, directing him to allow the prior of the hospital of St. John of Shaftesbury three trees (fusta) of the windfall wood of the king's park of Gillingham for the repair of his house. ${ }^{83}$ The foundation, therefore, cannot be dated later than the beginning of the thirteenth century. The chantry commissioners in the sixteenth century reported that it was ordained for the relief of five poor men who then lived by the alms of

${ }^{69}$ Hutchins, Hist. of Dorset, ii, 4 I 6 .

${ }^{70}$ Pat. 29 Hen. VI, pt. I, m. 8.

${ }^{71}$ Ibid. I Edw. IV, pt. 5, m. I 8.

${ }^{72}$ Ibid. 49 Hen. VI, m. I 2.

${ }^{73}$ Ibid. 13 Edw. IV, pt. I, m. 2.

${ }^{74}$ Ibid. 17 Edw. IV, Ft. 2, m. 29.

${ }^{75}$ Parl. R. (Rec. Com.), vi, 367.

${ }^{76}$ Hutchins, Hist. of Dorset, ii, $4 \mathrm{I} 6$.

$"$ lbid. ${ }^{8}$ Ibid.

${ }^{7}$ Valor Eccl. (Rec. Com.), i, 243.

${ }^{80}$ This last may be the same as the Antony Weldon of 1535. Chant. Cert. 16, No. 84.

${ }^{81}$ Chant. Cert. I6, No. 89.

${ }^{82}$ Hutchins describes this hospital as situated in the parish of St. Martin and near the church at the meeting of Hert Crope and Shetwell lanes; Hist. of Dorset, iii, 38 .

${ }^{63}$ Close, 7 Hen. III, m. 22. the town, the whole of the profits being received by the priest who officiated there. ${ }^{84}$

The house, or priory as it is occasionally termed, was in the patronage of the abbess of Shaftesbury and the diocesan registers give a succession of presentations by the nuns down to the Dissolution, beginning with William de Eggeclyve, priest, presented to the wardenship by the abbess and convent I I November, I $305^{.55}$ In April, I54I, Robert Fowke, the last warden or master, was presented by Edmund Wynter, knt., David Brokwey, gent., and Nicholas Tyddour, patrons pro hac vice by reason of the grant of letters of advowson made to them by the last abbess and convent of Shaftesbury. ${ }^{86}$ For some reason not very apparent the patronage of the house came temporarily into the hands of the king in 1381 , and in September of that year Richard II presented John Ridgway, chaplain, to the life custody of the hospital of St. John on the Mount at Shaftesbury, his appointment being shortly afterwards followed by that of John Bridport. ${ }^{87}$

Beyond the names of the different wardens the history of St. John's is almost a blank. The master in 1348 probably fell a victim to the terrible plague that ravaged Dorset in the autumn and winter of that year, for in the heavy list of presentations for December occurs that of John de Meleborn to St. John's, Shaftesbury, on the death of William de Godeford, late warden ${ }^{88}$ William Russel, called the prior of the hospital, was visited along with other rectors and vicars of the deanery by the diocesan in the church of Holy Trinity, Shaftesbury, in April, $1344 .^{89}$

In an inquisition made in 1499 the hospital was said to be founded by the king's ancestors. The property, consisting of five tenements, 4 acres of arable, $10 \frac{1}{2}$ acres of pasture, and half an acre of meadow, was valued at $\AA^{6}$. The support of the poor and the celebration of the divine services weekly and yearly had been neglected for the last twenty years, and had completely ceased in the last two years, during which David Knolle, chaplain, had taken the profits and also removed the ornaments of the hospital. ${ }^{893}$

On the confiscation of chantries this hospital was valued at $£_{4}$, with one bell worth 3 s. $4 d^{90}$

${ }^{84}$ Chant. Cert. Dorset, 16, No. 100.

${ }^{85}$ Sarum Epis. Reg. Simon of Ghent, ii, fol. 45.

${ }^{86} \mathrm{Ibid}$. Salcot or Capon, fol. $7 d$.

${ }^{87}$ Pat. 5 Ric. II, pt. I, m. I2, 19. These two exceptions, as against some twenty appointments by the nuns, seem to have led Tanner into the error of supposing that the house was of royal patronage. There is no ostensible reason for the king's action, the abbey then being 'full' and under the rule of Abbess Joan Formage.

${ }^{85}$ Sarum Epis. Reg. Wyville, ii (Inst.), fol. 193.

${ }^{89}$ Ibid. Waltham, fol. 73.

${ }^{89 a}$ Esch. Inq. file 896, No. $2 \mathrm{I}$.

${ }^{90}$ Chant. Cert. 16, No. 15. 


\section{A HISTORY OF DORSET}

It was granted by Edward VI with lands belonging to it in Shaftesbury, Motcombe, and Gillingham, to Kendal, Burgh, and others for the sum of f $^{1} 36$ I Is. $4 \mathrm{~d}^{91}$ The last incumbent, John Hame, received a pension of £. $155.4 d^{92}$

\section{Wardens or Priors of Shaftesbury HOSPITAL}

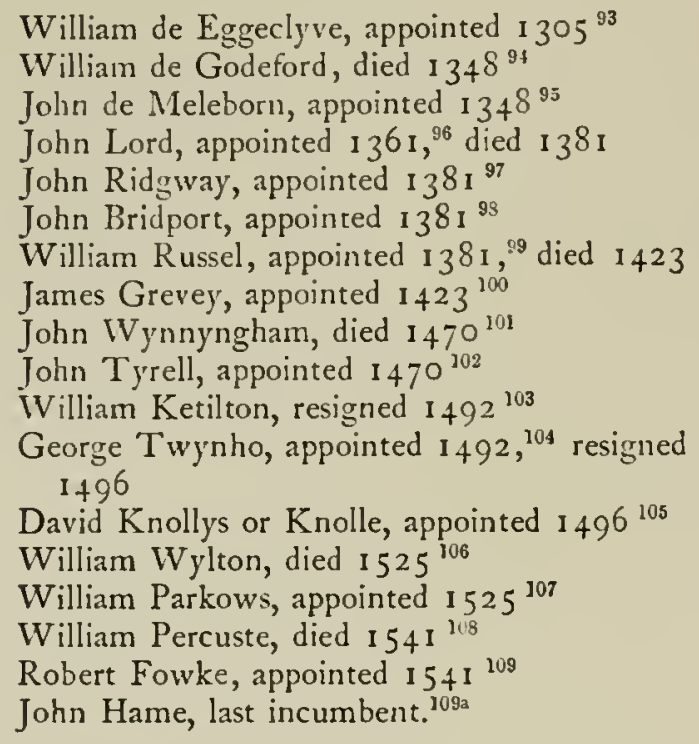

27. HOSPITAL OF ST. JOHN THE BAPTIST AND ST. JOHN THE EVANGELIST, SHERBORNE

A hospital here of comparatively late foundation ' was begun,' according to Leland, 'by devotion of the good people of Sherborne in the fourth year of Henry VI, and the king is taken for founder of it.' no On I I July, I 437 , eleven years after the date given of its inception, Henry VI granted a licence to Robert Neville, bishop of Salisbury, Humphrey Stafford, knt.,

${ }^{93}$ Hutchins, Hist. of Dorset, iii, 39.

${ }_{93}$ B. Willis, Hist. of Mitred Abbcys, ii, 72.

${ }_{93}$ Sarum Epis. Reg. Simon of Ghent, pt. 2, fol. 45.

is Ibid. Wyville, ii (Inst.), fol. 193.

${ }^{95}$ Ibid. $\quad{ }_{96}$ Ibid. (Inst.), fol. 278.

${ }_{97}$ The registers take no note of this and the following appointment by the crown (Pat. 5 Ric. II, pt. 1, m. 19), and stat = that William Russel was appointed on the death of John Lord. Sarum Epis. Reg. Erghum, i, fol. 44 d.

${ }_{93}$ Pat. 5 Ric. II, pt. 1, m. 12.

${ }^{99}$ Sarum Epis. Reg. Erghum, i, fol. 44 $d$.

${ }^{100}$ Ibid. Chandler, fol. 6 I.

${ }^{101}$ Ibid. Beauchamp, fol. 150.

${ }^{103}$ Ibid. Langton, fol. $40 d$.

${ }^{102}$ Ibid.

${ }^{105}$ Ibid. Blyth, ful. $26 \%$.

${ }^{106}$ Ibid. Campegio, fol. $3 d$.

${ }^{108}$ Ibid. Salcot or Capon, fol. $7 d$.

${ }^{109 a}$ B. Willis, op. cit. ii, 72.

${ }^{110}$ Itin. ii, 49. 'It yet standeth,' adds Leland, but most of its property had bcen dispersed; ibid. iii, 110.
Margaret Gogh, John Fauntleroy, and John Baret, to incorporate and establish a certain house of perpetual charity in Sherborne to the honour of God and St. John the Baptist and St. John the Evangelist for the reception of twenty brethren, twelve 'poor sick and impotent' men. and four women, with a chaplain who should pray for the good estate of the king and of the brethren of the house and their benefactors while they lived, and for their souls and those of all the faithiul departed 'when they shall have withdrawn from this light.' The brethren were yearly, or whenever it should be convenient, to elect a master from among themselves, and were empowered to fill up any vacancy that should occur in their number, and to remove or expel the master from his office or any of the poor men or women from the house; all the inmates should live under the rule and government ordained by the said bishop, Sir Humphrey Stafford, Margaret Gogh, John Fauntleroy, John Baret, or any four, three, or two of them. The master and brethren were declared capable of holding lands in the name of the society, and of pleading and being impleaded in the law courts of the land, they should use one common sea!, and might hold lands and rents in socage or in burgage to the annual value of 40 marks for the benefit of the poor men and women in the hospital, while the perpetual chaplain and his successors might acquire and hold the same to the value of Io marks, notwithstanding mortmain and all previous statutes to the contrary."I

Henry VI in October, 1448 , made a further grant to the brethren of the house that for a fine of $£ 10$ they might acquire lands and tenements to the annual value of $f 336$ s. $8 d$., ${ }^{112}$ and by a later deed reciting his former grant he licensed IVilliam Combe, John Downton of Folke, and William Couland to give and assign to IVilliam Smyth, then master of the hospital, thirty-nine messuages, two tofts, one dorecot, $39 \frac{1}{2}$ acres of land, 19 acres and one rood of meadow and I acre of grove situated in Sherborne, Beer Hackett, and Caundle, of the yearly value of $f .53^{s} .4 d$, to be held in part satisfaction of the 633 6s. 8 . $^{\prime 13}$ Bishop Richard Beauchamp of Salisbury is mentioned as a great benefactor to the house, ${ }^{114}$ which, indeed, was situated within his 'vill' of Sherborne, but he can hardly have been the founder as one report states; ${ }^{115}$ his predecessor Aiscough, according to an entry in his official register, dedicated an altar in the chapel of the hospital in 1442 , five years after its incorporation by royal charter. ${ }^{116}$

\footnotetext{
111 Pat. 15 Hen. VI, m. 5 .

${ }^{118}$ Ibia. 27 Hen. VI, pt. 1, m. 30.

113 Ibid. 32 Hen. VI, m. 15.

114 Hutchins, op. cit. iv, 294.

115 Magna Brit. Antig. et Nor. i, 567.

${ }^{116}$ Sarum Epis. Reg. Aiscough, fol. $97 d$.
} 


\section{RELIGIOUS HOUSES}

On the confiscation of colleges and chantries under Edward VI the house entered as "the hospital or house of leprosy of St. John the Evangelist in Sherborne' was found worth 6.358 s. 6d., out of which $\ell_{4}$ 3s. $6 d$. was deducted in rents resolute, leaving a clear income of $f_{3} 35$ s. which the officiating priest received half-yearly, $£ 56 \mathrm{~s} .8 d$., the residue, being applied 'to the finding of eleven poor and impotent men and four poor women according to the foundation thereof." ${ }^{\prime 17}$ The name of the last incumbent is not given, nor is he entered among those who received pensions. ${ }^{118}$

Masters of the Hospital of St. John the Baptist and St. John the Evangelist, SHERBORNE

John Deen, occurs I $44^{119}$

William Smyth, occurs $1454^{120}$

Henry Borman, occurs 1468121

\section{HOSPITAL OF ST. THOMAS, SHERBORNE}

Very little is known of this hospital or chapel dedicated to St. Thomas Becket, but commonly known as St. Thomas atte Grene or on the Grene, yet from a reference in a charter ${ }^{122}$ granted by Bishop Richard le Poor of Salisbury in 1228 to his tenants at Sherborne 'between St. Thomas's chapel and the castle,' it appears to have been in existence in the early part of the thirteenth century, and was probably founded during that period when dedication to the honour of that most famous and popular of English saints was high in fashion.

Presentation to the hospital was in the gift of the crown and the custody was usually held by king's clerks together with other benefices; on 20 June, I 395, Richard II ratified the estate of his clerk, John de Wendelyngburgh, as parson or warden of the chapel of St. Thomas on the Grene, ${ }^{123}$ Sherborne, and on 22 September of the same year following the death of John committed the wardenship of the hospital to Nicholas Slake, king's clerk; ${ }^{124}$ both these

${ }^{117}$ Chant. Cert. 16 , No. 91.

118 B. Willis, Hist. of Mitred Abbeys, ii, 71-2.

${ }^{119}$ Pat. 27 Hen. VI, pt. 1, m. 30.

${ }^{120}$ Ibid. 32 Hen. VI, m. 15.

${ }^{121}$ On 25 Nov., 1 468, Edward IV licensed Henry Borman, the master and the brethren of the almshouse of St. John the Baptist and St. John the Evangelist to acquire lands and other possessions held in socage or burgage to the yearly value of $\oint_{13}$; ibid. $8 \mathrm{Edw}$. IV, pt. 2, m. 4 .

${ }^{122} \mathrm{By}$ inspeximus of Richard II. Pat. 5 Ric. II, pt. I, m. II.

${ }^{123}$ Ibid. 18 Ric. II, pt. 2, m. 9.

${ }^{124}$ Ibid. 19 Ric. II, pt. 1, m. 18. wardens held the office in plurality with other benefices. In 1405 John Brunyng is given as rector of the Chapel de Grene according to the register of Dean Chandler. ${ }^{125}$

In the reign of Henry VIII Leland describes 'Thomas Bekettes chapelle by the New Yn' as still standing, but 'incelebrated.' 126 The college and chantry commissioners of Edward VI reported that it was worth 62 s., had no plate or ornaments, but two bells valued at $26 s$. $8 d .^{127}$ Roger Hord or Horsey, late incumbent, received the whole of the emoluments ${ }^{128}$ to his own use without performing any manner of service in the chapel; "there is no power (poor) people nor beadmen found nor relieved of the premises.' 129 The chapel was granted by Edward VI to John Doddington and William Ward. ${ }^{130}$

\section{Wardens of St. Thomas's Hospital, SHERBORNE}

John de Wendelyngburgh, occurs I 395 , $^{131}$ died in the same year

Nicholas Slake, appointed I $395^{132}$

John Brunyng, occurs $1405^{133}$

John Hord or Horsey, last incumbent ${ }^{134}$

\section{HOSPITAL OF ST. LEONARD, TARRANT RUSHTON}

At what date and by whom this house or hospital was founded it is impossible now to say. The first mention of it occurs in the reign of Edward I, when the advowson and lordship (dominium) of it were in the hands of the Deverel family, and they may have been the founders; at any rate in 1314 they made over the entire rights to the prior and convent of Christchurch, Twyneham. ${ }^{135}$ According to an inquisition post mortem, held as to his possessions

${ }^{125}$ Hutchins, Hist. of Dorset, iv, 257. The warden is mentioned again as 'rector of the Grene' in a grant of Henry VI in $145+$ to the master and brethren of the hospitaI of St. John the Baptist and St. John the Evangelist of Sherborne, enabling them to acquire thirty-nine messuages in the town, and describing one of these same messuages as situated between the tenement of the rector 'de la Grene,' called the George Inne,' on the north and the king's highway leading from the Grene to the Castle on the south; Pat. 32 Hen. VI, M. 15.

${ }^{126}$ Leland, Itin. ii, 49 ; iii, 110.

197 Chant. Cert. 16, No. 8

${ }^{129}$ Entered again as worth 66 s.

${ }^{129}$ Chant Cert. 16, No. 92.

130 Hutchins, Hist. of Dorset, iv, 257.

${ }^{131}$ Pat. 18 Ric. II, pt. 2, m. 9.

${ }^{132}$ Ibid. 19 Ric. II, pt. 1, m. 18.

${ }^{133}$ Hutchins, Hist. of Dorset, iv, 237.

${ }^{134}$ Chant. Cert. Dorset, 16, No. 92.

${ }^{135}$ Inq. p.m. $6 \mathrm{Edw}$. III (2nd Nos.), 97. 


\section{A HISTORY OF DORSET}

in Milborne Deverel or Cary, in March, $1332,{ }^{136}$ Elias de Deverel died in October the previous year, and on his lands escheating to the crown by reason of the forfeiture of his son and heir, John de Deverel, the then prior and convent petitioned the king to restore to them those rights in the house of St. Leonard of Rushton near Palmeresbrugg of which they had been unjustly disseised by the late donor and his son. The king ordered an inquiry to be made, and on 28 November, I 332, the jury found that the adrowson and custody of the house had been granted to IVilliam Quentyn, late prior of Christchurch, the convent and their successors by Elias de Deverel on the morrow of St. Nicholas (6 December), 1304 ; that then, in accordance with the terms of the grant and on the cession of the master, John Curteis, they had presented Robert de Horton, chaplain, to the custody and mastership of the house, to which he had been admitted on the feast of St. Thomas the Apostle (2 I December) the same year ; that subsequently, on 2 May following, they had been unjustly dispossessed of their rights by the said Elias de Deverel and John his son, and Robert de Horton, then master, had been removed and Ralph Lychet, chaplain, admitted to the custody in his place; and that the same Elias and John had continued to usurp possession of the house from that time up to the date of the attainder of John de Deverel, when it came into the king's hand. The jury further estimated its value at 40 s. $^{137}$

These facts having been ascertained, Edward III did not hesitate to make good the claim of the monks, his deed of restoration the following January, 1333, reciting that the original grant of the premises in the reign of Edward I had been made to the then prior, IVilliam Quentyn, and the convent without licence of the king, but that in consideration of a fine of 10 marks he had consented to pardon the lack of this forinality. ${ }^{133}$

The subsequent history of the house is unknown, and it is not entered in the chantry certificate of the county in the reign of Edward VI.

\section{Masters of Tarrant Rushton Hos- PITAL}

John Curteis, resigned in $1304^{139}$

Robert de Horton, appointed 1304, resigned $1305,^{140}$

Ralph Lychet, appointed I $305^{141}$

${ }^{136}$ Inq. p.m. 6 Edw. III (2nd Nos.), 59.

${ }^{137}$ Ibid. (2nd Nos.), 97.

${ }^{135}$ Pat. 7 Edw. III, pt. 1, m. $13,15$.

${ }_{139}$ The names of these three wardens are all giren in the inquisition of 28 Nov. 1332 ; Inq. p.m. (2nd Nos.), 97.

110 Ibid.

${ }^{141}$ Ibid.
30. THE HOSPITAL OF ST. MARGARET AND ST. ANTHONY, IVIMBORNE

The date of the foundation of this ancient hospital, commonly called St. Margaret's of Wimborne, is unknown. Tradition has reported that it was founded by John of Gaunt, but, as evidence has been found of its existence long before the reign of Edward III, the conjecture was probably based on the fact that the house was situated within the manor or Kingston Lacy, which formed part of the duchy of Lancaster ; it may at some time or another have been rebuilt or re-established by John of Gaunt or one of his descendants. ${ }^{142}$

From certain deeds found in a chest in the chapel the house appears to have existed as a house for lepers as far back as the reign of $\mathrm{King}$ John, and to have depended for its support almost entirely on the alms of the town and neighbourhood; a grant dated 1245 recited that for the encouragement of such charitably-disposed Christians as should contribute towards its relief Pope Innocent IV by

an indulgans or bulle did assoyl them of all syns forgo:ten and offinces done against fader and moder and of all swerynges neglygently made

This 'indulgans' granted of Peter and 'Powle' and of the said pope should hold good for fifty-one years and 260 days, provided a certain number of Paternosters and Ave Marias were repeated daily. ${ }^{143}$

In the absence of a sufficient endowment licence to beg must have been almost a necessity; and for that purpose Edward I in 1275 granted letters of protection for a year to the brethren and sisters of the hospital of St. Margaret and St. Anthony, Wimborne, ${ }^{144}$ and renewed the grant on the expiration of the term the following year, ${ }^{145}$ and again in 1286.246

The Chantry Commissioners of Edward VI valued the house at $295.8 d$., and found it was ordained for the relief of poor men, and that there were then eight who 'not only live by the profit of the said house but by the devotion of the people and inhabitants of the town of IVimborne.' 147

In the chapel of the hospital there was established in early days a chantry founded by John Redcottes and named after him ; it was annexed

14) In the beginning of an account book of the hospital of the sixteenth century the house is said to have been erected by the sometime duke of Aquitaine and Leicester, which shows that its early origin had been lost as far back as the reign of Elizabeth; Hutchins, op. cit. iii, 247 .

${ }^{143}$ Ibid. $\quad{ }^{144}$ Pat. 3 Edw. I, m. 23.

145 Ibid. 4 Edw. I, m. 19.

${ }^{146}$ Ibid. 14 Edw. I, m. 24.

${ }^{14 i}$ Chant. (ert. 16, No. 112. 


\section{RELIGIOUS HOUSES}

to the college or free chapel of Wimborne and is entered among its possessions, being held in the reigns of Henry VIII and Edward VI by the sacristan of the college in conjunction with his other office. At the time the Valor of 1535 was taken it was worth $f 56 \mathrm{~s} .8 \mathrm{~d}$, and was held by Thomas Yeroth, sacristan. ${ }^{148}$ According to the chantry certificate Simon Benyson, then incumbent, received for his stipend E.5 6s. 8d. arising out of certain lands 'called Dixon and Capons lands,' parcel of the duchy of Lancaster ; after his death these rents should be paid into the duchy. In the meantime he held another living to the value of $f .300^{149} \mathrm{An}$ annual pension was allowed him of $£ 5$ a year. ${ }^{150}$

The book of ancient accounts above mentioned further shows that from the year I 567 to 1683 the hospital was continued under the control and direction of two parishioners, annually elected and styled the guardians or wardens of St. Margaret's Hospital or Almshouse, assisted by the constable of the town and the stewards of the lord of the manor of Kingston Lacy, the latter signing the accounts on behalf of the lord of the manor. ${ }^{151}$
From 1683 the election of guardians ceased, and the entire management and control of the funds was placed under the stewards of the lord of the manor, to whom belonged the appointment of the poor to the almshouses. In a return to Parliament in 1786 the value of the house was given at $£ 35$ I Is. The hospital benefited largely by the will of the Rev. Wm. Stone, dated May, I 865 , whereby certain lands and tenements in the parish of Wimborne Minster were left in trust to the use of the almsmen only in St. Margaret's Hospital. The house is described as standing on the high road which runs from Blandford to Wimborne. ${ }^{152}$

\section{I. HOSPITAL OF WAREHAM}

The only reference to a hospital here is to be found in the return of the commissioners for chantries and colleges in the sixteenth century, which states that the hospital or house of charity in the town of Wareham, valued at $\ell_{9}$ I $3^{5}$., was founded for the relief of six poor and impotent men and five poor women 'to have their continual living there and so yt ys usyd.' ${ }^{153}$

\section{COLLEGE}

\section{WIMBORNE MINSTER}

One of the earliest religious foundations in this county was the nunnery built here at the beginning of the eighth century, converted on its restoration into a house of secular canons presided over by a dean, and subsequently known as the royal free chapel and college of Wimborne Minster.

The Saxon monastery was built by St. Cuthburh or Cuthburga, the daughter and sister respectively of the Wessex kings, Kenred and Ine, who after her union with Aldfrid, king of the Northumbrians, renounced married life and, with the consent of her husband, entered the abbey of Barking and became a nun under the rule of the Abbess Hildelitha. ${ }^{1}$ Various dates

${ }^{148} V$ alor Eccl. (Rec. Com.), i, 273.

${ }^{149}$ Chant. Cert. 16, No. J 07. He also held the sacristan's office of Wimborne Minster.

iso B. Willis, Hist. of Mitred Abbey's, ii, 72.

151 The lords of the manor were reputed the founders.

${ }^{152}$ Hutchins, op. cit. iii, 248.

${ }^{153}$ Chant. Cert. Dorset, 16, No. 117

1 Will. of Malmes. Gesta Regum (Engl. Hist. Soc.), i, 49 ; Flor. Wigorn. Chron. (Engl. Hist. Soc.), i, 49; Matt. of Westm. (Flores Hist. [Rolls Ser.], i, 367), Leland (Coll. i, $2 \mathrm{II}-\mathrm{I} 2$; ii, 387), and a few other writers give Ecgfrid, king of the Northumbrians, halfbrother to Aldfrid, as the husband of St. Cuthburga, but Capgrave, who in his life of the saint records a dialogue between her and her husband on the subject are assigned for her subsequent foundation at Wimborne. Cressy, whose account is generally adopted, gives the year $713 ;^{2}$ the Anglo-Saxon Cbronicle mentions it under 718 , but makes no definite statement as to when it came into existence. $^{3}$ The foundation must, however, be dated some years earlier and previous to 705 according to a letter of Bishop Aldhelm, written in that year, granting liberty of election to the monasteries under the charge of the bishop, who died in 709 , in which he mentions particularly 'the nuns in the monastery by the river which is called Wimburnia presided over by the abbess Cuthburga.' 4

'St. Cuthberga,' says Cressy, translating various passages from the Vita of Capgrave-

having built her monastery and therein a church to the Queen of Virgins, there macerated her body with almost continual watchings and fastings. She was humble both to God and man and mild to all. Many virgins she assembled in the same place; she permitted her body to enjoy no rest ; but importunately day and night her prayers sounded in the ears of a merciful God. She happily ended her days in the year of grace 727 , and her memory is celebrated by the church on the last day of August. ${ }^{5}$

of the renunciation of marriage, as well as her dying charge to her nuns, calls the king Aldfrith or Aldfrid;

Nora Legenda Anglie ( 1516 ), fol. 79-So.

${ }^{2}$ Ch. Hist. of Brit. (1668), lib. xxi, cap. 18.

${ }^{3}$ Op. cit. (Rolls Ser.), 39.

4 Birch, Gart. Sax. i, 168.

${ }^{5}$ Ch. Hist. of Brit. (1668), lib. : xi, cap. I 3. 


\section{A HISTORY OF DORSET}

According to Leland she was buried on the north side of the presbytery, but afterwards translated to the east end of the high altar of the church, ${ }^{6}$ which was subsequently re-dedicated in her honour. ${ }^{\text {? }}$

With St. Cuthburga is frequently associated as co-foundress her sister St. Cuenburh or Quinburga, also said to have been buried in this church, ${ }^{8}$ and who, if we accept her identification with abbess Cneuburga-the joint author of a letter addressed to Abbot Coengils of Glastonbury, Abbot Ingeld, and the priest IViethberht agreeing to a proposal for mutual intercessory prayer and asking in particular 'that remembrance may be had of our dead sisters,'-probably succeeded to the rule of the monastery on the death of the first abbess. ${ }^{9}$ The Eta to whom reference is made in the same letter may possibly be identified with Tetta the venerable abbess, said to be a sister of Æthelheard, the kinsman and successor of King Ine, who soon after became superior of the monastery and was responsible for the religious training and education of the sisters Lioba and Agatha, destined to carry abroad the benefits of the instruction they had received while under the care of 'that devout mother.'

A great proof of the ferfection of monastical discipline observed after the death of the foundress in her monastery is this: (again quoting Cressy") that St. Boniface the glorious apostle of the Germans, having founded a monastery of virgins at Biscoffsheim in Germany made choice of her disciples above all others, and particularly of St. Lioba, to plant religious observances there. This is testified by Rodulphus, disciple of Rabanus Maurus, in the life of Lioba written by him. ${ }^{30}$

St. Lioba died in a monastery near Mainz, 28 September, 757.

Besides the nunnery there appears to have been a monastery or 'cloister of monks' at IVimborne, built either by St. Cuthburga or her brother King Ine, strict regulations being laid down prohibiting any intercourse between the two sections of religious men and religious women.

Excepting priests who were to serve at the altar, no men should be permitted to enter the monastery of those religious virgins, nor any woman that of religious men. And that among the other obligations of the virgins at their profession this was one, never to step out of their cloister except upon a necessary .cause to be approved by superiors. ${ }^{11}$

'Leland, Itin. iii, 72 ; Collect. ii, 409.

7 The church occurs under this dedication; Close, $1+$ Hen. IV, m. 28 \%

'John of 'Tinemouth, 'Hist. Aurea,' Hickes, Thesaur. iii, 120.

${ }^{9}$ Haddan and Stubbs, Councils and Eccl. Doc. iii, $342-3$. She died three years after her sister, says Cressy, and is commemorated on 22 September; $C h$. Hist. of Brit. lib. xxi, cap. 18.

${ }^{10}$ Ibid.

${ }^{11}$ Ibid.
IVe are told in her life given by Mabillon that St. Lioba ${ }^{13}$ was fond of citing the example set by her former superior, Abbess Tetta of Wimborne, who presided over the houses of both men and women as over a double monastery, and whose observance of this regulation was so strict 'that she would not so much as permit the bishop's entrance' in the women's section. ${ }^{23}$

References to IVimborne in the ninth and tenth centuries afford ample proof of the importance of the town and the veneration paid to its Minster during the Saxon period. It was selected as the burial-place of King Æthelred, who died in $87 \mathrm{I}$ in consequence of wounds received in the battle fought against the Danes at Merton. ${ }^{\text {It }}$ The Anglo-Saxon Chronicle recording the death of king Sigferth, who killed himself in 962, adds, ' his body lies at IVimborne.' Is

Again, Wimborne was the centre of events attending the accession to the throne of Edward the Elder in 901, for Æthelwold, son of Fithelbert, an elder brother of Alfred, disputing the title of his cousin and relying on some measure of popular support for his own claim, seized the royal towns of Oxeley or Christchurch (Hants) and IVimborne, and investing the latter place with such troops as he could muster resolved to stand a siege, declaring that there 'he would either live or lie.' 'To the injury moreover of whatever cause he might possess, he forcibly abducted an inmate of the famous monastery 'without leave of the king and contrary to the bishop's ordinance, for she was a professed nun,' and made her his wife. King Edward meanwhile raising a powerful army for the defence of his kingdom and the vindication of religion marched into Dorset, and encamped at a place called Badbury, where there was a castle at no great distance from IVimborne. The courage of Æthelwold then apparently deserted him and he fled away by night and came to Northumbria, where he joined himself to the Danes and besought them to receive him into their company to fight against King Edward, being soon after made king by them. Edward the Elder in the meantime relinquishing the pursuit of the enemy contented himself with receiving the submission of the town, ordering the religious woman who had been abandoned by Ethelwold in his flight to be sent back to her nunnery. ${ }^{26}$

A blank in the history of IVimborne succeeds, and it is generally conjectured that the monastery

12 Acta Sanctorum Ord. S. Benedicti, Sacculum, iii (2), 247 .

13 Ibid. See Cressy, Ch. Hist. of Brit. lib. xxiv, cap. 4 .

"Anglo-Sax. Chron. (Rolls Ser.), i, 62 ; Matt. of Westm. Fortes Hist. (Rolls Ser.), i, 444.

${ }^{13}$ Anglo-Sax. Chron. (Rolls Ser.), i, 92.

${ }^{16}$ Ibid. 75 ; Matt. of Westm. Flores Hist. (Rolls Ser.), i, +78 ; Matt. Paris, Chron. Maj. (Rolls Ser.), $i,+35-6$. 


\section{RELIGIOUS HOUSES}

perished in one of the Danish raids of the period. The Danes, we are told, ravaged the country in the year 998 ; no details are given, but the AngloSaxon Chronicle, recording fruitless attempts to withstand the destructive march of the enemy, adds sadly: 'In the end they ever had the victory.' ${ }^{17}$ According to Leland Wimborne was rebuilt by 'King Edward,' supposed to be the Confessor, and by him was converted in to a house or college of secular canons with a dean at its head. ${ }^{18}$ No reference is made to it until the reign of Henry III beyond the statement in Domesday, that the church of Wimborne had a hide and a half and a virgate of land in Hinton. ${ }^{19}$ From the date of its restoration it appears to have enjoyed the status and privileges of a royal free chapel with college attached under the direct patronage of the crown. In I 3 I 8 Edward II addressed an order to Rigaud Asser, then papal nuncio, afterwards bishop of Winchester, forbidding him to exact aught from or to lay any imposition whatever on the dean and prebendaries of Wimborne Minster-

Whereas it is a free chapel of the king and altogether exempt with the prebends and chapels pertaining thereto from all ordinary jurisdiction and from all exactions, procurations and contributions whatsoever. ${ }^{20}$

Owing to this immunity from episcopal jurisdiction there are no entries in the diocesan registers which can throw light on the internal condition of the college. A solitary mention occurs in I 379 wherein William Crundell, proctor of the dean and college, was summoned with the proctors of Ford, Cerne, and Tewkesbury to appear before the bishop's commissary in the parish church of Sonning prepared to exhibit their title to all ecclesiastical benefices, portions, and pensions held by them. ${ }^{21}$

The earliest appointment to Wimborne that is recorded occurs at the beginning of the reign of Henry III, when Martin de Pateshull received letters of presentation to the deanery then vacant and at the royal collation, 6 December, $1223 .{ }^{22}$

17 Anglo-Sax. Chron. (Rolls Ser.), i, 108.

${ }^{18}$ Collect. i, 82 ; see also Itin. iii, 72.

${ }^{19}$ Dom. Bk. (Rec. Com.), i, $77 b$. This may be either in Hinton Martell or Little Hinton, as both are included in the survey of Hinton.

${ }^{20}$ Close, $11 \mathrm{Edw}$. II, m. Io. In the event of a general contribution by the clergy to the crown the king was in the habit of addressing a special order to the dean, appointing him collector of the subsidy due from all benefices pertaining to his chapel, which was exempt from the jurisdiction of the ordinary. Ibid. 8 Edw. JI, m. 9.

21 Sarum Epis. Reg. Erghum, i, fol. 29.

${ }_{22}$ Pat. 8 Hen. III, m. 12. The Rev. R. W. Eyton, in his Key to Domesday (Dorset,), suggests that Maurice, bishop of London, and $\mathrm{Hugh}$ his predecessor held half a hide in Oleham in the parish of Wimborne in virtue of the deanery, 'having in their time been deans of Wimborne,' but they are not included in any list of the deans of Wimborne.
The following year the sheriff of Dorset was directed to cause proclamation to be made that the market and fair formerly held within the cemetery of Wimborne should in future be held outside under the walls, on land belonging to the dean on the same days and with the same liberties and customs as formerly. ${ }^{23}$

The deanery was always held by men holding other ecclesiastical benefices and in many cases secular offices, and. was bestowed by the king on his clerks and court favourites as a reward for their services, and by no means always with a view to their spiritual fitness. Martin de Pateshull, early in the reign of Henry III, sat as a justice of the King's Bench, was a justice itinerant and constantly employed as a judge; besides other ecclesiastical benefices he held a prebend in St. Paul's, London, the archdeaconry of Norfolk, and in 1228 was appointed to the deanery of St. Paul's. ${ }^{24}$ On his death the following year he was succeeded at Wimborne, 20 October, by Randolf Brito, ${ }^{25}$ who in the previous December had been presented by letters patent of the king to prebends in London and Salisbury and to the rectory of Charing (Kent), ${ }^{26}$ and the March following appointed constable of Colchester Castle and warden of the ports of Essex. ${ }^{27}$ John Mansel, the notorious pluralist, who succeeded in 1247 on the death of Brito, had, as we may gather from the pages of Matthew Paris, ${ }^{28}$ a very distinguished career in many ways, but the positions which he held and the difficult negotiations in which he was frequently employed by the king can have left him no leisure to bestow on Wimborne, and the fact that he held the deanery is not even mentioned in the Cbronica Majora, which records his varied appointments. ${ }^{29}$

For examples of pluralism in this county we have only to turn to this deanery, a notorious instance being that of John Kirby the taxgatherer, who followed Mansel. The number of his clerical preferments, granted solely in reward for his services to the king, and with no regard to his fitness, ${ }^{30}$ created a painful

${ }^{23}$ Close, 9 Hen. I1I, m. 20.

${ }^{24}$ Le Neve, Fasti Eccl. Angl. ii, 308, 37 1, 482 ; Newcourt, Repert. i, 35 .

${ }^{26}$ Ibid. $\mathrm{M}$. II.

${ }^{25}$ Pat. 13 Hen. III, m. I. ${ }^{27}$ Ibid. m. 9 .

${ }^{23}$ Chron. Maj. (Rolls Ser.), vols. iii, iv, and v.

${ }^{29} \mathrm{He}$ held a prebend in London (Fasti Eccl. Anjl. ii, 397), was chaplain to Henry III, made chancellor by the king in 1243 (Pat. 27 Hen. III, m. 10), and the following year principal councillor (Matt. Paris, Chron. Maj. [Rolls Ser.], iv, 294). In the same year that he was presented to Wimborne he received the charge of the Great Seal and was made provost of Beverley (ibid. 601). In $125^{8}$ he witnessed a charter as chancellor of York (ibid. v, 672). Bilsington Priory in Kent was founded by him (ibid. v, 690-I).

${ }^{30} \mathrm{He}$ appears to have held only deacon's orders, and was ordained priest by Peckham the day before his consecration to Ely in $1286 ;$ Reg. Epist. Peckham (Rolls Ser.), iii, App. ii, I04 I. 


\section{A HISTORY OF DORSET}

impression in the minds of the more scrupulous and devout of the clergy, while the nature of his employment did not tend to add to his popularity. ${ }^{31}$ On his election to Rochester in 1285, Archbishop Peckham actively interfered and, on the ground of Kirby's notorious pluralism, desired the chapter to make another choice of a fit person. ${ }^{32}$ The archbishop did not interfere, however, when, in 1286 , the dean was promoted to Ely. ${ }^{33}$

No record seems to exist of the original endowment of the college and deanery, which at the beginning probably consisted of the great tithes of the parish, to which were added as time went on considerable gifts of portions of tithes and land. According to the Taxatio of 1291 the possessions of the dean and college were assessed at $f_{.71}$; the portion of the dean amounting to $£_{26} 13^{\text {s. }} 4 d$. from Wimborne, Kingston, and Shapwick; that of the four prebendaries $f$ ro each ; the sacrist $f, 46 s .8 d^{34}$ In 1349 , on the appointment of Reginald Brian, four commissioners were deputed, together with Thomas de Cary the sacrist, to survey the chapel, which was reported to be very defective in books and ornaments, and in need of repairs in the manse and houses as well as in the manors and other places in the country pertaining to the deanery, to the great injury of the then dean, ${ }^{35}$ who, the following year, was raised to the see of St. David's and subsequently made bishop of Worcester. The next occasion for an inquiry was in 1367 , when an inquisition was ordered to be held in the presence of Richard de Beverley, lately presented to the deanery, or his proctor and the executors of the late dean, Henry de Bukyngham, with a view to ascertain what damages and waste had occurred during the last

\footnotetext{
31 Just before the death of Henry III he was given the Great Seal, and, though he subsequently resigned it, appears to have been attached in some capacity to the chancery; the Annoies speak of him as vice-chancellor (Ann. Mon. [Rolls Ser.], iii, 315). In $128+$ he was made treasurer, but he was employed chiefly to travel the country and collect what sums he could for the king. The benefices with which his zeal was rewarded included the rectory of St. Burian's, Cornwall, the deanery of Wimborne, a canonry in Wells and York, and in 1272 the archdeaconry of Coventry; Wharton, Angl. Sacro, i, 637, note 4 ; Fasti Eccl. Angl. i, 568.

${ }^{32}$ Reg. Epist. Peckhom (Rolls Ser.), ii, 575.

${ }^{3}$ Wharton, Angl. Sacro, i, 637 .

"Pope Nich. Tax. (Rec. Com.), I 80 . Within the deanery of Pimperne the dean is said to have portions consisting of 13 s. $4 d$. from the church and chapel of Shapwick (ibid. 178), \&1 from Edmondsham, 10s. from Stanbridge or Little Hinton, and $L_{1}$ from Hampreston (ibid. 179); Hutchins, Hist. of Dorset, 139, 142, 435. The parishioners of Hampreston were formerly buried at Wimborne until 1440 , when they obtained a licence for their own burial-ground from Henry VI; Harl. MS. 6963 , fol. 56 .$$
{ }^{35} \text { Pat. } 23 \text { Edw. III, pt. 2, m. } 22 \text { d. }
$$

occupancy of the deanery, the nature of the defects, and whether they could be repaired within a cost of $£ 400$. The return made to the writ, giving the value of the dean's possessions, enumerates tithes in Shapwick, 100s. ; Kingston, 8 marks; Pimperne, 20s.; Bradford, 20s. ; Crichel, IOs.; parcel of Holt, with tithes of wool and lambs, $£^{8}$; tithes of Hampreston, $£_{4}$; demesne lands let to farm, 235.; tithes of wool and lambs, 40s.; and states that IVilliam Sewell, chaplain and farmer of the late dean, had 20 marks remaining in hand, and the reeve (praepositus) $\AA^{6}$ of arrears. ${ }^{36}$

Leaving the deanery, we find the staff of the college with sacrist and four prebendaries increased in the middle of the fourteenth century by the addition of four chaplains appointed to serve the chantry, known as the Great or Brembre's Chantry, founded in 1354 by the dean Thomas de Brembre, who, on 10 August of that year, obtained a royal licence to appropriate the advowson of the church of Shapwick, held in chief of the king, to the canons and college of Wimborne Minster for the sustentation of four chantry priests celebrating divine offices in the chapel under the sacrist according to the ordination of the dean. ${ }^{37}$ In addition to this grant the custodian and four chaplains obtained a licence enabling them to acquire 10 'marcatas' of land and rent in Walsford, Chalbury, Kingston, 'Duppleshegh,' and 'Cokeshull,' not held of the king in chief; while Richard de Corfton, at the same time, was permitted to assign to them one messuage, I 2 bovates of land, 16 acres of meadow, 5 acres of pasture, 2 acres of wood with 40 s. rent, and pasturage for sixteen oxen, twelve cows, forty pigs, and 400 sheep in the above places, valued at 7 Is. 4 d., to be held by the custodian and chaplains at the annual value of $f, 4$, in part satisfaction of the grant of 10 'marcatas.' 38 'The

${ }^{36}$ Inq. p.m. 41 Edw. III (2nd Nos.), No. 37.

${ }^{87}$ Pat. 28 Edw. III, pt. 2, m. 15. The church of Shapwick seems, from early times, to have becn attached to the deanery. In 1238 Henry III addressed letters to the bishop of Salisbury bidding him revoke the presentation he had made to the church on the ground that it belonged immediately to the deanery which pertained to the royal patronage. Pat. 2 Hen. III, m. 2.

${ }^{30}$ Pat. 28 Edw. III, pt. 2, m. 10. There may later have been some dispute in reference to this grant, for an entry in the Close Rolls of the last year of Henry IV states that Thomas Corfion testifies that he has released and quitclaimed to Richard Holhurst, sacrist of the church of St. Cuthburga of Wimborne Minster and custodian of the chantry of Thomas de Brembre, founded in the church, to Richard Skyll, William Vyncent, Richard Shephurd, and Thomas Pylle, chaplains, all personal actions which he may have or could possibly have against them 'from the beginning of the world up to the day of the "confection " of these present.' Close, 14 Hen. IV, m. 28. 


\section{RELIGIOUS HOUSES}

office of custodian of the chantry was held, ex officio, by the sacrist.

Besides the foundation of Dean Brembre, there was another and later chantry of equal, or even greater, importance in the church, founded by Margaret countess of Richmond and Derby but not completed till after her death. By a tripartite deed, dated 12 March, I 5 I I, between the executors of the will of the deceased countess, the dean and chapter of the college, and the sacrist or custodian and chaplains of the Great Chantry, reciting the grant procured by the countess of her son Henry VII by letters patent of I March, I497, for the foundation of a chantry of one chaplain in the royal free chapel or collegiate church of Wimborne 'to the praise and honour of Jesus and the Annunciation of the B. V. M.,' with licence to appropriate lands, rents, and benefices \&c., to the annual value of $f, 10$, to the said chaplain and his successors; and after the death of the countess and the appointment of her executors (Richard bishop of Winchester, John bishop of Rochester, and athers), the letters patent of Henry VIII, 7 August, I 509, in the first year of his reign, confirming the previous grant of his father and granting an additional licence to appropriate lands and rents to the annual value of $f^{6} 6$, besides the above $£$ I 0 , was established a perpetual chantry for the augmentation of divine service and for the souls of the said countess, her parents and ancestors, and all the faithful departed at the altar on the south side of the tomb of Jolin Beaufort, late duke of Somerset, and Margaret his wife, the father and mother of the aforesaid countess.

By this same deed Richard Hodgekynnes, B.A., was appointed the first chaplain, to reside in a house within the college opposite the chamber or dwelling of the sacrist and to teach grammar to all comers after the form and manner used at Eton and Winchester. Besides this duty he was bound to celebrate daily for the soul of the founder, and for the souls of her father, mother, and ancestors, special collects being appointed to be recited; an anniversary was fixed to be kept yearly on 29 July, whereon a requiem mass should be said, and at the end of the mass a distribution of 20s. made in the following manner:-To the sacrist of the college if he should be present in his surplice and amice, I6d.; to each chaplain 'present and devoutly singing,' $8 d$.; to every secondary and parish rlerk, $4 d$. ; to the sacrist for five wax candles to be burnt round the bier, and two on the altar during the mass, and for bell-ropes, $16 d$.; to those ringing the bells, $8 d$. ; the remainder of the 20s. should be distributed to the poor of the parish by the advice of the sacrist according to their necessities, thus :- to one, Id. ; to another, 2d. The said Richard Hodgekynnes should receive yearly $£_{1} \mathrm{O}$, and his servant or usher 40s., and he should present a yearly account, within Michaelmas and the Feast of All Saints, of his receipts and expenditure in the presence of the dean, or, in his absence, of the sacrist, and of the senior chaplain of the chantry of Thomas Brembre, and it should be deposited in a chest with three keys whereof one key should be in the custody of the dean, or, in his absence, of the sacrist, another in the custody of the senior chaplain, and the third should be kept by Richard Hodgekynnes himself and his successors. ${ }^{39}$

The deanery was held on the eve of the Reformation by the famous Reginald Pole, and according to the Valor of 1535 was worth f.29 8s. $4 d$. clear. $^{40}$ The office of the sacrist, held by Thomas Yeroth who also served the 'Redcottes' Chantry founded in the chapel of the hospital of St. Margaret and St. Antony within the manor of Kingston Lacy, ${ }^{41}$ was valued at $£ 59$ s. $4 d$. clear. ${ }^{42}$ The incumbents of the four prebends, Richard Sperkeford, John Starkey, Thomas Myllys, and George Lylly, received respectively the following stipends:fi 5 5s. 8d., fir 1 5s. 8d., f, I 5 I3s. $4 d$., and fi2 Igs. The number of chaplains attached to the Brembre or Great Chantry had been reduced from four to three, their names being given as Walter Gardener, Edward Thorpe, and John Ase, or Ace as he afterwards appears; each had a stipend of $f_{7}$ I Is. 1 od. Edward Laborne, the schoolmaster and chantry priest attached to the foundation of the late countess of Richmond and Derby, had a net income of $f_{9} 9$ I Is. $2 d^{43}$

In the return of the commissioners, appointed under Edward VI to take the value of the possessions of colleges and chantries and to report on their plate, goods and ornaments, the 'college or free chapel of our Sovereign Lord the king in Wimborne' was said to be worth $f 5$ I 5s. $6 d$., with 'rents resolute' of 66 I 3 s. $4 d$. and fees f6 $6 s$. 8d., reducing the clear income to $f 3^{8} 5$ s. $^{44}$ The sacrist's office after deducting 'rents resolute' of 6,3 I 4 s. Iod. was returned at $f, 5$ 2s. $4 d$. clear. ${ }^{45}$ The Great Chantry, with a deduction of f10 2s. $4 d$. in 'rents resolute,' was worth $f .347$ s. $5 d$., and had the following 'jewels' and 'ornaments' :-Three chalices weighing $55 \mathrm{oz}$., three pairs of old vestments worth 6s., two table borders, and one ladder 2 s.

Item I challice belonging to St. James weighing $5 \mathrm{oz}$. 2 basons of silver and gilt gyvty to the kinges Majestie by the parishioners of Wymborne so it [is] said= 500 . Total 8s., $110 \mathrm{oz}^{40}$

${ }^{39}$ A copy of the original of this deed is given by Hutchins, Hist. of Dorset, App. 3, iii, 271-3.

"Valor Eccl. (Rec. Com.), i, 273.

"For account of this chantry see under hospitals, p. 106.

"Valor Eccl. (Rec. Com.), i, 273.

${ }^{43}$ Ibid. 274-5.

"Chant. Cert. Dorset, 16, No. 24.

${ }^{45}$ Ibid. 25. 


\section{A HISTORY OF DORSET}

The chantry of Margaret, countess of Richmond, was returned at a clear income of $f^{6} 2$ s. o $\frac{1}{2} d$., and had no ornaments. ${ }^{47}$ The four prebends in the college called the 'first,' 'seconde,' 'thirde,' and 'fourthe staulle,' were worth respectively $£^{8}$ 1 os., $£_{7}$ I 5s. 2d., $£_{12}$ I 5s. 2d., and $£ 7$ is. Id. clear. ${ }^{48}$

Pole forfeited the deanery in 1537 and was succeeded at Wimborne by Nicholas Wilson. ${ }^{49}$ Some of the leading parishioners the following year addressed the dean a very respectful letter, saying they had been informed that 'Seynt Cutliborow's bed' was to be removed from their church.

And we know by our composycion that $y t$ ys the parishioners' goods and our chyrche ys in gret ruyn and decay and our toure ys foundered and lyke to fall and ther ys no money left in our chyrche box, and by reason of great infyrmyty and deth ther hath byn thys yere in our parysh no chyrche acle the whych hath hyndred our chyrche of $x x$ nobles.

The letter proceeded to ask whether the parishioners might sell the silver about the bead of the image, and apply the proceeds to the repair of their church. ${ }^{60}$

The college was dissolved in 1547, and we may gather the immediate effect of its suppression and of the withdrawal of the activity of the staff from the parochial and social life of the town from the second part of the commissioners' report of Edward VI. The chantry of the Countess Margaret," "founded to the intent that the incumbent thereof should say mass for the soul of the founder and to tech schooleing,' was empty, and complaints appear to have been made by the townspeople that their children had been deprived of the means of education provided for them :-

It is very requisite and necessary (ran the report) to have the said school maintained, for the town of Wimborne is a great market town and a thoroughfare and hath many children therein, and there is no grammar school kept within 12 miles of Wimborne, at which place the poor men dwelling in Wimborne and thereabout are not able to keep their children. Wherefore it is very requisite that the said school may remain still for the bringing up of young children in larnyng... without anything paying at all as it was in times past. ${ }^{32}$

"Chant. Cert. Dorset, 28.

48 Ibid. 29.

'L $L$. and P. Hen. VIII, xii (1), 1115 (42). At the close of 1536 , on the report that Pole was about to forfeit his promotion, William Marshall sought to procure the 'little dcanery' from Cromwell for his brother Thomas Marshall or his son Richard. Ibid. xi, 1355 .

Given by Hutchins from the parish records (Hist. of Dorset, iii, 1888). It is not noted whether so apparently reasonable a request was granted.

st With the exception of this chantry, the net value of which was returned at $£_{10} 12 \mathrm{~s}$. IId., the value of the rest of the offices had fallen in the second part of the report below that of the first.

${ }^{39}$ Chant. Cert. 16, No. 106.
From the sacrist's office, the last holder of which was Simon Benyson, ${ }^{63}$ a distribution was annually made to the poor of $20 .^{64}$ The clear income of the deanery, lately held by Nicholas $W^{T}$ ilson, then amounted to $f, 34$ ss. $7 d$.,

all which was employed as well towards his own portion and finding as towards the finding of poore men, in which said town of Wimborne be very many poore people unto the finding and relief whereof he did yerely distribute $£ 4$ at the lest. ${ }^{35}$

A note in reference to the four prebends in the college states :-

Mem $^{\text {d }}$ to have 4 priests to serve the cure in the parish of Wimborne because there be 3 chapelles wherein ther is devyne service, because the said chapelles be distaunt from the church of Wymborne 3 miles and are for the ease of the people. ${ }^{36}$

The report also serves to show of what the staff of the college consisted; besides the dean and sacrist, the four chaplains-afterwards reduced to three-ordained to serve the Great Chantry, the chantry priest and schoolmaster of the foundation of the Countess Margaret, there were four prebendaries who were bound out of their salaries to find and maintain four vicars and four 'secondaries' to discharge the cure of souls in the parish. The repetition of some of the names indicates that some offices were doubled; John Ace and Walter Matthew, chaplains of the Great Chantry, served as vicars of the first and third prebend. ${ }^{67}$

On its dissolution, in the first year of the reign of Edward VI, most of the possessions of the college were granted to (I) Edward, duke of Somerset, (2) to Giles Keylsway and William Leonard, and in 155 I to Edward, Lord Clinton. Notwithstanding the representation of the commissioners no steps appear to have been taken for the retention of the school till the reign of Elizabeth, when by a grant of the queen part of the property of the late college was vested in the governors of the free grammar school of Queen Elizabeth in Wimborne Minster in the county of Dorset. ${ }^{58}$

${ }^{53}$ He received a pension of $£ 5$ as late incumbent of Redcottes Chantry; Willis, Hist. of Mitred Abbcys, ii, 72 .

${ }^{4}$ Chant. Cert. 16, No. 108. This was probably the distribution ordained to be made annually at the discretion of the sacrist on the anniversary of the countess of Richmond and Derby and her parents.

3s Ibid. No. 111. The late dean was entered for a pension of 53 s. $4 d$. ; Add. MS. 19047 , fol. $8 d$.

${ }^{36}$ Chant. Cert. I6, No. III. Besides the free chapel of St. Peter within the town there were these three chapels outside the town: St. Katherine's of Leigh, St. Stephen's at Kingston Lacy, and St. James of Holt. Hutchins, Hist. of Dorset, iii, 228.

${ }^{57}$ Chant. Cert. 16, No. 109-11. They received a pension of $£_{0}^{6}$ each ; Add. MS. 19047, fol. $8 d$.

${ }^{s s}$ Dugdale, Mon. vi, 1452. 


\section{RELIGIOUS HOUSES}

\section{Deans of Wimborne ${ }^{53}$}

Martin de Pateshull, presented $1223^{6 j}$

Randolf Brito, presented $1229^{61}$

John Mansell, presented 1247

John Kirby, I 265

John de Berwick, presented I 286

Stephen de Malo Lacu or Mauley, presented $1312^{62}$

Richard de Clare, presented $1317^{63}$

Richard de Swynnerton, presented $1335^{61}$

Richard de Murymouth, presented $133^{65}$

Robert de Kyngeston, presented $1342^{66}$

Thomas de Clopton, presented $1349,{ }^{67}$ died in the same year

Reginald Brian, presented $1349^{68}$
Thomas de Brembre, presented $1350^{\text {es }}$

Henry de Bukyngham, presented 1361

Richard de Beverley, presented $1367^{70}$

John Carp, presented $1387^{i 1}$

Roger Coryngham, presented $1400^{72}$

Peter de Altobasso or Altobosco, presented 1412

Walter Medford, occurs 1415

Gilbert Kymer, presented $1423^{73}$

Walter Hurte, occurs 1467

Hugh Oldham, presented 1485

Thomas Rowthel, occurs 1508

Henry Hornby, occurs 1509 as an executor of the will of the countess of Richmond and Derby

Reginald Pole, presented $15^{1} 8^{74}$

Nicholas Wilson, presented $1537^{75}$

\section{ALIEN HOUSES}

\section{THE PRIORY OF FRAMPTON}

The Domesday Survey records that the manor of Frampton in Dorset was held by the church of St. Stephen, the Norman abbey of Caen founded by William the Conqueror 'for the weal of himself, his wife, his children, and his relatives," 1 and that 2 hides of land adjoining the manor were the gift of his queen Matilda, the whole being worth 40 s. $^{2}$ Henry II, confirming to the monks of Caen the gifts of his predecessors, enumerates the manor of Northam in Devonshire with its appurtenances, including wreck of the sea and dues of the ships calling there, given by Matilda in her last illness; the manors of Framptori and Bincombe in Dorset, the gift of the Conqueror together with 7 hides of land in East Hendred, Berkshire; the manor of Burton Bradstock, Dorset, given by Henry I, partly for the redemption of his soul and those of his father, mother and relatives, and partly in lieu of the crown and other ornaments belonging to it which William his father had bequeathed to the abbey; and the little manor (maneriolum) of Pantfield in Essex. ${ }^{3}$ Richard, archbishop of

59 The following are taken from the list given by Hutchins (Hist. of Dorset, iii, 186) from Browne Willis, verified and in some cases corrected according to the patent rolls and other official records; where no further reference can be found the list has been allowed to stand.

" Pat. R. Hen. III, m. 12.

${ }^{61}$ Ibid. $13 \mathrm{Hen}$. III, m. 1.

'2 Ibid. 5 Edw. II, pt. 2, m. 3 .

${ }^{63}$ Ibid. I I Edw. Il, pt. 1, m. 30.

${ }^{64}$ Ibid. 8 Edw. III, pt. 2, m. 5.

is lbid. 12 Edw. III, pt. I, m. 13.

${ }^{60}$ Ibid. $16 \mathrm{Edw}$. III, pt. 2, m. 14 .

${ }_{67}$ Ibid. 23 Edw. III, pt. 1, m. 31 .

${ }^{69}$ Ibid. m. 4.

${ }^{69}$ Ibid. $2+$ Edw. III, pt. 2, m. 17.

"Inq. p.m. 41 Edw. III (2nd nos.), No. 37.

${ }^{7}$ Pat. I I Kich. II, pt. 1, m. 27.
Canterbury, $1172-84$, confirming to the abbot and convent of St. Stephen's all their possessions in the province of Canterbury, includes the churches of Frampton, Bincombe, Winterborne, and Bettiscombe-saving the rights of the bishop of the diocese-according to the charter of Jocelin bishop of Salisbury. ${ }^{4}$ Henry III in I 252 granted to the prior and monks of Frampton the right of free warren within their demesne lands of Frampton, Ernley, Bettiscombe, Mosserigg, Burton Bradstock, and Bincombe, Dorset, and Northam (Devonshire), provided their lands should not lie within the king's forest. ${ }^{5}$

The Taxatio of 1291 gives the prior temporalities in this county amounting to $f_{6} 62$ 2s.; f.7 3s. 4d. from Northam, Devonshire, and f3 1 os. from East Hendred, Berkshire. ${ }^{6}$ The spiritualities of the priory are omitted. In the same year an order was sent to the treasurer and barons of the exchequer to acquit the prior of a fine of 100 s. in which he had been amerced for his claim for wreck of the sea within his manor of Northam. ${ }^{\text {? }}$

${ }^{73}$ Ibid. I Hen. IV, pt. I, m. 34.

${ }^{3}$ Ibid. 2 Hen. VI, pt. 1, m. 33.

"L. and. P. Hen. FIII, ii (2), 3943.

${ }^{75}$ Ibid. xii (1), $1115\left(t^{2}\right)$

1 See the Conqueror's charter for the abbey, Cal. Doc. France, 155.

${ }^{2}$ Donı. Bk. (Rec. Com.), i, $78 b$.

${ }^{3}$ Cal. Doc. France, 155-60. The charter of Richard $I$ in 1190 , contained in the inspeximus charter of Henry IV (Pat. 2 Hen. IV, pt. 1, m. 33), confirms the two manors of Frampton and Bincombe with their members; the manor of Northam, Devon, 7 hides of land at East Hendred, Berks ; Pantfield in Essex; Burton Bradstock, Dorset ; and a grant by Henry II of all kinds of fish cast up on their land.

'Cal. Doc. France, 162.

${ }^{3}$ Chatt. R. 37 Hen. III, m. 21.

${ }^{6}$ Pope Nich. Tax. (Rec. Com.), fol. 132b, $1 \delta_{3}$, $184,196$.

${ }^{7}$ Close, $19 \mathrm{Edw} . \mathrm{I}, \mathrm{m} .7$. 


\section{A HISTORY OF DORSET}

The cell of Frampton as a typical example affords very good material for a study of these alien dependencies, and from its history we may learn in a measure the vicissitudes of fortune that during the greater part of their existence alternately despoiled and restored them. As regards the attention they evidently attracted in this county it should be noted that their number and position near the coast made them legitimate objects of suspicion, and we have to remember that their prayers were naturally engaged, or supposed to be engaged, not for the armies of England and her king, but for her adversaries and an alien cause. ${ }^{8}$ On the seizure of lands held by Normans in England following the loss of Normandy in 1204 , the prior of Frampton is said to have secured his property from John by promising to pay a fine of 100 marks in two moieties, the first at Michaelmas, 1204, and the second at the Feast of St. Hilary following, and afterwards $£ 80$ yearly at the usual four terms, in return for which he was allowed the custody of the lands of the abbot of Caen in Somerset and Dorset. ${ }^{9}$ From this time $f 80$ per annum, or a proportionate fraction of it, seems to have been the sum demanded by the crown on the vacancy of the parent house occasioned by the death or cession of the abbot of Caen. ${ }^{10}$ Hugh de Neville was ordered 10 April, 1208, to restore to the prior of Frampton all his lands taken into the king's hands by reason of the interdict. ${ }^{11}$ The reign of Henry III passed without incident, but early in the reign of Edward I the cell excited suspicion, and the prior was required on a summons from the sheriff, April, 1275, to certify that neither he nor his house were in any way bound to any foreign merchant, nor had received from them money or 'arras' in exchange for their wool, which on the contrary the prior declared had been sold to Geoffrey and Thomas de Aune, burgesses of 'Corcestree,' and to Stephen Bray, burgher of Sefton. ${ }^{12}$

In 1294 the prior obtained letters of protection from Edward I for a year with other ecclesiastics who had granted a moiety of their benefices and goods to the crown ${ }^{13}$ and, in accordance with the principle of allowing the foreigner to escape none of the burdens imposed on the native clergy, in 1332 he was requested

8 This reason is set out among others in a letter of Edward II to the bishop of Salisbury in 1326 respecting the foreign cells in his diocese. Sarum Epis. Reg. Mortival, i, $27+d$.

${ }^{9}$ Rot. Norman. (Hardy), 126 ; Rot. de oblatis et fribus (Hardy), 199. In Oct. 1209, the king notified the sheriff that the first moiety had been paid into the Camera at Winchester on the Monday following the Feast of St. Michaelmas. Close, 6 John, m. 15 .

${ }^{10}$ Close, 8 Edw. II, m. 30.

${ }^{11}$ Ibid. 9 John, m. 3.

${ }_{12}$ Anct. Corresp. xvii, 125.

${ }^{13}$ Pat. 22 Edw. !, n1 8. to assist the subsidy raised on the occasion of the marriage of the king's sister. ${ }^{14}$ In December, I295, the protection granted to him the previous year was renewed, with the restoration of his lands and goods on condition that he should pay yearly a fixed sum at the exchequer for the custody, ${ }^{15}$ the grant being repeated March, I 297 , on the same terms. ${ }^{18}$

On the general seizure of the property of aliens in 1324 , the issues of the manors belonging to Frampton Priory taken into the hands of custodians by the king's orders from 8 October to the Io January following were valued at $626075.4 d^{17}$ An inquisition held to inquire as to the yearly value of the priory lands estimated Frampton with the advowson of the vicarage at 100 s. and the church held 'in proprios usus' at $£, 136$ s. to be worth $£ 58$ 4s. 9d. ${ }^{13}$ This measure, however, did not satisfy the king, and in September, 1326, in anticipation of a French landing, Edward II addressed a letter to the bishop of Salisbury pointing out the danger that lay in the position of the enemy's confederates near the coast, and desiring certain brethren dwelling in these parts to be transferred to other houses of the same order further inland. The bishop in his reply notified the king that in obedience to his order he had sent IVilliam Pyequier of the priory of Frampton up country to the monastery of Sherborne. ${ }^{19}$ As Edward III restored the lands and possessions of I I O alien houses a few days after his accession the following January, Frampton belonging to the abbey of Caen being of the number, this transference was probably not of long duration. ${ }^{20}$

A period of tranquillity ensued till the year I 337, when an outbreak of war caused foreign dependencies to be again seized, and Henry de Haydok, clerk, was deputed to take into the king's hand the lands and rents 'of foreign religious men of the power and dominion of the king of France' in this county, the sheriff to whom they had been delivered accounting for the issues of Frampton Priory then valued at 6.294 19s. 7 d. $^{21}$ The prior meantime was granted protection and allowed the custody of his house on condition of paying a yearly

${ }^{11}$ Close, 6 Edw. III, m. I6 d.

${ }^{15}$ Pat. 24 Edw. I, m. 21.

${ }^{16}$ Ibid. 25 Edw. I, m. 12 d.

${ }_{17}^{17}$ Mins. Accts. bdle. 1125 , No. 7 .

${ }^{13}$ B.M. Add. MS. 6164 , fol. 270 . The allowance made by the king to those foreign ecclesiastics whose goods and benefices he had seized was at the rate of 18d. a week with 40s. per annum for clothing and boots. Sarum Epis. Reg. Mortival, i, fol. 236.

${ }^{19}$ Ibid. fol. 274.

"Rymer, Foed. iv, 245-6. In fact the prior in 1338 was ordered to take up his station near the sea for the protection of the coast under penalty of being regarded as an adherent of the enemy. Rymer, Foed. (Rec. Com.), ii (2), 1062 .

${ }^{21}$ Mins. Accts. bdle. 1125 , No. 9 . 


\section{RELIGIOUS HOUSES}

farm of 690 and 10 marks. ${ }^{22}$ This payment included all incidental charges, and the king's escheator in $134 \mathrm{I}$ was ordered not to meddle further with the rriory, which he sought to enter on the excuse of the voidance of the abbey of Caen by the death of Simon the last abbot, as it was being farmed by the prior for the king; ${ }^{23}$ in the same way the collectors of the tenth granted by the clergy in $133^{8}$ were ordered to exact no more from the prior of Frampton, as he was already paying $£, 90$ for his farm. ${ }^{24}$ In December, 1341 , the foreign superior was ordered to appear before the council, and to bring with him all accounts and memoranda of payments made by him. ${ }^{25}$ The following month he received a promise that a quantity of wool requisitioned by the crown officials commissioned to take a moiety of wool in Dorset for the king's use should be paid for. ${ }^{26}$ An extent of the priory was ordered to be made at the close of $1344,{ }^{27}$ and in 1346 Edward III granted f, 100 of the farm of the priories of Frampton and Loders to William de Groucy, ${ }^{28}$ Thomas de Lancaster receiving a grant of $\oint_{100}$ of the farm of Frampton alone the following year. ${ }^{29}$

The waste and destruction attending the occupation of alien cells in the reign of Edward III resulted in a harvest of inquisitions under Richard II with the object of ascertaining the cause. A commission in 1381 was appointed to survey Frampton and its lands and to make inquiry into the damage done therein. ${ }^{30}$ The king, the year after, on the payment of 100 marks, licensed John Devereux, knt., to acquire the priory from the abbot of St. Stephen's, Caen, for life with successive remainder to Margaret his wife, John their son, and Joan their daughter, paying $f_{0} 80$ yearly farm at the Exchequer while the war should last. $^{31}$ The lessee presented in $13^{8} 7$ to the church of Frampton, which, except for an interval following the restoration of alien houses in $136 \mathrm{I}$, had been in the king's hands since I 337, and in 1385 the farm paid for the custody of the priory was remitted by letters parent of Richard II. Henry IV in 1400 confirmed the manor or priary of Frampton with its issues to Joan, the daughter

${ }^{29}$ Close, 1 I Edw. III, pt. 2, m. 13 ; Pat. I 1 Edw. III, pt. 2, m. 37 .

"Close, 15 Edw. III, pt. 3, m. 4. There was evidently some delay in complying, for the order was repeated in 1343 . Ibid. 17 Edw. III, pt. 2, m. 17.

${ }^{24}$ Ibid. 12 Edw. III, pt. I, m. 20.

${ }^{25}$ The order was transmitted to the sheriff the following month. Ibid. $15 \mathrm{Edw}$. IlI, pt. $3, \mathrm{~m} .5$. $6 d$. In 1345 , and again in 1347 , the prior, Lawrence de Brioco or Breoto, was summoned by name. Ibid. $19 \mathrm{Edw}$. III, m. 22 d.; 21 Edw. III, pt. 1, m. $6 d$.

${ }^{76}$ Pat. 15 Edw. III, pt. 3, m. 2.

${ }_{27}$ Ibid. $18 \mathrm{Edw}$. III, pt. 2, m. $12 d$.

${ }^{29}$ Ibid. 20 Edw. III, pt. 2, m. 1.

${ }^{29}$ Ibid. 2 I Edw. III, pt. 3, m. 34

${ }^{30}$ Ibid. 4 Ric. II, pt. I, m. $27 d$.

${ }^{31}$ Ibid. 5 Ric. II, pt. 2, m. 19. of John Devereux, who had survived her mother and brother, and with her husband, Walter FitzWauter, 'chivaler,' entered into possession in 1398.32 In 1402 after the restoration of alien houses, Frampton Priory, 'which is conventual,' was restored to Ralph de Nubibus, monk of the abbey of St. Stephen, Caen, on condition that he should maintain its former condition and pay to the king during the war the ancient apport due to the head house in time of peace, with other charges. ${ }^{33}$

It is, as a rule, extremely difficult to get any real idea of the internal condition of a foreign cell, and Frampton is no exception in this respect. The episcopal registers record that priors were presented by their superiors, the abbot of Caen or his proxy, to the bishops of Salisbury for institution, letters being subsequently issued to the archdeacon of Dorset for their induction. The resignation of a prior was also made into the hands of the ordinary, but though the house was of the Benedictine order and consequently could not claim exemption, there is no record that he exercised the right of visitation. A very common cause of misgovernment, the frequent and arbitrary withdrawal of the head of a dependent cell by the foreign superior, seems to have been present here, for in 1343 the bishop successfully petitioned the pope to confirm the presentation of Lawrence de Sancto Brioco to the priory in order to strengthen his position and prevent his arbitrary removal by his superior. ${ }^{34}$

Previous to the suppression of alien cells in I 414 the priory or manor of Frampton was made over by Henry IV to John, duke of Bedford, and Thomas Langley, clerk, keeper of the privy seal, for as long as the war should last for a yearly farm of $f, 936 \mathrm{~s} .8 \mathrm{~d}$., the grant under date of 2 March, 1414 , providing that a reduction should be made at the Exchequer in the event of the priory being injured and destroyed by the enemy (quod absit); it was followed in December of that year by another grant which remitted the payment of this rent and included William, prior of Ogbourne, as holding jointly with the duke and Thomas Langley, and again in 1410 by a licence enabling the duke to acquire from the chief houses in Normandy the whole, or part, of all the temporalities pertaining to the priories of Ogbourne and Frampton. ${ }^{35}$ Henry $V$ confirmed the grants of his father in the first year of his reign, ${ }^{36}$ but on the reversion of the priory of Frampton to the crown by the death of the duke of Bedford, it was given by Henry VI, I $6 \mathrm{No}-$

${ }^{39}$ Ibid. 2 Hen. IV, pt. I, m. 8. The February following, the king cancelled his previous grant of the profits of Frampton rectory to John Cheyne, knt., and Thomas Horston, clerk. Ibid. pt. 2, m. 31 .

${ }^{33}$ Ibid. 3 Hen. IV, pt. 2 , m. 22.

${ }^{31}$ Cal. Pap. Letters, ii, 26 ; iii, 187.

${ }^{36}$ By inspeximus of Henry V, Pat. I Hen. V, pt. 3 , m. 41 


\section{A HISTORY OF DORSET}

vember, $1+37$, to the dean and canons of the royal college of St. Stephen, Westminster, ${ }^{37}$ the gift being confirmed to them in $I+45,{ }^{38}$ and again on the accession of Edward IV. ${ }^{39}$ The Valor of 1535 gives the possessions of Frampton as still held by the college, who retained them down to the Reformation. ${ }^{40}$

\section{PRIORS OF FRAMPTON}

IVilliam Humez, I $207^{-1}$ f. $^{41}$

Guimund, I26I"

Robert ${ }^{43}$

Richard ${ }^{44}$

Martin, ${ }^{45}$ occurs 1296 and again in 1302

James de Troarno, presented $1302^{46}$

Richard de Montigney, presented I3I7, resigned $1329^{47}$

William de Rusca Villa, presented I 329 , resigned $1335^{48}$

Lawrence de Sasucto Brioco or Breoto, presented $1335,{ }^{49}$ occurs 1345 and $1347,{ }^{50}$ he presented to the vicarage in 13603

John Letour, collated by the bishop, $1377^{51}$

Ralph de Nubibus, collated by the bishop I $400^{53}$

${ }^{37}$ Pat. 16 Hen. VI, pt. 1, m. I 4.

ss The confirmation of 11 July, I 445, was given as the result of a pelition of William Walesby dean, and the canons of St. Stephen, setting forth that by an inquisirion held at Dorchester 1402 , it was found that a carucate of land within the manor had been granted by Henry IV on condition that a distribution of certain alms should be made to 'poor men,' that the carucate was valued at $t f s$, but that the distribution had ceased previous to the inquisition and the canons knew nothing of it, though the escheator continued to distrain them for the value of the land, and they prayed a remedy. The king in his reply stated that the possessions of the priory had been granted to the dean and canons in free alms and that, therefore, no exaction could be made from them. Ibid. $23 \mathrm{Hen}$. VI, pt. 2 , m. 8 .

${ }^{39}$ Ibid. Edw. IV, pt. 6, m. 1, 2.

${ }^{40}$ Valor Eccl. (Rec. Com.), i, +28

${ }^{11}$ According to a Cole MS. he was prior here until he was made abbot of Westminster in 1214 ; Dugdale, Mon. vi, 1000 . ${ }^{12}$ Ibid.

${ }^{43}$ This name is also given, but with no date and by no authority, in Hutchins and Dugdale.

"A seal found at Sydling in 1849 with the legend S. Ricardi Prioris de Fruntume, appears to be of thirteenth-century work; Foum. of Arch. Assoc. vii, $(1852), 162$.

${ }^{15}$ As authority for these dates, Hutchins gives a fine paid by the prior, $25 \mathrm{Edw}$. 1, and a presentation to the vicarage; Hist. of Dorset, ii, 300 .

${ }^{46}$ Sarum Epis. Reg. Simon of Ghent, ii, fol. $33 d$.

47 Ibid. Mortival, fol. 172.

${ }^{49}$ Ibid. Wyville, ii (Inst.), 40.

${ }^{49}$ Ibid. Wyville.

so Close, 19 Edw. III, m. 22 d. ; 21 Edw. III, pt. 1, m. $6 d$.

5l Sarum Epis. Reg. Erghum, i (Inst.), fol. I 5.

s: Ibid. Mitford, fol. $67 \mathrm{~d}$.
The fourteenth-century pointed oval seal of Prior Richard found at Sydling, near Frampton, represents the Virgin half-length, the Holy Child on the left knee, in the field on the left a crescent, on the right a star. In base, under a pointed arch with a carved gable topped by a cross on either side, the prior, half-length, in praver. ${ }^{53}$ Legend :-

\section{' ${ }^{\prime}$ ' RICARDI PRIORIS DE FRVMTVNE.}

\section{THE PRIORY OF LODERS}

This alien priory, cell to St. Mary of Montebourg, was founded about the beginning of the twelfth century in connexion with the manor which Richard de Redvers had given to the Norman abbey, said to be of his foundation. Henry I by charter confirmed the grant and testified to Roger, bishop of Salisbury, I 107-37, and Aiulf the chamberlain (sheriff of Dorset), that for the souls of his father and mother, of himself, his wife and children, and all his relations, he had granted to the abbey of Montebourg and Urse its abbot that the manor of Loders, which Richard de Redvers had given by his permission, should be assessed at five hides henceforth and for ever both in geld and other dues. ${ }^{53}$ Baldwin, earl of Exeter, confirming the gifts of his father to the abbey, which was to be wholly quit of all dues to the donor and his heirs, specifies the manor of Loders with all its appurtenances and the church, in Dorset, and the manor, appurtenances, and church of Axmouth, in Devonshire ; ${ }^{54}$ these are included in the charter of Henry II ratifying to the abbey the previous gifts of the reputed founder and his family. ${ }^{55}$

Besides the church of Loders the abbot of Montebourg held in Dorset before the end of the twelfth century the chapel of St. Andrew of Bradpole, the gift of William de Moreville ; ${ }^{56}$ the church of Powerstock, the gift of Roger Arundel $;{ }^{5 \pi}$ and the church of Fleet granted by Hawysia Redvers, the sister of Earl Richard, ${ }^{58}$ the last two being confirmed by Jocelin, bishop of Salisbury, in $1157 .^{59}$ About the year 1215 the abbot and convent of St. Mary, Montebourg, released

${ }^{53}$ B.M. Seals, lxii, 416 .

s3a Cal. Doc. France, 313 .

${ }^{3}$ Ibid. 314.

ss Dugdale, Mon. vi, 1097. Among other grants to the abbey by Henry II was one directing that the house, which was under his protection, should enjoy all such liberties and dues as it enjoyed in the time of his father; and another stating that the abbot and monks should be free of toll and passage and of all dues wheresoever they should go or whatever they should buy, provided it should be for the use of the monks. Cal. Doc. France 319.

${ }^{56}$ Ibid. 316.

${ }^{37}$ Chart. of Salisbury in Tacelfih and Thirtenth Cent. (Rolls Ser.), 26.

${ }^{59}$ Ibid. 28.

${ }^{59}$ Ibid. 29. 


\section{RELIGIOUS HOUSES}

to Bishop Herbert Poor and the chapter of Salisbury their churches of Powerstock and Fleet, ${ }^{60}$ and by a mutual arrangement were allowed to retain the church of Loders and chapel of Bradpole as a prebend in Salisbury, thereby entitling the foreign superior to a stall in the cathedral choir and a voice in the chapter. ${ }^{61}$ In the Taxatio of 1291 this prebend of Loders ' with the chapel' was assessed at 6.20 , the vicarage at $£ 5{ }^{62}$ the temporalities of the prior of Loders within the parish were reckoned at $f 26 .^{63}$ A commission was appointed on 18 October, 13 13, to investigate a complaint of the prior that John, rector of St. Mary's church in the neighbouring town of Bridport, had carried away his goods at Bradpole. ${ }^{64}$

The external history of Loders as an alien dependency follows very closely that of Frampton, with which it is frequently coupled during the period of the French wars. On its seizure by John in 1204 , together with the property of other Norman landowners in England, the land was reported to be worth $£, 33$ unstocked, with the stock f.40. ${ }^{65}$ The sheriff the following year was ordered to restore to Prior Baldwin full possession of his property 'which he holds of the abbot of Montebourg,' for which he had given two palfreys to the king with a promise to pay whatever he had formerly paid to the abbot, and not to transport any goods abroad without licence. ${ }^{66}$

The prior received from Edward I in 1294 , 1 295, and 1297 letters of protection with licence to retain the custody of his goods on the same terms and under the same circumstances as the prior of Frampton. ${ }^{67}$ On the seizure of alien property by Edward II in 1324 his goods within the manor of Loders and Bothenhampton, taken into custody from 8 October to 28 December, were valued at $\delta, 99$ 1s. $3 d .,{ }^{68}$ the extent of the yearly value of his lands was returned at $£ 5+8$ s. $5 \frac{1}{2} d$.; the church of Loders, which the monks held in proprios usus, a prebend of Salisbury, was worth $E_{.} 24$; the advowson of the vicarage 100 s., and of the vicarage of Bradpole $£_{10} 0^{69}$ On the eve of a threatened invasion of the French in the autumn of 1326 the bishop advised the king that in accordance with his mandate he had caused Ralph Pothyn of Loders Priory, a foreigner, to he transferred to the abbey of Sherborne as further removed from the coast. ${ }^{70}$

The outbreak of war in 1337 resulted in the priory being again taken into the hands of the

${ }^{60}$ Reg. St. Osmund. (Rolls Ser.), i, $225{ }^{61}$ Ibid. 226.

${ }^{62}$ Pope Nich. Tax. (Rec. Com.), 1816.

${ }^{63}$ lbid. $183^{b} . \quad{ }^{64}$ Pat. 7 Edw. Il, pt. 1, m. 1 I $d$.

Gis Rot. Norman. (Hardy), 124.

${ }^{66}$ Rot. de Finibus 1199-1215 (Hardy), 313.

${ }^{67}$ Pat. 22 Edw. I, m. 8; 24 Edw. I, m. $21 ; 25$

Edw. I, m. I $2 d$.

${ }^{68}$ Mins. Accts. bdle. I J 25, No. 7 .

${ }^{69}$ B.M. Add. MS. 6164 , fol. 270.

${ }^{70}$ Sarum Epis. Reg. Mortival, i, fol. 236. king, who restored it to the prior, 3 August, on condition that he should pay Io marks and a yearly farm of $£ 70$ for the custody, ${ }^{71}$ the payment of this amount superseding all other dues. The possessions of the priory at Loders and Bothenhampton, with the custody of which the sheriff had been charged, were valued at $£ 52$ 2s. and E3+ $175^{72}$ An interesting record under the year 1339 states that the king wrote to the bishop of Winchester cancelling his order for the removal of the prior of Appledurcombe in tha Isle of Wight and two of his monks from their priory near the sea coast to Hyde Abbey, owing to the war with France, desiring that they sliould be transferred instead to the house of the prior of Loders within the cathedral close of Salisbury, "which is further still from the sea."

Events in 1343 throw some light on a common enough feature of most dependent cells: the state of subjection in which the house was kept by the foreign superior. The bishop, we may note, beyond instituting the prior appointed by the abbot and convent of Montebourg and receiving official notification of his withdrawal, neither exercised nor attempted to exercise any jurisdiction in the priory; the check placed that year on the arbitrary methods of the abbot came from the king, who in February wrote to the sheriff that whereas he had committed to brother Roger, prior of Loders, an alien, the custody of his house for a certain farm, the abbot, his superior, on the false suggestion of the death of the prior had committed the management to another monk, and was endeavouring forcibly to remove the former contrary to the appointment made by the king, who forbade any such substitution to be allowed. ${ }^{74}$ The following year Roger Hariel, prior of Loders, obtained from the pope an indult that he should not be removed from the priory without reasonable cause, ${ }^{75}$ and as the next presentation does not occur until 136 I he secms to have made

${ }^{2}$ Close, 11 Edw. III, Pt. 2, m. 37.

${ }^{72}$ Mins. Accts. bdle. 1125 , No. 9. An inventory of the household goods of the cell, including beds or rather uno lecto $x x^{\text {s. }}$, is informing as to the internal equipment of a small religious house. Ibid.

${ }^{73}$ Rot. Aleman. 13 Edw. I1I, m. 6 d. On the other hand the prior of Loders and the heads of other alien cells as well as of native houses were ordered in 1338 to repair to manors nearer the sea in order to defend the coast from attack. Rymer, Foedera (Rec. Com.), ii (2), 1062 .

${ }_{74}$ Close, 17 Edw. III, pt. I, m. 27 . This order was addressed to the escheator in the Isle of Wight for the benefit of Roger Hariel, prior of Appledurcombe, as well as to the sheriff of Somerset and Devon for Roger, prior of Loders, who appear to be one and the same person, as Roger Hariel was certainly appointed to Loders in 1320 and occurs here in 1344 and later.

${ }^{76}$ Cal. Pap. Letters, iii, 116 . In February, 1346 , he received as prior of Loders another indult to choose a confessor. Ibid. iii, 210. 


\section{A HISTORY}

good his position. This is the nearest approach to any hint as to the internal condition of the house that can be discovered.

An inquisition held at Bridport the Wednesday after the Feast of the Annunciation, 1387 , states that the possessions of the priory in the parish of Loders at that date were worth 670 and at $\mathrm{Ax}$ mouth, Devonshire, $£ 30 .^{76} \quad$ Richard II, in the early part of 1399 , bestowed the house with all its appurtenances, rendering a yearly farm of $£ 80$ to the crown, on the Carthusian priory of St. Anne by Coventry, ${ }^{77}$ but the grant can barely have taken effect, for in November, almost immediately after his accession, Henry IV restored it to its former owners in the person of the prior, Sampson Trigal, ${ }^{79}$ the grant being confirmed to William Burnell, collated to the priory in March, $1401{ }^{79}$ On the final suppression of alien houses in I 4 I4 Henry $\mathrm{V}$ made over the possessions of this cell to the abbess and convent of the nunnery of Syon, which he had founded in the manor of Isleworth, Middlesex, the grant being ratified by Henry VI in $1424,{ }^{80}$ and confirmed by Edward IV in the first year of his reign, ${ }^{81}$ the manor appearing as parcel of the possessions of the abbey of Syon in the Valor of $1535^{82}$

\section{Priors of LODERS}

Baldwin, occurs in $1205^{83}$

$\mathrm{R}$ [oger or Robert], occurs in surrender deed of abbot of Montebourg, probably of the year $1213^{84}$

Robert, occurs $1308^{85}$

William de Carentonio or le Condu, presented I $313^{86}$ withdrawn 1320

Roger de Hariel, presented $1320^{87}$

Robert Dore, presented ${ }_{1} 361{ }_{1}{ }^{88}$ resigned ${ }_{1} 3_{4} 4$

Sampson Trigal, presented $1364^{89}$

William Burnell, collated $140 \mathrm{I}^{90}$

\section{THE PRIORY OF POVINGTON}

Povington, formerly a manor and now a hamlet in the parish of Tyneham in the isle of Purbeck, was granted to the abbot and monks of Bec-Hellouin in Normandy by Robert Fitz

${ }^{76}$ Add. MS. 6164, fol. 506.

7 Pat. 22 Ric. II, pt. 3, m. 4.

${ }^{79}$ Ibid. I Hen. IV, pt. 2, m. 13.

${ }^{2}$ Ibid. 2 Hen. IV, pt. 3 , m. 20.

so lbid. 2 Hen. VI, pt. 3, m. 20.

${ }^{81}$ Ibid. I Edw. IV, pt. 3, m. 1.

${ }^{62}$ Valor Eccl. (Rec. Com.), i, 425 .

${ }^{83}$ Rot. de Finibus, 1199-12 15 (Hardy), 313 .

${ }^{54}$ Reg. Rubrum, fol. 142 .

${ }^{65}$ Sarum Epis. Reg. Simon of Ghent, ii, fol. 73.

${ }^{66}$ Ibid. fol. 126.

${ }^{87}$ Ibid. Mortival, i, fol. 87 d.

${ }^{88}$ Ibid. Wyville, ii (Inst.), fol. 285.

${ }^{59}$ Ibid. fol. 305 .

${ }^{90}$ Ibid. Mitford.

\section{OF DORSET}

Gerold, ${ }^{91}$ a Norman who accompanied the Conqueror to England, and who is returned in Domesday as holding 'Povintone' of the king, the manor being valued then and in the days of Edward the Confessor at $f_{.}$I $1 .{ }^{92}$ In the roll of Norman landowners in England of the year I 205 the manor of Povington belonging to the abbot of Bec was valued at Ioos. unstocked, and at double that amount with the stock. The prior of Bec was reported to have removed since Easter eighty-five cheeses and all the wool of the flock, together with 1 mark from the sale of beans, I 5s. from the sale of oats, and 20s. $9 d$. of the Easter rent. ${ }^{93}$

Notwithstanding the many charters granted in favour of this Norman abbey by the Norman and early Plantagenet kings, ${ }^{94}$ the claim of the monks to their estates here did not pass unchallenged. As a result of a trial by wager of battle fought out between Avenel Fitz Robert and Henry abbot of Bec by his attorney, William de Wanecing, the former by a fine levied within fifteen days of Michaelmas, 1223, released to the said abbot his claim to the manor of Povington, and received by way of compensation the sum of 30 marks of silver. ${ }^{95}$

Towards the close of the thirteenth century the manor of Povington with its members of West Whiteway in the parish of Tyneham, Lutton and Blackmanstone in the parish of Steeple, and Milborne Bec in the parish of Bere Regis, had come to be reckoned as parcel of the priory of Ogbourne, Wiltshire, another cell to $\mathrm{Bec} ;{ }^{96}$ the temporalities of the prior of $\mathrm{Og}$ -

${ }^{91}$ The pancarta of this foreign abbey, granted by Henry VI (Pat. 12 Hen. VI, pt. 1, m. 13), contains inspeximus charters of Henry IV, Richard II, Edward III, Henry III, and Henry II, with a confirmation of the possessions of the monks by Henry I, including a grant of the manor of 'Ponniton' in the county of Dorset by Robert Fitz Gerold.

${ }^{2}$ Dom. Bk. (Rec. Com.), i, 80 .

${ }_{93}$ Ror. Norman. (Hardy), 123.

91 See collection of charters contained in Pat. 12 Hen. VI, pt. 1, m. 13, and Cal. Doc. France, 120-31.

${ }_{95} \mathrm{Feet}$ of $\mathrm{F} .7 \mathrm{Hen}$. III, 5 (26). Again in the autumn of 1225 Henry III directed the sheriff to delay a suit between Avenel de Purbeck and the abbot respecting a carucate of land with appurtenances in Milborne, and between John Fordham and the abbot in regard to the mill in Wareham until the following Easter, on account of the death of the proctor-general of the abbot in England, the abbot subsequently appointing Ralph de Exon, his monk, to act as his representative ; Close, 9 Hen. III, m. I ; ro Hen. III, m. 29 .

${ }_{96}$ In 1206 John signified to the sheriff of Bucks. that the prior of Ogbourne had paid f, 100 down for the right to hold in his custody all lands and possessions of the monks of Bec in England, so that he might be disseised of none of them save by the special command of the king, and that he had also engaged to send none of the issues abroad; Ror. de Oblatis et Finibus, 1199-1216 (H.rdy), 314. The town of 


\section{RELIGIOUS HOUSES}

bourne in Tyneham and Steeple, Milborne Bec and Povington being assessed at $f_{0} I I$ IOs. in the year $1291 .^{97}$

In common with other alien cells Povington was constantly taken into the king's hands during the wars with France. By an inquisition held on the occasion of its seizure 8 October, 1324 , by Walter Beril and Martin Roger de Blokkesworthe the goods found in the manor of Povington and Lutton were valued at $£ 5899^{98}$ The sheriff in 1337 was charged with the issues of Povington and Lutton, and of 'a certain place called Milborne Bek,' amounting to $f_{2} 28$ s. 9 d., which had been taken into custody by Henry Haydok, clerk, and delivered to him. ${ }^{99}$ The inquisition at Wareham the Monday after Easter, 1387 , probably ordered with a view to ascertain the cause of the steady decrease in value then taking place in most of the alien cells, showed that the possessions of the prior of Ogbourne at Povington and West Whiteway, Lutton, and Blackmanstone were worth $f_{6}$ i $^{\text {s. }} 4 d$. after all charges and deductions had been made. ${ }^{100}$

The vicissitudes of the manor during the fifteenth century were many and various, and one can hardly account for the contradictory cffect of many of the grants. Before the final suppression of alien priories in 14I4 Oghourne, with all its rectories, manors, land, and possessions, \&c., was granted by Henry IV to John duke of Bedford, who, piously recollecting the religious nature of the benefaction, made it over to the warden and canons of St. George's, Windsor, the gift being confirmed by Henry V. ${ }^{01}$ Henry VI, on the death of the duke in $1435,{ }^{102}$ granted the manor of Povington-together with pensions and portions in Milborne Bec, Turnworth, Charlton, and $\mathrm{Up}_{\mathrm{p}}$ Wimborne-parcel of the sometime alien priory of Ogbourne, which had reverted to the crown, to Richard Sturgeon, clerk, for life, and in 1442 bestowed the reversion of the manor with its members on John Carpenter, the master and brethren of the hospital of St. Anthony, London, for the exhibition and support of five boys or scholars 'well disposed ' at the university of Oxford, each of whom should previously have been well and sufficiently instructed in the rudiments of grammar at Eton College and should receive at the university $I O s$. per week until he

Povington was returned in 1285 , however, by the jurors of the hundred as belonging to the abbey of Bec-Hellouin, though they could not say by what title. The abbot claimed to have the fines (amerciamenta) of his tenants, the assize of bread and ale, and the right to hold a view of frankpledge within the manor; Ing. of Assess. reloting to Feud. Aids, ii, $23-4$.

${ }_{97}$ Pope Nich. Tax. (Rec. Com.), 183-4.

98 Mins. Accts. bdle. 1125, No. 7 .

${ }^{99}$ Ibid. No. 9.

${ }^{100}$ Add. MS. 6164 , fol. 506.

${ }^{101}$ Chart. R. I Edw. IV, m. 20.

${ }^{103}$ Inq. p.m. 14 Hen. VI, No. 36. had attained the degree of bachelor of arts. ${ }^{103}$ This arrangement notwithstanding, the king nine years later gave to the provost and college of Eton the farm or rent to be paid by John Newburgh, knt., for the custody of the manor of Povington to which he had been appointed the previous Michaelmas, 1450, together with the reversion of the same. ${ }^{104}$ Edward IV, in the first year of his reign, while confirming the previous grant to St. George's, Windsor, of the alien priory of Ogbourne and all its appurtenances by John duke of Bedford, granted the manor of Povington to William Beaufitz for the term of twenty years. ${ }^{105}$ In 1467 he made it over to Eton College, ${ }^{106}$ and again in 1474 made it the subject of another grant in favour of the chapel of Windsor. ${ }^{107}$

The schemes of the Yorkist king for the union of Eton and Windsor and the enrichment of the royal chapel of the latter by the endowments of Henry VI's college were foiled by the decision of Archbishop Bourchier. ${ }^{108}$ Edward IV by letters patent of May, I 478 , appears to have repeated his grant of this manor to Windsor, ${ }^{109}$ but Povington was, nevertheless, restored to Eton with other lands of which it had been deprived in anticipation, and remained in the hands of the college down to the reign of Henry VIII. ${ }^{10}$

There is in the case of Povington little to favour the presumption that a religious house was actually maintained here. A single reference to it as a 'priory' occurs years after it had passed away from its ancient possessors the abbots of $\mathrm{Bec},{ }^{111}$ and, in all probability, it would be most accurately described as a grange.

\section{THE PRIORY OF SPETTISBURY}

Robert de Bellomonte or Beaumont, earl of Leicester and count of Meulan, in the reign of William Rufus granted to the abbey of St. Peter of Préaux in Normandy, twin foundation to the other abbey of St. Leodegar or Leger on whom his father Roger had bestowed Stour Provost in this county, ${ }^{12}$ the manor of Toft, Norfolk, with the tithes of Charlton Marshall and Spettisbury, Dorset, the churches of these two vills, and the lands belonging to them; ${ }^{113}$ the earl by another charter testifying that his gift, made for

${ }^{103}$ Pat. $20 \mathrm{Hen}$. VI, pt. I, m. 5.

${ }^{104}$ Ibid. 29 Hen. VI, pt. 1, m. 9.

${ }^{105}$ Chart. R. I Edw. IV, m. 20.

${ }^{106}$ Pat. 7 Edw. IV, pt. 3, m. 13.

${ }^{107}$ Ibid. 14 Edw. IV, pt. 4, m. 1 .

${ }^{209}$ Hist. of Colleges of Winchester, Eton, \&x. (Ackermann), 29.

${ }_{109}$ Pat. 17 Edw. IV, pt. I, m. 1.

110 Valor Eccl. (Rec. Com.), iv, 2 I 6.

111 This is in the patent of Edivard IV in 1467;

Pat. 7 Edw. IV, pt. 3, m. I3.

113 Tanner, Notitia, Dorset, xxvii.

${ }^{13}$ Cal. Doc. France, 111. 


\section{A HISTORY OF DORSET}

the souls of the Conqueror and Matilda his queen, for the weal and prosperity of IVilliam king of the English, as well as for the souls of his own parents, Roger and Adelina, for himself and Henry his brother and all his predecessors, had been allowed and confirmed by King IVilliam at Whitsuntide when he first held his court in his new hall at Westminster. ${ }^{114}$ The valuation in the reign of John of the lands of Normans in England seized into the king's hand states that Spettisbury belonging to the abbot of Preaux was worth $f_{12}$ unstocked, and with the stock already there $f_{1} 15$; if stocked to the extent of its capacity it should be worth $f_{2} 20$; nothing had been removed therefrom." In 1291 the church of Spettisbury, in the deanery of IVhitchurch, together with the chapel of Charlton Marshall was assessed at $£ 10$. The prior of Spettisbury had a pension therein of 305. , and received $\bar{t}, 46 \mathrm{~s} .8 \mathrm{~d}$. from tithes; the temporalities in Spettisbury were reckoned to the abbot of Préaux or de Pratellis as worth $f_{0} 126 s_{0}{ }^{116}$ On 27 October, 1312, Thomas de Marisco of Spettisbury obtained a licence from the king enabling him to alienate a moiety of a mill in Spettisbury to the abbot and convent of Préaux in exchange for 2 acres of land and I rood of meadow in the same town. ${ }^{117}$

Little is known of the history of this alien cell up to the period, at any rate, of the French wars. Edward II in 1317 ordered his escheator to restore the manors of Toft (Norfolk), Spettisbury (Dorset), IVarmington (Warwickshire), and Aston (Berkshire) belonging to the abbot and convent of Préaux, which had been seized into the king's hand on the pretext of the vacancy of the abbey, alleging that these were originally granted by Robert, earl of Leicester and count of Meulan, with the consent of his progenitors, and that neither he nor they had been accustomed to receive any of the profits on the death of the foreign superior. ${ }^{118}$ The abbey seems to have placed a monk here at an early date to look after the property and conduct divine service, for the prior of Spettisbury is included among those ecclesiastics who in I $29+$ received from Edward I a grant of protection in return for a contribution

"Cal. Doc. France, I I1. By a subsequent charter in the reign of Henry II, Robert count of Meulan confirmed to the monks of Préaux all the land bestowed on them in Charlton by the gift of his knight Hugh, named the villein (cognomento Villanus); ibid. 1 17-18. Henry II confirmed the grant made to the abbey, his charter being inspected and confirmed by Edward I. Chart. R. 13 Edw. I, m. 21 , No. 69.

${ }^{115}$ Rot. Norman. (Hardy), 122.

${ }^{116}$ Pope Nich. Tox. (Rec. Com.), $178,184 b$.

117 Par. 6 Edw. II, pt. 1, m. 13. The following May the monks, on payment of a fine of 20 s., were pardoned their trespass in having acquired the above premises without obtaining a royal licence. Ibid. pt. $2, \mathrm{~m} .6$.

${ }^{119}$ Close, 1 I Edw. II, M. 22. to him from their goods and benefices; ${ }^{119}$ and in 1328 protection for a year was conceded by Edward III. ${ }^{120}$ Previous, however, to the year 1324 the foreign superior annexed this manor to the priory of Toft in Norfolk, the head house of the abbey in England; and in the capacity of proctor to the abbot the prior of Toft presented to the rectory of Spettisbury in March, 1327 , the king directing the bishop of Salisbury not to institute until it had been ascertained whether the late rector, Ralph Moreb, an alien, had died before or after 5 February, on which date Edward III restored the possessions of alien religious men seized during the late king's reign. ${ }^{1202}$

On the seizure of aliens' lands under Edward II the issues of the manor of Spettisbury, taken into. custody as parcel of the temporalities of the prior of Toft, 8 October, 1324 , and restored to his proctor the following 25 February, were valued at $6^{6}$ I $45.8 d^{121}$ On their re-seizure by Edward III in 1337 the issues with which the sheriff was charged amounted to $\AA_{25}$ I 7 s. $^{123}$ The goods belonging to the rectory, held by a Frenchman (Gallicus), were seized at the same time and estimated at $£$ I 2 os. $4 d^{123}$ They were subsequently restored to the foreign incumbent on condition that he should pay the king annually a farm of 100 s. $^{124}$

Towards the end of the century the abbot of Préaux was successful in letting his English property. Lewis de Clifford obtained a licence from the crown, 12 October, 1390, to acquire for life, with remainder to his son, the manor of Toft with Spettisbury and other possessions of the abbey of Préaux, on condition that he should pay annually during the continuance of the French war the sum of 6,80 to the king's exchequer, the payment of this farm being remitted later in the year. ${ }^{125}$ Henry IV, in $\mathrm{I}_{4} \mathrm{O}_{3}$, confirmed a grant of these manors by Lewis de Clifford to Thomas Erpingham, ${ }^{126}$ in whose possession they remained down to the suppression of alien houses by the Parliament of Leicester in 1414 , after which they were held in trust to the use of the said Thomas for the term of his life ${ }^{127}$ and subsequently, with the approval of Henry $V$, made over to the priory of Witham (Somerset), the first house of the Carthusian order in England. ${ }^{128}$ Edward IV, in the first year of his reign, confirmed to the Carthusian

119 Pat. 22 Edw. I, m. 8.

190 Ibid. 2 Edw. III, pt. 2, m. 17.

${ }_{180 a}$ Close, I F.dw. III, pr. 1, m. 9 ; see also Rymer, Foedera, iv, 246-7.

121 Mins. Accts. bdle. 1 I 5 , No. 7 .

${ }^{193}$ Ibid. No. 9.

${ }_{124}$ Close, 15 Edw. III, pt. 3, m. 6 d. ; 17 Edw. III, pt. 2, m. $27 d$.

${ }_{12 s}$ Pat. If Ric. II, pt. I, m. 2 I ; ibid. pt. 2, m. 46.

${ }^{126}$ Ibid. 4 Hen. IV, pt. 2, m. 8.

197 Ibid. I Hen. VI, Pt. 4, m. 15.

${ }^{129}$ Ibid. 7 Hen. VI, pr. 1, m. 12. 


\section{RELIGIOUS HOUSES}

house the manors of Spettisbury (Dorset), Warmington (Warwickshire), and Aston (Berkshire), lately belonging to the alien priory of Toft, together with all fees and advowsons pertaining to the same. ${ }^{\text {I29 }}$ The following February $(1462)$ he transferred the posiessions of Toft to the college of St. Mary and St. Nicholas-now King's College-Cambridge, ${ }^{130}$ with the exception of Spettisbury, which remained in the possession of Witham Priory down to the Dissolution, the Valor of $1535^{131}$ stating that the prior of Witham had rents here amounting to $£ 35$ os. Iod., besides the sum of 26 s. $8 d$. as the fee of William Frye the steward, and a pension of 30s. similar to the one paid to the prior of Spettisbury in $129 \mathrm{I}$.

\section{THE PRIORY OF WAREHAM}

An ancient monastery, probably the earliest religious foundation in this county, was built here in Saxon times, but afterwards destroyed in the Danish raid of $876 .{ }^{132}$ Cressy, in his account of the assault on Wareham by the Danes in that year, describes the house as ' a noble monasterie of religious virgins seated in the same town." "33

After the Conquest a priory or cell to the Norman abbey of Lire, founded by William Fitz Osborn, kinsman and marshal to the Conqueror, ${ }^{134}$ was established here in the early part of the twelfth century in connexion with the churches and lands in Wareham granted to the abbey by Robert earl of Leicester. A charter in the register of Carisbrooke Priory, the chief house of Lire in England, states that Henry II confirmed to the abbot and convent among their English possessions the church of Wareham with its appurtenances, the church of Gussage with Ioos. worth of land, and the church of 'Rinchorde' with its appurtenances, the gift of Robert earl of Leicester, with a hide of land in Wareham the gift of William de Waimura or Weymouth; while by another charter he confirmed to the abbey the churches of Wareham, with a hide of land given by Robert earl of Leicester, and an ounce of gold given by

i29 Pat. I Edw. IV, pt. 4, m. 6.

${ }^{130}$ Ibid. pt. 3, m. 23.

131 Valor Eccl. (Rec. Com.), i, 1 57-8.

138 Tanner, Notitia, under Dorset, xxix.

${ }^{133} \mathrm{Ch}$. Hist. of Brit. (1668), lib. xxviii, cap. iv. Leland describes this nunnery as situated between the two rivers, the 'Frome' and the Trent or Puddle, but it must not be confounded with that other monastery near the Frome in Somerset built by Aldhelm and included in the bull of Pope Sergius I in 701, granting privileges to various monasteries of the bishop's foundation, which was probably also destroyed by the Danes; Leland, Collect. ii, 388 ; Birch, Cart. Sax. i, 152 ; Tanuer, Notitia, under Somerset, xxi.

${ }^{134}$ Dugdale, Mon. vi, ro4o.
William de Waimuta, in the reeveship (praepositura) of Wareham. ${ }^{135}$

In 1290 the prior successfully petitioned the king to grant a licence for Peter Doget, chaplain, to alienate to the brethren a messuage and a carucate and a half of land in Whiteway ; ${ }^{1 * 6}$ and in 1329 , by a fine of 20 s., the prior and convent obtained a licence for the alienation in mortmain of a messuage and land in Whiteway towards the support of a chaplain to celebrate daily in the convent church for the souls of all the faithful departed. ${ }^{137}$

Besides the church of St. Mary, Wareliam, of which the prior was the rector, the prior held the presentation of the churches of St. Martin, St. Michael, and St. Peter within the town. In 129 I the spiritualities amounted to $f$ I 22 s. $9 d$. from the churches of Shapwick, Gussage (St. Michael), Holy Trinity Wareham, St. Mary Wareham, Knowle, Winfrith Newburgh, and East Stoke. ${ }^{138}$ The temporalities within Steeple and Tyneham, Whiteway, Egliston, Blandford, and Wareham, were worth $f 8$ os. $8 d .^{139}$

The priory is not mentioned in the general seizure of alien cells as the property of Norman landowners in 1204 , but it occurs on the eve of John's death in 1216 , when the king notified Peter de Manley that he had committed the abbey of Shaftesbury to the prior of Wareham during a vacancy, and that the abbey should remain under the king's protection solong as it was in the custody of Prior William. ${ }^{140}$ An order was subsequently issued in November in the first year of Henry III, directing the prior to cause the newly-elected abbess to have full seisin of all the possessions of the abbey. ${ }^{141}$

Edward III in 1294 granted letters of protection to the prior in return for a grant of a contribution from his goods, ${ }^{142}$ the letters being renewed in March, 1297, for Prior Nicholas Bynet. ${ }^{143}$ On the seizure of alien property in I 324 , the goods and possessions found in this cell by Walter Beril and Roger de Blokkesworthe, custodians of religious houses 'of the power and dominion of the king of France,' were found on inquisition to be worth $6.2714^{5}$. $6 d$., of which $f^{6}$ os. rod. came from the parish of Wareham. ${ }^{144}$ On being taken into the king's hands by Edward III in 1337, they were valued at

${ }^{135}$ See Chart. under Carisbrooke, Dugdale, Mon. vi, $10+1$, No. v.

${ }^{136}$ Anct. Pet. 10881 ; Pat. 18 Edw. I, m. I 8.

${ }^{137}$ Ibid. 3 Edw. III, pt. I, m. 17.

${ }^{138}$ Pope Nich. Tax. (Rec. Com.), 178,17 S6, $179 b$.

139 Ibid. $183-4$.

${ }^{140}$ Close, 18 John, m. 1, 2.

1:1 Pat. I Hen. III, m. 16.

${ }^{143}$ Pat. 22 Edw. I, m. 8. The prior of Wareham was also requested in 1332 to contribute towards the subsidy raised on the marriage of the king's sister; Close, 5 Edw. III, pt. I, m. 6 d.

${ }_{143}^{14}$ Pat. 25 Edw. I, pt. 1, m. 13.

146 Add. MS. 6164 , fol. 282. 


\section{A HISTORY OF DORSET}

f.39 16s. $2 d .{ }^{145}$ and the house was committed to the custody of the prior for the payment of IOS. and an annual farm of 40 . at the exchequer. ${ }^{\text {I46 }}$ A year later the prior of Wareham, together with the heads of nine other abbeys and priories, was ordered to remove to manors nearer the sea, for the defence of the coast in view of a threatened attack from the enemy. ${ }^{147}$

Information may be gathered as to the management of the cell in the middle of the fourteenth century from a complaint made by Prior Robert de Gascur or Gascourt, soon after his appointment in $1354,{ }^{148}$ as to the condition in which he then found it. According to the writ of inquiry issued the following year, the late Prior William de Noys, to whom the custody had been committed, had grievously abused his trust ; he had consumed and entirely dissipated the goods and chattels of the house, had alienated its property, and transferred abroad a large sum of money acquired by such alienations; the present head, in consequence, found he could not get a sufficient living for himself and his fellow monks, could neither pay the king the annual farm of fos. or 6 marks, nor restore the buildings which his predecessor had allowed to get out of repair, and he prayed the crown to appoint a remedy. ${ }^{149}$ IVe may here state that the episcopal registers record the presentation of priors to the ordinary by the abbots of Lire, or their proctors the priors of Carisbrooke, and their admission after having made profession of canonical obedience; but, as in the case of the larger priories of Frampton and Loders, no attempt seems to have been made by the bishop to exercise jurisdiction.

Richard II in I 39 I committed to Ralph Maylok, proctor of the abbot of Lire, the custody of all the possessions of the abbey in England, with the exception of the three priories of Carisbrooke, Wareham, and Hinckley (Leicestershire), for an annual rent of $£ 122$. In November, I394, the grant was renewed in favour of Thomas Wallwayn, Robert de Whytyngton, and William Slepe, but revoked the following jear on the petition of the abbot's proctor. ${ }^{150}$ An inquisition held at Wareham the Monday before Easter, I 387 , as to the possessions of the priory, stated that these were then worth fio after all deductions and charges had been reckoned. ${ }^{151}$ In the last year of his reign, the king, at the request of his nephew Thomas duke of Sussex, made over to Edmund, prior of Mount

145 Mins. Accts. bdle. 1125 , No. 9.

146 Close, 2 Edw. III, pt. 3, m. 6.

117 Rymer, Foed. (Rec. Com.), ii (2), 1062.

14 Sarum Epis. Reg. Wyville, ii (Inst.), fol. 264.

113 Hutchins gives a copy of the original of this writ of inquiry ; Hist. of Dorses, i, 87 .

${ }_{150}$ Pat. 18 Ric. II, pt. 2, m. 7.

${ }^{151}$ Add. MS. 6164, fol. 506 .
Grace in Yorkshire, the priories of Hinckley, Wareham, and Carisbrooke, paying respectively a yearly farm of $£ 50, £ 4$, and 110 marks, with the rest of the English possessions of the abbey, the farm of which amounted to 200 marks, for as long as the war should last, and quit of all payment of yearly rent. ${ }^{153}$

Upon the suppression of alien houses in $\mathrm{I}_{4} \mathrm{I} 4$, Henry $V$ bestowed on the Carthusian priory which he had founded at Sheen all the lands belonging to the abbey of Lire in England with the exception of the Hinckley priory, ${ }^{153}$ the $V$ alor of I 535 giving the Surrey foundation temporalities and spiritualities in this county amounting to E4t IOs. $8 d$. from estates that had formerly belonged to the late priory of W Wareham. ${ }^{154}$

\section{Priors of IVAReham}

\section{Roger, temp. Richard I ${ }^{155}$}

William, occurs $1216^{156}$

Nicholas Bynet, occurs $1297^{157}$

Peter de Deserto, presented I $302{ }^{158}$

John Mabere, presented 1309, ${ }^{159}$ died I3 I I

Hilderic de Pacoys, presented I 3 I I 160

Ralph, called Coudray, presented $1323^{161}$

William de Bally, presented 1329 , $^{162}$ resigned 1332

John de Bediers, presented $1332^{163}$

Michael de Molis, presented $1334^{164}$

William de Barly, presented $1343^{165}$

IVilliam de Noy's, presented I 349, resigned $1354^{166}$

Robert de Gascur, or Gascourt, presented I $354^{167}$

Ludovicus de Goulaffe, presented $1362,{ }^{168}$ resigned in same year

Peter de Ultra Aqua, presented $1362,{ }^{169}$ resigned $13^{6}+$

William de Minguet, presented $1364{ }^{170}$

Stephin de Barra, died $14{ }_{1} 2^{171}$

John Kyngeston, presented I 4 I $2{ }^{172}$

Walter Eston, presented $1416^{173}$

152 Pat. 22 Ric. II. pt. 3, m. I0-I I.

${ }_{153}$ Chart. R. 3 \& 4 Hen. V, No. 8 ; Pat. 2 Hen. VI, pt. $4, \mathrm{~m} .26-27$.

1st I'alor Eccl. (Rec. Com.), ii, 52.

${ }^{15 s}$ As witness to a charter (1 191-7) of Hawys, countess of Gloucester; Cal. Doc. Frince, 387.

${ }^{156}$ Close, I 8 John, m. I, 2.

${ }_{157}$ Pat. 25 Edw. I, pt. I, m. I 3.

135 Sarum Epis. Reg. Simon of Ghent.

${ }^{159}$ Ibid. i, fol. 79 d.

${ }^{161}$ Ibid. Mortival, i, fol. I1 4.

${ }_{162}$ Ibid. $178 d$.

${ }^{163}$ Ibid. Wyville, ii (Inst.), fol. 18.

164 Ibid. fol. 31 .

${ }^{106}$ Ibid. fol. 264.

${ }^{168}$ Ibid. fol. 295.

${ }^{170}$ Ibid. fol. $305 \mathrm{~d}$.

${ }^{173}$ Ibid.
${ }_{160}$ Ibid. fol. $106 d$.

165 Ibid. fol. I 3 I.

167 Ibid.

${ }^{163}$ Ibid. fol. 298.

${ }^{171}$ Ibid. Hallam, fol. 39 .

${ }^{173}$ Ibid. fol. $59 d$. 


\section{POLITIGAL HISTORY}

D

ORSET is tripartite, the three sections being felix, petraea, deserta ; clay, chalk, sand; vale, down, heath. ${ }^{1}$ Salient high ground stretches between the Axe and the Stour, thrusting to Poole Harbour a southern arm, the Chaldon and Purbeck downs, unbroken but by the gap of Lulworth. 'Dorset felix' is the alluvial fringe of this central mass, the valleys of the Stour and Char, and the land drained by the Birt and the Wey. The Frome valley, between the main plateau and the northern hills, is heathland. Dorchester guards it on the west, Wareham on the east, for it is the natural inlet into the heart of the county.

Such an area is a geographical nucleus, but lacks naturally defined boundaries. Its borders will impinge on the adjoining districts. Hence Dorset is ever closely connected with Somerset and Wiltshire. But the watershed of the Char and the Axe tended to strengthen the fortuitous circumstances dividing Devon from the West Saxon kingdom; while the development of Dorset and Hampshire was long differentiated by the marshes and heaths of the Avon, geographical features possibly reproduced in an old tribal boundary."

Dorset does not, like Hampshire, centre round its main water system. Unlike that of the Avon, the lower Frome valley is sterile, and its estuary difficult of navigation. The marshy flats running west from Chesil ${ }^{s}$ cause the county to look north, towards the fertile vale of Blackmoor, and to turn its back upon the seaboard, even as Weymouth long faced inland, away from the bay. Dorchester, ${ }^{4}$ communicating at ease with north and south, east and west, is the obvious political centre: Weymouth, called into being for its natural harbour, ${ }^{5}$ and separated from Dorchester only by the Ridgeway, gave access to the continent.

Of the British inhabitants little is known. The Druidic worship of the Poxwell temple, and the phallic rites connected with the Cerne giant, examples of the two types of British remains, point perhaps to occupation by different tribes (Goidel and Brython), perhaps merely to the Celt and the pre-Celtic Iberian of the round and long barrows respectively. ${ }^{6}$

Roman exploratory expeditions were succeeded by Roman colonization, but Dorset lay on the western fringe of both movements, and their influence

${ }^{1}$ H. M. Moule, in Quart. Rev. 1862 .

${ }^{2}$ See Guest, The Four Ways, Belgic Ditches; Early Engl. Settlements; Warne and Smart, Ancient Dorset; Warne, Map of Ancient Dorset; Camden, Britannia (ed. Gibson, 1722), i, 5 I ; Hubbard, Early Man on the Drouns; Neolithic Dewponds and Cattleways.

${ }^{3}$ Middendorf, Altenglische Flurnamen (Würzburg, 1900), i, 27.

- For the origin of the names Dorset and Dorchester, see Guest, Orig. Celt, i, 46, 372 ; Freeman, Norm. Cong. i, 49, 571 .

${ }^{5}$ It would seem that Weymouth was always the sea-station for Dorchester; Warne, Geltic Tumuli of Dorset, $1,2$.

${ }^{6}$ See Rhys and Brynmor-Jones, Welsh People, map, P. 75 (ed. 1902); see also p. 83 ; Seebohm, Tribal Custom in Anglo-Saxon Law, 397 (ed. I902); Willis-Bund, Celitic Church in Wales, I 2. 


\section{A HISTORY OF DORSET}

lacked intensity. No Dorset town received the higher municipal franchise ; while the villa-remains end at Lyme Regis. ${ }^{1}$

The long prevailing view of the West Saxon conquest was that, after their first settlement round the Solent, the Gewissas received a check at Badbury, ${ }^{2}$ that the thick forests then covering the present Dorset caused a check in their incursions, and led ultimately to the conquest of the Selwood by way of Wiltshire and Somerset, and not by sea. This conquest is said to have been very gradual, and to have taken place by distinct stages, between the conquest of Old Sarum, ${ }^{3}$ and the beginning of the eighth century. The victory of Deorham (577) threw open the Severn valley, and the invaders, (forced back upon the territories in their rear, by the insurrection of the Hwiccas, and loss of the Severn valley and the Cotswolds), poured thence over Mendip." Cenwalh's victory in $65^{8}$ 'aet Peonnum' is placed at Poyntington, near Sherborne, and called an incident in the attempted penetration of the forest barrier. ${ }^{6}$ Under Ine and his saintly kinsman Aldhelm, ${ }^{6}$ Christianity and education went hand in hand with military conquest, the new frontier-fortress of Taunton ${ }^{7}$ precluding help for the Selwood Britons from their hard-pressed kinsmen of Dyvnaint. At the same time the foundation of the West Saxon monastery at Wareham ${ }^{8}$ shows attempts at subjugation and colonization by way of the north-east.

Objections to this circumstantial reconstruction are fourfold. It is contended that the use of documents is uncritical, that the arguments from philology are faulty, and from archaeology untrustworthy. 9 Also it is said that Dorset has been planted with 'great stretches of woodland' on the basis solely of twelfth-century forest perambulations, and to suit the necessities of a preconceived theory. It is true that we have no good evidence of the extent of land under trees in the sixth and seventh centuries. But the assumption, though based on inadmissible evidence, would seem not unreasonable. Physical conditions would render very probable the presence of trees in great numbers. Even at the present day the area under trees is 37,600 acres, out of a total acreage of only 625,578 . The clay districts, amounting roughly to nearly half the county, naturally favour the growth of trees, and the chalk uplands ${ }^{10}$ show a wide distribution of superficial gravels, particularly along the borders of the vale of Blackmoor, on the chalk hills along the Piddle, at Durweston (where the chalk abuts on the Stour valley), on the chalk between Blandford and Dorchester, and at Dewlish. ${ }^{11}$ They also cover many even of

'See Smart, Introd. to Primaeval Ethnology of Dorset; Warne, Ancient Dorset; Sussex Arch. Coll. xxxiv, 239, sqq. ; F. J. Haverfield, 'Romanization of Roman Britain' (Proc. Brit. Acad.), ii, 8.

' Gildas, Hist. Sec.; Bede, Eccl. Hist. (ed. Plummer); Notes and Queries for Som. and Dors. i, 43 ; Noses and Queries (6th Ser.), xii, 461 ; (7th Ser.), iv, 208, 372.

${ }^{3}$ An. 552. Angl.-Sax. Chron. (Rolls Ser.), ii, 17.

'J. R. Green, Making of Engl. I 29, 339 ; Guest, in Arch. Journ. xvi, 109-1 7.

${ }_{5}$ Angl.-Sax. Chron. (Rolls Ser.), ii, 24,26 ; 'T. Kerslake, 'The Welsh in Dorset' (Proc. Dors. Field Ciub), iii, $\mathbf{S}$.

${ }^{6}$ Bede, op. cit. (ed. Plummer), ii, 308 , note.

'Angl.-Sax. Cbrom. (Rolls Ser.), ii, 39 ; Freeman, in Som. Arch. Fourm. xx, 31 , xviii, 37.

${ }^{8}$ Dugdale, Mon. Angl. vi, pt. iii, 1617 ; see Freeman, Engl. Torcns and Disss. 151.

${ }^{2}$ IV. H. Stevenson in Engl. Hist. Rev. 1902, p. 625 sqq.

${ }^{10}$ Geol. Surv. Maps, ii, plate; and ibid. Memoirs, 'Cretaceous Rocks,' i, 144-91.

"Analysis of Dorset soils, from Stevenson's Agricultural Report: Chalk, I 60,759 acres; sand, 85,1 57 ; loam, 37,746; gravel, 59,894; cornbrash, 29,700; clay, 117,331 ; miscellaneous, 13,427 acres. Damon, Geology of Weymouth (ed. I 884), 137. 


\section{POLITICAL HISTORY}

the highest levels in the county. ${ }^{1}$ As regards physical conditions there is thus no reason why Dorset should not have been one of the most thickly wooded of the southern counties. The theory of the main inhabited tracts, before the Saxon conquest, being the 'natural clearings' of the chalk outcrop ${ }^{2}$ receives confirmation from the fact that Celtic village-remains follow to a large extent the lines of ungravelled down. ${ }^{3} \quad$ Geography makes reasonable, on this supposition, the West Saxon advance from the north. The very places said to have been chosen for incursion upon the forest area are the intrusions of the chalk upon the surrounding clay, that is, of the natural clearings, upon the woodland. And it is that southern shore, supposed so long to have defied the Saxons, which exhibits a clay outcrop along the greater part of its margin, and which has a heavier rainfall and a higher mean temperature than the north of the county. To this day landing-places between Weymouth and Lulworth, and Lulworth and Swanage, are few and difficult; the chalk cliffs come in many places sheer down to the sea, and the shore is fringed with reefs and ledges. Such an inhospitable coast-line, flanked by a range of hills all but continuous and averaging $500 \mathrm{ft}$. in height, was unlikely to tempt, till earlier conquests had been exhausted.

Whether the generally accepted story is correct or not, of the main issues there can be no doubt. The Saxon conquest took place at a sufficiently late period, when either Christianity, or the satiation of the need of land and of plunder, or both forces acting together, prevented the extermination or expulsion of the earlier inhabitants. Proofs of this are both direct and inferential. No such close analysis of the Dorset dialect has been undertaken as would reveal the percentage of pre-Saxon words yet in use." But the laws of Ine make it plain that an appreciable British population remained side by side with the later Saxon settlers. ${ }^{6}$ The 'Ordinance Respecting the Dun-Saetas' is conclusive, and could only have been necessitated by the presence of such a population in large numbers in Dorset. ${ }^{6}$ How large a proportion that was, is shown by anthropological evidence. The Welsh physical type is, and it would seem has always been, dark and tall. ${ }^{7}$ Giraldus contrasts his countrymen, in their 'brunetness,' with the fair-complexioned Saxons. ${ }^{8}$ The relative brunetness of Dorset (I o per cent. excess brunet over blond) is even now greater than that of Somerset and Wiltshire ( 5 per cent. brunet excess), and much greater than that of Hampshire. It is in fact as high as Cornwall, and this in spite of the fact that in elevated districts some factor tends to increase blondness. ${ }^{10}$ The average Dorset stature is the same as that of Devon, whereas the averages

\footnotetext{
${ }^{1}$ Hutchins, Hist. Dorset (ed. 3), i, lxxxvi ; Mansel-Pleydell, Botany of Dorset ; H. Rider Haggard, Rural Engl. i, 257 and map.

${ }^{3}$ J. R. Green, op. cit. 8-9.

${ }^{3}$ Warne, Map of Anct. Dosset; Pitt-Rivers, Excavations in Cranborne Chase, etc. $1887-98$.

'Prior, 'Introduction to a Som. Glossary' (Som. Arch. Soc. Proc. xviii).

${ }^{5}$ Thorpe, Laws and Institutes (Rec. Com.), 45, 51, 53, 57, 60; see also Seebohm, Tribal Custom in Angl.-Sax. Law, 402-4; W. H. Stevenson, Life of Asser, 36, 37, 249 ; and Proc. Dors. Field Club, iii, 80, sqq., for a further philological argument, and for the argument from church invocations. A theory put forward by Sir H. Howarth (Engl. Hist. Rev. 1898, p. 670) was answered ibid. 1899, p. 32, sqq.

6 Thorpe, op. cit. I 50 ; sec also T. Kerslake, op. cit. ; Lappenberg, Engl. under the Angl.-Sax. Kings, i, 120.

${ }^{7} \mathrm{~J}$. Loth, L'Emigration bretonne en Armorique, xix; Reclus, Gégraphie universelle, II, viii, 6I2, is here incorrect.

${ }^{8}$ Giraldus Cambrensis, Opera (Rolls Ser.), vi, I 93.

${ }^{\circ}$ W. Z. Ripley, Races of Europe, 318.

${ }^{10}$ Ibid. 75
} 


\section{A HISTORY OF DORSET}

for Somerset and Wiltshire are lower. ${ }^{1}$ But such evidence as can be safely drawn from place-names does not give much support to the theory of a widespread and persisting Celtic remnant. ${ }^{2}$

Typical house-grouping is regarded as a constant race-characteristic, ${ }^{8}$ nucleated villages being considered Germanic in their origin, while ' in the land of hamlets and scattered steads' Celtic communities are traced. The accompanying map shows the disposition of nucleated and hamleted tenements.

The later hidation may also show Celtic influence still surviving, the relation between the hides and team-lands of Domesday being the basis of calculation. "Where the Saxon was thick on the ground, the hides were more, ${ }^{\prime}$ for the Saxon is the better agriculturist, and can make a smaller area support himself and his family, and pay Danegeld as well. ${ }^{5}$ The ratio of teamlands to hides changes gradually throughout southern England, rising steadily towards the west. It has been held to correspond to the waves of Saxon conquest, 'in each successive conquest the hides are fewer.' In the West Dorset hundreds of Whitchurch and Beaminster there are 249 team-lands to 200 hides, or $I^{\circ} 25$ per hide. The county average is practically one to one. ${ }^{6}$ This would seem to show a fair clearance of Welsh in West Dorset; and their survival in the east of the county goes to support the traditional view of the conquest of Dorset, not by sea, by way of the Frome valley, but by land, west before east, by way of Somerset and the vale of Blackmoor.

Once conquered, the speedy political absorption of Dorset in Wessex had been assured by the division of the West Saxon diocese and erection of a bishop's stool at Sherborne.? But far more influential in removing any remnants of old 'folk' feeling, as opposed to sentiment already semi-national, were the invasions of the Danes. These, both by chronology and by character, fall into two distinct groups-those of the ninth century which were mere plunder-raids (though not less dreaded on that account), and those of the later tenth and early eleventh centuries. The effect of these was political suzerainty, involving even in Wessex supersession of the old aristocracy, and in the non-noble classes admixture of blood. Both series of descents were made coastwise, thus differing materially, in method and conduct, from previous invasions. Unlike the Romans, whose normal method was to seize a point of coast and overrun the country thence with land forces, the Danes. attacked all round the coast, their superior seamanship enabling them to. make use of landing-places hitherto impracticable, such as Ringstead, Arishmill and Portland. ${ }^{8}$ The civilization of the West Saxons, and consequent abundance of provisions and value of booty, both facilitated and encouraged attacks from many points, and by many different war-bands.

Resistance was of a nature calculated to be ultimately successful. Naval battles were frequent. Ethelwulf was defeated (840) off Charmouth, but in

${ }^{1}$ W. Z. Ripley, Races of Europe, 327. $\quad$ 'Taylor, Words and Places; Proc. Anthrop. Inst. (1 885), 66.

'Maitland, Dom. Bk. and Beyond, 222, I5; Meitzen, Siedelung u. Agrarevesen der Germanen, ii, 1 19; Enquzte sur les Conditions de l'babitation en France. 'Les Maisons Types.' Paris, 1894, pp. 9-18 ; Cotta, Deutschland's Boden .... u. dessen Einscirkung (Leipzig, I 858), ii, 63, 599 ; W. Z. Ripley, Races of Europe, 8, 9, 10 ; J. Loth, L'emigration bretonne, 104, 1 I 8, 599 .

F. Baring in Engl. Hist. Rev. 1899, p. 297.

6 Eyton : hides, 2,321; team-lands, 2,332. Pearson : hides, 2,277 ; carucates, 2,303.

I Angl.-Sax. Chron. i, 68-9; ii, $3^{8}$; Wm. of Malmesbury, Gesta Pontif. (Rolls Ser.), 175 ; Haddan, Counc. and Docts. iii, $276 ; \mathrm{W}$. H. Jones, Episcopase in Dorses and Wilts.

${ }^{8}$ See Warne's Mas of Ancient Dorset; Angl.-Sax. Chron. i, 118 ; Hutchins, Hist. Dors. ii, 813. 


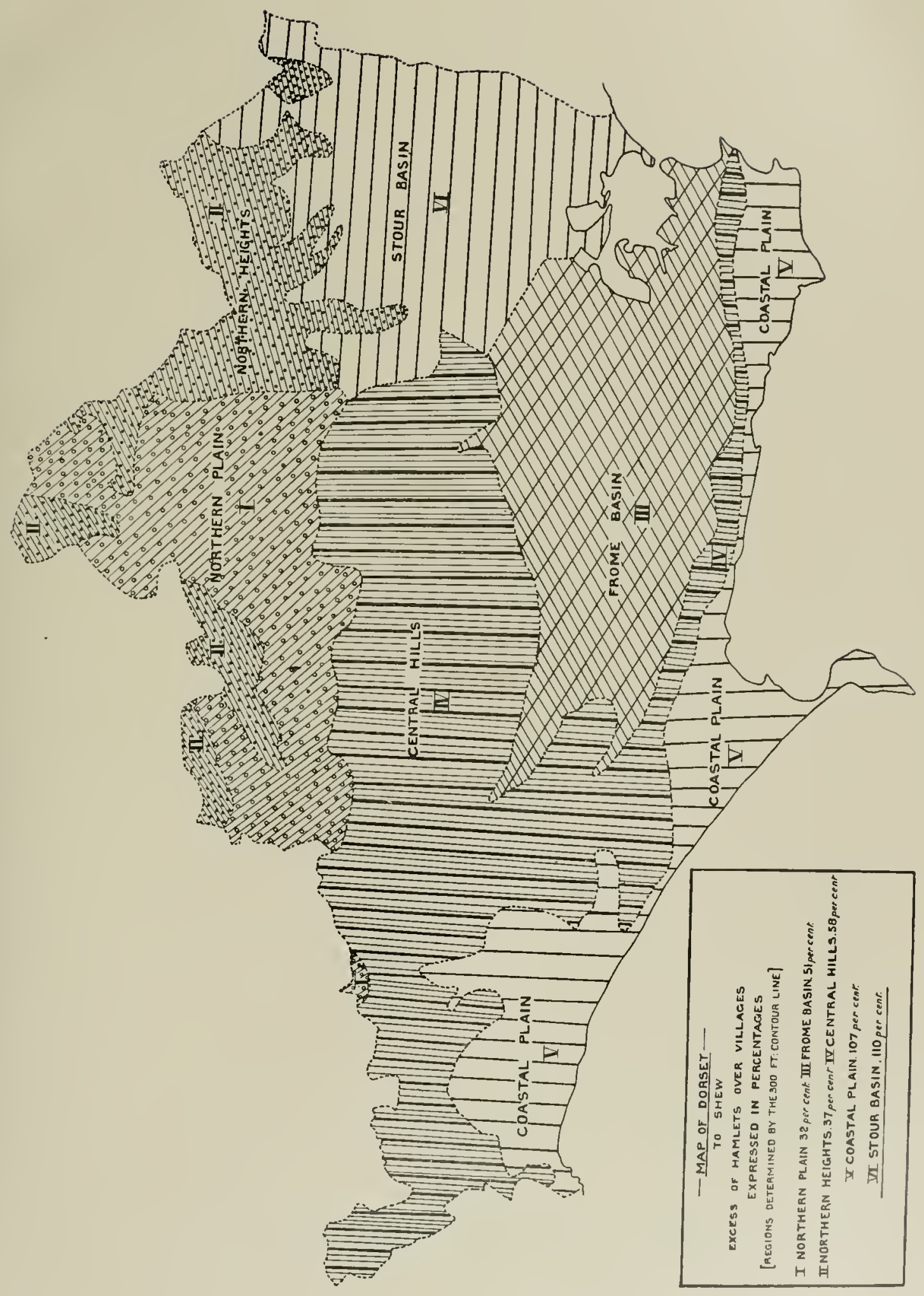





\section{POLITICAL HISTORY}

875 Alfred, putting out most probably from Wareham, 'fought against the crews of seven ships and took one of them and put the rest to flight." 1 The land resistance was as thorough and better organized. The alderman ${ }^{2}$ and the bishop are generally found leading the fyrd of the county. Somerset and Dorset frequently, and Wiltshire sometimes, join forces-an anticipation of their shrieval ties at a later period. In 845 the men of Somerset and Dorset, with their respective aldermen, Eanulf and Osric, and with the bishop of Sherborne, Ealhstan, ${ }^{3}$ defeated the Danes at the mouth of the Parret. But such pitched battles, however successful, did not stem the tide of invasion. Occupations of Wareham, and spoliation of the country thence, were only too frequent. ${ }^{4}$ But the victories of Merton (871) and Ethandun (876), in both of which the men of Dorset took their share, marked the end of Danish attacks for the time being.

The interval between the two series of descents was marked by constructive measures, constitutional and military. The military reorganization comes first in point of time, since it is associated with the name of Edward the Elder. But it cannot in reality be dissociated from the constitutional remodelling which went on, perhaps on a large scale, under Edwy and Edgar, to be continued and finally shaped by Cnut. To this period of peace and reconstruction belongs the development of the systems of boroughs and of earldoms. So far as Wessex is concerned, Dorset holds a position somewhat apart. While it was no part of the nucleus of the West Saxon kingdom, and thus included only a moderate portion of royal demesne, ${ }^{5}$ yet, being not only peculiarly open to attack by sea, but also the gate of the state, special precautions were taken for its defence. From this period probably dates the Burghal Hidage, ${ }^{6}$ representing a scheme of West Saxon defence, in which figure the Dorset boroughs of Shaftesbury, Wareham, and 'Brydian.' 7 The names of thirty-one burhs (twenty-seven assessments only) are given. They are divided among thirteen counties. Dorset is thus more than ordinarily well provided for. But more important than the number of burhs to a county is the number of supporting hides assessed to each. Of these Shaftesbury has 700 , Wareham 1,600, ${ }^{8}$ and 'Brydian' 1,760 , the latter being only exceeded by Bath and three joint assessments. Of these fortified places, where trade was already no doubt beginning, ${ }^{9}$ the importance of Shaftesbury and Wareham is obvious. A mint was one of the privileges of a borough. The Laws of Athelstan record two moneyers at Shaftesbury and two at Wareham. ${ }^{10}$ But it is to be noticed that the 'monetarii' of Domesday occur not only at these two places, but also at Dorchester and Bridport, the two latter having, in the interval, attained to borough rank. But 'Brydian' has been identified with Bredy, rather than with Bridport, on the ground, apparently,

1 Angl.-Sax. Chron. (Rolls Ser.), i, I $20,144$.

${ }^{2}$ H. M. Chadwick, Studies on Angl.-Sax. Institutions, $161,169$.

3 Angl.-Sax. Cbron. i, 132. Heahmund 8th bishop, and Waerstan 14th bishop (see Napier and Stevenson, Anecdota Oxoniensia, 108, note 14) also died in action against the Danes. Heahmund, bishop, was killed at the battle of Merton (871). Angl.-Sax. Chron. i, 140-141.

-Angl-Sax. Chron. i, 146, 145 (bis). $\quad{ }^{2}$ Maitland, Dom. Bk. and Beyond, 367, 498.

'Ibid. 504 .

7 The document is printed in Maitland, Dom. Bk. and Beyond, 502 ; Birch, Carr. Sax. iii, 671 ; Liebermann, Leges Anglorum, 9, 10. See also Proc. Soc. Antiq. xxxiv, 267, 268, for the further distinction between castles, forts, and burhs.

${ }^{8}$ Wareham was fortified at any rate by 876 . Asser's Life of $A$ lfred (ed. W. H. Stevenson), 36, 37 .

${ }^{9}$ Maitland, op. cit. 212 , sqq.

10 Thorpe, Laws and Instifutes, 514 . 


\section{A HISTORY OF DORSET}

that Little Bredy contains a 'King's Tun' (Kingston Russell).' It was, if so, important as guarding the one gap in the downs which connects south-east with south-west Dorset. This had been followed by the Roman road from Old Sarum through Dorchester to Exeter, and was rendered still more important through the necessity of rounding, in the alternative sea route, the dangerous Portland Bill.

Constitutional reorganization was more tentative and uncertain than that of the defensive system. Fluctuation in ideas as to the status of the alderman is a marked characteristic of this period. The alderman (the Danish word earl was only just beginning to be used) is sometimes military leader of the individual county, sometimes political head of a group of counties, possessed of powers only not royal. Both experiments were tried, and it would seem that Dorset had sometimes an earl of its own, ${ }^{2}$ while more than once it was a member of the great south-western group of shires. ${ }^{3}$

Want of political stability in Wessex no doubt contributed to Danish successes. In 982 Portland was ravaged by 'three ships of vikings," "and six years later the Danish army 'again wended eastward into the mouth of the Frome, and everywhere they went up as far as they would into Dorset; and a great force was often gathered together against them, but as soon as they came together, then was there ever through something flight determined on, and in the end they ever had the victory.' ${ }^{5}$ It is probable that the growing sense of religion in public feeling had been thoroughly outraged by the murder of Edward 'the Martyr' in $978 .^{\circ}$ The solemn splendour of the translation of his body by Dunstan and the alderman Alfhere, ${ }^{7}$ from Wareham to Shaftesbury, ${ }^{8}$ and the fresh charters granted to Sherborne Abbey ${ }^{9}$ do but express the spirit of ecclesiasticism then dominant in Dorset, and unlikely to succeed against the determined attacks of a virile nation.

It is to Domesday Book that we look to trace the process of substitution of a Norman for the Anglo-Danish land-holding class. Incidentally we may hope for further evidence upon uncertain happenings. To deal first with the latter question. It is stated that 'the Dorset towns' joined 'the Western Rebellion' of 1068 , and that William, on his way to dispose of the Exeter resistance, delayed to make an example of Dorset. ${ }^{10}$ The rebellion is said to have been engineered by Gytha and the sons of Harold by Edith Swanneck, who certainly were old enough, in 1069, to gather an Irish fleet and ravage the Devon coast." The territorial influence of Harold himself in Dorset was inconsiderable for an English king in a county which later possessed so much royal demesne. That of his family, considering the notorious rapacity of the house of Godwin, was small. If Dorset was, indeed, concerned in the rising, and received its punishment accordingly, we should expect to find either a widespread desolation throughout the county, as in the north, or else

${ }^{1}$ Maitland, op. cit. 502, note ; Kemble, Cod. Dipl. iii, 224-5, No. 6;6.

'Edgar, Law's (Rec. Com.), iii, 5 ; Cnut, Lawus (Rec. Com.), ii, i8, Ant. Lau's and Inst. 165.

${ }^{3}$ H. M. Chadwick, Studies on Angl-Sax. Institutions, 168-80.

- Angl. Sax. Chron. i, 236.

${ }^{6}$ Ibid. i, 234 . Henty of Huntingdon, Hist. Angl. (Rolls Ser.), 167.

${ }^{7}$ His festival was kept four times a year, Wynkyn de Worde, The Martirloge, 1526, who claims to follow Sarum use.

${ }^{3}$ Angl.-Sax. Chron. (Rolls Ser.), i, 234 ; Ann. Wig. ii, 13.

${ }^{9}$ Ann. Theokesb. (Rolls Ser.), i, 183 . iii, 345 .

${ }^{10}$ Freeman, Norm. Conq. iv, $15 \mathrm{I}$, and Exeter (Hist. Towns Ser.), 36 ; Palgrave, Engl. and Normandy, ${ }^{11}$ Dict. Nat. Biog. xxiv, 425. 


\section{POLITICAL HISTORY}

a line of wasted manors along William's route to Exeter. The Worcester chronicler says, 'he harried all the land he overran.' ' The traces of a conquering army, supported by the lands it traverses, will hardly be obliterated after twenty years, even though a January campaign will not cause the same damage as one undertaken in spring or early summer. But a map of the decreased or increased values of manors in Io87, as compared with the T.R.E. period, is barren of geographical results. Depreciation here evidently depended upon individual circumstances. Thus the lands of the widow of Hugh FitzGrip ('Hugh of Wareham' first Norman sheriff) have fallen in value in most cases. No doubt the woman could not manage them as advantageously as her husband. It is, however, only fair to add that though Hugh had 'reft unjustly' one hide of the manor of Abbotsbury from the monks of that foundation, his wife "since detained six unjustly." ${ }^{2}$ The lands of the church have very generally doubled and even trebled in value, ${ }^{3}$ probably in consequence of a more progressive agriculture and an increase in applied capital, both due to a new personnel. Exceptions tending to prove the rule are the lands of St. Mary of Glastonbury and of Bishop Odo of Bayeux. Against the former William had ever a grudge, and he seized 4 hides in Bagbere, part of the manor of Sturminster Newton, belonging to this monastery, and gave them to his cook Goscelin. The Bishop of Bayeux was under forfeiture at the date of the survey. ${ }^{4}$

Far otherwise was it with the Dorset boroughs. ${ }^{5}$ Dorchester, Bridport, Shaftesbury, and Wareham suffered heavily, on the authority of Domesday itself. Wareham illustrates the 'tenurial heterogeneity' of the typical old English borough.

T.R.E. there were $\mathbf{1 4 3}$ houses of the king's, now there are only 70 houses, 73 are waste. The Abbey of Fontanelle (the Norman house, S. Wandragesil) had 62 houses, 45 remain and 17 are waste. Other holders had 80 houses, of which 20 still remain, and 60 are destroyed. ${ }^{6}$

It is this destruction of town houses which has given rise to the story of the participation of the Dorset towns in 'the Civic League.'

But there are at least two other causes which would account for such house destruction at that date. One such was castle-building, and the necessity for an open space around the castle to prevent fire or the use of adjacent houses by a hostile body of troops. ${ }^{7}$ But Bridport certainly and Shaftesbury probably did not so early possess Norman castles; and though it has been claimed, but without certainty, that Dorchester Castle dates from this time ${ }^{8}$ the case of Wareham is beset with difficulties. The ' castellum de Warham' surveyed under Kingston ${ }^{9}$ is undoubtedly Corfe, ${ }^{10}$ and yet the wars of Stephen and Matilda and the Pipe Rolls of John ${ }^{11}$ show the presence of a castle at Wareham likewise, which may or may not have been built by

1 Angl.-Sax. Chron. (Rolls Ser.), i, 340.

${ }^{2}$ Dom. Bk. (Rec. Com.), i, 78. Hugh also took a virgate at Portisham from Abbotsbury Abbey, and the manor of Tatton from the Abbey of Cerne.

${ }^{3}$ Dugdale, Mon. Angl. (ed. I 817), ii, 472.

${ }^{4} \mathrm{His}$ manor of Rampisham T.R.E. was worth $£ \mathrm{r} 0$; T.R.W. only $\complement_{6}^{6} ;$ Dom. Bk. i, 77.

${ }^{5}$ Round, Feudal Engl. 436, 437 .

${ }^{6}$ Dom. Bk. i, 75 .

' Engl. Hist. Rev. Xx, 710.

' Hutchins, op. cit. ii, 365 . It only certainly existed in 1176 . Pipe R. $22 \mathrm{Hen}$. II, m. 9 d.

${ }^{\circ}$ Dom. Bk. i, 78 .

${ }_{10}$ Eyton, Key to Dorset Dom. 43, iii, n. 2.; Round, Feudal Engl. 339.

"Pipe Rolls, 6, 8, 9, 10 John, under 'Honour of Gloucester.' 


\section{A HISTORY OF DORSET}

William. It has been pointed out that there is a priori likelihood that William would not leave this important post, which was also a royal fortified borough, without a castle. It seems more likely that the confusion between Corfe and Wareham is a slip in Domesday Book rather than that the castle of Corfe was known as Wareham for a long period. The solitary Pipe Roll of Henry I mentions the castle of Wareham, and in I 106 Henry had imprisoned Robert of Belesme there. ${ }^{1}$

Domesday itself, however, tells us that the destruction of houses in Dorchester, Shaftesbury, and Wareham dates 'a tempore Hugonis vicecomitis,' the Wareham entry ${ }^{2}$ further describing it as continuing usque nunc. This clearly points to the exactions of the Norman sheriffs, for Aiulf would appear to have followed Hugh's example. Of Lincoln, Domesday expressly states that seventy-four houses 'which are waste within the limits of the castle are not so as the result of the oppression of the sheriff or his servants, but by misfortune, poverty, or fire,' ${ }^{3}$ thus plainly showing the frequency of shrieval exactions. None of the Dorset towns had been able to contract with Villiam to hold their liberties by a fee-farm rent. It has been seen that Hugh was an unscrupulous and avaricious man. His exactions would not improbably do much towards bringing these towns to destitution, since, unlike many country manors, they were without the protection of powerful owners, able to look after their interests. ${ }^{4}$

In the process of substitution of a Norman for an Anglo-Danish landholding class, Dorset, though eventually thoroughly Normanized, suffered a less violent convulsion than some of the eastern or midland counties. Normanizing tendencies had been actively at work during the reign of the Confessor. Certain geographical and personal causes tended to counterbalance the Godwin national party. The harbour of Wareham was more frequented than any port in southern England. This ensured the constant passage through the shire of Normans going to and from Vinchester and Westminster. King Edward himself had held in demesne more than a fifth of the county, and his preferences are undoubted. Emma his mother had held Wyke, Elwell, and Weymouth.' His sister, Countess Goda, married successively to Drogo count of the Vexin, Walter count of Mantes, and Eustace count of Boulogne, had held lands in Melcombe and Tarrant Hinton. After the death by poison of her son Walter, King Edward was her rightful heir. Brictric, Matilda's English lover, had lands in Ashmore, Boveridge, Mappowder, Loders, Affrington, Tyneham, and Tarrant Gunville. Further, even had the Godwin territorial influence been greater than was actually the case, the ravages of Godwin at Portland in 1052 , during his outlawry, ${ }^{6}$ must have earned him local ill-will. Even before the Conquest large tracts of land were in the hands of the Church, and her sons would be scandalized at the behaviour of Tostig, but still more indignant at the exactions of Harold. In the absence of danger from Welsh or other foes Harold did not become a hero in common eyes. He took from St. Mary of Shaftesbury the fat manor of Sture (East and West Stour)

\footnotetext{
1 Ann. Marg. Wint. and Waverl. (Rolls Ser.), i, 10; ii, 42, 44, 2 i j.

2 Dom. Bk. i, 78 .

- See also Eyton, Dorset Dom. 72 ; Engl. Hist. Rev. xx, 703-1 1, and ibid. 1902, pp. 296, 297 ; ibid. 25 , sqq.

5 Hutchins, Dorset, ii, 8 I 4 .

- Angl.-Sax. Chron. (Rolls Ser.), i, 3 I 9. 


\section{POLITICAL HISTORY}

worth $f_{0} 8$, and Cheselbourne, worth $f_{0} \mathrm{I} 6,{ }^{1}$ and from a certain priest 2 hides in Ilsington, valued at 20s. It must, however, be remembered that

such charges were almost matters of course after his death, for all churchmen whose lands had come into his hands, whether rightly or wrongly, would naturally try to get them back, and the Normans would put the worst construction on all his actions. ${ }^{2}$

This body of public opinion must have assisted the feudal tendencies already at work, the greater since the proportion of Danes among the holders of land T.R.E. was small. Of ninety-eight names of those holding T.R.E. only seven are pure Danish, though others with West Saxon names may possibly, like Gytha herself, have had a Danish descent. Of the twenty who, holding before r 066 , were still holding in 1087, only two have Danish names.

The Conquest undoubtedly accelerated the concentration of estates in a small number of hands. The Dorset tenants in capite, at the date of the survey, were $146 .^{3}$ To the king, either in demesne or by escheat, belonged in 1087 rather more than one-seventh of the county; to the greater feudatories taken conjointly rather more than one-third; to the lesser feudatories, king's thegns, king's serjeants, the four boroughs and a few unclassified landholders, about one-ninth. The various ecclesiastical persons and bodies, headed by the bishop of Salisbury, held little short of a third."

This was the great era of castle-building. ${ }^{5}$ William had obtained the land for his 'castellum de Warham' by exchange with the abbess of Shaftesbury for the advowson of Gillingham. It is now generally held that this castle, referred to in Domesday, ${ }^{6}$ is Corfe. It was almost certainly not only a new building, but new on that site. For if "the religious woman Alfthrith" to whom Edred granted Purbeck ${ }^{7}$ was indeed abbess of St. Edward, ${ }^{8}$ the abbey at Shaftesbury would seem to have held this land since 948 . It is not easy to account for Elfrida's palace at Corfe, ${ }^{9}$ for Edgar's grant to his queen was at Buckland. ${ }^{10}$ The chronicle states that Edward was killed at 'Corfgeat,' "' which may possibly have been Coryates; a charter of Canute to Abbotsbury mentions 'Corfgeat' near Portisham. ${ }^{12}$ There is also a Corfe, anciently a member of the manor of West Milton, now a hamlet in the parish of Powerstock. ${ }^{13}$ Camden thought there was a Saxon castle at Corfe, and that it must have been built after $94 \mathrm{I},{ }^{14}$ citing an inquisition of the time of Henry III 'before the building of the castle of Corfe, the abbess and nuns of S. Edward at Shasten had the wreck of the sea within their manor of Kingston.' He gives $94 \mathrm{I}$ as the date of the foundation of this abbey by Edmund, but Dugdale considers it to have been founded, perhaps by Alfred, at any rate before $900 .^{15}$ Research goes to show that there was no castle at Corfe before the Conquest. ${ }^{\mathrm{I}}$

${ }^{1}$ Dom. Bk. i, 78 .

${ }^{3}$ Ellis, Introd. to Dom. ii, 438 .

${ }^{5}$ G. T. Clarke, Mediaeval Milit. Archit. i, 23.

${ }^{6}$ Dom. Bk. i, $78, b .2$. See also Testa de Nevill (Rec. Com.), i $64 b$.

'Birch, Cartul. Sax. iii, I2, No. 868.

- See Bond, Corfe Castle, 9.

"Angl-Sax. Chron. (Rolls Ser.), i, 232-3.

${ }^{13}$ Hutchins, Dorset, ii, 319.

${ }^{15}$ Mon. Angl. ii, 47 I.

${ }^{16}$ Round, in Arcbaeologia, LVIII, i, 313 sqq. and Quart. Rev. July, I 89t; Mrs. Armitage, in Engl. Hist. Rev. I904, pp. 227, 450, and 1905, P. 711 ; and in Proc. of Scottish Antig. xxxiv, 287. See also Round, Grofficy de Mandeville, 328 ; Arch. Journ. 1x, and Antiq. xiii, 241.
'Article 'Harold,' in Dict. Nat. Biog. xxiv, 418.

'See Eyton, op. cit. 156.

${ }^{8}$ Dugdale, Mon. Angl. ii, 473 .

${ }^{10}$ Birch, Cartul. Sax. iii, 436, No. 1177 .

12 Mon. Angl. ii, 55, charter ii.

1s Camden, Britannia (ed. Gibson, 1721 ), i, 57 . i. 


\section{A HISTORY OF DORSET}

The remaining Dorset castles present almost equal difficulties. Gervase, in the Mappa Mundi (about whose date, unhappily, there is some obscurity), ${ }^{1}$ mentions Corfe, Sherborne, and Dorchester. But Lulworth and possibly Cerne are mentioned in 1139 and $1142 . .^{\circ}$ Bow and Arrow Castle, Portland, is said to have been built by Rufus. ${ }^{3}$ At any rate, Portland had a castle in I I $42 .^{4}$ There are also earthworks of the motte-and-bailey type at Sturminster Newton, Shaftesbury, Chelborough, and Powerstock. ${ }^{5}$ Powerstock was held, at the date of Domesday, by Roger Arundel, but may possibly have been fortified by John, into whose hands it came by exchange with Robert of Newburgh (to whom it had come from the Arundels) for a Somerset manor. ${ }^{6} \quad$ It is probable that some of these are among the adulterine castles of the reign of Stephen.

Situated on the line of the empress's communications between her English strongholds of Bristol, Oxford, and Devizes, and her continental base, the Dorset castles became important factors in the civil war, which shared with other mediaeval wars the characteristic features of absence of pitched battles and importance of castles. It is impossible to ascertain the sentiment of the county in the struggle between king and empress, for public feeling was both dominated and voiced by the great land-holders alone. Of these Robert of Gloucester, the empress's half-brother, stands above all others. His Dorset lands, part of the honour of Gloucester, came to him with his wife Mabel, daughter of Robert FitzHamon, who himself had married Sybil, daughter of Roger of Montgomery, and sister of Robert of Belesme, who suffered perpetual imprisonment in Wareham Castle. To FitzHamon Rufus, probably about Iogo, ${ }^{7}$ had given the inheritance called of Gloucester, which had originally been held by the Saxon Brictric, then by William's Queen Matilda, and which on her death had reverted to the crown. It included many Dorset manors. ${ }^{8}$ Among the empress's men were also Baldwin of Redvers, and William of Mohun. Baldwin descended from the 'francus' who in Domesday Book held three and a half hides in Mosterton in South Perrot, and not from the 'Baldwinus Vicecomes' or Baldwin of Moeles, sheriff of Devon, and constable of Rougemont Castle, Exeter. William of Mohun was lord of Dunster. ${ }^{9}$ The Mohun holding in Dorset included lands in Todber, Spettisbury, Winterborne Houghton, Hammoon, Chalbury, Iwerne Courtney, Broadwinsor, and Mapperton in Almer. ${ }^{20}$ Robert of Bampton (co. Devon), who was in rebellion against Stephen, ${ }^{11}$ had succeeded, by the female line, to the Domesday fief of Walter of Douai, which included lands in Winterborne Clenston and Purse Caundle. William de Cahaignes, who made the king prisoner at the battle of Lincoln (II4I), had

1 Stubbs places it about 1199 , Introd. to Gerrase (Rolls Ser.), i, p. xxix.

- Will. Malms. Hist. Norella (Rolls Ser.), ii, $557,594,595$; Gesta Stephani (Rolls Ser.), iii, 58. The latter, however, is quite as likely to be Cerney, near Cirencester. See Ramsay, Found. of Engl. ii, 388.

${ }^{3}$ Hutchins, Dorset, ii, 8 16.

- Will. Malms. op. cit. ii, 595 .

${ }^{5}$ Information supplied by Mrs. Armitage. See also Hutchins, op. cit. iv, 336,339 ; ii, 655, 318 ; Coker, Sury. of Dors. 100.

${ }^{6}$ Hund. R. (Rec. Com.), 97.

'Ord. Vit. Hist. Eccl. iii, 350 .

${ }^{8}$ See Round in Genealogist (New Ser.), iv, 129-40. Hutchins, op. cit. iii, 369, and 375, 376 follows Dugdale about the three FitzHamon heiresses, one of whom, he says, was abbess of Shaftesbury. But see the art. 'Fitzhamon,' in Dict. Not. Biog.

${ }^{\circ}$ See H. Maxwell Lyte, Dunster and its Lords, 2, 3 .

${ }^{10}$ Dom. Bk. i, 82 .

${ }^{11}$ Round, Feud. Engl. 486 ; Engl. Hist. Rev. $7,746$. 


\section{POLITICAL HISTORY}

obtained in maritagio Tarrant Keynston and Coombe Keynes, with his wife Alice, daughter of Hugh Maminot, the nephew and heir of Gilbert Maminot bishop of Lisieux. The bishop's Dorset holding was a lay fief, i.e. descended to his secular heir. ${ }^{1}$ William of Saint Clare ${ }^{2}$ was, at least in I I 40, on Stephen's side, for he witnesses the first charter to Geoffrey de Mandeville. ${ }^{3}$ The castle of 'Cernei' built by Miles of Gloucester, as has been said, may have been Cerne (co. Dorset), or Cerney. Some of the abbot's tenants in the vill of Cerne however owed duty of castle-ward at Corfe Castle, ${ }^{5}$ not at Cerne.

Robert of Gloucester in I I 37, after the Exeter rebellion of Baldwin of Redvers, fortified Wimborne, Corfe, Dorchester and Wareham against Stephen, ${ }^{\circ}$ probably encouraged by the king's absence in Normandy. When he returned, at the end of that year, Stephen most probably landed in Dorset. ${ }^{7}$ The following year, probably during the campaign in Somerset, he took Wareham, making Robert de Nicole castellan. ${ }^{8} \quad$ Robert of Gloucester recaptured it in I I $380^{\circ}$ Baldwin of Redvers, in August, I I 39, landed there with an advance army. ${ }^{10}$ He was now the empress's devoted adherent. Stephen hurried down to cut him off, but he threw himself into Corfe Castle, where the king laid siege to him; but hearing of the approach of the empress and Earl Robert, who had by this time landed in Sussex and were making for Bristol, he raised the siege." On his way back Stephen besieged and took 'Cernei' castle, which Earl Robert however garrisoned again the following year. ${ }^{12}$

Some time before II4I the empress made de Redvers earl of Devon, and Mohun earl of Dorset or Somerset-a fact noteworthy, since to Stephen alone are sometimes attributed the creations of this period. The status of the Mohun earldom is doubtful. The Gesta Stephani states $^{\text {I3 }}$ that he was made earl of Dorset. He founded Bruton Priory in I I 42 as earl of Somerset. ${ }^{14}$ It was unimportant that he took his distinguishing name from either county, for they were under one sheriff. But de Redvers himself already held the manor of Puddletown ${ }^{15}$ which carried with it the third penny of the pleas of the county. ${ }^{16}$ The empress's own charter of I I 42 to Aubrey de Vere, confirmed by her son Henry, offered de Vere a choice of Dorset or Oxfordshire, Berkshire or Wiltshire, for his new earldom. ${ }^{17}$

Robert of Gloucester committed Wareham to the safe-keeping of his eldest son William, and departed in June, I I 42 , also from Wareham, 'the empress's family haven,' on his mission to Geoffrey of Anjou. ${ }^{18}$ Stephen, recovered from his sickness, seized the opportunity to raid the enemy's own country. He marched on Wareham, burned the town, and took the castle. ${ }^{19}$ Sherborne Castle, built by the Justiciar, Bishop Roger of Salisbury, in I I $37,{ }^{20}$

1 Liber Niger (ed. Hearne), i, 8,3 ; Pipe R. Dors. I4 Hen. II, m. 2.

'Pipe R. Dors. 3 I Hen. I. ' 3 Printed Round, G. de Mandeville, 5 I, $52 . \quad$ 'Gesia Steph. 58.

s Dom. Bk. i, 76; Liber Niger, i, 77 ; Red Bk. of the Exch. (Rolls Ser.), i, 2 I 2.

-Ann. Mon. ii, 226.

${ }^{8}$ Ann. Theokesb. (Rolls Ser.), i, 46 ; Hen. Hunt. Hist. Engl. 26 I ; Ann. Wav. (Rolls Ser.), ii, 229.

9 Ann.Wav. ii, $226 .{ }^{10}$ Gesta Steph. 53 , and Intr. xxi-xxv; Round, G. de Mandeville, $278,279$.

"Gesta Steph. 53.

${ }^{12}$ Will. Malms. op. cit. 557.

"Round, G. de Mandeville, 271, 274, 277.

${ }^{16}$ Dom. Bk. i, 75.

${ }^{17}$ Round, op. cit. 180-3.

is Eyton, Dors. Dom. 75.

${ }^{16}$ Will. Malms. op. cit. 592.

${ }_{19}$ Ibid. 593 ; Gesta Steph. 93.

10 Ann. Winton, ii, 51 ; Will. Malms. op. cit. 547, 549 ; Gesta Steph. 49, 50 . 


\section{A HISTORY OF DORSET}

(a time when all who could fortified themselves), was already in his hands, from his seizure of the bishop in I I39. So when in December Robert of Gloucester returned, not with the empress's husband, but with her son Henry, her cause seemed hopeless. She was at the time closely besieged in Oxford. Instead of going to her help, the earl lingered to retake Wareham ' (which Stephen allowed to fall into his hands, sooner than abandon the siege of Oxford to go to its relief), and to occupy the two small castles of Lulworth and Portland.' The former castle had been held by William de Glastonia, who had lately turned traitor to the empress: Portland had been previously fortified by Stephen.

Immediately on the surrender of Oxford, Stephen marched on Wareham, reaching it probably about I January. Earl Robert, on its recapture, had most strongly fortified it." The king laid waste the adjoining country with fire and sword.

Next year he lost Sherborne Castle; William Martel the Dapifer, who was holding it for the king, was captured at Wilton, and was compelled to give up this castle, to regain his liberty. ${ }^{5}$ After the withdrawal of the empress, Dorset took no further part in the Civil War.

The reconstructions of Henry II are generally said to have involved the degradation of the fiscal earls, and the destruction of adulterine castles. The Mohun earldom of Dorset does not occur, even after I I 42 . But of the fate of the adulterine castles, or which of them were adulterine, we have no knowledge. The custody of Dorchester Castle was eventually granted to Earl Reginald of Cornwall. ${ }^{6}$ Eleven years later it appears under the honour of Gloucester. ${ }^{7}$ A bull of Eugenius III in I 46 had confirmed to the bishop of Salisbury the possession of his two castles of Sherborne and Devizes. ${ }^{8}$ But two agreements, in I I 52 and I I 57 , between Henry II and Bishop Jocelin, restoring the castle of Devizes conditionally to the bishop, do not seem to have been copied with regard to Sherborne Castle, which was taken into the king's hands. The hundred of Sherborne was restored in I 60 by the widowed countess Mabel of Gloucester and her son William to Bishop Jocelin. ${ }^{9}$

In I I 89 John married Isabel of Gloucester, third daughter of this William Fitz Robert. She was made heiress of the honour, for the benefit of her husband, who received confirmation of the earldom, ${ }^{10}$ but no castles were committed to his keeping. In I 189 , no place being assigned to him in the government, Richard purchased, or hoped to purchase, his loyalty by lavish grants, which included all crown rights over Dorset, Somerset,

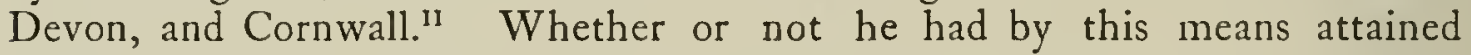
possession of the castles of these counties, he lost them again in II9I, at the Grand Council of Winchester ( 28 July), for the pacification of the

1 Will. Malms. op. cit. 594,595 .

Ann. Winton, ii, 53 ; Ann. W'ig. iv, 379 ; Will. Malms. op. cit. loc. cit.; Gesto Steph. 93.

${ }^{3}$ Will. Malms. op. cit. 595. The Newburghs probably did not acquire Lulworth before 1300 . They 2ppear at Winfrith in 1210.

- Gesto Stcph. 94.

- Hen. Hunt. Hist. Angl. 276 ; Gesto Steph. 96 ; Ann. Theokesb. (Rolls Ser.), i, 46 . See Round, op. cit. 147.

- Pipe R. 22 Hen. II, m. 9 d.

- Sarum Chart. (Rolls Ser. 97), I 3.

${ }^{10}$ Bened. Pet. Gesta Regis (Rolls Ser.), 78 ; Gervase, Opera, i, 458.

$"$ Bened. Pet. op. cit. 99. Roger of Hoveden, Cbron. (Rolls Ser. 51 ), 27. 


\section{POLITICAL HISTORY}

count and Longchamps over the Camville case. But in October he again got control of the royal castles, on the deposition of Longchamps. After the release of Richard from captivity John sent word from Normandy to have his castles put in order for a fresh rising. But Hubert Walter proceeding against the places fortified, and the king landing in England, John surrendered. A special iter of the justices that September (I I94) had, as one of its objects, to take account of all lands and goods forfeited by John or his followers under decrees issued against them, and not subsequently re-granted by the king to them. It appears that Dorset had been implicated, to some extent, in the last rising. Reginald of Saint Leodegar in Todber, Brian de Goviz in Kingston, and Lucia de Broll in Milborne ${ }^{1}$ lost their lands entirely. Walter de Turberville in Toller, ${ }^{2}$ and Eustace de Stokes in Lulworth, ${ }^{3}$ recovered them eventually, after temporary dispossession. Eustace de Stokes was a knight of Alured of Lincoln."

The time spent by John, when king, in the county has sometimes been exaggerated. Of $\mathrm{I}, 3 \mathrm{I} 4$ changes of place recorded of his court, ${ }^{6}$ ninetyfour only relate to Dorset. According to the Itinerary he spent I 31 days in the county, out of a rough total of 4,159 , about three per cent. only. ${ }^{6}$ This was remarkably little, since to a parsimonious king (whose frequent movements necessitated the seventeenth clause of Magna Carta) it was of import to have his court maintained free for a few nights at a time. ${ }^{7}$ He spent much money on strengthening his castles, and the Pipe Rolls for this reign have frequent mentions of expenses incurred for work on the castles of Dorchester, Sherborne, Gillingham, and Corfe. ${ }^{8}$ The king had been reinstated with the honour of Gloucester in I195, while still only count, but without its castles. On his accession he divorced his wife Isabel, on the pretext of Archbishop Baldwin's early objections to the marriage, on grounds of consanguinity. He deprived her of her patrimony, conferring the estates and earldom upon her sister's husband, Amaury of Montfort, but by the ninth year of his reign the honour was again in his own hands. He used Corfe Castle as a state prison as well as a fortress. Among its prisoners were the nobles of Poitou and Guienne whom he captured at Mirebeau ${ }^{9}$ (1202), the Lusignans, from whom he had abducted his new wife, Isabel of Angoulême. There also were confined Griffith, king of Wales, ${ }^{10}$ the princesses of Scotland, "11 given by their father as hostages in I 209, William of Albini, ${ }^{12}$ afterwards one of the twenty-five elected barones, ${ }^{13}$ and even his own queen. ${ }^{\mathrm{It}}$

In $\mathrm{I} 205$ the king, having been successfully resisted by the barons in the matter of service abroad, embarked, and put out to sea for three days, landing again at Studland, probably as a kind of protest against

' Pipe R. 6 Ric. I, m. I $3 d$.

' Ibid. 7 Ric. I, m. 17.

'Ibid. 1 John, m. I 7 d.

${ }^{5}$ Hardy, Itin. Arch. xxii, 125 sqq.

${ }^{6}$ He reigned from 27 May, 1199 , to 18 Oct. 1216. Four years of this time were spent in Normandy, for two more years the Itinerary is wanting.

'See Pipe R. of the bishopric of Winchester, p. 76. (Studies in Econ. and Polit. Sci.)

${ }^{8}$ See, inter alia, Pipe R. 2 John, m. 7 ; Pipe R. 10 John, m. II d.; Pipe R. 2 John, m. 7 ; Pipe R. 4 John, m. 7 .

Ann. Marg. (Rolls Ser.), i, 26 ; Pat. R. 4 John, m. 3.

"Pipe R. 5 Hen. III.

"Gervase, op. cit. ii, 102.

${ }^{12}$ Ann. Londiniensis (Rolls Ser. 76), i, 17.

10 Ann. Wint. ii, 68 . 


\section{A HISTORY OF DORSET}

the refusal of his military tenants to accompany him on the French expedition.' 'This he repeated in 1213 , again landing at Studland. ${ }^{2}$

After the Interdict ( 1208 ) and the excommunication of the king (1 209), Peter of Pontefract or Wakefield, a seer, prophesied that John would reign fourteen years and no more. John imprisoned him in Corfe Castle till the time for fulfilment of the prophecy should have expired. ${ }^{3} \quad$ The surrender to the papacy took place in I 2 I 3 ( 23 May), the fourteen years were up, counting from Ascension Day, I 199 (from which John's regnal years were dated), on 27 May. The prophecy therefore came true; in a sense, and the king had the prophet executed in Corfe Castle."

On the landing of the Dauphin in 1216 , John at first entrenched himself in the castle, but Louis, instead of advancing upon him, stayed to harry Hampshire. Nevertheless John, who had been at Corfe and Wareham till I $7 \mathrm{July}^{5}$ (the Dauphin landed 20 May), withdrew to Bristol.

One of the barons who had helped to call in Louis was William Longespée, the natural son of Henry II. He had married Ela, daughter and heiress of William earl of Salisbury (06. I I96), grandson of Edward of Salisbury, and successor to his Domesday fief. This had included the manors of Canford and Kingston, and the manor of Great Kingston had been added to the Salisbury inheritance by the marriage of the son of Edward of Salisbury with the daughter and coheiress of Ernulf of Hesding, successor to many of the lands of Ulward the White. Another of the rebellious barons was William of Montacute, sheriff of Dorset and Somerset from I 206 to 1208 , grandson of Drogo of Montacute, who at the date of Domesday had been in Dorset a tenant of the count of Mortain."

On the death of John the castle of Corfe was handed over to the regent, William Marshall (whose nephew John had already held Dorchester Castle ${ }^{7}$ ), by Peter de Mauley, one of John's Poitevin favourites, ${ }^{8}$ and formerly sheriff of Dorset and Somerset, and constable of Corfe. In $122 \mathrm{I}$ he was again sheriff, and in 1222 was made governor of Sherborne Castle, presaging the downfall of Hubert de Burgh, who had himself up to I 206 held the manors of Corfe Mullen and Milborne, with lands in Winfrith. ${ }^{9}$ Queen Eleanor of Provence, wife of Henry III, held lands at Warmwell, in the hundred of IVinfrith. ${ }^{10}$ The connexion with Dorset of another foreigner, the great Earl Simon, arose through his mother. The elder Earl Simon, 'the scourge of the Albigenses,' had married Amicia, sister and heiress of Robert de Beaumont earl of Leicester, sometimes also called 'Fitz Pernell' from his mother Petronilla, daughter of Hugh of Grantmesnil. Earl Robert had mortgaged at one time the manor of Blandford Forum to Aaron, a Jew of

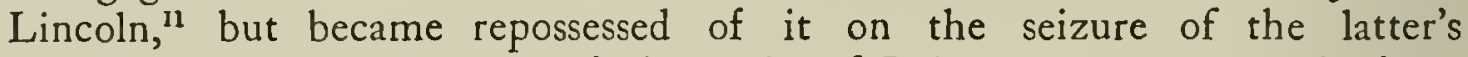
property. The inheritance of the earls of Leicester came originally from Roger de Beaumont, who as a very old man was holding at the time of the

1 Ralph of Coggeshall, Ctron. (Roils Ser. 66), I 52-4; Rog. Wend. Chron. (Rolls Ser. 84), iii.

2 Walt. Covent. Chror. (Rolls Ser. 58), ii, 212 ; R. Cogg. op. cit. 167 ; Rog. Wend. op. cit. iii, $261,262$.

'Walt. Covent. op. cit. ii, 209 ; Rog. Wend. op. cit. 240.

-Walt. Covent. op. cit. 212 ; Rog. Wend. op. cit. 255 ; Ann. Mon. 278; Chron. Th. Wykes (Rolls Ser. 36$)$, iv, 58 .

Dugdale, Baronage, i, 599 .

- litin. 'Dom. Bk. i, 79 .

- Liber Niger, i, 10z; Eyton, op. cit. 120.

${ }^{10}$ Hund. R. (Rec. Com.), 103. Plac. de Quo Warranto (Rec. Com.), 181.

1 Pipe R. 5 Ric. I, m. 8. 


\section{POLITICAL HISTORY}

Domesday Survey inter alia the valuable manor of Sturminster Marshall (involving also Lytchett Minster and East Almer), once Archbishop Stigand's. In 1258 , Henry III granted to the great Earl Simon (who had married his sister Eleanor) the manor of Bere, which he had from his father.

During the Barons' War Corfe came again to the front. In 1258 by the Provisions of Oxford it was placed in the hands of Stephen Longespée ${ }^{1}$ brother of William, who had been killed on crusade in 1250 . It was one of the three castles which, six years later, on the surrender of the Prince of Wales, Simon placed in the custody of his son the younger Simon, to prevent the effectual sending of foreign troops by the queen. ${ }^{2}$ Its connexion with the de Montforts ended with the captivity there of Aimery and Eleanor de Montfort, who had in I 275-6 been taken at sea off Bristol. ${ }^{3}$

The de Montfort lands in Dorset, on the fall of the great earl, lapsed to the crown. Edmund, son of Henry III, brother of Edward I, ${ }^{4}$ who in I 267 was made governor of Sherborne Castle, was granted Shapwick; ${ }^{5}$ Kingston and Blandford went to Henry de Lacy, grandson of John de Lacy (made earl of Lincoln 1232), who was son-in-law to Hawise, sister of that Randolf of Chester (o.s.p.) who had helped Henry III at Lincoln in I 2 I7. For this he was rewarded with the earldom of Lincoln, being nephew of the first earl, William of Roumare, who was himself nephew and heir of Robert son of Gerald, who, in Domesday, held Corfe Mullen, Lye, Ranston, and Povington. Henry de Lacy received full investiture of the earldom in 1272. In 1258 he had married Margaret Longespée, the above-mentioned heiress.

The Quo Warranto of I 275 did not, in Dorset, deal with the greater barons, with one exception. For the most part those summoned were ecclesiastics, such as the abbesses of Tarrant and Shaftesbury, the abbot of Cerne, and the dean and chapter of Salisbury. Their offences were mainly of the nature of taking wreck of the sea, or free warren, without authority. Among the local secular land-holders, William le Moyne, summoned for taking free warren, wreck of the sea, and assize of bread and ale, in Winfrith and Owermoigne, pleaded that he held in chief of the king by serjeanty, and that his ancestors had had these rights. ${ }^{6}$ Walter de la Lynde, summoned for the same cause, answered on the first count, a grant of King Henry's, which not improbably later gave rise to the legend of the White Hart of Blackmoor. The only great baron, among the secular land-holders, was Gilbert of Clare earl of Gloucester. Three years earlier the Hundred Rolls ${ }^{7}$ stated that, for years past, he had diverted to his own court Helwell, which formerly owed suit to the hundred court of Culliford Tree. In I 275 he was summoned for encroachments on the royal rights in the hundreds of Rowburgh, Haslor, Culliford Tree, Pimperne, and Ugscomb. He alleged in answer a grant of Henry I, made at Marlborough. The matter was ordered to be further inquired into. ${ }^{8}$ He was also accused of taking free chase on the highway between Shaftesbury and Blandford and 'over the hill from the west,' with a

\footnotetext{
${ }^{1}$ Provisions of Oxf.; Tit. Les Nums des Cheqeteins Chasteaus le rei. Stubbs, Chart. 392 ; Ann. Burton (Rolls Ser.), i, 453.

${ }^{2}$ Ann. Wig. (Rolls Ser.), iv, 453 ; Stubbs, Charters, (ed. 1895), 409.

3 Thom. Wykes, Chror. (Rolls Ser.), iv, 267 ; Gervase, op. cit. (Rolls Ser.), ii, 284.

Hund. R. (Rec. Com.), 97.

- Abbrev. Plac. (Rec. Com.), 184.

${ }^{5}$ Patent R. 5 I Hen. III, m. \&.

${ }^{7}$ Hund. R. (Rec. Com.), IOI.
}

- Plac. Abbrev. (Rec. Com.), 183 , Rot. 5 d. 


\section{A HISTORY OF DORSET}

list of further geographical details. To this he returned that a perambulation of the bounds and chase of Cranborne, in the reign of King John, had determined the rights of the earls of Gloucester. Further encroachments were alleged against him in the hundred of Combsditch; but it was admitted that he had assize of bread and ale, and wreck of the sea, in the manors of Weymouth, Portland, Wyke, and Elwell. ${ }^{1}$

Such checks upon the power of the great territorialists, though in themselves negative, were assisted by the parallel movement of increased privileges of town-dwelling communities. The fact that such definition of status and jurisdiction occurred somewhat late in Dorset does not imply that the powers now formally legalized had not hitherto been exercised. It would seem that the number of royal boroughs in the county had tended to make for peace between the burgesses and their overlord. In no case is there sign of previous strained feeling between the community as such and the overlord who grants the charter. The charters were therefore not extorted perforce, but were the result of handsome pecuniary compensation. Henry III gave charters to Bridport and Shaftesbury in $1252,{ }^{2}$ by which the former was incorporated, while Shaftesbury (whose mayor witnesses a charter in 1352$)^{3}$ obtained freedom that its burgesses should not be impleaded outside the borough during the visits of the justices in eyre, and that they should elect from among themselves two coroners to determine the pleas of the crown in the said vill. Weymouth, granted by Henry I to the monks of St. Swithun, Winchester, and exchanged by them with Gilbert of Clare for other lands, ${ }^{6}$ passed by the marriage of Gilbert's granddaughter Elizabeth to Lionel duke of Clarence (son of Edward III), who then obtained for the town certain liberties. Sherborne was never a borough, but belonged to the bishop of Salisbury. ${ }^{6}$ Melcombe, Bere Regis, Lyme, and Newton received charters from Edward I, ${ }^{7}$ by which the former obtained the usual freedom from extraburghal impleading, and that the burgesses should have their town at an annual fixed fee-farm rent in perpetuity. Bere and Lyme became free boroughs. The men of Wareham for many years had paid roo marks to have their town at fee-farm rent. ${ }^{8}$ It received a charter from William Longespée, ${ }^{9}$ as did also Poole, probably about $1248 .{ }^{10}$ Corfe Castle and Blandford were boroughs by prescription, but were not formally incorporated till I 576 and I 606 respectively. ${ }^{11} \quad$ Dorchester, which had hitherto paid $\oint_{0} 20$ by tale or $f_{0} \mathrm{I} 2$ blanch for the fee-farm rent of the town, ${ }^{12}$ an arrangement on a somewhat uncertain footing, ${ }^{13}$ obtained the perpetuation of this scale in ${ }^{1} 337,{ }^{14}$ having only obtained from Edward I that they might 'make at their own expense a prison to detain there the persons indicted for trespass and felony.' ${ }^{16}$

'Plac. Abbree'. (Rec. Com.), i 83 , Rot. 5 d.

2 Madox, Hist. Exch. 250, 290; Browne-Willis, Not. Parl. ii, 460-I; Mayo, Municip. Rec. of the Borough of Shafiesbury, 3 .

H. J. Moule, Calendar of W'eymouth Charters, 3.

${ }^{5}$ Hutchins, Dors. ii, 428 .

'Mayo, Municip. Rec. of the Borough of Shaffesbury, 3 .

'Browne-Willis, Not. Porl. ii, $44^{6}$; Pat. 19 Edw. I, pt. i, m. 22 d.; Chart. R. 13 Edw. I, No. I 36.

${ }^{8}$ Pipe R. 12 John, m. 7 d. ; rep. I3 John (nov' oblata).

${ }^{9}$ Hutchins, Dors. i, 82.

${ }^{10}$ Sydenham, Hist. Poole, $154,78$.

"Hutchins, op. cit. i, 471-2 ; Browne-Willis, Nor. Porl. (ed. I 716), ii, 39 I.

12 Dorchester Corp. MSS. A. 30 ; Madox, Hist. Exch. 195.

${ }^{13}$ Browne-Willis, Not. Porl. ii, +18.

"Dorch. Corp. MSS. loc. cit. ; Chart. R. I I Edw. III, m. 3, No. 26

is Dorch. Corp. MSS. loc, cit. 


\section{POLITICAL HISTORY}

The towns quarrelled among themselves as to their status and jurisdiction all through the fourteenth and fifteenth centuries. In I 432 Poole obtained an Act of Parliament reducing Melcombe for a time from a port into a creek, and erecting itself into a port. ${ }^{1}$ It was erected into a county by Letters Patent of ${ }_{5} 568$, but the borough was still subject to the authority of the Lords-Lieutenant of Dorset, the Privy Council, the year after, sending a special letter to ensure this. ${ }^{2}$ The burgesses of Dorchester in I 445 succeeded in enforcing certain jurisdictions as against those of Bridport. ${ }^{3}$ They had already ( I 4 I 4) drawn up by-laws for the governance of their town."

Eleven towns sent representatives to Parliament at one time and another. Dorchester, Bridport, and Lyme sent them continuously from I $295,{ }^{6}$ Shaftesbury from $1297,{ }^{\circ}$ and Wareham from $1302 .^{7}$ Weymouth and Melcombe (the latter summoned in I 305 and I 306 , but not replying) were represented from the reign of Edward II onwards. ${ }^{8}$ Sherborne was represented at the Great Council held in I $344^{\circ}$ Blandford was represented in Parliament on two isolated occasions ${ }^{10}$ (I 305 and $\mathrm{I}_{329}$ ). Poole was represented in I $34 \mathrm{I}$, I 363 , and 1369 , and then not again till 1453 or 1455 , after which it returned members continuously. ${ }^{11}$ Corfe Castle returned no member till $1572 .{ }^{12}$ The knights of the shire during the fourteenth and fifteenth centuries were drawn ${ }^{13}$ from that class of secondary landholders which furnished the "new men' of the Tudor county-administration. Their forefathers appear for the most part as knights of the great feudatories, but themselves inconspicuous. The families of Mowbanks (or Maybank), Turberville, Newburgh, Sifrewast, Goviz, Herring, Matravers and Filliol (many of them commemorated in place-surnames) now begin to come into prominence as representing the county in Parliament. It is not till the reign of Edward VI that the wellknown names of Strangways and Horsey occur in this connexion.

In spite of the growth of popular freedom, the local influence of the great barons was still strong in I 3 I I, when Gaveston fled to the west. The king was compelled to issue a proclamation (3o November) ordering search to be made for him. Dorset was mentioned as one of his probable hidingplaces. $^{1 *}$ Gilbert of Clare was the king's close friend, and Gaveston's brotherin-law; and Henry of Lacy ${ }^{15}$ (who had only just died, and had, indeed, ended his days in the county) had before his death come to an understanding with the king, probably with reference to Gaveston. ${ }^{16}$ Alice, daughter and heiress of Henry of Lacy and Margaret of Salisbury had, it is true, married Thomas of Lancaster, the son and heir of Edmund, son of Henry III, who held, in his own right, the manors of Kingston, Fordington, and Bere, ${ }^{17}$ together with other Dorset manors, ${ }^{18}$ both in his own right and in that of

\footnotetext{
Weymouth Charters, i, 26 ; Sydenham, op. cit. 4, 5.

Browne-Willis, Not. Parl. ii, 407 ; Sydenham, op. cit. 179 sqq.

${ }^{3}$ Dorch. Corp. MSS. A. 9, B. 2.

${ }^{5}$ Hutchins, op. cit. ii, $356,12,51$.

${ }^{7}$ Hutchins, op. cit. i, 84 .

${ }^{9}$ Browne-Willis, op. cit. i, 87 .

"Hutchins, op. cit. i, 25.

${ }^{13}$ See list in Hutchins, op. cit. i, p. xlv sqq.

14 Rymer, Foedera (orig. ed.), iii, 294.

${ }^{16}$ Cal. Docts. Scot. iii, 177.

${ }^{17}$ Duchy of Lanc. Misc. Rec. xi, 37 d. 69 d.; Feud. Aids, i, 17 ; Chart. R. 8 Edw. I, No. 73, m. 7, No. 37.

${ }^{18}$ Duchy of Lanc. Misc. Rec. xi, 55 .

Ibid. 'Dorchester Domesday.'

6 Browne-Willis, Not. Parl. ii, 478,483 .

${ }^{8}$ Ibid. ii, 433,452 .

${ }^{10}$ Ibid. ii, 391 .

${ }^{12}$ Ibid. i, 471 .

${ }^{15}$ Vide supra.
} 


\section{A HISTORY OF DORSET}

his wife Aveline, ${ }^{1}$ daughter of Isabella de Fortibus, Lady of the Isle of Wight. But his father-in-law's death was so recent that his influence would no doubt avail, for a time, to shelter Gaveston against the Earl of Lancaster. After the execution of the latter, in 1322 , his widow, Countess Alice, remarried without the royal assent. Her estates were seized, and most of them were given in 1323 to the younger Despenser, ${ }^{2}$ who had married Eleanor, elder daughter of Gilbert of Clare, and had livery of her purparty of his lordships and lands. ${ }^{8}$

Edward II was for a time confined in Corfe Castle before he was taken to Berkeley. One account even gave it as his place of execution. ${ }^{4}$ Hence probably arose one version of the story of his brother Edmund of Kent. It was said that the earl, being anxious to restore his brother, was made the victim of a plot by which a certain friar was persuaded of the truth of the tale that the king was still alive and in Corfe Castle. To this end the friar was smuggled into the castle, and was shown the supposed king. Reporting to the earl, the latter was persuaded to incriminate himself by a letter to the brother, whom he supposed still living, though captive : and this letter was used by Isabella and Mortimer as an excuse to ruin and execute him. It is, however, probable that Stow's account is much too detailed, and that the details given result from a mixture of the two facts of the temporary imprisonment of the king at Corfe, and of the application by the Earl of Kent to a certain friar to raise his brother's spirit for him. ${ }^{5}$

The Mortimers appear in 1285 as already holding lands in Dorset. Edmund Mortimer earl of March had lands in Winterborne Steepleton, and held Chilcombe, which, however, he subinfeudated to the prior of St. John of Jerusalem, as did Roger Mortimer, lord of Chirk, his manor of Stottingway in the hundred of Culliford Tree. ${ }^{6}$ Simon de Montacute (ob. 1 317 ), in return for services in Edward's Welsh campaign in 1277 , received additions to the Dorset lands which had descended to him from the original Drogo de Montacute of Domesday Book, tenant of the count of Mortain in Nyland and in Toller. ${ }^{7}$ In 1299 he was made constable of Corfe Castle. His grandson William, who helped Edward III to arrest Mortimer, was rewarded by grants of land forfeited by him, including Sherborne Castle, Corfe Castle, and Purbeck Chase. ${ }^{8}$ Later, Simon obtained also the manor of Canford, ${ }^{9}$ which had passed from Henry de Lacy and Countess Margaret to their daughter Alice. On the death of Thomas of Lancaster she remised it to the crown, who granted it to the Earl of Surrey for life, and then to Hugh le Despenser, and on his forfeiture to William de Montacute the elder. ${ }^{10}$ Later again he obtained the manors of Marshwood, Wootton, Worth, Frome Whitfield, and Poole. ${ }^{11}$ In I 337 he was created earl of

\footnotetext{
${ }^{1}$ See Dugdale, Baronage, ii, 114 ; Genealogist, May, 1905; Feud. Aids, i, I 5, 17, 19, 22, \&c.

'See Cat. Anct. Deeds, A. 2 I 4, $215,4587,249,250 . \quad$ 'Dugdale, Baronage, i, 392.

4 Ann. Bermondes. (Rolls Scr.), iii, 472 ; Vito Edwardi Secundi (Roils Ser.), 76.

${ }^{5}$ See Leland, Collectonea, i, 686 ; Stow, Chron. I 29 ; article on 'Edmund of Kent' in Dict. Nat. Biog.; Bond, Corfe Castle, 23.

${ }^{6}$ Feud. Aids, i, 3, 6, 20. See Hutchins, op. cit. ii, $8+5$, where it is included in the hundred of

${ }^{7}$ Dom. Bk. i, 79.

${ }^{8}$ Parl. R. ii, 60b; Chart. R. 4 Edw. III, m. I, No. 2.

${ }^{9}$ Chart. R. 9 Edw. III, m. 6, No. 26 ; Close, 2 Ric. II, m. 23.

${ }^{10}$ Chart. R. I I Edw. III, m. 26, No. 54.

${ }^{11}$ Ibid. 9 Edw. III, m. 3, No. 16 ; 10 Edw. III, m. 18, No. 36.
} Ugscomb. 


\section{POLITICAL HISTORY}

Salisbury, and his son William, the second earl, in 1356 came to an agreement with the Bishop of Salisbury about the long-disputed custody of Sherborne Castle. ${ }^{1}$ On 3 I July, I 38 I, he was appointed captain against the rebels in Dorset and Somerset; but the rebellion did not come to a head in Dorset. His great-grand-daughter and heiress Alice, by her marriage to Richard Neville (eldest son of the earl of Westmorland by his second wife, Lady Joan Beaufort, daughter of John of Gaunt), took the inheritance to the Nevilles. After the death of their son at the battle of Barnet it was granted by Edward IV to his own brother George (whom he had made duke of Clarence) on his marriage with Isabel Neville. The lands of the Duke of Clarence included the manors of Todber, Iwerne Courtney, Ibberton, Ranston, Wraxall, Chilfrome, Kentcombe, Mapperton, Puncknowle, Toller Porcorum, and the castle and manor of Corfe. ${ }^{2}$ The Edmund Mortimer of the reign of Richard II had married Philippa, daughter and heiress of Lionel duke of Clarence, third son of Edward III, who had died seised of the manors of Marshwood, Cranborne, Tarrant Gunville, Pimperne, Steeple, Wyke, and Portland, and the boroughs of Wareham and Weymouth. ${ }^{3}$ On her mother's side (as grand-daughter of the coheiress of Gilbert of Clare) she enjoyed also many Dorset manors." The heir to their grandson Edmund, who died in 1425, was declared to be Richard duke of York, who accordingly had livery of his lands. ${ }^{5}$

John of Gaunt had succeeded, in right of his wife Blanche (who was sister and heiress of Maud, daughter of Henry duke of Lancaster, brother and heir of Thomas, executed after Boroughbridge), to the manors of Kingston Lacy, Shapwick, and Maiden Newton, the Chase of Wimborne Holt, and the hundred of Badbury. ${ }^{6}$ This formed the nucleus of the Beaufort connexion with Dorset, the Yorkists, as has been said, being well represented also. The two Beaufort sons of the Duke of Lancaster who were laymen enjoyed the Dorset title. John, the eldest, was created marquis of Dorset in r 397, but degraded in I 399. In 1402 the Commons petitioned the king to restore to him the name and rank of marquis, but he himself was opposed to their request on the ground of the novelty and foreign sound of the title. ${ }^{7}$ His son Henry died, while yet a minor, seised of the castle and lordship of Corfe. Thomas, third of the sons of John of Gaunt by Catherine Swinford, was created earl of Dorset in I4I I and duke of Exeter (for life only) in I4I6. He died without issue in I426. Edmund Beaufort (his nephew and heir, and son of John, first marquis) succeeded as earl of Dorset in I 44 I, and was created marquis of Dorset in 1442, for his services at the relief of Calais. ${ }^{8} \quad$ His elder brother John duke of Somerset had succeeded to the lands of his grandfather John of Gaunt, and thus it came about that the Lady Margaret Beaufort, his daughter, and the mother of Henry VII, was born at Kingston Lacy. Edmund, the second marquis above mentioned, was killed at the battle of St. Albans in I 455, and left three sons, Henry, Edmund, and John, of whom the youngest, John, was killed at Tewkesbury. In $145^{2}$ Henry VI made a grant to Queen Margaret of lands in Dorset, mainly

' Close, 29 Edw. III, m. 36.

${ }^{3}$ Ibid. 168.

'Dugdale, Baronage, ii, 164 .

${ }^{5}$ Ibid. $15^{1-2}$; Acts of P.C. (ed. Nicholas), iii, 94-5.

${ }^{6}$ Dugdale, op. cit. ii, 114 .

'Ibid. i, 150.

${ }^{8}$ Parl. R. 20 Hen. VI, No. 3 ; Acts of P.C. (ed. Nicholas), v, 209. 


\section{A HISTORY OF DORSET}

in the neighbourhood of Weymouth.' She landed at Weymouth in $147 \mathrm{I}$, and was joined there by Somerset. It is said that many Dorset men took part in the succeeding campaign of Tewkesbury.

The title of marquis of Dorset was granted by Edward IV to Thomas Grey of Ruthyn (son of his queen, Elizabeth Wydville) in I 475, and he intrigued for the absent Henry Tudor. On his accession Henry granted Corfe Castle and manor to his mother; on her death Henry VIII granted them, together with the Isle of Purbeck, to the Duke of Richmond and Somerset. On his death they once more reverted to the crown, and later were again granted to the Duke of Somerset, this time to the Protector. On his attainder they again reverted to the crown, Elizabeth finally granting them to Sir Christopher Hatton. ${ }^{6}$

Dorset was associated with the rebellion of Perkin Warbeck in two different manners, answering to the two phases of that rebellion. The underlying motive of the first stage of the rising was protest against extortionate taxation. This ended, in June (1497), with the defeat of the Cornishmen at Blackheath. A purely personal sentiment for Warbeck began in the west country with his landing in Cornwall that September. It crumbled away on his flight.

The first rising found sympathizers all over the shire. The fines afterwards levied extend pretty generally throughout it. But the names of the more important families are absent from the Exchequer Roll of Accounts for the twelfth year of the reign (ending 2 I August, I 497, i.e. before the second rising began), which gives the list of fines levied. The Horseys, Strangways, Binghams, Trenchards, Martins of Athelhampton, Delalyndes, Mortons, and Rogers of Bryanston apparently held aloof. ${ }^{6}$ The boroughs of Dorchester and Bridport, and seven hundreds are implicated. The famous merchant, John Williams of Dorchester, was among the fined. A Turberville was fined in the hundred of Bere Regis. The monasteries sided generally with the commonalty in their disloyalty. The inhabitants of Abbot's Fee in Sherborne were fined nearly $f 40$, the abbot of Bindon $f_{20}$, and the tithings of Cerne Abbas and Milton Abbas respectively $\oint_{0} \mathrm{I} 5$ and $\oint_{0}$ io. John Okey, 'chaplain' of Buckland Newton, paid $f_{\text {I }}$ o, and John Mabbe, vicar of Netherbury, fo. The king treated the rebels with great leniency, ${ }^{7}$ proclaiming a general pardon in the western counties on their submission to his mercy. ${ }^{8}$ But the collection of the fine was accompanied by much unfairness, extortion, and embezzlement ; Harry Uvedale, bailiff of Purbeck, was the chief offender, while the complaints were voiced by one of the Claviles, and brought before Sir John Turberville (whose name occurs in Warbeck's Northumberland Proclamation), one of the king's council. The Dorset commissioners were Sir Amyas Paulet and Robert Sherborne. ${ }^{9}$

${ }^{1}$ Weymouth Chart. i, 10.

'Memorials of Hen. III (Rolls Ser. 10), xxxix, 24.

'Cal. L. and P. Hen. VIII, i, 334, 563 .

'Bankes, Corfe Castle, 29. App. B. vol, ii.

- Cal. Venet. State Papers, 1202-1 509, p. 260.

${ }^{8}$ Cal. of Pat. R. $24^{-2} 5$ July, 1497, m. 4 ; Pat. 13 Hen. VII, m. 6 d.

Letters of Ric. III and Hen. VII (Rolls. Ser.), ii, 75-6. See also Notes and Queries for Som and Dors. VII, lviil, 102. 


\section{POLITICAL HISTORY}

In the second rising also, the king had full confidence in the loyalty of the landed classes. He wrote (September 20) to the Bishop of Bath and Wells (Warbeck being then engaged in besieging Exeter): 'The Perkin and his company, if they come forward, shall find before them . . . the noblemen of South Wales, and of our counties of Gloucester, Wiltshire, Hampshire, Somerset, and Dorset.' ' The list of the fined was practically confined to the Pretender's line of flight from Taunton, by way of Sherborne, Blackmoor, and Cranborne Chase to Beaulieu. There was evidently no discontent with the Tudor monarchy, but merely pity extended to a fugitive.

The loyalty of the country gentlemen showed itself a few years later ( 1501 ) on the bridal progress of Catherine of Arragon. She was received with much ceremonial, and escorted from stage to stage; two or three miles before she came to Sherborne (from Exeter and Crewkerne) she was met by Sir Thomas de la Lynde, William Martin, Sir John Turberville, Sir Roger Newburgh, Richard Willoughby, William Barket, and Henry Strangways. These conveyed her to Shaftesbury, where she was met by another set of important gentlemen, and accompanied to Amesbury. ${ }^{2}$

At the Field of the Cloth of Gold Dorset was represented by Sir Giles Strangways, Sir Thomas Trenchard, and Sir Thomas Lynde. ${ }^{3}$ And to the suppression of the Northern Rebellion of 1536 the county contributed 1,050 men, viz. Sir Giles Strangways 300, Sir Thomas Arundel and Sir Edward Willoughby 200 each, Sir Thomas More and John Rogers, esq. roo each, and Sir John Horsey I $50 .{ }^{4}$ In 1538 there was some slight disaffection, ${ }^{6}$ but on the whole the Tudor period is barren of any stirring events. It is concerned mainly with questions of defence, and in it we get glimpses of electoral procedure, following on the borough controversies whose roots lay centuries deep. The county was fairly heavily charged for coat and conduct money, besides having to furnish contingents at frequent intervals. Thus in 1546 the coat and conduct money of 100 men raised by the county was $f_{0} 45$ I 6 s. $8 d .{ }^{6}{ }^{6}$ while in $1600, f_{0}$ I 9 I $6 s .4 d$. was the coat and conduct money charged for 50 men. ${ }^{7}$ Not so many men were apparently demanded for the wars of Henry VIII as for those of Elizabeth. Henry wanted money and men for his castles and garrisons. Sandsfoot Castle, built by him in I 540, was carefully munitioned, ${ }^{8}$ and gunners for the Isle of Purbeck and for Portland were not reduced in number till I $55^{2} .^{9}$

The execution of Lady Jane Grey and reconciliation of England with Rome seem to have produced slight disturbances in 1554 , for a letter from the Privy Council to the sheriff and justices of the peace mentions the late false rumours of a 'commocion' in Dorset, 'to the evil stirring of the people.' Two days later (3 I July) a second letter thanks them for their diligence and prays them to continue the same; and because they have a commission of oyer and terminer they are to proceed against the spreaders of these reports. In this connexion Edward Horsey was specially mentioned as 'of evill demeanour.' ${ }^{10}$ In I 557 the county was still suffering disturbance

'Ellis, Original Letters, i, 35, ser. i.

${ }^{3}$ L. and P. Hen. VIII, iii, pt. i, 24 I.

${ }^{5}$ Ibid. xiii, pt. ii, 473 .

${ }^{7}$ Ibid. 1600 , pp. $102,185$.

Ibid. 184 ; ibid. $155^{2-4}$, pp. 32, 34 .
'Letters of Ric. III and Hen. VII (Rolls Ser.), i, 406, 407.

'Ibid. xi, $23^{2}$.

6 Acts of P. C. (ed. Dasent), $1542-7$, p. 393.

${ }^{8}$ Ibid. $1550-2$, p. 172 ; ibid. $1549-50$, p. 393.

${ }^{10}$ Ibid. $1554-6$, pp. $168-9$. 


\section{A HISTORY OF DORSET}

from this cause, and 'the whole force of the shire' was to be held ready ' in case of rebellion.' I

In spite of this strong though evidently suppressed Protestant feeling there were a certain number of recusants in the reign of Elizabeth. No notice was taken of them till 1582 , when the apprehension was ordered of one Slade, a very dangerous Papist, also of any Jesuit or seminary priest. ${ }^{2}$ This followed hard upon riots against the sheriff, instigated by Henry Howard, son and heir of Lord Bindon. ${ }^{3}$ A prosecution for witcheraft had taken place in $1564 .{ }^{4}$ On 7 February, 1585 , a regular assessment of fines for recusancy was enforced, under the lord-lieutenancy of the Marquis of Winchester. ${ }^{5}$ In 1590 there was some sympathy with the recusants displayed: ${ }^{\circ}$ and in I 598 certain recusants were fined $f_{0} 15$ each towards the Irish Light Horse.? The names of the fined were Lady Sturton, Charles Sturton, esq., Mrs. Martin of Athelhampton, Henry Cary of Hamworthy, and Mr. Slade of Mawston.

The need of men for Irish service had been constantly brought home. Three hundred Dorset men served in 1573 , a hundred more were sent out in 1578 , another hundred the next year, a further hundred in 1598 , and another hundred and fifty in 1600 , with fifty more for the plantation of Lough Foyle, reinforced later in the year by an additional twenty; while in the same year resort was had to the method of levying from each of the principal gentlemen (viz. Sir George Trenchard, Sir Ralph Horsey, Thomas Freake, and John Fitzjames) 'one light horse and equipment and man and equipment."

The preparations to meet the Armada included the furnishing of Corfe Castle, Portland Castle, and the Isle of Purbeck with ordnance, ${ }^{9}$ a contribution of ship-money from Weymouth, Shaftesbury, Wareham, Dorchester, Blandford, Sherborne, and Cerne Abbas, for the 'two ships and one pinnace' to be set forth by Weymouth. The rest of the county, and Lyme and Chard, were afterwards also forced to contribute. A thousand foot, but no horse, were ordered to be sent to London by 6 August. This led to a lively but unavailing protest from the rest of the inhabitants, who feared the Spanish fleet and French attacks. 'Lances and light horse' were commanded to London by the 8 th. The clergy also raised a troop. ${ }^{10}$ Next year the lordlieutenant received instructions as to the levies and military stores, and how far they were to be kept on a war footing. A sale of powder in store at Dorchester was also ordered 'awaie nowe, when there is occasion to use yt, for yt is but bad powder, and the longer yt is kept the worse it wilbe." "I The expenses of the repelling of the Armada were met by a loan borrowed from 2,4 16 of the queen's subjects in the thirty-six counties, which amounted to nearly $£ 75,000$; it was impossible to meet them by ordinary subsidies, and an extraordinary subsidy large enough to bring in the sum required

1 Acts of P.C. (ed. Dasent), $1556-$ S, p. 87 . 'Ibid. $1581-2$, p. 446.

3 Ibid. 15S0-1, p. 217 . Ibid. 1558-70, pp. 200-1.

'Ibid. 1590-1, p. 358 'Ibid. 1598-9, P. 499 ; see also Hist. MSS. Com. Rep. vi, 2526.

B Acts of P. C. 1571-5, pp. 125-6; 1577-8, p. $240 ; 1598-9$, P. $499 ; 1597-8$, P. $329 ; 1600$, pp. 102, $247,416,439,790,798$. See also Dorch. Corp. MSS. and Weymouth Chart. v, 28.

Acts of P. C. 1588, p. 259 . $v, 26,32$.

${ }^{10}$ Ibid. 133, 301, 353, 171, 192, 181, 267. See also Ellis, Hist. Weymouth, 15; Weymouth Charters,

${ }_{11} A$ cis of $P$. C. $1588-9$, p. 389 . 


\section{POLITICAL HISTORY}

would have ruined the country and caused widespread ill-feeling. In the spring of $\mathrm{I}_{5} 87$ the loan was called for by circular letters, addressed under sanction, or by command of the Privy Seal, to the wealthier inhabitants of each county, whose names were furnished by the lords-lieutenant. In some cases the names given were of those who really could not pay. But in Dorset no remissions were allowed, and $\oint_{\mathrm{r}} \mathrm{r}, 95^{\circ}$ was paid by forty-seven of its gentry. Robert Freke of Cerne, John Miller of Came, Henry Coker of Mappowder, Robert Harley of Stalbridge, Thomas Chafyn, and James Hannam of Purse Caundle paid $f_{0}$ roo each. ${ }^{3}$ Matthew Chubb of Dorchester, assessed at $\oint_{0} 50$, wrote to Secretary Wolly, saying that 'neither the Lord Lieutenant, nor the Deputy Lieutenant, have certified the sufficiency of your suppliant to be able to lend Her Majesty any sum of money.' There is no record of how he fared. ${ }^{2}$

All this while the twin towns of Weymouth and Melcombe Regis had been carrying on a bitter quarrel. The old competitors of Dorchester (Lyme, Wareham, and Poole) had all withdrawn from the contest. Weymouth and Melcombe, however, continued their strife with unabated vigour, in spite of the so-called Act of Union of $157 \mathrm{I}$, which united the two boroughs 'in government, the peace, and entire jurisdiction,' also as to the receipt of the petty customs of 'the haven and watercourse;' but for 'private actions, suits, etc. . . . in leets and lawdays . . . they retained the same divided in their several towns.' ${ }^{3}$ This apparent settlement had been arrived at by a commission from the Privy Council, consisting of the Lords Justices Jeffery and Manwood. But the disturbances ran so high ${ }^{4}$ that in I 586 a fresh commission was sent to settle them. The matter was not ended till I6 I6, all the local lawyers being kept busy, on both sides, and 'Holandshed, a keeper of recordes in the Tower, delivered a 2uo Warranto to Best, and Best thought it to be forged, because he had it so good cheape.'

Interference with elections for Parliament is a common feature of this period. The Earl of Pembroke (steward of Weymouth, Wyke, Portland, and other royal manors) with ' $E$. Philippes gent.' selected the two representatives for Weymouth in $1585 .^{\circ}$ Lord Warwick chose the opposing two for Melcombe. ${ }^{7}$ Lord Bedford, in 1576 , wrote to the bailiffs of the former proposing that ' upon the return of your indentures you will send the same, with a blank for the name,' as he wished to nominate one of the members. ${ }^{8}$ In 157 I he had already selected one of the members for Poole; in I 58 I the Earl of Leicester assumed this privilege, in 1584 the recorder, Giles Estcourt, and in 1585 the Earl of Warwick. In Poole, at any rate, this state of affairs continued till the Commonwealth. ${ }^{9}$ So late as the county election of 1675 the Bishop of Bristol sent circulars to all his clergy instructing them which way to vote :-

I have sent my secretary into Dorsetshire on purpose to disperse these letters amongst you, and I hope you will be careful so to send these from one to another that the whole diocese will be sensible of my desire to them. ${ }^{10}$

'T. C. Noble : 'The names of those persons ... who subscribed to the Armada.' Notes and Queries for Som. and Dors. i, 33 sqq.

'Cal. S.P. Dom. Eliz. $1581-90$, p. 223 (114).

3 Weymouth Chart. ii, 4. Acts of P. C. $1575-7$, p. 368.

${ }^{6}$ Ibid. ii, 4 ; iii, $15 .{ }^{7}$ Ibid. i, 25.

${ }^{10}$ Christie, Life of the First Lord Shaftisbury, ii, 218. 


\section{A HISTORY OF DORSET}

In 1592 the grievance of purveyance, long felt, came to a head, owing to the extra burden imposed on the rest of the county by the exemptions claimed by the Isle of Purbeck, the liberties of Gillingham, Wyke Regis, Stour Preaux, the hundred of Whitchurch, and the liberties of Sutton Pointz

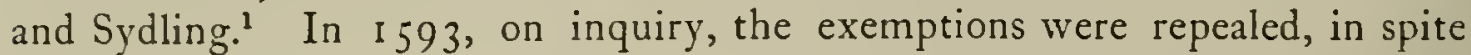
of the great efforts on behalf of the Isle of Purbeck made by William Bond. Purbeck also had to contribute towards the provision for Her Majesty's household.' This redressed the local exactions complained of in the Blandford division in $1591{ }^{3}$ which were heavier, from the exemptions of the town of Poole, the island of Purbeck, and the hundred of Whiteway.

In I 566 the joint shrievalty of Dorset and Somerset was discontinued, each county henceforth being administered by a separate sheriff."

The chief place among the illegal exactions of Charles $I$ is generally accorded to the unauthorized collection of ship-money; the first general writ for this was dated 1634 . The illegalities of billeting soldiers upon private persons, and of enforcing service for the public works were, however, more annoying in the years immediately preceding 1634 . The justices of the peace for the county complained in July 1632 that 'this little county' was taxed 'in equality with Hampshire and IViltshire,' which was the more unjust,

that they have performed the service of many thousand loads of stones in the Isle of Portland, for building the banqueting house, and that service is still continued upon them towards His Majesty's buildings, besides that there is $£ 5,000$ and upwards due to this county for billeting soldiers.

They, therefore, begged to be spared the carriage of 1,290 loads of timber out of the New Forest. ${ }^{5}$ It appears that the county eventually tacitly declined the service of this carriage. William Twyne, who did perform his share, could get no money therefor. ${ }^{6}$ In 1626 a thousand soldiers from Devon and Cornwall, under martial law, had been quartered in Dorset. ${ }^{7}$ In 1629 the corporation of Dorchester complained to the Council of the billeting of soldiers 'by a long space, for which they have received no satisfaction,' viz. in particular from 23 April to 3 August, I628, 'amounting to $£_{077}$ I 6 s., whereof $£_{2} 6$ only is paid and $£_{5} 5$ I 6 s. reste unpaid.' 8 With other similar items the sum soon mounted to $£_{2} 260$ igs. But in 1632 the lord treasurer wrote to the mayor of Dorchester to pay the $\oint_{0} 260$ odd, which was said to be 'in the hands of three or four men who collected the loan-money of the county.' "

This 'loan-money' was just possibly contributions, somewhat forced, towards the Cadiz expedition of 1625, or the later recovery of the Palatinate. ${ }^{\text {II }}$ But it is more probable that the reference was to an early ship-money writ. The corporation of Bridport possesses such a writ dated 5 November, $1628 . .^{12}$ It provides for the outfit of a man-of-war of 400 tons, with equipment and provisions for twenty-six weeks, and for an assessment to cover the cost. It contains the clause: "Should any person be found rebellious, they shall be committed to prison until further order is made for their delivery.'

${ }^{1}$ Acts of P.C. $1592-3$, pp. $354^{-6 .}$

${ }^{3}$ Ibid. $1591-2$, p. 306.

${ }^{3}$ Cal. S.P. Dom. $1631-3$, p. 381 .

'Weymouth Chart. iv, 71 .

${ }^{9}$ Ibid. $\quad{ }^{10}$ Cal. S.P. Dom. 1635-6, p. 66.

12 Notes and Queries for Som. and Dors. viii, 14 .

Ibid. 452, 457-8, $468-9$.

' Stasutes at Large, 8 Eliz. cap. 16.

'Ibid. 1633-4, p. 110.

8 Dorch. Corp. MSS. C. 9.

"Ibid. 1631-3, P. 210, an. 1631 . 


\section{POLITICAL HISTORY}

The nominal objects of the levy of ship-money were defence against invasion and defence against the pirates who had troubled the Dorset coast all through the preceding century, and whose raids were only ended by the sea-power of the Protectorate. It is probable that the government honestly believed in efforts then said to be making to invade England. A letter from Lord Suffolk in 1626 to the mayor and corporation of Weymouth and Melcombe speaks of the preparations for an invasion by Spain from Flanders. ${ }^{1}$ It seems to have been caused by a letter to him from the Privy Council, to order him to have the militia drilled, as the king had cause to expect an invasion from Spain and Flanders. ${ }^{2}$ Yet, in spite of continued levies of shipmoney, Dorset had no help against the pirates-Turkish and Algerian and often helped by the Dutch-whose attacks became worse, from 1610 on. Weymouth often joined Exeter and Dartmouth in attempts at repelling them, and resort was had to petitions to the Council. In 1636 the corporation endeavoured to enlist the favour of Laud, who

did protest (strikeing his hands upon his brest), that whilst hee had breath in his bodie, he would doe his uttmost endeavor to advance so necessary and conscquentiall a business . . . that within this twelve monethes, not a Turkish ship should be able to putt out. ${ }^{3}$

But nothing was done to help the county against this scourge. It was, therefore, all the more irritating to find that ship-money writs continued to be issued, the sums demanded having increased in severity. By 2 I March, I635, the sum received from the Dorset maritime towns under the writ of the preceding year was $f_{0} 1,400$, Gloucestershire and Hampshire having paid only $f_{0} \mathrm{r}, 000$ each." The method of procedure was to assess the county in a certain sum, and to make the sheriff responsible. He then divided this sum among the various corporate towns, and the remaining parts of the county. The corporate towns rated themselves and forwarded their contributions through their mayors. The sheriff assessed the sums to be paid by the various hundreds and parishes not included in the corporate towns, and collected from these by his 'servants' or bailiffs. So early as I 635 the men of Poole protested against the levy. ${ }^{5}$ But about the same time Sir Thomas Trenchard, sheriff (remonstrated with by the Council because he had not sent in a note to say how the ship-money was assessed by him, and how much to be paid by every hundred and corporate town), replied that he had already paid to Sir William Russell $f_{0} 3,100$, and to his own successor in office (John Freke) $£ 908$ is. 6d., with a memorial of the sum still owing, f.99 I 18s. 6d. He had been delayed in returning his account by the daily concourse of people to pay in their moneys to him. ${ }^{6}$ A list, drawn up by him in April, 1636 , of those who had not paid, shows that Sir Walter Erle, afterwards Parliamentary general, owed $f_{0} 36$ s. $8 \%$. for lands in Morden, £. 53 s. for lands in Combe Almer, and $\oint_{0} 4$ I Is. for lands in Chelborough. Sir William Strode would not pay, but suffered his goods to be distrained." This case is the first mention of distraint. But the method was necessarily soon resorted to in the collection of so unpopular a tax, at a time of peculiar hardship, when the county was suffering severely from plague ravages. In the assessment of $16{ }_{3} 6$ Shaftesbury paid nothing, so heavy was

${ }^{1}$ Hist. MSS. Com. Rep. v, 581 .

Ibid. vi, 103.

${ }^{3}$ Cal. S.P. Dom. 1635-6, p. I 2.

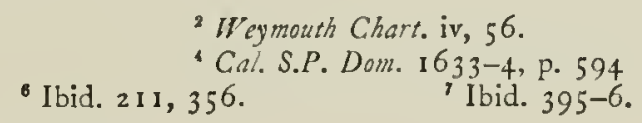

2 Weymouth Chart. iv, 56.

"Cal. S.P. Dom. 1633-4, p. 594

${ }^{6}$ Ibid. $211,356$.

7 Ibid. 395-6. 


\section{A HISTORY OF DORSET}

the loss from the disease. Poole then paid $\oint_{3} 30$, Dorchester $£_{445}$, Wareham $£_{25}$, Corfe Castle $£_{4} 40$, Weymouth and Melcombe $£_{3} 3$, Lyme $£_{40}$, Bridport $£_{2} 20$, and Blandford $£_{2} 5$. This was the sheriff's own assessment, the inayor of Dorchester having declined, with the other mayors of the county, at a meeting held 23 November, 1636 , to make any rate towards the $£_{5}, 000$ demanded. ${ }^{1}$ John Freke, the sheriff, wrote that autumn that the money was paid 'like drops of blood, and some sell their only cow, which should feed their children, and some come to the parish.' the new sheriff, took forty days 'expediting the agreements of the mayors of the corporate towns, and at the expiration was put to make the assessments himself." ${ }^{3}$ The assessment of 1637 was heavier on the towns than that of I636. Shaftesbury now paid $£_{5} 5$, Poole $£_{24}$, Wareham $£_{25}$, Corfe Castle $f_{40}$, Weymouth and Melcombe $f_{0} 8$, Lyme $f_{0} 40$, Bridport $\oint_{2} 20$, and Dorchester $f_{4} 45^{4}$ Sir Walter Erle was distrained, which with the similar treatment of 'some great ones, reduced the rest to conformity' for the time being. ${ }^{5}$ By I September only $£_{2} 200$ of the whole $£_{25}, 000$ was wanting. Arrears under the writ of 4 August, 1635 , still came in, in driblets, and the official return of the whole arrears of the county, in October, $16_{37}$, was $f_{1} 1,200 .^{6}$ But the old arrears were never all got in before new writs were issued, and disputes as to rating became more and more common, ${ }^{7}$ occasioning 'more than ordinary pains and trouble.' Richard Bingham, the new sheriff, who endeavoured to collect under a new writ of December, ${ }_{1} 6{ }_{3} 8$, found that the corporate towns could not agree upon their rating. ${ }^{8}$ So late as 4 February, I 640, Sir John Croke, sheriff in I639, had received no money under the writ of 1637 , though he had 'sent throughout the whole county the present sheriff's schedules and warrants.' He promised to 'do his best endeavours to collect so much of these arrears as may be had,' ' but evidently was not optimistic. The 'present sheriff' of Sir John's letter was William Churchill, who began office evidently meaning to collect all arrears. ${ }^{10}$ But in spite of his most active measures, he was as unsuccessful as his predecessors in collecting a tax which the county could not possibly pay, and against which feeling was running very high. Even in I $_{3} 1$ there had been serious rioting, and the Council wrote to the Justices of Assize to use extraordinary diligence in finding and punishing 'the offenders and encouragers of certain rebellions rather than riots lately committed on their circuit,' His Majesty charging them to proceed against the delinquents with all severity." Matters had not been improved by further vexatious illegalities, the tax of $6 d$. per $12 \mathrm{lb}$. on all the hard soap made in the county, ${ }^{12}$ and the close monopoly of this manufacture, the obligation imposed in $16{ }_{3} 6$ on every alehouse-keeper to become bound in $\oint_{2} 20$ not to dress any venison, red or fallow, or any hares, pheasants, partridges, or heath pout, ${ }^{13}$ and the abuses in the collection of the ship-money itself, the common report being that nearly $\oint_{0} \mathrm{I}, 000$ more was collected than was actually required. ${ }^{13}$

\footnotetext{
${ }^{1}$ Dorch. Corp. MSS. C. 9 .

3 Ibid. 4 Ig.

${ }^{6}$ Ibid. 504.
${ }^{8}$ Ibid. 1639, p. 17. See also Dorch. Corp. MSS. 'Minute Book of Council Meetings,' 22 Јал. 1639.

${ }^{9}$ Cal. S.P. Dom. $1639-40$, p. 426.

13 Ibid. 1637-S, p. 292.
'Ca. S.P. Dom. $1636-7$, p. 151.
Ibid. 542 Ibid. 1637, p. 400.
Ibid. $150-1$, and ibid. $1637-8$, p. 169 .
10 Ibid. $+5 i+, 556$.
13 Ibid. $1635-6$, p. 247.
11 Ibid. 1631-3, p. 107
"Ibid. I $63 \%$, p. +19 . If $S$
} 


\section{POLITICAL HISTORY}

Resistance by $\mathrm{r} 640$ had come to a head. The goods distrained yielded no money, for want of buyers. When there came buyers, the sale was a farce, and could not be proceeded with. Offers of $7 d$. and $9 d$. were made for an ox worth $f_{0} 8{ }^{1}$ The people also rescued their goods when distrained, beating off the bailiffs with bills and stones. Of $f_{0} 6,000$ the sheriff could, in half a year, get but $£_{3} 300$ from the entire county. ${ }^{2}$ One specimen of procedure will suffice : sending his servants to levy $\oint_{5} 5 \mathrm{r} 2 \mathrm{~s}$. $4 d$. on the goods of Lady Anne Ashley, on her farm at Martinstown, William Churchill, the sheriff, found that her servants, William and Roger Samways, came with violence and rescued two of her horses which had been seized. Two days later, Lady Anne having horses at Dorchester, the sheriff's servants endeavoured to distrain them, but William Samways again violently rescued them, saying that Denzil Holles (M.P. for the shire, and son-in-law to the lady) would bear them out in what they had done. 'The places and parishes adjacent take notice of these attempts, and by this evil example, many will be drawn away and presume to do the like.' ${ }^{3}$

At length even the civil authorities openly set their faces against the levy of the money. In 1640 none of the mayors of corporate towns had paid in anything at all five months after the issue of the writ," and the constables and bailiffs themselves refused, in many cases, to distrain. The Dorset troop in Yorkshire broke into something very like mutiny, and Sir Jacob Astley was obliged to court-martial and shoot one of the men. ${ }^{\circ}$

Poole has been called the head quarters of the Parliamentary cause in Dorset, ${ }^{\circ}$ but Clarendon says that there was no place in England more zealously Presbyterian than Dorchester. ${ }^{7}$ The citizens of the latter were stirred by the teaching and example of John White, ${ }^{8}$ rector of Holy Trinity parish, a man of powerful mind and personality. From having been a moderate Puritan, he became an ardent Covenanter, probably in consequence of the petty persecution to which he was subjected by the Court of High Commission. In 1632 a high churchman wrote of him, 'Good men are shy of this man in places where he is most and best known.' ${ }^{\circ}$ In I635 his letters and papers were seized, probably in his study, ${ }^{10}$ and on $10 \mathrm{No}$ vember, he appeared before the Court and took the oath to answer the articles against him. ${ }^{11}$ He was several times remanded for the 'insufficiency of his answers,' and incurred a rebuke for his non-observance of Good Friday. ${ }^{12} \mathrm{He}$ had already shown the tendency of his mind by promoting and organizing the settlement of New Dorchester, near Boston, Mass. The Calvin of Dorchester, in November, 1640, he took the Covenant himself, and induced many of his fellow-townsmen to follow his example. In his zeal for the Puritan cause he was emulated by his friend and rival, Ezra Benn, who became with him during the Commonwealth one of the 'Triers' for examining ${ }^{13}$ the qualifications of candidates for the cure of souls. Sir Robert

\footnotetext{
${ }^{1}$ Cal. S.P. Dom. I639-40, p. 24 I, and ibid. 1640, p. 599.

${ }^{3}$ Ibid. p. 536.

${ }^{6}$ Hutchins, Dorset, i, 8-10.

Ibid.

2 Ibid. I 640, pp. 599, 551 .

7 Hist. of the Rebellion, iv, 201 .

${ }^{8}$ Hutchins, op. cit. ii, 375,376 ; Athen. Oxon. ii, I I 4, I I 5 .

${ }^{9}$ Cal. S.P. Dom. I631-3, p. $402 . \quad{ }^{10}$ Ibid. I635-6, p. 79.

"Ibid. p. 108.

12 Ibid. pp. I I 6, $125,470,503,512,513$.

${ }^{13}$ Minute Bks. Dorset Standing Committee (ed. Mayo), p. xi. Dorch. Corp. MSS.
} 


\section{A HISTORY OF DORSET}

Foster, now the only Justice of Assize for the Western Circuit, ${ }^{1}$ was warned of the trend of local feeling by Lord Hertford: 'I find that many of the gentlemen and others of this county that stand well affected to the king's service . . . are very apprehensive what may pass at this your assizes, few of them will adventure themselves into that town, being at present in such a posture of war.' $\quad$ The report of Sir Robert himself, when he came into the west, was that 'the most appearance of arms was at Exeter and Dorchester.' 3 The town ${ }^{3}$ was the rendezvous for many volunteers of the Parliament. In February, 1642-3, many came to Dorchester for the great enrolment of that month, the townsmen supplementing any shortage in their accoutrements." The other Dorset towns did not thus' prepare themselves from the very first to take an active part in hostilities. Nevertheless the sympathies of Lyme, Poole, and Weymouth were always with the Parliament. And though each in turn was later occupied by the king's troops, yet each made a more gallant show than the county town. In smaller towns, where the influence of the territorial magnate was greater than the development of self-government, the tendency was to take as little part as possible in the war. Wareham alone, dominated by the influence of Corfe Castle, ${ }^{6}$ firmly held out for the king.

The importance of Dorset in the Civil War arose from its geographical position. It lay between the Royalist strongholds of the south-west and of Oxford. While the towns of Somerset were Parliamentarian, the fortresses of Sherborne and Corfe afforded keys respectively to the northern and southern communications with the west. On the other hand the sea-board towns, with their excellent harbours and proximity to the French coast, were of untold importance in the Royalist communications with their continental friends and helpers. Hence, while the county never saw any first-class engagement, its importance, both military and naval, never ceased during the whole war.

The first move in Dorset came from Lord Hertford, who threw himself into Sherborne Castle immediately upon the outbreak of war. ${ }^{7}$ This delayed the occupation of the towns by the local Parliamentary captains, Denzil Holles (M.P. for Dorchester) and Sir Walter Erle (D.L. of the county). Under the Earl of Bedford, they besieged the castle with 7,000 foot, but were dispirited by the vigorous and constant sallies of Lord Hertford, and the mutiny and desertion of the trained bands, ${ }^{8}$ who were deliberately disbanded by the sheriff of Dorset, ${ }^{9}$ Sir Anthony Ashley Cooper, a man, according to Lord Hertford, 'so loyal and affectionate for His Majesty's service.' ${ }^{\prime}$ Lord Bedford, unable to continue the siege, retired to Yeovil

${ }^{1}$ Cal. S.P. Dom. 1641-3, p. 364 ; Docquets of Letsers Patens (Rec. Com.), 10.

Cal. S.P. Dom. $16+1-3$, p. 37 1.

' 'The magazine from whence the other places were supplied with principles of rebellion,' Clarendon, Hist. of the Rebellion, iv, 213.

${ }^{3}$ Dorch. Corp. MSS. printed, Hutchins, op. cit. ii, 242.

- On the death s. p. of William, nephew and heir of Sir Chris. Hatton, his widow married Sir Edw. Coke. Their only child Frances married John Villiers, brother to the Duke of Buckingham, and created $V$ iscount Purbeck. Lords' Rep. on Dignity of a Peer, 45. On Coke's death, Lady Coke and her daughter sold the castie to Sir Jn. Bankes, of a Cumberland family, Attorney-General 1635, Chief Justice of Com. Pleas, 16 to.

"Docquets of Letters Patcmt (Rec. Com.), 27, 28.

${ }^{6}$ Hist. MSS. Com. Rep. x, pt. i, vi, 147 . Exceding Joyful News, 6 Sept. 1642.

- Dorch. Corp. MSS. B. $2 \$ b$.

${ }_{10}$ Cal. S.P. Dom. $1641-3$, p. 369 . 


\section{POLITICAL HISTORY}

before a small force under Sir Ralph Hopton and Colonel Digby. ${ }^{.}$Sherborne however, soon fell into the hands ${ }^{8}$ of the Parliament; for Lord Hertford, who feared Lord Brook ${ }^{3}$ was about to join Lord Bedford, and learning of the capitulation of Portsmouth (7 September), which gave all the south into the hands of the Parliament, abandoned the castle, and crossed from Minehead into Wales. The castle was not slighted, owing to the spirited conduct of Lady Digby, Bedford's sister, who swore to him that if he destroyed it she would die with it."

All through that winter and spring (1642-3), when Hopton, from his Cornish base, was gaining successes in Devon, Charles making headway in the midlands, and the Parliament gradually garrisoning the towns of Somerset, Dorset was still unattached to the national campaign. With Stamford's defeat by Hopton in May at Stratton (co. Devon) Waller was ordered to proceed against the Royalist army of the south-west. This he attempted by way of Hereford. But as a counter move (I 9 May) Hertford and Prince Maurice left Oxford for Salisbury to join hands with Hopton in Devon. Early in June the two forces met at Chard. Waller was now at Bath, and, after his defeat at Roundway Down, Bristol surrendered to the victorious Royalist cavalry (26 July). This changed the fate of the Dorset towns. Hitherto Dorchester, Lyme, Weymouth, Melcombe, and Poole had been occupied by local Parliamentary troops, under Sir Walter Erle and Sir Thomas Trenchard; and Portland and Wareham ${ }^{6}$ being now garrisoned by the Parliament, ${ }^{b}$ Corfe alone remained to the king. Two minor Parliamentary successes in February were the defeat of Lord Inchiquin's Irish regiment by the garrisons of Poole and Wareham, ${ }^{7}$ and the capture near Dorchester of one of Rupert's convoys with $£_{3}, 000$ ' to be sent into his own country." ${ }^{8}$ These had emboldened Erle and Trenchard to sit down before Corfe, defended by Lady Bankes. In spite of the ingenious 'filling their men with strong waters even to madnesse' ${ }^{9}$ they failed to inspire in them sufficient berserk courage to storm the castle. Erle (who had, on that occasion, "like Caesar been the only man that came sober to the assault, lest he should be valiant against his will') found the presence of Prince Maurice's army in Blandford, in June, enough for his fears. He departed, leaving Trenchard and Sydenham to continue the siege. The capitulation of Bristol, however, meant the king's success in Dorset. Prince Maurice sent on Lord Carnarvon to summon the Dorset towns; Dorchester, Weymouth, and Portland ${ }^{10}$ surrendered at once, without a blow struck, Strode having told in Dorchester horrid tales of the valour of the Royalist soldiers. ${ }^{11}$ Freedom from plunder was one of the conditions of capitulation. But Maurice on his arrival from Bristol with his foot and cannon, did not respect the agreement entered into by Carnarvon. John White suffered severely by this cavalier

1 Vicars, Parl. Chron. 146-9.

- It was not garrisoned by them till 20 April, 1643 . Vicars, op. cit. ii, 302-4.

${ }^{3}$ See Docquets of Letiers Potent (Rec. Com.), 395.

- Vicars, op. cit. 146-302.

'Which had been fortified for the Parliament in March, $16_{42}$, but had soon fallen into the king's hands. Vicars, op. cit. 81,82 ; Whitelocke, Memoriols, 74 .

${ }^{6}$ Rushworth, Collections, iii (ii), 684 .

- Vicars, op. cit. 3 .

Whitelocke, op. cit. 79.

'Mercurius Rusticus, 20 July, 1643.

10 'A place not enough understood, but of wonderful importance.' Clarendon, Hist. of the Rebellion, iv, 2 I 3.

${ }^{11}$ Clarendon, op. cit. iv, 211-12; Tanner MSS. 62, fol. 218. Erle to Lenthall. 


\section{A HISTORY OF DORSET}

looting, losing the whole of his library, as a revenge for his zeal in the popular cause. ${ }^{\text {t }}$

All Dorset, except Lyme and Poole, was now in the king's hands; and had not Lord Carnarvon, stung in his honourable pride, retired to the king, the Prince would have been compelled to follow up these victories. But 'staying too long at Dorchester and Weymouth, he summoned Poole, which returned so peremptory an answer, that he declined to attack it.' 2 Waller, who had now been made general in the west to oppose Prince Maurice, began to take measures for its defence. ${ }^{3}$ But the king's forces in the west were affected by the unfortunate disputes of Rupert and Hertford over the capitulation of Bristol, and of Maurice and Carnarvon over that of Dorchester. These, and the presence of the Parliamentary garrison at Plymouth, caused the abandonment of the advance on London. Maurice, leaving Poole untouched, was detailed to turn his attention to Exeter and Plymouth. The capitulation of Exeter (4 September) and the surrender, a few days previously, of Barnstaple and Bideford, had increased the importance of the two Dorset garrisons remaining in Parliamentary hands. In the autumn Poole Harbour was occupied by Lord Warwick, their admiral. But the former losses, together with that of Dartmouth (October I6) and the consequent danger to Plymouth, had the unlooked-for effect of forcing a reconciliation between Essex and Waller, the latter of whom was charged, at this crisis, with the raising of a western force."

The outcome of the summer's negotiations in English troops from Ireland landed at Minehead and Bristol, and the threatened landing of Irish soldiers themselves, caused a danger of a Parliamentary reaction in the southwest. Charles, with the double view of placating merchants and conveying his own despatches, established in November a weekly passage between Weymouth and Cherbourg. ${ }^{.}$Hopton's advance in December was checked by the Royalist defeats of Alton (20 December, I 643) and Cheriton (29 March, I 644). ${ }^{6}$

On his advance Waller immediately overran Wiltshire, and occupied Christchurch (Hants), threatening a move on Dorset. This calamity would have more than offset the capture of Wareham by Hopton on his eastward march in January, which had 'gained the king all Dorset save a sea town called Poole.' 7 But the city regiments declined to operate so far from their homes, and he, unable to advance into Dorset, had to draw back to Farnham, a reversion to the state of affairs before Cheriton.

In March ( 1644 ) Maurice, declining to join the king's main army (a necessary step to the securing of Gloucester for the king), ${ }^{8}$ blockaded Lyme

\footnotetext{
1 He was appointed one of the Assembly of Divines, I July, 16+3; see list in Masson's Life of Milson, ii, 5 I 5 .

'Vicars, op. cit. ii. 285 ; Clarendon, op. cit. iv, 213 . ' Commons Fournals, iii, 590 (15 Aug. 16+3).

4 Agostini to the Doge, $\frac{\text { Sept. } 29}{\text { Oct. }}$, Venetian Transcripts, P.R.O.

${ }^{5}$ Lord Warwick to Com ${ }^{\text {tee }}$ of Both Kingdoms. 1644 , 19 June. "Weymouth has been most serviceable to the enemy's designs and supplies of any port in England.' Cal. S.P. Dom. 1644, p. 252 . See also pp. 6 and 7.

${ }^{6}$ He had wished to secure his rear, before advancing, by the capture of the Parliamentary garrisons in Dorset and Wilts, but was overruled by Charles, anxious for his old plan of a southern advance on Sussex and Kent.

${ }^{7}$ Cal. S. P. Dom. 1644, p. 11 . The surrender of Wareham was attributed to the treachery of the captain of the watch, and was said to have been accompanied by 'divers rapes and cruelties.' Whitelocke, op. cit. 82 . But see S. R. Gardiner, Hist. Civ. War, i, vii. 'A reader has to be. . on his guard against stories of cavalier outrages, specially upon women, which are probably . . . imaginary.'

${ }^{8}$ Walker, Historical Discourses, 7.
} 


\section{POLITICAL HISTORY}

with 6,000 men. In April, by Rupert's counsel, he was formally entrusted with the suppression " of the south-western resistance. Charles having abandoned Reading and Abingdon to Essex went (3 June) to Worcester. Instead of crushing him there, Essex decided to go himself to relieve Lyme, while Waller was to pursue the king alone. ${ }^{2}$ The Committee of Both Kingdoms ordered Essex not to separate from Waller, but to send sufficient cavalry to relieve Lyme, and then to hasten to Oxford with his main army. ${ }^{3}$ This letter overtook him at Blandford. He replied that, in going to relieve Lyme, he was only carrying out their orders, which was true." $\mathrm{He}$ also pointed out that horse were no use in Lyme, and 'even if they could and should succeed. . . . I know not what my army should do without the horse the whilst, or how the horse should ever return to my foot again.' ${ }^{5}$ A day or two later, while still at Blandford with 1,300 horse and foot, he detailed Sir William Balfour to go and occupy Weymouth. On its capture by Lord Carnarvon the previous summer it had been commanded by Sir Anthony Ashley Cooper, then still a Royalist. He was high sheriff in I 643-4, and a commission from Charles to impress men in Dorset was addressed to him and to Ashburnham, who succeeded him in the governorship of Weymouth. ${ }^{6}$ Cooper's change of side took place in the early spring of I $644 ;^{7}$ on 6 March, information about him came before the Committee for Compounding. ${ }^{8}$ His reason for coming over was declared to be that 'he was fully satisfied that there was no intention of that side for promoting or preserving the Protestant religion and liberties of the kingdom.' He was a valuable recruit, having well-stocked property at Wimborne St. Giles worth $f_{0} 800$ a year. He declared that he had not made known his intention to any, and that, a month before he heard of the Declaration (which promised life and liberty to all who should come in before $6 \mathrm{March}$ ), he delivered up his commissions as sheriff of Dorset and governor of Weymouth, and was resolved to return to the Parliament. One of the committee said that he was "very cordial for the Parliament, and able to do good service by discovery of the enemy's designs and strength, and how to prepare against them, both at Poole and Wareham.' '

Upon the approach of the Parliamentary force William Ashburnham, now governor of Weymouth, garrisoned and retired into Portland Castle, alleging orders from Prince Maurice contingent upon such circumstances. Essex then himself advanced upon Weymouth, which at the request of the inhabitants he occupied (I 6 June), the Royal garrison retiring to join the Prince before Lyme. ${ }^{10}$ On the way Essex had 'delivered an elegant speech' at Dorchester, and Hugh Peters 'stirred up the town to see the miseries of the war,' and 'that God now offered them an opportunity to

${ }^{1}$ He was made Lieut.-Gen. of the South-including Dorset-in February ; Docquets of Letters Patemt, 163.

'A Dorset regiment (under Col. Sydenham) which Waller had with him was no more dependable, when far from home, than other county levies. Col. S.P. Dom. 1644, p. 220 . See also S. R. Gardiner, Hist. Gt. Civ. Wor, i, $340 ; \mathrm{ii}, 4$.

${ }^{3}$ Com. Both Kingdoms to Essex, 13 June, 16.4 ; Cal. S. P. Dom. 1644 , p. 228.

'See Committee's Letters, insisting on its relief by him; Ap. 28, May 7, 30; June 3, I I (bis) in Cal. S.P. Dom. 1644, Pp. $182-3,138,150,223,226,198$.

${ }^{5}$ Ibid. 234. ${ }^{6}$ Docquets of Letters Patent (Rec. Com.), 75.

${ }^{7}$ Christie, Life of the First Lord Shafiesbury, i, 47.

${ }^{8}$ Cal. Com. Compounding, ii, 839 . ${ }^{9}$ Ibid.

${ }^{10}$ Clarendon, op. cit. iv, 496-7; Mercurius Aulicus, 20 June, 1644; Cal. S. P. Dom. 1644, p. 270. 


\section{A HISTORY OF DORSET}

free themselves from the barbarous invaders,' which opportunity they forthwith embraced.'

Meanwhile the Royal cause was losing Lyme also. On 23 May Warwick had appeared off the town, ${ }^{2}$ to whose defence Blake, ${ }^{3}$ afterwards admiral of the Commonwealth, was heroically contributing. A few days later Warwick wrote: "the assistance of the ships saved the town ; "yet the Prince, whose operations had lately been much hampered by the bickerings of his own officers, ${ }^{6}$ was not compelled to give up the siege till I 5 June. That morning about 2 a.m. the garrison made a splendid sally. The admiral, writing to the Commissioners of the Navy about the men of Lyme, reported ' they have most valiantly defended themselves,' and the women behaved no less gallantly. ${ }^{6}$

Wareham, in spite of an attempt made upon it by Essex in June, ${ }^{7}$ held out for the king until early in August. Then Sir Anthony Ashley Cooper ${ }^{8}$ and Colonel Sydenham ${ }^{9}$ with 1,200 horse and foot stormed the outworks, whereupon the town surrendered upon articles. Most of the garrison were sent into Ireland, Lord Inchiquin ${ }^{10}$ having 'ordered his brother, Colonel O'Brien, ${ }^{11}$ to come over to his assistance, which was the occasion of so easy a surrender.'

Dorset enjoyed a temporary immunity from war in the late summer of this year (I644), during the western march of Essex, prior to his defeat at Lostwithiel (3 I August). The occupation of Weymouth in June had been followed by the presence of the admiral in Portland Roads frustrating the original plans for the queen's escape. ${ }^{12}$ The town was not without secret Royalist sympathizers, ${ }^{13}$ and the admiral laboured to make the fortifications more secure, utilizing some beginnings made by the Royalists on the Nothe peninsula. He also proposed to build a fort on 'another hill on the Weymouth side' (Jordan Hill ?), and to add 'three small bastions' to Sandsfoot Castle. ${ }^{14}$ Melcombe, he thought, 'being separated from the main by a causey only, will be sufficiently secured by a work already raised on the beach.' 15 He estimated the cost at $\oint_{0} 1,200$, and the requisite number of men at 500 , " to which, if 200 horse be added, they will not only secure these towns, but also keep the county of Dorset thereabouts in awe.' The Parliament allocated these resources for the defence of the town, the Committee of the West adding to them on their own account. By I 8 September, "the citadel is almost complete,' but 'there is still much to do.' ${ }^{16}$

${ }^{1}$ Cal. S.P. Dom. 1644 , pp. $270-1$.

Ibid. pp. $36 ;, 371$. Hugh Peters accompanied him on this naval expedition. He preached a thanksgiving sermon at Lyme on its relief.

3 ' Journal of the Siege,' printed Roberts, Hist. of Lyme Regis, 8z-9.

- Col. S.P. Dom. I644, May 30, p. 554 .

${ }^{6}$ Ibid. 535 ; Prince, Worthies of Devion, 84 .

s Ibid. 160.

${ }^{8}$ Commors foum. 10 July, $16+4$.

- Of Wynford Eagle, restored this month to the post of Governor of Weymouth, which he had held before the Royalist occupation. He was 'a gentleman of approved courage and industry, whose intention is to purge the town of all malignants'; Cal. S.P.Dom. 1644.

${ }_{10}$ Disappointed, Feb. 1644 , in not obtaining the vacant Presidency of Munster, which was given to Lord Portland, he changed sides on his return to Ireland, and fought for the Parliament.

${ }^{11}$ Made Governor on the Royalist occupation the previous January ; see Christie's Life of Shaftesbury, i, 60.

13 Cal. S. P. Dom. 1644, PP. 10, I 33, 263, 278, 309, 555 .

"Built by Henry VIII (1 539 ), when fortifying the south coast.

${ }^{13}$ Ibid. 301.

1s Cal. S. P. Dom. 1644 , Pp. 309, 310.

${ }^{16}$ Ibid. pp. $+61,489,516$. 


\section{POLITICAL HISTORY}

Charles's pursuit of Essex had been made by way of Somerset, but his return, after Lostwithiel, was through Dorset. Early in August Rupert, unable himself after Marston Moor and the surrender of York to leave his post in the north, had sent down into the west Goring, 'that double traitor, drunken, and dissolute.' The securing of Dorset against the return of the victorious Cavaliers became thus a necessity to the Parliament. Their horse, under Sir William Balfour, had escaped at Lostwithiel, and Essex himself, who had slipped away and gone by sea to Plymouth, had still some shreds of credit with the Houses. He was assured that Manchester and Waller had been ordered to march to Dorchester, to hold the ground till his own troops could be re-equipped. ${ }^{1}$ Through the intervention of Prince Maurice they were however unable immediately to effect the desired junction at Dorchester. ${ }^{2}$ But by 12 September they had joined forces. Their first step was to strengthen the port towns and 'block up Corfe Castle' by an addition of 500 men to the Wareham garrison. ${ }^{3}$ 'Then to Blandford, to endeavour the gathering of the Dorset and Wilts horse into a body.' Their position in Shaftesbury, the quarters chosen, was sufficiently insecure. The enemy were already near the county, the king expected daily, and Waller 'knew of nothing to hinder them from marching to London." He wrote from Poole (I 5 September), 'I have not one horse come to me out of this county to mount a musketeer, so that if the King advance, all I can do is to retire, before I be forced to run.' $5 \mathrm{He}$ and his colleague, Sir Arthur Hazelrigg, had in fact been misled by the lavish promises of troops made to them by the frightened people. "All the thousands we heard of . . . are now one troop of horse.' ${ }^{6}$ Among what troops he had disaffection was rife, and even desertion to the Royalists was in the air. ${ }^{7}$ This arose from the distress, amounting to absolute want, among both officers and men, from long withholding of pay due. ${ }^{8}$ A major of horse was fain to borrow sixpence of the general to get his horse shod.' Waller, writing (I 4 November) to the Committee of Both Kingdoms, begged for even a fortnight's pay for 'those poor foot . . . in Dorsetshire, which will be a great encouragement.' ${ }^{10}$

Nevertheless the Royalists were not much better off than was the Parliamentary army in East Dorset, watching their advance. So late as 29 September, Charles had got no further than Chard, and Waller reported that 'though he calls in the county, yet we cannot learn that his army increases.' II The king's march eastward was hindered, and his forces weakened, by the necessity of leaving men behind to block up the Parliamentary garrisons of Plymouth, Taunton, and Lyme, in order to safeguard his rear. ${ }^{12}$ On 30 September he left Chard, and at South Perrott met Rupert, who undertook to bring up 4,000 men from Bristol to join the army at Sherborne. ${ }^{13}$ Charles was at Sherborne from 2 October to 8 October. ${ }^{14}$ Waller

1 Lords Journ. vi, 699.

${ }^{3}$ Ibid. $423,502,506$.

3 Ibid. p. 506.

${ }^{8}$ Ibid. 124 .

Ibid.

' Cal. S. P. Dom. 1644 , pp. $477,480,482,486$.

Ibid. $489,542$.

- He himself at this time made a short expedition to Bridport (which had been held continuously for the Parliament since the beginning of the war), 'raising the posse com.' Symond's Diary, 24 Sept. 1644 (Camd. Soc.).

${ }^{18}$ Walker, Hist. Discourses, 80-8.

${ }^{19}$ Walker, op. cit. 98. Digby to Rupert, 20 Oct. 1644. Add. MSS. 18781 , fol. 297.

"Walker, op. cit. I65. 


\section{A HISTORY OF DORSET}

was forced to fall back before him, and thus to abandon the idea of making him fight at Shaftesbury, to cut him off from the garrison round Oxford. Manchester ${ }^{1}$ at Harefield (Hertfordshire) haggled incessantly, declining to join Waller at Shaftesbury, but expressing his willingness to join Essex at Newbury.

The second battle of Newbury (27 October, 1644) marks a fresh stage in the development of the war. It impressed upon the Parliament the unwisdom of trusting to local levies (which had failed as signally in Dorset as elsewhere), and it revealed the existence of the peace-party under Manchester and Holles. The ultimate overthrow of the king, even in his chosen stronghold the west, was involved in the determination to reorganize the military forces, and in the demonstration of the impossibility of compromise. The former resulted in the new model army of the following spring : the latter was the result of the private negotiations of Holles and Whitelocke with the Royalists.

The situation in Dorset in November was marked by an even division of forces. The king had Shaftesbury, Sherborne, Portland, and Corfe, while his enemies held Lyme, Weymouth and Melcombe, Dorchester, Wareham, Poole, and Bridport. Of these, Shaftesbury, dominating the vale of Blackmoor from its hill fortress, Sherborne, the as yet impregnable castle, Portland peninsula, whose guns commanded the harbours of Weymouth and West Bay, and Corfe, strong naturally and artificially, were individually the more valuable assets. Dorchester, a country town in a plain, and half surrounded by water-meadows, was, in spite of the great sums spent upon it, ${ }^{2}$ unable to withstand serious attack. Lyme and Poole ${ }^{3}$ had suffered so grievously already that, as fortifications, their value was much depreciated. But the possession of a series of coast towns, which included all the good harbours in Dorset, was of more importance to the Parliament than the maintenance of isolated fortresses, however strong. These, at best, could do no more than furnish troops to harry the immediate neighbourhood, while Lady Bankes at Corfe had no men to spare, even for this purpose, beyond the bare maintenance of her hold upon the castle." The possession of the seaports hindered communication with the queen at St. Germains, and drove a wedge between the Royalist districts of the south-west and of Hampshire.

Many gallant sallies were made this autumn ( 1644 ) by Sir Lewis Dives, step-brother of Lord Digby, and step-son of Lord Bristol, to whom Sherborne Castle belonged. In October $\mathrm{he}^{6}$ had been appointed serjeant-major-general of the king's army in Dorset, and made Sherborne his head quarters. ${ }^{\circ}$ In November the well-known Vandrusques was appointed to command the Dorset Parliamentary Horse. ${ }^{7}$ Dorchester was more than once occupied by eaci party in turn for a day or two at a time, in the course of the autumn and winter : for after the fiasco of June, I 643 , both sides had tacitly agreed

1 The House roted (2I Sept.) that Manchester and Waller should join forces against the king. Holles, M.P. for Dorchester, in vain urged that Essex should be included in this combination.

' $f_{19,000}$ was spent on the fortifications the year before; Hutchins, Dorset, ii, 343 .

3 'Poole was in great distress and scarcely tenable'; Commons Journ. App. 17 (10 June, 1644).

- Sir John Bankes died 28 Dec. 1644.

'For the frequent omission of the final 's' in Dives or Dyves see note, Gardiner, Hist. Gt. Civil W'ar, ii, 323 .

Walker, Hist. Discourses, 99.

${ }^{7}$ Cal. S.P. Dom. 1644-5, pp. 85, $113,124$. 


\section{POLITICAL HISTORY}

not to waste further money on fortifying such a weak position. There was, however, no lack of valour in the inhabitants, and particularly in the women.' The two Sydenhams were Dives's protagonists in these skirmishes : and after the governor of Poole (Major Sydenham) had defeated a troop of the queen's regiment ${ }^{2}$ near Blandford ${ }^{3}$ Sir Lewis Dives dislodged the victors from Blandford, but returning with his own men to Dorchester, was set upon at night by the rest of the Poole garrison, and 'charged through and through.'

All this winter there was talk of a Royalist 'Associated Counties,' to consist of Cornwall, Devon, Somerset, and Dorset, which should balance the Parliamentary eastern association. Prince Maurice and Lord Hopton had for months been endeavouring to mature the scheme. ${ }^{5}$ But the difficulties in the way were too great to allow of its being carried out. The hilly character of the districts chosen, and their deep inlets of the sea ${ }^{6}$ hindered alike easy communication and the growth of a common principle and sentiments. The two more eastern counties were not sufficiently stable in their attachment to the royal cause to make up for the presence of Parliamentary garrisons at Plymouth, Taunton, and Lyme. Yet Charles, reduced to catch at straws, sent down the Prince of Wales to hold court at Bristol in March.?

During the winter Goring ${ }^{8}$ had been carrying on minor operations based upon Devon and Dorset, and culminating in the siege of Taunton. Waller was ordered to relieve the town (6 November, 1644) and MajorGeneral Holborne had orders to push through Dorset towards it. In this relief column Cooper was in command of the Dorset contingent, which consisted of men drawn from the garrisons of Weymouth, Wareham, and Poole.?

News reached Westminster on 2 February, that a force under Dives and Sir Walter Hastings, governor of Portland, had seized one of the Weymouth forts, ${ }^{10}$ and on 9 February had taken the town itself. ${ }^{11}$ The rebels entrenched themselves across the river in Melcombe. Goring then came up with 3,000 horse and I,500 foot and artillery, and took over the command. Despite the strategic disadvantage of their position, the mere handful of men whom he, with characteristic insolence and carelessness, had neglected to crush, proceeded from Melcombe to retake the town of Weymouth, and force him back on Dorchester ( 25 February) with heavy loss. ${ }^{22}$ On the receipt of the original ill news from Weymouth, Waller had been ordered to its relief $;^{13}$ but owing to the mutiny of his cavalry at Leatherhead he was unable to go further. A few days later, however, Parliamentary, and indeed national, feeling was far more deeply stirred by the revelation of Glamorgan's schemes, and on the $27^{\text {th }}$ it was decided to send Cromwell himself into the west. Pending the organization of the New Model, which could not be put into

${ }^{1}$ Rushworth, Coll. iii (ii), 685. Whitelocke, op. cit. 91. Vicars, iii, 286 ; Merc. Civicus, 1x, 579-80.

- See Gardiner, op. cit. i, 326.

${ }^{3}$ Vicars, op. cit. i, 44 ; Whitelocke, op. cit. 103.

1 Perfect Diurnall, No. 71 .

${ }^{5}$ Cal. S.P. Dom. 1644, p. 49 ; Clarendon, Hist. of the Rebellion, ix, 6, 7.

' See Gardiner, Hist. Gt. Civil War, i, 7 I.

${ }^{7}$ Clarendon, Hist. of the Rebellion, ix, 6, 7 .

${ }^{8}$ Sent down into the west, Aug. I 644, vide supra. $\quad{ }^{9}$ Shaftesbury Papers (P.R.O.), ii, 46.

${ }^{10}$ Commons Foum. iv, 46 ; The True Informer, E. 269, 21 . 11 Warburton, Prince Rupert, iii, 58.

12 Clarendon, op. cit. ix, 7-9; Whitelocke, op. cit. 130 ; W. M. Harvey, Hist. of the Hundred of Wrilky, 91-94; Vicars, Burning Bush, I 8 .

${ }_{13}$ Cal. S.P. Dom. $1644-5$, pp. 306-7. 


\section{A HISTORY OF DORSET}

the field for a few weeks yet, he was ordered to join Waller, and both to march to the capture of Bristol.

All this time Goring was before Taunton. Before Cromwell came, he took the opportunity to make a dash for Waller at Shaftesbury and Gillingham. He 'beat up his quarters' twice in one week, thus costing the Parliament the palpably exaggerated loss of a thousand men. ${ }^{1}$ A slight success of Goring's over Cromwell the same month (March, I645) was also exaggerated by the Royalists till it became a defeat of some magnitude. ${ }^{2}$ Tradition of a Cromwellian skirmish lingers still at Fordington. ${ }^{3}$ The Royalists made it into a defeat of Cromwell, with all his own horse and the united forces from Taunton, Poole, and Weymouth, 4,000 in all, Goring's own numbers being put at $1,500.4$ But Goring was notoriously untrustworthy, particularly where his vanity was concerned, and even Clarendon makes but little of it. ${ }^{6} \quad$ It is true that Goring received congratulations on his victory $^{\circ}$ from Sir Francis Mackworth; but Mackworth had at this time need of his help in procuring supplies. Cromwell himself, not needing the support of exaggeration or falsehood, though he does not mention this particular skirmish, tells a different tale of a few days later: 'General Goring would not stand us, but marched away upon our appearance.'?

Waller gave up his command I 7 April ( 1645$)$, at his own earnest wish and in obedience to the Second Self-Denying Ordinance, and took his seat in the House. Early in May Goring left Somerset to join the king at Oxford. Fairfax, in command of the New Model, arrived at Blandford on the $7^{\text {th }}$, marching to the relief of Taunton. ${ }^{8} \quad$ Meanwhile Charles and Rupert marched freely out of Oxford to go north; Fairfax was sent back to besiege Oxford, and Goring went back as supreme Royalist commander in the west.

Even there the king's star was waning. After Naseby (1 3 June) it was a question how long he could continue to keep an army in the field. The reorganization of the Parliamentary forces had been but the last link in a chain which began with the resentment against plunderings of the royal troops. And in the west the summer of 1645 was memorable for the struggle between the representatives of these two forces. The New Model Army, which expressed dependence upon the professional soldier, and not the county levy, had to contend with the Clubmen, who originated in hostility to the war as it affected non-combatants. ${ }^{9}$ The movement known as that of the Clubmen was strongest in the three south-western counties of Dorset, Wilts, and Somerset. In Somerset it was not in line with the feeling in Dorset

${ }^{1}$ Clarendon, op. cit. ix.

'Merc. Aulic. 29 March, App. 11, 12, 19 : 'Mercurius Aulicus, the Oxford organ, remains untrustworthy to the end'; Gardiner, Hist. Gr. Civil War, i, p. vi.

${ }^{3}$ Moule, Old Dorset, 199. See Ludlcow Memoirs (ed. Firth), i, $47 \mathrm{I}$.

- Goring to Culpepper, 30 March, 1645 , gives the same figures. Clarendon MSS. No. 1856 . The account in Mercurius Aulicus is taken in tots from this letter.

${ }^{3}$ Hist. of the Rebelion, $\mathrm{v}, 143$ (ed. 1826 ).

'Cromvell's Letters (ed. 1888 ). Letter xix, izo. See also Carte, Ormonde Papers, i, 79; Commons Journ. 9 April, 1645 ; Whitelocke, op. cit. $411-12$; Cal. S.P. Dom. 1644-5, pp. 376, $384,393$.

8 'The state of Dorset when H.E. Sir Thomas Fairfax marched forth. The king had Portland Castle and Island, Corfe Castle and Sherborne Castle. The Parliament had the port towns of Poole, Lyme, and Weymouth.' Sprigge, Anglia Rediviva, xii, 16, 17.

- For the presence of foreign mercenaries in Dorset among the rojal troops, see Clarendon MSS. 1738 (4); Whitelocke, Memoirs, 171 ; Cal. S.P. Dom. $16+3,2+$ Nov.; Merc. Aulic. 3 Oct. 16+4. A Copie of the King's Message, 1644 (printed by the Dorset Standing Committee, and obviously unfair). For similar evils from the other side see the admissions of Essex in Cal. S.P. Dom. 1642, P. 402, and ibid. 1644, P. 335. 


\section{POLITICAL HISTORY}

and Wilts. ${ }^{1}$ In Dorset it was serious and widespreading; although it had seen no pitched battle of importance, the county had borne the brunt of the war, being constantly occupied by both parties ${ }^{2}$; and many marches to or from Devon were deflected into the county owing to the necessity of attacking or preserving communication with its seaports. Determination to declare neutrality and support it by force of arms was thus the original and ostensible cause of the rise of this third party. One of their banners bore the words :

\section{If you offer to plunder, or take our cattel, Be assured we will bid you battel.}

The regulations which they drew up to govern their own conduct ${ }^{4}$ show that the rank and file of the Clubmen were simple unlettered countrymen; but their leaders were not of the same stamp. They fall into two classes. The typical 'younger brother out of means,' ${ }^{, 6}$ with everything to win and nothing to lose, was drawn for the most part from a social stratum between that of the gentry, who were mainly Royalist, and the shop-keeping classes. The latter, having a shrewd political judgement, and a financial stake in the county, yet little sense of family, tended towards Parliamentarianism. There were also present certain avowedly Royalist divines, ${ }^{6}$ who, among an uneducated rabble, would necessarily have some authority. But though the bona fides of the mass of Clubmen was undoubted, their aim was higher than to enforce the neutrality of certain districts. They wished to 'give a law to either side," 7 and desired that the garrisons of Dorset and Wiltshire should be put into their hands 'till the King and Parliament agreed about their disposal.' They further sent a petition to the king ${ }^{8}$ begging him to 'lend his most favourable ear' to renewed peace proposals, when he should be invited thereto by both Houses, 'for which Proposalls the Petitioners have made their addresses unto them.'

Such a force was, however, bound to become the tool of one of the existing parties. Circumstances contributed early to throw the Dorset and Wiltshire Clubmen into the arms of the Royalists.

In Dorset there was no Royalist army under Goring to plunder the homesteads of the people : and the garrisons, being commanded by the gentry of the county, . . . were not likely to commit outrages, as long as the contributions for their support were regularly paid. ${ }^{9}$

The initial vague tolerance of the Parliament ${ }^{10}$ was outweighed by a disastrous affray at Sturminster Newton (29 June, I645) with Massey's men, and by the encouragement of the immediate advisers of the king. ${ }^{.1}$ In July the Clubmen made a hostile attack on the garrison of Lyme. ${ }^{12}$ On Fairfax's arrival at Dorchester (3 July) with the New Model, after Naseby, ${ }^{13}$ he was met by a ii, $264-5$.

${ }^{1}$ See Clarendon MSS. 1894, and Perfect Occurrences, 30 June, 1645; also Gardiner, Hist. Gt. Civil War,

2 'The Humble Petition of the Inhabitants of Dorset . . 8 July, 1645.' Oxford, 1645 .

${ }^{3}$ Sprigge, Anglia Rediviva, 89.

' 'The Desires and Resolutions of the Clubmen of the Counties of Dorset and Wilts'; B.M. King's Pamphlets, $102,47$.

5 'A List of the Country Gentlemen called the Leaders of the Clubmen for Dorset,' $16+5$.

${ }^{6}$ Sprigge, Anglia Rediviva, 64.

8 'The Humble Petition,' \&c. vide supra.

${ }^{9}$ Gardiner, Hist. Gt. Civil War, ii, 305.

"Clarendon, op. cit. v, 196-7, 199; Sprigge, op. cit. 63, 90.

12 Whitelocke, Memorials, 131 , and ii, 156. ${ }^{7}$ Ibid. 65.

${ }^{10}$ Sprigge, Anglia Rediviva, 7.

${ }^{13}$ Sprigge, op. cit. xi. 


\section{A HISTORY OF DORSET}

menacing deputation of Clubmen, and also by Colonel Sydenham, governor of Weymouth, with urgent accounts of the danger from 'these club risers.' Fairfax himself considered them, in spite of their ostensible neutrality, inclined to Royalism." Next day Fairfax, at Beaminster (burned 'by Prince Maurice, by reason of a falling out between the French and Cornish'), ${ }^{3}$ heard that Goring had finally abandoned the siege of Taunton. On the Ioth Fairfax routed him at Langport, and on the 23 rd Bridgwater surrendered. The Parliamentary forces in Dorset had now only to reduce Sherborne Castle and disperse the Clubmen, for Corfe, now as ever, remained outside the general campaign. Till this was done, however, the army could not with safety turn to the conquest of the districts west of the Parret. At a council of war (25 July) it was decided to begin both operations at once." On Friday, I, and Saturday, 2 August, Cromwell and Fairfax together viewed the castle and its defences. At the second inspection they 'conceived the place might shortly be reduced.' The siege was begun, but it was decided not to attempt assault till after the reduction of the Clubmen. These, hearing of the strict blockade of their ally, who had with him his own regiment, I 50 veterans, and some horse, assembled in force that Saturday, 2 August, at Shaftesbury, intending to drive off Cromwell and Fairfax. ${ }^{5}$ Having information of their meeting places, Cromwell sent Fleetwood with I, 000 horse to surround the town. About fifty of the leaders were captured." On the following Monday Cromwell marched himself towards Shaftesbury, no doubt to intercept that body of Clubmen whose appointed meeting at Sutton Waldron had been accidentally revealed to him. ${ }^{7}$ His scouts discovered a party encamped on Duncliff Hill, a place "full of wood and almost inaccessible." ${ }^{8}$ Resolving not to hazard men under such conditions, he sent word to parley. He went himself up the hill alone, and pointing out the error of their ways, ended by a successful appeal to their pockets. They were either convinced by his arguments or dismayed by his firmness, for they dispersed and went quietly to their homes. ' The next day he found a further and more formidable force of about 4,000 entrenched in an 'old Romane work' on Hambledon Hill, near Shroton (Iwerne Courtney). Again he attempted parley, but through the determined action of $\mathrm{Mr}$. Bravell, minister of Compton, ${ }^{10}$ who said 'he would pistoll them that gave back,' they refused a peaceful settlement. They repulsed a direct charge; but, Desborough taking them in the rear, some fled, many were made prisoners. These were quartered that night in the church at Shroton, and Cromwell, who tried his eloquence upon them, 'made them confess they saw themselves misled.'

1 Sprigge, op. cit. 62.

Ludlow, Memoirs, i, 473-4.

Sprigge, op. cit. 66-7. Its rebuilding was ordered to be paid for out of the estate of George Penny, a recusant of Toller, 9 Jan. $16+6$. Minute Bks. of Dorset Standing Com. 140, 271 (ed. Mayo). "The Dorset Committee is the only County Committee whose records are now available.' Gardiner, Hist. Gr. Civil War, iii, 200. 'Sprigge, Ang. Rediv. 83.

'Sprigge, op. cit. 86. 'A List of the Country Gentlemen,' \&c.

7 See the letter to Col. Bingham, printed Hutchins, i, I 3 .

- Sprigge, op. cit. 86-7 ; Cromwell's Letters (ed. 18+6), p. 141 ; Whitelocke, Memorials, 159.

${ }^{10}$ Whom Sprigge calls the leader of the movement. Toble of the Morion of the Army. He was sequestrated for joining the Clubmen, but was later restored (Triers : J. White, W. Benn, Symon Forde) on submission to the 'discipline of the Church of England as it is established.' See Mir. Bks. of Dorset Stonding Commitree, I I, 19, 45, 58, 220, 232 .

"Sprigge, op. cit. 88 ; Carlyle, Cromuell's Letter, $2 x x$. 'Two Great Victories.' 'Two Letters.' 'The Proceedings of the Army.' 


\section{POLITICAL HISTORY}

Cannon from Portsmouth and miners from Mendip set to work on the I 2 th, and by the 15 th forced Dives to surrender Sherborne Castle. It was an irreparable loss to Charles, for with it he lost many officers, gentlemen, and soldiers, valuable artillery and arms, and many important papers, which, immediately published by the Parliament, did much harm to his cause. ${ }^{2}$ In October the castle was utterly demolished.

The fall of Sherborne gave to the Parliamentary generals the command of the North Dorset route to the west; and with Bristol (surrendered I I September) it completed the chain of fortresses from the Channel to the Severn which hemmed in the king's Devon and Cornish forces, rendering them valueless through inability to co-operate with those of the Oxfordshire district. So far as the south-west was concerned, the strategy of the winter of $1645-6$ depended on this cordon drawn from Bristol to Lyme. The siege and fall of Corfe Castle was no integral part of these operations. But the grandeur of Lady Bankes's resistance and the pathos of her surrender have given to the episode a prominence disproportionate with its historical setting. In June (I645), after the receipt of the news of Naseby, Captain Butler, governor of Wareham, had straitened the siege. A month earlier Cooper had been ordered to 'sufficiently block it up' with a force drawn from the garrisons of Poole, Wareham, Lulworth, and Weymouth. ${ }^{2}$ Three of the signatories of this document are Dorset men: Denis Bond, Denzil Holles, and Thomas Erle. But Cooper's own opinion of the right method of dealing with the fortress had been strongly expressed the previous November: 'A few foot in Lulworth with a troop of horse will keep Corfe far better than Wareham. ' ${ }^{3}$ In September a party of horse from Oxford made an unsuccessful attempt at relief." In October, Bingham, governor of Poole, drew the blockade closer, and in December he was reinforced by 400 men from Fairfax, ${ }^{6}$ now engaged in the subjugation of Devon and Cornwall. The garrison at Chichester, commanded by Algernon Sidney, contributed Ioo foot to the siege in February, and on the Ioth Pitman, one of the officers of the garrison who had formerly served under Lord Inchiquin, offered to betray the castle to the Parliament. The offer was accepted, and the castle was taken, by this treachery, 26 February. ${ }^{7} \quad$ Sprigge gives forty-eight days as the length of this second siege, and puts Lady Bankes's losses at eleven killed. ${ }^{8}$ The castle was deliberately slighted on its capture. ${ }^{9}$

After the Battle of Worcester and the well-known episode in the oak tree, Prince Charles came to Colonel Wyndham's house in South Somerset. Here he remained some while in hiding, hoping to effect an escape by one of the Dorset ports. Sir John Strangways of Melbury and his son both attempted, but in vain, to arrange for the escape of the royal fugitive. At length Colonel Wyndham managed to prepare all for the Prince's departure from Charmouth. The plan, however, miscarried through the aroused

${ }^{1}$ Sprigge, Table of the Motion of the Army, and Ang. Rediv. 75-6; Whitelocke, op. cit. 152-3; Vicurs, iii, 255, 257-9; Rushworth, op. cit. iv, i, 59, 64, 77-8, 82, 88 .

${ }^{2}$ Cal. S.P. Dom. 1645 .

3 Christie, Shaftesbury, i, 70

'Ludlow, Memoirs, i, I31 ; Sprigge, op. cit. 188, 194 ; Whitelocke, op. cit. i, 571 , 580.

'Cal. S.P. Dom. 1645-7, Pp. 1 $80,281,269,319$.

${ }^{8}$ Table of the Motion of the Army.
${ }^{7}$ Vicars, op. cit. $4,372-3$.
Engl. Towns and Districts, 149 . Mr. Frecman apparently imagines the havoc wrought on the building

${ }^{6}$ Ibid. 348 . to have been entirely due to siege operations. 


\section{A HISTORY OF DORSET}

suspicions of the wife of the sailing-master upon whom all depended. The Prince and Wyndham spent an anxious night at Charmouth, and got safely away in the morning, owing to the dilatoriness of the parson Bartholomew Wesley, ', great-great-grandfather of John Wesley. From Charmouth they rode to Bridport (a juurney said to be commemorated in the local field-name 'Girtups') and thence on to Broadwindsor. Here they took shelter with a Royalist inn-keeper and his wife. Forty Parliamentarian troopers came to quarter in the very inn where they were, but while these slept the fugitives got away to Trent. Thence Charles went to Salisbury, and so after many adventures to the continent. ${ }^{2}$

The Royalist rising in the west in 1655 was not joined by any very large body of Dorset men. On the other hand, there can be no doubt that an appreciable Royalist sentiment did exist at that time in north-east Dorset, stimulated probably by dislike of existing militarism. On Sunday, I I March, I654-5, I00 men, under the leadership of Sir Joseph Wagstaffe, Colonel John Penruddock, and Mr. Hugh Grove, met at Clarendon Park, 3 miles from Salisbury. The leaders were all Wiltshire men, though Penruddock's mother was the daughter of John Freke of Iwerne Courtney and Melcombe, a well-known Dorset family. From Clarendon Park they rode to Blandford, where they were joined by eighty more men. Having vainly waited for further reinforcements, the whole force, now numbering nearly two hundred, rode back to Salisbury, and early on the Monday morning occupied the town, seizing the judges in their beds, for the western assizes were then on. Penruddock proclaimed Charles II. Again failing to attract recruits, they decided to make for Devon and Cornwall, hoping to get shelter with their friends, or at the worst to escape by sea. They took the road through Downton to Blandford, which they reached on Monday afternoon. Here

Penruddocke forced the crier to go to the Market Cross, to proclaim Charles Stuart King, who made 'Ho Yes' four times, but still when Penruddock (who dictated to him) said Charles II King, he the crier stopped, and said he could not say that word, and he was every time much beaten by them and yet told them they might kill him, but he could not say that word, though they should call for faggots and burn him presently; his constancy and faithfulness is taken notice of. ${ }^{3}$

From Blandford they rode to Sherborne, where they stayed two hours, and then to Babylon Hill, east of Yeovil ; they entered Yeovil at I p.m. on Tuesday. Going by Cullompton, Io miles only from Exeter, they were attacked by Crook at South Molton with a detachment of the Exeter garrison. Thinned in numbers, and disheartened, after some stand they surrendered, late on the Wednesday evening."

By Friday, the I6th, the indefatigable Desborough, major-general of the western counties, had arrived at Shaftesbury. He garrisoned Bridport to prevent escape, ${ }^{5}$ and wrote at once to the sheriffs of the five counties to appre-

${ }^{1}$ Gentleman's Mag. 1x, 427 .

${ }^{2}$ See Hutchins, ii, 2 is. The Boscobel Tracts, ed. J. Hughes $(1857)$. W. Wilson, Life and Times of Daniel Defoe, i, 112. Pulman, The Book of the Axe, 212 (4th. ed.). Proc. Dors. Field Club, viii, 9-28. Nous and Queries for Som. and Dors., i, 80, 136-7; iii, 306 ; iv, 6 ; v, $150,216$.

${ }^{3}$ Perfect Proceedings, 29 March to 6 April, $1654-5$.

- See the account in Wilts. Arch. Mog. xxxviii, 135, sqq. W. W. Ravenhill.

'Thurloe Papers, iii, 263. 


\section{POLITICAL HISTORY}

hend all suspicious persons, and to the justices of the peace to make diligent inquiries what persons had been absent from their habitations within the space of ten days past. He sent to Cromwell, a few days later, from Taunton, a list of the prisoners. ${ }^{1}$ Out of a total of 109 names twenty-four came from Dorset. Nineteen of these were imprisoned at Exeter, and five at Taunton. Only three 'gentlemen' appear in the list, namely Thomas Fitzjames of 'Henley' (Sixpenny Handley), James Huish of Kimmeridge, and Oxenbridge Fowell of Cerne Abbas. The rest are a very representative list of tradesmen (two clothiers, a tailor, a tanner, two weavers, a tapster, a miller, a cooper, two feltmakers, a baker, a chapman, and a currier), with a gardener, three husbandmen, and a warrener.

The spring circuit had been interrupted at Salisbury. The assizes were to have been held at Dorchester 15 March. It appears that they were omitted altogether that spring; but the prisoners were proceeded against by a regular commission of oyer and terminer, and by no extraordinary court. The court was to sit at New Sarum I I April, at Exeter on the i 8 th, and at Chard on the 23 rd. ${ }^{2}$ Some of the commissioners and the Attorney-General did go to Dorchester, but it was merely to rest over Sunday on their way to Exeter. On the return journey they stopped at Chard, and returned thence to London. Practically all the prisoners came from north-east Dorset, mostly from the Blandford and Sherborne district. One, however, came from Kimmeridge, and one from Cerne Abbas. St. Loe, though wrongly described in the indictment as of Salisbury, was a Dorset man. He had been taken up to London at once on his capture. On his examination ${ }^{3}$ he implicated also Captain Twyne, who lived near Blandford, and Captain Kirles of Woodyates. Arthur Collens of the Isle of Purbeck, who had been servant to Sir Joseph Wagstaffe, was also examined in London." The Attorney-General was Edmund Prideaux, member for Lyme, and a friend of Ludlow's. The first junior counsel for the Government was Roger, who had been member for Bridport in 1645 . Of the Dorset prisoners tried at Salisbury William Willoughby was the most interesting. ${ }^{5}$ An old man, he had had no hand in the plot, such as it was; but friendship had caused him to try to rescue one of the Royalists, and he was apprehended with the rest.

After the trials at Salisbury, the court, on its way to Exeter, stopped at Dorchester, spending Sunday, I 5 April, there. Prideaux wrote to Thurloe that day: 'I will give you a little account of some passages this day at church. Mr. Gower in his prayer after sermon blessed God for suppressing these people, and prayed the Lord to direct the judges that justice might be done. Mr. Bence (Benn?) in his prayers in the afternoon said that a treason was plotted, but blessed the Lord that nothing came to execution but the traitors.' ${ }^{\prime}$

The Dorset prisoners tried at Exeter were Thomas Fitzjames of Handley, and Robert Harris of Blandford, who were pronounced guilty by verdict; William Wake of Blandford, Charles Haviland of Langton, and Nicholas (Richard?) Broadgate of Blandford Forum all three confessed to the

\footnotetext{
${ }^{1}$ Wilts. Arch. Mag. xxxviii, 139.

${ }^{3}$ Thurloe Papers, iii, 314 . Wilts. Aich. Mag. xxxviii, 147.

- Perfect Diurnall, 26 March to 2 April, 1654-5.

${ }^{5}$ Coker's Visitation of Dorset (Harl. Soc.), xx, 99, 100.

${ }^{3}$ Cal. S.P. Dom. 1655, Pp. 90, 91, 97, $112,114$. 


\section{A HISTORY OF DORSET}

fact upon their arraignment. All five were condemned to death. ${ }^{1}$ Various persons sympathetic to the rebellion were examined at Maiden Newton in July. Apparently there had been some vague idea of seizing the town of Poole, for in May the justices of the peace were ordered to take bail of such as were taken upon this design. ${ }^{3}$ The finances of the Monthly Assessment Commissioner were thrown into confusion by the seizure, during the insurrection, of $\oint_{1} 2$ assessment money from Blandford, Sherborne, and other places."

There is ample material for ascertaining the working of the civil administration during this period, for the minute books of the Dorset Standing Committee have now been printed." They are the only records of such a county committee now available. The committee grew out of the ordinance of 3 I May, I 643, for the appointment of county committees to sequestrate the estates of delinquents. It was placed upon a working basis and its powvers defined I 9 August, I 643. Since the preceding March it had had a more or less informal existence, its sole object having then been to raise money. ${ }^{6}$ It consisted of seventeen members for the county, among whom were the M.P.'s for Dorchester, Lyme, and Melcombe (Denis Bond, Richard Rose, and William Sydenham), of eight members for the town and county of Poole (the mayor and seven aldermen), and of three for the town of Dorchester (the mayor and ex officio two aldermen). The committee had assessed the county in a weekly sum on 3 August. ${ }^{7}$ A month later the powers of county committees were extended by the Commons to the examination of witnesses against 'scandalous ministers' and those who had left their cures and joined the king's troops. ${ }^{8}$ The following year (I July, I644) the committee was invested with comprehensive powers. It was now empowered to administer the ordinances ${ }^{2}$ for the taking of the covenant, for the payment of fifths and twentieths, for sequestrations, for weekly assessments, and for the general maintenance of order and of freedom from plunder. Meanwhile the personnel was slightly different from that of the former committee, the Earls of Gloucester and Elgin having been added, and, while all the prominent members of the old committee had been retained, the numbers had been increased, but a few aldermen had dropped out, and Dorchester was no longer officially represented.

The Association Ordinance for the Five Western Counties was passed I 9 August, I 644; by it, to the committee of I July were added the Earls of Northumberland and Pembroke, John Lord Roberts, and Thomas Lord Bruce, and the members of Parliament for the county and for each borough. The county was assessed by the committee (I 8 October) for the relief of the army in Ireland at a weekly sum of $f_{0} 726 \mathrm{~s} .8 \mathrm{~d}$., while the contribution of Poole was fixed at I $6 s .8 \mathrm{~d}$. But by the following summer (26 August, I 645) the committee decided to put in force a weekly assessment for six months of only $f_{0} 437$ s. Iod. from the county and $f_{0} 5$ from Poole. ${ }^{10}$

"An Act for the Better Ordering and Managing the Estates of Papists and Delinquents' was passed 25 January, $1649-50$, which ${ }^{11}$ resulted in a

\footnotetext{
'W'ils. Arch. Mag. xxxviii, 255, 299.

1 Ibid. $1655-6,26$ Sept.

'Cal. S.P. Dom. 1655, p. 249.

5 By Canon Mayo.

${ }^{6}$ Scobell, Coll. of Acts and Ordinances, 1658 , xxviii ; Lords Fourn. v, 632 ; Husband, Coll. of Public Orders, 1646, p. 9. "Husband, op. cit. App. 4 .

Lords Fourn. vi, 612 ; Husband, op. cit. 514.

${ }^{10}$ Husband, op. cit. 563 .

"Ibid. 311 ; Walker, Sufferings of the Clergy, i, 74 .

"Scobell, op. cit. 101 .

slbid. 162.
} 


\section{POLITICAL HISTORY}

new sequestrating body for Dorset. This continued ${ }^{1}$ till I 4 March, I 653-4, when, in consequence of an Act of the previous February, ${ }^{2}$ one of their number, Dewy, was appointed sub-commissioner in the county. ${ }^{8}$

The functions of the committees had been varied. They included the seizing and scheduling of the real and personal estates of delinquents, the control over payments made by the treasurer of the county, the grant of compensation for damages, assessment and rating of obligations, and the alteration of such assessments. The committee also administered the National Covenant, and gave probate of wills. It controlled the county levies, and in 1647 (6 May) disbanded the county troop, raising two new troops of horse in 1648 (6 July), ${ }^{4}$ and disbanding them again in November. ${ }^{5}$ The committee had complete control of ecclesiastical affairs, administering the directory, examining into the delinquency of incumbents (an office delegated for convenience to certain unofficial sub-committees of 'Triers'), filling the places of sequestered clergy, and administering ${ }^{6}$ not only the benefices and the schools, but concerning themselves with details of appointments of parish clerks, repair of the churches and parsonages, and storage of the church keys.

In May, I66o, an address of congratulation to the king on his Restoration, 'numerously signed,' was sent from Dorset. ${ }^{7}$ But almost immediately signs of the old spirit began to come to light. These were invariably connected with the religious question. In February, I66 I, John Wesley (great-grandfather of the famous Methodist), vicar of Winterborne Whitchurch, was informed against for 'diabolically railing against the late king and his posterity, and praising Cromwell.' ${ }^{8}$ The three deputy lieutenants of Dorset and Somerset had by this time 'just cause of suspicion of a general disturbance,' and feared lest the disaffected should assist one another. ${ }^{9}$ Walter Stone of Sherborne prophesied a rising before November, and said that though only fifty of that town were in the plot the old soldiers would join. ${ }^{10}$ Next year 'the sectaries boast that they shall have their day soon, a rising in Somerset and Dorset is daily expected.' 11 The severities of the Clarendon Code, however, reduced the malcontents to outward submission, and it was reported in October, I664, that all was again peaceable. The Dissenters had indeed suffered greatly. The Quakers again fell victims, two hundred of them being imprisoned in Dorset in $1662 .{ }^{12}$ In December, I664, out of nine Nonconformist ministers at Dorchester five had been imprisoned upon suspicion of being implicated in the 'plot' above mentioned. Six ministers and seventy other persons were then in prison for Nonconformity. 'The town,' it was said, 'is most factious, and has daily conventicles.' ${ }^{13}$ Loyalty to the Stuarts, never very marked, was for the moment strengthened by the issue of the Declaration of Indulgence (1 5 March, 1672). A large number of nonconforming ministers instantly availed themselves of it at Dorchester. ${ }^{14}$ Charles II was received with much

\footnotetext{
${ }^{1}$ Cal. Committee for Compounding (1643), xiv ; C. H. Mayo, op. cit. xxii.

'Scobell, op. cit. 278.

${ }^{3}$ Thurloe Papers, iii, 263.

- Min. Bks. Dors. Com. fol. 205, 252; printed Mayo, 208, 273.

${ }^{6}$ Weymouth Chart. vii, $22-4$.

${ }^{8}$ Ibid. 504.

${ }^{9}$ Ibid. $1661-2$, P. 439.

"I Ibid. $1663-4$, p. 150.

${ }^{13}$ Ibid. 166I-2, p. 426.

"Dorch. Corp. MSS. c. I5, under dates 17 May, 4 April, 8 May, \&c. 1672.

Fol. I 25, 159; Mayo, 408, 47I.

'Cal. S.P. Dom. 1660-1, p. 4.

${ }^{10}$ Ibid. 526 .

${ }^{13}$ Ibid. $1664-5$, P. I 30 .
} 


\section{A HISTORY OF DORSET}

loyalty when he came to Dorset during the plague-scare of $1665,{ }^{1}$ and in 1683 there were loyal rejoicings over his escape from the Rye House Plot. Yet there was much sore feeling about the tampering with borough charters which marked the last years of his reign. In I 662 Charles had caused a Quo Warranto to be brought against Dorchester, which seems, however, to have been successfully resisted. ${ }^{3}$ In 1677 Charles granted a new charter to Shaftesbury, as the result of a Quo Warranto brought concerning the privileges of the borough." It is more precisely worded than that of 1604 , and contains two clauses ensuring the taking of the oaths of obedience and supremacy by all members of the corporation and their officers, and the reservation to the crown of power to declare void the election of any recorder or town clerk, in which case the mayor and burgesses are to proceed to the election of another in his stead. In I $68_{4}$ Charles attempted to set aside this charter, and issued letters patent providing a process for removal of the mayor, recorder, town clerk, or any of the capital burgesses, by Orders in Council, in return for substantial trading privileges. But the charter was never surrendered, and James II, in dealing with the town, did not grant it a new charter, but only acted under one of the clauses of the letters patent of $1684 .^{5}$

Lyme had, at the Restoration, professed strong loyalist sentiments, but shortly succumbed to nonconforming influences. ${ }^{\circ}$ In I 684 , warned by the example of Shaftesbury, the corporation decided freely to surrender their charter without waiting for a Quo Warranto. In December, only six weeks before his death, Charles granted a new charter, but without calling in or taking a surrender of any of the former charters. ${ }^{7}$ In 1687 James II brought a Quo Warranto against Weymouth; the town clerk was ordered to ride to London and plead the charter, with apparent success. ${ }^{8}$

The ancient strongly Protestant feeling was still alive, encouraged no doubt by the presence of Holles, who lived near Dorchester still, and was very popular. Monmouth, who had accompanied Charles II on his visit in 1665 , had been very well received in Dorset. He landed at Lyme (I I June, I 685 ), and lingered there a fortnight, 'training and animating his men,' "Io instead of pushing on at once to Exeter or Bristol. The men of Lyme received him with great rejoicings, and recruits poured in from all sides. In his grateful enthusiasm, he was moved to write-

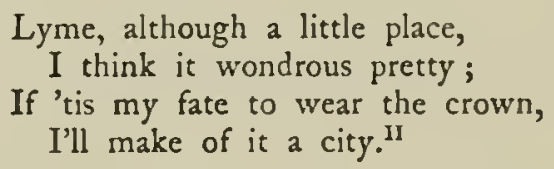

The militia of Dorset and Somerset, hastily called out, assembled at Bridport, where on the I 4 th they were attacked by part of Monmouth's force. This was defeated, and retired on Lyme. Meanwhile George Alford, mayor of Lyme (who had been forward, as an ex-royalist, to avenge himself after

${ }^{1}$ Hutchins, Dorset, i, I4 ; Weymouth Chart. v, 61.

${ }^{3}$ Dorch. Corp. MSS. c. 15.

- Hutchins, op. cit. iii, 104-12; Mayo, Shaston Records, 10, 11.

- Roberts, Hist. Lyme, $120-1$.

${ }^{8}$ W'eymouth Chart. iii, 141 , and p. 122.

- Dorch. Corp. Minute Bk. 28 Oct. 1661; 19 June, 1668.

${ }^{11}$ Quoted Roberts, Hist. Lyme, 152.

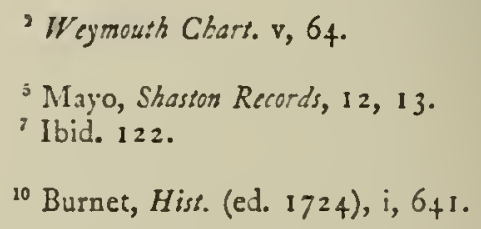




\section{POLITICAL HISTORY}

the Restoration upon the Independents of the borough, and who had waited upon Charles II in 1684 about the surrender of the charter ${ }^{1}$ ), had ridden to Honiton and to London to raise the alarm. ${ }^{2}$ On the 18 th Monmouth marched to Taunton.

After Sedgemoor, making his way towards Hampshire he was captured at Woodyates, just within the Dorset boundary, the horses having failed in Cranborne Chase." Lord Lumley's scouts-sent out all over Dorset-had done their work.

Kirke and his 'Lambs' did not, it is true, make Dorsetshire the scene of their operations. But the vengeance of James, though delayed till Jeffreys appeared, was not less certain. Early in September, the day after the execution of Alice, styled Lady Lisle, Jeffreys came to Dorchester." A copy survives of the Presentment to the Court at these 'Bloody Assizes,' made for one of the four judges, or for the Clerk of the Assize." 'Two hundred and fifty-one were sentenced at Dorchester; they were drawn from each of the coast towns, with twelve from Sherborne. ${ }^{6}$ A terrible 'Butchers' Bill,' methodically calculated, in the manuscripts of the Weymouth Corporation, testifies to their sufferings. But in Dorset, as elsewhere, the rebels were entirely confined to the middle and lower classes, none of the gentry supporting Monmouth. ${ }^{8}$

Dorset was no better satisfied with the accession of William and Mary than it had been with the return of the Stuarts. There was no active sedition, but a certain amount of quiet non-juring, and one may suspect much concealed dissatisfaction. Weymouth, which in 1662 had restored certain Royalist aldermen displaced in $1648,{ }^{\circ}$ suffered disqualification of no less than seventeen aldermen and capital burgesses, through their not taking the oaths under William and Mary. ${ }^{10}$ At the same time Howson, minister of All Saints, Dorchester, wrote: 'Our little government of this borough is composed of very ill members, who have been very backward in all public demonstration of joy, either for His Majesty's glorious accession, or his success against his enemies.' 11

In 1705 Defoe was concerned in scheming for Harley, apparently of no very dangerous or matured character, his correspondent and accomplice at Weymouth being a certain Fenner, a dissenting minister. Jonathan Edwards (the Anglican, not the American divine) was also concerned in it. The bearer of letters between them, James Turner of the Diligence privateer, turned queen's evidence, and they were all included in a warrant to bring them to Dorchester, as having received traitorous letters. ${ }^{12}$ Defoe speaks of the matter in his Review of the Affairs of France. ${ }^{13}$

'Roberts Hist. Lyme, 121 , 122.

${ }^{2}$ Lords Fourn. I 3 June, I 685.

3 'Account of the Manner of Taking the late Duke of Monmouth.' 5 ra. 2- B.M. ; Burnet, Hist. i, 644.

'See 'A Relation of the Great Sufferings of H. Pitman,' reprinted in Arber's English Garner, 337.

${ }^{5}$ B.M. Add. MS. 30077.

${ }^{6}$ Account of the Proceedings against the Rebels ${ }^{525.1209}$. A list of the names of the Rebels $\frac{512.12 .2}{515}$.

"Weymouth Chart. (ed. Moule), P. 85.

${ }^{9}$ Broadsides illustrating the history of the rebellion in Dorset are printed in extenso in Somers. and Dors. Notes and Queries, viii, 160 et seq. ; viii, 224 et seq. ; viii, 342 et seq.

Weymouth Chart. I 19.

${ }^{10}$ Ibid. 122.

$"$ Cal. S.P. Dom. I 689-90, p. 280.

${ }^{12}$ Weymouth Chart. iii, I 42.

${ }^{13}$ Preface to vol. vi, reprinted G. A. Aitken, Later Stuart Tracts, 245 ; Eng. Hist. Rev. Xv, 243 ; Hist. MSS. Com. Rep. xv, Io. 


\section{A HISTORY OF DORSET}

The eighteenth century was characterized by a number of disputed elections, turning mainly on the struggle between the freeholders and the mere householders as to the right to vote for members of Parliament. In Lyme the charter of Charles II in I 684 had provided that 'the burgesses to sit in Parliament for ever hereafter shall be elected by the mayor, capital burgesses, or freemen, or greater part, as heretofore in times past has been used and accustomed.' Ellis, writing of Weymouth in 1829 , admits that 'the inhabitants themselves have very little to do with the bonâ-fide election, as from the numerous frauds and subterfuges resorted to . . persons who are not at all connected with the town are made, for a bounty averaging from 5 s. to $30 \mathrm{~s}$., to profess themselves as bonâ-fide voters.' $\quad$ The number of voters, normally 200 , was in 1704 increased by malpractices to 648 . After a severely contested election in $183^{\circ}$ counsel on both sides agreed to the extension of the franchise to persons seised of freeholds within the borough, not being in receipt of alms. But almost immediately the old close system was reverted to. ${ }^{8}$ Bribery was apparently as rife at Corfe as at Weymouth : in 1784 the election expenses of John Bond, junior, and Henry Banks of Kingston Hall included the two items: 'To 45 voters at 13 s. each, $\oint_{2} 295$ s.,' and 'To two Persons to protect the Beer, $2 s .6 d .{ }^{3}$ Poole, owing to the acuteness of this question, constantly suffered from double returns. In 1654 , in the first Parliament assembled under the Instrument of Government, Cooper was returned for three constituencies-Poole, Wiltshire, and Tewkesbury. He elected to sit as member for Wiltshire." In I66I the election was impeded by the claims of certain non-resident burgesses. The question was referred to the House of Commons, who decided against the candidates returned by the votes of the non-residents. There was another double return in 1688 . In the disputed election of 1774 Sir Eyre Coote and Joshua Manger were nominated by the one party, and were opposed by Charles James Fox and John Williams, as candidates for the householders' party, which was now termed 'the commonalty interest.' At the election on is October I 30 householders voted for Fox and Williams, but their claims were not allowed by the sheriff, who accepted and returned only the votes of admitted burgesses, and returned Coote and Manger. Fox and Williams protested, alleging not only partiality of the sheriff towards the sitting members, but that by the law and custom of the land, as well as by the particular constitution of that borough, the right to exercise the franchise lay with 'the inhabitants and householders of the borough paying scot and bearing lot.' A committee of the House of Commons sat in 1775 to try the case, and decided that, down to the charter of Elizabeth, 'burgenses' in Poole charters meant inhabitants: that that year, by the new charter, the inhabitants were formed into a commonalty, as distinct from the burgesses. At the next two elections, in 1780 and 1790 , the returns were however again disputed, and were each again followed by the adjudication of a parliamentary committee, in 1780 with the same result as in 1775 , in 1790 ending in a compromise. The election of $179 \mathrm{I}$ led to the final victory of the right of election by select burgesses only. This continued till the Reform Act of $1832 .^{\circ}$ By that Act Corfe Castle was deprived of

'Op. cit. 44. 'Ibid. 80.
'Christie, Shaftesbury, i, I I 2.
3 Somers. and Dors. Notes and Queries, vii, 65.

${ }^{3}$ Sydenham, Hist. Poole, 256-66. 


\section{POLITICAL HISTORY}

representation, while Lyme, Wareham, and Shaftesbury were reduced to returning one member each; Weymouth and Melcombe (which had previously sent four between them, two for each) now returned two only, as a united borough. The county members, on the other hand, were increased from two to three, as some compensation for this decrease in borough representation. ${ }^{1}$

An Act passed the following year settled the inconvenience of the outlying portions of the county. Stockland parish and Dalwood township, lying geographically in Devon, but being hitherto part of Dorset, were now united with Devon; Thorncombe parish, and Burhall Downs and Easthay (part of the parish of Axminster), hitherto part of Devon, were made part of Dorset. Holwell parish, including the tithing of Buckshaw, which lay in Dorset geographically, was henceforth to be part of Dorset, instead of being an outlying part of Somerset.

By the Reform Bill of 1867 (Representation of the People Act) ${ }^{8}$ Lyme entirely ceased to be represented, not having a sufficient number of inhabited houses (683 only). Dorchester, Bridport, and Poole were each reduced to one member only. The Boundary Commissioners of i 867-8 did not see their way to recommending an extension of any of the existing boundaries of any of the Dorset boroughs. The population, stationary in the mid-Victorian period, decreased between $187 \mathrm{I}$ and $\mathrm{I} 88 \mathrm{I}$ from 143,478 to I $37, \mathrm{I} 46 .{ }^{4}$ Further reduction of representation was the natural outcome.

The Act of 1885 merged in the county the Dorset boroughs still remaining; thus Bridport, Dorchester, Poole, Shaftesbury (part of which lay however in Wiltshire), Wareham, and Weymouth and Melcombe vote now in the four divisions of the county. The number of county members was increased from three to four. The petty sessional divisions had only been adopted to a limited extent in the Boundary Acts of 1832 and 1868 , the hundred being still in theory the basis of electoral divisions. But it was growing obsolete, and the inconveniences of its often detached portions, together with the increasing difficulty of ascertaining its exact boundaries, led to the adoption, in the Act of 1885 , of the petty sessional division. The North Dorset division, under the new Act, accordingly includes the sessional divisions of Blandford, Shaftesbury, Sturminster, and part of Sherborne. The division of East Dorset includes the sessional division of Wimborne and part of that of Wareham with the municipal borough of Poole. South Dorset includes the municipal boroughs of Dorchester, and Weymouth and Melcombe, with part of the sessional divisions of Dorchester and of Wareham. The West Dorset division comprises the municipal boroughs of Bridport and Lyme Regis, the sessional divisions of Bridport and Cerne, and certain poorlaw parishes in the sessional division of Dorchester.

In I 685 , after the rebellion of Monmouth, the Duke of Beaufort was appointed colonel of a corps of musketeers and pikemen composed of men of distinguished loyalty, from the disturbed districts of Dorset, Somerset, and Devon. This, however, afterwards became known as the i ith North Devon

\footnotetext{
12 Will. IV, cap. 45.

2 and 3 Will. IV, cap. 64. For acreage and population involved see Notes and Queries for Somers. and Dois. $x, 86,87$.

- Rep. of Boundary Com. 1885 , pt. i, c. 4287 .

2 ${ }^{3} 30$ \& 31 Vict. cap. 102. ${ }^{3} 48 \& 49$ Vict. cap. 23. 


\section{A HISTORY OF DORSET}

Foot. A commission to raise troops for another regiment of dragoons, issued inter alia to Thomas Maxwell at Shaftesbury, resulted in the formation of a regiment in July, 1685 , which was joined by many Dorset loyalists who had fought against Monmouth, and which was afterwards known as the Princess Anne of Denmark's Regiment of Dragoons (now 4th Dragoons). ${ }^{1}$

The Dorset Regiment itself was not formed till 1702, during the preparations for war with France and Spain. It was raised in Ireland in 1702 , and was stationed there for five years. In 1707 it was sent to Portugal, to reinforce the troops after the battle of Almanza, gaining conspicuous honour, from making a determined stand with the $5^{\text {th }}$ and 20 th and Lord Paston's regiments, to cover the retreat of the Portuguese Army at the passage of the Caya. On the conclusion of the Treaty of Utrecht (I I April, I7 I3), the 39th went to Gibraltar, but later in the year was sent to form part of the garrison of Minorca, where it remained till I7 I9. It then passed some years in Ireland. ${ }^{2}$ In 1727 it took part in the recovery of Gibraltar, and in 1729 , on the conclusion of peace, was sent to Jamaica, where it arrived in 1730 . In 1732 it returned to Ireland, and in 1737 the Duke of Argyle was colonel. In I 744 the regiment was sent to England, and was employed for two years as marines on board the fleet. In 1746 it took part in the expedition to Brittany which attacked L'Orient, the head quarters of the French East India Company's shipping and stores in Europe. In 1747 and 1748 the 39 th again served as marines.

After the Peace of Aachen in 1748 the regiment spent five years in Ireland, going in 1754 to the East Indies. It remained at Madras till 1756 , and being the first king's regiment employed in India earned the motto still borne of 'Primus in Indis.' The gallant behaviour of the 39 th at Plassy in 1757 earned it the royal authority to bear the word upon the regimental colours. In $175^{8}$, on its return to Ireland, it was shipwrecked upon the Irish coast. A large detachment joined Ferdinand of Brunswick in 1759. In 1769 the regiment was besieged in Gibraltar, a siege which, in spite of three reliefs and reinforcements, was not finally abandoned till 1783 . The loss of the regiment during the whole siege was only five officers, ten sergeants, two drummers, and one hundred and thirteen of the rank and file."

On 3 I August, 1782 , the 39 th became the East Middlesex regiment, territorial denominations being then adopted. From 1783 to 1792 it continued in Ireland; in February 1793 it was sent to the French West Indies, and assisted at the captures of Martinique and Guadaloupe. The stay in Guadaloupe proved very deleterious to the health of the men. In I 794 it was in Ireland, in 1795 in Barbadoes. From Barbadoes in 1796 , the 39 th, together with a detachment of the Royal Artillery, proceeded against the Dutch colonies of Demerara, Essequibo, and Berbice, which were taken in April. They remained in Demerara till November, 1799. In October, 1800, they went to Surinam, and spent $180 \mathrm{r}$ there. On the conclusion of the Peace of Amiens in 1802 they returned to Barbadoes, and went thence to Antigua, reaching England in March, I 803. During the South American years they lost 2,000 men from climatic diseases alone.

'Hist. Rec. of Brit. Army (ed. Cannon), I Ith Foot, I, 2 ; $4^{\text {th }}$ Dragoons, 10.

'Hist. Rec. of Brit. Atmy, 39th Dorset Regt. 8.

I Ibid. 


\section{POLITICAL HISTORY}

On the renewal of hostilities in 1803 , under the Army of Reserve Act, a second battalion was added to the $39^{\mathrm{th}}{ }^{1}{ }^{1}$ composed of men from Cheshire, Shropshire, Warwickshire, and Worcestershire. In I 804, under the Additional Forces Act, ${ }^{2} 548$ additional men were raised in Dorset ${ }^{3}$ for the

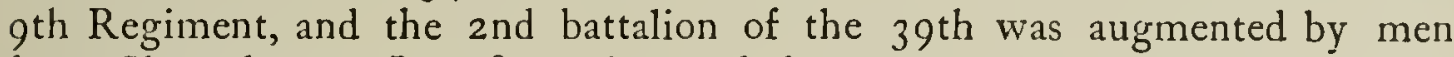
from Shropshire. In 1804 the 2nd battalion was in Guernsey, the Ist guarded the Sussex shore against the feared invasion by the Boulogne flotilla. The flank companies of the rst battalion took part in the Mediterranean Expedition of 1805 , and in January 1806 went to Sicily with the King and Queen of Naples, returning to Malta in February. The 2nd battalion remained in Guernsey till February i 806, when, after a short time at Cork and Dublin, all its united service men were transferred to a garrison battalion of the latter, and its disposable men were drafted into the Ist battalion at Malta. In 1807 the officers and non-commissioned officers of the 2nd battalion were recruiting in England. On 29 October, 1807, the name of the regiment was changed from the East Middlesex to the Dorset.

The 2nd battalion was largely recruited from the Militia, and spent I 808 in Guernsey. The flank companies of the Ist battalion went that year from Malta to Sicily, and in 1809 took from Murat, then king of Naples, the two islands of Ischia and Procida. They spent I 8 ro in Sicily. The 2 nd battalion went to Spain in 1809 , and in 1810 took part in the operations of Busaco, and distinguished itself greatly at the battle of Albuera ( 6 May). The ist battalion arrived at Lisbon in $\mathrm{I} 8 \mathrm{I} \mathrm{I}$, and was made up to full strength by all the effective men of the 2 nd battalion, the skeleton of which then embarked for England and arrived at Weymouth 2 March, I 8 I2. The ist battalion took part in the battle of Salamanca in 1812.4 The 2nd battalion remained at Weymouth till October, when they went to Exeter, but returned to Weymouth in December. The Ist battalion, which had lost heavily, but behaved with great gallantry at Vittoria (2 I June), was in all the operations against Soult in the Pyrenees, and on the Nive that winter, and was at Orthes and Toulouse in the spring of I 8 I4. The 2nd battalion spent 18 I 3 at Weymouth.

After the end of the war in Europe the Ist battalion went to North America, and was at Plattsburg, and in the ineffective Lake Champlain operations, ${ }^{5}$ returning to Europe just after the battle of Waterloo, in time to join the British Army at Paris. In the same year the effective men of the 2nd battalion were transferred to the Ist, and the former was disbanded 24 December, 18 I 5 .

The regiment remained in the Pas de Calais till 1818 , in December of which year it went to Ireland. In 1825 it was sent to New South Wales to keep order among the convicts. A depôt company was left in England, but by 1830 all the rest of the regiment was in New South Wales. It was at this time that Captain Charles Sturt, himself of a well-known Dorset family, made his two journeys into the interior of the continent $(1829,1830)$ to assist Darling. In $183^{\circ}$ the $39^{\text {th }}$ helped to put

\footnotetext{
43 Geo. III, cap. Ixxxii.

${ }^{3}$ Somers. and Dors. N. and Q. i, $15 t-5$.

5 Ibid. 63 .
} 


\section{A HISTORY OF DORSET}

down convict disturbances in the Bathurst district. In 1833 they were at Madras and Bangalore, in 1834 took part in a punitive expedition against the Rajah of Coorg, ${ }^{1}$ and in 1837 quelled an insurrection in Malabar. In 1843 the regiment formed part of the $5^{\text {th }}$ brigade of the 'Army of Exercise' in Gwalior. It took part in the succeeding operations, and was distinguished at the battle of Maharajpore. ${ }^{2}$ Part of the $39^{\text {th }}$ was with Sir Charles Napier's expedition in 1845 against the hill-tribes of Baluchistan, the mountain desert robbers. In 1847 the regiment returned to England.

The Ist battalion of the Dorset Regiment is nicknamed 'the Green Linnets,' from the old green facings, and from the habit of singing while on the march. The 2nd battalion is nicknamed 'the Flamers.' This battalion is the old 54th regiment, formerly called the West Norfolk. Cobbett served in it as a sergeant-major. The 2 nd battalion was sent out to Natal immediately on the outbreak of the South African War in I $899 .^{.3}$ It served with distinction under General Buller, taking part in all the battles leading to the relief of Ladysmith. At Alleman's Nek the heights were carried by the Dorsets. In October, I902, it returned to Portland, and it embarked for India 4 October, I 906 . The Ist battalion saw no active service during the South African War, remaining in India, chiefly in the Punjab, during the

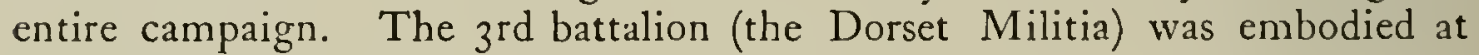
Shorncliffe, I 4 December, 1899 , and proceeded to Kinsale in March, 1900." It returned, however, to Dorchester in October, I $901 .^{6}$

The earliest in date of the twelve Dorset volunteer corps raised by June 1860 was the Wareham Corps. It was formed by 28 January, I 860 ; one of its earliest supporters was His Majesty King Edward. There is a Cadet Corps at Sherborne School.

Six troops of Dorset Yeomanry were raised in I794, viz. LieutenantColonel Damer's (Dorchester) troop, Major Frampton's (Moreton) troop, Captain Churchill's (Wimborne) troop, Captain Grosvenor's (Wareham and Charborough) troop, Captain Weld's (Lulworth) troop, and Captain Browne's (Maiden Newton) troop. The latter recruited as far south as Weymouth and Abbotsbury. Later in the year a seventh troop, under Captain Travers, was formed at Bridport. ${ }^{7}$ The troops met for the first time for exercise at Dorchester, 8 May, I794, under Colonel Lord Milton. After that they met at different places once a week, as appointed by the captains. On 17 September the king reviewed them under Maiden Castle. Exercise was continued till 22 October, when it ceased for the winter. The strength of the force at this time was 250 . They clothed and horsed themselves, receiving from the Government only a sword, one pistol, and holsters. They also requested the colonel to refuse any money offered by the county to assist them in expenses. No exercise apparently took place during haymaking and harvesting. ${ }^{8}$ In 1795 the number of the troops was reduced to five, since the king could not sign the commissions of Captain Weld and his son (the cornet of the Lulworth troop) as they were Roman Catholics.

\footnotetext{
1 Hist. Rec. of the Brit. Army, 39th Dors. Regt. 73.

3 Army Lists, Sept. 1899 , Jan. 1900.

'Ibid. Jan. 1900, March 1900.

'Captain M. F. Gage, Rec. of the Dorset Teomenry, 173.

${ }^{6} \mathrm{C}$. W. Thompson, Dorset reomonry, I2, It-15.
}

Ibid. 90.

- Ibid. Oct. 1902, Jan. 1903.

Ibid. 


\section{POLITICAL HISTORY}

In 1797 , however, a fresh troop was raised in the vale of Blackmoor under Captain Meggs. Under the fear of a French attack upon the Dorset coast, not only the volunteers, but the whole posse comitatus, consisting of 20,857 able-bodied men over fifteen years old, excluding peers and ecclesiastics, were ordered to be in readiness. This was done by the authority of the sheriff, not of the lord-lieutenant. ${ }^{1}$ During the second invasion-scare of 1798 three fresh troops were raised, Captain Tregonwell's at Cranborne, Captain Clavell's in the Isle of Purbeck, and a second in the vale of Blackmoor under Captain Bower at Shaftesbury. ${ }^{2}$ In 180 I there were only nine troops, but as Captain Bower was now adjutant it is probable that the Shaftesbury troop was the one disbanded. This first Dorset Corps of Volunteer Rangers came to an end on the signature of peace between England and France, in March, 1802 . Frampton, in his Memoirs, gives three reasons against the maintenance of a permanent yeomanry force in the county. He says the poor disliked yeomen forces of armed farmers, who could keep up the price of provisions, that the farmers themselves suffered under the sense of being always obliged to belong, if they had once joined, and that the attendance of yeomen diminished much as soon as the immediate fear of invasion was withdrawn. ${ }^{3}$

On the rupture of the Peace of Amiens the yeomanry was again raised, and consented to receive the allowance granted by Government for accoutrements; preparations made for removing stock were put under the control of such deputy-lieutenants and other gentlemen as were not engaged in any other military duty, thus relieving the Yeomanry officers. With the increased fears of invasion the regiment became more efficient. Their alertness was tested, in 1804 , by a rumour that the French had landed at Portland. Weymouth was thrown into confusion, till it was found that a fishing-fleet had taken refuge in the Roads during a fog. ${ }^{*}$

Lieutenant-Colonel Damer's death in May, I 807 , led to the command of Frampton, under whom the numbers of the corps greatly increased, the Secretary of State giving permission for the strength to be raised to twentyfour officers and $45^{\circ}$ non-commissioned officers and men." The regiment was disbanded in 1814 on the conclusion of peace. Frampton, with I 50 mounted men armed with constables' staves, dispersed the agrarian rioters at Winfrith in $1830^{\circ}$ : and in December of that year the Dorsetshire Yeomanry Cavalry was again raised. It now consisted of five troops, recruited mainly from West Dorset. A scheme to raise a regiment in East Dorset in $183 \mathrm{I}$ came to nothing. Instead, four independent troops were raised at Wimborne, Blandford, Wareham and the Isle of Purbeck, and Charborough. These were, however, disbanded in 1838 , with the exception of the Charborough troop, which had been disbanded in $1835 .^{\circ}$ The throwing out of the Reform Bill caused a serious riot at Sherborne in October, I831; the yeomanry were called out. The regiment assembled for 'permanent duty' for the first time in May, 1832 , at Dorchester. ${ }^{8}$ In June, I 843 , the title of 'Queen's Own' was given to it.

C. W. Thompson, Dorset Yeomanry, $23,25$.

${ }^{3} \mathrm{C}$. W. Thompson, Dorset reomanry, 49.

${ }^{3}$ Ibid. $84,86,89$.

${ }^{7}$ Gage, Dorset Yeomanry, 174.
${ }^{2}$ Gage, Dorset Yeomanry, 174.

'Ibid. 69 .

${ }^{6}$ Ibid. I08-9.

'C. W. Thompson, Dorset Veomanty, 127. 


\section{A HISTORY OF DORSET}

In 1879 the Yeomanry did not assemble for 'permanent duty' owing to the depressed condition of agriculture. It then consisted of six troops, viz. the Dorchester, Melbury, Blackmoor Vale, Sherborne, Blandford, and Wimborne troops. ${ }^{1}$

In 1893 the regiment was formed in two squadrons, the field troops of Melbury, Sherborne, and Dorchester having head quarters at Maiden Newton, and those of Blandford, Wimborne, and the vale of Blackmoor having headquarters at Blandford.

In I 901 the Queen's Own Dorsetshire Yeomanry was again reorganized and formed in three squadrons, with head quarters at Dorchester, Sherborne, and Blandford respectively. There is also a machine-gun section."

A meeting was held at Dorchester on New Year's Day, rgoo, in response to the Government's demand for 10,000 Imperial Yeomanry. By 8 January 120 men had applied to join the company, I I 5 only being required from each county. A machine-gun section was also formed, with two Colt guns, mounted on galloping carriages. ${ }^{3}$ The company was ordered to form part of the seventh battalion of Imperial Yeomanry. They entrained at Dorchester, 28 February, and reached the front 7 April. On 18 April a reinforcing draft, consisting of one officer and fourteen non-commissioned officers, was sent out. Altogether, there served in South Africa, of the original Dorset Yeomanry, ten officers and II 5 non-commissioned officers and troopers, two non-commissioned officers and twelve men of the machinegun section, the above-mentioned draft of April, I900, and a I901 draft consisting of one lieutenant and seventy-two men. The casualties were twenty-four, including two killed in action. To the 26th Company of Imperial Yeomanry Dorset contributed seven officers and their thirteen servants, and seven non-commissioned officers and men, with a reinforcing draft of one lieutenant, one corporal, and thirteen troopers."

On arrival in South Africa the Dorset Yeomanry acted temporarily under General Sir Leslie Rundle, and took part in the operations for the relief of Wepener. In May, joining Lord Roberts's army at Kroonstad, they advanced along the ruined railway lines on Vereeniging, across the Vaal. The Dorsets were the first to cross into Transvaal territory at this point. They participated in the advance on Johannesburg and Pretoria. After the armistice of early June they took part in the Diamond Hill action, and later some of the force formed part of the Pretoria garrison. Later they joined in the chase of De Wet, and were thus constantly on the move. They had the honour of protecting the retirement after Nooitgedacht, ${ }^{5}$ during which action they had been under fire fourteen hours, and in the saddle twenty-six hours. In January, I90I, they were in the action at Middlefontein. Much uneventful trekking followed, chiefly in the neighbourhood of Naauwport. They then took part in the operations in the Western Transvaal. New drafts of yeomanry, drawn from a somewhat different class of men, were sent out in May, I90I, and the original Dorset Yeomanry was then ordered home. The battalion left Cape Town on 3 June, I90I, and arrived at Southampton 25 June.

${ }^{1}$ Gage, Dorset 1 Comanry, 175.

${ }^{3}$ Gage, Dorset 1"comanry, 75-9.

Ibid. $127-30$.
'Royal Warrant, reomonry Reorganizotion, I $90 \mathrm{I}$.

'Ibid. Appendix C. 


\section{MARITIME HISTORY}

$\mathbf{I}^{N}$

$\mathrm{N}$ considering accessibility to invasion the development of shipbuilding in relation to harbours must, as well as other facts, be borne in mind. In early centuries the minor Dorset ports and river mouths admitted the vessels of small tonnage then in use, or in some places they could be beached; from the sixteenth century onwards a whole stretch of coast such as the West Bay, extending from Portland to the border of Devon, passed out of the sphere of possible operations because to be caught there in a gale from the westward was certain destruction as the larger ships then built could find no shelter except, in limited number, at Lyme. The eastern half of the county offered, in recent centuries, equally few advantages to an invader. Poole, at high tide, looks a capacious harbour, but its waterways are narrow and its anchorage limited, while the contracted entrance is further obstructed by a shifting bar which has not more than $14 \mathrm{ft}$. of water on it at high water spring tides. Studland and Swanage bays are sheltered from the westward ; but the former will not admit anything drawing more than I $2 \mathrm{ft}$., and the latter gives but a shallow and indifferent anchorage. From Durlstone Head to Weymouth Roads runs a line of lofty cliffs broken by a few coves and landing-places which may have received the vessels of Saxon and Danish marauders, and later coasters, but are of no avail for modern shipping. As in the case of the West Bay it would be the object of an invader to keep clear of this coast rather than to approach it. Thus of the 75 miles of Dorset coast at least three-fourths became a negligible quantity as facilities of transport increased and the national risk of invasion grew greater generally.

From the point of view of naval war, therefore, the interest strategically is confined to the projecting point of Portland, with its accessories Portland Roads and Weymouth Roads. The modern naval base is seldom a great commercial port ; the mediaeval base, unless far outside the radius of action and merely a feeder to supply the fleets, was invariably a place of commerce because its offensive capacity in war grew out of its success in the paths of peace. Thus Sandwich, Rye, Winchelsea, Weymouth, and Plymouth became bases for offence as they increased in maritime strength, as commerce caused the accumulation of ships, men, and matériel, all interchangeable for tracle or war, and as the area of maritime action widened. Melcombe, when ruined by the French in the fourteenth century, was becoming an important naval centre; its harbour, suitable for the vessels of that age and probably deeper than it is now, held the position relative to Cherbourg and St. Malo that Plymouth, later, stood in towards Brest ; and Weymouth Roads, like Portland Roads covered from all winds except those from east to south, was of equal 


\section{A HISTORY OF DORSET}

value commercially. The forbidding bluff of Portland guarded by its cliffs, by the westerly gales that sweep over it, by the dangerous Race, and by the Shambles, never allured a mediaeval invader to any attempt to secure a permanent foothold upon it; the natural strength which daunted the enemy of that period was the principal defence then of Portland Roads, but is still more effective now when improved by engineering and military art. Torbay, although not so safe an anchorage, was preferred in the eighteenth century because nearer Brest; when Cherbourg was suddenly enlarged into a great naval base and arsenal, the development of Portland, nearly opposite, but to windward, was the natural answer. The use of steam has greatly increased the strategical value of Portland. Although not a primary base, because it lacks appliances for docking and repairs, it holds a first place among those of its class, for, as it flanks Portsmouth and Plymouth, ${ }^{1}$ no enemy could venture to attack either of those places while an English fleet, even of inferior strength but able to fight, lay in the naval harbour. He must therefore deal with the Portland fleet first and either mask it with sufficient force while he carried out his main purpose or await its pleasure as to the time of action. Except as following a series of disasters which would, by their direct and indirect effects, render a further struggle here useless, no enemy or combination of enemies is likely to possess sufficient strength simultaneously to hold quiescent a fighting fleet at Portland and to attack one of the great naval arsenals. For his fleet there would be far more risk of disaster than probability of success about a serious bombardment at any useful range; and if he succeeded the English loss would not be so great as would be involved in the destruction of a huge dockyard, with the private property around it. The methods of attack in modern naval war are likely to enforce the use of Portland as a centre for ships delayed in sailing or awaiting admission to Portsmouth, for Spithead can never be used again with the confidence permissible before the era of torpedoes and drifting mines.

The name of the British tribe inhabiting Dorset, the Durotriges, or 'water dwellers,' seems to imply some especial relation with the sea; but a recent suggestion that the water in question was that of the marshes of Poole Harbour, and of the rivers emptying themselves into it, is a far more probable one than the supposition that the natives possessed any particular maritime aptitude. Unlike some of the other counties whose coast-line is broken by long beaches or stretches of salt-water marshes, that of Dorset offers little encouragement to beginners in navigation. If the Celtic appellation referred to the sea it involves the inference that the Durotriges were far more advanced in maritime affairs than any of the other races in Britain, for which there is no evidence either in history or in the numerous Celtic remains which have been found in the county. We may safely assume that such sea life as existed was confined to fishing close inshore from coves and sheltered bays, and that the Durotriges had made even less progress in navigation than their neighbours east and west.

Omitting the Roman era, considered elsewhere, we find that the principal Saxon advance north-westward was by land from their favourite place of debarkation in Southampton Water. It is both possible and probable that

'Portland to Plymouth, 75 miles; to Portsmouth, 60 miles; to Guernsey, 60 miles; to Alderney, 48 miles; to Cherbourg, 62 miles. 


\section{MARITIME HISTORY}

their failure at first to reach the coast from the centre of the county was retrieved, later, by a flank attack by way of Poole Harbour, thus turning the strong position of the marshes and forests of the Frome, although no evidence of such a movement has survived. If it did occur it is the only maritime incident connected with the West Saxon conquest of Dorset.

In 787, if the date given in the Anglo-Saxon Cbronicle be correct, came the first appearance of the Northmen in England, and the experience fell upon Dorset. According to one writer the landing-place was Portland ${ }^{2}$; and the king's reeve, ignorant of the character of the strangers, riding from Dorchester to inquire the cause of their coming, was killed, together with his attendants. Portland seems a less likely place of landing than either Poole or Weymouth Harbours, and, if they came from the eastward, it is difficult to understand why their first appearance should have been in Dorset when, to reach the county, they must have passed much more tempting coasts on their way. We read, however, that in the year 800 the northern shores of France were harassed by the Northmen ${ }^{3}$; that condition of things had existed for years previously, so that it is likely that the marauders of 787 had come across the Channel, especially as they were said to be from 'Haeretha-land,' now held to be Jutland, which was also the home of the pirates of 800 . Nearly half a century elapsed before their next appearance in Dorset, and by that time the lines of advance from the Baltic-eastward by way of the Frisian and French coasts, westward by way of the Orkneys and Ireland-were closing round England. In 833 a fleet appeared at Charmouth, where the Vikings were met by Egbert in person, who was overthrown, and in 837 another force, perhaps one which had just been repulsed in Southampton Water, landed at Portland; there the ealdorman Ethelhelm was defeated and killed by the enemy who remained in possession of the island. Again, in 840, they came to Charmouth and routed Ethelwulf, if the entry in the Cbronicle is not a repetition of the event of 837 . The first landing may have been due to chance, but assuming both entries to be correct it is not clear what attraction Charmouth or its neighbourhood can have had sufficient to account for two onslaughts in seven years. On the other hand the second landing may have happened but have been unintentional, in the sense that bad weather forced a roving party to seek a port.

Whatever temptation Dorset may have offered at first to invite attacks. in force they soon faded; the county is not mentioned again until towards the end of the long struggle of nearly fifteen years during which the Danes were fighting for the conquest of England. In 876 Guthrum, with his division, which had wintered in the Midlands, 'stole away' from Cambridge to Wareham. Probably he embarked in Orwell Haven and went by sea. That Guthrum, or some of those with him, knew the strength of the Wareham position affords reasonable presumption that they must have learned the topography of the district as the result of small raids not noticed by the chroniclers. Notwithstanding a solemn undertaking to leave the kingdom, part of the Danish army escaped and occupied Exeter; the remainder held Wareham until the spring of $877,{ }^{4}$ when they left by sea to raise the blockade

\footnotetext{
${ }^{2}$ Leland, Collect. iii, 2 I 4 (Chron. St. Neot).

S Patrologiae, ed. J. P. Migne, civ, 458 (Ann. Lauriosenses).

- Traditions of Danish slaughter still linger in the neighbourhood of Wool (Moule, OId Dorset, I 39 ). 


\section{A HISTORY OF DORSET}

instituted by Alfred and relieve their beleaguered comrades in the western capital. The relieving fleet was caught by a storm and driven into Swanage Bay where I 20 ships were wrecked. The Danes in Exeter thereupon surrendered, one more illustration of the effects-if not of sea-power- of sea affairs.

The supreme tactical advantage possessed by the Danes, in being able to seize a base wherever the sea broke upon a beach round England, was one that the Saxons had themselves used centuries previously although they had forgotten the lesson and lost their maritime aptitude. Even after the fifteen years' war which ended with the peace of Wedmore, a war only possible for the Danes because they held the sea, the fierce five years' fight between 893 and 897 was needed to make Alfred decide upon building ships in sufficient number to have some chance of meeting the enemy with success afloat. These ships, when in service, were manned largely by foreign mercenaries, which shows that the counties contained but a small seafaring population. However, the existence of a fleet ensured eventually the collection of a body of trained seamen to man it or it could hardly have continued. Incidental references indicate that Alfred's successors possessed fleets of some strength, while there was a law in force during the reign of Edgar (959-75) that every three hundreds, probably along the coast line, should provide a ship. This law may have fallen into desuetude or have been found insufficient, for in 1008, under the pressure of renewed Danish incursions, it was ordered that every 3 Io hides of land throughout the country should build and equip a ship. Dorset was not among the leading maritime shires of early centuries, but these laws, with the consequent necessity for serving at sea, must have tended to bring the backward counties into line with those more advanced; among the former Dorset would have been helped forward in this way in the absence of the stimulus of maritime commerce.

After a long interval of comparative peace the Danish ravages recommenced towards the end of the tenth century. The beginning of the next century showed signs of their preparation for the complete conquest of England. Nearly the first breath of the storm swept over Dorset where a pirate squadron appeared in 982 and ravaged Portland. It may be inferred that they were new to their work or weak in numbers, for otherwise they would surely have chosen some wealthier region. An invasion by Sweyn, king of Denmark, took place in 994 ; he was repulsed from London, and then ravaged the east and south coasts, but did not go further westward than Southampton Water. The turn of Dorset came again in 998 , when a force, probably from Ireland, after harrying the west coast during the preceding year, came south and sailed up Poole Harbour, from which 'they went up as far as they would' into the interior of the county. Between 1003 and I I I the Danes overran the eastern half of England from Norfolk to Wiltshire and Hampshire, but Dorset seems to have escaped the main bodies of the enemy. In IOI 3 came another great invasion under Sweyn, and King Ethelred and his family fled to Normandy. Sweyn died in I014; Ethelred returned but had to contend with Sweyn's son, Cnut, who arrived with a great fleet in IOI 5 with which he laid waste the coast from Kent westwards, finally harbouring in the favourite covert of Poole from which he marched over Dorset, Wiltshire, and Somerset. Cnut is said to have occupied Brownsea Island; no donbt 


\section{MARITIME HISTORY}

several earlier generations of Danes had also used it. Years of hard fighting followed until the death of Edmund Ironside in I017 left Cnut king of all England, but the area of struggle was outside Dorset, and a long period of peace succeeded the new settlement of the throne. Only one other maritime event of any importance is associated with the county previous to the Conquest. In 105 I Godwin and his sons had been banished; Godwin went to Flanders, Harold and his brother Leofwin to Ireland. Both father and sons returned with fleets in 1052, and that of Harold plundered along the coast of Dorset before he met his father at Portland. Godwin's men landed there ' and did whatever harm they were able to do.'

In connexion with some of the counties a coasting and foreign trade can be inferred, thus correlating a certain amount of shipping at the date of the Conquest, but there is no evidence concerning Dorset. Bridport and Wareham seem rather large places in Domesday, and must have been the principal ports. There was a fishery carried on from Lyme. As Bridport was famous for its cordage by the reign of John there is every probability that the trade was older than the Conquest, and if so it was one which must have especially aided the shipping development of the town until its harbour failed. The events of 1069 show that William had then no fleet available, but he was the last man likely to underrate the importance of maritime power, so that in I $07 \mathrm{I}$ and the following years his ships were acting in conjunction with his land forces. Between the last threat of a Danish invasion in 1083 and the loss of Normandy in 1204 there were few occasions for naval levies on a large scale, seeing that the Channel was not then a disputed tract but only the sea road connecting dominions under the same sovereign. In II I, at Milford Haven, there were collected 400 vessels to carry Henry II and his army to Ireland. From geographical situation and administrative arrangement, ${ }^{b}$ it is probable that Dorset furnished a quota to the expedition. A fleet conveying the main body of the Crusaders left Dartmouth in IIgo, but most of the vessels were obtained from the continental possessions of the crown. For upwards of a century only small fleets for transport purposes were required in the desultory dynastic wars occurring, and for these it was sufficient to call upon the Cinque Ports, London, and the adjacent districts. Wareham is the only Dorset port from which the combatants sailed, or at which they arrived, during the civil wars of Stephen's reign.

In March, 1208 , the authorities in the principal coast counties were ordered to cause all vessels to return to England before the ensuing Easter to be ready for the king's service. Lists of the ships and the names of the owners were also to be sent to London. Under 1205 we have the first station list of the king's ships, but as none was placed between Southampton and Exeter the Dorset ports were evidently not yet among the leading ones. A similar order to that of 1208 issued again in 1214 , but in the latter year the lists were to be confined to ships of 80 tons and upwards. ${ }^{7}$ If the inclusion of Dorset among the other counties was not a mere matter of routine, and there was a real expectation of finding vessels of 80 or 100 tons in its ports, it implies a considerable growth of trade and shipping during the

${ }^{5}$ With the exception of a few years Dorset and Somerset were under one sheriff, until 8 Eliz.; writs usually applied to both counties.

6 Pat. 9 John, m. 2.

"Ibid. 16 John, m. 16. 


\section{A HISTORY OF DORSET}

previous century. No doubt a contingent of Dorset ships and seamen was present in the fleet, made up from the ports generally, which won the great victory at Damme in I 2 I 3 .

In the reigns of John and Henry III we find notices of the Bridport cordage manufacture. In I2I 3 John ordered cables for his ships to be made there in such haste that the work was to be carried on night and day. ${ }^{8}$ In I 225 Henry directed the sheriff to buy two cables in the town and send them to Fowey for the use of the royal ships. ${ }^{9}$ In 1224 there was a general arrest of shipping in view of war with France ; in Dorset the bailiffs of Poole were called upon to prepare all its ships for service and to detain any foreign vessels coming there. ${ }^{10}$ This is the first notice of the town in relation to shipping. Weymouth occurs in 1226 , as well as Poole, when an order issued to stop any merchantmen sailing for French ports. Lyme is added to a similar writ in $1234 .^{11}$ Arrests of shipping were frequent during the reign of Henry, but they were seldom followed by any events requiring notice. In 1254 there was a levy of ships large enough to carry sixteen horses, and writs were directed to Poole, Weymouth, and Lyme." ${ }^{12}$ The last was becoming strong enough to carry on a war of its own; in 1265 the king ordered inquiry into the mutual injuries inflicted upon each other at sea by the men of Lyme and Dartmouch, which had led to 'enormous transgressions and homicides' by both parties. $^{13}$ As this was the period of the Barons' Wars, the anarchy existing in the state was reproduced on a smaller scale round the coast. But Dartmouth had long been a great and wealthy port; if Lyme could now fight it on terms of equality at sea it signifies a remarkable growth of prosperity in the Dorset town.

A distinctive feature of the maritime history of the thirteenth century is the appointment of one or more persons, sometimes for one county and sometimes for a group of counties, as keepers of the coast, a step towards the organization of systematic defence. John Marshal was keeper of the ports of Somerset and Dorset in I 215 , although this appointment was probably not altogether one of the later type."4 In I 224 Ralph Germun was keeper of the Dorset coast ; in I 235 Hamo de Crevecœur and Walerand Teutonicus had charge from Hastings to Poole. ${ }^{15}$ The office was not continuous, and most often comes under notice in time of war when the enemy happened to have the upper hand and be in command of the Channel. Thus in the reign of Edward III we find many nominations in the years immediately preceding the battle of Sluys in I 340 . The functions of the keeper were chiefly military, but were also judicial in matters relating to the sea and coast ; he was in military command both at sea and on land, and was given somewhat large powers. Practically, he was expected to crush piracy, to beat off raiders, to enable coasters and fishermen to sail in peace, and to summon the county to arms upon invasion. The office did not endure for long because, during the second half of the fourteenth century, the growth of the Admiralty Court, the increased power of the admirals, and, finally, the creation of the post of High Admiral lessened its importance. Historically, however, the keeper may

\footnotetext{
${ }^{8}$ Close, 15 John, m. 6.

${ }^{9}$ Ibid. 9 Hen. III, m. 13. Fishing nets were also made there (ibid. 7 Hen. III, m. 22).

${ }^{10}$ Pat. 8 Hen. III, m. 8 d. $\quad{ }^{\prime \prime}$ Close, ro Hen. III, m. 27 d.; ibid. 18 Hen. III, m. $25 d$.

${ }^{13}$ Ibid. 38 Hen. III, m. 5. ${ }^{13}$ Pat 49 Hen. III, m. 17.

" Pat. 17 John, m. 17.

15 Ibid. 19 Hen. III, m. I 4 .
} 


\section{MARITIME HISTORY}

be considered the ancestor of the conservators of truces instituted locally by Henry $V$, and of the later vice-admirals of the coast whom we find acting from the middle of the sixteenth century. A part of the system of defence under the care of the keeper was the line of fire beacons, corresponding to the modern coastguard stations, usually placed on a hill near the shore and guarded in war time by a watch from the neighbouring parishes. ${ }^{16}$ The Poole men were responsible for the beacon on Worbarrow Down. ${ }^{17}$

The Welsh wars of I 277 and I 282-3 were mainly fought by the feudal armies. The Cinque Ports furnished most of the squadrons-not large ones-required for the Welsh wars, but the later Scotch campaigns stirred the coasts to greater activity. The advance of Poole is manifested by its being the recipient, in I29I, with the chief ports, of a mandate to execute a truce with France. ${ }^{18}$ At the time when Edward was founding the new Winchelsea he apparently designed creating a town in Dorset on a similar plan, for a writ of 1286 recites that he was trying to settle a town and harbour 'at Gotowre in Studland parish,' at which the people were to enjoy the same liberties as those of the burgesses of Lyme and Melcombe. ${ }^{19}$ This seems to have been at Ower, on the south side of Poole Harbour, but as the new port must have been projected with a view to maritime action, it is not easy to see, however busy it may have been then, ${ }^{20}$ what advantages for the king's fleets it was expected to present greater than those afforded by Poole.

War with France followed a battle in the Channel in I 293 between the Cinque Ports and their allies and the French and their allies. The preparations in England included the construction of I I galleys at the king's cost, at various places; one, of I 20 oars, was ordered at Lyme, which was to be assisted by Weymouth. ${ }^{21}$ The town is here therefore classed among the great ports. ${ }^{22}$ The Scotch war of 1295 was the cause of levies round the south coast in the shape of a selection from among ships of 40 tons and upwards. ${ }^{23}$ There was an attempt to keep the intended place of concentration secret, the persons choosing the ships in Dorset and elsewhere being directed to 'bring them on a certain day to a certain place as instructed by word of mouth.' A large fleet was raised in 1297 to transport an army to Flanders; Edward, in calling upon the ports, including the three of Dorset, explained that the matter was among 'the greatest and most arduous that he has had to deal with in any times past. ${ }^{24}$ In March, I $30 \mathrm{I}$, the ports all round the coast were required to send ships by midsummer for the Scotch campaign; Poole, Lyme, and Weymouth were assessed at one vessel each. ${ }^{25}$ Again, in November, I 302 , the ports were warned for service to be ready by the following spring, Weymouth and Lyme being rated at one ship each while Wareham and Brownsea were joined with Poole for the third. ${ }^{26}$ This time security was

${ }^{16}$ Cf. Southey, Lives of the Admirals, i, 360 (quoting Froissart), as to the. method of constructing the beacons. See also Stubbs, Conss. $H$ iss. ii, 285 (2nd ed.), on mediaeval coast defence.

"Sydenham, Hist. of Poole, 99, who refers to a corporation MS. giving the names of those who were to find the hobelers to keep the watch.

${ }^{13}$ Pat. $19 \mathrm{Edw} . \mathrm{I}, \mathrm{m} .17 .{ }^{18}$ Ibid. $14 \mathrm{Edw} . \mathrm{I}, \mathrm{m} .24$.

${ }^{20}$ Hutchins (Hist. of Dorset, $\mathrm{i}, 463,3$ rd ed.) notices that Purbeck stone was formerly exported from Ower, and that in ancient times it was much frequented, as is shown by the deep tracks across the heath.

${ }^{2}$ K. R. Memo. R. 69, No. 77. The account of the expenses incurred still exists (Exch. Accts. K. R. bdle. 5 , No. 21 ).

${ }_{87}$ The seal of Lyme Regis, with a ship which presents some peculiarities, is of this reign.

${ }^{23}$ Pat. 23 Edw. I, m. 7, m. 6.

${ }^{23}$ Pat. 29 Ediw. I, m. 20.

${ }^{24}$ Close, $25 \mathrm{Edw}$. I, m. $17 \%$.

${ }^{26}$ Ibid. 30 Edw. I, m. 2. 


\section{A HISTORY OF DORSET}

required from the shipowners that their vessels would appear because some of the ports, amongst them Lyme and Poole, had neglected the orders of the previous year. Two of the king's clerks were sent round the coast to punish the defaulters at their discretion. ${ }^{87}$

Probably both shipowners and seamen found piracy or privateering more attractive than the royal service, but notwithstanding occasional disobedience there was no general disinclination to respond to the demands of the crown. The yearly levies of ships and men would seem to be destructive of commerce, but in reality were not nearly so injurious to it as they appear, for it was only during the summer months that the king's fleets were large in the number of ships. Moreover a trading voyage involved great risk of loss from wreck, piracy, and privateers, or in the sale of the cargo; the king's service meant certain pay for the fitting and hire of the ship, besides sixpence a day for the officers, and threepence a day for the men-very liberal wages allowing for the greater value of money. Thus both owner and sailor were on a safer footing in serving the king than in trading for themselves. The incessant embargoes that harassed commerce-then much increased-under Edward III were not yet common, and the alacrity with which most of the ports answered the demands made upon them shows that the assistance required was not oppressive, nor even unwelcome, especially as those who contributed to the sea service were freed from any aid towards that by land. There was no permanent naval organization at this time. The king possessed some ships of his own, and the commanders were usually charged with their maintenance. When a fleet was to be raised from the merchant navy a certain extent of coast was allotted to one of the king's clerks, or to a serjeantat-arms, who acted with the bailiffs of the port towns in selecting ships and men and seeing them dispatched to the place of meeting. If a ship did not appear, or the men deserted, they or the owner might be required to find security to come before the king; and although there was as yet no statute ${ }^{2 y}$ dealing with the offence they might, as we see, be punished at the discretion of the king or his representatives.

Wrecking and piracy were recognized, if illegal, industries, and the Dorset men were no better than their neighbours in practising them. The character and conformation of the coast must have provided much material for wreckers, for the clumsy mediaeval ship was doomed if caught either side of Portland in a gale from an unfavourable quarter. In the human factor appetite grew with what it fed upon until the deeds of the Dorset wreckers were notorious even in the nineteenth century. In I 305 a Spanish ship was wrecked near Portland; the crew escaped, but a commission of oyer and terminer names 235 persons known to have plundered the ship and broken it up. ${ }^{29}$ In the following year a Bordeaux vessel was lost under Corfe, and although some of the crew and two dogs escaped alive the people thereabouts carried away the cargo and destroyed the ship. ${ }^{30}$ Piracy became so prevalent that in I 3 I I the county had a commission of inquiry to itself in order to ascertain why so many foreign merchantmen were plundered in

"Pat. 30 Edw. I, m. If.

25 The first statute was 2 Ric. II, st. 1, cap. 4, by which deserters were fined double their wages and imprisoned for a year.

${ }^{29}$ Pat. 33 Edw. I, pt. i, m. $13 d$.

${ }^{\text {so }}$ Ibid. $3+$ Edw. I, m. $28 d$. 


\section{MARITIME HISTORY}

Dorset waters. ${ }^{81} \quad$ But in many instances the so-called piracies were merely cases of seizing enemy's goods in neutral ships and would, later, have merely provided suits in the Admiralty Court. Others can have had no such explanation. In I 322 a Plymouth ship was attacked for a whole day by crews hailing from Weymouth and Portland who, having at last driven her to Lyme, there boarded, ransacked, and scuttled her.

The constant warfare of the reign of Edward II caused continual demands to be made upon the ports. In I 308 Poole, Weymouth, and Lyme were each ordered to send one ship manned by 42 men for the Scotch war; ${ }^{32}$ in the following year Wareham is named among the passage ports of the south coast. ${ }^{33}$ A large fleet was required in 1310 , so that Poole, Wareham, Weymouth, Melcombe, and Lyme were assessed for one vessel each. ${ }^{34}$ A still greater effort was necessary in I 3 II ; Poole was linked with Lymington for three vessels, Wareham was again asked for one, Lyme for two, and Weymouth, no doubt with Melcombe, for two. ${ }^{85}$ In this case Southampton and Dartmouth were the only towns on the south coast, exclusive of the Cinque Ports whose organization does not admit of comparison, which sent three vessels each, so that we have here a measure of the relative importance of the ports. In I 313 thirty of the best ships between Plymouth and Shoreham were selected for service, for which Dorset may have supplied one or more; in I 314 there was another heavy levy for the Scotch war, for which Poole and Wareham sent one ship each, Lyme two, and Weymouth and Melcombe two. ${ }^{36}$ The exhaustion of the exchequer now forced the king to obtain vessels from the ports at their own cost, a demand in such contrast to the methods of Edward I that it must have brought home to shipowners the possible disagreeables of the crown service. In this way John de Norton was sent to the towns between Southampton and Falmouth in I3I6 to persuade them to set out as much shipping as they could at their own expense 'for better keeping of the English sea.' ${ }^{37}$ This was a request ; the next year came a command for ships to serve one month at the charge of the towns, and afterwards at the king's cost; Wareham was coupled with Beaulieu Abbey for a vessel, the other Dorset ports being set down for one each. $^{38}$ In I 3 I 9 the period of service at the expense of the towns was extended to three or four months, ${ }^{39}$ and the coast, generally, must have welcomed a two years' truce in I 320 with Scotland.

Besides their warfare in the service of the state several of the counties found themselves strong enough to carry on private wars of their own. In August, I 32I, the king issued inhibitions to the men of the Cinque Ports on the one side, and on the other to those of Poole, Lyme, Weymouth, and Melcombe in Dorset, ordering them to desist from the mutual homicides, robberies, and ship-burnings which they had been perpetrating. ${ }^{40}$ The Dorset ports were not fighting alone, for Hampshire, Cornwall, and probably Devon, were their allies in this county war, but that they should have been sufficiently strong and wealthy to contend with the Cinque Ports at this time shows their rise into importance.

\footnotetext{
${ }^{31}$ Pat. 5 Edw. II, pt. i, m. 24.

${ }^{33}$ Ibid. 3 Edw. II, m. 19 d.

${ }^{35}$ Pat. 4 Edw. II, pt. ii, m. 7.

7 Close, 9 Edw. II, m. I $3 d$.

${ }^{39}$ Ibid. $12 \mathrm{Edw} . \mathrm{II}, \mathrm{m} .3$.
}

${ }^{32}$ Close, 2 Edw. II, m. $22 d$.

${ }^{34}$ Rot. Scot. 3 Edw. II, m. 1.

${ }^{36}$ Rot. Scot. 7 Edw. II, m. 6.

${ }^{3 s}$ Rot. Scot. I I Ldw. II, m. 17.

${ }^{10}$ Close, $15 \mathrm{Edw} .11, \mathrm{~m} .32 d ., 31 d$. 


\section{A HISTORY OF DORSET}

The Scotch war was renewed in 1322 ; the ports were asked for naval aid to serve at their own expense as long as they could, and afterwards at that of the king. A thirteen years' truce with Scotland was arranged in 1323 , but war with France then threatened, and in May, I 324, the preparation of a large fleet was ordered; Weymouth was put down for ten ships, Poole, with its members, for four, and Lyme for two." Apparently this levy was considered a nuisance by those immediately concerned in satisfying it, for we find by a writ of June that some of the masters and mariners of Lyme, Poole, Weymouth, and Wareham had 'eloigned' themselves and their ships when the order was received, for which the king expressed his intention of punishing them. ${ }^{4}$ From the account of wages paid to those who obeyed we glean remarkable information concerning the size of ships of this period. From Weymouth came two of 200 tons each, one of 140 , and one of 120 tons; from Melcombe one of 120 and one of IIO tons; from Poole two of I 60 tons; and from Lyme one of 160 , and one of 140 tons. For the moment there was a possibility that the Dorset ports would move into the first rank. ${ }^{43}$ Isabella proceeded to France in 1325 to negotiate a peace between her husband and her brother, but it soon became evident that she was going to sacrifice the former in favour of her son. In 1326 invasion was seen to be imminent, and in August officials were nominated to survey and take up all ships of 50 tons and upwards." For the southern fleet the place of concentration was Portsmouth. Early in September it was decided to strengthen the royal fleets still further by calling upon those who had not been affected by the first levy to contribute to the equipment of more ships. Melcombe was charged with three ships and 76 men, Weymouth two ships and 82 men, Poole six ships and 163 men, and Lyme five ships and ${ }_{1} 6_{4}$ men. $^{45}$ It will be noticed that Bridport is absent from all these lists, and the fact that it does not appear in the minute survey of 1326 shows that it was known not to possess any sea-going craft. ${ }^{46}$ There was no harbour, ${ }^{47}$ but some sort of shallow river exit, unfit for shipping of any size, must have existed and this had gradually deteriorated since the Saxon era. Such aid as it could give probably went to assist Lyme.

A short war with Scotland marked the accession of Edward III, but there were no naval operations on a large scale. The Cobb of Lyme, which probably dates from the reign of Edward $I$, when the town was making such progress, ${ }^{48}$ is the subject of a writ in 1328 ; it was then much decayed, and a toll for five years on all merchandise was granted for its repair. ${ }^{49}$ It was said to be built of timber and stone, no doubt in the same way as is shown plainly in a map of the reign of Henry VIII. ${ }^{50}$ Another Scotch war commenced in I332, and for some years general arrests of shipping followed each other in quick succession. At last the towns were becoming impatient of the injury to commerce, due rather to the embargoes which preceded the actual taking up of ships than to the levies themselves; moreover the Scots had the unofficial assistance of France and Flanders, and for the first time carried on an effective maritime war. There were signs of

"Close, 17 Edw. II, m. I I d., $9 d$. "Ibid. m. 6 d. $\quad{ }^{43}$ Add. MSS. 26891 , fol. 50.

"Close, zo Edw. II, m. I $d$. "Ibid. m. 8. 18 Pat. 20 Edw. II, m. 21 . "Post, p. 189.

18 Ant?, p. 181 . Lyme was incorporated in 1284 , but the frosperity of the town must have followed the consiruction of the Cobb, which must, therefore, be early Edward I, if not of the reign of Henry III.

${ }^{\prime 9}$ Pat. 2 Edw. III, pt. ii, $m$ I 5.

${ }^{30}$ Post, p. 197. 


\section{MARITIME HISTORY}

restiveness in several parts of the kingdom. Edward met the difficulty by, in appearance at least, taking his subjects into his confidence, and in December, I $33^{6}$, sent a representative round the coast to explain 'certain things near the king's heart.' ${ }^{51}$ Also, he summoned delegates from the ports to meet him at Westminster and discuss matters when, we may be sure, social and other influences were brought to bear on them; Weymouth, Melcombe, Poole, Wareham, and Lyme, were all invited to send their burgesses. ${ }^{52}$

France declared war formally in $\mathrm{I} 337$, and expectation of invasion grew acute in Dorset and Hampshire, where beacons were held ready and keepers of the coast appointed. The anticipated blow fell upon Portsmouth in I 337, and on Southampton in $133^{8}$; but nothing is known to have happened in Dorset in either year. The statement in the Inquisitiones Nonarum of $\mathrm{I}_{340^{53}}$ that Portland had been burnt and devastated probably relates to I 339 , because there is a writ of that year discharging the men of Studland, Swanage, Whitecliff, and Herston of certain liabilities in consideration of the injuries suffered in a recent maritime raid.54 The landing here and at Portland is likely to have been the work of the same squadron. Edward went to Flanders with an army in 1338 , and the usual demands for shipping were made, Wareham sending one vessel, Melcombe three, Weymouth and Poole six each, and Lyme five. ${ }^{65}$ The French fought chiefly with hired Italian vessels, and although they were unable to win any striking success they were in superiority at sea until the great victory of Sluys, in I 340 , restored our supremacy for many years. By that time the strain of a period of more or less unsuccessful maritime war, and of commercial losses, was telling upon the English reserve of shipping therefore the sheriffs of the coast shires were ordered to prevent any sale of ships to foreigners. ${ }^{56}$ In consequence of the losses suffered by the ports it was necessary for the crown to come to their assistance, so that when those of the south and west promised, in I 340 , to equip seventy ships of roo tons and upwards as far as possible at their own cost, the Council undertook to help them with money 'as an especial grace. ${ }^{157}$ No doubt some of the Dorset ports obtained a share of the royal favour. To deal with the difficulties of the situation another advisory council of shipowners and shipmen was summoned to meet at Westminster in $134 \mathrm{I} ;{ }^{58}$ to this Weymouth and Poole each sent a single representative, whereas the great ports sent two each. The plan of holding what was a subsidiary maritime Parliament must have been found to have its advantages, for it was repeated in 1342 , I 344, and 1347 . In 1342 and 1344 Poole, Lyme, Weymouth, and Melcombe sent delegates; in 1347 Weymouth was omitted.

Complications arose in Brittany in I 342 through the death of the duke without direct heirs, leading to the dispatch of a large fleet and army under Sir Walter de Mauny, in March, while Edward himself crossed later in the year. In one fleet alone there were 357 vessels, of which Poole sent four, Weymouth and Melcombe four, and Lyme one. ${ }^{59}$ An undated list, probably

sl Close, Io Edw. III, m. 4 d.

${ }^{53}$ Op. cit. (Rec. Com.) 50.

${ }^{59}$ Rot. Scot. 10 Edw. III, m. 3 d.

${ }^{34}$ Close, is Edw. III, pt. i, m. 7 .

${ }^{55}$ Misc. Bks. of Exch. Tr. of Rec. 203, fol. 2886. We have here an opportunity of testing the accuracy of the chroniclers. Stow (Chron. [ed. 1615], p. 235) say's that Edward crossed with 500 ships; the pay" sheets show that, altogether, 338 were in commission from July to November, 1338 .

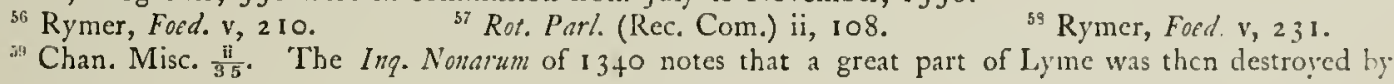
the sea. 


\section{A HISTORY OF DORSET}

relating to another fleet prepared for this expedition, gives a total of II 9 vessels, of which Poole sent three barges and Weymouth four. ${ }^{60}$ When Edward returned from Brittany in March, I 343, he landed at Weymouth, ${ }^{61}$ but there were reasons why his visit was not likely to be very welcome. After his arrival at Brest in the previous October, many of the transports had deserted, 'leaving him and his army in very great peril.' There could have been no secret about the fact that he intended to make an example of the transgressors, although the first writs relating to the matter did not issue until May. Two Weymouth vessels had left him, and if the owners or others concerned were present at his arrival in the town they probably lived through some unpleasant minutes; the men of three Poole ships and one of Lyme had also committed the same offence. ${ }^{62} \quad$ Altogether, from all the counties, 293 ships and their masters were scheduled, and it is certain that, at least in some cases, the owners were severely punished by fine or confiscation. The sum of upwards of $f_{0} 3,000$ was levied in fines varying in amount from 6 s. $8 d$. to $f_{0} \mathrm{I} 80$; the owners of a Poole ship paid $£_{335}$, and those of another of Weymouth $f_{40} .^{63}$ Usually, although threats were frequent and the possible penalties heavy, owners escaped lightly, the shipping interest being too powerful and important to be offended without serious consideration.

There was a truce with France from January, I 343, which lasted, except for small violations on either side, until the campaign of Crecy opened. For Edward's passage, a great fleet-from I,000 to I,600 sail, say the chroniclers -was collected, and another attended the siege of Calais. The original record, said to be a Wardrobe Account, containing a list of the fleet at Calais, appears to have perished; the existing copies, which offer internal evidence that the original MS. was in some places nearly or quite illegible when it was transcribed, are of the late sixteenth and early seventeenth centuries. There are discrepancies in these MSS. in the details relating to many of the ports, but in Dorset the figures are in agreement except in the case of Weymouth. Lyme sent 4 ships and 62 men; Poole, 4 ships and 94 men; Wareham, 3 ships and 59 men; of the six MS. copies available, five assign Weymouth 15 ships and 264 men, ${ }^{64}$ but the sixth gives it 20 ships with the same number of men. ${ }^{65}$ Melcombe, and the whole district around, must be included in Weymouth; with Melcombe it was evidently growing a big place. Its great neighbour to the east, Southampton, sent 2 I ships to Calais; Plymouth, to the west, rapidly growing into a powerful naval port, sent 26 ; with both it compares favourably, in view of a late start and some obvious disadvantages, but both without doubt possessed bigger ships than Weymouth and Melcombe although they do not appear in these lists. The mercantile and maritime importance of the towns is indicated by an order of 1347 directing the bailiffs to treat Venetian ships in a friendly manner; ${ }^{60}$ this associates them

"Chan. Misc. $\frac{i 1}{46 .}$ The great ports sent ships as well as barges, e.g. Southampton five ships and one barge.

${ }^{6}$ Close, 17 Edw. IlI, pt. i, m. $23 d$.

${ }^{62}$ Ibid. m. 4 d.; Pat. $17 \mathrm{Edw}$. III, pt. i, m. 17 d.

${ }^{63}$ Pipe R. 21 Edw. III, m. 29.

"Stowe MSS. 570 , fol. 23 ; ibid. 574 , fol. 28 ; Harl. MSS. 3968 , fol. 1 30 ; ibid. 246 ; Rawlinson MSS. (Bodleian) C. 846 , fol. 17 .

${ }_{65}$ Cott. MSS. Titus, F. iii, fol. 262 . The ships belonging to the eighty-three ports enumerated are nearly all small ones. Large vessels would only have gone aground off Calais at that time; small coasters of light draught were required. The Calais Roll is often quoted as a measure of the maritime strength of England in 1346 , but, even if it were reliable, it is plainly nothing of the sort. 1t may, however, be a guide to the amount of shipping engaged in the coasting trade.

${ }^{66}$ Close, 2 I Edw. III, pt. i, m. 8. 


\section{MARITIME HISTORY}

with only six other ports in England, and we may therefore infer the occasional arrival of a Venetian galley either for trade or for shelter. In 1352 Weymouth and Melcombe were the only ports in Dorset to which a writ was sent, repeating the inhibition on the sale of English vessels to foreigners, which is further evidence of their strength in shipping. ${ }^{67}$ Melcombe is frequently mentioned during this reign in relation to the export of wheat and as a passage port to France; in I 37 I the town authorities were directed to allow Portuguese merchants to trade there peaceably. ${ }^{68}$

The naval history of Edward III is an illustration of the fact that the uniform result of the destruction of an enemy's military fleets, formerly, was an increase of raids and privateering. Although naval victories were won and no resistance was, or could be, made to the transport of Edward's armies, the coasts were continually harassed by French incursions or the fear of them, while the sense of weakness was increased by the loss due to privateers and the exhaustion of the shipowning classes. In I 348 Bindon Abbey was practically in the hands of receivers, and the misfortune was attributed, among other causes, to the losses caused by the enemy's raids. ${ }^{69}$ The reference may be to the events of I 339 , but if, on the other hand, they were recent-and Budleigh, in Devonshire, had suffered considerably in I 347 -it shows that while the English fleets were in absolute command of the Channel, they were still unable to prevent those injuries which even the victor suffers in all wars. An unstable peace endured between I 360 and I 369 ; the recommencement of hostilities in the latter year was followed by a meeting of another council of maritime experts at Westminster, to which Weymouth, Poole, and Lyme sent representatives. ${ }^{70}$ The renewal of the war was attended by the complete loss of English supremacy in the Channel. Levy followed levy without result or with calamity, for while France was displaying an unexpected strength at sea England was suffering from the weariness of a long war and a weakening government. The Commons laid before the king the causes to which they attributed the decay of shipping, and in June, I 372 , after the defeat of the earl of Pembroke before Rochelle, the crown was reduced to collecting troops along the coasts of the maritime counties to repel invasion instead of defending them by fleets at sea. The ordinary rate of hire for ships taken up by the crown was $3 s .4 d$. a ton for every three months, but now both that and wages were left unpaid in contrast to the liberality Edward had shown thirty years earlier, when he could afford to make extra and unusual payments to help the equipment of the fleets. The year I 375 was marked by another maritime disaster in the shape of the capture or destruction in Bourneuf Bay of 39 merchantmen, ranging from 300 tons downwards. Three Weymouth ships, of which one was of 100 tons, were lost there. ${ }^{71}$

Edward III died 21 June, 1377 , and within a week of his death the French were raiding the south coast from Kent to Cornwall. Several towns were more or less wasted, and Melcombe is ranged among them by one chronicler; it must have suffered severely, for in December, I 378 , the burgesses petitioned to be allowed delay in paying the tenths and fifteenths, because lately 'burnt and destroyed.' ${ }^{2}$ In another petition of 1379 they asked

\footnotetext{
${ }^{67}$ Close, 25 Edw. III, m. $4 d$.

${ }^{6}$ Pat. 22 Edw. III, pt. i, m. 9.

"Chan. Dipl. Doc. P. 324.
}

\footnotetext{
${ }^{68}$ Rymer, Foed. (ed. 1816), iii, 929.

${ }^{70}$ Rymer, Foed. (ed. 1816), iii, 880.

i2 Close, 2 Ric. II, m. $22 d$.
} 


\section{A HISTORY OF DORSET}

for allowances to pay for walling the town. ${ }^{73}$ In I 388 the farm, as well as the tenths and fifteenths, was remitted for seven years, because 'often' burnt and destroyed by the enemy, the inhabitants having thereby been driven away. ${ }^{74}$ From this it may be guessed that it suffered again when the Constable, Oliver de Clisson, harried the coast in 1380 . These attempts at alleviation were fruitless, for in 1394 a further remission for twelve years was necessary. ${ }^{75}$ When this term expired the town was still 'poor and desolate,' whereas of old the customs and subsidies were wont to amount to $f_{0} 1,000$ a year. ${ }^{76}$ In 1410 there was further reason for petition, but here the customs and subsidies were stated as being at least 1,000 marks. ${ }^{76 a}$ In this a definite assertion is made that the town was burnt in the reigns of both Edward III and Richard II ; the exact date of the first attack must remain unknown, but it may have occurred a few days before Edward's death.

These petitions and allowances can be traced as late as I 433 , when

having consideration of its feebleness and non-sufficiency, nought inhabited nor of strength ... as it well seemed by the loss that John Roger and other had there late for lack and scarcity of help and people to withstand . . . your enemies,

so that traders feared to send or receive merchandise there, Melcombe was discontinued as a customs port, the collection being removed to Poole. ${ }^{77}$ The story of the ruin of Melcombe, due to two French attacks and acknowledged after half a century of struggle and decline, is of general as well as of local interest. It has been held ${ }^{77 a}$ that 'cross-ravaging,' i.e. raids for destruction and plunder such as French and English inflicted on each other in the mediaeval period, were of no value in helping towards the decision of a war. It is altogether questionable whether such raids were merely for plunder, ${ }^{78}$ but it is obvious that any permanent injury done to an element of national strength, such as a commercial town, reduces by that much the power of the state in the immediate war and in the endless national rivalry which is the cause and sequel of wars. Here, Melcombe, which had been climbing gradually to a place among the leading ports, soon ceased to be a revenue-producing portion of the body politic; its shipping must have nearly disappeared, and with its shipping its trade and seamen, for in 1407 there were only eight burgesses, and therefore few employers. By all this the nation was so much the poorer in its future contests with France. Locally, the effect of the disaster must have been widespread in the district to which it had been the seaport, for it was practically the only outlet between Poole and Lyme; the difficulty and cost of transit in transporting merchandise between the interior it had served and the eastern and western borders of the county must, for a time, have extinguished the nascent commercial spirit growing up inland. By this, again, the nation as a whole was the poorer. But for its association with Weymouth in the Newfoundland fishery, which gave it a term of renewed life for two centuries, it would at once have sunk to the condition of coast village from which it was rescued by the favour of George III. Moreover, it is not unlikely that had it continued to grow in the especial attributes of

is Rot. Parl. (Rec. Com.), iii, 70.

"Pat. 2 Ric. II, pt. ii, m. 12.

is Ibid. 17 Ric. II, pt. ii, m. 30.

Rot. Parl. (Rec. Com.), iii, 616. Before the assault of 1377 there were 24 sea-going vessels and 40 fishing boats belonging to the town. Hutchins, Hist. of Dorset ( $3 \mathrm{rd} \mathrm{ed}$.), ii, 450 .

i6. Rot. Parl. (Rec. Com.), iii, 639.

${ }_{77 a}$ Colomb, Naval W'arfare, 3.

77 Ibid. iv, 445 .

${ }^{i s}$ Cf. V.C.H. Sussex, 'Maritime History', ii, 1 fo. 


\section{MARITIME HISTORY}

a seaport, and, therefore, been able to supply naval necessaries, its position might have caused Henry VIII to select it as a fleet-base under the altered condition of naval operations against France in his reign.

It will be noticed that there is no reference to Weymouth in the foregoing petitions to king and Parliament. The town may have shared the fate of Melcombe or it may have escaped as poorer and less tempting than its neighbour ; in any case it was more difficult to attack and more easily defended than Melcombe.

The burgesses of Lyme petitioned in February, I 378 , that the town was being wasted by the sea and that the Cobb, large enough to shelter two or three barges-from which we get an idea of its size-had been destroyed in the gales of the previous November. ${ }^{78 .}$ In this nothing was said of any French descent, but in one of their numerous appeals for help-that of I 4 IO -they stated that the place had been burnt by the French in the reigns of both Edward III and Richard II. ${ }^{79}$ It is probable, too, that Poole was partly burnt in $1377 .{ }^{99 a}$ The misfortunes of their neighbours may have aroused the energy of the men of Bridport and tempted them to an effort to take the lead of Lyme. In I $3^{8} 5$ there was grant of a toll for three years to John de Hudresfeld who had begun to make a harbour, there having been none previously. The toll was continued for another year from I 388 , and again for three years from 1393 , to enable the bailiffs of Bridport, who then claimed to have begun the construction of the harbour, to finish it. ${ }^{80}$ The fact, however, that the toll was on goods exported or imported by water shows that there must have been some small shipping trade before the improvement was effected.

That the events of I 377 could have occurred proves that the English fleet was practically non-existent; in November of that year Parliament decided that the country generally, including inland towns, should be required to build ships by the following March, which is evidence of the known exhaustion of the ports. No town in Dorset was called upon, and that omission is almost conclusive that the county had suffered severely in the summer. For years the coast was more or less in a state of blockade ; alarms of invasion were frequent and the local levies were continually under arms. The marine of Weymouth was not entirely destroyed, for we find two ships, of which one was of 120 tons, taken up about I $383 .{ }^{80 a}$ When John of Ghent sailed for Spain in 1386 to obtain the crown of Castile his fleet of 57 ships included the Fames, 80 tons, of Poole. This ship was also engared in the passenger trade, now developing, in the carriage of pilgrims direct from England to perform their devotions at the shrine of St. James of Compostella. ${ }^{81 a}$ Another such vessel was the Katberine, of Lyme, newly built in $1395^{81 a}$

Formal hostilities with France ceased in 1389 , but although no declaration of war came from either side during the remainder of Richard's reign and that of Henry IV, the truce was only nominal. English and French royal fleets did not meet as declared enenies after a ceremonial rupture, but short of that the conditions differed nothing from open war. French and

\footnotetext{
${ }^{78_{2}}$ Pat. I Ric. II, pt. iii, m. $3 d$.

${ }^{70}$ Ror. Parl. iii, 640.

79a Froissart, Chron. cap. 378.

${ }^{80}$ Pat. 9 Ric. II, pt. i, m. 20 ; ibid. 12 Ric. II, pt. i, m. 3 ; ibid. 16 Ric. II, pt. ii, m. 10.

${ }^{80.3}$ Exch. Accts. K.R. bdle. 42, No. 22.

${ }^{5}$ Ibid. I 8 Ric. II, pt. ii, m. 15.

${ }^{81}$ Pat. 19 Ric. II, pt. i, m. 29.
} 


\section{A HISTORY OF DORSET}

English raided each other's coasts, and each made captures at sea. War was considered so certain in I $40 \mathrm{I}$ that in January not only the ports but many of the inland towns were ordered, singly or in combination, to build and equip ships at their own cost by the following April ${ }^{\mathrm{s}}$; Weymouth was grouped with Seaton and Sidmouth for a balinger between them, Lyme with Exmouth for one barge, and Poole, Wareham, and Melcombe together for another. It is difficult to say which town takes the lead as being considered the wealthiest in the county, but Melcombe is shown to have fallen from its former place. Parliament met on 23 January and protested against this call upon the country. Henry's position was too uncertain to permit him to insist, as he might have done, on the strict legality of his action, therefore he was compelled to content himself with a general arrest of shipping, in May, of the usual type, by which the same ports were affected. ${ }^{82 a}$ English merchants were reckoning up French spoliations to the amount of $f_{1} 100,000$, done under cover of the Scotch war, and the French chroniclers were recording the ravaging of their coasts by whole fleets of English pirates. The famous Henry Pay, of Poole, appears in 1402 as charged with piracy in company with other sailors belonging to towns of the south coast. ${ }^{83}$ By I 404 the political vane had veered and Pay was then empowered to fit out privateers, perhaps because the French had fallen upon Portland in the spring and swept it with fire and sword. They did not, however, escape scathless; probably their strength was very small, and when the inhabitants, reinforced from the main land, attacked them many were killed or taken prisoners. ${ }^{83}$ In 1405 an English fleet burnt 40 Norman towns and villages, and the French took some small revenge along the south coast. It had been intended that three galleys and 40 ships belonging to Castile should have joined a French squadron; but in the result only the three Spanish and two French galleys, under Don Pedro Niño and Charles de Savoisi, sailed in August. After operations in Cornwall and Devon they made Portland, where they met with little resistance. ${ }^{83 b}$ Then the writer of $L a$ Victorial digresses at length on the misdeeds of Henry Pay ('Arripay"), and as they were under the impression that Poole belonged to him it was no wonder that the commanders seized the opportunity to pay some old debts. They went into the harbour one morning towards the end of September and found the town unfortified but looking defensible and populous-so much so that Savoisi, whose feelings were perhaps less embittered, refused to allow his men to land. The Spaniards went ashore, and there was a sharp fight ; their object being revenge they tried to fire the place rather than to plunder it, and they did burn some buildings, including a large storehouse full of naval stores. Eventually the Spaniards were so hard pressed that the French had to come to their assistance; and although the Spanish writer says that the English were forced to give way it seems more likely, as the town was not burnt, that the French only succeeded in bringing off their allies. One of Henry Pay's brothers was killed in the defence. The redoubtable Pay was himself at sea in 1407 , and took a fleet of 120 French merchantmen, but it is uncertain whether he had any Dorset ships with him.

${ }^{53}$ Rymer, Focdera, viii, 172.

${ }^{623}$ Pat. 2 Hen. IV, pt. ii, m. 16.

${ }^{63}$ Close, + Hen. IV, m. 30 . m. A.)

3. Rymer, Focdera, viii, 356. The 'Raase' of Portland is noticed in I 408 (Roll of For. Accts. 1o Hen. IV', ${ }^{63 b}$ L.a Victorial (ed. Circourt et Puigaigre), Paris, 1567. 


\section{MARITIME HISTORY}

The closing years of the reign of Henry IV were somewhat more peaceful at sea than had been the earlier ones. Henry $V$ had perhaps formed his own opinion of the anarchy that had existed, for in $14 \mathrm{I} 4$ he instituted officials, called conservators of truces, in every port who, assisted by two legal assessors, and holding their authority from the High Admiral, were to have powers of inquiry and punishment in relation to all illegal proceedings at sea. ${ }^{84}$ They were to keep a register of the ships and seamen belonging to each port and acted as adjudicators in such cases as did not go before the Admiralty Court. They seem, so far as related to judicial functions, to have been a link on the civil side between the earlier keepers of the coast and the vice-admirals of the coast created in the sixteenth century. That the statute was strictly enforced and helped to produce quieter conditions at sea is shown by the fact that two years later the king consented to some modification of its stringency by promising to issue letters of reprisal when equitable. In I 435 it was entirely suspended, being found 'so rigorous and grievous,' said the Commons; in that year Burgundy broke away from the English alliance, and the shipowners foresaw hostilities and profits. In I 45 I it was brought into force again for a short time, and once more renewed by Edward IV.

Henry $\mathrm{V}$ began his reign with the intention of having a great fleet of his own. The custom of general impressment was now expensive, both to the shipowner and to the crown; moreover, it was slow in operation, while in the mind of a great soldier like Henry speed in concentration and in striking was a necessary element of his combinations. There were also political reasons for not disturbing trade, now beginning to take a wider flight. The system could not be, and was not, at once abolished, but it became much less frequent during the fifteenth century; a definite note of change is sounded in the establishment of cruisers round the coast in I4 I5, five vessels being stationed between Plymouth and the Isle of Wight. ${ }^{85}$ The great fleet of upwards of 1,400 vessels required for the campaign of Agincourt included a contingent from Dorset, but very many were hired in Holland and Zealand, either because the resources of the kingdom were insufficient or Henry resolved not to tax them unduly. In 1416 the French had a fleet at sea which contained some hired Spanish and Genoese vessels of large size; they were off Portland in May, and did some damage in the island, but as a whole their cruise was not very successful, and in August many of the ships of their fleet joined the Royal Navy by right of capture. For Henry's passage to France in I 417 another large fleet was collected, but out of one list of 238 vessels I 7 belonged to Holland and Zealand. Many of the English ports were unrepresented, and it seems clear that Henry had determined from the first to make war with as little economic disturbance as possible-to do with his own ships the fighting which cleared the road and to use foreign ones to transport his troops. There were, however, six Dorset ships in the fleet of I 417 , three from Poole, two from Wareham, and one from Weymouth. ${ }^{86}$ It has been noticed that the oversea transport of pilgrims to the shrine of St. James was springing up during the reign of Richard II. The business grew rapidly during the first half of the fifteenth century, and merchants and nobles seem to have been equally eager to obtain a share in what must have been a lucrative traffic. Most of the ships so employed

$$
{ }^{2} \text { Hen. V, cap. 6. } \quad{ }^{85} \text { Proc. of P.C. (Ist ser.), ii, 145. } \quad{ }^{66} \text { Rot. Norman. (ed. Hardy, 1835), 320-9. }
$$




\section{A HISTORY OF DORSET}

belonged to the southern ports, but any taken up for the purpose must necessarily have been of considerable size judged by the standard of that age. Ships of Weymouth and Poole were running frequently, and occasionally one from Wareham. ${ }^{87}$

After the death of Henry $V$ one of the first proceedings of the Regency was to sell off the Royal Navy by auction, but the loss was not felt at once, because there was no French force capable of contesting the dominion of the sea. There were arrests of shipping during the early years of the new reign, but there was now a general feeling that in this method 'the long coming together of the ships is the destruction of the country.' ${ }^{88}$ Vessels were still impressed for the transport of troops, but the cruising service was handed over to contractors who undertook to keep the sea with a certain number of ships and men for a specified time. Of course, the contractors desired to obtain as much money and go to as little expense as possible ; their guardianship was quite ineffective, and as early as 1429 the Commons petitioned about the pirates who were again becoming numerous in the Channel. ${ }^{89}$ Perhaps among the rovers referred to were the crews of the fames of Studland and Welfare of Swanage, who drove ashore a foreign ship and then plundered her. ${ }^{90}$ Parliament, in 1442 , expressed the general dissatisfaction with the contract system, and prepared a scheme by which it squadron was to be made up of selected ships from various ports. None of the large ships came from Dorset, but a barge and a pinnace, belonging to Harvey Russell of Weymouth, were chosen. ${ }^{91}$ All the vessels of this squadron seem to have been picked ships with a reputation. Poole replaced Melcombe as a customs port in 1433 , and in view of its promotion obtained a licence to fortify, but it seems to have been little, if at all, in advance of Weymouth in maritime importance; in 1454 the two places were joined for a contribution of $f, 50$ when certain nobles undertook to keep a fleet at sea. ${ }^{92}$ The Bridport Harbour of $1385-95$ can never have been a great success; by I 447 it was in a ruinous condition, and the burgesses were too poor to restore it. From the two archbishops and from thirteen bishops they procured indulgences by the sale of which they hoped to gain sufficient money to pay for the repairs. At the time politics were exciting more urgent interest and there was no great demand for indulgences; one of the collectors wrote that to his 'great shame and anger' he was not making enough to pay his expenses; another disappeared with all that he had received. ${ }^{93}$ There may also have been French raids checking coastal traffic and growth generally. According to one writer Bexington, near Abbotsbury, was burnt in such a descent in 1439 or 1440 , after which it was deserted. ${ }^{94}$ If this is true Bexington could hardly have been the only place in the county which suffered, and it is certain that in other counties there were similar attacks not recorded by the chroniclers.

There are extant several lists of ships taken up for the transport of troops in $1439,1440,1443,1447$, and $1452 ;{ }^{95}$ of these expeditions those of 1439

${ }^{57}$ Rot. Franc. pass. $\quad{ }^{89}$ Proc. of P.C. (Ist scr.), v, $102 . \quad{ }^{89}$ Ror. Parl. (Re : Com.), iv, 3 jo.

${ }^{90}$ Pat. 7 Hen. VI, pt. i, m. I 6 d. 'Sandwich' in the writ, but as late as the eighteenth century Swanage was often called Sandwich.

O' Ror. Parl. (Rec. Com.), v, 59

. Only sixteen towns were assessed, including London, Bristol, Southampton, \&c.

${ }^{93}$ Hiss. MISS. Com. Rep. vi, App. 495.

${ }^{93}$ Exch. Accts. K. R. bdie. 53 , Nos. 23, 24, 25, 39 ; bdle. 54, Nos. 10 , I t. 


\section{MARITIME HISTORY}

and 1440 sailed from Poole. Seeing that the lists represent only a portion, large or small, of the merchant marine, they show that notwithstanding war and weak government it was still flourishing, a few of the vessels being of 300 and 400 tons. None of this size came from Dorset; the largest, of 180 tons, belonged to Weymouth, and four others were also owned there, including one of 100 and one of $\mathrm{r} 20$ tons. There were six Poole ships, of which the largest was of $\mathrm{I} 60$ tons and the next of $\mathrm{I} 20$ tons; Swanage sent one vessel of 26 tons.

Sea-power played no great part in the wars of the Roses, both parties enjoying freedom of water transit. As a whole the ports were Yorkist in their sympathies, and the Weymouth people had so far impressed Edward IV with their affection for him that in 146 I he made them a grant of $f_{100}$ in recompense of the losses they had sustained in supporting him..$^{96}$ Almost simultaneously there was a pardon to Lyme-which, as usual, was pleading devastation by the sea- of arrears due to the crown, therefore that town also may be assumed to have been Yorkist in inclination. ${ }^{97}$ Margaret, with the Prince of Wales, landed at Weymouth, driven in by weather, on 14 April, I $47 \mathrm{I}$, the day the battle of Barnet was fought, but she probably received scant welcome for Weymouth was still in favour with Edward and receiving benefits from him in $1467 . .^{98}$ There were several arrests of ships in 1475 for the French war ; one of them, from Newcastle to Bristol, must be almost, if not quite, the last example of a general arrest affecting the whole country. In October, 1484, Henry Tudor sailed from Brittany to join the duke of Buckingham, who had revolted against Richard III. Henry's fleet was scattered by storm; he made Poole in his own ship, but was too wary to be enticed ashore among the enemies waiting for him. Neither Dorset nor any other county has much maritime history during the reign of Henry VII. The king was not ignorant of the value of sea-power, and he increased the crown navy, but his reign was peaceful and he preferred, for political reasons, to hire Spanish ships to act with his own where his predecessors would have used English ones. In relation to Dorset the most important event of the reign, although unrecognized at the time, was Cabot's Newfoundland voyage which, as the first cause of the fishery, was to have a far-reaching influence on the fortunes of Weymouth and Poole.

During these centuries there must have been many wrecks on the deadly Chesil beach, on Portland, and in the scarcely less dangerous bay between Portland and Durlstone Head. They do not appear in the records for, unless a cargo was of more than ordinary value, the time and money necessary to set in motion the cumbrous processes of the crown must have been prohibitive of appeal when survivors had seen their property shared anong the landowners in the vicinity of the wreck. The right of wreck was coveted by manorial lords and corporations, both for profit and as evidence of exemption from the inquisition of the High Admiral. Legally, if man, dog, or cat escaped alive from a ship it was no wreck, but if the cargo once came into the hands of those ashore there was small chance of recovery. Every corporation used such influence as it possessed to obtain local jurisdiction in admiralty matters, not only as a question of dignity and profit but even more in order to escape the arbitrary and expensive proceedings of the Lord Admiral's deputies, who

${ }^{96}$ Pat. 1 Edw. IV, pt. iv, m. 20.

2
${ }^{97}$ Ibid. pt. iii, m. 10.

193
${ }^{99}$ Ibid. 6 Edw. IV, pt. ii, m. 13. 


\section{A HISTORY OF DORSET}

brought much odium upon their master. In Dorset the crown had, from very early times, granted away much of its right of wreck; we find from the Hundred Rolls that in 1275 the abbey of St. Edward had such rights in the manor of Studland, the abbey of Cerne at Bridport, the abbey of Bindon at Waddon, the priory of Christchurch at Fleet, and, besides other private owners, the earl of Gloucester in the manors of Wyke, Weymouth, Portland, and Holwell.

In the reign of Edward II the abbey of Milton took wreck at 'Fromemouth,' Osmington, Holworth, and Ower. ${ }^{99}$ 'The reference to Fromemouth is interesting because the corporation of Poole claimed to have enjoyed admiralty rights, in a wide form, from time immemorial, although the legal recognition of them was comparatively late. Wreck on Brownsea Island was granted to the abbey of Cerne in I I $54,{ }^{100}$ and at the dissolution this passed to the earl of Oxford. In ${ }_{13} 64$ the Poole burgesses obtained a certificate from the mayor and barons of Winchelsea on which they pretended to rely in support of their claims, but the certificate only defines the extent of Poole harbour, and in any case would have no more value as evidence about admiralty rights than one from the town crier. The real recognition of their freedom from the Lord Admiral's inquisition is contained in an inspeximus of 4 September, I 526 , by Viscount Lisle, on behalf of the Lord Admiral, which placed their claim on a firm basis by confirming their exemptions. This inspeximus does refer to early exemptions which may have been exercised by prescription, and if such exercise had been tacitly allowed it is evidence of the maritime importance of Poole, for the crown only granted such rights by way of reward, or permitted them to be practised when the ports were able to render services of value to the state. But the Lord Admiral's deputies continued to act in Brownsea, possibly by succession from the earl of Oxford, and the conflict of authority gave rise to much friction. ${ }^{101}$ The Weymouth people insisted at one time that their admiralty rights were held in virtue of a grant from King Ethelred, ${ }^{103}$ but it is more likely that, as in the case of Poole, they had been permitted when Weymouth and Melcombe seemed growing into first-rate ports. The Ethelred basis was never admitted by the Lord Admiral, and there were frequent disputes between his officers and those of the town during the reign of Elizabeth; ${ }^{103}$ the charter of I July, I6I 6, at last gave Weymouth and Melcombe freedom from the Lord Admiral's visitations.

With the reign of Henry VIII the era of arrests and impressment of shipping may be said to have terminated. The port towns were still sometimes to be called upon to provide ships, but such towns were usually associated in order to lessen the expense and, eventually, the county as a whole contributed to the cost. Improvements in building and armament were now differentiating the man-of-war from the merchantman; the latter was of little use in fleets except, as an Elizabethan seaman said, " to make a show,' and to have required the ports to furnish real men-of-war would have ruined them. It was one of the purposes of Henry's life to create a national navy, and there was not a year of his reign that did not witness some accretion to its strength. Such merchantmen as he required were hired without

${ }_{99}$ Pat. 5 Edw. II, pt. i, m. 17.

${ }^{101}$ Post, p. $198 . \quad{ }^{109}$ Add. MSS. 12505 , fol. $392 . \quad{ }^{103}$ See bost, p. 198. 


\section{MARITIME HISTORY}

the exercise of the prerogative, but the more effective the royal navy became the less reason there was for the employment of armed merchantmen except under especial circumstances. It is not until the reign of Elizabeth that we find in force the further development of the right of impressment, the demand for fully-armed ships at the cost of the ports, which was the immediate legal precedent for the ship-money levies. The first war with France, of I 5 12-13, was fought almost entirely by men-of-war; there were some hired ships, as tenders and victuallers, with the fleets but none is known to have come from Dorset. It need hardly be said that although impressment of ships had practically ceased the impressment of men continued, and among the crews of the 15 I2-I 3 fleets 126 men came from the Chideock district. ${ }^{104}$ Shipwrights and caulkers were impressed at Poole at the same period to come to the new dockyard at Woolwich to help in the building of the Henry Grace de Dieu. ${ }^{105}$ Bridport was encouraged in the conduct of its particular industry, cables and cordage being bought there by the government; in 1530 a statute was enacted intended to benefit the town by preventing local competition. ${ }^{106}$ Melcombe was still impoverished, and even towards the end of the reign obtained reductions in the farm and in taxation on account of the destruction wrought so long ago by the French.

War with France and Scotland broke out again in 1522 but the ports play little direct part in the naval warfare of Henry VIII nor, if they had been called upon, were those of Dorset likely to have added any material strength to the national armaments. Lyme obtained a grant, in 1535, of f.20 yearly for ten years in consideration of the ruinous condition of the Cobb, and petitioned again in the following year that the town was decaying. ${ }^{107}$ In 1543 a return of shipping, generally, was called for in view of approaching war, from which we find that there were six vessels sailing from Lyme, of which the largest was of 72 tons; one of the owners lived at Bridport and another at Chard. ${ }^{103}$ Only I 3 seamen were named, probably those at home at the moment of registration. There were 19 men and one vessel of 14 tons at Charmouth, 14 men and one vessel of 18 tons at Bridport, two ships, of which the largest was of 60 tons, and 18 men at Weymouth and Melcombe, and three vessels, of which the largest was of 70 tons, at Poole. The biggest vessel owned in the county was the Mary and Fobn, of I 20 tons, belonging to Thomas Wade of Burton Bradstock; upwards of I 70 seafaring men lived in the villages along the coast.

About 1539 Henry feared that an alliance of the continental states would be formed against the kingdom. The new navy, although a mightier offensive weapon than any that England had hitherto possessed, was as yet an untried weapon. The preceding centuries were fraught with the lesson that the enemies of England were best met on the English seas, but there was a natural inclination, especially in an age which was tending towards formalism in military science, to fall back upon the orthodox defences of castles, sconces, and bulwarks to prevent a landing or to support a defending force. As early as 1535 the idea of fortifying the weak points round the coast was in the air, for Cromwell then noted in his 'Remembrances' that a small tax formerly paid to Rome might well be diverted to such a purpose. However at that

${ }^{10}$ Chap. Ho. Bks. ii, fol. 7.
${ }^{107}$ L. and P. Hen. VIII, viii, I 49 (12); ; ibid. x, I 79.

195
${ }^{106} 2$ I Hen. VIII, cap. I 2 .

${ }^{108}$ Ibid. xviii, 547 . 


\section{A HISTORY OF DORSET}

time Calais and Dover were the only places upon which money was being spent lavishly, and the fortifications elsewhere were not commenced until I 539. It appears that, at first, Lyme was the only Dorset port set down for defence, ${ }^{109}$ but when commissioners to 'search and defend the coasts' were shortly afterwards appointed their recommendations caused a larger plan to be framed. ${ }^{110}$ Sir John Russell became a peer in the spring of 1539 ; in April he surveyed the coast of Dorset and sent 'a plat' of it to Cromwell."11 This map is no doubt the one now in the British Museum Library, ${ }^{118}$ which shows proposed works at Bournemouth, Brownsea, Poole, Portland, Sandsfoot, the base of the Nothe at Weymouth, and at the end of Lyme Cobb. Fire beacons are shown on the downs along the coast and at North Haven Point. If the scheme was ever accepted in its entirety it was not carried out; the Bournemouth, Poole, and Lyme forts were dropped, and that at Brownsea was built by the Poole burgesses for it is never, at any time, found among the list of royal forts; it was garrisoned by the Poole men, and the earliest reference to it in 1545 shows that it was then under construction at their expense. ${ }^{113}$

The French ambassador was closely watching the progress of Henry's new defences and writing frequent reports about them to his sovereign. Those intended to close the Solent and cover Portsmouth he went to see for himself, for to know their strength or weakness was of vital importance to the French government. He did not proceed to Dorset, which was of secondary value militarily, and where the works were proceeding more slowly. There is a reference, in the shape of a payment to the master gunner there, to a block-house at Weymouth in 1543 , presumably the one at the foot of the Nothe. ${ }^{114}$ Portland and Sandsfoot were of the same type, architecturally, as the other large castles erected to the eastward, and were placed to cross their fire over Portland Roads. The local seamen must have been consulted about the position selected for Sandsfoot because, as it was placed, it leads in line with the north-east point of the isle of Portland, over the Shambles in four fathoms, thus affording a sailing mark for the navigation into the Roads and to Weymouth. At first all the coast defences, except those within the Cinque Ports, were placed under the control of the Lord Admiral, and regulations were drawn up for their government, ${ }^{116}$ but they soon passed out of his hands. Probably it was not considered advisable to entrust a subject with so much power.

War with France and Scotland recommenced in I 543, but the contribution of Dorset to it lay in the supply of men rather than ships. In I 545 it was calculated that 5,000 sailors would be required for the royal fleet in the summer, 'in which there will be some difficulty.' The men preferred privateering to the royal service, so that in August a circular letter was addressed to the mayors and others of the western counties intimating that if the seamen did not join the king's ships they would indulge their preference

\footnotetext{
ley L. and P. Hen. Ylll, xiv (1), 655.

${ }^{110}$ Ibid. 398. Among the commissioners were Sir John Russell, Sir Giles Strangeway's, and Sir John Horsey, for Dorset.

iil Ibid. 685 .

112 Cott. MSS. Aug. I, i, 31, 33 .

11. Hutchins, Hist. of Dorset ( 3 rd ed.), i, 649. In 1558 the Privy Cunncil, in writing to the corporation of Poole, speak of it as belonging to the town (ibid. $i, 8$ ).

iit Pat. $3+$ Hen. VIII, pt. iii, m. 26.

11s Lansd. MSS. 170, fol. 303 .
} 


\section{MARITIME HISTORY}

at the risk of their lives. The west country was swept bare of men; on 22 August Lord Russell wrote to the Privy Council that in Dorset and Devon the fishing boats were 'manned' by women ' which I think hath not been seen.' West-country privateering was so successful, and so dangerous to our relations with neutrals, that in April, I 546, Henry ordered that no privateers should sail from Dorset, Devon, and Cornwall, and that all at sea should be recalled. ${ }^{116}$ Poole had its share of this success, judging from a question relating to the payment of prize money which came before the Council. ${ }^{117}$ In 1545 a French fleet was outside Portsmouth and the operations there are recorded in all local and general histories; but it appears that they were also on the Dorset coast in I 544, although that fact has escaped notice. A witness giving evidence in 1580 mentioned that the French attacked Lyme in I 544 but were beaten off; ${ }^{118}$ possibly the new defences saved Weymouth a similar experience. It has been observed that the burgesses of Lyme obtained a grant in I 535 to enable them to repair the Cobb, which was then described as made "with great timber pight and pyled very deep in the ground, filled in with great rocks and stones between the said timber.' 110 Melcombe, in I 543, was again pardoned nearly the whole of the money due for its tenths and fifteenths, and therefore was evidently in no flourishing condition.

The occurrence of piracy and wrecking becomes more noticeable during the reign of Henry VIII, not because the offences were more prevalent - there were probably fewer cases than during preceding centuries-but because documentary evidence is more plentiful and because suppression was attempted more seriously. Henry was no more likely to allow his authority to be contemned at sea than on land; and to make it felt at sea, even in time of peace, was one way of enforcing the maritime supremacy of England he had always in view. No single life could have been long enough to see complete success, but the steps he took mark a great advance in the organization of repressive measures, and only the application or extension of them was left to his successors. It had been found that the existing system of trial for piracy was nearly useless, the offender having to confess before he could be sentenced, or his guilt having to be proved by disinterested witnesses who, naturally, could seldom be present at sea. By two statutes, $27 \mathrm{Hen}$. VIII, cap. 4, and 28 Hen. VIII, cap. I 5, such crimes were in future to be tried according to the forms of the common and not, as hitherto, the civil law. Probably for the better administration of these statutes and for other reasons-the execution of a treaty with France concerning depredations at sea, the strict protection of the king's and Lord Admiral's rights in wreck and other matters, the registration of the ships and men available and the levy of seamen, the examination of ships going to sea touching their armed strength and the peaceful nature of the voyage, the exaction of bonds from captains and owners as security for good conduct, and the safe keeping of prizes and prize goods-it was deemed advisable to have round the coast permanent representatives of the Lord Admiral who should be of higher social rank and armed with greater authority than the deputies who had hitherto visited each

\footnotetext{
${ }^{116}$ Acts of P.C. 13 April, 1546.

117 Ibid. 14 Oct. 1546.

113 Exch. Spec. Com. 715.

119 Exch. Misc. $\frac{x}{22}$. This construction is shown in the Cottonian map of 1539 .
} 


\section{A HISTORY OF DORSET}

county or district collecting the Lord Admiral's profits or maintaining his rights. The officers in question, the vice-admirals of the counties, were, in their civil functions, the descendants historically of the keepers of the coast and the conservators of truces of the thirteenth and fourteenth centuries, and there is not one of the duties of the vice-admirals which cannot be paralleled among those performed by their predecessors. Now, instead of acting temporarily, or subject to the hostile influence in Parliament of the mercantile classes, they became a band of crown officials stationed round the whole coast, supported by the power of the Tudor despotism and continued without any interruption during which their authority might diminish by discontinuance of action. ${ }^{120}$ It was practically a new police measure and, on the whole and under normal conditions, attained its object by rendering the difficulties of preparation, the chances of detection, and the probabilities of punishment greater so far as shipping set out with a criminal intent was concerned; while the vice-admirals' officers kept a close watch on the more evilly-disposed inhabitants of the coast who had hitherto helped pirates or indulged in wrecking with impunity.

The scheme did not come into operation simultaneously over all England but developed out of necessity and according to opportunity. The first nomination known by precise date is that for Norfolk and Suffolk in I 536 ; within a few years other vice-admirals were acting in most of the counties, Sir Hugh Paulet holding the appointment for Somerset and Dorset. The two counties were soon separated, and during the remainder of the century the Ashleys, the Howards of Bindon, Sir Christopher Hatton, and Carew Ralegh held the office. Hatton obtained wreck rights in the Isle of Purbeck for himself; ${ }^{121}$ Carew Ralegh filled the office between I 592 and 1603, when his appointment was revoked on account of some arrangement he had made with his deputy, John Randall. This man, Randall, was a thorn in the flesh for Poole; the exemptions of the town were too firmly based on the patent of 1526 to be really questioned, but Randall was in control at Brownsea, and in many ways, there and ashore, annoyed the corporation. The troubles of Weymouth have already been referred to. In I 570 the bailiffs withdrew all claim to admiralty jurisdiction except in relation to such disputes as originated in the town between burgesses; ${ }^{122}$ subsequently the union of Weymouth and Melcombe under charter may have infused fresh courage, for between 1590 and 1600 the tension between the two towns and the Lord Admiral was acute. In I 593 the mayor and others were cited before the Admiralty Court in London; what they had to expect there may be inferred from the Lord Admiral's order to the judge to arrest them as soon as they appeared on a charge of receiving pirates' plunder. ${ }^{123}$ In 1597 , again, the town officers were in trouble for neglecting press warrants; in the same year 23 of the principal inhabitants signed a protest complaining of the action of the previously mentioned John Randall. ${ }^{123}$ The Weymouth claim, if exercised, was never admitted by the Lord Admiral or the Privy Council, ${ }^{185}$ but the attitude of the

130 The patents of appointment were from the Lord Admiral, somecimes for life and sometimes during pleasure. I am indebted to Mr. R. G. Marsden, who has made a special study of the history of the evolution of the vice-admiralship (see Engl. Hist. Rev. July, 1907), for much information on this subject.

11 Pat. 14 Eliz. m. 9. '12 Add. MSS. 12505, fol. 173. "33 Ibid. fol. 392. 124 Ibid. fol. 423, 441.

125 Cott. MSS. Vesp. F. ix, fol. 247 ; Acts of P.C. xvi, 406 ; 26 July, 26 Aug. 1565. 


\section{MARITIME HISTORY}

latter body was largely due to the influence of the Lord Admiral, himself a member of it. There is no doubt that the privileges of the exempted towns were distinctly prejudicial to good government; in the case of Weymouth the notoriety attained by the joint towns in the matter of their dealings with pirates may be ascribed, in great measure, to a civic executive always weak and often not disinterested.

In the reign of Charles I the earl of Suffolk, another Howard, was vice-admiral both for Dorset and for the town and county of Poole; thereafter the two districts were often under the same head. Stricter legislation, the decline of piracy, and the increase of the navy, changed for the better after the Civil War and the Restoration the conditions that had made the vice-admirals useful, and their positions tended to become more and more honorary. During the eighteenth century the Paulets, either as marquises of Winchester or dukes of Bolton, with an occasional Trenchard or Strangeways, held the titular rank of vice-admiral of Dorset.

There is a reference in $155^{\circ}$ to certain 'bulwarks in Purbeck,' probably earthworks thrown up at Swanage and Studland to meet a temporary necessity. By 1552 the Privy Council had decided to reduce or disestablish a number of the permanent fortifications 'which stood the king's majesty in very great charges and in no service at all ;' among them were Sandsfoot and Portland, of which the garrisons were reduced. ${ }^{126}$ The uneasy political conditions at home and abroad soon forced the important Dorset fortresses into prominence again. In May, I 557, information was obtained that the French were meditating an attack on Portland; the care of the county was entrusted to Lord St. John, who was told to watch especially Poole, Weymouth, and Portland, soldiers being sent to the latter and the inhabitants mustered and organized. ${ }^{127}$ Philip II had dragged England into war with France, and it was necessary to reinforce the queen's fleets by hired merchantmen. There was none from Dorset with the Lord Admiral in the Channel, but there were two from Poole and Weymouth under Sir John Clere in the North Sea. ${ }^{123}$ In 1558 many of the ports, encouraged by advantages offered by the crown, sent privateers to sea, six sailing from Dorset as compared with 22 from Devon. ${ }^{129}$

The reign of Mary sent many of the outlawed and the discontented to the refuge of the sea, and the political unrest tempted others who were criminals by opportunity to seek fortune there. Both classes were called pirates, and after the failure of Wyatt's rising in February, I 554, the former are frequently in evidence in the Council minutes. In August the lords of the Council ordered the execution of certain pirates in Dorset, but there is little doubt that they were rebels. ${ }^{130}$ Henry Strangeways, belonging to the well-known Dorset family, seems to have begun his career as a pirate without such excuse of conscience, for in February, $155^{2-3}$, he was plying his trade in Irish waters with such success that two men-of-war were prepared at Portsmouth to seek him. ${ }^{131}$ Strangeways worked with the Cornish Killigrews, arch-pirates themselves, ${ }^{132}$ and was on sufficiently good terms with

\footnotetext{
${ }_{126}$ Acts of P.C. 26 Feb., 4 May, 1552.

${ }_{127}$ S.P. Foreign, I I May, I 557 ; ibid. Dom. Mary, x, Nos. 61, 62.

${ }^{128}$ Ibid. xi, No. 38.

${ }^{130}$ Acts of P.C. 9, 13 Aug. 1554.

13) See V.C.H. Cornwall, i, 488 et seq.

${ }^{129}$ Admir. Ct. Exemp. v, 288.

131 Ibid. 2 I Feb. 6 March, $1552-3$.
} 


\section{A HISTORY OF DORSET}

officials to use Portland Castle as a storehouse for his plunder. ${ }^{133} \mathrm{He}$ is next heard of on the coast of Suffolk, but in November, I 555, was in the Tower. No harm came to him of this, and it is quite certain that many of these adventurers, including Strangeways, were in secret communication with dignitaries of State, who, sitting in council, offered rewards for their bodies. ${ }^{194}$ In one state paper or another Strangeways' name is seldom missing for a month during these years. In September, 1559 , he was taken with eighty of his crew, tried in London and condemned to death, but reprieved at the last moment. ${ }^{13 * a}$ After the accession of Elizabeth he seems to have determined to go further afield, and, with a partner, planned to sail from Plymouth 'to take an island of the king of Spain's.' ${ }^{135}$ A declaration that they were only sailing as merchants brought permission to leave, but as he was in prison in December, I 560 , we may suppose that Spanish merchantmen were found easier to reach than one of Philip's islands. ${ }^{136}$ That, after his career, he was then liberated on promise of good conduct points to some powerful protection and former political services. It is an interesting example of heredity or family tendency to find, from I 587 onwards, a Melchior Strangeways continually proclaimed for piracy, although he was probably more of a privateersman. While Melchior was 'wanted,' John Strangeways was a deputy-lieutenant for Dorset.

The plague of piracy was bad enough during the reign of Elizabeth, but many of the cases which the sufferers so regarded were really seizures of enemy's goods in neutral ships and were questions for the judge of the Admiralty Court. In I56 I general directions to watch the coast were issued to the vice-admirals, for the great difficulty in extirpating the pirates lay in the help and sympathy extended to them everywhere. ${ }^{137}$ The peace of 1564 and the protests of the continental states forced Elizabeth to more energetic action; a circular letter to the vice-admirals called their attention to the suggestive fact that although many pirates bad been taken not one had been executed. ${ }^{13 s}$ A year later, recognizing that stronger measures were necessary - ' the inconvenience not yet being removed,' in the placid language of the commission-especial piracy commissioners with large powers were nominated for each county, and they were to appoint deputies at every creek and landing-place. ${ }^{139}$ As the pirates had friends and receivers in nearly every port these proceedings were not of much avail; the business became still more difficult to handle when the Prince of Orange issued letters of marque, many of which were taken out by Englishmen, while many Dutch ships had Englishmen on board. The Orange privateers were an element of high state policy, and Elizabeth did not hold it advisable entirely to crush them even if it had been in her power to do so. Subsequently the Spanish Netherlands followed the example of the Dutch and sent out privateers, the beginning of the affliction of 'Dunkirkers' which plagued the coast for more than a century, while Englishmen also obtained letters of marque from the Huguenot leaders in France.

${ }_{133}$ Marsden, Select Pleos of the Court of Aimiralty, ii, 85. George Strangeway's was captain of Port'and.

134 Cecil MSS. (Hist. MSS. Com.), i, 489 .

isia Mochyn's Diary (Camd. Soc.), 206, $212,213$.

13 Acts of P.C. 28 April, 1559.

13. S.P. Dom. Eliz. xviii, No. 23.

${ }^{136}$ Ibid. 2 May, 1559 ; S.P. Dom. Eliz. xiv, No. 60.

138 Acts of P.C. 23 Dec. 1564.

${ }^{39}$ Ibid. 8 Nov. 1565 ; S.P. Dom. Eliz. xxsviii, No. 9. For Dorset, Sir Wm. Paulet, Sir Hen. Ashley; Gco. Rogers, and Robert Coker. 


\section{MARITIME HISTORY}

Although foreign courts protested loudly it must not be supposed that England alone produced pirates. In June, I 574, the vice-admiral of Dorset wrote that 'there lies at this present so many pirates upon this coast, being Frenchmen, that no English ship is able to pass to any place without great danger. ${ }^{1+0}$ However, the English were undeniably the worst ; in 1577 new commissioners were appointed, and still more stringent methods of repression adopted, an attempt being made to strike at the root of the evil by reaching the aiders and abettors ashore. Persons who helped pirates, or dealt with them, were now to be prosecuted and fined, and the fines were to go towards compensating the victims; the takers of pirates were to have a proportion of the goods found on board, and commissions were to be granted to private persons to set out ships pirate-hunting. ${ }^{141}$ The new commissioners made many interesting discoveries in Dorset, not the least being the difficulty in obtaining disinterested jurymen; in one case a member of a Weymouth jury confessed himself a dealer with pirates, and there were no doubt many others from whom no avowal was forced. ${ }^{1+2}$ Three notorious pirates, Robert Hicks, ${ }^{143}$ Court, and John Callis, haunted the Dorset coast, and the reason for their preference is to be found in the long list of receivers with whom they did business. Their 'chief boatmen,' i.e. carriers, were $2 \mathrm{I}$ in number divided between Weymouth, Melcombe, and the villages along the coast east of Weymouth. There were six carriers with carts going inland and 75 other persons were named as buying from them or supplying them. ${ }^{144}$ One of the obstacles the government had to surmount lay in the fact that the pirates were often helped by men of higher social rank than those who consorted with them merely for a profit. When Court's ship was driven ashore Sir Richard Rogers of West Lulworth got her atoat again for the man he should have arrested. Callis, this same year, proposed to Walsingham to clear the Channel of pirates; he said that he knew enough about their habits to do more by himself than Elizabeth could if she spent $f_{0} 20,000$, and he inclosed a list of receivers. ${ }^{145}$

Notwithstanding the energetic proceedings of the commissioners conditions remained much the same. In I 580 a proclamation declared that the pirates 'at this day commit more spoils and robberies on all sides than have been heard of in former times.' ${ }^{146}$ 'There must have been still many receivers left in Dorset, for in the same year the plunderers of two vessels off Orfordness brought their spoil round to Swanage and Studland for sale. ${ }^{117}$ In fact, after their first blow, the commissioners of 1577 seem quite to have failed, for in 1582 an official in the Isle of Purbeck complained that pirates swarmed there, 'the common infamy of this poor island and me . . the place of their repair is here where in truth they are my masters . . . and when they choose to come on land, they are so strong and well-appointed as they cannot be on the sudden repulsed.' ${ }^{148}$ At the same time the burgesses of Poole petitioned

${ }^{160}$ S.P. Dom. Eliz. xcvii, No. 7 .

${ }^{141}$ Add. MSS. 34150 , fol. 61, 64. In 1559 the judge of the Admiralty Court held that all goods must be restored to the owners (S.P. Dom. Eliz. vi, No. I'); therefore the new regulation must have referred to property belonging to the pirates or unclaimed. There had been some doubt whether accessories ashore could legally be prosecuted (Acts of P.C. 6 June, 1577), and the opinion of the law officcrs of the crown was obtained (Harl. MSS. 168, fol. 114 ).

${ }^{143}$ For more about Hicks, see Y.C.H. Cornwall, i, 489.

${ }^{145}$ Ibid. Add. xxv, No. 60.

11 Acts of P.C. 15 July, 1580.

142 S.P. Dom. Eliz. cxiii, No. 9.

14 S.P. Dom. Eliz. cxiii, No. 24.

${ }^{146}$ Ibid. cxlvi, No. 11.

2

${ }^{118}$ S.P. Dom. Eliz. clvi, No. 1 (Fr. Hawley to Walsingham). 


\section{A HISTORY OF DORSET}

for protection against the same gangs who haunted Studland Bay 'to the utter undoing' of their trade, and who threatened to pull down the prisons and burn the town. ${ }^{1 * 9}$ Another noted pirate, Thomas Purser, was simultaneously threatening to burn Weymouth. ${ }^{150}$ In 1582 the jurisdiction of the privileged towns in matters of piracy was suspended for three years, in order to avoid the conflict of authority with the piracy commissioners which occurred in such places; and also, perhaps, because in some cases private interests interfered with the execution of justice. The latter cause was not likely to be an impediment at Poole. The outbreak of formal war with Spain in $15^{8} 5$ legalized much of the mischievous activity of the sea-rovers; and thenceforward, although there were many complaints from neutrals, there were fewer domestic outcries about piracy. Towards the end of the reign the 'Dunkirkers,' which name included the privateers from all the ports of Flanders, took the place of the English pirates.

The bounty system, inaugurated by Henry VII, by which an occasional tonnage allowance was made to the builders of new ships suitable for service in war, had under Elizabeth settled into a grant of $5 \mathrm{~s}$. a ton on all vessels of $\mathrm{I} 00$ tons and upwards. The expansion of trade and the attractions of privateering stimulated shipbuilding in all places where there was any maritime commerce, while the bounty conduced to an increase of size in new vessels. Dorset was never one of the leading maritime counties, but towards the end of the sixteenth century there began a new era of prosperity for it based on its share in the great Newfoundland fishery, and that prosperity was reflected in the capital sunk in shipping, and the number of seamen the shipping employed. We have seen that from at least the reign of John it had been usual to call upon the officials of the ports for returns of the ships and men available for service ; most of the earlier ones are lost, but several, complete or fragmentary, remain for the Elizabethan period. Usually the details only deal with vessels of I oo tons and upwards, as smaller ones were not considered useful for fighting purposes, but there is evidence that Dorset was fairly supplied with ships of under 100 tons of a size sufficient for the sea traffic particular to the county. War with France and Scotland existed in 1560 , which was the cause of the first Elizabethan list of that year. It was a return of vessels of 100 tons and upwards, but there is none for Dorset ; of 'mariners and sailors' there were 255 , but this is evidently only the number of men at home at the moment. ${ }^{151}$ The piracy commissioners of ${ }^{2} 565$ remarked, in their report on Dorset, that there was no harbour at Charmouth, but that, 'as at Bridport,' vessels were drawn up on the shore. ${ }^{152}$ Part of this paper is missing; but belonging to Charmouth, Chideock, and the neighbourhood there were only ten vessels, used for fishing and coasting, of which the largest was of 18 tons. Poole possessed two vessels of 50 tons each and other smaller ones; at IVeymouth and Melcombe one of 80 tons was the largest, and at Lyme one of 24 tons. By I 568 there was an improvement, for Poole then possessed two ships of 100 tons and Lyme one. ${ }^{152 a}$

${ }^{149}$ Cecil MSS. (Hist. MSS. Com.), ii, 538. They found the existence of gallows at Studland in bad taste, and cut them down no doubt amid much good fellowship (Moule, Charters of Weymouth, 154 ).

${ }^{150}$ Moule, op. cit. 154 .

${ }^{151}$ S.P. Dom. Eliz. xi, No. 27. The distinction between mariners and sailors is obscure and unnecessary to discuss here.

${ }^{152}$ Ibid. xxxviii, 9, 9 (i). Leland notices that the harbour at Bridport had ceased to exist when he visited the county (Itin. iii, 60).

158 Harl. MISS. 168, fol. 248. 


\section{MARITIME HISTORY}

In July, 1570 , a general embargo was ordered, and the vice-admiral reported that he had stayed nine ships of 30 tons and upwards, and 435 shipmasters and men ; many others, he said, were abroad. Here, three vessels of Lyme Regis, of which one was of 50 tons, are scheduled, one of 100 tons belonging to Melcombe, and one of 90 tons owned at Poole ; interesting details of the number of seamen and fishermen living in the villages along the coast are also given. ${ }^{153}$ In 1572 Thomas Colshill, surveyor of customs at London, compiled a register of coasting traders belonging to the ports. ${ }^{15 t}$ The Dorset section may be thus arranged :-

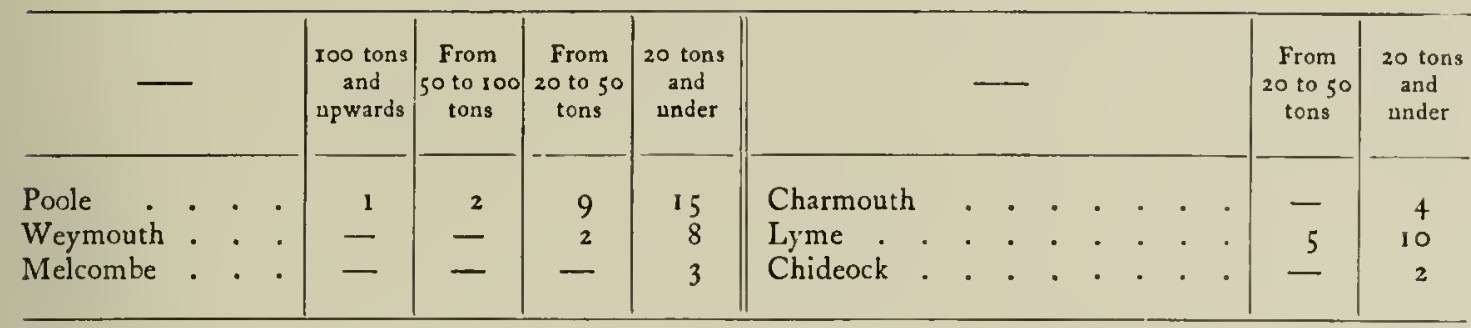

In 1576 a list was prepared of ships of 100 tons and upwards built since I $57 \mathrm{I}$, in which no Dorset port appears. A year later there was another survey of roo-ton ships, from which we find that Poole possessed two and Weymouth one, just reaching the limit; they must, therefore, have been older than $157 \mathrm{I} .^{155}$ The agents here of Philip II reported, almost with alarm, the rapid increase of shipbuilding in England, and the next return of I 582 supports the information they sent to Spain. ${ }^{156}$ Poole possessed six vessels of 100 tons and upwards, of which one was of 140 tons and another of I 30 tons, and Weymouth and Melcombe three, of which one was of 150 tons. Of between 80 and 100 tons there was one at Poole; of between 20 and 80 tons there were ten at Poole, 15 at Weymouth and Melcombe, and I 4 at Lyme. Those belonging to other places in the county were of under 20 tons. Of men there were 85 shipmasters and 560 seamen, comparing with 150 and I,9I3, respectively, in Devon. Allowing for the smaller craft omitted in this enumeration, the number for Lyme is in substantial correspondence with a return of 1586 , which gives it 23 vessels of all kinds, while 18 masters and 108 men lived in the town, and 80 others dwelling within a radius of four miles were employed in Lyme ships. ${ }^{167}$ The last Elizabethan list is for Poole in $159 \mathrm{I}$; there were then $2 \mathrm{I}$ vessels, of which the largest was of 70 tons, but this is probably only of ships then at home. ${ }^{168}$

The recovery of Weymouth and Melcombe, and the continued progress of Poole, were mainly due to their share of the Newfoundland fishery, which for many of the western coast towns was replacing the mediaeval over-sea trade soon to be engrossed by London and other of the great ports. It would be impossible to overrate the national value of this new school for the production and training of seamen which, with the previously existent North Sea and Iceland fisheries, largely created the marine which overwhelmed Spain in the sixteenth and the Dutch in the seventeenth centuries, thus clearing the way for trans-oceanic expansion. The Newfoundland trade not only employed

${ }^{153}$ S.P. Dom. Eliz. lxxi, Nos. 56, 56 (i).

${ }^{154}$ Ibid. Add. xxii. He excluded fishing craft, and, inferentially, vessels engaged in over-sea trade.

135 S.P. Dom. Eliz. xcvi, fol. 267.

${ }^{157}$ Harl. MSS. 368 , fol. I 24.

${ }^{156}$ Ibid. clvi, No. 45 .

${ }^{158}$ S.P. Dom. Eliz. cxxxviii, No. 142. 


\section{A HISTORY OF DORSET}

sailors, but necessarily required a certain number of 'green' hands, or landsmen, of whom a proportion became seamen by profession. There are no statistics for the early years of the fishery, but there are occasional indications of its increasing importance. During the first half of the sixteenth century it grew at the expense of the Iceland trade, and by 1542 was of sufficient size to be the subject of a section in an Act of Parliament; in 1548 there was a 'great ' Newfoundland fishing fleet causing anxiety for its safety, and the statute 2 and 3 Edward VI, cap. 6, forbids exactions from owners in the Newfoundland as well as in other fisheries. In 1578 there is for the first time a statement of the number of vessels actually present in Newfoundland waters, and a note of their increase; the municipal archives of Poole show that in 1583 there were ten or twelve Newfoundland ships sailing thence. ${ }^{169}$ The Elizabethan war put an end to the Spanish and Portuguese fishery, and greatly diminished that from France; the indirect result was to the advantage of English merchants from whom neutrals had to buy to supply the Catholic powers. The fishing fleet of ${ }_{15} 85$ was large enough to make it worth while to send out a warning that Philip had seized all the English ships in Spanish ports, and by 1592 Englishmen enjoyed so much reputation as experts that the Dutch were offering high pay for their services. The business had grown big enough to have rules and regulations drawn up for its management; in I $5^{8} 3$ a Poole owner was fined for sailing without the consent of the mayor and burgesses. ${ }^{160}$ In 588 the Primrose, I 20 tons, of Poole, sailed notwithstanding the embargo of $3 \mathrm{I}$ March; the Council ordered the imprisonment of Peter Cox, a part owner, and promised to deal with the master and others when the vessel returned. ${ }^{161}$ In ${ }^{5} 594$ there were roo sail due home in August; to join this fleet six Poole and five Weymouth ships had been released from embargo earlier in the year. ${ }^{162}$

In the reign of James I Lyme is included among the ports interested in the trade, ${ }^{163}$ but under that king England soon lost the unstable maritime superiority won under Elizabeth, and the western fishery was one branch of sea traffic which felt the effects. In I 622 the mayor of Weymouth wrote to the Council that in that year only I I ships had been sent to the fishery instead of 39 as before. ${ }^{164}$ If 39 was the high-water mark of one year, and the average was much less, it still shows of what vast importance to the prosperity of the Dorset ports the trade had become. Again, in 1627, the Poole men wrote that two years previously they had had 22 Newfoundland ships working, but that the number had fallen to four ; ${ }^{165}$ a year later they stated that their average had been 20 ships each season. ${ }^{166}$ Dorset was by no means the leading county in the Newfoundland trade; allowing a crew of only 25 men to a ship we may get some idea of the supreme influence the fishery must have had in the evolution of a new sea-faring population in the crucial years when the future of England depended on its success at sea. No other towns in Dorset than the four here mentioned seem ever to have sent out fishing ships, but no doubt men came, as in Devon and Cornwall, not only from along the coast but from inland. A paper, assigned to 1634 , gives

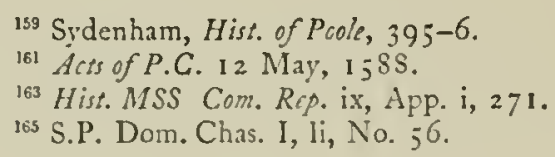

${ }^{160}$ Hutchins, Hist. of Dorset ( 3 rd ed.), i, 40.

16: S.P. Dom. Fliz. cexlviii, No. I.

16 S.P. Dom. Jas. I, cxxx, No. 22.

166 Ibid. ciii, No. 43 . 


\section{MARITIME HISTORY}

the recent yearly average from the western ports at 26,700 tons of shipping and $10,680 \mathrm{men}$, which was the highest point of prosperity the trade reached for the time. In 1640 Weymouth had 1,000 tons of shipping engaged in the fishery, but in 1670 the amount had fallen to $35^{\circ}$ tons $;{ }^{167}$ probably the deterioration of the harbour had much to do with this decline.

In the spring of $\mathrm{I}_{5} 85$ Philip II, breaking a promise of safe conduct, ordered the seizure of all English ships then in the Spanish ports. This act was answered here by the issue of letters of reprisal, which were only to be given to persons who could prove that they had suffered by the seizure ; this event, with Drake's expedition of the same year, marks the commencement of the Spanish War. Merchants of Lyme had suffered loss to the amount of $\oint_{2} 2,000$, and those of Melcombe to $\oint_{0} \mathrm{r}, 000$; Poole is in the list but the amount is destroyed. ${ }^{168}$ One of the vessels thus set out was the Susan of Lyme of roo tons.

The strained relations that had long existed between England and Spain had led to the exercise of precautions, in the years preceding 1585 , in the way of training the county levies and the repair of the coast fortifications. From the accession of Edward VI the latter had been neglected everywhere; a report of 1574 described Sandsfoot Castle as going to ruin, the walls cracked by frost and in some places nearly falling into the sea. ${ }^{169}$ There were five dismounted guns, but the wooden platforms were too rotten to bear them if mounted, and there was no ammunition. Portland Castle was found to be in as bad a condition, and Brownsea, it was said, had never been really completed. A silence of nine years follows; then there was another survey in $\mathrm{I}_{5} 83$ from which it appears that both castles were in a much worse state, and that the sea was undermining Portland. ${ }^{170}$ In this paper the batteries at Handfast Point and Peverel Point are again referred to, ${ }^{171}$ but they of course were in a very dilapidated condition. In 1582 the corporation of Poole had lamented the weakness of Brownsea Castle, and the report of $15^{8} 3$ emphasized this; it seems never quite to have been decided whether the town or the government was responsible for its upkeep. ${ }^{172}$ What was certain was that in none of these fortifications had there been any repairs done, or any necessaries and ammunition provided, for many years except at the expense of their commandants. In October, ${ }_{5} 83$, the question was at last dealt with, $f_{\mathrm{r}} 93$ ros. being issued for works at Portland, $f_{0} 34$ I $6 s$. 8d. for Sandsfoot, $f_{2} 202$ i Is. $8 d$. for Brownsea, $f_{2} 20$ for Peverel Point, and $f_{0}$ io for Handfast Point. ${ }^{173}$ In 1586 the deputy lieutenants of the county informed the Council that Portland Roads were quite unprotected by either of the castles, and that an enemy's fleet could ride there altogether out of range. ${ }^{174}$ This, taken literally, is untrue, but they probably included Weymouth Roads in the anchorage. They recommended the erection at Weymouth, which was defenceless, of two forts; the town, they said, was too poor to build them, but would maintain them if the queen bore the first expense. The Weymouth people had made a previous attempt to obtain ' a small bulwark' in 1583 when the pirate, Purser, had threatened to burn the town; the

167 S.P. Dom. Chas. II, cexcv. No. 76.

${ }^{169}$ S.P. Dom. Eliz. xcvii, No. 8.

${ }^{173}$ Saxton's map of Dorset of 1575 (Harl. MSS. 3324) shows a block-house at North Haven Point ; it is not mentioned in any document known to the writer.

${ }^{173}$ S.P. Dom. Eliz. clxx, No. gr.
108 Admir. Ct. Exemp. xiii, Nos. 2 I I-I 3. Imperfect.

170 Ibid. clxiii, No. 41. ${ }^{171}$ Ante, p. 199.

${ }^{174}$ Ibid. cxciii, No. 43 . 


\section{A HISTORY OF DORSET}

Privy Council then agreed that it would be advisable, but that the inhabitants must contribute to the charge. ${ }^{175}$ The proposal therefore fell through, as did that of 1586 , for Elizabeth did nothing for her subjects that they could possibly be made to do for themselves. In a narrow sense the queen's policy was shrewd, for the probability of invasion was obvious in $15^{8} 7$ and the Weymouth and Melcombe people were so alarmed by their helpless position that they were considering whether they would leave the town or bear the cost of defence themselves. ${ }^{176}$ They chose the latter course, and in a paper of I 588 refer to the fact that they had built 'a platform' at their own charge. ${ }^{177}$ From a contemporary plan it seems to have been placed on what is now the esplanade at Melcombe, but it remained without guns. ${ }^{178}$ The 'block-house' at Melcombe, often referred to in the municipal records, dates from 1567 , and a gunner was appointed in $1568 .{ }^{179}$

There was preparation for war in 1574, when the zeal shown by the leading gentlemen of Dorset caused Elizabeth to send them letters of thanks assuring them that their 'diligence and forwardness shall be holden in remembrance to their comfort.' ${ }^{180}$ ' No Dorset ship is known to have sailed in Drake's fleets of 1585 and 1587 , although men from the county are very likely to have been among the crews. In December, 1587 , when the political horizon was very black, military officers were sent into most of the coast counties to advise upon measures of defence ; ${ }^{181}$ Nicholas Dawtrey went to Dorset, but if he made any report no action was taken upon it. By the following April even Elizabeth was beginning to doubt the success of her diplomacy, and it was thought time to take fresh precautions. Sir John Norreys, a soldier of reputation, was sent round Kent, Sussex, Hampshire, and Dorset to inspect them, and his report on Dorset is dated 24 April. ${ }^{182}$ It is not a very illuminating document; no sufficient distinction is drawn between the small possibilities of landing at such places as Bridport and Charmouth, and the shelter offered by Portland Roads. The Armada carried no invading force of its own; its purpose was to ensure the crossing of Parma's army by destroying the English fleet, but if it had carried an adequate force Elizabeth and the Council might well have looked on Portland with anxious eyes. There is no trace in the deliberations of the Council and the soldiers that they ever recognized until the last moment that the junction with Parma was the key to the Spanish plans, and that the strategical centre, if attack was awaited, was therefore the eastern Channel, yet Norreys was quite content with garrisons of a few scores of men at Portland and Sandsfoot and a concentration of, nominally, I,500 men at Weymouth. It was argued that the Armada, riding in Portland Roads, would be exposed to south-east gales, and would therefore not dare to take up the anchorage ; but such gales are rare in summer, and something must inevitably be risked in war. Ralegh, the greatest English strategist of his generation, saw the importance of Portland, and in 1587 urged upon Burghley the necessity for

${ }^{173}$ Moule, Charters of Weymouth, 154 .

177 S.P. Dom. Eliz. ccix, No. 94 .

${ }^{18}$ Ibid. ccxiv, No. 11 ; Cott. MSS. Aug. I, i, 32.

${ }^{179}$ Pat. 10 Eliz. pt. viii, m. 28. It is called Weymouth in the patent.

150 Acts of P.C. 24 Oct. 1574. To Lord Howard of Bindon, Sir Henry Ashley, Sir John Yonge, and Nicholas Turbervile.

${ }^{181}$ Ibid. 26 Dec. 1587.

${ }^{126}$ Ibid. 157.

${ }^{152}$ Harl. MSS. $33^{2}+$, fol. 42 . 


\section{MARITIME HISTORY}

more powerful defences there. ${ }^{185}$ The admirals desired to go to meet the Armada on the Portuguese coast, a course of action which, if they had fought successfully, would have secured the safety of Portland and every other English roadstead.

The experience of 1587 and of later years showed that the brunt of the fighting had always to be borne by men-of-war, and that the chief value of armed merchantmen was to inspire the confidence given by number. This was understood in 1588 , however, only by a few seamen; therefore in that year the whole of the English coast was called upon to help, not by a general impressment but by sending ships according to order to join the royal fleet. On 3 I March a general embargo on shipping was proclaimed, the object being to retain not so much the vessels as the men. This was followed the next day by orders to the port towns to furnish ships at their own expense, all to be more than 60 tons. ${ }^{184}$ Weymouth and Melcombe were set down for two ships and a pinnace, Poole for one ship and a pinnace, and Lyme was linked with Chard and Axminster for two ships and a pinnace, the two inland towns having of course only to contribute towards the expense. There was an auxiliary order that most of the cost was to be borne by those persons who had profited by privateering. Both now and on subsequent occasions many of the ports sought excuses either to obtain a reduction in the demands made upon them or to have the county and adjacent towns joined with them towards the charges. Within a fortnight all the Dorset ports protested to the Council that there were various reasons why they were too hardly treated. The mayor and aldermen of Poole were the first to enlarge, within forty-eight hours of the receipt of the order, on their disabilities. They said that there was, at the moment, only one ship of above 60 tons in port, and that she was about sailing for Newfoundland, ${ }^{185}$ and that the Council were quite wrong in supposing that any of the Poole owners had made a profit by privateering, or, indeed, that any one of them had indulged in any speculation of the kind. The Council were besought 'to consider of the great decay and disability of this poor town' due to several causes, including pirates at Studland Bay, 'whereby we are utterly unable to perform your Lordships' commandment.' ${ }^{186}$ 'The corporation of Lyme followed on 9 April ; ${ }^{187}$ they had no ships at home of the required tonnage, but offered one of 40 tons, and complained that certain inhabitants of Axminster had already refused any payments in aid. They suggested that any future levies of the kind should be based on a wider assessment among more towns. The mayor and corporation of Weymouth did not answer until the 16 th ; ${ }^{188}$ they did not deny that prize goods had been brought, to some extent, into the two towns, but said that the owners mostly dwelt elsewhere, and that Weymouth and Melcombe were 'of small ability and in part decayed.' They added that notwithstanding their disabilities they would provide the assistance required, but requested the Council to add some other towns as contributories. There was no immediate answer to this, but in June the Council ordered that Dorchester was to help Weymouth. ${ }^{189}$ The question of revictualling these ships came up again in July,

${ }^{183}$ Lansd. MSS. 52, fol. 65.

${ }^{11}$ She sailed in defiance of the embargo (ante, p. 204).

${ }_{167}$ Ibid. No. 81.
${ }^{184}$ Acts of P.C. 3 I March, I April, I 588.

${ }_{186}$ S.P. Dom. Eliz. ccix, No. 70.

199 Acts of P.C. 23 June, 1588. 


\section{A HISTORY OF DORSET}

when Axminster and Chard were again refractory in bearing their share of the expense. ${ }^{190}$ The Dorset ports were not singular in their reluctance; the same unwillingness was being displayed nearly everywhere round the coast and was, in a great measure, due to the decadence of towns which had been relatively wealthy in mediaeval times.

From Lyme came the Facob, 90 tons, and the Revenge, 60 tons, Captain Richard Bedford; from Weymouth the Galleon, Ioo tons, Captain Richard Millard, and the Katberine, 66 tons; Poole was unrepresented. When the Spaniards were off Portland four more Weymouth ships, with 300 men on board, put off to share the danger and the honour; three of these were the Golden Rial, 120 tons, the Heatb Hen, 60 tons, and the Bark Sutton, 70 tons; ${ }^{191}$ the fourth was probably the Bark Bond. They perhaps helped by their presence to comfort the men-of-war who were really fighting the action off Portland on 23 July. A Spanish flagship was brought into Torbay on 26 July, and Carew Ralegh, elder brother of Sir Walter, at once asked that six of her guns might be sent to Portland Castle. ${ }^{192}$ It was late in the day to think of coast defences, but the Weymouth people, taking advantage of the arrival of another captured Spanish Hagship, the San Salvador, in Portland Roads, petitioned for some guns out of her for their platform which was built but not armed. ${ }^{193}$ The Council acceded to this request and ordered eight brass and six iron guns to be given to them. ${ }^{19}$ The San Salvador remained at Portland for some months; she was lost in Studland Bay, on her way to Portsmouth, in November. ${ }^{195}$ Her crew stayed, as prisoners, in Weymouth, and in December were behaving in a very disorderly manner perhaps because, as in Devon, they were left to starve or to depend on the charity of the country-side; the Council ordered them to prison and a diet of bread and water. ${ }^{196}$

The armed merchantmen were of little or no use during the Armada campaign, and the government must have regretted the vast expense entailed. In many cases the ships had been equipped by means of advances obtained from private individuals, and sent to sea long before the money necessary was collected. After the crisis it became still more difficult to collect the assessments, many of the corporations squabbling about their shares or attempting to evade payment altogether. In September, I 588, Axminster and Chard were still arguing with Lyme about their responsibilities; at Weymouth Captain Richard Millard had expended f.45 I about his ship, the Galleon, and was still unpaid. ${ }^{197}$ In the latter case the Council, believing that Weymouth was really poor, directed that Blandford, Cerne Abbas, Shaftesbury, and Wareham should be rated in aid. There must have been reasons, satisfactory to the Council, for the absence of any assistance from Poole, but there are indications that no great desire was felt in the town to render service to the state. In I 59 I troops for France were under orders to embark there; the mayor did his best to get ships but the owners unrigged them, whereupon the mayor committed the contumacious proprietors to prison, leading

${ }^{190}$ S.P. Dom. Eliz. ccrii, No. 43 .

${ }^{191}$ Ibid. ccxiv, No. I1. They are called volunteers, but the bill sent in to the government for the Golden Rial exists (ibid. ccxv, No. 20 (i)).

19: Ibid. ccxiii, No. 43 .

191 Ibid. No. 55.

${ }^{19 .}$ Acts of P.C. 3 I Dec. 1588.

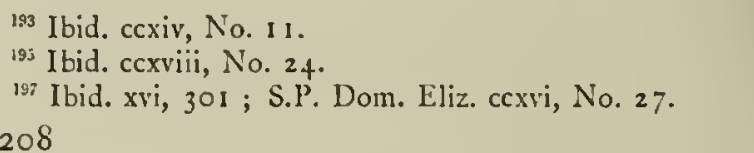




\section{MARITIME HISTORY}

them to use 'very bad language' and to threaten revenge. ${ }^{198}$ The Council called their language 'lewd and undutiful' and ordered the principal misdemeanants to be sent up to London.

The 1589 voyage to Portugal was a joint-stock affair under Norreys and Drake who hired their ships. Although nearly 80 were taken up Dorset does not appear to have supplied any. The ports were not again called upon by the queen for ships until the Cadiz voyage of 1596 was under consideration; but in the interval those of Dorset were carrying on what must have been a successful privateering war on their own account. Between 1587 and 1598 we find 23 ships of Weymouth, six of Lyme, and three of Poole engaged in prize-hunting, and that the business was followed so long points to good fortune. ${ }^{199}$ One of these vessels, the Bark Bond (owners John Bond and Wm. and Ric. Pitt) made an especial haul in I592, when she met the Grace of Dover which had on board the passengers and crew of the great carrack, the Madre de Dios, just taken by an English squadron and the richest capture of the reign. They were supposed to have been plundered before being put on board the Grace, but Captain Aire of the Bark Bond brought her to and managed to extract 50,000 ducats and many precious stones from them. A warrant to arrest Captain Aire issued later. ${ }^{200}$

The failure of the 1589 expedition had made Elizabeth avoid enterprises on a large scale; it was not, therefore, until the close of 1595 that an undertaking, of which the destination was then uncertain, was decided upon for the following year. On 2 I December a circular letter was addressed to the ports, generally, requiring ships to be ready by the next spring, armed, manned, and victualled at local charge for five months; Dorset was called upon for two. ${ }^{201}$ All the port ships were used as transports or for other subsidiary purposes in the Cadiz voyage; the Expedition and Catherime, which carried soldiers, and both of Weymouth, were the Dorset ones, and 130 seamen as well came from Weymouth and Melcombe. ${ }^{202}$ The attempts at evasion of payment were even more marked now than in 1588 ; towns and individuals everywhere shirked their assessments. Weymouth and Melcombe were charged with $f_{0} 400$, towards which the other Dorset ports were required to contribute $\AA_{\mathrm{I}} 60$, but there was great difficulty in obtaining it as well as the ratings in Weymouth itself. The only remedy the Council could apply was to order that refractory individuals should be sent to London to appear before them, a punishment which might obviously be made a very heavy one in view of the direct and indirect expense involved. By December, 1596, the mayor of Weymouth had written six times to the Council complaining that the corporation could not obtain payment of the $f_{0} 160$; in the following February it was still owing, and their lordships wrote to the deputy-lieutenants of Dorset that 'a great contempt' was being committed, and that if the money was not at once collected one of them was to appear in London. ${ }^{203}$ This threat proved unsuccessful, so that in May it was resolved that personal application should be made by a Council

${ }^{198}$ S.P. Dom. Eliz. ccxliii, No. 43 ; Acts of P.C. 20 Oct. 1592.

199 Harl. MSS. 598. The year given in the text does not mean that the business ceased in 1598 , but only that there are no accounts for any later date.

${ }^{200}$ Cecil MSS. (H1st. MSS. Com.), iv, 237 ; Lansd. MSS. 67, fol. 116.201 Acts of P.C. 2 I Dec. 1595.

${ }^{202}$ Moule, Charters of Weymouth, I 34 ; Cecil MSS. (Hist. MSS. Com.), vi, 293.

${ }^{203}$ Acts of P.C. 7 Sept. 7 Dec. 1596,27 Feb. 1597. 


\section{A HISTORY OF DORSET}

messenger to every one in Dorset who was still recalcitrant, and that on further refusal such should be brought before the Council. ${ }^{204}$ However, the debts incurred in relation to the Catberine were still unsettled in $1602 .^{.03}$ The revolt against these Cadiz assessments was so widespread, and so many awkward constitutional questions were being raised in some of the counties, that there was no further attempt to levy ships in the same way during the remainder of the reign.

Throughout these years of war Elizabeth, partly as the result of her uwn ignorance and nervousness and partly perhaps as a matter of policy, kept her subjects on tenterhooks of expectation of invasion. Recurrent panics followed year after year, and she did nothing to quiet them even when information in the hands of the government must have shown their baselessness. In I 598, when Philip was dying and Spain exhausted, ruined, and helpless, the usual fear recurred, and a new survey of the Dorset coast was ordered. ${ }^{206}$ Who undertook it is not known, but their conclusions, that 500 sail of 1,000 tons each might ride in Worbarrow Bay and Shipman's Pool, and that 600 or 700 sail of 1,000 tons could ride in Swanage and Studland Bays, do not inspire faith in their knowledge or capacity. ${ }^{207}$ They thought that in Poole Harbour 500 sail of 120 tons could find shelter; as there had been only $12 \mathrm{ft}$. on Poole Bar in $1539,{ }^{208}$ and as the depth was no doubt the same in I 598 , it was practically prohibited to an enemy's fleet. They said, what everyone knew, that Portland Roads was a tempting objective for an invader, and a Spanish spy in I 599 made the same report with the addition that it was nearly defenceless; this man also remarked that Poole was unfortified because only 50 or 60 -ton vessels could enter the harbour. ${ }^{209}$ One of the worst, because one of the most groundless, panics of the reign occurred in 1599 when preparations more befitting such a year as 1588 were made. No Spanish squadron was ever nearer England than Coruña, but a powerful fleet was mobilized in the Downs and thousands of the county levies called under arms. Naturally the towns took alarm; in August a petition came from Weymouth representing its weak state, and the inhabitants, in terror, were sending away the women and children and removing their property; a garrison of $\mathrm{I}, 000$ men was requested. ${ }^{210}$ On I I August they wrote, 'we have armed all sorts of our people that are able to make a stand at a street corner,' but all this desperate preparation to die in the last ditch was quite needless. However, they can scarcely be blamed for keeping step with the Council, who, on I 8 August, wrote to the deputylieutenants of Dorset that they were sorry to hear of the little regard which was being paid to the safety of Weymouth ' in this time of great danger.' ${ }^{211}$ As on I 4 A ugust they had themselves suspended further military levies, it was scarcely reasonable to write on the I 8 th blaming their subordinates for neglecting to collect men. The other Dorset towns were less nervous, and only stood ready without troubling the government; on 7 August the Council ordered the mayor of Lyme to hire a pinnace to scout on the Portuguese coast. ${ }^{212}$

204 Aces of P.C. 30 May, 1597.

${ }^{203}$ Moule, op. cit. 138.

${ }^{206} \mathrm{Harl}$. MSS. 3324 , fol. 62 .

217 Worbarrow Bay is rather more than a mile long and half a mile wide, but with no anchorage within 400 yards of the shore; Shipman's (or Chapman's) Pool is less than half the size of Worbarrow Bay.

${ }^{203}$ Cott. MSS. Aug. I. i, 31. ${ }_{209}$ S.P. Dom. Eliz. cclxx, No. 77. ${ }^{210}$ Ibid. cclxxii, Nos. 19, 25.

${ }^{211}$ Coke MSS. (Hist. MSS. Com.), i, 22. ${ }^{212}$ S.P. Dom. Eliz. cclxxii, No. 21 . 


\section{MARITIME HISTORY}

As piracy died down, the scourge of Dunkirk privateering, which was little different, became more and more virulent. Philip II had always hesitated to issue letters of marque, not for humanitarian reasons but because there were so few seamen in Spain, and permission several times given to his subjects had been in each instance speedily withdrawn. Philip III reversed this policy for Spain, and the governors of the Low Countries had never known any reasons for hesitation ; therefore, as Dunkirk, Sluys, Nieuport, and Ostend fell into their hands, they became privateer bases which inflicted terrible injury on English commerce. As early as 1590 the Weymouth burgesses were asked to set out two vessels at their own expense, to help to clear the Channel, with a promise that they might keep all they captured. ${ }^{213}$ In I 600 the masters of storeships, taken up for Ireland at Poole and Weymouth, were refusing to sail because they regarded their capture by Dunkirkers as certain. ${ }^{214}$ The accession of James I brought peace with Spain, but the Dutch and Flemish privateers now inflicted on the English the same miseries the latter had imposed on neutrals a generation earlier. What was far worse, because it added the horrors of slavery to material loss, was the appearance in the Channel of Mohammedan pirates, usually Algerines or Saleemen, from the Mediterranean. They came under the guidance of English and Dutch renegades, the former being mostly seamen thrown out of employment by the peace; and before long, aided by the rapid degeneration of the English navy, they established a reign of terror on the south coast. Like the pirates of the preceding reign, they found Swanage and Studland Bays convenient haunts, which caused a petition to be sent to the Privy Council that the block-house at Peverel Point might be repaired and armed as a protection against them..$^{915}$

The first naval armament for foreign service of the reign of James was due, nominally, to the necessity for chastising these Moorish pirates by attacking them in their lair at Algiers. The fleet, under Sir Robert Mansel, was really sent to the Mediterranean to give weight to the king's foreign policy at the moment, but it was a good excuse to make the ports, as chiefly interested in the ostensible object, bear most of the expense. A circular letter from the Privy Council in February, 16 18-19, recited that 300 ships and many hundreds of men had been taken by the Algerines within a few years, and that the king was resolved to extirpate them. To help towards this laudable purpose Weymouth and Lyme were each assessed at $f_{0} 45^{\circ}$, and Poole at $f_{0} 100 .{ }^{.16}$ The towns writhed as usual. The mayor of Poole lost no time in replying that their only trade, with one exception, was the Newfoundland fishery, and that they could not raise $f_{0}, 100$ but would try to send $\left\{50 .{ }^{217}\right.$ On ro March the mayor of Weymouth and Melcombe wrote to the judge of the Admiralty Court to ask his intercession; he said that on account of their heavy losses by the Algerines only $f_{0} 100$ had been raised; that the Council had judged of the wealth of the town by the customs returns, but that three-fourths of the customs were paid by inland merchants and that the townspeople were not interested in it. ${ }^{213}$ The Weymouth corporation volunteered a contribution of $f_{\mathrm{J}} \mathrm{1} 00$ in settlement, or offered to

${ }_{213}$ Acts of P.C. 4 March, $1589-90$.

${ }^{215}$ S.P. Dom. Jas. I, civ, No. 63 .

${ }^{217}$ Ibid. cvii, No. 39 .
${ }^{214}$ Ibid. 10 Oct. 1600.

216 Ibid. $\mathrm{cv}$, No. 89.

${ }^{21 s}$ Add. MSS. 36767 , fol. 377 . 


\section{A HISTORY OF DORSET}

advance $f_{0} 400$ if allowed to repay themselves by levying I per cent. on all goods inwards and outwards. This last course was adopted, but the result was that the inland shippers transferred their trade to Poole. ${ }^{210}$ The mayor of Lyme answered so quickly that little time could have been devoted to inquiry ; ${ }^{220}$ the town, he wrote, could not provide $f 45^{\circ}$, which should be raised from the merchants of Bristol and Exeter who were the principal shippers through Lyme. In May, 1620 , in response to further pressure from the Council, the mayor of Weymouth replied that shipowners in the town had lost $f_{0} 3,000$ at sea since April, 16 I $9 .{ }^{221}$

Mansel sailed in October, 1620 , and returned in August, I62 I, having done nothing. A commentary on his utility was supplied by the mayor of Weymouth, who wrote in 1622 that nearly every vessel sent to the Mediterranean from the town in $162 \mathrm{I}$ had been taken by the Algerines or other Moorish pirates. ${ }^{229} \quad$ Purely English piracy, although diminished, was by no means extinct. A general piracy commission had issued for all the counties in 1608 ; several pirates are mentioned as frequenting Dorset waters, and in 1623 an official expressed his opinion that the reason they flocked to Weymouth was that the people there traded with them and that the Admiralty Court officers connived at their presence. ${ }^{223}$

The plea of poverty constantly put forward by the ports, although relatively true, must not be taken too literally. For the reign of James we are able to measure, roughly, the amount of shipping belonging to most of them, and shipping is necessarily the gauge of their prosperity. Mr. R. G. Marsden has compiled a list of ships' names occurring in legal and historical documents of this period, and also in various printed sources; $;^{224}$ he has found 17 Lyme vessels mentioned, 19 of Poole, 20 of Weymouth, and one of Purbeck. ${ }^{225}$ There must have been many others that sailed through an uneventful career without attracting the attention of the law, the Admiralty officials, or the customs. There was also a certain amount of shipbuilding. A list exists of some 380 ships built between 1625 and 1638 , the certificate of building being necessary to obtain a licence to buy ordnance. ${ }^{206}$ Four were constructed at Weymouth, one, launched by Nicholas Awdney, being of 240 tons; the others were of under roo tons. Only one, of 80 tons, came from Lyme. Weymouth must have had something more than a local reputation in shipbuilding for in 1636 two officials came there to press shipwrights for the Sovereign of the Seas, then under construction at Woolwich. It was necessary to conceal their purpose so they brought the shipwrights together for a drinking bout, pretending to have a ship of their own in hand. But the officials got drunk themselves and revealed the secret, where-upon the shipwrights fled from the town, and one of the press-masters knocked up the mayor at $4 \mathrm{a} . \mathrm{m}$. for assistance while the other one roused the constables an hour earlier to feed his horse. ${ }^{.27}$

Mansel's abortive expedition of $1620-1$ served only to encourage the Algerines. Often the south-western coast was practically blockaded by them

${ }^{219}$ S.P. Dom. Jas. I, cix, No. 81 .

${ }^{221}$ Ibid. cxv, No. 57

${ }^{223}$ S.P. Dom. Jas. I, cli, No. 21.

${ }^{225}$ Qy. Swanage.

${ }^{227}$ Ibid. cccxxxvii, No. 18 ; cccxliii, No. +; cccxlviii, No. 90. is amusing but rather involved.
${ }_{320}$ Ibid. cv, No. $141 ; 27$ Feb. $1618-19$.

292 Ibid. cxxx, No. 22.

2:4 Trans. Roy. Hist. Soc. xix, 311 .

${ }^{826}$ S.P. Dom. Chas. I, xvi, xvii.

The story, as told in the State Papers, 


\section{MARITIME HISTORY}

so that the coasting and cross-Channel trade was stopped, and fishermen dared not go out. In $16{ }_{3} 6$ the western ports, including Poole, Weymouth, and Lyme, petitioned that the coast was 'infested' with Turks, and that they had lost, within the last few years, 87 ships worth nearly $f_{0} 100,000$ and 1,160 men. ${ }^{228}$ Wrought up to more active measures than writing petitions, the three Dorset joined with five Devon ports to send John Crewkerne, who had been town clerk of Lyme but was then living at Exeter, to London to see the principal members of the Privy Council individually; of the expenses incidental to the mission the three Dorset towns bore three-twenty-fourths. ${ }^{229}$ Crewkerne saw several members of the Council and found them all sympathetic, but Archbishop Laud was especially earnest; he 'gave this answer, striking his hands upon his breast, that while he had breath in his body he would to the uttermost of his power advance a business so necessary. ${ }^{230}$ The king promised, vaguely, such measures as would sweep the Algerines and Saleemen off the seas, but we find that in $163_{3} 8$ Poole and Weymouth were still suffering, and that 27 Algiersmen were then known to be in the Channel or bound for it. ${ }^{231}$ The inability to deal with these human vermin was only one indication of the general rottenness of administration which, during the reign of Charles I, consumed the resources of the country without result.

Under the stimulus of expected invasion some attention had been given to the coast defences, but after I 588 they were again neglected. In 1593 Portland was disarmed and left 'wholly unprovided,' all the brass guns having been taken away for use in the Navy. ${ }^{232}$ The ruinous condition of Brownsea, where there was not a gun mounted, was reported to Burghley in 1596 , but it was in much the same state when the panic of 1599 brought it again under notice; there was then only a caretaker in it. ${ }^{233}$ At the same time Portland and Sandsfoot Castles were said to be 'unfurnished,' which may mean much or little..34 As regards Sandsfoot it certainly meant much, for from another paper of the same date it is clear that part of the ramparts had fallen down and that the place was going to destruction from neglect. ${ }^{235}$ In 1610 there was a grant of $\oint_{2} 240$ for the repair of Sandsfoot, ${ }^{236}$ and then the fortifications everywhere were forgotten until 1623 , when relations with Spain were becoming strained. In July the Ordnance Office officials were ordered to survey the fortifications from the Thames to Cornwall; at Portland there were I 3 guns and at Sandsfoot IO, but the sea there was undermining the front. ${ }^{237}$ To put both castles in good condition it was estimated that $f_{0}, \mathrm{r}, 000$ would be required. At Weymouth, in 1622 , there were guns at the Nothe and in the Bulwark; in 1625 the corporation resolved that the block-house at Melcombe should be built up with stone. ${ }^{238}$ When it appeared probable that war with France was approaching the ports grew fearful of cross-Channel raids, and in 1626 estimates were prepared for two more batteries, one at Weymouth and one at Melcombe ; towards this the corporation offered $f_{0} 20$ of the cost. ${ }^{239}$ In 1628 there was no fort at the Nothe; in petitioning for one the corporation

${ }_{226}$ S.P. Dom. Chas. I, dxxxvi, No. 97.

$2: 0$ Hist. MSS. Com. Rep. iii, App. 346.

${ }^{332}$ Acts of P.C. 7 Aug. 1593.

${ }^{233}$ S.P. Dom. Eliz. cclvii, No. 77 ; Cecil MSS.

${ }_{234}$ S.P. Dom. Eliz. cclxxii, No. 25.

${ }^{236}$ S.P. Dom. Jas. I, Ivii, II Aug. 1610.

${ }^{238}$ Moule, op. cit. $17 \mathrm{x}$.
2.9 Moule, op. cit. 179.

${ }^{231}$ Coke MSS. (Hist. MSS. Com.), ii, $191,192$.

(Hist. MSS. Com.), viii, 152 ; Harl. MSS. 3324 , ful. 62.

${ }^{235}$ Cecil MSS. (Hist. MSS. Com.), viii, 148 .

${ }^{237}$ Ibid. cxlix, No. 104 ; Harl. MSS. 1326 , fol. $70,72$.

${ }^{239}$ Ibid. 174 .

213 


\section{A HISTORY OF DORSET}

said that 200 sail of any burthen could ride in the harbour. ${ }^{2 * 0}$ When the war had commenced I 6 guns were sent to Weymouth and five to Lyme; ${ }^{2+1}$ to receive these the burgesses of Lyme built a sconce at a cost of $\oint_{0} 200$, but the mayor complained that many of the inhabitants refused to contribute. ${ }^{2+2}$ The last notice of the county fortifications before the Civil WVar is of about $166_{3} 6$, when the annual cost of Portland Castle was $f_{0} I, 48$ I I 4 s. $2 d$. ; ${ }^{24 s}$ Sandsfoot is not in the list.

The war with Spain gave occasion for the Cadiz expedition of 1625 . The fleet was made up of men-of-war and hired transports, the counties not being required to find any armed ships. No Dorset vessel appears in the fleet list but the port of origin is not always given. In I 626 Charles, on the brink of war with France, resolved to follow the precedent of Elizabeth's reign and called upon the maritime shires for 56 ships to join the royal fleet. On 2 I June there was an order to press $25^{\circ}$ seamen in the county ${ }^{24}$ this was followed on the 30 th by a demand for two ships from Weymouth and Poole, 'with the other sea ports and towns of that part,' and for one from Lyme. ${ }^{975}$ Each vessel was to be of 200 tons and 12 guns, and to be victualled and stored for three months. The govermment, anticipating that there would be no ship of sufficient size belonging to Weymouth, offered to send one from London for the corporation to hire, promised that the service should be confined to the English coast, and directed that the proportion of crew to tonnage was to be two men for every three tons. The Dorset justices, who made themselves the spokesmen of the general discontent, were sharply reprimanded by the Council, but the contingent was reduced to two ships.

Originally the levies had been intended to meet at Portsmouth by 3 I July, 1626 , but that had been found to be quite impracticable and the preparations lingered until the following year. In the meanwhile the ports bombarded the Council with protests. The Poole men asseverated their inability; they said that they had lost $f^{8} 8,500$ by the enbargoes in France and Spain, and that the town had 400 widows and children to support. ${ }^{2+6}$ Lyme professed itself too poor and also dwelt upon the embargoes, while the inhabitants of Weymouth declared themselves to be quite unable to meet the requirements of the Council. ${ }^{27}$ In April, 1627, the Weymouth corporation stated the town losses at $f_{0} 2,600$, besides the drain on their resources in the support of the wives and children of seamen taken by the Algerines; they had seven ships embargoed at Rouen and five at Bordeaux. ${ }^{2+5}$ No doubt those ports whose principal business relations were with France felt the effects of war acutely; in September the mayor of Lyme wrote that there would be no trade again until there was peace with France, and that the customs receipts for the whole quarter were under $f_{1} 120 .^{249}$ Many of the Poole and Weymouth vessels embargoed abroad were probably Newfoundland ships bringing their catches straight from the Banks; it was no wonder that these southern ports reeled under the effects of such losses and a direct and heavy taxation, to which they in particular were subjected, when the same circumstances that caused it rendered them especially unable to meet it. Matters did not improve for

${ }^{240}$ S.P. Dom. Chas. I, ci, No. I 5.

${ }^{24}$ Ibid. xxxi, No. 107 ; xxxii, No. 106.

2nt Hist. MSS. Com. Rep. v, App. $58 \mathrm{I}$.

$2: 1$ Ibid. ccxlv, No. 49

243 Ibid. cccxl, No. 39 .

${ }^{246}$ S.P. Dom. Chas. I, 1, No. 57. One of the ships thus lost or detained was of 190 tons.

247 lbid. 1, No. 58 ; liii, No. 27 (i). $\quad 318$ Ibid. Ixi, No. $7 . \quad$ :19 Ibid. Ixxviii, No. 74. 


\section{MARITIME HISTORY}

them; in 1628 the Poole townsmen returned their losses within four years as 20 ships of 1,465 tons, there being only 16 , of 838 tons, left to work with. ${ }^{250}$

A condition of war led to returns of ships and men being again required. That of $1629^{251}$ assigned 20 vessels to Poole, including 2 of 150 tons, with 82 shipmasters and men. At Lyme there were 18 ships, 2 being of 80 tons, and II I men; at Weymouth and Melcombe 26 ships, the largest being of I00 tons, and $30 \mathrm{I}$ men. The totals for the county were 68 ships, I 35 masters and masters' mates, and 950 seamen and fishermen; of the smaller places there were 37 men living at Wareham, 36 at Swanage, 25 at Studland, 86 at Chideock, 35 at Charmouth, 49 at Bridport, 64 at Burton Bradstock, 64 at Abbotsbury, 35 at Wyke Regis, and 36 in the isle of Portland. At Ower, which Edward I had intended to make a flourishing port, ${ }^{252}$ there were only two. So far as the ships are concerned the foregoing can only refer to those at home at the date of examination, when the largest must have been at sea, for another return of ${ }_{1} 634^{253}$ gives Dorset six of from 100 to 250 tons. Notwithstanding their war losses the ports had sufficient capital and enterprise to follow privateering speculation vigorously. Between 1625 and 1628 the Leopard, 240 tons, Abigail, I 20 tons, Pilgrim, 200 tons, Elizabeth, Ioo tons, Sarab Bonaventure, I oo tons, and Stephen, roo tons, of Weymouth, the Garland, I6o tons, of Poole, and the Bonaventure, 100 tons, of Lyme, were among the large ships for which the owners obtained letters of marque. ${ }^{254}$ But not improbably some of these were hired and really belonged to other ports; the Leopard, however, was a Weymouth owned ship. In the year ending with February, I629, letters of marque were taken out for eleven Weymouth ships, three of Lyme, and one of Poole. ${ }^{255} \quad$ Here the largest Weymouth vessel was of i 40 tons.

Charles had issued ship-money writs in 1628 , but, alarmed at the feeling aroused, he withdrew them at once. Forced at last to choose between facing a Parliament and raising money by this method the writs of 20 October, I 634 , were sent out directed to Poole, Weymouth and Melcombe, Wareham, Lyme, and Bridport for a 4oo-ton ship armed, manned, stored, and victualled for twenty-six weeks' service. ${ }^{256}$ As the ships required were larger than those possessed by any port except London an equivalent in money might be paid to the Treasury, to be applied to the preparation of a king's ship, and the Dorset ports were therefore given the option of paying $f_{0} 2,204$. H.M.S. Adventure was allotted to Dorset, but it was found subsequently that a mistake had been made and the county rated too low in money. ${ }^{257}$ The second shipmoney writ was of 4 August, I 635 , and was general to the inland shires as well as to those of the coast; Dorset was required to find a 500-ton ship or $f_{5}, 000{ }^{253}$ The first assessments were $f_{0} 60$ on Poole, $f_{0} 100$ on Dorchester, $f_{0} 70$ on Lyme, $f_{3} 30$ on Bridport, $\oint_{2} 20$ on Wareham, and $f_{0}$ io on Corfe, but these assessments were afterwards altered, $f_{4} 40$ being then placed on Weymouth. ${ }^{259}$ In April, 16 36 , money was coming in freely, the county being

${ }^{250}$ S.P. Dom. Chas. I, ciii, No. 43.

${ }^{253}$ S.P. Dom. Chas. I, cclxx, No. 64 .

${ }^{251}$ Ibid. cxxxviii, No. 11 .

${ }_{252}$ Ante, p. I 8 r. comparatively large scale.

${ }^{2} 4$ Ibid. cxv.

2.6 Ibid. celxxvi, No. 64 .

${ }^{239}$ Ibid. cexcri, No. 69 .

Or perhaps the return o peace had encouraged ship-building on a

${ }^{255}$ Ibid. cxxxvi, No. 79 .

${ }_{237}$ S.P. Dom. Chas. I, cclxxxiv, No. 15 ; cclxxxvi, No. 7.

${ }^{2.39}$ Ibid. cccii, No. 78 ; Harl. MSS. $68+3$, fol. 93 . 


\section{A HISTORY OF DORSET}

only $699 \mathrm{I}$ in arrear, ${ }^{260}$ but in October there was a new ship-money writ, a new sheriff, ${ }^{261}$ and a different story. Freke may have been less persuasive than Trenchard or, more probably, the tide of resistance was rising; at any rate he found much more trouble, and began by distraining on his son to set a good example. He reported that the poorer people paid their money 'like drops of blood,' for to do it some were compelled to sell their only cow and come on the parish. ${ }^{262}$ In the latest assessments Weymouth and Melcombe were rated for $£_{85}$, Dorchester $£_{45}$, Lyme and Corfe $£_{40}$ each, Poole $£_{2} 4$, and Bridport $f_{2} 20 .{ }^{.23}$

The difficulty of collection grew greater with every month ; in September, 1637, the sheriff, Richard Rogers, distrained on Sir Walter Erle and others of the county gentry in order to frighten those lower in the social scale, but Dorset was still $\oint_{\mathrm{I}}, 200$ in arrear on the last writ. ${ }^{26 t}$ The fourth writ was not issued until January, I 639, and then the assessments were much reduced, Weymouth and Melcombe being put down for $\oint_{\mathrm{I}} 5$, Poole $\oint_{\mathrm{I}}$ 2, Wareham $f_{0} I 0$, Lyme $f_{0} I 7$, and Bridport $f_{0} 8^{265}$ By this time it was too late for any modifications to soften the universal spirit of opposition; the sheriff of 1640 , William Churchill, wrote to the Council in April that he had distrained on Lady Ann Ashley, but that her servants had rescued the horses, and that when an attempt was again made in Dorchester to seize them the same result followed; this, he thought, would be a bad example. ${ }^{266}$ A month later he wrote that he was still levying under distress warrants but that there were no buyers for anything taken ; ${ }^{267}$ by August he reported that he had levied $f_{2} 200$ at a cost of $f_{5} 5^{\circ}$ to himself, that the country people rescued by force the cattle seized, and that the constables were refusing to make returns or to assist the bailiffs. ${ }^{268}$ Only half the assessments had been collected, and he sent up the names both of those who refused payment and of those who were active in the rescues. But now the Long Parliament was sitting and sheriffs were to count for little in the immediate future.

Along the south coast the resistance to ship-money must have been intensified by the fact that while it was being paid, and while the pretentious fleets equipped with it were cruising uselessly, the Algerines and Saleemen were, as has been noticed, almost stopping Channel trade. Thus all the more considerable English ports, the worst sufferers from Charles's inefficient naval administration, stood by the Parliament even in Royalist counties. Poole and Lyme were ardently Parliamentarian, as were also Dorchester, Portland, and Wareham; Weymouth and Melcombe were of a more divided allegiance, but with a majority adverse to the king. Early in the Civil War the county came under the control of the Royalists, only Poole and Lyme remaining throughout in the hands of Parliamentary garrisons. The siege of Lyme is famous in local and national annals. As in the case of Plymouth, the Parliament was only able to keep its hold on the town in virtue of having the command of the sea, a supreme advantage to which, in its momentous influence in bringing about the final issue of the Civil War, no historian has yet done full justice. The siege commenced on 20 April, I644; on 27 April the Ad-

${ }^{200}$ S.P. Dom. Chas. I, ccexviii, No. 29.

${ }^{x}$ S.P. Dom. Chas. I, ccexxxiii, No. 4.

264 Ibid. ceclxvii, No. 2 ; ccclxx, No. 74.

${ }^{266}$ Ibid. ccccli, No. 13.

${ }^{269}$ Ibid. cclxiii, No. 26.
${ }^{261}$ John Freke, vice Sir Thomas Trenchard.

${ }_{2 / 3}$ Ibid. cccli, No. 8 I.

${ }^{263}$ Ibid. cccci, No. 38

${ }^{267}$ Ibid. cccclv, No. 7 . 


\section{MARITIME HISTORY}

miralty Committee of Parliament ordered their admiral, the earl of Warwick, to Lyme with his squadron, 'You well know what consequence the town is to shipping in the west." ${ }^{269}$ Supplies by sea began to come in by 26 April, which was 'a great encouragement'; and on 29 April and I I May reinforcements of seamen were put ashore. The admiral was off Lyme on 23 May, and found four vessels already in the anchorage from which powder and provisions had been landed. When Warwick arrived the garrison was in sore need, but corn and powder were sent ashore and the sailors of the squadron added fish and bread saved out of their rations, with shoes and clothes from their kits for the ragged and bare-footed men at the front. ${ }^{270}$ The squadron took part in the operations by sending the ships' boats along the coast towards Bridport, landing in the enemy's rear and thus diverting his attention. ${ }^{271}$ In the town men and women - the latter filled the soldiers' bandoliers while they foughtwere equally undaunted; but when Prince Maurice drew off on I 5 June it was because the fleet had enabled them to hold out for the coming of the army of relief under the earl of Essex.

Nothing exciting happened at Poole. Parliamentary ships appeared there off and on, and an occasional Parliamentary privateer set sail from the harbour. In 1644 the House ordered four guns to be sent to the town and four to Brownsea. ${ }^{272}$ Weymouth changed hands more than once, although Melcombe remained in the possession of the Parliament. But here again the retention of Melcombe and the recapture of Weymouth were largely due to aid brought by sea. When Warwick was there, in 1644 , he dwelt on its importance, 'and the relation that its safety has to H.M. navy,' whereupon the Parliamentary committee authorized the governor to put in hand the defences recommended by the earl, and this probably accounts for the appearance of a fort at the Nothe, where hitherto only guns behind a breastwork had been in position ; ${ }^{273}$ another, the New or Jetty Fort, ordered to be pulled down in 1663 , may date from this period. ${ }^{27}$ Several other forts were erected in the two towns during the war, but on the landward side. An order of 29 August, $1653,{ }^{276}$ for the disarmament of Weymouth and Melcombe must have caused the abolition of these. The Council of State directed an engineer to go to Weymouth in I 649 to build a 'citadel' there, but no record of his proceedings, if any followed, has come down to us. ${ }^{276}$ Sandsfoot Castle, of little importance, mainly followed the fortunes of Weymouth, and Portland surrendered to the Parliament 6 April, I646. When it yielded there were twenty-one guns in it and plenty of ammunition; the terms of surrender were designed to 'save the face' of the garrison who were to march out with drums beating and colours flying but who possessed neither drums nor colours. ${ }^{278}$ Many of them enlisted with the besieging force. Under the Commonwealth one company of foot was divided between Portland and Sandsfoot as garrison.

The first Dutch war of $1652-4$ was very pleasing to the seamen, and at first volunteers flocked in to man the State's ships. But after the volunteers

${ }^{269}$ S.P. Dom. Chas. I, di, 27 April, 1644. Warwick was also to have regard to the safety of Poole.

${ }^{870}$ An Exact and True Relation in Relieving Lyme, 1644; A Letter from the Rt. Hon. Robert, Earl of Warwirk,... 1644. ${ }^{271}$ Hist. MSS. Com. Rep. x, App. vi, $152 .{ }_{873}$ Commons' Journt 28 Sept. $16+4$. ${ }^{273}$ S.P. Dom. Chas. I, div, No. 58, July, $16+4$; Brief Relation of the Surprise of the Forts at II'cymouth, ... 16.t4.

${ }^{276}$ Ibid. iii, 20 Oct. 1649.

274 S.P. Dom. Chas. II, xc, No. 6.

${ }^{273}$ Ibid. Interreg. xxxix.

276a Add. MSS. 9299, fol. 220. 


\section{A HISTORY OF DORSET}

there was always a residuum who could only be reached by the press system, therefore in May, 1652 , a circular letter to all the counties directed the impressment of all seamen between fifteen and fifty years of age. Armed merchantmen were still used with the fleets but such ships were now never under 200 tons; it is doubtful whether there were any of sufficient size in Dorset therefore the county took little part in the war beyond finding men. The officials of both Poole and Weymouth were ordered, however, in March, I 652 , to report if there were any suitable vessels within their jurisdiction. Besides the fact that the number of seamen in England was insufficient to man the merchant navy as well as the much larger fighting fleets now commissioned, the difficulty in obtaining men was intensified by the counterattractions offered by privateers with their slacker discipline and greater chances of prize-money. In December, 16 52 , wages were raised in the State's ships, and other advantages promised. The men came in more willingly, but there was always a large deficiency. In the same month the mayor of Poole, having been ordered to press 66 men, wrote that he had been able to obtain only 30 , and found 'much difficulty' in the business. ${ }^{277}$ This happened before the publication of the advance in wages, \&c. ; a week later the mayor wrote that the notice had been received and proclaimed by beat of drum through the town with the result that men were going 'with more readiness.' ${ }^{278}$ The improvement was only temporary; six months later the press-master for the county was directed not to take more than one or two men out of each fishing boat, a severe enough measure in its modified form. ${ }^{279}$

The losses of Weymouth during the Civil War were estimated at $f_{0} 20,000,{ }^{280}$ which must indicate injury to the Newfoundland trade, but in I 657 both Poole and Weymouth were busily at work again. ${ }^{281}$ In this year we find, for the first time, notices of the deterioration of Weymouth Harbour from shoaling, so that ships were obliged to unlade in the Roads for want of quays at the entrance. ${ }^{252}$ As there had been no marked increase during the seventeenth century in the size of ships trading to and from the third-rate and fourth-rate ports, this seems to point to some comparatively sudden impairment. Another hindrance to trade was the presence of the Ostend and Dunkirk privateers, to whom there are numerous references at this period, off the ports. "Weymouth is infested with these rogues more than any other place,' wrote an official, ${ }^{23}$ but that they should come there was at least evidence of its maritime trade. After the Dutch war sailors were wanted for service in the West Indies, an employment regarded with terror by them on account of the death-rate from disease. Although a much smaller number of men than in the Dutch war was required for the war with Spain it was relatively more difficult to obtain them. In $16{ }_{5} 6$ the Navy Commissioners were informed that there were plenty of seamen in Lyme, Weymouth, and Poole, but that as soon as a man-of-war appeared at one port the men ran off inland and notice was sent to the other places. ${ }^{23 s}$ Both in Dorset and in other counties the mayors and constables were believed to warn the men and assist them to disappear temporarily. Many of the officials were themselves shipowners,

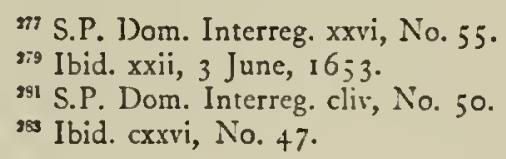

${ }^{2 i s}$ Ibid. $x x x$, No. 100.

${ }^{30}$ Ellis, Hist. of W'eymouth, 22.

99? Ibid, clviii, No. 17.

2st Ibid. cxxxii, No. 67. 


\section{MARITIME HISTORY}

and it was contrary to their interests to have their towns cleared of men with a consequent rise of wages and difficulty in getting merchantmen to sea. During the Commonwealth, Weymouth developed a large trade in the manufacture of canvas for the Navy, mainly under the auspices of the Pley family.

At the Restoration Portland was armed with 16 guns, but Sandsfoot is not included in the survey of $166 \mathrm{r}$; 285 the office of keeper of the castle was, however, granted in $1660 .{ }^{286}$ At Portland there was a garrison of 36 men, two matrosses (artillerymen) at Sandsfoot, and one master gunner was attached to Weymouth. ${ }^{287}$ Dorset was not within the area of actual operations during the second Dutch war but the ports suffered severely from the enemy's privateers. A levy of men in December, 1664, shows the county as then having 300 available, as compared with 700 in Devon, 300 in Hampshire, and 150 in Somerset. ${ }^{298}$ These numbers probably indicate the relative ability of each county although no guide to the gross totals. Shipwrights, also, were impressed for the royal dockyards, the mayor of Lyme writing in January, 1666, that he had sent up all in the town except two ; others were obtained from Poole. ${ }^{289}$ Early in 1666 Louis XIV joined the Dutch, and, as it was not known that he did not intend to give any real help to his ally, fears of raids or invasion were acute in the Dorset ports where their trade relations with France seem to have made them especially nervous. Portland and Sandsfoot Castles were of little use for protection; in December, I664, the duke of Albemarle had proposed that Sandsfoot should be demolished, ${ }^{290}$ and, taught by experience, there was a general feeling locally that ships were a better safeguard than forts. In July, I 666, they were 'very apprehensive' at Weymouth of a French landing; a year later, after the events in the Thames and Medway, they had still more reason to fear what might happen. The people of Lyme were 'much startled' when they heard of Ruiter's deeds in the Medway; then he came down Channel with his fleet and the whole coast was alive with preparation. Additional guns were mounted at Lyme, and a night watch set, while militia were brought to Dorchester and Weymouth. ${ }^{291}$ In the latter town they thought, on 6 July, that the moment had come when a fleet was seen bearing into the Roads but it proved to be composed of English merchantmen. The moment did come on 7 August, when 50 sail were in sight, really Dutch, and then drums beat and men mustered in the town. ${ }^{292}$ But peace had been proclaimed and Ruiter was sailing homewards, ignoring Weymouth.

For nearly two centuries Bridport is not mentioned among the ports; in I 670 the inhabitants had in view another attempt to make a harbour, and obtained a grant giving them powers to undertake the work..$^{293}$ In 1673 , however, nothing had been done, ${ }^{29 t}$ and in fact nearly another century elapsed before there was shelter even for small coasters. Some improvements had been effected at Weymouth remedying the defects noticed in 1657 , but in I67 I a bad south-east gale breached the 'Grand Pier' and destroyed $300 \mathrm{ft}$. of another one under the Nothe Hill, besides injuring the quays. ${ }^{995}$ The third

\footnotetext{
${ }^{285}$ W. O. Ord. Stores, lxxviii.

${ }^{287}$ S.P. Dom Chas. II, xxxviii, 47.

${ }^{258}$ Add. MSS. 9316 , fol. 79.

${ }^{290}$ Ibid. cvi, No. 76.

${ }^{293}$ Ibid. cclxxxiv, Aug. 1670.
}

${ }^{286}$ Docquet Bk. Chas. II, Sept. I 660.

${ }^{289}$ S.P. Dom. Chas. II, cxliv, Nos. $28,90$.

${ }^{291}$ Ibid. cex, No. 6.

294 Blome, Britannia.
${ }^{292}$ Ibid. ccxii, No. 97.

${ }^{295}$ S.P. Dom. Chas. II, cclxxxviii, No. 33 . 


\section{A HISTORY OF DORSET}

Dutch war caused the usual drain of men to man the fleets, and the customary troubles from the spoil made by privateers, but no incident of any interest affecting Dorset occurred. The landing of the duke of Monmouth at Lyme in June, 1685 , brought the county into prominence temporarily, but not in connexion with naval affairs, nor did the passage down Channel of William of Orange affect the coast. After Torrington's defeat off Beachy Head in 1690 there was certain expectation of invasion, and the county levies crowded to the ports, but Tourville stood westward to Torbay. His fleet was seen off Portland, much to the fear of Weymouth, and guns were mounted at Poole. Later in the war, in 1694 , the Ordnance Office sent three guns to Lyme, ${ }^{296}$ but in 1690 it was remarked that the result of hostilities with France was to destroy the trade of Poole, Lyme, and Weymouth, which was chiefly with that country, and that the principal business remaining was smuggling. ${ }^{297}$ Two Poole seamen, Peter Jolliffe and Wm. Thompson, were awarded gold medals and chains in 1694 and 1695 for heroic conduct in action against French privateers.

The war occasioned a great increase in the Navy, and, as a necessary consequence, more dockyards were required. Plymouth yard was founded in 1694, but the Admiralty desired another, which would undoubtedly have been established had the national finances permitted the expenditure. In 1698 several officials travelled round the south coast examining the harbours with a view to selecting one for the purpose, but their condemnation of Dorset was unhesitating. ${ }^{998}$ At Poole they found a depth of $16 \mathrm{ft}$. on the bar at high water spring tides, and, saying that very few vessels ventured into the harbour unless forced there, added that 'it affords nothing in our opinion proper or improvable for the service of the Navy.' At Weymouth there was sometimes only $3 \mathrm{ft}$. of water on the bar, which 'to add no more precludes entirely.'

There is a belief, unlikely to be well founded, that in the mediaeval period lights were shown from the chapels at St. Aldhelm's Head and St. Catherine, Abbotsbury. The seventeenth century saw the beginning of the modern lighthouse system, in which East Anglia led the way, probably by reason of the very large collier and other traffic coasting to and from London. As shipping trade increased and the profits from lights became greater, courtiers and others used what influence they possessed to obtain patents authorizing them to put up lighthouses and collect tolls. After the Restoration the competition for patents became very keen. The first applicant for Portland, in May, I 664, was Sir John Coryton, a large speculator in the business, who included it with six other stations he was anxious to light for his own and the public benefit. ${ }^{299}$ His petition was referred to the Trinity House Corporation to report upon, and as they were jealous trade rivals their answer was adverse. Coryton depended upon the influence of the duke of York, who, he boasted, never denied him anything; here he overrated his own or the duke's influence and no patent was granted. The matter was dropped for nearly half a century, and then Captain William Holman petitioned in 1700 for a licence. This, as usual, was submitted to the Trinity House, who reported that a lighthouse was needless and that if

${ }^{2} 6$ H. O. Mil. Entry Bk. iii, 216.

2:* S'oane MSS. 3233 .
298 Treas. Parers, 14 April, 1690 (Rep. of Customs Com.).

${ }^{299}$ Hist. MSS. Com. Rep. viii, App. i, $2 ; 2$. 


\section{MARITIME HISTORY}

it ever became necessary they would erect one. ${ }^{300}$ Holman was a successful Weymouth privateersman, whose name often occurs in official papers of the period. The Weymouth Corporation took up the question-indeed, Holman was probably their mouthpiece all through-and eventually, in order to prevent the privilege falling into private hands, the Trinity House obtained a patent for themselves dated 26 May, I7 16..$^{301}$ They built two lighthouses, an upper and lower, on the west side of Pörtland, and intended to lead between the Race and the Shambles; these were sublet on a lease which expired in $1777 .^{302}$

The lights were coal fires and, besides being feeble, were badly attended to ; in 1752 two Elder Brethren of the Trinity House happened to be passing Portland on a journey westward and noticed that the fires were not lit until two hours after sunset, that the lower light then glimmered faintly for an hour and ceased, and that the upper light burnt fitfully for a long time before it gave a steady brightness. ${ }^{303}$ When they commented on the matter they were told that often the lights did not show all night. In I 789 a new tower, built by William Johns of Weymouth, was erected further to the eastward for the lower light; it was then lit with oil, the upper one having been altered for oil in $1788 .^{304}$ In 1822 these lights were producing a net revenue of some $\oint_{2}, 300$ a year. ${ }^{305}$ Both lighthouses have been abandoned recently in favour of a new one erected I 30 yards from the eastern extremity of Portland Bill, standing I $4 \mathrm{I}$ feet above high-water mark and fitted with all the latest improvements. This, which shows an upper and lower light in the one tower, was lit in January, 1906.

A lightship was placed on the east end of the Shambles Shoal from I September, I859. The other shore lights are Weymouth north pier, I 867 , south stone pier, I896 ; Anvil Point, I881 ; Swanage pier, I897; Bournemouth pier, I880; Boscombe pier, I894 ; Poole, North Haven Point, 1848 , Sandbanks pier, 1898 ; and Lyme Regis, 1853 . The first Portland breakwater light was shown in $185 \mathrm{I}$, and afterwards from the fort at the end of the breakwater as then completed in 1876 ; the number and position of the lights have been continually changing recently as extensions have progressed.

The earliest sea marks used in navigation were prominent objects, such as church towers and natural heights. Of the latter there is no lack along the Dorset coast, and their existence has obviated the necessity for artificial beacons of which there is only one, that put up by the Trinity House on Portland Bill. The date of this is 1844 ; it probably succeeded an older beacon but one of no great antiquity. Wyke Regis church, in conjunction with the north-east end of Portland, has long been a leading mark to clear the Shambles, and St. Aldhelm's and St. Catherine's chapels, especially the latter, were old sea marks.

During the eighteenth century Great Britain, having won the command of home waters, was fighting for the mastery of the oceans therefore local maritime history ceased, for the most part, to have any intimate connexion with naval events. The chief anxiety on the coast now related not to the

\footnotetext{
${ }^{300}$ Hardy, British Lighthouses, 104.

${ }^{302}$ Parl. Papers, $1861, \mathrm{xxv}, 420$.

${ }^{301}$ Pat. 2 Geo. I, pt. iv.

${ }^{303}$ Hardy, British Lighthouses, 105.

${ }^{304}$ Parl. Papers, 1861 , xxv, 420; Kay Collection, B.M. Nos. 164, 165, 169.

${ }^{305}$ Parl. Papers, 18 22, xxi, 497.
} 


\section{A HISTORY OF DORSET}

enemy's fleets but to his privateers; against these local armaments still had their use. A survey of $17^{1} 4^{-1} 7^{306}$ tells us that Portland Castle had saved many ships from being taken by them during the recent wars; it had ten guns when surveyed but was in a dilapidated condition. There had been twenty guns at Sandsfoot in I69I, but in 1717 there were only three, of which one was old and rusty and two had been washed into the sea. In I70 I the Ordnance Office had seen no objection in allowing the corporation of Weymouth to pull down so much of the walls of the castle as might be sufficient to supply them with stones to repair their bridge, and the Treasury had sanctioned the proceeding. ${ }^{007}$ This, therefore, marks the definite abandonment of Sandsfoot. On the Isle of Portland there were batteries at the Bill, at Blacknor Point on the west side, at the pier and at Rufus Castle on the east side, and at the village of Chesil, but the guns were all honeycombed and useless. At Weymouth there was a five-gun battery on the Nothe and two others below, one being at the jetty ${ }^{303}$ and one between the Nothe and Sandsfoot. Here, also, the guns were in a condition which proves that there could have been little fear of attack during the preceding wars. At Melcombe there were four guns in the Blockhouse, eight in the Mountjoy battery, and two at the jetty. There were nine guns at Lyme, and from a notice of 1724 we learn that they were in two batteries or forts. ${ }^{509}$

In 1708 Weymouth petitioned for assistance from the Customs for the repair of the bridge, quays, and piers, as the harbour was 'choked up with sand occasioned by the ruins of the said quays and bridge,' so that only the smallest vessels could enter instead of those of 200 or 300 tons as formerly. ${ }^{.10}$ It was no doubt in consequence of the deterioration of the harbour that the Newfoundland trade deserted Weymouth in favour of Poole during this century. From a statement of the grievances of the Poole men against the French we find that the town sent forty ships to Newfoundland in $1725^{311}$ Defoe notices Poole in 1724 as 'the most considerable sea port in all this part of England . . . particularly successful for many years past' in the fishery. ${ }^{312}$ The Poole trade grew steadily until between 1769 and 1774 there were from sixty-two to seventy-four ships a year, and between i 787 and 1792 from sixty-five to eighty-four. ${ }^{313}$ The highest number from Weymouth was eight ships in 1773 , and Lyme seems to have given up the fishery. The American War of Independence inflicted great injury on Poole not only in the captures made on the Banks by privateers but also by the destruction of a trade with the colonies which had been increasing largely during the century. Some of the capital thus unemployed was transferred to the southern whale fishery to which Poole sent two ships in $178 \mathrm{I}$ and four in $1783^{314}$ The importance of the Newfoundland fishery in breeding seamen is shown markedly in the assessments of men on the ports in $1795^{315}$ where those places engaged in the traffic stand out in contrast to the others. The same influence had acted through three centuries, and had been of priceless value in filling the cadres of the Navy, but direct proofs such as that of 1795 are naturally infrequent.

${ }^{306}$ King's MSS. 45.

31: This is shown in the Survey of 1698 , ante, p. 220.

${ }^{310}$ Treas. Papers, criii, 17.

${ }^{313}$ Tour Througls Gf, Britain, i, Lettcr ii, 70.

${ }^{31}$ Parl. Papers, 17 56, 1xxiv, 274.

30 Treas. Papers, lxxiv, 32.

${ }^{303}$ Stukely, Ifin. Curiosum, 152.

311 Ibid. colv, 54.

${ }^{313}$ Parl. Papers, 1793, xlii, App. No. 6.

${ }^{313}$ Post, p. 224. 


\section{MARITIME HISTORY}

The state of war which, with the exception of one interval of peace, existed between 1739 and 1763 led again to local fears of attack from privateers. Guns were supplied by the Ordnance Office on condition that the towns built batteries and provided ammunition; ten were sent to Poole, seven to Studland Bay, seven to Swanage, and six to Lyme, where there were already five in position. ${ }^{316}$ Taylor's map of Dorset of $1765^{317}$ shows batteries on Peverel and Handfast Points, at North and South Haven Points (each four guns), and at Poole Head. At Weymouth only the Dock Fort under the Nothe is shown; neither Portland nor Sandsfoot is included in an official. survey of 1766 . There was not so much fear of invasion in Dorset as in some other counties during the Seven Years' War, but the vexations of war, especially impressment, bore heavily on both owners and men. In 1759, Captain Fortescue of H.M.S. Prince Edwoard was sued for taking so many men out of a Poole Newfoundland ship that she was lost; ${ }^{318}$ he was cast in $f_{1} \mathrm{r}, 000$ and costs, and no doubt got inscribed as well on the Admiralty Black Book for Boards of all political parties were equally desirous of preventing any case coming into court in which the question of legality of impressment might be raised.

Notices of wrecking, which must always have been common on the Dorset coast, become more frequent in the era of journals and newspapers. In January, I762, a French man-of-war, the Zenobie, was lost on the Chesil ; seventy-one of the crew saved themselves, but were robbed and stripped by the natives. The survivors were clothed and sent back to France by order of the king instead of being treated as prisoners of war. That the treatment these men received locally was no exceptional incident is proved by the fact that in I754 the Rev. Thomas Francklyn of Fleet preached a sermon on the subject, occasioned by what he had seen, in which he said that he had repeatedly expostulated with his neighbours and 'tried to stir up principles of compassion as well as honesty in their hearts. ${ }^{319}$ He then dwelt on the Wreck Act of 26 George II, cap. 19, just passed, which made plundering, destroying, and wrecking generally, felony punishable with death. The worst instance, within historic knowledge, both of wreck and wrecking on the Dorset coast occurred in I 795. Rear-Admiral Christian with a squadron of men-of-war and upwards of 200 transports with i 6,000 troops on board left St. Helens for the West Indies on 16 November; on the i th they were caught west of Portland in a terrible gale, and on the $\mathrm{r} 8$ th six transports went to pieces on the Chesil beach where 234 dead bodies were immediately thrown up, a number increased to 1,600 by the 26 th. The worst part of the story was the behaviour of the people ashore, mostly Portlanders, 'who are always praying for wrecks on their coast and whose whole attention was devoted to plunder ' instead of the rescue of the drowning. They were soon reinforced by ' a considerable mob from different parts solely intent on plunder,' until soldiers brought on the scene dispersed them with volleys of musketry. ${ }^{320}$ On 6 February, 1805, the Abergavenny, an East Indiaman, struck on the Shambles; she slipped off and the captain headed for Weymouth Roads where she sank in sight of the town, upwards of 300 of the passengers

${ }^{316}$ H.O. Ord. v, 29.
${ }^{313}$ Ann. Register.
${ }_{320}$ Ann. Register, 'Account of an Eyewiness'; Smith (Charlotte), Narrative of the Loss, \&c. Lond. I 796. 


\section{A HISTORY OF DORSET}

and crew being drowned. Operations with the diving bell to recover the specie she carried were continued off and on until I 8 I 2 , when the wreck was partly blown up.

A catalogue of wrecks is unnecessary, but the loss of a French ship off Weymouth in October, 1839 , may be mentioned because John Mantle, a coastguardsman, saved the people by swimming off to her with a rope, for which he received the Royal Humane Society's Gold Medal and other rewards. There was, however, no improvement in the habits of the local population. In the previous year three vessels were lost on the Chesil in November ; the coastguard officers reported that the shore was 'completely lined with men, women, and children whose only object was plunder . . . the people from Portland, who completely covered the beach, committed the most bare-faced plunder.' One officer describes them to his superior as 'the lawless barn-door savages of the coast. ${ }^{321}$ As recently as 1872 , when the Royal Adelaide broke up on the Chesil, scores of people were seen lying about the beach dead drunk as the barrels of spirits which formed part of her cargo came ashore. In September, I 859, the Great Eastern, while on her first trip, anchored in Portland Roads after an explosion on board; and in January, I 879 , the Constitution, the American frigate which took four British men-of-war during the war of I 8 I 2, was ashore in Swanage Bay but got off uninjured.

During the Revolutionary and Napoleonic wars there was no great apprehension in official circles of a descent on Dorset whatever fears may have been felt in the county. Such a descent could only have been in the nature of a diversion to assist a real attack on Portsmouth or Plymouth and was only possible in the absence of the fleets, a contingency which was not allowed to occur. In 1798 the Weymouth Corporation petitioned for a guardship to lie in Portland Roads but the Admiralty did not think it necessary to place one there. When the war commenced the supply of seamen was altogether insufficient to man the royal and merchant navies, although years of ever-widening commerce and of naval success had their effect, eventually, in attracting thousands of men to the sea. Therefore, besides the impress system, always working, and a suspension of certain sections of the Navigation Acts, Parliament sanctioned in I795 and 1796 an experiment analogous to the ship-money project of Charles I by requiring the counties each to obtain a certain number of men, not necessarily all seamen, for the Navy, who were to be attracted by a bounty to be raised by an assessment charged in every parish like other local rates. ${ }^{392}$ In 1795 the county was called upon for 142 , and in 1796 for 184 men, comparing with 393 and 509, respectively, for Devon and 236 and 306 for Hampshire. The ports, also, were required to procure sailors by the same means, an embargo being placed upon all British shipping until they were obtained; Lyme was rated for 23, Weymouth for 1 39, and Poole for 279 men. Dartmouth and Poole, the two great Newfoundland ports, show the highest numbers on the south coast, and Poole ranks twelfth in a list of 104 towns.

In 1798 men were needed more than ever, and the French government was known to be considering the possibility of raids, or a descent in force, in gunboats, fishing boats, barges, and the like. Therefore, to afford local

3.1 Parl. Papers, 1839, First Report on the Constabuiary Foree, 1 I9.

3.) 35 Geo. III, cap. 5 ; 37 Geo. III, cap. 4 . 


\section{A HISTORY OF DORSET}

the men-of-war which came from there from that year onwards. Other Dorset shipbuilders of the same date were Henry Chard at Lyme; Thos. Burt, Sam. Esther, Ric. Penny, Cherret and Wills, and Medowes \& Co., at Poole; Thos. Ayles, at Portland; Barnes \& Co., at Swanage; and Thos. Wallis, John Gleed, Simon Jenkens, and Thos. Brick, at Weymouth. ${ }^{332}$ The number of the Poole builders, and the fact that they did not care to tender for Admiralty contracts, shows that the Newfoundland trade there, then reaching its zenith, gave plenty of employment, but probably much of the work overflowed to Weymouth. Messrs. Cherret and Wills seem to have been the biggest firm in the county. The establishment of a packet service in I 794 between Weymouth and the Channel Islands must also have brought employment to the Weymouth builders. At first the packets were hired vessels, three, of 50 tons each, being in the service in $1807,{ }^{333}$ but, later, government ships were used. In 1837 the establishment was transferred to the Admiralty and steamers put on the station; in 1845 there were four running but none of them had been built at Weymouth.

The first Dorset lifeboat was stationed at Portland in 1.825 , followed by another at Studland in 1826 ; both were supplied and maintained by local subscriptions and there were no others for many years. Manby's rocket apparatus was placed at Portland and Bridport in 18 i 5 .

The principal naval event of the nineteenth century relating to Dorset is the construction of Portland Breakwater. It has been noticed that it was intended as a reply to Cherbourg when that port was enlarged and fortified to an extent that suggested that the French government hoped to make it another Brest. But, while Portland has grown in strength and importance, the developments of modern warfare have reduced the value of Cherbourg to such a degree that many French officers now regard it as worse than worthless-a trap, indefensible in itself, attracting an enemy to a weak part of the coast, and unable to protect the war ships sheltering within it. Certainly the Cotentin peninsula is very vulnerable to a power having the command of the sea, and it is significant that Cherbourg itself, although strongly fortified in the middle ages, was never able to resist English or French attack when held by either power during the Hundred Years' War. As late as I 758 , although then recently fortified in the most scientific manner, it fell easily into the hands of Bligh and Howe. The Portland Breakwater had been proposed towards the end of the eighteenth century when there were sometimes from 100 to 50 merchantmen taking refuge in the Roads. The government of that day had no reason from a military point of view to undertake the work, therefore nothing was done until Cherbourg seemed to be growing into a great naval base. The construction was commenced in August, I 847, under the superintendence of Mr. J. M. Rendel and Mr. John Coode, the latter succeeding Rendel, and after two years of preliminary work the first stone was placed on $25 \mathrm{July,} \mathrm{I849.} \mathrm{The} \mathrm{estimated} \mathrm{cost} \mathrm{was} \mathrm{to} \mathrm{be}$ $£ 589,000$, but the plans were subsequently altered and down to I 875 upwards of $\oint_{0} \mathrm{I}, 000,000$ had been expended. ${ }^{384}$

As finished originally the Breakwater, containing nearly 5,750,000 tons of stone, consisted of inner and outer arms, with an opening between them,

\footnotetext{
333 Parl. Papers, 1805 , viii, 485 . ${ }^{333}$ Ibid. $1809, x, 388$.

${ }^{334}$ Ibid. $1852-3$, xcviii, $609 ; 1876,1 x v, 546 ;$ Ann. Register, 1849.
} 


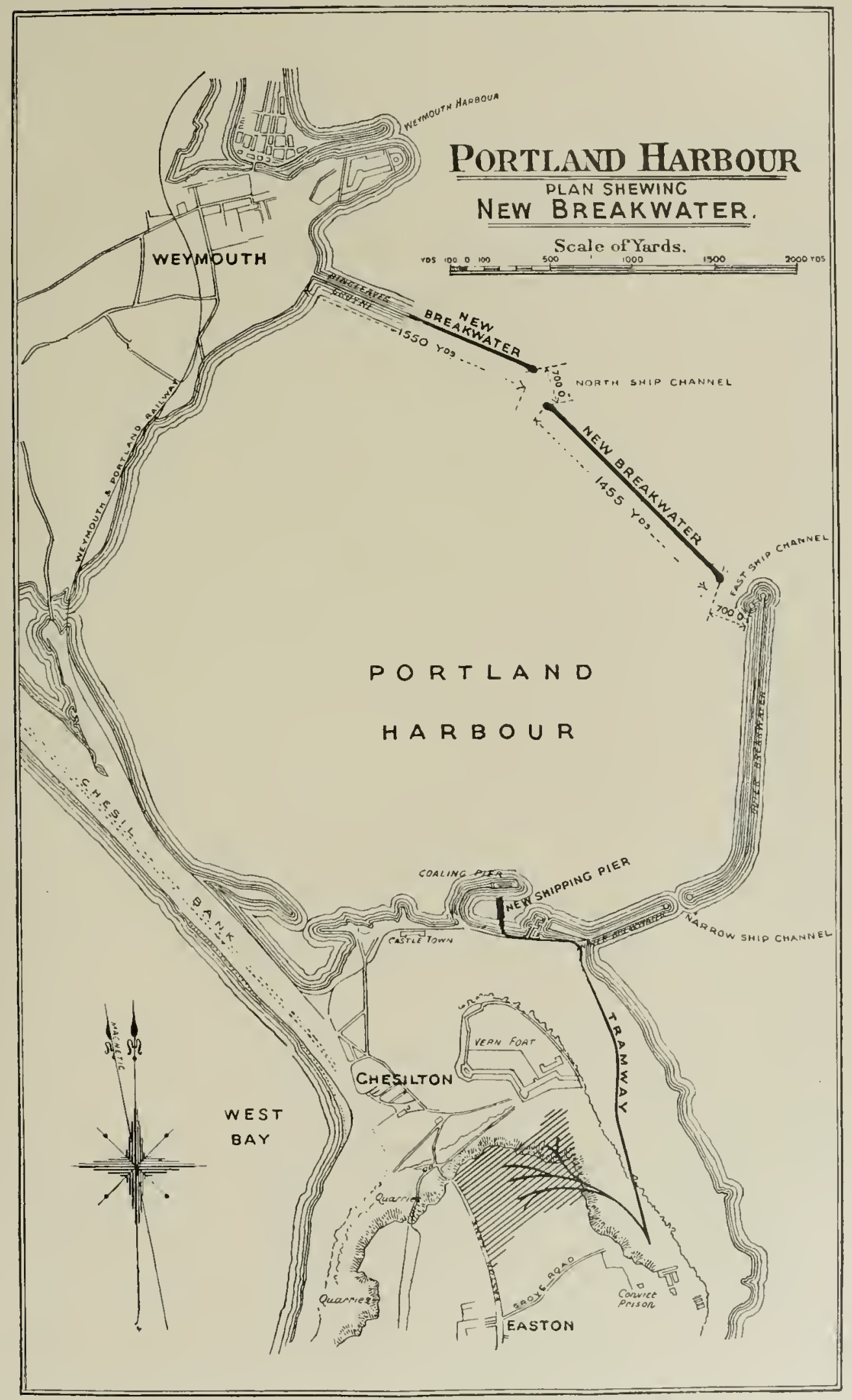





\section{MARITIME HISTORY}

protecting the Roads between east and south, the opinion of expert witnesses in 1845 being that a war fleet could not lie there in all weathers without such shelter. The inner arm is 1,700 and the outer arm 6,400 ft. long, the opening between them being $400 \mathrm{ft}$. wide; there are forts at the extremities of both inner and outer arms. As well as these forts other defences were planned in 1860 ; the Verne Citadel, high up on the northern bluff of Portland, in a position commanding a wide sweep of water towards the Dorset coast and out to sea, and a new Nothe Fort on modern lines, were added. Below the Verne, on the east side of the hill and some $200 \mathrm{ft}$. above the sea level, are the East Weir batteries; the position of the Verne, the Nothe, and the Weir, gives them a plunging fire while necessitating a high angle fire from the enemy's battleships, thus placing the latter under the most unfavourable conditions possible. The inner Breakwater Fort is considered a weak one, but that at the extremity of the outer arm is strong. From the Nothe at Weymouth to the extremity of the outer arm there were two miles of open water, and as the Breakwater approached completion the era of the torpedo began. As the torpedo and the torpedo boat improved in offensive capacity year by year the value of Portland, open to a more deadly form of attack than was possible in the old navy, decreased, but it was not until i 895 that additional works were commenced. The dangerous opening has been closed by the construction of two more breakwaters; one, 1,550 yards long, from the mainland at Bincleaves, and another, 1,455 yards long, called the New Breakwater. Between the Bincleaves and the New Breakwater, and between the latter and the old outer breakwater, are two openings, each $700 \mathrm{ft}$. wide. An area, of which 1,500 acres have not less than thirty feet at low water, is now inclosed, forming, in the opinion of naval men, one of the finest artificial harbours in the world.

In 1855 Poole Harbour, as a retired spot, was the scene of an experimental trial of a submarine boat intended for use against the boom at Cronstadt. The six men who went down in her were nearly drowned and the invention was not adopted by the Admiralty.

\section{APPENDIX}

List (Chronologically Arranged) of Men-of-War Built in Dorset with their Services to the Close of the Napoleonic War

[Abbreviations used :-Ch. $=$ Channel Station ; Med. $=$ Mediterranean ; W.I. $=$ West Indies ; N.S. $=$ North Sea ; N.A. $=$ North America ; C. and C. $=$ Convoy and cruising duties $; A . O .=$ Admiralty Order ; P.O. = Paid out of Commission ; R.S. = Receiving ship.]

Names of captains or of officers subsequently distinguished are within brackets (c. = captain). It should be remembered that only the chief movements of vessels are given. A ship may have been for some years in the Mediterranean, but have returned for short periods for repairs; such intervals are not noticed in the list of services, nor, if occupied in more than one employment in a year, is any other than the principal one usually named.

VIPER (sloop), 270 tons, I4 guns; built at Poole 1746. Services: C. and C. 1746-8 (c. Robt. Roddam); in June, 1747 , silenced and dismantled a battery and took or burnt 33 coasters at Cedeyra, near Cape Ortegal; W.I. I 749-52 (c. Corn. Smelt) and P.O. Made fireship and name changed to Lightning by A.O. 22 July, 1755: N.A. 1757-8 (c. H. M. Goostrey); C. and C. $1759-61$ (c. Jos. Norwood). Sold 1762.

AtTentrve (gunbrig), 178 tons, 12 guns; built at Bridport i 804 . Services: W.I. 1805-10 (Lieuts. John Harris and Robt. Carr). Broken up I 8 I 2. 


\section{A HISTORY OF DORSET}

CheErly (gunbrig), 177 tons, 12 guns; built at Bridport 1804 . Services: N.S. 1805 (Lieut. G. Huish); Ch. (Plymouth) 1806-8 (Lieut. G. Fullerton); Brazil I809-10; Ch. (Downs) I $811-12$; Baltic I813; N.S. I 814 . Sold I815.

FLY (sloop), 286 tons, 16 guns; built at Bridport 1805 . Services ; Ch. 1806 (c. W. H. Dobbie) ; Cape 1807 (c. John Thompson); Ch. (Downs) 1808-9; C. and C. 1810 (c. M. H. Dixon); Baltic 18I I-1 2 (c. Hen. Hyman). Wrecked $29 \mathrm{Feb}$. 1812, on the Isle of Anholt.

Indignant (gunbrig), 182 tons, 12 guns; built at Bridport 1805 . Services: Ch. 1805-6; Baltic 1807 . Downs, 1808-9. Broken up 1812 .

INTELLIGENT (gunbrig), 179 tons, 12 guns; built at Bridport 1805. Services: Ch. 1805-6

(Lieut. Nich. Tucker); Baltic 1807; Ch. 1808-9; off Cherbourg 1810-14. Sold 1815.

INVETERATE (gunbrig), I 82 tons, I 2 guns; built at Bridport 1805 . Services: Ch. 1806-7

(Lieuts. Horace Petley and Geo. Norton). Wrecked near St. Valery en Caux, I8 Feb. 1807.

CARrier (cutter), 54 tons, 6 guns; built at Bridport 1805. Services : Ch. (Lieuts. L. R.

Ramsey and Wm. Milne) took La Ragoten, 8, on 20 Feb. 1807, and L'Actif, 2, on 14 Nov. Wrecked near Étaples, 5 Feb. I 809 .

Frolic (sloop), $3^{84}$ tons, 18 guns; built at Bridport 1806. Services: W.I. 1808-1 3

(c. Thos. Whinyates). Taken I 8 Oct. I 812 by the American sloop $W a s p(56 \mathrm{k}$. and w.). Recaptured the same day by the Poictiers, 74, which also took the $W$ asp. Broken up by A.O. 2 I Oct. I 813 .

LaureL (6th rate), 520 tons, 22 guns; built at Bridport 1806 . Services: C. and C. 1807 (c. J. C. Woolcombe); Cape of Good Hope 1808, taken I 5 Sept. 1808 by La Cannoniere, 36, off Isle of France $(28 \mathrm{k}$. and w.). Retaken 12 April 1810 by H.M.S. Unicorn, and renamed Laurestinus. Cape 181 I (c. the Hon. Wm. Gordon); Ch. 1812 ; N.A. I8I 3 (c. Thos. Graham. Wrecked near Halifax, 21 Aug. I8I3.

Philomel (sloop), 384 tons, 18 guns; built at Bridport 1806 . Services: Med. 1807-1 4 (c. Geo. Crawley and Chas. Shaw). Sold 1817 .

EgERIA (sloop), 424 tons, 18 guns; built at Bridport 1807. Services: N.S. 1808-12 (c. Lewis Hole). Took Noesois, 10, 21 Dec. 1808, and Aalborg, 6, 2 March, 1809. R.S. Devonport 1825-60; Police ship, Devonport, I860-4.

Minstrel (sloop), 423 tons, 18 guns; built at Bridport 1807. Services: Med. 1807-14

(c. John Hollinworth and Robt. Mitford). Took Ortenzia, 10, I6 July, 1808. Sold I 817.

CURlew (sloop), 382 tons, 18 guns; built at Bridport I8II. Services: N.A. 1813-14 (c. Mich. Head). Sold in East Indies 1822.

SARACEN (sloop), 382 tons, 18 guns; built at Bridport 1812 . Services: Ch. 1812 (c. K. L. A. Harper), took Le Courier, 14, on 23 Sept. 1812; Med. 1813-14, landing parties took the islands of Zupano and Mezzo (Adriatic) with their garrisons in June 1813. Sold 1819.

Conflict (gunbrig), I 80 tons, 12 guns; built at Bridport I 812 . Services: Newfoundland (Lieut. H. L. Baker) 1813; C. and C. (A. M. Hawkins) 1814. R.S. Sierra Leone 1832-40. Sold I 841 .

CoNTEST (gunbrig), 180 tons, 12 guns; built at Bridport 1812 . Services: N.A. 1813-14 (Lieut. Jas. Rattray), cutters of Contest and Mobawk cut out an American privateer 14 July, 1814. Wrecked near Halifax I4 April, 1828 ; all drowned.

SNAP (gunbrig), 180 tons, 12 guns; built at Lyme 1812 . Services: C. and C. 1813-14

(Lieut. W. B. Dashwood), took Le Lion, I6, 6 Nov. I 8 I3.

Plumper (gunbrig), 180 tons, 12 guns; built at Bridport 1813 .

Swinger (gunbrig), 180 tons, 12 guns; built at Bridport 1813. Services: C. and C. 1814 (Lieut. A. B. Branch).

FURY (bombship), 325 tons, 8 guns; built at Bridport 1814. Services: Arctic Discovery $1821-3$ (c. Sir W. E. Parry); second voyage 1824-5 (c. H. P. Hoppner). Wrecked in the Arctic, 1825 . 


\section{SOCIAL AND ECONOMIC}

\section{HISTORY}

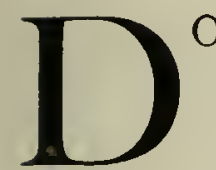

ORSET is, and always has been, primarily an agricultural and pastoral county, although owing to its varied soil and to its coast line and harbours, its interests and economic features have been many. At two periods the life of its towns may almost be considered to have equalled in importance that of the country districtsnamely, in the early days of their maritime importance, and later in the eighteenth and early nineteenth centuries, when they rose to be fashionable watering-places. But for the most part, both socially and from the point of view of its economic history, interest centres in the status and welfare of the people of its villages and country districts, and in the forces which regulated their lives.

The county was from an early date one of large landowners and extensive private franchises. In the north-west the bishop of Salisbury held the three hundreds of Sherborne, Yetminster, and Beaminster in the thirteenth century; in the north-east the earl of Gloucester was lord of the great hundred of Cranborne, while between the two Shaftesbury Abbey held the two hundreds of Sixpenny and Handley. ${ }^{1}$ The free manors of Fordington, Dewlish, Broadwinsor, and Chilcombe, and the liberties of Owermoigne Powerstock, and Sutton Poyntz were but a few of the franchises held by overlords sufficiently powerful to refuse suit to the hundred courts. ${ }^{2}$

Several of the chief landowners of the county held by serjeanty, some of the services due being of an unusual kind. Thus John Godwyne held half a hide in Purse Caundle in the thirteenth century by the serjeanty of keeping such of the king's dogs as were injured while he was bunting in Blackmoor Forest, and a contribution of $\mathrm{I} d$. a year towards the closing of Gillingham Park, ${ }^{3}$ while the house of Russel had to count out the king's chessmen in the royal chamber on Christmas Day, and to replace them in their bag at the end of the game." The lord of Winfrith was bound to hold a basin of water for the king to wash his hands on his birthday and at Whitsuntide; for this service he was entitled to the silver basins unless the earl of Oxford were present, in which circumstances the earl appropriated the basins and compensated de Newburgh by giving him his own robe. ${ }^{5}$ The lord of Wimborne was usher of the king's household, the le Moines

\footnotetext{
'Feud. Aids, ii ; cf. Assize R. 204.

Feud. Aids, ii, 5 .

' Hund. R. (Rec. Com.), ii ; Feud. Aids, ii.

- Abbrev. Rot. Orig. (Rec. Com.), ii, 29; Feud. Aids, ii, 6.

'Assize R. 201 ; cf. Red Bk. of Exch. (Roll; S:r.), 546; Feud Aids, ii, 9.
} 


\section{A HISTORY OF DORSET}

were keepers of the royal larder, William de Welles was the king's baker, and the Windsors of Broadwinsor were weighers of money in the Exchequer of Receipt at Windsor, ${ }^{6}$ while Bryanston was held by the serjeanty of finding one man with a bow without a bowstring, and an arrow without feathers, for the king's army. ${ }^{7}$

Below the ranks of the tenants in chief there seems to be no sufficient evidence upon which to base any calculation as to the relative strength of the free and villein classes. In I 244 , indeed, it was said that all the tenants of Mayne Hospital were freemen, ${ }^{8}$ but in most places the villeins would appear to have been in the majority in the thirteenth and fourteenth centuries. Thus on the manor of Coombe Keynes there were no free tenants, while there were at least seven villeins and seven cottars, and probably others not mentioned in detail. ${ }^{9}$ Again at Stottingway and Way Bayeux in I 288 there were only five free tenants as compared with thirteen customary tenants and three cottars, and at Ranston (in Iwerne Courtney) in I 274 there were five freemen and ten villeins, ${ }^{10}$ while at Steeple in 13 I 4 the customary tenants and cottars together numbered forty-four, only two freemen being mentioned." Later in the reign of Edward II there were at Hillfield four freemen and nineteen customary tenants of various ranks, and at Milton Abbas nineteen freemen and as many as ${ }^{5} 6$ villeins and cottars. ${ }^{18}$ Apart, however, from the fact that this evidence has been collected at haphazard from different parts of the county its ultimate value is small; for even were it possible to give an exhaustive list of the extents for every manor throughout the county, the fact that in many cases there is no mention of freemen ${ }^{13}$ would still remain a stumbling block. It is, of course, quite possible that in these cases the whole of the manor was occupied by unfree tenants, the more so as had there been freemen it would have been natural to find at least some mention of their rents, but from the point of view of the lord of the manor the villein, with his customary works and his rightless condition, was so much more important and valuable a factor in the manorial economy that it would be dangerous to draw too rigid an inference from the omission.

However this may be, it cannot be doubted that the villein population of the county was considerable, and a certain amount of information can be gathered as to its condition during the thirteenth and early fourteenth centuries. That the Dorset magnates occasionally availed themselves of their utmost rights with regard to their unfree tenants is clear. Nothing could be more illustrative of this fact than three records, unfortunately undated, in a Shaftesbury Abbey register, in which the abbess in full court quitclaims A.B. 'a nativitate cum omne sequela magistro C.D.' ${ }^{14}$ The form of these deeds of sale shows the mediaeval conception of villein status in its most crude form. Not only is the degrading term 'sequela' applied to the man's children, but he himself seems to be barely credited with an individual

${ }^{6}$ Assize R. zoI, m. 2, 2 d.; Red Bk. of Exch. (Rolls Ser.), 546-7; Feud. Aids, ii, 9.

Feud. Aids, ii, I.

${ }^{8}$ Assize R. 201, m. $4 d$.

- Chan. Inq. p.m. Edw. I, file 14, No. 1.

${ }^{10}$ Ibid. file 51 , No. 9 ; file 8 , No. 1 .

"Ibid. $8 \mathrm{Edw}$. II, file 43, No. 25. A simi'ar preponderance of customary tenants is noticeable at Cranborne, Pimperne, and Tarrant Gunville. But contrast Po tland and Wyke ; ibid. No. 26.

1) Hutchins, Hist. of Dorset ( 3 rd ed.), iv, 383, 501 , quoting Milton Abbey Custumal.

${ }_{13}$ e.g. Chan. Inq. p.m. Edw. I, file 51 , No. 9; Little Piddle and Edmondsham.

"Harl. MS. 61, fol. 89d. 


\section{SOCIAL AND ECONOMIC HISTORY}

existence; he is merely a member of the villeinage, as a sheep might be a member of the flock.

That the villein was rightless as against his lord is one of the first axioms of the thirteenth-century lawyers, but in the ordinary course of manorial history a good tenant, even though unfree, seems to have possessed a de facto if not a legal security of tenure. An instance, however, upon a Dorset manor about the year $\mathrm{I} 240$ shows how utterly defenceless his position might be if his lord chose to exercise his full rights. On the feast of St. Luke in that year Thomas Cusin, Hugh de Aula, and James de Ludinton came to the house of Gunilda de Stokes, carried her out into the fields, and took away all her goods. Whether Gunilda appealed to the manorial or local courts does not appear, but four years elapsed without her obtaining any redress. In the summer of 1244 the justices of assize came to Sherborne. What hope the unfortunate woman cherished of obtaining abstract justice at their hands is open to question. She brought her case before them, however, and Thomas was summoned. He acknowledged all her charges, and did not even seek to prove that he had any moral justification on account of her bad tenancy or default in rent, merely replying that he certainly 'took her goods as of his villein, and could eject her from her tenement as from his villeinage.' The case being put to the jurors they acknowledged that it was as Thomas said, and Gunilda was apparently dismissed without redress. ${ }^{15}$ In a society regulated by a code of justice of which this is an instance, it is hardly surprising to find an innocent man flying from his lord for fear ; ${ }^{16}$ it would be interesting to know more of the case of Walter Middewynter, who was presented by the jurors at the same eyre for having done so. It is at least satisfactory to know that the justices merely decided that as he had done no ill he might return if he would, but imposed no fine upon him, and gave his master no assistance towards forcing him to come back.

That there was probably very little real distinction in economic rank between the smaller freeman and the more wealthy villein is obvious; but any freedom of intercourse must have been strained by the risk of degradation to the free tenant. A case is recorded which occurred in the year I 232, when Isabella de Frome brought a suit against Gregory de Turri and Emma his wife for half of two parts of a knight's fee in Frome. Emma and Isabel were at least half-sisters, if they were not more nearly related, yet Emma and Gregory declared that they were not bound to answer the plea as Isabel was a villein, and that she certainly could lay no claim to the free inheritance. The land in dispute they stated should have passed from William le Fitzsamere their uncle to his sister and coheiress Christina, who, however, married a villein William Muc, and thus forfeited her claim to her moiety of her brother's inheritance. Isabel was the daughter of this villein marriage, and sister to Hugh Muc, a villein, still living. After the 'death of her first husband Christina married 'a certain knight,' and consequently received her inheritance, which had now descended to Emma the issue of the free marriage. Isabel, however, successfully repudiated all relationship with Hugh Muc and was awarded half the land in dispute with the exception of the capital messuage ${ }^{17}$ - probably a wise provision in view of the relations between the half-sisters.

$$
{ }^{15} \text { A.size R. 201, m. 4. } \quad{ }^{16} \text { Ibid. m. } 5 d . \quad{ }^{17} \text { Maitland, Bracton's Note Bk. Case } 702 .
$$




\section{A HISTORY OF DORSET}

There was, however, another side to the question-a plea of villeinage might occasionally prove a convenient escape from an awkward suit, and it was perhaps as well that a man who had once acknowledged himself to be a villein before the justices could not subsequently repudiate the confession. The policy of a certain Hamlin son of Ralph well illustrates this point. In or before the year 1220 he won his case in an assize of novel disseisin against Hugh de Gundeville, who had apparently ejected him from his tenement. Hugh thereupon brought a counter-plea that Hamlin had no power to sue him, as being his villein. He stated that in the reign of King John, before the justices in eyre, Hamlin had confessed himself to be a villein and to hold in villeinage. This assertion Hamlin denied, but when the records of the eyre were examined it was found that one Osbert Crede had brought an assize of mort d'ancestor against him, touching a carucate of land in Pimperne [Pimpre], and that he had refused to answer on the plea that he was a villein, and as such could neither acquire nor lose land. Hamlin, apparently finding that the suit was likely to go against him, absented himself, and after several vain attempts had been made to find him, it was decreed that Hugh should have him sicut villanum suum convictum, that the assize of novel disseisin which he had instituted should be quashed, and that Hugh should be quit of the fine which had been imposed upon him on the finding of the first assize. ${ }^{18}$

Hamlin's case further illustrates the fact that it was no impossible thing for a Dorset villein to be quite a substantial landowner; whether Hamlin himself was really a villein, or had only used the plea in the first instance as a subterfuge, neither the justices nor the jurors seem to have found any difficulty in the fact that he held as much as a carucate of land. Further evidence in the same direction can be obtained from the Shaftesbury Register where, in a survey of Cheselbourne, presumably of the reign of Edward I, or at least early in the fourteenth century, one of the villeins held an entire hide, and four others held half a hide each. ${ }^{19}$ There was a marked tendency in the county to indulge in minute classifications of the villein population, however; at Kingston Lacy they were known as carters, daywyns, forehors, akermen, and smalemen respectively. It seems clear that the carter held normally one virgate of land, and the daywyn, owing very similar services, may be supposed to have held nearly as much; the forehors and akermen appear to be classed together, but there is no definite statement as to the size of any of their holdings. ${ }^{20}$ Elsewhere the distinctions are somewhat different; thus at Spettisbury in $1324-5$ there were sixteen virgatarii, three holders of half a virgate, four fardelli holding 8 acres each, and eleven cottars. ${ }^{21} \quad$ At Sydling St. Nicholas and Hillfield the classification was similar, ${ }^{22}$ but at Hinton (St. Mary) a distinction was made between cotsetti

${ }^{13}$ Maitland, Bracton's Note Bk. Case 1411.

${ }^{19}$ Harl. MS. 6r, fol. 44 $d$. It is most unfortunate that these surveys are only preserved in a poor fifteenth-century transcript, with no reliable indication of their date. From the fact that they refer frequently to King Henry as the predecessor of the present king, and show evident signs of unsuccessful administration, it is tempting to refer them to the close of the thirteenth or early years of the fourteenth renturs. Cf. 'Religious Houses.' Cf. also the 2 virgate holdings at Broadwinsor in Chan. Inq. p.m. Edw. I, file 34, No. 3 .

${ }_{20}$ Mins. Accts. (Duchy of Lanc.), 11040 and 11192 , and ibid. (Gen. Ser.), bdle. 832, No. 13.

"1 Hutchins, Hist. of Dorset, iii, 517 , quoting a survey.

I Ibid. iv, 497, 501, quoting Milton Abbey Custumal. 


\section{SOCIAL AND ECONOMIC HISTORY}

and cotarii-the cotset's holding was 4 acres, that of the cottar consisted only of a house and curtilage. ${ }^{23}$

The real distinction between the various ranks of customary tenants, however, was probably between the comparatively substantial holder of from I 5 to 30 acres of land and the variously classified tenants of 8 acres or less. The virgatarii and semi-virgatarii were probably very near the borderland of freedom and practically on the same footing as the village priest-he indeed was free by virtue of his orders, but in the Shaftesbury Abbey Custumal, quoted above, he occurs certainly once among the list of virgate-holders, who owed three days' work a week in winter, and heavy August work. ${ }^{24}$

The virgatarii and semi-virgatarii, moreover, were probably in some cases at least employers of labour, for at Wyke, Kingston Lacy, and Shapwick, though their holdings were larger than those of the fardelli, akermen, or coterells, and must have employed more labour, they nevertheless were bound to do more work on the lord's demesne, so that they must have required to hire men either for the cultivation of their own holdings, or to perform their customary services. Thus at Shapwick, while the larger tenants owed three works a week from Michaelmas to the Feast of the Nativity of St. John the Baptist, the coterells were only required to do six winter works in the year, ${ }^{25}$ the summer works being alike for all the tenants on this manor as elsewhere in the county. ${ }^{26}$ Similarly at Kingston Lacy the carters and daywyns owed one work each week throughout the autumn and winter, whereas the forehors, akermen, and smalemen apparently owed summer works only, ${ }^{27}$ and at Wyke the virgate-holders had to send four men each, the half-virgate holders two men each, and the fardelli one man each to the three annual 'Bedereppes.' ${ }^{28}$

The very small holders on the other hand were probably themselves labourers, their own land being cultivated in their spare time much as the modern labourer may cultivate his allotment. On the Shaftesbury manors it was certainly from the ranks of the cottars and cotsets that the shepherd, cowherds, dairyman, and blacksmith were drawn. ${ }^{29}$ At Cheselbourne each of these servants had 5 acres quit of all dues except the royal geld, and was entitled to keep one animal in the pasture. Both here and at Iwerne Minster they appear to have been allowed a whole holiday on Saturday ${ }^{30}$ in the ploughing season until their own land was ploughed, and at Handley the

${ }^{23}$ Harl. MS. 61, fol. 6; d., 66. A distinction between the cotset and cottar seems to be made also in the Domesday Survey of the county-the former being of higher rank than the latter; cf. Maitland, Domesday Bk. and Beyond, 39.

${ }^{24}$ Harl. MS. 61, fol. $4+d$.

${ }^{26}$ Cf. ibid. 11040 and Harl. MS. 61, fol. $44 d$.

${ }_{27}$ Mins. Accts. (Duchy of Lanc.), 11040.

${ }^{23}$ Mins. Accts. (Duchy of Lanc.), 11045 , 11049.

${ }^{29}$ Harl. MS. 61, fol. 44 d., 46, 56

${ }^{30}$ From one point of view Sunday would appear to have been regarded as a holiday in mediaeval Dorset, that is to say, it is evidently reckoned amongst the festivals, which together with Saturdays were not regarded as working days on those manors where the customary tenants were bound to work every day in the week from Midsummer Day or 1 August (as the case might be) until Michaelmas Day [e.g. Mins. Accts. (Gen. Ser.), bdle. 834, No. 31 ; and ibid. (Duchy of Lanc.), Nos. I1 040,11045 , 11049]. Apparently, however, it was a popular day for the holding of markets and fairs (cf. Hutchins, Hist. of Dorset, iii, 233, 256; and Assize R. 20I, m. 5d., -06, m. I 4 d.), though these may very probably have been regarded as occasions of festivity. This can hardly have been the case with the sessions of the justices in eyre (cf. Assize R. 206, m. 10\%), tut possibly the jurors did not object to sacrificing their holiday in order to bring the seneschal of the earl of Lincoln to justice. 


\section{A HISTORY OF DORSET}

shepherd had the use of the lord's plough. ${ }^{\text {s1 }}$ This being the case with the demesne servants, it seems probable that the 5 -acre tenant also served as farm labourer on the 30 -acre villein holding, or had some trade such as carpentering or thatching in addition to farming his own land.

Wages in Dorset prior to the Black Death appear to have been rather low. For while in Oxfordshire in the early years of the fourteenth century the ploughman received 5s. $6 d$. and in Buckinghamshire from $5 \mathrm{~s}$. to $6 s .,{ }^{32}$ in this county he appears to have received only $4 s$. $6 d^{3 s}$ Similarly in Dorset between I 320 and 1327 carters, drivers (fugatores), and shepherds received $4 s$. $6 d$. or 5 s. a year each, while at about the same time in both Oxfordshire and Buckinghamshire the first shepherd earned 6s. and in Sussex he received $5 s .6 d ., 4 s$. being the wage of his junior; in Buckinghamshire the carter received $5 s .6 d$. or $6 s .8 d$., in Sussex he received $6 s .6 d$. , and in Oxfordshire the fugator received $6 s^{3.4}$ The Dorset cowherd in 1327 apparently received $3^{s}$. as compared with $4^{s}$. in Oxfordshire, and the dairyman $3^{s}$. as compared with a possible $4^{s}$. in Buckinghamshire. ${ }^{35}$ At Cranborne the more responsible servants, such as the park keeper and messor, on the other hand, were paid at the rate of $I_{2} \frac{1}{2} d$. or $2 d$. a day, which compares favourably with Sussex. ${ }^{96}$

On the Shaftesbury Abbey lands the manorial servants seem to have been paid in kind. The shepherd of Handley held 5 acres for keeping the sheep, and had a lamb and a fleece and one sheep at Martinmas, and the milk of sixteen sheep until lambing season, together with a measure of corn and another of oats; the ploughmen had one sheaf of 'rengo' during the reaping season and two sheaves when the corn was carried; the smith was bound to do certain repairs, in return for which he held 2 acres of land at a rent of 6d. and was entitled to the old iron and 'a cheese on a Sunday.' ${ }^{37}$ At Iwerne Minster the men who led the ploughs had $3^{d}$. and a cheese, while the herdsman was entitled to have two animals freely in the pasture and a sheaf in August, the swineherd had a pig, and the shepherd a sheep, a fleece, and the milk of one sheep. ${ }^{38}$ At Cheselbourne the payments were chiefly in corn2 acres in August - and flour-one bushel (ambra) for six weeks, or in the case of Eliens qui servit in aula, one bushel for four weeks. In addition the herdsmen all received milk from the demesne from Hockday to Michaelmas, ${ }^{39}$ and the oxherd, according to another survey, was entitled to have two animals freely in the pasture and twenty sheep in the sheep-fold, together with the ploughing of 4 acres with the demesne plough. ${ }^{40}$

With these may be compared the 'liveries of seven servants' accounted for at Spettisbury in 1324 , when each had a quarter of barley for twelve weeks, while the dairyman, 'hogherd, and porter' had a bushel for two weeks. $^{4 l}$ A similar system was also pursued at Steeple in the thirteenth

${ }^{31}$ Harl. MS. 61, fol. 56 ; cf. also fol. 59.

32 V'.C.H. Oxon. ii, 182 , note 1 ; ibid. Bucks. ii, 'Soc. and Econ. Hist.'

${ }^{33}$ Mins. Accts. (Gen. Ser.), bdle. 832 , No. 26 , and bdle. 834 , No. 28.

34 Ibid. bule. 832 , Nos. $3,5,26$; bdle. 834 , No. 28 ; V.C.H. Oxon. ii, 182 note; Bucks. ii, 'Soc. and Econ. Hist.'; and Sussex, ii, 83 , note 95.

${ }^{35}$ Mirs. Accts. (Gen. Ser.), bdle. 833 , No. 5. There seems to have been some doubt as to what was really due to them; it was, however, certainly not more than 3s.; V.C.H. Oxon and Bucks. loc. cit.

3. Mins. Accts. (Gen. Ser.), bdle. 832, No. 3 ; cf. bdle. 1027 , No. 22, and bdle. 1147 , No. 14.

${ }^{37}$ Harl. MS. 61, fol. $56 . \quad{ }^{38}$ IL id. fol. 45 d. Sc. $\quad{ }^{39}$ Ihid. fol. 44 d. \&ce. $\quad{ }^{10}$ Ibid. fol. 59.

"A deed quoted by Hutchins, Hist. of Dorset, iii, 517 . Perhaps this should be shepherd and swineherd. 


\section{SOCIAL AND ECONOMIC HISTORY}

or early fourteenth century, the allowance being very much the same in amount as at Spettisbury. ${ }^{42}$

But in addition to these regularly employed servants on the Dorset manors, a large amount of day labour was required, both for harvest work, such as threshing, mowing, reaping, and tossing, and for repairs about the farm buildings and houses. Upon these occasions a carpenter usually received $3 d$. a day, though for elaborate building works, such as the repairs of Corfe Castle in I $280-\mathrm{I}$, as much as $6 d$. might be paid, ${ }^{43}$ while work could be found for less skilled workmen who only received $2 \frac{1}{2} d 0^{44}$ A thatcher (coopterius) as a rule received $3 d$. a day between himself and his boy, though occasionally an extra $I d$. or $\frac{1}{2} d$. was allowed for the lad. ${ }^{45}$ Mowing was paid at $5 d$. or $5 \frac{1}{2} d$. an acre, and tossing at $2 \frac{1}{2} d$. or $3 d$. the day. ${ }^{40}$ In 1282 a sawyer at Corfe received $3 d$. a day, an unskilled labourer carrying stones, $8 x c$., $2 d$. or $2 \frac{1}{2} d$., and a woman making mortar $I d$.; the overseers of the works themselves only received I $s$. a week each. ${ }^{47}$ These wages were apparently in addition to food, for when the carpenters and sawyers were employed in the woods, Ralph received $\mathrm{I} d$. for going to the wood with fish and a pennyworth of bread. ${ }^{48}$

It is difficult to form any very clear idea of prices in Dorset at this period. At Wyke in 1 327-apparently a year of plenty-wheat was sold at $4 s$. the quarter, barley at $5 d$. the bushel, pulse at $6 d$., vetch at $6 d$., and oats at $4 \frac{1}{2} d . ; 9$ and in $\mathrm{I} 32 \mathrm{I}-2$ wheat was at $9 d$. a bushel, barley at $6 d$., and oats at $4 d$. the bushel. ${ }^{50}$ The following year, however, wheat rose to about I os. the quarter and barley was bought for $7 \mathrm{~s}$. $4 \mathrm{~d}$. or even $8 \mathrm{~s} .8 \mathrm{~d}$. the quarter; while at Cranborne in $1325-6$ the price of wheat was but little less, ${ }^{51}$ though other kinds of grain had fallen considerably. In I 325-6 cheese was sold at I 5s. the wey, and butter at $8 d$. the stone, ${ }^{62}$ and in 1327 the reeve of Steeple sold a rennet cheese for 1 os., and other cheese at IIs. Iod. the wey, and received Is. the stone for butter. ${ }^{63}$ Of the live-stock on a Dorset farm at this period oxen were the most expensive, ranging from $6 s$. to I 8 s. $6 \mathrm{~d}$. each, but usually being sold for over $10 s .^{54}$; cows were worth from 3 s. to 5 s., sheep about $10 d$. or Is. or even is. $3 d$. a head, hoggerels $8 d$., and lambs $6 d$.; pigs varied from $6 s$. to $2 s$., and geese from $2 d$. to $4 d$. each. ${ }^{65}$

All this would seem to imply a rather low economic standard in Dorset up to about the middle of the fourteenth century. There can, moreover, be

12 Mins. Accts. (Gen. Ser.), bdle. 833 , No. I.

42 Ibid. bdle. 834 , No. 26 ; bdle. 833 , No. 16 ; Exch. Accts. Works, bdle. 460, No. 27.

"Exch. Accts. Works, bdle. 460, No. 27.

${ }^{45}$ Mins. Accts. (Gen. Ser.), bdle. 833 , Nos. 1,$5 ; 832$, Nos. $3,26,28 ; 834$, No. 28. (tossing).

${ }^{46}$ Ibid. bdle. 832 , Nos. 3,28 ; 833 , No. 4 ; 834 , No. 28 (mowing); 832 , No. 26 ; and 833 , No. 5

${ }^{17}$ Exch. Accts. Works, bdle. 460, No. 27.

${ }^{48}$ Ibid.

${ }^{19}$ Mins. Accts. (Gen. Ser.), bdle. 834 , No. 28.

${ }^{50}$ Ibid. bdle. 832 , No. 26.

${ }^{51}$ Wheat, 8s. 8d. and 9s. $4 d$. the quarter; barley, $4 s$. and $4 s .4 d$. the quarter ; pulse, vetch, and dragget, 40\%. the quarter (pulse at midsummer, 6s. 8d.); oats, 2s. 6d. the quarter ; Mins. Accts (Gen. Ser.), bdle. 832 , No. 3 .

${ }^{2}$ Mins. Accts. (Gen. Ser.), bdle. 832 , No. 3 ; Assize R. 206, m. 20 , values cheeses at 8s. 'per pond'eight cheeses making one 'pond.'

${ }^{53}$ Ibid. bdle 833 , No. 5 .

${ }^{54}$ Ibid. (Duchy of Lanc.), No. 1125 , and (Gen. Ser.), bdle. 833, No. 17 , \&c.

${ }^{35} \mathrm{Ibid}$. No. 5 ; ibid. (Duchy of Lanc.), No. 1125 , and (Gen. Ser.), bdle. 832 , No. 3 ; bdle. 834 , No. 28 ; bdle. 833 , Nos. 1,5 . The fact that the customary allowance for the workers in the harvest field at Wyke was two bushels of corn or $16 d$, , one sheep or $12 d$, and one cheese or $5 d$, would seem to point to these as being average prices about the year 1314 (Chan. Inq. p.m. 8 Edw. II, file 43, No. 26). 


\section{A HISTORY OF DORSET}

little doubt that there was a considerable poor and potentially criminal class throughout the county. These were, in part, strangers who had wandered from other counties, and were beyond the reach of that local police organization which should normally have kept them in check. ${ }^{66}$ But out of a total of some seventy criminals presented and convicted before the justices in eyre at Sherborne in 1244, about sixty were Dorset men, of whom twenty-one owned chattels of under Ios. in value, and twenty-four others had no chattels at all. ${ }^{57}$ Out of these forty-five, thirty were convicted of theft, and the other fifteen of manslaughter, lisually arising from a quarrel.

These figures, together with the fact that in all only five freemen of independent position were convicted at this eyre, and of these only one, whose chattels were valued at I 3 s. $4 d$. and a house, was charged with theft, ${ }^{68}$ suggest that crime of this nature was generally the outcome of poverty, and that the criminal class was chiefly recruited from the lower ranks of the villeins, on whom hard times would naturally press with the greatest severity. That

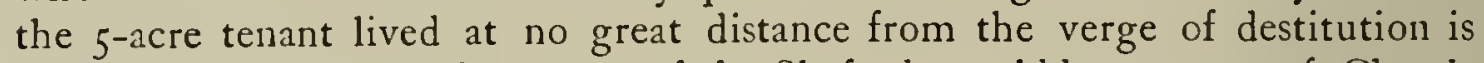
implied in an entry in the survey of the Shaftesbury Abbey manor of Cheselbourne, to the effect that the cottars used to owe service in the brew-house, but had been excused for some time on account of their poverty. ${ }^{69}$

Theft, burglary, cattle stealing, murder, and manslaughter seem alike to have been punishable with outlawry or hanging, ${ }^{60}$ and as the former either implied exile or the liability to pursuit and death at the hands of the first comer, the death rate must have been considerably raised by this means. The prevalence of epilepsy, constantly ending fatally, ${ }^{61}$ must also have tended to check the increase in population, while death by drowning under a mill-wheel, by being burnt alive, or by other accident seems to have been of common occurrence. ${ }^{62}$

The presentment of all these offences and accidents before the justices itinerant implies a degree of common action which it is difficult to realize ${ }^{63}$ but the whole of the local government and police administration of an English county in the Middle Ages was based upon a system of joint responsibility, starting at the narrow apex of the tithing or mainpast, and broadening down through the vill and the hundred to the wide basis of the county, which appeared collectively in the monthly county court, or at rare intervals in yet more representative form before the justices in eyre. ${ }^{64}$

The tithing was sometimes a unit within the vill, and sometimes was commensurate with the vill itself, as in the case of Hooke, where the reaper ${ }^{\text {os }}$ was attached by the tithingman, and the whole tithing for breach of the

${ }^{56}$ E.g. Assize R. 201, m. 1, \&c.

${ }^{57}$ Ibid. passim.

${ }^{58}$ Ibid. m. 7. Possibly some of the criminals who were in mainpast were free, but from the context in most cases this seems doubtful. They were, however, for the most part charged with brawling rather than theft, and do not affect the argument.

${ }^{39}$ Harl. MS. 61, fol. 59.

${ }^{60}$ Assize R. $201 \mathrm{Im}$. I, I d.; 206, m. 3, 7, 8, I4.

${ }^{61}$ lbid. 206, m. 8, 9 d. \&c.; 2 I 2 m. 7, \&c.

${ }^{68}$ Ibid. $20 \mathrm{I}, \mathrm{m} .2 d ., 5$ d., 2 I 2 passim.

${ }^{63}$ It extended beyond the sphere of mere police duties; upon one occasion the "community of the vill" of Fordington went so far in collective action as to sue a man who had offended it, by attorney, in the manorial court [P.R.O. Ct. R. (Gen. Ser.), bdle. 169, No. 26, m. 6, 7]

${ }^{6}$ Cf. Pollock and Maitland, Hist. of Engl. Lart, i, 202, 529 , Sxc.

${ }_{63}$ The Dorset reaper, messor, was apparently sometimes a person of considerable importance. At Cranborne he was highly paid (see above), and elsewhere he acted as rent collector [Mins. Accts. (Gen. Ser.), bdle. 834, No. 31] and keeper of the manor [Mins. Accts. (Duchy of Lanc.), I I 192]. Possibly in this instance his position had afforded an excuse for extortion and violence. 


\section{SOCIAL AND ECONOMIC HISTORY}

peace and robbery. ${ }^{66}$ The vills were responsible for the pursuit of malefactors, and were constantly amerced for default in this duty. ${ }^{67}$ When a suspected criminal was captured and placed in custody, pending the institution of proceedings against him before the sheriff, it was again the vill that was fined if he escaped ${ }^{68}$ from the prison to which he had been assigned. Thus when Nicholas Bird was imprisoned in Kingston Lacy prison on suspicion of theft, and escaped, the men of the vill of Barnsley [Bernardsleigh] were charged with his fight, because he was in their custody. Moreover, if a prisoner escaped, and the jurors attempted to conceal the fact, they were liable to another fine. ${ }^{69}$

Returned outlaws were the cause of considerable trouble both to the vills collectively and to individuals. It happened occasionally that after a man had been outlawed he returned to the county, either with a view to revenge, as apparently in the case of one John Furet who, after having been outlawed on account of a murder which he had committed, returned to Swyre, and was about to burn the parson's house, when he was fortunately discovered by Reginald Dylle, the parson's servant, ${ }^{70}$ or because he had found someone who was willing to harbour him, ${ }^{11}$ or apparently from sheer bravado, as did William le Curt, who returned to Milton and Blandford and wandered begging from town to town without molestation. ${ }^{72}$ When this was the case it was the duty of the first person who discovered the returned criminal to raise the hue and cry and to pursue and kill him summarily. ${ }^{73}$ As a matter of fact this seems generally to have been accomplished fairly speedily, but in one case an outlaw returned to Wareham by night, and betook himself to sanctuary in the church of St. Mary, whence he subsequently escaped, for which escape the borough was fined by the justices at the next eyre. ${ }^{7+}$

On more than one occasion, however, such pursuit ended disastrously for the pursuer. In one instance an outlaw, who had been harboured for three weeks by the bailiff of Hyde, attempted to return to his house at "Whitclyve' (in Rowbarrow Hundred) and was met by William son of Thomas, who raised the hue and cry, and in company with Helyas le Bercher pursued him and cut off his head. Thereupon Helyas, for some reason unspecified-possibly for fear of the bailiff, who had befriended his victim-took fright and fled. It was probably well for him that he did so, for the coroner came and viewed the body of the dead man and gave William son of Thomas over to the sheriff as a felon, whereupon he was detained in prison nearly a year ${ }^{75}$ and it was not until the justices in eyre visited the county again that full justice was done upon the bailiff, and Helyas was given leave to return from his voluntary exile if he chose. On another occasion several men lay in wait for an outlaw whom they knew to be concealed in the house of a certain Robert le Melliere of Stafford, but their victim showed fight and slew one of his would-be captors. Subsequently he was captured elsewhere and hanged, and Robert fled because he had concealed him. ${ }^{76}$

The presentment of crimes and accidents at the county court lay with the vills, ${ }^{77}$ but before the justices presentments were made by the jurors of the

66 Assize R. 201, m. 4.

68 Ibid. 206, m. $3,4$.

67 Ibid. 201, m. 1, \&c.

70 Ibid. $212 \mathrm{~m} .7$.

$"$ Ibid. m. I.

${ }^{69}$ Ibid. $201, \mathrm{~m}$. I.

22 Ibid. m. $10 d$.

73 Ibid. m. 7

"Ibid. 201 , m. 5 d.; cf. R. 206 , m. 7, where the vill of Shaftesbury was fined for receiving outlaws.

${ }^{26}$ Ibid. 2 I $2, \mathrm{~m} .1$.

77 Ibid. $201, \mathrm{~m} .1,5$. 


\section{A HISTORY OF DORSET}

hundred. Any neglect in this respect was punished by a fine, ${ }^{78}$ but on one occasion when the jurors concealed a theft before the justices they were actually committed to gaol. ${ }^{79}$ On the other hand if the jurors of a hundred presented pleas that were not within their competence they were again subjected to a fine. They were probably not often sufficiently zealous to incur this penalty, but in 1244 the justices amerced the hundred of Halstock on this account, and again for having taken and detained without warrant a chaplain who had been guilty of house-breaking. ${ }^{80}$

The verdict of the jurors at the eyre was checked by the presence of the coroner. When the jurors presented the death of a woman whom they called Isabel de Blandford, the coroner bore witness that her name was really Sibil, and a general fine was exacted for a false presentment, ${ }^{81}$ and upon the same occasion an amercement was levied because the jurors declared that the vill of Poorton had presented a certain case in the county court, and the coroner denied that it was so. ${ }^{82}$ It was the coroner's duty also to view the body of anyone who had met with a violent or accidental death, and all the vills of the neighbourhood were expected to be present at the view on pain of a fine, which was very frequently incurred. ${ }^{83}$ Upon one occasion the prior of Wareham was charged with having buried Nicholas Miller who had been drowned in the mill-stream at Westholme without this view. He was sentenced to amercement, but denied the charge and put himself on the county, where. upon the jurors found that he was not guilty, and proceedings were taken against the original jury for concealing the truth in their presentment. ${ }^{84} \mathrm{At}$ the same eyre the vill of Winterborne Steeple was charged with having buried a suicide before the coroner had arrived..$^{85}$

The coroner himself was occasionally fined for default in his duty. It was incumbent upon him when any accident occurred to attach the person, and value the chattels of everyone who was even remotely connected with the scene or instrument of the disaster. Thus, when Walter le Frere left his cart outside the door of a house while he went inside, and in his absence the mare which drew it ran over Matilda the daughter of John Forke, Walter ought to have been arrested, instead of which he ran away, and the coroner, who apparently made no attempt to recover him, was fined in consequence. ${ }^{86}$

In view of all these possibilities of amercement it is hardly surprising that the profits of justice were a valuable source of crown revenue in the Middle Ages. The sum, moreover, was swelled by the fact that suit of court was a burden of which the more wealthy citizen was glad to rid himself by a fine. Two instances of this occurred in 1244. The first was the case of the manor of Mayne Hospital, which did not appear by itself or in any hundred before the justices in eyre; it was subsequently testified that the men of the manor were all freemen, and one Nicholas de Mayne appeared and compounded for their collective default ${ }^{87}$ with a fine of I mark. The second case was the yet more important one of the knights and serjeants of

${ }^{8}$ Assize R. 201, m. 1, 5.

19 Ibid. $212, \mathrm{~m}$. 1. Cf. also the ominous order to the sheriff in the case of Hamlin son of Ralph, quoted above, to inquire diligently who were the jurors in the first assize, 'and to have them on such 2 day' \&c.

${ }^{80}$ Ibid. 201, m. 3.

${ }^{81}$ Ibid. 201, m. 6d.

${ }^{3}$ Ibid. 2 I 2, m. 1, 2, 4 .

84 Ibid. $212, \mathrm{~m} .6$.

${ }^{86}$ Ibid. 212 , m. 2 ; cf. m. 5 ; R. 206, m. 4 .

62 Ibid. m. 5 .

${ }^{85}$ Ibid. m. 7 .

${ }_{87}$ Ibid. 201, m. $4 d$. 


\section{SOCIAL AND ECONOMIC HISTORY}

the county, who all failed to appear before the justices and were consequently fined. ${ }^{88}$

At the same time there were certain limitations which hampered even the king's justice. The first of these was the benefit of clergy. Curtailed to a large extent by the Constitutions of Clarendon, it yet played an important part in the administration of the law. In Dorset it was used as a refuge by a variety of criminals such as poachers, murderers, and counterfeiters of the king's seal ${ }^{89}$-in the last case apparently without avail, as no one claimed the so-called clerk for the church, and he was consequently committed to gaol, whence he escaped, only to be outlawed by command of the justices in eyre. The second and more serious limitation was created by the existence of numerous private franchises, such as the broad liberty of Cranborne to which the sheriff had no entry, ${ }^{90}$ and where the right to hang thieves taken in the act was occasionally construed to cover thieves taken on suspicion only, and without formal indictment. ${ }^{91} \quad$ Yet the very presentment of these facts before the justices is, from one point of view, additional evidence of the strength of the central government, and of the alliance between it and the 'commonalty of the realm.' Vills might be subtracted from the hundred court by some powerful overlord, courts might be unjustly multiplied in Eggerton Hundred, the sheriff's tourn might be neglected in the hundred of Hasilor, ${ }^{92}$ pleas of vert and venison might be wrongfully held by the earl of Gloucester in the hundred of Pimperne beyond the borders of the forest, poor men might be distrained for debt by their wainage, ${ }^{93}$ foresters, bailiffs, and seneschals might make false exactions and purveyances, ${ }^{94}$ but when the justices arrived in the county upon their eyre, the jurors of the hundreds set forth all their grievances and all encroachments on the royal justice, which were thereupon examined, and, where necessary, fines were imposed upon the culprits ${ }^{95}$ or redress was ordered. ${ }^{96}$ Upon one occasion the jurors were fined for not having mentioned a wrongful exaction which had been made by the constable of Corfe Castle. ${ }^{97}$

What event or series of events really marks the transition from the early to the later Middle Ages in Dorset it seems impossible to determine. There is but little evidence of the extent of the ravages of the plague in the middle of the fourteenth century, ${ }^{99}$ and although there can be no doubt that Dorset and its neighbour counties were involved in the disturbances of $1381,{ }^{99}$ there appears to be no evidence to show that the rising had any economic effect, though socially no doubt the presence in the county of 'homicides, robbers, and insurgents' in unusual numbers was a real evil. Nevertheless, here as elsewhere, the fourteenth and early fifteenth centuries certainly saw the transition from a feudal to a commercial basis of society. The process was, however, in some respects a slow one; for instance, in the matter of commutation, while the virgate-holding customary tenants of Tarrant Gunville paid

${ }^{89}$ Assize R. $20 \mathrm{I}, \mathrm{m} .6 \%$.

${ }^{90}$ I bid. $206, \mathrm{~m} .4$.

9 Ibid. 201, m. 3 d.; R. 206, m. $16 d ., 20$.

${ }^{89}$ Ibid. 206, m. 6, 9 ; R. 2 I 2, m. 7, 13.

91 Ibid. m. 3.

${ }^{4}$ Ibid. 201, m. 5 d.; R. 206, m. 4, 6, 8, 18, 20; R. 212, m. 3, 4, I1.

${ }^{95}$ e.g. Ibid. 206, m. $4,5,6,8$.

${ }_{96}$ Ibid. m. 16 d., 20.

${ }^{97}$ Ibid. m. 20.

${ }_{98}$ See, however, Hist. MSS. Com. Rep. vi, App. 475 ; Rot. Parl. (Rec. Com.), iii, $129 a$. A complaint of the abbess and convent of Shaftesbury dated $1381-2$ stating that nearly all their tenants were dead of the plague.

${ }^{99}$ Cal. of Pat. $1381-5$, Pp. $73,136$. 


\section{A HISTORY OF DORSET}

I 4 s. for all services in I 3 I 4, the half-virgate holders 75 ., and the yet smaller tenants $45 .{ }^{100}$ and the tenants of Wyke occasionally commuted some few of their works as early as the year I 327, , $^{101}$ yet on the latter manor services were still only in part commuted as late as $145^{8-9,}{ }^{102}$ customary tenants still worked at Waterson in $1446-7,{ }^{103}$ and at Kingston Lacy as late as 1485 the tenants still performed their winter works according to custom; and out of a total of seventy-eight villeins of all classes owing daily services from 24 June until Michaelmas, the only commutations recorded are those of three carters, one daywyn, one forehors, eleven akermen, and one smaleman, and these only date from the year I 408-9. ${ }^{\text {104 }}$

In the same way the rise of wages seems to have been a gradual process. In $1360-1$ a carpenter at Tarrant still received $3 d$. a day, as also a thatcher, though the wage for threshing (which was piece-work) showed a tendency to rise, in spite of the fact that in one instance it was obviously kept down by competition. ${ }^{105}$ In $1369-70$ on the other hand, a carpenter, a sawyer, and men cleaning gutters, mending roads, and making fords at Cranborne, were all alike paid at the rate of $4 d$. a day, ${ }^{106}$ a rate which had been attained by carpenters, sawyers, and masons working at the Corfe Castle repairs as early as I $356,{ }^{107}$ though day labour there was still only paid at the rate of $2 \frac{1}{2} d$. or $3 d$. even in autumn when wages were at their highest. There is unfortunately not very much evidence as to the variations in the wages of the regular farm servants in the county after the Black Death. At Kingston Lacy, however, the swineherd received 3 s. a year, the carter, plough-drivers, shepherds, and cowherds, 5s. each, and the dairyman 4s. as late as $1374-5$, although the wages of day labour had risen to $3 d$. and $4 d .^{108}$ By the middle of the fifteenth century, however, the plough-driver (fugator) of Waterson received I 2s. a year, the carter I 6 s., and the two shepherds Ios. each. ${ }^{109}$

This should imply a real, if slow, improvement in the status of the Dorset labourer, for while wages rose prices remained fairly stationary. Thus in I $374-5$ barley was at $6 d$., oats at $5 d$., vetch at $5 d$., and pulse at $6 d$. a bushel, a pig was sold for 35 . $6 d$. and a ewe for $15 d$., while as late as $1446-7$ wheat was at $8 d$., oats at $3 d$., and barley at $6 d$. or $6 \frac{1}{2} d$. a bushel, and four sheep were bought for $4 s^{110}$

Another sign of the growth of the commercial spirit in the county at this period is the rise of a class of small traders setting the rigid rules of the mercantile system at defiance wherever possible, and the consequent development of the towns with their communal life. The first of these points is best illustrated by the history of the wool trade. Dorset was not

${ }^{100}$ Chan. Inq. p.m. Edw. II, file 43 , No. 25 ; cf. also Pimperne and Steeple.

101 Mins. Accts. (Gen. Ser.), bdle. 834 , No. 28.

103 Ibid. No. 3 I.

${ }^{103}$ Ibid. bdle. 833 , No. 36 .

104 Ibid. (Duchy of Lanc.), 11192.

${ }^{105}$ Thus at Tarrant in $1360-1$ threshing of corn 3d. a quarter, barley 2d. a quarter (and not more because J. D. threshed for $1 \frac{1}{2} d$.), vetches $2 \frac{1}{2} d$. and oats $1 \frac{1}{2} d$. a quarter [Mins. Accts. (Gen. Ser.), bdle. 833 , No. 18 ], and at Steeple in 1327 corn at $2 \frac{1}{2} d$. a quarter, barley and vetches $1 \frac{1}{2} d$. for nine bushels, and oats at $1 \frac{1}{4}$. for nine bushels [Mins. Accts. (Gen. Ser.), bdle. 833 , No. 5 ; cf. bdle. 832 , No. 3].

${ }_{106}$ Mins. Accts. (Gen. Ser.), bdle. 832, No. 4.

${ }^{107}$ Exch. Accts. Works, bdle. 460, No. 30.

${ }^{109}$ Mins. Accts. (Duchy of Lanc.), 11040.

${ }^{109}$ Ibid. (Gen. Ser.), bdle. 833 , No. 24 . No. 36 in the same series, which gires " 1 ploughman 16 s., 1 carter being a driver (fugator") 20s., 2 shepherds 20 s.' looks very like a scribal error for the same rate.

${ }^{110}$ Ibid. No. 36, and ibid. (Duchy or Lanc.), 11040 , but contrast bdle. 833 , No. 7 , where ewes were worth 2 s. and cows 10 s. in $1377-8$. 


\section{SOCIAL AND ECONOMIC HISTORY}

in the Middle Ages famous for the quality of its wool, though there was a cocket of wools at Melcombe before the reign of Edward I, and subsequently in 1364 a staple was established. ${ }^{111}$ In 1343 the enhanced price was only 8 marks, one of the lowest rates in the kingdom, ${ }^{118}$ and the religious houses, though they certainly kept considerable flocks in the sixteenth century, ${ }^{113}$ do not appear to have exported very largely in the fourteenth century. ${ }^{14}$ Moreover the value of Dorset wool was so small, and the cost of export to the staple at Calais so great, that the wool merchants joined with those of Wiltshire, Somerset, and Berkshire in I 393-4, in petitioning for the establishment of a more convenient staple in Normandy. ${ }^{116}$ But the disadvantages under which the county laboured seem only to have proved an incentive to the invention of underhand means of obtaining a return for their wool-growing. In 1376 it was stated that the people of Wiltshire, Bristol, Gloucestershire, and Dorset were exporting 'Wolyn-yerne' in 'tonelx pipes sakes et fardelx' to Normandy and Lombardy, thus defrauding the customs and injuring the knights and merchants of the counties who were 'dissivez en Drap pur cause du diversite le dit zern,' and that the trade was so flourishing that no servants could be got to work in the harvest-fields, but all made excuse 'en fesant le dit zern et par cel causes les Servantz sont le plus fols du corps.' ${ }^{116}$ Steps were taken to remedy this evasion of the customs and deception of the consumer, but in $13^{8} 9$ fresh complaints were made that cloth was being sold in Somerset, Dorset, Bristol, and Gloucester, folded and rolled together, large parts of which inside were damaged and not like the part shown outside, so that merchants who bought the cloth and exported it for sale beyond the seas were often 'at death's door, and imprisoned and put to fine and ransom by the foreigners on account of the cloth.'

The records of Bridport admirably illustrate civic development in the county between the fourteenth and fifteenth centuries. The view of arms in I 319 shows that the burgesses of Bridport only possessed a stick and a knife, or dagger ; just a few plutocrats had a sword, but no one had bow and arrows. ${ }^{118}$ Of the 180 burgesses only sixty-seven were taxed; the richest man owned one cow, two hogs, two brass platters, some hides, and a little furniture, the total value of his possessions amounting to $f_{0} 48 s$. A respectable innkeeper was assessed for two hogs, two beds, two table-cloths, two hand-napkins, one horse, one brass pot, and one platter, a few wooden vessels and a little malt. ${ }^{119}$ In 1323 Bridport had made some progress. The taxation for one-sixth mentions eighty persons assessed, even if some of these only had property amounting to $6 \mathrm{~s}$. The tax-payer who was valued in 1319 at 548 s. now owned property to the extent of $f_{0} 6$, whilst the possessions of the most wealthy man were rated at $f^{8.20}$ A century and a quarter later Bridport was scarcely the same place. Numerous fraternities, those of St. Nicholas, St. James, and St. Mary the Virgin, the 'Brotherhood of the Torches,' of 'St. Katharine,' and ' of the Light of the Holy Cross in St. Andrews Church,' prove the existence of a flourishing middle-class population. ${ }^{131}$ 'The expenses of the cofferers of the

"11 Rot. Parl. (Rec. Com.), i, 3 I 76 ; ii, 288a, $304 a$.

113 Ibid. ii, 1386 .

113 Valor Eccl. (Rec. Com.), i, 228, \&x.

11. Cunningham, Growth of Engl. Industry (ed. 1905), i, 632.

118 Rot. Porl. (Rec. Com.), iii, $322 b$.

${ }_{117}$ Ibid. iii, $272 a$; cf. also Cunningham, Growth of Engl. Industry (ed. 1905), i, 434-5.

"1s Hist. MSS. Com. Rep. vi, App. 49 I. $\quad{ }^{119}$ Ibid. Ibid. $49^{2}$. ${ }^{191}$ Ibid. 478. 


\section{A HISTORY OF DORSET}

vill of Bridport' show that a new causeway was being constructed, and other accounts mention considerable sums spent on the church. ${ }^{182}$ The inhabitants were sufficiently prosperous to repair and improve their own houses. If further proof were needed the 'view of arms' in $145^{8}$ is conclusive evidence of the increase of wealth and prosperity. Swords, bows and arrows were the order of the day, as well as daggers, bills, poleaxes, and spears : "the defensive' consisted of jacks, salets, bucklers, habergeons, and gauntlets. One inhabitant possessed a gun in addition to a bow, twelve arrows, a sword, and a buckler; and he was ordered to provide twelve more arrows by the next muster. ${ }^{198}$

Nothing is more striking at first sight than the complete autonomy of these towns, not unmixed with a feeling of rivalry in accordance with the mercantile theory that the advantage of one town must necessarily be to the detriment of another. This theory coincided with fact when both Weymouth and Melcombe Regis coveted the harbour which lay between them, or when the wool staple was removed from Melcombe Regis to Poole. In both these instances the matter was decided by Act of Parliament, but in general the relations between towns were settled by treaties between the governing bodies. Probably the existence of common property in the borough, the pasturage, fisheries, or reclaimed land, ${ }^{124}$ helped to foster the sense of unity among the burgesses even if it only existed for the purpose of maintaining those rights. Thus each town had its own miniature army, the burgesses headed by the mayor or someone appointed by him. ${ }^{125}$ To secure peace within the borough the burgesses watched by turns; if they failed to perform this duty or did not watch for the whole time they had 'to make answer to the Mayor and Commonalty.' ${ }^{200}$ In Shaftesbury there is some account of this primitive police system : the 'Belman' and three inhabitants of the borough were 'to watch in p'son or finde sufficient p'sons in their roomes to watch with the Belman eu'y night from nyne of the clock att night until ffive in the morning.' ${ }^{127}$ Each town also was responsible for its own public works : the merchants of Lyme Regis built the Cobb for the security of their ships soon after they rented the town of the king. ${ }^{19}$ At Wareham a 'Constitution of the Borough' enacted 'that every inhabitant endeavour his labour to amend and repair the key, in taking and carrying away the dirt, stones, and rubbish thereabouts.' ${ }^{120}$ At Bridport, where the burgesses were too poor to complete the repairs of the harbour, they gained the assistance of 'the Church,' not that of 'the State.' Collectors from the town went all over the country producing indulgences from the Primates of England, the Papal Legates, numerous bishops, and the rector of the parish church, to contributors towards the expenses of the harbour. ${ }^{130}$ Only in a very indirect sense did the towns seek help from 'the State' ; sea-

1" Hist. MSS. Com. Rep. vi, App. 492-3.

13 There were reclaimed lands in Poole; see Sydenham, Hist. of Poole, 63.

1 "Foolscap sheet in the Corporation Archives of Lyme; also Roberts, Soc. Hist. of Southern Cos. 101. A mayor who did not wish to be troubled with the office turned the matter over to the lieutenants of the county.

${ }^{116}$ Case of John Rogger of Weymouth; see Hist. MSS. Com. Rep. v, 578.

19 Though this document belongs to the latter half of the seventeenth century it doubtless describes the carly police system of Shaftesbury. C. H. Mayo, Rec. of Shaftesbury, 68.

${ }_{18} \mathrm{G}$. Roberts, Hist. of Lyme Regis, 15.

"Hutchins, Hist. of Dorset, i (Wareham), App. I 26 ; 1451 , 'Constitutions of the Borough' (29 Hen. VI).

in Hist. MSS. Com. Rep. vi, App. 495. 


\section{SOCIAL AND ECONOMIC HISTORY}

ports which were devastated by pirates or French inroads or suffered from 2 great storm, inland towns which had been laid waste by fires, petition for a reduction of the fee-farm. ${ }^{131}$

But the chief proof of this civic autonomy is to be found in the possession of a mint, so that the coinage of one town was foreign in another. Dorchester and other 'walled towns' of the county had a mint; Wareham and Shaftesbury possessed two mints each, ${ }^{138}$ a great source of wealth to the community.

The inhabitants of the towns were united not only by common responsibilities but by common pleasures. The 'Cobb Ale' of Lyme Regis, dating probably from the destruction of the harbour in 1376 , became an annual feast and fancy fair. ${ }^{13 s}$ Then the custom existed at Shaftesbury of the mayor carrying the 'Bezant' to Motcombe each year in recognition of its good water supply. ${ }^{134}$ Garland-day was the annual festivity at Abbotsbury; after a procession through the town the fishermen deposited garlands of flowers on the waves to bring luck to the mackerel fishing. ${ }^{135}$ All these customs belonged individually to the towns, and represented some characteristic of their civic life; the custom of one town would have been foreign and meaningless in another. The centre of life in each town was the parish church, and in its management, both financial and ecclesiastical, the popular voice made itself heard. 'The 'commonalty' of Bridport did not hesitate to criticize the chaplain of St. Andrew's, 'a stranger from Bretagne who was drunk every day, not fit for divine service,' and 'who sometimes celebrated it twice in the week, sometimes not at all.' 136

As to the people of the towns, 'the commonalty,' they were a distinct class whose rise made the growth of these independent towns possible. Hitherto the only 'considerable' men were the owners of land. Trade brought with it another criterion of importance, commercial wealth; burgage tenure lost its old simplicity and uniformity. ${ }^{137}$ The position of the burgess was one of great importance: he was the pivot upon which the whole machinery of town government turned. He had to contribute towards the maintenance of public buildings, to defend the town from invasions, to give watch and ward, to serve on juries; in return for these obligations he had the privileges of a taxpayer, in those days the exclusive right of trading in the borough. That aliens attempted to get trading privileges without paying for them is only natural; equally natural is it that the burgesses should have resisted these attempts. In Lyme Regis any stranger who came to reside and trade in the borough without becoming a freeman was obliged to pay 3 s. $6 d$. a week to the corporation, which sum was applied to the repairs of the Cobb and the sea-walls. ${ }^{138}$ In Wareham the 'Constitutions of the borough' declared that any stranger ' using his trade or occupation in the said borough, unless he was born or had served an apprenticeship in the said town,' was to pay 3 s. $4 d$. to the use of the mayor for opening 'his windows of his shop.' At the same time there was no attempt made to keep out aliens who had been burgesses in another town and were likely to become freemen again.

\footnotetext{
191 Rot. Parl. (Rec. Com.), iii, 70b, 5 I 5a, \&c.

133 Roberts, Social Hist. 335.

1ss Ibid. 231.

13' Hutchins, Hist. of Dorset, i, 79.

isc Notes and Queries of Somerset and Dorset, iii, 235-6.

${ }^{137}$ Hutchins, Hist. of Dorset, i, 77 (diff. size of burgages in Wareham).

${ }^{133} \mathrm{G}$. Roberts, Hist. of Lyme Regis, 22.
} 


\section{A HISTORY OF DORSET}

The only thing was that aliens had to bring some recommendation with them, and the usual custom was a letter from the bailiffs and commonalty of the old town to those of the new. Thus a letter from Sherborne to the mayor and bailiffs of Bridport declares 'that Henry the Brewer bearer of these letters is a lawful man and of good fame for so long a time as he has been conversant and dwelling in our parts of Shirburne.' ${ }^{139}$ But a community did more than this for its emigrant burgesses; it vigorously took up the cudgels on their behalf if they were 'falsely defamed ' in 'foreign parts.' A letter from the bailiffs and community of Dorchester put somewhat forcibly to the commonalty of Bridport that 'they had heard that a certain devilish spirit had falsely defamed one of our nation, and wrongly, that is to say Pires Cokeraul,' ' that he had been indicted in the vill of Dorcestre for divers things.' They write to certify that he is 'good and lawful and that no default has been found in him for falsity, and at the writers' peril they are requested to hold him as such.' ${ }^{140}$ But if letters could protect they could also pursue a delinquent from one town to another. The bailiffs and community of Dorchester proceeded to state 'that neither John the Taylor of Wynterborne nor his wife was ever held as good or lawful in their company; nor yet Adam (the Fiddler ?) nor his wife.' 'And for this we are glad at their departing out of our franchise; and we pray that you will hold them such in your parts as we hold them in our parts.' ${ }^{141}$ In some cases a new freeman would rely upon his position as holding a tenement or receiving a fixed annual income to secure the goodwill of the borough. In Wareham a certain standard of wealth, and that a low one, was considered sufficient. A 'constitution' declared that no inhabitant should take any stranger into the borough 'to dwell and inhabit, but shall first give sufficient surety to the mayor for the discharge of the town or parish wherein they shall soe be taken to dwell.' ${ }^{142}$ Probably it was under the circumstances of his entry being less public that the mayor stood surety for a new burgess in deeds of sale by affixing his official seal. Whether this was the case or not, at least the frequency of these official signatures proves the comparative fluidity of the burgess population between the Dorset towns. ${ }^{148}$ The position of the mayor, with its immense powers, military, judicial, and financial, was not always desirable. Responsibility for the fee-farm was no light matter with the frequent risk of the town being devastated by fire or pestilence; also the continual expense of the entertainment of great officials could become a burden. This was so much the view of the burgesses of Shaftesbury that a penalty of $f_{\mathrm{r}}$ ro followed the refusal to be mayor; at the same time the stipulation that no burgess could be compelled to undertake the office a second time within three years of the expiration of his former term saved the individual from ruin. ${ }^{144}$ Possibly it was partly for the benefit of the town treasury, as well as for the protection of the consumer, that trade was regulated in the towns. Markets and fairs, with the court of piepowder, were lucrative possessions; presentations for brewing contrary to the assize, selling ale in cups or other false measures, and tapping without due supervision, were among the most common of the

${ }^{139}$ Hist. MSS. Com. Rep. vi, App. 489.

140 Ibid.

10I Ibid.

"Hutchins, Hist. of Dorset, i, 125.

i4s Hist. MSS. Com. Rep. vi (Bridport); ibid. v (Weymouth and Melcombe Regis); also Mayo, Rec. of Shaftesbury, 35 .

ist C. H. Mayo, Rec. of Shafiesbury, 7. 


\section{SOCIAL AND ECONOMIC HISTORY}

petty law cases. ${ }^{145}$ At the same time the system must have been as costly as it was detailed: no manufacture was left unsupervised. If the jury at Lyme presented a shoemaker as 'faulty' for not causing the leather to be well curried, and the curriers were fined, ${ }^{140}$ it went still further into the matter and decreed how long the tanners should keep their hides in the tan-pit. Ale was tested to see that it was 'mighty of the corn' and sold in proper measures; each loaf had to be classified and stamped 'bene' or 'full weight.' ${ }^{147}$ Neither luxuries nor the staple commodities of food and absolute necessaries of clothing but were regulated, both in their manufacture and sale, throughout the Middle Ages.

In the civic fight for freedom much depended on the lord of the manor who owned the borough; also on the distant overlord, the king. Hence an intricate network of bribery of all royal or private officials who could in any way advance the interests of the community. Robert of Farendon, evidently a man of influence, was presented by the bailiffs of Bridport on different occasions with chickens, fish, beef, and veal; and at another time with a 'potell of wine.' ${ }^{148}$ Articles of horse-trapping were also popular gifts in Bridport, where they were manufactured locally. Some 'horse-nets' were given to the collector of the royal tallage, and the still more typical gift of a cord to the sheriff of the county. ${ }^{160}$ Bridport spent lavishly, but it belonged to the 'successful order' of towns, being a royal borough. It was generally the policy of the king to strengthen the power of the towns, so that the growth of Bridport was developed rather than checked by the overlord. Not that this was universally the case in later times, when the royal power was supreme ; in Shaftesbury Queen Elizabeth appropriated as of royal right lands belonging to the borough, on the plea that they had been wrongfully concealed from Her Majesty. Only in 1704, after passing through private hands, did they again revert to the borough. ${ }^{150}$ On the other hand, towns such as Sherborne never attained to much independence; the bishop and abbot kept too tight a hold upon their lay dependants. ${ }^{162}$ Religious corporations never die, and never have a minority, nor could the individual members go away to the wars. Near Sherborne all the manors belonged either to the bishop or the abbot: ${ }^{152}$ the religious rivalled the lay population of the borough. The ecclesiastical were distinct from the secular courts, whilst the right of sanctuary caused interference with lay justice. The bishop was lord of the fairs and markets, ${ }^{163}$ and owner of the corn-mills; ${ }^{154}$ the religious community throve on the town's wealth without ever being absorbed in its life. Frequent disputes arose between the monks and the townsmen, and the feud even extended into the abbey church. ${ }^{156}$ The nearest approach to popular independence in Sherborne was the committee of twenty-four townsmen to regulate the breweries, the number of retail houses, and the character of the ale. But although this committee represented all the trades in Sherborne the individual members were the nominees of the bishop. ${ }^{156}$ So

${ }_{106}$ Hist. MSS. Com. Rep. v (Weymouth and Melcombe Regis); vi (Bridport); also Rec. of Shaftesbury.

${ }^{160}$ Roberts, Social Hist. 185,453 ; MS. in archives of Lyme Regis.

${ }^{167}$ Hist. MSS. Com. Rep. vi, 494.

${ }^{150}$ C. H. Mayo, Rec. of Shaftesbury, 6-7.

${ }_{131}$ W. B. Wildman, Hist. of Sherborne (ed. 1896), 30. ${ }^{151}$ Ibid. $51 . \quad{ }^{153}$ Ibid.

IM Ibid. 5+. No man was to build any malt-mill within the manor or town of Sherborne whereby the cornmills 'should be hyndered.' ${ }^{15 b}$ See 'Religious Houses.' 161 W. B. Wildman, Hist. of Skerborme (ed. 1 896), 33. 


\section{A HISTORY OF DORSET}

completely did the bishop and abbot dominate the town and check its municipal growth that after the dissolution of the monasteries Sherborne sank into insignificance after being the most populous and frequented town of the county. ${ }^{167}$ Cerne Abbas shared the same fate; the life of the town was centred in the abbey, and with its suppression the town lost its chief subsistence. ${ }^{268}$ Sherborne is the town of Dorset most typical of Engiish ecclesiastical towns, if generalizations are permissible; but the other monastic towns of the county have a different history. Shaftesbury never fared better than when under the sway of the lady abbess, who from before the Norman Conquest owned one and by degrees obtained possession of the other manor. ${ }^{159}$ It was only after the Dissolution, when the new lords or their bailiffs regarded the manor as a source of revenue, when tenants were rackrented, and the manorial court looked upon as an instrument of fiscal extortion, that the town became involved in endless quarrels and litigation. ${ }^{100}$

An accumulation of causes, some of which dated back a considerable number of years, prepared the way for the distress of the sixteenth and seventeenth centuries. Comparatively early in the fifteenth century the arm of justice seems to have been relaxed. The Gaol Delivery Rolls ${ }^{101}$ for the period are full of charges of murder, robbery, and house-breaking, but offenders seem rarely to have been brought to justice: either no one was found to prosecute, or the jury returned a verdict of not guilty, or the accused was released under the terms of a general pardon. The inroads of the sea and foreign attacks had caused havoc to Melcombe and Lyme Regis, so that their fee-farm rents had had to be reduced and their contributions to taxes relaxed; ${ }^{183}$ and finally, in 1433 , 'for lakke and scarcete of helpe of peuple to withstand and resiste the malice' of the king's enemies the port of Melcombe was closed and the staple and other privileges of the port transferred to Poole. ${ }^{18 s}$ A century later Poole, Lyme, Shaftesbury, Sherborne, Bridport, Dorchester, and Weymouth were among the decayed towns upon which Henry VIII urged the necessity of effecting restorations. ${ }^{164}$

Nor was the distress confined to the towns. In $1435^{-6}$ the county was found to be utterly incapable of bearing its normal share of the burden of taxation, and a schedule was issued of "vills and boroughs desolated wasted destructed and depopulated' to which allowances must be made. The remittances to the boroughs included 50s. to Dorchester, 6os. to Shaftesbury, I 3 s. to Portland, I 3 s. 4 d. to Wareham, and 20s. 5d. to Bridport. ${ }^{10 s}$ A similar list was issued in I449-50. Unfortunately, both documents are in such 2 state of decay that comparison is difficult; but although at the later date in some cases the allowance is not so great, in other cases it is greater, and several places are included which were omitted in the earlier list. ${ }^{100}$ The distress, though it was perhaps most prevalent in the centre, does not seem to have been confined to any particular quarter of the county; thus, while Cranborne was apparently able to bear the full burden of its tax, the neighbouring parish of Wimborne St. Giles had to be pardoned I $8 \mathrm{~s}$. Id. in I 435 and 26 s. $8 d$. in

\footnotetext{
137 Camden, Brit. (ed. Gough), i, 45.

139 Mayo, Rec. of Shafiesbury, 16.

${ }^{160}$ Ibid.

${ }^{15 s}$ Hutchins, Hiss. of Dorset, iv, 15.

Rot. Parl. (Rec. Com.), iii, 70b, 443b, 616a, 639a, $515 a, 618 a, 640 a$; iv, $468 b$.

163 Ibid. iv, $444^{b}$.

ies Lay Subs. R. Dorset, bdle. 103 , No. 79.

${ }^{166}$ Ibid. No. 91.
} 


\section{SOCIAL AND ECONOMIC HISTORY}

1 449: and in the western extremity of the county Beaminster and Broadwinsor were apparently immune, while Stoke Abbott was excused I8s. Id. on the first assessment and IOs. on the second. About this time the commons of Dorset complained to the king that they, with the inhabitants of other sea-coast counties, had sustained many 'injuries oppressions and extortions' from soldiers who had come amongst them, and they prayed that the said soldiers might be 'put under restraint for such offences that the said counties may not be desolated or otherwise destroyed.' 187

Whether the decaying prosperity of the county had anything to do with the diminishing number of foreigners settled within its borders it is impossible to say, but between the years 1440 and 1468 the number of aliens-householders and others - fell from several hundreds to five, the greatest fall occurring between $\mathrm{I} 44^{\circ}$ and $\mathrm{I} 45^{\circ}$, at which date there were only five householders and eleven other foreigners. ${ }^{183}$

It seems probable that the existing distress was not enhanced by any great movement towards the inclosure of common fields or the conversion of arable into pasture land in the sixteenth century. Though there were undoubtedly some few common fields in the county at this period, ${ }^{180}$ they were probably not of very great extent, and Dr. Slater considers it likely that the land passed, at least in the south and west, directly from the condition of forest or moor into separate cultivation, though the cultivated patches were not as yet inclosed, and that where arable common fields existed they were small in area and surrounded by severally cultivated assart. ${ }^{170}$ There seems to be absolutely no evidence of rioting caused by inclosures, but in the reign of Henry VIII two separate suits in the Court of Star Chamber were brought against Sir William Fyloll, kt., lord of Winterborne Belet and Winterborne Herringstone, by the tenants of Bincombe and Winterborne Came respectively. These were obviously not ordinary cases of inclosure, but an attempt on the part of a great landowner to convert the arable fields of a neighbouring township into pasture for his own sheep, to pasture his sheep upon a common where he had no legal right, and to hinder those who had rights of common from availing themselves of them. ${ }^{171}$

In other cases inclosure seems to have been effected by a peaceable agreement with the tenants of the manor, as in the case of Long Bredy, where the lessee of the site of the manor some time before February, 1597, by agreement with the lord and the tenants, inclosed 'not only the land demised to him but also a good part of the commons and waste grounds of the manor which were assigned to him by such assent as aforesaid, in lieu of all the said sheep leaze common and common of pasture to him demised.' 172 A yet more interesting case is recorded at Shroton (in Iwerne Courtney), which lay open till I 548, when many of the tenants whose holdings were so small that they could not pay their rents, "departed the town and surrendered their copies to the lord.' The rest requested that they might continue to hold their lands, provided they paid their rents to the lord, "and they his tenants to maintain

\footnotetext{
${ }^{108}$ Ror. Parl. (Rec. Com.), v, 6 Ib.

${ }^{169}$ Lay Subsidy R. Dorset, bdle. I03, Nos. 83, 92, 96, 105.

${ }^{169}$ cf. Hutchins, Hist. of Dorset, iii, 569 ; iv, 4I, $50 \mathrm{I}$.

${ }^{170}$ Engl. Peasantry and the Enclosure of Common Fields, $238,240$.

${ }^{17}$ Star Chamber Proc. Hen. VIII, xix, 35, 369.

1" Chan. Enr. Dec. R. 97-6.
} 


\section{A HISTORY OF DORSET}

their living and hospitality.' It was accordingly arranged that six tenants 'chosen and sworn should tread out the lands of the manor and allot how much each tenant should have and so every one enclosed his land and so held it till to-day.' The 'more tenants' were allowed I 2 acres each, at a rent of 8 s., and 'the lesser' 8 acres at $6 s .8 d$. The 'borde lands'- 7 acres in extent-remained undivided, and were granted to several tenants at a rent of rod. an acre. Iwerne Common in the north-west of the manor remained open from 1 May until Christmas for cattle, and from Christmas to the middle of March for sheep. ${ }^{278}$

But if the increase of sheep-farming was not an important factor in the economic situation of the county in the sixteenth century, the dissolution of the monasteries probably was, for though 'the myght power and strenght' of the Dorset religious houses occasionally made them harsh as landlords, ${ }^{174}$ the extent of the charities and hospitalities of which they were the source was enormous. The various doles from Cerne Abbey alone amounted to nearly $£_{3} 35$ a year, ${ }^{175}$ and at Milton the distributions in money and kind were worth nearly $f_{05} 5$ in all, and included the daily maintenance of thirteen poor men of Milton, each of whom received a dish of flesh or fish worth $\mathrm{I} d$. every day, and seven loaves worth $3 d$., and three measures of beer worth $1 \frac{1}{2} d$. every Saturday. ${ }^{176}$ In these circumstances it is scarcely surprising that the county objected to the religious changes of the sixteenth century, and joined in part in the western rising of $1549,{ }^{177}$ for apart from the innovations in dogma and ritual which are usually supposed to have been at the root of the trouble in Devon and Cornwall, for Dorset men the Reformation created a real economic problem. Already overburdened with taxation, and threatened with the decay of its towns and the depopulation of its country districts, its entire system of charity was suddenly swept away, and some fresh scheme of poor relicf became necessary. The natural arrangement was a compulsory assessment for the poor, and this was established by Act of Parliament in I 572. In consequence of this Act the first poor rate was raised, each parish being made responsible for its paupers. This was resented as an innovation, and parishes tried to save themselves from a pauper population which they would have to support; hence a regular persecution of needy persons set in, which greatly accentuated their misery, and was an extraordinary interference with the liberty of the individual, dealing even with family ties. Andrew Ham of Lyme was ordered to remove his own sister from his house under a penalty of 40 s. $^{178}$ Later, the jury presented Edward Borough, who

\footnotetext{
keepeth a young child in his house, which is not to be harboured, and Poynter doth the like; and William Crewe keepeth his mother in his house, which is not to be harboured, and Poynter doth the like; and that John Donnet likewise harboureth his wife's sister: and Mary, Mrs. Barret's servant is not removed, being often warned and commanded to depart the town. ${ }^{178}$
}

In one instance a parson was called upon to give security to the overseers that he would provide for a poor man, with seven children, and three apprentices, should it be necessary, merely because he had allowed them to come into the parish. If he refused to guarantee their support he was to

${ }^{173}$ Harl. MS. 71, fol. 34-9 ; also quoted in Hutchins, Hist. of Dorset, iv, 89.

17 e.g. Star Chamber P'roc. He.r. VIII, i, 28-3c and Ct. of Requests, bdle. 6, No. 92.

175 Vaior Eccl. (Rec. Com.), 281.

178 Roberts, Social Hist. of the Southern Cos. 180.

177 Cal. S. P. Dom. $1547-80$, p. 19.

170 Ibid. $180-1$. 


\section{SOCIAL AND ECONOMIC HISTORY}

give 25 . or $2 s .6 d$. a week more to the poor rate until they left the parish. ${ }^{180}$ No one at Lyme could enter the town without the consent of the mayor, and no person could take any under-tenant into his house without the same permission. ${ }^{18 I}$ There was a two-fold barrier against immigration into the town. It was, no doubt, with the object of securing the artisan class already in the town from becoming chargeable that 'no artificer or trader was to take any apprentice from out of the town, if there be anyone fit in the town to serve him,' without, as usual, the consent of the mayor and chief burgesses. ${ }^{182}$ Again, Henry Webb, the new tailor, had a day given him by which he was to depart the town. Taken in connexion with a document at Weymouth, giving the names of such tradesmen 'as have liberty to use their trade,' not being freemen of the town, it would appear that even the number of tradesmen was regulated, for fear, presumably, that some should fail and so become chargeable to the town. ${ }^{183}$

Side by side with this severity, and in accordance with the Elizabethan Act of I60I, local means of a more charitable nature were taken to prevent persons eventually becoming chargeable to their parish. In I6 I6 a 'Hospital' was founded in Dorchester ${ }^{184}$ 'for the harbouring and setting to work of the children of the poor,' who were to be taught 'to spin and burle,' 185 and received wages every Saturday for the work which they had done during the week. The overseer of the 'Hospital' was to give a list, every three months, of what each boy and girl had earned, so that the town authorities might have some check upon its management. That the Elizabethan idea of providing work for the poor still prevailed in the early part of the eighteenth century is shown by the will of a certain Sir Samuel Mico of Weymouth, who left property to enable three poor children to be apprenticed every year. ${ }^{186}$

A part from this provision of work for the poor, it was during the sixteenth and seventeenth centuries, with the increased distress, that many of the charitable institutions were founded by private bequests. In I 559 Elizabeth gave a licence for the erection of almshouses at Wimborne, in pursuit of the will of the marchioness of Exeter. The almshouses were duly erected shortly afterwards by Lord Mountjoy, to whom the charge was entrusted, and endowed with a fixed rent. ${ }^{187}$ An almshouse was also established at Corfe Castle in I $62 \mathrm{I}$, through a fund bequeathed by Sir Edmund Uvedale for that purpose. ${ }^{188}$ There was a large almshouse at Sherborne 'for twelve poor men and four poor women' ; it was governed by twenty of the most substantial inhabitants, but when it was founded and whether by private or municipal enterprise is uncertain. ${ }^{189}$

Sometimes bequests, especially smaller ones, were funded and the proceeds distributed in annual doles. 'John Mathewe of Mynterne' left $f_{2} 20$ in trust to his wife, to pay 40s. yearly to the poor of Minterne. ${ }^{190}$ John Browne of Frampton, who died in 1670 , left $£ 50$ to the poor of Frampton. ${ }^{191}$ In one instance the minute capital of 40s. was bequeathed by a carpenter of Buckland Newton for the poor of his parish. Eighteen years afterwards the churchwardens of Buckland Newton received the comparatively large

\footnotetext{
${ }^{180}$ Roberts, Social Hist. of the Southern Cos. $183 . \quad{ }^{181}$ Ibid. I80-I. 189 Ibid. 187.

${ }_{183}$ Ibid. 180, $183 . \quad{ }_{181}$ Hutchins, Hist. of Dorset, ii, 397. ${ }^{183}$ Ibid. 399.

${ }^{186}$ Petty Bag : Proceedings of Commissioners for Charitable Uses, bdle. 48 , No. 1.

${ }^{197}$ Ibid. bdle. 10, No. $2 . \quad{ }^{189}$ Ibid. Ibid. bdle. 1, No. 5.

190 Ibid. bdle. ro, No. 2.
} 


\section{A HISTORY OF DORSET}

legacy of fio from a husbandman for the same purpose. ${ }^{192}$ In the case of Lady Dorothy Gorges, who died in I649, the large sum of $f_{1} 5^{\circ}$ was bequeathed to the poor of Gussage. ${ }^{103}$ Sometimes a certain class of poor person was favoured, as when Sir Samuel Mico left the interest on ${ }_{0} 500$ 'partly to a sermon, partly to poor decayed seamen of Weymouth' who possessed the qualifications of sixty years of age or upwards, and having been present 'at the hearing of the sermon.' 194

If these bequests had been duly carried out there would probably have been no record of their existence. But it was easy enough for the heirs and executors to appropriate such bequests when the judicial system was not so good as it is at the present day, and, above all, the means of communication between different parts of the country slow and very expensive. Lawsuits were the luxury of the rich man who had both time and money at his disposal. It was probably counting upon these advantages that the son of that Lord Mountjoy who built the almshouses at Wimborne thought it worth while to retain $f_{0}$ I 2 out of the interest of the endowment. ${ }^{195}$ Sir Edmund Uvedale's brother and heir probably thought that he was safe in appropriating the property bequeathed for the maintenance of the almshouse at Corfe Castle. ${ }^{196}$

Government did take measures to protect the poor by means of commissioners, the scope of whose inquiries shows the different classes of persons who benefited by charitable bequests. There was to be an examination into

all moneys, \&c., left in trust for the relief of aged, impotent, and poor people, maintenance of sick and maimed soldiers or mariners, of schools, \&c., repair of bridges, ports, havens, causeways, churches, seabanks, or highways, education or preferment of orphans, relief, stock, or maintenance of houses of correction, marriages of poor maids, supportation, aid, or help of young tradesmen, handicraftsmen, or persons decayed, relief or redemption of prisoners or captives, or aid or ease of other poor inhabitants concerning payment of fifteenths, setting out of soldiers, or other taxes, in any parish, town, or place in the county of Dorset, and any breaches of trust, \&c. ${ }^{197}$

But these inquisitions were not too frequent. The first on record was held at Blandford in 1623 , and it was only then shown up that the "John Mathewe legacy had not been paid for the last twenty-four years.' ${ }^{193}$ There was an inquest taken at Dorchester in 1677 , when it was discovered that the 'John Browne' bequest to the poor had been appropriated by the executors. The next recorded inquest at Dorchester was in 1709 , when it was proved that the poor of Buckland Newton had been deprived of their funds for the last seventeen years. As to the poor of Gussage they had never received any money on the death of Lady Dorothy Gorges, and no inquiry appears to have been made until 1676, twenty-seven years after her death. The court made an order that it should be paid to the churchwardens. But still this was no guarantee that the poor of Gussage received the bequest. If the heirs and executors honestly fulfilled a charitable trust the poor still ran the chance of being defrauded by the churchwardens or corporation on whom the trust eventually devolved. In the case of the 'Buckland Newton' charity the churchwarden trustees embraced the opportunity to repair the church. The corporation of Weymouth behaved no better with the legacy of Sir Samuel Mico. They ought to have put out thirty-three apprentices in eleven years, but they only

\footnotetext{
199 Petty Bag: Proceedings of Commissioners for Charitable Uses, bdle. 51 , No. 7.

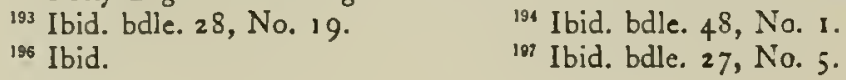

${ }^{195}$ Ibid. bdle. 10, No. 2.

108 Ibid. bdle. 10, No. 2.
} 


\section{SOCIAL AND ECONOMIC HISTORY}

put out five, and appropriated a balance of $\oint_{0} \mathrm{I} O \mathrm{I} 7 \mathrm{~s}$. As to the $\oint_{55} 500$ left to the sermon and seamen an unsuitable individual received a pension upon the strength of which he migrated to Cornwall, and part went in the satisfaction of a debt to one of the aldermen..$^{199}$ In short, corporations were scarcely more scrupulous than individuals: if they were capable of showing such cruelty as they did towards pauper immigrants, it was only one step further to appropriate private charitable bequests. Charity had been left for so many centuries in the hands of religious corporations that its necessity was little understood by political bodies, in whose eyes it was often an unwelcome innovation.

A more popular method of dealing with distress in the seventeenth century was by attempting to regulate the price and supply of the corn, apprenticing of children and the settlement of vagrants. In the distress of the years I $630-I$, justices of the peace throughout the country acting as Poor Law officers for their counties were under the strictest orders from the Privy Council to prevent all artificial enhancing of the price of grain, to see that the poor were supplied at as low a price as might be, and to suppress unnecessary ale-houses, to apprentice all poor children of a suitable age, and to deal stringently with vagrants and rogues. The system of apprenticing and the suppression of vagrancy and other disorders were probably beneficial, but the attempt to interfere with prices was of doubtful expediency. In Dorset, at any rate, there seems to have been no combination on the part of corn merchants to raise prices unduly..$^{200}$ The justices, indeed, considered that the interference of the state pressed over-hard upon the farmer; they stated that when wheat was under 5 s. the bushel and barley under $2 s .6 \mathrm{~d}$. "the husbandman cannot well maintain his tillage at the present prices of all other necessaries,' ${ }^{201}$ and this representation was probably correct, for from the neighbourhood of Bridport, in the same year, came the complaint that the cost of living was dearer 'almost by half than in former times, all foreign commodities, salt especially, being at such extraordinary prices,' while rents were high, and a considerable amount of barren land had been brought into cultivation at great cost by the use of marl and lime, "which is gotten at excessive charge.' 202

In the ordinary administration of their duties the Poor Law officers of the county could look to other sources of revenue beyond the money raised by the rates in the seventeenth and eighteenth centuries. Of these, one of the most important must have been the forfeitures of dishonest tradesmen. Several cases recorded in the archives of Weymouth and Melcombe Regis illustrate this point. In $1617 \mathrm{~J}$. Benville of Buckland was convicted of having brought to market $8 \mathrm{lb}$. of butter of short weight, for which default he was condemned to forfeit the butter, which was given to the poor; a similar fate befell William Bythywood whom the constables found in possession of a leg and shoulder of a calf killed 'sethence the time of Lent." ${ }^{203}$ Fines for drunkenness were also applied to 'thuse of the poore' at Melcombe, ${ }^{204}$ and as this was a common

199 Petty Bag: Proceedings of Commissioners for Charitable Uses, bdle. 48, No. I.

${ }^{200}$ Cal. S.P. Dom. $1631-3$, pp. $183,185,186,188$.

${ }^{201}$ Ibid. 185 . In March, 1631 , wheat was at 75. or 75.6 d. the bushel in the Dorchester division, but by the following November it had fallen to 5s., while barley was at 3 s. and a further fall was expected (ibid. $1629-31$, P. 547 , and $1631-3$, p. 185).

${ }^{202}$ Cal. S.P. Dom. $163 \mathrm{I}-3$, p. 186.

${ }_{202}$ H. J. Moule, Descriptive Catalogue of the Charters, etc. of Weymousth and Melcombe Regis, 56, 58.

${ }^{204}$ Ibid. 57. 


\section{A HISTORY OF DORSET}

offence and the fine of each case amounted to $5^{5 .,}$ the total income from this source must have been considerable. An alternative punishment was to sit in the stocks, E. Bouzer in I 652 being allowed to choose whether he would 'pay 5 s. or sitt vi houres by the heeles.' ${ }^{205}$

A variety of other offences came before the local authorities at this period, such as 'abusing the watch,' 'suffering on the Sabbaoth day to drincke sundry persons,' making armed assaults upon the house of the mayor, 'making comparisons with him .. . swering many fearfull oathes and using divers unfitt bragges,' disturbing the peace and setting the neighbours by the ears, allowing Frenchmen to drink at the time of evening prayer, and carrying on business without licence. ${ }^{208}$ The punishments allotted were as various as the offences. The man who insulted the mayor had to come and make public submission on the following day, abusing the watch was punished in the stocks, the five women who had disturbed the king's peace were found guilty by a jury, and it was ordered by the court 'quod praedicte Temperantia, K., Gratia, Alicia et Thomasina laventur, Anglice ducked'-the cucking-stool being also the punishment proposed for the wife of a certain 'poore impotent man' who was in the habit of troubling her neighbours. ${ }^{207}$ Swearing was punishable with a fine, Nicholas Marriner having to pay $3^{5 .} 4 d$. for one oath in $1652 .{ }^{203}$ Witches also came within the cognizance of the local authority, a deposition being made in the borough court of Melcombe and Weymouth by Edith Bull in I 647, to the effect that she had heard Damaris Harvey say 'that Avice Miles is a witch,' and that Amy Cotten 'never prospered after shee was cursed by the said Avice Miles.' ${ }^{209}$ A similar case of presentment for witchcraft occurred at Lyme at a somewhat earlier date. ${ }^{210}$ Rogues and vagrants-a class whose existence always constituted one of the problems of English rural life ${ }^{211}$ -were liable under the Vagrants Act to be returned to their birthplace or last habitation. An entry in the Melcombe borough archives for I 6 I 7 records that a vagrant person had been 'whipped and sent away by a passe,' but they were always liable to congregate at fairs and other popular gatherings, and appear to have caused considerable anxiety to the Dorset justices; for in 163 I they paid 40s. to their marshal 'for the great pains and care' he had given 'in the searching out and apprehending rogues and vagrants at fairs and other great places of meeting within this county.' ${ }^{212}$ "This may have been the outcome of the stringent orders under which the justices were placed at this time to return reports to the Privy Council of their activity in dealing with vagabonds. ${ }^{213}$

But while the new Poor Law system was struggling somewhat ineffectually with the distress caused by the dissolution of the monasteries, inclosures of land, and low wages, the whole country was plunged into far greater misery by the civil wars of the seventeenth century.

It would be mere speculation to say which of the towns fared worse; probably the decision would rest between those which were occupied by both parties alternately and the staunch Royalist centres which offered a stout resistance. Weymouth illustrates the former, and Clarendon tells us that the pillage committed by the soldiers of Prince Maurice was so great that

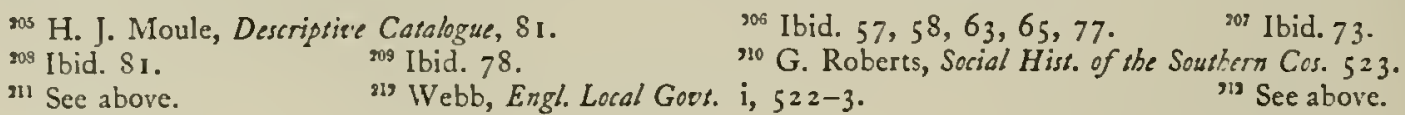




\section{SOCIAL AND ECONOMIC HISTORY}

the earl of Carnarvon went to the king at Gloucester and laid down his commission. ${ }^{214}$

To take an instance of a town which held out gallantly for the king, Corfe; the destruction of property and individual ruination were terrible. Those tradesmen who favoured the Parliamentary cause were pillaged by the garrison. To illustrate this, the petition survives of a certain Henry Browne that satisfaction may be granted him out of the estate of Lady Bankes for the 200 worth of goods which the garrison had taken from him, and for two houses which had been pulled down to furnish stones to discharge upon the besiegers. $^{215}$ On the other hand those tradesmen who survived the extensive requirements of their own garrison, being Royalists, were ruined when the town fell into the hands of Parliament. Writing to Sir Ralph Bankes in I660, Edward Harvey, a Corfe tradesman, adds-

What Colonel Bingham had of yours I know not; but I am sure that his soldiers had all my shop goods. I did write to Mr. Culliford whilst in London to advise me whether I should not have any satisfaction, and he advised me in the negative, that the Act would quit all men of all such actions. ${ }^{216}$

This apparently was the case : the Act of Indemnity and Oblivion required that Mr. Harvey should forget his shop goods.

Even Lyme, which held out successfully, expended $f_{0} 17,45^{8}$ in keeping up the garrison. ${ }^{217}$ Afterwards a sum of $f_{200}$ per annum was allotted them out of Lord Paulet's estate ; ${ }^{218}$ with the curious addition of 2,000 oaks from his woods to rebuild their houses, ${ }^{219}$ a fact which explains the frequent and devastating fires of those times. Considering the total destruction of the shipping and the general blow to trade, such inadequate remuneration was scarcely calculated to restore Lyme to the rank of a prosperous town. At the same time individuals were most conscientiously considered, even if it amounted to nothing beyond theory. A merchant named Alford had expended $f_{4} 4,200$ on the garrison, either in money or provisions; the 'Dorset Standing Committee' engaged the public faith of the kingdom to repay the sum, with 8 per cent. interest. ${ }^{220}$ In short one of the principal functions of this committee was to apportion sequestered estates among the towns which had been devastated in, and the individuals who had suffered for, the Parliamentary cause. A definite sum, generally one-fifth of the property, was settled upon the wife and children of the culprit, but in the case of great wealth a smaller proportion was held sufficient. ${ }^{221}$

The Puritan spirit in local government was by no means confined to the immediate years of the Puritan revolution, but at Melcombe there seems to have been an access of zeal to enforce industry and sobriety between the years 1642 and 1658 . An ale-house licence issued in 1642 adds to the usual restrictions placed on licensed victuallers a clause forbidding the landlord to allow 'haunting of the Alehouse on the Sabath Daie or festivall daies,' and four years later all the late town officers were presented for neglect in making presentments and considering abuses. In 1647 it was asserted that Constable

214 Clarendon, Hist. of the Rebellion, vii, 192.

s16 Bankes, Hist. of Corfe Castle, 249.

"15 Hist. MSS. Com. Rep. vi, App. 84.

18 Ibid. but Rushworth, Collections (abridged ed.), v, 339, says E1,000 per annum, which alters the question somewhat.

${ }^{20}$ Mayo, Minutes of the Dorset Standing Com. 165.

19 Rushworth, Collections, v, 339.

921 Ibid. $4^{8}$. 


\section{A HISTORY OF DORSET}

Edwards was unable 'to go or stand' on the last fast day, and in 1658 Mary Wood was presented for 'living an idle course of life out of service, therefore it is ordered that she be sent to Bridewell if taken at home again '; and a similar order was issued with regard to Susan Welman's daughter, 'a masterless person.' ${ }^{29 z}$

Another outcome of the triumph of Puritanism was the growing tendency to interfere with the amusements of the people. Unlawful games had indeed been punishable as early as the fifteenth century, ${ }^{223}$ but the Puritan even attempted to put down strolling players. In Dorchester, a Parliamentarian stronghold, this attitude towards them lingered on after the Restoration. On 6 October, I660, a certain William Darrant who came 'to this towne, to shew the dauncing of divers creatures on ropes, and dogs,' was refused although he brought a licence purporting to be from General Monck. ${ }^{834}$ Another application made in the following November to 'make shew of a puppet-shew called Patient Grizell, with music and six servants,' met with no better success, nor one of three months later to show 'Crispin and Crispianus.' In one instance a reason was alleged. Richard Pavey of London, of St. Giles in the fields, ' coming to shew a motion of the witches of the north,' was told 'that we have noe waste mony for such idle things.' 226

But the early years of the eighteenth century seem to have witnessed a serious outbreak of disorder in Weymouth and Melcombe at least. In 1700 three constables of the borough found Captain Harding and Mr. Leslie, aldermen, 'gaming and wrangling' in the 'Bear' at ro p.m., and in I 70 I two individuals were presented because they 'drancke punch to a greate hight,' after which at $8 \mathrm{p}$.m. they went to 'Melcombe town-end and fought with swords.' John Palmer was presented for blasphemous swearing in I $70 \mathrm{I}$, and in 1703 he swore four oaths for which he 'sate in the stocks." ${ }^{230}$ The representatives of the law seem, moreover, to have been powerless to enforce their authority at this time, for the gambling aldermen refused to leave the 'Bear' at the constables' order, and when the watchman entered the 'Bay Tree' to inquire into the cause of 'a great noise and swearing' which issued from it, the landlady 'took him by the shoulders and turned him out.' 297

At this time, to judge from the Weymouth documents, Dorset towns were typical instances of that English provincial life immortalized by Miss Austen ; some of the extracts from the minute books of the corporation printed by Mr. Moule might well be episodes taken from the pages of Pride and Prejudice. My lady was 'carried' to church by her servants, or driven about the town in her coach. The gentlemen resorted to the post-house to read the news. Letters were brought to the town by the 'diligence Privateer,' who apparently did not hesitate to open and read any that he thought might contain seditious matter; the post-boy journeyed between Weymouth and Dorchester, but unfortunately he was a wayward youth, and when charged by the postmaster with irregularity in his work and not blowing his horn, he assaulted that official in his own house and challenged him to fight. ${ }^{228}$

223 Moule, Descriprive Calalogue, 76, 78, 81 .

"3 See a Ct. R. of Shaftesbury quoted in Hutchins, Hist. of Dorset, iii, 89 , where presentments were made for dice-throwing and playing ad pilam manualem, in the reign of Henry VI.

"T. Tearn, Dorset, Co. Chron. See Roberts, Social Hist. 44.

"ss Ibid.

s' Ibid.

1:6 Moule, Descriptice Catalogue, 86 .

Is Ibid. 86, 88-9. 


\section{SOCIAL AND ECONOMIC HISTORY}

But a great change was not far distant for two at least of the ancient Dorset boroughs. About the middle of the century sea-bathing became one of the popular amusements of the fashionable world, and many of the decayed south-coast ports sprang to life again as watering-places. In September, I 748, R. Prowse and J. Bennet of Weymouth received twenty-one years' leases that they might erect ' two wooden bathing houses on the North side of the Harbour.' In 1783 the popularity of the town as a bathing resort had so far increased that a tax of $2 s .6 d$. a year was placed on every bathing machine. Six years later George III paid the first of a series of visits to Weymouth, where the duke of Gloucester already possessed a house, and in 1790 the duke of St. Albans was allowed to erect a seat on the esplanade opposite his house, and make steps on the sand there. This royal and aristocratic patronage led to rapid developments-new fire engines were bought in 1792 , and in 1800 the contract for building the esplanade wall was signed. ${ }^{229}$ In the meantime Lyme Regis had received a similar impetus to renewed life from the moment when Mr. Thomas Hollis bought the Three Cups inn and a whole row of houses in Bond Street. ${ }^{230}$ His influence brought Lord Chatham as a visitor, and it soon became a favourite resort for visitors from Bath, amongst whom in 1804 was Jane Austen, ${ }^{891}$ whose impressions of the town and its neighbourhood were recorded in Persuasion, written between I 8 I I and I 8 I 6 . In August, I 833 , the duchess of Kent and Princess Victoria were among the visitors. Here the Assembly Rooms were the great source of attraction. Many of the visitors had tea or coffee there every night at a charge of $6 d$., and twice a week they met for card-playing, while on Fridays dancing was indulged in ${ }^{239}$ In 1788 a certain William Morton Pitt attempted to bring Swanage into notice as a seaside resort, ${ }^{233}$ but his efforts were not so successful as were those of the patrons of Lyme and Weymouth, and it is only of late years that it has really extended its accommodation to any great extent and become popular.

But in spite of this periodical influx of fashionable society and the impetus to trade and enterprise to which it gave rise, the county as a whole was slow to alter. In its local government it long preserved a degree of informality which must have made slackness on the part of the magistrates very easy. No chairman of Quarter Sessions seems to have been elected until $1773{ }^{234}$ and though the judicial business of the court was conducted openly in 'County' business, there was no publicity to check expenditure or secure the ratepayers against fraud. ${ }^{935}$ Nor do the justices appear to have been particularly zealous in the performance of their duties. In 1752 the account of the Clerk of the Peace records the expenditure of considerable sums upon dispatching riding messengers through the county to try to persuade even two magistrates to hold a court of Quarter Sessions. ${ }^{230}$ Primitive methods were adhered to until a comparatively late date. The old hundred juries continued to be summoned and to make presentments before the justices certainly as late as $1752,{ }^{237}$ and the only way in which repairs of roads could be effected was by the presentment of the defaulting parish or parishes by a magistrate,

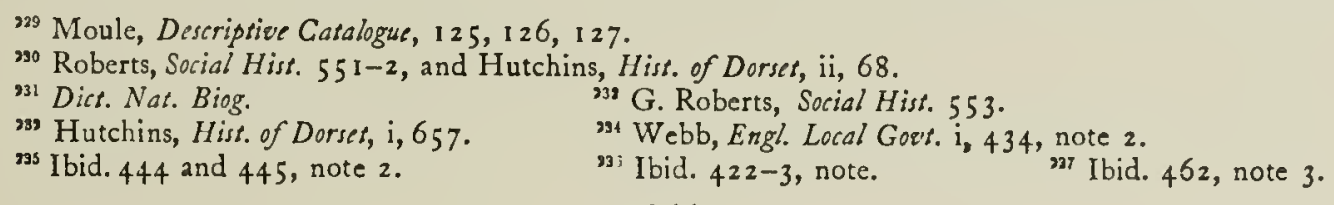




\section{A HISTORY OF DORSET}

who was thereupon empowered to see that the repairs were carried out. Upon one occasion in 1752 a single Dorset justice presented eight parishes on this account. ${ }^{238}$

The early years of the nineteenth century, however, saw considerable alterations. In 1825 it was decided that Quarter Sessions should in future always be held at Dorchester, instead of being continually transferred from borough to borough, ${ }^{238}$ and two years later the justices agreed to prepare and publish an annual account of their receipts and expenditure. Yet earlier, in 1809 , a regular engineer of the county bridges was appointed at a salary of f5,500 a year. ${ }^{240}$

In its agricultural methods also the county was slow to move. What is known as the agrarian revolution, in other words the adoption of the Norfolk four-course system, did not take place rapidly in Dorset. In I 793 Claridge lamented the backward state of the tillage compared with other branches of agriculture. This seems to have been due in a great measure to the immense importance attached to sheep-farming, which was advanced for that time, Dorset being rather a pioneer county in adopting improvements or even in experimentalizing in that one department of agriculture. ${ }^{841}$ Second only in importance to sheep-farming was the attention. bestowed on cattle-grazing and dairying which was centred in the rich vale of Blackmoor in the north.

Very subordinate to sheep-farming, cattle pasturage, and dairying was the tillage of the land. In Claridge's day, wheat, barley, and oats were cultivated in succession without the intervention of any green crop. ${ }^{2+2}$ In addition to this crude rotation the ground suffered from insufficient ploughing : it appeared to be the farmer's object 'to put the seed in with as few ploughings as possible,' ${ }^{243}$ and those few so carelessly done that the ploughman often varied three or four yards from a straight line. The Norfolk plough, drawn by two horses, had by no means come into general use; the oldfashioned plough drawn by four horses, and with two men to attend to them, being more usual. ${ }^{24}$ Comparatively little was done to improve the ground in the way of manure; and although draining was most successfully practised with the water meadows, it was never applied to land under tillage. ${ }^{845} \mathrm{~A}$ considerable amount of flax and hemp was grown in the neighbourhood of Bridport, ${ }^{246}$ where in good seasons it formed a very lucrative crop.

Claridge mentions that few parishes had recently been inclosed; ${ }^{\mathbf{4 7}}$ but with the nineteenth century inclosures became more numerous, though until I 840 they were always inclosures of common land. ${ }^{248}$

As the nineteenth century advanced, however, several improvements were introduced and became almost universal throughout the county $;^{248}$ it was about the middle of the century that most of the changes took place which brought Dorset to the epoch of its greatest agricultural prosperitythe adoption of artificial manures, the inclosure of what had hitherto been regarded as waste land, and the use of improved agricultural implenients. ${ }^{250}$

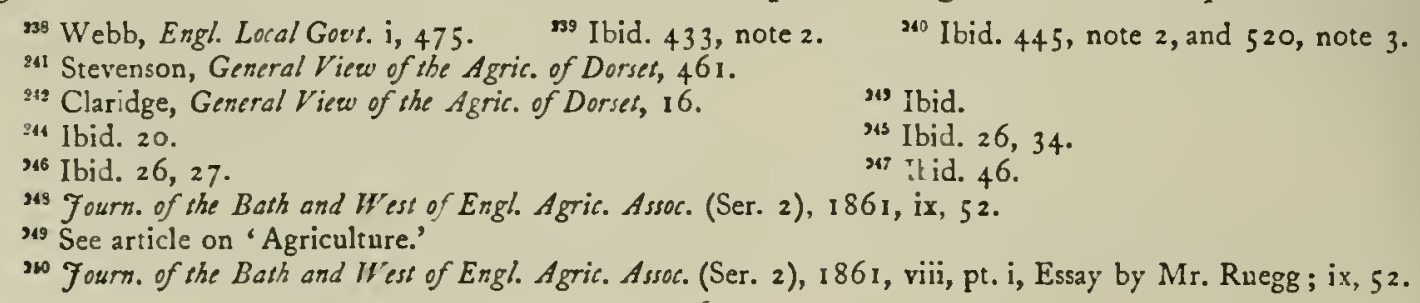




\section{SOCIAL AND ECONOMIC HISTORY}

But this prosperity was short-lived; agricultural distress, though not so marked in Dorset as in other counties, yet made itself felt in several directions. The year 1879 was a bad season for everything, and from that time may be dated the depression which has settled over modern agriculture, especially in the north and extreme west of the county. ${ }^{251}$ Gradually, but surely, farming has become unprofitable: of course bad seasons accentuate agricultural depression, but it was inevitable with the immense fall in prices. From the last half of the nineteenth century, in other words since the establishment of free trade, the price of corn has fallen. Speaking of the agricultural depression Mr. Rew said in 1895 :-

In addition to the fall in the prices of corn, there has been also a fall to some, though not to so great an, extent in the price of stock and a serious and permanent fall in the price of wool. As regards stock it must be remembered that it is always subject to fluctuation from year to year: still there is in later years a distinct fall in the level of prices. As regards wool, many farmers told me that they could not get more than tenpence a pound, whereas twenty years ago they could count upon is. $6 d$. the pound. ${ }^{252}$

One witness pointed out that this makes a difference of from $3^{s}$. to 4 s. per head per annum on each sheep. He was told that cows let at from $f_{2} 2$ to f.3 less than before, ${ }^{253}$ clearly showing that they were not so profitable as formerly. In West Dorset flax, which had been a considerable form of wealth, had become unprofitable, as it was worth $f_{0} 5$ the acre less than in 1884 , doubtless owing to foreign competition. ${ }^{.54}$ On the other hand the general fall in prices has brought some compensation, such as cheaper agricultural implements, artificial manures, and feeding stuffs, which must be remembered when considering the low price of the produce.

The effects of this depression have been, as regards the landowner, a fall in rents, ${ }^{255}$ which on the whole has been greater in mid and east Dorset, that is on the poorer soils. ${ }^{256}$ The average fall in rents on dairy farms has probably been from $\mathrm{I} 0$ per cent. to 20 per cent., though on the best dairy farms there may have been little or no reduction of rent; whilst on mixed farms the fall has been from 20 per cent. to 30 per cent., and on thin poor soils as much as 40 per cent. or 50 per cent. As regards the farmers who rent the land, it is in most cases quite an unprofitable occupation, especially for the occupiers of poor farms where corn-growing is the main pursuit. ${ }^{257}$ The receipts from stock-farming and dairying are considerably higher than those from corn-growing; and it is the fact that farmers do not rely on one or even on two branches of agriculture that has prevented the losses in Dorset being heavier than they have been in some counties. In Dorset farmers do not so much become bankrupt all at once, as lose gradually, a slow but sure process. $^{258}$ Naturally there is a shrinkage of the alreadyexisting farmers' capital, and bankers have become cautious about advancing money upon land. Under these circumstances it is not surprising that

251 Parl. Accounts and Papers, I $882, \mathrm{xv}, 25$.

${ }^{252}$ Ibid. 1895, xvii ; 'Rep. on Agric. Depression,' I I, I 2.

${ }^{2 i 3}$ Ibid.

${ }^{254}$ Ibid. 5 :-

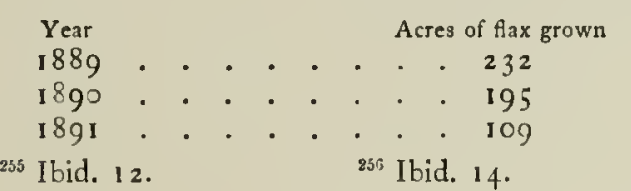

2

Table Showing Decrease in Flax-growing

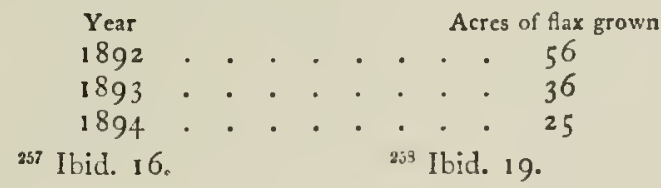




\section{A HISTORY OF DORSET}

larger farms are often vacated for smaller ones, or that tenants take to farming with insufficient capital. Also situation and convenience, with a view to more rapid profits, is the first consideration with tenants, so that farms in outlying districts are left vacant for those nearer the towns. Hence there have been considerable changes of tenancy, though not so many as in other counties, and, at any rate, land has not completely lost its market value. 259

The diminished value of land has naturally made the question of rates very prominent: the burden on land being now proportionately more heavy. In I $895 \mathrm{Mr}$. Wood Homer, the moving spirit of the "County Ratepayers' Defence Association,' calculated that the burdens on land amounted to Ios. the acre. ${ }^{260}$ There was much interesting discussion at the time, even such a far-fetched and doubtful remedy as bimetallism being considered.

But while the landowner and farmer have suffered severely from the agricultural depression the condition of the labourer has been one of real, though at first scarcely perceptible, progress throughout the nineteenth century. As early as I 8 I 2, what impressed Stevenson most was the rise in the standard of comfort of the agricultural labourer. This had been effected by the introduction of potatoes; each labourer grew his own potatoes, and that enabled him to keep a pig, so that he had the important additions of potatoes, pork, and bacon to his former diet of bread and cheese and water. The potatoes were grown upon the farmer's fallows in the upland farms, a portion being allotted in proportion to the family; but in the purely agricultural villages each labourer had his own potato ground, as regular an 'allowance' as his cottage and garden. ${ }^{261}$ The average wage, it is true, was still $6 s$. a week, ${ }^{262}$ and labourers were allowed corn at a fixed low price, but this meant more than in Claridge's day, as prices were constantly advancing. ${ }^{263}$ On the other hand cottages were of the poorest description, with mud walls composed of road scrapings, ${ }^{26 s}$ and as long as lifehold tenures were common there was not much chance of improvement. But towards the middle of the century several important changes affected the condition of the agricultural labourer. In I 834 the system of supplementing the wages of able-bodied labourers out of the rates was finally abolished. This system had commenced in Dorset about 1798 when wheat had risen to an immense price and wages had not risen in proportion. ${ }^{265}$ Payment according to a scale was adopted and relief made to depend upon the price of the loaf and the number of the family. The scale varied in different districts: in Blandford relief was given where there was more than one child, in Dorchester and Shaftesbury it was only allowed in families of three, or more, children. ${ }^{206}$ As the system of supplementing wages out of rates took root in Dorset there was a corresponding increase not only in poor-rate expenditure, but with the general demoralization an increase in pauperism and in crime. Thus, between

\footnotetext{
2:9 Parl. Accounts and Papers, 1882, xv, Mr. Little on Dorset, 27.

260 Ibid. 1895 , xvii, 28.

${ }^{261}$ Stevenson, General View of the Agric. of Dorset, 454

"6 Ibid. 453; Clarijge, 21.

${ }^{263}$ Stevenson, +52-3.

${ }^{24}$ Ibid. 85.

9is Parl. Accounts and Papers, 1834 , xxviii, App. A (i), $13 a$.

श6 Ibid. 1825 , xix, 375 .
} 


\section{SOCIAL AND ECONOMIC HISTORY}

1792 and $183 \mathrm{I}$, poor law expenditure had increased 2 I 4 per cent., expenses for prosecutions of crime 2, I35 per cent., whilst the population had only increased 40 per cent. ${ }^{267}$ Of course the increase in crime might partially be attributed to the depreciation of property, the distressed state of agriculture, and the injudicious repeal of several penal statutes relating to beer-houses, but mainly it was contemporaneous with the adoption of the 'Speenhamland Act.' The increase in pauperism was remarkable: in one parish, for instance, where families above two children were supported, the number of paupers, which had been not more than sixty in 1767 , had increased to 320 in $1824 .{ }^{268}$ Expenditure on able-bodied labourers soon far exceeded that on the aged and infirm poor. At Haselbury Bryan, one of the worst parishes, the monthly payment in I 822 when the system began was $f_{0} 8$ is. to the aged and $f_{7} 76 \mathrm{~s}$. $8 d$. to the labourers, but the next monthly payment to the able-bodied amounted to fi 3 ros. $7 d^{269}$ Farmers in this village would not employ the best labour, but preferred the inferior hands at low wages, which were supplemented by the rates. It was, therefore, scarcely surprising that there were riots in Haselbury Bryan in 1830 , though the chief result appears to have been an order given to the overseers to relieve ten more able-bodied families. ${ }^{270}$

On the other hand, More Crichel escaped from the trammels of this system : none but old and infirm people were on the parish books. ${ }^{271}$ Many labourers possessed cottages and lived in comparative comfort, and all could find at least a livelihood by road work. In 1834 the parish was upheld as a proof of what good management could do, the climax of excellence being the fact of only one appeal to the magistrates in five years.

In other districts, too, there was improvement before I 834 . In Beaminster, where wages were higher than in any other part of Dorset, ${ }^{272}$ inquiries were made as to the character of the applicants for relief. This was also the case in Cranborne; no allowance was made for children, and finally, after the death of the vicar, apparently an incubus on improvement, the scale system was abolished. ${ }^{273}$ But as long as the rate in aid of wages was allowed no improvement could be regarded as permanent; the position of the agricultural labourer was practically that of a pauper.

The year 1834 was marked by another event of which Dorset was the centre, but whose importance in the history of labour became rather national than local. This was the trial and transportation of six Dorset labourers in connexion with an oath administered to members of an agricultural union. Similar unions in Hampshire had succeeded in raising the rate of wages not only in that county, but also in the neighbouring districts. At Tolpuddle, in Dorset, an agreement was made between the farmers and the men that the wages should be those paid in other districts-namely, ros. a week. Subsequently, however, a reduction to $7 s$. was effected by the employers, in consequence of which the men made inquiries about the Grand National Consolidated Trades Union, and formed a society of their own upon similar lines. ${ }^{274}$ The farmers were alarmed, and in February, 1834 , placards were issued threatening anyone who joined the union with seven years' transporta-

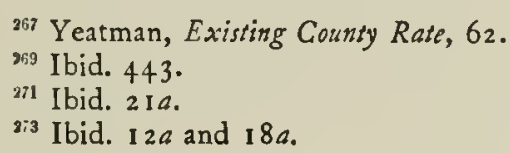

${ }^{268}$ Porl. Accounts and Popers, I 824, vi, 432.
${ }^{370}$ Ibid. 1834 , xxviii, App. A. (i), p. $20 a$.
${ }^{272}$ Ibid. 11 and $12 a$.
${ }^{271}$ Webb, Hist. of Trade Unionism, I $28-30$. 


\title{
A HISTORY OF DORSET
}

tion, and within three days James and George Lovelace and four others who had originated the movement were sent to gaol. Their trial began on I 5 March, 1834, at the Spring Assizes. They were charged with violating the Act of 37 George III (cap. I 23) against seditious meetings and the administration of unlawful oaths binding to secrecy. The judge in his charge dwelt at length on the enormity of trifling with oaths, and the cruelty of forcing men out of their scanty earnings to make

such a large and ample contribution as would not be endured by any class of men to the constituted authorities of the country or the maintenance of the government itself,

and declared that 'where men were included in societies of this kind the common-right obligation of every man of labouring as he pleased and for whom he pleased was taken away. ${ }^{275}$

At the trial the witnesses deposed to having been persuaded to join the society, at an entrance fee of I $s$. and a contribution of $I d$. a week; they gave a confused account of the mystery of initiation, during which they had been blindfolded, and had listened to a considerable amount of reading which they had not understood, and had finally taken an oath which they could not remember, on a book which 'looked like a Bible.' The rules of the society, which simply had for its object the maintenance of a fair rate of wages, and which strictly forbade all violence, and all political or religious discussion at its meetings, were read aloud. No charge of coercion or intimidation was brought against the leaders, but the jury found them guilty of

\begin{abstract}
administering and causing to be administered and aiding and assisting and being present and consenting to administer a certain unlawful oath and engagement purporting to bind the person taking the same not to inform or give evidence against any associate or other person charged with any unlawful combination and not to reveal or discover any such unlawful combination or any illegal act done or to be done and not to discover any illegal oath which might be taken.' 276
\end{abstract}

They were accordingly sentenced to seven years' transportation, and on 2 I March the Times wrote:-

This sentence, as regards the poor ignorant deluded men who are the objects of it, seems to us too severe; but it may be useful if it spreads alarm among those more acute and powerful disturbers of the town populations throughout England.

The first part of this sentiment was evidently shared by many throughout the country, and representations from various quarters were made to the government of the day, while a leading article appeared in the Times for I April again urging mercy. Lord Melbourne received a deputation of trade unionists favourably on 29 March, promising that no further steps should be taken until the king's pleasure was known; ${ }^{277}$ but the agitation had no practical outcome, and on 15 April Lord Howick announced in the House of Commons that the ship bearing the convicts had sailed for Botany Bay. ${ }^{278}$

The question now became a national issue; a great demonstration and procession was arranged to assemble in Copenhagen Fields on Monday, $2 \mathrm{I}$

275 Times, 18 March, 1834 .
977 lbid. I April, 1834 .
${ }^{276}$ Ibid. 20 March, 1834.

2is Webb, Hist. of Trade Unionism, $13 \mathrm{I}$. 


\section{SOCIAL AND ECONOMIC HISTORY}

April ; it was to march through London and to present a petition on behalf of the sufferers to the Home Secretary. It was the first such demonstration which had ever taken place in the metropolis. ${ }^{279}$ The Times reflects the panic and indignation which was felt by the supporters of the government. The aim of the processionists, it proclaimed, could only be to intimidate-else why such vast numbers? - consequently their action was little short of treason, and all self-respecting citizens were advised to be not so much as spectators of the demonstration. 'Home is the fitting post of every man whose active services are not called for by public duty. ${ }_{280}$ " The reception of their proposal in this spirit seems to have induced the trade unionists to entrust the actual presentation of the petition to a small delegation, but the Times considered that the march through London still savoured of coercion, and was convinced that the petition would 'at once be rejected as an attempt at doing violence to the crown. ${ }^{281}$

This expectation was fully justified by the events; in spite of the orderly conduct of the demonstrators-some 30,000 in number-and the respectful, though firm, wording of the petition, Lord Melbourne refused to receive any 'petition presented under such circumstances and in such a manner,' though if it should be 'presented on another day and in a becoming manner' he would receive it and lay it before the king. ${ }^{282}$

In the meantime the question had been taken up in the House of Commons, numerous petitions were presented, and Joseph Hume charged the government with cowardice, and anxiety to ' get hold of such victims as they could catch. ${ }^{283}$ In spite of the agitation, however, the punishment was not remitted until 1836 , and the prisoners did not finally return home until 1838 . Their ultimate release was due to the indefatigable zeal of the London Dorchester Committee, a body of sixteen workmen, who with the help of Thomas Wakley, M.P. for Finsbury, after nearly five years' agitation induced the same government as had sanctioned the exile to pardon the men and bring them home free of expense. Subscriptions were raised to provide five out of the six with small farms in Essex, the sixth preferring to return to Dorset. ${ }^{284}$

But although some thirty years later such a national disgrace as this would have been impossible, the general position of the Dorset labourer was still slow to improve. In $186 \mathrm{I}$, indeed, Mr. Darby commented on the benefit to the labourer from the agricultural revolution which had just taken place. Money wages were $2 s$. or 35 . higher than they were twenty years before-that is, they varied from $8 s$. to I I $s,{ }^{285}$ so that with the additional earnings amounting at least theoretically to about 3 s. $6 d$. a week, 'the labourer did not receive worse treatment than in any of the southern or midland counties.' But, of course, his position depended on his employer : his cottage might be a hovel, his garden and potato ground of the poorest soil, his fuel the commonest gorse, his corn almost worthless. As long as there is payment in kind the labourer will be dependent on the generosity of the farmer who employs him.

\footnotetext{
${ }^{378}$ Webb, Hist. of Trade Unionism, 132.

2 Ibid. 2 I April, 1834 .

${ }_{22}$ Ibid. 22 April, 1834.

290 Times, 19 April, 1834 .

283 Ibid. I 9 April and 29 April, 1834.

${ }^{284}$ Webb, Hist. of Trade Unionism, 133, note 2 ; p. 130 et seq. gives a full account of the case and its bearing on the general history of the unions.

${ }^{255}$ Fourn. of Bath and West of Engl. Agric. Soc. (Ser. 2), ix, 64 .
} 


\section{A HISTORY OF DORSET}

In 1868 , when Dorset was at the height of agricultural prosperity, the condition of the labourer was by no means proportionately improved. Cottages, with some notable exceptions, were often a disgrace to their owners, especially in the villages of Bere Regis, Fordington, Winfrith, Cranborne, and Charminster. If there was a second bedroom at all it was rather a 'closet not closed' off from the first, and in Charminster there was an average of seven persons to one house. ${ }^{287} \mathrm{Mr}$. Stanhope also brought to light other evils, doubtless of long duration. The habit existed in Dorset of hiring whole families: not only was the labourer expected to work, but his wife, or at least the daughters, were drawn in to field work, and the boys were taken away too early from school, and then kept on after they were grown up for the same purpose. ${ }^{988}$ Thus female labour was encouraged and the education and future prospects of the men neglected. Though wages had been raised by the agricultural revolution they were only paid once a fortnight, or even once a month, and it was only the married men who received additional perquisites. ${ }^{999}$

In some districts there was little or no market for labour. If the labourer was better off in the island of Purbeck, where the clay and stone quarries raised the general level of wages, in the Vale of Blackmoor, where the small farms were managed by the families themselves, additional labour was not wanted, unless it was of a very casual and unsatisfactory description. Where labour was hired it was at a low wage, and dairy farming gave little scope for piece-work, which might have raised the total earnings. ${ }^{290}$ After this gloomy view of the agricultural labourer, Mr. Little, who visited Dorset fourteen years afterwards, pronounced the position 'much improved.' ' On many estates labourers were well housed, much money having recently been expended on large properties in building improvements.' Wages, though they were still 'far below the standard of the south-eastern and northern counties,' in other words the mining and manufacturing districts, had 'increased ten per cent. to thirty per cent. during the last ten years. ${ }^{291}$ This was remarkable, as the agricultural depression was already felt ; and the fact still remains that the labourer has not suffered in the same way as the landowner and farmer have done. Of course the depression has meant a decreased demand for labour, as the farmer has had to economize. Land has again been inclosed for pastures, farms consolidated, and machinery more and more used in order to dispense with labour. But this decrease in demand has been counterbalanced by a decrease in the supply of labour, owing to the attractions of at least nominally higher wages in the towns, or in the mining districts. ${ }^{298}$ Probably those men who desire it can find work as agricultural labourers, and, in spite of the depression and low prices, wages have not fallen. In 1893 Mr. Spencer calculated that the average earnings of a field labourer amounted

956 The state of the cottages was so notoriously bad that public attention was attracted, and a meeting held at Blandford in $\mathbf{1} 8+3$ to consider the matter. The actual example was set by Mr. Sturt, who rebuilt a whole village on his model system. Two cottages, with three bedrooms in each, were placed side by side in the middle of an acre of land which they divided between them; half an acre being usually accepted as the maximum amount of land that a labourer can cultivate without neglecting his employer's work. Journ. of the Bath and W'est of Engl. Agric. Soc. (Ser. 2, 1 S60), viii, 221.

${ }^{287}$ Parl. Accounts and Papers, 1868-9, xiii, 80. Second report by Mr. Stanhope.

${ }^{9}$ Ibid. 78.

390 Ibid. $77,78$.

${ }^{91}$ Ibid. 1882, xv, 28 . Mr. Little on Dorset.

mo Ibid. 1893 , xxxv, 6, 7. 'The Condition of the Labourer in Dorset.' Mr. Aubrey Spencer. 


\section{SOCIAL AND ECONOMIC HISTORY}

to $14 s .6 d$. per week, and those of a carter or shepherd, who work longer hours, to $\mathrm{I} 5 \mathrm{~s}$. $6 \mathrm{~d}$. or $\mathrm{I} 6 \mathrm{~s}^{293}$ Average earnings have more recently risen to $15 \mathrm{~s} .6 \mathrm{~d}$. and those of carters and stockmen proportionately. ${ }^{294}$ Wages in the country, instead of following prices, have been upheld by the increased standard of comfort, and by competition with the towns owing to the modern fluidity of labour. Of course the Dorset agricultural labourer does not receive all his earnings in cash; sometimes he only gets $\mathrm{I} O \mathrm{~s}$. in money, though the average is certainly I $2 s$. a week. ${ }^{295}$ Dorset is one of the counties where money wages are lowest, and 'allowances' greatest, and of recent years piece-work has become very important on the large farms. ${ }^{298}$ This system of 'allowances' certainly is not economically sound, but it has always existed, and probably its evils are at a minimum in a county where the land is owned by large proprietors. It has always been the big landowners of Dorset who have set example in improved cottages, though the movement has never been general, and Mr. Spencer considered that there had been little improvement since the days of Mr. Stanhope. ${ }^{297}$ More recently the attention of sanitary authorities has been directed to the subject of over-crowding, bad drainage, and 'the smoke nuisance'; and any defects are freely commented upon. ${ }^{298}$

Other improvements of a social nature have also raised the condition of the Dorset labourer. Drink-money is now generally given instead of the beer or cider itself, ${ }^{299}$ so that if the Dorset peasant 'is terribly addicted to beer ${ }^{\prime}{ }^{300}$ he is at least not encouraged by his employer.

Women, even twelve years ago, very seldom worked in the fields, ${ }^{301}$ because the earnings of the labourer no longer rendered it necessary; nowadays it would be regarded as an anomaly. The hiring-fair tends to become a picturesque survival; it is fast dying out ${ }^{302}$ as the modern, more educated labourer can find work through advertisements, instead of being dependent on the chances of one day. But except in the northern and western parts of the county it has left its mark in yearly engagements, which may be more likely to lead to continuous service than in the days of annual hiring-fairs, when it became almost a custom for labourers to change their employers. ${ }^{309}$ The advantage of good clubs, either local or branches of national ones, is becoming more and more recognized, ${ }^{304}$ and membership is not so uncommon as it used to be ; but, unfortunately, it is still a point in which theory is in advance of practice.

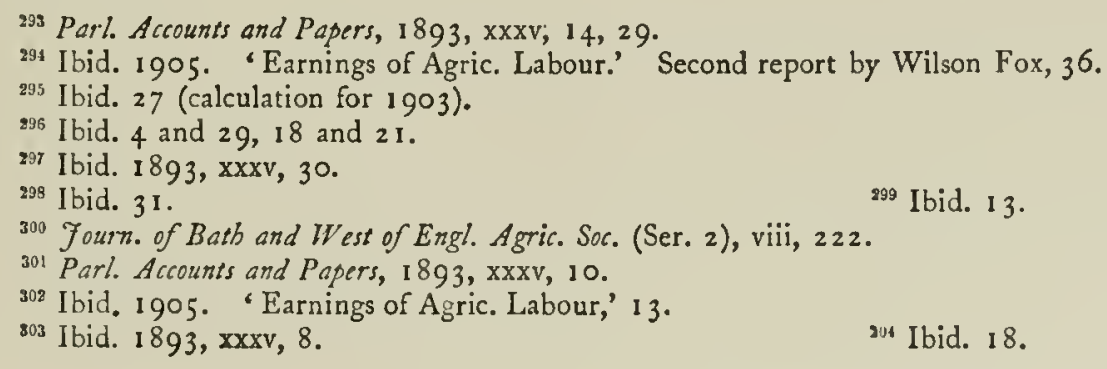




\title{
A HISTORY OF DORSET
}

TABLE OF POPULATION, 1801 TO I901

\author{
Introductory Notes
}

Area

The county taken in this table is that existing'subsequently to 7 \& 8 Vict., chap. 6I (I844). By this Act detached parts of counties, which had already for parliamentary purposes been amalgamated with the county by which they were surrounded or with which the detached part had the longest common boundary ( $2 \& 3 \mathrm{Wm}$. IV, chap. 64-1832), were annexed to the same county for all purposes; some exceptions were, however, permitted.

By the same Act ( $7 \& 8$ Vict., chap. 6r) the detached parts of counties, transferred to other counties, were also annexed to the hundred, ward, wapentake, \&c. by which they were wholly or mostly surrounded, or to which they next adjoin, in the counties to which they were transferred. The hundreds, \&c. in this table are also given as existing subsequently to this Act.

As is well known, the famous statute of Queen Elizabeth for the relief of the poor took the thenexisting ecclesiastical parish as the unit for Poor Law relief. This continued for some centuries with but few modifications; notably by an Act passed in the thirteenth year of Charles II's reign which permitted townships and villages to maintain their own poor. This permission was necessary owing to the large size of some of the parishes, especially in the north of England.

In 1801 the parish for rating purposes (now known as the civil parish, i.e. 'an area for which a separate poor rate is or can be made, or for which a separate overseer is or can be appointed') was in most cases co-extensive with the ecclesiastical parish of the same name; but already there were numerous townships and villages rated separately for the relief of the poor, and also there were many places scattered up and down the country, known as extra-parochial places, which paid no rates at all. Further, many parishes had detached parts entirely surrounded by another parish or parishes.

Parliament first turned its attention to extra-parochial places, and by an Act (20 Vict., chap. 19-1857) it was laid down (a) that all extra-parochial places entered separately in the I 85 I census returns are to be deemed civil parishes, $(b)$ that in any other place being, or being reputed to be, extra-parochial, overseers of the poor may be appointed, and $(c)$ that where, however, owners and occupiers of two-thirds in value of the land of any such place desire its annexation to an adjoining civil parish, it may be so added with the consent of the said parish. This Act was not found entirely to fulfil its object, so by a further Act (31 \& 32 Vict., chap. 122I 868) it was enacted that every such place remaining on 25 December, I868, should be added to the parish with which it had the longest common boundary.

The next thing to be dealt with was the question of detached parts of civil parishes, which was done by the Divided Parishes Acts of 1876,1879 , and 1882 . The last, which amended the one of 1876 , provides that every detached part of an entirely extra-metropolitan parish which is entirely surrounded by another parish becomes transferred to this latter for civil purposes, or if the population exceeds 300 persons it may be made a separate parish. These Acts also gave power to add detached parts surrounded by more than one parish to one or more of the surrounding parishes, and also to amalgamate entire parishes with one or more parishes. Under the I 879 Act it was not necessary for the area dealt with to be entirely detached. These Acts also declared that every part added to a parish in another county becomes part of that county.

Then came the Local Government Act, I 888, which permits the alteration of civil parish boundaries and the amalgamation of civil parishes by Local Government Board orders. It also created the administrative counties. The Local Government Act of 1894 enacts that where a civil parish is partly in a rural district and partly in an urban district each part shall become a separate civil parish ; and also that where a civil parish is situated in more than one urban district each part shall become a separate civil parish, unless the county council otherwise direct. Mean while, the ecclesiastical parishes had been altered and new ones created under entirely different Acts, which cannot be entered into here, as the table treats of the ancient parishes in their civil aspect.

\section{Population}

The first census of England was taken in 1801, and was very little more than a counting of the population in each parish (or place), excluding all persons, such as soldiers, sailors, \&c., who formed no part of its ordinary population. It was the de facto population (i.e. the population 


\section{SOCIAL AND ECONOMIC HISTORY}

actually resident at a particular time) and not the de jure (i.e. the population really belonging to any particular place at a particular time). This principle has been sustained throughout the censuses.

The Army at home (including militia), the men of the Royal Navy ashore, and the registered seamen ashore were not included in the population of the places where they happened to be, at the time of the census, until 1841 . The men of the Royal Navy and other persons on board vessels (naval or mercantile) in home ports were first included in the population of those places in $185 \mathrm{r}$. Others temporarily present, such as gipsies, persons in barges, \&c. were included in 1841 and perhaps earlier.

\section{General}

Up to and including 1831 the returns were mainly made by the overseers of the poor, and more than one day was allowed for the enumeration, but the $184 \mathrm{I}-\mathrm{Ig}$ I I returns were made under the superintendence of the registration officers and the enumeration was to be completed in one day. The Householder's Schedule was first used in $184 \mathrm{I}$. The exact dates of the censuses are as follows:-

\begin{tabular}{|c|c|c|}
\hline $\begin{array}{l}\text { Io March, I } 80 \text { I } \\
27 \text { May, I } 8 \text { I I } \\
28 \text { May, I } 82 \text { I }\end{array}$ & $\begin{array}{l}30 \text { May, } 1831 \\
7 \text { June, I } 841 \\
\text { 31 March, I } 85 \text { I }\end{array}$ & $\begin{array}{l}8 \text { April, I } 86 \text { I } \\
3 \text { April, I } 87 \text { I } \\
4 \text { April, I } 881\end{array}$ \\
\hline
\end{tabular}

\section{Notes Explanatory of the Table}

This table gives the population of the ancient county and arranges the parishes, \&rc. under the hundred or other sub-division to which they belong, but there is no doubt that the constitution of hundreds, \&c. was in some cases doubtful.

In the main the table follows the arrangement in the $\mathrm{I} 84 \mathrm{I}$ census volume.

The table gives the population and area of each parish, \&c. as it existed in I80I, as far as possible.

The areas are those supplied by the Ordnance Survey Department, except in the case of those marked ' $e$,' which are only estimates. The area includes inland water (if any), but not tidal water or foreshore.

t after the name of a civil parish indicates that the parish was affected by the operation of the Divided Parishes Acts, but the Registrar-General failed to obtain particulars of every such change. The changes which escaped notification were, however, probably small in area and with little, if any, population. Considerable difficulty was experienced both in $189 \mathrm{r}$ and I 90 I in tracing the results of changes effected in civil parishes under the provisions of these Acts; by the Registrar-General's courtesy, however, reference has been permitted to certain records of formerly detached parts of parishes, which has made it possible approximately to ascertain the population in I $90 \mathrm{I}$ of parishes as constituted prior to such alterations, though the figures in many instances must be regarded as partly estimates.

* after the name of a parish (or place) indicates that such parish (or place) contains a union workhouse which was in use in (or before) 1851 and was still in use in $190 \mathrm{r}$.

$\ddagger$ after the name of a parish (or place) indicates that the ecclesiastical parish of the same name at the 1901 census is coextensive with such parish (or place).

$O$ in the table indicates that there is no population on the area in question.

- in the table indicates that no population can be ascertained.

The word 'chapelry' seems often to have been used as an equivalent for 'township' in I $84 \mathrm{I}$, which census volume has been adopted as the standard for names and descriptions of areas.

The figures in italics in the table relate to the area and population of such sub-divisions of ancient parishes as chapelries, townships, and hamlets. 


\section{A HISTORY OF DORSET}

\section{TABLE OF POPULATION}

\begin{tabular}{|c|c|c|c|c|c|c|c|c|c|c|c|c|}
\hline - & $\begin{array}{c}\text { Acre- } \\
\text { age }\end{array}$ & I8OI & 1811 & I 821 & $18_{3 I}$ & $184 \mathrm{I}$ & $1 S_{51}$ & I 861 & 1871 & I88I & $189 I$ & 1901 \\
\hline $\begin{array}{l}\text { acient or Geographica } \\
\text { County }\end{array}$ & 632,270 & II 4.452 & 124.718 & 144.494 & 159.385 & 175.274 & 184.380 & 189,015 & 195.774 & $191,02 S$ & 194,568 & 8202,984 \\
\hline
\end{tabular}

\begin{tabular}{|c|c|c|c|c|c|c|c|c|c|c|c|c|}
\hline PARISB & $\begin{array}{c}\text { Acre- } \\
\text { age }\end{array}$ & 1801 & I8II & 1821 & $183 \mathrm{I}$ & $18_{4} I$ & 1851 & 1861 & I87I & IS8I & I39I & 1901 \\
\hline \multicolumn{13}{|l|}{$\begin{array}{c}\text { Blandford, North } \\
\text { Division }\end{array}$} \\
\hline $\begin{array}{l}\text { Anderson, or } \\
\text { Winterborne } \\
\text { Anderson }\end{array}$ & 597 & 97 & 68 & 78 & 54 & 43 & 59 & 62 & 80 & 64 & 66 & 57 \\
\hline $\begin{array}{l}\text { Blandford St. } \\
\text { Mary } \dagger \ddagger\end{array}$ & $I, 5^{8} 3^{\circ}$ & 292 & 326 & 358 & 363 & 407 & 367 & 409 & 447 & $36 q$ & 359 & $33 !$ \\
\hline Bloxworth. \pm & 2,827 & 182 & 168 & 210 & $25 !$ & 306 & 283 & 264 & 270 & 261 & 260 & 215 \\
\hline Bryanston $t$. . & $1,512^{\circ}$ & 99 & 98 & 79 & 155 & 144 & 167 & 206 & 232 & 259 & 242 & 300 \\
\hline Dewlish $\ddagger$. & 2,134 & 348 & $36 !$ & 386 & $36 I$ & 389 & $4+2$ & $45^{8}$ & 494 & 457 & 396 & 312 \\
\hline Durweston & $1,85^{\circ}$ & 332 & 376 & 454 & 418 & 468 & 406 & 364 & 355 & 376 & 472 & 396 \\
\hline Fifebead Nevillet $\ddagger$ & $791^{\circ}$ & 72 & 74 & 95 & IOI & 83 & 95 & 87 & 89 & 120 & 102 & III \\
\hline Hammoon \pm : & 693 & 59 & $5^{8}$ & 71 & 54 & 57 & 73 & 74 & 89 & 76 & $8_{3}$ & 69 \\
\hline Haselbury Bryan $f$ & 2,415 & 454 & 494 & 574 & $6 \mathrm{II}$ & 639 & 709 & 761 & $8 ; 2$ & 714 & 648 & $5+1$ \\
\hline $\begin{array}{l}\text { Langton Long } \\
\text { Blandford } \ddagger\end{array}$ & 1,811 & 72 & 108 & 160 & I 87 & 202 & 183 & 174 & 208 & 278 & 242 & 295 \\
\hline Pimperne $t+$ & $4,510^{\circ}$ & $3: 6$ & 325 & 426 & 489 & 545 & 517 & 495 & 420 & 399 & $39:$ & 375 \\
\hline $\begin{array}{l}\text { Steepleton } \\
\text { Iwerne } \dagger \downarrow\end{array}$ & $773^{\circ}$ & 18 & 23 & 23 & 36 & 34 & 44 & 59 & 39 & 73 & 61 & 49 \\
\hline Stourpaine $\ddagger$ & 2,375 & 380 & $4 ! 2$ & 499 & 594 & 637 & $62 I$ & 658 & 584 & 563 & 490 & 493 \\
\hline Tarrant Hinton $\ddagger$ & $2,32 \mathrm{I}$ & 192 & 217 & 278 & 241 & 278 & 319 & $25 \mathrm{~S}$ & $28 \mathrm{i}$ & 237 & 213 & I 55 \\
\hline $\begin{array}{l}\text { Tarrant } \\
\text { Keynston } \dagger \ddagger\end{array}$ & $1,962^{\circ}$ & 165 & 186 & 220 & 277 & 334 & 321 & 309 & $33^{\circ}$ & 272 & 260 & 212 \\
\hline $\begin{array}{l}\text { Tarrant } \\
\text { Launceston }\end{array}$ & 1,659 & 67 & 63 & 88 & 72 & 123 & 123 & 107 & 105 & 86 & $6 I$ & 80 \\
\hline Tarrant Rawston & 697 & 32 & 57 & 58 & 48 & 64 & 66 & 53 & 56 & 48 & 49 & 44 \\
\hline $\begin{array}{l}\text { Winterborne } \\
\text { Clenston } \dagger_{+}^{+}\end{array}$ & $1,406^{\circ}$ & 49 & 60 & 73 & 84 & 96 & 97 & 106 & $9 j$ & 112 & 103 & $9 i$ \\
\hline $\begin{array}{l}\text { Winterborne } \\
\text { Houghton }\end{array}$ & 1,974 & $16 I$ & 181 & 203 & 265 & 304 & 313 & 284 & 289 & 250 & 221 & 193 \\
\hline $\begin{array}{l}\text { Winterborne } \\
\text { Stickland } \dagger+\end{array}$ & $r, 340^{\circ}$ & 306 & 300 & 364 & 401 & 383 & 407 & 444 & 452 & 480 & 406 & 365 \\
\hline $\begin{array}{l}\text { Winterborne } \\
\text { Tomson }{ }^{2} \ddagger\end{array}$ & 477 & - & 32 & 43 & $4 I$ & 48 & 37 & 39 & 33 & 40 & 28 & 23 \\
\hline $\begin{array}{l}\text { Winterborne } \\
\text { Whitchurch } \dagger \ddagger\end{array}$ & $2,841^{\circ}$ & $43^{\circ}$ & 378 & 493 & 513 & 541 & 595 & 554 & 488 & 422 & 422 & 357 \\
\hline $\begin{array}{l}\text { Winterborne } \\
\text { Zelstone } \ddagger\end{array}$ & 848 & 233 & 244 & 245 & 233 & 222 & 224 & 199 & I97 & 145 & I 73 & 122 \\
\hline $\begin{array}{c}\text { Blandford, South } \\
\text { Division }\end{array}$ & & & & & & & & & & & & \\
\hline Affpuddle . . & 3,630 & 344 & $45 !$ & 441 & 442 & 507 & 488 & 455 & 438 & 477 & 434 & $35^{8}$ \\
\hline Arne . . & 2,671 & 96 & IOS & 134 & $17 \mathrm{I}$ & 168 & 138 & 139 & I 23 & 121 & 123 & 183 \\
\hline
\end{tabular}

1 Ancient County. - The County as defined by the Act, $7 \& 8$ Vict., cap. 6r, which affected Dorset to the following extent:-(a) added to Dorset (I) Holwell Parish (Sturminster Division) from Somerset, (2) part of Axminster Ancient Parish and the whole of Thorncombe Parish (Bridport Division), both from Devon, and (3) part of Hampreston Ancient Parish (Easl Shaston Division), from Hampshire, and (b) transferred from Dorset to Devonshire Stockland Ancient Parish.

The area of the County is taken from the I gor Census Volume, and does not include a part of Chardstock Parish, added to Devon under the provisions of the Divided Parishes Acts, though necessarily the population of this area is included.

The population in 1821 is exclusive of 436 militia, who could not be assigned to their respective parishes. (See also notes to Axminster, Hooke, Pulham, Tollard Royal, and Poole St. James )

1a Consisting of the Hundreds of Coombs Ditch, Pimperae, and Rushmore, and the Liberty of Dewlish.

2 The population of Anderson included that of Winberborne Tomson in 1801.

2. Consisting of the Hundreds of Corfe Castle, Bere Regis, Hundredsbarrow, Hasilor, Rowbarrow, and Winfrith, and the Liberties of Bindon and Owermoigne. 


\section{SOCIAL AND ECONOMIC HISTORY}

TABLE OF POPULATION, 1801-1901 (continued)

\begin{tabular}{|c|c|c|c|c|c|c|c|c|c|c|c|c|}
\hline PARISH & $\begin{array}{c}\text { Acre- } \\
\text { age }\end{array}$ & 1801 & 1811 & 1821 & 1831 & $184 \mathrm{I}$ & 1851 & $186 t$ & $187 \mathrm{I}$ & $188 \mathrm{I}$ & 1891 & I901 \\
\hline \multicolumn{13}{|l|}{$\begin{array}{l}\text { Blandford, South } \\
\text { Division (cont.) }\end{array}$} \\
\hline Bere Regis :- & 9,198 & 1,153 & 1,195 & $\begin{array}{r}1,344 \\
953\end{array}$ & $\begin{array}{l}1,483 \\
1,000\end{array}$ & 1,684 & $\begin{array}{l}1,814 \\
1,242\end{array}$ & $\begin{array}{l}1,624 \\
1,189\end{array}$ & 3,676 & 1,542 & 1,416 & 1,236 \\
\hline $\begin{array}{l}\text { Milborne Stile- } \\
\text { ham Hamlet }\end{array}$ & 885 & $\begin{array}{l}936 \\
217\end{array}$ & $\begin{array}{l}953 \\
242\end{array}$ & $\begin{array}{l}953 \\
264\end{array}$ & $\begin{array}{r}7,000 \\
313\end{array}$ & $\begin{array}{r}7,709 \\
290\end{array}$ & $\begin{array}{r}7,242 \\
320\end{array}$ & $\begin{array}{r}7,789 \\
288\end{array}$ & $\begin{array}{r}1,253 \\
310\end{array}$ & $\begin{array}{r}1,284 \\
258\end{array}$ & $\begin{array}{r}1,144 \\
272\end{array}$ & $\begin{array}{r}1,014 \\
222\end{array}$ \\
\hline $\begin{array}{l}\text { Shitterton } \\
\text { Tything }\end{array}$ & 一 & 一 & 一 & 127 & 170 & 225 & 252 & 147 & 113 & - & - & - \\
\hline Chaldon Herring $\ddagger$ & 3,095 & 226 & 247 & 240 & 270 & 285 & 328 & $34 I$ & 332 & 334 & 301 & 271 \\
\hline Church Knowle $\ddagger$ & 2,922 & 330 & 374 & 400 & 438 & 463 & 480 & 511 & 536 & 562 & 581 & 527 \\
\hline Coombe Keynes & 2,011 & 93 & 118 & 128 & 113 & 135 & 154 & 163 & 143 & 129 & I 19 & 120 \\
\hline Corfe Castle . & 8,932 & 1,344 & 1,376 & 1,465 & 1,712 & 1,946 & 1,966 & 1,900 & 1,806 & $\mathbf{I}, 777$ & 1,708 & $I, 440$ \\
\hline Holme, East $\ddagger$ & 1,070 & 30 & 39 & 42 & 55 & 59 & 61 & 50 & 66 & 89 & 90 & 75 \\
\hline Kimmeridge $\ddagger$. & 995 & 115 & 105 & 90 & 124 & I 54 & 178 & 185 & I 53 & 170 & 147 & 126 \\
\hline $\begin{array}{l}\text { Langton } \\
\qquad \text { Matravers } \ddagger\end{array}$ & 2,316 & 510 & 467 & 628 & 676 & 762 & 762 & 733 & 924 & 892 & 773 & 827 \\
\hline Lulworth, East $\ddagger$ & 2,304 & 364 & 383 & 353 & 345 & 392 & $45^{\circ}$ & 453 & 385 & 364 & 358 & 294 \\
\hline Lulworth, West $\dagger \downarrow$ & $2,573^{\circ}$ & 312 & 354 & 365 & 360 & 407 & 401 & 446 & 518 & 339 & 415 & 358 \\
\hline Moreton $\ddagger$ & 2,157 & 256 & 276 & 256 & 304 & 294 & 227 & 283 & $34 \mathrm{I}$ & 309 & 356 & $35^{6}$ \\
\hline Poxwell : . & 834 & 66 & 67 & & & $\{67$ & 69 & 82 & 78 & 86 & 82 & 82 \\
\hline $\begin{array}{l}\text { Watercombe } \\
\text { Extra Par. }\end{array}$ & 435 & & 07 & 13 & 99 & 27 & 20 & 37 & 59 & 54 & 63 & 32 \\
\hline Owermoigne $t \ddagger$. & $3,27 \mathrm{I}^{\circ}$ & 215 & 225 & 377 & 379 & 416 & 400 & 420 & 396 & 356 & 332 & 298 \\
\hline Steeple & 3,368 & 206 & 196 & 233 & 237 & 272 & 270 & 262 & 318 & 295 & 314 & 225 \\
\hline Stoke, East $\nmid \ddagger$ & $3273^{\circ}$ & 318 & 403 & 519 & 561 & 590 & 630 & 594 & 613 & 582 & 581 & 495 \\
\hline Studland . & 4,633 & 332 & 306 & 382 & 435 & 453 & 445 & 595 & 574 & 607 & 432 & 427 \\
\hline Swanage \pm . & 3,097 & 1,382 & 1,483 & 1,607 & 1,734 & 1,990 & 2,139 & 2,004 & $2,15 I$ & 2,357 & 2,674 & 3,455 \\
\hline Turners Puddle & I, 998 & 82 & I 34 & 98 & 82 & 122 & 109 & 111 & 128 & 119 & 87 & 78 \\
\hline Tyneham . & 2,981 & 187 & 200 & 240 & 247 & 250 & 276 & 272 & 269 & 275 & 260 & $23^{8}$ \\
\hline Warmwell † & $1,531^{\circ}$ & 105 & 86 & 82 & 87 & 94 & 149 & 148 & 205 & 173 & 178 & I 33 \\
\hline $\begin{array}{l}\text { Winfrith New- } \\
\text { burgh } \ddagger\end{array}$ & 5,015 & 569 & 602 & 764 & 891 & 963 & $\mathrm{I}, \mathrm{IOI}$ & 1,020 & 980 & 959 & 869 & 820 \\
\hline $\begin{array}{l}\text { Winterborne } \\
\text { Kingston }\end{array}$ & 2,559 & 335 & 377 & 464 & 564 & 567 & 584 & 589 & 508 & 520 & 500 & 390 \\
\hline Woodsford . & $\mathrm{I}, 76 \mathrm{I}$ & 132 & 147 & 159 & 182 & 158 & 183 & 193 & 232 & 183 & 168 & 146 \\
\hline Wool $\ddagger$ & 2,587 & 383 & $48 I$ & 453 & 467 & 505 & 545 & 590 & 602 & 509 & 521 & 497 \\
\hline Worth Matravers $\ddagger$ & 2,712 & 217 & 277 & 325 & $35^{6}$ & 376 & 396 & 350 & 297 & 302 & 229 & 227 \\
\hline \multicolumn{13}{|l|}{$\begin{array}{l}\text { Bridport } \\
\qquad \text { Divisiont }\end{array}$} \\
\hline Allin & $594^{\circ}$ & 716 & 94 I & 1,139 & 1,300 & $\mathbf{I}, 545$ & 1,748 & 1,915 & 1,890 & 1,709 & 1,563 & 1,431 \\
\hline$A s$ & $1,161^{\circ}$ & 170 & 181 & 190 & 228 & 233 & 224 & 223 & 229 & 209 & 194 & 179 \\
\hline $\begin{array}{c}\text { Axminster (part } \\
\text { of })^{4}+\end{array}$ & $44 \mathrm{I}$ & 一 & - & - & - & 30 & 23 & 22 & 9 & 23 & 10 & 19 \\
\hline Beaminster $\ddagger$. & 5,190 & 2,140 & 2,290 & 2,806 & 2,968 & 3,270 & 2,832 & 2,614 & 2,585 & 2,130 & I,915 & 1,702 \\
\hline mbe $t t$ & $667^{\circ}$ & 47 & 62 & 62 & 65 & 53 & 73 & 76 & 60 & 63 & 59 & 50 \\
\hline & 982 & 129 & I39 & 178 & 177 & 170 & $23 I$ & 194 & I99 & 223 & 202 & 155 \\
\hline ampton $\dagger \ddagger$ & $823^{\circ}$ & 334 & 344 & 385 & 424 & 533 & 548 & 546 & 572 & 536 & 493 & 424 \\
\hline & 1,007 & 575 & 789 & 926 & 1,018 & 1,357 & 1,391 & 1,449 & 1,549 & 1,567 & $1,64 t$ & 1,723 \\
\hline insor ${ }^{5} \ddagger$ & 6,303 & 1,094 & 1,172 & 1,387 & 1,570 & 1,661 & 1,516 & $1,53^{8}$ & I,499 & 1,256 & $I, 105$ & 994 \\
\hline Burstock ${ }^{5} \ddagger$ & 931 & 172 & 164 & 203 & 261 & 307 & 234 & 220 & 201 & 190 & 139 & 134 \\
\hline Burton Bradstock 6 & $2,680^{\circ}$ & 654 & 677 & 854 & 1,068 & 1,201 & $1,18 \mathrm{I}$ & I,010 & I,036 & 946 & 901 & 715 \\
\hline $\begin{array}{l}\text { Catlierston } \\
\text { Leweston }\end{array}$ & 245 & 20 & 18 & 27 & 27 & 36 & 32 & 34 & 33 & 25 & $2 \mathrm{I}$ & 38 \\
\hline Chardstock $\dagger$ & $5,800^{\circ}$ & 1,095 & 1,151 & $I, 256$ & $\mathrm{I}, 357$ & $1,4 \circ 5$ & 1,387 & 1,461 & 1,507 & 1,328 & 1,126 & 1,048 \\
\hline Charmouth $\ddagger$. & 445 & 369 & 451 & 607 & 724 & 620 & 664 & 678 & 644 & 626 & 535 & 560 \\
\hline Cheddington $\ddagger$ & 785 & 46 & 117 & 164 & 178 & 186 & 189 & 176 & 165 & I 14 & 112 & 123 \\
\hline $\mathrm{Ch}$ & 1,978 & 578 & 623 & 715 & 838 & 826 & 884 & 794 & 748 & 674 & 633 & $55^{I}$ \\
\hline Compton Valence $\ddagger$ & 1,322 & 69 & 70 & 86 & 104 & 116 & 137 & 136 & 146 & 126 & 115 & I10 \\
\hline Corscombe $\uparrow$. & $5,003^{\circ}$ & 515 & 563 & 632 & 714 & 810 & 772 & 753 & 755 & 653 & 623 & 543 \\
\hline
\end{tabular}

3 The area and the population (1801, $18 \mathrm{Ir}$, and $188 \mathrm{I}-190 \mathrm{I}$ ) of Shitterton Tything is included with the main part of Bere Regis Parish.

sa Consisting of the Hundreds of Beaminster Forum and Redhone, Eggerton, Godderthorne, and WhitchurchCanonicorum, and the Liberties of Broadwinsor, Frampton, Lothers and Bothenhampton, and Powerstock.

1 Axminster. - The remainder is in Devon (Axminster Hundred), where the entire population is shown 1801-183I. The part in this county was added to it by the operation of the Act, 7 \& 8 Vict. cap. 6 I.

5 Broadwinsor and Burstock. - The increased population in 1841 was due to a fair being held at the time of the Census.

6 Burton Bradstock included the population of Sturtbill Tything, I80I-1831, which, however, in $1841-190 \mathrm{r}$, is rightly included with Shipton Gorge. The area is included with that of Shipton Gorge. 


\section{A HISTORY OF DORSET}

TABLE OF POPULATION, I80I-IgoI (continued)

\begin{tabular}{|c|c|c|c|c|c|c|c|c|c|c|c|c|}
\hline Parish & $\begin{array}{l}\text { Acre- } \\
\text { age }\end{array}$ & 1801 & 1811 & 1821 & 1831 & $18+1$ & 1851 & 1861 & 1871 & 1881 & $189 \mathrm{r}$ & 1901 \\
\hline \multicolumn{13}{|l|}{$\begin{array}{l}\text { Bridport Divi- } \\
\text { sion (cont.) }\end{array}$} \\
\hline Frampton $+t$. & $3,508^{\circ}$ & 295 & $33 I$ & 418 & 376 & 391 & 392 & 435 & 474 & 421 & 391 & 378 \\
\hline Hooke ${ }^{7}+t$ & $1,237^{\circ}$ & 184 & 206 & 234 & 269 & 268 & 261 & 247 & 202 & 154 & 179 & 155 \\
\hline Laders $t \ddagger$. & $2,24 \mathrm{I}^{\circ}$ & 654 & 715 & 857 & 812 & 952 & 986 & 1,053 & 1,115 & 952 & 880 & $74 \mathrm{I}$ \\
\hline Long Bredy. . & 2,153 & 241 & 247 & 291 & 333 & 340 & 375 & 250 & 260 & 227 & 215 & 192 \\
\hline Mapperton $\ddagger$. & 821 & 72 & 83 & 123 & 112 & 94 & 85 & 92 & 94 & 103 & 87 & 76 \\
\hline Marshwood $\dagger$. & $3,396^{\circ}$ & 449 & 538 & 532 & 536 & 554 & 520 & 473 & 423 & 335 & 330 & 271 \\
\hline Mosterton . & 975 & 220 & 255 & 284 & 303 & $39 \mathrm{I}$ & 346 & 380 & 321 & $32 \mathrm{I}$ & 263 & 207 \\
\hline Netherbury . & 6,274 & 1,505 & 1,678 & 1,954 & 1,942 & 2,162 & 2,066 & 1,875 & $1,8 \times 9$ & 1,584 & 1,454 & 1,253 \\
\hline Perrott, South & 1,488 & 251 & 284 & 317 & 381 & 387 & 374 & 363 & 335 & 303 & 250 & 242 \\
\hline Pilsdon $\ddagger$ & 660 & 122 & 98 & 100 & 99 & 122 & 95 & 86 & 70 & 92 & 83 & 54 \\
\hline Poorton, North $\downarrow \ddagger$ & $664^{\mathrm{e}}$ & 75 & 80 & 89 & 89 & 112 & 109 & 92 & 88 & 61 & 63 & 42 \\
\hline Powerstock $t$ & $4,078^{\circ}$ & 802 & 924 & 1,oto & 1,024 & 1,090 & 1,044 & 1,067 & $r, 06 \mathrm{l}$ & 821 & 776 & $63 t$ \\
\hline Shipton Gorge ${ }^{7 a} \dagger$. & $1,528^{\circ}$ & 217 & 244 & 311 & 316 & 406 & 408 & 413 & 381 & 312 & 306 & 237 \\
\hline Stanton St. Gabriel & 1,070 & 100 & 123 & 112 & 101 & 106 & 90 & 75 & 88 & 71 & 48 & 57 \\
\hline $\begin{array}{l}\text { Stoke Abbas, or } \\
\text { Stoke Abbott * }+\end{array}$ & 2,327 & 486 & 496 & 615 & 587 & 808 & 826 & 703 & 671 & 551 & 499 & 419 \\
\hline Symondsbury $\dagger \ddagger$. & $3,925^{\circ}$ & 791 & 860 & 1,076 & 1,147 & 1,316 & $\mathbf{I}, 395$ & 1,352 & 1,328 & 1,221 & 1,183 & 950 \\
\hline Thorncombe $t+$ & $4,896^{\circ}$ & 1,092 & 1,189 & 1,322 & 1,368 & 1,425 & 1,317 & 1,277 & 1,198 & 1,095 & 931 & 785 \\
\hline Walditch $\ddagger$. & 295 & 134 & 126 & 141 & 164 & $19 i$ & 176 & 175 & 182 & 192 & 175 & 162 \\
\hline Wambrook $\ddagger$. & 1,867 & 138 & 174 & 201 & 217 & 223 & 245 & 286 & 291 & 263 & 231 & 201 \\
\hline $\begin{array}{l}\text { Whitchurch } \\
\text { Canonicorum }+\end{array}$ & $6, \mathrm{I} 13^{\circ}$ & 932 & 1,065 & 1,317 & 1,399 & 1,581 & 1,532 & 1,533 & 1,365 & 1,053 & 1,020 & 868 \\
\hline Winterborne Abbas & 1,514 & 156 & 151 & 170 & 133 & 206 & 195 & 205 & 209 & 198 & 207 & 170 \\
\hline $\begin{array}{r}\text { Winterborne Came } \\
\text { (part of }^{8}\end{array}$ & 1,544 & 26 & 32 & 34 & 62 & 140 & 137 & 116 & 134 & 144 & 130 & 103 \\
\hline $\begin{array}{l}\text { Wootton Fitz- } \\
\text { paine } t+\end{array}$ & 1,679 & 355 & 328 & 446 & 455 & 432 & 361 & 307 & 252 & 224 & 162 & 154 \\
\hline Wraxall : . ? & 968 & 54 & 76 & 62 & 70 & 65 & 87 & 83 & 88 & 97 & 62 & 47 \\
\hline \multicolumn{13}{|l|}{$\begin{array}{l}\text { Cerne Sub- } \\
\text { Division }^{\mathrm{Ba}}\end{array}$} \\
\hline Alton Pancras $\ddagger$ & 2,280 & 184 & 168 & 207 & 210 & 248 & 282 & 270 & 250 & 247 & 229 & 183 \\
\hline Buckland Newton $\ddagger$ & 6,250 & 652 & 695 & 843 & 786 & 914 & 990 & 972 & 1,138 & 855 & 873 & 755 \\
\hline Cattistock $^{8} \ddagger$. & 3,073 & 349 & 350 & 382 & 427 & 549 & 594 & 510 & 588 & $53 \mathrm{I}$ & 520 & 476 \\
\hline Cerne Abbas * $\ddagger$ & $3, \pi 49$ & 847 & 795 & 1,060 & 1,209 & 1,342 & 1,343 & 1,185 & 1,164 & 925 & 834 & 643 \\
\hline Cerne, Nether $\ddagger$ & 850 & 50 & 62 & 60 & 83 & 71 & 103 & 95 & 89 & 93 & 87 & 62 \\
\hline Cheselbourne $t \pm$. & $2,580^{\circ}$ & 268 & 273 & 336 & 352 & 346 & 408 & 432 & 408 & 337 & 243 & 194 \\
\hline Compton Abbas $\ddagger$. & 857 & 51 & 82 & 80 & 69 & 91 & 100 & II 7 & 98 & 66 & 51 & 50 \\
\hline $\begin{array}{l}\text { Godmanstone } \\
\text { Hawkchurch (part } \\
\text { of } 10:-\end{array}$ & 1,172 & 127 & 144 & 128 & 152 & 153 & 179 & 175 & 177 & 165 & 159 & 97 \\
\hline $\begin{array}{l}\text { Wyldecourt } \\
\text { Tything }\end{array}$ & - & - & 238 & 298 & 316 & 367 & 267 & 216 & 250 & 一 & - & - \\
\hline Hilton $\ddagger . \cdot \cdot$ & 3,044 & 462 & 512 & 610 & 685 & 730 & 761 & 833 & 800 & 663 & 567 & 502 \\
\hline Ibberton . . . & 1,384 & i57 & 168 & 222 & 225 & 232 & 218 & 237 & 226 & 187 & 137 & 133 \\
\hline Mappowder $\ddagger$ & $\mathbf{I}, 90 \mathrm{I}$ & 229 & 198 & 247 & 308 & 275 & 290 & 238 & 243 & 226 & 195 & 207 \\
\hline Melcombe Horsey $t$ & 2,157 & 118 & 129 & 153 & 172 & 173 & 191 & 208 & 190 & 183 & 182 & 136 \\
\hline Milton Abbas $\dagger t$. & $2,420^{\circ}$ & 544 & 619 & 767 & 846 & 833 & 915 & 1,014 & 942 & 956 & 787 & 677 \\
\hline Minterne $\mathrm{Mlagna}{ }^{\mathrm{H}} \dagger$ & $2,251^{\circ}$ & 321 & 367 & 311 & $33 \mathrm{I}$ & 354 & 396 & 380 & 352 & 322 & 339 & 306 \\
\hline Piddletrenthide $\ddagger$. & 4,497 & 449 & 462 & 590 & 680 & $67 i$ & 800 & 793 & 860 & 747 & 673 & 587 \\
\hline Pulham ${ }^{12} \ddagger$ & 2,416 & 190 & 269 & 272 & 302 & 323 & 288 & 302 & 296 & 269 & 266 & 214 \\
\hline Stoke IVake \pm . & 1,087 & 85 & 112 & 139 & 147 & 156 & 124 & 112 & 114 & 107 & 96 & 77 \\
\hline $\begin{array}{l}\text { Sydling St. Nicho- } \\
\text { las :- }\end{array}$ & $6,714^{\circ}$ & 556 & 593 & 690 & 767 & 822 & 799 & 803 & 803 & 692 & 696 & 527 \\
\hline $\begin{array}{l}\text { Sydling St. } \\
\text { Nicholas }\end{array}$ & 5,730 & 459 & 495 & 563 & 617 & 675 & 675 & 692 & 668 & 559 & 563 & $\$ 14$ \\
\hline $\begin{array}{r}\text { Hillfield Cha- } \\
\text { pelry } \dagger\end{array}$ & $1,584^{\circ}$ & 97 & 98 & 127 & 150 & 147 & 124 & 111 & 135 & 133 & 133 & 113 \\
\hline
\end{tabular}

7 Hooke. - The population given for 1801 is an estimate. is See note 6 , ante

8 Winkerborne Came Ancient Pavish is situated in Bridport and Dorchester Divisions. The entire area and popula. tion, I88 I-1901, are shown in Bridport Division.

8a Consisting of Buckland Newton, Cerne Totcombe and Modbury, and Whiteway Hundreds and the Liberties of Alton-Pancras, Piddletrenthide, and Sydling St. Nicholas.

${ }_{9}^{9}$ Cattistock and Frome St Quintin.-A number of labourers were present in 1851 engaged on railway construction.

10 Hawkchurch Ancient Parish is situated partly in Cerne Sub-Division and partly in Dorchester Division. The

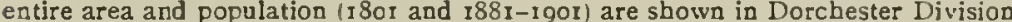

II Mintcrme Magna includes the area and the population $(1861-1901)$ of Gore Wood, which became a Civil Parish under the Act, 20 Vict., cap. Ig.

12 Pulham. - The population given for I8ar is partly estimated. 


\section{SOCIAL AND ECONOMIC HISTORY}

TABLE OF POPULATION, I801-1901 (continued)

\begin{tabular}{|c|c|c|c|c|c|c|c|c|c|c|c|c|}
\hline PARISH & $\begin{array}{l}\text { Acre- } \\
\text { age }\end{array}$ & $\mathrm{r} 8 \mathrm{or}$ & I8ri & $\mathrm{r} 82 \mathrm{r}$ & 1831 & $184 x$ & $x 85 x$ & $\mathrm{r} 86 \mathrm{r}$ & $187 x$ & r88r & $189 \mathrm{r}$ & rgor \\
\hline \multicolumn{13}{|l|}{$\begin{array}{l}\text { Cerne Sub- } \\
\quad \text { Division (cont.) }\end{array}$} \\
\hline $\begin{array}{l}\text { Woolland } \ddagger . \dot{ } \\
\text { Wootton Glanville }\end{array}$ & 1,137 & 123 & II 9 & 135 & II9 & I 24 & 107 & I32 & 128 & 120 & 155 & 142 \\
\hline Wootton Glanville & 1,705 & 275 & 287 & 309 & $33 \mathrm{I}$ & 342 & 328 & 300 & 314 & 237 & 238 & 175 \\
\hline \multicolumn{13}{|l|}{$\begin{array}{l}\text { Dorchester } \\
\text { Division }\end{array}$} \\
\hline Abbotsbury $\rfloor$. & 4,872 & 788 & 812 & 907 & 874 & 1,005 & 1,077 & 1,089 & 1,065 & 979 & 903 & 707 \\
\hline $\begin{array}{l}\text { Athelhampton, or } \\
\text { Admiston }\end{array}$ & 477 & 62 & 54 & 79 & 67 & 74 & 82 & 95 & 94 & 74 & 71 & 62 \\
\hline Bradford Peverell $\neq$ & 2,254 & 216 & 225 & 277 & 330 & 355 & 395 & 361 & 405 & 330 & 368 & 290 \\
\hline Bredy, Little ${ }^{13}$. & 1,613 & I34 & - & 126 & 165 & 196 & 226 & 199 & 204 & 193 & I 93 & 203 \\
\hline Broadway . & 1,051 & 210 & 264 & 282 & 385 & 498 & 610 & 614 & 712 & 761 & 774 & 821 \\
\hline Broadmayne & 997 & 215 & 254 & 277 & 362 & 490 & 486 & 506 & 477 & $5 \mathrm{II}$ & 479 & 390 \\
\hline Buckland Ripers + & $I, 255$ & 57 & 67 & 60 & 115 & 118 & III & 113 & 135 & I54 & 143 & 144 \\
\hline Burleston & 366 & $5 \mathrm{I}$ & 55 & 63 & 67 & 65 & $7 \mathrm{I}$ & 45 & 46 & 55 & 78 & 75 \\
\hline Charminster ${ }^{14} \dagger$ & $4,095^{\circ}$ & 416 & 446 & 556 & 596 & 827 & 905 & $\mathrm{I}, 020$ & 1,540 & 1,5 I 6 & $I, 446$ & 1,679 \\
\hline Chelborough, East & 967 & 73 & 80 & 96 & 83 & 96 & IOO & 93 & 106 & 113 & 76 & 69 \\
\hline Chelborough, West & 587 & 45 & 44 & 56 & 62 & $5^{8}$ & 64 & 73 & 72 & 62 & 57 & 62 \\
\hline Chickerell, West $\ddagger$ & $\mathbf{I}, 576$ & 255 & 321 & 409 & 430 & 531 & 577 & 660 & 812 & 819 & 814 & 943 \\
\hline Chilcombe $\ddagger$. & $45^{1}$ & 23 & 21 & 22 & 35 & 53 & 29 & 24 & 24 & 40 & 24 & 30 \\
\hline Chilfrome $t$. . & 971 & $8 r$ & 85 & 106 & III & 128 & 119 & 120 & 105 & 91 & 88 & 96 \\
\hline Evershot $t$. & $\mathbf{1}, 409^{\circ}$ & 497 & 485 & 567 & 569 & 566 & 606 & 595 & 494 & 500 & 371 & 353 \\
\hline Fleet $t$ : & 963 & 125 & 105 & 132 & 122 & 140 & 164 & 160 & 166 & 138 & 138 & 121 \\
\hline Fordington $* \dagger$. & $2,749^{\circ}$ & 888 & 1,094 & $\mathrm{I}, 275$ & 2,030 & 2,937 & 3,147 & $3,25^{8}$ & 3,277 & 4,095 & 5,076 & 6,224 \\
\hline FromeSt.Quintin ${ }^{14 a}$ & 1,032 & 132 & 125 & I 20 & 143 & 140 & 184 & 129 & 170 & 188 & 133 & 146 \\
\hline $\begin{array}{l}\text { Frome Vauchurch } \\
\text { Hawkchurch }\end{array}$ & $614^{\circ}$ & 81 & 67 & 105 & 135 & 180 & 171 & 171 & I So & 121 & 142 & II 5 \\
\hline 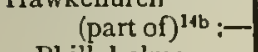 & & & & & & & & & & & & \\
\hline $\begin{array}{c}\text { Phillyholme } \\
\text { Tything }\end{array}$ & 4,088 & 679 & 533 & $55^{8}$ & 570 & 453 & 506 & 490 & 416 & 590 & $57 !$ & 463 \\
\hline Hermitage $\dagger$ & $75 \mathrm{I}^{\circ}$ & 123 & 119 & I 43 & 124 & 132 & 139 & 131 & 128 & I 13 & 115 & 100 \\
\hline Kin! & 1,166 & 59 & 185 & 79 & 76 & 85 & 84 & 63 & 70 & 70 & 61 & 67 \\
\hline Knigl & $2,339^{\circ}$ & 180 & 229 & 229 & 308 & 268 & 270 & 268 & 264 & 312 & 326 & 331 \\
\hline Langton Herring $\ddagger$ & 974 & I 56 & 153 & 152 & 205 & 260 & 246 & $24 \mathrm{I}$ & 232 & 255 & 207 & 155 \\
\hline Litton Cheney $t t$. & $3,817^{\circ}$ & 347 & 365 & 424 & 420 & 463 & 507 & 501 & 562 & $45^{8}$ & 463 & 381 \\
\hline Maiden Newion $\ddagger$ & 2,893 & 428 & 428 & 520 & 538 & 729 & 821 & 844 & 856 & 799 & 694 & 606 \\
\hline Melbury Sampford & 1,041 & 82 & $5^{2}$ & 78 & 53 & 43 & 55 & 60 & 65 & 70 & 108 & 85 \\
\hline $\begin{array}{l}\text { Milborne } \\
\text { St. Andrew }\end{array}$ & 1,747 & 172 & 192 & 244 & 240 & 287 & 335 & 327 & 291 & 309 & 286 & 239 \\
\hline Osmington $\ddagger$. & 2,209 & $257^{\circ}$ & 237 & 318 & 421 & 467 & 485 & 448 & 449 & 380 & 292 & 334 \\
\hline aton $\nmid t$ & $2,264^{\circ}$ & 263 & 287 & $35^{8}$ & 403 & 394 & 390 & 414 & $45^{8}$ & 397 & 339 & 279 \\
\hline Piddletown $\dagger \ddagger$. & $7,653^{\circ}$ & 909 & $870^{\circ}$ & 961 & 1,223 & 1,168 & 1,297 & $\mathrm{I}, 24 \mathrm{I}$ & 1,249 & 1,175 & 1,077 & $96 \mathbf{I}$ \\
\hline Portisham $\ddagger$. & $4,5 \mathrm{II}$ & 490 & 595 & 600 & 663 & 746 & 767 & 704 & 744 & 705 & 634 & 582 \\
\hline Portland ${ }^{16}$. & 2,897 & I,619 & 2,079 & 2,254 & 2,670 & 2,852 & 5,195 & 8,468 & 9,907 & 10,061 & 9,443 & 15,199 \\
\hline Preston $\ddagger$. . & 2,625 & 385 & 447 & 508 & 555 & 672 & 711 & 723 & 747 & 689 & 678 & 664 \\
\hline Puncknowle $\ddagger$ & 1,974 & 267 & 288 & 300 & 424 & 425 & 467 & 502 & 475 & 473 & 427 & 335 \\
\hline Radipole ${ }^{16}$ & 1,333 & I5 I & I 73 & 226 & 382 & 487 & 609 & 691 & 1,154 & 1,322 & 1,782 & 2,496 \\
\hline ham. & 2,095 & 265 & 347 & 368 & 416 & 420 & 412 & 356 & 393 & 290 & $25 \mathrm{I}$ & $19 I$ \\
\hline West & 1,015 & I 44 & 149 & 184 & 184 & 212 & 229 & 220 & 230 & 199 & 206 & 212 \\
\hline Stinsford $\ddagger$. & 2,071 & 227 & 339 & 337 & $3^{82}$ & 392 & 373 & 357 & 352 & 339 & 278 & 278 \\
\hline Stockwood . & 698 & $5^{6}$ & 39 & 33 & 33 & 28 & 43 & 60 & 54 & 70 & 49 & 30 \\
\hline Stratton . . & 1,716 & 233 & 253 & 262 & 310 & 331 & 394 & $35^{1}$ & $34 \mathrm{i}$ & 299 & 329 & $3 i 5$ \\
\hline Swyre $\downarrow$. & 1,129 & 176 & 207 & 210 & 226 & 231 & 254 & 277 & 260 & 213 & 154 & 148 \\
\hline Tincleton . & 900 & 122 & 125 & 142 & 171 & 187 & 176 & 154 & 175 & 146 & 160 & 160 \\
\hline Toller Fratrum \$:- & 2,294 & 195 & 187 & 189 & 190 & 200 & 217 & 182 & 214 & 204 & 150 & 173 \\
\hline Toller Fratrum & 506 & 46 & 45 & 37 & 56 & 67 & 54 & 45 & 58 & 54 & 30 & 47 \\
\hline $\begin{array}{l}\text { Wynford Eagle } \\
\text { Chap. }\end{array}$ & 1,788 & 149 & 142 & 152 & 134 & 133 & 163 & 137 & 156 & 150 & 120 & 126 \\
\hline Toller Porcorum $\ddagger$. & 3,173 & 340 & 384 & 499 & 540 & 543 & 527 & 500 & 486 & 446 & 417 & 337 \\
\hline
\end{tabular}

12 Consisting of Culliford Tree, George, Puddletown, Tollerford, and Uggscombe Hundreds, and the Liberties of Fordington, Isle of Portland, Piddlehinton, Sutton Poyntz, Wabybouse, and Wyke Regis and Elwell. ${ }_{13}$ The population of Little Bredy included with that of Kingston Kussell in $18 \mathrm{Ir}$.

It Charminster. - The increase in population in $187 \mathrm{I}$ is attributed to the erection of a County Lunatic Asylum and a County School.

14a See note 9, ante.

1tb See note Io, ante.

is Portland, Wyke Regis, and Weymouth. -Tbe increases in population in Igor are attributed mainly to the construction of the breakwater and to other Government works in progress at the date of the Census.

16 Radipole. - The women and children in the barracks were not included in the population in I821. 


\section{A HISTORY OF DORSET}

TABLE OF POPULATION, $801-1901$ (continued)

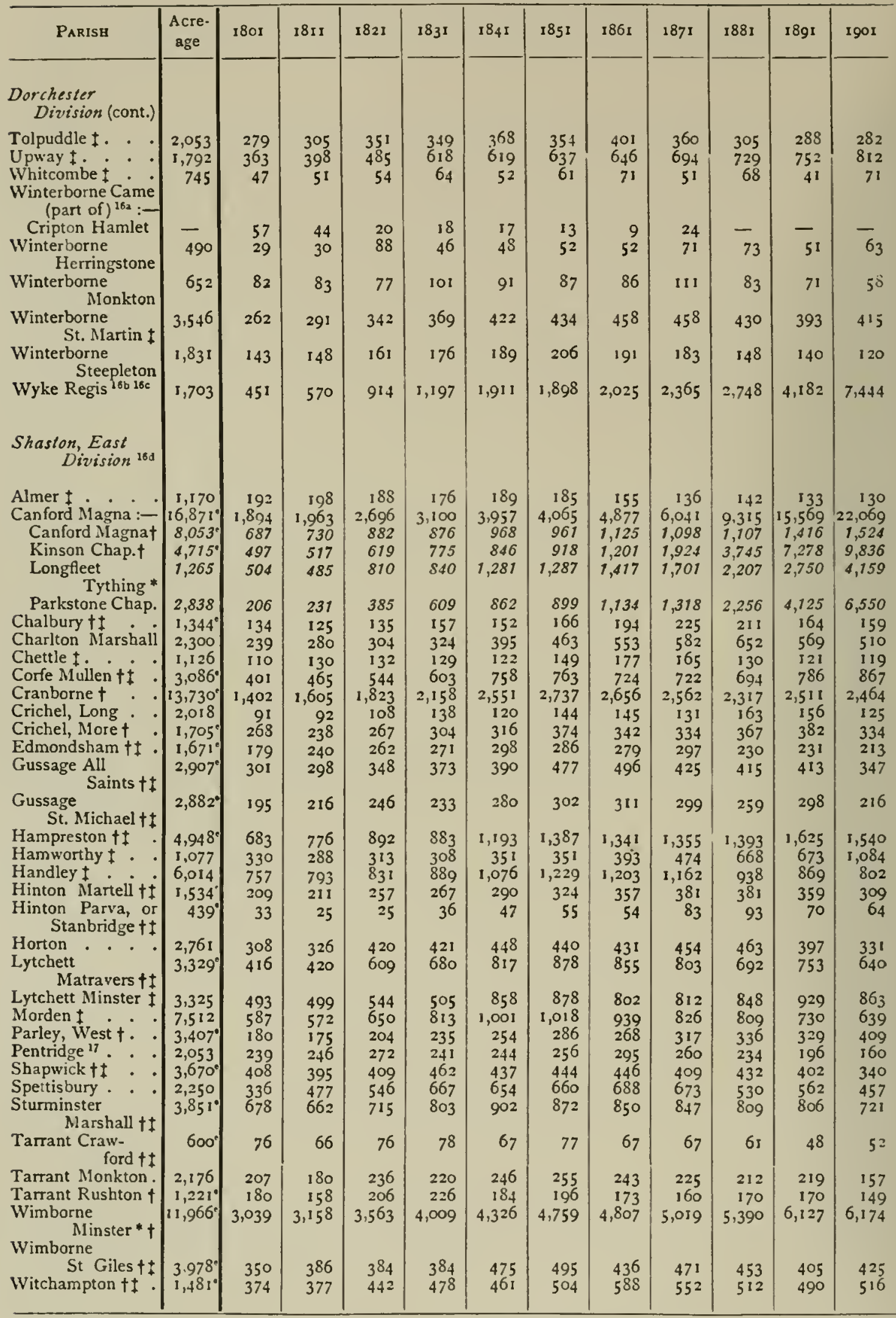

16. See note 8, ante.

$16 \mathrm{~b}$ See note I5, antc.

$16 \mathrm{c}$ See note 20 , fost.

16d Consisting of the entire Hundreds of Badbury, Cogdean, Knowlton, Loosebarrow, Monkton-up-Wimborne, and Wimborne St. Giles, and parts of the hundreds of Cranborne and Sixpenny-Handley.

17 Pentridge includes the area and population of East Woodyates, which became a Civil Parish under the Extra Parochial Places Acts. 


\section{SOCIAL AND ECONOMIC HISTORY}

TABLE OF POPULATION, 1801-1901 (continued)

\begin{tabular}{|c|c|c|c|c|c|c|c|c|c|c|c|c|}
\hline PARISH & $\begin{array}{l}\text { Acre- } \\
\text { age }\end{array}$ & I80I & I8II & I82I & $183 I$ & $I 8_{4} I$ & 1851 & 1861 & 1871 & $188 \mathrm{I}$ & $189 \mathrm{I}$ & I90I \\
\hline \multicolumn{13}{|l|}{$\begin{array}{l}\text { Shaston, East } \\
\text { Division (cont.) }\end{array}$} \\
\hline $\begin{array}{l}\text { Woodlands } \\
\text { Woodyates, West } \\
\text { Extra Par. }\end{array}$ & $\begin{array}{r}2,594 \\
817\end{array}$ & $\begin{array}{r}364 \\
13\end{array}$ & $\begin{array}{r}346 \\
20\end{array}$ & $\begin{array}{r}395 \\
9\end{array}$ & $\begin{array}{r}423 \\
18\end{array}$ & $\begin{array}{r}454 \\
14\end{array}$ & $\begin{array}{r}476 \\
13\end{array}$ & $\begin{array}{r}495 \\
20\end{array}$ & $\begin{array}{r}457 \\
38\end{array}$ & $\begin{array}{r}453 \\
33\end{array}$ & $\begin{array}{r}416 \\
49\end{array}$ & $\begin{array}{r}421 \\
54\end{array}$ \\
\hline \multicolumn{13}{|l|}{$\begin{array}{l}\text { Shaston, West } \\
\quad \text { Division }\end{array}$} \\
\hline Ashmore & 2,376 & 141 & 196 & 166 & 191 & 242 & 237 & 254 & 274 & 275 & 228 & 208 \\
\hline Belchalwell $\dagger$. & $1,308^{\circ}$ & 134 & 174 & 192 & 205 & 225 & 222 & 158 & 173 & 169 & 161 & 93 \\
\hline $\begin{array}{r}\text { Cann, or Shaston } \\
\text { St. Rumbold } \ddagger\end{array}$ & 987 & 203 & 267 & 365 & 435 & 523 & 513 & 547 & 574 & 560 & 501 & 479 \\
\hline Compton Abbas $+t$ & $1,516^{\circ}$ & 371 & 345 & 368 & $40 \mathrm{r}$ & 439 & 465 & 456 & $48 I$ & 402 & 299 & 245 \\
\hline Farnham $t+$. & $402^{\circ}$ & 88 & 76 & 75 & 94 & 117 & 128 & 121 & 105 & 101 & 108 & 72 \\
\hline Fontmell Magna + & $2,853^{\circ}$ & 628 & 670 & 733 & 743 & 876 & 832 & 875 & 842 & 731 & 637 & 566 \\
\hline Gillingham :- & $8,567^{\circ}$ & 2,510 & 2,740 & 3,059 & 3,330 & 3,661 & 3,775 & 3,957 & 4,037 & 4,131 & 4,079 & 4,096 \\
\hline Gillingham . & 7,739 & 1,873 & 1,992 & 2,246 & 2,520 & 2,760 & 2,806 & 3,036 & 3,177 & 3,293 & 3,303 & 3,380 \\
\hline $\begin{array}{l}\text { Bourton } \\
\text { Chap. } t \ddagger\end{array}$ & $828^{\circ}$ & 637 & 748 & 813 & 810 & 901 & 969 & 927 & 860 & 838 & 776 & 776 \\
\hline Iwerne Minster $\ddagger$. & 2,865 & 497 & 529 & 622 & 634 & 683 & 703 & 712 & 665 & 667 & 661 & 543 \\
\hline Melbury Abbas $\ddagger$. & 2,374 & 302 & 324 & 345 & 354 & 390 & 444 & 412 & 361 & 328 & 288 & 233 \\
\hline Motcombe $t$. & 5,063 & 917 & 999 & 1,184 & 1,405 & 1,538 & 1,535 & 1,433 & 1,453 & 1,411 & 1,309 & 1,273 \\
\hline Orchard, East $\dagger$ & $860^{\circ}$ & 166 & 144 & 193 & 201 & 173 & 219 & 227 & 244 & 233 & 166 & 168 \\
\hline Orchard, West. & 669 & 120 & 131 & 173 & 183 & 157 & 121 & 103 & 102 & 113 & 115 & 87 \\
\hline $\begin{array}{l}\text { Shillingstone, or } \\
\text { Shilling } \\
\text { Okeford }\end{array}$ & 2,272 & 380 & 385 & $43^{\circ}$ & 473 & 512 & 503 & 509 & 534 & 566 & 546 & $53^{2}$ \\
\hline $\begin{array}{l}\text { Tarrant Gunville } \\
\text { Tollard Royal (part }\end{array}$ & 3,469 & 408 & 444 & 487 & 502 & 518 & 475 & 441 & 395 & 348 & 369 & 303 \\
\hline $\begin{array}{r}\text { of }{ }^{18}:- \\
\text { Tollard Farnham } \\
\text { Tything } t\end{array}$ & $897^{\circ}$ & 174 & I9I & 208 & 220 & 224 & 218 & 217 & 253 & 184 & 193 & 203 \\
\hline $\begin{array}{r}\text { Turnwood, or Turn- } \\
\text { worth } \downarrow \ddagger\end{array}$ & $1,560^{\circ}$ & 82 & 77 & 72 & 78 & 89 & 103 & 150 & 151 & 115 & 127 & 147 \\
\hline \multicolumn{13}{|l|}{$\begin{array}{l}\text { Sherborne } \\
\quad \text { Division }{ }^{18}\end{array}$} \\
\hline Batcombe & $\mathrm{r}, 120$ & 155 & 121 & 177 & 178 & 171 & 227 & 184 & 177 & 127 & 123 & 98 \\
\hline Beer Hackett $\ddagger$. & 918 & 87 & 76 & 78 & IIo & 103 & 107 & 96 & $9 i$ & 83 & 85 & 60 \\
\hline Bradford Abbas & 1,216 & 480 & 516 & 533 & 595 & 652 & 621 & 585 & 578 & 510 & 523 & 391 \\
\hline Castleton $\downarrow$. & 71 & 125 & 123 & I 74 & 186 & 113 & 157 & 59 & 69 & 81 & $5 \mathrm{I}$ & 46 \\
\hline $\begin{array}{l}\text { Caundle, } \\
\text { Bishop's } † \ddagger\end{array}$ & $1,397^{\circ}$ & 282 & 294 & 312 & 376 & 365 & 397 & 371 & 383 & 335 & 325 & 277 \\
\hline Caundle Marsh $t+$ & $792^{\circ}$ & 46 & $5^{8}$ & 62 & 70 & 77 & 71 & 84 & 76 & 97 & 83 & 89 \\
\hline Clifton Maybank . & 1,296 & 40 & 47 & 66 & 60 & 70 & 72 & 73 & 65 & 80 & 80 & 64 \\
\hline Compton, Nether . & 918 & 371 & 395 & $45^{8}$ & 415 & 456 & 454 & 376 & 401 & 387 & 323 & 263 \\
\hline Compton, Over & 688 & 135 & 153 & 149 & 139 & 151 & 158 & 150 & 127 & 142 & 129 & 115 \\
\hline Folke $\dagger \ddagger$. . . & $1,722^{\circ}$ & 182 & 195 & 269 & 281 & 318 & 330 & 332 & 315 & 268 & 327 & 294 \\
\hline Halstock $\ddagger$. & 3,216 & 397 & 433 & 447 & 554 & 626 & 572 & 532 & 520 & $44 I$ & 400 & 357 \\
\hline Haydon $t t$. & $632^{\circ}$ & 83 & 79 & 109 & 123 & 116 & 109 & I 3 I & I I I & IOI & 80 & 89 \\
\hline Holnest $\dagger \cdot$. & $2,062^{\circ}$ & 160 & 127 & 162 & 159 & 139 & 163 & 147 & 135 & 101 & 118 & 127 \\
\hline $\begin{array}{l}\text { Leweston Extra } \\
\text { Par. }\end{array}$ & 314 & 7 & $175 ?$ & 8 & 18 & 7 & & 17 & 34 & 40 & 30 & 34 \\
\hline Lillington $\ddagger$. . & 1,830 & 128 & & 185 & 205 & 191 & 166 & 163 & 187 & 140 & 167 & 130 \\
\hline Long Burton & $\mathrm{I}, \mathrm{O} 4 \mathrm{I}$ & 216 & 287 & 327 & 361 & 386 & 389 & 336 & 372 & 379 & $33^{\circ}$ & 283 \\
\hline Lydlinch $\dagger_{+}^{+}$. & $2,446^{\circ}$ & 249 & 320 & 364 & 365 & 419 & 407 & 404 & 369 & 354 & 326 & 279 \\
\hline Melbury Bubb . & 1,243 & 107 & 123 & 129 & 121 & 126 & 157 & 136 & 141 & 147 & 120 & 86 \\
\hline Melbury Osmond 19 & 1,222 & 335 & 285 & 319 & 380 & 404 & 364 & 329 & 385 & 389 & 338 & 249 \\
\hline Oborne $t$. & 607 & 132 & 114 & 123 & 83 & 131 & 140 & 150 & 147 & 143 & 130 & 152 \\
\hline Purse Caundle $\ddagger$. & $1,55^{8}$ & 148 & 132 & 142 & 180 & $1 \ddot{8}_{3}$ & 177 & 185 & 176 & 194 & 160 & 145 \\
\hline Ryme Intrinseca $† t$ & $1,003^{\circ}$ & 123 & 151 & 159 & $17 \mathrm{I}$ & 193 & 216 & 217 & 240 & 203 & 163 & 159 \\
\hline Thornford $t$. & 1,465 & 256 & 297 & 329 & 383 & 394 & 410 & 415 & 444 & 413 & 397 & 370 \\
\hline Up Cerne $f$. & 1,123 & 68 & 74 & 84 & 88 & 107 & 94 & 75 & 109 & 76 & 84 & 65 \\
\hline Wootton, North $\ddagger$. & 668 & 67 & 60 & 64 & 78 & 84 & 75 & 76 & 72 & 69 & 77 & 67 \\
\hline
\end{tabular}

17a Consisting of the Liberty of Gillingham and parts of the hundreds of Cranborne and Sixpenny-Handley.

18 Tollard Royal Ancient Purish. - The remainder is in Wilts (Chalk Hundred). The population of the part in Dorset is estimated for 18 or.

19 Consisting of Sherborne and Yetminster Hundreds, and Halstock and Ryme Intrinseca Liberties.

19 Melbury Osmond. The increase in population in $187 \mathrm{r}$ is attributed to the withdrawal of a regulation made hy the late landlord, prohibiting the farmers from employing labourers with large families. 


\section{A HISTORY OF DORSET}

TABLE OF POPULATION, I80I-IgOI (continued)

\begin{tabular}{|c|c|c|c|c|c|c|c|c|c|c|c|c|}
\hline Parisa & $\begin{array}{l}\text { Acre- } \\
\text { age }\end{array}$ & 1801 & $181 \mathrm{x}$ & 1821 & 1831 & I84I & 1851 & $186 \mathrm{I}$ & $187 \mathrm{I}$ & $188 \mathrm{I}$ & 1891 & 1901 \\
\hline \multicolumn{13}{|l|}{$\begin{array}{l}\text { Sherborne } \\
\quad \text { Division (cont.) }\end{array}$} \\
\hline $\begin{array}{l}\text { Yetminster :- } \\
\text { Yetminster } \dagger . \\
\text { Chetnole Chap. } \dagger \\
\text { Leigh Chap. } \dagger_{+}^{+}\end{array}$ & $\begin{array}{r}4,32 \mathrm{I}^{\circ} \\
1,460^{\circ} \\
877^{\circ} \\
1,984^{\circ}\end{array}$ & $\begin{array}{l}947 \\
479 \\
168 \\
300\end{array}$ & $\begin{array}{r}1,052 \\
508 \\
177 \\
367\end{array}$ & $\begin{array}{r}1,125 \\
543 \\
239 \\
343\end{array}$ & $\begin{array}{r}\mathrm{I}, 199 \\
563 \\
236 \\
400\end{array}$ & $\begin{array}{r}1,246 \\
628 \\
222 \\
396\end{array}$ & $\begin{array}{r}1,333 \\
666 \\
227 \\
440\end{array}$ & $\begin{array}{r}1,430 \\
696 \\
269 \\
465\end{array}$ & $\begin{array}{r}1,519 \\
790 \\
256 \\
473\end{array}$ & $\begin{array}{r}1,357 \\
711 \\
243 \\
403\end{array}$ & $\begin{array}{r}1,329 \\
662 \\
272 \\
395\end{array}$ & $\begin{array}{r}1,085 \\
557 \\
215 \\
313\end{array}$ \\
\hline \multicolumn{13}{|l|}{$\begin{array}{l}\text { Sturminster } \\
\text { Division }^{192}\end{array}$} \\
\hline $\begin{array}{l}\text { Buckhorn } \\
\text { Weston }\end{array}$ & 1,705 & 307 & 297 & 327 & 403 & 460 & 484 & 509 & 559 & 517 & $49 I$ & 441 \\
\hline Child Okeford $t_{+}^{+}$. & $1,752^{\circ}$ & 498 & 620 & 694 & 612 & 648 & 773 & 783 & 878 & 846 & 820 & 716 \\
\hline $\begin{array}{l}\text { Fifehead } \\
\quad \text { Magdalen } \ddagger\end{array}$ & 973 & 240 & 269 & 296 & 241 & 229 & 218 & 200 & 206 & 344 & I30 & 121 \\
\hline $\begin{array}{r}\text { Hanford Extra } \\
\text { Par. }\end{array}$ & $60 \mathrm{I}$ & II & 9 & I3 & 10 & 19 & 5 & 6 & 17 & 56 & 43 & 56 \\
\hline Hinton St Mary $\ddagger$ & 1,069 & 266 & 306 & 297 & 303 & $36 I$ & 345 & 342 & 328 & 296 & 252 & 245 \\
\hline Holwell : $\cdot$ & 2,423 & 293 & 344 & $3+2$ & 405 & 397 & 462 & $49 j$ & 512 & 417 & 377 & 388 \\
\hline $\begin{array}{l}\text { Jwerne Courtney, } \\
\text { or Shroton } t\end{array}$ & $\mathbf{I}, 968$ & 420 & 518 & 512 & 557 & 605 & 689 & 620 & 651 & 623 & 560 & 474 \\
\hline $\begin{array}{l}\text { Kington Magna }+ \\
\text { Manston } \pm\end{array}$ & $\begin{array}{l}1,990 \\
1,373\end{array}$ & $\begin{array}{l}413 \\
109\end{array}$ & $\begin{array}{l}464 \\
\text { I IO }\end{array}$ & $\begin{array}{l}486 \\
140\end{array}$ & $\begin{array}{l}539 \\
1+9\end{array}$ & $\begin{array}{l}616 \\
127\end{array}$ & $\begin{array}{l}652 \\
134\end{array}$ & $\begin{array}{l}552 \\
152\end{array}$ & $\begin{array}{l}516 \\
168\end{array}$ & $\begin{array}{l}465 \\
187\end{array}$ & $\begin{array}{l}427 \\
193\end{array}$ & $\begin{array}{l}399 \\
128\end{array}$ \\
\hline Marnhull $\ddagger$ & 3,838 & 1,075 & $\mathrm{I}, 070$ & 1,273 & 1,309 & $I, 464$ & $\mathrm{I}, 48 \mathrm{I}$ & 1,444 & 1,453 & I,396 & $1,+15$ & 1,286 \\
\hline Margaret Marsh & 552 & 65 & 65 & 84 & 86 & 83 & 77 & 71 & 70 & 68 & 60 & 50 \\
\hline $\begin{array}{l}\text { Okeford } \\
\text { Fitzpaine } \dagger+\end{array}$ & $2,633^{\circ}$ & 476 & 470 & 499 & 620 & 675 & 6.43 & 685 & 701 & 602 & 557 & 600 \\
\hline Silton $\dagger_{+}^{+} \cdot \cdot$ & $1,257^{\circ}$ & $34 I$ & 384 & 409 & 396 & 385 & 368 & 306 & 315 & 245 & 218 & 221 \\
\hline $\begin{array}{l}\text { Stalbridge }++ \\
\text { Stock Gayland }+{ }_{++}\end{array}$ & 5,882 & 1,245 & $\mathbf{1}, 33 \mathrm{I}$ & $1,57 \mathrm{I}$ & 1,773 & 1,882 & I,90I & 1,929 & 2,096 & 1,816 & 1,705 & 1,504 \\
\hline $\begin{array}{l}\text { Stock Gayland }{ }_{+}^{+} \\
\text {Stourton Caundle }+\end{array}$ & $\begin{array}{r}849^{\circ} \\
2,004\end{array}$ & $\begin{array}{r}71 \\
277\end{array}$ & 52 & 63 & 66 & 60 & 63 & 50 & 66 & $6 I$ & 56 & 60 \\
\hline Stour, East . . & $\begin{array}{l}2,004 \\
1,786\end{array}$ & $\begin{array}{l}777 \\
380\end{array}$ & $\begin{array}{l}304 \\
432\end{array}$ & 325 & 349 & 394 & 450 & 395 & 409 & 374 & 295 & 234 \\
\hline Stour Provost . & 2,815 & 604 & 662 & $\begin{array}{l}470 \\
800\end{array}$ & $\begin{array}{l}531 \\
870\end{array}$ & $\begin{array}{l}554 \\
892\end{array}$ & $\begin{array}{l}538 \\
869\end{array}$ & $\begin{array}{l}426 \\
889\end{array}$ & $\begin{array}{l}437 \\
837\end{array}$ & $\begin{array}{l}451 \\
726\end{array}$ & $\begin{array}{l}444 \\
700\end{array}$ & $\begin{array}{l}409 \\
569\end{array}$ \\
\hline Stour, West & 1,040 & 132 & 172 & 205 & 219 & 237 & $22 \mathrm{I}$ & 215 & 197 & 165 & 158 & 132 \\
\hline $\begin{array}{r}\text { Sturminster-New- } \\
\text { ton-Castle* }\end{array}$ & $4,5+6$ & $\mathbf{J}, 406$ & $I, 46 \mathrm{I}$ & 1,612 & $\mathbf{I}, 83 \mathbf{I}$ & 1,920 & 1,916 & 1,880 & 1,965 & 1,859 & 1,863 & 1,877 \\
\hline $\begin{array}{l}\text { Sutton Waldron }{ }_{4}^{+} \\
\text {Todber } . .\end{array}$ & $\begin{array}{r}1,153 \\
379\end{array}$ & 188 & $\begin{array}{r}218 \\
81\end{array}$ & 206 & 236 & 251 & 257 & 248 & 217 & 188 & 175 & 175 \\
\hline Blandford Town & & & & & & & & & & & & \\
\hline $\begin{array}{l}\text { Blandford } \\
\qquad \text { Forum } * t t\end{array}$ & $862^{\circ}$ & 2,326 & 2,425 & 2,643 & 3,109 & 3,349 & $3,9.48$ & 3,900 & 4,052 & 3,791 & 4,014 & 3,850 \\
\hline Bridport Borough & & & & & & & & & & & & \\
\hline Bridport $\ddagger$. & 98 & 3,117 & 3,567 & 3,742 & 4,242 & 4,787 & 4,653 & 4,645 & 4,643 & 3,936 & 3,768 & 3,053 \\
\hline $\begin{array}{l}\text { Dorchester } \\
\text { Borough }\end{array}$ & & & & & & & & & & & & \\
\hline $\begin{array}{l}\text { All Saints }+. \\
\text { Holy Trinity }+ \pm\end{array}$ & $\begin{array}{r}25 \\
.360^{\circ}\end{array}$ & $\begin{array}{l}626 \\
06 I\end{array}$ & $\begin{array}{l}667 \\
087\end{array}$ & 652 & 667 & 692 & 814 & 946 & 923 & 912 & 813 & 894 \\
\hline St. Peter. . & 35 & 815 & $\begin{array}{l}987 \\
892\end{array}$ & $\begin{array}{l}1,052 \\
1,039\end{array}$ & $\begin{array}{l}1,269 \\
\mathrm{~J}, 097\end{array}$ & $\begin{array}{l}1,354 \\
1,203\end{array}$ & $\begin{array}{l}1,549 \\
I, 150\end{array}$ & $\begin{array}{l}1,601 \\
\mathbf{I}, 213\end{array}$ & $\begin{array}{l}1,625 \\
1,307\end{array}$ & $\begin{array}{l}1,565 \\
1,389\end{array}$ & $\begin{array}{l}1,301 \\
1,372\end{array}$ & $\begin{array}{l}\mathrm{I}, \mathrm{I} 78 \\
\mathrm{I}, 336\end{array}$ \\
\hline $\begin{array}{l}\text { Lyme Regis } \\
\text { Borough }\end{array}$ & & & & & & & & & & & & \\
\hline Lyme Regis $\ddagger$. & 1,237 & $I, 45 I$ & 1,925 & 2,269 & 2,621 & 2,756 & 2,852 & 2,537 & 2,603 & 2,290 & 2,365 & 2,095 \\
\hline $\begin{array}{l}\text { Shaftesbury, or } \\
\text { Shaston, Borough }\end{array}$ & & & & & & & & & & & & \\
\hline Holy Trinity $\dagger$. & $353^{\circ}$ & 923 & I,OII & I, I I 5 & I, 184 & $\mathrm{I}, 145$ & $\mathbf{I}, 122$ & 1,028 & 974 & 988 & 902 & 847 \\
\hline $\begin{array}{l}\text { St. James } \pm:- \\
\text { St. James. }\end{array}$ & 1,798 & 614 & 595 & 724 & 763 & 924 & 919 & 931 & 1,060 & 1,001 & 950 & 873 \\
\hline Alcester Liberty & - & $\begin{array}{l}380 \\
274\end{array}$ & $\begin{array}{l}354 \\
241\end{array}$ & $\begin{array}{l}436 \\
288\end{array}$ & $\begin{array}{l}536 \\
227\end{array}$ & $\begin{array}{l}590 \\
334\end{array}$ & $\begin{array}{l}487 \\
432\end{array}$ & $\begin{array}{l}589 \\
342\end{array}$ & $\begin{array}{l}588 \\
472\end{array}$ & $\begin{array}{l}543 \\
458\end{array}$ & $\begin{array}{l}535 \\
415\end{array}$ & $\begin{array}{l}478 \\
395\end{array}$ \\
\hline St. Peter $\dagger$. . & $72^{\circ}$ & S96 & 1,029 & 1,064 & I, I I I & $\mathrm{I}, \mathrm{IOI}$ & 1,032 & $\mathrm{I}, \mathrm{OOI}$ & 1,020 & 895 & 806 & 810 \\
\hline
\end{tabular}

19a Consisting of the Hundreds of Brownsball, Redlane, and Sturminster-Newton-Castle, and the Liberty of Stour Provost. 


\section{SOCIAL AND ECONOMIC HISTORY}

TABLE OF POPULAT1ON, 1801-1901 (continued)

\begin{tabular}{|c|c|c|c|c|c|c|c|c|c|c|c|c|}
\hline PARISH & $\begin{array}{c}\text { Acre- } \\
\text { age }\end{array}$ & I 8 or & I8II & 1821 & I $83 I$ & $184 \mathrm{I}$ & 1851 & I86I & $I 871$ & I $88 \mathrm{I}$ & 1891 & I9OI \\
\hline Sherborne Town & & & & & & & & & & & & \\
\hline $\begin{array}{l}\text { Sherborne* } \ddagger \text {. } \\
\text { Wareham } \\
\text { Borough }\end{array}$ & 6,497 & 3,159 & 3,370 & 3,622 & 4,075 & 4,758 & 5,242 & 5,793 & 6,129 & 5,636 & 5,690 & 6,095 \\
\hline Holy Trinity . . & 2,614 & 540 & 559 & 591 & 675 & 769 & 876 & 816 & 829 & 818 & 796 & 608 \\
\hline Lady St. Mary :- & $823^{\circ}$ & 785 & 816 & 961 & 1,120 & 1,446 & 1,606 & 1,643 & 1,501 & 1,476 & 1,603 & 1,408 \\
\hline Within* . . & 870 & 一 & 一 & 一 & 一 & 7,370 & 1,529 & 1,568 & 1,444 & 1,430 & 1,513 & 1,343 \\
\hline Without ${ }^{\prime}$. & $736^{\circ}$ & - & - & 一 & - & 76 & 77 & 75 & 57 & 46 & 90 & 65 \\
\hline $\begin{array}{l}\text { St. Martin :- } \\
\text { Within }\end{array}$ & $\begin{array}{r}4,053^{\circ} \\
20^{\circ}\end{array}$ & $\frac{302}{-}$ & 334 & 379 & 530 & $\begin{array}{l}531 \\
326\end{array}$ & $\begin{array}{l}596 \\
367\end{array}$ & $\begin{array}{l}617 \\
358\end{array}$ & $\begin{array}{l}737 \\
395\end{array}$ & $\begin{array}{l}730 \\
364\end{array}$ & $\begin{array}{l}675 \\
367\end{array}$ & $\begin{array}{l}720 \\
413\end{array}$ \\
\hline $\begin{array}{l}\text { Without }{ }^{-} \\
\text {Weymouth and } \\
\text { Mielcombe Regis } \\
\text { Borough }\end{array}$ & $4,033^{\circ}$ & - & - & - & - & 205 & 229 & 259 & 342 & 366 & 314 & 307 \\
\hline $\begin{array}{l}\text { Melcombe Regis } \\
\text { Weymouth Par. } \\
\text { Chap. }{ }^{19 \mathrm{~b} 20 *} \\
\text { Poole, County of } \\
\text { a Town }\end{array}$ & $\begin{array}{r}103 \\
77\end{array}$ & $\begin{array}{l}2,350 \\
1,267\end{array}$ & $\begin{array}{l}2,985 \\
1,747\end{array}$ & $\begin{array}{l}4,252 \\
2,370\end{array}$ & $\begin{array}{l}5,126 \\
2,529\end{array}$ & $\begin{array}{l}5,039 \\
2,669\end{array}$ & $\begin{array}{l}5,273 \\
2,957\end{array}$ & $\begin{array}{l}6,498 \\
3,515\end{array}$ & $\begin{array}{l}7,533 \\
3,828\end{array}$ & $\begin{array}{l}7,920 \\
3,630\end{array}$ & $\begin{array}{l}7,626 \\
3,591\end{array}$ & $\begin{array}{l}7,473 \\
4,497\end{array}$ \\
\hline St. James ${ }^{21}$. & 153 & 4,761 & $4,8 \mathrm{I} 6$ & 6,390 & 6,459 & 6,093 & 6,718 & 6,815 & 6,604 & 7,179 & 7,890 & 7,670 \\
\hline
\end{tabular}

19b See note I5, ante.

20 Weymouth Parochial Chapelry is part of Wyke Regis Ancient Parish (Dorchester Division).

21 Poole St. James.-The population is exclusive of $(\mathrm{I}) 1,119 \mathrm{males}$ in $183 \mathrm{I}$ employed in registered vessels at the quay, and (2) I 29 males ( $I$ belonging to the port) in I 84 I also on board vessels at the quay.

\section{Grneral Note}

The following Municipal Boroughs and Urban Districts were co-extensive, at the Census of I90I, with one or more places mentioned in the table :-

Municipal Borough, or Urban District Lyme Regis M.B.

Poole M.B.

Portland U.D.
Place.

Lyme Regis Parish (Lyme Regis Borough)

Hamworthy Parish, Longfleet Tything and Parkstone Chapelry (all in East Shaston Division) and St. James Parish (County of the Town of Poole)

Portland (Dorchester Division) 



\section{AGRICULTURE}

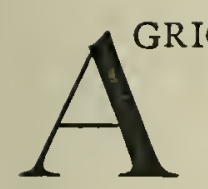

CULTURE in Dorset passed through many vicissitudes during the nineteenth century, and the lot of the agriculturist, bright as were its prospects in the earlier years, is now cast in very hard places. Indeed, so great has been the change that the farmer of 1800 , were he alive now, would scarce recognize his county. The number of sheep kept has dwindled, the corn area has become less, dairying is more general, the area of permanent and rotation pastures has increased, and many small minor industries, productive of great profit as they were, have completely died out. The period of depression which commenced in 1879 and culminated in 1895 and 1899 has left its mark on the county's chief industry, and it is not going too far to say that agriculture in Dorset is by no means in a prosperous state.

Fortunately the ill effects which the period of depression has left behind it have had the contrary effect upon the farmer himself. Whereas at the beginning of the century the Dorset farmer was looked upon by his neighbours as a man slow to change his primitive and antiquated methods of cultivation, there is now no farmer in the land who is so keen to essay improvements or who follows the progress of science in relation to the pursuit of agriculture with greater interest. But the depression has had its ill effect in so far that it caused many farmers to sell their land in order to provide capital for the continuance of their industry ; and so Dorset, which at one time was pre-eminently the county of the yeoman, has seen this most useful class of men almost extinguished within its borders. In his place has risen an excellent type of tenant farmer. The days of the 'three-bottle' man are past; the farmer of to-day is a keen, hard-working, practical man, who by dint of early rising and late retiring, and by constant supervision and close application to his work, manages to snatch a hard-earned livelihood from the land. Conservative he has always heen, and this trait of character is exemplified in his attitude towards a new-comer in the county. A practical man is welcomed, but years must pass before he is admitted into the fold of the Dorset farmer. Decades pass before he becomes 'one of them'; he is regarded, thought of, spoken of as a 'foreigner.' This is not a charge of inhospitality, and the stranger who makes the acquaintance of the native farmer is pleasurably gratified by the hearty welcome he receives.

The climate of Dorset is dry and salubrious rather than mild and bland, and the seasons, except in spots very sheltered or possessed of very warm soils, are less forward than those in parts of England not so far south. In the neighbourhood of the coast the rainfall is heavier in the winter than is needed, whilst conversely there is too little rain in the summer. As a necessary concomitant there is very little snow or frost during the winter months. Sea fogs, too, hang over the hills, with, it is suggested, prejudicial effects on the corn.

Dorset, unlike many, perhaps the majority, of our English counties, shows no one soil so predominant as to constitute a county characteristic. Towards the west on the lowlands it is mostly a deep rich loam; on the more elevated land it is a sandy loam intermixed with silex. In the northern and western parts, the vale of Blackmoor, 19 miles long and 14 miles broad, contains on various substratal clay foundations, limestone, \&c. some fine arable land as well as rich pasturage. Orchards here produce excellent cider. On the south, in the Isle of Portland and most parts of the Isle of Purbeck the soil is a stone brash. In the centre of the county the soil on the lowlands is a deep rich loam. The soil of the downs is generally a light calcareous earth covered by a remarkably fine turf. It is difficult to apportion the areas covered by the different soils, but some good judges put the percentages at :-Deep rich loam ten per cent.; a somewhat cold clay is credited with twenty per cent., and chalk with twenty-five per cent.; sandy formations occupy about fifteen per cent. and almost uncultivable rock is reckoned at ten per cent. This leaves twenty per cent. or one-fifth where the soils are very mixed even in a single parish or for that matter on a single farm. Serious geological disturbances and, geologically speaking, of no very remote date 


\section{A HISTORY OF DORSET}

appear to be indicated by the survey of the soils. IVood covers almost exactly five per cent. of the county area. Reckoning the area of the county at 632,272 acres we get the following table :-

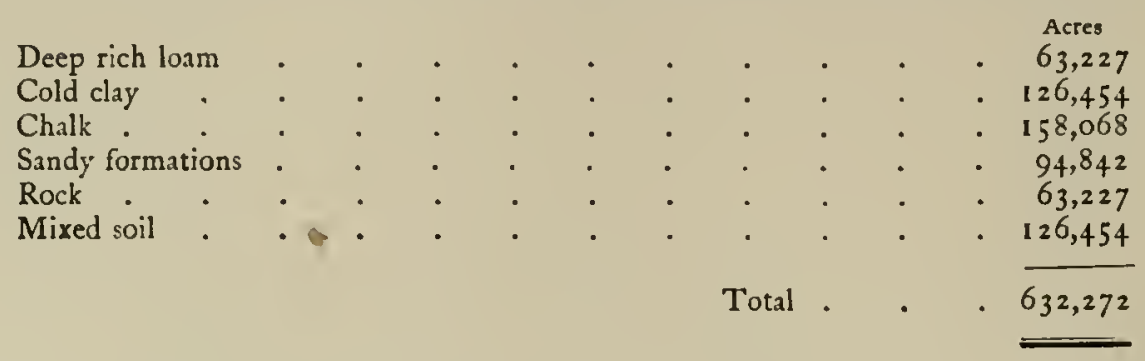

It must be remembered that no exact figures are available, and the above are only estimates which, however, will be found approximately correct.

Agricultural depression reacted on the landowners as well as upon the tenants. It is estimated that during the nineteenth century rents in Dorset declined in value by a half to a third and the fee-simple from forty to sixty per cent. In the light sand districts, where there are no special advantages by way of proximity to a town, it is found that even with careful management, after making necessary repairs to buildings and paying the land tax, there is practically nothing left as a net income for the owner, unless he has been fortunate enough to let his house and shooting at a good rental. In the best parts of the dairy districts the rents do not exceed 40 os. per acre, and some land is let at $15 \mathrm{~s}$. per acre; the arable districts are let at from 25s. to as little as IOs. per acre, all these rentals being tithe free. We do not wish to burden the reader with figures, but the following comparisons show how the value of rents in Dorset has declined :-

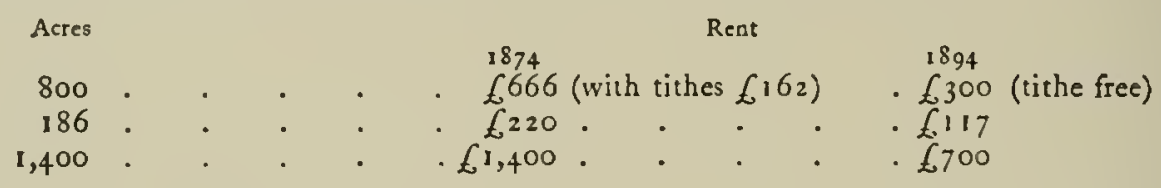

These three instances will give a fair idea of the decline in rent values. Yet there are few farms in hand, and the demand for farms up to 80 acres is fairly brisk. For larger farms the demand decreases in proportion to the number of acres. In regard to leases, the majority of farmers showed themselves as reluctant at the end of the nineteenth century to take a long lease as they were at the beginning. In 1800 leases were rarely granted for a longer period than twenty-one years, and even then contained a proviso to the effect that the tenant could yield up possession at four, five, or seven years if he so wished. Yearly tenancy is now the rule rather than the exception, though where a good tenant desires a lease he rarely has any trouble in getting it. There are few restrictions now included in the leases, though it is a commentary on the methods of cropping pursued by the Dorset farmer at the beginning of the nineteenth century when we find in the leases granted at that time restrictions as to sowing two corn crops together and the cultivation of fax and hemp. Also, it was stipulated that if two corn crops were sown together they should not be both of the same kind, and some grass was to be sown with the last crop.

The practice as to entry upon the land has not varied much. The incoming tenant enters upon the land at Michaelmas and takes the hay crop, though the late occupier took the after-shear. Formerly an obligation was upon the occupier to sow grass seeds among crops, but this is now generally done by the incoming tenant. This practice was dropped, as it was found that the outgoing tenant sometimes sowed infertile seeds, or baked the seeds before sowing. Repairs are mostly done by the owners.

The size of the holdings has increased. Since 1873 , the first year for which accurate returns are available, the average size of the holdings has increased from 86 acres to 95 acres in 1906 . Dorset is amongst the first counties in showing a large number of holdings of 1,000 acres and over. There are several farms in the county, held by father and sons and farmed as one holding, of over 2,000 acres, and one even reaches the huge size of 6,000 acres. Farms of 1,000 acres are quite common. As showing the decline in the number of acres farmed by landowners and yeoman farmers it may be mentioned that in 1871 an estimate gave 200,000 acres as farmed by their proprietors, whilst in 1906 the total was only 43,296 acres. In 1873 the Returns gave the acreage of inclosed land at 466,120 acres; in 1906 the figures stood at 476,140, showing that the inclosure of land was still on the increase. The increase in the size of the holdings is to be accounted for, too, by the fact that the number of men cultivating land has decreased. In 1873 the number of farmers making returns was 5,420 ; in 1906 the number stood at 5,012. 


\section{AGRICULTURE}

We are indebted to Mr. R. H. Rew of the Board of Agriculture, whose name will be familiar to Dorset men, for the following interesting Return, which gives proportion per 1,000 acres of land in the county, and the use to which it is put. The figures are for the year I 906 :-

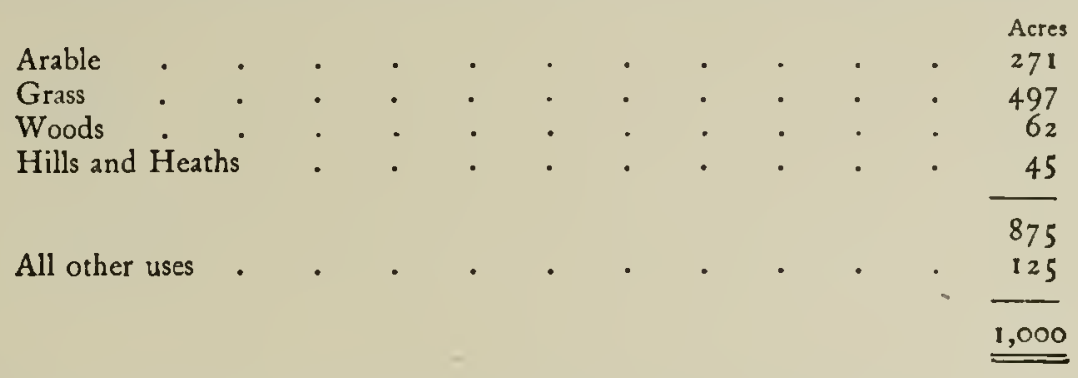

Agricultural statistics in Great Britain do not go back very many years, but the revolutionary period in our agriculture lies within the dates for which we have fairly precise returns, so that the first three-quarters of the nineteenth century may be briefly dealt with in Dorset as elsewhere. From I 801 to 1815 was a war period, with a feverish effort to cultivate as much land as possible for wheat, barley, oats, and pulse. With three per cent. consols down to sixty, it was not a time for government expenditure on statistics, agricultural or otherwise, and we shall never know exactly what areas were cultivated. All published estimates must be decreed void by reason of uncertainty. Owing to the war with France and the consequent self-dependence of the country, good and bad harvests exerted an extraordinary effect. Thus in February I 801 at Dorchester 200s. per quarter was paid for wheat ; but in October 70s. was accepted.

In 1809 we get a curious sidelight on the want of technical instruction. Dorset labourers were paid 9s. a week only, but girls could get 30s. a week, if clever, at plaiting straw. On 20 April of this year three days' incessant rain began in Dorset, and caused the worst floods since 1773 . The winter was wonderfully cold and the autumn-sown wheat was often killed, though a Dorset farmer notes in 1810 that the wheat berry of what ripened was remarkably fine. But the general result was so bad that it was estimated the crop would not exceed Io bushels an acre.

In 1815 began the great struggle for Free Trade. The Conservative government then in office passed a law prohibiting wheat imports when the price was under 80 s, a quarter. As the then average was 65 s. $7^{d}$. per quarter the import trade was practically killed. The issue, as we all know, was determined in 1846 . Thirty years' struggle had embittered feeling to the verge of civil war, and the victorious party showed no more moderation on their side than their opponents had done. It was 'all or nothing' with the combatants; yet, though the strife ended in 1846 , it was not until 1879 that British cereal agriculture really felt the full effect of the change. As late as 1877 , or thirty-one years after the Free Trade Act, the average price of wheat was $565.9 d$. a quarter, or 2s. Id. higher than in 1846 , the actual year of the statute. Thus it comes about that the full figures for Dorset which we have for 1873 are, although only thirty-three years old, of all the service that we want, for they relate to a time when foreign competition had made no inroad worth mentioning on the county agriculture. It will be well, therefore, to take the separate branches of agriculture in their respective divisions and place figures and comments together.

The cultivation of corn crops of all kinds has steadily declined, with the exception of the quantity of oats and rye sown. Oats show the greatest percentage of increase, though that for rye is but slightly smaller. In 1873 the percentage of corn crops to all crops was $24^{\circ} 8$. In 1906 it was 16.07 with a total of 76,551 acres under grain. With the exception of the year 1894 , which shows an increase over the preceding year of 3,500 acres, the Returns show a steadily diminishing quantity of about, in the earlier years, 3,000 acres per year, and latterly of about 1,000 acres. Bad seasons, low prices, and the laying down of land to pasture have all been responsible for this decrease, and it is questionable, when one comes to examine Dorset agriculture from the point of view of the Dorset farmer, whether he is not proceeding on the right lines. So far as feeding stuffs are concerned he can buy all the food he requires as cheaply as he can produce it. Indeed, there are farmers in Dorset who say that had they not to keep their land in cultivation it would pay them better not to grow corn crops at all.

Of the corn crops the principal, of course, is wheat, though it does not cover so large an acreage as some others. In I 873 wheat was grown on 46,740 acres. Even at that time wheat was unremunerative, and the total area was steadily diminishing. In 1875 the area was 44,384 and in 187641,329 acres, a decline of 3,000 acres. From 1876 to 1879 the decline, however, was only about 1,500 acres, but the latter superlatively bad year had its reflex in the Returns of 1880 , which give the total area of wheat as only 35,909 acres, a difference of 4,000 acres. Then the decline steadily continued year by year until 1899 , when wheat rose to a total of 


\section{A HISTORY OF DORSET}

25,060 acres, only to drop the next year, however, to 2I,8I 7 acres. In I 906 the figures stood at 20,254 acres, and there is very little hope that it will ever rise much above that figure. As prices are at present, a farmer, at all events in Dorset, cannot cultivate whent to compete with the imported article, and he can buy cheaper from the ship at Poole or Bristol than he can grow.

Like wheat, the barley area has steadily diminished. Bad seasons have had their effect, and Dorset farmers find it difficult to produce barley which can successfully compete with that produced by other counties and other countries. That mainstay of the barley-growing farmer-the breweris finding that he can use substitutes for barley which are cheaper, and where he finds he must have barley he prefers foreign barley which is thinner skinned, of a clearer colour, and more even quality. The Burton brewer, it is said, is becoming fonder of Dorset barley, but his recognition of it is very slow, and one or two bad seasons have made him very shy of the Dorset crop. Still, were brewers to encourage growers to produce good barley, there is not much doubt that the acreage under barley in Dorset at the present time would very materially increase.

In 1873 barley was cultivated on 38,269 acres. Two years later the area had increased to 41,329 acres, whilst in 1879 it had risen to 42,104 acres. Again that disastrous year shows its effect in a reduction of over 1,500 acres. In 1885 , in spite of the repeal of the malt tax, the acreage had decreased to 34,982 acres, but in the following year, owing no doubt to crop rotation, it had risen to 35,097 acres. From 1890 down to the present time, with the exception of 1894 , which shows an increase over the previous year, the area under barley has shown'a steady fall, until in 1906 the low figure of 21,995 acres was reached.

From the point of view of the tillage of the land the Returns of the acreage under oats afford us the most gratification. This, during the period from 1873 to 1906 , shows over fifty per cent. increase, due to the more extended use of oats as feeding stuff and to the enhanced value of oat straw, which has come to be recognized as equal to wheat straw. In dealing with comparison of prices between the two crops it must be remembered that oats give about $33 \frac{1}{3}$ per cent. higher return per acre than does wheat, and this usually more than compensates for the difference in price per quarter. Slight fluctuations there have been in the number of acres under oats, but generally speaking the Returns show a steadily increasing number of acres that are being cultivated under oats. In 1873 the number of acres sown was 20,992; in 190631,311 . With the exception of 1879 , which shows a total of 20,036 , the figures of the succeeding years have not been below those of 1873 .

The rye area has been almost a negligible quantity, at least so far as a corn crop is concerned. The cultivation of rye 'went out' to a great extent between I793 and I 815 , and has never since really come back into favour in Dorset. The use of other than wheat bread became, with a shilling loaf, the recognized sign of poverty, and as such was thrown off with the first return of good times. The areas given below, however, of course only refer to rye allowed to ripen into a corn crop. Rye cut green appears under a pastoral heading. On the figures it would appear that rye as a corn crop is slowly regaining popularity, but with the increased tendency in Dorset to lay more land down to grass it is doubtful whether it will ever rise to any prominence. In I 873 but 643 acres were cultivated for rye; in 1906882 acres were sown. But during this period the areas fluctuated somewhat largely. In 1883653 acres were down to rye; in 1885 only 575 , whereas in the following year the total was 773 acres. Again in 1893 a total of 1,457 acres was sown with rye, whilst in the following year the acreage rose to 2,996 . In 1903 the number of acres was 1,022 , and in the following year 1,049 acres.

When we come to consider the cultivation of green crops the decline in the acreage cultivated is as noticeable as it is in the cultivation of grain crops. The full total of acres under green crops in 1873 was $60,87 \mathrm{I}$. From that figure down to the 45,957 acres cultivated in 1906 is a big drop, which is particularly noticeable, of course, in the principal crop of swedes and turnips. Mangolds, however, show an increase, as will be seen from the figures. Potatoes have declined, as has the cultivation of the minor green crops. The diminution in the number of sheep has no doubt exercised some influence on the reduction in the acreage of roots, whilst the bad season of I 886, when the ravages of Ay spoilt the crop, and the bad season of 1899 , may have had something to do with the reduction in the area. The total for all green crops in 1873 included minor acreages not under the three chief crops. Among these minor acreages the most important were tares, lucerne, and rye cut green. These came to 8,794 acres altogether, but were not divided. The Returns of 1906 are better divided, Major Craigie's figures being as follows: Cabbage 49I, kohl rabi I Io, rape 1,606 , tares 4,649 , and lucerne 323 acres, giving a total acreage to the minor crops of 7,179 , as against the 8,794 acres in 1873 .

Land cultivated for potatoes has decreased in acreage in common with swedes and turnips. It is difficult to give a hard and fast reason for this reduction; their value as cattle feed is a negligible quantity, but with the increase in the number of pigs kept in the county it would seem likely to be profitable to continue to grow potatoes to the same extent as formerly. In 1873 the total number 


\section{AGRICULTURE}

of acres was 2,812, but in 1906 this area had diminished to 1,594 , the lowest figure since the Returns were initiated. The year 1885 showed a temporary rise to 2,453 acres, but in the following year the total went down to 2,226 , and since then has steadily descended to its present level.

Swedes and turnips, surely one of the most profitable crops for a sheep-rearing county such as Dorset is, show a decline of in round figures 10,000 acres since I873. At no time do the Returns show any check to the steady diminution in the area. Bad seasons have not been responsible for the decline in the number of acres; the rate of decrease has been steady and permanent. Dorset, as a county, was rather slow to take up the cultivation of turnips, but with the general practice prevalent in the county of feeding sheep off the land, it is difficult to see what sufficient reason there is for the diminished area. Of course the smaller number of sheep kept and the larger number of cattle is responsible primarily, but even this would hardly be the explanation of the full reduction. Labour difficulties have also played their part, and the consequence is that a crop which is essential to a sheep-breeding county is slowly declining. The acreage shown in the Returns for 1873 was 42,750 ; in 187940,680 , and about that figure in 1880 . The year I 890 showed a reduction to 36,919 acres, but in 1894 the area had risen to 37,150 acres. In 1900 the area was 32,371 , whilst in 1906 the figures had reached their present level of 30,709 acres.

Whilst one notes with regret the decline in the acreage of swedes and turnips, the increase which has taken place in the cultivation of the mangold is a satisfactory feature. It may be that its increased popularity is due to the greater results it gives to heavy manuring and the fact that it is a hardier crop. In any case the extended area under cultivation for mangolds compensates in some degree for the decreased area of swedes and turnips in so far as sheep feed is concerned. The year 1873 gives the total acreage as 5,183 , and with the exception of the years preceding and immediately following 1880 , when the acreage went down to 4,826 , that figure has remained the lowest total. The biggest jumpoccurs in the year 1900 , when the total was 6,167 acres as against 5,769 in 1899 . It may be taken that the increase is of a permanent nature, for the 1906 figures give 6,475 acres.

In regard to the minor crops no comparisons of any value can be given, but it is worth while recording that of the minor green crops only one, to wit tares, has received any great degree of attention from the Dorset agriculturist. Cabbage, which included thousand-headed kale, \&c., is grown very little, and kohl rabi hardly at all. The latter does not find much favour amongst flockmasters, as the trouble necessary to prepare it for feeding is not recompensed by the value of the food. Lucerne is practically only grown as a stand-by, though its cultivation can be traced back to the beginning of the nineteenth century, for Arthur Young in his Six IVeeks' Fourney through the Soutb of England speaks of a fine field of lucerne near Wareham.

Dorset in 1873 devoted 7 I 2 acres to flax, 9 acres to hops, and left 7,652 acres of arable land uncropped. In the earlier part of the nineteenth century one or two years' fallow was looked upon as being necessary to the well-being of land, but the agricultural scientists who have been teaching that bare fallow is unprofitable and bad farming may claim, in this agricultural county at all events, to have done good service, for in 1906 there were but 3,310 acres uncropped. In regard to hops, that culture has died out, foreign competition being too strong. The cultivation of flax, too, has been relegated to the past, foreign competition being one cause, and scarcity of labour, combined with the expensiveness of production, being another. As late as 1893 we get 36 acres of flax in the Returns, but for the past twenty years the cultivation of $\mathrm{Alax}$ in Dorset may be said to have been discontinued. In 1838 there were eighteen flax mills in Dorset, employing 656 hands. Eighty tons of flax were used weekly in a circuit of 20 miles round Bridport, one-tenth of which was grown in the neighbourhood.

Dorset, as a county, has not followed the culture of fruit to any great extent. The total of orchards in 1873 was 3,446 acres, and in 1906 4,492. Apples are grown, chiefly for cider, and the orchards are mostly situated in the west of the county. Nursery and market gardens, too, are but a minor consideration, the distance from any of the great centres of population being too great to allow of a lucrative return. The total does not much exceed 500 acres.

It is in considering the figures in regard to the acreage under grass that the great change which has overtaken the pursuit of agriculture in Dorset is most apparent. The scarcity and high cost of labour, the great increase in dairy-farming, and the unremunerative prices of corn crops have all aided in inducing the farmer to let his land go out of cultivation of grain and root crops. It might be imagined that some part of the increase is due to the greater recognition of the value of grass and clover as a rotation crop, but when figures are examined it will be found that less land has been broken up for clover and grasses and that the total acreage of permanent pasture has considerably increased. Rotation grasses have decreased in area by about one-sixth, whereas meadow and permanent grass lands have increased by nearly one-half. Out of, roughly, 480,000 acres cultivated in Dorset, pastures are responsible for 352,877 acres, leaving but some 130,000 acres for cultivation 


\section{A HISTORY OF DORSET}

of other crops. In 1873 the total of grass-land was 282,515 acres, and with the exception of the year 1880 , which showed a decrease of about 1,000 acres from the 1879 figures, the total number of acres under grass has steadily increased until it reached its present high figure. In I 906 some 122,429 acres, or nearly one-third of the total, were reserved for hay.

Rotation grasses and clovers form part of every field-course followed in Dorset. Sometimes it may be a quarter or an eighth, but there is little doube that the introduction of one and two years' ley has to some extent saved the rotation grass area from diminishing in even greater ratio than it has done. The decrease in the acreage of bare fallow is to some extent due to the farmer recognizing that more benefit is done to the land by sowing a grass crop than by allowing it to lie uncultivated. Yet there are many instances of farmers sowing grass for one or two years' ley with the intention of forming it into arable land later on and being forced to let the land lie in grass and become permanent pasture on account of the scarcity of labour. In all these reductions, too, the lack of capital is distinctly traceable, the cost of implements, seeds, and manures often being beyond the farmer's means. In 1873 the total number of acres sown with rotation grasses and clovers was 50,401. The bad season of 1897 showed an increase to 52,239 acres, but the following year the acreage went down to 51,656 . The year 1885 shows a jump to 52,157 , whilst 1886 shows a further increase to 53,285 acres. There the increase ends and the decrease begins. In 1890 only 51,556 acres were sown, whilst in the following year the total was but 50,304 acres. The number of acres remained about the same until I 894 , and the total of that year shows a decrease of over 4,000 acres on the preceding year's figures. That total remained about the same until 1900, when it was just under 47,000 acres, but the decline in the acreage of rotation grass is steadily continuing, for the 1906 figures give the total as but 42,528 acres.

A consideration of the total number of acres of perinanent pasture in the county of Dorset would infallibly lead one to the conclusion that it was essentially a county in which the breeding and fattening of stock was carried on to a greater extent than any other branch of agriculture. Yet the breeding and fattening of cattle has not been responsible entirely for the increase. When we consider that since the first reliable figures were available over 20,000 acres have gone into permanent pasture every ten years, we can only conclude that there must be a multiplicity of reasons which have been responsible for the change. From 232,114 acres in 1873 to 310,349 acres in 1906 is a big jump, and that it is no ephemeral condition is indicated by the steady rate of increase. The figures for 1875 showed the total at 262,427 , but the year following saw a reduction to 254,146 . However, this was but a temporary drop, and in 1885 we find the total acreage up to 277,503 and the following year up to 280,215 acres. Here, in five years, we have an increase of 23,000 acres. From that year the rate of increase has shown an addition averaging over 1,000 acres a year. The total for 1906 is the highest figure as yet reached in the proportion of permanent pasture to other land in the county.

In considering the number of horses, cattle, sheep, and pigs in the county during the nineteenth century we have to record an increase in the number of each class with the exception of sheep, and it is sad to notice that Dorset, pre-eminently a sheep county and one which gives its name to two distinct breeds of sheep, is gradually losing place in the first rank of sheep counties. Cattle, on the other hand, have increased by nearly one-third, dairy-farming being chiefly responsible. The number of horses, too, shows an increase of about one-seventh, and the number of pigs has increased by about one-fifth. With the large number of acres of pasture Dorset could carry more stock per acre than it does at present. The diminution in the number of acres of roots cultivated may be to some extent connected with this decline in the number of sheep, but it is certain that the smaller number of stock carried per acre now is not productive of so much good to the land as the larger number carried in years gone by. The reduction in the quantity of manure must be a serious matter, and the use of artificials cannot compensate for the loss of what is the most valuable of all manures. In all the percentages used in the following remarks it must be remembered that 'per acre' as used in the Board of Agriculture Returns means per 100 acres.

Dorset as a county has not gone in to a great degree for the breeding of shire horses. As early as 1800 the county surveyor for Dorset of that time referred to the class of horse used as being too light, and said that the breed might be considerably improved. The breed has been considerably improved, but Dorset is not a county in which the breeding of horses is likely to attain to the highest standard. The Compton Stud has done much in the improvement of the horses of the county, and the Blandford Farmers' Club has also assisted in this work by keeping an entire horse for the use of its members at a reduced fee. In 1873 the Returns showed Dorset as possessing 14,604 horses, whilst in 1906 the number had risen to 16,650 . This gives a percentage in 1873 of $3^{\prime} 1$ to the acre and in 1906 of 3.5 to the acre. The percentages are calculated in proportion to the acreage under crops, bare fallow, and grass. The rate of increase in face of these percentages has not been so great in proportion to the number of acres as in proportion to the total number of horses kept. Numerical progress has been steady, with no great fluctuation. In 1875 the total was 15,356; 


\section{AGRICULTURE}

in $1880,16,192$; whilst in 1885 it had fallen to 15,794 . The year 1890 saw the total up to I 5,970 and 1900 up to 15,558 .

It was after the disastrous year 1879 that farmers in Dorset commenced to pay greater attention to dairy supplies. That year reduced farmers' capital to such a degree that many of them found it imperative to turn their attention to a branch of agriculture which would yield them an immediate return for their outlay. In addition the growth of the large towns and seaside resorts was instrumental in increasing the production of milk by reason of the growing demand which the workers in the towns created. It must not be supposed that the increase in the number of cattle has been entirely with a view to milk-production, but this object has no doubt been the most important factor in bringing about the present situation. It is impossible to give figures for early years showing the growth of the milk supply from Dorset, which goes to London, Bournemouth, Weymouth, and other seaside places within or near the county, but some idea may be gathered from the fact that during 1906 there were dispatched by the London and South Western Railway to London and elsewhere nearly $5,000,000$ gallons of milk. As this would not represent the whole output of dairy produce, butter and cheese having to be considered, the value of dairy-farming to the county is at once apparent.

At the beginning of the nineteenth century the practice of the farmer keeping dairy cows was to rent them to a dairyman, who was in effect a small holder. This practice still continues in places, but as it was almost exclusively a product of large holdings the gradual levelling down of the farms has done away with the necessity for the dairyman, and the farmer now generally deals with the produce of his cows himself. Dorset butter is, of course, famous, though this branch has suffered, as in other counties, from foreign competition. Cheese, too, has somewhat declined, but high prices are gradually making the farmer turn his attention more to this product. Attention might well be drawn here to the famous 'blue vinny' cheese of Dorset. It is extremely popular in the county, but it is very difficult to obtain outside the county area. In appearance it is similar to Stilton, but has a more delicate flavour and in the opinion of the Dorset man is infinitely superior.

The fattening of cattle for stores, too, has made great strides, especially in the vicinity of the two great markets of Dorchester and Wimborne. Sales are held at Dorchester every Saturday and at Wimborne every Tuesday.

In 1873 the number of cattle totalled 75,232 with a percentage of $16 \cdot 1$ to the acre (every 100 acres). In 1906 the total was 94,405 , while the percentage had risen to nearly 20 per acre. Up to 1880 the figures varied but little, but in the five years ending I 885 there was an increase of 15,000 . The dry season of 1893 shows its effect in the figures for 1894 which go down to 79,955 . By the year 1899 the numbers had risen to 89,128 , but another bad season sent the figures down to 87,904 in 1900 . However, by 1906 the number of cattle kept had jumped to its present high figure of 90,405 .

The old breed of long-horned cattle, which at one time was almost the only breed in the county, is practically extinct, only one herd being known to exist now. Shorthorns were introduced in 1870 , and this breed is now the most common. There are several fine herds of Shorthorns to be seen within the county and one or two pedigree herds. Devon cattle are mostly to be seen in the west, but Shorthorns practically monopolize the rest of the county. Herefords are not popular, but at one time the popular dairy cow was a cross between a Devon and a Hereford, the latter for size and the former for constitution. The general all-round utility of the Shorthorn, both as a dairy cow and for fattening, has gradually made it more popular than the crossbreds, and it may be said that the majority of the cattle in the county are Shorthorns.

Sheep in Dorset enjoy the advantage of roaming over the chalky downs which suit the famous Southdown breed so well, and the manner in which they thrive in the county is evidence that Dorset is peculiarly adapted for sheep-breeding. It is all the more to be regretted therefore that the number of sheep within the county has shown such a great decrease. Much of this is to be attributed to the bad seasons which force farmers to sell regardless of price in order to find capital to continue cultivation of the land. In taking to sheep-breeding a farmer has to consider that he sees no return for his capital for twelve months. Possibly he may get a larger return in the end, but as has often happened in the past a farmer has had to take to some other branch such as milk production from which he gets an immediate return. Another factor has been the cutting up of large farms into smaller holdings and thus destroying what is essential to successful sheep-breeding-a good run. The first reason, however, apart from the effect of bad weather on the sheep, is the more true to fact, as witness the drop from 427,83 I sheep in 1873 and 498 , 010 in 1879 to 463,864 in 1880 , a decline of nearly 35,000 in one year. Farmers in Dorset do not desire a repetition of 1879 . Its influence is written largely in other branches besides sheep. Till 1885 the numbers remained much about the same, being in that year $460,37 \mathrm{I}$, but in the following year 1886 , due to the failure of the turnip and swede crop and a late winter, the numbers dropped to 448,635 . In 1890 the figures had 


\section{A HISTORY OF DORSET}

fallen to 418,945 , but the next year saw a rise to 438,567 . In 1893 occurred the drought which was, however, not responsible for the figures of that year being down to 410,134 , but in 1894 we get its full effect, there being nearly 30,000 sheep less, the figures standing at 383,693 . In 1899 there was a failure in the turnip crop and a cold and backward spring which inflicted great hardship on the sheep. Its ill effects are particularly shown in 1900 when the figures were $360,49 \mathrm{I}$, and it is an important fact to notice, especially when remembering the fecundity of Dorset sheep, that in the Returns for 1900 there were only 135,580 lambs as against 174,732 ewes. Compare this with the figures for 1906 , viz. 334,605 , out of which 177,576 were under one year old, and it needs little deduction to see in what sore straits the sheep were in 1900 .

Of the breeds in Dorset, for the purpose of this article only two, those directly connected with the county, need be considered. These are the Dorset Horn and the Dorset Down sheep. There are numerous flocks of Hampshire Downs in the county, as also one or two flocks of Southdowns.

Of the two breeds that of the Dorset Horn is numerically stronger within the county. The Dorset Horn Sheep Breeders' Association was established in I $89 \mathrm{I}$, and this society has affiliated to it the Anerican Dorset Horn Sheep Breeders' Association and the Continental Dorset Club, both with head quarters in America. The favour in which this breed is held extends not only to the adjoining counties of Somerset and Devon but also as far afield as New Zealand, Australia, Canada, and the United States.

The history of the Dorset Horn sheep goes back to the earliest records. In the Observations of Husbandry, published in 1757 , Edward Lisle remarked on the fecundity of the Dorset Horn sheep. WViliam Ellis in his Shipherd's Guide, published in 1749 , speaks of the Dorset variety as 'being especially more careful of their young than any other.' In Professor David Lowe's work on The Domestic Animals of the British Islands, coloured illustrations of Dorset Horn sheep were first given. These were in the possession of Mr. Michael Miller of Plush, who owned the last pure flock of original Dorset Horn sheep in the kingdom. They were characterized as a breed of sheep which, from time immemorial, had been naturalized in the county of Dorset. They had white legs and faces; their wool was fine and it weighed about $4 \mathrm{lb}$. the fleece. Their limbs were somewhat long, but without coarseness; their shoulders low, and loins deep and broad; their lips and nostrils black, though with a frequent tendency to assume a fleshy colour. They were a hardy race of sheep, docile, suited to the practice of folding, and capable of subsisting on scanty pastures ; their mutton was excellent.

The property of Dorset Horn sheep which remarkably distinguishes them is the fecundity of the females and their readiness to receive the male at an early season. They produce from $\mathrm{I} 30$ to I 80 per cent. of lambs, and have been known, like the sheep of some warmer countries, to produce twice in the year. They will receive the male as early as the months of April and May, so that the lambs are born in September or October, and ready for the butcher by Christmas. Within the last thirty years they have supplanted the Hampshire and Southdowns, especially in the neighbourhood of Dorchester and on those farms that are on the chalk and have good water meadows or pastures. They have within the past few years, owing to the larger area of turnips grown, and the use of cake and corn, together with careful selection, largely increased in size, proof, and weight of wool. The improved breed now comes to maturity quite as early as the best Downs, and may be described as straight and deep in the body, the ribs well arched, the loin broad, and the neck well set on. They are full in the shoulders, without coarseness, and the hind limb well let down towards the shank, forming a good leg of mutton with small bone. The general features are pleasing, the head standing well up, the horns thin with a symmetrical curl, the eye quick and lively, the face rather long and thin, and the lips and nose pink or flesh-coloured. They are excellent nurses, good folding sheep, and the mutton is well-flavoured; although they have been so much improved they, nevertheless, retain their hardiness and fecundity.

The general management of the breed in Dorset is as follows:-about one to one-and-a-half ewes are kept to the acre, according to the quality of the land and the amount of water-meadow pasture. They require plenty of room, and are generally allowed to roam the pasture in the day-time, being brought onto arable at night. The general lambing time for fock ewes is about Christmas and up to the middle of January. The off-going ewes are sold in lamb in September and October and lamb down in October and November. The flock ewes generally lamb down on the grass; they are then sent on to roots, the lambs being allowed to run forward. The lambs remain with the ewes till some time in May, and then go on to sound grass till the fodder crops, rye, vetches, or trifolium, are fit to feed. They remain on vetches till about the end of June. As most of the lambs are fattened, they receive as much cake and corn as they will eat, to fatten them as quickly as possible. The general allowance is about $\frac{1}{4}$ to $\frac{1}{2} \mathrm{lh}$. of cake or corn per day, with some peas. In a good season, with such keep, they would be ready to turn out about the first week in April. Lambs born in October and November receive good feeding and are generally ready for the 


\section{AGRICULTURE}

butcher when from ten to twelve weeks old, when they average 10 to $14 \mathrm{lb}$. per quarter, and go to the London market. They then make from 40s. to 50s. each.

The off-going ewes are fattened off as well as the lambs, and, when highly kept, are ready for market at the same time, and average from 22 to $28 \mathrm{lb}$. per quarter. Dorset ewe lambs have been bred from under twelve months old, the rams being put with them in November and December, and their produce being fit for the butcher in the following midsummer, realizing from 28 s. to 35 s. each.

This breed does better on the high sour lands than Down sheep, there being little risk in lambing them. The lambs yield from $2 \frac{1}{2}$ to $3 \mathrm{lb}$. of wool and the ewes from 5 to $7 \mathrm{lb}$., and yearling rams from 10 to $14 \mathrm{lb}$. The wool of the Horn lamb is much prized on account of its whiteness and the fine point it possesses, whilst the fleeces command better prices than those of most other breeds. The principal fair for the sale of Dorset Horn sheep, especially early lambing ewes, was formerly Weyhill, to which place they used to be driven a distance of fifty or sixty miles, and it was by no means uncommon for lambs to be born on the road. They do not undertake such a journey now, nearly the whole of them being brought on the last Thursday in September to Dorchester Poundbury Fair, established in 1848 , at which prizes are given for the best ewes. Some 13,000 to 16,000 sheep may be seen at this fair, and some of the ewes realize from 48 s. to 75 s. per head. A large annual sale of ewes, rams, and ram-lambs is held at Dorchester in the month of May. On these occasions ram-lambs fetch from five to twenty guineas each, and the best rams from fifteen to forty guineas each. Though the Dorset Horn sheep had a distinct class to itself at the Royal Agricultural Society's Show held at Battersea in 1862 , it was not until I 867 that this recognition was permanently established. Since then they have been regularly exhibited and prizes offered at the Royal and Bath and West of England Agricultural Societies and local shows. It is impossible to give the number of Dorset Horn sheep in the county, either for past or present years, but it may be sufficient to state that the Flock Book for 1906 contains the history of 45,302 ewes, 19,649 ewe hoggets, and 839 pedigree rams.

The breed of sheep known as the Dorset Down sheep, though enjoying but slight notoriety in present times, can trace its origin back to some eighty years ago. Its present type is rather an evolution of the Hampshire Down breed, in fact it was in its earlier days known as the 'Watercombe Breed of Improved Hampshire Downs.' Its establishment is due to the efforts of Mr. Thomas Homer Saunders of Watercombe, near Dorchester, who considered that the Down sheep then bred in the county, although a ' kindly' race of sheep, were deficient in size. He therefore selected the largest ewes he could find, and crossed them with rams of still larger size, and, by judicious crossing, in time he created a type of sheep that ultimately became known under the above title, which took its name from Mr. Saunders's farm. The sheep bred by Mr. Thomas Homer Saunders and Mr. Humfrey of Chaddleworth, near Newbury, who had experimented and produced a similar type of Down sheep, were largely introduced into the Down flocks of Dorset, and also into many of the flocks of Hampshire and Wiltshire, and in return the Dorset breeders have, to a large extent, resorted to the leading flocks of those counties for requisite changes of blood, with the result that the Durset Down breed now registered, although of finer bone and often of lighter colour, is closely related to, and possesses the principal features of, the Hampshire Down type, modified by local conditions.

A good type of Dorset Down should be free from all coarseness, the chief points being a rather long, full, clean face and under-jaw, with a bold bright eye and full muzzle; the ears should be fairly long, thin, pointed, whole-coloured, and carried well above the level of the eyes; the neck strong and well set on. The animal should be fairly fine-boned, and covered with a close fine fleece going well down to the hocks and knees, round the cheeks, and between the ears and on the forehead. It is desirable that the face, ears, and legs should be of a greyish-brown colour. The Dorset Down should embody the good points common to all breeds of sheep, but should be especially good through the heart and behind the shoulder; it should also have a well-let-down and rounded leg, and whilst not standing too short, there should be no tendency to legginess. The following are some of the chief characteristics of the Dorset Down breed as set out in the Flock Book :-

They are essentially a rent-paying type of sheep, especially adapted for thick-stocking, and are noted for their fecundity. They are of a very resourceful character, being capable of producing either sucking lamb at from 10 to $\mathrm{I} 2$ weeks old of the finest quality from $40 \mathrm{lb}$. to $48 \mathrm{lb}$. in weight, or at from 8 to 9 months old a well-finished carcase weighing from $66 \mathrm{lb}$. to $72 \mathrm{lb}$. of the very best quality of fleshy mutton, thus meeting the preponderating demand of the dead meat market for joints of more quality and less waste, which fact bids fair for the future progress of the breed. They possess a hardy and robust constitution and are very adaptive, being equally at home between the hurdles or in open grazing. 


\section{A HISTORY OF DORSET}

The principal sales of draft ewes and lambs are those held at Dorchester and Blandford during July, August, and September. Though strenuous efforts have been made to get a distinct class allotted by the Royal Agricultural Society they have not yet met with success. The Bath and West of England, however, have given a distinct class to this breed in their annual show, and the breed appears at all local shows. 'The Dorset Down Sheep Breeders' Association owes its inception to the Milborne St. Andrew Farmers' Club under the chairmanship of Mr. William Bedford of Bere Regis in 1904.

The general management of the breed differs very little from that of the Dorset Horn, the sheep being allowed to run in the pastures by day and brought in on arable at night. The carcase fetches on an average $\frac{1}{2} d$. to $I d$. more per $\mathrm{lb}$. than the Hampshire breed does, and an average clip of washed wool would be, lambs 2 to $2 \frac{1}{2} \mathrm{lb}$., ewes $4 \frac{1}{2} \mathrm{lb}$, and rams $9 \mathrm{lb}$. The Flock Book of the Dorset Down Sheep Breeders' Society for 1906 contains the registration of over 21,000 ewes, 8,000 ewe hoggets, and 350 rams.

The system of field farming now general in Dorsetshire is that known as the 'four-field system,' but on the large sheep farms round Blandford the five-field system is more prevalent, pastures being kept down two years instead of one. In that part of the county which adjoins the Yeovil district of Somerset the three-field system is general. On the hill farms of Dorset no systematic rule can be adopted. The failure of the crop is not unexpected and cannot be guarded against, so the occupier farms as he in his judgement thinks best, and as he has to pay the piper he may well be trusted to call for that tune which is most likely to suit the requirements of the season.

The Norfolk course of turnips, barley, clover, and wheat was introduced at the beginning of the nineteenth century but, with the natural conservatism of the Dorset farmer, was not much practised, and the old system of white straw crops still continued. Some farmers followed a course consisting of ( 1 ) turnips, rape, manured after ploughing in winter and spring ; (2) oats ; (3) beans, vetches, which were drilled and horse-hoed; (4) wheat ; (5) turnips, rape, \&c. ; (6) oats, \&ic., sown with clover $(7)$; clover ; (8) wheat. This was subject to variation, but the principle was never to have two white corn crops in succession. Summer fallowing was also practised as part of the course.

It was about the year 1850 that 'high farming' was first introduced into Dorset, and since that time the practice has spread until no farmer of any size or repute is to be found who sticks to antediluvian methods of cultivation. The practice has been fostered by the survey of the soils of Dorset undertaken by the college at Reading in 1898 , under the auspices of the Dorset County Council, which was productive of much sound service to the farmers. For wheat and oats it is general, where available, to distribute ro to 15 tons of farmyard manure per acre, and in spring to sow I cwt. of nitrate of soda per acre. After clover generally $2 \mathrm{cwt}$. of superphosphate or $3 \mathrm{cwt}$. of basic slag is applied. Where farm-yard manure is scarce an application of $4 \mathrm{cwt}$. rape dust and $4 \mathrm{cwt}$. basic slag, or $3 \mathrm{cwt}$. superphosphate, is recommended. For barley, after roots fed off, $2 \frac{1}{2} \mathrm{cwt}$. superphosphate or $2 \frac{1}{2} \mathrm{cwt}$. guano is applied, or, where following a cereal crop, $\frac{3}{4} \mathrm{cwt}$. nitrate of soda, 2 cwt. guano, or $2 \frac{1}{4} \mathrm{cwt}$. superphosphate and $2 \mathrm{cwt}$. kainit is applied. For turnips, it is usual to use farm-yard manure, about 10 tons to the acre, followed by 3 cwt. superphosphate, or instead of the dung I cwt. sulphate of ammonia and 2 cwt. kainit, the latter with I cwt. nitrate of soda. The different varieties of soils all require special dressings, and no particular fertilizer can be said to be in general use.

All implements common to agriculturists are in use in Dorset at the present day. Some reluctance was shown at the earlier part of the century, but the present-day farmer is widely awake to the advantages of labour-saving devices. Steam tackle has made great strides in Dorset, the implement firms letting the machines out on hire to farmers. At the beginning of the nineteenth century wheat was cut with smooth-edged hooks, and the scythe was very little used. Later the use of the scythe became more usual, and even to this day continues in some districts. This is very uncommon in England, though the use of the scythe for barley is recommended and known to produce a better sample. The old-time plough of Dorset was a single-furrow plough with the mould-boards usually covered with plate iron 9 in. wide, which was the breadth of the furrow. This was drawn by oxen, a practice which died hard, and even to this day there are one or two teams of oxen at work in the field. The harrow consisted of five beams, each of which contained five tines, 9 or $10 \mathrm{in.}$ apart. These harrows were sometimes drawn in pairs. There was also in use a smaller harrow for clearing ground of couch grass as well as an implement termed a nineshare plough, which would now be called a cultivator, and this latter did the work of the spring harrow. Sometimes instead of shares tines were inserted.

A wooden roller was used, which was in sections and covered with iron bands nearly 2 in. wide. This was used for rolling wheat, a smooth surface not being considered good. It corresponds to the rib-roller of to-day. Drills were not used much in the earlier half of the century, 


\section{AGRICULTURE}

owing to the labourers not being able to make use of them. At that time drilling was expert work, and men went from farm to farm on piece-work rates. Turnips were drilled by means of the Northumberland or Scotch turnip drill. Horse-hoes were used for turning a furrow from rows of peas, \&c., previous to their being moulded up by a double mould-board. Thrashing mills were worked by oxen and water power, all hand labour having been discarded. Chaff cutters were of one, two, and three blades. Wagons were lighter in build than in other counties, and the wheels wider apart, some being $5 \mathrm{ft} .6 \mathrm{in}$. In coming down hills one wheel was locked, and there was always a special thickened place in the tyre about $1 \frac{1}{2}$ in. thick on which the wheel slid. For sowing small seeds there was a sowing machine divided into divisions of $6 \frac{1}{2}$ in. apart, the perforations being in plates of tin and copper. Revolving circular brushes forced the seed through the holes. In about 1810 the Norfolk system of ploughing with two horses abreast was introduced, and harrowing was frequently performed with three horses abreast. For rolling, one to four horses were used.

Dorset has enjoyed a reputation for a century past for neat hedges. They consist chiefly of thorn, but sometimes of hazel, maple, and privet. The usual method is to chop away superfluous wood and to lay the top branches down, cutting the wood in such a way that it will grow again. No dead wood is used, and by this method, by the time the hedge requires re-trimming new wood has grown sufficiently to do this. The banks are built up almost perpendicularly.

If the lot of the farmer is not a prosperous one, it is pleasant to record that the lot of the farm labourer has greatly improved. The employment of women in the fields has almost entirely disappeared-a matter for congratulation, if only on humanitarian grounds. The cottages, generally speaking, are in good repair. Those of a modern type consist of one or two living rooms and scullery, with sometimes as many as three bedrooms. A great advance has been made since 1842 , when it was recorded that a family of eleven persons, total earnings 16 s. $6 \mathrm{~d}$. per week, lived in a cottage of only two rooms. At that time, too, it is recorded that a family of twenty-nine persons lived in one cottage. In 1842 female labour in the fields was common, and boys started work at six or seven years of age. In 1869 the guardians passed a by-law prohibiting the employment of boys under ten years of age. At this time women were employed picking up stones, working at hay and corn harvests, planting, digging and earthing potatoes, attending to the threshing machines, winnowing corn, dairying, and sometimes even leading horses at the plough. It is worth while recording, too, that in 1834 six Dorset labourers were tried and sentenced to transportation to Australia for seven years for the heinous crime of forming a trade union. Disgusted with the low wage and the generally low conditions of life, they formed a union for the amelioration of the labourer's life. The union was to be kept secret, but a report of it leaked out, with the results mentioned above. Thus ended one of the pioneer strikes of trade-unionism in this country, to the glorification of the men who subsequently became known as the 'Dorset martyrs.'

The passing of the Poor Law in 1849 was responsible for the change in the rate of labourers' pay. Prior to that time the outdoor relief induced the farmer to pay on the lowest scale he could, knowing full well that the parish would come to the aid of the poor labourer. Up to that time a labourer's wages were as low as $6 s$. a week, and rarely higher than Ios., with no special advantages. Out of this he frequently had to pay Is. or 1s. $6 \mathrm{~d}$. a week rent. Now, the wages are very seldom lower than IIs., and then only for a single man practically unskilled. The general wage varies from 125 . to as high even as 20 s. and 225 . a week, and in addition the labourer gets sometimes a cottage, and invariably coal and wood, which is carted free, and a plot of land on which to grow kitchen produce. He is usually allowed to keep a pig, though in some instances this has been refused, the farmer having cause to suspect that his own feeding stuffs were laid under contribution for the benefit of the labourer's pig. These wages do not, of course, include the extra allowances at harvest time.

Farm buildings have also greatly improved, though the low rents make the landlord reluctant to expend money in erecting new buildings or repairing old ones. Too often attention has not been paid sufficiently to convenience, the buildings in some cases being in a position which renders excessive carting necessary.

This article would not be complete without reference being made to the many excellent farmers' clubs now in existence in Dorset. These number six: the Blandford, Winfrith, Milborne St. Andrew, Gillingham, Shaftesbury, and Wareham and Isle of Purbeck. All these clubs send a representative to the Central Chamber of Agriculture, and, in addition, are centralized under the Dorset Joint Agricultural Committee. With the exception of the Wareham Club, all these clubs date back many years. The Blandford Club is the oldest, the date of its inception being 1848 ; but it is not many years the senior of the Milborne St. Andrew Farmers' Club and the Winfrith Farmers' Club, both of which were instituted in 1856 . These clubs have a total membership of about a thousand, of which the Blandford Club has the largest share with a membership list of 273. With the exception of the newly-formed Wareham Club, all the other clubs have a 


\section{A HISTORY OF DORSET}

membership ranging from one hundred to two hundred. The clubs meet periodically, generally once a month for eight months in the year, to discuss matters political and agricultural, and to listen to papers read by experts on methods of agriculture, progress of agriculture, \&c. The meetings have been found to be of great interest and utility to the members. The clubs further encourage the labourers to perfect themselves in their work by offering prizes in competition for hedging, ploughing, and other rural crafts. Prizes are also offered to the shepherd who shows the best result during lambing time. In this educational work the Dorset County Council ably supports the clubs by making grants of money towards the prizes, and by holding technical education classes at which the labourers can attend. 


\section{FORESTRY}

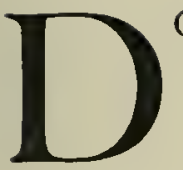

OMESDAY SURVEY, as is well known, pays particular attention to the woods of the various manors, as they were so invaluable for purposes of building, fencing, and fuel, and more especially for the feeding of swine on the acorns and beech-mast. Wherever a wood is entered, some indication of its size is also always set forth. Most of the Domesday commissioners were content to give a rough estimate of the size of the wood by stating the number of swine which it would sustain, or the number of swine payable to the lord for pannage rights; but in some counties, as is the case with Dorset, Derbyshire, Lincolnshire, and Oxfordshire, the size of the wood is given in lineal measure.

In the survey of Dorset the woodland is divided into three classes:-(1) silva, (2) silva modica, and (3) silva minuta. By the first term all well-grown timber is indicated, by the second wood that is less matured or where the timber trees are further apart, and by the third mere copse wood that is frequently felled at periodical intervals. In one case, namely at Rentscombe, there were fifty acres of silva infructuosa, by which term is apparently meant a wood that bore no fruit for the swine and was probably of ash. Mention is also twice made of mere scrub or brushwood (broca), namely on the manors of Canford and Lytchett; in each of these cases there was a parcel of I 20 acres of scrub.

In Dorset there were vast areas of both silva and pastura, more particularly on the royal demesnes. The wood of Wimborne, which was part of the ancient demesne of the crown, was five leagues in length by one in breadth; the wood of Dorchester four leagues by one; and that of Pimperne one league by half a league. The league (leuca) of Domesday was doubtless to some extent a customary and somewhat variable term; but it may generally be reckoned to correspond broadly with a mile and a half of our measurement. ${ }^{1}$

These measurements, and several others like them, probably signify the extreme length and breadth of the woods, and do not take into account the exact shape of the wood $;^{2}$ it must not, therefore, be assumed that Wimborne wood was precisely five square leagues, or 7,200 acres in extent. Eyton, ${ }^{3}$ in his elaborate analysis of the Dorset Domesday, gives tables showing that the then area of woodland of all kinds throughout the county amounted to 104,62 I $\frac{3}{4}$ acres, or about one-sixth of the whole surface. If to this is added the 206,494 acres of pastura, or rough open feeding ground as opposed to pratum, the conclusion is reached that about half the county was then of a wild or waste description and at least suitable to be considered forest. However this may be, that Dorset was to an unusually large extent given up to game may be gathered from other Domesday entries. Waleran the hunter (venator) held nine manors in Dorset, whilst amongst the king's thegns of this county three others, Aluric, Godwin, and Uluric bear a like title.

The use of the term 'forest' as implying a great wood is a comparatively modern rendering, which is false to its etymological origin. A forest, throughout Norman, Plantagenet and the earlier Tudor times, meant a great district, mostly waste, reserved for royal sport and under special forest laws. A certain amount of wood and underwood was necessary as covert for the game, but in several forests, such as those of Dartmoor, Exmoor, and the High Peak, the woodlands formed but 2 very small part of the whole area. The districts of Dorset that were technically forest included no small quantity of moor, heather, and down. ${ }^{4}$

The large amount of old royal demesne in this county, which was divided into six distinct groups, doubtless served as forest hunting ground for the later Saxon kings. Under the early Norman

${ }^{1}$ Eyton, Key to Domesday, 25.

Ballard, Dom. Inquests (1906), p. 166.

Sey to Domesday.

- In this necessarily brief summary of the story of the forests of Dorset, a certain knowledge of forest laws and customs has to be assumed, such as their local administration by swainmote courts, and the recurring visits of justices for holding Forest Pleas. The respective duties of foresters, verderers, woodwards, and regarders, \&c., are set forth in Turner, Select Pleas of the Forest (1902), or in a more popular form in Cox, Royal Forests (1905). 


\section{A HISTORY OF DORSET}

kings, and especially in the reign of Henry I, the area of the royal forests of England was largely extended for purposes of revenue, and although under Stephen it is probable that many of these extensions lapsed, his Angevin successor and his sons, as the Pipe Rolls bear witness, again took full advantage of their forest rights.

The Forest Charter of the beginning of the reign of Henry III much reduced the forest area, but left four distinct forests, namely those of Gillingham, Blackmoor, Powerstock, and Bere Regis; the last of these, however, ceased to be forest towards the close of the reign.

The various forest divisions in early days usually passed under the collective name of the forest of Dorset. As early as the reign of Henry I we learn that forest pleas were held in Dorset, and the name of at least one of the foresters of the court, Warin, is recorded on the Pipe Roll for II 30 . Several of the annual Pipe Rolls of Henry II contain brief references to the account rendered by the sheriff for the wastes, assarts, purprestures, and pleas of the forest of Dorset. The amounts greatly varied-I I $70-1, f_{0} 08$ 4s. $3 d_{0} ;$ I I $7 \mathrm{I}-2, f_{0} \mathrm{I} 9$ 8s. II $d . ;$ I I 72-3, 3s. IId.; I I 73-4, 3 s. $2 d . ;$ II $74-5,3$ s. $2 d . ;$ and $1176-7, £ 53$ s. $8 d$. The large total for the first of these years probably arose from its including the period when the occasional Forest Pleas were held by the justices. ${ }^{5}$

These Pipe Rolls remind us that the two great contiguous counties of Dorset and Somerset had for some time a joint sheriff. Nor is it surprising, as the vast stretch of woodland ran continuously across the borders of the two shires in several directions, that there was a certain amount of connexion in their forest rule. Thus, the chief forestership that was vested in WVilliam de Wrotham by Richard I extended over Dorset as well as Somerset. This forestership in fee of the whole bailiwick of the forests of the two counties descended from this William de Wrotham to his son of the same name, who was archdeacon of Taunton and a great organizer of the navy under King John. The office next descended to a nephew, Richard de IVrotham, who was a minor until r 225. Richard died without issue in $125 \mathrm{I}$, and his four married sisters became his heirs. The eldest sister Muriel had married Hugh de Placetis, and their son WVilliam de Placetis, or Plecy, succeeded as forester in fee for the two shires. He died in 1274 , and his son Richard in 1289 . Richard had no issue, and this hereditary office passed to his sister Sabina, who brought it in marriage to Nicholas Pecche. This forestership ended in $\mathbf{1} 337$ by sale, under Matthew Pecche, grandson of Nicholas. ${ }^{6}$

A general perambulation of the forests of Dorset was undertaken by fourteen knights early in the reign of Henry III, as a consequence of the Forest Charter of 1217 , whereby all that had been made forest since the day of the coronation of Henry II was to be restored. The report, as presented before Hugh de Neville, Brian de Insula, and three other justices, stated that Alan de Neville, the king's forester, had afforested all the high lands or downs of the county (omnia montana) after the above-named coronation, and therefore they ought no longer to be under forest rule and are part of the woods pertaining to Bere and the wood of Powerstock which were royal demesne, the latter having been obtained by the crown through exchange with Roger de Newburgh. King John had also afforested the whole island of Purbeck; and this was no longer to be forest, save for the warren of hares pertaining to Corfe Castle. The perambulation then proceeded to set out the exact bounds of the forests of Gillingham and Blackmoor, docking the former of certain woods that had been added since the accession of Henry II. ${ }^{\text {? }}$

In June 1228 Hugh de Neville was ordered to proclaim, both by word of mouth and by letter, to the men of Gillingham that they were free to pasture their animals in the woods of the king in accordance with the old customs. ${ }^{8}$

In November of the following year the sheriff of Dorset received a mandate to issue general summonses for the approaching Forest Pleas. ${ }^{9}$ Strictly speaking, Forest Pleas were supposed always to follow the Regard, or independent close inquiry held every three years by at least twelve knights of the shire called regarders, who drew up a report as to the condition of the particular forest, especially as to the assarts or inclosures and the purprestures or encroachments. In course of time, however, these pleas were held most fitfully and at very long intervals. Among the forest records of Dorset, however, are the presentments of two of these eyres of the reign of Henry III, which were held at the three years' interval, namely in 1257 and I 260 .

There are full accounts extant of the Forest Pleas of Dorset held before four justices in $1257 .^{10}$ Among the venison presentations made by the foresters and verderers in the forest of Bere we find

${ }^{6}$ Pipe R. (Pipe R. Soc.), xvi, 17 ; xviii, 75 ; xix, 193; xxi, 18 ; xxii, 24 ; and xxvi, $21-2$.

${ }^{6}$ See Hutchins, Dorset, iv, 517 ; Collinson, Somerset, iii, 63 ; and more especially Greswell, Forests and Deer Parks of Somerset $(1905), 138-47$.

3 From the Book of Cerne, Camb. Univ. Lib. cited by Hutchins, op. cit. iii, 662-3.

${ }^{8}$ Close 12 Hen. III, m. 7 .

${ }^{9}$ Close 14 Hen. III, m. $22 d$.

${ }^{10}$ For. Proc. Exch. T. R. No. 10. 


\section{FORESTRY}

the case of Hugh Fitzhugh de la More, who had taken the fawn of a roe deer. In consequence, he had been imprisoned at Ilchester, but apparently had been released before the date of the eyre, at which he did not enter an appearance. He was accordingly outlawed. Several trespassers were charged with taking two deer and a roebuck in the same forest; others with taking a hind and a roebuck in the same forest; another with hunting a hind; two others with hunting and one with taking a stag. The fines for these offences varied from a mark to half a mark. The vert or 'greenhue' presentments in Bere forest numbered thirty-four cases. The large majority of these charges were for small offences in taking green wood, and the delinquents were fined from $12 d$. to half a mark. One was excused on the score of poverty. Thomas, chaplain of Bloxworth, had not allowed himself to be attached, probably on the ground of his clerical privilege, and a mandate was accordingly directed to the bishop of Salisbury to produce him before the justices. Among graver charges, the heir of Richard de Wrotham, late master forester, was fined 535. $4 d$. since that officer had taken the 'coporones' or top and lop of a large number of oaks felled for the works at Corfe Castle under the direction of Master Gerard, the carpenter. These branches trimmed from the timber Richard de Wrotham had probably appropriated as a natural perquisite. The usual fine in small cases of trespass against the vert was $12 d$., and the same amount was levied on John, the son of Manser Dodde, who had discovered in the forest a swarm of bees and carried them off.

The venison presentments for the bailiwick of Gillingham, of which the record is slightly imperfect, included the taking of a buck and doe, of a fawn, of a brocket, two does, four does, two bucks and a doe, and several other fallow deer, as well as hunting with bows and arrows, and hunting with greyhounds. Among other offenders was John, the parson of Fisherton, who had not been attached and did not appear. In consequence, a mandate was directed to the bishop of Salisbury to produce him at Ilchester. The vert cases were upwards of sixty. The heavy fine of $305.3^{d}$. was imposed on two men who had sold cablish or wind-uprooted timber in 1256 , and IOs. IOd. for a similar offence in 1257 .

It was certified before the justices that eighty logs (ligna), forty from the park and forty from the foreign wood, had been used on the works at Gillingham, and six beams (fusta) for making sluices in 1251; six oaks for the works of the chapels of Corfe and Dorchester, in 1252; six timber oaks for the nuns of Shaftesbury, in I 253, and various other timber gifts to the Dominicans of Wilton and Gloucester, and to different religious houses and individuals, including sixty oaks and sixty ash trees to the earl of Cornwall in 1257.

The pannage fees of Gillingham Forest varied very greatly from year to year, in accordance with the abundance or the scarcity of acorns or beech-mast. The pannage receipts of 1250

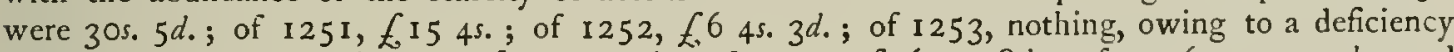
of mast and acorns; of $1254, £_{10} 3$ s. $7 d$.; of $1255, f_{16}$ Is. $8 d$.; of 1256,43 s. Iod.; and of 1257,50 s. 10d. Various chartered claims for forest privileges were made and sustained before the justices.

There is an imperfect roll presented at this eyre of the woodwards of the county of Dorset, who were sworn before the justices, beginning with John Malot, woodward of the king of the wood of Bere and five others of different private woods in that forest. The woodwards of Blackmoor actually numbered upwards of thirty; six of them were wardens of as many woods that pertained to the abbess of Shaftesbury. Their number is a proof of the extent and frequency of the actual woods within the Dorset forests, particularly of the Blackmoor division. A forest woodward was an important official. Though primarily responsible, as the term implies, for the actual timber and undergrowth of the district in his charge, he was also to some extent a technical forester, that is, he was at the same time responsible for the venison. To understand their position it is necessary to remember that there was never a single royal forest, all the lands of which were demesne. In each forest, and this was emphatically the case with that of Blackmoor, there were various woods that were private property, nevertheless these woods were subject to general forest jurisdiction, such as the free ingress and egress of the king's game.

Moreover, the owners could not, without the king's licence, do anything therein, such as felling timber, clearing undergrowth, building houses or sheds, establishing forges, or burning charcoal, that might be held to alarm or damage the deer. To look jointly after their own rights and those of the crown, owners of woods within a royal forest were not only permitted but required to appoint woodwards, who took oath before a forest justice to serve the king in the matter of venison, and who had the power to attach and present offenders.

The venison presentments of Powerstock included :-the charge against the men of Gerard de Bengham, archdeacon of Dorset, of hunting in 1251 in the forest with the archdeacon's dogs and taking a roebuck; each of the delinquents was fined 4s.; taking a roebuck with two greyhounds, and the taking of five other roebucks, two roe-does, and two stags by different offenders. The vert presentments of Powerstock numbered fifty-one, and the fines varied from the usual I $2 d$. to $3^{\text {s. In }}$ three cases an alibi was established. 


\section{A HISTORY OF DORSET}

The venison presentments of Blackmoor are imperfect, but they include the taking of two harts, several does, a fawn, and a buck. The vert presentments amounted to a hundred and thirty-nine separate charges.

Pleas of the Forest for Dorset were again held in 1270 , before Roger de Clifford and three other justices at Sherborne. ${ }^{11}$ The first membrane opens with a list of nine of those summoned to attend who were dead, and with the fines on defaulters varying from 2 s. to 20 s. The vert presentments for the bailiwick of Blackmoor amounted to eighty-three, the fines varying from I $2 d$. to half a mark; an alibi was established in two of these charges, and a few offenders were excused on the ground of poverty. The vert presentments of Gillingham for the same period numbered thirtythree, but these included a variety of cases in which oaks had been granted by licence, such as two oaks from Robert de Wychampton, dean of Salisbury, and a single oak for Master Nicholas de Cranford, parson of the church of Gillingham.

There is also an entry to the effect that 407 oaks had been felled at Gillingham since the last pleas by the king's orders, including 238 for repairs to the houses and court at Gillingham, and twelve for the works at the castle of Sherborne.

The venison presentments of Powerstock were solely concerned with the taking of roe deer, concerning which there were three cases; whilst the like charges at Blackmoor at these pleas were only concerned with fallow deer, involving the killing of a buck, a fawn, and fourteen deer. The Blackmoor presentments also included several cases of hunting and one of snaring, when there was no known capture of game. The Gillingham presentments were concerned with fallow deer, save a single case in which a stag (red deer) was killed. A large number of instances of inclosures and encroachments, contrary to the assize of the forest, were brought before the justices as the result of the regarders' reports.

These Forest Pleas dealt with the whole of the forests of the county, It may be as well now to give a few further selected particulars that can be gleaned from the general records as to the different forest divisions of the shire.

Gillingham, in the extreme north of the county, flanked by Somerset on the west, and by Wilts on the north and east, was originally one of the divisions of the widespread ancient forest district of Selwood.12 Various perambulations of Gillingham, of the reigns of Henry III, Edward I, and Elizabeth have been printed in the third edition of Hutchins's Dorset. ${ }^{13}$ Broadly speaking, whatever may have been its earlier limits, the bounds of Gillingham Forest, subsequent to the Forest Charter at the beginning of the reign of Henry III, were nearly conterminous with those of the ancient parish of Gillingham, which was one of the largest in the county, having a circuit of $4 \mathbf{I}$ miles, and an area of over 15,000 acres. Leland says that in his days it was 'four miles in length, a mile or thereboute in bredth.' 14

The bailiwick of this forest was usually in the hands of some person of note, who held it in serjeanty as the king's forester in fee, and was bound to maintain it at his own cost. This hereditary office, according to Coker, was held throughout the greater part of the reign of Henry III by IValter Joce. ${ }^{15}$ On his death in 1265 , it was found that Walter held of the king in chief a carucate of Jand in Gillingham and kept the forest, both vert and venison, at his own charge. ${ }^{16}$

At the death of John Joce, in 1310 , it was found that he held lands in Gillingham to the extent of a messuage and 137 acres by serjeanty of being forester in fee of Gillingham, and keeper of the park of the manor which was then in the hands of Queen Margaret, by grant of Edward I. ${ }^{17}$ $\mathrm{He}$ left two daughters heiresses; the elder, Amicia, conveyed this bailiwick, with its fees and profits, to her husband, William de Buggele, who died seised of it in I3I4. Two years later this forestership was alienated by the crown to William Hame and his heirs. In the reign of Henry IV the bailiwick of forest and park passed from Hame to Stourton, in which family it remained until the attainder of Charles Lord Stourton, when the office, valued at $f_{4} 0$ per annum, reverted to the crown. ${ }^{18}$

There was also a supcrior office in this forest over the forester in fee, the appointment to which rested with the crown at pleasure. In 1340 Edward III confirmed Matthew Beleval in the wardenship of Gillingham Forest for life, to which office he had been nominated by Queen Isabella on the death of John le Hayward. ${ }^{19}$

From time immemorial the abbess and convent of Shaftesbury had the right to take four horseloads of brushwood for fuel from this forest every day save Sundays. But in 1340, when one Geoffrey de Cotes, temporarily supplying the place of John de Monte Gomery, steward of Queen

\footnotetext{
"For. Proc. Exch. T. R. No. I1.

${ }^{13}$ Ibid. iii, 620-1, 66z-3.

"Coker, Surv. of Dorset (1732), 87.

Coker, Surv. of Dorset, 88 , where the name is misspelt "Foce.'

${ }^{16}$ Inq. p.m. 49 Hen. III, No. 2.

${ }^{18}$ Hutchins, Dorset, iii, 624 .

${ }^{17}$ Inq. p.m. 5 Edw. II, No. 42.

${ }^{19}$ Pat. $1+$ Edw. III, pt. I, m. II.
} 


\section{FORESTRY}

Philippa, was in charge of the manor, he one day saw the four horse-loads being carried to the abbey. Entirely ignorant of the privilege, Geoffrey ordered the foresters, in the name of his lady, not to permit them to take the brushwood any longer. Whereupon the convent made suit to the king, and their ancient privilege was speedily confirmed under privy seal. ${ }^{20}$

Mandate was issued by Edward I, in 1273, to Alan de Plogenet to deliver to Eleanor, the king's mother, the manor of Gillingham, with the hundred and forest and other appurtenances, then in his custody. ${ }^{21}$ About the same time writs were directed to the bailiffs, goodmen, and foresters of Gillingham, informing them that Gillingham had been assigned in dower to the king's mother. ${ }^{22}$

In 1318, when a large assignment of dower was made to Queen Isabella, the manor and forest of Gillingham, valued at $£ 80$ a year, formed a portion. ${ }^{23}$

In 1275 an inquiry was instituted on behalf of Master Nicholas de Cranford, parson of the church of Gillingham, touching his claim to the tithe of venison taken in the king's forest of Gillingham, of the hay and herbage sold in the glades thereof, and of the pannage; also to compensation for the tithe of the glade of Marleye, whereof he asserted that his predecessors were possessed when that glade was arable land and titheable to the church. ${ }^{24}$

The sheriff of Wilts was ordered in April, I280, to deliver Peter de Esquidemor, imprisoned at Old Sarum, for trespass in the king's forests of Dorset and Somerset, to twelve men who undertook to have him before the king in the Parliament after Easter next. ${ }^{25}$

At the close of the year $\mathbf{2} 279$ the king granted quittance of the common summons to attend the pleas of the Dorset forests to William de Mohun, the bishop of Salisbury, the abbot of Hyde, Matilda, widow of Robert Waleraund, Hildebrand of London, and Oliver de Ingham. ${ }^{26}$

In March, 129I, the sheriff of Dorset was instructed by the crown to cause a verderer to be elected for the for est of Gillingham, in the place of Roger Anketil, deceased. ${ }^{27}$

Edward I, like his predecessor, made frequent gifts of both timber and venison from Gillingham. Sarah de Merreth received seven oaks fit for timber in 1292, of the king's gift. Twelve oaks fit for timber were given to Eustace de Hacche, in the same year, to rebuild his hall. In the following year Walter de Aylesbury received six timber oaks. The constable of Corfe Castle, Richard de Bosco, obtained six oaks for the works at the castle in July, $1293 .^{28}$

The keeper of Gillingham was ordered in May, 1292 , to present the bishop of Salisbury with six bucks, of the king's gift ; in the following month a similar gift was made to Joan, wife of Alan de Plukenet; and in July a like gift was supplied to Eustace de Hacche. ${ }^{29}$

In the following year Roger Lestrange, forest justice, was ordered to. allow Peter de Chalone to have six live bucks out of Gillingham forest. ${ }^{30}$ In December, 1 293, the keeper of this forest was ordered to supply John Mautravers with ten does; and in the following January Robert de Bosco, of Corfe Castle, was supplied with four Gillingham does ; in July, I 294, Eleanor de Curtenay had four bucks, and in August, Nicholas de Sancto Mauro three bucks. ${ }^{3 \mathrm{I}}$

In August, I 2 I 5, King John sent his huntsman Albert de Capell, with two horses and fourteen buckhounds (damericii canes) to take bucks in his forest of Blackmoor. ${ }^{32}$

Henry III, in I223, gave John de Erleigh eight does and two bucks or brockets out of Blackmoor towards stocking his park at Duston. ${ }^{33}$ In the following year William earl of Essex and William Briwere had each the royal licence to take six bucks in Blackmoor, ${ }^{34}$ and venison gifts from Blackmoor were fairly frequent throughout the reign of Henry III. ${ }^{35}$

About the same period the king made several gifts of roofing-timber and of brushwood for fuel out of the Blackmoor Woods. Somewhat later, gifts including an oak in 1230 for the bridges of Corfe Castle, ten oaks in I 232 to the Earl of Lincoln, and sixty oaks to the abbot of Bindon, in I 233, for the fabric of his church. ${ }^{36}$

John de la Lynde, in I266, had a grant from Henry III of the bailiwick of the forests of Blackmoor, Gillingham, and Powerstock which he held for five years. ${ }^{37}$

Of this forest of Blackmoor, Leland (temp. Henry VIII) says that it 'streachid from Ivelle unto the quarters of Shaftesbyri and touchid witte Gillingham forest that is nere Shaftesbyri.' ${ }^{38}$ 'The earliest known perambulation of this forest, which seems to have been taken soon after the granting

${ }^{20}$ Pat. 14 Edw. III, pt. 2, m. 6 ; Misc. Chan. Bdle. 11, file 8 (13).

"2. Ibid. m. 5 .

$$
{ }_{23} \text { Pat. II Edw. II, pt. 2, m. } 30 .
$$

${ }^{26}$ Ibid. m. 11 d.

${ }^{21}$ Pat. 1 Edw. I, m. 15.

${ }^{25}$ Close, 8 Edw. I, m. 9 .

$10,9,5$.

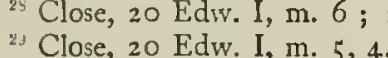

${ }^{30}$ Close, 21 Edw. I, m. 9.

${ }^{31}$ Close, 22 Edw. I, m. 13, 12, 6, 5 .

${ }^{32}$ Close, 17 John, m. 24 .

${ }^{2}$ Pat. 4 Edw. 1, m. 32 d.

${ }^{27}$ Close, i $9 \mathrm{Edw} . \mathrm{I}, \mathrm{m} .7$.

${ }^{35}$ Close, 12 Hen. III, m. 4 ; 13 Hen. III, m. 8 ; 14 Hen. III, m. 14 and pt. 2, m. 2 ; 15 Hen. III, m. $20,17,1 ; 16$ Hen. III, m. 10, $6 ; 17$ Hen. III, m. 17, 1 小.
${ }^{36}$ Close, passim.
${ }^{35}$ Leland, Itin. vi, ror.
${ }^{37}$ Plac. For. 54 Hen. III, cited by Hutchins, op. cit. i, 188. 


\section{A HISTORY OF DORSET}

of the Forest Charter at the opening of the reign of Henry III, occurs in the Book of Cerne in the Cambridge University Library; a translation is given by Hutchins, as well as a later one of the year $1300 . .^{39}$ The latter of these perambulations were made, inter alia, by Walter de la Ly'nde, Richard le Bret, and Ralph le Brox, former foresters in fee of this forest, and by Walter de Thornhull and Roger de Plumber, verderers of the same. In the 1300 perambulation the jurors recite a considerable number of vills, hamlets, and woods that had been afforested by King John and added to Blackmoor Forest, but which had been disafforested in the time of Henry III and again by a confirmatory writ of Edward I in I279. Among them were the vills and woods of Melcombe Matravers, Melbury Bubb, Batcombe, Wootton Glanville, Mappowder, West and East Dulham, Haselbury, Fifehead Neville, Fifehead St. Quintin, Caundle Haddon, Caundle Beyn, Caundle Purse and Duntish, with several others.

The manor of Bere or Bere Regis, about the centre of the county, was of royal demesne in Saxon times. ${ }^{40}$ King John had here a royal residence, sojourning at Bere for repeated short visits throughout his reign. ${ }^{41}$ In 1259 this extensive manor was granted by Henry III to Simon de Montfort, and hence ceased to be a royal forest. Ten years later it was granted to Edmund, the king's brother. Edmund in the same year granted a moiety of it including the wood of Bere to the abbess of Tarrant. This grant was confirmed by Edward I. ${ }^{42}$

As to the forest or wood of Bere, which is difficult at times to distinguish in the records from the forest of the same name in Hampshire, there are a few references on the Close Rolls of Henry III. Thus in I 230, the sheriff of Dorset was directed to assign forty oaks to Henry FitzNicholas out of the wood of Bere, for building the manor-house of Fordington; $;^{43}$ and in I23 I Hugh Paynel had a royal gift from Bere of three roebucks. ${ }^{44}$

The large parish or liberty of Powerstock, in the south-west of the county, gave its name to a compact, small forest district. It was not royal demesne at the time of the Domesday Survey, when it was held by Hugh of Roger Arundel. From the Arundels it passed by marriage to the Newburghs, and from the Newburghs it was acquired by King John, who exchanged it with Robert de Newburgh for lands in Somerset, and who then proceeded to make it a forest, as is definitely stated in documents of the reigns of Henry III and Edward I. ${ }^{45}$

Henry III gave the bailiwick of this forest to John de la Lynde; it was valued at a mark a year. He died in I 272, when Edward I accepted the homage of Walter de la Lynde, his son and heir for all the lands which John had held in chief, together witb the bailiwicks of the three Dorset forests of Blackmoor, Gillingham, and Powerstock. ${ }^{46}$

There are also occasional references to the wood or forest of Powerstock in the Close Rolls of Henry III. In I23I the king ordered that Thomas de Gorges of his houschold should alway's be allowed a reasonable amount of dead or dry timber out of Powerstock. ${ }^{47}$ In the following year Godfrey de Craucombe obtained the gift of six roe-deer out of Powerstock Forest, and six more out of the king's park at Newton, Somerset, towards the stocking of his park at Bere. ${ }^{48}$ At a perambulation of this forest, held in 1300 , Walter de la Lynde is named as taking part in it as forester in fee and Robert de Bingham as verderer. ${ }^{49}$ Although afforested as late as the time of King John, this comparatively small forest was not affected by the Forest Charter of Henry III, as it was genuine royal demesne. In the time of Edward III the manor and hundred of Powerstock were held by a subject in chief of the king, and hence it became practically disafforested. Coker, writing in 1732 and not understanding the nature of a forest, says, 'in former ages a forrest, but nowe it is most destitute of woodes." 50

Some reference must be made in connexion with Dorset forestry to that great tract of country known as Cranborne Chase. This great chase had originally been royal forest, but in quite early days passed into the hands of a subject, and hence, though retaining much of the local administration of a forest with some of its rights and customs, ceased to be under the particular jurisdiction of the king's justices in Forest Pleas. The 'Outbounds' or Outer Chase of Cranborne embraced not only the north-east corner of Dorset, but also a considerable extent in Wiltshire, together with certain parts of Hampshire. It contained about 800,000 acres and seventy-two parishes, including parts of the city of Salisbury and of the towns of Wilton, Shaftesbury, Blandford, Wimborne, and Ringwood. Within this vast circuit was the chase proper or 'In-bounds,' which was about

${ }^{3}$ Dorset, iv, 516-17.

"Close, 9 John m. 17, 13 ; 'John's Itin.' Arch. xxii.

"Hutchins, Dorset, i, I36; Close, + Edw. I. m. 7 .

"Close, 14 Hen. III, m. 74 d. "Close, I 5 Hen. III, m. 17.

${ }^{3}$ Testa de Nerill (Rec. Com.) I $65 b$; Hund. R. (Rec. Com.) i, 97 ; Perambulations of $c$. I 225 and I 300.

${ }^{46}$ Abbrev. Rot. Orig. i, $19 . \quad{ }^{47}$ Close, 15 Hen. III, m. I 2.

${ }^{4}$ Close, 16 Hen. III, m. 17.

49 This perambulation is given in extenso in Hutchins, Dorset, ii, 317 .

so Coker, Sursey of Dorset, 26. 


\section{FORESTRY}

ten miles in length, between three and four in width, and twenty-seven in circuit. The story of Cranborne Chase is full of interest, both in old days and in comparatively modern times. As the chief residence of the holder of the chase was in the Wiltshire portion of the inner circuit, it is thought best to give the sketch account of its history under Wiltshire Forestry.

The extant fifteenth-century records of Dorset forests are not numerous. The wood sale accounts of Richard Cressebien and Matthew Vynyng of the forest of Gillingham, for $1402-3$, are extant and in good condition. They are still inclosed in the leather pouch in which they were originally forwarded to London. ${ }^{51}$ There was a considerable number of oaks used this year for the lodge and pales of the park of Gillingham, as well as for the lodges of Dunhurst and Mardle within the forest. The sale is entered of numerous 'rothers,' which seems to have been a variant for roers or robora, a term for oak trunks. They varied much in value, doubtless according to size. Four rothers for Walter Hert, chaplain, were valued at 33 s. $4 d$. ; they were probably for the repair of the chapel. A rother for the prioress of Shaftesbury was only valued at $16 d$.

Pleas ${ }^{62}$ of the forest of Gillingham were held at Shaftesbury in September, 1490 , before Sir Reynold Bray, Edward Chaderton, clerk, and Richard Empson, as justices of the forest of Elizabeth, queen of England, on both sides of the Trent. Among the various officials who appeared were Philip Lucas, the deputy for Sir John Luttrell, sheriff of the county, who was not present in person; William Twynyhoe, esquire, lieutenant of the forest for Sir John Cheyne; William Goodwyn, ranger; Gilbert Thomson, parker of Gillingham, and two other foresters, ${ }^{53}$ the launder (the keeper of the launds or pasture grounds of the deer), the servant of the lieutenant, the bailiff and his fellows of the Hundred of Redlane, the two verderers, eight regarders, and the reeves and four men of each of the townships of Gillingham, Motcombe, and Bratton. The palmy days of forest law and its highly detailed administration were already fading away. About the most important business transacted was the due allotting of perquisites of oaks, roers, and bucks to the officials and the registering and confirming of old liberty claims within the forest. The jury of the Hundred of Redlane presented a list of various persons who had felled oaks, but in almost every instance they knew not the numbers nor the warrant. It will be noticed that at these pleas, Gillingham Forest was described as pertaining to the queen of Henry VII. From the days of Edward, Gillingham manor and forest were usually assigned to the sovereign's consort as part of her dower. It was part of the portion of at least two of the wives of Henry VIII, Ann Boleyn and Catherine Howard.

At a swainmote, or local forest court, of Gillingham Forest, held before Robert, the steward, on 18 January, 1534, the jury, on their oaths, presented John Netherwend and two others for having 'kylled a male dere called a Sowre at Middelhege within the quenes grace libertie and free warren adjoynyng to hyr graces Forest of Gyllyngham,' and further charged the same offenders with having 'kylled a doo with a halter a sowre with greyhounds at Wethers.' William Grymston was charged with carrying at his girdle five halters, and going with certain others on a night in November to a place called Hawkyns; also, on another occasion, going with others 'into Myddelhegge and there they sett up three halters but they kylled nothyng.' 'There were various other charges of killing fallow deer by night, in the park of Gillingham, against William Grymston, yeoman, and his servants. At a previous manor court of the manor of Gillingham, evidence had been given of the violence of Grymston in breaking the king's peace by armed threats against those who were witnesses of his poaching, especially against one Alexander Frances, 'and there dyd yll intrete hym offering to thrust his dagger in hym yf he did speke one word and otherwyse that is to say in suche wyse that he of his pore lyf was in dispayre. ${ }^{54}$

Various noblemen or gentlemen held the office of warden or constable of the forest of Gillingham in its later history usually in conjunction with like offices elsewhere; such were the earl of Warwick in the reign of Henry VI and Sir Humphrey Stafford in the time of Edward IV. From 1593 till 1604, Sir Walter Raleigh and his son Carew held the offices of ranger of the forest, steward of the woodwards' court, keeper of the park, and steward and bailiff of the manor of Gillingham. ${ }^{55}$

When the manor of Gillingham was granted to the earl of Elgin, part of the forest lands were reserved for the crown ; but in July, 1625, a lease was granted by Charles I to Sir James Fullerton, his old preceptor, for forty-one years of the herbage of Gillingham Park at the ancient rent of $f_{\mathrm{II}}$, together with 2,408 acres of waste at the rent of $12 d$. an acre, the latter to be

${ }_{51}^{51}$ Mins. Accts. bdle. 141, No. 11.

${ }^{52}$ D. of Lanc. For. Proc. bdle. 3, No. 2.

${ }^{53}$ The forestership in fee, as the proceedings record, was at this time in dispute. John Thornhill was apparently in possession and claimed a moiety at least, and a 'robur' was granted to his deputy who put in an appearance. But Humphrey Pokeswell also claimed the hereditary office in the right of Elizabeth his wife, and a date was fixed for the further consideration of the matter.

${ }^{54}$ Ct. R. ptfo. 170, No. 17.

${ }^{55}$ Hutchins, Dorset, iii, 624 . 


\section{A HISTORY OF DORSET}

improved for the king. The lessee was to maintain 400 deer in the park for the king's recreation..$^{56}$ But the following February Sir James Fullerton had a grant of all the deer within the forest and park. $^{57}$ In March, I628, a revised lease was granted to Sir James, under which licence was granted to dispark..$^{58}$

In August, I629, IVilliam Connock, one of the king's huntsmen, petitioned the king as to a royal grant made him in the previous year of trees to the value of $f_{\mathrm{I}} \mathrm{ro0}$ in the forest of Gillingham, and trees were appraised to him by the commissioners. These trees Connock afterwards sold for f. I 90 , and he was called upon to repay the overplus. He prayed that he might retain the overplus and his prayer was granted. ${ }^{53}$

It was about the close of 1628 that Charles I by commission formally disafforested Gillingham, allotting several shares to the commoners and borderers and making Sir James Fullerton farmer of the considerable crown portion with right to inclose and fence it. This inclosing of what had been for centuries common pasture land was vehemently resisted. Mobs, armed and disguised, threw down the fences, filled up ditches three miles in length, sawed up the rails, carrying them off or burning them, and threatened the farmer's workmen with death. They took an oath to be true to each other, and to rescue any who might be apprehended. Eventually sufficient force was obtained to secure the arrest of the ringleaders and early in 1630 the Attorney-General proceeded against Henry Hoskins and eighty-seven others for riot and destruction in the Star Chamber. Thirty of the delinquents (many of whom were of good position) were fined $f_{200}$ each, thirty-five $f_{1}$ oo each, and nine $f_{0}$ to each. All were bound to good behaviour for two years and additional fines were imposed for damages to Sir James Fullerton and to the two king'smessengers who had been assaulted. Hoskins, who was styled the colonel of the rioters, Alford the captain, Cave the lieutenant, and Miller the corporal were also set in the pillory with papers on their heads declaring their offence ${ }^{60}$ Sir James Fullerton, in 1630, was granted by the king the whole of the Star Chamber fines levied on the rioters. ${ }^{61}$

In considering the story of the deer and the timber of any particular county, both of which are included in the old significance of the term forestry, some attention should be paid to the private parks as well as to the actual forests or royal hunting. Parks or fenced inclosures for deer, containing more or less timber and coverts, could not be formed without royal licence; but not only were such licencés pretty readily granted to the larger landowners from the thirteenth century onwards, but the sovereign was frequently ready, as we have noticed in this county, to make grants of live deer for the purpose of park-stocking.

There is extant an interesting record ${ }^{62}$ of the Dorset parks, inclosures, and commons, drawn up in the year 1583 , for the information of the authorities who were anxious to encourage the breeding of horses for military purposes. Similar lists were prepared for several other of the southern counties.

The true certificate of all and every the parkes, inclosures and Comons within the said County expressing their severall circuits and names of the lords and owners of them And what nomber of horses mares and stalliands for brede are yearly kepte accordinge to the Statute.

Hundred of Cogdenne. - Imprimis there is within the said hundred two parks belonging to the house of Canford. The great parke called Canford Parke being one myle di in compasse And no mares kept there. The Litle parke called Lye Parke being a myle in compasse And no mares kept there Thearle of Huntingdon and Mr. John Baker owners of the said parkes but no dere in either of them.

Item there is within the said hundred a Comon about the compas of iij myles belonging to the house of Canford and the villages adjoining upon the said Comon are these viz. Corf Mullen, Mr. John Phillips and Mr. Thomas White of Fisleford lords of the said village.

Item Mr. Henry Trenchard Lorde of Litchet Matreverd and his tenants do entercomon upon the waste grounde of Cogdenne.

Item Sir Thomas Kitson knight lord of South Latchett and all his tenants do entercommon upon the said waste grounde of Cogden.

Item there are within the said hundred one other parke called Litchett park Mr. Henry Trenchard lorde thereof. And is in compasse I myle or more And no dere kept there And but one mare kept there according to the Assize of the Statute.

Hundred of Badburye.-Item there is a parke within the said hundred called Holte parke which is the Quenes majesties continent in compasse iij miles And there are deere kept. Mr. Thomas Lorell liath the herbage thereof by lease And doth kepe there I mare agreable to the Statute.

Item there is a Comon within the said hundred called Holte foreste which is her majesties and is compass iij myles And her majesties tenants do comon there. But no mares or Stalliands kept upon the same agreable to the Statute.
${ }^{26}$ S.P. Dom. Chas. I, vol. 4 , No. 97.
ss Ibid. vol. 15, No. 79.
57 Ibid. App. 563 .
${ }^{60}$ Ibid. vol. 159, No. 28 ; vol. 143, No. 66 ; Rushworth, Hist. Coll. 1639-4, No. 73.
${ }^{61}$ S.P. Dom. Chas. I, vol. 187 , No. 46.
${ }^{69}$ S.P. Dom. Eliz., vol. 163 , No. 20. 


\section{FORESTRY}

Liberty of Gillingham.-Item the Queens majesties parke of Gillingham is in compasse iij myles and deere kept there Sir John Zowche knight warden thereof And doth kepe ij mares there and the Fee fosters one mare agreable to the assize of the statute.

Item Mr. Thomas Morton esquire hath a ground in Gillingham called Bengfeldes in compasse one myle and doth kepe $\mathrm{ij}$ mares there according to the assize of the statute.

Hundred of Knowlion.-Item there is within the said hundred a parke called Woodland Parke Sir Francis Willoughbye Knt. lorde thereof And is in compasse one myle and better Mr. Ralph Lambert hath it to farme And doth kepe for bread iij mares in the parke and one stalland agreeable to the assize of the statute. And no deere is kept there.

Item there is within the said hundred one inclosed grounde in compasse one mile Thomas Goode owner thereof And doth kepe ij mares in the same agreeable to thazzize of the statute.

Hundred of Cranborne.- Item there is a parke within the said hundred called Blagden Parke The Queen majestie lady thereof And Mr. James Hannam farmer of the same And is in compasse iij miles And no deere nor mares or Stalland kept there.

Item there is within the said hundred one other parke called Alderholt parke Thearle of Pembroke lord thereof And is in compasse ij myle And no deere mare or stalland kept there.

Item there is within the said hundred a comon heathe called Cranborne Comon which is her Majesties containing in compasse iij miles and the entercommoners upon the same are these the town of Damerham which is the bishopes of Sarum; The villages of Harbridge and Litle Asheford And no mares or Stallands kept there agreable to the Statute.

Item there is also a comon within the said hundred called Bouslye Comon within the parish of Shilling Eckeford Mr. Brokesby lord thereof And is in compasse one mile and no mares or stalliands kept there.

Hundred de Whitchurch.-Item there is one parke within the said hundred called Chediocke Park belonging unto Sir John Arundell Knight containing in compass a mile and a half or thereabouts wherein are no deere But disparked and converted only to tillage And no mares kept there according to the statute.

ltem there is one other parke within the said hundred called Marshwood parke which is Sr Ame, Poulett land containing in compass iij myles or thereabouts But disparked and converted into diver tenements And no mares keep there according to the statute.

Item there is within the said hundred one other parke called Cricklake parke which is the land of one Mr. Baker in Kent But is likewise disparked and converted to pasture and tillage and containing in compasse two myles or thereabouts But no mares kept there according to the Statute.

Item there is within the same hundred one other parke called Wotton parke which is the land of John Wadham and Edmund Hardye esquire containing in compass one mile or thereabouts And in their occupation But no deere in the same neither mares kepte according to the Statute.

Hundred de Egerton.-Item there is one parke within the said hundred called Hooke parke which is the land of the right honourable the Lord marquis of Winchester containing in compass one myle or thereabouts and in his occupation in which parke there is as well deere kept as also mares according to the statute.

Hundred of Tollerford.-Item there is one parke within the said hundred called Melburye Parke which is the land of John Strangwaies esquier containing in compasse one mile and half and in his occupation in which parke there is as well deere kept as also mares according to the Statute.

Hundred de Shurborne.-Item there is one parke within the said hundred called Shurborne parke whereof Sir John Horsey knight is owner continent in compasse ij myles or thereabouts and in his occupation in which parke there is as well deere kept as also mares according to the Statute.

Item John Miller of Cane holdeth a certeine inclosed ground within the said hundred called Bailye continent in compasse by estimation a myle and somewhat more wherein are kept no mares according to the statute.

Item there is within the said hundred a Comon of her Majestie called Blackmore Comon continent by estimation in compasse $v$ myles And these villages and townships viz Folk Burton Holneste Busshopes Downe Blackmores ford and Lidlinche be entrecomoners upon whiche comon ar kepte and yearly breade a great nomber of mares and colts of small stature but very few or no stalliands according to the statute.

Hundred of Redlane.- There is within the said hundred two Comons whereof the one is parcel of the manor of Sutton Walron And is proper to thinhabitants thereof only And by estimation continent I myle in compasse The other is parcell of the manor of Chilockeforde and hath borderinge upon it the comons of Sturminster and Ockeforde fitzpaine and of Fiforde with others and continent likewise by estimation one mile in compasse or thereabouts But the pasturing of the said comons is not imployed to the breadinge or fostering of mares Stallands or colts but converted to the breadinge of other cattle and at certeyne tymes of the yeare to sheepe excepte it be only of a very few colts of small stature And of themselfes profitable to nothing.

Hundred of Yetmister.- Item there are within the said hundred two comons of her Majesties whereof one of them called Ryme Comon continent by estimation I myle and upwardes in compasse These villages videlt the tethinge of Ryme and the tethinge of Yelmister ar intercomoners and the other called Lye Comon continent the like compasse or thereabouts these villages viz. Lye Batcombe, Wolcombe Melburye Bubbe and Hiefeld which is the lands of George Trencharde esquire are entercomoners wherein are kepte and yearelye breade a great nomber of mares and colts of small stature But very fewe or no stallands according to the statute. 


\section{A HISTORY OF DORSET}

Hundred of Nestron. - Item there is within the said hundred two commons of her Majestie whereof one of them called West Comon continent by estimation I myle in compasse or thercabouts These Mannors viz Lidlinche West Bagber, East Bagber and Mr. Crokhorne his tenants of Haydon do entercomon The other called Gobson Comon continent the like compasse or thereabouts the Mannors hereafter mentioned be intercommoners viz. Chilockesover Ockeforde ffitzpain South Fifett Fifett Nevill and Plumber ar entercomoners upon whiche comons ar mares kepte accordinge to the statute.

Hundred of Bucklonde. - Item there is within the said hundred one Comon of her Majesties called Blackmore Comon continent by estimation vj myles in compasse or thereabouts wherennto these Manors viz Pulham Holwall Bucklande and Wotton Glanfeld do entercomon And upon the same ar Mares kept according to the statute.

Item within the said hundred one Henry Stoyett of Mylton holdeth by lease one enclosed ground called Duntishe Park being disparked and the lands of the Lord Morden continent by estimation one mile and a half in compasse wherein are not mares kept accordinge to the Statute.

Hundred of Whitcuay. - Item there is within the said hundred one farke called Melcombe Parke continent by estimation ij myles and a helf or thereabouts in compasse being the land of Sr John Horsey Knight And in his occupation in whiche parke he as well deere kepte as also Mares and Stallands according to the Statute.

The Isle of Purbeck, which is the name for the south-easterly corner of the county, though ceasing, as has been stated, to be a royal forest under forest laws in the time of John, long remained a home of the red deer, which roamed almost at will throughout the whole territory, extending twelve miles in length, and ten miles in the widest part from north to south. Within the warren or park of Corfe Castle there were also fallow deer. Documents of the fourteenth and subsequent centuries occasionally name the Forest of Purbeck; but it was more usually termed Chase, the correct title when held by a subject. The Constable of Corfe Castle, who held that office under various titles, was lieutenant of the whole island, and not infrequently denominated chief forester or warrener. In a quaint map of the Isle of Purbeck, drawn by one Ralph Treswell, circa. 1585 , red deer (both stags and hinds) are drawn as roaming about in all parts of the district. ${ }^{63}$ The author of a survey of the western counties, drawn up in 1635 , says of Purbeck :-

In this island doth range many goodly deere that are hedged in with a surer pale than wood (sea and river), which, when they are hunted will adventure into the sea and take salt soils, whereby they stand long and make brave sport, of which (having a fit opportunity and a little time to cast away) I had some part, much to my content. ${ }^{6 t}$

King James is said to have been the last of our kings who hunted here; he visited Corfe Castle in I615. The open heaths of the eastern side of the island were eminently suited as runs for the red deer. The last of these wild deer are said to have perished during the great Civil War.

There are but five deer-stocked parks at the present day in the whole of this extensive county. ${ }^{65}$

Charborough Park (Mrs. Ernle-Erle-Drax) is one of the finest parks in England; it is beautifully timbered on undulating ground. The area is 798 acres, and it is stocked with 400 fallow and 250 red deer. The park also contains 35 Brahmin cattle. There has been no planting done on this estate for many years, but the present owner is much interested in forestry and replanting has begun (1907) at Moram Park. Charborough Park was inclosed on its present lines early in the nineteenth century, but there had previously been a park of a smaller extent within its limits, and the park at Lytchett, a mile in compass, just mentioned in the 1583 survey, was near at hand.

Sherborne Castle (F. J. B. Wingfield-Digby, Esq.) The actual deer park has an area of 328 acres and is stocked with 280 fallow deer. There are also two Japanese deer. All the fallow deer are of a dark brown colour, and very few are in any way dappled. In addition to the park proper, there is a considerable extent of surrounding park-like grounds with finely displayed groups of timber and stretches of bracken, flanked with wood. The whole covers about 1,000 acres.

There are a large number of roe-deer living wild among the woods, particularly in the Old Park, Honeycombe, and Whitfield woods. Of late years a considerable area of woodland has been replanted.

Melbury House, Dorchester (Earl of Ilchester) is surrounded by a fine old well-timbered park of about 500 acres, stocked with about 500 deer, red, fallow, and Japanese. Here was an ancient seat

E3 'This map is preserved at Kingston Lacy ; a reproduction is given in the last edition of Hutchins' Dorset, i, 462 .

6t Lansdowne MS. 213.

${ }^{65}$ Some of the brief information as to Dorset parks is gained from Decr and Deer Parks (1867) and Whitaker, Deer Parks (1892), and some from local observation; but I am chiefiy indebted to the ready courtesy of the agents of the different estates. 


\section{FORESTRY}

and park of the old family of Strangways from whom the Earls of Ilchester are descended in the female line. It is thus mentioned by Leland in the time of Henry VIII :

This is a fair park hard by the manor place of Milbyri and yn this park is a pond, out of the wich issueth a broketh, that with the course of a right few miles goith into Ivelle Rvyer. . . Mr. Strangways now and late began to builde richely at his commune dwelling House in Milbyri Park, and caussed three thousand lode of free-stone to be fetched from Hamden Quarre nine myles of thither. ${ }^{\text {r. }}$

At the present time all kinds of forest trees indigenous to England grow luxuriantly in Melbury park; there are many of great age and size. The old historic oak tree has attained to the immense girth of $40 \mathrm{ft}$. Four elms in front of the house, part of a group of seven trees, are from I 20 to $125 \mathrm{ft}$. high, and about $27 \mathrm{ft}$. round the base of the trunk. Amongst timber in the park that is still growing may be mentioned an oak $25 \mathrm{ft}$. high and $18 \mathrm{ft}$. in girth, and a poplar $30 \mathrm{ft}$. high, $15 \mathrm{ft}$. in girth. ${ }^{67}$

Stock Gaylard Park (the Bishop of Worcester) is the oldest park in the county. William de Cantilupe had a park here, within the forest bounds of Blackmoor in $1248 .^{68}$ It is 75 acres in extent, and is stocked with about fifty fallow deer. Some of the old timber, both oaks and elms, is particularly fine. Recent measurements taken for this article show that one of the oaks has a girth of $17 \mathrm{ft}$. $6 \mathrm{in} .5 \mathrm{ft}$. from the ground, whilst the boughs stretch out to a diameter of $100 \mathrm{ft}$. Another oak has a girth of $\mathrm{I} 7 \mathrm{ft} .2$ in., whilst there are two elms with a girth of $\mathrm{I}_{4} \mathrm{ft}$.

Bryanston Park (Lord Portman), which was inclosed in 1760 , has an area of fifty acres; but a few years ago an additional $15 \frac{1}{2}$ adjoining acres was high fenced, where the deer are sometimes admitted when their own keep falls short and a change of pasture scems desirable. Except for landscape effect and making good the weak places in the old coverts, there has not been any extensive planting on this estate for some years.

With regard to the roe-deer, Dorset was evidently a favourite haunt in mediaeval days, as may be judged from the venison presentments of the forests of Blackmoor and Powerstock cited above. It is therefore particularly interesting to note that it is the one county in England where this graceful indigenous breed of small deer now run wild in considerable numbers. After having disappeared from Dorset for some two or three centuries, roe-deer were re-introduced at Milton about the beginning of the nineteenth century, and now they roam freely about the woods of the Vale of Blackmoor, under the general protection of the landowners. Occasionally they are seen in other parts of the county. About 1870 some of these Dorset roe-deer wandered as far as the New Forest, where a small herd is now established. In 1884 a few of these roe-deer were caught and transferred to Epping Forest, where they are now established. ${ }^{69}$

Several parks of the county, not now stocked with deer, have some claim on our attention, more especially Lord Wimborne's beautifully timbered old park of Canford Manor, which incloses about 800 acres. There were here two parks in Elizabethan days, distinguished as Great and Little; they are marked in Saxton's survey of 1575, and again by Speed in 1610. The Earl of Shaftesbury has a nobly timbered park, of upwards of 400 acres, around St. Giles House; Leland noticed a park here, which was then held by Mr. Ashley, an ancestor of the Earls of Shaftesbury. The small park and surrounding well-wooded hills, planted about a century ago, at Milton Abbas, afford about 5,000 acres of beautiful woodland scenery.

Other parks, all more or less well-wooded, are those of Holnest I 30 acres, Holme Priory 80, Kingston Lacy 420, Minterne House 100, Moreton House 100, and Whatcombe House I 60.

A General View of the Agriculture of Dorset was prepared in 1793, by John Claridge, for the Board of Agriculture. It was then estimated that woods and plantations covered 9,000 acres, that 86,000 acres were uncultivated or waste, and that 290,000 acres were 'Ewe Leas and Downs.' The county is spoken of as 'extremely barren both in timber and wood,' nevertheless there were several places appropriated to the growth of underwood, such as Duncombe in the Vale of Blackmoor, and Honeycombe Wood, near Sherborne. The underwood was cut at ten or twelve years' growth, and produced about five or six pounds an acre for faggots. There was some fine oak timber at Sherborne Castle, at Melbury, and in that part of the Vale of Blackmoor, in Mr. Sturt's possession. Several noblemen and gentlemen had made plantations about their places of residence, notably the Earl of Dorchester at Milton, Mr. Frampton at Moreton, and Mr. Portman at Blandford; nevertheless, Mr. Claridge considered that there was no part of England which he had ever seen so much in want of ornamental and useful woodland as Dorset. He proceeds to point out that most of the attempts at planting which he had seen have been upon too small a scale, and no sooner have the westerly winds from the coast attacked them, than they become miserable and unthrifty ;

${ }^{66}$ Leland, Itin. vii, 77 ; vi, 12.

${ }^{67}$ From information kindly supplied by Mr. W. H. Wells, Lord Ilchester's agent.

${ }^{68}$ Pat. 32 Hen. III, m. 4.

${ }^{69}$ Cox, Royal Forests, 86. 


\section{A HISTORY OF DORSET}

and this too arises from their being planted in nurseries, and of too large a size. The soil on the tops of the hills is particularly well adapted to the growth of beech, and oak would not fail to grow, provided there was a sufficient mixture of firs to shelter them in their infancy.

A revised and much extended report on the county, under the editorship of William Stevenson, was issued by the Board of Agriculture in 1812. The statement as to the scarcity of timber is repeated, and the quantity was said to be continually diminishing. The Vale of Blackmoor, very woody in former times, had merely hedgerow timber. Exclusive of woods and timber in parks, preserved for ornament, and therefore 'of little use to the public, there were only seventeen parishes that had timber woods, and many of them but thinly stored and chiefly underwood.' They were : Abbotsbury, 50 acres of oak timber; Charborough, 10; Fifehead Neville, 60; Hawkchurch, 50; trees worth $£ 5$ each; Chilton, I00; Hilton, 70 ; Sydling St. Nicholas, 100; Symondsbury, 20, some young and thriving; Stalbridge, 90 ; Stock Gaylard, 60; Stourton Caundle, 65 ; Sturminster Newton, 100; Tarrant Gunville, 250, ash and oak; Tarrant Monkton, 50; West Chelborough, 40 ; Winterborne Clenston, 320, 40 of which have some fine ash; and Winterborne Whitchurch, 44 acres, but only about five timber trees. This enumeration is under 1,500 acres; but there were in addition a number of copses, almost entirely of hazel, on the chalky soils. These copses were cut at about six or seven years old, for the purpose of hurdle making, without splitting the hazel. Some interesting information is given as to success in plantations of Scotch firs.

It is of much interest to note that the attention given to arboriculture and the principles of modern forestry during the last quarter of a century have brought about a stcady and by no means inconsiderable increase in the acreage occupied by woodlands. This increase during the decade ending 1905 shows an additional area of 52,483 acres given up to woods and coppices throughout England and Wales. In this growth Dorset has taken its full share. The acreage of this county given up to woods was in $1888,30,808$; in $1891,31,457$; in $1895,37,615$; and in 1905 , 38,869 . The agricultural returns of 1905 adopted an improved method of subdividing the woodland; they show that Dorset possesses 19,937 acres of coppice, that is of woods periodically felled and reproduced from the old stools; 1,366 acres of plantations, or woods planted within the last fifteen years, and 'other woods' which have an acreage in this county of 17,516 , giving the full total of 38,869 . Dorset cannot, however, be considered a well-wooded county, as its area is 624,341 acres.

For the most part its recent increase in woodland has been effected tor landscape or game purposes; there is but very little arboriculture on commercial lines, save on parts of Cranborne Chase and at Selwood, to the north of Shaftesbury. There are also considerable oakwoods at Marshwood in the west of the county, the timber of which is considered to be of inferior quality. In several parts of the Vale of Blackmoor, notably at Holnest and Mappowder, there are some exceptionally fine oaks. The elm grows to a great size in the neighbourhood by Beaminster and Bridport. The climate is so mild in the south-west, about Abbotsbury, that in recent years semitropical trees and plants have been found to flourish as in the Scilly Isles. 


\section{SPORT \\ ANCIENT \\ AND MODERN}

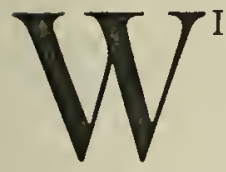

THIN the borders of the small county of Dorset a great variety of sport is to be found, interesting both for its antiquity and its excellence. The wild nature of the country and the smallness of the population have doubtless been greatly in favour of sport, and a strong love of it is inborn, not only in the leading families of the county, but also in the yeomen farmers of Dorset, a class of men whose equal can hardly be found anywhere out of England. Even among Dorset labouring men this love of sport appears, and they will be found always ready to tell the line of the hunted fox, the best spot in the river or bog to find wild-fowl, or the deep pool where the largest trout rises in the gloaming. Dorset is a county where every description of English sport may be enjoyed, save indeed deer-stalking; and even an imitation of this may be attempted with a rook rifle and a grazing roe-buck, on the edge of any of the great fir plantations.

Hunting naturally takes the precedence, whether of fox, roe, or hare; but at the same time shooting and fishing are of a very fine order, and, as will be seen from their individual history, hold a prominent position amongst the records of sport in England.

Racing and coursing are not carried on to any great extent in these days, but many notable horses have been bred and trained in the county. Polo has of late years received a great deal of attention in one part of the county, and some of the best players of the day belong to the club. A short notice of hawking will be found at the end of the article on shooting, and this sport deserves a mention, one of the finest flights of hawks in the world having been trained and flown in Dorset.

The ancient history of sport in the county brings before us more than one royal hunting ground. Domesday Book speaks of a forest and chase at Wimborne, of which there are no signs now. In the reign of Edward I we have mention of forests at Powerstock, Gillingham, and Blackmoor; anid Bere Wood is the remains of what was a great forest in the reign of King John. The decoy and the unique swannery at
Abbotsbury, where there are at least I,000 swans take us back to very ancient times.

Of historical hunting grounds in the county the two most famous perhaps are the Isle of Purbeck and Cranborne Chase, and in Hutchins's History of Dorset we read of Purbeck :-

The forest extended over the whole island, and the woods were well stocked with red and fallow deer and stags, especially in the west part, but these were destroyed in the Civil Wars, and few, if any, have remained in the memory of man.

In old evidences it is styled the 'Forest,' 'Chase,' and 'Warren' of Purbeck, and seems generally to have been reserved by our princes for their own diversion. King James I was the last of the English kings who hunted here.

The author of a Survey of the $W$ estern Counties in 1635 says :-

In this island doth range many goodly deere that are hedged in with a surer pale than wood, which, when they are hunted will adventure into the sea and take salt soils, whereby they stand long and make brave sport, of which (having a fit opportunity and a little time to cast away) I had some part, much to my content.

Cranborne Chase was also a royal possession, and its history is full of evidence of friction between the owners and the inhabitants of the chase. We read, for instance, that 'a certain deer came wounded into the vill of Kingston on the land of Hereward de Marreys, and the deer being weak, the villeins and women took it,' which coming to the ears of the steward of the earl of Gloucester, he sent his foresters to distrain for the said deer and "they took a thousand two teeth sheep and kept them till Hereward paid a fine of twenty marks.'

As early as 1343 hares and foxes were hunted in Cranborne Chase, and in an action taken against Philip, the forester of the earl of Gloucester, one accusation was that 'they take the dogs of the freemen in the Chase, where they had always been accustomed to hunt hares and foxes.'

In the article on fishing it will be seen in what early days the history of the Frome fishery begins and how it too was for centuries a royal preserve. 


\section{A HISTORY OF DORSET}

\section{HUNTING}

\section{FOXHOUNDS}

Dorsetshire may boast of being one of the first counties in Great Britain in which hunting under regular conditions was carried on; it is indeed claimed by some that the first pack of hounds, kept solely for the pursuit of the fox, was kennelled within its borders at Cranborne Chase. These hounds were kept by Mr. Thomas Fownes, who resided at Steepleton in the middle of the seventeenth century. $\mathrm{He}$ was a pioneer in the breeding of foxhounds, and his pack was supposed to have been the best of that day for looks and hunting qualities. They were afterwards sold to go to Yorkshire.

Our history of old days would be incomplete without a notice of the famous Peter Beckford, the author of Thoughts on Hunting, ${ }^{1}$ a standard work even in these days. He was born in 1740 , and five years after his birth his father, Julines Beckford, purchased the house and manor of Steepleton from Thomas Fownes. Mr. Paget, in his introduction to Thoughts on Hunting, says :-

Peter's innate love of sport found vent at first in keeping a pack of harriers, but these soon gave way to foxhounds. Thomas Fownes had given the neighbouring squires and yeomen a taste for foxhunting in its legitimate form, so that when Beckford announced his intention of reviving the glories of the Cranborne Chase hunt he was welcomed on all sides. From what source or sources he procured the foundation of his pack, it is now impossible to ascertain ; but judging the man from his writing, one does not deem it likely that he would spare either trouble or expense in getting the best blood. TWe may also consider it an established fact that by dint of careful breeding he brought his pack to a very high state of perfection; but what was their ultimate fate I have not y'et been able to trace. The Cranborne Chase country was not, even in Beckford's day, an ideal spot for hunting, as he says himself; but being then less cultivated and fenced it was probably much bester than as we know it now. They had, however,

1 The first edition of Thoughts on Hunting was published in 1781 , and many editions have been published since. It is a work full of information, knowledge, and experience, and every novice should read it, to prepare himself for the noble sport. The author is buried in the church at Steepleton, and on the marble slab of his vault is this simple inscription :

$$
\begin{gathered}
\text { P. B. } \\
\text { sibi } \\
\text { et } \\
\text { suis }
\end{gathered}
$$

\section{MDCCCIX.}

A memorial tablet gives his name in full, the date of his death, and this epitaph :

'We die and are forgotten - 'tis Heaven's decree; Thus the fate of others will be the fate of me.' good sport and killed their foxes, so that it may be presumed they enjoyed themselves, which is after all the chief object for which we hunt. The country which Beckford hunted was probably that which now is known as the South Dorset. We know he hunted beyond the Stour, as we have it on his authority, the occasion being when he crossed it in a flood and lost several hounds. To the north is the Blackmore $V$ ale, which is nearly as good a country as any in the shires, being a wide expanse of grass, though it is greatly spoilt by the majority of fences being planted on banks. From the little one can gather of Beckford's doings as set down by himself, I imagine he was not a very hard rider, and the big banks of the Vale may have had no great attraction for him.

Of Peter Beckford Sir Egerton Brydges in The Retrospective Review says :-

Never had fox or hare the honour of being chased to death by so accomplished a hunter; never was a huntsman's dinner graced with such urbanity and wit. He would bag a fox in Greek, find a hare in Latin, inspect his kennels in Italian, and direct the economy of his stables in excellent French.

To the real student of hunting he gives much information and advice as welcome to-day as when he wrote his letters. Of hounds he says :-

There are necessary points in the shape of a hound, which ought always to be attended to by a sportsman; for, if he be not of a perfect symmetry, he will neither run fast, nor bear much work: he has much to undergo, and should have strength proportioned to it. Let his legs be straight as arrows; his feet round, and not too large ; his shoulders back; his breast rather wide than narrow; his chest deep; his back broad; his head small; his neck thin; his tail thick and brushy; if he carry it well, so much the better. This last point, however trifling it may appear to you, gave rise to a very odd question. A gentleman (not much acquainted with hounds), as we were hunting together the other day, said : 'I observe, Sir, that some of your dogs' tails stand up, and some hang down; pray, which do you reckon the best hounds?' Such young hounds as are out at the elbows, and such as are weak from the knee to the foot, should never be taken into the pack.

A great excellence in a pack of hounds, is the head they carry; and that pack may be said to go the fastest, that can run ten miles the soonest ; notwithstanding the hounds, separately, may not run so fast as many others. A pack of hounds, considered in a collective body, go fast, in proportion to the excellence of their noses and the head they carry, as that traveller generally gets soonest to his journey's end who stops least upon the road. Some hounds that I have hunted with, would creep all through the same hole, though they might have leapt the hedge, and would follow one another in a string, as true as a team of cart horses. I had rather see them, like the horses of the sun, all abreast. 


\section{SPORT ANCIENT AND MODERN}

Peter Beckford is not less precise with regard to the qualities that should distinguish the huntsman :-

He should be young, strong, active, bold, and enterprising; fond of the diversion, and indefatigable in the pursuit of it : he should be sensible and goodtempered; he ought also to be sober : he should be exact, civil, and cleanly ; he should be a good horseman and a good groom : his voice should be strong and clear ; and he should have an eye so quick, as to perceive which of his hounds carries the scent when all are running; and should have so excellent an ear, as always to distinguish the foremost hounds when he does not see them : he should be quiet, patient, and without conceit. Such are the excellencies which constitute a good huntsman : he should not, however, be too fond of displaying them till necessity calls them forth : he should let his hounds alone whilst they can hunt, and he should have genius to assist them when they cannot.

Of the value of view halloos he gives the following amusing instances :-

My hounds being at a long fault, a fellow halloo'd to them from the top of a rick at some distance off. The huntsman, as you may believe, stuck spurs to his horse, halloo'd till he was almost hoarse, and got to the man as quickly as he could : the man still kept hallooing, and, as the hounds got near him, 'Here,' said he, 'here-here the fox is gone.' 'Is he far before us?' cried the huntsman. 'How long ago was it that you saw him ?' 'No, master, I have not seen him; but I smelt him here this morning, when I came to serve my sheep.'

\section{Other instances were as follows :-}

We were trying with some deer-hounds for an outlying stag, when we saw a fellow running towards us in his shirt: we immediately concluded that we should hear some news of the stag, and set out joyfully to meet him. Our first question was, If he had seen the stag? 'No, Sir, I have not seen him, but my wife dreamt as how she saw him t'other night.'

Once a man halloo'd us back a mile, only to tell us that we were right before, and we lost the fox by it.

A gentleman, seeing his hounds at fault, rode up to a man at plough, and with great eagerness asked him, If he had 'seen the fox ? "The fox, Sir ?' "Yes, d-n you, the fox ! did you never see a fox?' 'Pray, Sir, if I may be so bould, what sort of a looking creature may he be ? Has he short ears and a long tail ?' 'Yes.' 'Why, then, I can assure you, Sir, I have seen no such thing.'

To the field Peter Beckford gives excellent advice which might well be taken to heart in modern hunting days. He says :-

Few gentlemen will take any pains; few of them will stop a hound, though he should run riot close beside them; or will stand quiet a moment, though it be to halloo a fox. It is true, they will not fail to halloo if he should come in their way; and they will do the same to as many foxes as they see. Some will encourage hounds which they do not know; this is a great fault. Were every gentleman who follows hounds to fancy himself a huntsman, what noise, what confusion, would ensue! I consider many of them as gentlemen riding out; and $I$ am never so well pleased as when I see them ride home again. You may perhaps have thought that I wished them all to be huntsmen-most certainly not: but the more assistants a huntsman has, the better, in all probability, his hounds will be. Good sense and a little observation will soon prevent such people from doing amiss; and I hold it as an almost invariable rule in hunting that those who do not know how to do good are always liable to do harm. There is scarcely an instant during a whole chase when a sportsman ought not to be in one particular place; and I will venture to say that if he be not there he might as well be in his bed.

But we must leave Mr. Beckford and get ' forrard on.'

Mr. Phelips, history records, kept hounds at Cattistock, Mr. Chafyn Grove had some at Waddon about I768. Sir Granby Calcraft had his hounds at Rempstone, and the Right Hon. John Calcraft kept some at Puddletown about I 790. The Lulworth Hounds were kept by the Welds in Purbeck and hunted from I790 till I 8 I O. Amongst others who have kept hounds in the county was George IV, who when Prince of Wales, hunted from Crichel about I 800 , keeping the hounds at Puddletown. Mr. Yeatman and Mr. Hall hunted a great deal of what is now the Blackmore Vale country. During their time 'Billy Butler,' who was rector of Frampton, flourished and became a great friend of the prince. Mr. Butler was a great character, and many are the stories related of him. His friendship with his royal highness commenced in the hunting field under the following circumstances. After a long, fruitless draw, someone pointed Mr. Butler out to the prince, as a man who knew the haunt of every fox in the district, and being brought forward the rector advised that a certain gorse near at hand should be drawn. After hounds had been through it and no fox found, great disappointment was expressed, but Billy Butler was not defeated. Going up to the huntsman, he inquired which was the surest fox-finder in the pack. A hound named Trojan was pointed out. After making friendly overtures to this hound, he took him boldly up in his arms, struggled with him into the middle of the gorse, and after a little trouble got him to put his nose down. A slight whimper, then a deep note told the field the parson was right, and soon the whole pack were full cry on the line of a fine fox, which had lain close in the very thickest part of the gorse. This greatly pleased the Prince of Wales, and the friendship commenced thus favourably grew until Mr. Butler was a welcome guest at Crichel. Among many amusing incidents recorded of him it is said that the prince wishing to give him a present, told him to go into the stable and take any horse he fancied. Delighted with this offer, 'Billy' picked out a shapely chestnut and rode off with 


\section{A HISTORY OF DORSET}

it. A day or two afterwards a groom arrived and told the disappointed sportsman that he had taken a horse that belonged to someone else and at the same time handed him a cheque for $f^{1} 50$ to soften the blow. The generosity of the prince, however, did not end there, for a little later he gave the parson another look into his stables, saying : 'I am sorry you lost your horse, Billy ; go into my stables and take another.'

Of the runs during the time when $\mathrm{Mr}$. Yeatman hunted the country, there are some very interesting records in an old Hunting Fournal of the Blackmore Vale Hounds from 1826-1831, and a note at the commencement says :-

In perusing the Hunting Fournal of the Blackmoor Vale fox-hounds, it must not be forgotten : first, that a very considerable part of the country which their proprietor established in the spring of 1826 , had not been hunted at all for nearly thirty years; that the foxes had been systematically destroyed, and even that their haunts and earths were known to few, if to any persons, except to those who dealt in their destruction; secondly, that this small extent of country had never been hunted before by any gentleman as an entire country; thirdly, that at its extreme northeastern Wiltshire extremity the covers are of enormous extent, and so full of earths as to baffle the vigilance of the most careful and active stopper; fourthly, that a large portion of the country lying between Yeovil and Compton Castle is nearly destitute of cover of any description capable of holding a fox during the winter months, consisting almost entirely of sandy arable land, intersected by roads, and notorious as bad scenting ground; and lastly, that a system of annoyance, bordering on persecution, in the county of Dorset was not wanting to superadd difficulties to the whole of no ordinary kind, such indeed as must be continually kept in view by the courteous reader of the following pages.

Truly wonderful are the accounts of some of the runs, both for distance and duration, as the following two examples testify.

Friday, 29 October i 830 .- Hounds met at Inwood, where a very old and gallant dog fox was found immediately. After three ineffectual attempts (being headed by a large and anxious field) he got away on very good terms to Toomer Farm, and under Frith Wood. The hounds pressed him at the top of their speed through Purse Caundle to Hanover IVood, and away for Plumley IVood and New Lease Coppice; then across the inclosures for the village of Stourton Caundle, crossing the Caundle River for the plantations and park adjoining Stock House, and leaving the main covers to the left. Making their way over Blackrow Common for the River Lyddon the pack began to consider him as their own, running him at a killing pace by Rooksmoor to Haselbury Common, where the pack divided; one column of hounds running into the hunted fox in view one field short of Deadmoor IVood, and the other column of hounds running their fox to a drain under Wonston Hill near Mappowder, after a splendid run of two hours and fifty-five minutes over a good twenty miles of ground. The dead fox was given to the pack; the other was saved and bolted in security, after the pack had been sent home.

Tuesday, 22 March 1831.-The Blackmore Vale hounds met at Charlton Horethorne and were walked on to the celebrated gorse cover of Caundle Brake, where they found their fox immediately. Going away close to his brush through Frith Wood to Plumley Wood, they followed him to Ashcombe IVood, Haydon, and Goathill, making their way through Sherborne Park to Honeycombe Wood, crossing the corner of it by Lillington, through Thornford to Beer Hackett. Then sinking the hill at Knighton for Frankham Farm, within a few fields of Clifton IVood, they pressed him at akilling pace along the fine inclosures of the Yetminster Vale to Ryme, and through the covers of the earl of Ilchester at Melbury to Clarkham in Halstock parish, where they got up to him. Traversing the open common and inclosures at East Chelborough they went at a racing pace nearly to Corscombe, from whence the pack fairly turned him to West Chelborough, and there this gallant fox reached his earth in safety a few yards before the hounds, after a run of three hours and forty-five minutes, through fourteen parishes, over rather more than twentyfive miles of country.

It seems that Mr. Humphrey Sturt in the year 1805 or 1806 kept a pack of hounds at Clyffe, for Mr. John House of Anderson left a record of a great run with him in January of one of those years. A stump-tail fox was dug out at Milton Park, and brought over to Clyffe and let loose in a cellar. The frost being rather severe he was kept there for a day or two, and turned out at Lord's Down, near the old Dewlish Turnpike Gate, at about twelve o'clock. He went away over Milborne Farm, jumped the fence out of Milborne Eweleaze into the deer-park, then making across the open fields and downs for Whitechurch he turned to the left over Chescombe and Whatcombe Park, went straight ahead over Thorncombe and Down House, crossed the Blandford and Stickland road, down over the Clyffe, and swam the Stour between Blandford Bridge and Bryanston House. He ran strongly through the deer-park on to Mill Down, over the old Shaftesbury road to Pimperne, which was left on the right, straight on to Tarrant Hinton and Eastbury Park wall through Chettle to Thickthorn, and so to Thorny Down (still keeping the Salisbury turnpike road on the right). Keeping a straight course over the Minchington Downs and on to IVoodyates, he crossed over Verne Ditch or Boverley Dykes into IViltshire, straight on by the side of the road and the big open country to Harnham Hill within a mile of Salisbury. 


\section{SPORT ANCIENT AND MODERN}

Darkness coming on the fox was lost at the bottom of the steep hill, after hounds had been running this wonderful stout varmint for over four hours. They never went over the turnpike road but once from find to finish; and the distance by road from old Dewlish Turnpike Gate, where this fox was turned out, to the bottom of Harnham Hill is just 30 miles. About three days afterwards the old woodman at Milton Park declared he saw this same 'old stumpy' walking about in the same wood where he had been dug out about a week before.

In 1806 began Mr. Farquharson's long reign of over fifty years, during which he hunted the whole of Dorsetshire at his own expense, although Mr. Yeatman's hounds, Mr. Hall's hounds, and Mr. Drax's hounds were co-existent at different periods. After leaving Oxford Mr. Farquharson bought a pack of hounds from Mr. Wyndham, at first hunting them himself, but afterwards handing the horn over to Ben Jennings who came from Essex. Langton was his head quarters, and there he had stables built, the finest perhaps in the south of England. The kennels were at Eastbury, and at Cattistock on the other side of Dorset he had another hunting box, for the time he hunted that side of the country. Ben Jennings remained thirty years with him, and during his time, in March 1825 , occurred one of the runs of the century. The meet was Buckland Wood, and a very large field of the old school were present. A fox was found which broke away over the Vale to Dairy-house Coppice, and then through Clover Willow-bed to the Waddon and Corton Eweleaze. Up to this point the hunting had been very slow. In the long heather at Blagdon it was supposed a fresh fox must have moved out of a pit, and all at once the hounds took up the running, and turning to the left, went away over the Dorchester and Abbotsbury road and the higher side of Bridehead Farm into the Gorwell covers, and then turning to the right over the hill to Lower Kingston Russell. Crossing the meadows the fox went up the steep hill (leaving the Whatcombe earths on the right), on over the big downs, across the Bridport road (leaving Winterbourne on the right), and put his head straight over Higher Kingston Russell Farm. He crossed the Roman road into East Compton Farm ; bore to the right again over Southover and Littlewood farms into Frampton Hogleaze, and on into Frampton Court. Here this stout fox went down by the side of the watermeadows at Grimston and Stratton to Bradford Peverell, and from this place the horses began to stand still, one after the other. The chase, however, still continued over Fordington Down to Poundbury, thence to the Dorchester Barracks, and entering the top of the town this good fox ran down Durngate Street into the 'Plume of Feathers' yard, whence he was brought out and killed. The Dorset Assizes were being held, and the excitement was so great that the judges closed the courts for a time, and came out to see the fur. Lots of the horses died in Fordington fields and in the town that night, and many more were of little use afterwards: yet horses at that time of the year, says an old account of this wonderful run, were in good hunting trim.

When Jennings became too old for his duties, the famous Jim Treadwell came with some of Mr. Hall's hounds to be Mr. Farquharson's huntsman. Treadwell was born in 1800 at Stoke Talmage, and was for a time whip to Mr. Lowndes Stoke. Then he went into Berkshire to Mr. Codrington, one of the greatest scientists of his day in fox-hunting matters, and during the sixteen years that he remained with $\mathrm{Mr}$. Codrington he learned all that was worth learning both as to breeding hounds and then hunting them scientifically. From Mr. Codrington he went to Mr. Hall, and thence to Mr. Farquharson.

Treadwell had two sons. One was first whip to Lord Scarbrough and the other, Jack, was huntsman of the Quorn, whilst his brother Charles was for many years huntsman to the Bramham Moor. In 1 846 , whilst he was huntsman, the great Hilton Down run took place, and $\mathrm{Mr}$. Symonds has left this account of it:-

April 26th, 1846. Met at Bulbarrow in a cold sleet and snow, anything but a hunting morning. The old squire was not out. We found a fox at Balmer's Coombe, [which] ran across into Melcombe Park, and went into a drain. We left him there for another day. About two o'clock we went up into some short furze above the house towards Hilton, and up jumped a brace of foxes; the hounds caught the vixen, full of cubs, just going to lie down. Treadwell got off his horse, threw the vixen up on the hedge, and put the hounds on the old dog, which had ten minutes' start. They went through the Coombe, all down over the Cheselbourne downs to Bagber Coppice, which he did not enter; on to Milborne Wood, which was at that time all one cover (the middle part not being rooted), ran the straight ride right through without a turn, crossed the Dorchester turnpike, where Treadwell and myself viewed him going across a fifty-acre field on Milborne Farm, in the direction of Tolpuddle. On we went, over the large fields, tried the big earths in Tolpuddle Eweleaze, which had been stopped a few days before when the hounds met at Milborne Wood; went over the road between Tolpuddle and Burleston, through the water-meadows to Parke's dairy-house, right ahead to the end of Tincleton Hanging, leaving Cow Pound on the right, over Little Admiston farm into Ilsington Big Wood, which he went straight through without a check. All over Ilsington Heath to the top of Yellowham Wood, where he heard some guns (rabbiting going on) and turned short to the left, raced down over Bhompston and Duddle Heath to Morris Mill, down the water-meadows the north side of the River Frome to Lewell Mill on to Stafford, crossed over the river into Mr. Floyer's shrubbery; over Stafford Eweleaze, where the navvies were making the South Western Railway from Southampton to Dorchester, but they did not see our fox ; on to Came, where nearly every horse came to a trot; turned to 


\section{A HISTORY OF DORSET}

the right across Fordington Field, leaving the Weymouth road on the left, to where the South Western station now is, down into the water-meadows again to Stanton's factory, on to Goud's Mill, still on up the meadows near Stafford, when Treadwell saw an old hound hit the scent into a narrow hedge-row, with a brook on the other side; the rest of the hounds were outside. Treadwell cheered on the hounds as Druid gave his deep note till we got to the end of the hedge-row, where the fox and this single hound went into the brook together. Treadwell jumped off his horse, went into the water up to his neck, took the fox away from the single hound, and the pack ate him up as stiff as a stake.

As a proof of the great popularity of Mr. Farquharson, ${ }^{2}$ no less a sum than $f_{1} \mathrm{r}, 150$ was raised in 1827 to present him with a testimonial. Again at the end of fifty years' mastership $\oint_{0}, 800$ was collected and a magnificent pair of silver candelabra, together with a portrait by Sir Francis Grant of himself on his favourite horse Botanist, were presented to him. Mr. Farquharson died at Langton in 1871 in his eighty-seventh year.

\section{Blackmore Vale Hounds}

The old history of the Blackmore Vale Hounds ${ }^{3}$ is rather involved, but owing to the kindness of Lady Theodora Guest the following particulars have been obtained. Mr. Farquharson's country being far too large for any pack to hunt properly, one or two irregular packs of hounds sprang up. In 1826 the Rev. Harry Farr Yeatman of Stock Gaylard started a pack of hounds, with which he hunted chiefly hare, and occasionally fox and roedeer. He bought his hounds of Mr. Templar, a Devonshire friend, and hunted the Stock covers and a great part of Somersetshire. Mr. Hall, who lived at Holbrook House near Wincanton, was master in 1834 ; Mr. Portman of Bryanston, Blandford (afterwards first Viscount Portman), hunted a portion of the country by arrangement with Mr. Hall, from 183 I to 1840 .

'The record of Mr. Farquharson's hounds from I 837 to i 857 is as follows :-

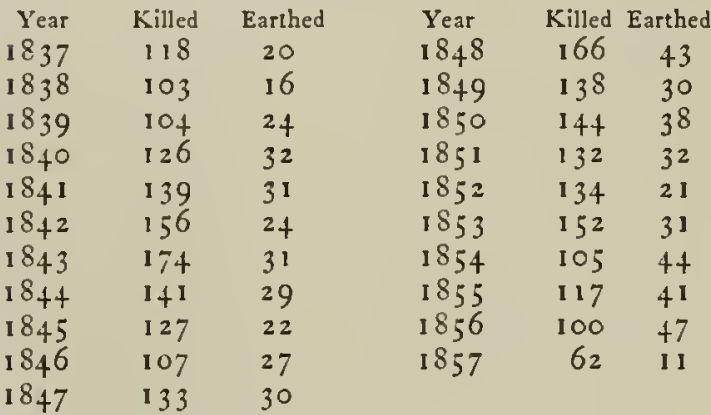

Hunted 2,787 days, and killed 2,678 foxes, and earthed 624 , thus accounting for 3,302 foxes; after deducting 12 blank days, this accounts for 515 more foxes than days the hounds found.
Meantime, Mr. Drax of Charborough Park near W imborne, and Holnest Park near Sherborne, started a pack of foxhounds in 1833 to hunt his own property, and in 1840 , having bought Mr. Portman's hounds, he became master of the whole Blackmore Vale country. In 1853 Mr. Drax sold his hounds to Mr. G. Whieldon of Wyke Hall near Gillingham.

That the Blackmore Vale country was regularly hunted by Mr. Hall in 1834 is proved by a printed copy of a meeting, a very interesting document still in existence, of which the subjoined is a copy :-

At a meeting of the

Friends of Mr. Hall's Hunt,

Holden at Sparkford Inn,

on the 2oth September, 1834 ,

Present-H. F. Yeatman, Chairman.

J. Lee Lee, M.P. W. C. Medlycott W. F. Knatchbull J. Goodden J. H. Wyndham R. C. Tudway

J. N. Quantock Jas. Bennett J. T. Tatchell

A. Tooke Robt. Leach Thos. Cave

G. Midlane Sealy Bridge R. Leach J. Andrews

Resolved unanimously 'that it is expedient that a sum of money be raised by subscription for the purpose of earth stopping and the preservation of foxes in the consolidated Vale Country, hunted by Henry Hall, Esq.; the said sum of money being to be raised in pursuance of a resolution passed at a meeting of the Blackmoor Vale Hunt assembled at the Henstridge Ash Inn, in the month of January, I 834.

That subscriptions for the above purpose be received (post paid) at the bank of the Messrs. Messiter and Co.; and that Henry Messiter, Esq. be requested to accept the office of treasurer to the consolidated Vale Hunt: such subscriptions being to be considered as due on the first day of October in each year.

That the undersigned persons be named as a Committee to carry the above resolution into effect, and to

${ }^{3}$ The list of successive masters and huntsmen is as follows :J. S. IV. Sawbridge- $1833-53 \cdot . \cdot$ Huntsmen
Erle-Drax

G. Whieldon - . (H. Honey $\left.\begin{array}{l}\text { Capt. Stanley : . } \\ \text { Viscount Dungarvan }\end{array}\right\} 1853-5 \cdot$. $^{\text {H. Honey }}$ Lord Harry Thynne 1855-6 . . W. Stansby R. Strachey . . . I $856-7$. . . Webb Capt. Stanley . . 1857-8 . J. Dinnicombe G. D. Wingfield- $1858 \quad(1858-63$. Turner Digby of Sher- $\}$ to $\left\{186_{3}-4\right.$. Wilson borne Castle ${ }_{1} 865$ I $863-76$ John Press Sir R. G. Gly'n, bart. $\mathbf{1} 865$ $\left.\left.\begin{array}{l}\text { of Gaunts House, } \\ \text { Wimborne }\end{array}\right\} \begin{array}{c}186 \\ \text { to } \\ 1884\end{array}\right\} 1876-85$ G. Orbell

Merthyr Guest of $\left(188_{4} \quad\left(\begin{array}{l}1885-6 . \\ 1886-90\end{array}\right)\right.$ Haines

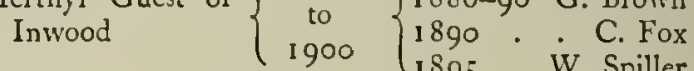
John Hargreaves $\left\{\begin{array}{c}1900 \\ \text { to } \\ 1905\end{array}\right\}\left\{\begin{array}{l}G \text {. Alcock, } \\ \text { kennel huntsman }\end{array}\right.$ Col.Percy Browne,C.B. I906 G. Alcock 


\section{SPORT ANCIENT AND MODERN}

guarantee to Mr. Hall the payment of a sum not exceeding Three Hundred Pounds per annum, for the above purpose.

J. Lee Lee, M.P. W. F. Knatchbull W. C. Medlycott

J. Goodden

H. F. Yeatman

R. C. Tudway

J. N. Quantock

A. Tooke

J. T. Tatchell

Jas. Bennett

G. Midlane

Robt. Leach

Thos. Cave

Sealy Bridge

R. Leach

J. Andrews

That whereas a very liberal offer has been made on the part of E. B. Portman, Esq. to surrender his claims to the covers of Inwood, Caundle Brake, Stalbridge Park, Frith Wood, and Fifehead Copse (as neutral covers) provided that Mr. Hall permit Mr. Portman to draw Stock Wood, Rooksmoor, and Thornhill Copse, when, and as often as it suits his (Mr. Portman's) convenience ; resolved, that in the opinion of this meeting it is desirable that such exchange of covers should take place; it being to be understood that the whole of the Blackmoor Vale country including Stock Wood, Rooksmoor, and Thornhill Copse is vested in Mr. Hall, and that this arrangement is now entered into on the part of $\mathrm{Mr}$. Hall, as a matter of accommodation to Mr. Portman; and it is further agreed that Mr. Hall shall be at liberty to draw Stock Wood, Rooksmoor, and Thornhill Copse, in each year in the months of November and February, on the condition that he accommodates Mr. Portman with a day's sport in the Annis Hill and Cherton Wood Country, in the months of November and February aforesaid; and that this arrangement is to be binding as long only as Mr. Portman keeps his fox-hounds; at the expiration of which period the whole of the aforesaid covers shall revert to Mr. Hall.

$$
\text { Signed, H. F. Yeatman, Chairman. }
$$

Resolved, that the cordial thanks of this meeting be given to Mr. Yeatman for his able and impartial conduct in the chair.

Signed, W. C. Medlycott.

The importance of this document to the county appears from another dated I 853 at the beginning of the dispute with Mr. Farquharson, which lasted until I 858, when Mr. Farquharson gave up the whole country, Mr. Digby of Sherborne Castle, Lord Portman, and other landowners, having joined in putting pressure upon him to give up a portion of his immense territory.

At a

Meeting of the Members of the

BLACKMORE VALE HUNT,

Holden by adjournment at Wincanton, on Monday, the 16th day of May, 1853 .

The Hon. Col. Boyle, M.P., in the Chair.

It was unanimously resolved, -

That this meeting has heard with very great surprise, through the medium of a letter addressed by J. J. Farquharson, Esq., to Lord Dungarvan, G. Whieldon, Esq., and Captain Stanley, joint masters of the Blackmoor Vale Fox-hounds, that he (Mr. Farquharson) considers that Inwood, Caundle Brake, and everything within that line, as belonging to his country, and that he has Sir Hugh Hoare's permission to consider the Stourhead covers the same.

It appearing to this meeting, beyond all doubt, that this newly made claim of Mr. Farquharson's can only be considered as adverse to the very existence of the Blackmoor Vale Fox-hounds, and to the efficient hunting of those covers in Dorset, Somerset, and Wiltshire, which they have occupied uninterruptedly from 1826 down to the date of Mr. Farquharson's letter of the 2 Ist of April, 1853 , it being certain-

First, that Mr. Farquharson voluntarily resigned and gave up the above recited covers, when the Blackmoor Vale Fox-hounds were established in 1826 , from which distant period down to the date of his present claim of the 21 st of April aforesaid, and for twenty-seven years in succession, Mr. Farquharson never made a demand for the restitution of these covers, either by application to the Blackmoor Vale committee of management, who were appointed in 1834 to conduct the affairs and business of the B.V. Hunt, or by any application to the honorary secretary of the said committee, or by any application to any master of the Blackmoor Vale Fox-hounds, in so far as the records of the Blackmoor Vale Hunt will furnish information; whilst, secondly, it appears certain that during the above twenty-seven seasons, Mr. Farquharson has never drawn with his fox-hounds any one or more of the above covers he now claims, nor exercised any one right or privilege so as to shew that he had not abandoned these covers, which he now lays claim to ; it being also certain according to the law and usages of fox-hunting, that Mr. Farquharson can have no right or title to the above recited covers; in proof and confirmation of which, it has been laid down by an ex-master of fox-hounds of very long standing, and who is now a standard writer of authority on the law of fox-hunting (See the work of Scrutator, page 124), that covers may become lapsed by any master discontinuing to draw them for seven years, or by his allowing another pack to hunt them without remonstrance and interference for that period-in these cases the master of an adjoining pack, with the consent of proprietors, may take possession of these covers, and they will become an integral part of his country-

It is therefore resolved, for these and other reasons, to reject the claims so unexpectedly preferred by Mr. Farquharson, and to request and encourage the Blackmoor Vale committee of management to continue to keep possession of the said covers thus claimed by Mr. F., and to do so in accordance with the powers vested in them by the resolution of the B.V. Hunt, recorded and published in years 1834,1837 , and 1840 , when it was resolved from time to time at public meetings of the Blackmoor Vale Hunt, that the Blackmoor Vale country, as a consolidated country (and including the very covers now claimed by Mr. Farquharson), should be vested in a committee of management, as an entire country, to be holden in trust for the members of the Blackmoor Vale Hunt.

That the thanks of this meeting be given to the chairman, for his able conduct in the chair.

(Signed) Robert Boyle,

Chairman.

With the resignation in 1859 of Mr. Farquharson came a readjustment of the country, and the Blackmore Vale hunt enlarged its borders, whilst some country was handed over to Lord Portman on the one hand and to Lord Poltimore on the other for the Cattistock hunt. 


\section{A HISTORY OF DORSET}

Mr. Drax, who hunted the county from I 833 to 1853 , had the support of all those farmers and landowners who naturally objected to the long distances necessitated by Mr. Farquharson's huge country. In 1840 he purchased Lord Portman's hounds, and the whole of his breeding may be found in The Blackmore Vale Hounds from 1833 to I 900 . He appears to have used all the good kennels, including those of the duke of Beaufort, Lord Middleton, Mr. Codrington, Mr. Assheton Smith, the duke of Rutland, Lord Fitzwilliam, and Sir T. Sykes.

Miss Serrell, in her most interesting book, Hound and Terrier in the Field, says :-

Mr. Drax had a great eye for colour in his own and his servants' dress in the field. The latter were atsired in canary-coloured plush coats, with blue collars bound with gold lace, and a gold fox with a silver brush on each side of the collar. For the rest they had red waistcoats, white breeches, white tops, black velvet caps, and white gloves. The members of the hunt sported scarlet, but the master came out in a sky-blue coat, a cream-coloured waistcoat embroidered with gold, and a top-hat. On certain days Mr. Drax would mount himself and his men on grey horses, though he did not by any means confine his establishment to horses of that colour.

After the retirement of Mr. Drax there appears to have been for a time a quick succession of masters, the names of Mr. Whieldon, Captain Stanley, Viscount Dungarvan, Lord Harry Thynne, and Mr. R. Strachey occurring between 1853 and 1858 . In 1858 the reins of office were taken up by Mr. George Digby IVingfield-Digby of Sherborne Castle. Mr. Digby became a most popular master, and being very fond of a fast ride over the Vale, he gave his attention to breeding pace in his hounds, so that he altogether changed the character of the pack. He specially favoured the Sparkford Vale, which is all grass and flying fences, and tradition has it that Mr. Digby was so unwilling to be deprived of a gallop in his favourite country that a fox would often travel with him in a basket under the seat of his brougham to be turned out if required. In Mr. Jigby's time John Press came as huntsman to the Blackmore Vale from the Cambridgeshire. He had been whipper-in to Mr. Farquharson's hounds under the famous Jim Treadwell, and afterwards was huntsman to the Crawley and Horsham and the Cambridgeshire. He is said to have been an extremely clever huntsman, and to have had almost preternatural ability to tell where his hunted fox had gone. When hounds were at fault he would catch them up, gallop off as straight as a line to some point which he had in his mind, recover the hunted fox, and kill him, so that often the field never knew that hounds had been off the line at all.

In 1865 Sir Richard George Glynn, third baronet, of Gaunts House, near Wimborne, took the hounds, and $\mathrm{Mr}$. Digby made over the whole establishment-horses, hounds, and hunt servants - to him, the kennels still remaining at Charlton Horethorne. Press remained with the new master for eleven years, and was soon recognized as one of the first huntsmen of the day. Miss Serrell gives us an amusing story of his resource in the field :-

It was early in the year, when Sir Richard met at Henstridge Ash. The first coverts to be drawn were those of Inwood, and Press, finding that there was no scent and no chance of sport, took his precautions to have a good day to his credit in spite of difficulties. In the first covert into which hounds were thrown they chopped a fox almost under the nose of the horse of the only member of the feld who happened to be within sight. Press was down in a moment, and as he took the fox from hounds he looked round, and seeing but the one man near, he exclaimed, "Not a word, sir, if you please,' and springing back into the saddle, he put the fox up on the highest branch of a fir-tree he could reach. Then with a touch on his horn he gathered and lifted hounds cleverly out of covert, and riding almost in a line with them, cheered and encouraged them on in the direction of the village. A good thirty minutes' gallop followed, by Templecombe and Stowell back to Henstridge Ash and up to the corert whence it had started. Here Press, well in front of the field, threw down the fox, and with a loud who-whoop celebrated the obsequies in due form, and received the congratulations of the field on a good day. The one somewhat mystified follower of the huntsman's tactics obeyed Press's injunction to keep the secret, and it was not till some time afterwards that a rumour of the day's proceedings came to be noised abroad. As Press explained the reasons for his manœurre, 'You see, sir, I knew' 'twas our only chance to-day, so I took it.'

After living in retirement at Milborne Port for a few years Press died in I 885 in the County Asylum at the age of sixty-seven.

Another famous huntsman succeeded him, George Orbell, who had commenced his hunting days with harriers in Hertfordshire. He then went as whip to Lord Poltimore, and from him to the Blackmore Vale, Sir Watkin IVynn's hounds, and the South Berks successively. After serving as kennel huntsman to the South Notts, and then as huntsman to the Craven, and after that to the Rufford, he returned to the Craven, from which pack he came to succeed Press with the Blackmore Vale.

Mr. Merthyr Guest, to whom Sir Richard Glynn gave the hounds, succeeded that gentleman in I 884 and remained as master till 1900 . He was a heavy-weight, a consistently hard rider, and always rode splendid horses well up to his weight. He had a great partiality for greys, and during his term of office it was a wonderful sight to see the master and all the hunt servants mounted on grey horses. After $1885 \mathrm{Mr}$. Guest increased the hounds to three packs and hunted six days a week, the huntsman 


\section{SPORT ANCIENT AND MODERN}

carrying the horn four times a week, hunting the dog and bitch packs separately, while Mr. Guest took the horn on Wednesdays and Saturdays, hunting a mixed pack of small dogs and large bitches himself. The huntsmen who served with him were Orbell (for one year), Haines, G. Brown, C. Fox, and W. Spiller. Strange to relate, George Orbell died in 1886 in a private asylum, insane like Press before him.

Mr. Guest had a fancy for light-coloured hounds, especially with tan markings, as catching the eye better when running. Another peculiarity of his, which became a distinguishing mark of the B.V.H., was that he never had the hounds' ears rounded, in spite of the verdict of fashion. He bred for nose and voice, and he never kept a mute hound. There was a great deal of Belvoir blood in his packs, and in 1885 new blood was brought into the kennels with hounds purchased at the sale of the New Forest pack, and Mr. Guest bred very successfully from these. In 1896 the Brocklesby dog pack was bought by him from Lord Lonsdale. When Mr. Guest gave up the country the hounds were sold at Rugby by Messrs. Tattersall, fetching about 900 guineas; one lot, S. Auditor, fetched eighty-two guineas alone.

The great run of the Blackmore Vale country during his mastership was on 30 December, I 884. The meet was at Jack White's Gibbet, and a fine dog fox was found quickly at Hadspen. He first took a sharp turn round Hadspen, which threw out some of the field, and then went away westward at a racing pace to Grove and over the hilly ground by Honeywick in the direction of Ridge Barn and Cole-crib, making for the railway near Wyke Champflower; he crossed it here, and on account of this line and the River Brue, the hounds were for some time alone. However, he ran parallel to the railway for some way, and then recrossed the Brue near Castle Cary station. Leaving the station on his left he raced on to Lamyat, swinging under Creech Hill to Milton Wood, where he did not dwell, but went on down to Evercreech town, outside of which the hounds came to a check, enabling those who had been thrown out by the river to rejoin them. A quick cast of Orbell's put them right, and after running under the railway between Evercreech and Shepton Mallet, hounds crossed the line again and went through Evercreech Park Farm to Pye Hill. After Pye Hill scent became cold, but the master, convinced that the hunted fox was in front, persevered towards West Pennard and on to Sedgemoor. Close to the road between North Wootton and Barrow the end came. The fox jumped right into the arms of an old woman standing at a cottage doorway and fell back almost into the mouths of the pack. The master was first up with Lady Theodora Guest, Mr. Rome of Compton Castle, Messrs. Turner, Berkeley Napier, Corp, Maidment, Richards, and one or two more. The time to the first check at Evercreech was fifty-eight minutes; to that under Pennard House two hours thirty-five minutes, and the last stretch from Pennard Church was a race of twenty minutes.

Another memorable run was that on 13 April 1889, from Pylle Station. Finding in Folly Wood, hounds ran on over Cockmill Farm into the wood, and at the top of the hill went along the lane as if for Pilton Park Farm. Bearing out of the lane, however, short of Pilton, they flashed over the Middleway road and ran down to the lower end of Goosefurlong. From this point they crossed the Hambridge Lane, and going over Withial they passed Stene Farm. Just short of Purbrook Chapel they took a line beside the road through Lottisham and Rookery Farm, and over Lower Farm towards Stone House. Swinging to the left at the brook hounds headed for Park Wood, and once more crossing Lower Farm and running down to the brook they crossed, and going through West Wood reached Wrangles, where the covert was being cut. Heading for Naydens there was a momentary check, but a hound named Drosky recovered the line silently, and as the master luckily saw her and put the pack on to her, they went on without loss of time towards New Inn Corner. They were now once more running the road, but hounds swinging off it to the right, ran down on to Bridgend Farm, and with a good head swung along by the side of the river to Mendip Farm. Here behind the farm-house they came up to their quarry, and pulled down a fine dog-fox in a thick brambly fence. The time was one hour and seven minutes, and the fox had never been seen from the start. The measured distance was 10 miles, and except for the one check, when Drosky hit off the line so curiously, there had been no time for any one to get up. There were only three people really in this run from find to finish, though a handy road enabled some to be up in time to see hounds break up their fox.

In I $900 \mathrm{Mr}$. John Hargreaves came from the Cattistock to take the Blackmore Vale country in succession to Mr. Guest, and had, of course, to build up a fresh pack of hounds. The dog hounds were bought from Mr. ChandosPole, who had bred them in the Cattistock country, and had hunted them three years subsequently in the hills of Derbyshire. The bitch pack was got together by $\mathrm{Mr}$. Hargreaves from some brought from the Cattistock, a draft from the Tyndale, young and old, a draft from the V.W.H. (Cricklade) old hounds, and some of his own breeding.

He was a great believer in Belvoir blood, and strove while breeding hounds to use only dogs of that blood, his experience being that for work, drive, and tongue nothing was better.

Mr. Hargreaves hunted the hounds himself, with George Alcock as first whip and kennel 


\section{A HISTORY OF DORSET}

huntsman. He was a bold rider with a great knowledge of both hound and country, and has been described as the finest gentleman huntsman of the day.

He has chosen two among many good runs during his mastership as especially worthy of notice.

I 8 February, 1904.-The dog hounds found in IVithy Tree Copse, one of Mr. Drake's coverts, and ran through Brooke, Butterwick, Longburton Gorse to Six Acres, and going across the road through Holm Bushes, went over the Vale. The line from this point was through Whitfield Wood and across the railway at the back of Yetminster to within a field of Clifton Wood. Here the fox turned sharp to the left, and leaving Ryme to the left, hounds raced along very fast past Caswells Gorse, where they pulled their fox down, stiff and cold, close to Drive End, Melbury. The distance as hounds ran was some fifteen or sixteen miles.

9 January, I 905.-Getting on to a stale line at Horrington the bitch pack puzzled it out slowly to Stowell Covert. Here they got on good terms with their fox, and ran very fast back over the hill through South Cheriton into the Vale. They crossed the Vale and went up over the hill to Sandley, where they got a good way behind the fugitive and hunted slowly on to Thorngrove, Sir Harold Pelly's house, near Gillingham. Thence they crossed the railway and River Stour into Lord Portman's country, and eventually ran into their fox in some cabbages in a garden at Mr. Honeyfield's farm. Time about one hour and fifty minutes-a IO-mile point- 16 as hounds ran.

In 1906 Colonel Percy Browne, C.B., who had been master of the South and IVest IVilts from $I 898$ to 1900 , took over the Blackmore Vale country, with George Alcock as huntsman, and under his auspices sport has been excellent. Alcock started his hunting career with the Dove Valley Harriers in 1879 . He served successively with the South Notts, the Meynell, the Blackmore Vale, and the Cattistock, finally returning to the Blackmore Vale. Colonel Percy Browne carries on the system of breeding favoured by his predecessor, and the hounds are a most workmanlike lot with lots of music and drive. There are plenty of foxes, the county is well in favour of hunting, and there are no troubles with shooting tenants.

The Blackmore Vale country is in the main a bank and double ditch country, chiefly pasture with big woodlands, but at the Sparkford Vale end the fences are of a flying description. It is about $2 \mathrm{I}$ miles north and south and 25 miles east and west, and is bounded by the South and IVest IVilts, the Cattistock, the South Dorset, and Lord Portman's. The subscriptions to the pack are regulated by the number of horses kept, and there is a splendid system for the wire and poultry fund, the country being divided up into some eighty districts, with an honorary overseer to look after each, so that a small amount of trouble keeps everything straight. The kennels are at Charlton Horethorne, where they have been for many years.

\section{The Cattistock}

Most of the country lies in Dorset, but there is a small portion in Somerset. It extends some 25 miles by 18 miles and adjoins the Blackmore Vale, the Taunton Vale, the East Devon, and on the other side the South Dorset. There is a great deal of pasture land with a little light plough and some downland, and part of the country is bank and double ditch with a few stone walls and a certain amount of timber. The Cattistock Hunt is of great age, although, like other Dorset packs, it has only hunted its present country since the resignation of Mr. Farquharson, who, as is mentioned above, hunted the whole of Dorset. In 176 I John, ninth earl of Westmorland, hunted a pack of foxhounds from Forston, and in 17 So there is a record of hounds called 'The True Blue Hunt,' kept at Cattistock Lodge by the Rev. J. Phelips. This gentleınan had a famous huntsman named Isaac Rogers, who was known by all as "The Doctor.' He was a great character, and countless anecdotes are told of him. Visiting a well-known pack of hounds renowned for their beauty, Rogers was asked his opinion of them.

' Why,' he replied, 'they be beauties to look at, but they bain't hafe so scraitched 'bout their faces as our old maister's be down to Montacute.'

Another good story is told of him, that on a good scenting day, when hounds in a thick fog had run clean away from the field, "the Doctor" was an hour trying to get to them, and when at last he reached them he found them coming back by themselves. Rogers was of opinion that they had killed their fox, and Mr. Pheiips remarked to him, 'You had better get off and smell their breath. That will soon tell you.' 'No, no, maister,' returned the old man, with a knowing look, 'that 'll never do. A pretty story would be carried up along into the New Forest next April, that the Doctor didn't know when his hounds had killed their fox without getting off to smell the breaths o' 'em.'

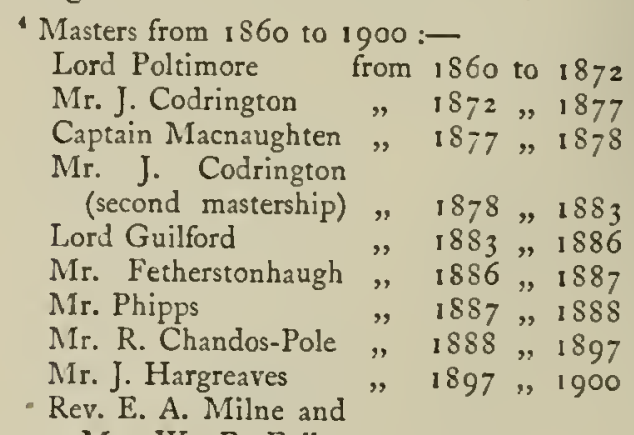
Mr. W. F. Fuller , 1900 


\section{SPORT ANCIENT}

Rogers died at the age of seventy-four, having spent sixty years of his life in the service of Mr. Phelips. The epitaph his master had put on his tombstone was as follows:-

Now, the 'Doctor' is laid, and over his head May the turf be as light as a feather,

And if not very warm, it will do him no harm, Who ne'er valued the wind nor the weather.

He's no longer in view, but to give him his due, Though not born nor bred for a college,

Death ne'er drove to the earth a man of more worth, More science, or practical knowledge.

Isaac Rogers his name: a huntsman whose fame

From the Yeo to the Avon resounded :

At his musical voice Clift Wood would rejoice,

Dev'rill Longwood its echo rebounded.

As in life's busy burst he was never the first

To hit off a fault in a neighbour,

Now he's fairly stopt in, let us hope that he'll win

The brush of reward for his labour.

After Mr. Farquharson had given up his hounds, the first to take the Cattistock country was Augustus, second Lord Poltimore, who married Miss Sheridan of Frampton Court. For twelve seasons he hunted the country at his own expense with John Evans as huntsman, and showed some excellent sport. John Evans had been Lord Poltimore's valet at the University. He used to remark, with a smile, that he had had a University education, and that although he had never taken his degree, he was very near it, for he had lived next door to someone who had done so. He was always well mounted and had an extremely clever first whip, who used to gallop and hold up his cap when he viewed the fox on. The result was they had some wonderful hill gallops with the bitch pack, and although this lifting was hardly hunting, the riding contingent had some capital sport. At Lord Poltimore's retirement in 1870 his dog hounds fetched extraordinary prices, the average being about $£ \mathbf{I} 54$ a couple. ${ }^{5}$ All but one lot, which was bought by Sir Algernon Peyton, went to Major Brown.

In 1872 a committee was formed, and the Cattistock, under Mr. Codrington's mastership, became a subscription pack. Twice Mr. Codrington had a five years' office, Captain Macnaughten taking the mastership in 1877 and 1878 , when owing to private affairs $\mathrm{Mr}$. Codrington was absent from the county. It is said of this master, that although under stress of circumstances he would ride very hard, as a rule he preferred to avoid too much jumping, and once on being shown a horse which the would-be seller pressed on him as a perfect jumper, he exclaimed after mature deliberation, 'Well, I suppose we can soon cure him of that.'

${ }^{5}$ They were sold on 13 April, 1870 , with this remarkable result :-Lot 1,3 couples, $£_{2} 31$; lot 2 , 3 couples, $£_{4} 83$; lot 4,3 couples, $£ 409$ 10s.; lot 5 , 3 couples, $f_{5} 525$; lot $6,3 \frac{1}{2}$ couples, $f_{6} 630 ; \operatorname{lot} 7$, 3 couples, f6$_{6} 30$.

\section{AND MODERN}

His successor was Dudley, seventh earl of Guilford, who had been at one time master of the East Kent. He was a determined straight rider who on taking the hounds hunted them himself with Jim Beavan as first whip. $\mathrm{He}$ bought twenty-five couples of hounds from Mr. Codrington, a draft from the kennel of the late duke of Grafton, and in addition purchased Mr. Bellew's bitch pack. His mastership was sadly concluded in his third season by his death on 19 December, 1885 , after a fall in the hunting field. Though the accident was of a very grave nature it does not appear that a fatal result was anticipated, for the master on the following Saturday morning ordered the hounds to be taken to Corscombe (at which place the meet was announced to take place), remarking, 'I suppose I am in for six weeks at least.' But all hopes of recovery were speedily disappointed, for delirium came on soon afterwards, and his lordship remained in an unconscious condition until shortly after nine o'clock the same evening, when death released him from his sufferings. Lord Guilford, who was only thirty-four years of age, was president of the Dorchester Agricultural Society, and had acted as one of the judges at the society's shows every year during his residence in the county.

A memorial brass was placed in Waldershare Church near Dover, where he was buried, by his Dorsetshire friends, as a testimony of their regard. It bears the following inscription.

In affectionate remembrance of Dudley Francis North, seventh earl of Guilford, who was born 1851 , and died from an accident while hunting with the Cattistock Hounds in the county of Dorset, 19 December, 1885: This memorial is erected by his sorrowing friends in that county.

The two succeeding masters remained but a season each. They were Mr. Rupert P. Fetherstonhaugh and Mr. J. Phipps; but the next master, Mr. Reginald Walkelyn Chandos-Pole of Radbourne in Derbyshire, remained nine seasons with the Cattistock. He had been one of the joint masters of the Meynell, a welter weight, riding 18 stone and having out three splendid horses a day.

When he took over the country the pack hunted two days a week, but Mr. Chandos-Pole added to the thirty couples of hounds already in the kemnel another pack of dog hounds, purchased from the Blankney. When he gave up the Cattistock he took away some of these hounds and with them hunted the Peak district. Later on $\mathrm{Mr}$. John Hargreaves purchased them in 1900, when he took the Blackmore Vale. In 1897 this gentleman, before he became master of the Blackmore Vale, took over the Cattistock country from Mr. Chandos-Pole, and hunted there for three seasons, showing, as did his predecessors, wonderfully good sport. 


\section{A HISTORY OF DORSET}

In 1900 the Rev. E. A. Milne of Chilfrome came to the hunt as master. He has remained with them up to the present, taking in 1906 into joint partnership as master Mr. William Fleetwood Fuller, late master of the North Bucks Harriers, with which pack Mr. Milne had also been associated. A rare judge of horse and hound, popular with all classes, 'Parson' Milne is an ideal master. His own huntsman, he is known as the 'fox killer,' a sobriquet he has well earned, for no man can hunt a fox from find to kill better. For some years Newman was his first whip, and Levi Sheppard, who had been huntsman to Mr. Fred Radclyffe at Hyde, was kennel man. The present kennel huntsman and first whip, who was for some time huntsman to the Holderness, is Medcalf, a bold rider, a good man in kennel, and a first-class whip.

In breeding his hounds Mr. Milne has been chiefly to Lord Rothschild's and the Belvoir, and he has got together a fine lot of hounds, with bone, size, and quality. Whipster by Woldsman - Lively, one of the hounds bought at Lord Poltimure's record sale by Sir. A. Peyton, was largely used as a stallion hound in Lord Rothschild's pack, and a great deal of his blood has thus got back again into the Cattistock kennel. Sapper is perhaps the best stallion hound in the home kennel, and a nice young hound coming on is Deputy. There is no damage or poultry fund, and the farmers scorn the idea of such a thing, being all enthusiastic followers of the Cattistock. In 1903 the master and Lord Digby decided to give as a compliment to the best yeomen farmers a button, limited to twentyfive recipients; it is a black one with the monogram of the hunt, and needless to say it is a highly prized honour. The county is a varied one, with hill, vale, and big coverts, and is stiffly fenced. On the whole there is very little wire, and this hindrance to hunting is becoming less used. Foxes are very plentiful, and there is no trouble with shooting tenants.

In the season $1906-7$ 901 brace of foxes were killed and fifty-three earthed in I 7 I days' hunting.

A famous run was that which took place on 29 November, Ig0 I, from the Artillery Barracks at Dorchester. The fox was found at $\mathrm{Hog}$ Hill, and ran round Maiden Castle Rings to Monkton and then over the hili to the waterworks. From this point hounds ran very fast to Miss Miller's covert, over the road to Came, and on to Sutton Poyntz. Here they swung rather to the right through Broadway to Dairy House, leaving Huish on the left, and by Rodden Hill nearly to Gorwell, then down the hill to Abbotsbury, where they killed their fox. Distance I3mile point, two and a half hours.

On I 2 January, 1906, hounds met at Langton Cross Roads and found two foxes in the day, running tremendous points both times and losing both foxes. The first run was from the Cross Roads covert and on to the coastguard station, leaving $W_{y k e}$ on the right, to Rodden and on by Langton, through Thresher's Gorse to Dairy House and over the railway into the Wadden Vale. Going through the Vale the run continued to Ashton Gorse and by Ashton Farm House to Maiden Castle Rings, over the road and railway to Herringston, where the fox was lost. Point 10 miles. The second fox was found at the Monument, and after twisting about for some time went away by IVell Bottom straight to Ashton Gorse and Ridgeway Hill, and running all the Came coverts was lost near Poxwell. Point 9 miles.

\section{The South Dorset ${ }^{6}$}

The country is about 20 miles long by 15 wide, entirely situated in Dorset. It adjoins Lord Portman's, the Blackmore Vale, and the Cattistock Hunts. Heath, arable, pasture, and hilly country are to be found within its borders, whilst banks, timber, and flying fences divide the fields. IVire is very prevalent in some parts, especially near Dorchester, and there has been considerable trouble in keeping up the stock of foxes, owing to the letting of most of the shootings; but this is happily a matter of the past, better feeling existing generally between all parties.

In 1858 , when Mr. Farquharson gave up the whole country, Mr. Charles Radclyffe took up this side, and Mr. Farquharson bequeathed to him the distinctive white collar which is still the mark of the South Dorset Hunt. In the early part of the history of this hunt the hounds were more generally known as Mr. Radclyffe's, and were kennelled at Hyde, the home of the master.

Mr. Radclyffe was a very fine horsemen not only over a country but 'between the flags,' and his beautiful seat on a horse is well portrayed in the presentation picture of him on his favourite grey horse painted by Stephen Pearce. He had three very good huntsmen, George Kennett, Tom Davis, and Henry Beviss; of the trio perhaps the most famous was Kennett, one of the very best huntsmen of his day. He had been in Herefordshire with Lord Gifford and then went to the V.W.H.; from this pack he came to Mr. Radclyffe and remained many years with the South Dorset. Afterwards he was with Mr. Platt, master of the North Herefordshire, then with Lord Fitzwilliam, and ended his hunting career with the Fife. On 16 March,

\footnotetext{
${ }^{6}$ Masters of the South Dorset : 18;8-1907 :Mr. C. Raddlyfe. . . . $1858-82$ Mr. F. Radclyffe . . . . . 1 $\$ 82-6$ Mr. (afterwards Sir) Elliot Lees $1886-7$ Mr. Fetherstonhaugh-Frampton $1887-94$ Mr. J. Ashton Radcliffe . . 1894
} 


\section{SPORT ANCIENT AND MODERN}

1863, during his time Mr. Radclyffe's hounds had a wonderful run from Whitchurch. Drawing Horse Close Coppice, a fox, which proved to be an extraordinary one, was found in a pit on Kingston Farm. He went straight over Bere Down to Hayward's, across Milborne Down; leaving the fox-pound on the right, to Milborne Rings, over the meadows and on to Warren Hill, where he was viewed two fields ahead. The scent was breast-high as he went over the big corn-fields on Mr. Homer's Farm, over Tolpuddle Eweleaze, down Burleston Hill, and on across the water-meadows. Here the pace began to tell, but at the top of Basing Hill there was a long check at the cross-roads, which eased the horses and gave the fox a good mile or two to the good. Kennett cast down the hollow track way, and the hounds hit it over the Dewlish road on to Paull's Farm. Over into the Druce hedge-rows and then keeping straight on across Druce Eweleaze over the Muston meadows to Burn Coppice hounds ran on that badscenting plough-land for two miles to Doles Ash, which was left on the right. Thence they crossed the road leading from Plush to Piddletrenthide, up over the hill between Alton and Plush, on over the flat, leaving Whatcombe Wood a little on the right, through the centre of Armswell big cover into the vale below, to Alton Common, where a dairy-house stands in a large yard. There Mr. Radclyffe and George Kennett saw the fox, which was dead beat, go round the corner of a hay-rick close to the yard gates, but after that could not make him out, although they tried all the cow stalls, pig-styes, and out-houses. At length $\mathrm{Mr}$. Radclyffe, knowing the fox had not gone on, ordered the hounds home. There were very few left to see the end of this grand run, which was the best of all Kennett's runs with foxhounds. The fox was afterwards found curled up in an out-house, and having been marked was turned adrift. $\mathrm{He}$ was killed three years afterwards from Admiston Withy Bed, giving a good fast forty minutes.

Mr. Fred Radclyffe succeeded his father, and with Levi Sheppard, a Dorset-bred man, as huntsman hunted the country for a few years, showing good sport. During his time several good runs were recorded. Meeting is March, 1884, at Black Hill, Bere Regis, Sheppard took hounds on to Horse Close, where Mr. R. Cave turned up a fox out of a small pit. The fox made straight through Horse Close in the direction of Whitchurch, turned as if for Longthorne, which he passed on the left, then crossing Chescombe Farm to Milton Park, bore away to Luccombe Hill. There he was twice headed, and went straight ahead over the hill by Hewish Farm in a direct line for Bagber Coppice, which, however, he left a little on the right, straight into Milborne Wood. Leaving the wood, he ran the turnpike road as far as the old Dewlish gate, then up the lane to Crawthorn Farm into the long plantation, where Henry Symonds saw him in the middle of a field standing still listening till the hounds were in view. Not done for yet, he ran another thirty minutes on to Basing Hill, and over the turnpike for Puddletown, when he turned to the right over Paull's Farm to Druce House. Headed back there, he turned across the large arable fields and through the hedgerows, and ran the road which leads to Dewlish for half a mile, and bearing to the right for Puddletown, he was killed in the open by Mr. Paull's house. Time, 3 hours and 5 minutes. The distance from point to point, Io miles; ground run over, 20 miles.

Mr. (now Sir) Elliott Lees ${ }^{7}$ was for one season master in succession to Mr. Fred Radclyffe, and moved the hounds to kennels at Sturminster Marshall. After a brilliant season he presented the hounds to the country.

Mr. Rupert Fetherstonhaugh-Frampton, of Moreton, was the next master, and hunted hounds himself with Stephen Burtenshaw as first whip. The hounds were removed to Bere Regis, where some excellent kennels were built on a most healthy site. The ex-master of the Cattistock, who had assumed the additional name of Frampton in 1887 , was a rider sans peur et sans reproche. One of his best runs was on $4 \mathrm{No}-$ vember, 1889 . He found a fox in Warmwell Wood and ran througl Knighton Wood to Empool, through Hope Wood to Watercombe Tunnel, where the fox was headed. Taking to the heath Reynard made for Bincombe, and going over White Horse Hill was killed in a stable at Sutton Poyntz after a good two hours' run. In I $894 \mathrm{Mr}$. Frampton resigned and Mr. Ashton Radcliffe, under whose management the hounds have gone on steadily improving in type and quality, was induced to take the mastership. Mr. Radcliffe is a good huntsman in the field and a most patient and persevering master of the kennel. Having a keen eye for the true type of hound, and keeping that type always before him, he has gone on year after year building up a pack of level, well-matched hounds. Many a good judge of foxhounds has pronounced the South Dorset as they are now one of the smartest and best-looking packs of hounds in the provinces. Mr. Radcliffe began his hunting days under Sir Charles Slingsby with the York, and with the Bramham Moor when Mr. George Lane-Fox was master and Charles Treadwell (brother to the famous Jim 'Treadwell) was huntsman. At one period he helped his cousin, Mr. Platt, with the North Herefordshire, when

7 Sir Elliott Lees, while member for Birkenhead, was winner of the House of Commons Point to Point in 1887 on Damon, after having won the Blackmore Vale Point to Point in the previous year on the same horse. 


\section{A HISTORY OF DORSET}

the latter was away, and then hunted the Rochdale Harriers from I 880 to i 887 with great success. He has had several good kennel huntsmen during his time. Old Bartlett was his first, who had been huntsman to the V.W.H. (Lord Bathurst's), and also to Lord Fitzwilliam's hounds. After him came Kane Croft, who remained seven years, a capital kennel huntsman and whip who had gained his experience in Ireland, Hertfordshire, the Isle of Wight, the Belvoir, and the Woodland Pytchley countries. Then came Stratton, who had been huntsman to Lord Portman's, and has now gone to the Fife.

IVilliam Maiden, who is now kennel huntsman, came to the South Dorset from the Newmarket and Thurlow. Before that he had been with the County Galway, East Sussex, Heythrop, Essex, Brocklesby, Lord Galway's, and Duke of Buccleuch's hounds. When Mr. Radcliffe first came to the South Dorset there were but few really home-bred hounds, the rest of the pack being drafts from the Belvoir, Cheshire, and Lord Portman's. He sent some of his best bitches to the Oakley to start building up his pack and to get bone, and after that chiefly to the Belroir for quality and straightness, and to the Grafton, a pack he considers to transmit good working powers. The produce have been a very fast, level, and musical lot of hounds, with wonderfully good necks and shoulders and plenty of bone. One of the best runs the South Dorset have had in Mr. Radcliffe's mastership was on 16 November, 1896 . Meeting at Cheselbourne they found in a pit between Cheselbourne and Dewlish a fox that ran by Milborne Wood and Athelhampton to Tincleton Hang and down to Clyffe House. Crossing the water meadows by Woodsford he went through Knighton Wood and Withby Bed and was killed in a cottage garden at Broadmayne, every hound being up at the finish. The time was one hour and fifty minutes and the point was something over ten milesfifteen or sixteen as hounds ran. There was no real check all through, and three sets of watermeadows and three rivers were crossed.

The South Dorset Hunt has gone through several serious crises from dearth of foxes and other causes, but things are brighter now and, with a popular master as Mr. Radcliffe is, will so continue. The backbone of the hunt is to be found in the strong support of the yeomen farmers, who form a large portion of the field and go as well as they preserve foxes. The most interesting covert in the country is Melcombe Park, a huge succession of woods. It lies on the edge of the South Dorset Hunt, adjoining the Blackmore Vale and close to a portion of Lord Portman's country. Although nearly every week, sometimes more than once, one of the packs runs through or into this covert, it is always full of foxes, and the writer has seen as many as ten or eleven foxes in a single morning there. In some parts of the country there are wild expanses of heath where will be found the worst of riding with the best of foxes. But a Dorset heath man will ride the roughest part as fast and as safely as the best of country, the great secret of course being to ride it fast and leave the horse alone.

\section{Lord Portman's Hounds}

The history of these hounds, like that of other Dorset packs, begins in 1858, when Mr. Farquharson gave up the county. Their country extends some fifteen miles north and south and eighteen miles east and west, lying chiefly in Dorset, but with a small portion in Wilts and Hants. The country is bounded by the South and IVest WVilts, the Blackmore Vale, the South Dorset, the Wilton, and the New Forest. Edward, first Viscount Portman, got together a small pack in the first instance, with his son, the present Viscount Portman, acting as field master, and John Dinnicombe as huntsman. At first foxes were so scarce that in the sixty-two days' hunting of the first season five days were blank, only twentynine foxes were killed, and twenty earthed. But matters soon improved; foxes were better preserved when covert owners found they would be hunted.

J. Smith succeeded Dinnicombe and remained as huntsman for many years. In 1873 he was succeeded by Dyer, who was a very short time with the pack ; but Joe Moss, the next huntsman, who had whipped in to Dyer, carried the horn for twenty-six years, and was a most capable and popular huntsman. He was born in Suffolk, and started his hunting career in Essex, where his father hunted a pack of harriers at $I V$ rittle. His first experience with foxhounds was with the Surrey Union; then he served with Lord Leconfield's hounds in Sussex under Shepherd. After a while with the Puckeridge he went to the Cattistock, when Lord Poltimore was master. He began with Lord Portman's as whip to John Smith in 1870 , and after two years he went to the Duke of Buccleuch, then to Mr. Corbet in Cheshire, where he found in the Cheshire kennels the Poltimore bitch pack, which had been purchased for a large sum of money, and afterwards had to be destroyed on account of hydrophobia.

After that he returned to Lord Portman as whip to Dyer and eventually succeeded him as huntsman. His two successors, Stratton and Sharpe, did not stop many seasons, and the present huntsman is Sam Dickinson, who is doing extremely well. His previous experience had been with the Fitzwilliam, Burton, Lord Galway's, and the Rufford. 'The hounds are from some of the best strains of blood in England, and at different periods the Belvoir, Oakley, Fitzwilliam, 


\section{SPOR'T ANCIENT}

Poltimore, Grafton, Warwickshire, Brocklesby, Grove, and Lord Portsmouth's have been utilized. The territory comprises light hill country, some heath, a strongly fenced vale mostly grass, and a good deal of woodland. Wire has been greatly taken down in the vale, but rabbit netting in the hill country is a great hindrance. Some country loaned in 1858 in the east and north was given up when foxes became more numerous, and a small exchange of country was made with the Blackmore Vale when Mr. Wingfield-Digby was master of that pack. Two or three small coverts have been planted, and Lord Portman rents one large covert called Doncliffe, and two small gorses.

The kennels were rebuilt about 1889 on the plan of Lord Misldleton's, and are perfect models. Foxes are plentiful in some districts, but in other parts of the country, owing perhaps to the increase of shooting tenants, are not so well preserved. The farmers, as in other parts of Dorset, are keen sportsmen and staunch supporters of the hunt.

On I6 January, I890, these hounds had a memorable run. Meeting at Harley Gap they found in the gorse close by; the fox made his point for Lord Shaftesbury's Harley Wood, and, breaking at the lower end, crossed the down to Waite. At Monkton, where there was a check, Moss cast by the meadows to the bridge, where hounds hit off his line. $U_{p}$ to this time the pace had not been great, but now commenced what was perhaps one of the fastest runs on record. Over that splendid open country, with hardly a fence, it was a perfect race to Water Lake through Cranborne Farm to Blagdon Hills. Hounds drove their fox without a moment's check into Martin Wood, where a man was holloaing, but as they still stuck to his line, Moss showed good judgement in letting them alone. Without a pause they pushed him on to High Bowlesbury, and away into the open again, across Ridley Farms to Allingford Water and Rockbourne Knoll. Here the fox was seen stealing away by the Down Farm for the Tenantry Down, and was pulled down just before reaching New Buildings. Thirteen miles as the crow flies, and sixteen miles as the hounds ran. Time, from find to finish, I hour I 2 minutes.

\section{POINT-TO-POINT RACES}

In connexion with the Dorset hunts the Blackmore Vale and Lord Portman's hold annual point-to-points at the end of the season. The Blackmore Vale have races for heavy-weights and light-weights open to the Dorset hunts, also heavy-weights and light-weights open to farmers ard one open race.

Lord Portman's have races for red coats, heavy-weights and light-weights, and farmers' welter and light-weights.

\section{AND MODERN}

\section{STAG-HUNTING}

\section{The Ranston Bloodhounds}

For some eight seasons, George second Lord Wolverton hunted the carted deer (and sometimes a drag) with a pack of bloodhounds, chiefly over the Blackmore Vale country. These hounds originated from a draft of eight couple of bloodhounds ${ }^{8}$ bred in County Meath by Captain Roden of Kells. In 1875 the Ranston pack numbered $16 \frac{1}{2}$ couple standing 27 in. at the shoulder, and according to Major Whyte-Melville 'their limbs and frame were proportioned to so gigantic a stature, and thanks to the Master's care in breeding, and the freedom with which he had drafted, their feet were round and their powerful legs symmetrically straight.' As a rule they hunted red deer, chiefly hinds; a few stags were kept, but they did not answer so well. James Young was Lord Wolverton's first huntsman, to whom John Boreham succeeded. Tom Lane, the head keeper, had charge of the deer, drove the deer cart, and sometimes carried the drag, as did also Stark, who was a bold horseman and knew the country well. As with all packs of bloodhounds, it was always either a very good or a very bad day with them, since they hunted entirely by scent, never raising their heads for a view.

A good run is recorded by Miss Serrell with these hounds. On 7 March, 1874 :-

Lord Wolverton's fixture was at Fifehead Magdalen, as he had settled to look for a hind that had been seen for some days feeding with the cows on Loder's Farm at Buckhorn Weston. This hind had given a capital forty minutes from Manston the week before, and had been lost at the end of the day near Rodgrove.

The hounds and the field-the latter numbering about one hundred, were shut into the yard for twenty minutes, and then the chase started over the open-trenched fields and their stiff fences in the direction of Rodgrove. Thence towards Shanks, and at a gallop down the lane till there was a short check close by Langham. Hounds soon recovered the line, and crossing a ploughed field, bore down to the South Western railway, and passing under the arch, went round towards Eccliffe Mill till the river lay in front. A somewhat deep ford here let both hounds and field through, and going fairly straight for Stour Provost, the pack crossed the Todber Road, and leaving Nash covert on their right, came down once more to the river. For a while they ran along the bank till they came to City Mill, where they crossed, the narrow plank bridge at this point allowing the field to get over in single file. At Pentridgc the Somerset and Dorset railway had to be crossed, and now the pace, which up to this point had been good, grew slower. The hounds, however, never left the line, and the big doubles that lay in their path, and which they could cross but slowly, brought out their decper and more

'Captain Roden's hounds had come from Mr. Jennings in Yorkshire and Mr. Cowen of Blaydon Burns. 


\section{A HISTORY OF DORSET}

angry tones. Near Bagber the hind was viewed in the Blackwater, but before hounds came up she was off, and the field, now reduced to fifteen in number, went on by the Bagber brickfields and over Haydon Common to Stoke Wake. Here the gallant hind was taken, after a run of two and a half hours, the earlier part of which had been at racing pace. The Lady Theodora Grosvenor and Mrs. Clay Ker-Seymer were well up till near the end, the only members of the field who were actually up when the deer was taken being Mr. Merthyr Guest, Mr. Clay Ker-Seymer, and one of the whippers-in.

An amusing incident occurred during one of the drag hunts, showing the way in which the hounds evidently ran the foot and not the drag. The man who was carrying the drag, feeling thirsty, left it at a little distance from a publichouse, and having gone to the house and slaked his thirst, returned and continued on his way. When the hounds arrived at the spot they did exactly the same, going straight to the publichouse (causing great fun), and returning to the spot where the man had picked up his bait, went on and finished the run.

After parting with the bloodhounds (the pack going to Lord Carrington), Lord Wolverton built a new house at Iwerne Minster, near Shaftesbury, and kept a pack of smart harriers, which he hunted himself on deer and hare and showed great sport.

\section{Roe-Deer Hunting}

Roe-deer hunting deserves considerable notice in the history of the county, for Dorset, being one of the very few homes of the wild roe-deer, is the one part of England where the roe has been systematically and regularly hunted. Their existence here is due to George second earl of Dorchester, who somewhere about the year 1800 turned down a few Scottish roe-deer in the woods of Milton Abbey. From this source Mr. Mansel-Pleydell in I 829 took some to the Whatcombe IVoods, and they now have become very numerous and fairly widely spread throughout the county. Nearly all the large coverts now hold roe-deer, one of their favourite haunts being Hethfelton Plantation, where they are strictly preserved by Mr. J. IV. T. FylerHenbury. Roe-deer are also found in Bere Wood, Melcombe Park, Milton Abbey, Ilsington and Yellowham woods, and in some of Lord Ilchester's coverts.

The earliest regular pack of roe-deer hounds was kept by Mr. Mansel-Pleydell, who hunted them for some fifteen or sixteen years. Mr. Yeatman of Stock House and Mr. James Harding of Misterton hunted roe and hare indiscriminately.

Mr. Drax, and later on Mr. Charles Radclyffe of $\mathrm{Hyde}$, kept special packs for roe-deer, as well as packs of foxhounds, and in quite recent years Lord Ilchester kept a pack of roe-buck hounds.
According to the Sporting Magazine for I 824 , Mr. Pleydell's pack consisted of 18 couple of dwarf foxhounds and a few moderate-sized harriers. They had finished that season in April, having killed fourteen brace of deer. In the middle of the season they killed six consecutive times, each deer giving a good run of from three hours to three hours and a half. The huntsman was IVilliam Rice, who is buried at Milborne, and on his tombstone it is stated that 'he was the first man that ever hunted a pack of roe-buck hounds.'

Of these hounds a record of one run is related by Mr. Symonds in Runs and Sporting Notes from Dorsetshire.

The roe-buck hounds of E. M. Pleydell, Esq. of Whatcombe House, closed the season with a brilliant day's sport on Saturday, 5 April, i 828 .

They threw off at Elcombe Wood, and in about ten minutes a fine buck was riewed going over the opposite hill in gallant strle for Escombe, through which he passed and made for Turnworth; here he remained a few minutes, and then broke orer the downs into the Vale of Blackmoor to Ibberton, where being headed by some labourers, he ascended the hill, and skirting Ibberton Park, ran to Houghton Wood, passed through that extensive covert, and turned through the inclosures of M. Davis, Esq., to a coppice at some distance near Durweston. Thence he made for Elcombe and again attempted the hill ; but his strength failing, he turned back into covert, and passing directly through, broke on the other side; and the whole pack (with the exception of one couple of hounds) ran into him in view in a short furze brake on the down, after a run of one hour and forty minutes without a single check, and the greater part, particularly in the open country, at speed.

The mountain harriers kept and hunted by Mr. James Harding of Higher IVaterson enjoyed wonderful sport after roe for several years about 1830 and onwards.

Mr. Charles Radclyffe in 1856 commenced roe-deer hunting with hounds bought from Mr. Bellew. They were foxhounds crossed with bloodhounds, most tenacious of the line of the hunted deer, seldom changing except when a fresh deer got up in view. These hounds are reputed to have given grand sport, and the account of one run with them on 3 April, 1857 , will show their powers of endurance.

This run was from Lytchett High Wood, of 4 hours 10 minutes, and the distance run was about 25 miles. The deer broke away for Lytchett Manor House through the covers and over the Bailey Gate and Posle Road, went straight ahead, taking all the Henbury plantations in his line. Turning to the right over that enormous extent of wild heath nearly to Poole Junction, he bore to the left for Hamworthy, where he turned short back and went right through the Henbury covers again; he then crossed the Blandford and Wimborne turnpike, took the meadows, and crossed the River Stour near White Mill. The refresher was much needed, for this strong animal went straight for Badbury Rings as fresh as ever, took 


\section{SPORT ANCIENT AND MODERN}

a turn round the old Roman encampment, came back over the downs, crossed the old Blandford turnpike and the fine open country to Kingston Lacy House. Here he got into the meadows again and hid for some time in a large spear bed. He jumped up in full view, went over the river again, which gave him fresh life once more, ran the south side of the river (here wide and much swollen with heavy rains) for two miles, and took refuge under Julian's Bridge close to the town of Wimborne, where he stood under the archway close to the bank, with his fine head and antlers just out of the water. He was soon got out and killed. All were wet through, and the horses were thoroughly done up, for it had been raining all the time from start to finish.

Those who have hunted the roe-buck say that at first the quarry runs short, not much in front of hounds, but once forced into the open will run very straight and far. It is remarkable that although hares and foxes are often chopped the roe-buck scarcely ever is, and even when surrounded his agility and strength enable him to evade hounds. Even the oldest roebuck has never been known like other stags to stand at bay; it will allow itself to be taken without any attempt at defence.

It is strange that regular hunting of this quarry which gives such excellent sport has now ceased. Several attempts, indeed, have been made to revive an interest in it, and at odd times packs of harriers have had a day after the roe, but no systematic roe-deer hunting is now carried on in Dorset.

\section{HARRIERS AND BEAGLES}

Dorset has very little history of hounds kept exclusively for hare-hunting. During the last century, at different times and in different places, both beagles and harriers have been kept for brief periods, but none have been kept on as a county pack, with the single exception of the Sparkford Harriers. ${ }^{9}$ As far back as 1830 the Rev. Nathaniel Bond of Creech Grange, kept a pack of harriers in Purbeck; and later on, from I 856 to I 860 , the Bonds had a pack of beagles at Grange. From 1862 to 1870 the third earl of Eldon had a very sporting pack of harriers at

- These hounds have recently come under the mastership of Mr. F. J. B. Wingfield-Digby of Sherborne Castle, and will probably be kennelled there for the future.
Puncknowle; and afterwards these hounds also came to Grange until I 875 .

From I 865 to I 867 Mr. John Smith-Marriott hunted a pack from Sydling Court, commencing with very small beagles, but going on to draft foxhounds.

Mr. Crane had a wonderful little pack of pocket beagles at Southover in the latter part of the nineteenth century, and $\mathrm{Mr}$. Sheridan of Frampton Court hunted a pack of beagles in his portion of the Cattistock country. These hounds, which belonged to his daughter, Mrs. William Hall Walker, gave great sport, and once ran a fox for two hours and twenty minutes, very nearly handling him. In quite modern days Mr. Harry Mills had a small pack of large beagles and small harriers, moving them to Grange afterwards, and increasing their size. For a short time he hunted in the Isle of Purbeck, but troubles with shooting tenants and other reasons eventually brought this pack to an end. At the present time Mr. Montague Radclyffe has a smart pack of foot beagles at Hyde.

\section{OTTER HUNTING}

Otters abound in Dorsetshire; but the hunting of them has not received much attention, although it is now of a more regular and systematic character than formerly. Miss Serrell for a few seasons, about 1890 , hunted the otter with a pack of her wonderful terriers around Fifehead Neville and killed quite a number, the terriers taking to the sport with great zest and determination. After that Mr. Courtenay Tracey took over the rivers, and has visited and hunted them more or less ever since, extending his rivers year by year and getting good sport.

His pack of about twenty couple consists of a few couple of pure otter-hounds, some foxhounds, and some a cross between the two; the latter he esteems for this kind of sport, as they stand the coldness of the water better than the pure foxhound, and are truer hunters than the pure otter-hound. $\mathrm{He}$ is ably assisted by Mr. Twynham and Mr. F. Rigden; no days seem too long, no distances too great, for these hounds and their master to accomplish. Mr. Tracey's otter-hounds are kennelled near Salisbury, and the kennel huntsman is Tom Stubbington. 


\section{A HISTORY OF DORSET}

\section{RACING}

As far as modern racing is concerned Dorset has none, although some good racehorses are bred within its borders, and there is an excellent training stable near Blandford. In olden days races were held annually at Blandford, where the old racecourse still exists, and also at Sherborne and Weymouth. Blandford races were held on the downs in the parish of Tarrant Monkton, and date back to very early times in the history of racing.

The races, however, have been discontinued since 1843 , having gradually dwindled into unimportance. Some curious items are preserved respecting them in the time of James I, when public races were established in many parts of the kingdom, although it is not improbable that in this town horse-racing may date from a much earlier period. They appear to have been encouraged by the town authorities, who provided an entertainment during the week of their continuance, besides engaging 'players' for the further amusement of the company, who were probably accustomed to attend these races periodically, as an established scene of festivity and amusement.'

As far back as 1603 there is a record of races at Blandford, and the following account of moneys expended is of interest :-

Blandford Races, 1603.

John Cleves, Town Steward or Chamberlain of the Borough.

Dr. for Money received at the Races

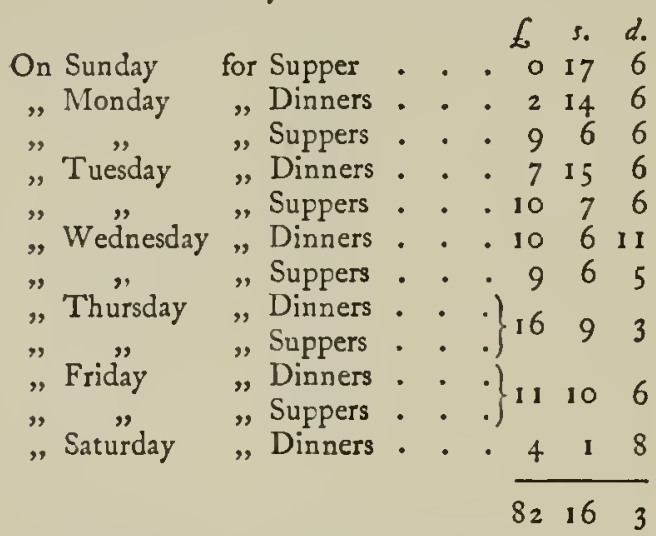

Received for the play, six nights fiI $_{7} \mathrm{~s}$.

There is also a long list of noblemen and gentry who attended the races in their coaches and six, among whom are mentioned Lord Milton of Milton Abbey, Lord Shaftesbury of St. Giles, Lord Arundel of Wardour Castle, Mr. Sturt of Crichel, Mr. Willett of Merley House, Mr. Portman of Bryanston, Mr. Weld of Lulworth Castle. Other early Dorset patrons of the turf were Humphrey Sturt, esq., Henry William Berkeley Portman, esq., Francis Seymour, esq.,

\footnotetext{
${ }^{1}$ Hutchins, Hist. of Dorset.
}

and Thomas Erle-Drax, esq., as appears by the list of subscribers in 1757 to an old book on racing by Reginald Heber, entitled The Historical List of Horse Matches run and of Plates and Prizes run for in Great Britain and Ireland.

It is interesting to note that owing to the length of the races, the weight carried, and the several heats run by the same horse in a day, the racing of those days was a very different matter from that of our times.

1777 .

Blandford, Dorsetshire.

On Tuesday, 22nd of July, £50 for $4 \mathrm{yr}$. olds, colts 8 st. 7 lb., fillies 8 st. 4 lb., winner of one plate this year to carry $3 \mathrm{lb}$., of more $5 \mathrm{lb}$, extra.

$$
2 \text { mile heats. }
$$

Mr. Tombs' ch. f. Cornish Lady by Prophet, I plate . . . . . I-I

Mr. Parke's b.c. Briskin . . . . 2-2 At starting 2 to $I$ on Briskin.

On Wednesday the $23 \mathrm{rd}$, 650 given by the Members for the County for $5 \mathrm{yr}$. olds $8 \mathrm{st}$. $7 \mathrm{lb}$., for $6 \mathrm{yr}$. olds 9 st., and aged 9 st. $7 \mathrm{lb}$. Winners of $£ 50$ plates this year to carry $4 \mathrm{lb}$. extra, of King's Plates since the 5 th of April, Io lb. extra.

$$
4 \text { mile heats. }
$$

Mr. Hibberd's b.h. Omnium, 5 yr. old $\cdot . \cdot 2 \cdot 2-I-1$

Mr. Bowles' b.h. Codrus, 6 yr. old, 2 plates . . . . 1-2-2

These horses must have run 12 miles in heats. In I8I6, on Tuesday, 29 July, we have the record of a Maiden Plate of $£ 50$ run off in four mile heats.

Mr. Tate's ch. h. Lismahago by

Acacia, 9 st. Io lb. . . . 2-1-1

Mr. Wilson's b.c. Wooton, 4 yrs.

8 st. 2 lb. . . . . . $1-2-2$

In August I 8 I 2, a race was run at Sherborne, with the following result :-

f5o for all ages. Heats thrice round.

Mr. Farquharson's Wood Daemon

by Lop, aged, 9 st. . . . . . I-I

Mr. Williams' ch. g. Picaroon, aged,

8 st. I I lb. . . . . . . . 3-2

Mr. Radclyffe's Small Hopes, 6 yrs.,

9 st. 4 lb. . . . . . . $2-3$

One of the most interesting points of the old Blandford racecourse is Telegraph Hill, where used to stand the Semaphore, with which messages could be sent to London almost as quickly as an electric message gets there now. It was one of a series of semaphore signal stations on the high hills between Blandford and London, each taking up the message and passing it on.

Both Blandford and Weymouth held races for king's and queen's cups. 


\section{SPORT ANCIENT AND MODERN}

\section{RACING CELEBRITIES}

The foremost place among racing celebrities of the county belongs to the first Lord Alington, who from his earliest years took the greatest interest in the turf. The late Sir Francis Doyle, who was a distant cousin of the Sturts, used to relate that Gerard Sturt, when an Eton boy in I 839-40, backed Lord George Bentinck's famous filly, Crucifix, for all her races as a two and three-year-old, and wound up by landing a treble event bet when, in 1840 , she won the Two Thousand Guineas, One Thousand Guineas, and Oaks. ${ }^{2}$

In 1849 colours were first registered for Mr. Gerard Sturt, as he was then-light blue jacket and white cap ; and the first of his many trainers was John Day of Danebury.

His first successes worthy of record were gained when he and his staunch confederate, Sir Frederic Johnstone, transferred their horses to William Day's care at Woodyates, which that good trainer and fine judge of racing had leased from the earl of Shaftesbury. Perhaps the most remarkable of the lot was Brigantine, which William Day bought for Sir Frederic Johnstone as a yearling for 150 guineas. This mare, trained at Woodyates, won for Sir Frederic the Oaks and the Ascot Gold Cup in I 869. She subsequently remained in Lord Alington's stud at the White Farm at Crichel until 1882 .

The real interest attaching to Lord Alington's racing life, so far as it affects the majority of modern racegoers, commences with the period when, about the year 1882 , he became for the first time a patron of John Porter's famous training establishment at Kingsclere in Hampshire, of which his partner, Sir Frederic Johnstone, was already a supporter. There is no occasion to recapitulate in detail the names and performances of the numerous thoroughbreds in training which belonged jointly or severally to Lord Alington and Sir Frederic Johnstone between I88I and Ig03. Are not their names, ages, pedigrees, and performances, as well as the jockeys who rode them, exhaustively recited by John Porter in his entertaining work Kingsclere, published in 1896? Before he joined the Kingsclere stable Lord Alington's triumphs had been principally confined to handicaps, selling stakes, and two-year-old races. With each and all of his many previous trainers, William Day alone excepted, he had been singularly unsuccessful. At Danebury, at Littleton, at Findon, at Newmarket, where for fifty years he had horses under the charge of several trainers, some of whom, by his orders, kept his connexion with their stables a profound secret, he was seldom cheered by victory. All, how-

The editor of the Sportsman has most kindly supplied a great deal of information concerning Lord Alington's racing life. ever, was changed when the partners threw in their lot with William Day at Woodyates. The long list of prizes won by Lord Alington (then Mr. Gerard Sturt) and Sir Frederic Johnstone is given by William Day in his Raceborse in Training (p. 99), from which we quote the following passage :-

That some estimate may be formed of the merits of the animals my horses met, I will summarize a few of the races they won. Handicaps:-Chester Cup, Cambridgeshire, Royal Hunt Cup, and Somersetshire Stakes, three times each ; the Metropolitan, Goodwood Stewards' Cup, Great Eastern Handicap, Goodwood Stakes, and Northamptonshire Stakes, twice each ; the Portland Plate, Cesarewitch, Chesterfield Cup, Stewards' Cup at Chester, the Doncaster and Lincolnshire Handicaps; the Newmarket, Lincoln, Goodwood, Doncaster, and Stockbridge Nurseries, the Shrewsbury and other small handicaps. Among two-year-old victories I may include the New, Molecombe, and Lavant Stakes, the Ham and Findon Stakes, the Criterion, and the following weight-for-age races: The Oaks, Goodwood, Derby (twice), Queen's Vase at Ascot (twice), the Ascot and Goodwood Cups, the Two Thousand Guineas (twice), Royal Stakes, and, finally, the Yearling Stakes at Shrewsbury, not to mention others.

In 1883 St. Blaise running in the name of Sir F. Johnstone won the Derby.

In 189 I Common won the Triple Crown.

In 1894 Throstle won the St. Leger.

In 1891 Lord Alington sold Common to Sir J. Blundell Maple for one of the largest sums ever paid in the United Kingdom for a racehorse, and in 1894 he sold Matchbox, which ran second in the Derby to Lord Rosebery's Ladas, to Baron de Hirsch for $f_{1}$ 5,000.

Towards the end of his life Lord Alington generally had a few horses in training with Walters at Pimperne, and many of them were successful. He died in I904 and was succeeded by his son the Hon. Humphrey Napier Sturt, who still keeps some good horses in training with the same trainer.

The late Lord Wolverton had a few good horses in his time, the most famous of his breeding was The Bard. The late Mr. Ralph Bankes of Kingston Lacy also did a little racing, and he won quite a good number of the smaller events between the years I88I and I902. Amongst his best horses were Camiola which in I 894 won five races at Hurst Park and Kempton Park, and Perseverance, the winner between 1899 and I 90 I of seven races at Ayr, Birmingham, Kempton Park, and Newmarket.

\section{TRAINING ESTABLISHMENTS AND STUD FARMS}

Now that Mr. Gilpin has left Langton and gone to train at Newmarket the only trainer left in the county is Mr. Alfred Walters at Pimperne. The father of the present trainer of this stable was Mr. W. Walters, who himself was the son 


\section{A HISTORY OF DORSET}

of John IValters, one of three brothers, all trainers, well known about I 840 . He began riding in pony and galloway races when ten or eleven years of age. After that he rode under Rules of Racing and later on was a well-known steeplechase rider under National Hunt Rules. In I 863 he commenced as private trainer to Sir C. Rushout, near Moreton in the Marsh, moving afterwards to Earls Croome, thence to IVroughton, and finally coming to Pimperne in I 885 . Among the best horses trained at Pimperne were Goldseeker and Tyrant, which between 1886 and 1890 won between them the following races:-The Doncaster Welter Plate, the Cleveland Handicap, and the Portland Plate at Doncaster ; the September Handicap at Manchester; the City and Suburban; the IVelter Handicap at Newmarket; the Chester Cup and the Great Cheshire Handicap ; the Great Northern Handicap at York; and the DoncasterSpring Handicap. Among other winners trained by Mr. Walters the best have been Clarion, Monsieur, Goodlake, Hibernian, Bonny Kate, Mountain Knight, Bobbie Burns, and Satyrica.

It would be impossible to find a healthier spot for horses, or a more perfect training ground, than this on the old Blandford racecourse, with distances to suit preparation for all races. Beautiful firm and springy turf on a good subsoil covers the whole; and nicely undulating downs abound. Above all its recommendation is its isolation, for here are no crowds, no jostling, no touts to worry the trainer in his trials, the horses run no risks, and have every opportunity for good work without hindrance.

A notable stud farm is situated at The Knoll, Corfe Mullen, where with excellent paddocks and every modern convenience Captain $\mathrm{H}$. Y. Mills (late 6th Inniskilling Dragoons) takes in about thirty-seven mares for breeding purposes. Amongst these mares is Concussion, dam of Hammerkop, Sirenia, and Water Chute. Hammerkop won the Cesarewitch in 1905, and the Alexandra Cup at Ascot in 1905 and 1906. Sirenia won the Duke of York Stakes, the Kempton Jubilee in 1900, and in Ireland was unbeaten as a two-year-old. Another mare in the paddocks is Clarehaven, winner of the Cesarewitch in 1900 , and here may be seen many other winning mares.

Eager by Enthusiast-Greeba stands at The Knoll, one of the most popular horses that ever ran, and the champion sprinter of his time. Although no classic race fell to his lot, he won no less than $£ 15,000$ in stakes and won a good race every time he appeared at Ascot.

Mr. William Martin of Moor Court has also bred a few useful thoroughbreds at his farm near Bailey Gate, but they have always been sold before entering upon their racing career.

\section{POLO}

Polo, as a county game in Dorset, dates from the year 1900, when the Blackmore Vale Polo Club was formed, and this club now is admitted by all to be the leading country club of the day. The president is Major Earl Cairns, the hon. secretary and treasurer H. E. Lambe, esq., Stalbridge, and the assistant hon. secretary the Hon. L. Lambert, Milborne Port.

In 1907 there were thirty playing and seventyfive non-playing members; of the former the best known are perhaps Captain Phipps Hornby (late of the Rifle Brigade), Colonel Duth (late of the 8th Hussar Team), Captain A. Courage (of the great I $5^{\text {th }}$ Hussar Team), Mr. J. Hargreaves (of the Freebooters Team), and the Hon. H. Grosvenor (late of the I4th Hussars).
This is the only county club which can boast four grounds-three boarded and one unboarded-all situated some three miles from Sherborne.

Polo commences on I March, and ends on 3i August. About seventy days' polo are played on the grounds cach scason, with two annual tournaments.

In I 904 the club won the 'County Cup' after having been runners up for the two preceding years. In 1905 and 1906 the team were runners up at Ranelagh for the County Clubs Junior Championship, which was instituted by the Blackmore Vale Polo Club and was afterwards taken over by the County Polo Association.

\section{SHOOTING}

We have encountered many difficulties in compiling the following short account of shooting in Dorset. Of late years nearly all the shootings have been let to newcomers, and now very few landlords keep them in their own hands. From these latter only statistics have been obtained; it has been found impossible to get returns from the present shooting tenants.

In old days there certainly was not anything like the amount of what may be termed artificial game-that is to say, home-reared pheasants, partridges, and wild duck; but the shooting was of a more sporting character when the oldfashioned country squire enjoyed moderate days with his neighbours who supported and participated in other sports as well.

Dorset is a county eminently suitable by nature for almost every variety of bird and animal, and in every part of it a varied bag may be had. There are good coverts of all sizes for 


\section{SPORT ANCIENT AND MODERN}

pheasants, fir plantations famous for woodcock, bog, river, and harbour ${ }^{I}$ for wildfowl, upland and arable for partridges and hares, whilst the heath swarms with rabbits.

Grouse have been imported, but with no success; and a few years ago there was a very fair sprinkling of blackgame, but these have steadily decreased of late years.

The most famous perhaps of all the big shooting manors is Crichel, the home of Lord Alington, where His Majesty the King has shot on more than one accasion. The shooting has steadily improved for many years and some memorable bags ${ }^{2}$ have been made. As many as 260 hares have been killed in the turnips in one day by three guns, and 1,540 in the season. Hungarian partridges reared on the estate have wonderfully improved the stock, and there are now great quantities of birds.

Lord Wimborne's Canford estate is also a famous shoot, notable as being one of the first places in the county where partridges were reared, as far back as 1886 , for driving purposes, 150 brace being killed in a day.

Milton Abbey has always been an estate notable both for pheasants and partridges, the latter having immensely increased of late years. It is almost unique for high pheasants, the coverts all being hanging woods on the side of the hill.
The Lulworth estate contains the best hare and partridge land in the county, and some remarkable bags have been made there year after year.

Rushmore, Melbury, and Colonel Brymer's coverts at Ilsington, are all good shoots, while Charborough $^{3}$ is remarkable for being the first place in the county where pheasants were extensively reared.

On Brownsea Island situated in Poole Harbour Mr. Van Raalte rears a large quantity of game, and round its shores there is exccedingly good wildfowl shooting.

Encombe, the property of Lord Eldon, is a good shooting manor, but more preserving was done in the past than is now the case.

Grange Woods used to be celebrated for woodcock, as many as forty being sometimes flushed in a day, when they had just come in.

Woodcock and snipe are not nearly so plentiful in Dorset as in former days. The writer has seen records of as many as thirty woodcock killed in one day, and it was no uncommon thing for two guns to kill between forty and fifty snipe in a day, whereas now half a dozen woodcock or four couple of snipe would be considered good. Taken all round the shooting in Dorset is of a very fair description, and of a really sporting order with regard to wildfowl.

\section{FALCONRY}

There are few places in England where the general characteristics of the country are so suited to the sport of falconry as those which are found in the county of Dorset. For here we find large tracts of open moorland, big fields, with here and there broad stretches of open down-land, all of which are essential to the successful pursuit of hawking. Not only is the Dorset falconer favoured with excellent grounds over which to carry on this fascinating sport, but he is also fortunate in living in a county which is still one of the greatest strongholds of our most noble British falcons, the peregrine (Falco peregrinus). Between St. Alban's Head and Bridport there are

1 Those who have turned over the pages of Hawker on Shooting will remember the wonderful bags of duck, teal, and widgeon that Poole Harbour has afforded, a happy hunting ground in days of yore both to the punt gunner and shoreman.

2 The best three days consecutively were in 1900 :-

\begin{tabular}{rrrrrrrr} 
& & Pheasants & Hares & \multicolumn{2}{c}{$\begin{array}{c}\text { Rab-Wood- Vari- } \\
\text { bits }\end{array}$} & Tock & ous \\
Jan. 23 & - & 1,551 & 123 & 189 & 1 & 9 & 1,873 \\
24 & - & 1,018 & 65 & 81 & 4 & 4 & 1,172 \\
25 & - & 1,517 & 68 & 385 & 4 & 4 & 1,978 \\
Total . & - & $-4,086$ & 256 & 655 & 9 & 17 & 5,023
\end{tabular}

In one rise on II Dec. 1896,708 pheasants were killed at one stand, the rise lasting three-quarters of an hour. still several eyries or these falcons, where annually, in spite of wanton destruction by guns and traps and the depredations of egg hunters, a fair number of young peregrines are bred each year. From time to time the lover of bird life may recognize the graceful flight of these splendid falcons, as they sail high over the Dorset moors or open downs. For many years the writer used to employ men to watch and guard most eyries of peregrines along the Dorset cliffs. On occasions certain of the young birds, commonly called eyesses, would be taken from the nests for the purpose of training them, others being left and allowed to fly away. The local cliff climbers were paid a good price for all birds whether taken or not, in order to outbid the professional egg hunters who were always willing to pay a certain price for the eggs.

It was early in 1887 that the writer first commenced his attempts at falconry. Acting under the advice of an old friend, the late Major C. H. Fisher of Stroud in Gloucestershire, the greatest falconer of his day, he began by training two eyess peregrines taken from a nest near Lulworth Cove. Although he has owned innumerable falcons and hawks and flown them in many lands since those days, his earliest

${ }^{3}$ At one time guinea-fowl and wild turkeys were placed in the Charborough coverts for shooting. 


\section{A HISTORY OF DORSET}

vicissitudes, pleasures and disappointments, pertaining to the first few seasons of a career as a falconer, will ever linger in his memory. He has in recent years trained and flown in Dorset peregrine falcons, Barbary falcons, merlins, goshawks, sparrowhawks, and even sakers and larmers imported from Asia, and with them he has taken such quarry as herons, blackgame, pheasants, partridges, wild duck, snipe, pigeons, rooks, crows and seagulls with the falcons, larks with merlins, and hares and rabbits with the goshawks. The best places for flying hawks in Dorset are the open moorlands around WVareham, Wool, and Bere Regis, the downs near Blandford and the surrounding country, and such places as Fordington Fields near Dorchester. Two other sportsmen have kept and trained hawks in Dorset during recent years. Colonel Thompson of the 7 th Dragoon Guards, when acting as adjutant of the Dorset yeomanry some years ago, kept and trained hawks at Charminster, and Mr. G. Blaine, who was for a few seasons the tenant of the Bere Regis manor, kept a fine establishment of trained hawks at that place. Time, space, and the nature of this article do not admit of any detailed account of the actual method by which hawks are trained and flown. Nothing but a fine day spent with a falconer and his hawks in such places as a grouse moor in August, or on the downs in spring when riding hard after good rook hawks, will give the reader an idea of the immense time and patience which are required ere a falconer can render tractable and subservient to hiswill one of nature's wildest creatures. Then for the nonce he may imagine himself once more back in the olden days, when falconry was the sport of kings, and hawking parties issued forth from every stately hall or castle in Merrie England.

\section{ANGLING}

The fishing in Dorset is extremely good in some parts; salmon, trout, and all descriptions of coarse fish may be taken, and some very good sea line fishing is to be found on the coast. The principal fishing rivers are the Frome which, rising near Rampisham, flows into Poole Harbour; the Piddle which rises above Piddletrenthide and empties itself into Poole Harbour; and the Stour, with its tributaries, which rises in the north-east corner of the county, and flows into the sea at Christchurch.

Dorset salmon fishing, although not nowadays first class as regards the number of fish taken, is first class for the size of the fish. Trout fishing is really first class, for there are few places in the United Kingdom with better natural trout streams, and where the water is carefully preserved the skilled angler may make phenomenal bags. Many a big catch has been made with the wet $\mathrm{Aly}$; but of the best fish the greatest number, whether in the Frome, the Tarrant, or the Piddle, have certainly fallen to the lot of the dry fly fisherman. Coarse fishing in many of the rivers is really good, and excellent sport may be enjoyed by the skilled bottom fisherman.

\section{The Frome}

The history of salmon fishing on this river is of great antiquity and importance, but it is as an industry rather than as a sport that we find early mention of it in the accounts of the honour of Gloucester. In I 544 Henry VIII made a grant of the manor and borough of IVareham to Catherine of Aragon, including all sporting and fishing rights.

In $156 \mathrm{I}$ the Frome salmon fishery was leased to a certain Francis Browne and
Anne his wife, at $69 s$. 4d. with a fine of f20. In 1582 it appears to have been granted to Edmund Frost and John IValker. In the same year it came into the possession of Sir Christopher Hatton and after that went to Sir John Bankes. From him it passed to the Calcraft family, who have held it ever since; the present owner being Captain Marsden, R.N., nephew of the late IVilliam Calcraft of Rempstone. Hutchins in his History of Dorset relates that an old fisherman of ninety-three had told him of a catch of forty-seven salmon weighing sixty score, which, being unsaleable at IVareham, were carried on to Bindon Fair and sold at $2 d$. a lb. The best netting was below IVareham Bridge, and in one year 150 salmon were taken-all big fish.

It was not until quite modern times that rod fishing for salmon was introduced on the Frome, but after several successful years of the nets, when Messrs. Panton \& Son had the netting rights of the Calcraft estate, it was attempted. The first to try the rod was the late General Hankey, who was stationed at Dorchester about I 868, and though permission was granted when he asked leave of Mr. Bond of Creech Grange, the idea of catching a fish was laughed at. Beginning at Holme Bridge, he fished steadily down to a pool about 400 yards below the present Swanage Railway Bridge. Here he hooked a fish which from its play he imagined to be a pike, and after about a minute it broke away without showing itself. Having fished the river down, he returned to the same pool and in it rose, hooked, played and landed a salmon of $28 \mathrm{lb}$, a clean fresh run fish. On examination he found the tongue split and bleeding, which proved it to have been the fish he had hooked 


\section{SPORT ANCIENT AND MODERN}

already. The pool is still called Hankey's Pool, and many fish have been caught there since. Soon after this Mr. Montague Guest, Mr. C. Hambro, Mr. Sidney Osborne, and Mr. Fred Fane took the best of the fishable water, from Stoke Mill to Wareham. In their best season, in spite of the nets below, forty-seven clean fish were taken on the rod, besides a large number of kelts returned to the river. Of late years the number of salmon coming up in the spring and summer months has for some quite unaccountable causes greatly decreased, and if a dozen fish are caught in a season, it is considered a good year, and that with no nets on the water at all. It is true that in the old days more trouble was taken, a water bailiff was kept on, the farmers cut the weeds once and often twice in a season, pike were netted in the lower reaches constantly, and steam tugs coming from Poole to Wareham kept an open passage free from weeds and mud, which is not now the case. And yet quite as many fish are seen in the winter months, November, December, and January, making their way to the spawning beds even as far up the river as Highford Common.

One most remarkable feature of this river is the fact that grilse or parr have never been seen in it, and only fish of very large size are taken. So large are they that it is the opinion of many who have fished the water that, had a record been kept, the average would have been between 27 and $30 \mathrm{lb}$. As proof of that, a year or two ago Captain Radclyffe fishing in the early part of the season, took seven fish on the fiy averaging $29 \frac{1}{2} \mathrm{lb}$. The record fish taken on the rod are one of $46 \mathrm{lb}$. caught by Mr. Osborne, using a prawn, and one of $4 \mathrm{I} \mathrm{lb}$. caught by Captain Radclyffe, using a fly.

The Frome as a coarse fishing river would take a very prominent position, were it not for its more important salmon fishing. There are pike, roach and dace in quantities and of good size between Wareham and Moreton; above that they give way to trout preservation. At Holme Bridge between Wareham and East Stoke we have seen enormous catches of roach and dace, some running up to $1 \frac{1}{2} \mathrm{lb}$. and over. The pike fishing is extremely good, fish running up to about $20 \mathrm{lbs}$. Mr. R. Butler took one of $21 \mathrm{lb}$. quite recently in the Hethfelton Water, which is strictly preserved by Captain J. W. T. Fyler.

There is good trout fishing at Moreton, where Mr. Frampton by careful and systematic netting has destroyed most of the pike and has stocked the river with good sized trout, which are doing well. Going on through West Stafford the river improves more and more towards Dorchester. The best water is that belonging to the Dorchester Club, which has a world-wide reputation. and the stretch belonging to $\mathrm{Mr}$. Sheridan of Frampton Court. The Dorchester Fishing Club, which has done a great deal for the preservation of trout, is limited to twentyfour members. The extent of fishable water belonging to the club is about six miles, which was reclaimed from the hands of netting poachers through the energy of the late Captain Mansel, who for many years was hon. secretary of the club. Among its most renowned members have been Mr. Selwyn Marryatt, Mr. W. H. Pope, and Major Cumberland. Of the first-named it has been said that he could place his rod between his arms behind his back and in that way cast a fly as deftly as most ordinary fishermen. At one time there were some immense fish below the town, and Major Cumberland caught several of them up to $7 \frac{1}{2} \mathrm{lb}$. in weight on the artificial fiy. Since, however, the new drainage system has been finished in Dorchester, these big fish have disappeared. Mr. Sheridan's water is extremely good and most carefully preserved; the water is well stocked and full of large fish, which rise well to the dry fly.

\section{The Piddle}

The Piddle, which runs parallel with the Frome, has also a reputation for salmon, but as the only good part is tidal, little has been done by rod-the biggest fish recorded was taken in 1898 in the nets and weighed $42 \mathrm{lb}$. As in the case of the Frome, many fish are seen in the winter months on the spawning beds. This river is undoubtedly, without exaggeration, one of the most prolific of trout-yielding streams in the south of England. The best part of it lies between Brian's-Puddle and Binnegar, the very pick of it between Chamberlayne's and Hyde. There is more than one record of a good rod taking forty brace in the Hyde water, and on one occasion Captain Radclyffe, to prove its capacity, caught $5^{8 \frac{1}{2}}$ brace in one day, of course returning most to the water. They run a fair size, and on most of the fishings there is a I lb. limit. On the lower reaches there are some very large fish, and the writer has twice killed, on the May Fly, fish of nearly $5 \mathrm{lb}$. and many of $3 \frac{1}{2} \mathrm{lb}$. A few years ago this portion was seriously depleted of fish, but by judicious management the water is now well stocked with large fish. Mr. Lindler, the present tenant, has established a fish hatchery at Bere Regis, the only one in the district, which is doing remarkably well. Going further up there is very fine fishing through Affpuddle, and right up to Puddletown, all the water being in the hands of private owners who preserve it most carefully, more particularly the water at Southover, and Tolpuddle which belongs to Mr. Crane. Mr. Homer's water at Burleston deserves notice, large-size trout being caught here, the record fish in 1906 being $3 \mathrm{lb}$., while the average for all years is $4 \frac{1}{2} \mathrm{lb}$. 


\section{A HISTORY OF DORSET}

\section{The Stour}

The Stour is almost entirely a coarse fishing river, although at the mouth salmon ${ }^{1}$ come up. The pike fishing in many parts of the river is excellent, and all through from IVimborne to Blandford they are caught in considerable numbers and of a fair size. Chub, perch, dace, and roach are also to be found in plenty in most of the reaches. In the tributaries of the Stour there is good brown trout fishing, and Sir Richard Glynn has established a fish hatchery near Fontmell Magna, where he has gone in extensively for rainbow trout. Captain Radclyffe says :-

The small stream here is particularly adapted for these fish, whose peculiarity is that they will make off down stream for the sea, but as there are a number of small mills, with the assistance of iron gratings, the downward march of these fish is retarded. $\mathrm{By}$ constant restocking of the highest mill dam pools a really good supply of fish is kept up, and they grow very quickly and take the fly well.

In the Tarrant, another tributary, there is good brown trout fishing and the fish thrive well and rise well. Unfortunately at intervals this river runs quite dry, and constant restocking is necessary to keep up a supply.

\section{SEA FISHING}

Angling for salt water fish on the coast of Dorser has been for many years on the increase. Poole Harbour is by no means a bad spot, but for the most part all fishing there, both with net and line, is carried on by professional fishermen. The Swanage coast, Warbarrow Bay, Arish Mell, and Lulworth Cove all offer opportunities to the sportsman, but by far the

${ }^{1}$ Five or six years ago a gentleman fishing near the bridge at Blandford with a spinning bait for pike took a salmon of $12 \mathrm{lb}$. This is one of the few recorded instances of the capture of a salmon on a rod in this river. As in the Frome, salmon come up in the winter to spawn. best fishing is to be obtained at Weymouth. There is an excellent anglers' club here, which under the title of the Weymouth and Dorset Sea Angling Society is federated with the National Council of Sea Anglers. The president of the society is Mr. S. H. IVallis, a very practical angler, winner against I 84 competitors of the Corporation Cup and Gold Medal at the Folkestone Festival in 1906, when he beat the whole record of the south coast, his biggest fish being two congers respectively $30 \mathrm{lb}$. and $22 \mathrm{lb}$. and a pollock whiting of 13 lb. The honorary secretary is Mr. J. Rogers, and there are about 300 members. The fishing grounds extend over more than ten miles of good rocky bottom, and there is excellent conger, bass, whiting, pollock, and mackerel fishing. The largest conger caught on line weighed $42 \mathrm{lb}$, and bass have been caught up to 13 or if $\mathrm{lb}$. This is the only place in England where bass fishing can be followed all the year round, and as many as 100 in a day have been taken by one rod. In the Fleet waters they take the fly well, and on one occasion two rods took over ten dozen good fish there. The mackerel afford excellent sport, and the record for them was 100 dozen taken on the line by Mr. A. Brown sailing single handed, his fore sheet hauled to windward. Unfortunately the fishing is being considerably hurt by netting in the backwater, which is one of the finest breeding grounds imaginable. This netting is carried on to an enormous extent with no close season, and bushels of the brown shrimp have been taken out, so that this epicurean morsel for choice fish is nearly exterminated. Now and again a shark visits the water, and on one occasion a large one was hooked on a trot and towed the angler out to sea at a great rate, having to be cut loose for fear of a capsize.

The fishing at Weymouth is carried on both from the quay sides on shore and also from boats; the local fishermen are good guides.

\section{GOLF}

It can hardly be claimed for Dorset that the county is a golfer's paradise. There is but little golf in the county, and none of it is of the true seaside quality, although the Dorset Club makes a gallant effort to provide real golf for its numerous supporters on its famous course at Broadstone.

Vithin the county there are no more than seven recognized golf clubs, and it argues a lack of enterprise and enthusiasm for the game in Dorset folk that so much of the magnificent rurf of its downs and so vast an area of its characteristic sandy heath is unutilized for the royal and ancient game. Dorset is, however, a sparsely-inhabited county, and it is possible that the courses it has are sufficient for the needs of its players.

It was not until the beginning of the last decade of the nineteenth century that the wave of enthusiasm for golf, which was sweeping like a torrent over England, reached our county; and to Bridport belongs the honour of having instituted the first golf club within its borders. In February I89I, the IVest Dorset Club opened a nine-hole course with a circuit of about one and a half miles on some sixty acres of fine down turf on the slopes of the west cliff at Vest Bay. The hazards here are gorse, dis- 


\section{SPORT ANCIENT AND MODERN}

used quarries, roads, and stone walls; and the best time for play is in the spring and autumn months.

In 1892 was founded the Isle of Purbeck Golf Club, whose links are two miles from Swanage on the north side of the road to Studland. This very hilly nine-hole course has a length of about a mile and a half; the hazards are hedges, gorse, ponds, with some artificial bunkers.

The Lyme Regis Golf Club was initiated in I 893. Its nine-hole course is $500 \mathrm{ft}$. above the sea on the cliffs between Lyme and Charmouth. Golf had already been played for some time on Lenthay Common, near Sherborne, when in I 894. the course of the Blackmore Vale Club was opened a mile and a half to the north of the town. It was laid out on undulating ground on either side of a road which with its high hedges formed a hazard at more than one of the nine holes. The club has recently gone back to links on Lenthay Common.

The Ashley Wood Club has a down course of nine holes two miles from Blandford. It was opened in 1896 . The turf is good, and gorse is the principal hazard. The old Dorchester Club, founded in the same year, has now amalgamated with the Weymouth Club under the name of the Weymouth, Dorchester, and County Club. The course of eighteen holes is on Came Down two miles from the county town. 'The hazards are furze, chalk-pits, tumuli, a pond, and some ditches.

In compiling this sketch of Sport in Dorset the writer has endeavoured to obtain an accurate account of each description of sport both of the past and present and each detail has been verified.

His best thanks are due to masters of hounds, who have most courteously given endless information, and each kennel has been visited by the writer. With regard to shooting some difficulties have arisen, and very few shooting men in the county have supplied either information generally or statistics in particular.
The great course of the Dorset Club, opened in 1898 , is the outcome of a prodigious expenditure of money, labour, and ingenuity. It lies about midway between Wimborne and Poole at Broadstone, partly on the eastern edge of the great heath that, under different names, extends from Corfe Mullen to Moreton, and partly in the park of Merley Hall. On the wild and hilly heath portion Tom Dunn, who designed the course at the direction of Lord Wimborne, laid out the first six and the last four holes. The thick growth of ling, gorse, and fern which, rising shoulder high, covered the sandy hill-sides, was cut away, bogs were drained, and turf was laid, tees were levelled, vast putting greens were made and bunkers built, and after years of work ten magnificent holes, of which it is not easy to find the equal on any inland course, appeared. It has been said by a judicious critic of Broadstone that if the vast ditch and rampart hazards were replaced by artfully arranged pot bunkers this could be made one of the finest courses in Europe, and many may be found to agree with this dictum so far as it applies to the holes at the beginning and end of the round. But the long seventh and the five holes in the park are less enjoyable.

The course is $3 \frac{1}{4}$ miles round, and the long carries required from the tees form what is perhaps the most marked characteristic of this excellent course, where the tees are like putting greens and the greens themselves of lavish dimensions. Meetings are held in the spring and autumn.

For the history of racing, the stud farms and training establishments have been visited, and at these the utmost assistance has been given. The writer wishes to express his gratitude more especially to Captain Eustace Radclyffe, who has not only supplied a great deal of general information, but has himself written an article on falconry for this work; to the Lady Theodora Guest for the loan of many interesting documents bearing on hunting; and to the Editor of the Sportsman for racing particulars. 



\section{INDUSTRIES}

\section{INTRODUCTION}

I

NDUSTRIAL Dorset, at first sight seems a contradiction, the county being preeminently agricultural. The real value of the composite wage of its labourers has formed the subject of economic discussion again and again. The curious method by which cows are let out to the dairy-farmers has received as much commendation as it has provoked criticism ; few persons, however, could tell what industries flourished between Poole and Lyme Regis; and if the famous quarries of Purbeck and Portland were left out of account, most would probably assert that the chief trade of Dorset was in butter and cheese. Yet political economists point out that had not the burgesses of Bridport insisted on maintaining their monopoly for rope-making in the reign of Henry VIII, their town might have become a great manufacturing centre. ${ }^{3}$ If this had come to pass, the advantages offered by the coal-bearing north would probably have been outweighed by the facts that for long years Dorset produced the finest hemp in the English market, and that this manufacture is dependent to a great extent on skilled labour, an aptitude for which is transmitted from parent to child. But the burgesses 'stabbed themselves with their own dagger,' ${ }^{2}$ and instead of a mighty city with suburbs stretching out to include Burton and Beaminster, Powerstock and Toller Porcorum, there remains one of the most picturesque parts of this beautiful county, "which has often been styled the garden of England.' ${ }^{3}$

However, although the hemp industry was undoubtedly injured at the time by the shortsighted policy of the burgesses of Bridport, it was by no means destroyed; and after passing through various vicissitudes it is still the pride and mainstay of Bridport.

As regards manufactured goods, the county is to a great extent in the first stage of industrial development. It has scarcely been affected by the industrial revolution which has been so admirably described by Mr. Arnold Toynbee.

\footnotetext{
${ }^{1}$ Gibbins, Industrial Hist. Engl. 101.

'Bohn, Coll. of Proverbs, 202.

${ }^{3}$ England Displayed (1 769), 64.

4 Toynbee, Industrial Reviolution, 5.
}

There are factories and mills, but a great many of the workers work in their own homes; the most important operations, both in the hemp and gloving industry, are performed by hand; a considerable proportion of the work is done by women, while the children often take their turn as soon as school hours are over.

Dorset was well equipped to take its stand as an industrial county in the seventeenth and eighteenth centuries. But its equipment is now old-fashioned, and much of it obsolete. In all the descriptions of Dorset, and of these there are many, great stress is laid on the excellence and abundance of raw material: of wool, of hemp, of stone, and of clay. Leland, Camden, Cosmo III, duke of Tuscany, and a host of others join in dwelling on the quantity and quality of the sheep reared on the "beautiful pastures' of the downs. ${ }^{5}$ Time has made no impression on the truth of Camden's description of Dorset, 'garnished with many a green hill whereon feed flocks of sheep in great number with pleasant pastures likewise and fruitful valleys." ${ }^{6}$ Defoe was told 'that there were six hundred thousand sheep fed on the downs within six miles of the town' of Dorchester. He writes, 'I do not affirm this to be true, but when I view the country round I confess I could not but incline to believe it.' 7 Gilpin quotes and objects to a poetical description of the

Dorsetian Downs

In boundless prospect spread, here shagged with woods,

There rich with harvest, and there white with flocks. ${ }^{8}$

$\mathrm{He}$ holds that even poetical licence is not warrant enough to call red sheep white. His observation held good until late in the nineteenth century, for the 'ruddle-man' went his rounds year by year and dipped the sheep in red ochre. Great quantities of sheep are still raised in

\footnotetext{
46, 47 .

s Cosmo III, Travels in Engl. (Magalotti, 1668),

${ }^{6}$ Camden, Britannia (ed. Holland, 16 Io), i, 51.

' Defoe, Tour Through Gt. Brit. (1724), i, 64 .

${ }^{8}$ Gilpin, Observations on the Western Parts of Engl. 292.
} 


\section{A HISTORY OF DORSET}

Dorset for the sake of their wool as well as for their meat, but the cloth industry which at one time depended on the local wool has left the county.

Fields of hemp do not lend themselves so readily as flocks of sheep to picturesque descriptions, and even flax is only beautiful when its dazzling blue flower is in bloom; but the fact that the rich damp soil round Bridport produced the best hemp in England is continually mentioned. Hemp is no longer grown in the neighbourhood, though the common nettle belonging to the same botanical family springs up with unparalleled vigour and luxuriance. The homegrown flax can no longer compete with that of Ireland or Belgium, but it is used locally mixed with hemp or cotton.

In the Middle Ages the marble of Corfe won wide recognition, and Dorset sculptors not only wrought at home, but were summoned to a distance by king and prelate as the ablest of their time. Portland stone was exported at least as early as the reign of Edward I, and the stone of the quarries of southern Dorset is still the county's one pre-eminent gift. The clay found round Poole and Corfe Castle was not so widely known as the stone of Purbeck and Portland, but constant allusions are made by topographers of the last three centuries to its intrinsic qualities as a good clay for tobacco pipes, and to its value as an export to London.

Besides raw material, Dorset possessed and still possesses all the power required by eighteenthcentury machinery. It is covered with a network of little streams, which rush out of the sides of the chalk downs. These make up in speed what they lack in volume; some are strong enough to drive water-wheels within a quarter of a mile of their source. Numerous mills are mentioned in Domesday Book, but very few of them still work. Almost all the corn is ground by steam mills, and many of the watermills are in ruins; others have totally disappeared.

Besides industries which were promoted by the enterprise of individuals and the fallacies of public bodies, there were those based on a false estimate of mineral riches. Pottery and quarrying do not fall under this definition, but most of the attempts to work the other minerals found between Poole and Weymouth have had little lasting success. The least important of these minerals is gypsum, which occurs in the lower Purbeck strata of Durlaston Bay, and was once worked to a limited extent. ${ }^{9}$ There are more references to the alum industry, which was set up more than once in Dorset, but never took root permanently in the county. ${ }^{10}$ Thus all the advantages which Dorset possessed have decreased in value; the streams are left to irrigate the water-

\footnotetext{
${ }^{9}$ Green, Kimmeridge Shale, its Origin, 2.

${ }^{10}$ See infra.
}

meadows; the cloth industry, now requiring machinery, steam power, and coal, has migrated to Yorkshire; and better hemp can be imported from Russia.

The disadvantages to industry from which Dorset has suffered have varied from time to time. At present the most powerful drawback to commercial enterprise is the lack of coal ; but this deficiency had no practical effect until the introduction of machinery at the end of the eighteenth century. Another handicap is the distance from London, and this was intensified, until railways were built, by the inadequate means of communication. Even now it is still a factor to be considered in any industrial problem, and at any time up to the nineteenth century it would be hard to overestimate its influence.

The older roads seem to have been far from satisfactory. The county is famed for its downs; and the roads in use in Dorset were to a large extent ancient ways along them, while even the new lines of route made by the Romans in their very directness occasionally admitted very steep gradients. Modern road-builders have found it impossible to avoid steep hills, but their roads tend to follow the valleys rather than the ridges or slopes of the downs.

The Roman roads were wonderfully made; but if the presentments of the eighteenth century are any criteria, the surface and upkeep of roads and bridges must have been in a deplorable condition. Year by year the roads are presented as out of repair, ${ }^{11}$ and sometimes as under water, and the bridges as in a broken-down state. ${ }^{12}$ The expense of carriage by road is continually referred to in the county records. The cost of transporting soldiers, vagabonds, paupers, and convicts, as well as that of sending luggage and messengers, was always heav'; a good example is the cost of conveying a lunatic to Bedlam in 1794 , which amounted to $£_{11} 1$ Is. $6 d .^{13}$ At the beginning of the last century ${ }^{14}$ the turnpike roads, and even the by-roads when on dry soil, appear to have been on the whole in a satisfactory condition, and a surveyor of experience observed that they possessed sufficient convexity to cast off the water after sharpshowers, which drained away and was soon absorbed in the chalky substratum. In the chalk districts fints were then used for the repair of the turnpike roads, but elsewhere limestone broken with hammers. In the west of the county, however, and in some parts of the vale of Blackmoor, the by-roads were even then miry and scarcely passable in winter, while in summer the large, rough stones with which they abounded rendered them far from pleasant, whether for horses or wheeled vehicles. In

\footnotetext{
$"$ Sess. R. 1709, 1720, 1752, S.c., \&.c. ; County

Rec. Quarter Sess. $1712,1763,1,64$, Sic.

${ }_{12}$ Ibid.

is Stevenson, op. cit. 439 .
} 


\section{INDUSTRIES}

southern Dorset at the present time Forest marble and the refuse of Purbeck and Portland stone are often used locally, but the main roads are mended with stone brought from a distance.

Before the advent of railways heavy merchandise was, if possible, sent by sea, exported from Poole, Weymouth, Bridport, and Lyme. There was often no other alternative. Though Dorset was well watered, a writer in 1769 says :

there is not in the whole county, one river rendered navigable by art; nor indeed any stream that would be of sufficient advantage to the county, to induce persons to undertake it, except the Frome, which might easily be rendered navigable from Wareham to Dorchester; and could not fail of paying the necessary expenses at the same time it would prove of the greatest advantage to the county by reviving the manufactures which formerly flourished there. ${ }^{15}$

However, the Frome was never canalized, and at present the only canal in the county is one in the north, in the upper course of the Stour. ${ }^{16}$ It is called the Dorset and Somerset canal, but it was never completed, and is not used. Consequently, until railways were built, all goods had to be sent by road or by sea, and the baneful influence of the cost of carriage is clearly seen in the history of the hemp industry.

Coaches from London supplied the news of the world and the correct time to a number of small villages along their route, which were cut off from such luxuries when the coach service ceased in $1830,{ }^{17}$ as the supplanting railway followed a different line, and does not yet touch all the villages through which the coaches passed. The introduction of the motor car has, however, recently brought some of these villages into more frequent contact with the great world outside.

From these general observations on the industries of Dorset we must now proceed to notice very briefly a number of crafts which we are unable to deal with in any detail. Some of them, as for instance glove-making, still occupy an important place in the county, others are either practically extinct at the present day or of comparatively slight economic importance.

Salt-making, one of the most necessary industries of mediaeval England, was actively carried on in 1086 at several places on the Dorset coast. Two entries ${ }^{18}$ occur relating to salters (salinarii) at Lyme. At Charmouth ${ }^{19}$ sixteen salters are mentioned, while at Ower, ${ }^{20}$ which belonged to the Benedictine house of Milton, thirteen salters rendered 20s. At Studland ${ }^{21}$ again no less than thirty-two salinae are recorded. Beside these, as we learn from a much later rental ${ }^{22}$ of the

${ }^{15}$ Engl. Displayed (1 769), 64.

${ }^{16}$ Faunthorpe, Geography of Dorset, 11 .

${ }^{17}$ Quarter Sess. Rec. ${ }^{19}$ Dom. Bk. fol. $77 b, 85$

${ }^{19}$ Ibid. $80 . \quad{ }^{20}$ Ibid. $78 . \quad{ }^{31}$ Ibid. 80.

${ }^{22}$ HarI. MS. 61. It contains entries of as late a date as the first decade of the fifteenth century, but may be in substance much earlier. abbey of St. Edward at Shaftesbury, Arne (Hern) in Purbeck was devoted entirely to the manufacture of salt, and over twenty tenants held one or more salt-pans each. Benegarus, one of the most substantial of these, held a sixteenth part of the hide which formed the manor of Arne at a rent of $30 d$, and also three salt-pans, for which he paid 8s. yearly, and in addition was bound to render three week-works of salt as well as one week-work from his land. Some tenants, however, as Sampson, who held three salt-pans for 9s. and two week-works, do not seem to have lad any share in the arable land. Numbers of the tenants on other manors of the St. Edward's Abbey were bound to carry a certain amount of salt from Arne when required. For instance, ' all the men of Fontmell ought to carry away 20 seams of herrings (allecium) from Wareham, and 20 seams of salt from Hern.' ${ }^{23}$ So also Oswy, a virgater of Iwerne, had to carry salt and herrings; other tenants were subject to a similar liability.

In the fifteenth century there existed a considerable export trade in salt with France. On 25 June, 6 Edward IV, a pinnace, ${ }^{24}$ Le Typhan of Cherbourg, Pierre Blanc master, carried out of Poole not only broadcloth, but forty quarters of salt worth $f_{4} 4$ s, , on which a foreign merchant paid Is. $0 \frac{3}{4} d$. in customs duty and 4s. $2 \frac{1}{2} d$. as his share of the subsidy. So also a 'creyer,' the Mary of Poole, on 30 September, ${ }^{25}$ 7 Edward IV, included amongst her cargo, probably consigned either to the Channel Islands or the French coast, twenty-one quarters of salt at 2s. the quarter, on which the English owners only paid the subsidy at the rate of Is. in the f. I. Salt was, however, even at this time also imported into Dorset from abroad, and gradually the local manufacture dwindled and disappeared before the competition of the salters of Worcestershire and Cheshire.

At one time there were ship-yards in every one of the Dorset ports. But Lloyd's latest Yacht Register only mentions one firm at Weymouth and three at Poole.

A brief account of the industry at Poole during the seventeenth and eighteenth centuries is given in Hutchins' History of Dorset.

We have no ancient accounts of the number of shipping in this port. In 1649,8 ships went hence to Newfoundland and two to Barbadoes : but after the Restoration this trade increased and flourished. In 1736 , one hundred and forty four sail belonged to this town. In $174 \mathrm{I}$, forty nine ships of this place had been taken since the commencement of the war with Spain. In 1743 thirty-one ships were taken since the beginning of the war with France, on a general computation worth, one with another, $\{37,200 \ldots$ four ships exclusive of the thirty one

${ }^{23} \mathrm{Harl}$. MS. 6i, fol. $65 a$.

24 K.R. Cust. Accts. 6 Edw. IV, bdle. I Iy, No. 8.

${ }^{25}$ Ibid. 7 Edw. IV, bdle. 119 , No. 9. 


\section{A HISTORY OF DORSET}

were retaken. In 1750 one hundred and twenty six ships belonged to this port including brigs, snows, bilanders, sloops, whereof there were in the harbour 58 , on the stocks 8 , Abroad 60 . In 1770 , two hundred and fifty ships belonged to the town. ${ }^{35 a}$

About 1790 there belonged to this port two hundred and thirty sail of shipping, with burden 21,301 tons, and employing about 1,500 men; about one hundred and forty ships were employed in the foreign trade, and the remainder in coasting and fishing: besides the number of men actually employed in navigating ships, there were annually a very considerable number of men employed in the fishery on the coast of Newfoundland. ${ }^{25 b}$

Later the building of Leith smacks and revenue cutters gave employment for many hands. ${ }^{25 c} \mathrm{Be}-$ fore 186 I the building of yachts proper was begun, and in 1903 one ship-yard had

a patent slip capable of hauling up vessels of 200 tons, and another added in 1892 capable of hauling up vessels of over 400 tons. $^{23 d}$

When Lloyd's last Yacht Register was drawn up there were thirty-five yachts afloat which had been built at Poole, varying in burden from 3 to IOI tons; but the largest, the Sperenza, has been broken up this summer. ${ }^{25 e}$ Although the yachts built are few in number, some of them are very fast, ${ }^{25 f}$ but of course they do not in any way compete in popular estimation with the worldfamous yachts built at Glasgow and Newcastle.

It is said that 4,000 women and children were employed at Shaftesbury in I 793 in making all kinds of shirt buttons, ${ }^{26}$ the rate of payment being $5 \%$. per gross of twelve dozen, the worker finding her own thread. ${ }^{27} \mathrm{Mr}$. Atchinson was the chief employer of labour. In 1812 he had I,200 women and children in his employ, for the latter of whom he established schools in different parts of the county. While learning their craft, which usually occupied from three to four weeks, the children received no pay, as they 'spoilt much thread.' 88 At the expiration of that time they were paid $1 d$. a day for two months, then Is. a week for two months more, with an increase for a year, the best hands earning from 10 s. to 125. a week. $^{29}$ The farmers, we are told, objected to this industry, as it drew the women from the fields,

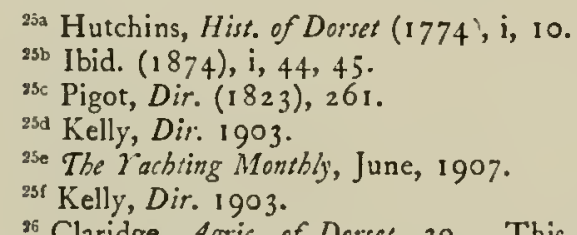

${ }^{26}$ Claridge, Agric. of Dorses, 39. This industry was ' taken to' by Shaftesbury, according to a modern writer, 'in despair,' and, according to the same authority, the town 'fared somewhat indifferently' at the new departure. Treves, Highruays and Bywuys in Dorset, 7.

${ }^{27}$ Stevenson, Agric. of Dorsct, 449.

${ }^{25}$ Ibid. $\quad$ Ibid. 453 . where they could only earn $9 d$. a day, to the button factories. ${ }^{30}$ The price of mould buttons, when finished, was from $8 d$. to 35 . per dozen, wire work being is. $6 d$. to 4 s. a gross. Girls have been known to make twelve dozen a day, though the average was from six to seven dozen. The first operation, that of casting, or covering the wire, was performed by children of six or eight, the filling being done by more expert hands. The manufacture of fine wires for the button trade was largely carried on in the town in $1830 .{ }^{31}$

At Blandford in 1797 the women and children were chiefly employed in making thread and wire buttons for shirts, a few being similarly employed at Durweston. ${ }^{32}$

The manufacture of stockings has been largely carried on at different places in the county. At Wimborne in $1793,1,000$ women and children were engaged in knitting worsted stockings, the worsted costing from $2 d$. to $2 \frac{1}{2} d$. per oz., the finished stocking selling at from $3^{\text {s. }} 6 d$. to 4 s. per pair. ${ }^{33}$ Stalbridge stockings, "the finest, best, and highest prized in England,' were in high repute in Defoe's time, ${ }^{34}$ the industry continuing to flourish until the introduction of machinery dealt the inevitable blow at this as well as at other home industries. Poole was making silk stockings in 1756.35 A few women were knitting stockings at Corfe in $1802 .^{36}$

The industry seems to have been underpaid, and the districts where it was carried on are generally noted as being very poor. It was connected with Wimborne from very early day's, and it would be interesting to discover if the doles left by pious benefactors were in any way responsible for the small remuneration gained for the knitting of stockings by those whom the hope of these doles had attracted to the shadow of the Minster.

Cotton yarn was largely spun at Abbotsbury in 1750 for the manufacture of stockings. ${ }^{37}$

Dorset glovers seem to have escaped the notice of historians, although members of the craft must have been fairly numerous in the fifteenth and sixteenth centuries, there being frequent references in the Bridport Documents to glovers who were fined for overcharging. ${ }^{38}$ No trace is forthcoming, however, of the existence of any gild or organization corresponding to those of Perth and Worcester. Glovers, nevertheless, are mentioned in Law Court Reports, and in lists of inhabitants of the towns, although no topographer includes gloving among the local indus-

${ }^{30}$ Ibid. 449.

${ }^{31}$ Pigot, Dir. 1830, p. 291.

${ }^{32}$ Eden, State of the Poor, ii, $146,150$.

${ }^{33}$ Claridge, Agric. of Dorset, 40.

${ }^{34}$ Defoe, Tour through Gt. Brit. i, 333.

${ }^{36}$ Dodslcy, Descrip. of Roads, 21.

${ }^{36}$ Brayley, Beautics of Engl. and W'ales, iv, 388 .

si Cooke, Topog. Dorses, 62.

${ }^{36}$ Wainwright, Bridport Doc. K. 31, 35, 62. 


\section{INDUSTRIES}

tries of the county. Some clue to the apparent oversight may be gathered from the fact that the more important glove-making centre of Yeovil was within easy reach, and it is probable that, even at a very early date, the Dorset glovers were chiefly employés of those of Somerset, rather than manufacturers on their own account.

According to the evidence of $\mathrm{Mr}$. Willmott, silk manufacturer, before a Select Committee on the Silk Trade in $18_{3} 1$, there was no gloving carried on at Sherborne at that date except in the form of a home industry, the gloves being sent over from Yeovil and Milborne Port, and sewn by the Sherborne women in their cottages. ${ }^{39}$ Gloving was formerly carried on at Beaminster, ${ }^{40}$ at Cerne Abbas, ${ }^{41}$ and Bere Regis. ${ }^{42}$

At the present time the trade centres in Sherborne and includes Gillingham and Sturminster Newton, though in earlier days glovers were found all over the county.

There are 45 men and 631 women who work at this trade, and of these the majority are home workers. ${ }^{43}$ The industry is carried on by Dorset firms, who manufacture gloves from start to finisl in the county, and by London and Worcester firms who have established glovesewing branches in Dorset.

There are three factories in Sherborne in which the process of glove-making is carried through all its stages; the skins are prepared and dressed, then the gloves are cut out, sewn, stitched, buttoned, and finished. But glovesewing is practically a home industry, very little of this being done in the factories. The kinds of gloves made are 'Lamb, Kid and Goat.'

As a rule the workers congregate in North Dorset, but occasionally in other parts women are found making the heavy shapeless thumbed gloves with which hedgers protect their hands while working. The industry is especially important as a home industry in contradistinction to the silk weaving, which is carried on in the mills. On account of its smallness, and of the clearness of the issue, Sherborne should yield a distinct answer if an investigation were undertaken as to the relative advantages of home and factory work for women. Glove-sewing ranks next to the hemp industry in providing work for Dorset women, but it is not nearly so widespread, nor so independent, as it would not be hard at any moment for the manufacturers to have their gloves sewn elsewhere.

The fame of Dorset pillow-lace has been somewhat eclipsed by that of Devon; the industry was, however, profitably carried on in three towns at least in the county during the eighteenth century. Blandford in Defoe's day was 'chiefly

\footnotetext{
${ }^{39}$ Parl. Rep. on Silk Trade, 1831 , p. 284.

${ }^{40}$ Green, Rural Indus. of Engl. 72.

${ }^{4}$ Pigot, Dir. 1830 , p. 280.

12 Green, Rural Indus. of Engl. 74.

"Population Returns, 56.
}

famous for making the finest bone-lace 4 in England. 'They showed me,' he adds, 'some so exquisitely fine as I think I never saw better in Flanders, France, or Italy, and which they said they rated at above $\$ 30$ sterling a yard.' 45

In 1594 bone lace could be bought at 1 s. $4 d$. per yard; in 1685 , largely owing to the increased fashionable demand, the price ranged from 2 s. $4 d$. to 30 s. $^{46}$

In 1750 Broad Street, Lyme Regis, was ' chiefly inhabited by lace-makers, who worked at their doors in the summer.' 17 In 1752 prizes were awarded by the Anti-Gallican Society to Lyme lace, the specimens submitted being ' ruffles of needle point and bone lace.' ${ }^{48}$ A narrow cap piece was valued at four guineas, five guineas a yard being considered a not exorbitant price. A lace dress for Queen Charlotte was made at Lyme, the lace-makers also taking in work from Honiton and Colyton. ${ }^{49}$ The last of the lacemakers was Catherine Power, who excelled in the production of designs of interlaced initials and other ornaments. ${ }^{50}$

Up to 1780 much blonde lace, both white and black, was made at Sherborne. ${ }^{51}$

In 1875 a few makers were at work at Charmouth. ${ }^{62}$

Hat-making had a brief existence as a Dorset industry in I 791 , when it was introduced as an employment for the prisoners in the new gaol at Dorchester, which was run, so the county boasted, on humanitarian and economic lines. Materials and instruments were procured, and a hatter imported to teach his art; but the latter speedily decamped, and the justices of the peace, coming to the conclusion that prison labour was nut profitable, directed the clerk to make inquiries about treadmills. ${ }^{53}$

The manufacture of bandstrings, which went out of fashion about 1720 , was largely carried on prior to that date at Blandford. ${ }^{54}$ Bandstrings were laces or ribbons used for securing the bands worn around the neck, and which sometimes appeared like a hanging bow in front, or like a stout silk cord with pendent tassels. ${ }^{55}$

The commercial activities of Sherborne were transferred, as its cloth trade gradually passed away, to the production of liaberdashery wares, with which the town supplied the west of England markets. ${ }^{56}$

4 Defoe, Tour, i, 330-1.

${ }^{45}$ So called from the use of bone pins prior to the adoption of those of metal.

${ }^{46}$ Rogers, Agric, and Prices in Engl. v, 558.

${ }^{17}$ Roberts, Hist. Lyme Regis, 118.

${ }^{48}$ Palliser, Hist. of Lace, 354.

4 Roberts, Hist. Lyme Regis, 380.

${ }^{50}$ Ibid. $\quad{ }^{51}$ Palliser, Hiss. of Lace, 354.

${ }^{52}$ Palliser, op. cit.

${ }^{53}$ Dorset Accounts (1 791), iii, 75 .

${ }^{54}$ Cox, Magna Britannia, i, 560.

${ }^{55}$ Dillon (Fairholt), Costume in Engl. ii, 28

${ }^{55}$ Rural Elegance Displayed (1768), 268. 


\section{A HISTORY OF DORSET}

Cranborne had a short-lived ribbon-weaving industry in the eighteentl century, ${ }^{57}$ whilst Bridport, in addition to its specialities of ropes and sailcloth, also made, and still makes, linen thread. ${ }^{58}$ Melbury Osmond was noted in the early part of the last century for the manufacture of staymakers' tape, known as 'Melbury iron tape,' ${ }^{99}$ besides its 'extensive trade in horn buttons and plated buckles.' ${ }^{60}$ Snuff was being manufactured at North Chardstock in $1812 .^{61}$ Straw-plaiting was introduced into Swanage early in the nineteenth century. ${ }^{62}$ 'Dorchester Cakes' were a delicacy which has not escaped the notice of various travellers.

Stained glass was at one time made in Dorset.

Before the Reformation [say's Aubrey] I believe there was no county or great town in England but had glasse painters. Old $-\mathrm{H}_{2}$ rding of Blandford in Dorsetshire, where I went to schoole, was the only country glasse painter that ever I knew. Upon play daies I was wont to visit his shop and furnaces. He dyed about $16+3$, aged about 83 or more. ${ }^{63}$

A thriving trade was carried on at an early date in Lyme Regis by letting the right to cut and harvest the oare growing on the rock-ledges, 500 acres being left dry at low water. In the reign of Edward VI Roger Garland, mayor, 'received of the man that burns the oare, that was due unto the town, 27s." ${ }^{64}$ In 1569 an 'arrearage' of oare, 20s., appears in the town accounts. The right of gathering was let in 1589 for three years at 40 . a year, the renters being protected by law. A fine of 40 s. was inflicted in one case in $1569 .{ }^{65}$ In 1580 an order was made by the Court of Hustings that none were to burn the oare within the parish and liberty without licence from Mr. Mayor. ${ }^{66}$ Thomas IVood, who was fined 2s., seems to have been the first offender against this decree. ${ }^{67} \mathrm{Mr}$. John Roze "for charges of the oare ashes" received f. I I I s. $8 d$. at this date.

In Elizabeth's reign near Canford on the Dorset coast, 'James, Lord Mountjoy, studious in mineral matters, began to make calcantum, or vitriol (we call it copperas), and to boil alum.' ${ }^{68}$

Early in the eighteenth century this latter was manufactured at Kimmeridge by Sir William Clavell of Smedmore, ${ }^{69}$ but the works, after the owner had expended $\ell_{4}, 000$ upon their con-

\footnotetext{
${ }^{37}$ Hutchins, Hist. Dorset, ii, 137.

${ }^{58}$ Ibid. i, 233.

${ }^{59}$ Stevenson, Agric. of Dorset, 450.

${ }^{60}$ Hutchins, Hist. Dorset, iv, 439.

${ }^{61}$ Stevenson, Agric of Dorset, 450.

63 Ibid.

${ }^{6}$ Hutchins, op. cit. (1874), i, 2 1 6.

*t Roberts, Hist. Southern Counsies, 388.

${ }^{65}$ Ibid.

${ }^{66}$ Court of Hustings Book of Lyme.

${ }^{67}$ Roberts, Hist. Southern Counties, 389.

${ }^{68}$ Hutchins, Hist. Dorset, ii, 110.

s9 Ibid. i, 172.
}

struction, besides building a pier $100 \mathrm{ft}$. long, $60 \mathrm{ft}$. broad, and $50 \mathrm{ft}$. high, for the export of the alum, ${ }^{70}$ were 'seized to the king's use,'il all the alum houses and mines in Dorset having been granted to Paul Pindar for twelve years. ${ }^{72}$ After his disastrous 'setting up' of the forfeited alum industry, Sir IVilliam attempted to establish salt works and a glasshouse. The glasshouse at Kimmeridge had 'come to perfection' in 1732 , when it seemed 'likely to redound to a good benefit'; ${ }^{73}$ but sixteen years later ruined buildings and heaps of ashes were all that remained of the works. ${ }^{74}$ 'Bluish stones,' yielding 'such an offensive savour and extraordinary blackness that the people labouring about those fires were more like furies than men, ${ }^{75}$ were used as fuel in the glasshouse. This was of course the Kimmeridge coal, 'a highly bituminous layer of shaly stone about $2 \mathrm{ft}$. IO in. thick with its partings, and of a dark brown colour,' whence its local name of blackstone. It breaks with a conchoidal fracture and readily ignites. ${ }^{76}$ This shale has been in use from time immemorial, ornaments and vessels made from it figuring amongst Roman remains at Weymouth and at Silchester; whilst it was extensively used as fuel in the neighbourhood of Kimmeridge, 'for which purpose however its abominable odour renders it unsuitable.' When the price of coals was high the shale was worked at 6 s. a ton. ${ }^{77}$ It is still occasionally employed.

The whole of the mineral property at Kimmeridge is now leased to the Kimmeridge Oil and Carbon Company, who carry on the manufacture of paraffin. The Blackstone seam yields 120 gallons to the ton, or 66 gallons when largely distilled, the common shale only yielding 33 gallons. ${ }^{78}$ The company use the coal for fuel, and for improving the illuminating power of coal-dust, as well as for the extraction of the oil. The residual coke and carbon which are left after the distillation of the oil can be used as a deodorizer, a disinfectant, \&c., and as a manure; whilst an insecticide has also been made from the oil. ${ }^{79}$

A 'Bituminous Manure Company' was established at Wareham in 1848 for the production of manures, jet varnish, paints, mineral spirits, naphtha, machine oil, and asphalt. Twenty thousand shares were issued at $£, 5$ each. ${ }^{80}$

To the lively Diary of Celia Fiennes in the reign of William and Mary we are indebted for

\footnotetext{
${ }^{70}$ Coker, Surv. of Dorset, 47.

${ }^{n}$ Ibid.

${ }^{73}$ Hutchins, Hist. Dorset, i, 172.

${ }^{73}$ Coker, Surv. of Dorset, +7 .

74 Hutchins, Hist. Dorset, i, 172.

${ }^{75}$ Coker, Surv. of Dorset, 47.

${ }^{76}$ Mem. Geol. Sury. 1906, p. 14.

7 Warne, Ancient Dors. $27 \mathrm{~S}$.

${ }^{78}$ Mem. Geol. Surv. 1898 , p. 54.

${ }^{79}$ Ibid.

${ }^{80}$ Warne, Ancient Dorset, 278.
} 


\section{INDUSTRIES}

an eye-witness's account of the making of copperas at that date on Brownsea Island-

The stones being found about the isle in the shore in great quantities. There is only one house [she writes] which is the Governor's, besides little fishermen's houses; they being all taken up about the copperas works; they gather the stones and place them on ground raised like the beds in gardens, rows one above the other and are all shelving, so that the rain dissolves the stones, and it drains down into trenches and pipes made to receive and convey it to the house which is fitted with pans four square and of a pretty depth at least i 2 yards over. They place iron spikes in the pans full of branches, and so as the liquor boils to a candy it hangs on these branches, I saw some taken up. It loaked like a vast branch of grapes. The colour of the copperas not being much differing it looks clear like sugar candy, so when the water is boiled to a candy, they take it out, and replenish the pans with more liquor. I do not remem- ber they added anything to it, only the stones of copperas dissolved by rain into liquor as I mentioned at first. There are great furnaces under it keeping all the pans boiling. It was a large room or building with several of these large pans. They do add old iron and nails to the copperas stones. ${ }^{.1}$

Sir R. Clayton had copperas works at Studland, which were, however, in ruins in 1700. The stones in this case were brought from the Isle of Wight. ${ }^{82}$

Hutchins records an attempt made in 157 I by Sir Thomas Smith to transmute iron into copper on land which he leased from Lady Mountjoy near Poole at a rental of $f 300$ per annum, hoping to find the means of making vitriol there ; but the attempt, we are told, came to nothing. ${ }^{83}$

The iron foundry which existed at Bridport in I 812 was not supplied with native ore, though a vein of ironstone is found near Abbotsbury.

\section{QUARRYING}

The best and most widely used stone quarried in Dorset has been obtained from the Purbeck and Portland formations. " Purbeck marble earliest won an extended repute; at the present day the Isle of Portland furnishes the largest quantities of excellent building stone.

In barrows of a very ancient date slabs of the local limestone were used for lining or covering the sepulchral chamber, while the excavations at Silchester $^{2}$ and Verulamium ${ }^{3}$ have shown that marble from the Upper Purbeck strata ${ }^{33}$ wasduring the period of Roman occupation employed for decorative work. The Saxons had little need for opening up fresh quarries, but for a few churches they used the Purbeck limestone, which was also early in request for fonts ${ }^{4}$ and sepulchral slabs. From the Roman period till the twelfth century little if any demand existed for Purbeck marble; but with the passing of the massive Norman fashion of building the marbler came into his kingdom. Indeed, it has been well said ${ }^{5}$ that nearly every English church of any size that was built from 1170 to $135^{\circ}$ imported for its structure these polished dressings which . . . were not only moulded and chiselled with delicate foliage, but were carved too into fine head corbels or into relief panels of figure subjects.

Fiennes, Through Engl. on a Side-saddle, 5-6.

${ }^{92}$ Hutchins, Hist. Dorset, i, 219.

${ }^{83}$ Ibid. ii, I IO.

${ }^{1}$ A. Strahan, Geology of Isle of Purbeck and Weymouth, 236.

${ }^{2}$ Arch. liii, pt. I, 266.

${ }^{3}$ Teste the late Mr. Micklethwaite.

ia The Purbeck marble is not crystalline, but really a dark Paludina limestone, or shell conglomerate.

" The font of Studland is rudely axed out of Purbeck 'burr'; Trans. Dors. Nat. Hist. and Antig. Field Club, xii, 176.
Already in the twelfth century Purbeck marble was being exported as far as Dublin for architectural use, whilst such effigies as that in the south porch of Abbotsbury church, or those of Bishop Iscanus at Exeter and Bishop Jocelyn at Salisbury, furnish flat reliefs soon to develop into the fully modelled figures of the knights at the Temple Church, the Peterborough abbots, or that unique royal effigy in Purbeck marble on the tomb of King John at Worcester. But it is no part of our task to trace the aesthetic development of sculpture in marble ; ${ }^{6}$ a few notes only are offered in illustration of the quarrying industry of Corfe and its neighbourhood.

By the thirteenth century ${ }^{7}$ Corfe had become

${ }^{5}$ Archit. Rov. xii, 5.

${ }^{6}$ The reader is referred to the valuable series of articles by Messrs. Prior and Gardner on 'Mediaeval Figure Sculpture in England' which appeared in the Archit. Rev. during 1902 and the following years.

${ }^{7}$ Several early records of conveyance of marble and stone from Purbeck exist. Probably the marble mentioned as sent to Clarendon in Pipe R. $23 \mathrm{Hen}$. II, m. 10, was from Purbeck. Cf., as to marble sent to Chichester, Close, 6 John, m. $2 ; 8$ John, m. 4 . It was also liberally used in Sussex at Boxgrove. Later we hear of "lapides Regis qui sunt apud Suthampton et venerunt de Purbec ad operationem castri nostri Wintonie' (Lib. R. 21 Hen. III). As regards export beyond the bounds of England, Purbeck seems to have been used in Dublin almost as early as the last ten or fifteen years of the reign of Hen. II. Geoffrey of Coldingham, in describing the work of Bishop Hugh Pudsey at Durham, and the marble used in the Galilee, uses the words 'A transmarinis partibus deferebantur columpnae et bases marmoreae' [Hist. Dun. Script. Tres. (Surtees Soc, ix), 11], and Symeon of Durham also refers to the marble as 'addito de longinquo' [Opera (Rolls Ser.), i, 168], but mentions neither Purbeck nor Corfe. 


\section{A HISTORY OF DORSET}

famous all over England as the head quarters of the marble industry, but the particulars recoverable as to the quarries themselves, their manner of working, or their possessors, are scant and disappointing. A few incidental facts can be gleaned from the remaining records of the Isle of Purbeck or the fuller series of fabric rolls of great royal works, while a comparison of the sixteenth-century marblers' code with the customs of Portland may suggest some general conclusions.

A claim, we believe, has occasionally been asserted by the quarriers of Purbeck to enter any uncultivated land in search of stone on the authority of a traditional but non-existent charter, but such a right has never been legally established, as in the old mining fields of the Forest of Dean, or Derbyshire. It is more probable that the regular practice was to obtain the licence of the owner, or in the case of royal demesne of the constable of Corfe Castle, though encroachment may have occasionally been winked at or condoned on account of the lucrative dues paid for the right of carrying the stone. Indeed, it may be suspected that most of the quarries, even in the thirteenth century, were private enterprises undertaken either on behalf of the lord of a manor or else by quarriers working in partnership and holding a lease or licence from the crown. Some of the more valuable of the ancient quarries lay in the parish of IVorth Matravers near Quarr, which indeed took its name from them. ${ }^{8}$ These disused workings extend in a westerly direction through Haycroft and Downshay. ${ }^{9}$ It is possible

$s$ The marble strata and the beds beneath them are also clearly seen at Peveril Point, where, as Mr. A. Strahan notes, "the coast crosses the strike of a number of small folds at right angles.'

${ }^{9}$ At Woodyhide between Afflington and Downshay considerable quantities of Purbeck marble were dug even in the last century. Mr. Woodward, in his Furassic Rocks of Britain, gives the following section of a marble pit open in 188 , and situated $150 \mathrm{yds}$. north of Coome Farm and half-a-mile east of Langton :-

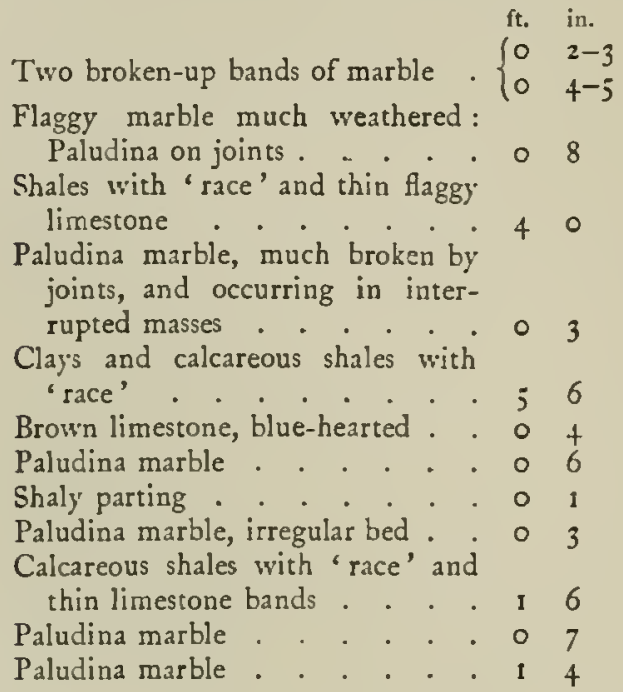

Beneath this last bed, another of Paludina marble had that to one of these quarries may be referred an entry on the roll of Pleas of the Crown for the year 52 Henry III, ${ }^{10}$ that IValter le Vel and Hugh le Mochele were crushed (oppressi) in the quarry of Peter de Clavile, where they were digging stone with a certain pick ${ }^{11}$ (besca) valued at $6 d$. 'The verdict was 'misadventure.'

The Purbeck marble and stone conveyed to IVestminster for the abbey and the king's palace seem as a rule to have been bought ${ }^{12}$ from merchants or such quarry-owners as Peter and William de Clavile. It is well known, however, that quarries both for chalk and stone were occasionally opened up in manors belonging to the crown or leased during the progress of royal works, and in one of the earliest detailed accounts now extant of the works at St. Peter's, Westminster, we hear of stone from 'the king's quarry,' 13 but its position is not stated. ${ }^{14}$ In the greater number of cases, however, when Corfe marble or stone is mentioned, some note of purchase is added, and royal officers were stationed in the Isle of Purbeck to superintend the buying and to ensure that the king was fairly dealt with. For instance, about $1257,{ }^{15}$.35 was paid to Nicholas Red and his fellows, 'viewers of the purchases of the king's marble at Purbeck for the king's works at IV estminster.' A few of the letters sent by the king's representatives at Purbeck with consignments are still extant. They are brief and businesslike.

also been exposed. The marble of this quarry varied in colour, green, bluish-grey, and occasionally red from the presence of iron. It generally weathered brown outside.

${ }^{10}$ Assize R. 202, m. 23, under hundred of Rowbarrow.

" 'Besca' is generally translated 'spade,' but here a pick or 'kevel' seems to be intended.

1s 'In marmore empto apud Corfe ad operationes ecclesiae Westmonasterii'; Pipe R. 4 t Hen. III, m. 8. Cf. also Pipe R. 42 Hen. III, m. I2. As to stone 'In 9 navatis libere petre et dure de Chorf emptis ad idem, pro petra et frecto et discargatione $\complement_{4} 8$ i is. $6 d$.' ; Accts. Exch. K.R. bdle. 467 , No. 7 (4), 67 Edw. I; cf. Westm. Misc. Press 6, B. 3, P. $22, \pi$.

${ }^{13}$ Accts. Exch. K.R. bdle. 467, No. 1.

14 It is possible that this quarry was at Purbeck, but it is equally likely that it lay somewhere on the slopes of the North Downs, whence enormous quantities of stone were procured for the royal works at Westminster and elsewhere. Towards the end of the fourteenth century we hear of a quarry taken on lease at Chaldon in Surrey. Stone from Chaldon was also being used a century before ; cf. Mr. M. S. Giuseppi, F.S.A., 'Stone Quarries,' in V.C.H. Surrey, ii, $2-8 a$; Scott, Gleanings from Westminster Abbey (2 nd ed.), App. 258 ; Accts. Exch. K.R. bdle. 467 , No. 7 (4). It may be remembered also that there is a Chaldon in Dorset, and Mr. A. Strahan states that "A small exposure of Upper and Middle Purbeck strata marks the axis of the Chaldon anticline, and some old limestone quarries in them are said to have been opened for stone for Burton Church.' Op. cit. 106.

15 Pipe R. 42 Hen. III, m. 12. 


\section{INDUSTRIES}

Robert de Bremele writes ${ }^{16}$ to Master John of Oxford :-

I am sending you one shipload of marble by William Justise, whom you may pay for freight $5 \frac{1}{2}$ marks and 10 shillings, and if God prospers us I will send you a shiplo.sd before Whitsunday, and a third if I can find a ship to carry the said stone. You may expect me (sciatis adrentum meum) in Whit-week and not before because the season is now at hand in which, if I am absent, your business cannot be carried out well (non bene possint expediri).

On another occasion it is possible that some remonstrance had been addressed to Purbeck regarding slackness at the quarries, for Richard le Wyte of the quarry at Purbeck writes ${ }^{17}$ to Robert de Beverley that the bearer, Peter de Sarcesye, had expedited the king's work at the quarry as much as he could, and had purchased and brought two shiploads of stone. The most valuable supplies from Corfe consisted no doubt of the well-known marble, but we also hear of a freestone. This may have been the stone in modern times called Purbeck-Portland. But the matter is uncertain, as the Corfe merchants supplied apparently more than one variety of stone. In a Westminster fabric account for the years $6 \& 7$ Edward I we read :- ${ }^{18}$

To Edward of Corf on the same day (Morrow of Palm Sunday) for $1300 \frac{1}{2}$ stones from the island (petre de insula), for the stone and freight $£ .53$ s. $4 d$. To the same for 16 yards (virgis) and 2 feet of hard Corf stone (dure petre de Corf) 22s. . . . To Robert of Corf ${ }^{19}$ on the day aforesaid for 55 yards of Corf stone, for the stone and freight $6417 \mathrm{~s} .6 \mathrm{~d}$. For discharging it 2 s. 6 d.

The term 'stone from the island' is undesirably ambiguous, as the phrase may refer to stone from the well-known quarries ${ }^{193}$ of the Isle of Wight, and even the Isle of Portland is possibly not excluded. Yet as the merchant is a Corfe man the expression may embody an early use of the term 'island' as applied

${ }_{16}$ Accts. Exch. K.R. bdle. 467 , No. 1.

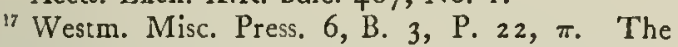
quarry here referred to seems to have been on the land of the Claviles.

${ }^{15}$ Accts. Exch. K.R. bdle. 467, No. 7 (6). Sir J. C. Robinson kindly suggests that the 'hard stone' here mentioned may be the local 'burr,' an extremely durable building stone used to a very great extent at Corfe Castle, as well as in the tower of the fifteenthcentury church at Swanage.

${ }_{19}$ Probably the Robert le Blund who supplied marble for the Eleanor crosses.

${ }^{193}$ The stone from these was used to a very large extent, both at Winchester and at Christchurch Twyneham. When Winchester Castle was being repaired early in the third decade of the thirteenth century, much of the stone employed was 'petra de Insula' (see Accts. Exch. K. R. bdle. 49I, No. 13). to Purbeck. The determination of the point must, however, be left to the judicious reader.

Not only was stone and marble bought at Corfe for the king's works at Westminster, but even for new building or the repair of already existing structures at Corfe Castle stone was sometimes ${ }^{20}$ but not invariably purchased in the neighbourhood. Yet on one occasion at least an attempt made by the constable of Corfe Castle to obtain stone cheaply at the expense of his neighbours provided work for the lawyers. The officer in question, Elias de Rabayne, during his tenure of office was indeed peculiarly unfortunate in quarrelling with the Purbeck landowners. One of them, William de Clavile, complained ${ }^{21}$ that on the Tuesday after All Hallows, 5 Edward I (1 277), the constable had caused five of his oaks to be cut down and carried to Corfe Castle, and furthermore in the Easter week following had ordered one John Doget to open up a quarry within the close (clausuram) of the aforesaid William at Holne, from which stone had been raised against the landowner's will. Clavile complained to the king, and an injunction was served on the constable ordering him to cease his infringement of Clavile's rights and to offer compensation for the wrong, but this the aggressor ignored.

The constable in answer declared that his predecessors who had held the castle and warren of Corfe had been wont both to cut down trees and make quarries and thence carry stones for the repair of the castle of Corfe when necessity required. He had simply followed precedent in the matter, and furthermore he had taken a part of the stone ${ }^{22}$ in order that he might send it to the Tower of London in obedience to the king's writ. He demands that inquisition should be made thereupon. Richard de Colleshulle the sheriff, however, deposed that the constable had no right to take the stone and timber or meddle in the work of repairing the castle, since viewers were appointed to see to the business, to whom he as sheriff made the necessary payments for the expense of materials.

${ }^{90}$ See Accts. Exch. K.R. bdle. 460, No. 27 ; bdle. 461 , No. 5 .

${ }^{21}$ Assize R. 205.

22 The only stone found at Holne is apparently a reddish grit or sandstone, and this appears at Corfe to a small extent only in the Butevant Tower and adjacent walls. Elias does not apparently say that he had actually sent any to the Tower, and it is doubtful whether his statement was literally true even as it stands. He might have possibly at some time received a royal order to procure and send 'freestone' to the Tower, but it is hardly likely that the rough stone of Holne would be brought the long journey from Purbeck when Kentish rag and Reigate stone were so easily obtainable. See also the sheriff's statement above. 


\section{A HISTORY OF DORSET}

The jury found that wood and other necessaries could be taken in the warren, ${ }^{23}$ but pointed out that although the constable had used one oak for repairing a bridge, the rest taken had been made into charcoal for his private profit. They also evidently regarded the quarry as an unwarrantable encroachment, and fixed the damages in respect of the timber and stone removed at one mark. It is significant that when building operations and repairs were in progress at the castle of Corfe a few years later than the date of this trial large quantities of stone were purchased ${ }^{24}$ from Sir Peter [Doget] (probably the chaplain at the castle chapel), Lawrence Cok, John Lenard, and Thomas Cusyn. Indeed, it inay be reasonably suspected that the best quarries of marble and possibly of freestone at Purbeck were during the thirteenth and fourteenth century in private hands. Occasionally, however, the officers in charge of the work of repair at Corfe Castle seem to have directly employed quarriers to raise stone in the vicinity of the castle. For example ${ }^{25}$ in $1377-8$ wages were paid to Ralph Ridell, John Waytenan, Benet Waytis, William Fynche, Benet Kydell, Michael Domersham, IVilliam Pyell, Thomas Hugon the less, Ralph Rossekyn, Philip Coule, and Richard Combe, eleven masons (latomorum) called 'Roughmasons and Quarreours,' working at digging stones at the quarry at Purbeck and shaping (scapulancium) and preparing the same stones there. They were paid at the rate of $6 d$. a day, and were assisted by four 'garciones' or mates. Several of these rough masons also worked on the castle with John Combe, Master William Wynford, John Harpetre, and Philip Colyn, who were apparently masons in the higher sense and did no rough quarry work.

Not only was marble and stone raised and exported in block from Purbeck, but a local school of sculptors produced to order polished marble dressings and effigies which they sent to all parts of England. It seems likely from inspection ${ }^{26}$ that the marble capitals and bases sent to Chichester ${ }^{27}$ in the early years of the thirteenth century were worked at Purbeck, while the mouldings ${ }^{28}$ of the Purbeck work at

${ }^{23}$ In another similar case, Elias de Rabayne 8 . abbess of Shaftesbury, the jury laid down that 'omnia necessaria ad opera ipsius castri perficienda et etiam focalia cum moderamine' could be taken 'in boscis predictis ron clausis vicinibus castro predicto,' but that Elias had taken wood in other manner than his predecessors. It wonld appear from this and other cases that the right claimed by the crown to take timber and stone for the repair of Corfe Castle was limited to the uninclosed portions of the Warren of Purbeck.

24 Accts. Exch. K.R. bdle. 470 , No. 27.

${ }_{25}$ Ibid. +61 , No. 9. ${ }_{26}$ Archit. Rev. xv, 175.

${ }^{27}$ Close, 6 John, m. 2 ; 8 John, in. 4.

${ }^{28} \mathrm{Mr}$. IV. R. Lethaby, 'How Exeter Cathedral was Built,' in Archit. Rev. xiii, 1 75, 176.
Winchester Presbytery, Wells Chapter-house, and Exeter are very similar.

Orders were sent to the Corfe sculptors for effigies, and we hear ${ }^{29}$ just after the middle of the thirteenth century that Ioos. is to be paid for a certain image of a queen to be cut in marble stone and then carried to Tarrant Keynston (Tarente Monialium), there to be placed on the tomb of the Qucen of Scots. Again, early in the reign of Edward I the sheriff accounted ${ }^{30}$ for the expense of a marble altar ${ }^{31}$ made in Purbeck and delivered as a royal gift to the Carmelite friars in London. Occasionally, how ever, for especially important work a famous sculptor ${ }^{32}$ was by royal command summoned to a distance and took with him the tools and raw materials of his craft. This documentary evidence is confirmed by the deep layers of marble débris containing fragments of mouldings and foliations, the chips from the workshops, which have come to light in the course of excavations within the town of Corfe. ${ }^{33}$

Owing to the long series of royal works undertaken in IVestminster and London during the thirteenth and fourteenth centuries and the natural advantages of the capital as a distributing centre, a number of Purbeck marblers ${ }^{34}$ settled far away from their Dorset homes and in some cases probably never returned. It may be that whenever the services of Purbeck men

${ }^{29}$ Pipe R. 38 Hen. III, m. 9.

to Hutchins, op. cit. i, 466 .

${ }^{31}$ Purbeck marble was a favourite material for altar slabs. Some examples still remain as in the Lady Chapel at Christchurch, Hants, in Corton Chapel, and elsewhere. On Monday, II March, 1353 (?), 24s. was paid to Thomas Elyot, a merchant, "for a certain marble stone bought for an altar in eadem revestiaria.' Accts. Exch. K.R. bdle. 471, No. 6, which relate to works at Westminster and the Tower.

${ }^{32}$ ' Et Magistro Simoni de Well ad expensas suas in eundo versus Westmonasterium ad mandatum Regis ad faciendum ibidem quendam tumulum ultra corpus Katerine filie Regis 2 marcas per breve Regis. $\mathrm{Et}$ in cariagio utensilium suorum ad operacionem dicti tumuli + s. $8 d$.' Pipe R. +1 Hen. III, m. 8 .

${ }^{33}$ Hutchins, op. cit. (last edition), vi, $466 \mathrm{n} 6$.

${ }^{34}$ One of these may be mentioned in illustrationAdam de Corfe. Early in the fourteenth century we find him settled in London as a stone and marble merchant, and about 1307 supplying for 50s. a slab of marble to place on the high table of the king in the Great Hall of Westminster (Add. MSS. 30263, fol. is b). A few years later he is apparently contracting for the new pavement at St. Paul's, and about 1315 also supplies stone for an archa goterarum beneath the 'cameram Marculphi super Thamisiam in fundamento,' since the fundamentum of the former arch was weak and worn out by the tide of the Thames (Autta Thomisise) (Add. MSS. 17361, fol. 14). From the records of the City quoted by Mr. Lethaby we learn that Adam de Corfe lived in Farringdon Ward, and on his death in 1331 left a tenement in East Street, Corfe (W'cstminster and the King's Craftsmen, 186). 


\section{INDUSTRIES}

were required for a considerable time, as at Exeter, a tendency existed as at Westminster towards the formation of a school of craftsmen trained in the tradition of the marble workers of Corfe.

By the limited scope of this paper we are absolved from trying to account in detail for the artistic skill of the Purbeck craftsmen. Opportunity in the main calls forth latent faculty, and at Corfe, maybe, an indigenous Celtic strain, possibly reinforced later by Breton immigration, ${ }^{35}$ tempered Saxon heaviness. Again, the later settlement of foreign artisans ${ }^{36}$ may have furnished a certain stimulus; but this, even reckoned at its highest value, did little more than whet the already keen edge of native craftsmanship.

It is impossible to catalogue here the names of known masons, marblers, and merchants who hailed from Corfe and its neighbourhood during the Middle Ages. But one family was so prominently connected with the marble industry of Purbeck for nearly a century and a half that it may be cited as in some measure typical, though the precise relationship between the different members of it is often a matter of doubt or even quite unknown. The first William Canon whose connexion with the Purbeck marble industry is certainly known was already apparently an owner of property there before 1288 , and is found associated with John le Mayr of Corfe and others in certain litigation, ${ }^{37}$ and on the death of Queen Eleanor supplied marble for some of the crosses erected in her memory, especially that of Charing. ${ }^{38}$ In 1291 (Thursday before Quindene of Easter, 19 Edward I) he was sitting with other fellow burgesses on a jury to determine the extent of the castle and chase of Corfe. ${ }^{39}$ About this time he was also contracting for the marble required in the reconstruction of the cathedral church of Exeter, and it is most likely that he was the William Canon who paid for marble supplied there in 1310.40 The William Canon, however, who was men-

${ }^{35}$ Cf. Engl. Hist. Rev. Oct. 1907.

${ }^{36}$ Cf. the case of Durand ' the carpenter,' of Domesday, from whom probably descended Gerard 'the carpenter' of the thirteenth century and the De Moulhams. John, as we know, introduced foreign artisans into Corfe. Cf. Pipe R. 17 John, m. Id. and Close, 16 John, m. 15 .

${ }^{37}$ Assize R. $210, \mathrm{~m} .13 d$.

${ }^{38}$ Accts. Exch. K.R. bdle. $3 \sigma_{3}$, No. J. John and Robert de Corfe and the brother of the second of these, William le Blund, are also mentioned in this connexion. Robert de Corfe supplied worked marble for the crosses at Waltham, Northampton, and Lincoln, and with Robert Pavy, 'asshelers,' for the cross of Charing.

${ }^{39}$ Hutchins, op. cit. i, 496.

${ }^{10} \mathrm{P}$. Freeman, Arcbit. Hist. of Exeter Cathedral, 28. William Canon also wrought the marble of the choir screen, though an imager was later brought down from London pro imaginibus talliandis. tioned in the Vicesima Roll of 1327 (I Edward III) was possibly his son, who had succeeded to his father's business and was carrying on the great work at Exeter. If this is the case William Canon the second, even in 1327 , was one of the more substantial men of Corfe, a deputy collector (subtaxator), and paying 2 s. towards the subsidy, the amount contributed also by John Vicary, and these ratings were only exceeded by the $2 s .6 d$. levied on William de Moulham ${ }^{41}$ and the 3 s. levied on William Steynor. By 1334 the great contract for the supply of marble to Exeter carried out by William Canon (junior) in succession to his father was practically completed, ${ }^{42}$ and in the subsidy-roll ${ }^{43}$ of 1334 ( 7 Edward III) William Canon is found paying the highest rate of all in the town of Corfe, 4s. o $\frac{1}{2} d$. John Canon also, perhaps a brother or cousin, who had figured in the subsidy of Edward's first year assessed at $6 d$., now paid $12 d$. And the same amount was also paid by a certain Adam Canon at Welle in Bindon Liberty. About twenty-three years after, William Canon, ${ }^{44}$ if he may be identified with the second William Canon of Exeter, now full of years and honours, was mayor of Corfe, and commissioned with a certain clerk, John de Kingston, to survey all defects in the king's castle there. He may have died about this time, as his colleague alone appears to have acted in handing over the work to William of Derneford, the next mayor. ${ }^{45}$ In the last decade of the fourteenth century a third William Canon ${ }^{46}$ is found carving angels at Westminster at 20s. apiece, but whether or no he was the son of the great contractor does not appear. Other members of the family are occasionally heard of, as Master Edmund Canon, ${ }^{47}$ master stone-cutter, who was paid $\delta_{1}, 76$ s. for working from 5 June, I 357 (3 I Edward III), until 4 June of the following year, on the stalls of St. Stephen's chapel at the daily wage of Is. $6 d$.; Richard Canon, ${ }^{48}$ who sells marble; and as late as 1422 John Canon, ${ }^{49}$ evidently a master mason, who is ordered with the assistance of William Wilflete, clerk, to select and take stone-cutters and other artisans for royal works at Hertford Castle and elsewhere.

All through the fourteenth century the export of marble from the Purbeck quarries continued

${ }^{41}$ Lay Subs. R. bdle. I03, No. 35.

${ }^{42}$ Exeter Fabric RR. cited by Oliver, Lives of Bishops of Exeter, 383 .

${ }^{43}$ Lay Subs. R. bdle. 103, No. 5. This assessment was for a fifteenth and a tenth.

${ }^{44}$ Accts. Exch. K.R. bdle. 460, No. 30.

${ }^{45}$ Various mayors of Corfe were on several occasions chosen as viewers when repairs at the castle were required. No doubt they were or had been in most cases engaged in the quarrying industry.

${ }^{16}$ B.M. Add. R. 27018.

47 Smith, Antiq. of W'estm. 200.

${ }^{49}$ Pat. 2 Hen. VI, pt. 3, m. 25 d. 


\section{A HISTORY OF DORSET}

actively, though the close of the interior rebuilding of the cathedral church of Exeter probably synchronized with the beginning of inevitable decline. Yet the abbey of IVestminster was a good customer of the Corfe merchants right into the fifteenth century, and we hear of the sacrist ${ }^{50}$ journeying to Purbeck and his expenses amounting to $£^{2} 5$ s. $2 \frac{1}{2} d$.

After I 400 the demand ${ }^{51}$ for Purbeck marble both for structural and monumental use very much lessened, and alabaster grew in farour as the fittest naterial for sculptured effigies. The best quality seems to have been procured in the neighbourhood of Chellaston in Derbyshire, whence it was exported all over England and even to the continent. But gypsum is by no means confined to the midland counties. Even in Dorset it occurs in the Lower Purbeck strata of Durlston Bay, and though not worked commercially at present has undoubtedly been quarried in times past and even comparatively recently for making plaster of Paris. Certain entries found in the Customs Accounts of Poole ${ }^{52}$ in the latter half of the fifteenth century may suggest that the Corfe marblers, feeling that their trade was slipping from them, turned their attention at least for a time to working in alabaster. ${ }^{5 g_{3}}$ However this may be the entries are of sufficient interest to be noted as a slight contribution to the history of alabaster in England. The pinnace Le Gabriell, of Poole, of which Robert Gosselyn was master, left the port carrying two 'tabylys de alabastre' value $f_{0} 3$. These were apparently the property of William Filat. Another pinnace, ${ }^{53}$ the Nicholas of Warehom, left under the

\footnotetext{
${ }^{50}$ Scott, Gleanings from I'estm. Abbey (and ed.), App. 259.
}

${ }^{31}$ However, it was still in request for high-class sepulchral work. See the contract made by John Bourde of Corfe Castle, marbler, 15 May, 35 Hen. VI, to make a tomb of marble for Richard Beanchamp, earl of Warwick, in the Lady Chapel on the south side of St. Mary's Church at Warwick. Slabs of good and well-coloured marble, 2 in. thick and of convenient breadth, were also to be provided for paving the chapel. Hutchins, op. cit. i, $464 b$.

${ }^{32}$ P.R.O. Cust. Accts. K.R. bdle. 119 , No. 16 (18-19 Edw. IV).

${ }^{53}$ Although the entries may suggest that one or more pockets of gypsum of sufficient strength and beauty for ornamental work had been discovered locally and used up, ret on the other hand the alabaster referred to may have been obtained from Chellaston or Nottingham. Sir J. C. Robinson is of opinion that the entries relate to Nottingham work brought to Poole for export to France, Spain, and Portugal, especially the two latter countries, with which Poole had much trade.

${ }^{33}$ About two months before this we meet with an entry of a vessel entering the port with alabaster. As it stands alone it is just possible that the clerk who made the fair copy wrote intravit in error for exirit (see, however, the preceding note). It reads "Batalla vocata le Nic[holas] de Wareham unde Arnulphus mastership of Thomas Togyll on 14 August, and the Customs Accounts mention consignments for which Richard Harres was responsible, 'vj tabylys de alabaster' worth $f^{6} 6$, and a case (pypa) of images worth 26s. $8 d$. Nearly a month later (9 September) there left a skiff (scapba) called the Mary of Poole, of which John Duet was master, carrying ' $\mathrm{j}$ tabyll of alabastre' value 20s. Four days later a 'batalla' called the Margaret of 'Kyhavy,' master John Wade, took out another table of alabaster worth 20 s. Some three years after this a mutilated entry ${ }^{\text {st }}$ shows us an outgoing Poole vessel whose master was IVilliam Mellett carrying twenty tables of alabaster worth f. $^{26}$ I 3 s. $4 d$.

Marble, however, was still an article of export, for the Leonard of Poole, under the mastership of IVilliam Newborough, left the port late in the reign of Edward IV, 55 with 5 casks (doliis) of marble on board valued at $£ 3$ Ios., so that John Russe, a denizen, paid thereon in subsidy 3s. $6 d$. The Purbeck stone exported seems at this time to have been largely for roofing purposes. Early in the reign ${ }^{56}$ of Edward IV a foreign ship with a Dutch or Flemish master took out 30,000 stones called 'sclatte stones,' valued at $f_{0} 4$. On this he paid is. to the Customs as well as a subsidy of 4 s. Another foreign ship about 20 years later ${ }^{67}$ took on board 30,000 'helyng stones' worth 45s. Caen stone was still occasionally imported in some quantity, ${ }^{58}$ and now and again a Norman marbler settled at Corfe and took out letters ${ }^{59}$ of denization.

In the reign of Henry VIII Purbeck stone ${ }^{60}$ was being used at Portchester, probably in this instance for roofing purposes, but little is heard during the sixteenth century of Purbeck marble, while in the two following centuries Portland stone of the best beds took precedence of Purbeck, though both have often been used in conjunction. For paving, however, a bluish stone from Purbeck has always been in demand.

The Purbeck quarriers and stone merchants have long formed a close society known as the 'Company of Marblers or Stone Cutters of the Isle of Purbeck,' but of its exact origin atdd

Marchall est $m$ [agister] intravit 22 die Junii ... De Rogero Lane indigena pro vj pety tablys de alabastre et una imagine de Virgine Maria val \&..' Amongst the miscellaneous cargo of an entering French ship in 1505 were two candlesticks, a holy water stoup and ' $\mathrm{j}$ Saynt Johnis hedde,' doubtless of alabaster. Cust. Accts. K.R. bdle. 120 , No. 10 (19\& 20 Hen. VII).

${ }^{31}$ Cust. Accts. K.R. bdle. 119, No. $18 \quad(22$ Edw. IV).

${ }^{35}$ Ibid. bdle. 119 , No. 20.

${ }^{36}$ Ibid. bdle. 119 , No. 8 (6 Edw. IV).

5: Ibid. bdle. 120 , No. 3 ( $3 \& 4$ Hen. VII).

${ }^{59}$ Ibid. bdle. 119 , No. 12, \& $\mathrm{c}$.

${ }^{59}$ Pat. 6 Edw. IV, pt. 2, m. 20.

${ }^{60} L$. and $P$. Hen. $Y I I I, x, 780$. Purbeck stone is still largely exported from Swanage to Portsmouth. 


\section{INDUSTRIES}

history little is known, as no early records are forthcoming. ${ }^{61}$ Copies of their rules, however, go back to the sixteenth century, and some of these are probably of great antiquity, as for instance the regulation-

That no man of the Company shall set into his fellow-tradesmen's quarr to worke there without his consent within 12 moneths and a day, nor to come into any part of that ground within a hundred foote of his fellow-tradesmen's quarr upon the forfeiture of 5 poundes to be paid unto the owner of the quarr un to whom the offence shall be dun. Neither shall no man in this company worke partners with any man, except it be a freeman of the same company, upon the forfeiture of 5 poundes.

There were also restrictions as to the number of apprentices. These, after their seven years' probation, were admitted at the annual meeting on Shrove Tuesday at Corfe Castle. According to the rule-

Upon any acceptance of any apprentice into the company he shall paie unto the wardings for the use of the company $6 s$. $8 d$., a penny loafe and two pots of beer.

Apparently the new freeman appeared in court with the penny loaf in one hand and a pot of beer in the other, and on paying the half-mark was declared free, his name being entered in the register. The newly-admitted quarrier was, however, unable to take an apprentice until seven years after his admission. The wife of a freeman on paying is. could also be admitted to the freedom of the company, and was then enabled if she survived her husband to take an apprentice and carry on the business. At the annual meeting a warden and a steward were appointed. The business of the first of these was to arbitrate between quarriers in disputes arising out of their craft, and especially in regard to encroachments. In difficult or important cases it might be necessary to summon the whole body to determine the matter. The last man of the company married in any year provided a football, and this, as we know from a rule recorded later than the sixteenth century, was to be carried to Ower-

As also a present to be made of one pound of pepper as an acknowledgement in order to preserve the company's right to the way or passage to Owre key according to antient and usual custom.

Although Ower has long ceased to be, as it was in the heyday of the marbler's trade, the port whence the stone was shipped, this custom is still observed. By the eighteenth century the stone was carried in carts to the 'bankers' at Swanage, and there stored till it could be put on board the stone ships. ${ }^{62}$ And Swanage still

${ }^{61}$ The early records seem to have been burnt at Corfe Castle in a fire about 1680.

${ }^{63}$ Hutchins, op. cit. i, 682 . retains its position as the practical head quarters of the trade in Purbeck stone.

An edition of the rules of the company drawn up in March, 1697-8, recites the ancient rules substantially as before, but certain articles are added in order to meet the difficulties and inconveniences arising from the trade being in the hands of a number of small dealers with very slight capital, and in fact to organize the trade as a joint stock company. The preamble of these articles declares that the stone dealers, by reason of the deadness of the trade,

have of late yeares made it their practice to carry their said stone to London in small quantities, having but little stocks. And in order to dispose thereof have and still doe endeavour to undersell one another to the infinite prejudice of the stone trade, by means whereof the price and value of the said stone is so lessened and beate down that scarce anything can now bee gotten by it.

It is, however, probable, as the editors of Hutchins' History of Dorset point out, that the notorious slackness of trade in Purbeck stone at the end of the seventeenth century was partly due to the inferior stuff supplied. 'This inference may perhaps be legitimately drawn from a curious document of 1687 , ten years earlier than the date of the revised rules. In this certain persons,

being inhabitants of several parishes of Sandwich and Langton within the Isle of Purbeck and county of Dorset marblers and merchants in the said trade,

bound themselves to resist the claim of the London buyers to have the stone examined and to deduct the cost of the search from the price of the material delivered. This suggestion of the poor quality of the stone is supported by an allusion in the articles of 1697 to the breaking of the stone by the manager if found to be unmerchantable.

The measures taken to consolidate and control the Purbeck stone trade in 1697 seem to have borne fruit, as during the eighteenth century considerable activity is discernible. For instance a tough red stone from Purbeck was used for building Ramsgate Pier, and between June, 1750 , and September, 1752, the Harbour Trustees of that town employed fifty sail in transporting 15,000 tons of stone from Dorset to the Isle of Thanet. $^{63}$ Again, between January, 1764 , and January, I771, Purbeck stone was shipped to the extent of 94,000 tons, ${ }^{64}$ according to the Customs Records. In fact the yearly output at that time was probably at least 14,000 tons.

The nineteenth century saw renewed activity in the Isle of Purbeck in marble quarrying,

${ }^{63}$ Hutchins, op. cit. i, 657 .

${ }^{64}$ Possibly the real amount was much greater, as owing to the absence of any duty no great care was taken in securing accurate returns. 


\section{A HISTORY OF DORSET}

which had practically ceased at the end of the eighteenth century. This revival was due in part to the needs of church restorers, ${ }^{65}$ though local marble has also been occasionally employed to some extent in new work, as for instance in the church built by the earl of Eldon at Kingston.

The stone quarries in the neighbourhood of Swanage continue to be worked in much the same manner as they have been for centuries. They are not open workings, since the best beds of stone lie very deep. Indeed the approaches are inclined shafts to the depth of a hundred feet or more. In 1877 there were at least ninety-two of these stone mines worked, as the late Sir C. Le Neve Foster reported,

by 1,2 or 3 men underground, who are in many cases the owners as well as the occupiers. Their work is often most irregular; if the men can find work as masons, they abandon their quarries for a time, and do not return to them till other work is slack.

The annual output of dressed Purbeck stone and marble amounted in that year to 11,816 tons IO cwt., besides I,4 I I tons, IO cwt. of undressed stone.

The marble from the Upper Purbeck Series can be got in blocks seven or eight feet long, but seldom more than a foot in thickness. Its gradual disuse towards the close of the Middle Ages was in part perhaps due to change of fashion or in part to the fact established by experience that it was lacking in durability. The local 'burr' of the Upper Purbeck Series has been largely used for local buildings in the past, and was employed in the nineteenth century during the restoration of Wimborne Minster. It is a compact sandy limestone and occurs in thick beds.

From the principal veins ${ }^{66}$ of the Middle Purbeck Series, the Lane-and-end or Laning Vein, the Freestone Rag, the Freestone Bed and Upper Tombstone Bed, Brassy Bed and Lower Tombstone Bed above the Cinder Bed, and below it the Button, Feather, Cap and New Vein, considerable quantities of good stone are still obtained suitable for kerb-stones, paving, building and tiling purposes. The limestones of the Lower Purbeck Series found in the Isle of Purbeck proper are of little value. Outside it they furnish good material at Portisham.

In the cliffs between Durlston and St. Albans headlands beds of the same general character as those in the Isle of Portland have been largely quarried under the name of Purbeck-Portland. Some excellent oolitic stone was long worked

${ }^{65}$ e.g. Temple Church and later the Chapter House at Westminster and Exeter Cathedral.

${ }^{66}$ For a full account of the various veins, see Hutchins, op. cit. i ; Damon, Geology of Weymouth; Woodward, Furassic Rocks of Britain, v ; A. Strahan, Geology of Isle of Purbeck, $91 \mathrm{et} \mathrm{seq}$. underground here in galleries as at Winspit and Tillywhim. ${ }^{67}$ From the ledges of these cliff quarries the stone was shipped into stoneboats when the weather permitted them to lie close in shore. Smeaton was of opinion that this stone was inferior in colour to the best stone from Portland Island, harder to work, and, as he was informed, not in general near so durable. ${ }^{68}$

Long before the period of recorded history the stone of Portland Island was doubtless occasionally quarried, and indeed of its very ancient use for sepulchral purposes evidence actually exists. A tomb possibly of the Early British period excavated in the Purbeck beds and immediately above the upper 'dirt bed' was found in 1897 in the Combe Fields Quarry between Weston and Southwell. Internally it was lined with flat Purbeck stones or 'slats' horizontally laid and pugged in clay, behind which the roof of the chamber was in part roughly arched and covered with slabs of stone. ${ }^{68}$ Other similar tombs and cists of stone slabs from the Upper Portland beds have also been discovered on the island. ${ }^{69}$

Edward the Confessor had granted to St. Swithun's, Winchester, Portland with other manors, but the Conqueror seems to have treated the gift as invalid, ${ }^{70}$ though his son Henry Beauclerk again confirmed to the monks the manor 'as King Edward had given it them.' "1 It is possible that during their tenure of Portland the monks of St. Swithun's may have exported stone to a distance, but of this no documentary evidence exists. ${ }^{72}$ The stone used by Walkelin

${ }^{67}$ Damon, Geology of Weymouth (1884), 199. The Tillywhim Quarry derives the second portion of its name from the crane or 'whim' used to lower the stone into the boats. See Robinson, A Royal W'arren, 93. The 'best bed' of Purbeck-Portland stone is thickest at Seacombe Quarry, where it reaches $8 \mathrm{ft}$. with $4 \mathrm{ft}$. of inferior stone above it (Strahan, op. cit. 64 ).

${ }^{68}$ Smeaton, Eddystone Lighthouse, 66.

in this tomb was found a mortar formed out of the 'Roach' bed with a pestle of flint. Another chamber was afterwards opened close by, of similar construction, but nothing was found in it. It was probably used for the storage of grain; ex inform. Mr. J. Merrick Head.

69 Proc. Dorset Nat. Hist. and Antig. Ficld Club, xix, 128, \&c. Captain Mascall, R.E., 'List of Remains discovered in neighbourhood of Verne Hill,' in Damon, Geology of Weymouth, 2 to et seq.

${ }^{70}$ In Domesday Portland is surveyed as "Terra Regis.'

$"$ B.M. Add. MS. 29436 , fol. I 4

"Some of the stone, however, found in the Norman work at Christchurch Twyneham cannot be distinguished from Portland oolite, and may not unlikely have come from quarries at Wyke or Portland. Mr. J. Merrick Head informs us that the earlier of the two ruined churches at Portland, which is of twelfthcentury date (? I I $40-60$ ), is built partly of local stone and partly of Purbeck marble. The original toolmarks are still visible. Rufus Castle, which lies 


\section{INDUSTRIES}

at Winchester is supposed in the main to have been procured from Quarr in the Isle of Wight.

In the thirteenth century Portland passed to the Clares by exchange, and from them later to the earls of Ulster, the earls of March, and thus in the fifteenth century to the crown. During the whole of this time there can be no doubt that quarries within the island were worked for purely local use, but even as early as the beginning of the fourteenth century Portland stone in considerable quantities was being exported as far as Exeter, as the Fabric Rolls ${ }^{73}$ of the Cathedral Church bear witness; and fifty years after, if not much earlier, it was in request for the constant fresh building or reparatory work proceeding at the royal palace of Westminster and elsewhere in London. ${ }^{74}$ Towards the close of this century, however, there was for a time at least a lull in the activity of the quarry belonging to the manor, for we read in a Minister's Account for the year 20-21 Richard II that in respect of the issues of the quarry nothing was returned. ${ }^{75}$

For the next century and a half little is heard of the Portland quarries, though there is no reason to doubt their continued working. ${ }^{76}$

within the grounds of Pennsylvania Castle, is also built of the same local stone, and is a fine example of the great durability and strength of Portland oolite. The angles and walls are in general as sharp and intact as on the day they were built, and the additions and openings for defensive purposes equally so. The tool-marks are distinctly shown on the stones of this building.

${ }^{73}$ Cited by Freeman, Archit. Hist. of Excter Cath. 123. It also seems to have been used in the choir of Christchurch Twyneham; Ferrey and Britton, Antig. of Christchurch (1841), 15. Mr. J. Merrick Head points out that there exists in Portland a locality known as Priory, where quarries have long since been opened and are now disused.

$"$ Cf. Pat. 23 Edw. III, pt. 3, m. 32 d. and Accts. Exch. K.R. bdle. 47 I, No. 6 (25-28 Edw. III). 'Thome Elyot pro $\mathrm{j}$ navata petrarum de Portland empta pro fundamento muri palacie iuxta aquam reparando $E^{\text {I I }} 5$ s.' At the same time two shiploads of rag cost only $£_{2} 2 \mathrm{~s}$. It was used in connexion with the Portland stone in the same work. A very large amount of Portland stone was also purchased for the King's Chapel at Westminster and for the Tower. See Accts. Exch. K.R. bdle. 470 , No. 18 , and bdle. 471 , No. I (2 I-22 Edw. III).

${ }_{75}$ Mins. Accts. (Gen. Ser.), bdle. 832 , No. 29.

${ }_{76}$ The fifteenth-century ruined church of Portland was built of local oolite resembling Top Bed. The original tool-marks still appear on the north front. The main walls of Wyke church are built of a stone very similar to Portland oolite, which, however, may have been quarried outside the limits of Portland manor. The main walls of Sandsfoot Castle near Weymouth were built of Portland stone in the reign of Henry VIII. The stone is generally in excellent condition; certain decayed blocks in the interior are not from Portland, but were procured from a quarry in the vicinity of the castle.
Leland, ${ }^{77}$ however, notes that 'the people be good there in flyngging of stonys and use it for defence of the isle,' and he adds further they 'be politique inough in selling their commodities, and sumwhat avaritiose.'

Elizabeth had reigned about fifteen years when depositions were taken by commission ${ }^{78}$ as to the crown rights in Portland, and amongst the interrogatories administered was the following:

What quarries [are] within the saide demeane lands? What rent the Quenes Majestie hathe byn aunswered for the same and what it would yerelie yielde, and who hath taken the profittes thereof?

The reply given to these questions is instructive. One deponent declared

that there is no quarry of stones whereof the Quenes Majestie hath bene aunswered any rent of the same [and he explained further] that the custome of the island is and hath bene by all the tyme of his remembrance, that is if any man do break any ground of the Quenes demaynes he must have warrant from the officers for the quarringe and getting any stones there and also must compound and agree for them and touchinge stones lyinge uppon the ground in a certayn common called Wathe which have bene solde in oure tyme and [sic] the profittes thereof have bene taken and converted to the use of all the inhabitants ... and that if any quarry be broken by the princes commandement or license that then the tenants ought to have thereof half of the profittes that [the stones] are sold for and in consideracion of breakinge the ground and consuminge of their grasse in lyinge and carryinge away the same to the waterside. ${ }^{75}$

${ }^{77}$ lin. Dorset.

${ }^{78 a}$ It may be interesting to compare with this certain presentments of the last century, concerning which Mr. J. Merrick Head kindly furnishes us the following note :-

At a Court Baron and Court of the Island and Manor of Portland together with the Court of Survey concluded on $7 \mathrm{July}, 1846$,

It was presented, after the Homage had made $x$ personal survey and perambulation of the island and Manor, inter alia, "That all stone exported from the Common or Commonable lands doth pay $12 d$. per Ton; one moiety of such $12 \mathrm{~d}$. belongs to the Lord or Lady in Chief, and the other moiety to the tenants; and by Ancient Grants, and also by one from Her present Most Gracious Majesty, we have 3d. per Ton given us out of Her Majesty's said moiety, which makes Her Majesty's part $3 d$. and ours $3 d$.

'And all such Stone as is for Her Majesty's own use is free, paying nothing.

- And likewise we that are Tenants for our Buildings within the Manor take for our use what Stone we please, paying nothing and asking no leavc. And all such Stone liable to such Tonnage as aforesaid is accounted for at our Courts on the oaths of the persons exporting the same, and the duty paid to the Queen's Recciver or his Agent and divided as before mentioned. All Stone raised and drawn from the Quarries in the Farm has time out of mind paid to 


\section{A HISTORY OF DORSET}

About twenty years later (I 594) under warrant from Lord Burghley, a survey or view ${ }^{79}$ was taken by IVilliam Pitt 'of the quarries of stone and mines of oare earth which will burne within the Islande of Portlande.' He found the sea-cliffs for the most part 'all full of workes and quarries of stone,' and further discovered 'in the same clyffes and in the sandes and shoares . . . and in other places round aboute and in other places there but especially eastewardes from $\mathrm{Her}$ Majesties Castell there a kind of black stone or o-re earth of minerall matter apte to burne which is not granted by lease but remaineth in $\mathrm{Her}$ Majesties hands as parcell of her manner and

the Tenants $3 d$. per Ton, but by Her Majesty's late Grant 3\%. cut of every 12d. payable to Her MIajesty for such Stone has been granted to the Inhabitants, as appears by such Grant, which 3d. to the Tenants and Inhabitants is for damage done to the herbage on the Commons by laying rubble or rubbish thereon, but Stone drawn in the Quarries on the Farm for Her Majesty's use pays nothing.'

Also presented, "That all the Tenants and persons belonging to the parish employed by them (but no other persons) have had time out of mind a right to open and work what Quarries they please in the Commons or Commonable lands, provided they do not thereby hurt or injure the Highways, paying the Customary duty; and all Tenants from time immemorial have raised what stone they pleased in their own respective tenements, as they are freeholders and never did pay any acknowledgement to any person for the Stone so raised in their own respective grounds.'

Then follow presentments as to deposit of rubble on weirs or rubble grounds, and payment in respect of same; and for erecting piers with cranes or sheers for shipping off stone; also presentments of commons and commonable lands, and of the queen's quarries, and of the custom and practice of making an arrangement in respect of labour and payment for the same; and of forfeiture in certain events such as improperly stopping or obstructing the working of quarries.

Further presentment, that where in working quarries in either parish or private lands in the cliffs a public road or way would be destroyed or worked through if the work were continued, it is the custom for the proprietor of the adjoining land to allow an equally conrenient roadway through such land for the public on receiving the tonnage-dues for the stone raised under the road so intended to be worked through, and that no person shall work any quarry in the cliffs nearer than $18 \mathrm{ft}$. of any private lands, unless or until he shall obtain from the owner of such private land a substituted road or way of at least $18 \mathrm{ft}$, and so as often as occasion or necessity shall require.

These extracts are given to show the peculiarity of the customs existing at Portland in respect of quarrying of stone; other customs are also given, and reference should be made to the Court Rolls for more detailed information. It may be mentioned that the presentments cannot always be relied upon; some of them are in opposition to common and statute law, and are of questionable legality.

${ }^{29}$ B.M. Add. MS. $299 ; 6$, fol. I i $\$ 6$. islande of Portlande of which stone or oare earth Her Majesties tenantes in the said Island doe sometimes take and gather to burne for want of woodes and other fewell and may be valued togaether with the said workes and quarries of stone in yerely rent to Her Majestie xs.' Besides these, certain stone quarries had been leased for various terms yet 'indetermined, with certain exceptions in the saide grante unto one Nicholas Jones at the yerely rent of 5s.'

Although, as the foregoing references prove, stone had for many hundreds of years before the seventeenth century been quarried in Portland, yet the wide and established repute of the 'merchantable' stone of the true Portland beds received an enormous extension from its use by Inigo Jones in the reign of James I, especially in the building of the Banqueting House at Whitehall and the additions made to the fabric of Old St. Paul's. In connexion with the first of these enterprises, a new pier was built at Portland at a cost of 6.712 rgs. $2 d$. and a lasting impetus was given to the quarrying industry of the island. ${ }^{80}$

It may be remarked, however, that the quarrying of stone at Portland for the work at Old St. Paul's and its carriage to London met with certain obstacles in the next reign, ${ }^{81}$ and as a result a spirited remonstrance was addressed in 1637 to the archbishop of Canterbury. From this it appears that Ralph Bunn and John Elliott 'who have wrought in the quarry at Portland about the stones for the IVest End of the Cathedral Church of St. Paul in London ever since that work begun,' had been taken by the press-gang for the royal navy to the great hindrance of the work. Furthermore complaint was made that the 'ships which did bring the stones for St. Paul's had their men pressed out of them the last year, and could not be released though they had a warrant from the officers of the navy.' The press-gang, indeed, held the warrant invalid, as it was without the Admiralty seal, and therefore sufficient warrants were prayed for by the petitioners to secure both quarrymen and sailor:. Laud on the reception of this appeal at once took action, and on 20 April informed Mr. Secretary Nicholas that 'it is His Majesty's express pleasure that sufficient warrant

*o It may be noted that, in the purchases made by the Corporation of the City of London in 1630 for the repair of Newgate Prison, while Purbeck stone cost only $5 d$. a foot, Portland stone was priced at is. $8 d$. Rogers, Agric. and Prices in England, v, 511 . In the reign of James $I$ also large quantities of Portland stone were employed in building or repairing the town houses of certain noblemen, as, for example, the dukes of Richmond and Buckingham. Several references to the Portland quarries will be found in the contemporary State Papers, e.g. S. P. Dom. Jas. I, cxiii, No. 71 ; cxr, No. 75 ; cxlvi, No. 6r ; clux, No. 25 , Sx.

${ }^{81}$ S.P. Dom. Chas. I, ccclii, No. 57. 


\section{INDUSTRIES}

be given to secure both the one and the other as is here desired.'

The increased demand for Portland stone from this time forward gave ample employment to the quarrymen who were free of the island, and after the Great Fire it was extensively used in the rebuilding of London, where St. Paul's Cathedral and the churches of Wren are sufficient monuments of its strength and beauty. ${ }^{82}$ In 1696 the inhabitants of Portland are said to have been about 700 in number, ${ }^{83}$ while the fees or king's rents amounted to $145.4 d$. per annum at $3 d$. per acre, besides which there existed an inclosed farm of $f_{10}$ per annum which had then yet thirty years to run. The herbage of all uninclosed ground was common to the fee-tenants, but as to the quarries worked by them in such common land a fee of $12 d$. per ton on all stone raised was due to the crown as an acknowledgement. The writer of the account we are here quoting states that Charles II

gave by sign manual $9 d$. of this $12 d$. for the use of the poor inhabitants of the island which has been continued to them by succeeding princes, and the other 3d. is paid to the Receiver of the fee farm rents of Dorsetshire for account of the Crown, the same being first adjusted at the Courts held for the manor.

But no acknowledgement was paid for the quarries found and worked in the inclosures.

The right to work in the quarries, however, was restricted to such as were 'free of the island.' According to the account we have been following:

All natives of the Island are free both sons and daughters, and the daughters have this privilege that if one of them marry an alien, and have for her dowry a paddock (or little inclosure) by vertue thereof she invests her husband with the freedom of the quarry, and from that time he is admitted free. Every paddock is divisible into as many parts or shares as the owner pleases, and each part has an equal title to the quarrys with the whole. An instance may explain this: A has an inheritance of an acre and has four daughters to bestow it upon. He divides it by partition-walls into four parts and gives each of them a part. The conveyance ${ }^{84}$ is in this manner. After Evening service on a Sunday when the churchwardens and some of the best inhabitants are placed in the church porch he stands up and expresses himself to this effect: I, $\mathrm{A}$, desire you my neighbours to take notice, that I give to each of my daughters an equal share of my paddock

${ }^{89}$ It is impossible to give a complete catalogue of buildings of importance in London which have been constructed mainly of Portland stone. Amongst secular edifices the Horse Guards, Somerset House, the General Post Office, the India House, the Foreign Office, and the Reform Club, may be mentioned.

${ }^{83}$ Stowe MS. 597 , fol. $42 b$ et seq.

${ }^{81}$ 'They say... that "customary lands have always been accustomed to be aliened by those that have been customary tenants thcreunto either by surrender in the court of the said manor of Portland, or by last will and testament or by fice gift at the Church Door.' Proc. in Chan. Eliz. ii, I ; i, 2, 63. For the modern development of this practice since $18+5$ see Somers. and Dors. $N$ and $Q$. vii, 322. cailed __ and bounded \&c. as it now lies divided in four parts. Whereupon the assembly rises, and blesses by name the daughters. And now each of these daughters intitles the man she marrys to all the Privileges of the King's quarrys, which renders her a good fortune to a mason many whereof go from London and marry thus in Portland. ${ }^{83}$

The following contemporary table gives some notion of the prices of Portland stone shipped from the island at the close of the seventeenth century :-

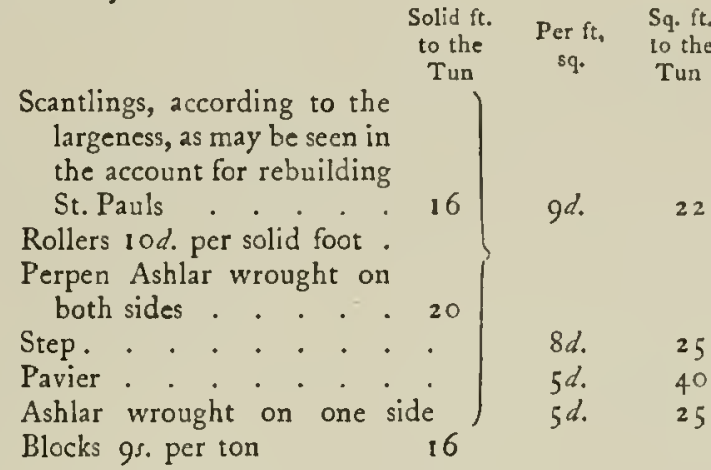

The rates above include the tunnage duty.

Sir Christopher Wren, ${ }^{85}$ who employed Portland stone in his work on St. Paul's Cathedral, seems to have come into conflict with the quarryowners of the island during the progress of his undertaking. ${ }^{85 \mathrm{~b}}$ On $12 \mathrm{May}$, 1705 , we find him writing to them in the following terms:-

Gentlemen, I have perused yours of the $9^{\text {th }}$ to myself and Mr. Bateman, and find you'll never make a right use of any kindness for which reason you may expect less of mine for the future. You have been paid hitherto beforehand, but without your better behaviour, you shall not be paid so again, though you may always depend on what is right. I shall not add to my last direction about the money, till that be fully complied with, nor at present tell you the price charged to the Duke of Buckingham. As for the stone sent to Greenwich, I know no risk you have run, nor of any proposed to you ; so that you have no pretence to higher pay, on that account. 'Tis all one to me what your jury do. It shall not alter any measures of mine, except in endeavouring that the tunnage money you claim by a pretended grant from the Crown, be disposed to better purpose than you apply it to, you having no manner of right to it, as I shall easily make appear, and also represent to the Queen your contesting her right, and your contempt of her authority ; for, though 'tis in your power to be as ungrateful as you will, yet you must not think that your insolence will be always borne with, and though you will not be sensible of the advantage you receive

${ }^{85}$ Some curious details as to Portland marriages will be found in Smeaton, Eddystone Lighthouse, $65 n$.

85a I am indebted to Miss E. M. Hewitt for this and the following paragaph.

st Wren had control of the quarries from 1675 to 1717. Many of the blocks which were excavated at that time, but rejected for his purfose, remained for several years lying about in or near the quarries; Phillimore, Mem. Sir C. Wren, 221. 


\section{A HISTORY OF DORSET}

by the present working of the quarries, yet, if they were taken from you, I believe you might find the want of them in very little time; and you may be sure that care will be taken both to maintain the Queen's right, and that such only be employed in the quarries as will work regularly and quietly, and submit to proper and reasonable directions, which I leave you to consider of, and am

\section{Your friend,}

Chr. Wren.

P.S.-I am sorry Mr. Wood has paid you the tunnage money, but if I have not a better account of your behaviour, I shall endeavour that you be made to refund it; and whether your jury present Mr. Wood or not for the stone, 'tis all one to me. If you take upon you to pay the duty for any stone, for St. Paul's or other uses that I give orders for, you shall not have one farthing allowed you for it.

To Mr. John Elliott, Bart. Comber, Thomas Ouseley, Ben Stone, Henry Atwel, Robert Gibbs, at Portland. ${ }^{85 c}$

The allusion to Greenwich in the above letter is explained by reference to the Treasury Papers of 1702 , concerned with the report of James Mountague to the Lord High Treasurer, on the petition of the directors of Greenwich Hospital touching the demand by the islanders of Portland of $12 d$. per ton and $6 \dot{d}$. by the commissioners of all stone shipped for the use of the hospital. In this report we find it set forth that the whole island is the queen's manor. Also that time out of mind a duty had been paid of Is. a ton, $3^{d}$. of which was in consideration of the damage done to the herbage by the quarry workings. ${ }^{85 d}$

We are unable here to trace further in any detail the history of the Portland quarries, but a few notes may be allowed on the different strata of stone and the fashion of working. In a typical quarry the strata in descending order may be found ${ }^{86}$ as follows :-

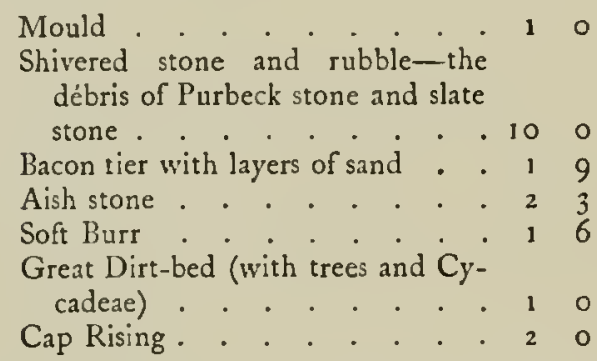

These are excavated and then the top-cap is reached, with a thickness of from 8 to $10 \mathrm{ft}$. A

8se Hutchins, Hist. Dorset, ii, 818 .

${ }^{55 d}$ Cal. Treas. Papers, 1702 , vii, 498.

${ }^{66}$ It must be remembered, however, that the thickness of the different strata varies considerably according to the nature and position of the quarry. A shorter section of a quarry as known among the quarrymen is furnished ns by Mr. J. Merrick Head. The names are in descending order :-Soil, Rubble, Soft Burr, Dirt Bed, Cap, Skull-Cap, Roach, Whitbed, sometimes Curf Bed, Base Bed, Flint Bed. very thin dirt-bed follows between this and the Skull-Cap ( $2 \mathrm{ft} .6$ in.), which is succeeded by the True Roach, which averages from $2 \mathrm{ft} .6 \mathrm{in}$. to $3 \mathrm{ft}$. The Top-Cap, Skull-Cap, and True Roach are generally blasted off to get at the 'merchantable" stone beneath. For heavy engineering works, however, True Roach, which is very light brown in colour, furnishes excellent material. It weathers well, is tough and strong, and owing to its resistance to the action of water is suitable for dock and sea-walls and breakwaters. ${ }^{87}$

Next below the True Roach are found the

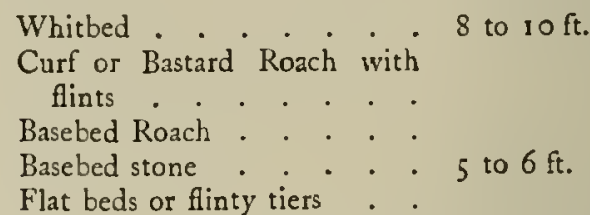

Whitbed 88 is in many respects the most valuable of the Portland series. 'The material with which the fine oolitic grains are cemented together is hard and crystalline. This stone, if of good quality, weathers excellently, and is markedly superior in this respect to Basebed, which resembles it in appearance, but is softer, more easily worked, and adapted rather for internal work. Bastard Roach or Curf may be distinguished from True Roach by the absence of the fossil known as the Portland Screw (Cerithium Portlandicum), which seldom if ever occurs in Curf. Its weathering qualities are poor.

Smeaton, ${ }^{89}$ the builder of the Eddystone Lighthouse, on his visit to the Portland quarries, remarked how-

When the merchantable blocks are cleared of the cap the quarrymen proceed to cross-cut the large flats which are laid bare with wedges. The beds being thus cut into distinct lumps the quarryman, with a tool called a 'kevel,' which is at one end a hammer and at the other an axe, whose edge is so short or narrow that it approaches towards the shape of a pick, by a repetition of sturdy blows soon reduces a piece of stone, by his eye, to the largest square figure which it will admit.

At the present day blocks of from IO to 12 tons can be obtained easily if required. The mode of carriage of stone for shipment down the hill was formerly by large wooden trollies with solid wheels of wood, drawn by a team of horses, three behind, two abreast, and one following-the three behind operating as a drag.

The whole island is full of the quarries, which are wrought from open faces. The stone is

${ }^{87}$ It has also been used for fortifications, as it was found by experiments to offer morc resistance to shellfire than even Cornish granite.

${ }^{85}$ The colour is more commonly white, but a brownish hue is perceptible in some of the best stone. Nores on Building Construction, iii, 'Portland Stone.'

${ }^{69}$ Eddystone Lighthouse (1791), 62 et seq. 


\section{INDUSTRIES}

worked by the 'Ope' joints, known as 'Southers,' 'Ope Gullies,' north to south, 'East and Westers,' which cross 'Southers' and 'Rangers,' south to east.

The marks placed on the stone when quarried to indicate its measurement and weight are shown in the illustration here given. A horizontal line is placed on the block of stone. Each of the perpendicular lines across it represents 10 cubic ft. The downward oblique line to the right represents 5 cubic ft., and each stroke following I cubic ft. up to Io cubic ft. Then instead of continuing these strokes (making in all Io cubic ft.) an additional perpendicular stroke is added to the horizontal line and so on. The oblique upward line to the left must be placed in such a position that if produced it would bisect the right angle, but must not be allowed to touch it. This line represents half a cubic foot. If the blocks of stone are very large, figures are sometimes substituted for the marks. The amount of stone represented in the diagram is

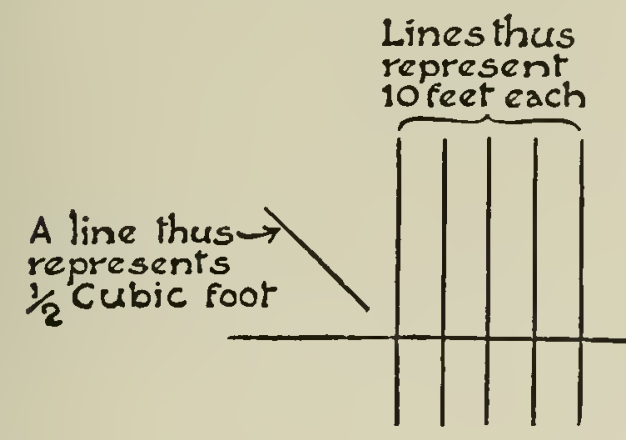

At the beginning of the last century upwards of 25,000 tons of Portland stone were annually exported, and the stone was then sold at $q d$. a foot at the quarries, and was rising in price, ${ }^{90}$ while a quarryman working in the island expected 2s. $6 d$. a day. In 1812800 men and boys, I 80 horses, and 50 ships were engaged in the stone trade of Portland, and from 20,000 to 30,000 tons were being exported every year at prices varying from 16 s. to 24 s. per ton of 16 cubic ft., the duty being $6 s$. a ton. ${ }^{91}$ In 1839 the annual output of the Portland quarries was estimated at 24,000 tons, that is about one acre of good stone, while it was believed that 2,000 acres of stone remained unworked. In 1855 the Portland railway carried 22,995 tons of Block and 3,547 tons of Roach, while a further amount was shipped directly from the island. In 1865 the amount carried by the Portland quarries railway reached 81,649 tons, but in 1875 this figure had been reduced to 56,841 tons, and in 1882 to 45,967 tons. Besides the quantity carried on

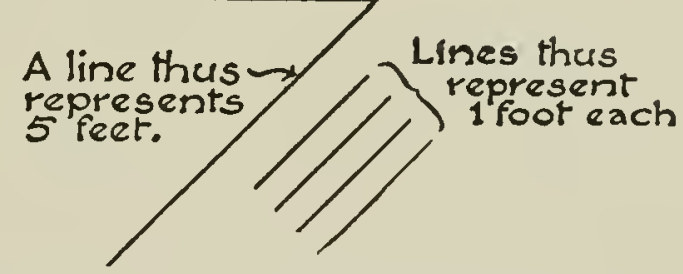

$59 \frac{1}{2}$ cubic $\mathrm{ft}$, and it may be remembered that the measurement of a ton of Portland stone is I 6 cubic $\mathrm{ft}^{89 \mathrm{a}}$

According to the opinion of the Commissioners of 1839 the stone in the north-eastern part of the island $i$; superior to that in the southwestern part. Although many of the quarries belong to the crown and are worked by convict labour, some of the best are still privately owned. It is impossible to give here a complete list of the Portland quarries, but the Waycroft, Wide Street, Maggot, Weston Independent, Inmosthay, Tout, and Bowers may be mentioned. ${ }^{89 b}$

${ }^{59 a}$ Ex informatione Mr. J. Merrick Head.

${ }^{59 \mathrm{~b}}$ It was presented 7 July, I 846 , that the queen's quarries were in part of the farm and demesne lands called Grove, Way Croft, Bowers, and Under Kingbarrow, and that other quarries were on Vern, on Higher Down, in Wide Street, at Sturt, in East Weir, and in Yelland Cliffs (Yeolands) and West Cliff. Since then large quarries have been opened in Combe Fields and Portland Bill. Ex informatione Mr. J. Merrick Head.

the railway, large shipments varying from 5,000 tons or less to 10,000 tons were removed directly from the island every year during the latter half of the last century. And to get the total output we must add to the figures mentioned the stone won by convict labour for government works, and the enormous quantity, especially of Roach, used in the making of the breakwater between 1847 and $1862 .{ }^{92}$ Since 1882 the amount of stone quarried in Portland has largely increased, and immense quantities have been used of late years in inclosing Portland Roads by other breakwaters, in order to form a secure harbour for naval defence.

The Portland beds have also been worked

${ }^{90}$ Hutchins, op. cit. ii, 8 I 9.

${ }^{11}$ Stevenson, View of Agric. of Dorset, 55.

${ }^{93}$ For most of these figures we are indebted to the valuable account of the Geology of W'eymouth and Portland by Mr. Robert Damon and The Rep. of the Royal Com. on the Selection of Stone for the New Houses of Parliament (1839). 


\section{A HISTORY OF DORSET}

from the Middle Ages, at least near Upwey and Preston, where the bed corresponding to the Portland Basebed is known as ' IVhite Freestone.' About the middle of the reign of Edward III we hear ${ }^{93}$ of 'Wynesbache" (WVindsbatch) stone being carried from IVestminster to the Tower, and Preston is also occasionally mentioned towards the end of the fourteenth century as the locality whence stone was exported to London. ${ }^{94}$

In Portisham parish Hutchins mentions a quarry of stone used for paving and tiling, and about a mile east of the 'Hardy Monument' a quarry was opened to provide stone for the bridges of a local railway. The best freestone bed is inferior to the Basebed of Portland island. Of the quarries of purely local repute in Southern Dorset no account can be given here, but references are occasionally found in records, as for example to the quarry on Allington Hill, whence IVilliam de Legh, in the thirteenth century, permitted the hospital of St. Mary Magdalen of Bridport to take stone for necessary uses. ${ }^{94 a}$

In respect to ornamental stone it may also be noted that septaria from the Oxford Clay of Radipole Backwater, when cut into slabs and polished have been used as tops for fancy tables. ${ }^{95}$

It is possible that oolitic iron ore found in the upper part of the Coral Rag at and near Abbotsbury may have been quarried in the early mediaeval period, when, owing to the difficulty of transporting Gloucester iron and the expense of Spanish iron, local bloomeries were not infrequent

\section{THE HEMP INDUSTRY}

One of the oldest industries in Dorset is that connected with the manufacture of hemp and flax; in importance it ranks next to quarrying. The centre of the trade, which has been chiefly concerned with the production of ropes, sail-cloth, and nets, has been, from time immemorial, the town and neighbourhood of Bridport, though there are mills also at Poole and Hamworthy. There is no direct reference to the industry in Domesday, although it has been pointed out by Mr. Eyton, in his study of the Dorset Domesday, that Bridport, the smallest borough in point of burgesses, and with fewest acres of annexed territory, was taxed at the rate of a full firma noctis, a fact which he considers to have been 'the coordinate of a great commercial position.' ${ }^{2}$ Having regard to the very primitive character of the

${ }^{93}$ Accts. Exch. K.R. bdle. 47 I, No. 6 ; cf. Pat. 24 Edw. III, pt. 1, m. 31 .

" One of the masons employed on the royal works in London as early as 1348 was one William of Prcston. See Accts. Exch. K.R. bdle. 471, No. 1.

${ }^{92}$ Hist. MSS. Com. Rep. vi, App. 486.

${ }^{93}$ Strahan, Geology of Isle of Purbeck, 236. in places where little or no iron is worked to-day. But no documentary evidence of the smelting of Dorset iron has been published. IVe hear, however, that the Constable of Corfe ${ }^{96}$ in the thirteenth century took from the abbess of Shaftesbury for her land in Blackenwell twenty-four horse-shoes as rent, while a rental of Kingston ${ }^{97}$ shows us Beorn the smith doing all the iron-work and shoeing exacted of him by the abbess for his half-virgate, but the metal employed may have been obtained from Hampshire.

To conclude, a mere mention can be made of a very few of the northern quarries of the county. At Sturminster and Marnhull the lower beds of the Coral Rag yield an excellent oolitic building stone which has been employed locally to a considerable extent. The limestone layers occurring in the Forest Marble are frequently quarried for flagstones, and at Long Burton, not far from Sherborne, the finer varieties have been polished for ornamental use as chimney-pieces, under the name of Yeovil Marble.

The latest government returns of the stone raised in Dorset during the year 1906 show that 8,147 tons were raised from mines, ${ }^{98}$ and 94,463 tons from quarries. Underground and above ground at the mines, which included a good many workings for clay, producing $35,03^{8}$ tons of this material, $26 \mathrm{I}$ persons were employed. Inside and outside the quarries, which besides the stone showed an output of 122,437 tons of clay and 700 tons of chalk, the number of workmen reached 1,057 .

rope-making industry, it is reasonable to suppose that even in 1086 the 'human spiders' had begun their long, monotonous tranp, and that the manufacture for which they were to be so widely renowned accounted in some measure for the high figure at which Bridport was rated. However this may be, the town's seal bears witness to the fame and profit which were brought to Bridport by ropemaking, for on it are engraved three 'cogs' or hooks employ'ed in this industry. There seems to be no record of the exact date when the use of this seal was granted to the borough, though there are repeated notices of it in the sixteenth and seventeenth centuries.

The documentary evidence concerning ropemaking begins in $12 \mathrm{I}$, and the interest of the

${ }^{96}$ Add. MS. 24775 , fol. 67

${ }^{97}$ Harl. MS. 61, fol. 62

${ }^{93}$ The greater portion of the stone derived from mines no doubt came from the Isle of Purbeck.

'The people of Bridport have been styled by Defoe the 'best artists in ropes, cables, and nets.' Tour through Great Brit. i, 327.

'Eyton, Key to Domesday, 73. 


\section{INDUSTRIES}

history lies in the antiquity of the manufacture, in its sometime national importance, and in the obscurity which involves the withdrawal of the manufacture of heavy cordage, as the reasons which are at present suggested are considered inadequate by experts.

There have been three great periods in the history of the Dorset industry. During the first of these the town was chiefly concerned in the making of rope and tackle for the royal navy, and this culminated in the statute of Henry VIII, ${ }^{3}$ which destroyed the rivalry of its near neighbours. During the second, the connexion between Bridport and the Newfoundland fishery reached its highest point in the prosperity induced by the French war (1792-1815). During the third period, nets of every description, from a billiardtable net to a trawl, have been sent all over the world.

In the Pipe Rolls for Somerset and Dorset, 13 John, the sheriff accounts for moneys which he has paid for 3,000 weighs of hempen thread, according to Bridport weight, for making ships' cables, and for the expenses of Robert Piscatoris whilst he stayed at Bridport to procure his nets." Two years later, in 1213 , King John sent a letter to the sheriffs of Dorset and Somerset, commanding them as they love themselves and their own bodies to buy for his use all the oats they could lay hands on. They were to seize the money from abbeys or wherever they could get it upon loan or in any other manner, and they were "to cause to be made at Bridport, night and day, as many ropes for ships both large and small as they could, and twisted yarns for cordage.' 6

In this year a French fleet, prepared by King Philip at the instigation of Pope Innocent, was lying in the port of Damme ready to invade England. An English fleet under William Longsword, earl of Salisbury, fell upon it and took or sunk well-nigh every vessel. Perhaps this was some satisfaction to the inhabitants of Bridport, as it is most unlikely that they ever received full payment for the rigging which they made.

In 5 Edward I Michael de Langestone and John de Hokestone, bailiffs of Plympton, addressed a complaint to Richard de Ramesham and Nicholas Prikeny, bailiffs of Bridport, enjoining them to admonish Robert Lautrepays to pay to John de Stodbury, their burgess, $3^{5}$. $8 d$., or else the hemp and cords which he agreed to deliver to him a fortnight before Michaelmas last; also to admonish a similar offender, David

3 'An Acte for the true Makynge of great cables, halsers, ropes, and all other takelinge for shippes in the Boroughe of Burporte in the Countye of Dorset.' Stat. 2 I Hen. VIIJ, cap. I 2.

'Rot. Pip. Dors. and Somers. 13 John (Rec. Com.).

${ }^{3}$ Wainwright, Bridport Doc.

${ }^{6}$ Ibid. Nos. 12, I3. de Wynterburne, ' who is vulgarly called Davye,' to satisfy the same John for I I st. of hemp and cords which he had covenanted to deliver at the preceding Christmas; the said Davye having had yarn to the value of $4 s, 2 d$, and he to receive the rest when he had given satisfaction as to the said hemp and cords. Robert Stok was to be 'admonished' with regard to I2 st. of cord which he should have delivered by St. John the Baptist's Day, having received 5 s. $6 d$. on account for yarn. John le Cherwode again had failed to deliver 4 st. of hemp by Mid-Lent, though he had been paid $\mathrm{I} 2 d$. The bailiffs of Plympton in conclusion informed those of Bridport that, pending satisfaction, they had confiscated the boat of Richard Blanchard. ${ }^{7}$

Interesting references abound in ancient records at an early date to the frequency and importance of the hemp trade of Bridport. 'Cultures,' or lands cultivated with hemp and flax, are mentioned in deeds, \&c. of the reign of Edward III, whilst 'searchers of Alax and hemp' held office in the reign of Richard II. ${ }^{8}$

The following entry appears in an accountbook of St. Michael's Chantry of Munden or Mondene in Bridport in 1453 under the head of 'Necessary Expenses': half a bushel of hempseed, $3 \frac{1}{2} d .^{9}$

In 45 Edward III Nicholas Tracy granted to John Feldaye and Matillidis his wife one rood of hempland lying in the 'culture' called Ponchesford in Bridport. ${ }^{10}$

Those municipal gifts to great personages which were such a feature of the mediaeval social system, and which were invariably representative of local industry, took traditional shape at Bridport, where the corporation made frequent offerings of webs, reins, horse-nets, and girths to those whose friendship they were desirous to secure. ${ }^{11}$ Cords and yarn figure repeatedly in assessments; whilst hemp is continually recorded as part of a man's possessions, and with it lucelli, hempen wicks for lamps and torches. ${ }^{12}$ Forfeitures of yarn and hemp appear in the Bailiffs' Accounts, I 8 \& 19 Richard II, in one instance to the amount of 9s. $6 d$., and of hemp-seed to the extent of $4 \frac{1}{2} d .{ }^{13}$

Hemp was grown in Bridport and then sent to Plympton to be made into rope-yarn. It was next sent back to Bridport to be made into rope, and when finished was sent again to Plympton, presumably to be used by the navy. ${ }^{14}$

Not only was yarn sent to Bridport to be spun into rope, but rope-makers were sent all over the kingdom to exercise their handicraft. In 16 Edward II the late sheriff petitioned ${ }^{15}$ for 79 s.

${ }^{7}$ Hist. MSS. Com. Rep. vi, App. 489 .

${ }^{8}$ Ibid. $476 . \quad{ }^{9}$ Ibid. 479.

${ }^{10}$ Ibid. 11 Ibid. 490.

${ }^{12}$ Ibid. $492 . \quad{ }^{13}$ Ibid.

${ }^{14}$ Ibid. 489 .

15 Ibid. 


\section{A HISTORY OF DORSET}

which he had paid for the expenses of six ropers proceeding from Bridport in the county of Dorset to Newcastle-on-Tyne.

In the documents belonging to the Bridport Corporation there is very little direct reference to the making of ropes until the town procured its Act of Parliament in the reign of Henry VIII, but there are several allusions to the fact that flax and hemp were ordinary crops, while in the lists of forfeitures yarn, hemp, and hemp-seed continually occur.

The manufacture of ropes seems to have gone on steadily increasing from the thirteenth to the first quarter of the fifteenth century, when for some time a great quantity of rope was imported from Genoa and Normandy. But Bridport recovered its pre-eminence, and orders for cables were again received. In March, 1486 , a command was sent from the dockyard at Portsmouth to John Browne of Bridport, to deliver 'a pair of takkes [tackle] and a pair of shets weighing $7+\mathrm{I} \mathrm{lb}$., and for a hauser for a tye weighing $500 \mathrm{lb}$.' the total cost being f6 8 s. $4 d^{16}$

The industry seems to have been badly organized, and the regulations oppressive, consequently manufacturers tended to leave Bridport and set up rival businesses, near enough to share in the supply of excellent hemp, but beyond the reach of the burgesses' rules. The inhabitants of Bridport noted this tendency with increasing uneasiness. Tradition says that they were finally stung into action by jealousy of the rope-walks at Burton Bradstock, a village within three miles of their town hall. They petitioned for an Act of Parliament limiting the industry to their own town. The preamble to the statute 21 Hen. VIII, cap. I2, explains their position, their fears and their precautions, as clearly as possible. 'The Bailiffs burgesses and other inhabitants' of Bridport represent to the king that

where they out of time that no man's mind is to the contrary, have used and exercised to make within the same the most part of all the great cables, halsers, ropes and all other tackling as well for your royal ships and navy as for the most part of all other ships within the realm, by reason whereof your said town was right well maintained and inhabited, your Highness and your subjects right well served, until now of late, many diverse and evil disposed persons, intending the destruction of your said town for their private lucre and advantage, have withdrawn themselves into the country in diverse places there taking farms and using husbandry out of the said torn and also daily resort to buy and provide hemp and thereof make cables, ropes, halsers, traces, halters and other tackle, being by the said persons slightly and deceivably made by reason whereof not only buyers of the same have been continually thereby deceived, but also the prices of the said cables, halsers, traces, halters and other tackle thereby greatly inhaunsed, and your said town or borough by means thereof is likely to be destroyed, ruined and desolated if speedy remedy be not by your Highness in that case provided.

Evidently the burgesses saw no advantage in competition, and they had probably persuaded themselves quite honestly that the only reason they objected to other rope-walks was because of the inferior quality of the goods produced and the disrepute into which such quality plunged the industry.

The Act they obtained was curiously shortsighted and petty. It prohibited any persons living within five miles of the town from selling hemp except at the Bridport market, and further enacted

that no ferson or persons other than such as dwell and be inhabitants within the said town, shall make, after the feast of Easter next coming, out of the said town any cables, halsers, ropes, traces, halters or any other tackle

except for their own private use. Various penalties were imposed on those who broke the statute. The hemp and rope forfeited were divided between the king and the informer. In the first place its action was only to endure until the next Parliament, but the statute was confirmed and continued by various Parliaments in the reigns of Henry VIII, Edward VI, Mary, Elizabeth, and James I.

The natural result of this statute with its fivemile limit was to drive manufacturers further away, and a great part of the industry is said to have migrated to Yorkshire, where it could develop more freely.

The lines on which the trade was organized are indicated by the draft of the lease of the common beam and weights preserved among the Bridport documents. ${ }^{17}$ This manuscript is not dated, but, judging from the writing, it is not later than Elizabeth's reign, and it is probably earlier.

The bailiffs, with the assent of the burgesses, let to farm to Morgan Moore for 21 years at a rent of $L_{t}$ per annum, the common beam and weights used for the only weighing of hemp within the borough of Bridport, with all the usual fees, profits, penalties, commoditics, and advantages, and do constitute him their officer and minister for viewing, surveying, and searching of hemp, and for the true making of cables, hawsers and ropes according to the statute in that case provided. The lessee is probibited from transferring the lease, from enhansing or raising any payment or duty, and from demanding a larger fee for the winding of hemp than heretofore has been payable. He is also required yearly, on Michaelmas Day, to deliver to the Bailiffs a book containing the names of all persons that have hemp growing within 5 miles of Bridport, the quantity grown by them and the value thereof, and to inform the Bailiffs what fore-stalling and regrating are carried on, and what conveyance from the said market contrary to the Statute. 


\section{INDUSTRIES}

The impression left by this lease is that the manufacturers were subject to, if they did not actually suffer, an amount of supervision which probably became more and more irksome, despite its laudable object of upholding the prestige of the hempen goods made in Bridport.

Among the numerous uses to which Bridport rope was applied was that of hanging men ; and the custom was so common that when a man was hanged he was said to be "stabbed with a Bridport dagger.' Leland seems to have heard this saying in the Midlands, and to have understood it literally, for he left a note in his Itinerary, 'at Bridport be mac'e good Daggers,' 18 when he should have written 'good hempen ropes for hanging rogues.' 'There is also a morality play called 'Hycke Scorner' (probably printed early in the reign of Henry VIII), in which one of the characters, 'Imagynacyon,' makes the grim remark that the inhabitants of Newgate have "ones a yere some taw halters of Burporte.' Probably in the sixteenth century the town's halters were as famous as its hawsers, and the demand for the first article was out of all proportion to the demand that exists to-day; but they could not have been such a profitable item as hawsers, especially in Elizabeth's reign, when the fabulous riches of America inflamed men's minds, and the prohibitions of the Spaniards stirred up their obstinacy.

Historians of Bridport have sought in vain for evidence that the town sent any ships to help to fight the great Armada, but they comfort themselves by maintaining that nearly if not quite all of the cordage and ropes for the English fleet of that time was supplied by Bridport; as the victory was due in great part to superior seamanship, and as such skill is of no avail without trustworthy rigging, the inference redounding to the honour of the town is obvious.

If the fact about the rigging of the English fleet be true, it would account for the myth with regard to the power and the extent of 'the statute,' as the Bridport burgesses called it, which sprang up in the forty odd years between the time it became law and the visit of Camden. It is true he collected his information in the years I 575-86, i.e. before the great sea victory, but he may have found the town all agog with excitement over some order for rigging, as there must have been continuous supplies from Bridport if it were responsible for so much rigging in I 588 . His version of the myth is all the more interesting, as it is quoted by almost every writer who mentions the hemp industry in the seventeenth and eighteenth centuries. He wrote :-

In our time in respect of the soil using the best hemp and the skill of the people for making ropes and cables for ships, it was provided by a special statute to remain in force for a certain set time, that ropes for the navy of England should be twisted no where else. ${ }^{19}$

${ }^{18}$ Leland, lin. (ed. Hearne, 1710 ), vii, 48.

${ }^{19}$ Camden, Brit. (ed. Holland, 1610 ), i, 54.
But most probably the statute never did confer this monopoly, and was never intended so to do. The sccond clause of 2 I Henry VIII, cap. I 2, reads as a general prohibition of rope-making except at Bridport, but it is qualified by the first clause, which forbids the sale of hemp grown within five miles of the town except at the Bridport market, and by the fifth clause, which gives permission to people ' $\mathrm{d}$ welling within the said distance,' i.e. five miles, to make whatever kind of rope they need for their own use and occupation. Later writers have taken Camden's description as a convenient high-water mark by which they can ascertain the degeneracy of their own days.

The close conmexion between Bridport and the royal navy was seriously affected in I6ro, when a contract was signed with William Greenwell and Thomas Still, 'merchants in London trading for the East country,' by which they undertook to erect a rope-walk at Woolwich, and thence supply the navy, delivering their goods as required at the government stores in Deptford. Later a royal rope-walk was established at Portsmouth, and in the second half of the seventeenth century hemp yarn was imported from Holland. ${ }^{20}$ The choice of Woolwich and Portsmouth for the new rope-walks points at once to Bridport's heaviest handicap in the industrial race. Some trade had been driven away by rules and regulations, but it is safe to say that much more was lost through its position. The ropes required for the navy were very bulky, and the cost of their carriage must have been a considerable item. It was considered cheaper and more convenient to set up rope-walks near the ships, and to import the hemp, than to bring the ready-made ropes, either by land or sea, from Bridport.

The Dorset hemp was the best in England. This is asserted by everyone, and is never disputed. Drayton mentions the

Bert whose bat'ning mellowed bank, From all the British soil for hemp most hugely rank, Doth bear away the best.

And in his poetical journey round the coast of Dorset he describes

$$
\begin{aligned}
& \text { Bert port, which hath gained } \\
& \text { That praise from every place, and worthilie } \\
& \text { obtained } \\
& \text { Our cordage from her store, and cables should be } \\
& \text { made } \\
& \text { Of any in that kind most fit for marine trade. }{ }^{21}
\end{aligned}
$$

But whether poet laureates or country clergymen, the panegyrists never discuss the relative quality of English and foreign hemp; and, judging from the climatic conditions which are required to bring the plant to perfection,

$$
\begin{aligned}
& { }^{20} \text { Pepys, Diary, i, } 330 . \\
& { }^{21} \text { Drayton, Polyolbion, Song } 2 .
\end{aligned}
$$




\section{A HISTORY OF DORSET}

English hemp was probably always somewhat inferior to that grown in Holland and Russia.

However, despite the growing import of foreign hemp, and the fact that government orders became less and less frequent, the industry at Bridport continued to flourish, and in the latter years of the sixteenth century a new source of trade was opened up, and another and local monopoly was established which lasted for about two hundred and fifty years. The Newfound. land fishing industry was founded by IVestcountrymen in Elizabeth's reign and grew steadily in importance. Ships were sent from all along the Dorset coast; but Bridport itself was more interested in the new market for its goods than in the fishing profits, though it took its share in them when occasion arose. It supplied most of the heavy cordage, nets, and tackle to the fishing fleet. As time went on the town seems to have specialized in nets and fishing tackle and to have gradually left off supplying heavy ropes except to Bridport-built ships. This change seems to have taken place before 1770 , as from that time twine, nets, and seines are always mentioned first in the lists given of the hempen products of Bridport. Rope-walks fell more and more into disuse, though ropes were made at Bridport Harbour until the shipyards were closed late in the nineteenth century. There are still some rope-walks in Bridport itself, but they no longer make the enormous hawsers, about 25 in. in circumference, which were once used for mooring vessels. This branch of the trade was killed by the introduction of chain cables, which after various experiments were served out to the navy in I 8IO-II, and were universally adopted after the disasters which befell the merchantmen bringing supplies to the English soldiers in the Crimean WVar. The men-of-war rode at safety in the roughest weather, relying on their chain cables; but the merchantmen, with hempen hawsers, continually broke away from their anchors.

There are various references to the hempen industry by writers in the first half of the eighteenth century. Though the monopoly described by Camden has come to an end, yet the 'town is still in vogue for that sort of manufacture in I 720:" 22 Twelve years later Coker found that the people of Bridport 'reap their best commodity from their skill in making up hemp, and their trade in linen thread, which is sold weekly in great abundance.' 23

But it is from descriptions of the Newfoundland fishery that the clearest idea of the extent and importance of the industry can be gatliered. The connexion between Bridport and Newfoundland, though it has passed through various

\footnotetext{
"Cox, Magna Brit. (1720), 3 I 3.

${ }^{23}$ Coker, Surv. of Dors. 23.
}

phases, has never been entirely broken, and cottagers in Dorset still rejoice in the extra orders for fishing tackle which follow a good season, while 'hands' are still thrown out of work by the shortage in orders which inevitably accompanies a bad season in Newfoundland.

When their harbour was in good repair the merchants of Bridport sent out cargoes of nets in their own ships, until sailing vessels were superseded by steamers; but until I74I there are continual notices that the harbour was ruined and choked up with sand. This harbour is formed by the little River Brit, which is not strong enough to make a safe channel through the sand-bars which occur at its mouth.

There are constant references to building or repairing Bridport Harbour, the piers which were rebuilt in $1741-2$ seem to have been fairly effective, and by the end of the century a considerable amount of trade was carried on. The harbour accommodated vessels of 150 tons. The ships which were sent to Newfoundland often took out apprentices, to be bound to masters at their journey's end, and after the fishing season was over some of the ships themselves were sold to inhabitants of Newfoundland, who employed them for fishing, or for trading with America and among the West Indies. Probably some were used for smuggling rum, which was a profitable source of income in the eighteenth century.

The merchants at home arranged what ships and what cargoes they would send out, and the town was filled with the busy hum of work. Besides their own ventures the merchants fitted out most of the other boats that sailed to Newfoundland at the end of the eighteenth and beginning of the nineteenth century. ${ }^{24}$ And even after the English fishing fleet was ruined, Bridport still supplied all the nets and fishing tackle required in Newfoundland. But a factory was set up on the island and protected by bounties and import duties; this gave the homemade a distinct advantage over the English goods. The factory in Newfoundland was further benefited by the introduction of the use of cotton for fishing purposes, as its nearness to the United States lessened the cost of the cotton which was used. Bridport still supplies a great deal of fishing gear to Newfoundland, and the bulk of goods exported is still very considerable, though the connexion is no longer so important as it once was. Bridport has ceased to put so many of its eggs in one basket, and Newfoundland trusts to some extent to its own skill.

About the middle of the eighteenth century a branch industry was developed, and Bridport began to emulate its Somerset rival, West Coker, in making sail-cloth. Pococke is the first to 


\section{INDUSTRIES}

notice this new departure, and he mentions a curious use to which inferior flax was put:-

They have (he writes) a great manufacture of twine, cables, sail-cloth and coarse cloths not exceeding is. a yard, the county producing abundance of hemp and flax; when the latter happens not to be good they thatch with it, and it lasts much longer than any other material. ${ }^{25}$

Coker sail-cloth was famed for its excellence, which was said to be due to some particular quality in its water. The Bridport manufacturers, not to be outdone, changed the style of their town and labelled their goods as coming from 'Bridport, near Coker,'"6 though the towns are about fifteen miles apart and have no connexion with each other. At one time the manufacture of sail-cloth seemed to be all-important, and to be much more profitable than net-making; but its importance has died down, while that of net-making has developed and increased. There are only a few sail-cloth mills still working.

There are three very pessimistic accounts of the condition of the hemp industry between 1760 and 1770 , but the two published in 1769 , England displayed by a Society of Gentlemen and the Description of England and IVales, published by Newbury and Carman, echo each other word for word, and with regard to Bridport are probably both based on the sixth edition of Defoe's Tour through Great Britain, which came out in $176 \mathrm{I}$, but in some cases described the state of affairs which existed in 1724. This would account for the fact that all three describe Bridport Harbour as choked with sand, which was true in 1724; and that they agree in saying 'there are scarce any remains' of the once flourishing hemp industry. Defoe was much interested in the mackerel fishing when he came along the coast road from Abbotsbury in I 724, and whether he was tired or whether he was pushed for time when he reached Bridport it is impossible to say, but his description of it is meagre, uncomplimentary, and, as far as concerns its industry, contradictory to every contemporary writer. Probably the only information supplied by the three pessimistic accounts is the fact that Bridport derived a certain amount of profit from its position on the great western road between London and Exeter. There may have been some temporary depression in the industry as it is peculiarly liable to such depression, but it is much more likely that all the descriptions are derived from a mistaken view of the condition of the trade in 1724 .

The rector of Wareham, Mr. Hutchins, collected his information at the same time as the 'Society of Gentlemen.' Pococke says that

${ }^{25}$ Pococke, Travels through Engl. (1750), ii, 87.

${ }^{26}$ From local information.
Hutchins had begun working at his county history in I $75^{\circ}$ when they met at Wareham, though it was not published until 1774. He alludes to 'the resort of travellers' as one of the 'supports' of the town, but says that 'the staple trade is large seines and nets used in the British fishery and other hemp manufacture ; ${ }^{27}$ this is corroborated by the references to Bridport goods which occur in histories of Newfoundland.

The next forty years mark the zenith of Bridport's connexion with Newfoundland as they mark the zenith of the fishing industry on which that connexion so largely depended. A description of the industry in 1802 is the first to mention the circle of dependent villages in which netting as a home industry kept pace with the increase of the demand for nets :-

The manufacture at Bridport is at present varied, but perhaps flourishes more than in any former time and furnishes employment not only for the inhabitants of the town, but for those likewise of the neighbouring villages to the extent of ten miles in circumference.

It consists of seines and nets of all sorts, lines, twines, and small cordage and sail-cloth. Upwards of 1,500 tons of hemp are worked up annually and nearly 10,000 hands are employed. ${ }^{93}$

Mr. Britton does not state how he arrived at this last number, and it seems curious in view of the fact that in 1821 , when a census was taken of the families engaged in handicrafts, there were only IO,8I I in the whole of Dorset. A rough calculation of the families so engaged in the division and borough of Bridport and the various hundreds in which the industry flourished gives a total of 2,164 families, but this would include all the masons, smiths, carpenters, and cobblers. If these families were deducted the total would probably fall below 2,000, and it is highly improbable that a family would have averaged five persons capable of making up hemp. Allowance should also be made for the fact that according to the report on the census of $182 \mathrm{I}$ the population of Dorset had increased from I I9, I00 in 1801 to 147,400 in 1821 . However, the whole description was considered so good that it did duty for sixty years, and is reproduced verbatim as an accurate contemporary account in 1864 .

There are various other references to the industry throughout the nineteenth century, but its history is really a history of the reorganization of the trade under the new conditions involved by the use of machinery, and of its development under the spur of competition; it can therefore best be gathered from a description of this reorganization.

The handicraft continued unchanged from early days until the introduction of machinery

${ }^{27}$ Hutchins, Hist. Dorset (1774), i, 233.

${ }^{29}$ Brayley and Britton, Beautics of Engl. and ITales (1801), iv, 519. 


\section{A HISTORY OF DORSET}

at the end of the eighteenth century. This view of the industry is not contradicted by the evidence afforded by the Bridport records. Probably an account, pieced together from oral tradition, of the way the work was done towards the end of the eighteenth century would give a fairly accurate picture of the work at any given time in the preceding centuries. The only changes necessary would be in the costumes of the workers.

Originally, the ropes were made of the hemp grown in the neighbourhood and sold in the Bridport market. ${ }^{29}$ A rough division of labour was usually practised, the work was divided between the 'combers' and 'spinners,' names which still survive; the spinners were assisted by 'turners,' boys or girls who turned the spinning-wheel; these have been replaced by steam. The raw hemp was given out to the 'combers' to be combed, and when thus prepared was spun into yarn by the 'spinners,' and finally was twisted into the required thickness of rope. This last operation seems to have taken place in the master spinuer's rope-walk. Both the spinning and the twisting were carried on in the long gardens belind the workers' houses; and the yarn, twine, and ropes were dried on hooks called 'waggles' which were fixed in front of the houses. These processes have given to the town of Bridport its distinctive features-the two main streets are curiously broad, and the gardens lying behind the houses which front these streets are very long in proportion to their breadth. The custom of drying the twine, \&c., on 'waggles' in the main street was maintained until within the last thirty years. The rope, yarn, and raw hemp were all subject to inspection by an official appointed by the town council.

The rope-walks and spinning-walks were all open, and old inhabitants say that they were very picturesque. Most of the rope-walks still in existence have been roofed over. Longfellow's description of rope-making is most vivid and accurate :-

In that building, long and low, With the windows all arow, Like the port-holes of a hulk, Human spiders spin and spin. Backward down their thread so thin Dropping each a hempen bulk.

At the end an open door, Squares of sunshine on the floor, Lights the long and dusty lane. And the whirring of the wheel Dull and drowsy makes me feel, All the spokes are in my brain.

${ }^{29}$ Stevenson gives the following list of hempgrowing parishes in the county in 1812 : Bridfort, Loders, Bradpole, Powerstock, Symondsbury, Chideock, Bothenhampton, West Milton, Walditch, Stoke Abbott, Beaminster, Netherbury, and Abbotsbury. Agric. of Dors. 287.
There was one rope-walk of which the tale is still told that for some reason it was so dark that the spinners had to walk to and fro with lighted candles on their shoulders to enable them to see what they were doing. The story suggests Rembrandtesque effects of light and shade.

Old workers living in Bridport report curious customs in connexion with the open rope-walks, which seem to point to some corporate organization of the details of the work. Trees grew in most of the walks, these were usually 'witheys,' i.e. willows, and they were all cut on Christmas Day. In autumn and winter, as the days drew in, the work was done by artificial light, but despite the natural differences of different walks with regard to the date when artificial light became necessary, the lanterns were all put up in the first week of October amid general rejoicings; and they were all taken down on the last Friday in February.

Besides the lantern festival in October the workers rejoiced in various other especial feast days. On Shrove Tuesday they received 'Pancake money,' which amounted in the case of 'Spinners' to $3 d$. a head, and in the case of 'Turners' to half as much. On Easter Tuesday all hands ceased to work at four o'clock, and some, at any rate, betook themselves either to cock-fighting or to jumping in sacks for Easter cakes. Whitsuntide they celebrated by eating treacle rolls. ${ }^{30}$

Among the Bridport documents is an indenture dated 20 June, 1683 , by which the overseers of the parish apprenticed ' $a$ poor fatherless and motherless child,' John Baillie, to John Keich, spinner, who undertook to teach and instruct his apprentice "in the craft and mistery and occupation of a spinner.' The apprenticeship was to last until the boy was twenty-four years old, and on his discharge the apprentice was to be given two suits of apparel. ${ }^{31}$

This system of binding out the 'parish' cliildren may, or may not, have worked well in the seventeenth and eighteenth centuries; it scarcely ever led to open revolt, as very few cases between apprentices and masters came before the quarter sessions for Dorset. There is a good deal of hearsay evidence as to what happened in the early nineteenth century. The children were bound by indentures to the age of twenty-one, and worked as their masters thought proper, sometimes working from 4 a.m. to 9 p.m. They did not earn wages until after they were twenty-one years of age, when they could work for whatever master they chose, and earned $\delta d$. a day. The employers of apprentices received money from the parish. ${ }^{32}$ This account is perhaps biased, since the people who remember

${ }^{30}$ Local information.

${ }^{31}$ Bridport Doc. K. 13

${ }^{32}$ Local information; my informant thought the facts only applied to women. 


\section{INDUSTRIES}

are the workers and not the masters, but the fact about the long hours is most probably true.

Children, other than apprentices, employed as 'turners' began to work at six, seven, or eight years of age, turning the spinning-wheel from $6 \mathrm{a} . \mathrm{m}$. in the summer and $7 \mathrm{a} . \mathrm{m}$. in the winter until 8 p.m. or 9 p.m. They received $1 s$. $9 d$. to 25 , per week. ${ }^{33}$

The making of twine, whether for immediate sale or for use in nets, followed the same lines as rope-making. 'The hemp was prepared by the 'combers' and then given over to the 'spinners.' Nets seem to have been made in the same way from time immemorial, and the description of a woman netting to-day would probably be equally true as a description of her ancestor working in King John's reign as far as the actual netting went, but the woman of to-day works far fewer hours and earns more in coin, if not in kind, than her ancestor did.

Present Organization.-This is dependent partly on the goods made and partly on the materials used. To recapitulate, the goods that are made in Bridport are :-

Rope: Of this a little is now made, but not of the heaviest kinds.

Twine, thread, and small cordage of every description: The speciality of the town is a particular kind, which is known as Bridport laid twine.

Nets of every variety made by machinery and by hand: Machine-made nets are chiefly used for drift nets for herring, sprat, mackerel, and pilchard. Among the various nets made by hand are :- -seines-these are very long, but not very wide; one side is loaded with lead, the other buoyed with corks; some of them are as much as 190 fathoms long; trawl nets-these are dragged along the bottom by fishing boats; minnow nets and trouting nets. Besides fishing nets, all sorts of nets for games, sports, and practical purposes are made, for cricket, tennis, billiard-table pockets, forage, hammocks, hatchways, laundries, \&c.

Sail-cloth : Of this a small quantity is still made.

The materials used are hemp, Manilla fibre, flax, and cotton.

It is obvious that Bridport manufacturers can no longer depend on home productions to supply the raw material they need, and as a matter of fact, hemp is no longer grown in Dorset, but is imported from Russia and Italy. The Russian hemp is sometimes shipped direct to Bridport, at other times it is sent to an East-coast port by sea and then is transported by rail. The connexion between Russia and Bridport is so close and so firmly established that at Riga there is a special brand of hemp which is called the "Bridport selection,' and this is said to be the best of all the Russian hemp. The Italian hemp is imported through London or Liverpool.

${ }^{33}$ Local information.
A small quantity of Manilla fibre is imported from the Philippines; this is the only fibre which is now spun by hand; it is used for the trawl twine for which Bridport is so justly famous.

Flax is imported from Russia, Belgium, Holland, and a little from Ireland, though Irish flax is generally kept for finer manufactures. A very small proportion is still produced locally. There was a flax market at Yeovil until within the last twenty years, and still from time to time a farmer grows a field or so of flax and sells his crop to Bridport manufacturers, though the knowledge of the proper way of ' retting, i.e. soaking and preparing, the flax is becoming more and more rare.

A feature of the last half century has been the introduction and increasing use of cotton in the industry. This is imported in the form of cotton yarn. It is made up into nets, lines and twines. The majority of machine-made nets are composed of cotton.

The introduction of machinery marked the beginning of the reorganization of labour which was involved by the gradual substitution of mills and all that they imply for the old system of home-work. This process was very slow. The first step was taken when water-power was applied to turn the spinning-wheels. $U_{p}$ to that time a boy or girl supplied the power required by the single wheel, and each man span alone, usually in his own premises. Water was in its turn superseded by steam ; sometimes water-power was not used at all, but the change was made directly from human power to steam-power; in other cases the water-power was retained until late in the nineteenth century. The introduction of water or steam necessarily implied that the spinning-wheels were brought together and driven by one force, usually at the head quarters of each manufacturer for which the individual men had worked. Despite the use of steam or water to turn the wheels the spinning was almost all done by hand; this continued to be the case until within the last fifty years, although spinningmachinery was introduced between 1789 and I $80 \mathrm{I}$.

The 'combers' followed the 'spiruners' to the mill. This move was probably dictated by a desire to economize in space and to institute some method of supervision, for a good deal of the combing is still done by hand. Some of the hemp is 'balled or rolled' before it is 'combed or heckled,' then it is roved and spun, and finally twisted into threads. Cotton yarn also undergoes this last process. All this is done in the mills. The men work by time and by piece. The wages are so influenced by the kind and quantity of the work done and by the individual skill and industry of the worker that it is almost impossible to give any figures about them which would not be called in question. The aristocrat among the workmen is the man who makes small cordage, as this branch of the industry 


\section{A HISTORY OF DORSET}

is highly specialized and successful results depend on the individual skill of the worker.

The use of machinery has brought into the mills most of the home workers on rope, twine, thread, and sail-cloth, but in netting it has only affected certain kinds of work. At present there is no satisfactory machine for making nets with square meshes or making nets which decrease and increase in size, consequently there is a large field open to the home worker.

Nets are fabrics in which the threads cross each other at right angles, leaving a comparatively wide open space between them. The threads are also knotted at the intersection. The open spaces in the net are called meshes."

The machinery by which nets are made is very ingenious, but it is the same at Bridport as at Musselburgh or in the United States. The art of net-making by hand is also universal, and has been practised from the earliest times by the most savage as well as the most civilized nations, but its organization as a by -industry seems peculiar to this neighbourhood.

Net-making is called 'braiding' in Dorset; it is chiefly carried on by women. There is a great deal of competition for the work, which can be done at home in the intervals of housework. The twine is given out from the mill; some mills have special net foremen. It is generally brought by the carriers to the various villages where the women live. Different arrangements are made by the different mills as to the payment of the carriage of the twine and the nets. At one time there existed a set of middlemen who carried the work to and fro, and many of these thoroughly understanding the business were able to render considerable services both to the manufacturers and the braiders. A few black sheep among the middlemen used their position to trade on the ignorance of the women; but this has now been effectually stopped, and when a woman receives twine she receives also full particulars of the work required, the length and breadth which the net is to be made, and the rate of pay which will be given her.

The work is paid either by the length of net inade, or by the weight or length of the twine worked up, and varies in accordance with the size of the mesl. The ordinary measure of payinent is so much per 'ran,' a local standard of length. The industry is said to circulate a large sum of money annually in the cottage loomes in the neighbourhood of Bridport.

Braiding is in itself pleasant, healthy, and clean, and is a very popular form of work. It is very picturesque in the summer in those villages where the women work out of doors, securing their nets to a hook in the wall and talking busily as they braid. When the work is carried on

$$
\text { s Chambers, Encyclopedia. }
$$

indoors in the general living-room of the family, the larger nets take up too much room to be very convenient, but they can be easily put aside and packed away into a very small space.

Though braiding is only a branch of the hemp industry, it is itself very much subdivided and localized. The lines of division follow the mesh which the women net, and are in no way dependent on the firms which may chance to employ the women. Thus small-meshed netting is made in one district and large-meshed in another. There is not much change in the kind of mesh which any particular village makes. This is handed down from mother to daughter, and any innovation is regarded with disfavour. This rule is so universal that if a firm which usually supplies large-meshed nets chances to want small-meshed nets, or vice-versa, it is obliged to send to a village where the nets it may require are made, even if it has had no previous connexion with that village and has employed a totally different set of women.

The successive generations of workers are trained from childhood. They are quite young when they begin to take their turn in helping their mothers to braid. The elder women complain that the present school regulations prevent the children from learning to work as well or as fast as the previous generation; but then, even before school regulations were invented, the same complaint was made, though some other reason was given to explain the inferiority of the younger generation.

The hemp industry is fixed in this neighbourhood by the hand-made nets, as the production of these is dependent on home-workers. Machinery and factories might be transplanted; but one can scarcely conceive anything more immovable than the inhabitants of small Dorset villages, the houses of which seem to have become one with the hillsides on which they are built. And this impression is true despite the apparently contradictory fact that many of the workers have changed their homes anmually, as their husbands, who are usually agricultural labourers, have seen fit to change their masters, for the custom of engaging men by the year is not far-reaching, and often it only involves a re-apportioning of houses and families on 6 April, when the change takes place. The establishment of a by-industry is often suggested as an adequate method of preventing the exodus from the country to the town, but people who are of the opinion that such a course of action is sure to succeed will do well to shut their eyes to the facts about the country districts of South and West Dorset, where braiding is carried on, as there the population is rapidly decreasing, and it would be hard to say that the by-industry had any counter effect.

According to the census of 1901,597 men, 


\section{INDUSTRIES}

733 women, and 33 children are employed in the hemp industry, ${ }^{35}$ but this is probably an understatement. All Bridport is directly or indirectly dependent on the mills, except for the few people attracted there to supply the needs of the agricultural district round the town, while the women in the surrounding villages habitually or occasionally supplement their husband's or father's wages. The handicraft is also practised by the widows of agricultural labourers who wish to keep themselves and their children out of the workhouse, but their earnings are usually augmented by outdoor relief. In the town the workers earn their living at the mills, but in the country the earnings are only supplementary to agricultural wages, and though the netting industry is of great value to the villages it has no pretension to being anything more than a byindustry.

The goods which are made in Bridport and its neighbourhood are sent all over the world. Perhaps the most important are nets and fishingtackle, but other twine and goods are also exported, and numbers of government contracts are executed in the town. The industry necessarily fluctuates with the fishing seasons, and the workers are usually busier from January to June than from July to October. Bridport receives every kind of order, from government contracts to orders for twine from the old-fashioned fishermen who make or mend their own fishing or rabbit nets.

Some of the present houses of business have almost continuous records from 1813 to the present day, and before 1813 occasional records which carry the practical history of the industry far back into the eighteenth century. Briefly the history of the nineteenth century seems to have been that when the manufacturers lost their monopoly in Newfoundland they opened up other markets all over the world, so that Bridport twine is used everywhere. When they were hard pushed by machine-made nets they developed the industry of hand-made nets, which already existed in the thirteenth century, and as competition has become more and more severe they have tended to develop each in an individual direction, so that while they all supply twine and nets of every description, each has a branch of the manufacture to which he devotes special attention. The whole industry is flourishing and seems to owe its success to its old-fashioned methods which can be maintained, but scarcely initiated, in the twentieth century.

\section{FISHERIES}

The fisherman's craft has had a numerous following among Dorset men from a very early date, ${ }^{1}$ although the records of the industry have been somewhat overshadowed by the neighbouring fisheries of Devon and Cornwall, one branch at least of the ancient Dorset fishing, that of the pilchard, formerly caught in considerable quantities off the coast, having actually passed almost exclusively to the last-named county. ${ }^{2}$

The returns ${ }^{3}$ belonging to the year 1340 , known as Inquisitiones Nonarum, show that the Dorset fishing industry was of considerable importance. In Portland the fisheries were worth fIO, 'in qua proficuum dicte ecclesie maxime consistit,' and the surveyor, forsaking for a moment his dry official fashion of setting down the returns, tells us further, "also the said parish

${ }^{35}$ Population Returns, Dors. I 901, p. 8.

1 We are told in Domesday Book that at Lyme, which belonged to the church of Salisbury, the fisheries tenants rendered $15 \mathrm{~s}$. to the monks in respect of their fish (ad pisces). An early grant of King Athelstan to the monks of Abbotsbury of certain 'waters' adjoining their monastery, seems to a Weymouth historian to suggest the ancient repute and abundance of the fishing there. Ellis, Hist. Weymouth, 5 .

'Ibid. $24^{2}$.

2 For this and the five following paragraphs $\mathrm{Mr}$. C. H. Vellacott is responsible.

Ing. Non. 50a. has been burnt and destroyed by the enemies of England and the sheep and other belongings (catalla) carried away:' Again, in the adjacent district of Wyke and Weymouth, ten fisheries were valued at $£ 3$, and at Preston also the sea fisheries were considerable. Further east, in the Isle of Purbeck, the tithes of the fishery at Corfe Castle reached I $2 d$., in Studland 2s., and the same amount at Worth with Swanage. At Wareham fisheries also flourished, ${ }^{5}$ but the tithes are classed with those of other products. In Holy Trinity parish, however, tithes of fish and salt together reached half a mark. It is a fair inference from these returns that the vigorous export trade in marble and stone from Ower naturally attracted the best enterprise and skill of the Isle of Purbeck. The fisheries at Portland and Wyke were then of more economic importance than the quarries-for the heyday of the Portland stone trade was yet to come. As the marblers' craft declined in the late fifteenth century, Corfe, which had been famous all over England for its marble, found new associations for its name, and the Customs Accounts often

B We know that Wareham herrings were of great repute. Many of the tenants on the manors of the abbey of Shaftesbury were bound to carry herrings from Wareham as the rental of that house clearly shows. Sec Introd. re 'Salt.' 


\section{A HISTORY OF DORSET}

mention Corfe herrings, ${ }^{6}$ and occasionally Corfe hake.

Now and again Cornish fishing boats came sailing into Poole, maybe bound on a deliberate trading venture, perhaps driven up Channel before a sou'-wester, or fleeing from the pirate or alien privateer. Early in February, ${ }^{7} 1467$, such a squadron of the Cornish fishing fleet arrived together, the George and Michael of Fowey, the Catberine and Margaret of Mousehole, and the Saint Fames (Sen Fame) of 'Ive.'

The George carried 20s. worth of hake, 'millwell,' and ling, and half a last of herrings valued at Ios., and Is. 6d. subsidy was paid to the king's officers. The Michael, of Fowey, may have been a slightly bigger boat, and brought 2 marks' worth of fish called 'hakis,' half a mark's worth of 'pullokes,' 3 burden of 'milwell,' and ling valued at the same amount, and of less importance, 2,000 herrings 'in rowme' worth $20 d$, and 2 cades of herrings priced at Iod. The master paid in subsidy 2s. $1 \frac{1}{2} d$. Rather less than a month before, on 16 January, Weymouth had also received a like visit from the Andrew and Peter of Fowey, and the Thomas and Michael of [St. Michael's] Mount.

Ships from the Netherlands, Normandy, and the Channel Islands brought in salted fish, congers, and broad fish, and took away much cloth on their return voyages. In February, ${ }^{8}$ I 467 , a Zeeland ship, beside hops, brought in 3 lasts of herrings worth $£ 9$, on which 9 s. subsidy and 2s. $3 d$. customs duty were paid, 6 barrels of salmon worth 5 marks, on which a quarter of a mark subsidy and $10 d$. in customs were due, and half a hundred of salt fish at $6 \mathrm{~s} .8 \mathrm{~d}$., on which the customs duty was only $\mathrm{I} d$. and the subsidy $4 d$.

Some of the local ships also did a large trade carrying cloth, salt, and other commodities abroad and bringing back fish. For instance, on 5 February, 1468 , the 'creyer' Mary, ${ }^{9}$ of Poole, with Robert Johnson as master, brought in as cargo $4 \frac{1}{2}$ lasts of herrings valued at $f_{1}, 8,8$ cades of red herring at a quarter mark the cade, 3 barrels of red herring at half a mark the barrel, and I 7 barrels of herring at 4 s. the barrel, besides 700 hake at 1 mark the hundred, a barrel of salmon value 6s. $8 d$., and 300 dry hake at 3 s. $4 d$. the hundred. The subsidy paid amounted to fi 9s. 3 d. Many years later, 23 October, 1503 , we hear ${ }^{10}$ of a local skipper, German IValsche, landing from his boat, the Peter, of Poole, ten congers ${ }^{11}$ worth 3 s. $4 d$., on which he paid $2 d$. subsidy, and also 4 dozen 'breyms, couners and why-

${ }^{6}$ See K.R. Cust. Accts. late fifteenth century, possim.

7 K.R. Cust. Accts. bdle. I 19, No. 8.

8 Ibid.

${ }^{9}$ Ibid. No. 9.

${ }^{10}$ Ibid. bdle. 120, No. 10.

"In a thirteenth-century grant from Mary, abbess of Shaftesbury, to her butler, congers are mentioned as well as plaice, rays (skate?), and salmon. tynges, worth 20d., on which only $1 d$. was demanded.

In the Isle of Purbeck the local fisheries were very active in the sixteenth century, and the exercise of the craft was regulated by ancient customs enforceable in the local courts. A very frequent presentment ${ }^{12}$ is that made by the tithings of Studland, Ower, and Swanage, on I 7 October, 1513, that certain persons are ' common fishers on the sea coast (costream maris) in their boats, and do not keep their tides (tidas) as of ancient time they are bound to do.' The offenders were amerced $4 d$. each. Other common offences ${ }^{13}$ detrimental both to the health and pockets of the lieges were visited with an amercement of $3 d$., when Richard and Thomas IVeryng and Robert Symond sold 'pisces fetosos ac male olentes,' and likewise took excessive gain.

In 1538 Leland described Lyme as ' having good ships and using fishing,' "Lulworth and Swanage being also mentioned as 'fisher towns.' 15 Lyme was 'frequented with fishermen' in Camden's time. ${ }^{16}$

The fisheries of Dorset, in addition to that of the pilchard, have been the mackerel fishery, which still flourishes along the coast from Abbotsbury to Bridport, the oyster fishery of Poole, and the Newfoundland fishery, to which Poole, IVeymouth, Lyme Regis, and sometimes Bridport, formerly sent their ships. This fishery, however, has long passed into the hands of Newfoundland fishermen. ${ }^{17}$

The fisheries were largely drawn upon for the conventional offerings to great personages, which invariably took the form of local products. Shrimpis (prawns) of Lyme were thus presented by the mayor in 1557, at a cost of $4 d$. per hundred, crabs 'given to Mr. Poulett,' costing from $2 d$. to $4 d$. each. ${ }^{18}$ In the same year Sanders Davy was paid 2s. 2d. to carry a broad (flat) fish to my Lord St. John, the manner of taking this fish, it may be mentioned in passing, being with baited hooks set along a ground-line called a trot. ${ }^{19}$ From a bill for shellfish bought for an entertainment offered to the judges on circuit at Lyme, in 1674-5, some idea may be gleaned of market prices at that date. Thirty lobsters cost $f^{\prime}$ I Ios., six crabs, 6s., I 00 scallops 55., 300 oysters 4 s. $^{20}$ According to Bolin,

13 P.R.O. Ct. R. bdle. 169, m. 13 (5 Hen. VIII).

${ }^{13}$ Ibid. ( 38 Hen. VIII).

16 Leland, Itin. iii, 48.

${ }^{16}$ Camden, Brit. i, 51.

17 The chief traffic of Poole in 1826 was said to be the Newfoundland fishery. Paterson, Roads, 380.

${ }^{18}$ Roberts, Soc. Hist. Southern Countics, 10.

${ }^{19}$ Ibid. 10.

20 Ibid. 25. Brownsea Island was noted for crabs and shrimps in the seventeenth century, Swanage enjoying the like reputation for lobsters and crabs. Fiennes, Through Engl. on a Side-soddle, 6, 7. 


\section{INDUSTRIES}

Dorset dorsers (peds or panniers) were either first found out or generally used in this county, the fish-jobbers using such contrivances, he adds, to bring up their fish above 100 miles from Lyme to London. ${ }^{21}$

The manufacture of lobster-pots, baskets with a small hole on top, was extensively carried on along the coast in $1812 .{ }^{22}$

Poole has always had a thriving fishery, the plaice of that port being esteemed 'peculiarly excellent.' ${ }^{23}$ In I 550 the Admiralty Court of Poole was ordered to inquire if any fished on Sundays, or suffered any engines to be in the seas that day to take fish withal. ${ }^{24}$ All fishermen within the bounds of the port might sell fish taken there, and not elsewhere, at competent prices. ${ }^{25}$ 'Beyond the memory of man,' it was a custom in the Poole fish-market that all fish was to be exposed for one hour therein before being carried to be sold at any other place. ${ }^{26}$ The burgesses of the town received for one last of herrings $4 d$., and the same for every hundred of salted fish. ${ }^{27}$ The fishermen of Wareham claim the right of fishing in Poole Harbour on payment of a nominal fine to the lord of Corfe Castle. ${ }^{28}$

Although the herring fishery on the Dorset coast has never attained to the dimensions of the similar industry on the east coast, there have been times of abundance in its history, as, for example, in 1793, when Mr. Davies of Swyre bought a shoal of herrings for manuring his land at Is. per load. ${ }^{29}$ Several curing-houses were started about this date by Mr. William Morton Pitt at Swanage for smoking and curing these fish, numbers being dispatched to the London and Portsmouth markets. ${ }^{30}$

The most thriving of eighteenth-century Dorset fisheries was the mackerel fishery of Abbotsbury, which gave employment to the greater part of the inhabitants at that date. ${ }^{30 \mathrm{a}}$ By ancient custom $I d$. every day was paid for every kind of fish taken, and $6 d$. for three turbots, mackerel, however, being exempt from impost. The tax was afterwards compounded for at 40 s. per annum. ${ }^{30 \mathrm{~b}}$ From I 746 to 1758 very few mackerel were taken, the scarcity being attributed to the scouring of Bridport Harbour. ${ }^{30 c}$ The season lasted from about the middle of March to Midsummer, and the catch was with nets and seines. Stevenson writes in 1812 of

${ }^{21}$ Coll. Proverbs, 202.

${ }^{22}$ Stevenson, Agric. of Dors. 449.

${ }^{23}$ Pigot, Dir. 1823 , p. 270 . In the eighteenth century Poole sent fish to Devizes, whence it was carried to Oxford. Aflalo, Sea-Fishing 1nd. 286.

${ }^{24}$ Roberts, Soc. Hist. Southern Counties, 239.

${ }^{25}$ Hutchins, Hist. Poole, 3 I.

${ }^{27}$ Ibid. 30.

${ }^{29}$ Claridge, Agric. of Dors. 18.

${ }^{30}$ Hutchins, Hist. Dors. i, 259.

${ }^{30 a}$ Engl Displayed (1769), 63 .

${ }^{30 b}$ Hutchins, Hist. Dors. i, 538.

${ }_{30 c}$ Ibid.
30,000 to 40,000 being caught at a draught near Abbotsbury, and sold at $\mathbf{I} d$. per $100 .^{30 \mathrm{~d}}$

In the summer of I 724, Defoe, travelling along the coast road from Abbotsbury to Bridport, 'all the way on the sea shore,' saw 'ships fishing for mackerel, which,' he explains-

they take in the easiest way imaginable ! for they fix one end of the net to a pole set deep into the sand, then the net being in a boat, they row right out into the water some length, then turn and row parallel with the shore veering out the net all the while until they have let go all the net, except the line at the end and then the boat rows on shore, when the men haling the net to the shore at both ends bring to shore such fish, as they surrounded in the little way they rowed, this at that time proved to be an incredible number in so much that the men could hardly draw them on shore. . . In short such was the plenty of fish that year, that the mackerel the finest and largest I ever saw, were sold at the sca side a hundred for a penny. ${ }^{31}$

A traveller of to-day would see practically the same sight if he chose a prosperous summer for his journcy. The pole spoken of by Defoe is nowadays dispensed with, as there are generally enough loafers on the shore to hold one end of the rope attached to the seine while the net itself is being towed out to surround the fish; an anchor is sometimes used, and when this is the case it is deeply rooted in the sand. The seine is paid out as the boat is rowed through the school of mackerel. Then both ends are hauled in ; the net is preceded by a glimmer of whitebait as these leap madly on land to avoid the voracious mackerel, who take no heed of the encircling net in their eager pursuit of food. The whitebait are left on the sand, and the mackerel are sold at a very low rate, though not at a 'hundred for a penny.'

The mackerel approach the coasts in the spring; some fishermen say that they are bent on finding suitable ground for spawning; others that they are hunting for food, which is more abundant near the land. This second theory is more usually accepted as correct.

In and just before the season men are stationed with telescopes on vantage ground all along the coast-for instance by the remnants of the old village cross at Swyre, on the cliff-head at Burton Bradstock. Their duty is to report the first approach of the mackerel. This is shown by a darker patch on the sea, by curious ripples, and by the company of greedy birds. Usually the crew are waiting in a neighbouring public-house, or in a convenient cottage with a hogshead of cider. Report states that three hogsheads of cider have been consumed by men waiting for long-delaying fish. The payment for this makes a great hole in the money earned when the fish do come; while as Dorset cider is a quarrelsome

\footnotetext{
30d Stevenson, Agric. of Dors. 72.

${ }^{31}$ Defoe, Tour through Great Brit. (1724), iii, 327
} 


\section{A HISTORY OF DORSET}

drink, its consumption leads to rough language and rougher behaviour. Sometimes when two crews crossed their seines in pursuit of the same school of fish they 'larrupped' one another with their tongues while their friends on the beach assisted in the quarrel with pebbles; ${ }^{33}$ but such behaviour and drinking is exceptional, and not typical of the industry.

When the fish are seen the look-out signals or shouts, and at once the men run down pellmell to the beach, their heavy boots thundering and their coats flapping as they run. The nets are snatched up from the beach where they were drying; the boats are hastily launched, and the school is pursued-often fruitlessly, often with moderate success, and occasionally with results similar to those described by Defoe.

A man may wait night after night for a week or more and earn nothing, and then if he happens to stay at home one night it may chance that his partners earn $f_{1}$ or $f_{2}$ each. The money earned is divided into shares, of which the boat has two, the seine two, and each of the crew one. The loafers who help to pull in the net are usually paid with a few of the inferior fish.

All the mackerel-fishing by day and by night is carried on in the same way. The fish are inclosed in a seine the ends of which are attached to long ropes, and these are gradually drawn in until the seine is brought to the shore. The end of the rope left on shore is called the "long arm,' and the end taken in the boat the 'ship arm,' and sometimes the 'short arm.' The best idea of the picture made by the fishermen and their nets can be obtained by imagining Raphael's cartoon of 'The Miraculous Draught of Fishes" with typical English fishermen clothed in seaboots and jerseys instead of Italians in conventional draperies.

At Abbotsbury a farmer, whose son now farms in his stead, had an especially long seine and a larger boat (pulling six oars instead of the usual four); with these he was able to make larger sweeps and to inclose larger hauls. As he had horses at his disposal he was in the habit of hitching one to the 'long arm,' so that the horse with one man could pull the net in, saving both labour and expense. His name and the name of his boat still live on the beach and among old fishermen, but his practice has not been followed.

In Defoe's time a 'guard or watch was placed on the shore in several places,' and he found these to be officers appointed by the justices and magistrates of the towns about 'to prevent the country farmers buying the mackerel to dung their land with, which was thought to be dangerous as to infection. ${ }^{33}$ Similar abundance and

39 From local information.

${ }^{39}$ Engl. Displayed (1 769), 75 . similar precautions are recorded in other histories and descriptions of Dorset.

At the present time the fish is sent to London from Bridport by the Great Western Railway. I 906 was an especially good year, and a great deal of money was divided among the crews along the coast.

Though the supply of mackerel is precarious, the fishermen derive a fairly steady income by catching herring, cod, whiting, rock salmon, grey mullet, red mullet, and occasional lobsters. These are usually hawked through the inland villages by fishwomen, each of whom has her own particular beat.

Many of the men do odd jobs on shore, and nearly all possess or rent a potato ground, so that they are able in some measure to supplement their earnings from the fishery, while their wives, daughters, and younger sols make nets for the manufacturers at Bridport.

The pilchard fishery at Lyme Regis was new in 1724.34 It seems to have been fairly successful. In I 769 merchants of Lyme were reported to have "engaged with good success in the pilchard fishery ; ${ }^{35}$ they are represented as taking up the industry because the fishing in Newfoundland had become less profitable. Yet, as Defoe pointed out, the interest in the pilchard fishing has never been so considerable as it is farther west, ' the pilchards seldom coming up so high eastward as Portland and not very often so high as Lyme.' This sound geographical reason still holds good, though the movements of the pilchards vary from year to year, and a certain number of Dorset men are engaged in this fishery.

The commercial relations between Dorset and Newfoundland, growing out of the early attraction of IVest-countrymen to the North American fishery, have been long and close, forming a chapter in the economic history of the county which no student of the subject can afford to ignore. According to the evidence of merchants, many of whom were Poole men, before a Parliamentary Committee in 1793 , the Newfoundland fishery was regarded as part of the fishing industry of Dorset ${ }^{36}$ whilst the intimacy of the commercial relations alluded to above is clearly shown by an order of the Star Chamber in 1633 , whereby the mayor of Weymouth, in conjunction with his brethren of Southampton and other neighbouring seaports, was to 'take cognisance' of all offences and

34 Defoe, Tour through Great Brit. (I 724$),$ i, 330.

${ }^{35}$ Ibid. 242.

${ }^{36}$ According to a letter quoted in the above evidence, written by Mr. Antonie Parkhurst, and published in Hakluyt's Voyages, the Newfoundland fishery was firmly established in 1574, a fleet of thirty ships sailing in that year to the colony, the number increasing rapidly, until ffty were dispatched in 1578 ; Parl. Rep. Nercfoundland Trade, 1793, p. 2. 


\section{INDUSTRIES}

crimes committed on the soil of Newfoundland, the vice-admiral in Dorset being similarly empowered to proceed against offenders by sea. ${ }^{37}$ In 1649 Poole had eight ships engaged in the trade with Newfoundland. ${ }^{38}$ No small profit was reaped by those who took part in these expeditions in the reign of James $I$, the merchants of Lyme Regis, 'being engaged in trade to Newfoundland, acquired large fortunes and raised the town considerably.' 'This town, in common with Poole and Weymouth, suffered by the loss of this trade, temporarily caused by the war of the Spanish Succession. Weymouth seems to have recovered more quickly than the other two towns, for even before the Peace of Utrecht 'its trade began again to flourish, and the merchants fitted out 20 ships for Newfoundland in 1711.39

At Poole, in 1724, Defoe found that 'a good number of ships were fitted out every year to the Newfoundland fishing in which the Poole men were said to have been particularly successful for many years past.' 10 In 1732 Weymouth and Melcombe Regis had as many as ' 80 sail of ships and barks engaged in the Newfoundland industry.' 41 This number was probably exceptional, and refers to a record year rather than to the average number of vessels sent out.

The editors of the sixth edition of Defoe's Tour through Great Britain rival Defoe himselt in the clearness with which they describe this industry, and their account is corroborated by every writer in the eighteenth century.

The principal branch of the foreign commerce of Poole's inhabitants is the Newfoundland fishery, to which they send every spring in time of peace upwards of seventy sail of vessels from the burden of IoO to I 50 tons, laden with provisions, nets, cordage, sailcloth, and all sorts of wearing apparel, with variety of other commodities for the consumption of the inhabitants and their servants. The smaller vessels fish on the banks, and make two or three trips every season. Their returns are in cod, oil, skins, and furs, and in autumn they export their fish to Spain, Italy, and Portugal. This is a trade not more profitable to those concerned than beneficial in general to the kingdom, as it subsists a prodigious number of hands, occasions a great export of our commodities and manufactures, and breeds excellent seamen ... In time of war they have hitherto suffered extremely, and as this is so exceedingly detrimental to a trade which is so apparently serviceable to the Royal Navy it deserves notice. ${ }^{2}$

This description is as true of Dorset as a whole as it is of Poole in particular, though the industry seems to have had an especial attrac-

\footnotetext{
${ }^{37}$ Reeves, Hist. Newfoundland, 9.

${ }^{38}$ Hutchins, Hist. Poole, 39.

${ }^{39}$ Cox, Magna Brit. 549.

${ }^{40}$ Defoe, Tour through Great Brit. (1 724$), 319$.

"Coker, Surv. of Dors. (1732), 35.

42 Defoe, Tour through Great Brit. (1761), 3 19.
}

tion for the adventurous and reckless sailors of that town. Throughout the eighteenth century the trade with Newfoundland was the most important commercial venture in the county, and Dorset seems to have been the largest adventurer in this trade.

In the 'Report of the Committee appointed to enquire into the state of Trade in Newfoundland in $1793^{\circ}$ an analysis is given of the number of ships sent to Newfoundland between 1769 and 1792 by the various towns engaged in the industry. In this analysis Poole and Dartmouth are shown to have sent more ships than any of the other towns. In the years I774, I 787 , and 1788 Poole sent fewer ships than Dartmouth, though the total tonnage sent by each town was almost the same. In the remaining years Poole sent more ships or ships of greater tonnage than Dartmouth, e.g. in I 791 Dartmouth sent eighty-three ships whose total tonnage was 7,254 tons, while Poole sent seventy-eight ships whose total tonnage was 9,528 tons. ${ }^{43}$

These ships were usually built in the towns in which their owners lived, and shipbuilding was a considerable business in Poole ${ }^{44}$ and Lyme Regis, ${ }^{45}$ Poole being famed for "Leith smacks" and revenue cutters, while Bridport received most of the orders for cordage, sails, and nets for Newfoundland-bound ships at the end of the eighteenth and beginning of the nineteenth centuries. ${ }^{46}$

The history of the industry is bound up with the history of Newfoundland, and this consist, as Chief Justice Reeves pointed out, ${ }^{47}$ in the history of the quarrel between the adventurers and planters. There are numerous descriptions of the origin and growth of these two classes, and one of the best seems to be that given by Mr. George Garland to the Select Committee on Newfoundland Trade on 19 June, I $817:-$

When the trade was first established the merchants and their immediate servants were the only classes of persons engaged in it. The merchant residing in England made his outfit in the spring of the year, both as it represented the number of servants he engaged and the quantity of provisions and tackle he provided on a scale proportioned to the extent to which he intended to carry on the fishery. The fish was wholly caught, cured, and exported by his own servants, and a very small establishment (if any) was left in the island through the winter. In process of time, however, a third class of persons sprang up consisting of servants and sailors who had chosen to

'3 Rep. Select Com. Nerufoundland Trade (1793), 4 .

" Pococke, Travels, i, 87. See Introduction.

4s Hondbook of Travel round the Southern Caast of Engl.

(1849), 301 .

${ }^{16}$ Harvey, Hist. of Newfoundlond, 37.

17 Reeves, Hist. of the Govt. of the Island of Newfoundland (1793), 21 . 


\section{A HISTORY OF DORSET}

remain in the island after the period of their servitude had elapsed, and of their descendants born in Newfoundland. These persons, denominated planters, procured supplies of all the necessaries of life and implements for the fishery from the merchants, engaging to pay for the same in fish and oil."

The quarrel between these two classes arose from their different views as to the government of Newfoundland, and was complicated by trade disputes. The merchants or adventurers wished to treat Newfoundland as a 'great ship moored to England' ; and pointed out how an industry organized on the original lines was an excellent preparatory school for the Royal Navy, how two or more 'green men' (i.e. men who had not previously sailed to Newfoundland) were trained on every ship, and how the industry fulfilled every condition required by the patriotism and political economy of the eighteenth century, besides incidentally being very profitable to themselves, Every requisite of life and labour was sent from England, and was paid for by fish, \&c., or by foreign gold from the Mediterranean.

The planters clamoured for peace, justice, and security in the long winter months when the riffraff on the island did what was right in its own eyes, and the respectable people were powerless, since the fishing admirals were in England and the governors, usually naval officers, were in winter quarters. The adventurers thought good government too expensive a luxury, and were bitterly jealous of any rights acquired by the planters, and of any steps which tended to make colonization of the island normal. Their commercial instinct was right; the planters were necessarily their most dangerous rivals.

Though long delayed by the strenuous opposition of the men of Dorset and Devonshire, a Supreme Court of Justice was established in Newfoundland in 1793 , and the first resident governor was appointed in $18 \times 6 . .^{49}$

After England became mistress of the sea the fish-markets of the world were in her hands. But with the end of the French war the Dorset industry flagged. The merchants who petitioned for relief in 1817 explained that most of their fish had been sold in Spain and on the coasts of the Mediterranean, at the close of the war the price of fish had fallen, and both France and the United States paid considerable bounties on the fish caught, which still further lowered the price. ${ }^{50}$ Despite the merchants' appeal to the precedent of the help given by Mr. Pitt, the government decided to ignore their petition, and England was to a large extent driven from the industry. But the stimulus given by the bounties of France and the United States was not sufficient to keep the fishing out

\footnotetext{
${ }^{19}$ Rep. Select Com. Nerwfoundland Trade (1817), 4.

${ }^{49}$ Harvey, Hist. of Newfoundland, 49.

${ }^{50}$ Rep. Select Com. Newfoundland Trade (1817), 39-
}

of the hands of the planters, whose advantageous position placed them beyond the reach of artificial competition, so that what England lost, her colony gained. The connexion with Dorset is still maintained, and the fish, no longer caught by Dorset men, are still in many cases captured in Dorset nets.

There are two oyster fisheries on the Dorset coast; one known as the Fleet Oyster Fishery at Wyke Regis, the operations of the company being almost exclusively concerned with the fattening of oysters in the waters of the Fleet, quantities of French oysters being laid down for this purpose. ${ }^{51}$

The fame of Poole oysters, now chiefly culled by the Poole Oyster Fishery Company, Hamside, Poole, ${ }^{62}$ was already established by the seventeenth century, when an order was issued by the corporation that the shells, formerly thrown into the sea after the oysters were opened for pickling, should be piled up on the strand. ${ }^{63}$ So extensive was the bank thus formed that at the present time many warehouses on the harbour are built upon a foundation of oyster shells. ${ }^{64}$ In 1720 Poole oysters were ' of great esteem in all places where they could be had,' 55 whilst Defoe's testimony is to the effect that-

this place is famous for the best and biggest oysters in all this part of England which the people of Poole pretend to be famous for pickling, and they are barrelled up here and sent not only to London, but to the West Indies and to Spain and Italy and to other parts. ${ }^{56}$

Poole oysters, moreover, were reputed to contain the largest pearls found in English waters. ${ }^{57}$ In 1802 forty sloops and boats were engaged in the oyster industry, ${ }^{68}$ bringing in an income of from $f 6,000$ to $f, 7,000$ per annum. ${ }^{59}$ According to a long-standing regulation in this fishery the last day's catch was thrown into the channels in the harbour, where the oysters were left to fatten during the winter. ${ }^{60}$ Owing to the want of proper regulation of the fishery the beds became gradually exhausted, ${ }^{61}$ although in 1849 Poole oysters were still maintaining their good name. ${ }^{62}$ It was not until 1885 that authority was given to the corporation to oversee the fishery, 200 acres being granted in 1887 to a local company in Wareham Channel, ${ }^{63}$ the beds once more becoming productive. ${ }^{64}$ The cor-

${ }^{31}$ Local Govt. Bd. Rep. 1896, p. 62.

${ }^{53} \mathrm{Kelly}$, Dir. 1903 , p. 320.

${ }^{53}$ Hutchins, Hist. Poole, 41.

${ }^{54}$ Kelly, Dir. 1903, p. 140.

${ }^{55}$ Cox, Magna Brit. 557.

${ }^{56}$ Defoe, Tour through Great Brit. i, 318.

${ }^{37}$ Ibid. $\quad{ }^{68}$ Hutchins, Hist. Poole, $8 \mathrm{I}$.

${ }^{59}$ Brayley and Britton, Beauties of Engl. and $W$ ales, iv, 413 .

${ }^{60}$ Ibid. ${ }^{61}$ Kelly, Dir. 1903, p. 140.

${ }^{63}$ Handbook Travel Southorn Countics, 296.

${ }^{63}$ Kelly, Dir. 1903, p. 140. 


\section{INDUSTRIES}

poration now possess jurisdiction over the greater part of Poole Harbour, save in certain portions of the Wareham Channel, held by the Poole Oyster Fishery Company, and the fishery known as South Deep, which is apparently common ground. The corporation employ a water-bailiff, whose duty it is to control the fishing, especially with regard to infringements of the rule forbidding the taking of oysters under the prescribed dimensions. Licences to dredge are issued yearly at fixed sums. In 1893-4 only seven such licences were applied for, fees and tolls in that year ainounting to $£ 5$ I 5 s., the oysters taken amounting to 8,346 . In $1894-5$ the numbers were 33,702 . There are no storage pits in connexion with the company's fishery, the oysters being promptly disposed of in the best and most accessible markets. The best grounds for dredging are considered to be near Saltern's Pier, Brownsea Quay, and Stone Island. ${ }^{65}$ The operations of the company are largely those of laying down oysters in Wareham Channel brought from East River, Caen Bay, and the Solent, a 'Several' Oyster and Mussel Order having been obtained from the Board of Trade. There are a few private storage pits at Poole for the growing, fattening, and storage of oysters laid down in spring for the following autumn. ${ }^{66}$

Oysters are hand-dredged at Wyke from October to March. ${ }^{67}$

Other shell fisheries ${ }^{67 a}$ on the coast are for cockles, which are picked all the year round at Poole, where periwinkles are also gathered from September to April. Swanage has pots for crabs and lobsters from April to October, and for prawns from January to April. The latest reports from this station, however, are to the effect that 'crabs were scarcer, and are apparently becoming more so each year.' ${ }^{8}$ Crabs, lobsters, and prawns are caught at Chapman's Pool by pots and set nets; crabs and lobsters at Warbarrow in pots all the year; crabs and lobsters at Lulworth all the year, prawns from September to the end of the year; crabs, lobsters, and prawns at Weymouth are taken by pots from April to September, escallops being dredged from December to March. ${ }^{69}$ At Portland the crab and lobster fishing season is from February to October; at Portland Bill, all the year. Fishing at this station, it may be mentioned in passing, is said to be on the decline, owing, it is thought, to the presence of octopi, and the carrying on of

${ }^{65}$ Local Govt. Bd. Rep. 1896, p. 63.

${ }^{66}$ Ibid. $\quad{ }^{67}$ Ibid.

${ }^{67 a}$ For information contained in this paragraph and the following table the author is indebted to $\mathrm{Mr}$. Martyr, of the Bd. of Fisheries and Agric.

${ }^{6}$ Ann. Rep. Sea Fisheries, 1905, p. 60.

${ }^{69}$ Ibid. 59 . gun practice in the vicinity. ${ }^{70}$ Burton has a fishery for crabs and lobsters in pots from April to August, Lyme Regis from May to July, and from April to September, whilst prawns are caught all the year round. ${ }^{71}$

The quantity and value of fish landed at each fishing station in Dorset in 1905 is as follows :- i2

\begin{tabular}{|c|c|c|c|c|c|}
\hline \multirow[b]{3}{*}{ Statrons } & \multirow{2}{*}{\multicolumn{2}{|c|}{$\begin{array}{l}\text { QunNtity } \\
\text { Wet Fish }\end{array}$}} & \multicolumn{3}{|c|}{ Valuz } \\
\hline & & & \multicolumn{2}{|c|}{ Wet Fish } & $\frac{1}{0}$ \\
\hline & 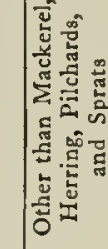 & 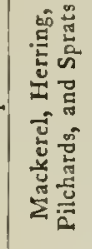 & 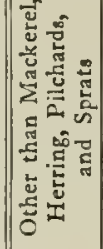 & 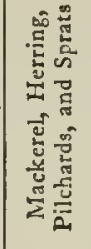 & 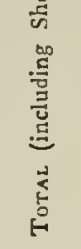 \\
\hline South Coast & Cwt. & Cwt. & $£$ & $k_{0}$ & $£$ \\
\hline Poole . . . & 855 & 6,956 & 1,526 & 1,504 & 3,464 \\
\hline Swanage & 8 & 55 & 8 & 19 & $44^{\circ}$ \\
\hline Chapman's Pool & - & - & - & - & \\
\hline Warbarrow & 19 & 32 & 24 & 30 & 216 \\
\hline Lulworth . & 5 & 4 & 5 & 3 & 331 \\
\hline Weymouth & 499 & 207 & 424 & 198 & 1,390 \\
\hline Portland . & 290 & $9+7$ & 329 & $54 \mathrm{I}$ & $1,2: 1$ \\
\hline Portland Bill . & 30 & - & 24 & & 228 \\
\hline Wyke . & 144 & 1,475 & 144 & 685 & 84 \\
\hline Abbotsbury & 10 & 2,903 & 4 & 962 & 96 \\
\hline Burton & - & 829 & - & 296 & 302 \\
\hline Lyme Regis & 122 & 639 & $6_{3}$ & 166 & $54^{8}$ \\
\hline
\end{tabular}

The latest reports to hand regarding the Dorset fishery may fitly bring this article to a close :In the case of most of the fishing stations the industry is a 'declining' one. 'Unsettled weather' also has had an unfavourable influence upon the fishing, whilst the withdrawal of the herring from these waters continues; in the case of Lyme Bay, for instance, herrings 'did not seem to enter in any large shoals.' Very few herrings were caught at Poole with drift nets. ${ }^{73}$

The modern Dorset fisherman, according to Mr. Aflalo,

displays an apathy in fishery matters which can only be attributed to the paucity of fish in these waters, as well perhaps as to the paramount agricultural interest and the desire to cultivate the summer visitor. ${ }^{74}$

\footnotetext{
${ }^{70}$ Ibid. 60.

${ }^{n}$ Ibid.

"Ibid.

${ }^{73}$ Ann Rep. Sea Fisheries, 1905 , pp. 59-60.

74 Aflalo, Sea Fishing Industry, 266-7.
} 


\section{A HISTORY OF DORSET}

\section{CLOTH}

Dorset of the downs, commercially concerned with agricultural pursuits, and with the manipulation of its abundant earth products, its hemp and flax, presents, with regard to its cloth trade, none of those features of industrial romance which characterized the history of the craft in other counties. Easy access, moreover (even in times when the problem of the highways pressed heavily upon the mediaeval commercial traveller), to the neighbouring great clothing centres of IVilts., Devon., and Somerset, rendered the Dorset housewife and husbandman independent of the local loom. ${ }^{1}$ The wool of Dorset took but a secondary place in the kindred values of the same commodity in other parts of the kingdom, the price in 1343 being only 8 marks, one of the lowest rates, as pointed out elsewhere in this volume, ${ }^{2}$ in the kingdom. ${ }^{3}$ Twenty years later, Melcombe Regis, which possessed a cocket of wools prior to the reign of Edward I, was made a staple town, a privilege which was taken away by Henry VI, who bestowed it upon Poole." The price of Dorset wool in the reign of this king was 66 s. $8 d$. per sack. ${ }^{5}$

The early woollen industry of the county is nearly always mentioned in connexion with the kindred industries of Somerset and Wiltshire, as for example in the reign of Richard II, when the clothworkers of the west of England seem to have incurred legislative censure, forasmuch

As divers plain cloths that be wrought in the counties of Somerset, Dorset, Bristol and Gloucester be tacked and folded together and set to sale, of which cloths a great part be broken, broused and not agreeing in the colour neither be according to Breadth nor to no manner to the part of the same cloths shewed outwards, but be falsely wrought with divers wools to the great deceit, loss and damage of the people, in so much that the merchants that buy the same cloths and carry them out of the realm to sell to strangers be many times in danger to be slain, and sometimes imprisoned and put to fine and ransom by the same Estrangers, and their said cloths burnt or forfeit, because of the great deceit and falsehood that is found in the same cloths when they be untacked and opened to the great slander of

1 Dorset spinners, it would appear, were employed by the clothiers of other counties, those of Cerne Abbas being thus engaged in 1750 for the Devonshire clothiers. Pococke, Trovels through Engl. ii, 143.

'See 'Soc. and Econ. Hist.' for details of the state of the trade in the fourteenth century.

Rot. Parl. (Rec. Com.), ji, 1386 .

I lbid. i, 317b; ii, 288a, 304a. Edward III appointed Gilbert de Portesham and William the Marshal collectors and receivers of the customs of wool at Melcombe; Walter de Frampton and John Baker being similarly appointed 35 Edw. III ; Ellis, Hist. Weymouth.

${ }^{s}$ Rogers, Agric. and Prices in Engl. iii, 704. The wool-tax was assessed on Dorset in the reign of Edw. III as follows : 480 sacks, 21 stone, $4 \frac{3}{4} \mathrm{lb}$. the Realm [of England]. It is ordained and assented that no plain cloth tacked nor folded shall be set to sale within the said counties but they be opened upon pain to forfeit them so that the buyers may use them and know them as it is used in the county of Essex. ${ }^{6}$

There were further regulations with regard to the sealing of cloth by the workers, weavers, and fullers, permission being given to buyers to fold or tack their cloth as they chose to ensure easy carriage. The necessity for the statute was obvious when the penalties incurred by merchants abroad were so severe, and the frauds practised by the Dorset men among others so outrageous. The statute shows clearly that cloth was made in this county and exported even in the fourteenth and fifteenth centuries, when the greater part of English trade consisted in raw wool, and not in manufactured goods.

The cloth-making towns of Dorset have been Sherborne, Dorchester, Lyme Regis, Wareham, Shaftesbury, Beaminster, Bere, Sturminster, and Gillingham.?

Dorchester 'formerly gained much by clothing ${ }^{\prime} ;{ }^{8}$ but the industry was almost entirely destroyed by the disturbances caused by the Civil War, and by a great fire. ${ }^{2}$ The material first made here was broadcloth, the manufacture of serges being afterwards substituted for it. The fame of the former fabric, however, still lingered in the town in 1720 , when Defoe visited it. ${ }^{10}$

The fifteenth century saw the rise of Sherhorne to importance as a cloth-making town. Leland considered it 'the best town' in his time for the woollen manufacture in the county. ${ }^{11}$ Both he and Camden attributed its exceptional prosperity to this trade. ${ }^{12}$ The cloth made in Sherborne was of the same character as that produced in the other towns in Dorset, namely the fine Spanish medley or mixed cloths, which Defoe explains to be

such as are usually worn in England by the better sort of people and also exported in great quantities to Holland, Hamburg, Sweden, Denmark, Spain and Italy.

$\mathrm{He}$ also describes the organization of the industry :

These towns are interspersed with a very great number of villages.... hamlets and scattered houses in which, generally speaking, all this manufacture is performed by the poor people ; the Master clothiers who generally live in the greater towns sending out the wool weekly to their houses, by their servants and horses, and at the same time bringing back the yarn that they have spun and finished, which then is fitted for the loom.

${ }^{6}$ Stat. 13 Ric. II, cap. 11 .

${ }^{7}$ Defoe, Tour through Great Brit. i, 334.

${ }^{8}$ Coker, Surv. of Dors. 69.

- Hutchins, Hist. Dors. i, $373 . \quad{ }^{10}$ Defoe, op. cit.

1 Leland, Itin. ii, 47. ${ }^{12}$ Camden, Brit. i, 173. 


\section{INDUSTRIES}

The spinning was usually done by women and children, while the men tended the sheep or tilled the land. 'The 'especially good turf' of the county fed an 'incredible number' of sheep, as writer after writer reiterates, and the wool produced was 'fine to an extreme,' 13 and much coveted by clothiers, ${ }^{14}$ being in esteem for broadcloths. ${ }^{15}$ The industry was first attracted to this district by 'the infinite numbers of sheep,' but owing to the agricultural changes, and to the extent of the manufacture, wool had to be obtained from all parts of England and occasionally from Ireland, though no reliance could be placed on the supply from the latter source. Wool imported from Spain was, as its name 'Spanish medley' implied, mixed with the British wool to make the broadcloth.

In 1725 the industry was flourishing and increasing; and though a check was given to the trade by the war on the continent from $1742-8$, by the Seven Years' War, I 756-63, and by the energy of the French, who had succeeded in capturing the trade in the East, ${ }^{16}$ the "making and vending fine serge and felling sheep, of which they have great quantities, 17 continued to be sources by which the county was much enriched. The making of serge seems to have been independent of the neighbouring counties, and to have stayed longer in the county. Although it could be described as not very considerable in $1751,{ }^{18}$ and although the 'fine serge' had become 'linsey woolsey at about 14d. a yard' in 1754 , $^{19}$ it was still flourishing in $1761,{ }^{19 a}$ and until late in the eighteenth century.

This apparent contradiction usually holds good of any Dorset industry. The whole industrial population is inconsiderable, and the number of men and women engaged in any one industry would scarcely be enough to run a big Lancashire factory, but the industries are in a healthy and sound condition, and are far more important than mere numbers would seem to warrant.

The most graphic and detailed account of the woollen industry, as it was carried on in North Dorset in 1725 , is that given by Defoe, ${ }^{20}$ and though he has been called the greatest conceivable liar, his facts about Dorset are corroborated by all the standard historians, and his descriptions can be vouched for by eye-witnesses in cases where the custom has come down to the present day. The only exception to this is his account of Bridport, as before mentioned.

${ }^{13}$ Defoe, Tour through Great Brit. (1725), 42.

"Description Engl. and Wales (1769), 211 .

is Tour through Western Counties (1807), 16.

is Tour through Great Brit. (6th ed. 1761).

${ }^{17}$ Cox, Magna Brit. 554.

${ }^{18}$ Postlethwayt, Dict. of Trade (1751).

${ }^{19}$ Pococke, Travels (1 754), ii, 146.

${ }^{193}$ Tour through Great Brit. (6th ed. 1761).

${ }^{20}$ Ibid. (1725).
The whole plain, embracing Somerset, Wiltshire, North Dorset, and Gloucestershire, was at that time busied in weaving wool.

One of the effects of the diminution of the demand for woollen goods was that the industry gradually contracted in its area, and was no longer carried on in this county.

Dorset sheep in the middle of the eighteenth century were still famed as some of the largest and finest brought 'to Smithfield Market both for flesh and wool,' and 'surprising quantities of wool'21 were still produced, but the wool was carried into Somerset and Devonshire, ${ }^{22}$ and less and less was woven in Dorset. In 1769 Sherborne had altogether given up competing in the weaving of medley cloths, ${ }^{23}$ but the rest of the county had a 'considerable manufacture ${ }^{24}$ of woollen goods, though it is stated to be less than it had been in preceding years. ${ }^{25}$ From this date onwards this industry is usually mentioned as one of the vanished glories of Dorset, though cloth is given as one of the products of the county in $1780 .^{26}$

In 1678 wool kerseys ${ }^{27}$ were one of the chief commodities of this shire. ${ }^{28}$ Dorset cloth in 1689 was priced at $6 s$. per yard. ${ }^{29}$

A Dorset woollen manufacture which flourished in the eighteenth century at Shaftesbury and Sturminster was that of swanskin, a coarse white cloth largely utilized for soldiers' clothing, and for that of the Newfoundland fishermen. Sturminster had 1,200 persons engaged in the industry in I793, the output from the town being from 4,000 to 5,000 pieces of $35 \mathrm{yds}$. each per annum. ${ }^{30}$ The cost of the material was from Is. $6 d$. to $2 s$, per yard. ${ }^{31}$ In 1812 Stourton Caundle had a manufactory of swanskin made from lambswool. ${ }^{32}$ By 1823 the trade of Sturminster in this commodity, so long specially associated with the town, was 'annihilated.' ${ }^{33}$

"Description of Engl. and Wales (1769), 248.

${ }^{2}$ Postlethwayt, Dict. of Trade (1751).

${ }^{3}$ Engl. Displayed (1769), 65.

${ }^{24}$ Like other western and southern cloth-making centres Sherborne owed the decadence of its woollen manufacture to the development of the trade in the north ; Hutchins, Hist. Dors. ii, 366.

${ }^{35}$ Engl. Displayed (1769), 65.

${ }^{26}$ A Brief Description of Engl. and Wales (1780).

${ }^{n}$ Kersey, a coarse, narrow, woollen cloth; Dillon, Fairhoit's Costume in Engl. ii, 264. Of this fabric Professor Rogers writes :- 'It was early naturalized in England, and widely manufactured, especially in the west of England'; Agric. and Prices in Engl. v, 576.

${ }^{29}$ England's Remarques (1678), 40.

${ }^{39}$ Rogers, Agric. and Prices in Engl. v, 573.

${ }^{30}$ Claridgc, Agric. of Dors. 39. Macpherson in his Annals of Commeree, iv, App. 4, alludes to the existence at Sturminster in 1805 of 'a manufactory of baize called swanskin.'

${ }^{31}$ Claridge, Agric. of Dors. 39 ,

${ }^{32}$ Stevenson, Agric. of Dors. 450.

${ }^{33}$ Pigot, Dir. (1 823 ), 276. 


\section{A HISTORY OF DORSET}

In 1793 the textile industry of the county was chiefly concerned with the manufacture of sail-cloth, centering in the town of Beaminster, where Messrs. Cox \& Co. alone employed 600 persons, 2,000 people being employed in the locality altogether..$^{34}$ The firm had another establishment at Bridport, where 1,800 persons were employed, out of a total of 7,000 engaged in the industry in the town and neighbourhood. ${ }^{35}$ Women and children earned $8 d$. a day, spinning $4 \mathrm{lb}$. at $2 d$. per $1 \mathrm{~b}$., children being paid at the rate of $2 d$. to $3^{d}$. a day for turning a wheel. ${ }^{36}$ Sail-cloth was made in pieces of $40 \mathrm{yds}$., selling at from $15 d$. to $17 d$. per yard. ${ }^{37}$ Sacks for grain or flour were made at 37 s. per dozen, capable of containing 4 bushels or 9 gallons. ${ }^{38}$ Young girls were largely employed in the manufacture at Loders in 18 I $2,{ }^{39}$ the woollen manufacture at this date being spoken of as 'almost confined to Sturminster and Lyme Regis,' 10 the latter manufacturing broadcloth and Alannels, whilst Sturminster had four or five clothiers and 300 weavers, chiefly engaged in the production of swanskin, the amount, however, showing a marked decline in the trade. ${ }^{4 l}$ Beaminster was producing wool-cloth, Cerne Abbas had a small manufactory of dowlas, ${ }^{42}$ Fifehead Neville of swanskin, Gillingham of bed-ticking, Oborne of cloth, Silton of ticking and dowlas, Stickland had two serge weavers, Stoke Abbott made sailcloth, sacking, and narrow cloth. ${ }^{43}$ In 1823 Gillingham had five manufactories of tick and dowlas ; ${ }^{41}$ at Lyme Regis, Stanton, England \& Glyde were employing more than 200 persons in the manufacture of broad and narrow woollen cloth. ${ }^{45}$ In I 830 plain and striped cottons were being made at Poole and Abbotsbury ; ${ }^{46}$ at Beaminster the Birt was propelling three mills for spinning linen yarn for the sail-cloth manufacture. ${ }^{47}$ Linsey woolsey was being produced at Shaftesbury. ${ }^{48}$ Some linen was being manufactured at Sherborne in 1826.49

The main part of the industry had always been situated on the borders of the county, and it is not wonderful that in a time of depression and contraction of trade, it should have been drawn to the larger centres in Devonshire, Somerset, and Wiltshire. It never returned to Dorset, because with the revival and expansion of the irade came the introduction of machinery, and then the bulk of the woollen industry migrated northwards. There seems to have been no distress caused in Dorset by the decay of its clothiers, perhaps because this was gradual, and because several short-lived industries sprang up, while long-standing manufactures such as brewing, sail-cloth making, and lace-making received a fresh impetus.

\section{SILK}

The silk industry of Dorset, which has always been chiefly concerned with the throwing rather than with the manufacture of the raw material, ${ }^{1}$ cannot claim a lengthy record. It is chiefly carried on at Sherborne, where the settlement of silk throwsters dates, according to Hutchins, from I 740, when, he states 'they erected mills on Sir Thomas Lombe's plan.' ${ }^{2}$ Sir Thomas Lombe introduced into England from Savoy a machine for working organzine, for which he obtained a patent in 1718, and a reward of $f_{1} 14,000$ in 1732 . Stalbridge and Cerne Abbas were also engaged in the industry in the eighteenth century, ${ }^{3}, 150$ women and children finding employment in spinning silk at the former town in $1790^{.4}$ At both places the work consisted chiefly in twisting and making up the raw silk into skeins. ${ }^{5}$ At this date no woven fabrics were actually produced in London. The spun silk which was

\footnotetext{
${ }^{34}$ Claridge, Agric. of Dors. 37.

${ }^{35}$ Ibid. 38.

${ }^{37}$ Ibid. 39.

${ }^{39}$ Stevenson, Agric of Dors. $447^{\circ}$ "Ibid.
${ }^{40}$ Ibid. $44^{8}$.

"Dowlas, coarse linen cloth; Dillon, Fairholt's Costume in Engl. ii, 150.

${ }^{43}$ Stevenson, Agric. of Dors. +50.

"Pigot, Dir. (1823), 268.
}

to form the warp and weft ot such fabrics was prepared in silk-mills, all in country districts. ${ }^{6}$

In 1823 all manufactures, except that of silk, had ceased in Sherborne. John Gouger and Thomas Willmott were then engaged in silk throwing in the town. ${ }^{7}$ From the evidence of the last-named manufacturer, given before the Select Committee on the silk trade in 1831 , interesting details may be gathered relative to the conduct of the industry at that date. Mr. Willmott was then the sole manufacturer of silk in Sherborne, his mills being three in number, one erected in 1751 , and the others in 1813 , the power in all three cases being water, ${ }^{8}$ whilst the silk thrown at the mills, on commission, was Italian tram and organzine. ${ }^{9}$ The number

15 Ibid. 269.

4 Ibid. 274.

- Paterson, Roads, 454.

' Green, Rural Industries of Engl. 73.

${ }^{3}$ Hutchins, Hist. Dors. ii, 366.

${ }^{3}$ Stevenson, Agric. of Dors. $44^{8}$.

- Claridge, Agric. of Dors. 39.

${ }^{3}$ Stevenson, Agric. of Dors. 448.

${ }^{6}$ Dodd, Days at the Factories, 4.

7 Pigot, Dir. (1823), 274.

${ }^{8}$ Parl. Rep. Silk Trade (18 31 ), 278 .

${ }^{9}$ Ibid. 282. 


\section{INDUSTRIES}

of women and children employed had been 800 in $1793,{ }^{10}$ but had declined by 1826 to 600 , working 8,000 spindles, ${ }^{11}$ whilst by $183 \mathbf{I}$, I 50 persons, using only 3,000 spindles, were employed. ${ }^{12}$ The workers were divided into mill-hands, whose average wages were $4 s .6 d$. per week, ${ }^{13}$ and winders, whose industry was a cottage one, carried on in many instances in conjunction with agricultural pursuits. ${ }^{14}$ In I 829 $2 s$. $3 d$. per $\mathrm{lb}$. had been paid for winding fine silks, the payment in 1831 averaging is. per $\mathrm{lb}^{15}$ The decline in prices was to be attributed, according to the witness, to the introduction of foreign thrown silk, and the severe competition with foreign manufacturers. ${ }^{16}$

According to the latest census returns, I 6 women and 19 men are employed in the silk industry. ${ }^{17}$ Silk 'throwing' is still a principal feature of the craft, but silk weaving is now undertaken at Sherborne, where many new looms have been set up by Messrs. J. \& R. Willmott. Further improvements are contemplated, but the industry is handicapped by the sudden changes of fashion and by the variations in the yield of silk crops, these difficulties naturally pressing more heavily on a small than on a large industry.

\section{POTTERY AND TILES}

Dorset is abundantly provided with the raw material for the manufacture of bricks, tiles, and pottery, clay of various qualities being yielded by the different geological formations of the county, more especially by the upper formation of plastic potter's and pipe-clay and sand known as the "Poole Trough.' 1 From the earliest date, the industry has centred around Poole, Wareham, Norden, and Corfe. ${ }^{2}$

It is not known when the clays of Dorset were first worked $;^{3}$ many roughly-made vessels having been found near Wareham, evidently constructed, according to experts, from this raw material, and used for the ashes of the dead before the Roman occupation of Britain. These funeral urns alone have survived the passage of time, no trace remaining of the earthenware vessels which must have been in daily domestic use. The Roman discovery and manipulation of the Dorset clays will be discussed elsewhere in the section of this volume dealing with the antiquities of the county; after the Roman withdrawal from their area, the clays continued to be worked, with more or less regularity, according to the stress of economic conditions or the fluctuating demand for earthenware vessels. ${ }^{4}$

${ }^{10}$ Claridge, Agric. of Dors. 40.

${ }^{11}$ Parl. Rep. Silk Trade, 278.

${ }^{13}$ Ibid. 279.

12 Ibid.

${ }^{13}$ Ibid. 279.

14 Ibid. 280

${ }^{16}$ Ibid. 280 .

${ }^{17}$ Pop. Ret. 1901, p. 56.

${ }^{1}$ Kelly, Dir. (1903), 1. De Luc, on his geological travels through Dorset in 1826 , noted ' a yellowish clay, mixed with sand, commonly called loam, and used for bricks,' and 'a pure bluish clay, of which pottery and tiles are made.' Geol. Travels, ii, 29.

"Woodward, Geol. Engl. and Wales, 27 I. De Luc notes in his geological travels the 'very deep excavations at Corfe whence is taken white clay for pipes and earthenware.' De Luc, Geol. Travels, ii, 193. The character of 'pure potter's clay' is 'soft, white, and unctuous.' Mem. Geol. Surv. 1898, p. 191.

${ }^{3}$ "The white and mottled clays of the Bagshot series have been worked for centuries.' lbid.

- From local information.
In early days the port of export for the clay was Wareham, ${ }^{5}$ and around the traffic a longstanding quarrel grew up between this town and Poole, which is still unsettled, though an Order in Council of 1666 directed that "no dues were to be paid on tobacco pipe-clay.' 6 The real commercial importance of the industry seems to date from the eighteenth century, when the clay however, was noted primarily as raw material for export, rather than as forming the nucleus of a local manufacture. ${ }^{7}$

Poole clay, so termed from being shipped at Poole in Dorset, is chiefly raised in the neighbourhood of Wareham, and is extensively employed in the British Potteries; it is an example of a tolerably pure clay (that is, one containing a large proportion of silicate of alumina, with free silica, but without injurious ingredients) which has been accumulated far from any decomposing crystalline rocks such as granites, porphyries, and the like. It is known also in the potteries as 'blue clay.' Its geological position is in that portion of the Tertiary or Cainozoic beds which occur above the chalk of Dorset.

'White Pipe clay' occurs in the Bagshot sands, and is worked round Poole Harbour and in the district further west. ${ }^{8}$

In the same geological series occurs

a bed 20 feet or more in thickness of white vr red mottled pipe clay extensively dug for the manufacture of earthenware, and used in the local potteries or shipped from Poole Harbour. ${ }^{9}$

Besides these special clays there are various local brick earths which are found in the Bagshot, Oxford, Reading and Wealden series.

'The pipe-clay of Warcham was 'cstcemed the best in England.' Engl. Displayed (1769), 69. See also Postlethwayt, Dict. of Trade.

${ }^{6}$ Hutchins, Hist. Poole, 38

${ }^{7}$ In 1823 the export from Warcham annually was 10,000 tons to London, Hull, and Liverpool. Pigot, Dir. 277.

${ }^{8}$ Woodward, Geol. Engl. and Wales, $271 ; M \mathrm{~cm}$. Geol. Surv. 1899, p. 139. 


\section{A HISTORY OF DORSET}

Brick-making is the less important of the two industries connected with clay in Dorset, but it is simpler to consider it first. The rapid increase in building, especially in the sea-coast towns and in Dorset's near neighbour Bournemouth, has led to a considerable demand for bricks. These are made in various places from the different clays. In the district round IVeymouth almost all the bricks are made of Oxford clay, ${ }^{10}$ while the mottled clays of the IVealden beds are used near Swanage, and in the area round Dorchester the best bricks are made at Broadmayne, where a bed of clean loam ten or twelve feet thick occurs in the Reading series." This is used for the 'Broadmayne speckled bricks,' which are employed for building in Weymouth and Dorchester. ${ }^{12}$

In 1728 the clay was worth 30 s. a ton at London, this value increased to 50s., but by 1796 it had fallen to 145 or 15 s. a ton. ${ }^{33}$

Hutchins' history gives a detailed account of the extent and importance of the other branches of the clay industry in his time :-

Nearly 10,000 tons are annually exported to London, Hull, Lirerpool, and Glasgow, etc., but the most considerable part to Liverpool for the supply of the Staffordshire potteries, and to Selby for the use of the Leeds potteries. The principal pits are on the Norden and Wital farms, the former belonging to Wm. Moreton Pitt and the latter to John Calcraft, Esq., and the clay taken from the same is in great repute with the Staffordshire and Yorkshire potteries, from its peculiar excellence, and being the principal ingredient in the ware commonly called Staffordshire ware so universally in use in this kingdom as well as in many other parts of Europe."

From this time forward the export of clay has always been considerable. In 1831 it

had extended to 34,290 tons, and in 1851 it reached 69,286 tons according to the clearances at the Poole

${ }^{10}$ Mem. Geol. Sure. I 899, p. 237.

11 Ibid. I $S 9 S$, p. 46 .

12 Geol. Dorchesier (Mcm. Geol. Surv.), i 899, p. 46. The speckled effect is due to the presence of minute nodules of manganese oxide. The method of making Broadmayne bricks is as follows: "The work begins by the heading of the clay or taking off of the top soil. The clay is dug mostly in the winter months, and cast back loosely or wheeled back into a heap to soak for the coming season of brick-making which begins about March or the beginning of April. The clay is worked (tempered) in a pugmill turned by a horse or donkey, or trodden by men's naked feet. The new-made bricks are wheeled to the drying ground on long barrows and placed in rows (hacks), and when dry enough sent to the kiln. It takes two or three days to burn the bricks, and about as long to cool them.' Barnes, Glosscry of the Dors. Dialect, 5 1.

${ }^{13}$ Hutchins, Hist. of Dors. ( 1796$)$, i, 172.

1 Poole clay, according to Jevitt, was sent to Selby for the Leeds potteries in 1796. Cercmic Art, 269 . It was also used in the body of Swansea ware. Ibid. 570 . custom house; of this amount about 52,268 tons were employed in the manufacture of the finer kinds of earthenware, chiefly in the Staffordshire potteries, and 16,018 tons for ordinary stone ware, tobacco pipes, alum making, etc. ${ }^{15}$

In 1878 the amount exported from Poole was 73,130 tons, while the total quantity of pottery and other clays produced in Dorset during that year amounted to 79,205 tons of the estimated value of E1 $9,800 .^{16}$

At the present time (I 907) Messrs. Doulton \& Co. alone raise over 18,000 tons of clay per annum from their Dorset pits (though this of course forms only a portion of the supplies necessary for the production of their wares at Lambeth). In the raising and export of this clay they employ on an average fifty men per day. ${ }^{17}$ Besides this London firm, there are Dorset firms which export raw clay, as well as those which have factories in the county.

The clay is now used in almost every part of the world for the manufacture of fine earthenware goods, ${ }^{18} \mathrm{e.g}$. it is used for all kinds of stoneware pottery, for bottles, jars, chemical apparatus, sanitary fittings, electrical insulators, and drain pipes. ${ }^{19}$ It is also employed in Dorset in the manufacture of tiles and every kind of architectural pottery.

Both Brown Island and Brownsea Island, situated in Poole Harbour, contain clay similar to that found on the mainland; and both have been the seat of experimental manufactories. Just before 1750 , a certain Mr. Brock began making tiles on Brown Island. ${ }^{20}$ This attempt to establish the industry was unsuccessful, as was an attempt about 100 years later to make pottery on Brownsea Island, ${ }^{21}$ some specimens of this last are preserved in the Geological Museum in Jermyn Street.

The Architectural Pottery Company was established at Poole in 1854 by Messrs. Thomas Sanders Ball, John Ridgeway, Thomas Richard Sanders, \& Frederick George Sanders. In I $857 \mathrm{Mr}$. Ridgeway retired, and in $186 \mathrm{I}$ Mr. Ball, the firm then continuing as Messrs. T. R. \& F. G. Sanders. The output comprised patent coloured and glazed bricks and mouldings; semi-perforated and pressed, patent mosaic, tesselated, encaustic, vitreous, and other varieties of glazed wall tiles, embossed and perforated tiles, quarries, and fire-clay goods.

is Catalogue of Specimens, Museum Practical Gcology.

${ }^{16}$ Hunt, Mireral Statistics (1 \$78), 139.

1: From information kindly supplied by Messrs. Doulton \& Co.

${ }^{18}$ From local information. Pipe-clay for local use is obtained in the Dorchester area from Trigon Farm, Sandford (where the beds are 10 ft. thick), and Station Heath. Geol. Dorchister (Mem. Geol. Surv. 1899 ), 57.

19 From information kindly supplied by Messrs. Doulton \& Co.

${ }^{20}$ Pococke, Trazels (1754), 87.

"Catalogue of Specimens, Museum Practical Geology. 


\section{INDUSTRIES}

The clays used in this pottery were the Purbeck, Cornish china, and Wareham clays; for the plain quarries, clay from the Canford estate was largely utilized. ${ }^{22}$

The Bourne Valley Pottery, owned by Messrs. Sharp, Jones, \& Co., produces glazed stoneware sewage and sanitary pipes, terra-cotta vases, figures, chimney-tops, and garden edgings, $\& c .{ }^{23}$

The Kinson Pottery, Limited, was established at Kinson, near Poole, in the middle of the last century, with twelve kilns, a boiler, enginehouse, drying-sheds, stables, and offices. Closed for a few years, it was acquired by the present company in 1867 , and since this date they have manufactured stoneware drain pipes, also various goods in terra-cotta. Twenty-seven acres of clay of three different qualities are at the disposal of the potter at this site, some of the beds being $40 \mathrm{ft}$. in thickness. ${ }^{24}$

In 1812 there were two potteries at Beaminster producing a coarse ware, which was also manufactured at Cranborne. ${ }^{25}$

It is hard to discover when tiles were first made in Dorset in modern times; probably the Romans made them, but after that the mists descend, and the glimpses that can be caught of the industry are vague and unsubstantial. However, between 1770 and 1780 , the oldest firm in Dorset took over its present business from its predecessors. This business was even then a 'going concern.' 26

At the present time tile-making is one of the special features of the clay industry in Dorset. These tiles are used all over the world in shops, restaurants, and bathrooms, in stations, hotels, ocean-liners, and government offices. To ensure perfect tiles, attention has necessarily to be paid to the nature of the clay employed and to the processes of manufacture. The clay pits now worked are situated round Wareham, near Corfe Castle, near Poole, near Corfe Mullen, and near Hamworthy. The clay is not used by itself, but is mixed with various other ingredients. It is to a certain extent coloured naturally by oxide of iron; this gives to the clay, when burnt, tints varying from light buff to deep red, chocolate, or even black. Clay has a peculiar property which has to be reckoned with in making tiles; unlike most bodies it shrinks when exposed to heat owing to the loss of moisture, so that a 6-in. tile must measure say $6 \frac{1}{2} \mathrm{in}$. before being burnt. Some clays shrink less than others because, among other reasons, they contain a larger proportion of silicate. These points must be noticed in choosing the raw material, or the colour, shape and size of the tile will be uncertain.

32 Jewitt, Ceramic Art, 236.

${ }^{23}$ Ibid. 238.

24 Ibid. 239.

${ }^{25}$ Stevenson, Agric. of Dors. 450.

${ }^{26}$ From information kindly supplied by Messrs. Pyke Bros., Wareham, and others.
When the material is chosen, the process of manufacture is most interesting. The clay has first to be changed into a meal-like dust suitable for the tile-maker, and for this different clays, or it may be different ingredients, such as ground fint or china stone with clay, are carefully blended, as experience may suggest, and are then 'slipped,' i.e. placed with water in a machine called a 'blunger,' where the mixture is tormented until the solution is thoroughly diffused. It is then passed through a set of sieves of extreme fineness and finally forced through a filter-press of cloths to expel the moisture, which drips from the press into a tank, leaving the solid matter between the cloths. This water is driven back into the blunger, only to go through the round with a fresh mixture. There are also other ways of drying the 'slips' as the mixture is called. When dry the solid matter is ground, and, after a final sifting, becomes dust ready for the tile press.

This machine is, in its essentials, a steel box of the shape and size inside of the required tile, and a very powerful screw-press applied by means of a large fly-wheel, worked by hand, as steampresses are often unsatisfactory. The box is filled with the fine dust slightly damped, and pressure is applied; after this a compact tile with a firm smooth face is taken out of the press. Of course the dust is not of the same clay, nor of the same ingredients for all tiles. The tiles described are those in which blended clays have been turned into dust, which may also be coloured by a stain. For these tiles the upper die or stamp must have a true, firm face, but if an embossed tile be required the upper die has the pattern in reverse like a seal. The tiles are dried at a temperature of about 80 degrees for some days after being made, and are then placed in open fire-clay boxes called 'seggars' or often 'saggers.' These, when placed in the kilns, practically close one another. The 'seggars' are stacked in the kilns to be 'fired,' a process which takes about a week, after which they emerge hard and fit for use as unglazed or biscuit tiles.

Buff, red, and salmon tiles are produced by blending naturally colouring clays according to the proportion of iron they contain ; grey, chocolate, and black tiles by using ironstone and manganese as a stain. White tiles cannot be obtained by burning a simple clay, but this lias to be mixed with white ball clay which is found in Dorset and Devon, ground flint and china clay, felspar and stone. The whole mixture has to pass through the 'slipping' process. The 'slip' is coloured blue with cobalt and green with chromium. Encaustic tiles which have on them patterns of floral or other designs in two or more colours are much more complicated to manufacture. They were formerly made of plastic clay, the pattern being stamped on the partially hardened clay, and then filled up with clay of a different colour, after which 


\section{A HISTORY OF DORSET}

the whole was generally glazed. This was the monastic method which came in with the Gothic architecture about the end of the twelfth century. Until quite recently a somewhat similar method was in use, and indeed some encaustics are still made of the plastic clay. More cominonly, however, the dust process is used and the pattern is produced not by a stamp, but by variously-coloured dusts laid on the body of the tile by means of flat plates of metal having the pattern cut in them.

A glazed tile is made in the same way as an unglazed tile up to the biscuit stage, but then it has to be 'dipped' (i.e. partly immersed in liquid glaze which covers the face and a slight portion of the thickness) and again burnt in a different kiln, generally at a lower temperature. The 'dipper' must be very careful, both of the tile and of himself; of the tile, for anything getting into the glaze on the tile would be fixed by the firing; and of himself because no portion of the glaze must be allowed to enter the mouth by any carelessness in cleansing the hands or otherwise. Lead or borax, Cornwall stone and fint, various oxides for colouring, all enter into the composition of different glazes. The most useful, but also the most dangerous ingredient, is the lead, but so many precautions are now taken both in the handling and preparation of this mineral that the danger of lead-poisoning is reduced to a minimum. Many experiments have been made with leadless glaze, but as far as experience yet goes the results are hardly satisfactory. The tiles, when dipped, are exposed to a less heat than in the biscuit kilns, in order to melt the glaze only, the watery portion of which has been absorbed in the porous biscuit tile. Generally this takes place in a muffie-kiln, in which the process resembles baking in an oven, the tiles being exposed neither to the flames nor to the gases produced by the fires. Glazing requires great knowledge and skill in the mixing of the glazes and in the degree of heat for the firing, the surface of the tile being very liable to 'eraze' or make little cracks from the unequal expansion of the glaze and the body of the tile. If more than one colour is required the glazes are applied with a brush, and this is termed decorating. Sometimes the pattern is obtained in another way. It is printed in colours either by lithography or copper-plate process, and these colours are fixed by firing.

The glazed and unglazed 'tesserae' for mosaic patterns are made in the same way as the glazed and unglazed tiles, and are then carefully gummed face downwards on paper which has the pattern marked on it and are finally laid in a prepared bed of cement.

Besides tiles and tesserae, hand-painted panels and faïence pilasters, fitted for the decoration of shops, tube stations, and house fronts, are prepared in Dorset. They are especially suitable for out-door use as the glaze on their surface renders them impervious to frost and to the action of all but extremely powerful acids. ${ }^{27}$

Tiles and faïence are at one extremity of the handicraft in Dorset; at the other are the pitchers and bread-pans of partly porous, partly glazed, red and yellow clay which are carted round the country by their makers, or exposed for sale in small local shops. Their weight and the ease with which they break are obvious disadvantages, but their old-fashioned shapes appeal to some people as much as their cheapness does to others. The greater number of them come from Gillingham, where, according to the county gazetteer, every second man is a potter.

\section{BREWING}

In the Middle Ages brewing was a general and necessary industry, and hardly a manor or township court roll but contains some reference to it. Entries in enrolments of proceedings in the courts of Melcombe Regis, I 396-8, contain frequent notices of transgressors, both men and women, repeatedly fined for brewing contrary to the assize, for selling ale in cups (in ciphis), or in vessels without seal (signo), or for tapping (tappare), without due supervision. In 1397 John Shudde, who, it may be mentioned in passing, appears from these records to have been the incorrigible rogue of the community, was presented for

breaking the arrest of a cask of ale which had been arrested by the under-bailiffs; for they had tasted it (astavere), supposing (rightly) that the said ale was bad, not good and sound for the body of man.'

${ }^{37}$ Information kindly supplied by Messrs. Carter \& Co., Poole. $\quad{ }^{1}$ Hist. MSS. Com. Rep. v, App. 576.
At the Law Court of 'Hokke' Term, holden I 5 May, I397, Edith Ketys with five others was amerced in the sum of $3 d$. for breaking the assize, also for using cups and other false measures. ${ }^{2} \quad$ In 1456 the ale-tasters presented that Geoffrey Sammyse had brewed twice and Alianor Houpere once, and sold ale against the assize. He was amerced $2 d$. and she $1 d 0^{3}$

At a Law Court held is April, I583, at Weymouth, it was ordered that

the beer and all brewers and sellers within this liberty shall sell their drink under the range at $3 d$. the gallon, and being stale at $4 d$., and to use just measures upon pain for every that make default to forfeit $2 s .6 d .^{\star}$

On I May, I627, Avice Locke, widow, offended 'against the form of the Statute' by

'Ibid. $577 . \quad$ 'Ibid. 578.

Ibid. 586. 


\section{INDUSTRIES}

selling smaller beer (minorem cervisiam) than at the rate of one ale-quart (unum le alequarte) for $1 d .^{5}$

The brewing industry was of early importance at Lyme Regis, where the abbot of Sherborne claimed the assize of beer in $1280 .^{6}$ In 35 Henry VIII Isabella Stansby and another, common brewers, were presented for brewing ale 'not mighty of the corn,' that is, too thin and unwholesome, and also for selling the same in unlawful measures, and were fined $6 d$. In I 572 brewers were ordered to brew with fuel, not with hard or faggot wood, on pain of $5 \mathrm{~s}$. In I 578 six common brewers only, including retailers of ale and beer, were licensed in the town, besides the brewer 'who doth and shall keep the Beer House.' 7 None were to sell beer in 1582 except in hooped pots, jugs and cups being expressly forbidden. ${ }^{8}$

Municipal regulations were many with regard to the conduct of the industry. Tipplers or retailers were forbidden to sell to any craftsman or servant except in company with a stranger. ${ }^{9}$ In 1612 none were to tipple more than one hour in one house. By a decree dating from 1599 beer was forbidden to be sold during Divine service. Mr. Hooker of Lyme at a later date was fined 2s. 6 d. for brewing on a fast-day. ${ }^{10}$

The alewife here, as elsewhere in mediaeval times, an important member of the community, gave frequent trouble to the authorities, who, at Weymouth, in the reign of Charles I, forbade brewing to be carried on by women; they were, instead, to buy of the common brewers at the following rates :-

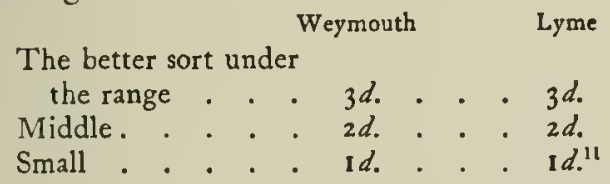

At Lyme in 1653 the Widow Brooks was dismissed from brewing and selling ale 'for divers disorders.' 12 Bodily punishment was frequently inflicted on offending alewives, as in the case of Mary Somers, who was whipped at Lyme in 1653 for selling ale without a licence. ${ }^{13}$

It is desirable ${ }^{14}$ to note here the earliest indications of the change of taste by which the old English ale (cervisia) was gradually supplanted by beer in the strict sense, that is, the hopped liquor. It is probable from notices of a considerable import trade in hops which we find elsewhere, ${ }^{15}$ that beer was brewed in Dorset

${ }^{5}$ Hist. MSS. Com. Rep. v, App. 586.

${ }^{6}$ Roberts, Hist. of Lyme Regis, 11 .

7 Ibid. 453.

${ }^{9}$ Ibid. 453. ${ }^{10}$ Ibid. 254.

1 Roberts, Soc. Hist. Southern Counties, 456.

${ }^{12}$ Ibid. 454. ${ }^{13}$ Ibid.

14 For this paragraph Mr. C. H. Vellacott is responsible.

is V.C.H. Suss. ii, $26 \mathrm{I}$. before the middle of the fifteenth century, but however this may be, it is certain that by the reign of Edward IV regular supplies of hops were arriving in the port of Poole from the Netherlands. In the sixth year of his reign, ${ }^{16}$ the Mary Knyght, of 'Tergose' in Zeeland, master Adryan Cornelis, brought in 6 'pokis' of hoppes valued at $f_{1} \mathrm{l}$, which paid $\mathrm{Is}$. in subsidy and $3 d$. in customs duty. On the I6 September, a 'scowte' called the Katherine ${ }^{17}$ of Bergen op Zoom (Barowe), William $V$ an Acon, master, entered with 2 sacks of hops on board worth 30s. The alien master paid on these is. $6 d$. subsidy and $4 \frac{1}{2} d$. customs duty. In the following year the same vessel brought in again 2 sacks of hops as well as a great quantity of Flemish tiles. This time apparently the hops were valued at Ios. I od., and the 2 'pokes' of hops brought in by the James, ${ }^{18}$ another Dutch 'scowte,' of 'Tergoos,' on 24 February, 1468 , were entered at IOs. only. But such fluctuations in price will be understood by any person conversant with the history of the hop market. The export trade in ale from Poole to the Channel Islands was very considerable in the fifteenth century, and early in the reign ${ }^{19}$ of Henry VII we hear not only of ordinary ale, but of an export of no less than 22 casks (dolia) of 'byre' worth $£^{22}$. Malt also had long before this been exported from Dorset, since, on 30 September, ${ }^{46} 67$, the Mary, of Poole, took out, amongst a miscellaneous cargo, 12 quarters of malt valued at 4 s. the quarter.

As regards the Irish trade, ${ }^{20}$ it may be well worth notice that a Youghal vessel which entered Poole late in the reign of Henry VII with fish, as well as mantles and $98 \mathrm{yds}$. of frieze, took back a store of food stuffs, bacon, corn, and oatmeal, and also canvas and malt.

Malt mills were forbidden to be built within the town or manor of Sherborne in mediaeval times, 'whereby the corn mills,' the property of the bishop, "should be hindered. ${ }^{21}$

The thriving export trade in beer which Poole carried on with the Channel Islands during the reigns of Elizabeth and James I involved the brewers in litigation with the corporation, who levied an impost of 4 s. per brewlock of 3 tuns, or $\mathbf{I}$ d. per kilderkin, on all beer thus exported. ${ }^{22}$

The brewing industry was turned to account for the employment of-

Idle persons committed to the House of Correction at Sherborne in 1623 , when it was ordered that they should be set to the grinding of malt, which was to be

16 K.R. Cust. Accts. bdle. I 1 9, No. 8 (6 Edw. IV).

${ }^{17}$ Ibid.

${ }^{18}$ Ibid. No. 9 (7-8 Edw. IV).

19 Ibid. bdle. 120 , No. 3 (3-4 Hen. VII).

${ }^{20}$ Ibid. No. 10 (I 9-20 Hen. VII).

"Wildman, Hist. Sherborne, 54. See "Soc, and Econ. Hist.'

${ }^{23}$ Roberts, Soc. Hist. Southern Counties, 455. 


\section{A HISTORY OF DORSET}

supplied by all alehouse-keepers brewing in their own houses, the master of the House of Correction being authorised to take not above $\mathbf{1} d$. for a bushel ground in the said House. ${ }^{33}$

In I6 30 'there were great fears of a scarcity' in the malt supply; it was therefore ordered that no person in the county of Dorset should presume to convert any grain into malt, except farmers on their own land, until the licence should be renewed. ${ }^{24}$

Strong beer was to be sold at this date at 12 s. the hogshead, the small beer being priced at 9 s. the hogshead. ${ }^{25}$

At the General Sessions at Blandford in 1639 , every innkeeper selling one quart of best beer and two of ordinary beer for more than $I d$. was fined $f I, a$ similar fine being inflicted on unlicensed innkeepers. ${ }^{26}$

In 1650 complaints were lodged by the brewers of Weymouth against the importation of 'foreign beer,' that is, beer brewed out of the borough, the said beer being bought by the innkeepers to the prejudice of the brewers. A tax of I $2 d$. was levied on every hogshead, 'to go to the poor.' ${ }^{27}$

Welsh coal was being largely employed in drying the malt made in Dorset in 1793, when the demand for that commodity in the county reached a total of from 10,000 to 12,000 bushels, Io to 14 bushels going to a hogshead of $6_{3}$ gallons of strong beer. ${ }^{28}$

Cerne Abbas had a good trade in malting and brewing in $1823 .^{29}$

Dorchester ale has been enthusiastically praised for two centuries ${ }^{293}$ by county historian, novelist, and poet. It is still well-known in the south and west of England, though its export to London is no longer so important as formerly. The industry has suffered various vicissitudes, but is at present in a flourishing condition and is rapidly increasing.

References in the Minute Books of the corporation of Dorchester show that the brewers were very busy in the seventeenth century. The traffic of their wagons was so great and the pavement of the town so damaged by the 'brewers' cart-wheels by reason of their iron bonds' that on I 3 June, I6 3 , they were forbidden to 'carry any beer abroad in the town with iron bonds.' But it was not until early in

${ }^{23}$ Somers. and Dors. N. and $\mathrm{Q} . \mathrm{i}, 2 \mathrm{I} 2$.

21 Roberts, Soc. Hist. Southern Counties, 456.

${ }^{25}$ Ibid. $457 . \quad{ }^{26}$ Ibid. I 78.

${ }^{27}$ Ibid. 458.

${ }^{28}$ Claridge, Agric. of Dors. 19, 20.

${ }^{29}$ Pigot, Dir. 1823 , p. 266.

$\mathrm{ma}$ It is of interest to note that as early as 1340 the 'consuetudo cervisie' at Fordington was estimated at 20 s., so that even then a considerable quantity of ale was brewed in the neighbourhood of Dorchester. Inq. Non. $49^{b}$. the eighteenth century ${ }^{30}$ that their beer became famous, then as Mr. Cox explained,

since by the French wars [The war of the Spanish Succession] the coming of French wine is prohibited, the people here [i.e. Dorchester] have learned to brew the finest malt liquors in the kingdom, so delicately clean and well tasted that the best judges not only prefer it to the ales most in vogue as Hull, Derby Burton \&c., because 'tis not so heady, but look upon it to be little inferior to common wine, and better than the sophisticated which is usually sold."

Here the ale is praised because it was not heady, but this quality became one of its especial characteristics less than a hundred years later. In I 754 Pococke found Cerne Abbas was 'more famous for beer than in any other place in this county.' ${ }^{32}$ This town, together with Shaftesbury, Blandford, and Dorchester, traded in malt; and the 'incomparable' ${ }^{33}$ beer of Dorchester, great 'quantities of which are sold in London,' 34 is mentioned again and again by the eighteenthcentury writers.

Hutchins agrees with Cox in giving the French War as the reason for the extension of malting and brewing, and further states that the townspeople sent 'great quantities of excellent beer to London and to foreign parts, but since 1725 this trade is decayed.' ${ }_{35}$ However, beer still continued one of the best-known products of Dorchester; in 1788 it was described as having ' ever been esteemed excellent and sent to various parts of the world.' 38

In the early nineteenth century the beer and ale were as highly praised as in the eighteenth, but their characteristics seem to have somewhat altered. In 1802 the strong beer of Dorset was 'famous,' the ale was 'also particularly celebrated and in some respects unequalled.' 37

Some blight seems to fall later upon the industry, and less is heard about the Dorset ale. The only explanation suggested is the excessive cost of transit ; the ale and beer being usually conveyed in wagons, as there were no navigable rivers and no canals near Dorchester.

The largest brewery now existing was established early in the nineteenth century and is famous for the excellence of its water for brewing

${ }^{30}$ William Gawler praises the beer of Dorchester in the following terms in 1743 :-

-What town such British nectar can produce?

'Boston and Nottingham in vain compare,

'Whilst foreign kings delight in Dorset Beer !'

Somers. and Dors. N. and Q. $x, 87$.

${ }^{31}$ Cox, Magna Brit. 1720 , p. 67.

"Pococke, Travels (1754).

${ }^{33}$ Engl. Displayed (1 769$), 67$.

${ }^{34}$ Description of Engl. and Wales (1769), 229.

${ }^{35}$ Hutchins, Hist of Dors. ii, 338.

${ }^{36}$ Shaw, Tour to the West of Engl. (1788), 469.

${ }^{37}$ Britton, Beauties of Engl. and Wales (1 802 ), 324 . 


\section{INDUSTRIES}

purposes. This water has been obtained by sinking an artesian well through some $600 \mathrm{ft}$. of solid chalk to the lower greensand.

Most of the barley for the malt is grown and purchased in the neighbourhood, which is a great advantage to the farmers attending the Dorchester markets.

The Dorchester beer is brewed as follows :The barley is taken to one of the various maltinghouses and is there malted, screened, cleaned, and bushelled; after that at the brewery the malt is crushed and conveyed to a twin grist hopper by a Jacob's ladder. When required for mashing, the ground malt and water is passed through a Steel's masher, whereby the malt is saturated at a mixing heat of $150 \mathrm{deg}$. or thereabouts according to the lightness or heaviness of the beer required to be brewed. The general proportions are about one and a half to two barrels of water to a quarter of malt, finishing with a little more water of a higher temperature.

From the Steel's mashing machine the mixture, in its saturated condition, falls into the mash tun, when the revolving rakes are set going until the 'goods' rise to the proper heats, the object of the operator being to prevent coagulation or setting of the 'goods'; hence the rakes are kept going until the goods are seen to touch the line of saccharification. The operation lasts from five to six hours, and about two hours after the mashing process is completed the draining of the wort from the goods (or grain) takes place. The draining is accomplished, slowly at first, by several cocks placed in the bottom of the mash tun, and the wort is carried to the coppers through main pipes constructed of copper and lined with tin. The object of boiling the wort is not only to break it up, but to eliminate a large quantity of albumen, which from its changeable nature is best out of the beer. It is at this stage that the hops are added, which not only give flavour to the beer but impart to it a keeping quality. It is then cooled in open coolers and refrigerators; after this follows fermentation. The skimming system as practised in London and elsewhere is the method of fermentation which has been in use since the Dorchester brewery was founded. Finally the liquor is conveyed to slate racking or settling tanks, from which it is racked in to the casks. ${ }^{33}$

According to the census of 1901, 293 maltsters and brewers carry on their trade in Dorset, and besides these there is a large staff of clerks, travellers, and managers who are employed by the different brewers. There are various other breweries in the county besides that at Dorchester, one being at Bridport; Dorset ale indeed seems to have regained the proud position it occupied in the eighteenth century, whilst Dorchester is still famous for 'health and beer.' 39

\section{CIDER}

There is no doubt that even in the Middle Ages cider was made in Dorset as in Sussex, to meet local requirements, but unfortunately specific notices are hard to come by. However, as early as 1291 cider (cisera) is referred to in an enrolled account of the abbey of Shaftesbury. ${ }^{1}$ In the Inquisitiones Nonarum of 1340 the tithes of cider are probably included under the stereotyped form 'other small tithes,' and only exceptionally, as in the case of the parish of Beaminster, ${ }^{2}$ is cider mentioned by name. By the reign of Edward IV we also hear of cider being brought into Poole from abroad. A vessel (batalla) named the Mavye of 'Reyle,' Wrenche Herbert master, brought in amongst its cargo 1 pipe of 'sidre,' valued at 3 s. $4 d$., and Stephen Cressyn, a foreigner, paid thereon $\frac{1}{2} d$. in customs duty and $2 d$. in subsidy. ${ }^{3}$ Again at the beginning of the next century, the Barbaray of 'Rever Jobles,' entered Poole Haven under the command of her master, Thomas Viron. Amongst the cargo, besides great store of apples, pears,

${ }^{38}$ From local information.

${ }^{39}$ Clarke, A Tour through the South of Engl. (1 793).

${ }^{1}$ Pipe R. 19 Edw. I; Cf. V.C.H. Sussex, ii, 263.

${ }^{2}$ Non. Inq. (Rec. Com.), $51 b$.

${ }^{3}$ K.R. Cust. Accts. bdle. 1 I 9, No. 20.

nuts, and other fruits of the earth, were 3 'poncheons de pery,' containing I cask (dolium), valued at ICs. On this consignment of liquor the foreign merchant, James Seron, paid $1 \frac{1}{2} d$. in customs duty and $6 d$. as his share of the subsidy. ${ }^{4}$ After disembarking her cargo she loaded up with English goods and returned home, but reappeared ${ }^{5}$ at Poole two months after with more apples and nuts, but instead of perry brought a hogshead of dry wine (vini non dulcis), a barrel of verjuice (verg'), and two butts of Runnay or Roumey wine, ${ }^{6}$ which contained 1 cask and I hogshead of dry wine.

An orchard of cider apples has long formed part of every Dorset farm, but the cider made in the county has been almost exclusively manufactured for home consumption. The process was frequently superintended by a travelling brewer, who was an authority on the proper flavouring and clearing of the liquor. The Vale of Blackmoor has always been the pre-eminent ciderproducing district in the county. In 1788 apples

4 Ibid. 19-20 Hen. VII, bdle. 120, No. 10.

${ }^{5}$ Ibid.

6 Possibly the Romaney wine mentioned by Mr. André Simon, Hist. of Wine Trade in Engl. i, 213,218 , 282 , \&c. 


\section{A HISTORY OF DORSET}

were raiscd 'in abundance' on the land lying between Charmouth and Bridport, the cider from which sold at 75 . to 125 . a hogshead. ' In 1793 a hogshead of 63 gallons was valued at a guinea to $30 .^{8}$ In 1802 the Vale of Blackmoor still maintained its reputation for cider apples. $^{9}$ At Dalwood in 1812 the best cider was made from bitter apples, the following varieties being specially suitable; Jersey, Buckland Marylebone, and Langstone. ${ }^{10}$ Near Sherborne the practice was to mix 6 bushels of sweet apples with 3 bushels of a sharp or bitter variety, ${ }^{3]}$ and it was generally considered that 20 bushels would make a hogshead of cider. ${ }^{12}$ At Powerstock a single tree was known to yield 7 hogsheads in one season. ${ }^{13}$

One well-known orchard ${ }^{\text {If }}$ in the beginning of the last century was that of Mr. Ottan at Wootton Fitzpaine. It was in extent about 20 acres, and the trees were on an average $20 \mathrm{ft}$. apart. The yield varied considerably, but in general it was thought to be about 10 hogsheads per acre. As to the methods employed in manufacture Mr. Ottan observed that when cider ferments too much

it should be checked as much as possible; and this may be done by straining the sediment which is left after racking off through a canvas bag, and putting the clear liquor thus obtained among the cider.

He also pointed out that sour-bitters and clusterapples were useful to make cider keep well, and sometimes one pound of hops was added to each hogshead for the same purpose.

Cider often known by the name of liquor or drink was constantly given to the labourers at hay-

${ }^{7}$ Shaw, Tour to W'est of Engl. (1788), 454.

${ }^{9}$ Claridge, Agric. of Dors. 25.

- Britton, Beauties Engl. and Wrales (1802), iv, 322.

${ }^{10}$ Stevenson, Agric. of Dors. 321.

11 Occasionally a few crabs were substituted for the bitter apples.

is Stevenson, Agric. of Dors. 322.

${ }^{13}$ Ibid. 'Ring-houses' were formerly to be found in some places where the owners of orchards could have their apples made into cider. Roberts, So:: Hist. Southern Counties, 454.

14 Ibid. 321 . time and harvest, and enormous quantities were consumed. At the beginning of the last century at Netherbury labourers had 2s. 6d. a day and 12 pints of cider. At Wootton Fitzpaine the men often drank 2 gallons of liquor a day, and at Dalwood the harvesters got half a pint of cider each for every ridge they went down. ${ }^{15}$

The picture of the Dorset orchard, drawn in I 897 by one observer, is a gloomy one.

Of the many counties I have critically inspected, Dorset has proved one of, if not the most disappointing. In all directions small and occasionally large orchards are to be seen, no holding or farm being apparently complete without one; but the trees are truly in a wretched plight, to be matched for their drapery of moss and lichen in other parts of the county, but surely not out of it. ${ }^{16}$

The same authority found the trees unpruned and the land uncleaned; whilst the cider was "poor stuff,' much of it being unfit to drink. ${ }^{17}$ Again, it must be confessed that the late Mr. Farquharson, at one time member of Parliament for a division of the county, declared that although he made cider on his estate he could never get it of prime quality, and this he attributed to the character of the soil. On the other hand that excellent judge Mr. C. W. Radcliffe Cooke tasted draught cider near Corfe Castle almost equal to the best Herefordshire. ${ }^{18}$ Indeed, round Wareham the making of cider was at one time regarded as so important according to a correspondent of Mr. Cooke's that people were allowed to be called out of church to attend to it. The truth seems to be that only certain soils in the county are really suitable for vintage fruit, and that sufficient enterprise and care have not always been used in the management of the orchards and the making of the liquor. Yet with improved methods of cider-making Dorset should maintain her place beside her W Western sisters Somerset and Devon in this ancient and characteristic industry.

${ }^{15}$ Ibid. 436.

16 'The Wasted Orchards of England,' Gordener's Mag. 1897.

${ }^{17}$ Ibid.

Is Cooke, Book about Cider and Perry, 9. 




\section{CENTRAL UNIVERSITY LIBRARY}

University of California, San Diego

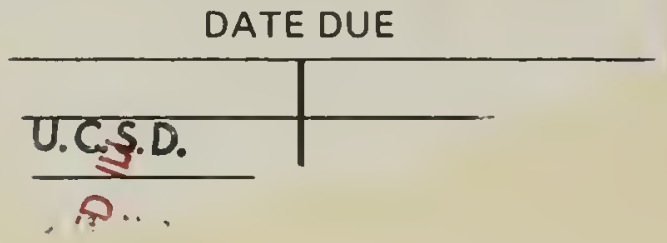


LIBRADM

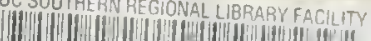

D 000969047

$000969047 \quad 0$ 
